\title{
Clero secular y territorialización parroquial en la diócesis de Córdoba, 1875-1925
}

Prácticas y poder pastoral en el marco del proceso de romanización de la Iglesia y modernización del

Estado

\section{Milagros Gallardo}

Tesis para optar al grado de doctora en historia Directora: Dra. Andrea Reguera UNCPBA/CONICET Co-director: Dr. Guillermo Banzato UNLP/CONICET 


\section{Resumen}

Nuestro estudio analiza el complejo proceso de Romanización de la Iglesia Diocesana de Córdoba entre 1875 y 1925, centrándose en el análisis de las formas en que la Iglesia intentó reacomodarse a la situación que le creaba la vasta modernización en curso y el avance del proceso de secularización. La Iglesia católica de Córdoba sabiéndose portadora de una experiencia que trasciende las fronteras de una cultura nacional, se instituyó como reproductora de valores universales, instaurando un programa que aspiró, entre otras cosas, a la consolidación de un sistema cultural y social de matriz católica, que podrimos denominar como un proyecto integral orientado a construir una "nueva cristiandad" o una "nación católica".

El clero parroquial de campaña fue uno de los agentes fundamentales del proceso, y la parroquia el gozne o la bisagra sobre el cual la Iglesia organizó su poder pastoral en el territorio diocesano, reestableció y consolidó sus vínculos con la sociedad, estimulando a sus feligreses a un mayor compromiso en pro de una mayor militancia en la causa católica, e impulsó una pastoral litúrgica, sacramentaria y devocional destinada a las multitudes.

El primer paso de este largo y complejo proceso consistió en reorganizar una institución debilitada que había sufrido los vaivenes de la anarquía; las guerras civiles, la sedevacancia de la silla episcopal y la escasez de su clero. Este proceso de institucionalización fue analizado en tres tiempos: 1) la fragilidad (1875-1888); 2) el fortalecimiento (18891904); y 3) la consolidación (1905-1925) y se tomaron tres variables amplias: la

territorializacion eclesiástica; el clero secular como actor político, social y religioso de cambio y el poder pastoral parroquial. 


\section{INDICE}

$\begin{array}{ll}\text { DEDICATORIA } & 15\end{array}$

$\begin{array}{ll}\text { AGRADECIMIENTOS } & 16\end{array}$

$\begin{array}{ll}\text { INTRODUCIÓN } & 19\end{array}$

PRIMERA PARTE: CONSIDERACIONES TEÓRICO-METODOLOGICAS 34

CAPITULO 1: LA HISTORIA RELIGIOSA EN LA ENCRUCIJADA:

DE LA HISTORIA INSTITUCIONAL A LA SOCIO-CULTURAL 35

1. Los derroteros de la historia religiosa 35

1.1 La historia religiosa francesa $\quad 35$

1.1.1 Lo religioso y la historia social 38

1.1.2 Historia y sociología religiosa $\quad 40$

1.2 Historia religiosa y mentalidades: una mirada estructuralista 43

$\begin{array}{ll}\text { 1.3 La historia religiosa y lo político } & 47\end{array}$

1.4 La historia religiosa fuera de Francia $\quad 50$

$\begin{array}{ll}\text { 1.4.1 Italia } & 50\end{array}$

1.4.1.1 Las estructuras diocesanas $\quad 55$

1.4.1.2 Las estructuras parroquiales $\quad 56$

$\begin{array}{ll}\text { 1.4.1.3 El personal eclesiástico } & 57\end{array}$

$\begin{array}{ll}\text { 1.4.2 España } & 58\end{array}$

1.5 Historiografía religiosa americana y argentina 61

1.6 Historiografía religiosa cordobesa $\quad 65$

1.7 Debates que atraviesan el campo de la historia religiosa 69

2. El clero secular como campo de estudio $\quad 71$

2.1 Los estudios biográficos sobre el clero $\quad 71$

2.2 La historiografía biográfica sobre el clero cordobés 73

2.3 El clero urbano y la conformación de elites $\quad 79$

$2.4 \mathrm{El}$ clero rural parroquial $\quad 83$

2.5 Clero e inmigración $\quad 84$

3. El aporte de nuestro estudio 86 
1. La historia religiosa: perspectivas de abordaje para su estudio 90

$\begin{array}{ll}\text { 1.1 La nueva historia institucional } & 90\end{array}$

1.2 De las instituciones a las prácticas: el ámbito parroquial 102

1.3 De las prácticas y de las formas de la experiencia 107

2. La historia social del clero parroquial 112

2.1 El clero secular: cuestiones metodológicas $\quad 113$

3. El aporte conceptual de la sociología religiosa 120

$\begin{array}{ll}3.1 \text { Modernidad y secularización } & 120\end{array}$

3.2 Modernidades múltiples 123

4. La religión como elemento transformador de la sociedad 127

CAPITULO 3: FUENTES: ALCANCES Y LIMITACIONES 129

1. Tratamiento metodológico: el juego de escalas 129

2. Fuentes de tipo normativo 130

2.1 Los concilios y sínodos diocesanos 130

2. 2 Autos y decretos. Edictos, circulares y cartas pastorales 131

2.3 Visitas ad limina y visitas pastorales 132

2.4 Administración diocesana 136

3. Fuentes oficiales 137

3.1 Fuentes nominales, cuantificables y estadísticas para el estudio del clero 137

3.1.1 Expedientes de órdenes 137

3.1.2 Libros de registro del Clero: de órdenes, de títulos, de licencias, de clero diocesano y extra diocesano, de asistencia a diversas actividades 138

3.1.3 Los libros de alumnos, exámenes, conducta, premios del seminario, socios de la asociación lauretana

4. Fuentes nominales más cualitativas. Las hagiografías: perfiles biográficos, elogios, coronas, oraciones fúnebres y notas necrológicas 142

5. Vida parroquial: clero, asociaciones parroquiales y feligresías 144

6. Denuncias, informaciones sumarias y juicios 145

7. Fuentes periódicas: prensa, revistas y boletines parroquiales 146 
7.2 Revistas y boletines parroquiales

8. Fuentes estadísticas nacionales y provinciales 146

9. Cartografía

SEGUNDA PARTE: CONTEXTO HISTÓRICO

CAPITULO 4. IGLESIA CATOLICA Y ESTADO LIBERAL:

AVANCES Y RESISTENCIAS

1. Gregorio XVI (1831-1846) y Pío IX (1848-1878): el enfrentamiento con la modernidad cultural y liberal

2. Hacia una nueva cristiandad: la defensa de los pueblos

2.1 León XIII (1878-1903) y el compromiso con la modernidad

2.2 Pío X (1903-1914) y el intento de recobrar la hegemonía religiosa y moral en un nuevo imperio universal cristiano

2.3 Benedicto XV (1914-1922) y Pío XI (1922-1929): la Iglesia misionera

3. Iglesia y liberalismo en América Latina

4. La romanización de las Iglesias de América Latina

4.1 La Iglesia y el Estado liberal-conservador argentino en la segunda mitad del siglo XIX

4.1.1 La segunda mitad del siglo XIX

4.2 Historizar el proceso de romanización argentino

4.3 El fenómeno de la secularización: una posible periodización

CAPITULO 5: LA PROVINCIA DE CÓRDOBA

1. Cartografía política y organización territorial

2. Esbozo general sobre la economía y la sociedad del período

3. El proceso de colonización

4. El poblamiento de los departamentos de la provincia: vieja y nueva colonización

5. El poder político

5.1 Córdoba ¿una modernidad católica? (1877-1912) 209

6. El proceso de institucionalización de la iglesia diocesana de Córdoba 215

6.1 La debilidad institucional (1810-1858) 
7. El inicio del cambio: José Vicente Ramírez de Arellano (1859-1873)

7.1 Erección de nuevos curatos

1. La institucionalización de la Iglesia diocesana (1876-1904) 239

2. Los conflictos con el Estado (1880-1890) 240

3. El gobierno de la diócesis 243

3.1 Los obispos franciscanos Esquiú y Tissera 243

3.2 Provisores y gobernadores del obispado 251

3.3 El dominico Fray Reginaldo Toro (1888-1904) 254

3.4 La consolidación: Zenón Bustos y Ferreyra: Instaurare omnia in Christo (1905-1925) 259

3.4.1 La cuestión social como inquietud compartida 263

3.4.2 El orden social y la cuestión "del otro" 268

4. Los instrumentos de la reforma: sínodos y visitas pastorales 273

4.1 Los Sínodos diocesanos: su importancia 273

4.1.1 El Sínodo de 1877

4.1.2 El Sínodo de 1906

4.2 Las visitas pastorales: herramientas para el buen funcionamiento $\begin{array}{ll}\text { de la diócesis } & 280\end{array}$

\section{TERCERA PARTE: LA DINÁMICA ESPACIAL DE LA IGLESIA}

1. La precepción del espacio diocesano por parte de los obispos 293

2. Conocer el territorio... Las visitas pastorales entre 1877 y 1904

2.1 Visitas pastorales a los departamentos de vieja colonización (1877-1887) 299

2.1.1 Las Visitas de los Obispos Álvarez y Esquiú 300

2.1.2 La Visita del Obispo Tissera 301

2.1.3 Consideraciones sobre las Visitas Pastorales 312 
2.2 Vistas a los departamentos de nueva colonización (1877-1887)

2.2.1 Visitas del Obispo Fray Reginaldo Toro y sus Auxiliares (1888-1904)

2.2.2 Visita de Filemón Cabanillas a los curatos de nueva colonización 1900-1903

2.2.3 Visita de Filemón Cabanillas a los curatos de nueva colonización

2.2.3.1 Itinerarios de las Visitas del Obispo Toro y sus auxiliares

2.2.4 Obispo Zenón Bustos y Ferreyra: Visitas abiertas en los años 1905 y 1912

3. Lectura de conjunto de las visitas pastorales

CAPÍTULO 8: LA GEOGRAFÍA ECLESIÁSTICA DE CÓRDOBA

1. El territorio diocesano provincial a la luz de los informes de los párrocos de 1890 a 1893

2. La cuestión económica

3. La geografía eclesiástica a la luz de los informes y autos de las visitas canónicas (1905-1925)

3.1 Parroquias rurales de vieja colonización en el noroeste provincial

3.1.1 Congruidad y sustentabilidad económica

3.1.2 Consideraciones generales del obispo/visitador sobre la región del

Noroeste

3.2 Parroquias de colonización mixta ubicadas en el centro de la provincia

3.3 Parroquias de colonización inmigrante del sudeste provincial

3.3.1 Rentabilidad económica de los curatos de San Justo

3.3.2 Sustentabilidad económica

\section{CAPÍTULO 9: LA EXPANSIÓN PARROQUIAL COMO FENÓMENO}

DE TERRITORIALIZACIÓN

1. La parroquia como marco de referencia de la campaña

2. La expansión parroquial como fenómeno de territorialización 407

2.1 La recuperación de antiguos templos para el culto $\quad 420$

2.2 La construcción de nuevas iglesias 
3. Dificultades en el proceso de expansión parroquial 433

3.1 Territorios y jurisdicciones 433

3.2 Traslados de sedes $\quad 439$

3.3 Las propiedades eclesiásticas de cada curato 446

3.4 Conflictos en la administración y control de templos 447

CUARTA PARTE: EL CLERO SECULAR COMO GRUPO SOCIAL 463

CAPÍTULO 10: UN NUEVO MODELO DE CURA, DISTINTO PERO NO

DISTANTE DE LA FELIGRESÍA 464

1. El perfil del clero deseado $\quad 465$

1.1 El clero en la prensa local $\quad 467$

1.2 El clero parroquial en los escritos de los obispos 478

1.3 El clero según la feligresía $\quad 485$

2. La formación destinada a modelar el perfil de un clero romanizado 491

2.1 El seminario conciliar 491

2.2 El plan de estudios $\quad 496$

$\begin{array}{ll}2.3 \text { La biblioteca del seminario } & 501\end{array}$

3. Seminaristas que accedieron a órdenes: cuando la necesidad prima sobre el ideal 501

4. Formación permanente del clero 503

CAPÍTULO 11: LA COMPOSICIÓN DEL CLERO SECULAR 506

1. El clero existente en 1875

1.1 Distribución, funciones y cargos 507

1.2 Origen social 508

2. El clero propio nativos e inmigrantes (1875-1925) 510

2.1 Clero propio: cantidad 511

2.2 Carrera eclesiástica: nivel de perseverancia/deserciones 516

2.3 Características socio-culturales $\quad 519$

2.4 Grupos proveedores de vocaciones y zonas geográficas de proveniencia $\quad 520$

3. Familias proveedoras de vocaciones: el caso de los Ferreira 522

4. Miembros del clero capitular $\quad 524$ 
4. 1 El beneficio capitular 528

4.2 Clérigos que accedieron a la mitra episcopal 534

5. El clero parroquial 536

5.1 La provisión de curatos $\quad 536$

$5.2 \mathrm{El}$ clero diocesano parroquial de origen inmigrante 539

CAPÍTULO 12: CLERO SECULAR INMIGRANTE EXTRA DIOCESANO 545

1. Cantidad y tiempo de permanencia 546

2. Criollos e inmigrantes: su distribución en el espacio diocesano 552

3. Políticas de incorporación del clero inmigrante 557

4. Ocupación del clero inmigrante: relaciones sociales y meritocracia 567

5. ¿Cadenas migratorias clericales?

6. Movilidad del clero inmigrante 573

7. De capellanes a párrocos, una aspiración del clero inmigrante 575

8. ¿Capellanes con dependencia de párrocos o curas particulares? 579

9. Motivos para emigrar 587

10. Imágenes y representaciones 588

10.1"Ignorante, ocioso, jugador, avaro y mercader" 589

10.2 “Digno, celoso, prudente y de buen espíritu sacerdotal: merecedor en consecuencia de toda benevolencia y consideración” 591

QUINTA PARTE: LAS PRACTICAS 594

CAPITULO13: CLERO Y FELIGRESÍAS FRENTE AL AVANCE SECULARIZADOR DEL ESTADO 595

1. La actitud del clero parroquial frente a las políticas secularizadoras $\quad 600$

1.1 Registro Civil y secularización de los Cementerios 600

$\begin{array}{ll}\text { 1.2 Morir sacramentado } & 613\end{array}$

2. La ley de matrimonio civil $\quad 615$ 


\section{CAPÍTULO 14: EL LUGAR DEL CLERO PARROQUIAL:}

ENTRE LA SECULARIZACIÓN DE LA POLÍTICA Y LA SECULARIZACIÓN

$\begin{array}{ll}\text { DE LA SOCIEDAD } & 630\end{array}$

1. La política un campo de disputa. Obispos, clero parroquial y feligresías 630

1.1. Los curas y los procesos revolucionarios de la década de $1870 \quad 630$

1.2 El caso del cura Pablo Lynch 633

$\begin{array}{ll}1.3 \mathrm{El} \text { caso del cura Luis Tagle } & 638\end{array}$

2. El clero y la política en los albores del siglo XX (1880-1905) 642

3. El clero y la política y la norma vs la costumbre (1906-1925) 645

4. Secularización de la sociedad: el clero frente a librepensadores, socialistas, anarquistas y masones $\quad 661$

4.1 El socialismo y el anarquismo en el discurso eclesiástico 662

4.2 Las logias masónicas $\quad 666$

5. El clero frente a la celebración del XX de Septiembre 673

CAPÍTULO 15: LAS NUEVAS PRÁCTICAS PASTORALES, ESTRATEGIAS DE CRISTIANIZACIÓN DE LA VIDA MODERNA

Y DE MODERNIZACIÓN DE LA VIDA CRISTIANA 681

1. El poder pastoral: la parroquia como núcleo de la vida religiosa en la campaña $\quad 681$

2. La consolidación de un nuevo modelo de parroquia 685

3. La acción católica parroquial: reforzar la identidad católica y fomentar $\begin{array}{ll}\text { la militancia } & 689\end{array}$

3.1 La organización de la acción católica $\quad 694$

3.2 Las actividades parroquiales $\quad 696$

3.2.1 Los boletines $\quad 696$

3.2.2 La prensa católica en Marcos Juárez 701

3.2.2.1 "La Familia Cristiana” vs "La Patria degli Italiani” y

"La Vanguardia" 701

3.2.3 La acción religiosa $\quad 704$

3.2.4 La predicación $\quad 712$

$\begin{array}{ll}\text { 3.2.5 Enseñanza de la Doctrina Cristiana } & 714\end{array}$ 
3.2.6 El rol de las familias en la enseñanza del catecismo

3.2.7 La acción benéfica y asistencial

3.2.8 Acción social

4. El "Comitato Parrocchiale" de Sampacho

5. La parroquia como espacio de militancia católica: la UPCA

5.1 La Unión Popular Católica Argentina

5.2 Creación de la UPCA en Córdoba

CONCLUSIONES

FUENTES 


\section{INDICE DE MAPAS}

1. Provincia de Córdoba en 1867

2. Departamentos de la provincia de Córdoba en 1877

3. Departamentos de la provincia de Córdoba en 1887

4. Departamentos de la provincia de Córdoba en 1904-1925 199

5. La diócesis de Córdoba en $1877 \quad 216$

6. Curatos de la provincia de Córdoba en 1858-1869 233

7. División eclesiástica de la provincia de Córdoba en 1877296

8. Departamentos colonizadores 298

9. Visitas Canónicas de los Obispos Alvarez, Esquiú y Tissera, 1874-1886 316

10. Visitas Pastorales del Obispo Toro y sus auxiliares, 1888-1904 325

11. Visitas Pastorales realizadas por el Obispo Zenón Bustos 328

12. Curatos y capillas en la Provincia de Córdoba en 1893

13. Jerarquización económica de los curatos según entradas de fábrica, 1890-1893 347

14. División de la Provincia de Córdoba en Departamentos de Antigua Colonización y Colonizadores $\quad 350$

15. Parroquias del Departamento de San Justo en 1925

16. Parroquias de los Departamento de Tercero Abajo, Unión y Marcos Juárez en 1925

17. Parroquias de los Departamento del sur en 1925

18. Jerarquización económica de los curatos según rentas del beneficio, 1905-1910

19. Curatos de la provincia de Córdoba, 1875-1905-1925 409

20. Curatos de la provincia de Córdoba en 1904 
INDICE DE TABLAS

1. Departamentos de vieja colonización. Población 1879

2. Departamentos de vieja colonización. Población 1926206

3. Departamentos colonizadores. Población $1879 \quad 208$

4. Departamentos colonizadores. Población $1926 \quad 208$

5. Provisores que gobernaron la diócesis de Córdoba (1810-1858) 217

6. Fechas de inicio de libros parroquiales 222

7. Creación de departamentos y curatos 1858-1871 231

7. Ordenaciones del clero secular de Córdoba. 1859-1876 236

8. Confirmaciones en los curatos de vieja colonización. Obispos Álvarez y Esquiú 301

9. Gira Pastoral del Obispo Tissera, 1886

10. Confirmaciones en los curatos de nueva colonización. Obispos Álvarez y Esquiú

11. Territorialidad y religiosidad a través de los Informes parroquiales de 1890-1893 334

12. Arancel eclesiástico, $1891 \quad 340$

13. Aproximación económica de los curatos a través de los Informes de los párrocos de 1890-1893 343

14. Salarios mensuales y jornaleros extranjeros en la Provincia de Córdoba según Pelliza en 1888

15. Jerarquización económica de los curatos según entradas de fábrica 346

16. Renta del beneficio y fábrica del curato de Tulumba, quinquenio 1906-1910 358

17. Movimiento económico de Tulumba, 1906

18. Jerarquización económica de los curatos según rentas del beneficio, $\begin{array}{ll}1905-1910 & 398\end{array}$

19. Distribución regional del crecimiento parroquial 408

20. Evolución de templos, 1875-1925 414

21. Departamentos de vieja colonización. Población-Templos, 1879

22. Departamentos de vieja colonización. Población, 1926

23. Departamentos colonizadores. Población, $1879 \quad 418$

24. Departamentos colonizadores. Población-Templos, 1926 
25. Plan de Estudios del Seminario Conciliar, 1906

26. Distribución del clero secular. Córdoba, 1875

27. Ordenaciones presbiterales del clero secular de Córdoba, 1875-1925 511

28. Extranjeros ordenados y domiciliados en la diócesis. Córdoba, 1875-1925 512

29. Origen geográfico del clero ordenado en la diócesis de Córdoba, 1875-1925 514

30. Ordenaciones presbiterales del clero regular de Córdoba, 1875-1925 515

31. Tonsurados y órdenes menores en la diócesis de Córdoba, 1875-1925 518

32. Alumnos del Seminario diocesano. Tonsurados y primeras órdenes, $1875-1925$

33. Zonas geográficas de proveniencia de los ordenados en la diócesis de Córdoba, $1875-1925$

34. Presupuesto para el clero

35. Miembros del Cabildo Eclesiástico de Córdoba, 1875-1925

36. Presbíteros cordobeses que accedieron a la Mitra Episcopal

37. Clero extranjero oficialmente registrado entre 1875 y 1925

38. Clero secular extranjero que ejerció su ministerio en la diócesis de Córdoba entre 1875 y 1925 según regiones de origen de procedencia

39. Clero secular extra diocesano inmigrante que ejerció el ministerio parroquial en la diócesis de Córdoba entre 1875 y 1925

40. Salida de clero secular extra diocesano inmigrante que ejerció el ministerio parroquial en la diócesis de Córdoba entre 1875 y 1925

41. Arribos y Salidas del clero secular extra diocesano inmigrante que ejerció el ministerio parroquial en la diócesis de Córdoba entre 1875 y 1925

42. Clero extra diocesano inmigrante. Años de permanencia

43. Párrocos de los curatos del norte entre 1875 y 1925

44. Párrocos de los curatos del oeste entre 1875 y 1925

45. Párrocos de los curatos del centro entre 1875 y 1925

46. Párrocos de los curatos del sudeste entre 1875 y 1925

47. Matrimonio civil y religioso entre 1907 y 1910

48. Comuniones en Sampacho 728

49. Asociaciones parroquiales $\quad 729$ 
50. Asistencia al catecismo

51. Juntas parroquiales de la UPCA en Córdoba 


\section{INDICE DE GRAFICOS}

1. Población, 1879-1926 207

2. Población, 1879-1926. Departamentos de vieja colonización 207

3. Departamentos colonizadores. Población, 1879-1926 209

4. Visitas pastorales a la campaña cordobesa 299

5. Renta mensual del beneficio y la fábrica de los curatos del norte de la Provincia de Córdoba, 1906-1910 356

6. Renta mensual del beneficio y la fábrica de los curatos del oeste de la Provincia de Córdoba, 1906-1910

7. Renta mensual del beneficio y la fábrica en los curatos del este, departamento de San Justo, 1906-1910

8. Renta mensual del beneficio y la fábrica en los curatos de Tercero Abajo, 1906-1909

9. Renta mensual del beneficio y la fábrica en los curatos del este, 1906-1909 388

10. Renta mensual del beneficio y la fábrica en los curatos del sur, 1906-1909 392

11. Evolución de curatos, 1875-1925

12. Evolución de capillas, 1875-1925 415

13. Número de habitantes por templo 418

14. Número de habitantes por templo 419

15. Evolución de parroquias por regiones, 1875-1925 420

16. Evolución de capillas por regiones, 1875-1925 420

17. Ordenaciones presbiterales del clero secular diocesano. Córdoba, 1875-1925 512

18. Ordenaciones presbiterales según nacionalidad, 1875-1925 513

19. Alumnos del Seminario Conciliar. Tonsurados y primeras órdenes según Nacionalidad $\quad 519$

20. Clero inmigrante. Años de permanencia 551

21. Años de permanencia de clero extranjero por quinquenio 552

22. Departamentos del noroeste. Matrimonios, 1907-1910 626

23. Departamentos del sudeste. Matrimonios, 1907-1910 628

24. Comuniones en Sampacho 728

25. Participación en asociaciones parroquiales 730 
ANEXOS

ANEXO I: CARTOGRAFÍA

1. Mapa de Córdoba de 1871 - Curatos y Capillas (1875)

2. Mapa de Córdoba de 1905 - Curatos y Capillas (1905)

3. Mapa de Córdoba de 1924 - Parroquias y Capillas (1925)

ANEXO II: TABLAS

Tabla 1. Ordenaciones presbiterales, 1859-1875

Tabla 2. Clérigos seculares diocesanos que no alcanzaron el presbiterado, 1875-1925

Tabla 3. Visitas Pastorales en la Provincia de Córdoba: Obispos Álvarez, Esquiú y Tissera

Tabla 4. Visitas Pastorales en la Provincia de Córdoba: Obispo Toro y auxiliares

Tabla 5. Visitas Pastorales en la Provincia de Córdoba: Obispo Bustos y auxiliares

Tabla 6. Arancel eclesiástico 1907

Tabla 7. Rentas del beneficio y la fábrica de los curatos de la Provincia de Córdoba, 19061910

Tabla 8. Expansión parroquial en la campaña cordobesa, 1875-1904

Tabla 9. Expansión parroquial en la campaña cordobesa, 1905-1925

Tabla 10a. Iglesias, capillas y oratorios en la campaña de Córdoba, 1875

Tabla 10b. Iglesias parroquiales y capillas filiales de la campaña cordobesa en 1905

Tabla 10c. Iglesias parroquiales y capillas filiales de la campaña cordobesa en 1925

Tabla 11. Distribución del clero. Córdoba, 1875

Tabla 12. Ordenaciones presbiterales del clero diocesano secular o "clero propio", 18751925

Tabla 13. Clero regular secularizado en la diócesis de Córdoba, 1875-1925

Tabla 14. Ordenaciones presbiterales del clero regular en Córdoba 1875-1925

Tabla 15. Carreras personales de los capitulares, 1875-1925

Tabla 16. Familias proveedoras de vocaciones. Los Ferreira

Tabla 17. Clero extra diocesano inmigrante, 1875-1925 


\section{ANEXO III}

1. Cuestionarios de las Visitas Pastorales 1906-1917-1924

\section{ANEXO IV}

1. Plano Río de los Sauces 1905

2. Plano Río de los Sauces 1925

3. Caricaturas: curas en elecciones

4. Foto de segadora (1910)

5. Foto fiesta del XX de Septiembre

6. Entierro en Pozo del Molle (1923)

7. Foto Misiones rurales, 1890

8. Foto Misiones rurales, 1918

9. Procesión en Sacanta

10. Procesión en Reducción (1899)

11. Procesión en Inriville (1929)

12. Procesión Colonia Vignaud

13. Procesión La Playosa

14. Templo La Playosa (actual) 


\section{Dedicatoria}

A Mariquita, mi madre, quien desde el cielo me guía y acompaña en la senda del perfeccionamiento humano y profesional.

A Juan Luis, mi padre, quien con su ejemplo de vida me transmite la ilusión por el trabajo intelectual y la pasión por la verdad.

A Carlos Ibarguren, mi abuelo, quien me inició, desde niña, durante los veranos que pasábamos juntos en el campo, en el gusto por la lectura y la historia.

A Guillermo Gallardo, mi tío abuelo, con quien, siendo director del Archivo Histórico Nacional, compartimos horas de conversación entre documentos, fichas y borradores de investigación.

A mis hermanos y amigos, que hicieron posible, con su apoyo, paciencia y comprensión, que esta tesis llegara a buen puerto. 


\section{AGRADECIMIENTOS}

Esta tesis es resultado de diez años de investigación, fruto del trabajo y el esfuerzo personal, así como de la ayuda recibida por personas e instituciones que durante estos años me apoyaron e hicieron posible la realización dela misma. Las circunstancias de mi vida me llevaron a iniciar tardíamente el camino de la investigación histórica, la cual inicié haciéndola compatible con un trabajo que permitiera mantenerme económicamente. Por lo tanto, robando horas al día y a las noches fui avanzando en esta ardua tarea de creación intelectual.

Agradezco profundamente a mi directora de tesis, Dra. Andrea Reguera, y al Centro de Estudios Sociales de América Latina -CESAL-, el centro de investigación que dirige, donde actualmente trabajo. La incorporación al CESAL y la participación en los diversos proyectos de investigación y transferencia, por ella impulsados, hicieron posible la asistencia a congresos y varias estancias de investigación académica en el exterior, entre las que cabe mencionar, la Universidade do Vale do Rio dos Sinos -UNISINOS- (Brasil), gracias al Proyecto CAPG-BA, "Estudios de historia comparada Brasil-Argentina", en los años 2010, 2011 y 2013, financiado por la Secretaría de Políticas Universitarias/Ministerio de Educación (Argentina);en la École des Hautes Études en Sciences Sociales-EHESS- / Centre de Recherche Historique -CRH- (París-Francia), en 2013, que me permitió asistir a seminarios y consultar bibliografía en la Biblioteca de la Maison des Sciences de 1'Homme -MSH- y de la EHESS sobre el tema de mi investigación; y, por último, en el Consejo Superior de Investigaciones Científicas -CSIC/Madrid- Instituto de Historia (MadridEspaña), en 2015. En Andrea encontré una directora comprometida y apasionada por su trabajo, siempre dispuesta a la consulta y abierta a la discusión. Sus planteos y preguntas supusieron un desafío para repensar problemas y cuestiones teórico-metodológicas, su profunda inteligencia y aguda mirada acompañaron, casi cotidianamente, mis pasos en la elaboración de esta tesis. Sin su apoyo no hubiera sido posible culminar con éxito este trabajo. Quien además, como amiga, también supo sostenerme cuando flaqueaba y darme ánimo cuando vacilaba.

También extiendo mi agradecimiento al Dr. Fernando Barba y en su nombre a todo el Doctorado de la UNLP, Universidad estrechamente vinculada a mi familia materna, en la cual varios de sus miembros han ejercido la docencia durante años. Gracias por haberme aceptado para cursar el doctorado en tan reconocida institución, de extensa y fructífera trayectoria. Agradezco también al Dr. Guillermo Banzato por aceptar la co-dirección de esta tesis ante la Comisión del Doctorado. 
En este agradecimiento, quiero incluir a Rosario García O’Neil y a su tío, Borja Medina (SJ), historiador, profesor e investigador emérito de la Universidad Gregoriana de Roma, quien me facilitó la consulta de los Archivos Secretos Vaticanos.

Mi agradecimiento a la Dra. Beatriz Moreyra, quien me acompañó durante los primeros años, abriéndome un espacio en su grupo de investigación, y gracias a la financiación de proyectos dirigidos por ella, de los cuales formaba parte, recibí una ayuda económica que me permitió solventar parte de una estancia de investigación en Roma. Agradezco también al Centro Estudios Históricos "Prof. Carlos S. A. Segreti", y a todos sus miembros, en el cual comencé a desarrollar mi labor como investigadora en formación.

No quiero dejar de mencionar la generosidad de los profesores que me acompañaron y facilitaron el camino en estos años. Al Dr. Dominque Iogna-Prat, Directeur d'Études de l'EHESS y Directeur de Recherche del Centre National de la Recherche Scientifique CNRS- (París-Francia), quien con sus comentarios y recomendaciones bibliográficas me ayudó a pensar metodológicamente algunos problemas de la historia religiosa. Al Dr. Maurice Aymard, Directeur d'Études de l'EHESS y de la MSH, y a la Dra. Elda González, Directora de Estudios Iberoamericanos del Instituto de Historia del CSIC/Madrid, quienes tuvieron la gentileza de cursar una invitación para desarrollar una estancia de investigación en sus respectivas instituciones. A quienes dedicaron tiempo a la lectura de mis trabajos en congresos y jornadas, por los comentarios y sugerencias recibidos, gracias Dr. Michel Bertrand de la Universidad de Toulouse (Francia)y Dr. Luiz Fernando Medeiros Rodrigues, Dra. Eliane Deckmann Fleck yDr. Martin Dreherde UNISINOS (Brasil).

También va un especial agradecimiento a todos aquellos colegas que se han interesado por mis trabajos, y se han tomado el trabajo de leerlos, comentarlos y presentarme sugerencias para mejorarlos, sus miradas críticas y siempre constructivas me permitieron repensar temas, enfoques y abordajes.

Quiero agradecer al personal de los Archivos consultados, por su dedicación y por facilitarme con una sonrisa e infinita paciencia todos los documentos que solicitaba: a María Celina Audisio, directora del Archivo del Arzobispado de Córdoba; a Daniel y Marcela, siempre incondicionales. A Inés Farías, directora del Archivo Histórico Franciscano de Río Cuarto -Fray José Luis Padrós; a la Lic. Gabriela Parra Garzón, directora del Archivo Histórico de la Provincia de Córdoba; y un recuerdo especial para NicolásMoretti, quien me facilitó la consulta de los Archivos Salesianosde la Casa Inspectorial y del Archivo del Colegio Pío Xde Córdoba.

A todos los miembros del CESAL, mi lugar de trabajo, en particular a Graciela Nogar, vicedirectora del CESAL, y Guillermina Jacinto, miembro del Consejo Directivo del centro, quienes con su apoyo y comprensión hacen que ir a trabajar cada día sea muy agradable. También a todo los integrantes, en particular a Leonardo Canciani, Josefina 
Irurzun, Julián Arroyo, Guillermo Campos, Damián Decarli y Leandro Di Gresia,quienes, por su dedicación al trabajo, su seriedad académica y su calidez humana hacen posible un espacio de trabajo, intercambio y convivencia que nos ayuda a crecer y mejorar a todos y cada uno.

Por último, aunque primera en la intención, quiero agradecer a mi familia nuclear y ampliada. Por su apoyo en los momentos de desánimo y oscuridad, por su confianza y su cariño, sin ellos hubiera sido muy difícil llegar al término de este camino y comenzar la andadura de una nueva etapa. A mis amigos, que me animaron a seguir adelante pese a las dificultades, a Miguel y Angélica, que me abrieron las puertas de su casa en Tandil, donde paso muchas horas al día. 


\section{INTRODUCCIÓN}

El trabajo que aquí presentamos es el resultado de más de diez años de consulta en archivos eclesiásticos y estatales. La idea surgió cuando comencé a trabajar en un equipo dirigido por Beatriz Moreyra, quien pensaba en el problema de la modernización en la provincia de Córdoba, sus alcances, desajustes y limitaciones. En el grupo estaba quien miraba el Estado y sus políticas públicas, quien analizaba el fenómeno desde abajo, buscando a los que sufrieron el impacto negativo del progreso y el desarrollo, "los pobres", y también quien abordaba a los intelectuales que pensaron la modernización y la cuestión social. Yo me sumé al equipo a fin de analizar el rol de la iglesia en ese complejo proceso de trasformación social, política y económica.

La primera inquietud fue acercarme a la problemática de la Iglesia y la cuestión social. Al introducirme en el tema, advertí su complejidad y la dificultad para resolver qué significaba la Iglesia. A quién iba a estudiar, ¿a los obispos? ¿A los políticos y legisladores católicos? ¿A las asociaciones católicas? ¿A las órdenes y congregaciones? ¿Al clero regular y secular? A poco de andar, percibí que el motor de la acción católica durante el período de estudio tenía nombre y apellido, el clero secular. A partir de ese momento, la investigación dio un giro hacia ese actor social, un grupo concreto, definido y de particular importancia en la sociedad cordobesa.

La imagen predominante en la historiografía es la de un grupo hegemónico, homogéneo y combativo, que implementó una tenaz "resistencia", practicada con singular decisión, a

fin obstruir el avance liberal (Roitenburd, 2000; Vidal, 2000; Moyano, 2008). A su vez, la historiografía confesional muestra la existencia de un clero monolítico, un cuerpo colegiado que actuó en defensa de los intereses de la Iglesia católica contra los errores del liberalismo, presentando una versión triunfalista de la Iglesia cordobesa frente al avance liberal (Bruno, 1981). Al analizar la dinámica de los comportamientos y su estructura social y relacional, vi que, al contrario de lo que se sostenía, era un grupo diverso, heterogéneo y muy involucrado en la esfera pública provincial. Con posturas que iban de la intransigencia al diálogo con la modernidad liberal. Se trataba de un actor que era a la vez agente y promotor de importantes cambios que se produjeron en la iglesia y en la sociedad del período. Era, además, un universo abarcable como objeto de estudio y que me serviría como lente para 
analizar los cambios sociales y los procesos estructurales que vivió la provincia en su camino hacia la modernización. Cambios que se expresaban mediante dos procesos que eran el anverso y el reverso de una misma moneda, la modernización: se trataba de la consolidación del estado provincial-con la consecuente secularización y laicidad-, y la institucionalización de la iglesia diocesana en clave romanizada.

La Iglesia ha sido interpretada como un obstáculo estructural para el advenimiento de las relaciones sociales y las instituciones modernas. La tendencia general ha sido considerar al catolicismo del siglo XIX y comienzos del XX como una historia de fracasos y crisis, producto de la fuerza reaccionaria del catolicismo y de la fuerza ineludible de la modernidad hacia el progreso (Blackbourn, 1991). Una mirada más cuidadosa del proceso de institucionalización, me permitió observar, a distintos niveles de escala, la capacidad que demostró la institución católica para sobrevivir y mantenerse influyente en la vida social. Siguiendo el planteamiento de Hervieu-Léger (2005),percibí que la modernidad y la religión no son excluyentes una respecto de la otra y, por lo tanto, en la modernidad, la religión y la tradición tienen un rol que la autora denomina "potencial creativo de la tradición". Sin erradicar la identificación de la religión con el universo de la tradición, ésta no fue excluida del universo de la modernidad.La religión no se vuelve socialmente irrelevante en la modernidad, sino que encuentra nuevas significaciones sociales que pueden ser comprendidas mediante el estudio de casos particulares.

La Iglesia no fue ajena al proceso modernizador que impulsó la elite liberal cordobesa. Al decir de Marie-Danielle Demélas e Yves Saint-Geours (1988: 164)para Ecuador, la Iglesia articuló grupos sociales opuestos, palió las flaquezas de una administración ineficaz y educó a una población muy poco alfabetizada desde la caída de las estructuras coloniales. Si bien perdió la batalla por mantenerse como religión de Estado, y el control de los registros de los momentos más importantes de la vida del ciudadano (nacimiento, matrimonio y muerte),logró, sin embargo, cimentar una nueva inserción en una sociedad más permeada por la diversidad cultural y religiosa.

Como diría Sol Serrano (2008), no cabe duda de que es un período en que el estado se seculariza, la sociedad se hace más plural y la cristianización se expande.Esta afirmación, a simple vista, podría parecer contradictoria, pues ¿es posible el avance del cristianismo en un país cuyo estado se seculariza y la sociedad comienza a experimentar el pluralismo 
religioso y social? Si a la religión se la asocia con la tradición (Hervieu-Léger, 2005) y a la secularización y el pluralismo con la modernidad, ¿cómo se dio la relación entre la religión y la modernidad provincial?

Para resolver esta cuestión, leía varios autores. Jacques Le Goff (1995: 165), remitiendo al filósofo de la modernidad Henri Lefebvre, señala un dato interesante y es la distinción entre modernidad y modernismo. La modernidad, dice, difiere del modernismo como un concepto en vías de formulación. La primera tendencia -certeza y arrogancia-corresponde al Modernismo; la segunda -interrogación y reflexión crítica- a la modernidad. Estos son dos inseparables aspectos del mundo moderno. La modernidad se vuelve hacia lo no cumplido, lo esbozado.Siguiendo el razonamiento del autor, la modernidad es el resultado ideológico del modernismo. Pero-ideología de lo no cumplido, de la duda, de la crítica- la modernidad también es impulso hacia la creación, en una ruptura explícita con todas las ideologías y la teorías de la imitación.

Con la intrusión a la modernidad en el tercer mundo, sigue diciendo el autor, el criterio económico se vuelve primordial: en el conjunto de la economía moderna, la piedra de toque de la modernidad es la mecanización, más aún, la industrialización. Un signo de la modernidad será la racionalización de la producción. La economía de lo moderno se relaciona no ya con el progreso en general sino con el desarrollo o, en un sentido más estricto, de acuerdo con algunos economistas liberales, con el crecimiento. En economía, el proceso de secularización significa, ante todo, la diferenciación de las instituciones específicamente económicas, con la incorporación de la racionalidad instrumental como principio fundamental de la acción.

En Córdoba, el desarrollo económico y el progreso no se dieron al margen de la religión. Córdoba experimentó una modernidad que mantuvo a la religión como un elemento constitutivo del orden social, por lo tanto, podría hablarse de una modernidad católica, donde, como sostiene Michel Lagrée para Bretaña, una región católica por excelencia, donde la iglesia y la religión tuvieron un rol activo en el proceso de trasformación social. El proyecto de transformación institucional de la Iglesia católica de Córdoba confraternizó con el proyecto de construcción del Estado, que buscó la manera de articular religión (sociedad eminentemente católica), modernismo (progreso, desarrollo y crecimiento económico) y modernidad (proyecto futuro fundado en la ciencia y la técnica). 
El período abordado en esta tesis es un período de transición, 1875-1925. Todos sabemos que en historia no hay nacimientos ni ocasos absolutos. El devenir histórico es un juego incesante de innovaciones y permanencias, en el que ningún cambio, por súbito y profundo que sea, supondría un corte tan radical como para que lo nuevo y lo viejo no se solapen de algún modo (Guerra, 2000). Precisamente por eso, el concepto historiográfico de transición sirve para dar cuenta de este tipo de situaciones. Desde este punto de vista, toda transición puede ser contemplada como una solución de continuidad entre el eclipse de un viejo estado de cosas declinantes y el surgimiento de un nuevo orden ascendente. Si entendemos la transición como un conjunto de pequeñas transformaciones encadenadas de las que emerge finalmente un orden político o social muy diferente del anterior, no cabe duda que el período analizado en nuestro trabajo es una transición que conlleva, como señalamos ut supra, dos importantes procesos: la organización de un Estado Nacional y la consolidación de una Iglesia Argentina. Ambos procesos implican la transición de una sociedad de tipo tradicional a una sociedad en vías de modernización, de un sistema de cristiandad a una sociedad pluralista y secular, de iglesias locales a una Iglesia Romanizada, de un catolicismo urbano y más bien ilustrado a un catolicismo rural y más popular.

Todavía no hay acuerdo respecto al momento en que la Iglesia católica se convierte en un actor político y social central de la historia argentina. Susana Bianchi (1997: 19) sostiene que la Iglesia argentina comienza a cobrar importancia institucional recién en la década de 1930. Para Roberto Di Stéfano y Loris Zanatta (2000: 312), hasta el año 1899, la Iglesia era una institución incapaz de seguir el paso de las transformaciones del país, pues carecía de la articulación jerárquica imprescindible para gestionar la vida católica, garantizar la disciplina y la sólida formación del clero, atraer nuevas vocaciones, asegurar la administración de los sacramentos, la ortodoxia de las devociones y el respeto a la moral católica. La historiografía a nivel nacional coincide en presentar una imagen de debilitamiento y crisis de la Iglesia en el tercer cuarto del siglo XIX, cuyas principales manifestaciones estarían dadas por la presencia de diócesis excesivamente extensas, con frecuentes sedes vacantes, escasez de curas para servir en las parroquias de campaña, el debilitamiento de la disciplina eclesiástica y la indiferencia religiosa por parte de la población. 
En este sentido, para la Iglesia diocesana cordobesa, el sínodo de 1877 significa un hito importante en el proceso de consolidación, fue de suma importancia pues se celebró luego de 160 años sin que se realizara esta práctica $^{1}$ (Dellaferrera, 1997). La asamblea fijó las estrategias institucionales para reestablecer la disciplina eclesiástica, proveer el mejor gobierno de la diócesis y reformar las costumbres. ${ }^{2}$ Este sínodo hizo suyos los lineamientos propuestos por el Concilio Vaticano I celebrado en Roma en 1870.

En términos políticos, el año 1877 también fue bastante significativo para la provincia, pues llegó al poder el grupo liberal autonomista, ligado al gobernador Antonio del Viso (1877-1880), lo que significó un cambio ideológico en la vida local, después de diez años de dominio del Partido Nacionalista, ligado a la figura de Bartolomé Mitre. Este cambio representó el inicio de un largo control político ejercido por una fracción de la clase dominante, vinculada al Partido Autonomista Nacional, cuya figura central era el General Julio A. Roca, quien dominó la escena política tanto nacional como cordobesa desde 1880 hasta la reforma del sistema electoral en 1912.Lainvestigación finaliza en 1925, año de la muerte del Obispo Zenón Bustos, que marca el fin de una etapa y el inicio de una nueva gestión episcopal, en la que Monseñor Fermín Emilio Lafitte, nacido en Francia y formado en Buenos Aires, asumió el gobierno de la diócesis en 1927. Pocos años más tarde, en 1934, Córdoba fue elevada al rango de arquidiócesis. Este hecho puso de manifiesto la madurez de la Iglesia cordobesa, la finalización del proceso de consolidación eclesiástica diocesana y el indicio de lo que Loris Zanatta (1996) denomina “el mito de la Nación Católica".

En cuanto a la delimitación espacial, tomé la campaña cordobesa por entender que es allí donde se pueden ver mejor las relaciones sociales entre clero, feligresías y autoridades civiles; los cambios y las permanencias en los vínculos entre curas y comunidades; las diversas formas de intervención del clero en la vida social y la manera en que las feligresías conciben el ministerio pastoral.

\footnotetext{
${ }^{1}$ Pedro Miguel de Argandoña convoca el sínodo diocesano de 1752. Si bien sus textos se perdieron, se conservan las "Reglas directivas y doctrinales que se han de observar en el Colegio Real y Seminario Nuestra Señora de Loreto y Santo Tomás de Aquino". Estas Reglas estuvieron vigentes hasta 1865, año en que se reorganizó el seminario que había sido cerrado durante el período rosista.

${ }^{2}$ Archivo del Arzobispado de Córdoba (en adelante: AAC), Actas de las sesiones del Sinodo diocesano de 1877, f. 499.
} 
Abordé dos mundos diferentes, que aunque se dan la espalda, conviven en el mismo tiempo y en espacios geográficos muy próximos entre sí, el noroeste, por un lado, y el sudeste, por el otro. Ambos poseen características peculiares en función del espacio geográfico, las actividades económicas, la distribución y composición de la población. El noroeste, serrano y montañoso, posee una actividad económica y social de tipo tradicional, con una población mayoritariamente criolla, que se mantuvo anclado en actitudes y comportamientos atávicos. El sudeste, pampeano y cerealero, presenta las localidades con mayor dinamismo económico y social y una población que contenía un alto porcentaje de inmigrantes.

El trabajo que presento aquí tiende a mostrar cómo una institución -la Iglesia Católicainfluye en la formación política y social provincial y, sabiéndose portadora de una experiencia que trasciende las fronteras de una cultura nacional, se instituye como reproductora de valores universales, instaurando un programa cultural específico que aspira, entre otras cosas, a la consolidación de un sistema cultural y social de matriz católica. En este contexto, el clero parroquial de campaña fue el eje y la bisagra sobre el cual la Iglesia reorganizó sus vínculos con la sociedad. La comunidad parroquial se convirtió en el medio para reunir, instruir, formar y organizar a los católicos, implementar nuevas formas de culto, resignificar antiguas devociones, promover nuevas iniciativas sociales, procurando cristianizar diversas formas culturales de la vida social. Dirigir, orientar y controlar la acción y el comportamiento del clero fue una estrategia implementada por la jerarquía eclesiástica para llegar a la pastoral de multitudes y a lo que algunos autores denominaron el mito de la nación católica (Zanatta, 1996).

Para logarlo era necesario organizar una institución que había sufrido los vaivenes de la anarquía y las guerras civiles, la sede-vacancia de la silla episcopal y la escasez de su clero. Este proceso de institucionalización será analizado en tres tiempos: 1) la fragilidad (18751888); 2) el fortalecimiento (1889-1904); y 3) la consolidación (1905-1925). En el transcurso de la investigación, vi la necesidad de introducir, a modo de antecedente y de referencia, un período que escapa a nuestro análisis (1859-1874), al cual es necesario referirnos por considerarlo el comienzo del proceso en cuestión y que fue sin duda el inicio del cambio. 
Las características centrales de este proceso de reforma y evangelización renovada fueron: a) la profesionalización del clero, un intento de crear un cliché, una matriz de formación a través del seminario, con la intención de lograr un clero más uniforme. Una de las consecuencias de este proceso fue la separación del clero del resto de la sociedad. Se aspiraba a un clero distinto, aunque no distante de la sociedad; b) la decisión de "conversión" de la sociedad, hacia adentro y hacia afuera del pueblo cristiano, un intento de resignificar la cristiandad medieval, mitificándola en lo que se denominó "la nueva cristiandad", cuyo objetivo central era llegar a una pastoral de multitudes; c) la construcción de un modelo de Iglesia alineada con Roma, que reconocía en la figura del Papa la autoridad máxima y su fuente de legitimidad frente al estado liberal. El poder cada vez más centralizado del obispo y el paulatino proceso de clericalización, en el que la figura del párroco comienza a tener mayor centralidad en la conducción de la grey católica.

La iglesia encuentra dos grandes desafíos que resolver. El primero tiene que ver con redefinir sus relaciones con el estado. Un estado que también se está consolidando y que necesita precisar sus espacios de competencia, un estado que se seculariza y que busca poner a la Iglesia en otro lugar. Esta situación puso a la iglesia en riesgo frente al espacio público estatal. La Iglesia se vio en riesgo, porque se pasó de un sistema social, en el cual la composición social formaba la iglesia, es decir Iglesia y composición social estaban íntimamente ligadas, a otra instancia, a partir de la segunda mitad de la década de 1870,en la que el Estado asume funciones que eran antes propiamente eclesiásticas. El control que tenía la iglesia antes pasa al estado, que comienza a ejercer el control social antes en manos de la iglesia. En esta batalla por definir los espacios de competencia, el estado triunfa. La sanción e implementación de las leyes laicas: el registro civil, la secularización de los cementerios, el matrimonio civil, la secularización de la universidad, garantizan al estado el control sobre los ciudadanos que otrora tenía la Iglesia. La iglesia cede al estado no sin resistencia esos instrumentos de control. El segundo desafío está orientado a consolidar su relación con la sociedad y hace referencia a esa -decisión de "conversión", hacia adentro y hacia afuera del pueblo cristiano antes, es el desafío de consolidar lo que se llamó "una nueva cristiandad". Para analizar esta cuestión era necesario abordar el problema de la formación de la comunidad, para ello me remití a los sociólogos de la corriente alemana Max Weber y Georg Simmel que son profundos pensadores de la comunidad. Me detuve a 
pensar dos cuestiones: la primera, es la relación entre comunidad y territorio; y la segunda, el territorio como espacio de proyección de la institución. Si la Iglesia se proponía cristianizar cada comunidad debía garantizar su presencia en ella. Esta nueva cristiandad suponía garantizar una presencia real y efectiva de la Iglesia en el territorio y lograr la adecuación de las conductas de los feligreses a los principios morales y creencias católicas. Para lograr esa presencia, primero había que ocupar el territorio, un medio para lograrlo era impulsar la construcción de templos en cada comunidad cristiana. El objetivo era la existencia de un templo cada tres o cuatro leguas, a fin garantizar una presencia real. Más el templo era necesario pero no era suficiente, ya que se trataba de una ocupación estática, por ello el clero se propuso no sólo atraer a los fieles al templo, sino también salir del templo para estar presente en todo el espacio social, plazas, calles, campos, etc.. Para lograrlo, se promovieron procesiones, peregrinaciones $y$, en general, fiestas religiosas que convocaban a feligreses de otros parajes y regiones. Se trató de una estrategia destinada a la ocupación simbólica del espacio. De esta manera, el espacio religioso se convierte en un espacio que trasciende las fronteras locales para ejercer una influencia a nivel regional. El clero impulsó lo que Philippe Boutry denominó una "Teología de la visibilidad”.

El trabajo que presento analiza justamente cómo se desarrolló este proceso y la clave para comprenderlo es, a mi parecer, una institución y su personal. Esta institución es la parroquia, y su personal es, primordialmente, el clero secular. La parroquia se constituye en el gozne sobre el cual se apoya todo el movimiento reformador. Analizar la parroquia es analizar la reforma "al ras del suelo". Haciendo uso del juego de escalas, es elegir una escala de observación que permita acceder a la experiencia de los propios actores, ir de arriba hacia abajo y de abajo hacia arriba, de las normas y modelos a las prácticas y experiencias.

Cuando Joseph Morsel señala que la relación entre cambio social y cambio espacial es compleja, y establece la idea de una traducción espacial de los fenómenos sociales, advierte que para comprender la espacialización social es necesario considerar el hecho de que cada sociedad produce su propio espacio, o sea, cualquier sistema social es, por sí mismo, un sistema espacial, en consecuencia, no hay cambio social que no esté acompañado por un nuevo dimensionamiento del espacio. En el proceso de formación de aldeas y villas, hasta mediados del siglo XIX, hay una convergencia entre pertenencia comunitaria y parroquial. 
A partir de entonces, la historiografía marca el declive de la parroquia como eje vertebrador del espacio social. Al analizar la estructuración, restructuración y expansión del tejido parroquial, en la segunda mitad del siglo XIX, descubrí que la parroquia adquiere un nuevo rol, vinculado a una pertenencia identitaria. En el dimensionamiento del espacio, sobre todo en el sudeste cordobés, el templo parroquial no deja de ocupar un lugar central alrededor del cual se establecen nuevos pobladores. La Iglesia, edificio, se impone en el paisaje y busca convertirse en el lugar de congregación y de control de los hombres. La densificación de la red parroquial, la residencia habitual del cura en el lugar, las periódicas visitas pastorales permitieron el afianzamiento y la presencia de la iglesia diocesana en las nuevas regiones incorporadas al proceso productivo una vez finalizada la expedición al desierto. La Iglesia se proyecta sobre el espacio y busca hacer más visible su poder. Siguiendo el planteo de un antropólogo colombiano (Zuleta Ruiz, 2013: 35-40), tomé tres criterios para analizar la parroquia y su personal -párrocos, ayudantes y capellanes-, en la campaña cordobesa de entre siglos:

a) El proceso de fijación de las creencias en el espacio.

b) Las estrategias utilizadas para la trasferencia de creencias, conocimientos y valores, es decir, el modo en que los ministros de la Iglesia implementaron y ejecutaron acciones destinadas a lograr la religión práctica de los creyentes y un mayor compromiso social y religioso para enfrentar los peligros de los "enemigos de la religión". En otras palabras, analizar el ejercicio del poder pastoral sobre las comunidades encomendadas.

Para poder llevar adelante ese ambicioso plan reformador, la jerarquía necesitaba contar con agentes capacitados, es decir un clero acorde a las nuevas necesidades, un clero "nuevo". Para ellos era imperioso modelar, depurar conductas y orientar la formación hacia los objetivos propuestos. Por ello, el corpus central de este trabajo, que se vincula a la historia social del clero, siguiendo los derroteros de la renovación, se basa no sólo en el estudio de las grandes estructuras objetivas (Iglesia y Estado) sino también, y fundamentalmente, en las conexiones entre las transformaciones (ideológicas, políticas, económicas, sociales y culturales) y las experiencias de clérigos y feligreses, condicionadas por sus diferentes entornos.

En orden a estas cuestiones, a continuación presento las hipótesis de las cuales partí y guiaron mi investigación. 


\section{HIPÓTESIS DE TRABAJO}

I- Para fortalecer la cohesión de la Iglesia ante los estados seculares, el papado inició un proceso orientado a hacer pasar a América del catolicismo colonial al catolicismo universal de Roma. La Diócesis de Córdoba fue clave en la expansión y consolidación de dicho proceso en Argentina. Este coadyuvó a la evolución y consolidación de la institución eclesiástica diocesana, que redefinió las características de su autoridad, sus reglas de funcionamiento interno, sus normas de comportamiento, valores y representaciones, y también reformuló sus relaciones con la Santa Sede, el Estado y la sociedad.

II.- En el contexto de modernización social, desarrollo económico y laicidad estatal, la Iglesia cordobesa, coaccionada por la amenaza de perder su hegemonía religiosa, ideológica y cultural, pasa a un primer plano y, en la pugna entre las nuevas fuerzas sociales y políticas, logra trascender y reasumir su rol de árbitro y la dirección moral y religiosa de la nueva sociedad que emerge. Esta trascendencia se debió, en gran medida, al modo específico de ejercer el gobierno y la dirección de las almas, pues en el aparente continuismo institucional, desplegó capacidad inventiva, generó múltiples cambios y reacomodos, entre los que destaca la resignificación de la parroquia y la figura del párroco en su rol de pastor de almas. Es en el gobierno de las parroquias donde se plantea el reconocimiento de los curas como pastores, pues cada comunidades la que permite, apoya y cuestiona las formas pastorales de gobierno. Por lo tanto, la parroquia, inserta en la comunidad, es el espacio pastoral que une estrechamente el poder pastoral y la organización institucional eclesiástica.

III- La religión también tiene su dimensión material y el territorio es el espacio de encuentro entre la religión y la sociedad. El impacto de la religión sobre el territorio se expresa en los lugares de culto, pues estos son indicadores de una pertenencia religiosa visible en el espacio. De esta manera, la distribución en el territorio provincial de iglesias, capillas y oratorios da cuenta de la configuración territorial y social de la iglesia diocesana de Córdoba y el modo en que la iglesia, una entidad espiritual, se configura también como entidad territorial y social. El resultado de este proceso fue la paulatina consolidación de comunidades cristianas en el nuevo espacio territorial provincial del sudeste y la 
reafirmación y reorganización de las antiguas comunidades de fieles en el noroeste. Este proceso remite a un estrecho vínculo entre la institución y la sociedad y pone en evidencia solidaridades, conflictos e intereses al interior de la iglesia, y también hacia afuera, con "los otros", librepensadores, masones, socialistas y anarquistas.

IV-La paulatina secularización implicó un reacomodamiento de la religión y, por ende, del lugar asignado al clero. Esto, sin embargo, no significó la pérdida de su influencia en la sociedad, pero sí su recomposición. Si los grupos se definen por sus propiedades relacionales, por sus imágenes recíprocas y por su capacidad de imponer una imagen de sí mismos a los otros, entendemos que el clero secular se constituyó en un actor clave en el complejo proceso de modernización económica y social que experimentó la sociedad cordobesa del período de entre siglos. El clero parroquial de campaña constituyó una pieza central, fue el eje sobre el cual la Iglesia reorganizó sus vínculos con la sociedad. Desempeñó un rol de primordial importancia, su poder pastoral se convirtió en una estrategia implementada por la jerarquía eclesiástica para llegar a la pastoral de multitudes. La figura del pastor de almas adquiere centralidad, dado que la comunidad parroquial se convirtió en el medio para reunir, instruir, formar y organizar a los católicos, implementar nuevas formas de culto, resignificar antiguas devociones, promover nuevas iniciativas sociales y procurar cristianizar diversas formas culturales de la vida social.

V-La Iglesia de Córdoba, en la primera mitad del siglo XX, enarboló la bandera de la nación católica. Proclamó que sus intereses coincidían con los de la mayoría de la población y se valió de una especie de "nacionalismo religioso", que vinculaba patria y religión, que buscaba congregar a la población cordobesa en torno a su liderazgo. $\mathrm{Su}$ discurso y sus prácticas contribuyeron a crear el mito de la "nación católica". Su acción contribuyó a aportar un elemento de unidad para las grandes mayorías. Si entendemos la nación como una comunidad imaginada, la Iglesia de Córdoba elaboró un discurso e implementó unas prácticas que aspiraban a dotar de sentido a ese destino común denominado Patria.

Los objetivos son los siguientes:

1.- Estudiar el proceso de institucionalización de la Iglesia diocesana de Córdoba, 
identificando sus rasgos centrales.

2.- Cartografiar la dimensión material de la religión en el espacio diocesano, identificando la construcción, y re-edificación de templos (iglesias, capillas y oratorios) en el marco de un proceso de territorialización del poder.

3.- Redefinir los perfiles eclesiásticos que se construyen en la segunda mitad del siglo XIX y en las primeras décadas del XX.

4.-Analizar el papel que jugó el clero parroquial y secular cordobés en el proceso de Romanización que experimentó la Iglesia Argentina en la segunda mitad del siglo XIX y primeras décadas del XX.

5.- Reconstruir el universo clerical del período, identificando los diversos subgrupos.

6.-Analizar las trayectorias personales de los miembros del clero secular de Córdoba.

7.- Identificar los rasgos centrales del nuevo modelo parroquial.

8.- Comparar su implementación en las regiones del nor-oeste y del sud-este provincial

9.- Definir las políticas eclesiásticas implementadas en orden a mantener la hegemonía cultural en el espacio diocesano provincial.

10.- Delimitar las prácticas del clero en el ámbito parroquial de la campaña provincial

La tesis consta de cinco partes. En la primera, se abordan las cuestiones teóricas y metodológicas y consta de 15 capítulos. El primer capítulo nos introduce en el derrotero de la historia religiosa -y el lugar que ocupa hoy-, sus principales aportes y debates. La segunda parte de este capítulo aborda un campo de estudio específico, el clero secular. Es un capítulo de corte historiográfico que busca presentar un estado de la cuestión. El segundo capítulo centra el análisis en los marcos conceptuales que regulan el trabajo, los aportes conceptuales brindados desde diversas ciencias como la sociología religiosa, la antropología histórica, la historia social y socio-cultural. El último capítulo está dedicado a las fuentes, sus alcances y limitaciones, y a los vacíos y estrategias metodológicas para los respectivos abordajes.

La segunda parte presenta el contexto histórico. Dado que la iglesia es una institución de carácter universal, vi conveniente, por el impacto que el proceso conlleva a nivel regional y local, sintetizar el recorrido de las relaciones del papado con los estados liberales durante la segunda mitad del siglo XIX. Mostrar las estrategias de resistencia, en una primera etapa, y 
luego de diálogo. El capítulo segundo está dedicado a la provincia de Córdoba y a los procesos de transformación económica y social que experimentó durante el periodo analizado en esta tesis. El último punto de este capítulo se centra en el poder político. El tercer capítulo se detiene y analiza el poder eclesiástico, la debilidad institucional en la que se encontraba la Iglesia al inicio del análisis. Las estrategias que comienzan a implementarse a partir de la asunción de Ramírez de Arellano como obispo in partibus de la diócesis mediterránea en 1859.

En la tercera parte de la tesis, comienza la investigación propiamente dicha, que se desarrolla a lo largo de nueve capítulos. Esta tercera parte centra el análisis en la dimensión territorial del hecho religioso, analiza en qué medida los obispos diocesanos articularon y resignificaron el espacio diocesano en función del proceso de modernización social. Una de las preocupaciones principales de este capítulo es abordar la dimensión material de la religión, tomando el territorio como un espacio de encuentro entre la religión y la sociedad. Me interesa ver el impacto de la religión sobre el territorio. Los lugares de culto son indicadores de una pertenencia religiosa visible en el espacio. Iglesias y capillas nos permiten analizar la configuración territorial y social de la iglesia diocesana de Córdoba y acercarnos a la dimensión espacial de lo social y a las dimensiones socio-espaciales de la religión. Una categoría analítica guía las reflexiones del capítulo, la de espacialización o territorialización eclesiástica, que se realiza a través de la creación de una red de lugares sagrados (parroquias y capillas).Para elaborar este capítulo, he centrado el análisis en los territorios. Con la renovación de la historia política o institucional, se iniciaron los estudios de los "territorios" y la "territorialidad" y las cuestiones vinculadas a la dominación y organización del territorio por parte de un poder particular. Uno de los aportes más sólidos de estos abordajes está vinculado a los procesos de territorialización del poder. Estos estudios permitieron dar el paso de la idea de "territorio" como un espacio limitado, definido, controlado, por el ejercicio de la autoridad, a la concepción de una pluralidad de "territorios". Entendiendo que el espacio jurisdiccional no es cerrado, sino que está permeado por los otros espacios. Los historiadores comenzaron a plantearse el problema relativo a la superposición compleja de espacios civil, parroquial, agrario, lingüístico, etc. (Lagrée, 1992). El primer capítulo de esta parte analiza la presencia de la autoridad sobre el territorio provincial, para ello se recurrió al estudio de las visitas pastorales, a fin de ver, 
justamente, el espacio territorial como zona de dominación episcopal, de poder y de orden. En el segundo capítulo vemos la expansión parroquial como fenómeno de territorializacion, analizando el crecimiento parroquial a lo largo del período, sus objetivos, alcances, dificultades y limitaciones. El tercer y último capítulo de esta parte se centra en un tema árido pero necesario, "la geografía eclesiástica de Córdoba". El objetico principal es acceder a la precepción de las autoridades eclesiásticas (párrocos y obispos) respecto de la grey encomendada a su cuidado pastoral. Informes relativos a la situación de cada curato, los interrogatorios y autos de las visitas canónicas fueron las fuentes utilizadas para elaborar un statu animae de la diócesis, agrupando los curatos en dos grande regiones, las de nueva colonización (sur y este) y los de antigua colonización (norte y oeste).

La cuarta parte de la tesis se centra en analizar el grupo que llevó a cabo el proceso de transformación, el clero secular. Se trata de una aproximación al clero como grupo social, sus formas de acción y organización, sus mutaciones y recomposiciones a lo largo de un período de profundos cambios sociales y económicos. El primer capítulo analiza el perfil del clero deseado, pues está íntimamente vinculado a la función que se espera cumpla en la sociedad. Para ello, se recurrió a la prensa, a fin de ilustrar el clero esperado por la sociedad de entonces y a los documentos episcopales para adentrarnos en la mirada de la jerarquía sobre el modelo clerical que se esperaba imponer. Luego, se presentan las acciones destinadas a logar el perfil deseado. El segundo capítulo analiza la composición, los distintos grupos que configuraron el clero secular, la evolución de las ordenaciones sacerdotales y las carreras sacerdotales. Para ello, se realizó una base informática que nos permitió identificar el número y el nombre de cada clérigo que asciende en la carrera sacerdotal, desde las órdenes menores hasta el presbiterado y luego diversos cargos y funciones. Ello permitió elaborar un índice de ordenaciones anuales, que muestran los periodos de expansión y estancamiento de la población clerical. A partir de estos datos, me pregunté por qué, no obstante la falta indudable de beneficios, la población clerical fue aumentando. Precisado el número de clérigos que había por habitante, pude elaborar un censo de clérigos para este período específico de la diócesis. Los grupos proveedores de vocaciones y las zonas geográficas de proveniencia. Luego, procedí a presentar dos grandes grupos, el clero capitular y el clero parroquial. En este último grupo, encontré tres subgrupos en relación a su origen social ya su incardinación. Lo que las fuentes denominan clero propio y clero 
extraño. El primer grupo está compuesto por los "hijos del país", los inmigrantes o hijos de inmigrantes formados en el seminario e incardinados en la diócesis de Córdoba. El segundo grupo lo compone el clero "gringo" o extranjero. Se analizan las políticas de incorporación y la ocupación y distribución del clero en el espacio diocesano.

Por último la quinta parte analiza las prácticas del clero vinculadas al proceso de secularización. El capítulo 13 plantea las prácticas del clero y de las feligresías frente al avance secularizador del estado, se analizan desde esta óptica la implementación de las leyes laicas vinculadas al registro civil, secularización de los cementerios y matrimonio civil. El capítulo 14 analiza el proceso de secularización de la política y las resistencias del clero secular a abandonar las prácticas políticas partidarias. Por último el capítulo 15 se propone identificar las nuevas prácticas pastorales, y analizarlas como estrategias de cristianización de la vida moderna y de modernización de la vida cristiana. El capítulo tiene como objetivo presentar el poder pastoral parroquial y la re-significacion de la parroquia en sus múltiples dimensiones. 


\section{PRIMERA PARTE}

\section{CONSIDERACIONES}

\section{TEÓRICO - METODOLÓGICAS}




\section{CAPITULO 1 \\ LA HISTORIA RELIGIOSA EN LA ENCRUCIJADA: \\ DE LA HISTORIA INSTITUCIONAL A LA SOCIO-CULTURAL}

En general, el análisis del clero se encuadra dentro de tres grandes líneas historiográficas. En primer lugar, la sociología religiosa, que permite el abordaje de la religión vinculada al estudio de la cultura y los procesos de secularización. Con las herramientas teóricas de esta disciplina, analizaremos el reacomodamiento de la religión en un contexto político-cultural y económico-social que se modernizaba y se diferenciaba progresivamente de la herencia colonial. En segundo lugar, aquella que asiste a un renacer de los estudios políticos e institucionales, que nos permitirá establecer vinculaciones con la historia política, al abordar las relaciones entre Iglesia y Estado, los movimientos anticlericales y el influjo de las vivencias religiosas en las opciones políticas. En tercer y último lugar, la historia social-religiosa renovada, corpus central de nuestra tesis, que prioriza no sólo el estudio de las grandes estructuras objetivas, como la Iglesia o el Estado, sino, y fundamentalmente, las conexiones entre las transformaciones -ideológicas, políticas, económicas, sociales y culturales- y la forma y carácter de vida de los clérigos, condicionados por diferentes entornos que tratan de proporcionar percepciones vívidas del funcionamiento real de las sociedades. Esta vía es transitada ampliamente por la historiografía social europea y americana.

\section{Los derroteros de la historia religiosa ${ }^{1}$}

\subsection{La historia religiosa francesa}

La historia religiosa renovada comienza a practicarse en Francia en los años 60 del siglo pasado, al margen de la Universidad, en el marco abierto y, ante todo, informal del Grupo de La Bussière, en la que los miembros, en su mayoría historiadores profesionales y hombres de fe, buscaron superar no sólo las divisiones rígidas de aquellos países donde existía separación entre Estado e Iglesia, sino también entre las esferas laicas y eclesiásticas y la división entre la historia de la sociedad y las ciencias de lo divino (teología, liturgia, derecho canónico), desde una perspectiva interdisciplinaria que aspiraba a conjugar las miradas de la historia, las ciencias de lo

\footnotetext{
${ }^{1}$ Algunos balances sobre la historia religiosa europea se encuentran en el Dossier "La historia religiosa en Europa (1980-1993)", Anuario Historia de la Iglesia, vol. 4, Pamplona, 1995. Para la historia religiosa francesa, véase MAYEUR (1995); LAGRÉE (1999); SORREL (2004); AURELL y PEREZ LOPEZ (2006); CORTÉS PEÑA, LÓPEZ Y MUÑOZ (2007).
} 
divino, la antropología, la sociología, la etnografía y el arte (Iogna-Prat, 2002). Historiadores de la antigüedad, medievalistas, modernistas y contemporaneistas, además de filósofos, sociólogos, antropólogos, teólogos, etc., formaron parte de este grupo. Por lo tanto, ${ }^{2}$ en la trayectoria de este grupo, se pueden ver reflejados los ritmos de la evolución del llamado "retorno de lo religioso" en la historiografía francesa (Langlois, 1987: 100; Dosse, 2003: 219-239).

Los años 70 marcaron un punto de inflexión en el desarrollo de la nueva historia religiosa debido a varias cuestiones coyunturales, como el interés generado por la historia de las mentalidades, la inserción de algunos miembros del grupo en puestos relevantes de la Universidad, lo cual les permitió ejercer una influencia que comenzó a percibirse en los campos de investigación, en los temas de tesis, en las publicaciones, etc. Además, el grupo de La Bussière, abrió sus puertas a integrantes de otras confesiones, convirtiéndose en un espacio interreligioso. Jean-Marie Mayeur creó, en la Universidad París XII, un grupo de investigación sobre catolicismo y protestantismo, que, en 1975, escribió la historia religiosa de Francia de los siglos XI a XX (Langlois, 1987: 99).

En la década del 80, la tendencia se consolidó. ${ }^{3}$ En 1983, las Éditions du Cerf dedicaron una colección denominada "Historia" a la renovación historiográfica religiosa en Francia, publicando un primer libro con las ponencia de los miembros de grupo de La Bussière. ${ }^{4}$ Este "retorno a lo religioso" superó esa tendencia que durante mucho tiempo consideró a la historia cultural y religiosa como un conjunto de posturas marginales, cuya contribución a la explicación del pasado sólo podía tener un carácter menor y complementario, ya que el centro de interés y de la explicación histórica se ponía en los hechos políticos, primero, y en los fenómenos socio-económicos, después.

\footnotetext{
${ }^{2}$ El grupo fue creado en 1958. Toma su nombre del lugar de reunión, la Abadía de Le Bussier. Historiadores como Jean Chelini, Charles de la Roncier, Marc Venard, formaban parte del grupo, quienes se propusieron introducir, en el ámbito académico, la perspectiva historiográfica abierta por Gabriel Le Bras. A este grupo original, se agregaron nuevos miembros, como Francis Rapp, Jacques Lebrun, Jaques Gadille, Jean-Marie Mayeur, Jean-Marie Hilaire, Gerard Cholvy. En 1967, sus miembros ya eran una treintena, incorporándose Michel de Certau. Le siguieron Dominique Julia, Anfre Vauchez, Claude Langlois, Herve Martin, Etienne Fouillox, François Dosse, Bauberot, Michel Sott, Jacques Revel, Michel Lagrée, Phillipe Boutry, Nicole Lemaitre. En 1986, eran108 los participantes en el grupo (Cfr. DOSSE, 2003).

${ }^{3}$ Los historiadores de historia religiosa francesa moderna y contemporánea se agruparon en 1977 en la asociación GRECO, dirigida por Jean Delumeau y que en 1986 alcanzó a nuclear a más de 235 investigadores y 15 equipos de trabajo distribuidos en las principales Universidades francesas (Cfr. LANGLOIS, 1987: 100).

${ }^{4}$ Groupe de La Bussière. Practiques de la Confesion: Des peres du desert a Vatican II. Quinze etudes d'histoire, Éditions du Cerf, Paris, 1983.
} 
El artículo publicado en 1980 por un miembro de Le Bussier, Willem Frighoff, titulado "El paso de la historia de la Iglesia a la historia religiosa", señala este cambio de concepción. Sin embargo, también se debe remarcar que lo religioso no estuvo ausente en el devenir historiográfico anterior a Le Bussier, sino más bien que es el producto, la consecuencia, de los análisis de historiadores como Auguste Fliche, sobre las instituciones eclesiásticas; Henri Marrou, sobre el personalismo cristiano; Lucien Febvre, sobre las mentalidades; Alphonse Dupront, sobre la antropología religiosa; y Gabriel Le Bras, sobre las prácticas culturales tan apreciadas por la sociología religiosa (Iogna-Prat, 2002).

Para Michel Lagrée (1999: 413), la historia religiosa francesa abreva, justamente, en una triple herencia intelectual. La de Durkheim y sus sucesores (Henri Hubert y Marcel Mauss), centrada en las "representaciones" colectivas que nutrió la historia de las mentalidades durante al menos dos decenios y que buscó vincular lo religioso con lo cultural. La segunda vertiente está vinculada al trabajo de André Siegfried, sociólogo e historiador, pionero de la sociología electoral. El descubrimiento de este autor, por parte de los historiadores franceses, preocupados por analizar el vínculo entre las actitudes religiosas/políticas y la descripción espacial, cartográfica de esos fenómenos, fue hacia mediados del siglo XX. A partir de entonces, los trabajos sobre esta temática nutrieron el campo de la historia política. La tercera herencia, aunque no menos importante, fue la de Max Weber, que, si bien fue más tardía, fue más sostenida por los historiadores que se interesaron en el papel social del protestantismo, que por los sociólogos, que exploraron más a fondo sus tesis sobre el desencantamiento y la secularización.

Pretender realizar un balance exhaustivo de la producción religiosa es una tarea titánica, pues, como señala Christian Sorrel (2004: 251), en los últimos años, la religión se ha convertido en una dimensión ineludible en los estudios históricos de las sociedades, ejemplo de ello es, por ejemplo, Francia cuyo $13 \%$ de las publicaciones registradas en la Bibiliographie annuelle de l'Historire de France, responde a este campo renovado. Una clara manifestación de esta tendencia es la aparición en 1988 de la Histoire de la France religieuse bajo la dirección de Jacques Le Goff y René Rémond, cuyos temas dan cuenta de la centralidad que en las últimas décadas ha tenido la cuestión religiosa y el retorno de viejos temas planteados a comienzos del siglo pasado. 


\subsubsection{Lo religioso y la historia social}

En las obras de los padres fundadores de la Escuela de Annales, Lucien Febvre y Marc Bloch, el fenómeno religioso fue abordado en clave analista, es decir, una historia orientada según problemas, diferenciándose de los historiadores vinculados a la escuela metódica y a los historiadores eclesiásticos. Febvre, por ejemplo, criticaba a los historiadores eclesiásticos, porque éstos trataban fenómenos religiosos como algo esencialmente relacionado a los "abusos institucionales" y a su corrección, en lugar de considerarla como "una profunda revolución del sentimiento religioso". Bloch, en cambio, tiene una mirada sobre el hecho religioso desde las demandas de la sociedad. Para él, la Reforma Luterana se debió al surgimiento de la burguesía, que "necesitaba un religión clara, razonable, humana y mansamente fraternal". Este cambio de enfoque propuesto por Bloch, plantea, justamente, la recepción, apropiación o no apropiación del núcleo central de las creencias. En este sentido, se percibe un intento de eslabonar la historia religiosa y la historia social. Peter Burke (1993: 27-28) sostiene que "existe en esta obra una tensión entre el vivo interés por la historia social de la religión y su deseo, igualmente igualable, de no reducir las actitudes y valores espirituales a meras expresiones de los cambios producidos en la economía o en la sociedad". En su trabajo sobre Rabelais, la interrogación del personaje sobre la religión se transforma en una investigación sobre el problema de la incredulidad en el siglo XVI. Caracteriza cada horizonte cultural como un sistema coherente de signos y de instrumentos y realiza un análisis preciso y técnico del término "ateo" usado por un puñado de poetas, y concluye que éste era utilizado con frecuencia para hacer referencia a múltiples cosas, debido a que el aparato conceptual del período era demasiado primitivo. Esta constatación llevó a Febvre a una audaz caracterización de la cosmovisión de toda la época (Burke, 1993: 35), que hoy, sin duda, tiene algunos críticos. Particularmente interesante resulta el análisis referido a Martín Lutero. El autor plantea el problema de las relaciones del individuo con la colectividad, la iniciativa individual con la necesidad social (Febvre, 2010: 9). El planteamiento metodológico es fiel a la concepción analista, pues plantea que las cuestiones referidas a la historia de Lutero no pertenecen al dominio de lo religioso, sino al dominio social, político e, incluso, económico (Febvre, 2010: 14). Se orienta a una historia cultural que englobe la vida afectiva e intelectual en el nivel de la experiencia del individuo y en sus relaciones con otros individuos, una historia más inclinada hacia la psicología colectiva. 
Por su parte, Marc Bloch, en los Reyes Taumaturgos, procura explicar la institución monárquica desde la perspectiva de la larga duración, vinculándola a las corrientes intelectuales, sentimentales, místicas de la mentalidad de la época e integrándola al conjunto de disposiciones afectivas y morales en la estructura social. En palabras de Bloch, citadas por Revel (2005: 98), esta “interpretación por el adentro de los hechos de organización social será la ley de mi enseñanza, así como es la ley de mi esfuerzo personal". El texto es una historia de los milagros. Analiza el rito del toque y plantea la discusión sobre el problema de cómo explicar que la gente creyera en semejantes "ilusiones colectivas". Puede considerarse como un ensayo de sociología histórica y/o antropología histórica, pues abordaba tanto un sistema de creencias como una sociología del conocimiento. Lo que el propio Bloch denominaba "representaciones colectivas" (Burke, 1993: 25). La visión de Bloch podría ser una anticipación de la antropología histórica, que sólo -y en un contexto muy distinto- se desarrollará a fines de los años sesenta (Revel, 2005: 98).

Esta línea de investigación de historia social, que incluye el fenómeno religioso, desaparece casi por completo después de 1945, sepultada por la primacía otorgada a las estructuras económico-sociales. La escuela de Annales se orientó a la realidad económico-social y sus representantes estimaron que esa realidad permitía captar la historia "profunda" de los pueblos y de las sociedades humanas, considerando, además, que los métodos cuantitativos, que ocupaban un puesto privilegiado en las ciencias exactas, podían aplicarse también a los hechos sociales (Gerbot, 1982: 172). Revel (2001: 65-86) advierte que esta historia privilegia lo económico porque las relaciones sociales que se anudan aparecen particularmente densas y visibles en esta perspectiva, $y$, en cierto sentido, se convierte en una instancia que determina $-\mathrm{o}$ al menos condiciona fuertemente-, el conjunto de los funcionamientos sociales.

Para algunos historiadores económicos como Max Weber, la ética protestante pudo contribuir a fundar el capitalismo moderno, motivo por el cual la religión se convirtió en un factor de explicación de las realidades socioeconómicas. En tanto, para la historiografía marxista, no cabía considerar el hecho religioso más que en el plano de las superestructuras. Esta se presentaba como el producto puro de una coyuntura socioeconómica, sin auténtica realidad y, como tal, excluido de la explicación histórica. 


\subsubsection{Historia y sociología religiosa}

En sintonía con el espíritu de los Annales, Gabriel Le Bras, colega de Estrasburgo de Febvre y Bloch, intentó introducir en la historia de la Iglesia el paradigma de "historia global" que ésta proponía como alternativa a la tradición historicista y que bregaba por llegar a una síntesis integral, cuyo núcleo de estructuración no fuera el Estado sino "lo social”. Le Bras fundó una escuela de historiadores eclesiásticos y de sociólogos de la religión, que se dedicaron a estudiar el problema de la descristianización en Francia desde fines del siglo XVIII. Le Bras negó que la historia de la Iglesia fuera simplemente la de sus instancias institucionales, como sus colegas de Annales negaban que la historia en general fuera simplemente del Estado y sus relaciones, diplomáticas o militares. Le Bras creía en una historia de la Iglesia que, en diálogo con las ciencias sociales, abordase el análisis de los distintos niveles que la nueva historia social preveía para el estudio de las sociedades del pasado: el económico, el social y las mentalidades. El interés se centró en poner el acento en las estructuras y procesos y no en los acontecimientos, acciones, personas y decisiones singulares. La historia social ponía el acento en los aspectos de las situaciones "colectivas de la historia", en tanto que la historia política ponía el acento en lo "genial individual". Le Bras, como buen sociólogo, concibió la historia religiosa con un sentido más abarcador. Desde el punto de vista metodológico, sus trabajos sintetizaban muy bien la originalidad de una corriente que se apoyaban en la sociología y, en lo que podría denominarse, la primera historia de las mentalidades, al estilo de Bloch y Febvre (Delumeau, 1973: 157). Sus trabajos, y los de sus discípulos, abrieron vastos horizontes a la historia religiosa ${ }^{5}$ e inspiraron investigaciones tendientes a explicar el comportamiento religioso al interior de los grupos sociales, particularmente, de la campaña francesa. Un aporte significativo a la historia religiosa vinculada con la sociología fue la elaboración de un material eminentemente empírico destinado a medir la práctica religiosa, que constituyó un buen indicador para analizar el compromiso de las poblaciones a sus sistemas de creencias (Lagrée, 2002: 54).

La historia religiosa se inclinó, además, a la fe y sus realidades. Dentro de esta perspectiva, se encuentran los estudios de psicología religiosa, como la Histoire $d u$ sentiment religieux en France del abate Bremond (1916-1933), once volúmenes, y los primeros pasos sobre la práctica religiosa realizados por Le Bras antes de 1939. En

\footnotetext{
${ }^{5}$ Los trabajos de Le Bras han sido reunidos en una obra de dos tomos (1955-1956).
} 
1945, el abate Bremond, discípulo de Le Bras, publicó Problemes missionnaires de la France rurale. Si bien es cierto que el modelo braudeliano fue poco sensible a la dimensión religiosa, cabe señalar que Robert Mandrou, otro de los discípulos de Febvre, se ocupó de los fenómenos relacionados con el pensamiento y las creencias y estudió la cultura popular, basándose en fuentes hasta entonces poco exploradas, como la literatura difundida por medio de libros de divulgación vendidos en ferias y poblaciones rurales por comerciantes ambulantes -almanaques, coplas, recetas, narraciones de prodigios o vidas de santos. Mandrou elaboró un inventario de los temas más recurrentes y concluyó que esa literatura había alimentado durante siglos una visión del mundo imbuida de fatalismo y determinismo, de portentos de ocultismo, que habría impedido a los lectores la toma de conciencia de su propia condición social y política, con lo que habría desempeñado, tal vez conscientemente, una función reaccionaria. Mandrou definió esa literatura como el "reflejo de la visión del mundo" de las clases populares del Antiguo Régimen. Publicó un estudio sobre los magistrados y brujos de la Francia del siglo XVII. La crítica que hizo Carlo Ginzburg (1999: 12) con el correr de los años es que Mandrou atribuyó tácitamente a las poblaciones populares una absoluta pasividad cultural y a la literatura "popular" una influencia desproporcionada, ya que los campesinos eran en general analfabetos, los que eran capaces de leer constituía una escasa minoría.

Alguien que se abocó al estudio de lo sagrado y del hombre religioso fue Alphonse Dupront. Le interesaba "lo religioso" como un absoluto, fuera de las contingencias históricas y culturales. Este enfoque se caracterizó por la convergencia de las influencias de Mircea Eliade con la antropología de lo sagrado y, sobre todo, de Carl Jung, con su teoría del inconsciente colectivo. La forma más acabada y más pura sería el Homus religiosus. La religión, de hecho, es la que modelaría a la cultura (Lagrée, 1999: 412; 2002: 38). También centró su investigación en las peregrinaciones concebidas como una búsqueda de lo sagrado y un ejemplo de sensibilidad colectiva. Tomó como objeto de estudio las cruzadas y se acercó a ellas analizándolas como un caso de sacralización, como una guerra santa para alcanzar la posesión de lugares sagrados. Su interés por los "santos lugares" inspiró a algunos de sus discípulos a investigar los cambios producidos en el trazado de las iglesias y la significación simbólica de esos cambios. Dupront combinaba el interés de los grandes temas, como lo sagrado, con la precisión en cuanto al inventario o la cartografía de las imágenes milagrosas. En sus 
trabajos, encontramos una aproximación de la historia de la religión, la psicología, la sociología y la antropología (Burke, 1993: 73).

Como señalan Jean-Claude Schmitt y Dominique Iogna-Prat (2002: 399), “junto al árbol de los Annales, convivió un bosque de corrientes contemporáneas que cohabitaron con la Historia-Problema, que también tuvieron su dinámica propia. Una de ellas es la antropología religiosa cultivada por Alphonse Dupront, la cual, por intermedio de Paul Alphandery y, sobre todo, de Henri Berr, se alimenta del proyecto definido por Émile Boutroux en el último tercio del siglo XIX, de una síntesis operada por la Filosofía, deudora de todos los saberes sobre el hombre y la sociedad, y promotora de una psicología metafísica interesada en explorar las profundidades colectivas. Otra de estas corrientes fue la historia de las instituciones eclesiásticas, objeto de fricciones repetidas entre Marc Bloch y Augustin Fliche, ${ }^{6}$ pero que atraviesa toda la historiografía francesa del siglo XX, haciéndose la columna vertebral de las ciencias sociales". La Historia de la Iglesia de Fliche y Martin pretendía ser la primera síntesis científica de la historia del cristianismo (Gerbot, 1982: 187).

La historia religiosa, surgida de los horizontes de una historia global, se mostró sensible a influencias y presupuestos ideológicos. Cierta tradición, nacida del positivismo y del historicismo del siglo XIX, siguió inspirando fuertemente parte de los estudios actuales. En esta línea, los trabajos de historia religiosa tuvieron como postulado fundamental y subyacente la distinción entre sociedades avanzadas y sociedades primitivas, entre pensamiento racional y pensamiento salvaje. Introduce un juicio de valor que define culturas periféricas o atrasadas en el sentido de inferioridad frente a las civilizaciones del progreso, mejor estructuradas, más ricas y complejas. Esta jerarquización de las culturas supone que unas son importantes, susceptibles de perfección y capaces de sacar a la especie humana de su barbarie original y otras son de menor interés. Las sociedades avanzadas tendrían, en este aspecto, una misión humanitaria. Su deber consistiría en educar, hacer progresar a los pueblos y grupos sociales primitivos e incorporarlos a un ascenso cultural común. Es la historia religiosa, imbuida de espíritu misionero, la que en el siglo XIX sustentó la europeización del mundo y las conquistas coloniales. La cultura y el cristianismo europeos fueron

\footnotetext{
${ }^{6}$ Historiador de la Iglesia y medievalista francés, nació en Montpellier en 1884 y falleció en 1951. Escribió, en colaboración con otros autores, la Historia de la Iglesia desde los orígenes hasta nuestros días, dirigida por V. Martin. También, La réforme grégorienne et la reconquête chrétienne (tres volúmenes, 1924-1937). Colaboró en las colecciones de Cavaignac (Historia del mundo) y Goltz (Historia general) con dos obras fundamentales: La cristiandad medieval (1929) y La Europa occidental de 888 a 1125 (1930) (Cfr. http://www.biografiasyvidas.com).
} 
considerados modelos imitables. Como advierte Gerbot (1982: 193), "en la galaxia europea propiamente dicha se definieron unas jerarquías. Opusieron la cultura de la elite aristocrática y después burguesa, a las culturas populares". La historia religiosa muestra la influencia de este sistema de oposiciones, que se manifiesta tanto en las rivalidades confesionales como en la distinción entre religiones populares y no populares y en el interés concedido a las estructuras eclesiásticas, a las controversias doctrinales y a las relaciones ente Iglesia y Estado. Esta actitud elitista también se notó en las relaciones entre capitales y provincias, en el marco de las historias nacionales, en donde es preciso destacar la función privilegiada reservada a la cultura de las capitales en detrimento de las culturas de las provincias. También se ha notado el influjo de la tradición marxista y estructuralista que sin duda trascendieron a algunas opciones metodológicas como fue la fascinación por lo cuantitativo.

\subsection{Historia religiosa y mentalidades: una mirada estructuralista}

En los años 60, salieron a la luz las aportaciones metodológicas y teóricas de Georges Duby y Jacques Le Goff. Ellos, entre otros, reclamaron la atención de los historiadores acerca de una materia de investigación que, salvo en los autores arriba mencionados, había estado muy relegada, la mentalidad colectiva. Duby proponía la constitución de una historia social de las lógicas mentales, muy vinculada a la psicología colectiva. En su trabajo pionero, fechado en 1961, definió la nueva especialidad. Duby propuso la historia de las mentalidades como un "plan de investigación de una historia verdaderamente sicológica", convocando a los historiadores a "conceder una atención particular a una de las ciencias, especialmente joven y conquistadora: la psicología social". Lo que va a dominar es la historia lenta y profunda. No es una casualidad que el período que más moviliza a los historiadores franceses sea la Edad Media y Moderna, la larga duración de las sociedades preindustriales, antes de las mutaciones que van a trastornarlas. También es comprensible la inclinación hacia la historia rural, pues era el sitio de las evoluciones lentas, analizadas en términos de sistemas o estructuras (agrarias, sociales o culturales), que privilegiaba las relaciones del hombre con el medio, tomadas casi siempre en el marco limitado de un país, de una región, en cuyo interior estaba permitido afinar el análisis poniendo de manifiesto las interrelaciones multiplicadas entre los diversos órdenes de fenómenos tomados en la duración (Revel, 1999: 74). 
En este contexto, Duby escribe tres libros en los que la cuestión religiosa se presenta como protagonista del mundo medieval: Tiempos de las catedrales (1966), Los tres órdenes o lo imaginario del feudalismo (1978) y El caballero, la mujer y el cura (1981). En ellos, el marxismo es un eficaz instrumento de análisis. Los conceptos de clase y las relaciones de producción atraviesan los textos. En la Europa de las catedrales, analiza las relaciones entre las producciones culturales y las estructuras sociales. Al autor le interesa entender cómo el plano espiritual repercute en el material. En Los tres órdenes, plantea la división tripartita de la sociedad feudal: "Unos están consagrados particularmente al servicio de Dios, otros a conservar el estado por medio de las armas, otros a alimentarlo y a mantenerlo mediante el ejercicio de la paz. Estos son nuestros tres órdenes o estados generales de Francia, el clero, la nobleza y el tercer estado" (Duby, 1992: 29). Con esta enunciación, Duby pretende mostrar la forma como se organizó la sociedad feudal en Francia, la potencia y la injerencia de los discursos, al igual que los ritos de orden social y religioso, el análisis del lenguaje y la forma como estos van creando un vínculo con el imaginario colectivo. Si bien el objetivo central del texto es mostrar cómo se crea la representación mental que define la estructura del feudalismo, también demuestra la permanencia de un sistema. Para Duby, la Iglesia y, en particular los obispos de los siglos X y XI, contribuyeron a justificar el régimen feudal, pues entiende que el cristianismo es una "ideología" que sostiene la desigualdad. En el apartado dedicado a los "Órdenes", señala que "se entiende por ordo la organización justa y buena del universo, aquello que la moral, la virtud y el poder tienen la misión de conservar". El orden dentro del imaginario consistía en que una parte de la sociedad debía obedecer y la otra conducir a los obedientes, un sector era el nacido para ordenar al otro, unos debían estar por naturaleza por encima de otros. Para Duby (1992: 118), "el orden se presenta de este modo como el fundamento sacralizado de la opresión". Duby tiene una concepción althusseriana de la religión, la entiende como una estructura ideológica, en este sentido los tres órdenes es un texto dedicado a analizar cómo, según él, "la ideología cristina" permea, a través del discurso, a la sociedad francesa por varios siglos.

Retomando el problema de la descristianización, Michel Vovelle, en su libro Piedad barroca y descristianización, valiéndose de los testamentos, analiza las actitudes frente a la muerte. Para el autor, el lenguaje de los testamentos reflejaba el sistema de representaciones colectivas. En su trabajo, verificó cambios importantes entre los funerales barrocos del siglo XVII y la modestia de los del siglo XVIII, cambios que 
permitían identificar una tendencia hacia la secularización. Sugiere que la descristianización de los años de la revolución francesa fue un proceso espontáneo, no impuesto desde arriba, y que ese proceso formaba parte de una tendencia más general. Su trabajo inspiró la utilización de las estadísticas en numerosos trabajos sobre las actitudes frente a la muerte (Burke, 1993: 78).

La desigual repartición de las capacidades culturales, de los bienes y de las prácticas culturales (actitudes ante la vida y la muerte), se convirtió en el objeto central de múltiples investigaciones. Las diferencias sociales no podían ser pensadas sólo en términos de fortuna o dignidad, sino que eran producidas por diferencias culturales.

Los estudios sobre fenómenos como la descristianización, la piedad popular, las supersticiones, dieron espacio a la renovación de la historia religiosa. Se retomaron los métodos que aseguraron las conquistas de la historia socioeconómica, como las técnicas de la estadística regresiva y el análisis matemático de las series. De la primacía que se otorgaba a las series y, por lo tanto, al establecimiento y tratamiento de los datos homogéneos, repetidos y comparables en intervalos temporales regulares, se desprenden dos consecuencias. La primera, es el privilegio otorgado a las fuentes masivas, bien representativas y disponibles durante un período largo: por ejemplo, los inventarios post mortem, los testamentos, los catálogos de bibliotecas, los archivos judiciales, etc. La segunda, consiste en la tentativa de articular, de acuerdo al modelo brodeliano, las diferentes temporalidades (larga duración, coyuntura, acontecimiento), el tiempo largo de las mentalidades, que frecuentemente resiste al cambio, con el tiempo corto de los abandonos o de los desplazamientos rápidos de creencia y de sensibilidad. Otra característica remite a la manera ambigua de pensar la relación con la sociedad. La noción de mentalidad parece estar dedicada a borrar las diferencias con el fin de establecer las categorías intelectuales o afectivas compartidas por todos los miembros de una misma época. Vovelle (2007) la definiría años después como "la historia de las visiones del mundo".

En 1960, Jacques Le Goff publicó un famoso artículo sobre el tiempo de los mercaderes y el tiempo de la Iglesia en la Edad Media. Como señala Burke (1993: 74), la cuestión del tiempo no era nueva, ya había sido tomada por Febvre en su estudio sobre la incredulidad. Febvre se había referido al "impreciso y flotante" sentido del tiempo, en un período en que la gente ni siquiera sabía su edad exacta y medía el día, no por relojes, sino por la trayectoria del sol. Le Goff, afinó las generalizaciones de Febvre, que eran bastante imprecisas, y abordó el conflicto entre los supuestos del clero y los 
supuestos de los mercaderes. Se reprochaba que la ganancia del mercader supusiera una hipoteca del tiempo que sólo pertenecía a Dios. El usurero actuaba contra la ley natural universal, porque vendía el tiempo. Según Le Goff, la concepción del tiempo que se oculta tras ese planteamiento pone en cuestión toda la vida económica en el albor del capitalismo comercial. Le Goff insistía en la "mediación" de las estructuras mentales, de los hábitos del pensamiento o del aparato intelectual, en otras palabras de las mentalidades, y observaba el surgimiento, durante los siglos XII y XIII, de nuevas actitudes frente al tiempo, al espacio y a los números. Este texto plantea la función del clero como grupo dominante, regulando la actividad de toda una sociedad y su paulatino declive, con "el tránsito del tiempo de Dios al de los hombres" (Le Goff, 1983: 74), en las centurias finales del Medioevo. Además es un texto que se abre al campo de la investigación sobre el espacio y el tiempo.

Jean Delumeau (1973), que había comenzado como historiador económico y social, cambió su interés y pasó al estudio de la reforma y de la llamada descristianización. Interesándose después por los miedos y la culpabilidad en occidente. Para nuestro estudio, ha resultado particularmente interesante el texto, ya clásico, El catolicismo de Lutero a Voltaire, en el cual Delumeau plantea un acercamiento metodológico de arriba abajo y de abajo arriba. Se acerca al proceso reformador a nivel de las políticas eclesiásticas y a nivel de las masas, de la mente colectiva. Esta mirada le permite señalar que las consecuencias de las dos reformas -la de Lutero y la de Roma-, constituyeron dos aspectos complementarios de un mismo proceso de cristianización, cuyo impacto y límites están aún por determinarse. El autor advierte que, a pesar del esfuerzo emprendido por la Iglesia católica y el protestantismo entre los siglos XVII y XVIII, para "cristianizar" a la población de sus respectivos ámbitos, "la cristianización estaba muy lejos de haberse completado en el momento en que las revoluciones políticas y económicas se adueñaron de Occidente para trastornar sus cimientos" (Delumeau, 1973: 275). Según Delumeau, las dos Reformas, protestante y católica, habían tratado de restituir al cristianismo su carácter sagrado, pero, en contrapartida, se deshumanizaron al olvidar cristianizar lo profano, y, esta inconsciencia, respecto a los valores terrenales y humanos, fue su "debilidad congénita”. Para Delumeau, la causa de la Reforma sería capaz de transmitir unas necesidades que estaban surgiendo en esa nueva época, una época en la que el individualismo ganaba terreno y los fieles necesitaban una teología más sólida y más viva, y, sobre todo, un clero más instruido. 
El cuestionamiento y el abandono de las tendencias estructuralistas e impersonales se manifestó en una serie de "retornos": al sujeto, a lo político, a lo micro, al acontecimiento. Este "retorno del sujeto" se manifiesta en trabajos de antropología histórica, historia de las mentalidades, historia desde abajo y nueva historia cultural. En ellos, se examina la vida de los hombres pertenecientes a las élites o a las clases inferiores, el gran hombre o el hombre común, los marginados y los excluidos. La tendencia hacia la individuación, hacia el hombre singular e irrepetible, que, en una dimensión cronológica única, actúa, piensa, desea, imagina y recuerda, ha cristalizado en la biografía, que se presenta como un camino para comprender y entender una época, del mismo modo que las series estadísticas de precios, proporcionadas por la historia económica, han servido para explicar la evolución económica.

Tanto Duby como Le Goff han expresado las estructuras históricas a través de la vida de un individuo, de forma tal que la biografía complementa la historia estructural. Ciertas personalidades como Guillermo el Mariscal, Leonor de Aquitania, Francisco de Asís o Alfonso rey de Francia son al mismo tiempo testigos privilegiados y reveladores de su tiempo. Para Duby, el personaje excepcional cumple, para el historiador, el mismo papel que el acontecimiento, tiene la ventaja de "ser revelador". Duby valoró en Leonor de Aquitania, el comportamiento, la mentalidad, las representaciones del mundo que se revelaban a través del personaje; por medio de él, el autor da a conocer la condición común de la sociedad de su tiempo. Como advierte Iogna-Prat (Schmitt e Iogna-Prat, 2002: 399), “así, Jacques Le Goff, aprovechando la figura privilegiada de San Luis, ha mostrado como esquivar el obstáculo de las convenciones textuales, de los lugares comunes y de los modelos de comportamiento: el rey santo hizo suyos tales modelos al punto de encarnarlos y de forjar sobre ellos su modo de existir".

\subsection{La historia religiosa y lo político}

Más recientemente, también los contemporaneistas, siguiendo a René Remond y Jean-Marie Mayeur establecieron puentes con la ciencia política. El historiador de lo religioso se vio sorprendido por el peso del evento y de lo político, entre la coyuntura y la estructura, desde la separación de Iglesia y Estado hasta la guerra por la educación escolar y desde las dos guerras mundiales hasta las guerras coloniales. No es extraño entonces que la exploración del vínculo entre la religión y la política se constituyera en una dimensión esencial de la investigación. La concepción renovada de "lo político", entendiéndolo como un campo donde se articula lo social y sus representaciones, como 
la "matriz simbólica en la cual la experiencia colectiva se enraiza y se refleja al mismo tiempo" (Rosanvallon, 1996: 30), pues lo político "concierne a la organización de la sociedad y a las relaciones de autoridad y subordinación entre los actores sociales, todo lo que los constituye y regula sus relaciones (Guerra, 1993: 243). Esa ampliación del terreno considerado como político desborda los límites que acotaban el espectro y, como consecuencia, ensancha la naturaleza de lo político cuantitativamente, pero, sobre todo, cualitativamente. Lo político toca muchas cosas, está en relación al estudio de los comportamientos de las escuelas, de las convicciones, de los recuerdos, de la memoria y de la cultura. No es un hecho aislado, está en relación con los grupos sociales, las tradiciones del pensamiento (Remond, 1996: 59), en otras palabras, la sociedad civil, sus diferentes grupos y sus formas de acción y organización se han convertido en temas que conciernen muy directamente a la historia política (Sabato, 2001: 7).

En consonancia con los giros metodológicos contemporáneos, la nueva historia política ha privilegiado, como centro de estudio, a los actores $\mathrm{y}$, fundamentalmente, los vínculos, definidos como la formalización de las relaciones entre los actores primarios y el funcionamiento de los sistemas políticos. En otras palabras, como la relación siempre fechada de un actor con otros actores: parentesco, amistad, enemistad, solidaridades sociales, lazos de clientela, etc. "Los actores no son conocibles aisladamente sino en relación con los demás actores circundantes. Sus actividades y sus acciones dependen del campo estratégico en el que se encuentren: del marco geográfico o social, de sus relaciones de oposición o afinidad con otros actores" (Guerra, 1993: 241). En muchísimos casos, las actitudes de los actores no son sólo consecuencias de su propia identidad, sino también del lugar que ocupan en un marco geográfico o político determinado. Existe entre lo político y lo social una amplia zona de contacto y de ósmosis, que se puede llamar cultura política, donde los valores, las creencias de una sociedad, juegan un papel de primer orden (Sirinelli, 1993: 30; Guerra, 1998). En este sentido, pude afirmarse que lo político se encuentra en todos los actos de la vida social, esto puede observarse en la significatividad que ha adquirido el papel de lo ritual, lo ceremonial y lo reiterado, una concepción política de los lazos familiares y parentales, las formas de jefaturas, el clientelismo político.

De allí que la historia religiosa francesa contemporánea centre su atención en abordar las relaciones entre Iglesia y Estado, los movimientos anticlericales o el influjo de las vivencias religiosas en las opciones políticas y el análisis de los parámetros religiosos en los comportamientos electorales (Lagrée, 1999: 414). En este sentido, se percibe el 
intento de descifrar la naturaleza del vínculo religioso y el sentido de la relación entre convicciones religiosas y preferencias políticas en el contexto de pluralismo mayoritario y regresión de las prácticas religiosas. Estudios que también han abordado las crisis político-religiosas, como el caso Dreyfus y la condena de la Acción Francesa, las corrientes de ideas, como el progresismo, los partidos demócrata-cristianos, el posicionamiento de las autoridades religiosas en la vida política y social y de las opciones frente a la guerra y al paz. Este conjunto de trabajos se esfuerza por comprender la interacción ente el acontecimiento político y el factor religioso.

En relación a la cuestión de las preferencias políticas de los creyentes, han surgido debates sobre dos temas centrales, el primero, concerniente a la actitud de los obispos frente al Régimen de Vichy y, el segundo, guarda relación con la noción de "resistencia cristiana". Otro de los grandes temas que ha convocado a los historiadores del hecho religioso han sido las guerras mundiales, en particular la segunda. El análisis se centró en la cuestión obrera del catolicismo de las posguerras. Éste se fue ampliando para tomar en cuenta, de forma no selectiva, el esfuerzo de incorporación y de conquista que condujo, a lo largo del siglo XX, a la creación de una densa red de obras y movimientos para adultos y jóvenes. Se estudian, además, los método educativos, la pedagogía espiritual, la sociabilidad recreativa y las modalidades de compromiso eclesiástico, cívico o político (Sorrel, 2004: 257-258).

El tema desborda el campo religioso y lleva a reflexionar sobre el contenido subjetivo del vínculo social y de las identidades colectivas. El fenómeno es abordado desde diversas perspectivas. Una de ellas privilegia la historia interna de las Iglesias y evalúa el lugar de las otras iglesias y movimientos en su esfuerzo de defensa o de conquista, que se expresa, particularmente, en el proyecto de contra-sociedad, basado en el integralismo. Cabe señalar el interés por el estudio de la relación entre religión y cambio social, el cambio en las iglesias inducido por el contexto general y por las respuestas a los desafíos externos, en un movimiento de acción/reacción, como lo ha demostrado Lagrée en relación a la cristiandad bretona. La tesis de Lagrée (1992) analiza justamente el factor religioso en el desarrollo de la modernización de la región, advierte que, en el caso de Bretaña, las transformaciones sociales, económicas y culturales fueron posibles con el aval y el concurso de un catolicismo que mantuvo su hegemonía durante mucho tiempo, en este sentido el catolicismo se desempeñó como uno de los motores de la modernización. El autor discute la postura weberiana, según la cual el espíritu de iniciativa protestante fue el único agente religioso de modernización, 
mientras que el catolicismo se identificaba con el estancamiento y el atraso debido a su celo por la religión (Fouilloux, 2002: 80).

No podemos dejar de mencionar el interés de los historiadores de lo religioso por los intelectuales. El auge de la nueva historia de las ideas, atenta a considerar el sustrato en el cual se originan los sistemas de pensamiento, y también a la recepción, ha llevado a la realización de trabajos que buscan comprender la función de los intelectuales en las Iglesias, particularmente en la Iglesia católica, obsesionada por la crisis de los tiempos modernos. Son trabajos que contribuyen a consolidar una historia intelectual del catolicismo, cuyo programa y método son definidos por Étienne Fouilloux como una historia no teológica de la teología que aspira a explicar cómo el catolicismo se desplazó de la reacción antimodernista al aggiornamento conciliar, influenciado por el pensamiento francés (Sorrel, 2004: 260).

\subsection{La historia religiosa fuera de Francia}

\subsubsection{Italia}

Si bien la centralidad de Francia en el desarrollo de la historia religiosa es evidente, ésta no es el único ámbito donde se ha consolidado la historia religiosa. En Italia, un primer momento de la renovación de la historia religiosa se vincula a la influencia de la sociología religiosa de Gabriel Le Bras y Fernand Boulard, si bien tuvo débiles repercusiones, debido a las profundas divergencias entre el catolicismo italiano y el francés. En Italia, el catolicismo asumió una verdadera hegemonía en todo el país, mediante una "política cristiana" -alimentada también por la cultura-, que confluirá en la creación de la democracia cristiana. A diferencia del caso francés, donde el catolicismo intentó medir - para dominar y combatir-, los orígenes, el desarrollo y las consecuencias de la descristianización contemporánea, la diversidad de problemáticas engendró metodologías diferentes, la historiografía católica italiana privilegió una aproximación en términos de historia cultural (tanto intelectual como espiritual) y política (organizaciones, movimientos y partidos), en el momento en que Le Bras y sus discípulos se preocupaban por cuantificar y cartografiar las evoluciones cronológicas y las disparidades regionales. Ahora bien, ambas historiografías se proponían arriesgar la hipótesis de un país enteramente católico (Boutry, 1986: 812).

Un segundo momento de la renovación de la historia religiosa italiana, se sitúa en 1970, cuando surge la preocupación por desvincular la historia de la Iglesia de las reflexiones teológicas y encarar una historia religiosa que tuviera por objeto a la Iglesia, 
no en su acepción dogmática sino fenomenológica, es decir, comprendiendo todas las manifestaciones de vida, pensamiento y organización. Se toma el año 1972 como el inicio de la renovación de la historia religiosa italiana, que es cuando aparece el primer número de la revista fundada por Gabriele De Rosa, Ricerche di storia sociale e religiosa. El mismo De Rosa insistió en la importancia de recuperar los trabajos de un sacerdote historiador, relativamente poco conocido en Francia, Giuseppe De Luca (1898-1962), fundador de la Edizioni di storia e letteratura (Roma). Éste venía desarrollando, en oposición a las críticas de inspiración "modernista" o "positivista", el estudio de las devociones populares, como contraste a las demasiado elitistas o universitarias historias del sentimiento religioso o escuelas de espiritualidad. Se trataba de una vía autónoma, la historia de la piedad, que tenía por objeto tomar en consideración, analizar y comprender el conjunto y las formas de devoción y prácticas religiosas populares en Italia.

De Rosa llevó adelante una particular metodología y un singular acercamiento a la sociología y la antropología (Canevaro, 1995: 324). Sus trabajos, junto a los de Angelo Gambasin y Antonio Cestaro, pusieron el énfasis en la necesidad de un doble enfoque: "social y religioso", enfoque que conjuga estrechamente el análisis de la piedad popular -incluyendo sus formas más alejadas de la ortodoxia- y las estructuras en las que se inserta esa vida religiosa, el contexto demográfico y social, el papel del clero y de los obispos. En una perspectiva de penetración del magisterio de la Iglesia católica en la sociedad civil, que constituye el fundamento de la reforma tridentina hasta finales del siglo XIX. Es decir, la confrontación entre el magisterio de la Iglesia y la piedad popular, por un lado, y el análisis de las estructuras parroquiales, por el otro. Philippe Boutry (1986: 812) se refiere a ella como a una "Historia católica global", que pretende insertar lo más completamente posible el conocimiento de la vida religiosa en el contexto histórico global -demográfico, geográfico, económico, social, político y cultural.

Esto ha sido particularmente tratado por aquellos que han analizado la acción reformadora de los prelados pos-tridentinos que han puesto el acento en el proceso de burocratización que experimentaron las diócesis católicas en la segunda mitad del siglo XVI, con el fin de reorganizar las propias administraciones diocesanas, otorgando una mayor centralización del poder a los obispos, las curias diocesanas y los vicarios generales y provisores. Funcionarios que surgen como depositarios de la jurisdicción espiritual y temporal del obispo y, por lo tanto, como elementos esenciales de la 
administración diocesana, en contracara al peso que, en épocas pasadas, tuvieron otras instancias institucionales, como los cabildos eclesiásticos (Palomo, 1997: 122).

Esta perspectiva de análisis se vincula con el estudio de las actitudes religiosas y morales del clero y de la sociedad de Antiguo Régimen, que utilizan como fuentes de estudio las visitas pastorales, a fin de observar la aplicación de la reforma tridentina y las resistencias -que desde las comunidades de fieles se manifestaron en numerosas ocasiones-, a las directrices que emanaban de la jerarquía católica.

Desde una perspectiva diferente, aparecieron trabajos centrados, específicamente, en las visitas pastorales, analizadas como instrumentos de control del territorio y, por consiguiente, del gobierno de las diócesis, similares a los procedimientos utilizados por otras instancias de poder como la monarquía o la inquisición. Esta voluntad de controlar el espacio diocesano llevó a la necesidad de redefinir las competencias de todo el personal eclesiástico, desde el obispo y sus vicarios hasta los curas párrocos. Autoridad que "a modo de red periférica que se extiende por todo el territorio, ejerce un control regular sobre la vida religiosa y moral del clero y la sociedad. Esta red se extiende a lo largo de la edad moderna a través de una figura como la del párroco, que es objeto de lo que se ha denominado proceso de profesionalización, en el que sus funciones en la cura de almas se delimitan progresivamente, su disciplina externa e interna se acentúa, su formación se especializa en función de las competencias que se le asignan y su número crece progresivamente, sobre todo a lo largo del siglo XVIII, dentro de un fenómeno de sacerdotalización del propio grupo clerical” (Palomo, 1997: 124).

En este sentido, las estrategias destinadas a la moralización de la población también fueron objeto de estudio. Federico Palomo (1997: 127), en el análisis de la historiografía cristiana y el disciplinamiento social, las encuadra bajo el título de "transmitir la virtud", es decir, la preocupación de la jerarquía por elaborar y transmitir modelos de vida y de comportamiento que permitan influir en las conciencias individuales y en la capacidad de generar parámetros de comportamientos sociales. Dichos modelos se transmitían mediante diversos medios, como la confesión, la difusión de una pedagogía católica, dirigida a la infancia y juventud. Se trataba de planteamientos pedagógicos que consideraban a la educación cristiana como un vehículo no sólo para la salvación del propio individuo, sino también para su formación dentro de una obediencia a la Iglesia, que se convierte, a su vez, en obediencia al poder político, que hace del discípulo un miembro disciplinado de la sociedad. El surgimiento de instituciones que, dirigidas a diversos públicos, están 
destinadas a la educación de la niñez y de la juventud, como las congregaciones o escuelas de catecismo y los colegios.

La enseñanza de la doctrina cristiana se constituyó en el instrumento más importante para la iniciación en el conocimiento de los principios fundamentales de la fe católica, a la vez que desempeñaba una función integradora dentro de la comunidad. De esta manera, "las lecciones de catecismo fueron una de las actividades que los prelados postridentinos trataron de impulsar dentro del ámbito parroquial, imponiendo tanto a los progenitores la obligación de enviar a las mismas a sus hijos, como a los curatos la exigencia de impartir dichas lecciones. En este sentido, Adriano Prosperi ha señalado la función educadora que debió desempeñar el clero parroquial, más importante incluso que la de los maestros de primeras letras" (Palomo, 1997: 130). Este carácter disciplinador de la instrucción doctrinal ha sido subrayado también en varios trabajos recientes, como los de Angelo Turchini y Miriam Turrini, sobre las escuelas de catecismo, cuya difusión se expandió enormemente después del Concilio de Trento por todas las diócesis católicas, en las que se impartía un cierto grado de alfabetización e instrucción religiosa a los alumnos, así normas relativas a las buenas costumbres, destinadas a otorgar herramientas para lograr un buen comportamiento.

Otro punto destinado al proceso de cristianización de la sociedad pos-tridentina tiene relación con las misiones ambulantes, llevadas a cabo por los jesuitas y capuchinos y cuyo fin era el afianzamiento de la fe en las comunidades rurales mediante la predicación intensiva, la enseñanza de la doctrina, la administración de los sacramentos y la celebración de las funciones religiosas. En el marco de los estudios referidos a la actividad misionera, en los últimos años cobró importancia el enfoque comunicacional, el análisis de las formas comunicativas utilizadas por los misioneros en la predicación, en las que se señalan sus formas características en el contexto de desarrollo -la ruralidad-, y se focalizan en los modos del lenguaje utilizados. Como señala Palomo (1997: 136), la historiografía italiana de los últimos años, vinculada a las prácticas de disciplinamiento social, ha puesto de manifiesto "el sentido que asume la acción desarrollada por la Iglesia católica en los siglos XVI-XVII, donde el carácter religioso aparece estrechamente ligado a una función 'política' que hacía de todos los instrumentos empleados por los agentes eclesiásticos, vehículos para la imposición de una disciplina social, basada en la obediencia".

Estas investigaciones se vinculan con aquellas que analizan la piedad popular, que buscaban identificar los elementos inmemoriales, transmitidos de generación en 
generación, y los de nueva creación, y la tensión generada por el compromiso entre la prescripción religiosa de las elites eclesiásticas, sobre todo en un período de reforma, y la demanda popular. Estos estudios tuvieron en Italia dos vertientes, una católica y otra laica. La primera - generada por De Rosa-, coloca en el centro de su problemática -hasta llevarla al conjunto de los comportamientos sociales y culturales-, al magisterio de la Iglesia, el papel del episcopado y del clero y la norma de la ortodoxia católica. Esta línea de investigación ha sido relativizada, incluso discutida por otros investigadores, más propensos a un enfoque en términos de etnología cultural o antropología histórica, que encuentran el punto de referencia en la obra de Ernesto de Martino, La tierra del remordimiento, quien, entre 1950 y 1960, desarrolló un enfoque muy diferente de la vida religiosa popular y de la cultura mágica campesina, sin referencia explícita a la ortodoxia de origen clerical, buceando en lo que denomina prácticas mágicas.

La antropología religiosa italiana, por lo tanto, se desdoblaba en dos versiones, la versión católica, con Giuseppe De Luca y Gabriele De Rosa, y la versión laica, con Ernesto de Martino y Antonio Gramsci. Sin embargo, en los dos casos, el acento está puesto en la religión campesina del sur de Italia, asociada a la magia y el arcaísmo. De la convergencia de la historia de las mentalidades y la antropología italiana nació el interés por la religión de las grandes mayorías, las estructuras del sentimiento religioso, la relectura de los grandes documentos del folklore y la etnografía (Lagrée, 2002: 44).

Las investigaciones traducen una ampliación considerable de perspectivas y problemáticas de la historia religiosa italiana, pero también reflejan problemas de articulación entre una historia religiosa renovada y una historia política retrasada, todavía hoy, centrada en la cuestión del Risorgimento y de la Unidad.

Un núcleo importante de trabajos se centra, para los siglos XIX y XX, en la renovación de la Iglesia romana y en las cuestiones relacionadas con los diversos catolicismos (liberal, ultramontano y social) y con el ejercicio de un rol unificador de la Iglesia romana sobre las diversas Iglesias de los estados de la península antes de la unificación italiana. Dos son, según Boutry (1986: 805), los polos en los que se asienta la renovación de la historia religiosa italiana, la restauración de la Iglesia romana, por un lado, y la renovación del catolicismo italiano, por el otro. A través de los estudios, se desprende, por un lado, la imagen de un catolicismo italiano profundamente pastoral, y, por la otra, independiente del Estado, incluso en ruptura con él. Estos estudios se desarrollan en el marco temporal del neo-guelfismo de 1840 a las protestas vehementes del pontificado de Pío IX. 
Estas investigaciones han dado lugar a una multiplicación de trabajos de reflexión política, religiosa y filosófica, que abordan un catolicismo considerado en sí mismo, sin finalidad apologética, y que tienen gran tradición de la historia de la cultura italiana. Conjugar un enfoque más amplio y más rico del hecho religioso con una sensibilidad más a fin al espíritu de época, tal parece ser la vía fecunda de la nueva historia religiosa italiana de los siglos XIX y XX. Así, a diferencia de la historiografía francesa, la italiana estuvo centrada, en primer lugar, en el estudio del movimiento católico como antecedente y explicación del auge de la democracia cristiana en la posguerra.

La renovación historiográfica de los años 80 significó un giro en los estudios religiosos italianos de los siglos XIX y XX, los cuales se desprendieron de una mirada exclusivamente política y adoptaron un sesgo social de lo religioso. El interés se manifiesta en el surgimiento de investigaciones locales y diocesanas sobre la "religión vivida". Este cambio de objeto, de la historia del movimiento católico a la historia social de lo religioso, se observa, por ejemplo, en la trayectoria de De Rosa (Montero, 2004: 268).

Los temas centrales de investigación en el campo religioso salieron en Ricerche di Storia Social e Religiosa, que dirigía Gabriele De Rosa y podrían agruparse en torno a tres grandes bloques: los estudios de las estructuras parroquiales, los trabajos monográficos diocesanos y del personal eclesiástico.

\subsubsection{Las estructuras diocesanas}

En cuanto a las investigaciones sobre las estructuras diocesanas, encontramos dos modelos. Uno, la estructura tradicional de la Italia meridional, que es una estructura antigua, independiente del poder episcopal, profundamente inscripta -económica, social y mentalmente-, en la existencia de las comunidades campesinas del Reino de Nápoles. La iglesia ricettizia apareció como una forma original y específica del catolicismo meridional, hasta su progresiva desaparición a lo largo del siglo XIX, los intereses y la sensibilidad religiosa de las poblaciones rurales del Mezzogiorno. Un segundo modelo tiende a tomar la evolución de la estructura parroquial italiana, simbolizada en la parroquia de Venecia, cercana al modelo creado por el Concordato Napoleón, manifiesta la permanencia de formas de ius-patronato laico heredadas del Antiguo Régimen. Fue el objeto privilegiado de los trabajos de Angelo Gambasin. Las estructuras diocesanas fueron estudiadas, sobre todo, desde la perspectiva de las relaciones de la Santa Sede con los diferentes Estados italianos, a través de los numerosos concordatos concluidos durante el transcurso del siglo XIX. 


\subsubsection{Las estructuras parroquiales}

Los trabajos de Gaetano Greco (2013: 3) sobre las estructuras parroquiales en Italia analizan las diferencias regionales de las parroquias italianas, fruto de diversos recorridos históricos, tradiciones y prácticas de gobierno muy diferentes tanto en el campo eclesiástico como en el civil. Estos recorridos condicionaron el devenir de la historia italiana. El autor sitúa la creación de la estructura parroquial en la edad media y, en particular, en las regiones centro-septentrionales, aunque reconoce su presencia en el sur de la península. En el medioevo italiano, las diócesis se articulaban en su interior en distritos menores llamados pievanati, o sencillamente pievi, los cuales comprendían una población de fieles y el territorio en el que éstos vivían. La parroquia aparece como una forma de organización capaz de tener una fuerte relevancia social mucho más allá de la Edad Media. En este contexto, la relación entre iglesias, parroquias y capillas adquiere capital importancia para la mejor comprensión de la dinámica de desarrollo en el centro y norte de la península.

En la antigüedad tardía y temprana edad media, el empeño de las autoridades eclesiásticas estuvo dirigido a distinguir dos categorías de edificios sagrados presentes en la campaña. Las pocas Iglesias públicas del siglo IX, dependientes de la cátedra episcopal, que gozaba de los derechos sacramentales del bautismo y la sepultura, contaba con un clero estable, tenía suficiencia económica, mediante la recolección del diezmo. El otro edificio era una multitud de iglesias menores, de fundación o propiedad privada, los derechos eran bastante libres y estaban sujetas formalmente a la primera (se trataba de basílicas, oratorios y capillas). Este sistema de capillas con pueblo duró largo tiempo en la Italia centro-septentrional, donde la escasa competencia territorial de la gran propiedad de fundación laica impidió que la capilla privada adquiriera funciones con cura de almas. Esta realidad constituye una singularidad italiana, pues en el resto de la cristiandad europea no era común que una iglesia rural estuviera sujeta a otra, pues cada una tenía la plenitud de los derechos sacramentales. A partir del siglo XII, comienza a denominarse, a estas parroquias rurales con plenitud de derechos sacramentales y cura de almas, parroquias. A partir del siglo XIII, los cambios demográficos, la construcción de villas nuevas y el incremento de la pastoral eclesiástica en la insistencia sobre la necesidad de los sacramentos, provocó una "revolución pastoral" que llevó a la multiplicación de capillas no dependientes, transformándose en parroquias con plena autonomía sacramental y cura con residencia estable. En esta evolución, las comunidades locales desempeñaron, con frecuencia, un 
papel decisivo, que activaron, ante las autoridades eclesiásticas, las solicitudes para la elevación del estado de sus iglesias (de capillas a parroquias) y asumieron los costos relativos al mantenimiento del clero y los gastos de construcción o ampliación de los edificios. En este rol decisivo de la comunidad local, jugó un papel importante el esfuerzo comunitario en favor de las agregaciones sociales y la emancipación política de los centros rurales. Se trató de un proceso que superó los límites de la edad media (Cruzel, 2010: 3).

\subsubsection{El personal eclesiástico}

Las investigaciones sobre el personal eclesiástico, tanto secular como regular, son abundantes. Estas pueden agruparse en función de las diversas regiones italianas. Para la región lombarda, contamos con los trabajos de Xenio Toscani; para la Italia septentrional, con los de Giovanni María Dal Molin; en tanto que los estudios para la Italia central son menos numerosos. La cuestión de la formación del clero es inseparable de la del reclutamiento. En este sentido, son interesantes las observaciones generales de Elena Brambilla.

Los debates sobre la formación del clero en los siglos XVI y XVII en Italia estuvieron vinculados a los conceptos de reforma católica y disciplinamiento y a los términos de identidad y profesionalización del sacerdocio. Un instrumento imprescindible para lograr una homogenización del clero fueron los seminarios, impulsados por Trento. En este campo, la historiografía también debatió sobre los "éxitos" o "fracasos" de la reforma tridentina. Como señala Maurizio Zangalli (2007: 103), "ha llegado el momento de poner en común los resultados obtenidos y de explotar las posibilidades ofrecidas por nuevas fuentes, por un uso diferente de las antiguas y por nuevos panoramas historiográficos que se han abierto en los últimos años”. Los trabajos de Zangalli sobre el clero plantean la necesidad de dar un paso adelante y dejar atrás los antiguos debates, teñidos de valoraciones ideológicas.

Parece que ha llegado ya el momento de abandonar, por parte de la historiografía católica, la reprobación de las malas costumbres del clero para dar todavía más realce y aureolar los resultados alcanzados por las reformas; y, por parte de la historiografía laica, la acusación más o menos indignada hacia una Iglesia que habría malogrado su deber y que habría mantenido a las masas de fieles conscientemente bajo su sujeción sin procurarles lo necesario para elevarse social y espiritualmente. Parece que tanto en un caso como en otro actúan consideraciones y valoraciones que exceden el ámbito histórico: si el sacerdote fue como fue, o permaneció como tal largo tiempo durante los siglos XVI y XVII, es ciertamente 
porque se malograron las misiones renovadoras de tantos prelados, porque no todos supieron ser santos como Carlos Borromeo, así como, ciertamente, por la voluntad centralizadora de Roma, que dejó menos espacio a la iniciativa en el ámbito local, pero también, y sobre todo, porque con aquello se contentaba, o mejor, no pedía otra cosa, la sociedad en la que aquel sacerdote se encontraba actuando, y por los necesarios compromisos que Iglesia y Estados debieron aceptar dentro de una lógica pesadamente condicionada por el fenómeno macrohistórico de la carrera hacia la estatalización, hacia la sacralización del aparato público, hacia la centralización de los poderes (Zangalli, 2007: 106).

Esta cuestión nos lleva a pensar, sostiene Zangalli, en qué medida el lastre de aquella Iglesia tan laica -cuyas raíces se hunden en los siglos bajomedievales- inhibió también una innovación importante como la erección de los seminarios, más allá de las intenciones de los obispos, prelados de la curia y autoridades laicas. Y en esa clave retoma la pregunta que se hacía Domenico Sella (2000: 157) en un importante trabajo sobre la Italia del siglo XVII: “¿podía la Iglesia, podían los Estados, no adaptarse a situaciones relativas a las estructuras sustentantes y de largo período de las sociedades con las que tenían que habérselas? Y, al fin y al cabo, ¿no se ha tratado de un 'intercambio bilateral' que poco a poco modificó aquel sistema y, con los tiempos largos de los cambios histórico-económicos e histórico-sociales, además de históricoeclesiásticos, activó dinámicas de cambio, obviamente sólo en el momento en que ciertas exigencias se conjugaron con momentos de viraje en el seno del entramado social?". Esta mirada cuestiona la imposición unilateral de la obediencia que se le atribuye a la iglesia y propone analizar la manera, los modos, en que obtiene tal obediencia, en un juego dialéctico entre alto/bajo donde se establecen puntos de convergencia entre ambos polos y se identifica lo alto con el poder y lo bajo con la sociedad.

En cuanto al clero regular, desde hace algunos años ha sido objeto de estudios sistemáticos, particularmente en este contexto de supresiones y de renovación de los establecimientos de regulares que caracteriza a Italia en el período de la Restauración.

\subsubsection{España}

Por su parte, la historiografía religiosa española revela un importante retraso respecto de la francesa e italiana. Según Feliciano Montero (2004: 271), el reto principal, desde el punto de vista institucional, consiste en desconfesionalizar y secularizar la investigación. El autor presenta un balance de la historia religiosa 
española en el cual advierte la influencia de la historiografía francesa en el impulso que tomó la historia religiosa española en los últimos 30 años.

La colección de la Casa de Velázquez da cuenta de esta estrecha y fructífera relación. El volumen $n^{\circ} 87$ de 2004, titulado "L'histoire religieuse en France et en Espagne", reúne una serie de trabajos agrupados en tres grandes secciones: la primera, "Méthodes, Archives et Enjeux", la segunda, "Les échelles et les espaces, paroisses, diocéses, congregations, mouvements de laïcs" y la tercera, "Nouvelles relectures et perspectives de recherches". La publicación constituye un interesante balance sobre el estado de la cuestión de las diferentes temáticas de historia religiosa. El volumen fue el resultado de un coloquio destinado a comparar la producción religiosa entre ambos países.

La sección dedicada a las parroquias y al clero parroquial tiene dos artículos, uno de Philippe Boutry, "Paroisse et clergé parroissial en France", y el otro de Antón Pazos, "Parroquias y clero parroquial". En este texto, el autor señala tres grandes líneas de investigación en relación a la temática planteada, el número de clero parroquial, la formación que recibieron y su acción pastoral.

Sería una tarea que excede el objetivo de este trabajo presentar una evolución de la historia religiosa española, sin embargo consideramos importante mencionar a uno de sus mentores, Antonio Domínguez Ortiz. El número monográfico de la Revista "Historia Social", publicada con motivo de su fallecimiento, lo denomina "historiador social”. En la introducción al dossier, advierte que el eje conceptual de los trabajos no fue la clase social, ya que siempre creyó que la complejidad de las relaciones sociales no se podía encerrar en el mero conflicto o lucha de clases. Siempre se interesó por lo económico y se adelantó en el tratamiento de temas que luego serían abordados por la historia de las mentalidades. Analizó variables del comportamiento social como el honor, el prestigio, el clientelismo familiar. En el campo de los grupos sociales, la investigación de Domínguez Ortiz se centró en la nobleza y el clero, los estamentos privilegiados. Su obra maestra fue La sociedad española en el siglo XVII. También, El estamento nobiliario (1963) y El estamento eclesiástico (1970), que luego refundiría en su libro Las clases privilegiadas en la España del Antiguo Régimen (1973). El siglo XVIII sería abordado en La sociedad española del siglo XVIII (1955).

En el dossier de la revista, Arturo Morgado García dedica un trabajo al tratamiento del clero que realiza Domínguez Ortiz. A partir de este maestro, se abrió una serie de líneas de investigación vinculadas al clero. En función de nuestro interés, particularmente importante nos resultó la consulta del trabajo de José Manuel Cuenca 
Toribio, Sociología de una elite de poder de España e Hispanoamérica contemporáneas (1976), que analiza la jerarquía eclesiástica entre 1789 y 1966; también, los trabajos de María Luis Candau Chacón (1993), vinculados a una historia social del clero sevillano del siglo XVIII, y los de Arturo Morgado García (2000 y 2006).

El interés por lo periférico y lo marginal suscitó el estudio por el clero de campaña, planteando interrogantes respecto al mundo clerical comprendido por clérigos sin oficio ni beneficios -curas sueltos-, por capellanes y por auxiliares de parroquias. Un universo desarticulado, difuso y difícil de identificar, debido, entre otras cosas, a su gran movilidad social. Los trabajos de Avelina Benítez Barea ayudaron a pensar el clero rural parroquial, en particular su libro El bajo clero rural en el Antiguo Régimen (Medina Sidonia siglo XVIII (2001), sobre todo el capítulo dedicado al clérigo y su entorno. También, los textos de Joan Bada Elías (1994), María Teresa Benito Aguado (1994) y Catalina Valenzuela García (2006).

Para el clero contemporáneo, son de particular importancia los trabajos de Antón Pazos sobre el clero navarro entre 1900 y 1936, fruto de su tesis doctoral (1990), y el de Manuel Revuelta González, "Clero viejo y clero nuevo en el siglo XIX” (1979). Algunos obras más generales, vinculadas al estudio de la Iglesia en la España moderna, son las de Andrés Gallego y Antón Pazos (1999) y la de Enrique Martínez Ruíz y Vicente Suárez Grimón (1994), Iglesia y Sociedad en el Antiguo Régimen (vol. I), de la cual destacamos los capítulos de María Teresa Benito Aguado, que analiza las perspectivas de abordaje del clero en relación a la historia social; el de Jesús Bravo Lozano, "Clero rico, clero pobre"; el de Joan Bada Elías, relativo al clero secular; y el de Tomás Mantecón, que analiza la capacidad del clero secular para morigerar disputas entre los campesinos montañeses del siglo XVIII.

Como hemos visto, existen excelentes balances de historiografía religiosa en los espacios arriba mencionados, ${ }^{7}$ que nos permiten concluir que la historia religiosa ha presentado una importante renovación metodológica que ha hecho posible la inclusión de temáticas religiosas y espirituales en los ámbitos epistemológicos e institucionales de la historia globalmente considerada (Aurell y Pérez López, 2006: 15). Por último, queremos señalar que la revisión que aquí se presenta no pretende ser, en ningún caso,

\footnotetext{
7 Pueden consultarse los siguientes balances, en BARRIO GOZALO (1990); ZIEGLER (1996); GALLEGO y PAZOS (1999); LAGRÉE (1999, 2002 y 2004); CORTÉS PEÑA, LÓPEZ y MUÑOZ (2007).
} 
exhaustiva, de hecho, hemos optado por presentar únicamente los trabajos que nos han sido de mayor utilidad a la hora de plantear y desarrollar nuestra investigación.

\subsection{Historiografia religiosa americana y argentina}

El campo de renovación de la historia política tuvo gran impacto en el estudio de las independencias iberoamericanas (Demélas y Saint-Geours, 1988; Brading, 1994; Taylor, 1999; Di Stefano, 2000 y 2004; Enríquez, 2005; Ayrolo, 2006; Connaughton, 2010). Uno de los aspectos que atraviesa la renovación de los múltiples campos de la historia política (instituciones, estado y formas de gobierno, relaciones internacionales, dominación y guerra), son las diversas relaciones entre religión y política, relación que emerge como una de las formas innovadoras de acercamiento a lo político (entendido como un universo abierto y su interacción con las representaciones que participan en la formación de la conciencia individual). Poder, religión, política y conciencia se entrecruzan y entretejen (Cárdenas Ayala, 2007: 197).

Quizá uno de los textos que fue punta de lanza en este campo sea el de William Taylor (1999), Ministros de lo Sagrado, texto que a la hora de estructurar nuestra tesis nos abrió una perspectiva interesante. El trabajo analiza la cultura política tardo colonial, en la que la religión y los sacerdotes fueron parte integral de la misma. El libro está organizado en tres partes. En la primera, aborda su objeto de estudio, la arquidiócesis de México y la diócesis de Guadalajara con un título por demás sugestivo: "La política, el lugar y la religión presenta el espacio geográfico diocesano". En la segunda, analiza a los curas párrocos como grupo social, sus orígenes, sus formaciones y sus carreras. En la tercera, se dedica a los feligreses. Y en la cuarta, analiza la política de la vida parroquial. Todas y cada una de estas partes se vinculan a las relaciones entre tres actores centrales del proceso, el gobierno, el clero y los feligreses. Al analizar a los curas párrocos, los presenta como auténticos mediadores "los curas párrocos fueron figuras significativas, dotadas de un poder social y espiritual formalizado mediante ritos de diferencia y obediencia. En cuanto expertos del lenguaje sagrado, de la escritura y de los ritos de paso, se esperaba de ellos una mediación no solo entre el hombre y Dios sino también entre los miembros de una sociedad colonial dividida y multirracial" (Taylor, 1999: 22).

Una de las problemáticas que atraviesa los estudios político-religiosos es el proceso de secularización que experimentan las repúblicas americanas a lo largo del siglo XIX. Para el caso de Chile, el libro de Sol Serrano ¿Qué hacer con Dios en la República? 
(2008), se inscribe en la renovación de la historia política. La autora enmarca su análisis en el proceso de secularización de América Latina. Su afirmación de que "es preciso estudiar la secularización en América Latina como proceso y no como progreso" fue un primer disparador para analizar la cuestión. Cuando afirma, luego de un denso estudio empírico, que la secularización en América Latina, y específicamente en Chile, no produjo una declinación de la fe religiosa, como sí sucedió en Europa, y que, por lo tanto, las teorías de la secularización son eso, teorías válidas para cualquier sociedad que vive un proceso de "modernización", que es necesario historizar. Para la autora, el proceso de secularización en Chile, durante el siglo XIX, si bien supuso la separación del catolicismo del Estado, no significó un retroceso para la Iglesia, ni un alejamiento de la sociedad de la religión, por el contrario, fue un fenómeno muy positivo que permitió una inserción comprometida y eficaz del catolicismo en la esfera pública moderna. Al instalarse la Iglesia chilena en un nuevo espacio público fuera del Estado, se convirtió en la fuerza más sólida de la sociedad civil, por lo tanto, la secularización, en lugar de perjudicar, fortaleció a la Iglesia y al catolicismo.

Para el caso mexicano, Elisa Cárdenas Ayala analiza la revolución mexicana (19081913), desde Jalisco, en el contexto del "derrumbe" del porfiriato y el ascenso del maderismo. La autora analiza el movimiento católico liberal y democrático y las herramientas y estrategias utilizadas en el conflicto. Entre ellas, destaca a la prensa como expresión política de un sector católico, imbuido de la rerum novaroum y el catolicismo social. Lo interesante del trabajo radica, entre otras cuestiones, en la mirada regional del proceso y, desde ese lugar, la puesta en tensión de las visiones dominantes de la revolución mexicana, además, incluye a algunos sectores vinculados al catolicismo, como los operarios guadalupanos, que desembocará en la creación del Partido Católico Nacional (1911), “transformado en movimiento armado, atrajo sobre todo a los medios rurales, que le aportaron sus propias reivindicaciones".

En esta línea de análisis, que busca mirar los procesos políticos desde la óptica de la secularización y los procesos de laicización, se encuentran los trabajos de Roberto Di Stefano, en particular su libro Ovejas Negras (2010).

Las biografías colectivas son un campo que comienza a desarrollarse. Un ejemplo es el trabajo de Marie-Danielle Demélas e Yves Saint-Geours sobre el siglo XIX en Ecuador. Demélas toma tres biografías: la de Eugenio Espejo, Vicente Rocafuerte y García Moreno. El primero, un hombre de transición, pertenece a la segunda mitad del siglo XVIII y su vida alcanza a proyectarse hasta comienzos del siglo XIX; el segundo 
es el hombre de la primera mitad del siglo XIX, y, a través del tercero, se puede tener una idea de lo que fue la segunda mitad de ese siglo. El texto supone un estudio que analiza el lugar de la religión en la construcción del poder en un Ecuador surcado por el personalismo político y el caudillismo. Es sumamente interesante el planteo que se hace de la religión como elemento configurador del poder. En el caso de García Moreno, su tarea fundamental fue la consolidación del estado nacional (Demélas y Saint-Geours, 1988: 148), ejerciendo su gobierno en pleno período del proceso de romanización de las iglesias americanas. Los autores muestran claramente cómo el caudillo toma la religión como base de sustentación de su poder y le otorga a la Iglesia un lugar preeminente en el proceso de modernización social y económica del país. "El análisis preciso de las relaciones entre el Presidente y la Iglesia de su país, demuestra que el (poder) civil no estuvo realmente subordinado al religioso. Además la apertura de los archivos vaticanos ha dejado entrever la importancia del conflicto que enfrentó el pretendido teócrata con el clero. Por tanto, la Iglesia católica no estaba destinada solamente a inspirar un estado clerical, ella fue en realidad el instrumento de un proyecto nacional con miras a la consolidación del Estado, que García Moreno había captado muy bien [...] La Iglesia trabajará bajo la autoridad del dictador, articulando los grupos sociales opuestos, paliando las flaquezas de una administración ineficaz, educando a una población menos alfabetizada, desde la caída de las estructuras coloniales" (Demélas y Saint-Geours, 1988: 163).

En Argentina, la historia religiosa ha sido durante años patrimonio de la historiografía confesional católica y, con frecuencia, estuvo limitada a la historia institucional de la Iglesia, las definiciones teológicas y las controversias doctrinales. Por tanto, era una historia autónoma y, en cierta medida, desligada de la historia de las sociedades y más ligada a la teología. Sin embargo, en los últimos diez años aparecen cuestionamientos serios a este tipo de historiografía que ha despertado el interés en medios académicos ajenos a la iglesia católica e, incluso, en algunos casos tradicionalmente críticos respecto a ella.

Roberto Di Stefano presenta algunos balances de la historiografía eclesiástica que, a grandes rasgos, ofrecen una visión de su evolución en Argentina. Esta historia aparecía como una historia eclesiástica que podía leerse en forma paralela a la historia nacional o sólo vinculada a ella por las intervenciones que hubiera hecho el Estado en "sus cosas" (Di Stefano, 2002: 173-202; 2005: 111-116). Ejemplos de ello son los clásicos trabajos del padre Cayetano Bruno, Historia de la Iglesia en Argentina (doce volúmenes), 
fuertemente institucionalista y organizada en torno a los avatares de la jerarquía a través del tiempo, o la obra más general de Juan Carlos Zuretti, Nueva Historia Eclesiástica Argentina. En este sentido, es importante rescatar aquellos trabajos pioneros, que analizan la organización territorial, la estructura, composición, organización y estrategias eclesiásticas en su relación, especialmente conflictiva, con el Estado (Auza, 1983 у 1987).

Las producciones pioneras sobre historia religiosa argentina han venido de la mano de los sociólogos. La sociología religiosa argentina ha desarrollado varias líneas de investigación en torno del grupo de trabajo del CEIL PIETTE. Una de ellas se concentró en los aspectos político-ideológicos de los años treinta en adelante. Fortunato Mallimaci (1988b) analizó la creación y la metamorfosis del catolicismo "integral" argentino durante la aparición del peronismo. Otra línea de investigación desarrollada por este grupo hace referencia al vínculo entre religión y modernidad. En este campo, cabe destacar el texto Modernidad, Religión y Memoria de Mallimaci (2008).

En el campo de la historia, un ejemplo de la renovación historiográfica es el libro de Roberto Di Stefano y Loris Zanatta, La Historia de la Iglesia en Argentina, texto que nos ha sido de gran utilidad, pues si bien es una obra general, los autores nos introducen en uno de los temas que nos convoca, que es el proceso de romanización de la Iglesia argentina. Ambos autores plantean el impacto de este fenómeno desde una mirada centrada en la problemática porteña y esbozan, con algunas pinceladas sugerentes, el modo en que el proceso se desarrolló en el interior del país. El trabajo centra su atención en la Iglesia de Buenos Aires y hace referencia a las Iglesias del interior, desdibujándose, en algunos casos, las particularidades de las comunidades religiosas locales, que quedan subsumidas en la entidad nacional. La lectura del citado trabajo sugiere que el proceso de romanización alcanzó un punto sin retorno con la elevación de Buenos Aires a la categoría de Archidiócesis (1865). Este acontecimiento marcaría el paso de la pluralidad de iglesias a la unidad, de la autonomía de las diócesis, entendidas como verdaderas iglesias particulares, a lo que hoy conocemos como Iglesia argentina, "una institución cada vez más autónoma y en conformidad a los tiempos modernos, preparada además para influir sobre el nuevo curso de la historia nacional" (Di Stefano y Zanatta, 2000: 303-310). Algunas de las hipótesis formuladas por los autores han sido de suma utilidad y serán motivo de análisis y comparación a lo largo de nuestro trabajo. 


\subsection{Historiografía religiosa cordobesa}

A nivel provincial, la historiografía muestra una producción aún incipiente y sumamente focalizada, relacionada sólo con algunos aspectos específicos y concretos. Las cofradías y congregaciones asentadas en las Iglesias de Córdoba en el período colonial han sido abordadas por Ana María Martínez (2000, 2006, 2007).

Los trabajos de Silvano Benito Moya han buscado superar no sólo las divisiones entre las esferas laicas y eclesiásticas, sino también la división entre la historia de la sociedad y de las ciencias de lo divino (teología, liturgia, derecho canónico). Sus trabajos se insertan en el campo de la cultura escrita, concretamente en el de la cultura teológica de las elites letradas de la Universidad de Córdoba del Tucumán. Su objetivo ha sido demostrar que la universidad colonial buscó también dar solución a los problemas políticos y sociales desde la teología. La Universidad contribuyó a solidificar un determinado orden social y una cultura legítima y a sujetar los lazos de los súbditos para con sus soberanos, ligando mejor a la sociedad con el aparato de dominación (Benito Moya, 2013: 309). En su trabajo "Filosofía, Teología y Cánones en el Río de la Plata" sobre el estudio de la Teología en América Latina, procura rescatar el pensamiento de seis profesores jesuitas de la Universidad de Córdoba en el siglo XVII. En ellos se perciben las preocupaciones propias de su siglo, en sus escritos asimilan las doctrinas filosóficas y teológicas de su tiempo y ofrecen una síntesis didáctica para sus estudiantes universitarios. Algunos intentan no apartarse de la escuela teológica jesuítica, teniendo a Francisco Suárez como su principal representante, pero en sus conclusiones o resolución de argumentos se acercan a tesis anselmianas o escotistas. Otros, en cambio, plantean un eclecticismo en la búsqueda de resoluciones propias a los problemas teológicos y canónicos de su tiempo (Benito Moya, 2005: 366).

El proceso de las autonomías provinciales es tomado por Valentina Ayrolo en su libro Funcionarios de Dios y de la República. Clero y política en la experiencia de las autonomías provinciales. En él, aborda el complejo proceso de formación del Estado provincial cordobés durante el período 1820-1852, centrando su mirada en la relación entre el Estado y la religión; analiza el proceso a partir de la conciencia y la voz del propio clero, actor legitimado y convocado por el poder civil, aceptado y respaldado por la gente. El texto considera la institución eclesiástica como la ventana a través de la cual es posible penetrar en la complejidad del mundo social y el clero secular se convierte en la vía privilegiada de ese acceso. Ayrolo se interna en la vida política de la provincia de Córdoba durante la primera mitad del siglo XIX, examina las complejas relaciones entre 
la Iglesia y el Estado en una sociedad en la que los poderes civiles y eclesiásticos se fundían en una amalgama político religiosa, constituyendo lo que Ayrolo denomina una "Provincia-Diócesis". El trabajo parte de una premisa clara, descentrar el análisis y abordar - desde una mirada regional- las causas de formación y consolidación del Estado provincial, recuperando las especificidades propias. En el caso de Córdoba, este recurso le permite ponderar matices, puntualizar diferencias y visualizar particularidades en un proceso que la historiografía tiende a homogeneizar a partir de una mirada centrada en el puerto.

El texto de Ayrolo se estructura en tres partes. La primera centra su análisis en el Patronato, uno de los mecanismos que utilizó la elite cordobesa para garantizar su legitimidad política. Los tres capítulos que componen esta primera parte muestran un abanico de cuestiones: la dimensión simbólica de las prácticas involucradas en la construcción, conservación, reproducción y legitimación del poder, las relaciones de alianza y oposición, de autoridad y subordinación del alto clero secular y las elites dirigentes. Sostiene que el clero fue el heredero de la única legitimidad que no fue puesta en duda en la convulsión revolucionaria y que continuará siendo el depositario del sentido moral católico romano de la sociedad. El modelo de sociedad y de Estado propuesto se asentó más en el pasado que en el futuro, de manera tal que los hombres de la Iglesia "se convirtieron en los referentes de una sociedad cuyo imaginario era aún de antiguo régimen" (Ayrolo, 2007: 17). Se trató de un grupo que se encontraba estrechamente vinculado a la élite dirigente, cuyos miembros pertenecían al mismo sector socioeconómico, habían sido formados en las mismas aulas, compartían filiaciones familiares y negocios, tenían identidad, unidad de principios y objetivos. La autora reconstruye la acción del grupo clerical a través del ejercicio de sus funciones y actividades, las redes de relaciones, las estrategias de mediación social y la acción política, demostrando que, para algunos, la carrera eclesiástica se convertía en un mecanismo de acceso a la elite local.

$\mathrm{Al}$ analizar las prácticas efectivas del patronato, Ayrolo nos introduce en el complejo mundo de las relaciones de poder de una diócesis que califica de pluri-estatal, debido a la superposición de jurisdicciones, civiles y eclesiástica. Profundiza el análisis sobre la capacidad y la forma en que los gobiernos hicieron uso de la prerrogativa del patronato, situación que acarreó la existencia de muchos patronatos en una sola diócesis. El patronato se constituyó en una herramienta clave que permitió a los sectores dirigentes el mantenimiento de la unidad cultural a través del resguardo de la identidad católica 
romana. La forma del ejercicio del patronato remite a una cultura política, entendida no sólo como un sistema de símbolos y significados, sino también como una práctica; un repertorio de competencias, un régimen de racionalidad práctica y un conjunto de estrategias que guiaron la acción, a través de la cual también se movilizaron los símbolos. La autora explica cómo la elite utilizó estos mecanismos en la construcción de la legitimidad política, reapropiándose de los recursos simbólicos a su alcance, construyendo, por ejemplo, la imagen de un papado a la medida de las necesidades locales, en un período en que la Santa Sede era lejana y estaba prácticamente ausente de la vida cotidiana de los habitantes de Córdoba, la elite dirigente fue capaz de crear una imagen del pontífice que le servía a los fines de mantener la unión entre los fieles, el clero local y el Papa.

En la segunda parte de su libro, "Clero y feligresía, un juego de espejos", la autora nos introduce en la visión que tenían los fieles de su clero y viceversa. Para ello, recurre a la voz de los propios actores, a través de cartas, denuncias, quejas, reconvenciones y juicios, para reconstruir el perfil del clero, un clero escaso y disperso, más empobrecido y menos cultivado que el de la generación del período revolucionario, compuesto por sacerdotes que no siempre llevaron una conducta ejemplar. Sin embargo, esas acciones, en ocasiones desviadas de la norma, no tuvieron una repercusión negativa en la sociedad política debido al lugar que en ella ocupaban la Iglesia católica y la religión: ellas eran el pilar, el sostén, que daba coherencia al orden social y el clero era el cuerpo profesional encargado de salvaguardarlo (Ayrolo, 2007: 233).

En la tercera parte, analiza la estructuración del nuevo orden político y la relación entre lo secular y lo religioso en el contexto de las autonomías provinciales. Ayrolo entiende que en el sistema político imperante, los gobiernos cordobeses pretendieron servirse de la Iglesia, considerando a sus hombres -el clero secular- como funcionarios y custodios morales del nuevo orden, concluyendo que "el clero cordobés no sólo hizo posible que la religión fuese el cemento social y la base moral de la virtud ciudadana, sino que colaboró de forma invalorable e incuestionable con la construcción de la provincia-diócesis, ayudando a hacerla creíble y fiable" (Ayrolo, 2007: 212).

El trabajo llena un vacío en la historiografía provincial, abordando el estudio de un grupo social, el clero secular, sin el cual, dadas las características peculiares de Córdoba, resultaría imposible entender de manera cabal la vida política de esta jurisdicción durante la primera mitad del siglo XIX (Gallardo, 2008a: 385-390). 
El aporte de Silvia Roitenburd (1980 y 2002) respecto a la influencia del catolicismo en la vida política y cultural provincial es muy interesante. Sin bien la autora no se aboca a la realidad estrictamente eclesiástica, estudia una fracción de la Iglesia de Córdoba, el alto clero y el laicado intelectual, actores de primera línea en la construcción de la cultura católica cordobesa. A su parecer, estos actores desplegaron una práctica que delineó un proyecto global de nación basado en la imposición de valores restrictivos, adhiriendo a corrientes de matriz eclesiástica integrista y desarrollando una ofensiva antiliberal. Se trata de un interesante análisis políticoideológico del discurso del nacionalismo católico cordobés. Este trabajo nos permite acercarnos a la acción del laicado católico principalmente en dos campos, la educación y la prensa. La acción del laicado católico, junto al accionar del clero, fue uno de los aspectos nodales de la romanización, razón por la cual dicho trabajo adquiere particular interés.

Una de las dimensiones de la romanización consistió en el desplazamiento de la acción eclesiástica hacia la problemática social, dando origen a lo que se denominó "el catolicismo social". La jerarquía promovió la creación de organizaciones católicas destinadas a la formación y ayuda a los trabajadores. En Córdoba, aún son incipientes los trabajos que se asoman al estudio de este nuevo asociacionismo católico decimonónico. El trabajo de Pablo Vagliente (2002) sugiere algunas líneas de abordaje interesantes al analizar los modelos asociativos desde dos perspectivas fundamentales: los modos diferenciados de pensar los objetivos institucionales y los modos de organización interna de dichas asociaciones. Una de las asociaciones estudiadas fueron las cofradías. Para el autor, las del siglo XIX fueron una respuesta ideada para frenar la amenaza liberal en su proyecto de Estado-Nación (separación estricta Iglesia-Estado), la ideología antirreligiosa y anticlerical (de asociaciones masónicas, ante todo) y la acción disociadora de los grupos más radicalizados de la sociedad. Resulta particularmente interesante la hipótesis sostenida por el autor respecto a la incorporación del factor religioso en la conformación de lo público. Sobre esta cuestión, Vagliente señala que las asociaciones civiles creadas con fines explícita o implícitamente religiosos, que ocupan la escena pública, terminan por responder claramente a un patrón de modernidad. Se trata de asociaciones voluntarias que median entre el Estado, la Iglesia y la sociedad, que establecen, en el orden interno, relaciones signadas por la igualdad y la capacidad de los laicos para la acción social responsable. 
Desde una perspectiva político-institucional, Gardenia Vidal (2006, 2010 y 2011) se asoma al análisis del Círculo de Obreros Católicos de Córdoba. A través de sus actas de sesiones ordinarias, la autora reconstruye la composición, el número de socios y las actividades principales de la institución. En trabajos posteriores, se adentra en las relaciones más personalizadas y cotidianas de los miembros de la institución, en los que procura reconstruir los estilos de sociabilidad que se impulsaron desde ella. La misma autora aborda otra asociación, nacida a la sombra de la romanización, la Unión Popular Católica Argentina.

En un artículo, Pablo Biderbost y Lucas Utrera (2004) analizan la misma institución desde una perspectiva estrictamente sociológica. A los autores les interesa conocer las cualidades culturales que conformaban las actividades de esos centros. Visualizan a los círculos obreros como instituciones creadoras de cultura e instrumentos de dominación y concluyen que se constituyeron en una importante instancia que sirvió para impulsar el apostolado social de los laicos.

En el marco del proceso de romanización, especial trascendencia adquiere la preocupación de la jerarquía por formar, modelar y unificar el laicado católico a fin de garantizar la eficacia de su accionar. El laicado se había caracterizado por ser un grupo de gran heterogeneidad y de actuación sumamente dispersa. En esta etapa, comenzó a surgir como un nuevo actor eclesial y social. Los trabajos de Jessica Blanco (2005, 2008, 2012) analizan una de las instituciones laicales más importantes del período, la Acción Católica de Córdoba. Blanco se propone la reconstrucción de esta institución haciendo hincapié en su estructura, organización, funcionamiento y transformaciones; analiza el peso y la significación que tuvo, no sólo en el campo católico, sino en la conformación de la cultura política cordobesa.

Como puede observase, los avances historiográficos en relación a la problemática eclesiástica han sido significativos. Un punto central de los mismos ha sido insertar el análisis de los procesos eclesiásticos en el marco de transformaciones más amplias.

\subsection{Debates que atraviesan el campo de la historia religiosa}

Este recorrido por la historiografía religiosa, nos permite plantear algunos de los debates que han atravesado el campo y, de alguna manera, siguen orientando las investigaciones más recientes. Estos debates se han centrado -para Christian Sorrel-, en tres grandes cuestiones, a las que podría agregarse una cuarta, propuesta por Dominique Iogna-Prat. 
En primer lugar, el fenómeno de la descristianización, iniciado por Gabriel Le Bras. El debate se centra en la pertinencia misma del concepto y en la periodización del fenómeno. La problemática se mueve del tiempo corto de la revolución industrial a la larga duración, de la descristianización a la cristianización, rebatido por Jean Delumeau, de un modelo de desafección lineal e irreversible referido a la Revolución Francesa, a un esquema de flujo y reflujo, propuesto por Gerard Cholvy e Yves-Marie Hilaire, que insisten en las diferencias regionales y revisan evidencias demasiado fácilmente aceptadas como la descristianización de la clase obrera (Sorrell, 2004: 253-254).

Se cuestiona también la excesiva dependencia del análisis sociológico, de las normas institucionales y su escasa pertinencia respecto a grupos religiosos minoritarios, pues esta herramienta de medición, que reveló ser pertinente para un catolicismo de obligación cultural, no resulta útil para el posterior estudio del protestantismo (Lagrée, 2002: 54).

La tercera crítica radica en la exterioridad de los enfoques respecto de las creencias, representaciones y discursos. Estas críticas se relacionan con el segundo debate, referido a la devoción popular, en la encrucijada de la reflexión del lugar de lo sagrado en la Revolución Industrial, aquí se inscriben algunas proposiciones de la historia de las mentalidades, que investiga el campo de las creencias religiosas, rechazando el criterio de "ortodoxia". En cuento a épocas más contemporáneas, los especialistas dudan entre una interpretación limitada de religión popular, forma de sacralidad de la sociedad rural tradicional, y una interpretación englobante, que la identifica con la religión vivida y pone el énfasis en su aptitud de renovarse y ser vector de internalización del cristianismo, según el modelo devocional ultramontano de mediados del siglo XIX.

El tercer debate, se organiza alrededor de la relación del catolicismo con la modernidad política y social, muy especialmente alrededor de discurso intransigente. Jean-Marie Majeur fue uno de los primeros en señalar la insuficiencia del esquema de interpretación dualista (derechas-izquierdas, intransigentes-liberales, conservadoresprogresistas). Emile Poulat, sociólogo preocupado por modelizar las estrategias frente a la modernidad, insiste en la existencia de un conflicto entre socialismo, liberalismo y catolicismo intransigente.

El cuarto debate, del cual habla Iogna-Prat, es el de las relaciones entre la "Nueva Historia" y la "Historia Positivista" del siglo XIX. Señala que no se debe juzgar solamente a la "escuela positivista" con la vara de su erudición, que era grande, y de su sentido "crítico", que era agudo. De lo que se trata más bien es de la concepción de la 
dinámica de una sociedad y los encasillamientos propuestos por la "antropología histórica" de todos estos puntos. Los trabajos actuales marcan avances innegables, no importando si ellos ceden tarde o temprano su lugar a nuevos conceptos historiográficos. Pero, sobre todo, hay que llamar la atención sobre la importancia de la ruptura heurística de comienzos de siglo: viejo o no, el positivismo y sus certidumbres teóricas fueron condenados por la concepción relativista del saber científico, que se impuso entonces, y que nutre todavía hoy nuestra reflexión (Iogna-Prat, 2002).

\section{El clero secular como campo de estudio}

Consultada y analizada la producción historiográfica referida al clero secular desde una perspectiva social, lo hemos organizado en cuatro grandes núcleos que, de alguna manera, han repercutido en las investigaciones sobre el clero americano. Nos referimos a: a) los estudios biográficos; b) El alto clero y formación de élites; c) el bajo clero; y d) clero e inmigración.

\subsection{Los estudios biográficos sobre el clero}

Los especialistas de lo religioso no abandonaron nunca el estudio biográfico, a pesar del lastre de la hagiografía y de los ataques de la escuela de Annales, especialmente en tiempos de Braudel, contra un género considerado falto de pertinencia epistemológica y a pesar del desplazamiento del interés de las elites hacia el pueblo.

La biografía ha sido uno de los campos de elaboración de las metodologías innovadoras en la historia religiosa, en consonancia con la renovación producida en la historiografía en general (Lagrée, 1999: 418). Esto puede comprobarse en el caso de la tesis de Jean-Marie Mayeur-søbre la biografía del abad Lemire, publicada en 1968. E1 autor ve a su personaje como representativo de un medio particular, el de los católicos franceses bajo la Tercera República. Lemire fue un sacerdote parlamentario de una circunscripción en el norte de Francia, elegido durante 35 años para ocho legislaturas, se singularizó por su compromiso con el mundo político y por la duración de su arraigo electoral. Si bien sus ideas sociales y políticas no fueron de una gran originalidad, o singularidad especial, la restitución de su trayectoria biográfica constituye un apoyo para mostrar mejor cómo ciertos medios católicos sociales respondieron a las peticiones de su tiempo.

François Dosse (2007: 208) advierte que "en muchos sentidos, en efecto, el hombre es representativo. Cuando está aislado, ese mismo aislamiento es revelador”. El trabajo 
de Mayeur, como bien señala Sorrel (2004: 255), está atento a trazar la coherencia o las rupturas de un itinerario que se despliega en su singularidad, sin separarlo de los discursos ni de las tensiones de la sociedad.

Los investigadores de lo religioso han dado mayor peso a las figuras de obispos y pastores y se han orientado a la configuración de redes generacionales y militantes alrededor de hombres influentes. Bernard Guénée escribió en 1987 su libro Entre l'Église et l'Etat. En él muestra las trayectorias de cuatro prelados con la intención de aportar respuestas a preguntas generales gracias a casos singulares. El autor toma obispos del mismo entorno espacial, pero no de la misma época. Los prelados, cuyas vidas se describen, se insertan en un período que va de fines del siglo XIII a fines del siglo XV. Todos ellos eran intelectuales y dejaron escritos. Pertenecían a una elite social, aunque no estaban en la cima. Formaron una especie de cadena histórica a lo largo de dos siglos. Durante esos siglos, Francia experimentó toda clase de desgracias. Dificultades económicas, la hambruna y la peste del siglo XIV, que mató a un tercio de la población y, finalmente, el comienzo de la Guerra de los Cien Años. Estas dificultades hicieron que las personas quisieran un rey más fuerte, dándose el nacimiento doloroso del Estado moderno. Los cuatro prelados vivieron en este período difícil e incierto, en la Iglesia y en el estado, entre la Iglesia y el Estado. El Concordato de Bolonia de 1516 confirma la corriente galicana y el rey pudo controlar a la Iglesia en su reino. Estos cuatro obispos son de alguna manera la cadena que permite cubrir todo el período: Bernard Gui nació en 1261 y murió en 1331, Gilles Muisit nació en 1272 y murió en 1353, Pierre d'Ailly nació en 1357 y murió en 1420, Thomas Cuenca nació en 1412 y murió en 1490. Estos cuatro obispos, si bien tenían diferencias, también tuvieron puntos comunes. Nacimiento, ambición, conocimiento y talento, familiares y amigos. En los cuatro, sus nacimientos no impusieron sus propios destinos. La movilidad y el deseo de avanzar en la jerarquía eran una realidad. Desde sus humildes inicios, los cuatro prelados, a través de la ambición, se convirtieron en "hombres de autoridad". La universidad les dio el conocimiento revelado y el talento les ayudó para llegar a ser funcionarios de la Iglesia y el Estado. Ser un buen estudiante, estudiar y tener éxito no era suficiente. Había que tener relaciones, éstas se basaban, fundamentalmente, en la familia, si ésta estaba bien colocada en la sociedad. Si las familias de los cuatro prelados pudieron pagar por su educación, también podrían encontrar apoyo para sus carreras. Las redes de sociabilidad y la amistad jugaron un papel importante. Los cuatro no nacieron en las más altas esferas de la sociedad, sus orígenes sociales no los 
predestinaban a ser prelados, se necesitaba voluntad y ambición para llegar hasta ahí (Dosse, 2007: 133).

El trabajo dirigido por Nicole Lemaître, Histoire des curés (2002), estudia a los curas a través del tiempo, no sólo como ministros de lo sagrado, sino también como actores sociales, en sentido amplio. Los capítulos escritos por Michel Lagreé (2002: 250-361) presentan las oposiciones entre las tendencias galicanas y ultramontanas, la evolución del modelo de párroco a lo largo del siglo XIX, y desde una perspectiva comparativa analiza los regionalismos que dieron lugar a diversos modelos de párrocos.

\subsection{La historiografia biográfica sobre el clero cordobés}

Al analizar la producción biográfica provincial sobre el clero decimonónico, podemos decir que el valor de las obras es disímil. El género ha tenido cultores muy variados, desde el investigador profesional hasta el escritor cuasi-profesional, ya sea civil o eclesiástico. ${ }^{8}$ Las biografías se refieren a miembros del clero que actuaron en dos grandes procesos, el revolucionario independentista y el de la modernización del último cuarto del siglo XIX y primeras décadas del XX. Casi todos los biografiados son miembros del alto clero cordobés, sacerdotes que se destacaron en su labor pastoral y social, siendo algunos de ellos fundadores de congregaciones religiosas femeninas. ${ }^{9} \mathrm{La}$ producción, en líneas generales, es anterior a la década de 1960 y se inscribe en los lineamientos de la biografía tradicional. Si bien en la última década han aparecido algunos trabajos más renovadores, como la biografía del Deán Funes, escrita por Miranda Lida (2006).

En la historiografía más tradicional, prevalecen dos tipos de enfoques, uno positivista y otro más hermenéutico. El primero propicia una historia con una fuerte preocupación heurística, que se manifiesta en la búsqueda de fuentes, consideradas el único medio para alcanzar "la verdad" en la reconstrucción histórica. Privilegia un modelo de conocimiento del pasado basado en el documento escrito y voluntario, el cual es considerado un "reflejo" de la realidad. La afanosa preocupación por la búsqueda de una muy estricta "objetividad" desembocará en una clara renuncia a la dimensión interpretativa. Esta concepción positivista convivió con otra línea historiográfica que, sin desmerecer el valor documental de la fuente, sostenía que la tarea del historiador era

\footnotetext{
${ }^{8}$ A modo de ejemplo, citamos a Efraín Bischoff y su biografía sobre el cura Gabriel Brochero (1981) y al presbítero Francisco Compañy, biógrafo del Vicario Clara (1955).

9 David Luque fue el fundador de las Esclavas del Corazón de Jesús (1872); Gerónimo Clara el de las Hermanas Concepcionistas (1878); José León Torres de las Hermanas Terciarias Mercedarias (1887).
} 
entender las intenciones de los actores, procurando interpretar el fenómeno social en términos de motivos y significados. El principal representante de esta corriente de pensamiento fue Enrique Martínez Paz (1950), quien escribió la biografía del Deán Funes. Ambas líneas convergen y conviven en la producción provincial hasta muy entrado el siglo XX.

Otra característica presente en los textos analizados es el carácter regional de la producción. Los autores cordobeses ponen de manifiesto su preocupación por alcanzar una interpretación nacional desde el interior del país (Altamira, 1949; Martínez Paz, 1950). Martínez Paz, en su libro sobre el Deán, afirma que la "biografía de un cordobés, escrita por otro desde Córdoba, tiene que tener alguna peculiaridad, por razones de una diferente perspectiva geográfica, cultural, sentimental, sin remover desórdenes y agravios, lo cierto es que las glorias de la capital no han sido siempre nuestras glorias, y que el brillo de su heroísmo no han alumbrado por igual nuestro suelo". El autor se propuso criticar metódicamente lo que él consideró parte de un mito: "la leyenda del oscurantismo de Córdoba": "Durante un largo tiempo, las preocupaciones de un partido liberal, a la manera del siglo pasado, se ocupó de deprimir el ambiente de Córdoba intelectual, por ventura han quedado suficientes documentos para destruir esa intencionada leyenda [...] de la contrarrevolución del interior" (Martínez Paz, 1950: 1819).

La segunda característica general trasunta la preocupación por explicar la supuesta excepcionalidad del individuo seleccionado. Los autores parten de la premisa de que las respuestas de significación histórica están fundamentalmente en las cualidades del protagonista y el interés se centra en la vida del personaje; el propósito que les mueve es estudiar su vida y su personalidad por su propia importancia histórica. Aspecto éste que se ve reflejado en la misma selección de clérigos biografiados, se trata de personajes que han tenido una participación activa en el proceso revolucionario, ya sea apoyando $u$ oponiéndose al mismo (Cabrera, 1916; Altamira, 1949; Martínez Paz, 1950; Tonda, 1949, 1961, 1981). José Luis Romero, en su ensayo Sobre la Biografía y la Historia (1945), señala la presencia de una doble perspectiva en el género biográfico: la arquetípica y la individualista. La primera pone al héroe en su calidad de arquetipo, como expresión de los ideales colectivos, vale decir del individuo despersonalizado en la medida en que en él se encarna un proceso colectivo. En esta línea, Martínez Paz (1950) hace jugar al personaje elegido -el Deán Funes- con el tiempo que le tocó vivir. "Vivió en un tiempo de penumbra, entre la Colonia que desaparecía y la gestación 
dolorosa de la nueva nacionalidad. No puede arrojarse sobre él una luz demasiado viva; vivió una época de matices, de colores cambiantes, él fue por excelencia un hombre de su tiempo...". La biografía individualista otorga centralidad a la vida de un individuo considerada en su absoluta y radical singularidad. Los trabajos de Américo Tonda (1949: 290) y Calixto del Corro de Pablo Cabrera (1916: 5-19-82-109) presentan al personaje desde una perspectiva modélica, procurando presentar sus "virtudes más sobresalientes".

El centenario de la muerte de Funes, ocurrida el 10 de enero de 1829, suscitó una polémica entre historiadores. Se entabló un debate cruzado entre historiadores de Buenos Aires y el Interior. Entre Rómulo Carbia, porteño, por un lado, y Enrique Martínez Paz, cordobés, por el otro. El debate se centró en aspectos metodológicos e ideológicos. Para Carbia, formado en la Nueva Escuela Histórica, las reglas del método y la objetividad eran elementos esenciales a la hora de hacer historia. Para los cordobeses, más vinculados con el presentismo de Robin George Colingwood y el historicismo de Benedetto Croce, los documentos eran necesarios para alcanzar la comprensión del proceso histórico, pero no eran todo. “[...] el juicio de una obra no puede hacerse con independencia del móvil que se persigue al realizarla y fuera del ambiente propio de su tiempo. [...] No me inquieta el juicio de los historiadores profesionales sobre el célebre "ensayo", las obras de los hombres se juzgan según los hechos y no según las reglas de una dogmática artificial; esta es la aberración que pretende levantar el intelecto contra la vida" (Martínez Paz, 1936, XI). Son notables las diferencias entre un biógrafo porteño y uno cordobés. La mirada sobre el personaje y su época es notoriamente diferente. Carbia, para defenderse, sostiene que "contra la objeción de que me concreto demasiado en Buenos Aires, en el análisis de un fenómeno general del país, que tal hago por ser evidente que fue allí donde se desarrollaron los hechos fundamentales que constituyen el asunto en estudio (La revolución). El lado que diría provincial de la cuestión, es accesorio y sólo aporta corroboraciones secundarias a las generales que aquí aparecen" (Carbia, 1945: 14). A su vez, Martínez Paz afirma que lo que se ha hecho con Funes fue una "obra de difamación". Argumenta que Carbia, al terminar una polémica sobre la ortodoxia del Deán, manipula las fuentes interpretando maliciosamente la documentación (Martínez Paz, 1950: 83).

En síntesis, las biografías que se han escrito sobre el Deán a lo largo de la primera mitad del siglo XX constituyen una muestra de la influencia del contexto de producción en la elaboración de las obras. Las mismas reflejan el clima intelectual del momento, 
poniendo de manifiesto las polémicas entre positivistas/ historicistas, católicos/ liberales y Buenos Aires/ Interior.

Otro importante tipo de documentos son las hagiografías, perfiles y semblanzas no académicas de santos. Cuando a Jacques Le Goff le preguntaron los motivos de la selección de su personaje "San Luis, Rey de Francia" para escribir una biografía, entre otras cosas, respondió que, si bien uno de los principales obstáculos era la escasez de fuentes, pudo contar con el excepcional testimonio de un personaje cercano al rey, Jean de Joinville, autor de una historia de San Luis: "Joinville es el primer laico que escribe la vida de un santo, además en lengua vulgar, es decir, en francés y no en latín. Habiendo vivido la intimidad de San Luis, Joinville fue un testigo privilegiado de su vida cotidiana. Aunque admiraba mucho al rey, Joinville sabía también juzgarlo y no dudaba en regañarlo cuando estimaba, por ejemplo, que no se portaba bien con su mujer. De hecho, el título de la obra da fe de esta distancia que el autor tomaba respecto al tema. Este documento me permitió pues llegar al individuo, a ese que he llamado el 'verdadero' San Luis, y 'arrastrar' con él gran parte de la sociedad y problemas de su época" (Le Goff, 1996).

Testimonios de este tipo se encuentran en los ensayos escritos por personajes contemporáneos al biografiado, que han tenido una relación de amistad con él. El interés radica en que rescatan una historia de vida y se convierten, por lo tanto, en un documento de época, que nos habla de la vida y de la muerte, de las construcciones mentales, que nos permite asomarnos al imaginario social. Por lo tanto, este tipo de textos se han convertido en fuentes que son de particular interés para la historia cultural de las representaciones.

Tal es el caso de una de las primeras biografías (hagiografías) del Obispo Esquiú y de José Gabriel Brochero. La autoridad del autor de la primera biografía sobre Esquiú proviene de haber sido "su amigo, admirador y confidente, y como tal ha conocido sus intimidades y es eco fiel y autorizado de las tradiciones vivas de la familia y de la sociedad, en una época que ha sido precisamente suya" (Córdoba, 1917: VII). Lo mismo se puede afirmar de las biografías sobre Brochero escritas por dos de sus amigos, Ramón Cárcano (1885) y el Padre Domingo Acevedo (1928), su sucesor en el curato. Cárcano expresa al respecto que "supo despertar la estimación de profesores y condiscípulos, entre los cuales se hallaban jóvenes que más tarde han adquirido una elevada posición política y social, como el doctor Juárez Celman, Tristán Achával Rodríguez, Genaro Figueroa, Miguel Nouguez y otros" (Cárcano, 1885: 78). Entre los 
que se encontraba seguramente el mismo biógrafo, quien completa la semblanza afirmando que "Brochero es la personalidad más acabada del Cura de Campaña [...]. Tiene la vocación del sacerdocio y el sentimiento de su misión sagrada, abnegación de sí mismo, desprendimiento del mundo, amor al prójimo, rara resistencia y actividad en el trabajo, rudeza de vida, piedad en obra, virtud en acción, pensamiento en el cielo y penitencia en la tierra, he ahí las notas que al unísono resuenan en el diapasón de su alma" (Cárcano, 1885: 62-63).

Estas biografías permiten acercarnos a la representación del modelo de clero deseado. La mayoría de estos trabajos se apoya en fuentes testimoniales, memorias y escritos de los personajes biografiados, en recuerdos y vivencias de personas relacionadas con el sujeto de estudio. Si bien son escenas costumbristas, pintorescas y de tipo anecdóticas, reproducen imaginarios colectivos que permiten acercarnos al mundo de las representaciones. Adquieren calidad de fuentes de época. Recogen testimonios orales, que se hubieran perdido y que permiten recuperar al sujeto en sus circunstancias más íntimas y cotidianas. Muchas de ellas transcriben relatos de vida estampados en diarios personales, cartas o testimonios de fieles, amigos o conocidos. Adquieren un valor privilegiado para la historia social, dado que permiten acercarse a la historia de las costumbres, de las prácticas ordinarias, que tejen la trama de las relaciones cotidianas (Chartier, 2000: 27). Estas fuentes pueden constituir un punto de partida válido para la investigación del papel asignado a los obispos y a los párrocos, sus condiciones materiales de vida, su formación y sus actividades.

Los ensayos biográficos de Fray Mamerto Esquiú, el Vicario Clara, Fray Reginaldo Toro, el Cura Brochero o el Pbro. Torres, nos presentan la figura del sacerdote dedicado a las tareas del gobierno de la Iglesia, preocupados por la realidad social de la provincia y el incremento de la pobreza. La lectura de estos textos nos permite acercarnos a las representaciones sociales de la época; construcciones culturales que intentan proyectar una imagen deseable del sujeto y de la sociedad. Creaciones que sirven para dirigir la memoria en cierta dirección y hacia objetivos prefijados (Lavrin, 2005: 2). En este sentido, las biografías nos ofrecen representaciones del "buen cura", de la pobreza, de la enfermedad, de la religiosidad, de la familia, etc.

La creación de un modelo de clérigo ejemplar, digno de imitación, está presente en todas las biografías del período analizadas. La representación de la pobreza es otro elemento común en los textos. La pobreza ya no se presenta como la virtud evangélica, símbolo del Cristo pobre. La imagen de la pobreza está ligada a la enfermedad, la 
ignorancia y la delincuencia. Deja de ser algo bueno para convertirse en un mal endémico de la sociedad. La biografía de Clara sitúa al clérigo en el ambiente de pauperismo de los sectores de la ciudad (Compañy, 1955: 131). El biógrafo del Obispo Esquiú recoge los recuerdos de infancia del solar familiar, describiendo con detalle la vida cotidiana rural en su provincia natal, el autor construye un modelo de familia cristiana vinculado al modelo de comunidad religiosa (Avellaneda, 1917: 4). Los testimonios recogidos por los biógrafos de Brochero presentan una vívida imagen de la manera de trabajar, evangelizar y civilizar. Los textos están salpicados de anécdotas que revelan las costumbres y modos de vida serrano.

En síntesis, estas biografías de clérigos del siglo XIX se enfocaron en el mundo de la privacidad: la vida familiar, la amistad, la vida en la ciudad o en las sierras, a pesar de las limitaciones inherentes al alcance explicativo, constituyen verdaderas "fuentes de época", que permiten, con un renovado cuestionario metodológico, echar luz sobre aspectos opacados o poco contemplados del clero y la sociedad cordobesa de la segunda mitad del siglo XIX. Una revista de la historiografía provincial permite apreciar la escasa producción de obras biográficas escritas en el siglo XIX. Podría decirse que el interés en estudiar la vida del clero es un fenómeno del siglo $\mathrm{XX}$, que es cuando se publican todas las biografías analizadas. El estudio de la vida de los personajes principales del clero, satisfacía las exigencias de los dictados de la historiografía del momento, inclinada a resaltar las acciones de los grandes héroes. A partir del comportamiento heroico, la biografía se identifica como la forma ideal para exaltar $-\mathrm{o}$ combatir- la personalidad individual $\mathrm{y}$, en general, como instrumento de la función didáctica que la dirigencia política o la jerarquía eclesiástica atribuye a la historia. Desde esta perspectiva, puede sostenerse, siguiendo la argumentación de Bourdieu (1997), que las maneras de hablar no son inocentes y que la lengua que se habla estructura las representaciones del grupo al que se pertenece.

La selección temática de la producción biográfica está guiada por la influencia determinante del personaje estudiado. No entran en consideración criterios que busquen construir a través de la biografía una estrategia adecuada para abordar determinados fenómenos, como la mentalidad, los liderazgos, el poder, la cultura popular, las estructuras burocráticas, los negocios, la vida cotidiana, las prácticas religiosas, el comportamiento, etc. Estas líneas de abordaje están aún prácticamente ausentes de la historiografía religiosa provincial. 
Si las biografías son "creaciones culturales", que intentan proyectar una imagen deseable de un sujeto y de una cultura $\mathrm{y}$, por lo tanto, se constituyen en una "representación" (Lavrin, 2005), podemos señalar que los textos biográficos de la segunda mitad del siglo XIX sobre el clero cordobés, proponen un modelo de clérigo ejemplar, por lo que se trataría de una creación destinada a aglutinar voluntades y crear una "mitología" social que sirva de emblema al grupo y a la sociedad. No es casual que la mayoría de las biografías fuera escrita a partir de la década de 1940, período en que se estaba construyendo lo que Loris Zanatta denominó "El mito de la nación católica", proceso en el cual el clero desempeñó un rol de suma importancia. Si la representación sirve para dirigir la memoria en cierta dirección y hacia objetivos prefijados, las biografías pueden convertirse en un elemento importante en la construcción de la memoria histórica de la Iglesia Cordobesa, cuya historiografía sostiene que el renacimiento católico de mediados del siglo XX se debió, en gran medida, a la vida ejemplar de un número considerable de clérigos.

\subsection{El clero urbano y la conformación de elites}

Es una de las líneas que se viene desarrollando en Argentina, en sintonía con los avances europeos y americanos. Los trabajos pioneros sobre las elites se caracterizaron por un análisis de lo social que jerarquizaba los niveles de fortuna, distinguía los tipos de ingreso y clasificaba las profesiones. Era a partir de esta red social y profesional, dada de antemano, que podía hacerse la reconstitución de los distintos sistemas de organización social, pensamiento y comportamientos. Las primeras formas de abordar este campo de investigación partieron de un planteamiento macro-analítico que implicaba una definición de los grupos sociales según criterios esencialmente socioeconómicos o étnicos. François-Xavier Guerra (2000: 118) señala la insuficiencia de criterios clasificatorios y unidimensionales con los que se distribuye a los hombres concretos en categorías previamente definidas y dicha distribución se realiza a partir de un criterio que se considera esencial. Señala, además, que una sola variable no basta para definir la pertenencia a un único grupo social, ni tampoco, que en el registro de las identidades, una persona sea ni para sí misma ni para las demás, una sola de esas cosas. Por su parte, Simona Cerutti (1995) señala las limitaciones de una reconstrucción elaborada a priori, a partir de criterios externos a los propios actores sociales y expone las ventajas de utilizar criterios de clasificación social definidos por la propia sociedad. Advierte el interés de abordar a la sociedad no tanto en función de las categorías externas, sino 
partiendo de las propias jerarquías que operaban dentro de dicha sociedad. Esta línea de trabajo está en consonancia con la definición propuesta por George Duby en 1974 en relación a que los grupos sociales pueden identificarse a partir de una reflexión relativa a las mentalidades y comportamientos capaces de expresar actitudes, decisiones, aspiraciones y deseos específicos de esos actores (Bertrand, 2000: 69).

Las propuestas revisionistas centradas en la revalorización del sujeto y de la acción de hombre, en el carácter dinámico, relacional y construido de las identidades sociales, en el rescate del acontecimiento, en las miradas micro, han propiciado una forma cualitativamente distinta de entender el funcionamiento de la sociedad, de explicar la conciencia, las acciones de los individuos y de concebir la naturaleza, la génesis y los mecanismos de transformación de las relaciones e instituciones sociales (Cabrera, 2001: 13). En este contexto, se inscribe el debate sobre los grupos sociales recogido en una

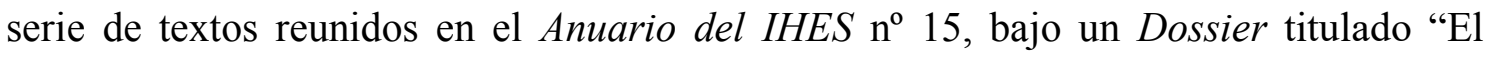
análisis de los grupos sociales: balance historiográfico y debate crítico". En su trabajo dentro del dossier, Guerra (2000: 117) advierte la insuficiencia de criterios empleados para definir a los grupos sociales y señala la necesidad de distinguir aquellas categorías que son esencialmente instrumentos de análisis, aunque tengan un fundamento en la realidad, de los grupos propiamente dichos que no son realidades puramente clasificatorias sino conjuntos estructurados de individuos. Las elites son concebidas, no ya como un todo global, como un conjunto homogéneo, sino como una realidad plural y sumamente evolutiva, que tiene íntima relación con el modelo cultural y la transmisión del sistema de valores (Langue, 2000: 101).

Las elites eclesiásticas se revelaron como un elemento de primer orden para la comprensión de la concepción, naturaleza y relaciones de poder y de los procesos de estructuración e integración social fuertemente vinculados a las dinámicas y estrategias individuales, familiares y grupales. Recién en la década del 80, aparecen los primeros estudios sobre el clero, los historiadores comienzan a interesarse por los orígenes sociales, la formación y las formas de sociabilidad del clero (Boutry, 1986c). Las investigaciones sobre el alto clero o las élites clericales y, particularmente, sus carreras eclesiásticas, han ayudado a comprender el funcionamiento y conformación de ese segmento del estamento clerical, han permitido avanzar en el conocimiento de sus orígenes, su conformación interna y sus intereses (Cuenca Toribio, 1976; Candau Chacon, 1993; Morgado García, 2000 y 2006; Aguirre Salvador, 2004; Di Stefano, 2004; Enríquez, 2005; Ayrolo, 2006). 
Escasos han sido los trabajos propiamente prosopográficos, entre los cuales no podemos dejar de mencionar el de Jacques Oliver Boudon, L'épiscopat français à l'époque concordataire (1802-1905): origines, formation, nomination (1996). El trabajo se inscribe dentro de la serie de estudios consagrados a las elites francesas contemporáneas. El método prosopográfico le permite sobrepasar, ir más allá de las figuras excepcionales para desgranarse en lo colectivo, lo normal, las ideas recurrentes. El estudio sistemático de los orígenes sociales, de la formación y de la carrera seguida por los quinientos quince sacerdotes hechos obispos en el curso del siglo XIX, permite aportar respuestas sobre el modo de acceder a la mitra episcopal en la Francia del período. Bajo el régimen del Concordato, el nombramiento de los obispos estaba en manos del jefe de Estado, si bien la Santa Sede conservó el derecho de control sobre estos nombramientos. Los expedientes de los archivos vaticanos, le permitieron seguir los juegos complejos de las relaciones, donde se entrecruzaban los intereses de las redes, tanto políticas como eclesiásticas. El trabajo plantea no sólo la cuestión de la selección de los candidatos, al autor le interesa comprender cómo era el cuerpo episcopal, cómo se constituyó y cómo evolucionó, para ello analiza varias etapas en la vida de los prelados, el período pre-sacerdotal, la vida de sacerdote y su candidatura episcopal. Aborda los orígenes geográficos del episcopado francés, que aunque bien repartido por todo el territorio, sobreabundan los prelados de origen urbano. En cuanto a los orígenes sociales, señala un retraimiento de los obispos de origen noble y un crecimiento de los de origen burgués. La ordenación presbiteral se realizaba alrededor de los 25 años y la episcopal a los 52. Las trayectorias son múltiples, y también más rápidas, cada vez menos administrativas y más pastorales. Sobresalen la administración parroquial, la enseñanza y la administración diocesana, ancladas en el medio urbano. Esto explicaría una participación importante en el medio intelectual de la época, se percibe una predilección por los estudios eruditos y una cierta desconfianza hacia la teología. La mayoría de los prelados adhiere a la movida liberal en el plano religioso más que en el político, sobre el que adoptan una postura conciliatoria sin adherir al régimen establecido. El ultramontanismo progresa lentamente a partir de 1835, más en el clero en general que en el cuerpo episcopal. Por lo tanto, religiosa y políticamente, son más bien moderados, podría decirse que adoptan una política de espera y conciliación respecto a los poderes públicos; apoyan la romanización en detrimento del galicanismo y del liberalismo sin que triunfe la intransigencia anti-moderna. Esta homogeneidad socio-religiosa y política se explica según diferentes factores, entre ellos, 
las modalidades de nombramiento por la administración de los cultos en busca de personalidades conciliadoras. La cooptación por un pequeño grupo de una veintena de arzobispos y de cardenales a través de los padrinazgos y las redes de dimensiones múltiples. La tercera parte del trabajo analiza las modalidades de acceso al episcopado.

En general, se han privilegiado más las investigaciones sobre el episcopado, considerado una elite funcional, fácilmente discernible en el campo social y religioso. En esta línea, se inscribe el trabajo de Catherine Gremion y Philippe Levillain, Les lieutenants de Dieu. Les évêques de France et de la République, publicado en 1985, quienes, desde una perspectiva sociológica, analizan el episcopado francés de fines del siglo XX. Este, si bien se encarna en instituciones visibles, como asambleas, comisiones, secretariados permanentes, se muestra como una estructura perfectamente homogénea y colegiada, a diferencia del episcopado de fines del siglo XIX, que se mostraba con sus grupos fuertemente tipificados, como los galicanos y los ultramontanos, con sus orígenes diferenciados en grandes señores y "paisanos mitrados". El análisis sociológico de filiación bourdieulana, ${ }^{10}$ de las vías de acceso al episcopado, permiten a los autores, mediante un estudio prosopográfico y generacional, distinguir claramente los grupos diversos que componen el episcopado francés, los misionarios y los militantes. Los primeros saldrían de las canteras propias del ministerio parroquial, la enseñanza católica y los movimientos y asociaciones piadosas. Los segundos se reclutarían de las filas de la Acción Católica. Una de las principales críticas a este trabajo radica en la reducción del campo de estudio a los obispos, excluyendo a los vicarios episcopales, las curias diocesanas, los canónigos y demás clérigos que pertenecen a la elite eclesiástica y que tienen cierta responsabilidad en las decisiones de la Iglesia francesa respecto de las designaciones episcopales (Lagrée, 1987: 168). El episcopado se percibe como un campo de fuerzas que asegura la reproducción del poder, como un campo de luchas dentro del cual los agentes se enfrentan para conservar o transformar la estructura.

Otros trabajos sobre el alto clero se inscriben en el marco más amplio de la historia de la familia. El análisis histórico de las estructuras de la parentela y sus representaciones, su misma complejidad, el lugar esencial de la parentela simbólica, las funciones de todas las formas de parentesco, en el dinamismo de las sociedades, lo encontramos en los trabajos de José María de Imícoz. En particular, es de destacar el

\footnotetext{
${ }^{10}$ Me refiero al texto de Pierre Bourdieu y Monique de Saint Martín, "La Sagrada Familia” (1982).
} 
estudio de la función que cumplían los clérigos al hacer pasar a América a sus sobrinos (de Imícoz y García del Ser, 2008).

En el ámbito provincial, el trabajo específico referido a las elites eclesiásticas locales es el de Valentina Ayrolo, Funcionarios de Dios y de la República (2007), del cual hablaremos más adelante.

\subsection{El clero rural parroquial}

El deslizamiento del interés hacia los sectores populares, los grupos marginales, lo que podríamos denominar "la periferia del mundo social" y la inversión de la mirada de abajo hacia arriba, ha planteando interrogantes respecto al mundo clerical de campaña comprendido por clérigos sin oficio ni beneficios, curas sueltos, capellanes y auxiliares de parroquias, que algunos autores han denominado "proletariado eclesiástico" (Rosa, 2006: 63). Un universo desarticulado, difuso y difícil de identificar, debido, entre otras cosas, a su gran movilidad social. Esta perspectiva de análisis ha comenzado a desarrollarse en la historiografía religiosa (Benítez Barea, 2001: 21-60; Pazos 2004: 201-224; Valenzuela García, 2006: 741-770). Pierre Pierrard, en el capítulo segundo de La vie quotidienne du prête français au XIX siècle 1801-1905 (1986), analiza el clero de origen rural, su reclutamiento, su formación en los seminarios menores y sus carreras sacerdotales.

En líneas generales, el campo de la historia religiosa se vio ampliamente permeado por la historia social, con una fuerte influencia de la antropología histórica, en particular, en los estudios sobre el personal eclesiástico, las prácticas y los sistemas de representación. La antropología histórica ha renovado de manera sustantiva la historia religiosa, política y económica de los últimos años. En Argentina, los trabajos de María Elena Barral (2006-2007) se inscriben en esta línea de análisis.

El libro de Barral, De sotanas por la Pampa. Religión y sociedad en el Buenos Aires rural tardocolonial (2007), nos introduce en la vida de la campaña desde el interior del mundo eclesiástico. Su análisis de las prácticas religiosas le permite mostrar la complejidad de las formas de intervención y mediación social que tuvo el clero bonaerense a fines del XVIII y principios del XIX. Desde una perspectiva microanalítica, penetra en los actores sociales de la campaña, como diría Michel Bertrand (2002), "se propone descubrir la racionalidad a través de un conjunto de hechos en apariencia confusos y, para muchos [...] anodinos”. El tratamiento cuantitativo y el análisis cualitativo de las fuentes le permiten brindar una visión del 
entramado parroquial en el mundo rural. La autora muestra un espacio con escasas estructuras institucionales eclesiásticas en relación a la extensión territorial, pero con un peso cualitativamente significativo. El universo clerical tampoco es cuantitativamente significativo, alcanza su punto máximo en el primer cuarto del siglo XIX, llegando a ser cuarenta y siete los clérigos que circulan por la campaña. Establece la proporción existente entre regulares/seculares y determina la función que ejercía cada uno, concluyendo que los cargos de vicario en un beneficio curado eran ejercidos por el clero secular y que los regulares sólo actuaron en calidad de tenientes, curas sustitutos o simplemente para prestar algún servicio religioso. Esta realidad revela un claro desplazamiento del poder que había ejercido el clero regular hacia el clero secular. Mediante datos dispersos y fragmentarios, verdaderos indicios, logra reconstruir algunos "linajes de párrocos", como el caso de la parroquia de San Nicolás, cuya sucesión entre tíos y sobrinos se prolongó durante décadas. Reconstruye, a su vez, "jirones de vida" de algunos párrocos destinados a las parroquias más importantes, Pilar, Luján y San Nicolás.

La autora analiza cómo los pobladores rurales, dentro del espacio eclesiástico, organizaron su vida comunitaria, ampliaron sus redes y establecieron jerarquías sociales. Para ello, examina un conjunto de hechos inherentes a la vida cotidiana, como el calendario religioso, con sus ciclos de Pascua y Navidad, los rituales de la vida y de la muerte, las limosnas, las creencias y las devociones, todos ellos elementos de un mundo simbólico, a través del cual logra dar una imagen de una región que ya no puede ser percibida como un "desierto social". Esta mirada cambia la visión de un espacio inerte por un espacio que construye prácticas sociales.

\subsection{Clero e inmigración}

Las transformaciones ideológicas de las sociedades del siglo XIX trajeron consigo una comprensión diferente de la naturaleza del clero y, por lo tanto, un cambio de ubicación dentro del orden social general. El deslizamiento de una sociedad sacralizada hacia una sociedad más secularizada implicó la redefinición del lugar que debía ocupar la Iglesia y, por ende, el clero en el nuevo contexto social americano. Quizá esta sea la causa de que los trabajos sobre el clero de fines del siglo XIX y primeras décadas del XX sean escasos, pues la historia religiosa ha privilegiado el análisis del laicado, actor social que asume el protagonismo en el escenario eclesiástico del período. El interés que había suscitado el clero para el período anterior, se desplazó hacia la actuación de los 
católicos frente a las demandas de la Iglesia y los embates del poder civil. La pugna entre el Estado y la Iglesia por la conquista de la sociedad es analizada a través del prisma del llamado catolicismo social. El proceso de secularización trajo consigo la emergencia de movimientos anticlericales, lo que llevó a centrar los estudios del clero en la óptica del clericalismo y el anticlericalismo (Lagrée, 2002; Pellistrandi, 2007; De La Cueva Merino y Montero, 2007).

En el caso argentino, el fenómeno de la secularización, en las décadas centrales del siglo XIX, ha sido abordado por Roberto Di Stefano (2004, 2009, 2010, 2013), Jaime Peire (2000) y Nancy Calvo (2006). Para el período de entre siglos (1870-1930), los historiadores han atribuido un rol de importancia a las nuevas actitudes de los inmigrantes europeos que arribaron a la Argentina en el marco del proceso de secularización y cambios culturales experimentados en el país (Devoto, 1999). Algunos autores señalan que, en forma paralela, se produce el fenómeno del robustecimiento del clero como factor de poder - a través del aumento del número de sacerdotes y de la reorganización interna de la Iglesia-, y el fortalecimiento del catolicismo como religión popular, alentado básicamente por el aluvión inmigratorio europeo (Santamaría, 1990: 140). Desde esta perspectiva, los estudios migratorios han aportado una mirada enriquecedora a los estudios sobre el clero. Si bien Oscar Álvarez Gila (2005: 77) señala la carencia de una reflexión historiográfica profunda sobre las actividades que desarrolló la Iglesia en los diversos países americanos respecto a los inmigrantes durante los siglos XIX y XX, cada vez son más los trabajos que abordan la Iglesia, concretamente el clero, y la inmigración en Argentina, enfoque que, hasta hace unos diez años más o menos, no había sido abordado por los estudios históricos, ni por los cultivadores de la historia religiosa. Un aspecto importante que se ha tratado son las políticas eclesiásticas en relación a la inmigración en general y al clero inmigrante en particular (Pazos, 1997; Ceva, 2000). En líneas generales, los trabajos han priorizado la acción del clero regular y las congregaciones religiosas (Auza, 1990; Bernasconi, 2005), dejando en un segundo plano al clero secular (Álvarez Gila, 1998 y 2001). Queda aún por abordar, entre otras cuestiones, el impacto de la inmigración en la constitución social de los cuadros eclesiásticos.

Cabe agregar que la mayoría de los estudios sobre el clero y la inmigración en Argentina se centra en el espacio porteño, pampeano-bonaerense o santafecino (Santamaría, 1990; Stofell, 1994 y 1997; Auza, 1994 y 2001). Pocos autores se han dedicado a estudiar el fenómeno a nivel diocesano en las provincias del interior que han 
vivido el impacto del aluvión inmigratorio. Para el caso de Córdoba, no contamos con estudios específicos. En este sentido, como veremos a lo largo de la tesis, el fenómeno de la inserción del clero inmigrante en el espacio Cordobés adquiere características peculiares, no siempre coincidentes con la realidad bonaerense o santafesina.

\section{El aporte de nuestro estudio}

Pese a que la modernización argentina ha sido un tema muy convocante, los estudios sobre la Iglesia en este período son escasos. Nuestro trabajo viene a llenar un vacío historiográfico, tanto por su temática como por la temporalidad abordada. Las cuestiones específicas planteadas en los estudios sobre el medioevo, nos ayudaron a pensar problemas análogos al de la Iglesia diocesana de Córdoba entre 1877 y 1927 y que desarrollaremos en el próximo capítulo, destinado a las cuestiones teóricometodológicas.

Los especialistas de historia religiosa americana en el período colonial e independiente y de las autonomías (Ayrolo, Barral, Peire, Taylor, Aguirre Salvador, Connaughton, Cárdenas Ayala, Di Stefano, Serrano, Demélas) advierten que la Iglesia colonial y tardo independiente no se distinguía de la sociedad. La sociedad era la Iglesia y la iglesia era la sociedad. Era un claro sistema de unanimidad religiosa. Luego, a partir del período rivadaviano, en Buenos Aires, se inicia, lentamente, el proceso de secularización, que recibirá un fuerte impulso en la década del 80 del siglo XIX (Di Stefano, 2008 y 2010). Los trabajos de Roberto Di Stefano y María Elena Barral para Buenos Aires y de Valentina Ayrolo para Córdoba dan cuenta de la fragilidad de la territorialidad diocesana. Luego del período revolucionario, las diócesis sufrieron frecuentes y prolongadas vacancias, los párrocos, con frecuencia, no cumplían el deber de residencia y los patronos laicos administraban los bienes eclesiásticos.

El período que abordamos en la tesis es de transición, a lo largo del cual se consolida el estado nacional, donde la matriz administrativa eclesiástica es, en gran medida, asumida por ese estado en formación. El control de nacimientos, matrimonios y defunciones pasará a manos del estado, la salud dejará de ser prerrogativa exclusiva de la Iglesia y pasará a la administración estatal de los hospitales. La educación, en manos del clero y las congregaciones religiosas, pasará, muy paulatinamente, a ser controlada por el estado, al igual que la asistencia social y la beneficencia. El clero, otrora omnipresente en la comunidad, con funciones religiosas, políticas, periodísticas, 
docentes, económicas, judiciales, dejará a un lado aquellas funciones que no respondan directamente a su condición clerical para abocarse al ministerio pastoral y social.

Por otro lado, nos interesa analizar la función de las autoridades eclesiásticas como agentes de construcción del espacio particularmente rural. La Iglesia, edificio, se impone en el paisaje y busca convertirse en el lugar de congregación y de control de los hombres. La reflexión de Iogna-Prat (2010), referida a la "monumentalidad del edificio sagrado" o la "petrificación de lo sagrado", sugiere que la consagración de las iglesias hace referencia a un lugar de identidad de una comunidad. Se pertenecía a sociedades cristianas a través de una relación sacramental fijada en un terreno. En las llanuras del sudeste cordobés de fines del siglo XIX, podían visualizarse Iglesias de grandes dimensiones, construidas en espacios casi vacíos, en aldeas o villas con poblaciones de 1.000 a 1.500 habitantes. El templo y sus campanarios fueron sin duda un símbolo de identidad para cada comunidad. La Iglesia proponía mostrar, de esta manera, las raíces cristianas de la sociedad cordobesa de antiguo y nuevo cuño. También podríamos aventurar que se trata de una demostración de poderío, de control de la Iglesia sobre las poblaciones rurales y, por qué no, suponer que la Iglesia compitió con el estado en la ocupación de los espacios. En el caso cordobés, la "espacialidad parroquial” también está directamente relacionada con los cambios sociales. El sudeste pampeano, casi desierto u ocupado por tribus indígenas, comienza a ser poblado por inmigrantes, que se nuclean, se constituyen como comunidades con lazos familiares, espirituales, sociales, económicos, etc. Estas comunidades están vinculadas a los espacios sagrados, concretamente a las capillas y parroquias. Generalmente son los mismos pobladores los que levantan el templo que los congrega como comunidad católica.

La parroquia se convirtió en el eje sobre el cual se articuló el proceso reformador diocesano. La iglesia, como institución, afirmó definitivamente su presencia en el territorio mediante la cristalización de una malla (red) de circunscripciones que iban de la diócesis a las parroquias, de esta manera el territorio se conformó en un espacio de proyección de una institución. La densificación de la red parroquial, la residencia habitual del cura en el lugar, y las periódicas visitas pastorales permitieron el afianzamiento y la presencia de la iglesia diocesana en las diversas regiones de la provincia, éstas proyectan la institución sobre el espacio diocesano y hacen visible su poder de control. Desde esta perspectiva, y a este nivel en la escala de análisis, la afirmación de Peppoloni (2001: 44) respecto a que, “en realidad, la doctrina social de la Iglesia es un programa abstracto que se basa fundamentalmente en la revelación, la 
razón y las ciencias sociales" que pierde entidad, ya que esa doctrina social toma cuerpo y se materializa, de alguna manera, en este período, en la institución parroquial.

Sin duda, la Iglesia católica, en general, y el clero secular, en particular, jugaron un papel activo y transformador en el proceso modernizador que experimentó la provincia de Córdoba desde fines del siglo XIX hasta la tercera década del XX. Articuló diversas estrategias para adaptarse a los cambios y mantener su influencia en la vida social provincial. La Iglesia, por lo tanto, no fue ajena al proceso modernizador que impulsó la elite liberal -cordobesa-, al decir de Demélas y Saint-Geours (1988: 164) para Ecuador, la Iglesia articulará grupos sociales opuestos, paliará las flaquezas de una administración ineficaz y educará a una población muy poco alfabetizada desde la caída de las estructuras coloniales.

Un segundo aporte tiene relación con los estudios sobre los diversos grupos sociales. Como puede observarse, los estudios sobre el clero secular en Argentina se refieren, fundamentalmente, al período colonial y rosista (Di Stefano, Caretta, Ayrolo, Calvo, Lida) y luego da un salto al siglo XX (Lepera, Touris, Morello). Esto se debería a tres causales principales: en primer lugar, porque, para los investigadores, comenzó a tener mayor importancia el estudio de los cambios experimentados por la Iglesia en el paso del Antiguo Régimen a la modernidad, en este sentido, el proceso de secularización redefiniría el rol que debía cumplir el clero en una sociedad secular-moderna, perdiendo, desde este punto de vista, su rol tradicional; en segundo lugar, porque, para estos mismos investigadores, dentro de la Iglesia comienza a adquirir mayor importancia, como actor social, el laico y los movimientos laicales; y, en tercer lugar, porque, en razón de lo expuesto precedentemente, los estudios del clero se enmarcan en una problemática más compleja y más amplia que incluye los estudios referidos a los movimientos anticlericales y a las relaciones de la Iglesia y el estado.

El deslizamiento de una sociedad sacralizada hacia una sociedad secularizada implicó la redefinición del lugar que debía ocupar la Iglesia y, por lo tanto el clero, en el nuevo contexto social. Las transformaciones ideológicas de las sociedades trajeron consigo una diferente comprensión de la naturaleza del clero y, por ende, un cambio de ubicación dentro del orden social general. En la producción de la segunda mitad del siglo XIX y primeras décadas del XX, la temática clerical se diluye en la problemática 
del fenómeno de la secularización. El interés se ha centrado en los conflictos generados a partir de dos posturas contrapuestas: el clericalismo y el anticlericalismo. ${ }^{11}$

La investigación se centra en el análisis de las formas en las cuales la Iglesia intentó reacomodarse a su nueva situación, con el fin de conservar su papel como conductora de los valores y de la educación de las nuevas generaciones. La Iglesia católica cordobesa persiguió un proyecto de transformación cultural y social que iba más allá de la negociación y cesión -con frecuencia conflictiva- de algunas de sus prerrogativas al poder político estatal. Estos cambios se reflejaron tanto en el proceso de centralización, burocratización, profesionalización de sus actividades y de su personal, como en la transformación de la simbología utilizada para convocar a sus fieles. Esta simbología dejó de apelar a referentes locales para concentrarse en representaciones universales. Así es que, no obstante haber sido relegada en el campo político por el avance liberal, sobre todo en la las ultimas centurias del siglo XIX, la Iglesia conservó una gran influencia en la definición de normas sociales y culturales de la sociedad. Buscó insertarse en un discurso de cambio, al mismo tiempo que mantenía el control sobre la transmisión de los valores morales y sociales de las nuevas generaciones. En Córdoba, el proyecto de transformación institucional de la Iglesia confraternizó con el proyecto de construcción del Estado que buscó articular religión, modernidad y Estado. La Iglesia debía constituirse en el cimiento de la integración social y la burocracia católica en agente modernizador.

${ }^{11}$ Para ampliar este tema, véase LAGRÉE (2002); REVUELTA GONZALEZ (2002); DE LA CUEVA MERINO y LÓPEZ VILLAVERDE (2005); AUBERT (2005); PELLISTRANDI (2007); DE LA CUEVA MERINO y MONTERO (2007). Para el caso argentino, DEVOTO (1990); CALVO (2001); DI STEFANO y PEIRE (2004); DI STEFANO (2009 y 2010). 


\section{CAPITULO 2 \\ MARCO GENERAL DE CONCEPTUALIZACIÓN}

\section{La historia religiosa: perspectivas de abordaje para su estudio}

En este capítulo, nos proponemos vincular el fenómeno religioso a la historia general provincial y analizar la incidencia de las particularidades económicas, sociales y políticas en los comportamientos religiosos. El trabajo trata de desentrañar una realidad altamente compleja, la de una confesión religiosa -el catolicismo- y la de un conglomerado institucional -la Iglesia-, que, sin lugar a dudas, han jugado y juegan en Argentina un rol de primer orden en campos que exceden en mucho el ámbito religioso de por sí altamente relevante (Di Stefano y Zanatta, 2000: 7). El análisis de la Iglesia y de su personal, el clero secular, se enmarca dentro de la nueva historia religiosa presentada en el capítulo anterior. Dentro de los enfoques desarrollados por "la renovación", nos interesa, fundamentalmente, centrar la investigación en tres cuestiones teórico-metodológicas vinculadas a las siguientes líneas de investigación: a) La renovación de los estudios institucionales; b) la historia social-religiosa que prioriza, como tema central, a los actores y sus experiencias condicionadas por diferentes entornos y, sin duda, por transformaciones mayores -ideológicas, políticas, económicas, sociales y culturales; c) el campo de las prácticas. Estas vías transitadas ampliamente por la historiografía religiosa europea tratan de proporcionar percepciones vívidas del funcionamiento real de las sociedades. La intención está centrada en el clero como un grupo social, particularmente el clero parroquial, destinado a servir las parroquias de campaña.

\subsection{La nueva historia institucional}

La revalorización del Estado y de las demás instituciones estatales y no gubernamentales ha sido encarada por la historia institucional renovada. El estudio de las estructuras institucionales, conjuntamente con la acción, intención y pensamientos de los actores responsables de ellas, resulta esencial para conocer las reglas del juego social. Las investigaciones que se han realizado dentro del enfoque de la nueva historia institucional han conseguido en los últimos años una creciente aceptación. Las teorías institucionalistas que, como su nombre lo indica, ponen el énfasis en la penetrante influencia de las instituciones sobre la conducta de los actores sociales se han revertido, dando lugar a una concepción más antropológica que apunta a la consideración de que 
son, justamente, los actores los que hacen funcionar y pensar a las instituciones (Douglas, 1986: 28).

Las investigaciones de Dominique Iogna-Prat nos han abierto horizontes para pensar algunos problemas relacionados con la institucionalización de la Iglesia católica de Córdoba. En sus trabajos plantea cuestiones metodológicas relativas al modo de analizar la institución en los tiempos de la reforma gregoriana. ¿Por qué estos trabajos nos fueron de utilidad? Porque, como señala José A. García de Cortázar (2012), se trató de una reforma impulsada por Roma, que fortaleció la autoridad papal a nivel espiritual -y también temporal-, frente a las autoridades seculares, alegando en favor de la libertad de la Iglesia. Se gesta una concepción diferente de la Iglesia. Aunque todas las Iglesias tenían sus fundadores, sólo la de Roma había sido fundada por Cristo a través del primado de Pedro. Por lo tanto, en Roma, todas las Iglesias tenían su madre y su cabeza y se consolida el título de Iglesia Universal. Roma imprimió una mayor centralización administrativa en favor del pontífice y los obispos, se valió de los enviados pontificios para establecer un vínculo directo entre el papado y las diócesis. Se procede al nombramiento de obispos en todas las sedes vacantes y se crean nuevas sedes. En el orden disciplinario, se apunta a la reforma de las costumbres del clero. Además, la reforma gregoriana impulsó el fenómeno de la territorialización eclesiástica, aumentando la densidad de la red parroquial. Esta territorialización implicó la fragmentación de antiguas parroquias, de grandes dimensiones físicas, y la multiplicación de núcleos de poblamiento, que la administración eclesiástica trataba de controlar. Todas estas cuestiones están también comprendidas en el proceso reformador, impulsado por Roma en la segunda mitad del siglo XIX.

Iogna-Prat, en su trabajo La Maison de Dieu (2006), estudia cómo se forma, dentro de la sociedad cristiana, la iglesia en tanto institución. Su tesis consiste en mostrar cómo se dio el fenómeno de institucionalización de la Iglesia. Analiza, detenidamente, el problema relativo a la definición de la iglesia y la dificultad de diferenciar la iglesia edificio de la iglesia institución, pues ambas tienden a confundirse. Iglesia, para el autor, es un término bífido que da cuenta tanto de un aspecto material, como de uno sociológico y espiritual, esta realidad plantea el problema de la relación continente contenido.

La Iglesia material puede comprenderse como continente de la religión cristiana. La categoría propuesta por Iogna-Prat en relación a la "monumentalización del edificio" o la "petrificación de lo sagrado" está asociada a la función social del templo como 
génesis de la construcción social. Iogna-Prat señala que la territorialización del lugar sagrado está íntimamente relacionada con la reforma gregoriana y da cuenta del lugar que ocupa la Iglesia en la sociedad.

Un segundo aspecto se vincula con el problema de cómo la iglesia se transforma y da lugar a nuevas formas. En este caso, el autor analiza el paso del período escolástico al absolutismo, lo que él denomina "la modernidad sacralizada". El paso de la Iglesia al Estado, la aparición de nuevos marcos, nuevos encuadramientos, la idea de cómo se concibe una comunidad política, ya sea ésta el Estado, ya sean las ciudades, que asume funciones que antes eran propiamente eclesiásticas, por lo tanto, el control que antes tenía la Iglesia pasa al estado y a las ciudades.

El autor analiza un fenómeno masivo, de alcance sociológico, el de la iglesia en dos momentos: del 500 al 1200 y del 1200 al 1700, en el período que denomina premodernidad. Al analizar el primer período, del 500 al 1200, señala que la iglesia era la sociedad y la sociedad era la iglesia. La iglesia se concebía como un todo social, era una institución que se imponía a toda la sociedad. Para el autor, esto se debió a la creación del término iglesia, que generó una metonimia entre el continente y el contenido. La iglesia como contenido significó iglesia como continente, la paradoja fue que si bien el edificio no tenía un verdadero interés, a partir del 1200, este edificio se corresponde con un monumento emblemático. Para ser miembro de la iglesia como institución había que pasar por la Iglesia edificio. Para el autor, un ejemplo de esto es el matrimonio, un acto social por excelencia, durante mucho tiempo fue un acto que se celebraba en las casas particulares, en los domicilios, luego, pasó a celebrarse dentro de la iglesia, de esta manera comienza a percibirse la sacralización del matrimonio. Entre 1200 y 1700, la Iglesia, concebida como la totalidad de la sociedad, comienza a ser una noción criticada y rechazada. Se ve la evolución del modelo de estructura social. La estructura de la Iglesia da paso a nuevas estructuras como la ciudad y el Estado.

Roberto Di Stefano y Jaime Peire, entre otros autores, advierten que la Iglesia colonial y tardo independiente no se distinguía de la sociedad. La sociedad era la Iglesia y la Iglesia era la sociedad. En un claro sistema de unanimidad religiosa. Luego, a partir del período rivadaviano, en Buenos Aires, se inicia lentamente, como ya dijimos, el proceso de secularización, que recibirá un fuerte impulso en la década del 80 del siglo XIX. Estas cuestiones nos llevaron a pensar en Córdoba la transición de una sociedad de unanimidad religiosa, en la que Iglesia y sociedad se identifican, y en la que la iglesia como contenido significó iglesia como continente, en la que el edificio, el templo, no 
tenía un verdadero interés, a una sociedad en vías de secularización, que comienza a diferenciarse Iglesia y sociedad. El edificio se convierte en un monumento emblemático a partir del tercer cuarto del siglo XIX. El ascenso de la elite liberal al gobierno y la presión de la sociedad católica, dio lugar a un tipo de modernidad singular que fue una "modernidad católica", que incorporó el factor religioso en la conformación de lo público (Vagliente, 2002: 124).

Un trabajo de García de Cortázar sobre la territoralización de la actividad pastoral durante el proceso de la reforma gregoriana, señala que ésta se llevó a cabo promoviendo la aparición de vicarios del obispo tanto en las ciudades como en las áreas rurales, aumentando las unidades de encuadramiento social, como son las diócesis, arcedianatos y parroquias. La reforma dio origen a una densificación de la red parroquial y a una multiplicación de núcleos de poblamiento que la administración eclesiástica trató de controlar. Identifica y analiza los factores que impulsaron la fragmentación parroquial, entre los cuales señala la dimensión física y demográfica, la concentración/dispersión del poblamiento, las distancias que debían recorrer los feligreses para llegar a la parroquia. En este sentido, tomamos la definición de territorio que propone Bernard Lepetit (1996: 83) al decir que es "una formación espacial que no depende solamente de la organización de un espacio, sino de prácticas de actores que se desarrollan según lógicas poco conmensurables".

Aquí es importante incorporar el análisis que García de Cortázar (2012: 292-295), realiza respecto a la fragilidad de la territorialidad diocesana anterior a la reforma gregoriana, entre los factores que señala se encuentran los largos períodos de vacancia episcopal y el abandono de las sedes y advierte que la porosidad de los patronatos laicos, que se apoyaban en las relaciones personales más que territoriales, bloquearon la aparición de una territorialidad eclesiástica autónoma. Para el caso Argentino, tanto Roberto Di Stefano y María Elena Barral para Buenos Aires como Valentina Ayrolo para Córdoba, dan cuenta de la fragilidad de la territorialidad eclesiástica diocesana. Luego del período revolucionario, las diócesis sufrieron frecuentes y prolongadas vacancias, los párrocos con asiduidad no cumplían el deber de residencia y los patronos laicos administraban los bienes eclesiásticos.

Si retomamos la argumentación de García de Cortázar (2012: 278), vemos que éste analiza la cristalización de la implantación territorial de la Iglesia a través de una precisa jerarquización de circunscripciones ordenadas al compás de la fiscalidad y la afinación de la especialización de lo sagrado, en la fijación de un templo y un cementerio, con 
valor de referentes principales, tanto en lo religioso como en lo social, para la comunidad local. Ello, unido al ascetismo institucionalizado en sus múltiples manifestaciones, dará un completo panorama de la visibilización de la Iglesia del siglo XII. Visibilización en el sentido de que la Iglesia Templo, que encapsula a la Iglesia Comunidad, pasó a dejar huellas tangibles en ese conjunto de procesos que siguió a la reforma gregoriana, lo cual permite hablar de una segunda cristianización comandada por el papado que aseguró el éxito del modelo romano de Iglesia.

Para el caso americano, y particularmente argentino, las postrimerías del siglo XIX se constituyeron, sin duda, en una segunda cristianización, o re-cristianización, también impulsada por el papado, que culminó con la implantación del modelo romano de Iglesia. Sin embargo, como desarrollaremos en la segunda parte de la tesis, estas miradas teóricas, unidas al análisis empírico de las fuentes, en particular aquellas que nos permitieron analizar las múltiples manifestaciones de la visibilización eclesiástica (templos, ritos, asociaciones, visitas pastorales), nos llevaron a poner en tensión los conceptos ya canonizados relativos al modelo de ruptura, que coloca en los años 30 el punto de inflexión y que sostiene un supuesto pasado de debilidades y fracasos y que recién a partir de la década mencionada comenzaría el exitoso renacimiento católico (Auza, 1983; Mallimaci, 1988b y 1993). Como veremos, el proceso no resultó tan lineal, como lo presenta este modelo, y el llamado renacimiento católico inició su andar, en Córdoba, a mediados del siglo XIX, recibiendo un nuevo impulso con el Concilio Plenario de América Latina (1899) y el Sínodo diocesano (1906).

Otra categoría importante planteada por García de Cortázar (2012: 257) tiene relación con el análisis de la reforma propiamente dicha. Así, advierte que los frentes de la reforma fueron: a) la separación del clero del resto de la sociedad; b) la voluntad de conversión del mundo hacia adentro y hacia afuera del pueblo cristiano; c) el consenso respecto de la responsabilidad de la salvación colectiva; y d) la dirección romana de la reforma que, en palabras del autor, procuraba "asegurar la jefatura papal en la dirección de la cristiandad", es decir tanto dentro de la Iglesia institución como de la iglesia comunidad universal. Considera que la primacía de la Iglesia de Roma no era ni reconocida ni rechazada a comienzos del siglo IX, simplemente apenas podría ser ejercida en un mundo que, desde el debilitamiento del Imperio Carolingio, había visto un retorno a micro-comunidades. En esas circunstancias, ni siquiera los arzobispos eran capaces de controlar a los obispos sufragáneos, quienes mantenían una relación más estrecha con el monarca reinante que con el metropolitano que lo consagraba. 
Volviendo a la realidad argentina, son numerosos los autores que advierten que en el período pos-revolucionario, el papado no era ni conocido ni rechazado, simplemente estaba ausente. El trabajo de Ignacio Martínez (2013), analiza justamente ese proceso por el cual Roma busca instalarse como conductora de las Iglesias americanas. Los procesos de independencia del imperio español habían sido los catalizadores de un retorno a las micro-comunidades, al poder local, los curas mantenían una relación estrecha con los gobernadores provinciales que los elegían y mantenían en el cargo (Di Stefano y Zanatta, 2000; Ayrolo, 2007; Di Stefano, 2010).

Finalmente, García de Cortázar analiza los instrumentos de la reforma y señala la importancia de dos de ellos: $1^{\circ}$ la prosecución de un proyecto en el que el orden divino se reflejaba en la tierra mediante el cumplimiento de las exigencias morales que correspondían a cada estado; y $2^{\circ}$ la aplicación, de manera sistemática, de una panoplia de medidas para lo que los reformadores debieron utilizar la fortaleza moral y los apoyos políticos. Estas medias apuntaban a diversos órdenes: a) disciplinario; b) institucional; c) constitucional; y d) político.

En lo disciplinario, la reforma apuntaba a la conducta moral del clero, a la eliminación de la simonía y de la investidura laica; en lo institucional, al restablecimiento de la vida en común en las instituciones religiosas y el nombramiento de obispos; en lo constitucional, los puntos centrales de la reforma apuntaron a implantar la autoridad pontificia mediante cartas papales y la creación de enviados pontificios que actuaban por encima de los metropolitanos y trataron de establecer un vínculo directo entre el papado y los obispos. Además, se promovió la centralización, en manos de la sede romana por decreto de 1059, que reservaba la elección del papa a un reducido número de cardenales (García de Cortázar, 2012: 265).

La lectura de este trabajo nos permitió pensar los instrumentos de la reforma diocesana cordobesa y las medidas implementadas en los diversos órdenes y visualizar las resistencias encontradas a nivel institucional, social y político.

Por otra parte, la tesis central de otro medievalista, Michel Lauwers (2005: 269), supuso un estímulo para pensar otro problema, la iglesia, una entidad espiritual, se configura también como entidad territorial y social. Lauwers identifica la función social de la Iglesia en la temprana edad media, mediante dos movimientos diferentes, el de espacialización y el de espiritualización o sacralización. La espacialización se realiza de dos maneras, a través de la creación de una red de lugares sagrados y de la expansión de lo sagrado en torno a los lugares de culto, en particular el cementerio. El cementerio 
ocupa un lugar central en el proceso, pues aparece como una suerte de "imagen concreta" de la Iglesia, arraigando a la comunidad espiritual de cristianos en la tierra, cerca de los lugares de culto, y participando del fenómeno de extensión de lo sagrado mediante círculos concéntricos alrededor de ellos. La espacialización sería entonces el fenómeno de expansión de la sociedad cristiana, a través de polos sagrados y la consagración de iglesias y cementerios. Una segunda etapa de esa expansión estaría dada por la territorialización del lugar sagrado. En cuanto a la espiritualización, Lauwers caracteriza los esfuerzos de la institución eclesiástica por establecer en la tierra una comunidad espiritual. Estos esfuerzos se reflejan en la necesidad de fijar un parentesco de lazos espirituales que definan a las comunidades de fieles como una forma de estructuración de las sociedades. En este sentido, analiza los discursos de los clérigos en pos de construir una imagen de iglesia en la que están presentes todos los miembros vivos y difuntos. La Iglesia militante, purgante y triunfante.

La categoría de ineclesiamiento, utilizada por Lauwers, hace referencia a un fenómeno de larga duración y se identifica con el movimiento progresivo de la inclusión de la Iglesia en la sociedad. En palabras de Dominique Iogna-Prat (2010: 25), se trata del proceso por el cual la Iglesia, como institución, es creadora del espacio social. Este proceso está directamente relacionado con el discurso de la reforma gregoriana y hace referencia a la Iglesia y a su lugar en la sociedad. En este sentido, ineclesiamiento se refiere a la Iglesia como centro de la organización social del espacio, en el que la parroquia y el cementerio cumplen una importante función social y se constituyen como agentes de construcción social. La parroquia deviene como una convergencia de relaciones entre cada parroquiano, la iglesia y el sacerdote, y como base para la ocupación, tanto en sentido residencial como productivo. La parroquia es el lugar donde se realiza la única relación espacial más importante de las representaciones cristianas: la relación entre el cielo y la tierra (Iogna-Prat, 2010). Siguiendo esta línea de argumentación, el trabajo apunta a analizar la parroquia como centro de la organización social del espacio y a ver la convergencia de relaciones (sobre todo espirituales, productivas y sociales) entre parroquiano, cura e institución, que permiten visualizar el lugar que ocupaba la iglesia en esas sociedades concretas, tomando como ejemplo la parroquia de la colonia Sampacho. Pensando esta cuestión de las relaciones sociales, consideramos el trabajo de Sol Serrano, ¿Qué hacer con Dios en la República? (2008), que nos iluminó para comprender la nueva relación que los católicos establecen entre sí, con el cura y la institución parroquial, en las repúblicas americanas de la segunda mitad 
del siglo XIX. En este contexto, la relación entre "el cielo y la tierra", tan propia de sociedades de unanimidad religiosa, en que la sociedad de los vivos tiene una intensa vinculación con la vida supra-terrenal y el mundo de los muertos va perdiendo densidad. El vínculo de los vivos con sus muertos se expresa en la solidaridad para alcanzar la otra vida, de allí la cantidad de misas gregorianas, novenarios, etc. El espacio sagrado de la muerte se desliza de lo que otrora era el "campo santo" o cementerio bendito hacia la tumba individual bendecida. De esta manera, el catolicismo redefinió el espacio sagrado de la muerte como un espacio individual. Los cementerios se secularizaron, el muerto era recibido en el templo donde se desarrollaba el rito fúnebre $\mathrm{y}$, de allí, el difunto era llevado al cementerio municipal, donde el cadáver recibía la bendición religiosa antes de ser enterrado. Como advierte Serrano (2008: 222 y 253) era el tránsito de lo sagrado desde el terreno común hacia el individuo. La secularización de los cementerios no expresó la secularización de la muerte, sino el pluralismo de los vivos, pues la individuación no implicaba descristianización.

A medida que avanza el siglo XIX, el catolicismo muta y entra de lleno en el espacio público moderno, a través de las asociaciones laicas, destinadas a la defensa de la religión en una sociedad cada vez más plural. Los muertos dejan de ser prioridad del mundo de los vivos. Esta nueva sociabilidad católica trae consigo el desarrollo de vínculos entre individuos concretos, que ya no miran la vida después de la muerte, sino que buscan mejorar el mundo presente. El catolicismo se inserta en la esfera pública moderna en la que construye nuevas prácticas políticas y sociales y reacomoda su modo de actuar. En esta línea, surgen nuevas asociaciones, insertas en el espacio parroquial, destinadas a mejorar la vida de los obreros, de las mujeres y de los niños.

La institución parroquial adquiere cada vez mayor importancia. El trabajo de Joseph Morsel (2009) considera la parroquia medieval como una entidad administrativa que organiza, espacialmente, las comunidades de los fieles cristianos, constituyendo así una forma de territorialización llamada "espacialización de lo social". Para este autor, la organización de núcleos de habitantes, en torno a los lugares de culto, es visto como una de las fases del proceso de formación de comunidades de habitantes. La formación de una comunidad de habitantes asume una forma importante de articulación espacial y hace clara referencia a un modelo de interpretación de las transformaciones socioespaciales. Para Morsel, la relación entre cambio social y cambio espacial es compleja, y establece, también, la idea de una traducción espacial de los fenómenos sociales. Advierte que para comprender la espacialización social de la edad media es necesario 
considerar el hecho de que cada sociedad produce su propio espacio, o sea, cualquier sistema social es, por sí mismo, un sistema espacial. Por lo tanto, no hay un cambio social que no sea acompañado por un nuevo dimensionamiento del espacio. Morsel (2007: 165) señala que, en el proceso de formación de las ciudades, hay una convergencia entre pertenencia comunitaria y parroquial. Los límites de la parroquia servirán para modelar los límites comunales. Para el autor, la relación social básica que identifica y une a los miembros de una comunidad es el hecho de habitar, de ser habitante, se trata de una relación más o menos duradera entre una persona o un grupo y un lugar. Al momento en que las personas se definen como habitantes, pasan a definirse como ocupantes de un lugar específico. La formación de comunidades de habitantes corresponde a la formación de los lugares de residencia. Morsel aclara que habitar no significa solamente ser de algún lugar y tener vecinos. Los estudios de los fenómenos de formación de comunidades muestran que habitar significa igualmente producir en un lugar. En sintonía con estos planteamientos, el problema que nos interesa analizar es, justamente, partir de la idea de que cada sociedad produce su propio espacio, por lo tanto, cualquier sistema social es, por sí mismo, un sistema espacial y, por ende, no hay cambio social que no esté acompañado por un nuevo dimensionamiento del espacio. Nos preguntamos entonces, ¿cómo las comunidades parroquiales cordobesas de fines del XIX y comienzos del XX construyeron y redimensionaron el espacio? y ¿Qué relación tuvo este fenómeno con los cambios sociales que se produjeron en el espacio pampeano cordobés en el marco de la formación de comunidades?

El segundo problema que surge es el proceso por el cual, la Iglesia como "lugar de culto" nos lleva al concepto de cristiandad como noción geopolítica. Para ser más precisos, y con otras palabras, la iglesia no sólo es el templo, sino la comunidad de cristianos que habitan una aldea, una provincia, un país, un continente o el mundo. Este juego de escalas nos permite ir de lo general a lo particular y de lo particular a lo general. Como advierte Bernard Lepetit (1995: 80), la variación de escalas no es patrimonio del investigador, ni el producto del proceso de construcción de la investigación, es, ante todo, la experiencia de los actores. Lepetit toma el término escala de la cartografía y advierte que existen dos jerarquías paralelas, por un lado, la cuestión de las "escalas" que depende del dominio de la cartografía y, por el otro, la de los "niveles" de los fenómenos y las organizaciones espaciales que depende de la naturaleza de las cosas y de la estructuración del mundo. La dificultad del manejo de la escala proviene de esta dualidad: “según la escala, se cambia también la 'óptica' y el nivel de 
información" pero "nada dice cómo los fenómenos y las estructuras cambian si la mirada sobre ellos se modifica". Elegir una escala consiste entonces en seleccionar un nivel de información que sea pertinente con el nivel de organización a estudiar. La adopción de una escala es, primero, la elección de un punto de vista de conocimiento (Lepetit, 1995: 81). En este sentido, no es lo mismo analizar el proceso de romanización a nivel parroquial que a nivel universal, la cristiandad local, provincial o nacional. Nuestro análisis varía haciendo uso del juego de escalas, herramienta metodológica que complejiza y enriquece la explicación del problema.

Una última cuestión metodológicamente interesante, planteada tanto por García de Cortázar como por Iogna-Prat, tiene relación con la "construcción del otro" y las alteridades del cristianismo. Los autores analizan la percepción cristiana de los judíos y musulmanes, advirtiendo que, a medida que cobra vigor el proceso de refundación de la institución eclesiástica y se sentía la cohesión de la sociedad cristiana, se perfilan con claridad las corrientes cristianas desviadas de la ortodoxia. En relación a este doble movimiento de ordenar y excluir, Iogna-Prat demuestra, en el estudio que realizó sobre el Abad cluniacense Pedro el Venerable, la fuerza que a mediados del siglo XIII había adquirido el proceso de construcción del otro, fuera hereje, judío, musulmán o reo de brujería. Por otra parte, se afianza la elaboración de la imagen de la religión musulmana, y de su profeta Mahoma como encarnación de la figura del anticristo, esta percepción negativa del otro se consolida con las tres primeras cruzadas (García de Cortázar, 2012: 347-350).

¿Pueden aplicarse estas categorías medievales, propias de un modelo eclesiástico reformador -como fue la Reforma Gregoriana-, a un período y a un espacio absolutamente diferente como es la diócesis de Córdoba durante el proceso de romanización? Entendemos que, sin caer en una descontextualización, se podrían tomar ciertas categorías, puesto que nos encontramos ante algunos fenómenos análogos. En primer lugar, la Iglesia es una institución milenaria, portadora de valores universales, que se ha mantenido a lo largo de la historia y que, por lo tanto, es posible rastrear ciertas continuidades en su modus operandi. En segundo lugar, en ambos casos, se trata de una iglesia reformadora, que está llevando a cabo una transformación que comienza en el seno de las comunidades y aspira a la conquista espiritual de toda la sociedad. Reforma que además fue impulsada desde Roma con un modelo propio y una matriz que debía ajustarse a la realidad americana y que por cierto generó dudas y resistencias. 
En el caso cordobés, la reforma fue impulsada también desde Roma y comenzó con las órdenes regulares, mercedarios, franciscanos y dominicos. Tres de estos monjes reformadores llegaron a ocupar la silla episcopal cordobesa y aspiraron a colocar a la religión en un lugar central de la vida social provincial. Tanto el "clero gregoriano" como el "clero romanizado" tienen como proyecto de conjunto la cristianización de la sociedad. Y en tercer lugar, consideramos que, en ambos casos, podría hablarse de una Iglesia de frontera, frontera con una fuerte impronta cultural, en el caso cordobés una frontera al sur, con el infiel (indígena) y una frontera interna, planteada como una diferencia con el otro, una alteridad ante el "infiel", el "hereje" o el "librepensador" (indígena, masón, protestante, socialista o anarquista). La Iglesia, en ambos momentos, se adentra en una lógica "contra religiosa" e invita a sus miembros a comprometerse, a formar parte del cuerpo de la Iglesia como milites Christi y hacer frente a aquellos que no lo son (disidentes y herejes). La visión del otro -en una sociedad en vías de secularización-, como era la cordobesa finisecular, se plasma en un discurso que alerta sobre el protestantismo, el socialismo, la acción de sectas masónicas y el anticlericalismo en general. Realidades que se perciben como verdaderos enemigos de los valores cristianos. ${ }^{1}$

En un contexto histórico absolutamente diferente, se dan, a nuestro entender, procesos análogos, el paso de una sociedad tradicional, de unanimidad religiosa, que concibe la no diferenciación de esferas (espiritual-temporal, civil-religiosa) a una sociedad que comienza a diferenciarlas mediante un lento proceso de secularización.

Como señalamos ut supra, el período que se aborda en la tesis es de transición, en el cual se va consolidando un estado nacional, donde parte de la matriz administrativa eclesiástica es asumida por el estado en formación. El control de nacimientos, matrimonios y defunciones pasará a manos del estado, la salud dejará de ser prerrogativa exclusiva de la Iglesia y los hospitales tendrán una administración estatal. La educación, en manos del clero y las congregaciones religiosas, será muy paulatinamente controlada por el estado, al igual que la asistencia social y la beneficencia. El clero, otrora omnipresente en la comunidad, con funciones religiosas, políticas, periodísticas, docentes, económicas, judiciales, irá dejando de lado aquellas funciones que no respondan directamente a su condición clerical, para abocarse, aunque paulatinamente, al ministerio pastoral y social.

\footnotetext{
${ }^{1}$ Archivo del Arzobispado de Córdoba [en adelante AAC]. Fondo Zenón Bustos. "La Revolución social", Pastoral del 23 de noviembre de 1918.
} 
Por otro lado, nos interesa rescatar la función de las autoridades eclesiásticas como agentes de construcción del espacio. La Iglesia, edificio, se impone en el paisaje y busca convertirse en el lugar de congregación y de control de los hombres. La reflexión de Iogna-Prat (2010) referida a la "monumentalidad del edificio sagrado" o la "petrificación de lo sagrado", sugiere, como dijimos, que la consagración de las iglesias hace referencia a un lugar de identidad de una comunidad. Se pertenecía a sociedades cristianas a través de una relación sacramental fijada sobre un terreno.

En las llanuras del sudeste cordobés de fines del siglo XIX, y en las villas serranas del norte y el oeste, comienzan a visualizarse Iglesias de grandes dimensiones, construidas de planta o reconstruidas, en espacios casi vacíos o en aldeas y villas con poblaciones de 1.000 a 1.500 habitantes. El templo y sus campanarios fueron sin duda un símbolo de identidad para cada comunidad. La Iglesia se proponía mostrar, de esta manera, las raíces cristianas de la sociedad cordobesa de antiguo y nuevo cuño. También podríamos aventurar que se trata de una demostración de poderío, de control de la Iglesia sobre las poblaciones rurales y, por qué no, suponer que la Iglesia compitió con el estado en la ocupación de esos espacios.

En el caso cordobés, la "espacialidad parroquial" también está directamente relacionada con los cambios sociales. El sudeste pampeano, casi desierto u ocupado por naciones indígenas -que a partir de 1879 fueron desplazados hacia el sur, o directamente aniquilados por la guerra-, comienza a ser poblado por una mayoría de pobladores inmigrantes, que se nuclean, se constituyen en comunidades con lazos familiares, espirituales, sociales, económicos, etc. Estas comunidades se vinculan a los espacios sagrados, concretamente a las capillas e Iglesias parroquiales. Generalmente, son los mismos pobladores los que levantan el templo que los congrega como comunidad católica. La parroquia, al igual que durante la reforma gregoriana, se convirtió en el eje sobre el cual se articuló el proceso reformador diocesano. Así como en la edad media, la Iglesia, como institución, afirmó definitivamente su presencia en los reinos mediante la cristalización de una malla de circunscripciones que iban de la provincia o arquidiócesis a las parroquias y el territorio se fue conformando por el espacio de proyección de una institución (García Cortázar, 2012: 228). En Córdoba, en la segunda mitad del siglo XIX, la densificación de la red parroquial, la residencia habitual del cura en el lugar, las periódicas visitas pastorales, permitieron el afianzamiento y la presencia de la iglesia diocesana en las diversas regiones de la provincia. La Iglesia también se proyecta sobre el espacio diocesano y hace más visible 
su poder de control. El poder pastoral con una multiplicidad de prácticas, implementa estrategias de control en cada comunidad, estas estrategias no siempre dieron el resultado esperado, pues, como veremos, encontraron resistencia por parte del clero y los fieles.

\subsection{De las instituciones a las prácticas: el ámbito parroquial}

La aspiración de la Iglesia diocesana de construir una nueva cristiandad, choca con una realidad que indica una falta de adecuación cada vez más evidente entre los medios y los marcos de la pastoral, por un lado, y las necesidades de una población que experimenta grandes cambios demográficos, por el otro, debido a la incorporación y distribución de nuevos pobladores inmigrantes en el territorio. La jerarquía eclesiástica local puso en marcha un engranaje conformado por una serie de procedimientos y prácticas destinadas, no sólo, a transferir el conocimiento, la doctrina y la moral católica, sino también a la asimilación de la misma y a su manifestación en el comportamiento de la población. El objetivo de la institución eclesiástica era mantenerse como una fuerza que integra, organiza y conduce a la nueva sociedad provincial, cada vez más plural, y amenazada por el estado de corte laicista y liberal, por un lado, y una sociedad que integraba componentes percibidos como enemigos del catolicismo (masones, protestantes, socialistas, anarquistas y librepensadores), por el otro.

En este contexto, nos propusimos analizar la "noción de institución" en la formación del espacio social. Es decir, analizar la naturaleza espacial del hecho institucional. Para ello, partimos de la idea de articular dos cuestiones, por un lado, el uso simbólico del espacio, en calidad de espacio significante, es decir, la creación de espacios sacros en lugares que podríamos denominar profanos, propios de una sociedad en vías de secularización (espacios público, calles, plazas, colonias, aldeas, villas, etc.); por otro lado, el uso funcional del espacio, que se impone por motivaciones no sólo de orden religioso, sino también económico y social. La institución fundamental en este proceso reformador fue, sin duda, la parroquia, sobre este eje institucional se articuló la acción de la iglesia con la sociedad. Por ello, siguiendo el planteo de un antropólogo colombiano, Fabián Zuleta Ruiz (2013: 35-40), tomamos tres criterios para analizar la parroquia en la sociedad cordobesa finisecular: a) los procedimientos utilizados para la transferencia de conocimientos y valores; b) la fijación de las creencias en el espacio, dando lugar a la formación de identidades sociales y culturales; c) la cuestión de la 
gobernabilidad, es decir, la dirección pastoral del individuo y de las comunidades. Pasemos a desarrollar estos criterios.

a) Al centrar el análisis en el aspecto procedimental de una acción institucional centrada en la trasferencia de conocimientos y valores, nos llevó a relacionar este interés con la necesidad de explorar el terreno de las prácticas, es decir, acercarnos al modo en que los ministros de la Iglesia implementaron diversas estrategias y ejecutaron acciones destinadas a lograr los fines propuestos.

b) Una de esas prácticas fue, sin duda, la preocupación por fijar espacialmente las creencias que profesan, esta dinámica de acción incide en un aspecto sensible del análisis de las formaciones sociales y culturales, nos referimos a la formación de identidades sociales, concebidas como un elemento dinamizador de la cohesión social. Esta cuestión dio origen a una red institucional, densa y compleja, compuesta por santuarios, iglesias, parroquias (con todas sus instituciones y funciones), capillas y colegios católicos que fueron articulando toda la comunidad cristiana a lo largo y ancho de la provincia.

c) El problema de la institucionalización en un momento de cambio o transición, como fue el proceso de modernización del Estado y romanización de la Iglesia, remite al problema de la conversión, la transmisión y el paso de esquemas y principios de una organización social a otra. La cuestión problemática de la transición (de una sociedad tradicional a una moderna) afectó principalmente al modelo de organización pastoral.

Estas cuestiones remiten al problema de la gobernabilidad. Cuando hablamos de gobernabilidad, nos referimos a la dirección pastoral del individuo y de las comunidades y el desarrollo de las artes de gobernar en el espacio social. En el contexto de modernización social, desarrollo económico y laicidad estatal, la Iglesia coaccionada por la amenaza de perder su hegemonía ideológica y cultural, pasa a un primer plano. En el forcejeo entre las nuevas fuerzas sociales y políticas, la Iglesia logra trascender las presiones y reasumir su rol de árbitro, de director espiritual y moral de la nueva sociedad que emerge. Esta trascendencia sugiere interesantes interrogantes en torno al arte específico de gobernar de la Iglesia, pues, en el aparente continuismo institucional, ella despliega una capacidad inventiva, generando múltiples correspondencias y reacomodos entre las figuras y las modalidades del actuar institucional. En este contexto, en el último tercio del siglo XIX, adquiere una importancia radical la figura del pastor de almas, quien está llamado a velar por la salud e integridad de todos los miembros de su comunidad. Por ello, analizar las técnicas, procedimientos y estrategias 
desarrollados por el clero secular para modelar conductas, modificar la vida cotidiana de individuos y grupos, dirigir conciencias y situar todo esto en el espacio, nos permitió visualizar el proceso de restructuración y organización de la sociedad y el rol de la Iglesia y sus agentes. El resultado de este proceso fue la paulatina consolidación de comunidades cristianas en el nuevo espacio territorial provincial (sudeste) y la reafirmación y reorganización de las antiguas comunidades de fieles católicos (noroeste). Este proceso da cuenta de un estrecho vínculo entre la institución y la sociedad y pone en evidencia, también, la confrontación entre comunidad e institución, confrontaciones que remiten a un conflicto al interior de la organización eclesiástica, pero también hacia afuera, vinculado a las interpretaciones entre las realidades sociales y las estrategias espaciales de la Iglesia en relación a su visión del gobierno y al arte de conducir. La Iglesia enseña a sus pastores a gobernar y a la gente a dejarse gobernar.

Este juego de gobierno de unos por otros, del gobierno cotidiano, del gobierno pastoral, se concibió durante siglos como la ciencia por excelencia, como el arte de todas las artes. Esta visión de gobierno refleja un tipo de autonomía que, curiosamente, pone a la institución en una relación compleja con la comunidad particular en la cual se inserta. Se establece un tipo de relaciones que va institucionalizando una labor pastoral con leyes, reglas, técnicas y procedimientos propios. Es, en este nivel de autonomía de la cura de almas, que el gobierno pastoral de las parroquias, por su vínculo primario con las comunidades, va a plantear el tema del reconocimiento de los curas como pastores.

Justamente, la comunidad es el referente espacial que se sitúa en la incómoda situación fronteriza entre el adentro institucional y el afuera social. La comunidad es, sin duda, el espacio social y vital que permite y apoya la difusión de las formas pastorales de gobierno. La comunidad, entonces, es el punto de partida abierto a diversos tipos de intervenciones y de cambios. La parroquia, inserta en la comunidad y en el espacio pastoral, es la que une estrechamente el poder pastoral y la organización institucional eclesiástica. Sin duda, la parroquia sufrió considerables trasformaciones a lo largo de la historia, fue transformada o integrada a otras formas, pero nunca fue suprimida. Bruno Restif, en su libro La Revolution des paroisses (2006), analiza la reforma católica del siglo XVI y los cambios en el espacio sacro-parroquial. La parroquia es tomada como el marco de aplicación de la reforma, analiza la relación entre el desarrollo artístico y las aplicaciones de la reforma litúrgica de Trento. Lo interesante del trabajo es, justamente, el análisis de las vicarías locales o decanatos, una institución intermedia entre la parroquia y la diócesis, que contribuyeron al 
encuadramiento religioso de la campaña y que le permitieron al autor analizar los agentes de cambio "al ras del suelo". El concepto de "civilización parroquial” permite comprender y vincular los conceptos de parroquia-comunidad de fieles y mirar el proceso de reforma como un cambio cultural, tendiente a lograr una "nueva cristiandad" (Restif, 2006: 13-20).

Con esto presupuestos, se puede aventurar que la noción funcional de parroquiacomunidad de fieles que asume la Iglesia para desplegar su estrategia de intervención en las sociedades americanas de fines del siglo XIX, concretamente después del Concilio Plenario de América Latina en 1899, es una noción pragmática, concebida como modelo o matriz de una estrategia global e integral de ordenación territorial y social, vinculada a la expansión de la laicidad y secularidad del estado y al pluralismo social.

El proceso de secularización es incompleto y relativamente lento y, por consiguiente, se percibe una realidad subyacente ambigua y compleja, que ubica al Estado en la Iglesia y a la Iglesia en el Estado. La diferenciación de esferas política y religiosa es una construcción que, a nuestro entender, no llega a cristalizar definitivamente. Esto dará origen a la existencia de relaciones de mutua dependencia entre ambas instituciones. La Iglesia no alcanza la autonomía que desea y el estado no logra prescindir de la Iglesia. En este sentido, al pensar en la institución eclesiástica, centramos el interés en los lazos interpersonales que se generan, se articulan o refuerzan tanto al interior como hacia el exterior de la misma. Pensamos en la mutación de la institución eclesiástica a partir de las mutaciones y transformaciones de los individuos; las nuevas prácticas generan nuevas reglas en función de los nuevos contextos sociales. Las reglas y las normativas constituyen un elemento central y determinante de la vida social y son las instituciones las que asumen, en gran medida, dicha función.

La iglesia católica de Córdoba organizó a las sociedades y puso a la comunidad asociada al territorio - parroquia (comunidad de creyentes), parentesco (comunidad de parientes), bautismo (paso obligado para incorporarse a la comunidad de creyentes)-, como base de su lógica de articulación de las identidades y pertenencias. En este sentido, pensamos la institución parroquial como un proceso histórico de larga duración, durante el cual se trasforma y se re-genera. Durante los cincuenta años que abarca nuestra investigación, la Iglesia provincial logra extender su principio de universalización, enriquecer y diversificar el conocimiento del cual ella era portadora (doctrina, creencias, principios ético-morales), mediante una figura dinámica y abierta a la comunidad, integrada a una plataforma institucional singularmente creadora $\mathrm{y}$ 
aglutinante como es la parroquia. Con la llave comunidad-parroquia, la iglesia logra posicionarse y cumplir funciones civilizatorias de gran importancia, pues la parroquia aparece como un agente poderoso de reproducción cultural, capaz de articular el mundo local de una comunidad a los intereses y al programa pastoral de la Iglesia universal. La parroquia significó un espacio de revitalización de su proyecto espiritual, pues es una institución que posee una versatilidad capaz de adaptarse a las cambiantes condiciones del medio social en el que se inserta. Un artículo publicado en la "Revista Eclesiástica de Buenos Aires", en 1912, es un claro ejemplo de la versatilidad de esta institución capaz de cambiar y re-adaptarse al medio social.

\begin{abstract}
La labor que cada pastor de almas despliegue en pro de la resurrección de aquella familia que se llama parroquia, será la más meritoria, la más saludable, la más eficaz. Pero a los esfuerzos reconstructores del párroco debe añadirse la cooperación de todo católico, de toda la familia católica [...], es necesario que junto a la actividad religiosa y espiritual del párroco, florezca una acción moral y social que inspire y conforme aquella, siempre obediente y fiel $[\ldots]$ los tiempos ya muy diferentes piden y exigen providencia nuevas, adecuadas y eficaces. De esta realidad deben estar todos convencidos; este hecho debe existir en la conciencia de cada uno, sea del párroco como de todo fiel, de manera que a los confines más extendidos del error responda un campo más amplio de saludables actividades. ${ }^{2}$
\end{abstract}

La conciencia de que los tiempos son muy diferentes y, por lo tanto, piden y exigen providencias nuevas, adecuadas y eficaces, da cuenta de la necesidad de "resucitar" la institución parroquial. El trabajo de Mauro Ronzani, L'organizzazione spaziale della cura d'anime e la rete delle chiese (secoli V-IX) (2014), nos llevó a pensar el proceso de consolidación del poder episcopal y parroquial. El autor plantea la relación entre el poder episcopal y el control del territorio. En Galia fue limitado por los grandes propietarios que construyeron oratorios, eligieron y mantuvieron a los curas oficiantes. En Italia meridional, el Papa de Roma fue capaz de ejercer el control efectivo, pues sólo él podía autorizar a los obispos a consagrar los nuevos edificios para la celebración del culto, con disposiciones más restrictivas sobre las funciones de los oratorios privados y los derechos de su constructor. La consagración se realizaba sólo en vista de su apertura al culto público, existiendo serias preocupaciones sobre posibles abusos del fundador (Ronzani, 2014: 544).

En el espacio cordobés, a medida que el proceso de romanización avanzaba, la costumbre de los propietarios de construir oratorios y capillas en sus dominios, seleccionar y mantener a los sacerdotes que oficiaban durante todo el año en ellas

\footnotetext{
${ }^{2}$ Revista Eclesiástica del Obispado de Buenos Aires (1912: 419) [en adelante REOBA].
} 
comienza a ser contralada por la autoridad episcopal diocesana. La autoridad comienza a ejercer un control más estrecho sobre los templos y sus funciones. Por este motivo, otro aspecto significativo y clave para comprender los criterios básicos de la organización eclesiástica en la Córdoba del siglo XIX, es el cambio en la práctica de la administración de los sacramentos, en particular el bautismo y el matrimonio. Respecto al primero, será cada vez menos frecuente la administración realizada por seglares o "bautizadores" fuera del templo, y, en cuanto al segundo, se limita la celebración en domicilios particulares. Para formar parte de la comunidad cristiana, será necesario recibir el bautismo en el templo. La iglesia contenido (creencias, doctrina, principios éticos, sacramentos, ritos) se vincula cada vez más con la Iglesia continente (templo).

En la investigación, proponemos indagar, de manera conjunta e interrelacionada, tanto la estructura institucional eclesiástica como las acciones, intenciones y pensamientos de los actores sociales, efectivos responsables de ellas. Es decir, nos parece necesario examinar el proceso no sólo desde el punto de vista estructural centrándonos en una descripción de los dispositivos institucionales-, sino también desde una perspectiva que coloque en el centro al hombre que ha protagonizado $y$ experimentado, a la vez, dicho proceso histórico. Intentaremos dar cuenta de la hermenéutica de los actores, "buscar múltiples motivos y sentidos -objetivos y subjetivos, racionales e irracionales, materiales y espirituales, estructurales e individuales-, presentes en el accionar individual y colectivo que busca comprender" (Mallimaci, 1987: 3). La reflexión sobre los procesos de romanización/ modernización no sólo tiene sentido a nivel de la estructura social, sino también de las personas que lo han experimentado y lo protagonizaron. Por todo lo dicho, el clero se convierte en uno de los actores más comprometidos en el proceso de romanización de la iglesia local y nos permite incorporarlo al estudio de la sociedad no como un elemento aislado y diferenciador, sino como un agente activo y transformador de las dinámicas sociales.

\subsection{De las prácticas y de las formas de la experiencia}

Como hemos señalado ut supra, el análisis del poder pastoral remite a las prácticas en relación a la construcción y o afianzamiento de una religiosidad popular, o un intento más ambicioso de crear/conservar una cultura católica, que impregne todos los resquicios de la sociedad provincial, según la propuesta del modelo romanizador. Abordaremos este fenómeno desde una doble perspectiva, una acción ejercida "desde arriba", a través de una serie de disposiciones dirigidas a la población, emanadas de la 
autoridad episcopal e implementadas por los curas párrocos, vinculadas a prácticas de alfabetización, catequización, ritualización, etc. Que, al mismo tiempo, supuso una participación activa "desde abajo". La Iglesia no actuó sobre poblaciones como si fueran sujetos pasivos, la renovación católica no fue el producto de una imposición, se trató de una realidad compleja, construida por la interacción de ambos actores, Iglesia y sociedad. Las diversas comunidades manifestaron intereses, resistencias e inquietudes que se tradujeron en estrategias concretas de acción, en concordancia o en disidencia con las iniciativas jerárquicas. La preocupación por invertir la mirada sobre la sociedad, orientando el foco de interés desde abajo hacia arriba, a partir de las experiencias de los feligreses -en su mayoría pobladores rurales-, y del clero rural parroquial en buena parte inmigrante, se debe a que la inversión de perspectiva nos permite sostener, parafraseando a Lepetit (1996: 72), que "es por lo bajo que se opera la construcción del sistema". La elección de esta escala de observación está vinculada al nivel de información pertinente con el nivel de organización a estudiar, en este caso, el parroquial.

Marc Forster (2001: 15) señala que la identidad católica no sólo fue producto de una imposición política de confesionalización-disciplinamiento, sino de una realidad construida con una activa colaboración popular, cuyo éxito se fundó -como evidencia su extensión-, en una respuesta a las necesidades e inquietudes de la población. En esta línea de análisis, nos preguntamos, más que por el éxito o el fracaso de la reforma, cuáles fueron las demandas de la sociedad y si la Iglesia dio una respuesta a las mismas.

El libro de Sol Serrano (2008) nos permitió pensar la importancia de las prácticas, pues desde esta mirada pueden revertirse muchos principios sostenidos por la historiografía durante años. Las escalas, como afirma Lepetit, nos muestran otra realidad. En una entrevista, Serrano (2008b) advierte que si se observa sólo la doctrina o la ideología, el catolicismo se opone a la formación del espacio público, como lo afirma la historia de las ideas clásicas, dando la imagen de un catolicismo reaccionario y nada más. "Pero si uno pasa esa primera etapa, la de la historia de las ideas a la historia política, ve que se desarrollan prácticas modernas: asociaciones, prensa, partidos, movilización social, etc. Y si de esta historia de las prácticas políticas pasamos a las prácticas religiosas, tenemos que pasar a la demografía. Pues bien, sólo un bajo porcentaje de la población de la diócesis de Santiago tiene acceso regular a los sacramentos, por lo tanto la mayoría de la población no llega a la Iglesia institucional sino con dificultad. Pero si vamos más al fondo, comprobamos que esa sociedad logra 
llegar casi en forma total a un sacramento: el morir penitenciado (extrema unción)". Este ejemplo es útil para comprobar que analizar la práctica de la unción le permitió a la autora preguntarse ¿qué tan relevante y profunda fue la descristianización?

El objetivo de las autoridades eclesiásticas de formar un sujeto cultural y socialmente católico, mediante la acción de inculcar ideas y confirmar la creencia, es llevado a cabo, fundamentalmente, por los pastores con cura de almas. La enseñanza sistemática de un breve catecismo, la utilización de un rico repertorio de imágenes, las ceremonias rituales, la construcción de templos, son algunos ejemplos del rol jugado por el clero para formar conductas y definir perfiles sociales. En los comienzos del siglo XX, un momento en que tanto las doctrinas y prácticas políticas, como la necesidad de las enseñanzas constitucionales republicanas, cobraron relieve debido a la existencia de tensiones sociales, agitación popular y radicalización de algunas posiciones políticas, el régimen conservador vio necesario utilizar la plural utilización de vías o instrumentos encaminados a conformar los pensamientos y conductas cívicas desde una particular toma de conciencia. La Iglesia, sin lugar a dudas, fue una pieza clave en este contexto. Los gobernadores acuden al obispo para solicitar la colaboración de los párrocos a fin de "instruir al pueblo" para el conocimiento de sus derechos y obligaciones (solicitan que reciban a los funcionarios del censo nacional, que tomen conocimiento de la ley de ahorro postal, que envíen a su hijos a la escuela, manden a las parejas al registro civil antes de administrar el matrimonio, combatan la embriaguez, el abigeato, la adicción al juego y demás males de la campaña).

Además, las misiones volantes y las visitas pastorales fueron otro instrumento de penetración, cuyo objetivo apuntaba a que la religión no fuera sólo una doctrina para ser conocida, sino para ser vivida. Zenón Bustos, obispo de Córdoba entre 1905 y 1927, advierte sobre la necesidad de las misiones religiosas para moralizar nuestras campañas y civilizar a los salvajes de nuestras fronteras. ${ }^{3}$ La iglesia, por lo tanto, fue una alternativa eficaz y apropiada para la regulación de las conductas sociales en una sociedad con escaso nivel de escolaridad, en la cual el valor y la utilidad de la palabra eran muy importantes. El predicador era, por ende, un mediador entre la dirigencia y las clases populares. Cuando la llamada cuestión social emerge con huelgas y reclamos, preocupando a dirigentes y funcionarios, el Estado provincial y la Iglesia unen sus esfuerzos con la intención de moralizar al pueblo, afirmando reiteradamente que socialistas y anarquistas tenían como finalidad trastocar los fundamentos de la sociedad

\footnotetext{
${ }^{3}$ AAC. Fondo Franciscano Zenón Bustos sin clasificar. Escrito monográfico: "Necesidad del principio religioso como elemento político".
} 
civil, llevándola a su destrucción. Para el Estado, la preocupación principal era mantener el orden social y una herramienta para lograrlo era la enseñanza de principios morales.

El filósofo catalán Jordi Riba, en un artículo titulado "Filosofía política, república y educación del ciudadano”, analiza la educación cívica en la Francia de la III República y advierte que "se cree que toda educación cívica se ha de construir a partir de la idea de patria. Esta idea es entendida no sólo como principio director del ciudadano, sino como principio fundamentador de la moral. La patria viene a ser el fuego sagrado de los antiguos, sin él no es posible la existencia en la casa. Las virtudes que aseguran su existencia son la honestidad, la prudencia, la temperancia, la fuerza de la voluntad, la actividad, la justicia y el civismo" (Riba, 2006: 74). El manual, Le petit livre de l'homme et du citoyen, publicado en 1881, afirma que "la verdadera escuela de la humanidad es el patriotismo", si a este principio se le añade el lema del catolicismo político francés, que afirmaba que "la religión presidiendo la educación es la mejor escuela de patriotismo" (Mayordomo, 1995: 130), podríamos afirmar que estos principios enmarcan la posición de la Iglesia y el Estado provincial en el período analizado. Ambos tienen la firme creencia en la eficacia y acción bienhechora del orden moral sobre la sociedad, por lo tanto, buscan fundamentar, en el mundo moral, las bases del equilibrio social y, en este orden, la religión juega un papel central.

Las elites dirigentes, fueran del partido que fueran -liberales, conservadores, demócratas o radicales-, excluyendo al socialista, compartían la visión de que la religión, como elemento moralizador, era necesaria para morigerar las conductas desviadas. La consideración del gobernador Del Viso después de una visita a la cárcel provincial es clara, "el gobierno no puede atribuir tantos crímenes sino a la falta de moralidad y a la ignorancia y al completo olvido de los deberes religiosos". 4 Años después, el obispo de Córdoba Zenón Bustos, en un escrito titulado "Necesidad del principio religioso como elemento político", señalaba el fundamento religioso de toda sociedad:

Si es cierto que el ciudadano pertenece a su Patria por los indestructibles y sagrados vínculos que lo ligan a ella, también lo es que pertenece a la Religión por lazos más poderosos a causa de la dualidad de su ser. El vínculo que lo liga a la Religión será más fuerte si su conciencia le enseñan que en la religión está la base de toda sociedad, la fuente de toda ley y el progreso social, los elementos de la dicha pública y privada, la garantía más sólida de las instituciones humanas, de los gobiernos y de los pueblos, la primera necesidad social acrecida con la democracia

\footnotetext{
${ }^{4}$ AAC. Legajo 39.
} 
por la misma debilidad relativa de los frenos que ella impone, el único catecismo que civiliza al ignorante [...] la única ley que sobrevive a la destrucción de las demás, la única que purifica las costumbres, modera las pasiones, releva el infortunio, calma los más grandes dolores, ordena la justicia y da moderación a los que mandan como a los hombres y a los pueblos la obediencia y la confianza: la única que dirige al hombre interior por medio de su leyes y ministros. ${ }^{5}$

Esta acción moralizadora de la sociedad mediante la religión está reservada, en gran medida, al clero. Ya que el obispo está convencido de que "con la escuela religiosa, la iglesia de la Parroquia, los sermones de su Pastor, y la doctrina del catecismo se civiliza e ilustra la inteligencia del pueblo, y el aldeano sale de allí más filósofo en el verdadero sentido de la filosofía”. El obispo cierra la exposición, señalando que el primer esfuerzo "para prevenir las frecuentes convulsiones y revueltas de nuestra patria, como para promover la deseada unión entre sus hijos es restablecer y arraigar en el ánimo de todos, los principios religiosos y la buena moral que ellos encierran. Si la reforma no empieza por éstos será inútil que se proclamen las teorías más rígidas y austeras de gobierno y administración".

La preocupación compartida por la Iglesia y por el Estado sobre la formación del sujeto, según el modelo republicano de organización social y territorial, llevará a procurar modelar un ciudadano respetuoso de las leyes, educado, laborioso y comprometido con el bien común social (más allá de su creencia religiosa particular), por lo tanto, las conductas que se aparten de este perfil se convierten en punibles, motivo por el cual, párrocos, jefes políticos, jueces de paz, coinciden en combatir comportamientos que afecten al orden social establecido: el amancebamiento, la ebriedad, el juego y demás "conductas escandalosas". Esto se debe a que, en general, la sociedad estaba organizada según un conjunto de convenciones fundadas en la utilidad más que en las obligaciones de un contrato, por ello, socialmente, la ley se convierte en el resultado de las relaciones entre las necesidades y las instituciones (Iglesia/Estado), en un sistema positivo y funcional que encuentra, en la utilidad, su principio, modelando las acciones y prefigurando la satisfacción de necesidades.

En este sentido, la pregunta metodológica que surge es ¿cómo las instituciones estatuyen conductas individuales y sociales según sus principios e intereses y cómo estos se reflejan en determinadas modalidades de ordenación del espacio? Un ejemplo claro es el modelo de colonización agraria implementado en la llanura cordobesa en el último tercio del siglo XIX. Al mecanismo de colonización, se suma una concepción territorial, que busca asimilar y acomodar las estructuras de la Iglesia a las estructuras

\footnotetext{
${ }^{5}$ AAC. Fondo Franciscano Zenón Bustos sin clasificar. Escrito monográfico: "Necesidad... ob.cit".
} 
del Estado y utilizar a las parroquias y a los curas como germen administrativo rural del Estado. De esta manera, la creación de nuevas circunscripciones civiles (departamentos) se realizan en sintonía con las circunscripciones eclesiásticas. Obispo y gobernador acuerdan las nuevas circunscripciones y en función del acuerdo se modifican y rectifican los límites. Además, en esta etapa primera etapa (1870-1880) es frecuente que el cura párroco cumpla las funciones de jefe comunal y lleve adelante el proceso de urbanización del territorio. Un claro ejemplo de ello fue el cura Cabanillas en la localidad de Bell Ville, quien distribuyó las tierras de la iglesia para ser pobladas, creó la comuna, fue nombrado su primer presidente e hizo erigir un sólido y monumental templo. Lo mismo sucedió en el curato de Santa Rosa de Río Primero, Calamuchita, etc. Más, a medida que avanzó el proceso de laicidad estatal, se desencadenó la puja entre la Iglesia y el Estado y, particularmente, de sus respectivas burocracias, al rivalizar ambas por el dominio territorial. Un ejemplo de esta realidad puede verse con motivo de la implementación de las leyes laicas, fenómeno que sacó a la luz rivalidades entre jueces de paz, jefes políticos, maestros y curas; o cuando, en 1904, el juez de paz de Cruz Alta fundó una logia masónica y, debido a las redes y vinculaciones del cura párroco, fue desplazado de su cargo. Como desarrollaremos a lo largo del trabajo, estas burocracias dispusieron de mecanismos y estrategias espaciales, vinculadas a las figuras territoriales (curas, jefes políticos, jueces de paz, electores, etc.). Aspiramos a dar cuenta de la hermenéutica de los actores, buscando "múltiples motivos y sentidos -objetivos y subjetivos, racionales e irracionales, materiales y espirituales, estructurales e individuales- presentes en el accionar individual y colectivo que se busca comprender". En palabras de James Lockhart, nuestro objetivo es "buscar detrás de las instituciones el plasma vital de las relaciones sociales" (cit. en Chacón Jiménez, 2008: 146).

\section{La historia social del clero parroquial}

El objetivo de este apartado es analizar, justamente, a una de esas figuras territoriales, concretamente a los curas párrocos y su poder pastoral. Por lo tanto, otro de los ejes centrales de la presente investigación se inserta en el campo de la historia social. Jürgen Kocka (1989: 115), define la historia social como "historia de las estructuras, los procesos y las acciones sociales, del desarrollo de las clases, estratos y grupos, de sus movimientos, conflictos y cooperaciones". En otras palabras, se trata de una historia que prioriza, como tema central, no sólo el estudio de las grandes estructuras objetivas, sino, y fundamentalmente, las conexiones entre las transformaciones mayores - 
ideológicas, políticas, económicas, sociales y culturales- y las acciones, intenciones y experiencias de vidas condicionadas por diferentes entornos. Siguiendo a Kocka, nos interesa analizar cómo están relacionados, en un movimiento coyuntural, las disposiciones variables del comportamiento en determinados grupos, comunidades y organizaciones de intereses, la eficacia de las instituciones y ciertas decisiones políticas (Kocka, 1986: 159). El problema, por lo tanto, se entiende a través de los campos de la historia social, la historia política y la historia cultural. Nuestro interés está puesto en alcanzar a comprender la sociedad cordobesa de entre siglos, a través del lente que nos proporciona un grupo social determinado, que ha tenido una importancia particular en la sociedad provincial, el clero secular diocesano.

Es una constatación compartida por numerosas autores (De Imícoz, 1996: 17; Guerra, 2000: 117; Bertrand, 2002: 11; Moreyra, 2002; Reguera, 2007; Remedi, 2009), la insuficiencia de los criterios empleados durante mucho tiempo para definir a los grupos sociales a partir de la identificación de los individuos por una gama muy restringida de roles y funciones de tipo socio-profesional. Las propuestas revisionistas, centradas en la revalorización del sujeto y de la acción humana frente al poder de las estructuras, en el carácter dinámico, relacional y construido de las identidades sociales, en el rescate del acontecimiento y en las miradas micro, han propiciado una forma cualitativamente distinta de entender el funcionamiento de la sociedad, de explicar la conciencia y las acciones de los individuos y de concebir la naturaleza, la génesis y los mecanismos de transformación de las relaciones e instituciones sociales (Cabrera, 2001: 13). Estos enfoques han nutrido a la producción sobre el clero, reconfigurando la práctica historiográfica de la historia religiosa. En este contexto, enmarcamos el debate en torno a los grupos sociales y la construcción de identidades.

\subsection{El clero secular: cuestiones metodológicas}

Abordar el clero como grupo social, nos ha llevado a indagar respecto al modo en que se han estudiado los grupos sociales (Reguera, 2007). Uno de los debates referidos al estudio de los grupos sociales tiene que ver con el "concepto de elite", concepto que los historiadores hemos tomado de la sociología. Desde esta disciplina, Peter Waldmann (2007) señala que el concepto de elite no es un concepto neutro. Desde su creación a fines del siglo XVIII, tuvo una fuerte carga política y emocional. Primero, sirvió a la incipiente burguesía industrial europea para cuestionar los privilegios hereditarios de la nobleza, y después, hacia fines del siglo XIX, la elite se transformó en un concepto de 
rechazo y control de la incipiente sociedad de masas y, al mismo tiempo, en un instrumento para relativizar las nuevas tendencias democráticas. Vilfredo Pareto, Gaetano Mosca y Robert Michels defendieron la tesis de que, independientemente de la constitución formal de un país, en realidad, siempre hay una minoría que tiene el poder y lo dirige. Esta minoría puede cambiar de composición, cooptar nuevos elementos o, incluso, ser derrocada por una contra-elite, pero siempre son grupos reducidos los que gobiernan. En el siglo XX, después de la experiencia del nazismo, que había sido influenciado por las teorías de Pareto, el concepto de elite adquirió otro sentido adicional. Algunos politólogos y sociólogos llegaron a la conclusión de que, en una democracia moderna de masas, los dirigentes políticos difícilmente pueden mantener un contacto directo con el pueblo. Necesitaban de algún grupo que articulase las inquietudes y los reclamos de las masas, a la vez que explicarles, interpretarles y justificar, a las masas, las decisiones gubernamentales. Esta tarea de intermediación recaería sobre las elites (Waldmann, 2007: 10).

El problema central parte, pues, de un concepto previo al del contenido de la elite. Las teorías sociológicas clásicas habían sido concebidas en base a sociedades aún relativamente homogéneas. Se suponía, por lo tanto, que sus elites debían formar un cuerpo homogéneo. Estarían compuestas por miembros unidos por una procedencia social similar, lazos sociales comunes, nexos familiares y un estilo de vida parecidos. Después del primer tercio del ochocientos, se extendió el impacto de cambios acelerados en la economía y sociedad europeas, que irían acompañados del protagonismo de un nuevo pero complejo grupo social. En contraste con el pasado, no eran ya el abolengo de la sangre y el privilegio los que otorgaban el mayor rango. La distinción ganada mediante la fortuna económica y la cualificación profesional pasó a merecer un superior reconocimiento social. Estos procesos de industrialización profundizaron la diferenciación social y tuvieron el efecto de que las elites también se diversificaran. Hoy ya nadie se refiere a la elite de un país, sino que se hace referencia a elites de diversos tipos, económicas, políticas, intelectuales, administrativas, etc., o a elites principales o secundarias. Las elites son concebidas, no ya como un todo global, como un conjunto homogéneo, sino como una realidad plural y sumamente evolutiva, que tiene intima relación con el modelo cultural y la transmisión del sistema de valores (Langue, 2000: 101).

En esta línea de argumentación, el clero secular constituye un grupo heterogéneo y plural, compuesto por individuos que tienen algo en común, el ministerio sacerdotal, y 
lo ejercen cual si fuera una profesión. Sin embargo, estos individuos formaban parte de diversos estratos sociales, aristocracia, clase media y baja. Juan Carlos Agulla (1968: 27), al referirse a la elite del poder en Córdoba, señala que la aristocracia era el estrato social que representaban las personas que a comienzos del siglo XX detentaban el poder en Córdoba. Se trataba de un estrato social que tenía la función de gobierno, en la medida en que todas las elites dirigentes provenían de ese estrato social. Según el autor, basándose en crónicas periodísticas, documentos de época y trabajos especiales, afirma que la estratificación social en Córdoba antes de 1918 constituía un sistema de ordenamiento vertical de la población sobre la base de relaciones de poder. Estas relaciones ordenaban las ocupaciones de la gente y con ello se establecía una escala de prestigio. El ejercicio de los roles ocupacionales fijaba el estatus de la gente, los cuales se ordenaban en estratos sociales. El acceso a los roles ocupacionales dependía de una serie de factores, algunos de tipo adscripto a las personas y otros de tipo adquirido. Este hecho hacía de los estratos sociales ordenamientos más o menos cerrados o más o menos abiertos, según la preeminencia de esos factores. En gran medida, respondía a un sistema de tipo estamental, en la medida en que había un presupuesto familiar para el acceso a los estamentos altos con ciertos canales institucionalizados de movilidad vertical. En la parte más alta de la pirámide de prestigio ocupacional, se encontraba una aristocracia doctoral, compuesta por los doctores, licenciados, maestros y bachilleres de la Casa de Trejo. ${ }^{6}$ Eran fundamentalmente abogados, médicos, ingenieros, escribanos y algunos teólogos y sacerdotes de jerarquía. El ejercicio de sus profesiones universitarias les fijaba un alto estatus y un gran prestigio social, que los hacía disponibles para el acceso a las más altas dignidades. Los más "selectos", por su capacidad o habilidad profesional, constituían las elites dirigentes de esa aristocracia en los distintos sectores institucionales de la comunidad (burocracia oficial, universidad, justicia, iglesia católica). Los miembros menos selectos de esa aristocracia doctoral ocupaban los rangos inferiores de la función de gobierno, eran los funcionarios de ministerios, de la municipalidad, de un banco etc. Tenemos, por lo tanto, un sector del clero que forma parte de la elite provincial, por ende, podemos referirnos a ella como la elite eclesiástica.

Kocka (2000: 398) señala la incidencia de la cultura en la conformación de la identidad burguesa europea. La formación de la burguesía fue dependiente de la coyuntura, "no solo el carácter de la burguesía, sino también el tono de su existencia

\footnotetext{
${ }^{6}$ Nos referimos a la Universidad de San Carlos.
} 
varía en el espacio y en el tiempo". Esto mismo podría aplicarse al clero secular cordobés, la identidad clerical estuvo fuertemente condicionada por la cultura. La ciudad de Córdoba, al menos hasta 1918, era aún una sociedad fundada en valores religiosos y morales. Por lo tanto, el clero constituía un grupo con prestigio social. En este sentido, Enrique Martínez Paz (1983: 249) no duda en afirmar el carácter teológico escolástico de la cultura de la ciudad mediterránea.

En este contexto, también hay que señalar que la composición del clero secular varió en razón de las niveladoras influencias del liberalismo y la inmigración. De esta manera, nos referimos a un grupo que, a lo largo del período estudiado, ha ido cambiando los criterios de pertenencia y admitiendo a nuevos miembros de otros estratos sociales.

Retomando la argumentación de Kocka (2000: 35), tampoco resulta fácil determinar la composición de la burguesía, pues el carácter plural de la misma radica en la dificultad de identificar a los componentes de este grupo social, pues existen categorías intermedias o marginales bastante amplias, cuya adscripción a la burguesía o bien no está clara o bien es variable. Forman parte de la burguesía comerciantes, fabricantes y banqueros, propietarios de capital, empresarios y directores, médicos, abogados y otras profesiones liberales, profesores de enseñanza secundaria y profesores universitarios, jueces y funcionarios de la administración más alta, también naturalistas, ingenieros, diplomados y expertos cualificados situados en cargos directivos de las grandes empresas, etc. Este heterogéneo conjunto social conforma diversos tipos de burguesía, una burguesía de negocios, una burguesía ilustrada y una pequeña burguesía.

En el caso de Córdoba, el sociólogo Agulla sostiene que, hasta comienzos del siglo XX, todavía podía describirse a la sociedad mediterránea como impregnada de costumbres aristocráticas, en un ambiente dominado por el prestigio de un título universitario y las respetables figuras de los comerciantes y estancieros. Este panorama comenzó a transformarse cuando la población inmigrante, abandonando poco a poco el aislamiento rural, mezcló a sus hijos con el medio criollo y asumió funciones preponderantes en la política, el comercio y también, paulatinamente, en la iglesia. El éxito económico de algunos inmigrantes del este y sur de la provincia, les permitió enviar a sus hijos a estudiar a la universidad, que luego de la reforma de 1918 se había democratizado. La Unión Cívica Radical otorgó a los hijos de inmigrantes, especialmente italianos y españoles, la posibilidad de participar en las decisiones políticas. El clero también comenzó a ser una opción para la segunda generación de inmigrantes, cuyos hijos ingresaron en el seminario local. 
En este contexto de movilidad social, incorporamos las propuestas de Guerra, Levi, Bertrand y Lepetit, de analizar a los actores dentro de los contextos más amplios creados por relaciones de dependencia, clientela, amistad, caridad y vecindario, es decir, toda una red de relaciones imprecisas pero significativas que constituyen lo que Giovanni Levi (1990: 15) denominó la "herencia inmaterial” de cada ser social.

Por ello, hemos abordado al clero como un "microcosmos social", un lugar donde desembocan individuos procedentes de muy diversos mundos sociales. Individuos que unidos por el común denominador de su función, se estructuran, se sitúan en su interior (Benito Aguado, 1994: 44). El clero es un actor social de capital importancia, se constituye en un agente transformador de la Iglesia y de la sociedad de la que forma parte. Se aborda el espacio social como espacio de relación, reconstruyendo las relaciones sociales concretas que existieron entre las personas, las cohesiones y rupturas que caracterizaron al clero en sus formas de organización social, señalando cuáles fueron los criterios según los cuales se formaron jerarquías y estratificaciones sociales (Pro Ruiz, 1995: 58). El análisis de redes de relaciones sociales del clero nos permitió prestar especial atención a los vínculos que existieron tanto entre sus miembros como con otros grupos. El estudio de esos vínculos nos hace explicar la conducta de las personas, reconstruir las relaciones sociales concretas y definir su contenido, intensidad y demás características relevantes. En este contexto, se inserta el análisis de la sociabilidad del clero. Este procuró crear espacios de sociabilidad formal e informal, cuyo objetivo central era, sin duda, afianzar la identidad católica en las respectivas feligresías. La parroquia adquiere en este contexto un rol social polivalente.

Los textos de Maurice Agulhon (1994: 56) definen la sociabilidad "como la aptitud de vivir en grupos y consolidar los grupos mediante la constitución de asociaciones voluntarias", parafraseando al autor, se podría afirmar que, al igual que el obrero, el cura de campaña llegará a preconizar la asociación no sólo como instrumento de ayuda mutua, sino también como instrumento de producción autónoma, colectiva, de hecho, la asociación concebida como cooperativa es uno de los aspectos claves del catolicismo social llevado adelante por algunos curas párrocos.

La fe de una comunidad también se mide por el número de vocaciones religiosas. Por este motivo, en el marco del espacio diocesano cordobés, analizaremos los ritmos de las ordenaciones. La observación de los orígenes sociales y geográficos de los futuros clérigos. El análisis de los sistemas de acceso a la carrera eclesiástica, los criterios de selección, las causas de ordenación, las mecánicas de provisión de cargos y beneficios, 
nos permitió plantear el "cursus honorum eclesiástico" como una carrera ascendente de plazas con las que el individuo era retribuido en relación a diversas variables, sus méritos propios, las relaciones e intereses familiares o el servicio a la Iglesia y a las almas (Venard, 1968; Julia, 1985; Pazos, 1990; Candau Chacon, 1993; Taylor, 1999; Morgado García, 2000; Aguirre Salvador, 2004; Di Stefano, 2004; Enríquez, 2005; Dainville-Barbiche, 2005; Airiau, 2006; Gicquel, 2008; Launay, 2010).

El trabajo de Dainville-Barbiche (2005) se detiene particularmente en analizar los destinos de los sacerdotes de París en el siglo XVIII. Esto le permitió identificar la relación entre reclutamiento, lugar de origen, "necesidad de la iglesia", voluntad del obispo, estrategias personales y familiares. Para ello, analiza el sistema beneficial que, sin duda, condiciona las estrategias y determina el espacio en el que éstas se despliegan. En nuestro caso de estudio, el proceso de profesionalización de la carrera eclesiástica se inserta en un proceso más amplio, como fue el proceso de romanización de la Iglesia, en tanto se trataba de actores a los que el concilio asignaba un rol decisivo en la reforma de la iglesia y en el rescate católico frente a las ideologías seculares (Di Stefano y Zanatta, 2000: 366). Tomamos aquí algunas observaciones del libro de Forster, Catholic revival in the Age of the Baroque, en el que analiza el renacimiento católico de la Alemania barroca. El autor señala la relevancia del concepto de profesionalización del clero en la cura de almas. Define precisamente la importancia de atribuir al término "profesionalización" no un sentido genérico o descriptivo referido a "los hombres de lo sagrado". El autor ubica el término en el marco de un fenómeno que se colocará en el centro del movimiento llevado a cabo por la renovación que marca la era posttridentina. Una de las piedras angulares del fenómeno estaría dada por el intento de crear un cliché, "una matriz de formación", a través de seminarios, con la intención de lograr un clero más uniforme.

Durante el período analizado en nuestro trabajo, el joven aspirante al sacerdocio debía poseer ciertos requisitos previos (ser hijo legítimo, varón, de conducta honesta, con inclinación al sacerdocio, etc.). A lo largo de once años era formado en la cultura básica religioso-eclesiástica, al menos para alcanzar el nivel necesario para el ejercicio del ministerio con cura de almas, exigencia que debía cumplir hasta el más humilde sacerdote de campaña. Los estudios más específicos, como la competencia para resolver casos más complejos de teología moral, estaban reservados sólo a algunos. La formación básica estaba destinada a adquirir la competencia y capacidad para celebrar y administrar sacramentos, conocer y enseñar el catecismo y la historia sagrada. Esta 
primera formación se orienta a lograr un perfil de sacerdotes de conciencia, piadosos, de conducta moral recta, obedientes a la autoridad y disponibles a las necesidades de la Iglesia y de su prelado, es decir con mínimas pero sólidas habilidades básicas (Gallardo y Martins, 2014). El modelo de cura es, sin duda, el Santo Cura de Ars, Juan Bautista María Vianney, profusamente analizado por Philippe Boutry (1986, 1995, 2008).

Nuestra investigación centra su atención en los párrocos y en los que cumplen con esa función, es decir pastores con cura de almas, incluyendo vicarios, ecónomos, tenientes, capellanes, excluyendo el variado mundo de los que, habiendo recibido sólo las órdenes menores o incluso aquellos que habiendo recibido el orden in sacris del presbiterado, no se dedicaron a la tarea pastoral de una manera sistemática.

En este campo, resultó de particular importancia la lectura del libro de William Taylor, Ministros de lo Sagrado. El análisis sobre cómo impactaron las medidas centralizadoras de los Borbones en los curas párrocos permitió pensar el problema del impacto de las medidas centralizadoras de la iglesia en el proceso de romanización. Taylor (1999: 42) señala que "cuando la retórica regalista de amor y caridad logró filtrarse en las presentaciones de los sacerdotes ante los obispos, las audiencias y los virreyes del final del siglo XVIII, ello pudo implicar una crítica a las reformas regalistas de un tal criticismo que llegaron a plena floración al final de la lucha por la independencia en 1821, cuando los clérigos reclamaron [...] por su defensa de la amenazada religión de Jesucristo, contra una España que había abandonado sus afanes y obras cristianas". Esta crítica a las formas regalistas, ante una religión cristiana amenazada, también fue uno de los argumentos esgrimidos por parte del clero parroquial ante el avance secularizador del estado cordobés a fines del siglo XIX. Asimismo, los capítulos cuarto y quinto, "Llegar a ser cura párroco" y "Las carreras de los curas párrocos", nos ayudaron a pensar la problemática para nuestro período de estudio y nos otorgaron herramientas metodológicas para elaborar un cuadro de situación sobre las categorías de parroquias, desde las más a las menos deseables.

En cuanto a la formación, los curas debían tener lo que hoy llamaríamos una "formación permanente", que incluía la participación en reuniones destinadas a analizar casos de la vida pastoral, llamadas "conferencias del clero", asistir a retiros espirituales anuales y participar de toda una serie de iniciativas libremente organizadas por los propios sacerdotes, como las hermandades sacerdotales (Hermandad de San Pedro, Círculo del Clero, etc.). Como se ve, la formación continua debía -o debería continuarluego de la ordenación in sacris, realidad que no siempre se cumplía. Este "proceso de 
profesionalización" llevó a delimitar progresivamente funciones en la cura de almas, a acentuar y velar por la disciplina, externa e interna, a especializar la formación en función de las nuevas competencias asignadas y a aumentar su número, que creció, progresivamente, sobre todo a comienzos del siglo XX.

Además del párroco, nos ha interesado analizar, en particular, una figura que se encuentra en la "marginalidad del clero parroquial", los capellanes, figura que fue perdiendo cada vez más autonomía y que terminó siendo subsumida a la autoridad del párroco y reemplazada por la figura de los tenientes o ayudantes. Generalmente, ocupaban estos puestos curas extranjeros, ocupados en las colonias de inmigrantes italianos.

Por todo lo expuesto, y como señalamos ut supra, la figura del pastor se presenta como un lente a través del cual mirar la sociedad cordobesa, construir una historia social del clero cordobés a nivel de las bases parroquiales, que nos permite mirar la Iglesia y la religión integradas en la complejidad del juego social y advertir la compleja y ambigua relación entre catolicismo y sociedad. Al mismo tiempo, comprobar que la imagen homogénea y compacta del clero, que presentaba la historiografía tradicional, desaparece, dando lugar a un universo diverso, complejo, estratificado y socialmente construido, inserto en las problemáticas sociales, culturales y políticas provinciales.

\section{El aporte conceptual de la sociología religiosa}

\subsection{Modernidad y secularización}

Las tesis más radicales sobre el fenómeno de la secularización plantean una visión teleológica del catolicismo en la modernidad, que ha sesgado muchos de los procesos de transformación experimentados por la Iglesia Católica tanto en el siglo XIX como en el XX. La Iglesia y la religión han sido interpretadas como obstáculos estructurales para el advenimiento de las relaciones sociales y de las instituciones modernas, es decir que concibe a la Iglesia católica como una fuerza oscurantista y a contracorriente de los tiempos de la modernidad. Pensamos que una visión más cuidadosa de los procesos de transformación de la Iglesia permitiría entender la asombrosa capacidad que ha demostrado la Iglesia católica para sobrevivir y mantenerse atenta e influyente en la vida social. La tendencia ha sido considerar al catolicismo del siglo XIX y comienzos del XX como una historia de fracasos y crisis, producto de la fuerza reaccionaria del catolicismo y de la fuerza ineludible de la modernidad hacia el progreso. Consideramos que la religión debe ser interpretada como una serie de instituciones, símbolos y 
prácticas que tienen la capacidad de adaptarse, con mayor o menor facilidad, a diferentes contextos sociales, políticos y económicos.

En nuestro análisis, tomaremos el concepto de secularización sólo como una coordenada interpretativa propia del siglo XIX, un fenómeno histórico que, en cuanto tal, tiene un origen que está en estrecha relación con el proceso de emancipación de la sociedad burguesa, cuando se plantea una oposición de fondo entre el presente histórico, que se lo define como época moderna, y el pasado o la tradición. Esto motivó que la categoría de secularización, y su derivado secularismo, implicasen ciertas connotaciones ideológicas y valorativas, llegando a significar, en círculos ante todo anticlericales y progresistas, el proyecto de emancipación del hombre moderno - del sujeto burgués- de la tutela de la Iglesia, mientras que otros círculos, conectados con grupos eclesiásticos, lo entendieron como descristianización. En este trabajo, abordaremos dos dimensiones de la secularización, la laicización o emancipación del estado y la sociedad del dominio de la Iglesia, y la dimensión de la participación eclesial de los católicos. En el contexto histórico seleccionado, sería una extrapolación entender la secularización como declive o decadencia de la religión, o como un proceso de desacralización de la sociedad que llevaría a la desaparición de las religiones, al menos del espacio público (Seman, 2007: 42).

Por modernidad, entendemos una realidad subjetiva, cuya representación la construye el sujeto, como el paso, con todas las contradicciones, riesgos y posibilidades subyacentes del antiguo orden social, político, económico e ideológico, a uno nuevo. Jacques Le Goff, tomando a Henri Lefebvre, distingue entre modernidad y modernismo, "la modernidad difiere del modernismo como un concepto en vías de formulación" (Le Goff, 1995: 165), por lo tanto, la modernidad se presenta como un modelo, el modernismo como la concreción o puesta en práctica de dicho modelo, y la modernización como el resultado de dicho proceso. Le Goff sintetiza esta idea señalando que la modernidad "difiere de los fenómenos sociales, como una reflexión difiere de los hechos". La modernización, por lo tanto, supone pensar el tiempo, concebido en términos de historicidad, pensar cómo se produce este pasaje, en el cual los componentes del antiguo orden adoptan un signo diferente. El pasaje hacia la modernidad no es unívoco ni lineal. Le Goff distingue tres tipos o formas de modernización: una modernización equilibrada, una conflictiva y una tercera tentativa. En la primera, la penetración de lo moderno no destruye los valores de lo antiguo; en la conflictiva, la tendencia a lo moderno crea graves conflictos con las tradiciones 
antiguas; y en la modernización a tientas, la modernidad trata de conciliar lo moderno con lo antiguo, no a través de un nuevo equilibrio general sino mediante opciones parciales (Le Goff, 1995: 165). En este sentido, la modernidad religiosa fue sin duda una modernidad conflictiva, que generó conflictos a nivel -sobre todo-, político y una modernidad a tientas, pues lo antiguo, o tradicional, seguirá teniendo mucho peso.

Estudiar la modernidad presupone la construcción, por parte de los sujetos, de nuevas formas de relacionarse, de pensar, de actuar, de organizarse, de hacer las cosas, de concebirse y de identificarse. Desde una particular perspectiva, la modernidad puede ser comprendida como parte de las herramientas metodológicas a la que se recurre para el análisis de la sociedad y de los sujetos que la componen. Como categoría analítica, no tiene una sola cara, ni es un evento único. Por el contrario, es un evento múltiple, cuyas representaciones son igualmente múltiples. Concebida como herramienta que incita al pensamiento, la modernidad ofrece la posibilidad de explicar las diferentes maneras en que la sociedad, los sujetos y la realidad se articulan y reconstruyen permanentemente. Hablar de modernidad significa hablar de los tiempos y de los espacios en los que este fenómeno se concretó, significa hablar de nuevos actores sociales que orientan y dan sentido al nuevo orden, de las relaciones que emergen, nuevos problemas surgidos del paso de uno a otros órdenes y de nuevas categorías de análisis, que permitirán repensar, problematizar y explicar la estructuración emergente, los tiempos, espacios, conflictos resultantes y sujetos que lo orientan.

La modernidad es un proceso en el que se pueden distinguir tiempos y espacios y, sobre todo, individuos, quienes, a través de sus interacciones, representaciones e imaginarios, establecen, recreándolas permanentemente, las formas que adquieren aquellos conceptos y la propia modernización. Al concebirla como proceso, podemos hacer cortes temporales. Al seguir esta línea de reflexión, la modernización nos permite articular lo micro con lo macro o, si se prefiere, los niveles individuales con los institucionales. Lo cual no es otra cosa que, por una parte, reconocer que la reflexión sobre la modernización no sólo tiene sentido a nivel de la estructura social, sino también a nivel de las personas que la componen; por otra parte, no es más que poner al individuo en el centro del proceso y, con ello, concebirlo como capaz de insertarse en una sociedad y, sobre todo, en un mundo de vida diferente al de sus predecesores. Asimilar las transformaciones que trae consigo la modernidad, recrearlas y construir así el nuevo orden que supone dicho proceso. Más todavía, le permite elaborar su identidad o ampliarla, tomando como referente los códigos simbólicos, redes de relaciones, 
formas de hacer las cosas, sistemas de creencias, conocimientos, conductas y actitudes que permean y dan sentido a su mundo de vida. En suma, es reconocer que la modernidad y el individuo guardan un estrecho vínculo que imposibilita cualquier intento de hablar de una sin el otro. Mallimaci (1996) sostiene que modernizar es un proceso clave alrededor del cual se tejen alianzas, enfrentamientos, conciliaciones: ¿qué hacer frente a la modernización? ¿Negarla, sustituirla, conciliar, penetrarla, marginarse? Estas preguntas suponen un primer disparador para abordar el análisis de las formas en que la Iglesia intentó reacomodarse a la situación que le creaba la vasta modernización en curso y el avance del proceso de secularización.

\subsection{Modernidades múltiples}

El proceso de modernización implicó un fenómeno de secularización de la sociedad. Las tesis más radicales sobre la secularización plantean una visión dicotómica, oponiendo tradición y modernidad. La Iglesia ha sido interpretada como una institución de corte tradicional y, por lo tanto, como un obstáculo estructural para el advenimiento de las relaciones sociales y de las instituciones modernas.

La teoría clásica de la secularización sostiene tres postulados centrales: que la secularización implica la pérdida de la religión en las sociedades modernas, con el consiguiente declive y retroceso de las prácticas y creencias religiosas; que se trata de un proceso de privatización de la religión, unido a la diferenciación y autonomía de las distintas esferas; que se produce el desencantamiento del mundo, es decir la desacralización de la realidad. La conclusión sería que la modernidad y la religión entraban, por lo tanto, en inevitable contradicción, produciéndose la fragmentación y marginalización de la fe que conlleva la pérdida de influencia de las instituciones religiosas en las sociedades modernas (Louzao Villar, 2008: 336).

Danièle Hervieu-Léger (2005), con una mirada crítica, disiente con este planteamiento y rescata tanto las permanencias de la tradición en la modernidad, como la presencia de elementos modernos en sociedades tradicionales. La perspectiva metodológica propuesta por Hervieu-Léger (2005: 140) para el análisis de los fenómenos religiosos en sociedades modernas, nos aporta algunas categorías útiles para nuestro trabajo. Una de ellas es el "potencial creativo de la tradición". La autora propone re-articular la relación de la tradición con la religión en el interior de la modernidad. Sin erradicar la identificación de la religión con el universo de la tradición, ésta no fue excluida del universo de la modernidad. Lo que indica es que la religión está 
presente bajo una nueva forma que es la tradición en la modernidad. El planteo sostiene que la modernidad y la religión no son exclusivas la una respecto de la otra y, por lo tanto, en la modernidad, la religión y la tradición tienen un papel creativo. La religión no se vuelve socialmente irrelevante en la modernidad, sino que encuentra nuevas significaciones sociales que pueden ser comprendidas mediante el estudio de casos particulares. Los diversos modos de transmisión de la religión y de socialización religiosa utilizados por la institución como catequesis, misiones, organizaciones parroquiales con fines beneficiales, de culto y de instrucción religiosa, la prensa y la educación son un ejemplo del dinamismo modernizador de la tradición.

El concepto de "modernidades múltiples" le permite afirmar que cada sociedad construye su propia modernidad. Los rasgos o principios modernos consiguen formas múltiples e institucionalizaciones variadas. José Casanova (2007) sostiene que hay algunos elementos o rasgos comunes compartidos por todas las sociedades modernas que ayudan a distinguirlas de sus formas pre-modernas o "tradicionales". Pero estos rasgos o principios modernos consiguen formas múltiples e institucionalizaciones variadas. De esta manera, hay tanto una civilización de la modernidad como la transformación continua de las civilizaciones históricas pre-modernas bajo condiciones modernas, lo que ayuda a dar forma a las modernidades múltiples. Las cualidades modernas no se desarrollan necesariamente en contraste o a expensas de la tradición, sino que lo hacen más bien a través de la transformación o el ajuste pragmático de la tradición. Las modernidades múltiples rechazan tanto la noción de una ruptura radical moderna con las tradiciones, como la noción de una continuidad moderna esencial con la tradición. Todas las tradiciones se transforman radicalmente en los procesos de modernización, pero también tienen la posibilidad de modelar sus propios caminos para la institucionalización de los rasgos modernos.

Estas herramientas conceptuales nos permiten sostener que la religión no se vuelve socialmente irrelevante en la modernidad, como lo sostienen algunas tesis radicales de la teoría de la secularización, sino que encuentra nuevas significaciones sociales que pueden ser comprendidas mediante el estudio de casos particulares. La historiografía latinoamericana no ha asumido aún la profunda historicidad del fenómeno de la secularización. Continúan latentes interpretaciones canónicas, herederas de la interpretación liberal del siglo XIX. ${ }^{7}$ La renovación historiográfica en el campo de la

\footnotetext{
${ }^{7}$ A partir de las dos últimas décadas del siglo pasado, el paradigma de la secularización comenzó a ser cuestionado y la idea de un regreso de lo religioso comenzó a abrirse camino. A ese respecto, Peter Berger y Thomas Luckmann subrayan que uno los errores en las teorías de la secularización es la
} 
historia religiosa y, por lo tanto, la preocupación por historizar la secularización, ${ }^{8}$ es relativamente reciente.

Karel Dobbelaere (1994) señala que la secularización es un proceso que se realiza en planos diversos y que no hay correlaciones necesarias con lo que ocurre en cada uno de ellos, los niveles propuestos son el estructural, el institucional, el funcional y el individual.

Valentina Ayrolo, María Elena Barral y Roberto Di Stefano (2012: 10-11), en la introducción de Catolicismo y secularización en la Argentina, primera mitad del siglo $X I X$, siguiendo la clasificación de Dobbelaere, advierten que la secularización estructural, dada por la creciente autonomía de las esferas sacra y secular, se expresa en ámbitos como la política, la economía y la ciencia. Autonomía que no implica necesariamente separación, ya que entre ambos campos pervivirán múltiples vasocomunicantes y se producirán importantes transferencias simbólicas. Este nivel es el más evidente en la primera mitad del siglo XIX. En tanto, el segundo nivel se relaciona con la secularización de las instituciones nacidas en el ámbito eclesiástico a partir de motivaciones principalmente religiosas y se transforman paulatinamente en una institución secular. La secularización funcional se refiere a aquella que atañe a las funciones sociales previamente ejercidas por instituciones religiosas, como el caso de la caridad, que se seculariza con el nombre de beneficencia, educación, atención hospitalaria, etc. Por último, la secularización funcional se vincula con la pérdida de referencias religiosas en las conductas individuales que podrían traducirse, por ejemplo, en la caída de los índices de práctica religiosa.

Cabe señalar que lo que ocurre en el plano de la laicización, es decir el primer nivel, no se correlaciona, directa y linealmente, con lo que ocurre en el segundo (la secularización de las instituciones nacidas en el ámbito eclesiástico) o tercer plano (la pérdida de referencias religiosas en las conductas individuales). Cada plano puede convivir con la persistencia de lo religioso. De manera tal que Jean Bauberot (2004), al analizar los procesos de secularización francesa, presenta diversos umbrales. El primer umbral de la secularización es el propio de los procesos de laicización. Antes de seguir

convicción de que la modernización conduce ineluctablemente a una pérdida de importancia de la religión. Para los autores, este paradigma debería ser sustituido por el análisis de la interacción entre las fuerzas de la secularización y las de una contra-secularización. Ambos consideran que, en oposición a la idea de des-cristianización, la religión, en lugar de desaparecer, parece recobrar una gran vitalidad y que el proceso de secularización es una constante únicamente en Europa (Cfr. BERGER y LUCKMANN, 2001).

${ }^{8}$ En esta línea, se encuentran los trabajos de DEMELAS y SAINT-GEOURS (1988); CÁRDENAS AYALA (2007); CONNAUGHTON (2007); DI STEFANO (2008 y 2011a y b); SERRANO (2008); AYROLO, BARRAL y DI STEFANO (2009). 
adelante consideramos importante definir qué entendemos por laicidad. Olivier Tschannen (2004: 356-364) sostiene que es uno de los componentes de la secularización: designa cierta manera de relación, no entre política y religión sino entre la institución política y las instituciones religiosas. Es decir, la diferenciación a nivel institucional de lo político y lo religioso.

Una vez definido el concepto, continuamos con el análisis de Bauberot. El autor caracteriza este primer umbral con tres propiedades, la fragmentación institucional, por la cual el estado ya no pretende garantizar la "salvación" de los ciudadanos sino ocuparse exclusivamente de sus intereses terrenales y, por lo tanto, se considera incompetente para imponer doctrinas religiosas propiamente dichas. La religión ha dejado de ser portadora de un sentido que abarque todos los aspectos de la vida. Instituciones que antes tenían que tomar en cuenta sus normas, o se situaban bajo su influencia, como la escuela, se autonomizan. Los maestros se convierten en nuevos clérigos, aptos para poner bajo tutela a la población y dar sentido a las conductas sociales. La Iglesia, sigue siendo la institución religiosa dominante, aunque opone resistencia. Ella continúa siendo la institución portadora de la socialización moral, por ende, en este umbral, la moral religiosa es la que otorga la legitimidad moral a la sociedad. En este primer umbral de secularización, se reconoce cierto pluralismo hacia los cultos más reconocidos y cierta tolerancia, aunque no muy fuerte, hacia el librepensamiento. La actividad del clero se restringiría a la administración de sacramentos. Este umbral, históricamente, se habría dado en Francia entre 1789 y 1806, en el marco de una modernidad ascendente en la que están en desarrollo los procesos de laicización.

El segundo umbral implicaría una disociación institucional. La Iglesia deja de considerarse una de las instituciones que estructuran a la sociedad. La religión puede funcionar al interior, pero debe adoptar socialmente forma de asociación. Otras prácticas, como la escolar, se han vuelto socialmente obligatorias, la religión tiende a ser una opción facultativa. Además, al volverse un "asunto privado", la religión perdería su dimensión social y su acción sería reemplazada por la de instituciones laicas. La cuestión de la utilidad de la religión para la sociedad, su papel moral, no es oficialmente de pertinencia pública. Otras instituciones como la escuela tienden a reemplazarla en ese espacio, la moral, por lo tanto, es una moral laica, no religiosa. La libertad de conciencia y la libertad de culto no distinguen entre cultos reconocidos y no reconocidos. Cada ciudadano es poseedor de la libre elección y el libre rechazo de la 
religión. En virtud del pluralismo religioso, el Estado reconoce diversos cultos, garantizando su libertad y posibilidades de expresión. Históricamente, este umbral se ubicaría, en el marco temporal francés, entre 1880 y 1905-1907, coincidiría con la modernidad hegemónica, en la cual la laicidad está establecida con la separación de la Iglesia del Estado.

El tercer umbral coincide con la modernidad tardía y tendría como fecha paradigmática el año 1968 (Bauberot, 2004a: 23 y 2004b: 99). No viene al caso desarrollar sus características en estas líneas.

\section{La religión como elemento transformador de la sociedad}

La modernización no es necesariamente sinónimo de modernidad. Siguiendo a numerosos autores, entre ellos a Emile Poulat, puede señalarse que la hostilidad persistente de la Iglesia católica contra el mundo moderno no implica ninguna postura en contra de la modernización. Para ello, nos apoyamos en un trabajo, cuyas principales orientaciones metodológicas pone en tensión la idea tan extendida, y prácticamente canonizada hace veinte o treinta años, de que la evolución religiosa está más o menos determinada por la evolución económica y social. Michel Lagrée, en Religion et cultures en Bretagne, 1850-1950, sostiene la postura inversa: que las transformaciones sociales, económicas y culturales de Bretaña hacia 1880 sólo fueron posibles con el aval y el concurso de un catolicismo que mantuvo su hegemonía durante mucho tiempo. Para el autor, el factor religioso, sin que se le pueda atribuir la exclusividad de la modernidad, ha desempeñado un papel de motor.

Esta hipótesis de trabajo, que considera a la religión como elemento dinamizador de la sociedad, puede ser aplicada a la región del sudeste cordobés en el período analizado. En la campaña cordobesa, la sociedad se identificaba con el universo de creencias, conductas, sensibilidades y prácticas católicas. Esta realidad se verá, en cierta medida, modificada por el crecimiento demográfico producido por el impacto de la inmigración, fenómeno que llevó a que la sociedad dejara, paulatina y progresivamente, de coincidir con el universo religioso católico. Como hemos señalado ut supra, la Iglesia de Córdoba buscó adaptarse a las nuevas realidades, modificando sus estructuras, su percepción de la cambiante realidad social y buscó el modo más adecuado para actuar en ella.

Si bien el proyecto liberal impactó con fuerza en las relaciones entre Iglesia y Estado, en cambio, la transformación de las relaciones entre Iglesia y sociedad fue un proceso más lento, debido, sin duda, al arraigo de la religión católica en gran parte de los grupos 
sociales de la provincia de Córdoba. La Iglesia y sus fieles trazaron diferentes caminos de conducción de la fe, crearon nuevos circuitos de transmisión de sus valores y apelaron a nuevos símbolos religiosos para posicionar sus ideas sobre el orden social (Di Stefano y Zanatta, 2000). 


\section{CAPITULO 3}

\section{FUENTES: ALCANCES Y LIMITACIONES}

\section{Tratamiento metodológico: el juego de escalas}

Las fuentes son trabajadas desde diferentes escalas. Aquellas que nos permiten analizar el proceso desde una perspectiva macro y de larga duración, y aquella otras que nos facilitan un análisis desde lo micro. En este sentido, la perspectiva metodológica propuesta por Bernard Lepetit (1996) del "juego de escalas”, nos permite mirar el proceso desde diversos ángulos y temporalidades diferentes, mediante un vaivén permanente entre los distintos niveles de análisis. Como señala Michel Bertrand (2002), nos proponemos utilizar una perspectiva de análisis a nivel micro que permita desplazar la observación "desde la estructura a la coyuntura para, en una última instancia, regresar a la globalidad", en este sentido, son las mismas fuentes las que inducen y permiten realizar unos y otros estudios.

Además, la posibilidad de cruzar la documentación proveniente de diversos niveles de archivos, central (Vaticano), regional (diocesano) y local (parroquial), evita que nos formemos una imagen distorsionada de la realidad diocesana. Los archivos de la parroquia, si bien son muy importantes, si se trabajan aisladamente pueden generar imágenes parciales o engañosas.

Por otro lado, es dable señalar que, en los archivos parroquiales, no siempre se encuentra documentación sistemática e informes significativos sobre la primera mitad del siglo XIX, esto debido tanto a la debilidad institucional de la Iglesia diocesana cordobesa, como a la simbiosis que existía con los poderes civiles. Por lo tanto, para este período, es muy difícil elaborar un mapa completo de la organización eclesiástica, dado que no existen fuentes más importantes que las visitas pastorales. Estas, afortunadamente, comenzaron a realizarse cada vez con mayor periodicidad a partir de 1859 , lo que constituye un elemento fundamental para poder elaborar una cartografía de la organización eclesiástica de la segunda mitad del siglo XIX.

En función de esta propuesta de abordaje metodológico las fuentes han sido agrupadas en función de su utilización. 


\section{Fuentes de tipo normativo}

Entre las fuentes de tipo normativo, ubicamos los concilios y sínodos diocesanos y los documentos emanados por la autoridad episcopal diocesana: los autos y decretos de los obispos y gobernadores eclesiásticos, los edictos, las circulares y las cartas pastorales.

\subsection{Los concilios y sínodos diocesanos}

La Iglesia es una organización fuertemente institucionalizada. Las normas emanadas por los concilios han de ser puestas en práctica por cada obispo en su diócesis, para lo cual cada uno de ellos suele celebrar sínodos diocesanos en los que sacerdotes y otros fieles escogidos de una Iglesia particular prestan su ayuda al obispo. Los sínodos son, por lo tanto, asambleas eclesiásticas, destinadas a profundizar en algún aspecto de la vida de la Iglesia. Es una reunión periódica y obligatoria de algunos miembros del clero diocesano con su obispo para adoptar reformas y correcciones necesarias a la disciplina religiosa de sacerdotes y laicos.

El Concilio de Letrán (1215) estableció universalmente la celebración anual de sínodos para que legislaran los aspectos primordiales de la vida sacramental de las respectivas diócesis. Los sínodos se convierten en un instrumento adecuado para controlar al clero parroquial, con frecuencia poco instruido para la labor que se le exigía. El análisis de los sínodos diocesanos nos permite abordar los lineamientos normativos de la Iglesia local. Los sínodos son una fuente eclesiástica muy consultada en lo estudios eclesiásticos europeos y americanos coloniales. La utilidad de la misma radica en que permite analizar la normativa eclesiástica en el campo del deber ser, en otras palabras, acercarnos a las políticas de gobierno y confrontar la norma con la práctica. En la diócesis de Córdoba, entre 1877 y 1927, se desarrollaron dos sínodos diocesanos, el primero, en 1877, fue un exponente de los lineamientos del Concilio Ecuménico Vaticano I; el segundo, se convocó en 1905 y asumió las directivas del Concilio Plenario para América Latina, celebrado en Roma en 1898, en relación a la vida de la Iglesia a nivel diocesano.

En un proceso de cambio, como el que nos proponemos abordar aquí, esta fuente nos permite delinear el perfil del clero deseado y observar la evolución de ese mismo perfil. El Sínodo de 1877 fijó las estrategias institucionales para "restablecer la disciplina eclesiástica, restaurar la sana doctrina, [...] para proveer por este medio el mejor 
gobierno de la diócesis y reformar las costumbres". ${ }^{1}$ Habían pasado más de 270 años sin que se realizara un sínodo, por lo tanto, a partir de esta fecha comienza un proceso de consolidación de la Iglesia local. El único estudio sobre esta asamblea lo realizó Nelson Dellaferrera para el Sínodo del siglo XIX. El sínodo no ha sido publicado y este trabajo presenta las principales disipaciones del mismo, nosotros hemos consultado la versión original manuscrita del mismo. En cuanto al Sínodo de 1906, hemos trabajado con la edición impresa. ${ }^{2}$

Algunas de las dificultades que presentan estas fuentes radican en que pueden ser un mecanismo mimético por parte de la autoridad diocesana que reproduzca, o sea simplemente órgano de difusión, de los decretos del Concilio Vaticano I y Plenario para América Latina y, de esta manera, pierdan su carácter local y original, fruto de la propia dinámica evolutiva de la diócesis.

A pesar de estos problemas, $y$ al hecho de admitir que esta documentación posea filtros y espejos deformantes, como señala Carlo Ginzburg (1982: 18), una fuente que no es objetiva no quiere decir que no sea inutilizable.

\subsection{Autos y decretos. Edictos, circulares y cartas pastorales}

La administración eclesiástica generaba una prolífica documentación que nos ha sido de suma utilidad para nuestro trabajo. Además de los sínodos, consultamos las disposiciones emanadas de la autoridad eclesiástica (obispo, gobernador eclesiástico o provisor). Estas se emitían bajo la forma de autos, decretos o edictos. En el Archivo del Arzobispado, los Libros 39, 40 y 41 contienen esta información (L. 39, Autos y Edictos 1876-1905; L. 40, Autos y Edictos 1905-1920; L. 41, Decretos y Edictos 1920-1925).

Los edictos y las cartas pastorales se colgaban en la entrada de los templos o se leían durante el oficio de la misa. Tenían como finalidad hacer llegar a los fieles las decisiones del obispo de la Diócesis referentes a las más variadas cuestiones (prohibiciones de fiestas - por ejemplo la del XX de Septiembre-, reglamentaciones sobre el ayuno cuaresmal, prohibición de lectura de "mala prensa", etc.). Estas fuentes proporcionan valiosa información sobre la vida y reglamentación religiosa cotidiana de la diócesis.

Hemos reconstruido la serie de pastorales, carta-edictos y circulares, documentos que se encuentran en varias ubicaciones del Archivo. El Legajo 53 contiene las pastorales

\footnotetext{
${ }^{1}$ AAC. Actas de las Sesiones del Sínodo diocesano de 1877, f.499.

2 Sínodo diocesano celebrado en Córdoba por el Iltmo. y Rmo. Señor Obispo Don Fray Bustos y Ferreira. En el año del Señor MCMVI. Resoluciones y Apéndices, Córdoba, Tip. "La Industrial,” 1907, 265 p.
} 
emanadas entre 1854 y 1903 y una Caja, rotulada Pastorales (1900-1925), completan la documentación del período, sin bien es necesario que aclarar que en esta ubicación no se encuentra la totalidad de los documentos. Incluso, hemos hallado varios de ellos dispersos en las múltiples cajas que contienen la documentación de las parroquias.

Las pastorales son cartas del obispo dirigidas al clero y feligresías de la diócesis por diversos temas, cuestiones relacionadas con festividades de la Iglesia (Jubileos Pontificios, Conmoraciones de Jesucristo, la Virgen o los Santos, tiempos litúrgicos como Cuaresma, Pascua o Navidad) y devociones varias (mes del Rosario, Sagrado Corazón, Novena, etc.). Administración y gobierno de la diócesis (anuncios de comienzo o finalización de visitas ad limina, pastorales, creación de nuevas parroquias, ampliación del seminario diocesano), y acción católica (prensa católica, educación católica, círculo de obreros, cuestión social, enseñanza del catecismo, etc.). Muchos de estos documentos son programáticos y contemplan orientaciones respecto a la forma de proceder. Hemos trabajado un total de ciento ochenta documentos. A partir de 1900, año en que se crea la "Revista Eclesiástica" del Obispado de Buenos Aires, la sección destinada a la Diócesis de Córdoba comienza a publicar estos documentos.

\subsection{Visitas ad limina y visitas pastorales}

Las visitas ad limina debían realizarse cada cinco años, los obispos debían viajar a Roma para presentar, al Romano Pontífice, un informe sobre la situación y administración de la diócesis. La frecuencia de sedes vacantes dificultó su concreción y los obispos de Córdoba comenzaron a vivir esta obligación, de manera sistemática, recién a partir del último tercio del siglo XIX. Para nuestro período, contamos sólo con tres visitas ad limina, la primera, la del Obispo Fray Reginaldo Toro en 1892 y dos de Fray Zenón Bustos y Ferreyra en 1908 y 1913. Las mismas fueron consultadas en el Archivo Nunciatura Argentina en los Archivos Secretos Vaticanos.

En tanto, las visitas canónicas o pastorales eran competencia del obispo y las efectuaba personalmente o por medio de un delegado o vicario. Las visitas son consideradas una fuente privilegiada de la sociología histórico-religiosa. Ya lo había advertido Gabriel Le Bras en 1949, cuando, en la perspectiva de una historia total propuesta por la escuela de Annales, propuso un proyecto destinado al estudio capilar de las visitas pastorales en Francia. En el artículo publicado en la Revue d'Histoire de l'Église de France advierte que las visitas pastorales constituyen una masa documental 
capaz de proporcionar una explicación histórica del estado del catolicismo en diferentes regiones de Francia.

El interés por el estudio de las visitas se vuelve a plantear en el contexto de la renovación de los estudios sobre el Concilio de Trento y la Reforma católica. Debido al sostenido interés por explorar más a fondo el impacto y la recepción de la reforma se produjeron numerosos estudios sobre las visitas pastorales y se procedió a la sistematización de las mismas. ${ }^{3}$

En el texto clásico de Gabriele de Rosa, Tempo religioso e tempo storico (1987), el autor presenta la visita pastoral, en su globalidad, como una fuente útil no sólo para el estudio de la iglesia, sino también de la sociedad civil y religiosa, además, dado su dinamismo, esta fuente abre la entrada a una visión interna del trabajo del clero y de los ordinarios. El autor interpreta la visita no sólo como un instrumento construido por Trento para erradicar la herejía y restaurar la ortodoxia doctrinal, sino que las considera fuentes valiosas para conocer las condiciones morales, religiosas, sociales y económicas de la diócesis y útiles para verificar el efecto real de los decretos conciliares en la vida de las personas. Esta fuente nos permite mirar hacia dentro. Pero, pese a la riqueza de su contenido, aún no han sido utilizadas por la historiografía religiosa provincial.

Las características formales y exhaustivas facilitan un uso serial, en tanto su contenido permite abordarlas desde una perspectiva cualitativa (Venard, 1999: 95). El objetivo de las visitas era, por un lado, el control de los bienes eclesiásticos y su administración, y, por el otro, el control del personal, que comprendía a los eclesiásticos y sus deberes clericales. Este documento consta de tres cuerpos: un cuestionario que el párroco debía responder por escrito previo a la visita, la visita propiamente dicha, y el informe de la misma con el auto respectivo (Canobbio, 1999: 78). Si bien en el archivo diocesano no existe un fondo que reúna las visitas del período, cuenta con dos libros que recogen los autos de las visitas, las fechas, los lugares y, en algunos casos, el visitador que la realiza. A lo largo de los años que ha durado esta investigación, hemos ido recogiendo y organizando información fragmentaria y dispersa, a fin de tener una visión más acabada relativa a la cantidad, contenido y lugares de las giras pastorales. Además, la consulta sistemática de los legajos y cajas con documentación sobre las parroquias de Córdoba, nos ha permitido realizar una aproximación cualitativa $\mathrm{y}$ cuantitativa de las visitas realizadas y, en algunos casos, reconstruir el itinerario de la

\footnotetext{
${ }^{3}$ En Francia, el equipo formado por Julia y Venard llevó a cabo la sistematización y publicación de las visitas pastorales efectuadas en Francia hasta 1801, incorporando, en los últimos años, suplementos que completan aún más dichas guías o repertorios.
} 
gira y las consideraciones del visitador. Cabe advertir que la documentación más rica y completa se encuentra para el período de Fray Zenón Bustos, quien realizó dos largas giras por las provincias de Córdoba y La Rioja, de las cuales sólo se ha podido acceder a las pastorales de apertura y cierre, a los cuestionarios de las visitas y a las disposiciones registradas en los respectivos autos de cada visita.

También contamos con dos relatos o crónicas de visitas redactados de primera mano por Filemón Cabanillas, quien actuó como Secretario de la visita de Fray Capistrano Tissera (1885-1886) y como Visitador, en su carácter de Obispo auxiliar de Córdoba (1901-1904), durante el gobierno del Obispo Fray Reginaldo Toro. Un vacío importante supone no haber podido localizar los informes de las visitas realizadas por Fray Reginaldo Toro. Hemos procurado salvar este vacío con otras fuentes complementarias, como la serie de informes remitidos a la curia por los párrocos durante 1890 y 1893, en los cuales se informa sobre varios aspectos de la vida religiosa y el estado material del curato y dos notas dirigidas por el obispo al ministro de Hacienda, Culto e Instrucción Pública, en las cuales relata su actividad pastoral y las visitas realizadas.

Como ya señalamos, Zenón Bustos realizó dos giras pastorales en las que recorrió, de forma completa, todos los establecimientos católicos de la diócesis. Hemos reconstruido cada visita a través de la búsqueda minuciosa de los cuestionarios, cuyas respuestas, por parte de los párrocos, y los autos del obispo correspondientes a cada una, volcamos en una planilla de Excel y en una cartografía histórica, con el fin de realizar un mapa cartográfico de las visitas realizadas. Fueron en total 228 visitas realizadas entre 1877 y 1919, fecha esta última, en la que enfermó y se retiró del gobierno efectivo de la diócesis. A tal efecto, podemos señalar que se trata de documentos muy idóneos para informarnos sobre la práctica religiosa, pues las respuestas enviadas por los sacerdotes al obispado componen un informe sobre el estado espiritual, organizativo y material de cada parroquia.

En síntesis, los sínodos y las visitas pastorales son piezas significativas, pues estos instrumentos de relevamiento daban al obispo el control de la diócesis y el termómetro de la efectividad de las reformas implementadas. El cura debía ser un colaborador del obispo y una guía y un modelo para los parroquianos. Los autos muestran la preocupación del prelado por evitar desviamientos y resistencias, tanto del clero como de la sociedad. Además, la fuente permite la comparación de datos entre las parroquias vecinas y facilita la comprensión de los fenómenos relacionados con el desarrollo 
histórico-religioso de un área geográfica determinada. También permite analizar los datos de una parroquia a través de las visitas recibidas a lo largo de varios años.

La cronología de las giras pastorales (1878-1881-1889-1901-1903 y 1906-19171922), sugiere, en primer lugar, una verificación del grado de consonancia, tras las disposiciones sinodales, de aquellos aspectos de la "sociedad cristiana" que los padres sinodales individualizaron como objeto de intervenciones normativas (deber de residencia, predicación, atención de los enfermos, catequesis de niños y adultos, etc.).

Los decretos del Concilio Vaticano I (1870) y del Plenario de América Latina (1889) y la sanción del Código de Derecho Canónico (1917) fueron fundamentales para la reorganización pastoral, pues imprimieron la cura animorum sobre la predicación y la administración de los sacramentos, definiendo minuciosamente los requisitos culturales y morales del clero parroquial sobre el cual recaía tal reforma.

Esta voluntad de controlar el espacio diocesano pasó, asimismo, como lo han puesto de manifiesto algunos aportes recientes, por la creación o la redefinición de competencias de toda una oficialidad (obispos auxiliares, vicarios foráneos, inspectores de parroquias), que se vincula, estrechamente, con la autoridad del prelado y que, a modo de red periférica, se extiende por todo el territorio y ejerce un control regular sobre la vida religiosa y moral del clero y la sociedad. Esta red se prolonga a lo largo del período analizado, a través de la figura del párroco, que es objeto de lo que se ha dado en llamar "proceso de profesionalización", por el cual sus funciones se delimitan progresivamente, su disciplina externa e interna se acentúa, su formación se especializa en función de las competencias que se le asignan y su número crece progresivamente, sobre todo a lo largo del primer tercio del siglo XX.

Estas bases administrativas y de control permitieron, a la jerarquía diocesana, ocupar una posición privilegiada en la comunicación entre la curia y las parroquias (curas y feligreses). Las estructuras administrativas con las que contaba la Iglesia, le permitieron ejercer un papel esencial como autoridad en los territorios periféricos en los que la presencia del Estado era aún muy débil.

Lamentablemente, esta fuente tiene importantes limitaciones. Las visitas eran bastante breves, pues las autoridades eclesiásticas se detenían el tiempo preciso para realizar y/o controlar el inventario de la situación material en la que se hallaba la iglesia parroquial y preguntar, a algunas personas de reputada conducta moral, sobre cuestiones referidas a la situación religiosa y moral de la parroquia. Con frecuencia, el obispo y la comitiva que lo acompañaba visitaban varias localidades en una jornada, circunstancia 
que impedía realizar una profunda tarea de control pastoral de las comunidades rurales. En el transcurso de la visita, el prelado, frecuentemente, decía misa, impartía el sacramento de la confirmación a niños y adultos y era acompañado por religiosos que celebraban simultáneamente misiones.

El análisis secuencial de las visitas, junto con otros cuestionarios e informes permite, entre otras cosas, reconstruir la geografía de los lugares religiosos (parroquias, santuarios, capillas, oratorios), y sus respectivas advocaciones, lo que nos permite elaborar una imagen del territorio, vinculada a las transformaciones del espacio sacrodevocional, vinculadas a la identidad comunitaria. También las visitas nos permiten conocer el número y grado de cofradías y otras asociaciones parroquiales, evaluar la cantidad de escuelas católicas que funcionaban en el espacio de las parroquias, medir la vitalidad de la economía parroquial y determinar cuáles eran sus recursos financieros. Las visitas también nos informan sobre conductas cotidianas que la iglesia desaprobaba, uniones civiles, concubinatos, actividad de logias masónicas y/o escuelas protestantes. Las crónicas de los viajes también nos ponen en contacto con el territorio diocesano y la precepción que del mismo tenía la autoridad eclesiástica.

Con la documentación contenida en estas fuentes, elaboramos una base de datos con seis variables.

1. Datos curatos: nombre, departamento, fecha de erección, sedes (lugar, titular, fechas), dimensiones territoriales, modificaciones territoriales (desmembramientos, anexiones).

2. Propiedades: templos, titular, ubicación, fecha de construcción, condición alcanzada (sede parroquial, iglesia filial, capilla, oratorio público/privado), casas: parroquial, otras, cementerios, colegios, terrenos, capellanías.

3. Órdenes religiosas: año de instalación, actividad.

4. Rentas del beneficio: derechos de fábrica, donaciones, primicias.

5. Visitas pastorales: fecha, visitador, lugares visitados.

\section{Fuentes.}

\subsection{Administración diocesana}

Hemos consultado la documentación referida al gobierno y administración diocesana. La correspondencia entre la curia y el gobierno nacional y provincial, las Actas del Cabildo eclesiástico (Leg. 2, T. 2). Los libros copiadores de notas de 
secretaría. Esta información ha sido completada con las respuestas de las parroquias a las circulares de la curia, solicitando informes de diversa índole.

El Fondo Zenón Bustos. En el Archivo del Arzobispado se encuentra un Fondo de seis cajas del referido obispo. Contiene documentación relacionada con su gestión al frente del gobierno de la diócesis. Esta documentación ha sido ampliada con el Fondo de Fray Zenón Bustos, proveniente del Archivo de los Franciscanos, el cual contiene documentación relacionada con la vida del fraile. Datos biográficos, escritos, cartas, recortes periodísticos, etc. y su actuación en la orden franciscana.

El Fondo Monseñor Lafitte consta de tres cajas que contienen documentos sobre la gestión episcopal. Hemos trabajado con la correspondencia entre el obispo y su clero, en particular el clero ordenado en el período anterior.

\section{Fuentes oficiales}

Leyes y Decretos de la provincia de Córdoba, correspondencia oficial del Ministerio de Culto, solicitudes de subvenciones.

\subsection{Fuentes nominales, cuantificables y estadísticas para el estudio del clero}

Quienes han estudiado el reclutamiento del clero suelen poner de manifiesto las dificultades que se presentan a la hora de obtener series de datos cuantificables. ${ }^{4}$ Para nuestro estudio, hemos consultado, como fuente principal, los expedientes de órdenes, completando y supliendo vacíos de información con los diversos libros de registro del clero que se encuentran en el archivo diocesano. Listas, registros de órdenes, licencias, títulos, etc.

\subsubsection{Expedientes de órdenes}

Una fuente central para nuestra investigación, que nos permite una primera vía de acceso al clero como grupo social, es la constituida por los expedientes de ordenaciones. Cada clérigo produjo, cuando solicitaba una orden sacerdotal, un expediente. Estos se encuentran agrupados en el Legajo 24, compuesto de varios tomos ordenados en razón de los años de ordenación. Para nuestro período, hemos trabajado los tomos IX, X, XI, XII y XIIbis, correspondientes a los años 1865-1912. A partir de esa fecha, los

\footnotetext{
${ }^{4}$ En su trabajo sobre el clero, Roberto Di Stefano señala tal dificultad. Así mismo, para aquellas diócesis que conservan sus archivos completos, como las francesas, los investigadores señalan, igualmente, la escasez de datos seguros a pesar del rigor estadístico de algunos obispos. En el caso de Córdoba, el Obispo Zenón Bustos inició un importante trabajo administrativo de control sobre el clero, sin embargo, estos registros no reflejan la realidad respecto al ingreso y circulación del clero extra diocesano.
} 
expedientes no están abiertos a la consulta. Cada expedientes lleva el nombre del candidato y la fecha de inicio del expediente, ya sea para las órdenes menores (primera tonsura y cuatro primeras ordenes: acolitado, exorcistado, lectorado y ostiario) y/o ordenes mayores (subdiaconado, diaconado, presbiterado). Por lo tanto, es necesario recurrir a otro tipo de fuentes para suplir este vacío.

Cada expediente comienza con la solicitud del interesado para acceder a las órdenes, en la que se explicitan los motivos que lo llevan a acceder al estado clerical y, en su caso, el título de ordenación ofrecido o solicitado (patrimonio, servicio a la iglesia o capellanía). El título está estrechamente ligado al sostenimiento económico del futuro clérigo. El título de patrimonio consistía en la hipoteca de bienes raíces para que sirviera de congrua del ordenado. Además, constan las partidas de bautismo y confirmación, y en caso de no hallarse éstas, se recurre a la declaratoria de testigos que acrediten esos actos. También existe una declaración de treos o cuatro testigos, que no debían ser parientes, sobre la vida y buenas costumbres del ordenando, este último requisito desaparecerá a medida que nos acerquemos a fines del siglo XIX. Hasta ese momento, para el ingreso al clero secular, los testigos debían responder un cuestionario sobre el conocimiento del candidato, si comprendía en las generales de la ley, si sabía y le constaba que fuera hijo de legítimo matrimonio y sus padres eran católicos y de buena fama, si conocía la vida y las costumbres del solicitante, sus creencias religiosas, su inclinación al estado eclesiástico, la frecuentación de los sacramentos y si, por el contrario, había oído que el solicitante hubiera cometido algún crimen infamante o tuviera algún defecto que lo indujera a irregularidad para el estado que aspiraba, si le conocía aplicación al estudio y si cumplía con sus deberes, como alumno del seminario.

Se trata de una serie documental que, con sus limitaciones, permite conocer los orígenes del clero, la procedencia geográfica, la edad de los ordenandos, los estudios, las motivaciones para el ingreso a la carreara eclesiástica y sus expectativas y, en algunos casos, la ocupación de sus padres, las relaciones de compadrazgo, etc. Cabe señalar que, de la totalidad de expedientes, hemos trabajado sólo aquellos que pertenecen al clero secular de la diócesis, dejando de lado los correspondientes al clero regular y al clero secular extra-diocesano, que, por diversas circunstancias, estudió en el seminario diocesano y recibió las órdenes en Córdoba. El número de seculares de la diócesis, ordenados de presbíteros en el período, suma un total de 155. Esta fuente, aunque incompleta, ya que hay expedientes que se han perdido y no constan los clérigos cordobeses que estudiaron y se ordenaron en Roma, ha sido completada con otro tipo de 
documentación, como los diversos libros que registran actividades del clero y que se describen a continuación.

3.1.2 Libros de registro del Clero: de órdenes, de títulos, de licencias, de clero diocesano y extra diocesano, de asistencia a diversas actividades

Los dos libros de órdenes abarcan el período que va de 1859 a 1925. En ellos, se asienta el nombre y apellido de quienes recibieron las sagradas órdenes, su condición, (secular o regular), el lugar, fecha y ministro de la ordenación. Esta fuente resulta indispensable para reconstruir la curva de ordenaciones a lo largo del período estudiado, el porcentaje de seculares y regulares. Hemos asentado 1.346 registros de las ordenaciones (menores y mayores) realizadas entre 1869 y 1925 . A partir de esta fecha, la documentación no está disponible a la consulta. Motivo por el cual, los datos de los ordenados entre 1919 y 1925 fueron extraídos de la "Revista Eclesiástica del Obispado de Buenos Aires" y de las crónicas periodísticas.

Por su parte, en los libros de títulos y licencias se asientan los nombramientos y el otorgamiento de permisos para ejercer el ministerio en la diócesis. La información contenida en estas fuentes ha sido completada con los registros del clero diocesano y extra-diocesano, realizados durante la gestión del Obispo Zenón Bustos (1905-1919). Los libros de títulos y de licencias son dos fuentes que nos permiten conocer las trayectorias individuales de cada miembro del clero. Se trata de las licencias para celebrar misa, predicar, confesar y/o ejercer el ministerio y de los nombramientos a diversos cargos. La primera nos brinda información sobre las actividades, los desplazamientos y la movilidad del clero, incluido aquel que no tenía beneficio, que al carecer de capellanía, patrimonio o cargo permanente, se veía obligado a contratarse como ayudante eventual en las festividades de los curatos $\mathrm{u}$ ocupar cargos provisoriamente. Un análisis sistemático del libro de licencias, nos permitió acceder a un conocimiento más profundo del clero carente de títulos y beneficios. Los títulos del clero son dos libros que contienen los nombramientos otorgados al clero de la diócesis entre los años 1859 y 1927. El análisis de los mismos nos permitió seguir las trayectorias y carreras individuales de los clérigos.

Asimismo, los libros de registro de curas diocesanos y extra-diocesanos nos fueron de suma utilidad para determinar la cantidad e identificar el clero extranjero inmigrante. El registro comienza a llevarse a partir de 1906, cuando asume el gobierno de la Diócesis el Obispo Zenón Bustos y Ferreyra. Estos libros consignan los datos principales del 
clero propio y extranjero. Para los primeros, registra nombre y apellido, fechas de ordenación, cargos, ocupaciones y destinos ejercidos hasta el momento del registro, y para los segundos, datos personales, fecha de arribo, licencias, diócesis de origen y algunas observaciones.

En cuanto a los libros que recogen la asistencia del clero a diversas actividades, hemos consultado el de asistencia a ejercicios espirituales, el de conferencias de moral y liturgia y el del círculo de estudios del clero. La información contenida en este tipo de documentación nos permitió acercarnos a los espacios de formación y sociabilidad clerical.

Finalmente, también pudimos consultar los Procesos Canónicos, para acceder al Arzobispado de Buenos Aires (Mons. Uladislao Castellano), y al Obispado (Mons. Juan Martín Yaniz, Mons. Abel Bazán, Mons. José Luque, Mons. Inocencio Dávila y Mons. Carlos Echenique.), en los Archivos Secretos Vaticanos.

Este conjunto de fuentes sobre el clero ha resultado de suma utilidad para abordar una cuestión central de nuestra investigación, que es poner la atención en el ejercicio del ministerio con cura de almas en años caracterizados por la intensa circulación de sacerdotes forasteros, que las fuentes denominan "extraños”. Estos registros, de alguna manera, dan cuenta de algunas iniciativas de los obispos destinadas a controlar un clero denso, en su mayoría inmigrante, que constituyó, a falta de clero "propio", un verdadero reservorio de vicarios, capellanes, ayudantes o coadjutores, de comunidades católicas inmigrantes y nativas. En esta perspectiva de control, puntual y orgánico, se coloca la preocupación de los obispos por revisar los títulos y licencias del clero, controlar si todos los sacerdotes que celebraban misa tenían su respectivos celebrat y ejercer su control en la movilidad y circulación del clero.

Estas fuentes nominales nos permitieron visualizar la complejidad de las carreras y las elecciones sociales de los miembros del clero, de manera tal que este sector, que a primera vista podría considerarse un grupo social homogéneo, no responde necesariamente a una unidad de acción y de funcionamiento colectivo. Consideramos que, más allá de la categoría profesional que caracteriza al clero, como "ministros de lo sagrado" (Taylor, 1999: 113), el clero secular se constituyó como un grupo social complejo, con marcadas diferencias hacia el interior y múltiples relaciones hacia el exterior. Se trató de un actor social profundamente imbricado con la sociedad provincial, que participó activamente de los procesos políticos y económicos y en las transformaciones sociales que experimentó la diócesis en el período de entre siglos. 
Con este grupo significativo de fuentes, elaboramos una base de datos, "Clero secular", destinada a realizar el estudio prosopográfico del clero secular, y que tuvo en cuenta diez variables, a saber:

1. Datos personales: Nombre y apellidos, fecha y lugar de nacimiento y/o bautismo; fecha y lugar de muerte, salida de la diócesis, abandono del ministerio.

2. Diócesis de origen: En nuestro estudio, encontramos abundante clero extranjero que, con licencias o incardinado, trabaja en la diócesis de Córdoba de modo estable. También es frecuente encontrar clero extranjero, formado y ordenado en Córdoba, que obtiene las letras dimisorias de su obispo y permanece como clero de la diócesis.

3. Estudios: Título obtenido (maestro, licenciado o doctor). Al separarse los estudios de teología de la Universidad, los seminaristas realizaban sus estudios en el seminario y en los expedientes no figura el título adquirido, simplemente, son presbíteros. Instituciones educativas.

4. Ordenaciones: Fechas, edad, lugar y ministro. Título otorgado.

5. Cargos y funciones eclesiásticas desempeñados: Fecha de nombramiento, tipo de cargo, años de permanencia.

6. Cargo y funciones civiles/políticas desempeñados: Fecha, tipo de cargo y años de permanencia.

\section{Otras actividades.}

8. Juicios, denuncias, observaciones: Motivo, denunciante, resultado.

9. Familia, fortuna/reconocimiento social: Nombres del padre y de la madre. Hermanos, tíos, sobrinos. Actividades.

\section{Fuentes.}

En total, trabajamos un universo de 204 sacerdotes ordenados en la diócesis, pertenecientes al clero secular (algunos se ordenaron siendo religiosos y luego pasaron al clero diocesano), y 223 extranjeros o "extraños", también seculares, que ejercieron su ministerio de manera temporal o permanente, pero que no fueron incardinados formalmente.

3.1.3 Los libros de alumnos, exámenes, conducta, premios del seminario, socios de la asociación lauretana

Estos registros nos fueron sumamente útiles para completar las trayectorias personales y analizar los espacios de sociabilidad. Además, los informes y los planes de estudio permitieron analizar la concepción y el perfil del clero deseado. 


\section{Fuentes nominales más cualitativas. Las hagiografías: perfiles biográficos,}

elogios, coronas, oraciones fúnebres y notas necrológicas

Los perfiles biográficos son breves ensayos escritos casi contemporáneamente a la vida del biografiado que, al igual que las oraciones fúnebres, rescatan una historia de vida, algunos condensan una época. Como señala Jacques Le Goff (1996), la biografía escrita contemporáneamente a la vida del biografiado suele ser un texto fundamental para llegar al conocimiento del individuo. La mayoría de estos trabajos se apoya en fuentes testimoniales, memorias y escritos del personaje biografiado y en recuerdos y vivencias de personas relacionadas con el sujeto de estudio. Estos textos, a pesar de las limitaciones inherentes al alcance explicativo, constituyen verdaderas "fuentes de época", que permiten, con un renovado cuestionario metodológico, echar luz sobre aspectos opacados o poco contemplados en interpretaciones previas.

Los perfiles biográficos sobre el clero de la segunda mitad del siglo XIX están centrados en el ámbito pastoral, ponen de relieve la figura del clérigo como agente de una actividad predominantemente social y espiritual. Desde esta perspectiva, los perfiles biográficos constituyen un punto de partida para la investigación del papel asignado a los obispos y a los párrocos, sus condiciones materiales de vida, su formación y su actividad. Los ensayos biográficos de Fray Mamerto Esquiú, el Vicario Clara, Fray Reginaldo Toro, el Cura Brochero o el Pbro. David Luque, nos presentan la figura del sacerdote desvinculado de la actividad política partidaria y dedicado a sus tareas de gobierno de la iglesia, preocupado por la realidad social de la provincia y el incremento de la pobreza. La lectura de estos textos permite acercarnos a las representaciones sociales de la época, construcciones culturales que intentan proyectar una imagen deseable del sujeto y de la sociedad. Creaciones que sirven para dirigir la memoria en cierta dirección y hacia objetivos prefijados (Lavrin, 2005: 2). En este sentido, las biografías nos presentan las representaciones del "buen cura".

Como señalamos ut supra, estas biografías adquieren calidad de fuentes de época. Recogen testimonios orales, que se hubieran perdido, y que permiten recuperar al sujeto en sus circunstancias más íntimas y cotidianas. Muchas de ellas transcriben relatos de vida registrados en diarios personales, cartas o testimonios de fieles, amigos o conocidos. Adquieren un valor privilegiado para la historia social. "Permiten acercarse a la historia de las costumbres, cuyo objetivo último es 
el conocimiento de las manifestaciones sociales públicas o privadas. Acercarnos a las prácticas ordinarias, 'sin cualidades', que tejen la trama de las relaciones cotidianas" (Chartier, 2000: 27).

Los elogios y coronas fúnebres son discursos laudatorios, pronunciados en los funerales, que circularon en forma de pequeños folletos y fueron reproducidos por la prensa y algunos incluidos en biografías posteriores. Para el espacio cordobés, encontramos una apreciable cantidad de ellos. Muchos miembros del alto clero, obispos, vicarios, fundadores de congregaciones, canónicos y párrocos tienen sus elogios. Son numerosos los pronunciados en funerales de una notable cantidad de sacerdotes de la segunda mitad del siglo XIX: los Obispos Esquiú, Toro y Zenón Bustos, el Vicario Emiliano Clara y Udalisdao Castellano, el Cura Brochero, el Canónigo David Luque, son algunos ejemplos. Por otra parte, a partir de 1900, la "Revista Eclesiástica" tiene una sección destinada a notas necrológicas. Ellas son variadas en extensión y en densidad de contenido y han sido de gran utilidad para rescatar las figuras de curas "anónimos" que pasaron su vida en una alejada parroquia de campaña. Estas notas recuerdan la vida sacerdotal, algunas retratan la vida del clérigo, aportando datos de nacimiento, familia, trayectoria etc. Como señala Dosse (2003: 229-30), refiriéndose a la conceptualización de Michel de Certeau respecto de la hagiografía, se trata de un género literario, un discurso de virtudes que, más que referirse a lo que pasó, remite a lo que se consideraba ejemplar en el momento de la redacción. Su estructura específica, por lo tanto, tiene por objeto una eficacia práctica y una doble función para delimitar, distinguiendo un tiempo y un lugar. Por este motivo, se convierten en un documento sociológico, en la expresión de una comunidad eclesial. Ciertamente, la totalidad de estos elogios apuntan a construir la imagen de un hombre ejemplar, exaltando sus virtudes. Dada las circunstancias y el contexto para el que se escribieron, se trata de escritos laudatorios en los que se cuida, particularmente, la prosa, que adquiere un tinte más bien poético.

Los perfiles y las hagiografías construyen la imagen de un clero reformado según las pautas propuestas por Roma, un pastor dedicado a la atención de los fieles, la administración de los sacramentos y el impulso de actividades con fines sociales, desvinculado de la actividad política, cuya principal función era de tipo espiritual y social. Las oraciones y elogios fúnebres nos fueron de gran utilidad para acercarnos a las representaciones del clero como grupo, pues se trata de 
ensayos escritos por clérigos sobre la vida de otros clérigos. Bourdieu (1999: 69) insistió en la función performativa de los discursos, sosteniendo que las maneras de hablar no son inocentes y que la lengua que se habla estructura las representaciones del grupo al que pertenecemos. En cuanto al análisis de los procesos de construcción de la opinión colectiva, y su vinculación con los procesos de producción de los grupos sociales, Bourdieu señala que "la opinión colectiva, para ser tal, debe ser construida mediante la palabra hablada o escrita y el gesto simbólico, donde el rol del portavoz es clave para la constitución misma del grupo" (Martínez, 2007: 255).

¿Para qué sirven estas aproximaciones, por momentos profundas, detallistas y sutiles?, se pregunta Andrea Reguera (2008: 55), y responde "para tomar al sujeto como pretexto para toda una serie de problemas que lo involucran, lo incluyen, lo destinan, Todos ellos, en realidad han servido de pretexto para iluminar sobre un determinado contexto que de alguna manera y en ciertos puntos nos resultan desconocidos, sobre las representaciones, los valores, las creencias que esos personajes generaron en un momento determinado y han dejado entrever a través de diversas huellas discontinuas".

\section{Vida parroquial: clero, asociaciones parroquiales y feligresías}

Los Legajos número 47, 48, 49, 50, 51, 52 y las cajas de parroquias contienen una amplia y variada documentación referida a la vida parroquial de los diversos curatos. Se trata de seis Legajos con más de 600 documentos cada uno (Leg. 47 Morteros; Leg. 48 Villa Nueva; Leg. 49 San Francisco; Leg. 50 Cruz Alta; Leg. 51 Ischilin; Leg. 52 Bell Ville) y 36 cajas ordenadas alfabéticamente con documentación relativa a las 77 parroquias del período analizado. Esta documentación ha sido completada con el Libro 28, que registra el movimiento religioso de los curatos entre 1905 y 1912, y las planillas, que informan el movimiento económico de los curatos, enviadas durante los años 1905 a 1912. Esta información nos ha permitido elaborar una tipología de curatos en relación a los beneficios obtenidos por el cobro del arancel, entradas de fábrica, limosnas, donaciones. etc.

También se han encontrado estatutos, reglamentos, memorias y actas de asociaciones y congregaciones parroquiales. Conferencias Vicentinas, Círculos Obreros de la ciudad de Córdoba y Río Cuarto, Apostolado de la Oración, Congregación de la doctrina cristiana, Unión Popular Católica Argentina. Correspondencia entre obispos, curas y 
feligreses. Este tipo de documentación esta dispersa en diversos fondos documentales, legajos y carpetas de parroquias arriba descriptas.

El Leg. 42 contiene notas a los obispos y los dos Fondos Zenón Bustos tienen documentación muy variada. El primero, es un Fondo del Archivo Franciscano, que contiene documentación no clasificada sobre su vida privada, correspondencia y sus funciones en la orden franciscana; el segundo, trata sobre la gestión episcopal.

También existe un Legajo que contiene planos y datos sobre las parroquias, recogidos y ordenados por el Pbro. Liendo en 1956.

Por último, pudimos completar la información con documentación remitida por el clero, principalmente inmigrante, directamente a la Internunciatura, que se encuentra en los Archivos Secretos Vaticanos.

\section{Denuncias, informaciones sumarias y juicios}

A fin de analizar la situación del clero, recurrimos a este tipo de documentación a nivel de tres escalas diferentes, local/parroquial, curia diocesana/estado provincial y nunciatura apostólica. Identificamos las denuncias enviadas por los curatos a la curia: el tratamiento administrativo que recibieron en ella (desestimación, informe, información sumaria, etc.) y accedimos a documentación denunciatoria enviada directamente a la Nunciatura Apostólica.

Las fuentes presentadas fueron sistematizadas en otra base de datos, organizada en función del objeto del estudio vinculado a la vida parroquial, los vínculos y relaciones. Esta base se compone de los siguientes campos:

1. Parroquia: Nombre, ubicación.

2. Personal parroquial: Clérigos/seglares, número, título/función, años de permanencia, motivos de renuncia o remoción.

2. Cofradías, congregaciones y asociaciones parroquiales: Fecha de creación, fines, cantidad de miembros.

3. Funciones litúrgicas: Tipo de función, año, asistencia de fieles.

4. Misiones: Lugar, fecha, resultados.

5. Fieles: Cantidad, credo, práctica religiosa, confesión y comunión anual.

\section{Fuentes.}




\section{Fuentes periódicas: prensa, revistas y boletines parroquiales}

La prensa es una fuente cualitativa clásica que nos ayudará, complementariamente, a completar la información requerida oportunamente. En este sentido, mencionaremos los siguientes que hemos utilizado:

\subsection{Periódicos}

1. "El Progreso" (1868 a 1881). Diario de tendencia liberal, dirigido por Gil Navarro

2. "El Eco de Córdoba" (1876 a 1878). Diario católico, dirigido por José María Vélez

3. "Los Principios" (1895-1897-1900-1905-1910-1915-1922). Diario de la Sociedad Juventud Católica

4. "La Voz del Interior" (1900-1915)

5. "El Porvenir" (1886-1889-1890-1891-1892)

6. "El Pueblo" de Río Cuarto (1893-1895). Órgano del Club Unión Cívica de Río Cuarto

7. "El Pueblo" de Río Cuarto (1914-1919)

8. "El Tribuno" de Río Cuarto (1897)

9. "Vita Coloniale". Periódico Salesiano de difusión en las Colonias (1915-1920).

\subsection{Revistas y boletines parroquiales}

1. Revista Eclesiástica del Obispado de Buenos Aires (1901-1925)

2. Boletín Eclesiástico de la Diócesis de Córdoba (1924-1935)

3- Boletín Parroquial de la Diócesis de Río Cuarto (1907)

3. Boletín Diocesano Obispado de la Villa de la Concepción de Río Cuarto (2000-2006)

4. Boletín Parroquial “La Semana Católica”, Parroquia de Río Cuarto (1923-1926-19281932-1933)

5. "La Familia Cristiana”, Parroquias de Marcos Juárez, Cruz Alta, Arteaga y Esquina (1913-1925)

6. “Acción Franciscana”, Río Cuarto (1920-1933)

7. "El Cruzado", Parroquia de Dalmacio Vélez.

\section{Fuentes estadísticas nacionales y provinciales}

El Anuario Estadístico de la Provincia de Córdoba y otras publicaciones de la Dirección General de Estadística de la provincia de Córdoba nos ha posibilitado el 
acceso a datos relacionados con la densidad de población y la colonización. Se consultaron los Anuarios de 1878, 1901, 1902, 1905 y 1926.

\section{Cartografía}

La cartografía contemporánea del período analizado ha sido de gran utilidad para trabajar la territorialidad religiosa.

- Martin DE MOUSSY, Description geographique et statistique de la Confederation Argentine. ATLAS, Imprimerie Adolphe, rue Jacob 56, Paris, 1869 (Carta de Córdoba y San Luis. Plancha XII).

- Manuel RÍO y Luis ACHAVAL, Geografía de la provincia de Córdoba. Atlas, Buenos Aires, Compañía Sudamericana de Billetes de Banco, 1905.

- Mapa de la Provincia de Córdoba. Paz Soldán. Atlas Geográfico Argentino. Grabado por Erhard Hermanos, 8 Calle Nicole, Paris, Imp. Erhard Hermanos - Félix Lajouane, Editor, Buenos Aires, 1888.

- Mapa Físico de la Provincia de Córdoba, 1871.

- Mapa Departamental de la Provincia de Córdoba, 1871.

- Mapa de la Provincia de Córdoba, 1926. 


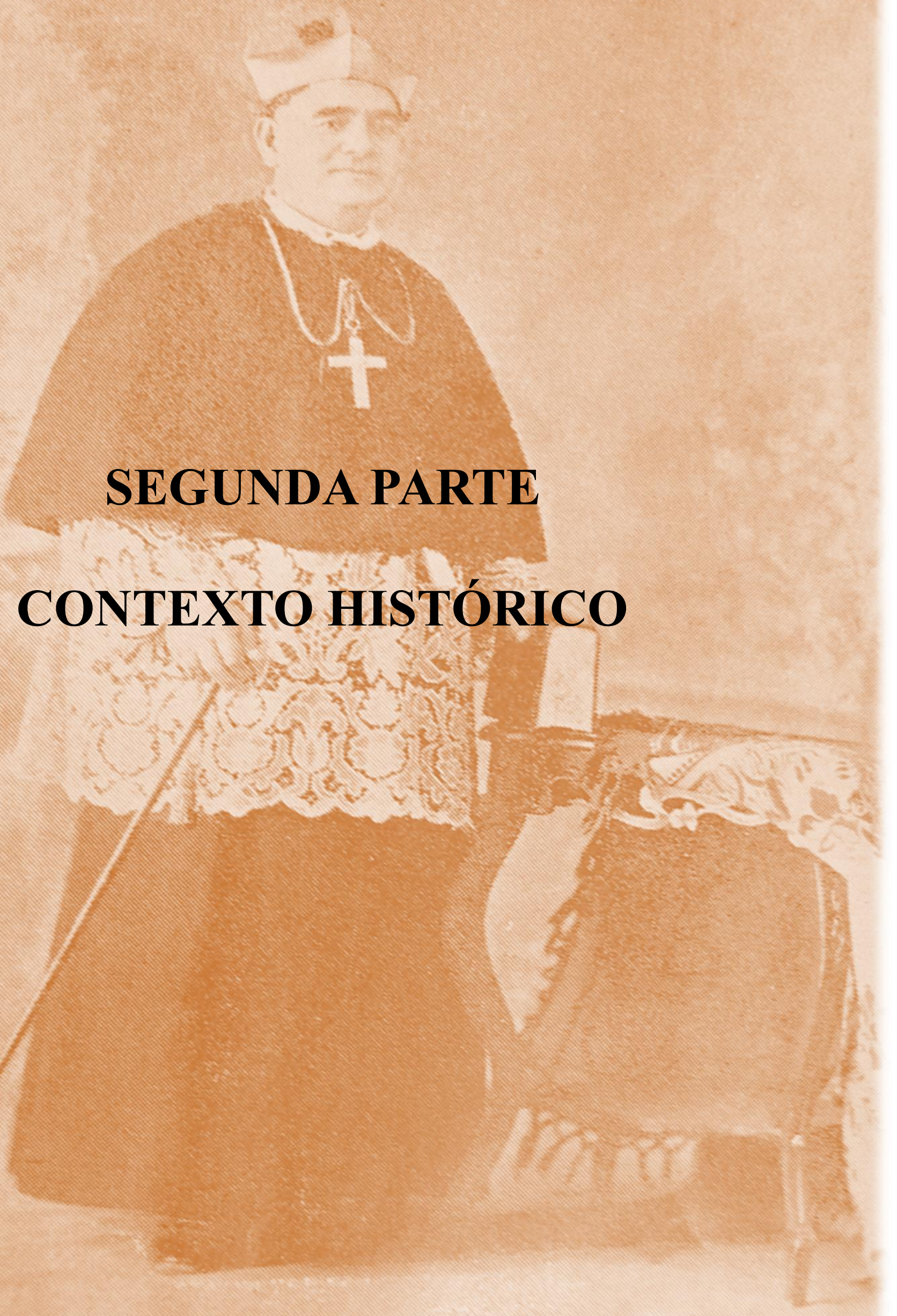




\section{CAPITULO 4}

\section{IGLESIA CATOLICA Y ESTADO LIBERAL: AVANCES Y RESISTENCIAS}

Para un conocimiento sintético de la relación entre la Iglesia y los Estados liberales de la segunda mitad del siglo XIX, hemos consultado una serie de textos generales. ${ }^{1}$ El liberalismo político decimonónico se enmarca en el proceso de secularización, entendido como un proceso de diferenciación funcional de esferas, al estilo weberiano. Proceso que implica la creciente autonomía de la política, la ciencia y la economía con respecto a la religión. Cada una de estas esferas se mueve según su propia lógica autónoma, completamente independiente de la matriz religiosa tradicional. Con ello, la propia esfera religiosa también se especializa y se repliega de alguna manera sobre sí misma. En este contexto, el liberalismo tenía como valores prioritarios la libertad, entendida como autonomía, y la noción de individuo. Proporcionaba una visión optimista del hombre y de la historia, entendía que el avance de la razón científica y las reformas políticas llevarían a las nuevas naciones a un futuro más humano, libre de supersticiones y de temores. La industrialización y la economía de mercado crearían una sociedad más rica y diversificada. Ciencia, reforma política y economía señalan los campos centrales de aplicación de los principios liberales, en tanto, la esfera religiosa, las creencias, deberían pasar a formar parte de la conciencia individual.

Después del proceso revolucionario de Francia, restaurados los Borbones en el trono, no se produjo el restablecimiento del antiguo régimen. La hora del absolutismo había pasado y comenzó a prevalecer el constitucionalismo, cuyo modelo era el régimen constitucional inglés, que preveía un liberalismo de orientaciones pragmáticas, profundamente respetuoso del individuo y de la propiedad privada. El constitucionalismo francés, impulsado por los llamados liberales doctrinarios, reivindicaba la libertad promulgada en 1789 y bregaba por la moderación y el equilibrio, en oposición a los excesos cometidos durante el terror. Uno

\footnotetext{
${ }^{1}$ REDONDO (1979); ALDEA y CÁRDENAS (1987); JEDIN (1988); MEYER (1991); FARRELL (1992); DUSSEL (1994); CÁRCEL ORTÍ (2003); CORTES PEÑA (2006); CORBIN (2008); CARMONA FERNÁNDEZ (2010).
} 
de sus principales representantes fue Montesquieu, cuyos elogios a la constitución inglesa sirvieron como punto de partida para los pensadores de las revoluciones americanas, Benjamin Constant, Chateaubriand y Alexis de Tocqueville.

El iluminismo también abrió los surcos para otra corriente, apoyada en el principio de orden y progreso, denominada positivismo. El positivismo apareció en Francia con Augusto Comte en la primera mitad del siglo XIX. Se presentaba como la necesidad de reformar la vida social, para lo cual era necesario reconstruirla sobre bases científicas, dejando de lado la influencia religiosa o filosófica. Huir de la metafísica y de la religión para buscar, como única verdad, la ciencia fundada en datos positivos, que tiene como válido sólo aquello que puede probarse empíricamente. La interpretación comteana de la evolución histórica de la cultura occidental, se apoya en dos postulados de evidencia. El primero, la ecuación entre sabiduría, riqueza y felicidad, y el segundo, la existencia de una ley universal de progreso que pasaba por tres etapas: teológica, metafísica y positiva. Tenía la certeza de que el hombre iba a ser cada vez más sabio, que la sabiduría le haría cada vez más rico y la riqueza más feliz. Se trataba, por lo tanto, de un progreso material, donde los resultados se medían por la técnica y la riqueza. Los positivistas también adhirieron al argumento de Voltaire: "Dios no es una realidad trascendente, sino una idea abstracta, fabricada por el hombre y muy útil, como los son las hipótesis de trabajo o los supuestos previos, que se abandonan cuando se descubre la realidad" (Fazio, 2010: 159).

Producto de la Revolución Francesa se impone una nueva categoría política que, en lenguaje hegeliano, es "la sociedad civil", cuya característica central es su laicidad. A partir de 1789, el carácter laico de la sociedad cobra vigencia hasta llegar a establecer, tal como lo expresa la constitución de la República Francesa, la incompetencia del estado en asuntos religiosos y de la iglesia en problemas de estado (Poupard, 1987: 975).

La vida de la Iglesia en el siglo XIX se desenvolverá en torno a cuatro grandes cuestiones que, de manera simplificada, se podrían enumerar de la siguiente manera: las relaciones con el Estado, las relaciones entre la fe y la razón (cuestionadas fuertemente por la Ilustración), la doctrina sobre la unidad en torno a la cabeza, es decir, el Papa, debilitada por el regalismo y las iglesias nacionales o galicanas, y la evangelización y el impulso de la piedad popular. 
Las manifestaciones piadosas, que analizaremos más abajo, se inscriben en el marco de lo que algunos autores denominan la resistencia católica y podrían leerse en clave política como un símbolo contra las revoluciones liberales, tanto en Francia como en Italia (Boudon, Caron y Jon, 2001: 159).

\section{Gregorio XVI (1831-1846) y Pío IX (1848-1878): el enfrentamiento con la modernidad cultural y liberal}

La necesidad de consolidar la cohesión de la Iglesia frente a los estados liberales y las ideologías seculares, llevó a los pontificados de Gregorio XVI (1831-1846) y Pío IX (18481878) a enfrentarse con la modernidad cultural y liberal. La relación de la Iglesia con los Estados y sus políticas laicistas dio lugar a una visión "ultramontana", que impulsó a los pontífices hacia una actitud defensiva e intransigente. Intransigencia entendida como "el rechazo de toda transacción, es decir de todo retroceso, de toda concesión, de todo acomodamiento, de todo compromiso de todo lo que pudiera poner en peligro la conservación y la trasmisión de la fe" (Boutry, 2008: 183). Defensiva porque la Iglesia tendió a aislarse del mundo moderno, adoptó un sistema de educación destinado a proteger a los católicos de los "males de la modernidad", viéndose a sí misma como una fortaleza asediada. El Papa recomendaba a los obispos "librar del contagio a los fieles que han sido encomendados a vuestro cuidado" (Pío IX, 1873: 19).

Frente al marcado racionalismo liberal de las clases dirigentes, el catolicismo romano imprimió un fuerte impulso a la piedad del pueblo apoyándose en dos pilares fundamentales: la devoción Mariana y la piedad Cristológica. El Papa Pío IX consagró el mundo católico al Sagrado Corazón de Jesús y el 8 de diciembre de 1854 definió el dogma de la Inmaculada Concepción. Esta definición dogmática estuvo precedida y sucedida por una serie de apariciones de la Virgen (Rue du Bac, 1830; La Salette, 1846; Lourdes, 1858; Pontmain, 1871; Pallevoisin, 1876 y, finalmente, Fátima, 1917). Estas apariciones le dieron un gran crecimiento a la devoción mariana en el orbe católico, fomentando el fervor popular y generando un fenómeno de desplazamientos masivos hacia los lugares de las apariciones, que congregaban a miles de fieles en las fechas de las respectivas apariciones. Todas ellas transmitían mensajes relacionados con la paz, la devoción y el desagravio a Jesucristo por los pecados de los hombres. Las apariciones de María llevaban alguna 
imagen de Cristo. La Inmaculada de La Salette tiene un gran crucifijo sobre el pecho y la Virgen de Pontmain aparece con un crucifijo entre las manos. ${ }^{2}$ Estos fenómenos impulsaron la multiplicación de asociaciones marianas, entre las que se destacaron las Hijas de María. Se multiplicaron las prácticas religiosas vinculadas a la devoción mariana como el mes de María, el rezo del Santo Rosario, la novena a la Inmaculada. Aumentaron considerablemente las Iglesias dedicadas a la Virgen, generando una profunda renovación del culto mariano en todas las regiones católicas.

La Piedad, centrada en la humanidad de Cristo, se renovó mediante la devoción al Sagrado Corazón. El 18 de septiembre de 1864 Pío IX beatificó a Margarita María de Alacoque, quien difundió la devoción al Sagrado Corazón de Jesús. En 1875, se construyó, al lado de la antigua iglesia cluniacense de Paray-le-Monial en París, la gran Basílica del Sacré Coeur, centro de peregrinación de una multitud de fieles, más de 100.000 peregrinos entre 1873-1875.

El romanticismo católico europeo construyó una visión ideal de la cristiandad, una edad media mitificada, reinventada para enfrentarse a la disolución social que nacía del individualismo liberal, "la nueva cristiandad" se convertirá en la imagen que hay que alcanzar. Al respecto, Philippe Boutry (1997: 222) advierte que la edad romántica utiliza otra vez la palabra cristiandad (o civilización cristiana). Ese ideal, vuelto muchas veces hacia un pasado mítico, otras, proyectado hacia un futuro todavía por nacer, contiene una fuerte crítica a las luces y al liberalismo y un cuestionamiento de su filosofía en nombre de una referencia a la tradición. Este tradicionalismo filosófico siguió caminos diversos, en el caso del tradicionalismo católico español, que es el que nos interesa por nuestra investigación, tuvo como principales representantes a Jaime Balmes y Donoso Cortés. ${ }^{3} \mathrm{La}$ jerarquía eclesiástica, crítica del liberalismo, no cesó de proceder por afirmación, reclamación, confirmación y exaltación de sus dogmas, de su disciplina, de sus creencias y de su historia. El argumento de la tradición inseparable del argumento de la autoridad, refuerza la exigencia fundamental de una conservación íntegra del depósito de la fe, así

\footnotetext{
${ }^{2}$ Visión: “La Señora se veía triste y sostenía un gran crucifijo rojo en el que estaba inscrito: 'Jesucristo'. A las 8:30 p.m., la gente cantó, 'Ave, Maris Stella', y el crucifijo desapareció. Ella de nuevo sonrió y dos pequeñas cruces aparecieron sobre sus hombros. Ella bajó sus manos y un velo blanco la fue cubriendo desde los pies hasta la corona. Alrededor de las 8:45 p.m., los niños dijeron: 'ha terminado"”.

${ }^{3}$ El tradicionalismo católico español, tendrá gran influencia en nuestro país, los autores mencionados fueron leídos y comentados en los cursos de Cultura Católica, iniciados en 1922, por iniciativa de algunos jóvenes intelectuales católicos, como Atilio Dell'Oro Maini, Tomás Cáceres, Rómulo Ayerza, Santiago O’Farrell, etc.
} 
como una visibilidad del culto y de la institución eclesial, entendida como manifestación histórica concreta y actual de la misión y de la centralidad de la iglesia en el espacio y la sociedad, en el conjunto de sus manifestaciones, sean éstas arquitectónicas (santuarios, iglesias, capillas, cementerios, cruces, establecimientos religiosos, etc.), sacramentales (confesiones, comuniones, bautismos, matrimonios, sepulturas cristianas), litúrgicas (procesiones, fiestas patronales, novenarios, misas solemnes y rogativas), económicas (colectas, óbolo de San Pedro, primicias, etc.), sociales (órdenes, congregaciones, cofradías, asociaciones religiosas). Esta teología de la visibilidad se nutre de las elaboraciones dogmáticas del Concilio de Trento y es en la edad romántica, según Boutry (1995: 226227), cuando adquiere una dimensión y una densidad nuevas. Este romanticismo católico, participa asimismo de una reescritura de la historia, que erige como modelo político, social y religioso a la Cristiandad de una edad media mítica recreada.

En esta recreación, el edificio, el templo, adquiere gran importancia. En el período independentista y de las autonomías provinciales, el edificio no tenía verdadero interés, a partir de 1880, el edificio se corresponde con un monumento emblemático. Para ser miembro de la iglesia institución era necesario haber pasado por la Iglesia edificio. Un ejemplo de ello es el matrimonio, un acto social por excelencia que durante mucho tiempo se celebró en las casas particulares, luego, pasó a celebrarse dentro de la iglesia. Simbólicamente, en una sociedad que se seculariza, la Iglesia como edificio da entrada al sacramento.

Otro punto interesante es la importancia que adquiere el dogma eucarístico y la recomendación de la comunión frecuente. La Eucaristía tiene lugar durante la transustanciación, que se realiza en un tiempo que es el de la Misa y en un lugar que es el culto. La Iglesia reelabora la doctrina del lugar del culto como base de su poder pastoral. Esta reacción eclesial, frente a la crisis institucional provocada, primero por la revolución francesa y luego por la consolidación de los estados liberales, llegará al otro lado del Atlántico, donde se pondrán medios similares a los implementados por la iglesia europea. La cuestión romana no hizo más que acentuar este proceso.

En 1865, el Papa Pío IX, amenazado por las tropas garibaldinas, hizo un llamamiento a los hombres católicos para que acudieran en su ayuda. Creó una serie de cuerpos para la defensa de los territorios pontificios. Comenzó una movilización de católicos, más de 
16.000 hombres provenientes de Francia, Flandes, Canadá, Bélgica, Irlanda y Suiza se alistaron baja la bandera Papal. Uno de los cuerpos que se creó para la defensa de los estados pontificios fue el de los Zuavos Pontificios. Se enfrentaron a Garibaldi y defendieron, el 12 de septiembre de 1870, la Porta Pía. Una vez desparecido el Estado Pontificio las tropas papales se disolvieron. Tras la caída de los Estados Pontificios, Roma pasó de ser la capital de la Cristiandad y ciudad Santa para ser la capital de un Estado Moderno, cuya administración laicista procuró transformar el carácter religioso de Roma, mediante medidas destinadas a suprimir las casas religiosas, expropiar y vender su patrimonio, suprimir escuelas, universidades, archivos, bibliotecas y otras instituciones católicas. Se expulsó a los jesuitas de su sede en la curia generalicia y el Colegio Romano. Se establecieron severos controles a las escuelas confesionales. Los católicos italianos se replegaron de la vida pública durante los setenta años que duró la cuestión Romana. En 1874, salió a la luz un documento de la curia romana que contenía el principio de non expedit, y, en 1877, el Papa emitió un nuevo documento en el que sostenía, de manera explícita, la no participación de los católicos en la vida política italiana bajo la fórmula "ni electos ni electores". Prohibición que se mantendrá formalmente hasta la finalización de la cuestión Romana mediante la firma de los pactos de Letrán en el año 1929.

El Concilio Vaticano I promulgó dos Constituciones dogmáticas la Dei Filuis y la Pastor aeternus. La primera, ratificó la antropología cristiana respecto de la relación entre fe y razón y la capacidad del hombre de llegar al conocimiento de Dios a partir de su razón, al igual que ratificó la presencia de Dios en el mundo creado y en el hombre. Esta doctrina se alzó en contraposición de la antropología liberal que buscaba hacer del hombre un ser autónomo, responsable sólo ante su propia conciencia y escindida de Dios y de la creencia. La segunda, proclamó la infalibilidad pontificia en materias de fe y de costumbres cuando habla ex cathedra.

La desaparición de los estados pontificios fue sin duda el fenómeno visible del fin de una época de la historia de la Iglesia. Ello fue el símbolo de que algo estaba cambiando, sin duda con el pontificado de Pío IX tuvo lugar el fin de la Iglesia del Antiguo Régimen y el surgimiento de una Iglesia que encontraría nuevos cauces para su acción en el mundo moderno. La iglesia de Roma tomó como causa propia, la defensa de la religiosidad popular y la construcción de una nueva cristiandad. 


\section{Hacia una nueva cristiandad: la defensa de los pueblos}

La jerarquía eclesiástica, crítica del liberalismo positivista, construyó una visión ideal de la cristiandad, al estilo de una edad media mitificada, reinventada para enfrentarse a la disolución social que nacía del individualismo liberal, la nueva cristiandad se convertirá en la imagen que había que alcanzar. Philippe Boutry (1997: 222), como dijimos arriba, advierte que ese ideal contiene una fuerte crítica hacia las luces y el liberalismo y un cuestionamiento de su filosofía en nombre de la tradición. Tradición que no siempre es tradicionalismo, como bien señala Hervieu-Léger (2005: 146), quien al analizar los fenómenos religiosos en sociedades modernas, dice que se trata de un "potencial creativo" de la tradición, que buscará mecanismos de control y regulación destinados a transformar la herencia de la tradición en normas para el presente y el futuro.

El desafío de la jerarquía fue re-articular la relación fundadora de la tradición con la religión en el interior de la modernidad. La religión se hace presente bajo una nueva forma que es la tradición en la modernidad (Hervieu-Léger, 2005: 140).

\subsection{León XIII (1878-1903) y el compromiso con la modernidad}

El pontificado de León XIII guía a la Iglesia por un difícil camino que va de la condena y el retraimiento a un compromiso con la modernidad. La Iglesia ya no podía limitarse a tratar con los Estados, pues la modernidad se manifiesta como un fenómeno de masas. En la obra de León XIII, entrevemos el empeño y el empuje hacia una "modernidad cristiana". El pontífice asume el compromiso de unificar las exigencias de la religión con las de una sociedad que inevitablemente salía del régimen de cristiandad. El pontífice reconocía el valor de las democracias modernas, con gobiernos elegidos por el pueblo, la participación de los ciudadanos en la administración pública, la igualdad jurídica y la verdadera fraternidad entre los hombres (León XIII, 1881: Diuturnum Illud).

La encíclica Rerum Novarum (1891), ${ }^{4}$ marcó un nuevo rumbo en las relaciones entre la Iglesia y la modernidad. El proceso de industrialización concentró grandes masas de trabajadores en las periferias de las ciudades industriales, las masas, que, hasta el momento

\footnotetext{
${ }^{4}$ León XIII, a lo largo de su pontificado, constituyó un importante cuerpo de doctrina sobre la constitución de la Civilización Cristiana y las normas de la vida en ella, adaptadas a las condiciones de la vida moderna. La preocupación del pontífice radica en el modo de llevar adelante la cristianización y la espiritualización de la vida moderna, considera que el progreso de la civilización no se opone a la religión ni a la existencia de la Iglesia y que es falsa aquella civilización que choca con la doctrina y las leyes de la Iglesia.
} 
habían permanecido "cristianas", se alejarán, progresivamente, de la religión bajo las banderas del socialismo o del anarquismo. Para hacer frente a la cuestión social y a la descristianización de los sectores populares, León XIII, entre otras medidas, procuró armonizar las exigencias de la religión con las de una sociedad que, inevitablemente, abandonaba el régimen de cristiandad. Una sociedad que paulatinamente se iba secularizando.

El gobierno de León XIII estuvo marcado por el intento de reconquistar a la sociedad civil, mediante la puesta en marcha de un catolicismo en movimiento (Bastian, 1990: 13). Se impulsó la acción y el compromiso de los seglares. Para ello, se valió de la actualización y resignificación de las terceras órdenes y de la creación de nuevas asociaciones católicas con fines asistenciales, benéficos, religiosos o sociales. Estas medidas señalan la preocupación del Papa por despertar la responsabilidad social de los católicos seglares y orientar su acción hacia la búsqueda de soluciones cristianas a los problemas sociales que suscitaba el mundo moderno. Etienne Fouilloux (2002: 79) advierte que la Iglesia no se limitó sólo a condenar el mundo moderno, sino que contrapuso a éste un modelo de sociedad anti-liberal y anti-socialista, se trató de un modelo integral, en cuanto englobaba todas las edades, todas las condiciones y todas las actividades humanas. Este modelo tuvo una fase casi exclusivamente defensiva, durante la cual lo que se trataba era de resguardar las cristiandades de los ataques anticlericales, para pasar luego a una fase más ofensiva, destinada a construir una "nueva cristiandad", fundada en el reinado social de Jesucristo.

Paralelamente a esta cuestión, el pontificado de León XIII reforzó la idea de que la ciudad eterna, Roma, era el factor esencial de la unión de los cristianos. Roma se convertía en la ciudad santa como centro de la Iglesia Universal y sede de la cabeza suprema, no sometida a ninguna autoridad: la Roma del sucesor de Pedro y vicario de Cristo. Oskar Koller (1988: 58) señala que León XIII aspiraba a un pontificado que "en el mundo surgido de la revolución, volviera a asumir con las correspondientes adaptaciones, la misma misión histórica universal que había desempeñado en la edad media y recobrara la hegemonía religiosa y moral en un nuevo imperio universal cristiano". El objetivo no se lograría restableciendo las instituciones medievales, sino mediante una fe robusta, reforzada en la conciencia de los pueblos. Se proponía vincular las naciones, los pueblos (no los estados) a la autoridad de la iglesia como centro moral del mundo. Para alcanzar esa renovación 
general de la sociedad, el Papa proponía volver a Santo Tomás de Aquino, quien fuera el artífice de la filosofía cristiana en la Alta Edad Media.

León XIII persiguió, a lo largo de todo su pontificado, la recuperación de la influencia social de la Iglesia y buscó apoyarse en las masas populares para presionar a los gobiernos en favor de la Iglesia y contrarrestar la acción de las corrientes de pensamiento ateas. La meta que perseguía era "remediar mediante el reconocimiento de la autoridad moral del vicario de Cristo, el estado de este mundo moderno, desgarrado social y políticamente y caído hacia fines del siglo XIX en una profunda postración” (Koller, 1988: 62).

En la encíclica Humanus Genus de 1884, el pontífice propone la creación de los Círculos Católicos de Obreros, o "gremios de trabajadores, creados para defensa conjunta, al amparo de la religión, de sus propios intereses y de las buenas costumbres" (León XIII, 1884: 24), a fin de poner remedio a los problemas que sufría la clase trabajadora. Los objetivos principales de los círculos eran proteger los sentimientos religiosos y la moralidad de los obreros, cultivar en ellos las virtudes propias de su estado, amor al trabajo, sobriedad, economía y espíritu de familia, fomentar la verdadera amistad y el sano esparcimiento y fomentar la educación intelectual y los conocimientos técnicos de los obreros.

\subsection{Pío X (1903-1914) y el intento de recobrar la hegemonía religiosa y moral en un nuevo} imperio universal cristiano

El fallecimiento de León XIII abrió las puertas del pontificado al patriarca de Venecia, celoso pastor almas, un hombre bondadoso y a la vez enérgico, que demostró una enorme fuerza pastoral, transformando la diócesis de la que fuera obispo-Mantua- en un ejemplo de organización y actividad eclesiástica. El Cardenal Sarto, devenido, en 1903, en el Papa Pío X, será el hombre que llevará adelante un programa que dará primacía al "ministerio interior" de la Iglesia, su centro de interés radicaba en las cuestiones pastorales, la administración de las diócesis y la estructuración de las obras de la iglesia. Es decir, las cuestiones del apostolado cristiano y de la vida religiosa. Se presentaba como un simple párroco rural, un hombre práctico y de sobrada experiencia pastoral. Estaba convencido de que el servicio de Dios y de las almas exigía una seria transformación en todos los terrenos.

Su programa pastoral estuvo en consonancia con León XIII, y lo explicita en la encíclica sobre la acción católica, Il Fermo Proposito, de la siguiente manera: 
[...] los católicos deben estar decididos a combatir por todos los medios justos y legales contra la civilización anti-cristiana: reparar los gravísimos desórdenes que de ella provienen; introducir de nuevo a Jesucristo en la familia, en la escuela, en la sociedad; restablecer el principio de la autoridad humana, como representante de la de Dios; tomar muy a pecho los intereses del pueblo, y particularmente los de la clase obrera y agrícola, no sólo infundiendo en el corazón de todos la verdad religiosa [...], sino cuidando de enjugar sus lágrimas, suavizar sus penas, mejorar su condición económica con bien concertadas medidas; trabajar por conseguir que las leyes públicas se acomoden a la justicia y se corrijan o se destierren las que le son contrarias; defender, finalmente, y mantener con ánimo verdaderamente católico los fueros de Dios y los no menos sacrosantos derechos de la Iglesia (Pío X, 1905).

Para introducir de nuevo a Jesucristo en la vida social, impulsó la práctica de la comunión frecuente. El decreto de diciembre de 1905 "amplía libertad a todos los fieles cristianos, de cualquier clase y condición que sean, para comulgar frecuente y diariamente". Otra manifestación de la piedad cristo-céntrica fue la difusión masiva del símbolo de la Cruz. La Cruz está presente en las casas, en las calles, en las esquinas, en los edificios, en las rutas y en el pecho de muchos fieles (Boudon, Caron y Jon, 2001: 160).

La acción católica debía estar bajo el riguroso control del clero, no compartía la idea de que los católicos dieran a su acción social una impronta algo propia e independiente de la jerarquía, en este sentido, llevó adelante un proceso de centralización y clericalización. No aprobaba que algunos sacerdotes orientaran su acción hacia el plano político, ni veía la necesidad de crear partidos confesionales, pues era consciente del peligro de comprometer la religión en conflictos puramente secundarios y temporales, en los que la iglesia no debía inmiscuirse. El lema del Papa era Instaurare Omnia in Cristo, la restauración de la sociedad cristiana (Aubert, 1988: 530-538).

Pío X llevó adelante la reforma de la curia romana, suprimió órganos y departamentos superfluos, y creó nuevas instituciones apropiadas a las necesidades y separó las cuestiones administrativas de las judiciales. Le otorgó mayor jerarquía a la Secretaría de Estado, de ella dependerían los diferentes países que anteriormente lo hacían de la Congregación de Propaganda Fidei, aunque hacía tiempo que ya no eran países de misión (Gran Bretaña, Estados Unidos, Canadá) y la Congregatio por negotii eclesiasticis extraordinaris (explicar que atribuciones tenía). Con la reforma, la curia abarcaría tres tipos de órganos, 
Congregaciones (11), ${ }^{5}$ Tribunales $(3)^{6}$ y Oficios (2). ${ }^{7}$ La otra reforma llevada a cabo por el papa incluía el derecho canónico para adecuar el derecho eclesiástico a la práctica jurídica contemporánea. Este fue sin duda un nuevo paso en el camino de la centralización y una herramienta de uniformidad para la Iglesia Latina (Aubert, 1988: 552-562).

Quizá una de las cuestiones centrales del pontificado de Pío X radique en el modo de comprender las relaciones con los poderes civiles. Su política de relación con los estados fue más intransigente que la de su predecesor, fue un defensor de los derechos de la Iglesia sin considerar la oportunidad política, esto lo llevó a situaciones realmente tensas con diversos gobiernos. El conflicto más importante fue el suscitado con el Estado francés. La ley de 1905, no sólo determinó la separación entre Iglesia y Estado, sino que también procuró dar una estocada mortal al sostenimiento económico de la Iglesia, ya que establecía que las llamadas asociaciones culturales, de las que estaba excluida la jerarquía eclesiástica, administraran las propiedades de la Iglesia, convirtiéndose en un poder alternativo a los obispos. El objetivo último de la ley era dañar la constitución jerárquica de la Iglesia. El pontífice se opuso con firmeza y escribió varias encíclicas dedicadas al caso francés. La Iglesia de Francia perdió la personería jurídica y, con ella, todo su patrimonio, incluyendo los templos donde se celebraban las funciones religiosas. A cambio, reconquistó su propia libertad y el control total de los nombramientos de los obispos, competencia, hasta ese momento, del estado, según el concordato napoleónico. De esta manera, el Papa había anulado, de golpe, tres siglos de galicanismo de Iglesia nacional, llevando de nuevo el catolicismo francés, disciplinariamente, a la plena fidelidad romana. En síntesis, con Pío X culmina un largo período de la historia de la Iglesia, es el ocaso de las interferencias con la política y de los estrechos vínculos entre "tronos" y "altares".

\subsection{Benedicto XV (1914-1922) y Pío XI (1922-1929): la Iglesia misionera}

Benedicto XV fue el papa de la primera guerra mundial. Elegido pontífice en septiembre de 1914, desde el inicio de su pontificado bregó por la paz del mundo y realizó continuos llamados a la conciencia de los gobernantes. Siguió con la política de centralización

\footnotetext{
${ }^{5}$ Congregación Consistorial, la de los Sacramentos, la del Clero, la del Indice; la congregación para la Canonización de Santos, Congregatio por negotii eclesiasticis extraordinaris, la de Breves, la del Santo Oficio, la de Propaganda Fidei, la de los Estudios, la de los Obispos.

${ }^{6}$ Para el fuero externo, La Rota y la Sacra Penitentiaria, para el fuero interno, la Signatura Apostólica.

${ }^{7}$ La Secretaría de Estado y la Cancillería Apostólica.
} 
iniciada por Pío X. A nivel interno, continúo la reforma de la Iglesia iniciada por sus antecesores. La política de centralización administrativa y organización se puso de manifiesto con la promulgación del Código de Derecho Canónico de 1917, que tendrá vigencia hasta 1983. Su impulso pastoral se plasmó en el gran movimiento misionero de la primera mitad del siglo XX. La carta Apostólica Maximum Illud del 30 de noviembre de 1919, fue una llamada a difundir el evangelio en tierras paganas. Además, impulsó la presencia activa de los católicos en la vida política, suprimiendo la prohibición de Pío IX (el non expedit), que los católicos participaran de la vida política. Paralelamente, definió el rol de la Acción católica, otorgándole un claro lineamiento desvinculado de la política.

La guerra mundial puso en evidencia la crisis de la sociedad occidental y de la cultura de la modernidad. Sus escritos se refieren a esta crisis, con sus diversas manifestaciones, las causas que la provocaron y los medios posibles para su superación. Las causas del gran desorden mundial estarían dadas porque el fundamento de la sociedad moderna estaba alejado de los principios cristianos. Cuando la sabiduría cristiana dejó de ser el cimiento sólido sobre el que se construyó el ordenamiento estatal, se provocó un derrumbamiento que pudo significar el fin de la comunidad humana. Por ello, cuando una sociedad se construye sin tener en cuenta los valores cristianos, se alteran los conceptos de fraternidad y autoridad, provocando la lucha de clases, debido, primordialmente, a la codicia de los bienes materiales (Fazio, 2009: 35).

Los medios propuestos por el pontífice para superar la crisis son fundamentalmente dos. El primero, lo expone en la encíclica Pacem Dei Munus de 1920. Para alcanzar la paz, dice, es necesaria la caridad, el amor mutuo entre los hombres, siguiendo las enseñanzas de Jesucristo. La caridad no sólo debe vivirse a nivel individual, sino también en las relaciones entre los estados y las naciones. El segundo, lo expresa en la encíclica Sacra Propediem de 1921, escrita con motivo del centenario de la fundación de la tercera orden franciscana, en la que hace un llamado a todos los cristianos a incorporarse, pues entiende que es una manera eficaz de promover la caridad y la paz en el mundo convulsionado por el odio y las guerras. 


\section{Iglesia y liberalismo en América Latina}

Uno de los procesos centrales de la historia de la Iglesia en América Latina durante el siglo XIX, ha sido la compleja relación entre el liberalismo imperante en la estructuración política y económica de las repúblicas surgidas del movimiento emancipador. Como señala Roberto Di Stefano, en los procesos revolucionarios que se desarrollan entre 1770 y 1850 , se impone una visión liberal. La aplicación de los principios de la Europa liberal de la primera mitad del siglo XIX, influyó en las relaciones entre las nacientes repúblicas y la iglesia. Dado que el liberalismo es un término polisémico, cabe distinguir algunas acepciones del liberalismo político que se aplicó en América a lo largo del siglo XIX.

Se pueden distinguir tres acepciones del liberalismo político. a) La primera se identificaría con la doctrina que sostiene la limitación de los poderes del estado en nombre de los derechos de las personas. Este liberalismo se identifica con el anti-despotismo y estuvo representado por la tradición pactista española que inspiró los movimientos insurgentes. El pueblo, titular de la soberanía, establece un pacto con los gobernantes para que ejerzan el poder de acuerdo a justicia. En caso de no cumplirse el pacto, debido a un uso despótico del poder, el pueblo tomará las medidas necesarias para restablecer la justicia. b) La segunda acepción del liberalismo político hace referencia al nuevo régimen, a la conciencia que tienen sus representantes de estar fundando un hombre nuevo (partir del individualismo), una sociedad nueva (a partir del contractualismo) y una nueva política (a partir de un nuevo principio de legitimidad -el de la soberanía nacional-, y de las nuevas formas de poder derivadas del mismo). Por lo tanto, los elementos centrales de este liberalismo fueron el sistema representativo, la opinión pública, como manifestación de la voluntad nacional, y el constitucionalismo, basado en un contractualismo sustentado en el individuo. La libertad y la igualdad fueron los pilares de una nueva concepción del ser humano como ser social y estuvieron en la base de la nueva perspectiva de la política: la soberanía popular o nacional, cuyo corolario, en términos de funcionamiento institucional, es el gobierno representativo. Según esta concepción, la monarquía hispánica fue considerada despótica, estamental y corporativa. En ella, se mezclaban viejas tradiciones políticas como el pactismo y el iusnaturalismo. c) La tercera acepción sería una facción o partido político que pretende generar un cambio en la sociedad que lleve a una mayor autonomía individualista y que excluya cualquier otra posibilidad política como 
fundamento del orden social. En este sentido, el estado liberal debe transformar, desde arriba, una sociedad tradicional que no responde a dichos principios, a través de una legislación que tienda al individualismo contractualista. Esto significa, entre otras cosas, la eliminación o el debilitamiento de los cuerpos intermedios entre los individuos y el estado. Este tercer tipo de liberalismo será el que se instaure en la segunda mitad del siglo XIX y entable una lucha con la Iglesia, considerada como un baluarte del orden tradicional y principal obstáculo a la modernización de la nación (Fazio, 2010: 161).

Roberto Breña (2010) pone en tensión, cuestiona y matiza el supuesto de la entidad liberal, es decir, la presencia, homogeneidad y consistencia del liberalismo del siglo XIX, tanto del primer liberalismo español (1808-1824), como el de la emancipación americana (1808-1825), mantenido por la historiografía política del primer cuarto del siglo XIX. El autor no duda de que el liberalismo jugó un papel central en el proceso español, aunque presenta sus reservas respecto a si es pertinente la utilización del sustantivo liberalismo y del adjetivo liberal para describir y explicar los procesos emancipadores americanos. $\mathrm{Su}$ hipótesis central afirma que: "El carácter liberal de los procesos emancipatorios americanos deber ser circunscripto, matizado y contrastado. Esto hay que hacerlo no porque muchos de los principios políticos que los inspiraron no fueran liberales, sino porque, en el contexto hispánico de aquel momento, esos principios no bastan para caracterizar como liberales, sin más, a dichos procesos" (Breña, 2010: 158). Por lo tanto, es necesario cualificar su presencia, solidez y alcances. En su argumentación, deja fuera de discusión que el liberalismo estuviera presente en el ideario que alimentó a los movimientos, en el discurso que los acompañó, en los aspectos institucional-formales que los caracterizaron, pues es prácticamente imposible concebir un movimiento político de emancipación en el mundo occidental que no sea liberal de modo significativo (por la influencia de la independencia de Estados Unidos y la revolución francesa). Sin embargo, sostiene que era débil por varias razones, en primer lugar, el liberalismo político que estaba surgiendo era muy incipiente en el mundo hispanoamericano, además, sus valores fueron rechazados con frecuencia por varios líderes americanos y, en segundo lugar, se trataba de un contexto profundamente tradicional en términos sociales (presencia ubicua e ingente de la Iglesia católica y una economía muy poco desarrollada en términos relativos) (Breña, 2010: 160). Esta realidad 
incidió en las relaciones del estado con la iglesia y con la sociedad, que seguía siendo mayoritariamente católica.

En otro texto, Breña (2011) advierte que junto al liberalismo se encontraba presente otra corriente de pensamiento, el historicismo nacionalista -en España había sido enarbolado por Jovellanos en su Discurso de 1780-, que articulaba la idea de unir la legislación y la historia nacional. Planteaba la imposibilidad de obtener un conocimiento cabal de la constitución y de las leyes españolas sin el estudio de la propia historia. Se trataba de una idea que reflejaba la tensión entre tradición y reforma. En el sexenio 1808-1814, caracterizado por el vacío de poder provocado por la invasión napoleónica, esta idea poseía una cierta maleabilidad y permitió apoyar tanto la continuidad histórica como la innovación política. El objetivo era argumentar a favor de una constitución que equilibrara las prerrogativas de la soberanía real con los privilegios del clero y de la nobleza, así como los derechos del pueblo. Allí estaban contenidos los elementos centrales del historicismo nacionalista (el apego a la legislación histórica, la admiración hacia las asambleas visigodas y las cortes medievales, la decadencia política española, ligada a la desaparición progresiva de las Cortes del escenario político), y una serie de principios relacionados con la libertad civil (seguridad personal, de la propiedad y jurídica, libertad económica, educación pública, libertad de imprenta). El historicismo nacionalista también fue invocado por los americanos cuando se produjo la crisis de 1808 .

Este nacionalismo historicista, que reafirmaba la soberanía nacional, dificultaba la admisión de una institución internacional como la Iglesia católica. Cualquier pretensión de Roma de ejercer su autoridad en cuestiones espirituales y de jurisdicción eclesiástica sin consultar al estado, sería interpretada por los gobiernos patrios como una inadmisible lesión a la soberanía nacional. Este es el núcleo central de la cuestión sobre el Patronato. La aspiración de las nuevas repúblicas era la de mantener el derecho del Patronato, de manera tal que se contara con una iglesia bajo el control estatal. Los gobiernos americanos no estuvieron dispuestos a ceder las prerrogativas sobre la iglesia que había gozado la corona española. En tanto, el papado comenzaba a concebir una reforma específica para los territorios americanos, sin la vigencia del Patronato. Roma calibraba las posibilidades de establecer una relación directa con los prelados y ejercer mayor control sobre ellos (Di Stefano, 2000 y 2004; Ayrolo, 2007; Martínez, 2013). 
El largo siglo XIX verá las tensiones generadas entre Roma y los nuevos estados. Los gobiernos americanos recurrieron sistemáticamente al placeat para los documentos oficiales eclesiásticos. Paralelamente, la Santa Sede reunía informes sobre diversos asuntos de la administración y del desarrollo de las iglesias americanas. Un paso importante para fortalecer el vínculo con los prelados fue, sin duda, el envío de delegados en misiones específicas de reconocimiento, como la misión Mussi en 1824 (Ayrolo, 1996).

Para algunos autores (Soneira, 1878; Dussel, 1983; Ayrolo, 2007), alrededor de 1850, es cuando se consuma la ruptura definitiva con la cristiandad colonial. Dussel (1983) sintetiza este hecho señalando que las nuevas naciones empiezan a sentir la influencia del mundo anglosajón a través de los colegios, el progreso técnico, la ingeniería y el comercio. El clima intelectual que impera está teñido de las ideas del romanticismo, el positivismo y el secularismo. En el plano social, la inmigración comienza a transformar las estructuras sociales y demográficas y en el campo de las ideas, el socialismo comienza, de manera muy lenta, a propagarse entre los grupos de inmigrantes urbanos y el proletariado industrial. Para Di Stefano (2000), la cristalización de esta fractura debe mirarse a la luz de los ásperos conflictos que enfrentaron a la Iglesia con el estado laico en los años ochenta, pues estos conflictos representaron, también en Argentina, el síntoma de la progresiva separación entre la autoridad temporal y la espiritual, el Estado y la Iglesia, el ciudadano y el fiel, orgánicamente unidos en el pasado.

En tanto, el vínculo de Roma con los prelados americanos se fortaleció con la ampliación del sistema de nunciaturas durante el pontificado de Gregorio XVI, la injerencia directa de Roma en las nominaciones episcopales, que propiciaron la sustitución progresiva del clero reformista y liberal por el conservador y ultramontano, la creación del Colegio Pío Latinoamericano en Roma en 1858, bajo la dirección de profesores jesuitas de la Universidad Gregoriana, estrechamente vinculada con el papado, y el dogma de la infalibilidad pontificia declarado en 1870. Todas estas medidas reforzaron tanto el centralismo como el verticalismo romano (Bastian, 1990: 10-11; Cárdenas Ayala, 2008: 9196).

Al calor de las contiendas provocadas durante el proceso de laicización del estado, este vínculo con Roma se afianzó y el proceso de romanización adquirió un nuevo ritmo. En 1873, el papa Pío IX se refiere a la situación de la Iglesia en los territorios americanos, 
advirtiendo que son tiempos "tan molestos para los católicos, que sus gobiernos parecen negar con sus hechos la fe que profesan. Pues, allí se emprendió, hace algunos años, una guerra tenaz contra la Iglesia, y comenzáronse a destruir sus instituciones y los derechos de esta Apostólica Sede" (Pío XI, 1973: 19). La preocupación por "restaurar" la iglesia en América Latina llevó al Papa a convocar, en 1899, el Concilio Plenario para América Latina.

\section{La romanización de las Iglesias de América Latina}

¿De qué hablamos cuando nos referimos al proceso de romanización? Se podría sintetizar en el interés de Roma por las iglesias de América Latina. Roma adquiere cada vez más importancia como rectora de los asuntos eclesiásticos de América Latina, motivo por el cual este proceso recibe el nombre de "romanización". El Concilio Vaticano I (1870) supuso un hito importante de la romanización, pues por primera vez acudieron 48 obispos americanos, entre los que figuraban cuatro de los cinco obispos de las diócesis argentinas. ${ }^{8}$ Éstos regresaron dispuestos a reactivar la vida eclesial de sus diócesis. El programa de acción contemplaba la mejora en la formación y aptitud del clero, la ampliación de la participación de los laicos, en especial en la educación y en la prensa, la cristianización de la cultura, la cuestión social y el diálogo con el mundo moderno (Luque Alcaide, 2003: 76).

Además, el vínculo con Roma se afianzó mediante la renovación de la práctica de las visitas ad limina de los obispos, la preocupación por la aplicación del Concilio Vaticano I en las diócesis americanas, en particular las cuestiones relativas a la implementación de reformas en los seminarios ${ }^{9}$ y el impulso de sínodos provinciales y asambleas episcopales regionales,${ }^{10} \mathrm{el}$ recurso a la figura del nuncio apostólico, destinada a fortalecer la figura del papa frente a los estados, "el nuncio representaba al papa como verdadero soberano espiritual de los católicos del respectivo país, distinguiéndose por tanto de cualquier otro embajador" (Köhler, 1988: 63). A su vez, la creación de nunciaturas, posibilitó la apertura de un canal de comunicación entre Roma y las diócesis americanas. La Internunciatura de

\footnotetext{
${ }^{8}$ Buenos Aires, Salta, Paraná y Cuyo. No asistió Ramírez de Arellano, obispo de Córdoba, por encontrarse enfermo y anciano.

${ }^{9}$ Se modificaron los planes de estudio, se introdujeron la filosofía tomista y algunas materias como sociología y ciencias de la naturaleza.

${ }^{10}$ Concilio Plenario para América Latina, realizado en Roma en 1899 y los sínodos diocesanos de Córdoba en 1877, Salta en 1903, Buenos Aires en 1905 y nuevamente en Córdoba en 1906.
} 
Brasil, con sede en Río de Janeiro, era la única existente en América del Sur desde 1848. Atendía los asuntos de Brasil, Perú, Boliva, Chile, Uruguay y Argentina. ${ }^{11}$ En 1877, se enviaron delegados apostólicos y se establecieron nunciaturas en todos los países. ${ }^{12} \mathrm{Se}$ perfilaba la imagen de una Iglesia nacional cada vez más articulada a nivel interno y organizada según la imagen del modelo romano: centralizado y jerárquico (Di Stefano y Zanatta, 2000: 302; Di Stefano, 2004: 92).

El Pontificado de León XIII continúa con la mirada puesta en América Latina y resuelve convocar el Primer Congreso Plenario de América Latina. A este Concilio, asistieron 13 arzobispos y 40 obispos, de los cuales siete eran argentinos, entre los que se encontraba el Obispo de Córdoba, Fray Reginaldo Toro. ${ }^{13}$ El objetivo del Concilio era unificar las directrices de la disciplina eclesiástica en las diócesis latinoamericanas. En el discurso introductorio, el Obispo de Montevideo, Mariano Soler, sintetizaba las aspiraciones de la asamblea del siguiente modo:

esto será lo único que nos propondremos en este Sínodo, a saber, tomar con unánimes pareceres y perfecta concordia, aquellas determinaciones que sirvan, principalmente, para conservar íntegro e inviolable en nuestras respectivas diócesis el depósito de nuestra santa Fe, para defender los intereses y las saludables doctrinas de la Iglesia católica, para mantener intacta la disciplina del clero, formar en la ciencia y en la piedad a los jóvenes clérigos, proveer a la cristiana educación de la juventud de ambos sexos, y fomentar más y más cada día la moralidad, la religión y la piedad en sus corazones; para eliminar los vicios, instruir a los fieles en la saludable ciencia de la doctrina católica, y volver a traer a nuestros conciudadanos descarriados, a la senda de la religión y de la virtud ${ }^{14}$ (CPAL, 1906).

Una de las cuestiones que llama la atención es justamente la preocupación por afirmar la "romanidad" de la Iglesia. Los obispos argentinos acogieron las disposiciones conciliares, en particular, aquellas recogidas en el título VIII, referidas a la formación del clero. En este aspecto, los prelados dedicaron sus esfuerzos a la formación de un clero "romanizado", que

\footnotetext{
${ }^{11}$ ASV. Secretaría de Estado, N 1089-I-II.

12 Mons. Angelo Di Pietro fue enviado a Argentina, permaneciendo hasta 1879, cuando fue reemplazado por Mons. Luis Matera, quien, debido a los conflictos durante la presidencia del general Roca, en octubre de 1884, debió abandonar el país, instalándose en Uruguay.

13 Mons. Uladislao Castellano (Arzobispo de Buenos Aires) y los siguiente obispos: Reginaldo Toro (Córdoba), Pablo Padilla (Tucumán), Rosendo de la Lastra (Paraná), Juan Agustín Boneo (Santa Fe), Mariano Antonio Espinosa (La Plata) y Matías Linares (Salta).

${ }^{14}$ Actas y decretos del Concilio Plenario de la América Latina celebrado en Roma el año del Señor de MDCCCXCIX, Tipografía Vaticana, Roma, 1906, p. 593. Traducción oficial.
} 
debía enfrentarse a las vicisitudes y problemas que planteaba un Estado liberal y una sociedad en vías de secularización.

La asamblea elaboró un diagnóstico que percibía a la iglesia americana en un estado de gran debilidad interior y amenazada a nivel externo. La debilidad estructural se debía a varios factores. El primero era geográfico, ya que la organización territorial de fines del siglo XIX era muy parecida a la de siglos anteriores, diócesis compuestas por inmensos territorios, grandes distancias y escasas comunicaciones entre poblaciones dispersas. Diócesis realmente inabarcables por sus extensiones. Respecto a las parroquias, los problemas de las diócesis se reproducían a escala, eran muy extensas, con población dispersa y aislada. Cada parroquia tenía varias capillas filiales, a las que el párroco tenía obligación de hacer sólo una visita anual para instruir a los fieles y facilitarles la obligación de cumplir con el precepto anual de la confesión y la comunión. Estas capillas eran, en realidad, comunidades casi aisladas de la sede parroquial. El segundo factor de debilidad institucional estaba vinculado con la ignorancia religiosa del pueblo. Si bien el pueblo en Latinoamérica permanecía fiel a la Iglesia católica, también se podía afirmar que su religiosidad no se ajustaba, en muchos casos, a los criterios propuestos por Roma en tiempos de León XIII. Quizá el problema que se percibía con mayor fuerza era la dificultad de que las conductas se ajustasen a los criterios morales, principalmente en el ámbito familiar. Otra cuestión a la que el Concilio le otorgó importancia fue al problema de la embriaguez. A estos preocupaciones, se sumaba la amenaza de lo que el Concilio consideraba los "enemigos de la fe", es decir, protestantes, masones, librepensadores y socialistas.

En línea con el Concilio Vaticano I, que afirmó una progresiva disminución de la autoridad de los Cabildos Catedrales en favor del aumento de las prerrogativas de los obispos, el Plenario Latinoamericano dispuso tratar esta cuestión, ya que eran frecuentes las tensiones entre los obispos y sus respectivos cabildos, y éstos estaban interesados en fijar las competencias de los canónigos y garantizar la libertad del obispo para otorgar los diversos beneficios. E1 Plenario, en el decreto 229, establecía que:

Por lo que toca a los servicios que hay que prestar al obispo en el gobierno de la diócesis, recuerden los canónigos que ellos constituyen el senado del obispo. Jamás podrán desempeñar propia y santamente tan importantes funciones, si no veneran al 
obispo como su padre y pastor y, formando con él un solo cuerpo, se proponen en todo y por todo el bien de la Iglesia únicamente.

Del análisis del documento estructurado en 16 títulos y más de 100 capítulos se desprenden las siguientes conclusiones:

1) La Iglesia aparece como una comunidad de extraordinaria homogeneidad cultural y religiosa. La coherencia global de sus obispos, la unidad de sentimientos, borra la distinción entre las diferentes iglesias latinoamericanas y entre éstas y Roma. A nuestro entender, presenta una iglesia más ideal que real. Para Bautista García (2005: 115), la jerarquía Romana mostraba mayor interés en imponer un esquema de reforma uniforme a todas las iglesias, que en analizar las diferencias que los obispos latinoamericanos veían en sus iglesias. En principio, Roma no pareció distinguir entre las diferencias que moldeaban el catolicismo en cada región latinoamericana, partiendo del supuesto de una "identidad común" entre los países que anteriormente habían estado bajo el dominio de alguna potencia europea de origen latino. A pesar de que esta percepción eludía el reconocimiento de las diferencias específicas que presentaba la cuestión eclesiástica en cada país, la práctica diplomática que Roma ejerció por medio de sus delegados especiales, enviados a algunas repúblicas, muestra el ejercicio de una atinada política que intentó dirigir las acciones de los jerarcas eclesiásticos en América Latina, bajo las estrategias concretas trazadas desde el Vaticano y enfocadas a resolver los problemas de las iglesias locales.

2) El plan de reforma y el programa de acción fue claro y se basaba en los siguientes ejes.

a) La reforma del clero y las instituciones eclesiásticas; b) el establecimiento de un nuevo tipo de relaciones con el poder civil, que le permitiera frenar el impacto de las reformas liberales; c) la condena de los errores modernos; d) la conducta prudente y distante de los católicos hacia aquellos que no compartían su creencias, la mayor presencia de los laicos en el entramado social, a fin de garantizar una mayor influencia de la iglesia en la sociedad; e) el respaldo de las feligresías cuya lealtad era disputada por los gobiernos civiles.

Este esquema de reforma articuló dos tendencias, una restauracionista y otra modernizadora. Combinó una mirada nostálgica hacia el pasado, unida a cierta desconfianza y hostilidad hacia algunos aspectos de la modernidad, con un proyecto que apuntó hacia el futuro, intentando poner a la Iglesia en el camino de la modernización de sus instituciones, sus métodos, y de la capacitación del clero. Ampliar la convocatoria, 
compromiso y participación activa de sus feligreses. Podríamos afirmar que tradición y modernidad son los dos conceptos que se entrelazan en el concilio. Para la Iglesia latinoamericana, el Concilio supuso un gran impulso. Además, como advierte Diego Picardo y Antón Pazos (2002: 143-145), en el libro de Actas y Decretos del Plenario, podría considerarse como el vademécum del párroco rural, que tantas veces se hallaba aislado y con dificultades para resolver dudas en su tarea pastoral, pues recuerda las verdades de la $\mathrm{Fe}$, menciona los principales errores doctrinales en boga, desarrolla todo lo relativo al culto divino, explica lo relativo a sacramentos y sacramentales. El capítulo dedicado a los párrocos y los registros parroquiales constituye un excelente resumen de las enseñanzas del derecho y la teología pastoral sobre las obligaciones de los curas. Se enumeran, en particular, el deber de residencia, el celo por el moribundo, la predicación y el catecismo, el culto divino, la administración de los bienes parroquiales, la caridad hacia los pobres y la recta confección de los libros parroquiales. Por lo tanto, los decretos del Concilio resultan "una excelente complicación de buena parte de la legislación eclesiástica".

El Concilio Plenario para América Latina y las reformas propuestas por Pío X formaron parte de ese "Modelo Romano", según el cual se procuró modelar a las Iglesias americanas.

\subsection{La Iglesia y el estado liberal-conservador argentino}

\subsubsection{La segunda mitad del siglo XIX}

En Argentina, el proyecto de país que comienza a gestarse al inicio de la segunda mitad del siglo XIX fue impulsado por una generación que recibió la calificación genérica de liberal. Basaba su proyecto en la inmigración europea sajona, considerada mano de obra cualificada, la conquista del territorio ocupado por los indios, a fin de destinarlo a la productividad agropecuaria, y la inversión de capitales extranjeros en transportes, en particular el ferrocarril, y entidades crediticias. La libertad de comercio y la libre navegación de los ríos fueron presentadas como indispensables para el progreso. Se rechazaba el pasado colonial y la herencia hispánica, considerándola una etapa superada, y se mostraba una minusvaloración de lo criollo. Ricardo Zorraquín Becú (1964: 8) distingue la etapa que va de 1862 a 1880 como propia de un liberalismo moderado, que, respetando los derechos humanos, procuró enaltecer la cultura y el desarrollo espiritual. "Se quiso 
ahogar las manifestaciones que se consideraban regresivas (el caudillaje, las resistencias localistas), para dar paso a un criterio civilizador que, imitando lo europeo, facilitara el adelanto del país".

Domingo F. Sarmiento, en su "Civilización y Barbarie", expone la contraposición del hombre ilustrado - civilizado- de las ciudades, con el gaucho de la campaña, al que califica de bárbaro. El Facundo aparece en 1845 como folletín en el periódico "El Progreso" de Santiago de Chile. El fondo argumental de esta obra consiste en el enfrentamiento de la barbarie gaucha y la civilización europea. Sarmiento insiste allí en que el país debía ser devuelto a la civilización de la que gozó en tiempos de Bernardino Rivadavia, la cual "traía sabios europeos para la prensa y la cátedra, colonia para los desiertos, naves para los ríos, interés y libertad para las creencias, crédito y banco para impulsar la industria; todas las grandes teorías sociales de la época para modelar su gobierno; la Europa, en fin, para vaciarla de golpe en la América y realizar en diez años la obra que antes necesitara el transcurso de siglos". Este texto nos revela qué entendía Sarmiento por civilización y hasta donde llegaba su optimismo racionalista y positivista. Europeizar significaba que los valores hispánicos diesen paso a los valores anglosajones. Sin embargo, otro miembro de la Joven Argentina será quien se vuelva contra esa concepción de Sarmiento, Juan Bautista Alberdi, quien dice: “Tenga cuidado señor Sarmiento, en vista de los ejemplos célebres que acaban de probar ante el mundo aterrorizado, que se puede ser bárbaro, sin dejar de ser instruido, y que hay barbarie letrada mil veces más desastrosa para la civilización verdadera, que la de todos los salvajes de la América desierta" (Alberdi, 1887: 156).

En este período de la historia argentina y latinoamericana, se experimenta un significativo proceso de modernización. En un contexto de crecimiento demográfico, fruto de la inmigración, Argentina se inserta en el ámbito del comercio mundial como país productor de materias primas. Los grupos dirigentes se lanzaron a un proyecto de modernización muy vinculado con el pensamiento liberal. Los sectores populares permanecieron fieles a los cánones de la vida tradicional, imbuidos de espíritu religioso, mientras que una gran parte de los intelectuales y grupos de poder se alejó de la visión católica. Los promotores de los cambios modernizadores intentaron imponer una nueva visión del hombre y de la sociedad, en la que el individuo era radicalmente autónomo e ingresaba mediante un "pacto" a la vida social. El Estado, como organización jurídica y 
política de la sociedad contractual, se erigía en una instancia moral: se trataba de un estado "docente", que debía imbuir a las mentalidades de los ciudadanos de las nuevas ideas que tendían a la libertad individual y al progreso económico. Era un Estado celoso de la soberanía que no permitía ninguna injerencia externa o superior que estableciera la moralidad de sus actos. La moral propugnada por el estado liberal era una moral laica, científica, que giraba en torno a la libertad de conciencia y al progreso material. Esta ideología pretendía liberar "la conciencia colectiva de las ataduras atávicas heredadas de un pasado autoritario-clerical" (Fazio, 2010: 172).

Sin embargo, el ideal liberal no llegó a todas las capas sociales, ni tuvo la eficacia esperada. Los trabajos de Roberto Breña dan cuenta del peso de la tradición hispano católica en las repúblicas americanas y la dificultad que tuvieron las elites liberales para bajar el proyecto al "ras del suelo", es decir a la sociedad. El autor pone en tensión, cuestiona y matiza el supuesto de la entidad liberal, es decir-presencia, homogeneidad y consistencia- del liberalismo en los procesos del siglo XIX. Su hipótesis formulada para comprender el alcance liberal de los proceso emancipatorios americanos, sin duda es válida para el proceso de consolidación del estado de la segunda mitad del siglo XIX. Breña (2010: 160) afirma que el carácter liberal debe ser circunscripto, matizado y contrastado. Esto hay que hacerlo no porque muchos de los principios políticos que los inspiraron no fueran liberales, sino porque esos principios no bastan para caracterizar como liberales sin más a dichos procesos, por lo tanto, es necesario cualificar su presencia, solidez y alcances. En su argumentación, primero, y en su demostración, después, señala que deja fuera de discusión que el liberalismo estuviera presente en el ideario que alimentó las revoluciones, en el discurso que las acompañó y en los aspectos institucional-formales que las caracterizaron, dado que era prácticamente imposible concebir un movimiento político de emancipación en el mundo occidental que no fuera liberal de modo significativo. Pero también habría que afirmar que el carácter liberal era débil, pues el liberalismo político estaba surgiendo y, por ende, era muy incipiente. En el mundo hispanoamericano, sus valores fueron rechazados con frecuencia por varios líderes americanos y, sobre todo, porque se trataba de un contexto profundamente tradicional en términos sociales (presencia ubicua e ingente de la Iglesia católica y una economía muy poco desarrollada en términos relativos). 
Si bien no cabe duda de que en la segunda mitad del siglo XIX las corrientes liberales y positivistas se posicionaron a nivel de las elites dirigentes, es interesante analizar cómo estas corrientes de pensamiento llegaron a las bases populares y se materializaron en prácticas concretas. El grupo intelectual y político que accedió al poder en la década del 80, y que perduró hasta el centenario, recibió el apodo de generación del 80 y suele asociársela con el predominio intelectual del liberalismo. La llegada de Julio A. Roca al poder estuvo signada por las promesas de llevar adelante el desarrollo y el progreso del país y hacer realidad las promesas esperadas desde la organización constitucional de la nación. Esta generación se propuso como finalidad excluyente la consecución del progreso. Cuatro son las cuestiones centrales que estos hombres debieron enfrentar: la cuestión económica, que los enfrentó con la consecución de medios y recursos para el desarrollo; la cuestión política, fuertemente vinculada con la cuestión electoral y, como advierte Natalio Botana, con la crisis de legitimidad del régimen y la libertad de sufragio; la cuestión cultural, vinculada fuertemente con el problema religioso; y la cuestión social, promovida por las condiciones de trabajo, la inmigración, la concentración urbana, las crisis económicas y financieras.

Algunos autores sostienen que esta generación no poseía un pensamiento fundador, sino ejecutor, que ellos fueron los albaceas del plan progresista del 53/60 (Segovia, 2000: 263). Casi todos los actores del 80 combinaban, según Segovia, progresismo con dosis de escepticismo, liberalismo con cuotas de conservadurismo y democratismo y, a la hora de gobernar, eran prácticos y utilitaristas. Quienes avanzaron en la crítica del régimen, debieron marginarse o fueron marginados, ejemplo de ellos fueron los católicos liberales, que, al oponerse a las reformas de Roca y Juárez Celman, fueron censurados y puestos al margen de la vida política. Lo mismo puede decirse del liberalismo radical de los hombres de 1890: el régimen no modificó su legitimidad montada en el sufragio limitado y fraudulento, por lo que los opositores se convirtieron en revolucionarios, autoexcluyéndose de la legitimidad. En este contexto, Segovia sostiene que más allá de las coincidencias de la clase política, en lo fundamental se pueden observar cuatro corrientes de ideas en el seno del liberalismo genérico: el liberalismo positivista, el conservadurismo liberal, el liberalismo católico y el radicalismo liberal, portador de un incipiente democratismo.

Los elementos que permiten identificar el liberalismo genérico son: una república representativa, un optimismo progresista en lo económico, material e intelectual, la 
protección y el desarrollo de las libertades individuales, tomando la libertad individual como base de la vida social, la división de poderes, el control del gobierno, un poder ejecutivo fuerte, un federalismo de unidad, libertad política, democracia limitada, libertad económica sostenida desde el Estado. A todo esto se suma la confianza ilimitada en el progreso, la fe en el desarrollo y la modernización del país. Nadie se define fuera del liberalismo, las disputas siempre son internas (Segovia, 2000: 264).

La principal corriente interna de este liberalismo genérico es el liberalismo positivista, que sostiene una política apartada de toda vinculación religiosa, que lleva a la separación y alejamiento decisivo de la Iglesia. El programa ya no es el propio del liberalismo espiritualista y romántico que lo precedió, sino que alcanza un tinte materialista y con frecuencia ateo. La política se funda en el deseo de mantener la paz y lograr el adelanto material, en tanto se afianza el poder de la nación, las provincias pierden su autonomía y el federalismo se convierte en una apariencia (Zorraquín Becú, 1964: 8).

Dentro del núcleo liberal, había sectores que no compartían el positivismo dominante, o que lo atenuaban. Tal es el caso de los liberales católicos. Eran también liberales, pero sus creencias se fundían en la tradición humanista y religiosa de occidente. Cuando los positivistas atacan sus cimientos, los católicos marcan diferencias y se convierten en opositores. Otro matiz, o corriente, está constituido por un sector también liberal, que incorpora elementos del conservadurismo provenientes del romanticismo, el historicismo europeo y el republicanismo norteamericano. Por último, perfila el liberalismo radical, con tintes democráticos, que hará de la libertad electoral su bandera (Segovia, 2000: 270).

En el tercer cuarto del siglo XIX, es cuando se da el mayor enfrentamiento entre el liberalismo positivista y la iglesia, ya que el desarrollo de la idea republicana también significaba poner fin al predominio eclesiástico: república y laicismo son conceptos que en ese momento van unidos. En el intento de apartar a la Iglesia de la vida social y política, de verla recluida a las sacristías, algunos liberales comenzaron a presentarse como anticlericales y no sólo se opusieron a la injerencia eclesiástica en la vida política, sino que también se propusieron someter y subordinar la vida religiosa a la sociedad política. Con este objetivo llevaron adelante un programa de reformas que tendía a hacer retroceder a la Iglesia católica, centrado en los siguientes puntos: enseñanza laica, matrimonio civil, registro civil y secularización de los cementerios (Segovia, 2000: 276). 
A partir de 1880, con el triunfo de Roca para ocupar la primera magistratura, nacía la dicotomía entre un Estado que no renunciaría a su proyecto ideal de sociedad liberal y que, al no alcanzarlo, iba a darlo por supuesto, y una sociedad que no renunciaría a sentirse y a reconocerse católica. Especie de esquizofrenia que, al extremarse, acabará por desembocar en un statu quo recíproco en las décadas siguientes.

El positivismo, con sus principios de progreso, materialismo y cosmopolitismo, llevado plenamente a la práctica por la Generación del 80, comenzó a ser cuestionado por figuras destacadas de la "Generación del Centenario". Hombres formados en el clima de ideas de 1880, comenzaron a defender los principios antiliberales y se constituyeron en los primeros "nacionalistas", en su mayor parte eran vástagos de antiguas familias provincianas, que buscaban en lo hispano un factor histórico decisivo del carácter nacional argentino frente al peligro de desnaturalización del país y la amenaza de dependencia económica. La crisis de representación del liberalismo, su incapacidad para reaccionar frente a los retos de la modernidad -como la aparición de la política de masas-, el acomodamiento de instituciones tradicionales, como la Iglesia y el ejército, a las nuevas corrientes secularizadoras, posibilitó el surgimiento de un nuevo nacionalismo que acabó por prevalecer sobre el nacionalismo laico y progresista, trabajosamente construido y defendido durante el siglo XIX. Este nacionalismo estuvo sin duda imbuido de los ideales románticos europeos.

En Argentina, a comienzos de la nueva centuria, se puede observar una reacción al liberalismo positivista que había imperado en las elites intelectuales argentinas y latinoamericanas. En muchos ambientes de la cultura latinoamericana, surge la valoración de lo católico, lo hispánico, lo indígena y lo mestizo, como un conjunto de elementos diferenciales y específicos. Para ejemplificar esta postura de la autoafirmación de lo latinoamericano frente al cientismo, representado por el progreso material y la actitud imperialista de Estados Unidos, nuevo adalid del mundo civilizado, aparecen intelectuales como José Enrique Rodó, Rubén Darío, José Martí, que ponen de manifiesto un distanciamiento radical con la generación anterior, representada por Sarmiento, referente de un siglo que había negado sus raíces hispanoamericanas.

Cuando en 1892 se celebró el cuarto centenario del descubrimiento de América, Rubén Darío plasmó, en un poema, su sentimiento de frustración, al comprobar que el continente 
estaba aún muy lejos de convertirse en la sociedad de libres e iguales a la cual aspiraron los promotores de la independencia. En la poesía dedicada a Colón, surgen los elementos que definen el alma americana. Lo hispano, lo indio, lo mestizo y el catolicismo. Este hispanoamericanismo surgió como una alternativa cultural frente a las manifestaciones más agresivas del imperialismo estadounidense (Fazio, 2010: 222).

El panorama político institucional del primer cuarto del siglo $\mathrm{XX}$ argentino presenta un cuadro bastante más diversificado que la segunda mitad del siglo anterior. Se consolida una conciencia latinoamericana. El proceso modernizador trajo consigo una industrialización creciente, acompañada de una migración interna del campo a las ciudades y un flujo inmigratorio procedente de Europa, que modificó las sociedades y abrió el espacio político, que, en el siglo XIX, había sido ocupado por una oligarquía minoritaria que se hizo con el poder, dividida habitualmente entre conservadores y liberales. El cambio social se manifestó también en la presencia de nuevas ideologías políticas, como el socialismo, el anarquismo y el marxismo.

Cuando el proyecto liberal comenzó a mostrar fisuras y a percibirse incapaz de dar respuesta a los conflictos generados entre el capital y el trabajo y aumenta la preocupación por los “desordenes y perturbaciones sociales", la clase dirigente buscó en la Iglesia un instrumento cohesión y armonía social. Función ésta que nunca había dejado de ejercer, pero que, en este período, adquirió una particular relevancia. La iglesia se convirtió en una herramienta necesaria y funcional al Estado y el proyecto de restauración católica de la sociedad adquirió una peculiar importancia (Zanatta, 1996). Las reformas electorales y el cambio de tendencia cultural antes mencionada crearon el campo de cultivo para los movimientos populares o de masas, que incorporaron al juego político a grandes sectores de la población que habían quedado afuera, como meros espectadores. Luego de la reforma electoral de Roque Sáenz Peña, por primera vez y a través de elecciones limpias, llegó al poder Hipólito Irigoyen, líder de la Unión Cívica Radical, partido de ideología popular, basada en el krausismo.

Al liberalismo oligárquico del siglo XIX, le sucedieron movimientos con una base de mayor representación popular que generaron una nueva relación con la Iglesia. A diferencia de los partidos liberales, estos movimientos (radicalismo y luego peronismo) incorporaron a 
sus filas grandes masas del pueblo católico y, como consecuencia, modificaron las relaciones con la iglesia (Zanatta, 1996).

\subsection{Historizar el proceso de romanización argentino}

Aún no hay consenso entre los historiadores respecto a la temporalidad de este proceso. Abelardo Soneira (1978: 54) sostiene que en el período que va de 1858 a 1898 se consuma la ruptura definitiva con la cristiandad colonial, produciéndose un proceso de romanización creciente, enmarcado por dos hechos: la creación del Colegio Pío Latinoamericano y el Concilio Plenario para América Latina. Para Roberto Di Stefano (2000: 334), en cambio, el proceso es más amplio y puede retrotraerse a la Misión Mussi en 1824. Considera que el Concilio de 1899, fecha que muchos estudiosos consideran germinal, para el autor, sin embargo, permite comprender hasta qué punto los progresos del modelo eclesial romano y los conflictos entre liberales y católicos estaban indisolublemente vinculados. Entiende que la obsesión liberal por el ultramontanismo, presente en la prensa y en los debates públicos, era un indicio de la romanización de la Iglesia argentina. En tanto, Elisa Luque Alcaide (2003: 71-89) también lo entiende como un fenómeno de larga duración, que despegaría en la década del 50 y cobraría nuevo impulso a partir de la del 70, con el Concilio Vaticano I, entendido éste como un hito importante en la recuperación de la Iglesia de América Latina. Si bien no es tarea fácil datar el inicio y el término de dicho proceso, podemos afirmar que se trató de un proceso lento y complejo, que tuvo diferentes ritmos, momentos de quietud y otros de mayor aceleración, y estuvo profundamente imbuido de conflictos y tensiones.

Dicho proceso tuvo diferentes momentos, quizá el más estudiado haya sido, sin duda, la década del 80, debido a los conflictos con el Estado liberal en torno a la sanción de las leyes laicas y la cuestión del Patronato, entre otras cuestiones. Luego de este período de polarización religiosa, siguen unos años que, para algunos autores, son de "letargo" institucional (Di Stefano y Zanatta, 2000: 311). Este aletargamiento, que se habría producido en 1890, en el seno del catolicismo argentino, habría redundado en una lenta serie de progresos para el avance de la Iglesia sobre la sociedad argentina: las asociaciones parroquiales y las instituciones eclesiásticas crecían a un ritmo muy espaciado, los diversos ensayos para la organización de las fuerzas católicas no parecían dar resultados de provecho, mientras las publicaciones católicas se mantenían a un nivel de subsistencia y no 
había ninguna que se destacara por sobre las demás. Este letargo, sin embargo, logró ser superado en la década de 1930 y iniciándose, entonces, un proceso de "renacimiento católico" de vastas consecuencias (Lida, 2007: 54). Fortunato Mallimaci (1993: 46-60), presenta, para Buenos Aires, la imagen de un catolicismo que, por debilidad, contemporizó con el Estado liberal de fines del siglo XIX y, que, hacia 1920, comenzó a ser reemplazado por un catolicismo integral, que procuró la catolización del Estado como medio para imbuir la sociedad de valores cristianos. En esta misma línea, Roberto Di Stefano (2000) señala que hacia fines de la década del 20 se comenzaba a respirar una brisa de "renacimiento católico", de la que veinte años atrás no había ninguna señal. El Congreso Eucarístico representó sin duda el ápice de este clima.

Si bien esta periodización referida al renacimiento católico podría aplicarse a la Iglesia de Buenos Aires, creemos que para Córdoba debe ser matizada, pues, como veremos en el próximo capítulo, el renacimiento católico fue un proceso sostenido que hunde sus raíces en 1877 (quizá antes), cuando se realiza el primer Sínodo diocesano del siglo XIX. El Sínodo, primero en Latinoamérica, es, sin duda, una manifestación exterior de un proceso de consolidación institucional que ya se venía gestando, por lo tanto, consideramos que la década de 1890 y la primera del siglo $\mathrm{XX}$, no pueden verse como un período de retraimiento eclesiástico, sino más bien como una de las fases del período de crecimiento y consolidación institucional.

La historiografía es coincidente al considerar que el avance del estado liberal fue posible gracias a la debilidad institucional de la Iglesia. La hipótesis central del trabajo de Loris Zanatta (1996) sostiene que la debilidad estructural de la Iglesia garantizó la implantación de las llamadas "leyes laicas" y la consiguiente consolidación del Estado liberal, sin embargo, señala que, en la primera década del siglo XX, cuando el proyecto liberal comenzó a mostrar fisuras y a percibirse incapaz de dar respuesta a los conflictos generados entre el capital y el trabajo, aumenta la preocupación por los "desórdenes y perturbaciones sociales", por ello, la clase dirigente buscó en la Iglesia un instrumento de cohesión y armonía social. Función ésta que nunca dejó de ejercer pero que, en este período, adquirió una particular relevancia. La iglesia se convirtió en una herramienta necesaria y funcional al Estado y al proyecto de restauración católica de la sociedad. Por su parte, Di Stefano y Zanatta (2000), coinciden en que, en la década del 80, las bases institucionales de la Iglesia 
eran extremadamente débiles. El paso del progreso estaba marcado por una elite impregnada de ideales liberales y positivistas, entre cuyos objetivos sobresalía laicizar el Estado y la sociedad. Sin embargo, la institución eclesiástica no se mantuvo pasiva ni ajena a las transformaciones que experimentaba la sociedad. En este sentido, sacudida por las transformaciones de más largo alcance que abatieron a la Iglesia Universal, la Iglesia argentina aceptó el desafío y comenzó a sentar las bases, primero lentamente y luego con mayor celeridad, para la maduración institucional y doctrinaria que habrá de culminar en el siglo XX.

Estas miradas no condicen con la realidad eclesiástica cordobesa. A lo largo de este trabajo, veremos que la imagen que surge no muestra a un Estado fuerte desplazando a una Iglesia débil, más bien se trata de dos actores sociales protagónicos que actúan en igualdad de condiciones. Aquí, es preciso advertir, al menos, dos escalas en el nivel de análisis, ya planteadas ut supra, que no necesariamente se corresponden, en primer lugar, el proceso de laicidad del estado liberal y, en segundo lugar, el proceso de secularización de la sociedad. Como advierte Elisa Cárdenas Ayala (2008: 85-106) en su texto sobre la construcción de un orden laico en América Hispánica, el proceso tuvo rasgos comunes, aunque, sin duda, también diversos ritmos de construcción. En Córdoba, la Iglesia había sido el pilar y el sostén que daba coherencia al orden social, siendo la religión la matriz que unificaba el creer, el poder y la autoridad. Lo religioso estaba de tal manera arraigado en la sociedad, que seguirá siendo un criterio normativo de comportamiento para amplios sectores sociales (Ayrolo, 2007). La secularización no llegó a penetrar con fuerza en la totalidad de la sociedad mediterránea, el proceso fue lento y sus ritmos diversos, a nivel regional, no fue igual la secularización de las nuevas sociedades del sudeste que la de las antiguas sociedades del noroeste, o de la ciudad capital. Parafraseando la hipótesis de Demélas y Saint-Geours (1988), podríamos sostener que las élites cordobesas, al intentar transformar la sociedad, rechazaron aspectos de modernidad que fueron reemplazados por elementos de corte tradicional, como la religiosidad, sin la cual no habría sido posible ningún cambio. Por último, advierte Cárdenas Ayala (2008: 99), “en tanto no cobre auge el anticlericalismo, el carácter nacional y público de la religión católica no se discute: lo que se discute y se negocia, en cada caso es la amplitud de las facultades del estado en materia religiosa". 


\subsection{El fenómeno de la secularización: una posible periodización}

Las referencias teóricas presentadas en el Capítulo 2, son el marco de referencia de la periodización propuesta por Di Stefano para identificar los umbrales de la secularización en la diócesis de Buenos Aires, que nos servirán de referencia y comparación para la realidad cordobesa. El autor señala que el primer umbral se ubicaría en la primera mitad del siglo XIX, con dos etapas bien diferenciadas, la primera, de 1820 a 1830, y la segunda, de 1840 a 1850. En la primera, prevalecieron las críticas por los privilegios y autonomías de las órdenes religiosas y un cierto recelo hacia la Santa Sede, que comenzaba a actuar en el continente con sus representantes y delegados (recordemos que Mussi no pudo entrar en Buenos Aires), y la existencia de discursos sobre el pasado colonial que pintaban la conquista de América con tonalidades sombrías, tildando las acciones de la Iglesia de despotismo eclesiástico. En todos estos registros se reclama, velada o explícitamente, la preeminencia de las autoridades religiosas locales, del clero ilustrado y de las autoridades civiles -sobre la base del Patronato-, por sobre las prerrogativas de los regulares y de Roma. En la segunda etapa de este primer umbral de secularización, irrumpe el antijesuitismo militante, que se alimenta de la batalla del jesuitismo, protagonizado en Francia en 1843. Observa que si bien estos registros muestran un espacio de disidencia, no se cuestiona a la religión o a la Iglesia en sí. "El blanco son las eclesiásticos fanáticos acusados de difundir la monarquía contra la república; el conservadurismo contra el liberalismo, el oscurantismo contra la ciencia, la tradición hispana contra el progreso al que están destinadas las antiguas colonias americanas, el despotismo romano contra la libertad de la iglesia". Siguiendo con la argumentación del autor, tres serían los modelos de secularización posible en este primer umbral, los cuales estarían relacionados con algún tipo de disidencia religiosa. El primero estaría dado por la intransigencia Romana que niega que el patronato que reclaman los gobiernos patrios sea inherente a la soberanía, concibiéndolo, en cambio, como una mera concesión pontificia. El segundo estaría directamente relacionado con las tendencias galicanas en clave republicana, en el cual, el catolicismo es reconocido como religión oficial y la iglesia se reorganiza como un segmento religioso del estado en construcción. Este modelo se orienta a moldear la sociedad política, que acompaña y apuntala la formación del Estado. El tercer modelo es el de la libertad religiosa, que postula una ruptura más radical entre la figura del ciudadano y 
la del fiel creyente. La iglesia y el Estado son entidades que no sólo deben diferenciarse, sino que deben ser, además, absolutamente independientes entre sí. La libertad de conciencia se conjuga con la paridad de oportunidades para todos los grupos, con exclusión de aquellos que puedan socavar la moral y las costumbres o debilitar la fidelidad política debida al Estado (Di Stefano, 2008: 169). El autor señala que ninguna de estas matrices de pensamiento pone en duda la importancia radical de la religión en la preservación del orden social y a la iglesia como agente civilizador. En tanto, en el plano institucional, se verifica un proceso de construcción de la Iglesia por parte del Estado y de la Santa Sede, a veces en consenso, otras en abierta discordia, pero con un objetivo similar, la institucionalización y la centralización.

El segundo umbral de secularización comenzaría a partir de los procesos de laicización a que dio lugar la construcción de los Estados nacionales a partir de la década de 1870 y, principalmente, la de 1880. Ahora se pone el acento en otro aspecto de la secularización, la laicización, entendida como emancipación de las instituciones políticas y civiles respecto de la institución religiosa. La construcción de un orden laico implica la formulación de valores, convicciones y utopías de carácter secular, capaces de proporcionarle una legitimidad propia, sobre la base de ideas de trascendencia, desprovistas de carácter confesional. El nuevo modelo combina a veces, de manera inestable y oscilante, un registro laicista centrado en una fidelidad al estado nacional, que adquiere connotaciones trascendentes, con la defensa a ultranza de la libertad religiosa en sentido cosmopolita. La pluralización del campo religioso se concibe como una necesidad tan perentoria como la construcción de un Estado laico, que ha de ser neutro, pero, a la vez, eficaz en la tarea de proyectar la nacionalidad hacia un nuevo horizonte de trascendencia, el del progreso científico (Di Stefano, 2008: 172).

En este segundo umbral de secularización, la tradición regalista, defensora del patronato, tiende a veces a opacarse y, tal vez, a sacrificarse en aras de un estado relativamente neutro, mientras el discurso plenamente liberal de la libertad religiosa como derecho individual y la pertenencia a las iglesias como elección voluntaria, cobraban cada vez mayor peso. La religión se reorganiza, se transfiere a la lealtad patriótica, al culto laico de la ciencia, a la defensa de la autonomía individual, a la identidad de clase. En defensa de esta autonomía se despliegan los más encendidos ataques contra las "injerencias" del clero en la vida 
personal y familiar. De allí que sea inevitable el choque con un catolicismo que, en su formulación tridentina, ha reafirmado la idea de que la salvación humana requiere no sólo la fe, sino también las obras y, que, por ende, se ha propuesto a sí mismo como espíritu tutelar de la moralidad personal y colectiva (Di Stefano, 2008: 173).

En el caso cordobés, para Valentina Ayrolo, la Iglesia, en la primera mitad del siglo XIX, había sido el pilar y el sostén que daba coherencia al orden social, siendo la religión la matriz que unificaba el creer, el poder y la autoridad. La autora demuestra la indisoluble unidad entre elite gobernante y clero católico. "La fuerte cohesión interna y su pertenencia indiscutida a la elite gubernamental unificó sus intereses. En esta empresa común de mantener un orden terrenal a la imagen celeste, lo que implicaba nociones absolutistas del poder político, cada uno tenía asignada su tarea. Al clero le correspondía guiar a los hombres en el camino del logro de la vida eterna. Al Estado, encarnado en los hombres políticos de la elite, le correspondía velar porque ese camino fuese seguro y efectivo. Ambos constituían las partes de un proceso único en el que convergían la religión y la patria: cuerpo y alma, una unidad" (Ayrolo, 2007: 234). Esta definición, y su explicación de la realidad cordobesa nos lleva a pensar que el proceso secularizador no habría tenido demasiada incidencia a lo largo de la primera mitad del siglo XIX.

En Córdoba, ciudadano y fiel creyente continúan siendo sinónimos. Sin embargo, si se toma la periodización propuesta por Di Stefano, y se analizan los modelos de secularización posible, podríamos señalar que el primer y segundo modelos, por él presentados, fueron, sin duda, comunes a ambos espacios. El primero, aquel que estaría dado por la intransigencia Romana, negando que el patronato, reclamado por los gobiernos patrios, fuera inherente a la soberanía y concibiéndolo, en cambio, como una mera concesión pontificia. En el segundo -relacionado con las tendencias galicanas en calve republicana-, el catolicismo es reconocido como religión oficial, la iglesia se reorganiza como un segmento religioso del Estado en construcción y el patronato es concebido como inherente a la soberanía del pueblo y no como una concesión pontificia. Pensamos que este modelo, en la provincia mediterránea, tuvo sus propia peculiaridades, pues el estado provincial no implementó la reforma rivadaviana.

Sin embargo, los gobiernos provinciales consideraban a la Iglesia como parte del estado y a los clérigos como funcionarios de éste, desde una perspectiva política, el patronato fue 
una prerrogativa defendida y considerada inherente a la soberanía desde el inicio del proceso revolucionario. De todos modos, esto no implicó en Córdoba un umbral de secularización, pues, como señala Martínez Paz en La Formación Histórica de Córdoba (1983: 19), al reconstruir la serie de sucesos que crearon a Córdoba como entidad provincial y explicar la parte que le correspondió como protagonista en el proceso de organización nacional, en un intento de interpretación nacional dese el interior del país, advierte una sociedad interconectada, con una estrecha e imbricada relación entre iglesia, sociedad y poder político, que llevó a marcar una cabal diferencia entre la ciudad puerto y la ciudad mediterránea. Sin embargo, en la etapa vinculada al primer umbral, no se percibe, en Córdoba, síntomas de hostilidad o distanciamientos con Roma, es más, las autoridades eclesiásticas, tempranamente establecen relaciones con Roma (Ayrolo, 1996) y, en cuanto a las prerrogativas de los regulares, no sólo permanecen intactas, sino que son parte importante de la construcción de las autonomías provinciales. Martínez Paz, en su Historia de Córdoba, advierte, justamente, la religiosidad del Reglamento provisorio de 1821 de Baigorri. El gobernador Bustos, en 1822, a raíz de una insubordinación de los regulares franciscanos contra el Provincial, ordenó el sometimiento de los frailes y, en caso de que salieran del territorio de Córdoba, al lugar que les señalase el Provincial (Martínez Paz, 1983: 85). Por último, la elite cordobesa siempre se jactó de pertenecer a la ciudad doctoral con características propias, una sociedad que estimaba los valores religiosos y morales sobre todos los demás.

El tercer modelo, vinculado a la libertad religiosa, postula una ruptura más radical entre la figura del ciudadano y la del fiel creyente. La iglesia y el Estado son entidades que no sólo deben diferenciarse, sino que, además, deben absolutamente independientes entre sí. Este modelo, en Córdoba, no lo vemos cristalizar hasta la segunda mitad del siglo XIX, aunque, cabe señalar que estas cuestiones aún no han sido estudiadas por la historiografía de la primera mitad del siglo XIX cordobés. Lo que sí podemos afirmar es que este modelo comienza a ser visible a partir de la segunda mitad del siglo XIX, cuando las elites liberales de corte laicista y positivista asumen la conducción política de la provincia. Este umbral de secularización se vincula directamente con el concepto de laicización. Siguiendo la caracterización de Jean Bauberot, nosotros encuadramos, en estos años, la preocupación del Estado por garantizar los derechos de sus ciudadanos. Nacimientos, matrimonios, 
defunciones y, en menor medida, la educación, pasarán a ser controlados por él. Si bien la fragmentación institucional es una realidad cada vez más evidente, dado que el proyecto liberal impactó con fuerza en las relaciones entre Iglesia y Estado -entre autoridades civiles y autoridades eclesiásticas-, lo cierto es que lo religioso estaba de tal manera arraigado en la sociedad, que seguirá siendo un criterio normativo de comportamiento para amplios sectores sociales. Incluso, la elite política liberal nunca llegó a romper los lazos que la unían con la Iglesia, ni siquiera en los tumultuosos años 80 y 84, cuando se debatían estas leyes denominadas "laicas”. Hasta el sector más liberal, el núcleo juarista, reconocía la utilidad social de la religión y la función social del clero. Esto puede observarse, por ejemplo, en el apoyo brindado a la actividad del cura Brochero. ${ }^{15}$ En este umbral de secularización, la legitimidad social está dada por la moral religiosa, es por ello que los fundamentos de la colaboración entre Iglesia y Estado radicaron en la necesidad que tenía el Estado de llegar con su autoridad a las regiones rurales y a los sectores más desamparados, siendo la Iglesia la única institución que poseía una estructura y un poder de penetración social que superaba, incluso, los del propio Estado.

El estado requirió esta colaboración de la iglesia para aquellas tareas que implicaban la concientización de la población, el control de la vagancia, del vicio del juego o del consumo de alcohol, además del envío de los niños a la escuela, la realización de censos, la aplicación de algunas leyes como la ley de ahorro. En 1868, el Gobernador Félix de la Peña envió una nota al Obispo Álvarez en la que le solicita su colaboración “dirigiendo una pastoral exhortatoria a los párrocos y curas vicarios de la campaña encargándoles hagan valer la influencia que les da su sagrado ministerio para infundir en los padres de familia y vecinos pudientes de su feligresía el más vivo interés por fomentar y proteger la educación en la campaña". ${ }^{16}$ En 1877, el Inspector General de Escuelas envió una circular a los curas de campaña pidiendo que predicaran los domingos para que los padres enviaran a sus hijos

\footnotetext{
15 Fue el párroco de San Alberto (1869-1907), curato que abarca una gran extensión del oeste serrano cordobés, $3.327 \mathrm{kms}^{2}$, la mayoría de sus 10.118 habitantes está signado por la pobreza. Desarrolló allí una obra de colosal envergadura, impulsó y gestionó obras de infraestructura, vías férreas, construyó acequias para el riego, delineó sesenta y seis caminos vecinales, proveyó a la población de molino, creó un colegio de niñas, una casa de ejercicio espirituales y evangelizó a la población. Brochero encontró en la elite liberal juarista el apoyo económico para el sostenimiento de sus obras pastorales. Sobre el tema, puede consultarse AYROLO y FERRARI (2005).

${ }^{16}$ AAC. Leg. 38, TI. Comunicaciones con el Gobierno Provincial, 1860-1875.
} 
a la escuela. ${ }^{17}$ En 1876, el gobernador pidió al obispo la realización de misiones para disminuir la criminalidad en la campaña, debían realizarse en toda la provincia: "que no quede una sola pedanía donde no se hiciese oír la predicación evangélica”, ya que el gobierno "no puede atribuir tantos crímenes sino a la falta completa de moralidad y a la ignorancia o completo olvido de los deberes religiosos. ${ }^{18}$ En 1890 , el gobierno solicitó la colaboración de los curas para infundir confianza en los feligreses respecto de los agentes destinados a realizar el censo general provincial de edificación, comercio, industrias, agricultura, ganadería y población. ${ }^{19}$

En el momento más álgido del conflicto relativo a las leyes laicas, el gobernador envió una nota al Obispo Tissera respecto de la conducta del cura de Pocho, quien se oponía a la enseñanza impartida en la escuela fiscal solicitando su remoción. El inspector general de Escuelas señaló que no había de "permitir que los curas de campaña obstaculicen en manera alguna el fiel cumplimiento de las leyes especialmente las que se refieren a la educación común. Todo esto sin prejuicio de la disposición en que ha estado y está el gobierno de llevar el más perfecto acuerdo con la autoridad eclesiástica y de coadyuvar en la esfera de su acción al funcionamiento regular de la misma”. ${ }^{20}$ Lo más interesante de esta nota es justamente la aclaración del funcionario respecto de la "esfera de acción" que le corresponde a la Iglesia. El rol de la Iglesia se plantea a partir de la necesidad de fortificar el Estado. Por lo tanto, el gobierno diseñó una política tendiente a transferir gradualmente ciertas funciones desempeñadas por la Iglesia a distintas ramas del aparato estatal en formación. En los años 80, se puso sobre el tapete la necesidad de avanzar hacia una reformulación más profunda del rol del aparato eclesiástico. Los cambios en la estructura del Estado pondrían en primer lugar la necesidad de concretar reformas hasta ese momento postergadas. El gobierno provincial, identificado con el ideario liberal, reivindicaba para sí los espacios ocupados hasta entonces por la Iglesia, en particular aquellos que afectaban directamente la constitución de los individuos en tanto ciudadanos. Espacios que signaban los hitos más importantes de la vida de una persona, el nacimiento, la educación, el matrimonio y la muerte. La controversia se dirimía en el interés de la Iglesia por conservar

\footnotetext{
17 AAC. Leg. 39, TIV. Comunicaciones con el Gobierno y las Autoridades Provinciales, s/f. Circular del 08/07/1877.

${ }^{18}$ AAC. Leg. 39, TIV. Comunicaciones con el Gobierno y las Autoridades Provinciales. Nota del 17/04/1876.

${ }^{19}$ AAC. Leg. 39. Comunicaciones con el Gobierno Provincial, s/f. Nota del 19/03/1890.

${ }^{20}$ AAC. Leg. 39. Comunicaciones con el Gobierno Provincial, s/f. Nota del 26/01/1885.
} 
el carácter religioso del espacio social y la decisión del estado de laicizarlo. El punto de fricción radicaba en las atribuciones de cada poder. Lo que no estaba en cuestión, lo no se ponía en duda era la centralidad de la religión en la regulación de los comportamientos sociales.

Una peculiaridad de la laicidad del estado cordobés es que no incluía ni la neutralidad respecto de la religión católica, ni la supresión de la enseñanza religiosa en las escuelas. Respecto del primer punto, el artículo $2^{\circ}$ de la Constitución Nacional de 1853 prescribe "que el gobierno federal sostiene el culto católico apostólico romano", tal expresión sustituyó las disposiciones de los ensayos constitucionales anteriores que consagraban a la religión católica como religión del estado. Sin embargo, Córdoba al dictar la Constitución Provincial de 1855, reformada luego en 1870, mantuvo el principio de religión del Estado, consagra la religión católica como religión de la provincia, establece el deber del gobierno de protegerla y el de todos los habitantes de respetarla. Esta concepción traerá también sus dificultades en las relaciones entre autoridades civiles y eclesiásticas, pues el gobernador, haciendo uso de las atribuciones otorgadas por el derecho de patronato, incursionará en asuntos internos de la Iglesia, tales como el nombramientos de eclesiásticos para cargos capitulares, el nombramiento o la remoción de curas párrocos, etc.

Otra cuestión interesante relativa a la laicidad del estado provincial y sus relaciones con las autoridades eclesiásticas es, sin duda, la aplicación del decreto nacional de 1881 , relativo a la provisión de curatos, a través del cual, el Presidente de la República, Julio A. Roca, disponía que era "atribución del patronato intervenir en la concesión de curatos a perpetuidad" y que "los gobernadores como Vice-Patronos por delegación y como Agentes del Poder Central" debían contribuir a que se practicara en el territorio de sus respectivas jurisdicciones las resoluciones que, como Patrono, dictara el Gobierno. Los dos primeros artículos del referido decreto establecían que: $1^{\circ}$ Los curas párrocos que sirven en la capital, cuyos nombramientos datan de más de cuatro meses, continuarán al frente de sus parroquias en la calidad de propietarios, y no podrán, por lo tanto, ser removidos salvo en caso de sobrevenir causa legales que exijan su remoción; $2^{\circ}$ El señor arzobispo de Buenos Aires dará cuenta al P.E. nacional de las vacantes que ocurriesen en el término de cuarenta días y llamará a concurso para proveerlas [...] Es interesante ver que el gobierno de la provincia de Córdoba mediante el decreto del 01/08/1886, firmado por el Gobernador 
Olmos y Ramón Cárcano decreta que $1^{\circ}$ “el señor arzobispo de Córdoba hará la provisión de los curatos de las ciudades y departamentos de esta Provincia”; $2^{\circ}$ Que los curatos servidos por curas cuyo interinato no exceda los cuatro meses serán sacados a concurso; $3^{\circ}$ Los curatos a cuyo concurso no se presente ningún candidato serán provistos por el obispo, de la misma forma que indica la ley de la Recopilación de Indias. En Córdoba se continúa con la práctica habitual para la provisión de curatos. El obispo continuará siendo quien los provea.

Respecto del segundo punto, la supresión de la enseñanza religiosa en las escuelas, el gobierno de la provincia no secundó la implementación de la ley 1420 que propiciaba el carácter laico de la enseñanza. La ley provincial de educación común de 1884, sólo reconoció la gratuidad y obligatoriedad escolar, pero no reglamentó la laicidad de la educación pública, ésta se mantuvo en manos de la Iglesia, quien nombraba a los profesores de religión en las escuelas públicas hasta avanzadas las primeras décadas del siglo XX. La práctica habitual consistía en que desde el gobierno se pidiera al obispo diocesano la nómina de profesores de religión destinados a ocupar el cargo en las escuelas públicas. Por otro lado, la secularización llegó a la enseñanza superior. Es interesante recordar aquí que la Universidad, institución de origen eclesiástico, pasará, en este período, a ser gestionada por el Estado. La Facultad de Teología y Cánones dejó de funcionar en ese claustro y se trasladó al seminario conciliar, donde se comenzaron a dictar las clases de Derecho Canónico y Teología. Esto no significaba que el clero no hubiera opuesto resistencia a las leyes laicas, como veremos en la quinta parte de esta tesis, y las dificultades que tuvo que sortear el gobierno provincial para implementarlas en los curatos de campaña.

Este umbral de secularización, según Bauberot, preveía que la actividad del clero se redujera a las cuestiones religiosas y a la administración de los sacramentos. Vale decir, el clero dejaría otras actividades consideradas "más mundanas o seculares", como la activa participación en política partidaria. Pero como Córdoba era una provincia fuertemente clericalizada, el clero seguiría siendo un sector influyente en la sociedad. No sólo desarrolló funciones espirituales, sociales y culturales, sino también algunos de sus miembros participaron activamente en la vida política provincial. Muchos aspiraban a la conformación de un partido católico, al estilo belga o alemán, el cual podría llevar en sus listas candidatos clérigos. En tanto esto no se concretara, participaban activamente en los 
diversos partidos conservadores y en las filas del partido radical. Rosendo Liendo, cura de Arroyito, ganó, en 1912, una banca parlamentaria para los conservadores, sus opositores se quejaron en la columna del diario "La Voz del Interior" -fechada días antes de las elecciones de 1915-, por las actividades políticas del sacerdote. En sorna advertían que "el señor cura no consiguió más que el juzgado de paz de esta localidad (el cual lo desempeña hoy en su segundo período) para su hermano". ${ }^{21}$ En 1915, Pastor Isla, cura y vicario de San Carlos Minas, alternaba su ministerio con el cargo de senador provincial por el partido demócrata. El cura Luis Leal, senador por el mismo partido, era, según "La Voz del Interior" "más hábil, más ducho en ganar elecciones, que para ganar almas... manda en Minas como un señor feudal en su castillo o un cacique sobre su tribu, aquél es el dominio de su soberana voluntad. Jefe político, jueces de Paz, comisarios, son sus siervos... no admite en su imperio de Minas más candidaturas legislativas que la suya, cuando se cansa de ser diputado, se entretiene en ser senador...". 22 En 1917, tres clérigos ocupaban bancas parlamentarias, pese a las reticencias del obispo. Un político conservador y ex gobernador provincial, Ramón Cárcano, pedía al prelado diocesano la autorización para que el cura de Calamuchita, Saravia Caminos, fuera como candidato en su lista. Las argumentaciones del caudillo no lograron obtener el permiso del prelado, que, en 1915, había publicado un auto que prohibía la participación política del clero diocesano. En las elecciones de ese mismo año, varios curas fueron como candidatos de ambos partidos, Ardiles y Amuchástegui, por el radicalismo, Varas, Isla y Liendo, por el partido demócrata. Volveremos sobre el clero y la cuestión política en la última parte de este trabajo, aquí sólo nos interesa mostrar que el umbral de laicización, en el cual el clero se ocuparía sólo de las actividades propias de su ministerio, no llegó a materializarse en Córdoba hasta, al menos, la segunda década del siglo $\mathrm{XX}$, que es hasta donde llega nuestra investigación.

Otra característica de este umbral es, para Bauberot, el pluralismo religioso, que, en el caso de Córdoba, tampoco llegó a consolidarse. Como señalamos ut supra, la Constitución provincial, reformada en 1870, mantuvo la religión católica como religión de la provincia, es decir religión de estado. Esta disposición coexistía con la libertad de cultos, que permitió el establecimiento de comunidades religiosas no católicas, particularmente protestantes,

\footnotetext{
${ }^{21}$ La Voz del Interior, 06/01/1915.
}

${ }^{22}$ Ibid., 21/11/1915. 
aunque la Iglesia y la religión católica siguieron ocupando un espacio privilegiado en el escenario político y social provincial. De hecho, los informes eclesiásticos y los censos de población muestran que la población no católica era relativamente escasa. ${ }^{23}$ Manuel Río y Luis Achával (1904: 415) sostienen que en 1895 los habitantes de la provincia eran: un $99,8 \%$ católicos y un $0,2 \%$ de otras religiones, en números absolutos se traducía en 350.499 católicos y 734 no católicos, de estos últimos, 677 correspondían a las diferentes comuniones protestantes, 47 a israelitas y 10 a otras religiones. Por lo tanto, la gran mayoría de los inmigrantes que se instaló en la provincia era de religión católica. Lo llamativo era que pese a las reiteradas quejas de la jerarquía respecto a la indiferencia religiosa de la sociedad, gran parte de la población se preocupaba por cumplir con la Iglesia. A lo largo del trabajo, veremos el alto porcentaje de ciudadanos que accedió a los sacramentos. Volviendo a la caracterización planteada por Bouberot, podemos afirmar que, en Córdoba, la laicización fue un proyecto inconcluso. El estado cordobés mantuvo la confesionalidad en la Constitución, en las escuelas estatales se mantuvo la enseñanza religiosa y el clero siguió participando en la actividad política. Esto no significa que la secularización no avanzara a ritmos más acelerados en otros campos, como la economía, la ciencia, la enseñanza universitaria, la prensa, los espacios de sociabilidad, etc.

En cuanto a la privatización de lo religioso, propio del segundo umbral de laicización propuesto por Bauberot, o la secularización funcional según Dobbelaere, fue lenta y el proceso muy complejo. La acción de la Iglesia implicaba una ética, un sistema de valores que suponía el respeto a las leyes y al orden social. En este sentido, Beatriz Moreyra (1998: 19) analiza el rol del estado y de las instituciones de la sociedad civil frente al crecimiento, las crisis y desajustes sociales provocados por el proceso de modernización. En este marco, estudia cómo las elites dirigentes implementaron estrategias sociales a través de mensajes y discursos con un alto contenido moral y religioso, llevando a cabo políticas destinadas a la internalización de esos valores en vastos sectores de la población. En un contexto de conflictos sociales, la iglesia se convirtió en una institución útil y eficaz para mantener la paz y evitar la confrontación entre las clases sociales.

\footnotetext{
${ }^{23}$ La visita canónica realizada por Zenón Bustos entre los años 1906-1913, da cuenta de unos 1.200 protestantes en la ciudad, ninguno en los curatos del norte y del oeste y cerca de 1.000 distribuidos en los curatos del este y sur, principalmente en Cruz Alta, San Francisco, Río Cuarto y Leones.
} 
Las conclusiones de sus trabajos llevan a afirmar que en las primeras décadas del siglo XX primó hegemónicamente un modelo mixto de protección social, unido a una concepción residual del estado. El modelo de asistencia social predominante en la sociedad cordobesa en el período de modernización estuvo caracterizado, dice la autora, "por una relación de interdependencia entre las caridades de estructura esencialmente celular y fuerte impronta religiosa y el Estado, relación que implicaba que los funcionarios públicos confiaban en una pléyade de instituciones caritativas para servicios sociales sin un esquema planificador, y las caridades dependían del Estado para su funcionamiento legal y económico" (Moreyra, 2009: 156). Esa tupida y dispersa red asistencial comprendía un buen número de congregaciones religiosas, sobre todo -aunque no únicamente- femeninas, y asociaciones seglares mayoritariamente católicas -Conferencias Vicentinas, Damas de la Providencia, Asociación de la Inmaculada Concepción, Damas de la Misericordia, Liga de Damas Católicas y un largo etc. Si, como advierte Moreyra, los resultados institucionales en materia de asistencia social no respondían únicamente a posturas ideológicas, sino también a las tradiciones culturales y a los modos de vida predominantes, "este modelo de política social exterioriza una visión de la elite del campo social como la expresión de una modernidad particularista que se caracterizó por una visión del mundo favorable a la presencia de las estructuras y los contenidos de lo religioso en la cultura, mientras que la economía avanzó con mayor firmeza hacia una apertura cosmopolita (Moreyra, 2009: 280).

Este breve panorama nos permite sostener que en Córdoba la modernidad no estuvo íntimamente ligada a la secularización, que sin duda existió, pero que no fue ni total, ni muy intensa. La modernidad llegó con el progreso económico, el desarrollo científico, aunque sin modificar sustancialmente la base católica de la sociedad. La modernidad otorgó a la Iglesia una herramienta fundamental para llevar a cabo su tarea en la sociedad, los derechos del individuo, amparados en ellos los católicos se organizaron y conformaron diversas asociaciones y siguieron incluyendo en el marco de sociedades donde el pluralismo religioso comenzaba a ser una realidad. La Iglesia ya no era un todo social, comenzaba a ser una parte, pero, sin duda, una parte muy importante. Existieron algunos sectores relacionados con el socialismo que entendían la secularización como un elemento constitutivo de la modernidad, aunque no lograron imponer su mentalidad al conjunto de la sociedad. Por lo tanto, en términos generales, Estado e Iglesia se complementaron y 
colaboraron en la búsqueda de soluciones a los problemas sociales que generaba el proyecto de modernización. Como diría Sol Serrano (2008), la Iglesia perdió la batalla por mantenerse como religión del Estado, pero cimentó una nueva inserción en la sociedad permeada por la diversidad cultural y religiosa. No cabe duda de que es un período en el que el estado se seculariza, la sociedad se hace más plural y la cristianización se expande.

Córdoba experimentó una "modernidad conservadora" que mantuvo la religión como un elemento constitutivo del orden social, por ende, podría hablarse de una modernidad católica, donde, como sostiene Michel Lagrée para Bretaña, la iglesia y la religión tuvieron un rol activo en el proceso de trasformación social. El proyecto de transformación institucional de la Iglesia confraternizó con el proyecto de construcción del Estado, que buscó articular religión y modernidad. Como veremos más adelante, uno de los ejes sobre el cual se construyó el accionar de la Iglesia para llegar a la sociedad fue la expansión y profundización de la vida parroquial; cada parroquia se convertiría en un espacio de socialización católica, garantizando la presencia institucional y disciplinada de la Iglesia en el terreno social y político, medio eficaz para reconstruir la sociedad según los principios y la praxis católicos (Romero, 1997: 4).

En este sentido, coincidimos -aunque con algunos matices- con la hipótesis que plantea Miranda Lida cuando afirma que "a pesar del impulso secularizador que se desarrolló a lo largo del siglo XIX y que encontrará su principal exponente en las leyes laicas dictadas en la Argentina en la década de 1880, el liberalismo no desembocó nunca en un anticlericalismo militante ni agresivo. Aún en los momentos de mayor auge del liberalismo, el Estado participó del proceso de conformación y consolidación de la Iglesia nacional; no fue en absoluto su enemigo. El debate entre católicos y liberales en ocasión de las leyes laicas de enseñanza y de matrimonio civil, dictadas en la década de 1880, no dividió las aguas en la sociedad argentina. El saldo de estos debates no fue una Iglesia perseguida y vilipendiada, sino más bien el inicio de un proceso de consolidación del catolicismo argentino" (Lida, 2007: 53).

Para nosotros es necesario plantear un matiz, pensamos que, efectivamente, el estado liberal no desembocó en un anticlericalismo militante y agresivo, aunque en la sociedad civil aparecieron grupos minoritarios (masones, socialistas y anarquistas), que llevaron adelante prácticas anticlericales con un alto grado de agresividad. En Córdoba capital, los 
acontecimientos producidos con motivo de la Reforma Universitaria de 1918 se convirtieron en puntos de inflexión y de alerta. En esta instancia, es cuando Estado e Iglesia aúnan esfuerzos por neutralizar los desórdenes sociales. Por otra parte, en el caso cordobés, la sanción de las leyes laicas -momento más álgido del liberalismo estatal-, no fue, a nuestro entender, el inicio del proceso de consolidación de la Iglesia como señala Lida, dado que, como demostraremos a lo largo de la tesis, el inicio de este proceso se retrotrae a veinticinco años atrás, cuando finalizan las sede vacancias y comienza el proceso de institucionalización eclesiástica. Las leyes laicas constituyeron, sin duda, uno de los jalones, pero, sin duda, no es el inicio de dicho proceso. 


\section{CAPITULO 5 \\ LA PROVINCIA DE CÓRDOBA}

La provincia de Córdoba es una provincia mediterránea, comprendida dentro de una zona templada, que limita al norte y al noroeste con la provincia de Santiago del Estero y Catamarca y al sur con la Gobernación Nacional de la Pampa, hoy provincia. Al este limita con las provincias de Santa Fe y Buenos Aires y al oeste con La Rioja y San Luis. Esto límites se definieron a lo largo de las dos últimas décadas del siglo XIX. ${ }^{1}$

A mediados del siglo XIX, la provincia abarcaba un territorio considerablemente menor al actual y sólo una parte del mismo se hallaba efectivamente ocupado. Silvia Romano (1993) señala que en 1850 la superficie de la provincia se estimaba en 8.000 leguas $^{2}$, limitando al noroeste con las provincias de La Rioja y Catamarca, donde se extendía el vasto y despoblado desierto de las Salinas, con una extensión de $20.000 \mathrm{kms}^{2}$. En 1867, la provincia comprendía 5.000 leguas $^{2}$ con una población aproximada de 60.000 habitantes. Hasta 1879, la población se concentró en el centro y oeste provincial, convirtiéndose en las zonas más ricas de la provincia. La fortuna de las grandes familias provenía principalmente del comercio de mulas (Converso, 1993).

El territorio es una extensa llanura que se eleva de este a oeste hasta formar un macizo montañoso que atraviesa la provincia de norte a sur, denominado Sierras de Córdoba y San Luis. De la región comprendida al oeste del macizo montañoso, aproximadamente 20.000 $\mathrm{kms}^{2}$ pertenecen a la provincia y corresponden, desde el punto de vista geográfico, a los llanos de La Rioja. Al noroeste y nordeste, posee una extensa depresión, donde se encuentran las Salinas Grandes y la laguna de Mar Chiquita, al norte de Mar Chiquita existen otros depósitos salados, como la laguna de los Porongos, la del Toro, etc. Los ríos que se desprenden de la zona montañosa forman el sistema hidrográfico de la provincia y sirvieron para realizar la demarcación política de la provincia.

La llanura que comienza al pie de la falda montañosa se extiende hacia el litoral, mucho más allá de los límites de las provincias de Santa fe, Buenos Aires y La Pampa, y

\footnotetext{
${ }^{1}$ Los límites de la provincia de Córdoba con los de las provincias de Santa Fe y Buenos se definieron por fallo de la Suprema Corte de Justicia del 18/03/1882. Los límites con San Luis se definen el 26/11/1883, por el árbitro de la cuestión, el Presidente de la República Julio A. Roca. En cuanto al límite con La Rioja fue acordado por convenio del 12/11/1894.
} 
comprende lo que habitualmente se denomina la región pampeana. Cinco ríos principales atraviesan esta llanura de oeste a este (Río y Achával, 1904).

H. C. Ross Johnson, un viajero inglés que transitó la región en 1867, dice que "Córdoba constituye un excelente territorio para el cultivo de cereales y la cría de ganado. Los mejores bueyes de carga se han desarrollado en esta provincia. Hacia el norte y oeste se halla magníficamente cubierta de bosques y las sierras vecinas contienen minas de plata, estaño y cobre, algunas de las cuales se explotan, pero en escala sumamente reducida y de acuerdo a procedimientos rudimentarios. La oveja no se desarrolla en Córdoba, pero algunos pocos pobladores ociosos que la generalidad, poseen grandes rebaños de cabras, las que por su extraordinaria producción anual rinde excelentes resultados por su sebo y cuero, a pesar de que este mercado es sumamente insignificante" (Johnson, 1867: 72).

Hasta bien entrada la década de 1870, una amplia zona del este y sur sufría las invasiones y malones indígenas. Si bien la necesidad de avanzar y fortalecer la línea de frontera fue una preocupación permanente del gobierno provincial, este anhelo no llegó a concretarse pese a los variados esfuerzos y diversas iniciativas. ${ }^{2}$ En 1858, un gran malón paralizó el comercio con el litoral, desbastó a la población del Tío y asoló las estancias de la zona. Por el sur, el fortín de Fraile Muerto era una de las últimas poblaciones blancas. A decir verdad, la línea de frontera se mantenía prácticamente inalterable desde el siglo XVIII. Según Silvia Romano (2002: 41), la política de frontera se limitó a repeler las invasiones indígenas, o bien a conservar cierto statu quo mediante relaciones amistosas entre parcialidades y mantener despejadas las rutas comerciales que atravesaban la región.

$\mathrm{Al}$ este y sur de la provincia las fronteras aún no estaban delimitadas. Johnson al llegar a Fraile Muerto advierte que todos los hombres que viajaban por esos lugares iban fuertemente armados, "dado que en estos parajes estamos a cuatro o cinco leguas de lo que podríamos llamar la frontera sur de los indios, los que últimamente han estado causando muchas tribulaciones por los continuos raid efectuados dentro del territorio, asesinando

\footnotetext{
${ }^{2}$ En 1854, el presidente Justo J. de Urquiza envió en comisión al coronel Du Graty con el fin de realizar un relevamiento del estado de la frontera. El informe señalaba que las fronteras norte y este estaban totalmente desprotegidas y prácticamente destinadas a ser defendidas sólo por los vecinos de la zona. El periódico $E l$ Imparcial, durante todo el primer semestre de 1858, repitió un breve comentario, lamentándose del estado de total abandono de la frontera cordobesa. Se contaba con una fuerza de treinta o cuarenta hombres a pie, desnudos y muertos de hambre. Los malones hacían sus entradas con facilidad, se llevaban los animales de los pobladores y, en ocasiones, diezmaban los fortines, pueblos y establecimientos fronterizos (El Imparcial, enero-mayo 1858).
} 


\section{Mapa 1}

\section{Provincia de Córdoba en 1867}

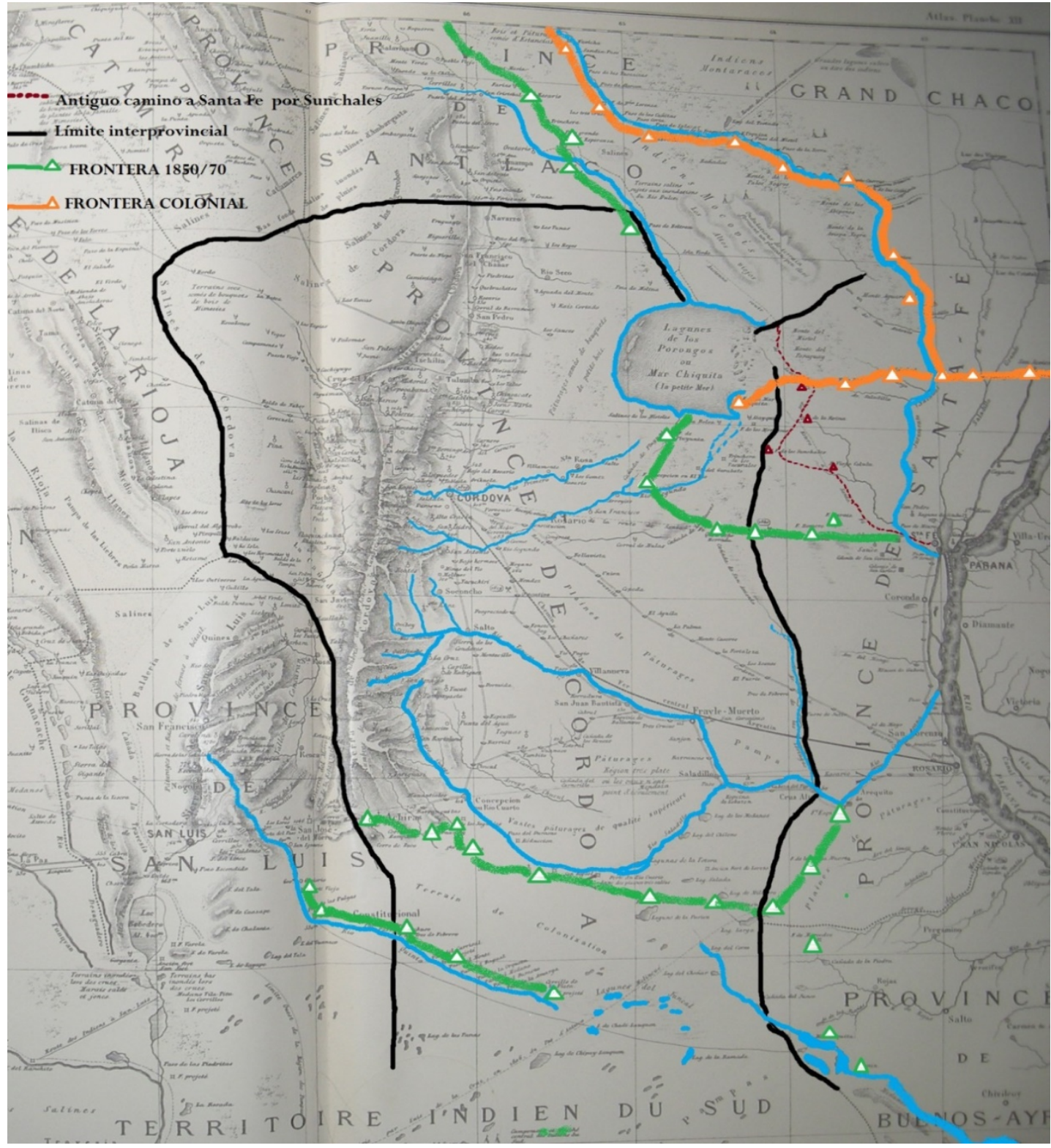

Fuente: Elaboración propia en base al Atlas de Martin De Moussy, Description geographique et statistique de la Confederation Argentine, 1869. Carta de Córdoba y San Luis, Plancha XII.

hombres, robando las mujeres, caballos, ganado y pertenencias de los infortunados estancieros y eso hasta ahora con la mayor impunidad" (Segreti, 1998: 463). 
La frontera quedó definitivamente instaurada cuando Buenos Aires lideró el rumbo político y económico del país. Cuando, en 1879, la frontera sur de Córdoba quedó libre, comenzaron a formarse estancias de grandes dimensiones, estas tierras se adjudicaron a capitalistas extranjeros, compañías de tierras, militares que participaron en la frontera y hombres del poder, tanto cordobeses como y porteños.

\section{Cartografía política y organización territorial}

A partir de 1870, vemos un creciente interés por parte del estado provincial para llevar adelante el proceso de formación y delimitación del territorio. Para ello, era necesario definirlo, cuestión que requería tanto la recopilación de toda la información existente referida a las características físicas y las potencialidades económicas del espacio a controlar, como la búsqueda e identificación de los antecedentes de reconocimientos territoriales efectuados en el período colonial. Para la sistematización de la información obtenida se contrató a dos técnicos cordobeses, Manuel Río y Luis Achával, quienes escribieron tres volúmenes y un atlas titulado Geografía de la Provincia de Córdoba. El texto, encargado por el gobernador José Figueroa Alcorta, tuvo como fin reafirmar la unidad provincial en la diversidad de sus "marcos naturales". Reafirmar la unidad en la diversidad era, sin duda, una de las mayores preocupaciones de los hombres de gobierno, civil y eclesiástico, del tercer cuarto del siglo XIX.

En 1815, durante el gobierno del coronel José Javier Díaz, la provincia se dividió en 12 departamentos que coincidían con los antiguos curatos. ${ }^{3}$ En 1822, los departamentos de Río Seco, Tulumba y Tercero Abajo se dividieron para crear los de Tercero Arriba, Ischilín y San Francisco del Chañar. En 1856, por decreto del gobernador Ferreyra, se dividieron los departamentos de Punilla y Segundo Abajo, del primero se desprende el departamento de Cruz del Eje y del segundo el departamento de Río Segundo, con cabecera en Villa del Rosario. ${ }^{4}$ En 1858, el gobernador Fragueiro, dividió los departamentos de Anejos, Tulumba y Río Seco: ${ }^{5}$ Anejos Norte con cabecera en Jesús María y Anejos Sur con cabecera en Alta

\footnotetext{
${ }^{3}$ La ciudad, Anejos, Calamuchita, Punilla, Río Cuarto, Río Segundo, Río Seco, Santa Rosa, Tercero Abajo, Pocho, Tulumba y San Javier.

${ }^{4}$ AAC. Libro de Notas, 1859-1873, f.15.

${ }^{5}$ AAC. Leg. 2, TII. Cabildo Eclesiástico (1858-1910) s/f. Decreto del Gobernador Fragueiro del 12/10/1858. Auto del Provisor en Sede Vacante Eduardo Ramírez de Arellano del 18/11/1858. Dictamen del Cabildo Eclesiástico del 09/11/1858: "Quedan divididos los tres curatos de Anejos, Tulumba y Río Seco, cada uno en
} 
Gracia. Luego, el departamento de Tulumba se fracciona y se crea el de Totoral y el de Río Seco para fundar el de Sobremonte. A su vez, el departamento de San Javier se divide y da lugar al nuevo departamento de San Alberto. El $1^{\circ}$ de diciembre de 1859 el mismo gobernador divide el departamento de Río Segundo y crea, por decreto, el nuevo de San Justo (en honor a Justo José de Urquiza), con cabecera en Villa Concepción. ${ }^{6}$

En 1860, la villa de Fraile Muerto, luego denominada Bell Ville, pasa a ser cabecera del nuevo departamento de Unión. ${ }^{7}$ En 1862, el gobernador Justiniano Posse divide el departamento de Pocho en dos secciones administrativas y se crea el nuevo departamento de San Carlos Minas. ${ }^{8}$ Un mes después, el poder ejecutivo provincial, a pedido de la autoridad eclesiástica, para salvar la incongruidad en que quedaba el curato de Pocho, modifica las divisiones administrativas a fin de que ambos curatos pudieran tener congrua sustentación para sus párrocos. ${ }^{9}$

En 1870, se dicta la Constitución provincial que contempla la existencia de 22 departamentos, como puede observarse en el Mapa 2 correspondiente al año 1871.

Con la conquista del desierto, se incorporaron nuevos territorios y se definieron los límites interprovinciales. El Mapa 3 muestra la organización administrativa territorial de la provincia hasta la división departamental de 1888.

dos doctrinas o beneficios curados cuya comprensión y denominación será en lo espiritual y eclesiástico la misma que se les determina en las respectivas secciones por los decretos del $\mathrm{G}^{\text {no }}$ del 12 y 16 del $\mathrm{C}^{\mathrm{te} \text { ". }}$

${ }^{6}$ AAC. Leg. 2, TII. Cabildo Eclesiástico (1858-1910) s/f. Decreto del Gobernador Fragueiro del 01/12/1859.

"Art $3^{\circ}$ : No obstante estar colado el actual beneficios del Río $2^{\circ}$, el $\mathrm{Gob}^{\text {ño }}$ de acuerdo con la autoridad diocesana procederá a la división Ecc ${ }^{\mathrm{a}}$ en conformidad a la administrativa, tan luego como pueda verificarse". ${ }^{7}$ AAC. Libro de Notas, 1859-1873, s/f.

${ }^{8}$ AAC. Leg. 2, TII. Cabildo Eclesiástico (1858-1910) s/f. Decreto del Gobernador Justiniano Posse del 23/05/1862.

"Art 1": Queda dividido el departamento de Pocho en dos secciones administrativas separadas por una línea de Este a Oeste, comprendiendo la sección del Sud que continuará conservando el nombre del departamento actual las pedanías de Chancani, Pocho y Salsacate con sus límites reconosidos, y la del Norte que tomará el nombre de Departamento de Minas las pedanías de Palmas, Guasapampa, San Carlos y Siénaga del Coro con sus límites reconosidos".

${ }^{9}$ El 28 de junio de 1862 el Poder Ejecutivo decreta que: "Debiendo establecerse por la autoridad eclesiástica dos beneficios canónicos en los departamentos de 'Pocho' y 'Minas' en reemplazo del actual curato de Pocho y a fin de obviar el inconveniente que pudiera presentar la reducida extensión del $1^{\circ}$ de dichos departamentos por no ofrecer suficiente congrua el beneficio que en él se funda, acuerda y decreta: Art $1^{\circ}$ Queda dividida la Pedanía Las palmas en dos secciones separadas por una línea que tirada de el puesto denominado Agua Blanca se prolongará por la quebrada del mismo nombre hacia el naciente siguiendo la cuchilla de Macho Gayco hasta los serros, y de éstos tomado el camino que va a Salsacate [...] hasta tocar los límites convenidos de la Pedanía de Salsacate. Art. $2^{\circ}$ La sección que queda al Sud de dicha línea queda anexada a la Pedanía de Pocho, del de departamento del mismo nombre y la sección del norte que continuará perteneciendo al departamento de Minas. Art. $3^{\circ}$ Comuníquese, publíquese y dese al libro de Acuerdos". 


\section{Mapa 2}

Departamentos de la provincia de Córdoba en 1877

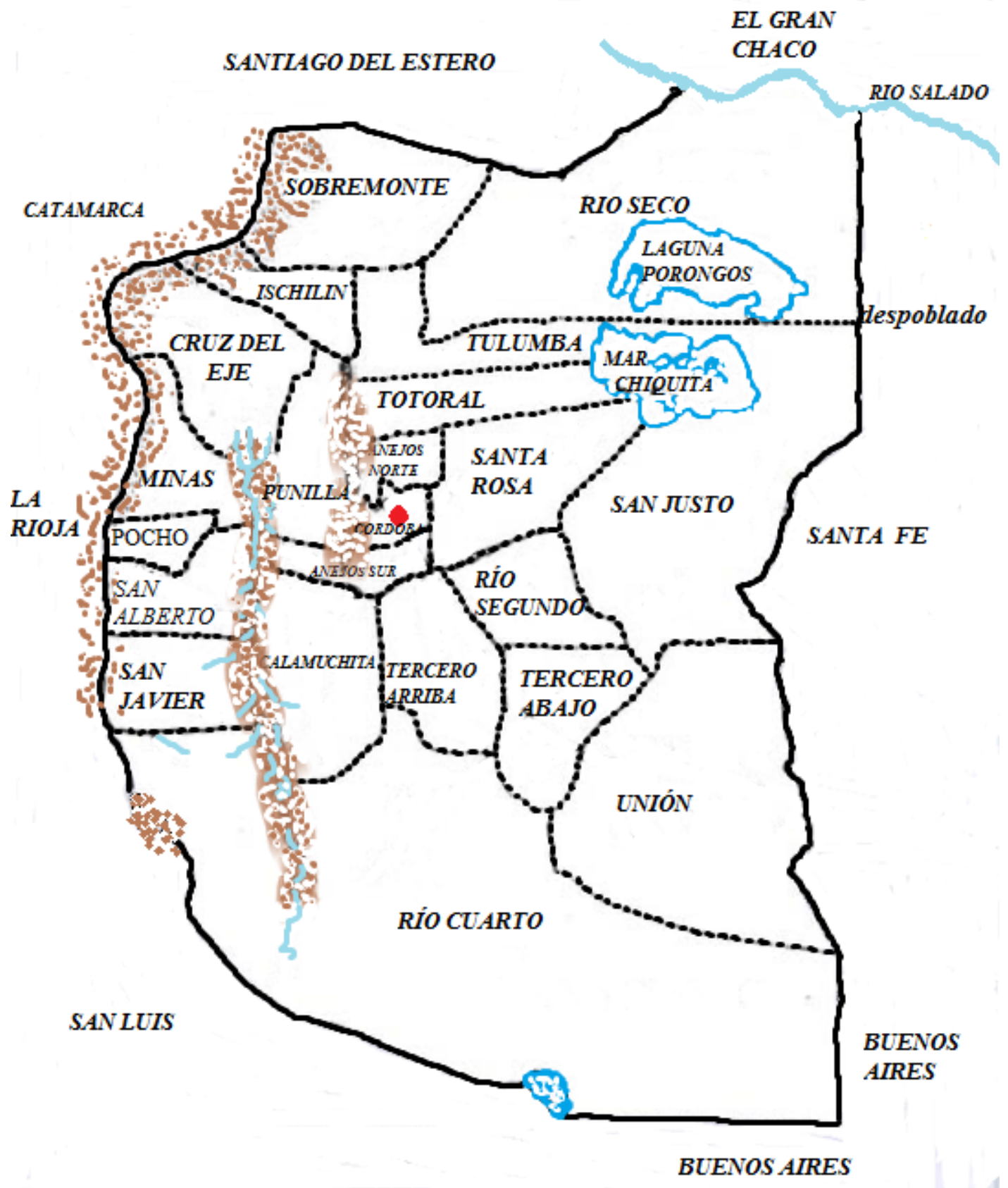

Fuente: Elaboración propia en base al Mapa de la Provincia de Córdoba de 1871, Departamento Topográfico de la Provincia de Córdoba. 


\section{Mapa 3}

\section{Departamentos de la provincia de Córdoba en 1887}

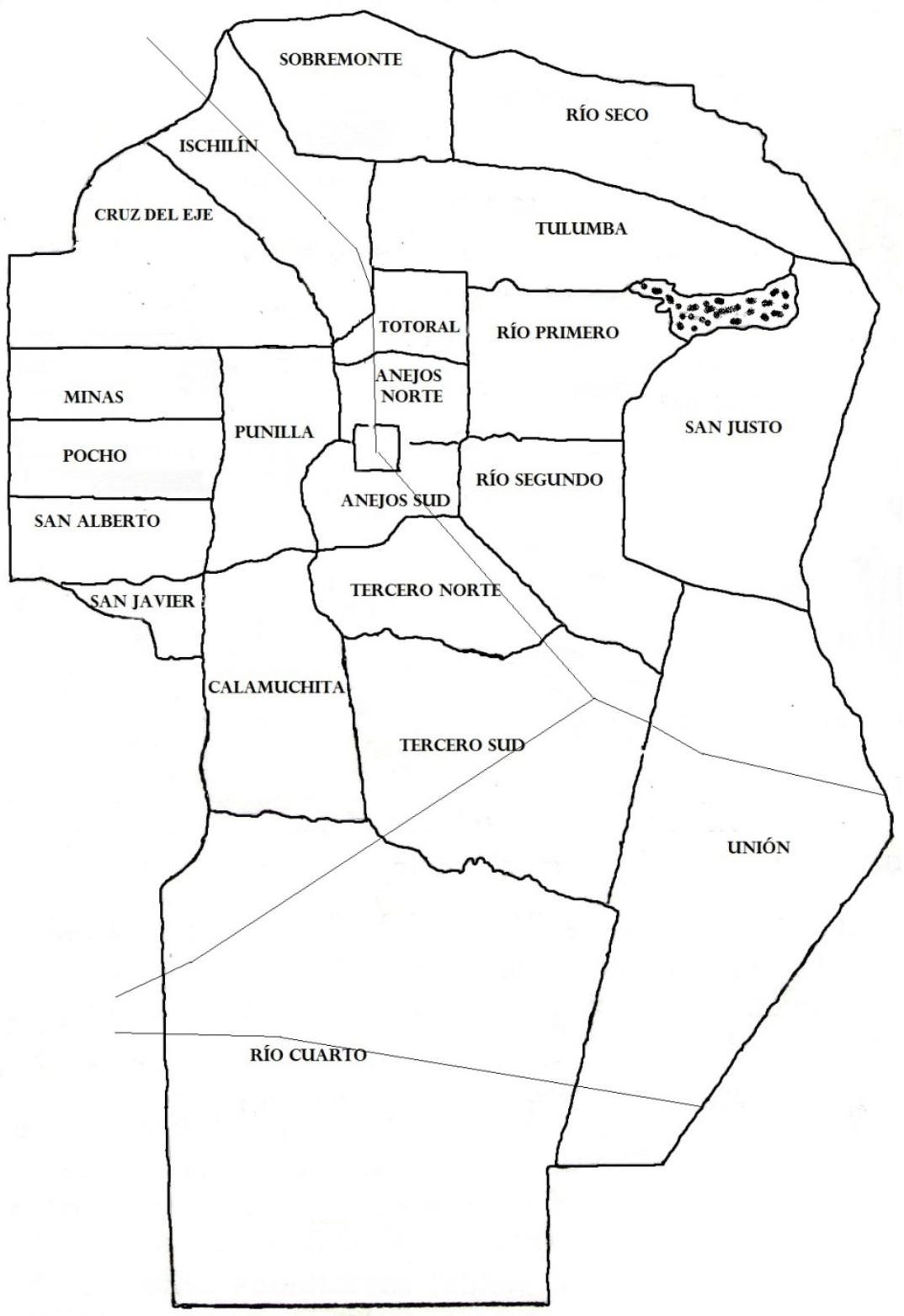

Fuente: Elaboración propia en base al esquema del mapa de Mariano Felipe Paz Soldán, Atlas Geográfico de la República Argentina, Lajouane, Buenos Aires, 1887. 


\section{Mapa 4}

\section{Departamentos de la provincia de Córdoba en 1905-1925}

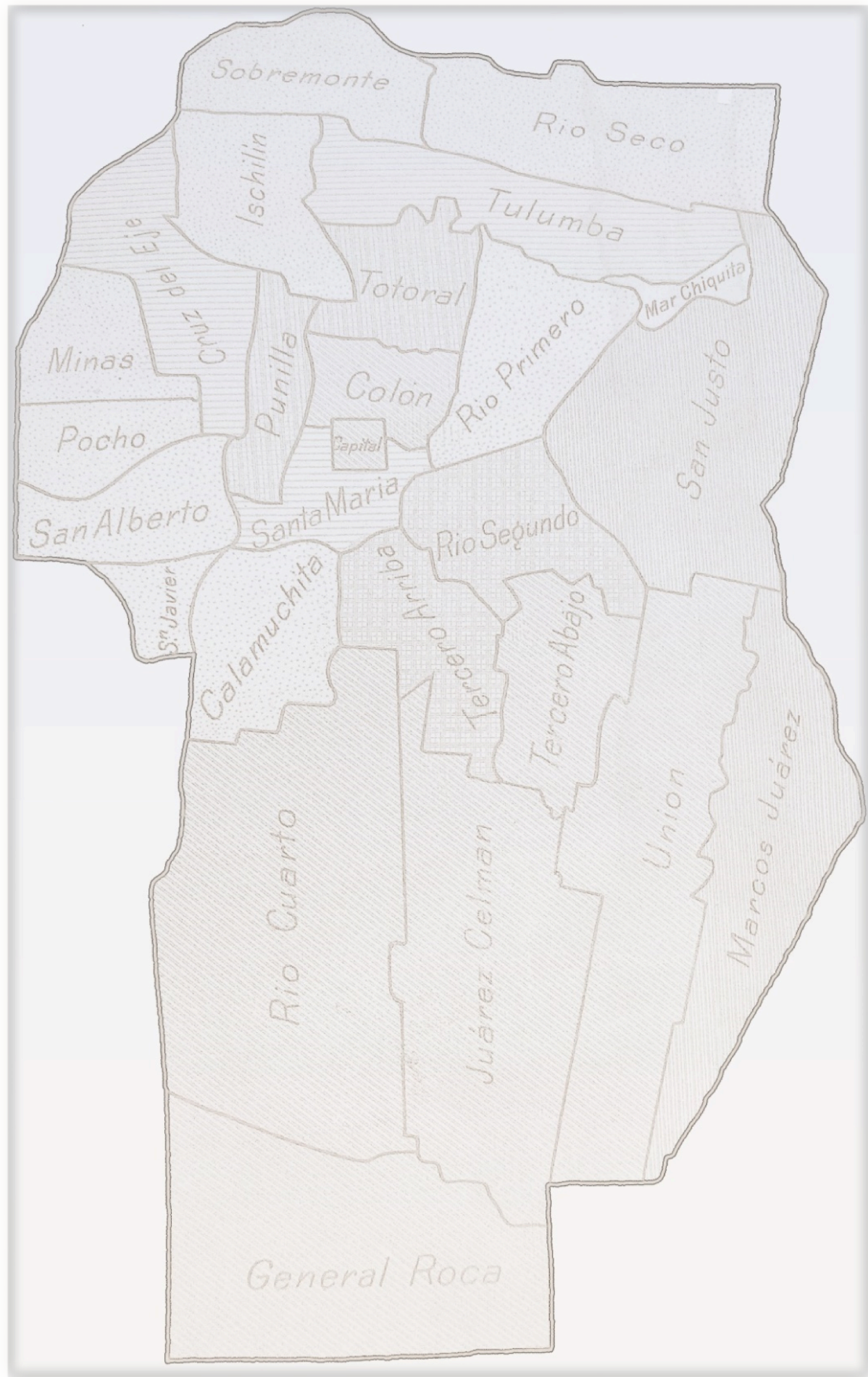

Fuente: Elaboración propia en base al mapa de Manuel Río y Luis Achával, Geografía de la Provincia de Córdoba, Publicación Oficial del Gobierno de la Provincia de Córdoba, Córdoba, 1904. 
En 1888, mediante la ley del 14 de julio, se divide el departamento de Río Cuarto, conformándose los departamentos de Gral. Roca y Juárez Celman y, en el mes de noviembre del mismo año, se divide el departamento de San Justo, creándose el nuevo de Marcos Juárez y así queda constituida la provincia hasta 1934. Paralelamente a esta organización territorial, a nivel civil, se realiza la organización territorial eclesiástica.

\section{Esbozo general sobre la economía y sociedad del período}

Hasta 1870, Córdoba fue una provincia enteramente criolla, incluso en 1890, el porcentaje de extranjeros apenas llegaba al 10\%. El censo nacional de 1869 establecía el total de la población cordobesa en 210.508 habitantes. En cuanto a su distribución, el 70\% de la población se concentraba en el norte, el oeste serrano y el centro -capital y departamentos Anejos norte y sur. El núcleo urbano principal era la ciudad de Córdoba, que contaba con una población de 34.500 habitantes (Pelliza, 1888: 21).

La cuestión relativa a la propiedad de la tierra era muy compleja. Desde tiempos coloniales se habían entregado extensas mercedes en el norte, el centro y el oeste de la provincia. ${ }^{10}$ Emilio Rojas Villafañe (1976: 121) señala que comprendían territorios de 50 a 200 leguas $^{2}$. Algunas de esas propiedades, transmitidas a los descendientes y sometidas a mayorazgo, se subdividieron después de la sanción del código civil de 1870, por las leyes de sucesión hereditaria. Muchas de ellas fueron abandonadas por sus dueños y ocupadas por familias criollas sin más títulos que una posesión que iba de padres a hijos. Los conflictos que se generaron en torno a los títulos de propiedad también serían para Rojas Villafañe un factor de la marginación de la zona. Esta realidad impactará también, como veremos más adelante, en los títulos de propiedad de los territorios que, teóricamente, pertenecían al obispado de Córdoba. A esto hay que agregarle la dificultad que, como señala Ana Inés Ferreyra (2007: 18), “era habitual que estas grandes propiedades rurales fueran vinculadas a una capellanía entre otras cosas, para asegurar la permanencia de la propiedad dentro del clan familiar".

En el sur de la provincia, se otorgaron mercedes extensas de tierras, la mayoría ocupada por tribus indígenas. Casi toda la superficie de los departamentos actuales de Unión, Marcos Juárez, Juárez Celman, Sáenz Peña, Río Cuarto y Gral. Roca eran terrenos fiscales,

\footnotetext{
${ }^{10}$ Para más datos, véase GRENON (1960).
} 
sobre los cuales el gobierno español había concedido mercedes con la obligación de poblar. A partir de 1854, el gobierno de la provincia de Córdoba comienza a vender y a conceder donaciones de tierras en el sur. Rojas Villafañe (1976: 63 y ss) presenta los datos de las ventas, consignando el comprador o beneficiario, la extensión, el precio, el escribano actuante, etc. Las ventas y adjudicaciones por servicios prestados al estado iban de 4 a 300 leguas. Muchas de estas tierras se adjudicaron -en el marco del proceso de inmigración y colonización-, a compañías de tierras y capitalistas extranjeros.

Dicho proceso producido en el país a partir de la segunda mitad del siglo XIX, modificó sustancialmente la estructura económica y social cordobesa. El movimiento colonizador, que se inició en entre Ríos y Santa Fe, se extendió luego a las zonas pampeanas del sudeste Cordobés y Buenos Aires.

\section{El proceso de colonización}

Con el trazado del Ferrocarril Central Argentino, que unió Rosario y Córdoba, se inició el período de la colonización privada. La compañía ferroviaria contemplaba la formación de colonias agrícolas y la creación de centros urbanos, junto a las estaciones proyectadas. El 13 de marzo de 1870, el trazado se completó, llegando hasta la ciudad de Córdoba. Al compás del avance de los caminos de hierro, el departamento de San Justo comenzó a llenarse de pueblos y colonias. En 1903, las colonias establecidas en el departamento de San Justo son más de medio centenar, en su mayoría, los colonos eran propietarios (Anuario Estadístico, 1904: 114 y ss). Al departamento de San Justo le siguen Juárez Celman, Tercero Abajo, Unión y Marcos Juárez.

El anuario estadístico provincial califica a la colonización que se desarrolló en Córdoba como la efectuada por la segunda generación de colonos, o sea, argentinos, hijos de inmigrantes, "son hijos de los primeros colonos llegados al país, nacidos en su mayor parte en la provincia de Santa Fe y que luego han construido su hogar en ésta". ${ }^{11}$ El vasto fenómeno de la colonización agraria alteró, profundamente, tanto la estructura económica como la fisonomía social de la provincia. Al lado de la Córdoba artesanal, radicalmente ganadera, criolla, tradicionalista, centrada en su antigua capital y en las poblaciones históricas del oeste y el norte, se erigió la Córdoba de la colonización, con una nueva

\footnotetext{
${ }^{11}$ Anuario Estadístico de la Provincia de Córdoba, Publicación Oficial, Córdoba, 1901. Introducción .
} 
sociedad, fundada en la inmigración extranjera, el desarrollo de la economía agraria y la producción para la exportación ultramarina (Ferrero, 2003: 22).

Al cabo de cuatro décadas, Córdoba se convertía en una de las principales provincias agrícolas del país. Los nuevos valores políticos, una nueva y desconocida ética del trabajo, una psicología y una cultura desarraigada de lo nacional, acompañaron este fenómeno, que constituyó, como lo señala James Scobie (1968) y lo reafirma Ezequiel Gallo (1984), una verdadera "revolución política".

Entre 1880 y 1888 , las áreas sembradas de trigo y maíz aumentaron espectacularmente, incidiendo en el rápido crecimiento de la región sudeste. Para Roberto Cortés Conde (1979: 97-181), tres fueron los rasgos centrales que caracterizaron esta expansión agrícola:

a) Los cambios producidos en la distribución regional de la producción cerealera. Las nuevas tierras se destinaron fundamentalmente al trigo.

b) El cambio ocurrido en las formas de colonización agrícola. Disminuyó la colonización oficial, el papel del Estado se restringió a otorgar facilidades a quienes emprendieran el negocio colonizador.

c) El impulso de los empresarios privados desde fines de la década del 80, en particular la actividad de grandes compañías anónimas. Entre ellas, cabe destacar la Compañía de Tierras, creada por el Ferrocarril Central Argentino.

El ferrocarril fue un elemento central en el progreso económico y productivo al posibilitar la reducción de los costos del transporte. En 1870, las líneas férreas unieron Buenos Aires y Córdoba, pocos años después, en 1876, el ferrocarril del norte llegaba hasta Tucumán. En 1873, las líneas de hierro unieron Villa María y Río Cuarto, ramal que seguirá hasta Villa Mercedes (San Luis), San Juan y Mendoza. El Ferrocarril Central Norte construyó el ramal de Deán Funes a Chilecito y La Rioja. Los rieles llegaron a Chilecito el 23 de junio de 1898. En el sur, los ramales de las líneas del Ferrocarril Buenos Aires al Pacífico y del Ferrocarril Andino atravesaban la provincia de Córdoba. El tendido de las líneas férreas, la actividad agrícola y comercial dio origen a nuevos núcleos de población y a la reactivación de antiguas villas, o fortines.

Hasta 1870, la población de Bell Ville (antiguo fortín de Fraile Muerto) continuaba estancada en razón de los peligros de las invasiones indígenas. En tanto Villa Nueva, 
situada un poco más alejada de la línea de frontera, crecía a ritmos más acelerados, dando lugar al poblado de Villa María.

Richard Arthur Seymuor, un inglés que se instaló en la zona en la década de 1860, describía la región y señalaba la existencia de "algunos fortines esparcidos a lo largo de aquella línea, pero actualmente apenas sirven para contener a los salvajes. Todos los campos al sur de Fraile Muerto, por los que ahora andábamos, encuéntranse completamente deshabitados y se extienden hasta una región tan poco conocida como el desierto del Sahara [...] Todos los terrenos de los alrededores de Fraile Muerto han sido fraccionados por el gobierno de la Provincia de Córdoba en lotes fiscales de dos o cuatro leguas cuadradas de extensión, que se venden en remate en la capital de la provincia”. En el viaje que realiza a la ciudad, en vistas a comprar uno de esos lotes fiscales, describe las villas que atraviesa, así, por ejemplo, de Villa Nueva dice que es un "pueblito situado a unas diecisiete leguas de Fraile Muerto y a treinta y tres de Córdoba. Era entonces una localidad muy pobre, pero, desde la llegada del ferrocarril, ha crecido mucho y algún día probablemente adquirirá importancia" (Segreti, 1973: 449).

Año y medio después, el cambio que se había producido en Fraile Muerto era notable, “este pueblo había adelantado bastante desde nuestra llegada a su casa de posta quince meses atrás. El ferrocarril desde Rosario funcionaba ya, y su provisional estacioncita se parecía a muchas de la campiña inglesa [...] El tránsito de la línea aumentaba diariamente [...] y el tránsito de pasajeros era también intenso [...] Además de la estación había aparecido también una fonda o pequeña hostería, un gran adelanto sobre la vieja casa de posta [...] Se había construido en el pueblo un buen número de casa nuevas, las que ahora contenían unos mil habitantes" (Segreti, 1973: 251).

Río y Achával (1904: 22) señalan que, en 1904, “el viajero que hace no más de treinta años recorría los caminos en la pesada diligencia bajo la peligros de la asechanza del indio cercano, creería ahora encontrarse en un país distinto o en la alucinación de un vértigo. Tan completa es la transformación operada en tan breve lapso de tiempo".

\section{El poblamiento de los departamentos de la provincia: vieja y nueva colonización}

En el espacio de una centuria, el siglo XIX, la población de Córdoba pasó de 45.000 habitantes a 450.000. En los primeros cincuenta años, apenas alcanzó a duplicarse y tasa de 
crecimiento respondió, fundamentalmente, al crecimiento vegetativo. En la segunda mitad del siglo, es necesario tener en cuenta a la inmigración europea como elemento dinamizador del crecimiento poblacional, la cual llegó a cuadriplicarse. La población total de la provincia durante el período de nuestro estudio fue la siguiente: 254.164 habitantes en $1879^{12}$ y 1.013 .128 en diciembre de $1926 .^{13}$

Las Tablas que presentamos a continuación, nos permiten ver el crecimiento poblacional a nivel departamental. Dado que la capital tiene carácter de excepción, y no será objeto de nuestro estudio, no la incluimos en el análisis. En función del establecimiento de los inmigrantes, hemos tomado la siguiente clasificación: departamentos de vieja y nueva colonización. Los primeros se ubican en el norte y oeste provincial y los segundos en el este y sur -cabe aclarar que Río Primero, Río Segundo y Tercero Arriba, si bien se los analiza en el marco de los departamentos de vieja colonización, ubicados en el centro de la provincia, recibieron un gran flujo inmigratorio, estos nuevos pobladores se sumaron a una importante población criolla ya establecida en el lugar.

En los departamentos de vieja colonización el crecimiento poblacional no fue homogéneo, ya que aquellos que se vieron beneficiados por la llegada de las líneas férreas, como San Javier, ${ }^{14}$ y Cruz del Eje, ${ }^{15}$ aumentaron considerablemente su población. Los departamentos limítrofes a los de nueva colonización (Río Primero, Río Segundo y Tercero Arriba), recibieron un caudal importante de aporte inmigratorio, mientras que el resto la mantuvo e incluso disminuyó, como puede observarse en los Gráficos 1 y 2.

\footnotetext{
${ }^{12}$ Memoria anual de la Oficina de Estadística de la Provincia de Córdoba, Publicación Oficial, Córdoba, 1881.

${ }^{13}$ Datos del año 1926. Publicados en el Anuario de la Dirección General de Estadística de la Provincia de Córdoba de 1929.

${ }^{14}$ En 1900 fue inaugurada la Estación en San Javier, parte del Ferrocarril Buenos Aires al Pacífico, del ramal de Villa Mercedes a Villa Dolores.

${ }^{15}$ Luego de la inauguración, en 1876, del Ferrocarril de Córdoba a Tucumán, se construyó un ramal que vinculó Cruz del Eje con la estación de Deán Funes. Cruz del Eje se convirtió en un importante nudo ferroviario, donde convergieron tres líneas férreas: a) La línea de Córdoba a Tucumán con escala en Deán Funes; b) La línea de Laguna Paiva, hacia el oeste, pasando por Deán Funes y Cruz del Eje; c) El ramal de Córdoba a Cruz del Eje. En 1890 se habilita la Estación Ferroviaria de Cruz del Eje y se inicia la construcción de los Talleres Ferroviarios.
} 


\section{Tabla 1}

\begin{tabular}{|c|c|c|c|c|c|}
\hline \multicolumn{6}{|c|}{ DEPARTAMENTOS DE VIEJA COLONIZACIÓN } \\
\hline \multicolumn{6}{|c|}{ POBLACION 1879} \\
\hline $\mathbf{N}^{\circ}$ & DEPARTAMENTO & $\begin{array}{l}\text { Pedanías } \\
\quad N^{\circ}\end{array}$ & $\begin{array}{l}\text { Extensión } \\
\text { en kms }\end{array}$ & $\begin{array}{l}\text { Población } \\
1879\end{array}$ & $\begin{array}{l}\text { Habitantes } \\
\text { por } \mathbf{k m}^{2}\end{array}$ \\
\hline 2 & Anejos Sud & 7 & 3815,6 & 8.290 & 2,17 \\
\hline 3 & Anejos Norte & 4 & 1650,72 & 7.434 & 4,50 \\
\hline 4 & Punilla & 7 & 3977,96 & 7.905 & 1,99 \\
\hline 5 & Calamuchita & 7 & 5631,01 & 10.684 & 1.89 \\
\hline 6 & Río Segundo & 9 & 3490,86 & 14.349 & 4.11 \\
\hline 7 & Río Primero & 11 & 6954,67 & 17.036 & 2.45 \\
\hline 8 & Tulumba & 5 & 5439,26 & 8.208 & 1.51 \\
\hline 9 & Totoral & 4 & 4032,08 & 8.001 & 1,98 \\
\hline 10 & Río Seco & 4 & 25274,97 & 5.856 & 0,23 \\
\hline 11 & Sobremonte & 5 & 8145,36 & 7.096 & 0,87 \\
\hline 12 & Ischilín & 6 & 2949,64 & 15.367 & 5.21 \\
\hline 13 & Cruz del Eje & 4 & 6792,31 & 14.381 & 2.12 \\
\hline 14 & Minas & 4 & 4032,08 & 9.387 & 2.33 \\
\hline 15 & Pocho & 3 & 1515,41 & 7.658 & 5.05 \\
\hline 16 & San Alberto & 6 & 3490,86 & 11.534 & 3.30 \\
\hline 17 & San Javier & 5 & 4410,94 & 15.374 & 3.48 \\
\hline 18 & Tercero Arriba & 6 & 4952,16 & 5.815 & 1.18 \\
\hline & TOTALES & 91 & 91603,80 & 168.560 & 1,84 \\
\hline \multicolumn{6}{|c|}{$\begin{array}{l}\text { Fuente: Memoria Anual de la Oficina de Estadística de la Provincia de Córdoba, } \\
\text { Publicación Oficial, Córdoba, } 1881 \text {. }\end{array}$} \\
\hline
\end{tabular}




\section{Tabla 2}

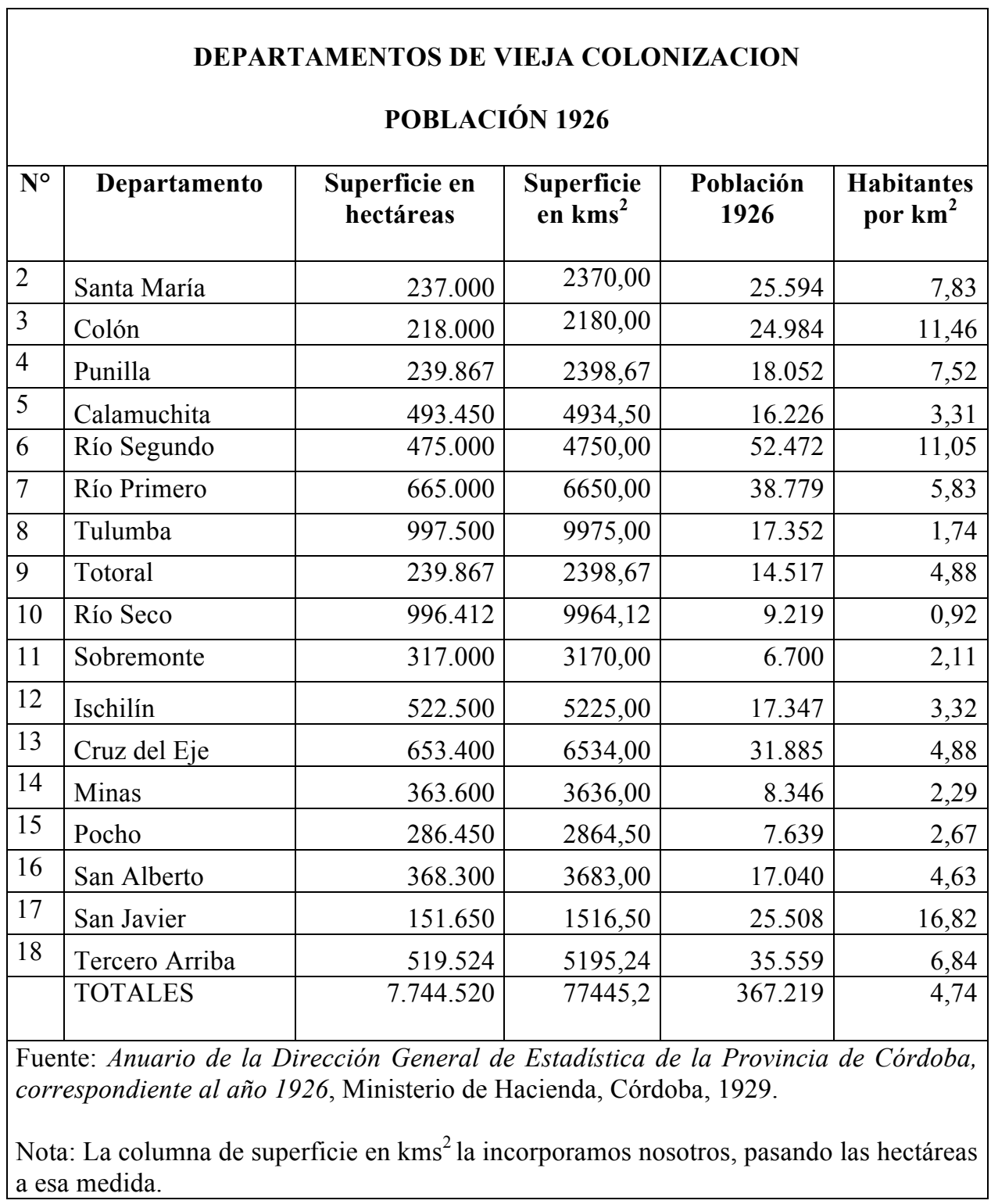




\section{Gráfico 1}

\section{Población 1879-1926}

Departamentos de Vieja Colonización

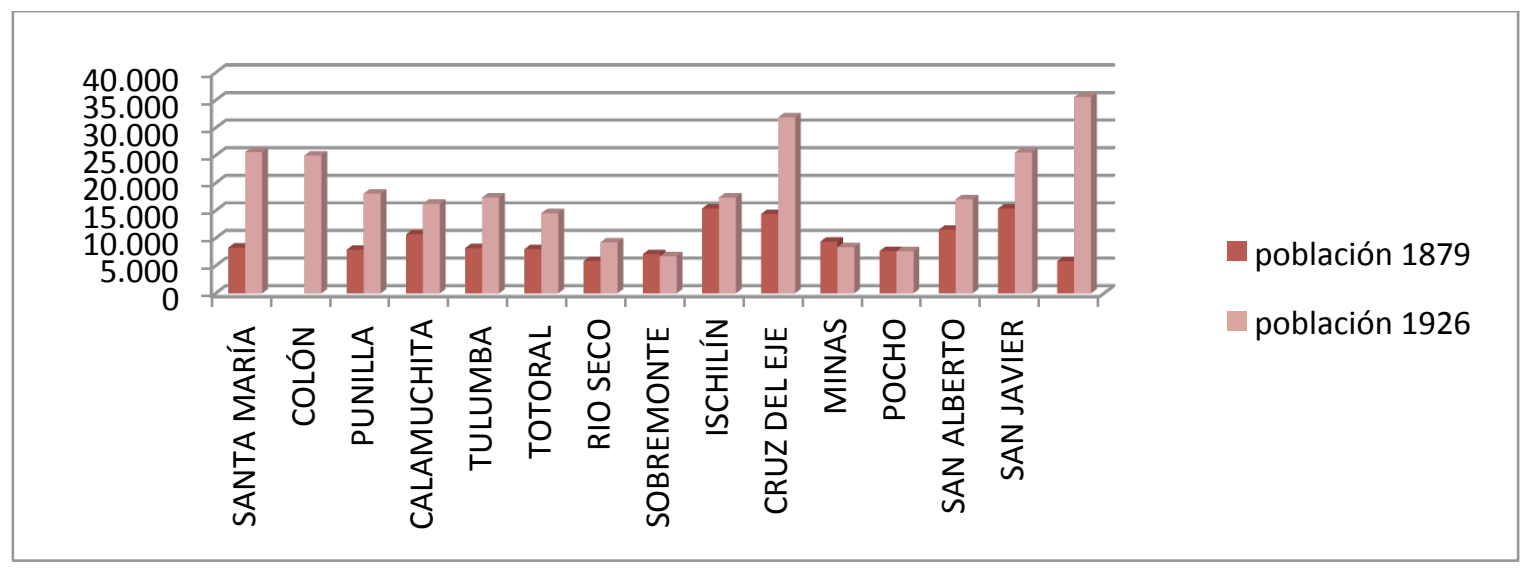

Gráfico 2

Población 1879-1926

Departamentos de Vieja Colonización

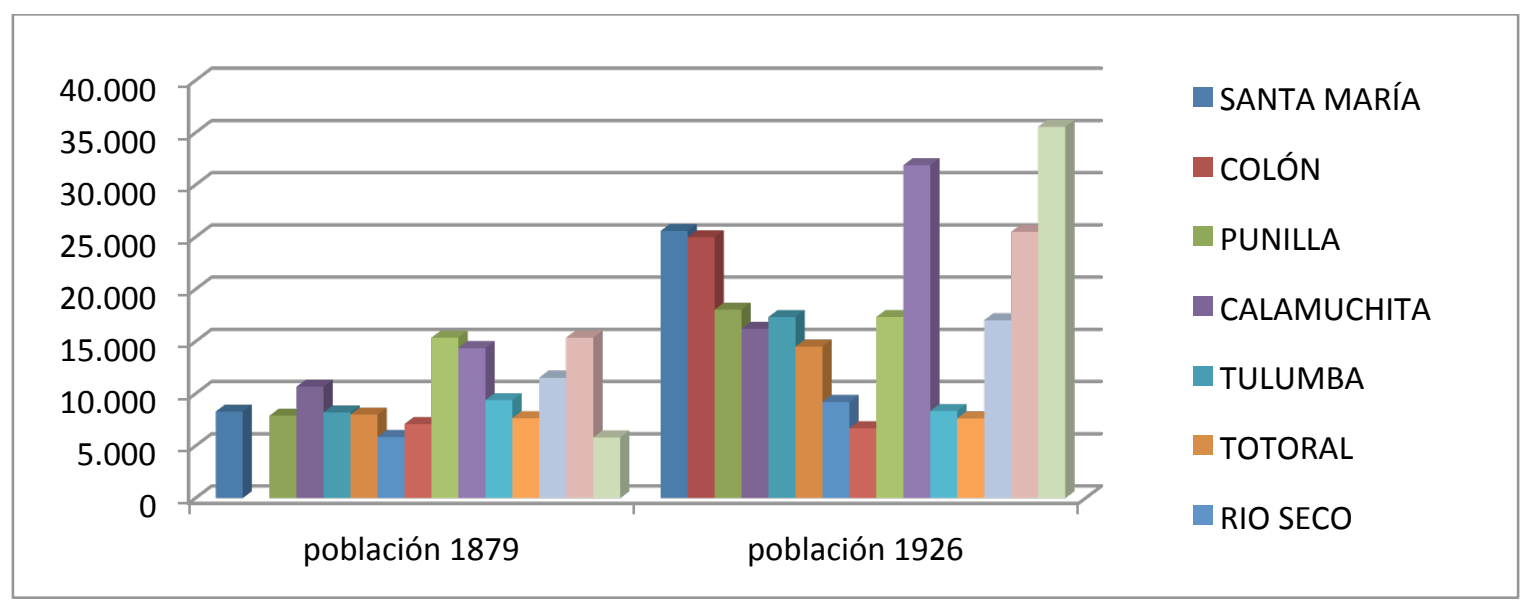

En los departamentos de nueva colonización, la población, en 1879, era exigua, gran parte del territorio se encontraba, como hemos reseñado ut supra, bajo el dominio de las naciones pampas y tehuelches. Una vez incorporado al "proceso civilizador", el crecimiento cuantitativo de la población aumentó considerablemente. En 1926, fecha en que finaliza nuestra investigación, pueden observarse los siguientes guarismos. 


\section{Tabla 3}

\begin{tabular}{|c|c|c|c|c|c|}
\hline \multicolumn{6}{|c|}{ DEPARTAMENTOS COLONIZADORES } \\
\hline \multicolumn{6}{|c|}{ POBLACION 1879} \\
\hline $\mathbf{N}^{\circ}$ & Departamento & \begin{tabular}{|c|} 
Pedanías \\
$\mathrm{N}^{\circ}$ \\
\end{tabular} & $\begin{array}{c}\text { Extensión } \\
\text { en kms }\end{array}$ & $\begin{array}{c}\text { Población } \\
1879 \\
\end{array}$ & $\begin{array}{c}\text { Habitantes } \\
\text { por } \mathbf{k m}^{2} \\
\end{array}$ \\
\hline 19 & Tercero Abajo & 5 & 5.141 .590 & 8.464 & 1.64 \\
\hline 20 & Río Cuarto & 5 & 40.510 .317 & 15.018 & 0.37 \\
\hline 21 & San Justo & 4 & 17.102 .552 & 6.218 & 0.36 \\
\hline 22 & Unión & 4 & 18.401 .480 & 6.596 & 0.36 \\
\hline
\end{tabular}

Fuente: Memoria Anual de la Oficina de Estadística de la Provincia de Córdoba, Publicación Oficial, Córdoba, 1881.

\section{Tabla 4}

\begin{tabular}{|c|c|c|c|c|}
\hline \multicolumn{5}{|c|}{ DEPARTAMENTOS COLONIZADORES } \\
\hline \multicolumn{5}{|c|}{ POBLACION 1926} \\
\hline $\mathbf{N}^{\circ}$ & $\begin{array}{c}\text { Departamentos } \\
\text { colonizadores }\end{array}$ & $\begin{array}{c}\text { Superficie en } \\
\text { hectáreas }\end{array}$ & $\begin{array}{c}\text { Población } \\
1926 \\
\end{array}$ & $\begin{array}{c}\text { Habitantes } \\
\text { por } \mathbf{k m}^{2}\end{array}$ \\
\hline 19 & Tercero Abajo & 487.104 & 44.121 & 9,06 \\
\hline 20 & San Justo* & 1.558 .800 & 82.914 & 5,32 \\
\hline 21 & Unión & 1.365 .858 & 74.788 & 5,48 \\
\hline 22 & Rio Cuarto & 1.843 .425 & 85.283 & 4,63 \\
\hline 23 & Marcos Juárez & 1.073 .437 & 68.180 & 6,35 \\
\hline 24 & Juárez Celman & 1.251 .670 & 47.549 & 3,8 \\
\hline 25 & Gral. Roca & 1.366 .271 & 35.150 & 2,57 \\
\hline Fues & $\begin{array}{l}\text { e: Anuario de la Dir } \\
\text { * Comprendía la lag }\end{array}$ & $\begin{array}{l}\text { ón General de Est } \\
\text { de Mar Chiquita }\end{array}$ & $\begin{array}{l}\text { ica de la Provinci } \\
84.500 \text { has. }\end{array}$ & ordoba, 1926. \\
\hline
\end{tabular}

En el Gráfico 3, damos cuenta del aumento de la población que experimentaron los departamento de nueva colonización entre 1879 y 1926. 


\section{Gráfico 3}

\section{Departamentos Colonizadores. Población 1879-1926}

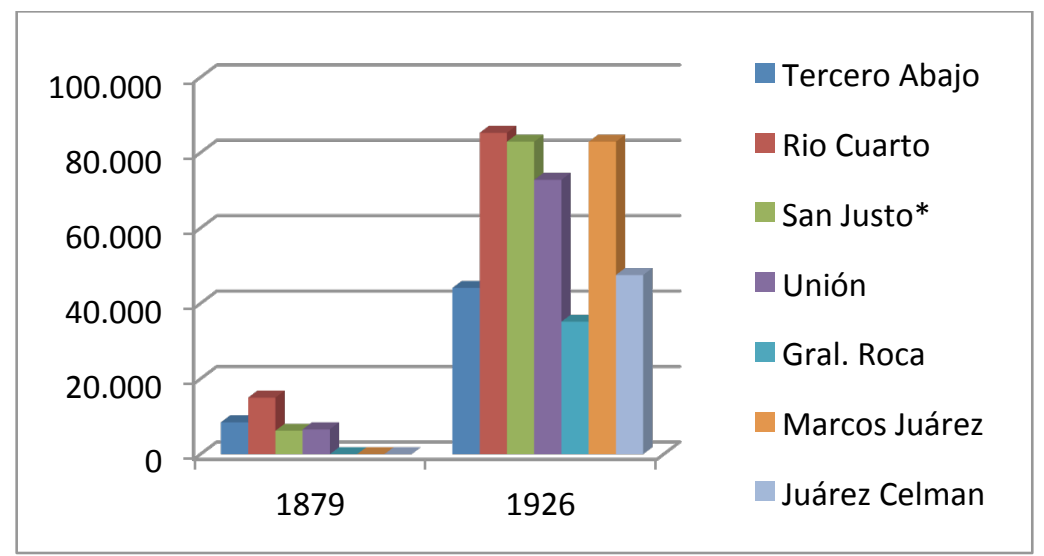

La Dirección General de Estadísticas de la Provincia de Córdoba de 1938, reproduce un gráfico relativo a la evolución de la población entre 1869 y 1926, en el cual puede observarse el crecimiento demográfico de la provincia a lo largo de los 50 años que se trabajan en esta tesis (Cfr. Gráfico 1 en Anexo II).

\section{El poder político}

5.1 Córdoba ¿una modernidad católica? (1877-1912)

Entendemos que la religión no debe quedarse rezagada en el camino rápido del progreso humano y menos por cuestiones de mera forma, creemos sí por el contrario que llevando en sus manos el baluarte inalterable de su fe y de su moral ella debiera presidir la marcha del mundo imprimiendo una fisonomía aún más hermosa a toda la civilización [... ]. Llamando la atención al clero en cuanto a lo que es práctico en el interés de que se aperciba del rol que viene jugando ante la conciencia moderna con grave daño a la religión y a sus propios intereses por cuestiones de régimen, de forma y de disciplina y de nada más ("El Progreso", 21/07/1880).

A partir de 1867, tras el derrocamiento del gobernador Mateo Luque, el último gobernador federal de Córdoba, se inicia un proceso que culminará con el acceso al poder del grupo liberal. Hasta 1877, la política cordobesa estuvo dominada por el Partido Liberal Nacionalista, organizado a comienzos de la década de 1860, en estrecha vinculación con el mitrismo. Vínculo que se quiebra cuando el partido decide apoyar la candidatura de Domingo F. Sarmiento (1868) y luego la de Nicolás Avellaneda (1874). Frente a este 
partido, emergía la oposición del Autonomismo Liberal. Desde el punto de vista político, la desaparición del Partido Federal fue el símbolo del ocaso de una época. Los "caudillos de sable" dejaban lugar a una nueva generación de líderes políticos que, surgidos de la fracción ultra del mitrismo cordobés, supieron retomar las mejores tradiciones autonomistas y fusionarlas con las ideas modernas del liberalismo en boga. En términos políticos, el año 1877 fue bastante significativo para la provincia. El grupo que llegó al poder en Córdoba, ligado al Gobernador Antonio del Viso (1877-1880), significó un cambio ideológico en la vida local. Liliana Chaves (1997: 17) señala que se inicia un período de estabilidad política, reflejado en la sucesión regular de autoridades y en el cual se registraron dos fenómenos: el reforzamiento progresivo del estado en el territorio cordobés y una sucesión de realineamientos políticos que separaron la antigua división entre federales y liberales.

Para la elección de gobernador de 1877, se acordó una fórmula negociada por ambos partidos. Los nacionalistas, que eran el sector con más poder, promovió al Dr. Enrique Rodríguez como candidato a gobernador; mientras los autonomistas lograron colocar en la vicegobernación al Dr. Antonio del Viso. Pero la muerte del mandatario electo antes de su asunción dejó a Del Viso al frente del ejecutivo provincial y, con él, el autonomismo liberal inició un período de profundas transformaciones, en el cual se crearon las condiciones que permitieron la modernización económica y política de la provincia. Se ponía fin a un ciclo. El diario "El Progreso" del 13 de julio de 1881, tituló su editorial "La Montonera". En ella, se expresa claramente el ideario del nuevo gobierno:

La montonera desaparece de todos lados, huye despavorida a ocultar su espanto en los oscuros bosques o entre los serros, así que les llega la noticia funesta de haber desaparecido, la circunstancia que aprovecharon para lanzarse tras de aventuras, en busca de dinero y de charqui. Liendo, el comisionado del Gobierno para perseguir la montonera del Minas y establecer el orden en ese importante departamento ha vuelto antes de ayer con su división completa, sin una baja [...]. Ha traído la fausta nueva de haberse concluido del todo la montonera [...]. La montonera esa resistencia armada contra la pacífica posesión de bienes ha terminado. La paz está establecida en todos los rumbos de la Provincia, el pueblo puede entregarse de lleno a la conquista de los medios que han de producirle en las alas prósperas del progreso en la realización de sus grandes y nobles ambiciones; ser una Patria feliz, que luzca las bellezas creadas por el arte en las riquezas de la industria, y aumentar el foco luminoso de la ciencia moral para hacerse distinguir con su propia luz desde los rincones mas escondidos del mundo. Este es el anhelo de los pueblos cultos. Córdoba lo es, y encierra en su dilatado seno cuanto precisa para su felicidad, su riqueza es variada y abundante, grande en lo material y grande en lo moral. 
Pocos días después, el mismo periódico apostilla, "así ha terminado la montonera del bandido Leal, que no volverá a aparecer más, nuevo campeón libertador de las vacas ajenas". 16

Si bien cabe señalar que, en lo político, la provincia se rigió por un orden definido según los ideales del liberalismo republicano, siguió, sin embargo, reservado a las viejas élites. Estas habían afirmado su posición como titulares del poder a partir de mecanismos de control político y fundamentos sociales de legitimación de carácter tradicional (Chaves, 1997: 17). Laura Cucchi (2014) señala que las novedades de la llegada a la gobernación en 1877 fueron, por un lado, la renovación generacional de la clase gobernante, compuesta por hombres que provenían de los grupos profesionales universitarios y otros jóvenes que recién comenzaban su carrera pública y, por el otro, la modificación de las reglas del funcionamiento político habituales, generando estrategias de negociación y oposición entre las fuerzas políticas. "Esa estrategia le permitió echar rápidamente raíces en la arena local y proyectarse exitosamente en el ámbito nacional" (Cucchi, 2014).

La concepción alberdiana de la "república restrictiva" fue, según Natalio Botana (1994), la fórmula operativa del régimen desde el 80 y tiene un significado si se la entiende como un sistema de hegemonía gubernamental que se mantiene gracias al control de la sucesión. La elección se trastocó en designación del gobernante por su antecesor y la fuerza se concentró en los titulares de los papeles dominantes revestido de la autoridad de los grandes electores. La fórmula prescriptiva ofrecía una respuesta satisfactoria, pero no suficiente, los únicos que podían participar en el gobierno eran aquellos habilitados por la riqueza, la educación o el prestigio. Desde el 80, el aumento de la riqueza consolidó el poder económico de grupos que fueron naturalmente aptos para el dominio. Se confundía el poder económico con el político. La oligarquía tenía el control económico, que es también político, y que se corrompe por varios motivos, es una clase gobernante con espíritu y conciencia de pertenecer a un estrato político superior. La oligarquía se da cuando un pequeño número de actores se apropia de los resortes fundamentales del poder, sobre todo localizados en posiciones privilegiadas en la estratificación social (Botana, 1994: cap. III). Este sistema político, encuadrado en la transición hacia la modernidad, puso de manifiesto las tensiones entre el pasado con sus tradiciones y la emergencia de una nueva realidad, la

\footnotetext{
${ }^{16}$ Diario El Progreso, 19/07/1881.
} 
cual implicaba el ordenamiento social sobre la base de una economía capitalista, el estado en tanto sistema jurídico diferenciado de la sociedad civil y la Iglesia como una más de las instituciones religiosas de la sociedad civil, aunque, sin duda, la más importante. Capitalismo económico, liberalismo político (estructura de poder basada en la división republicana y en la representación) y pluralismo religioso, conformarán las bases del sistema en construcción.

El proyecto de modernidad liberal de 1880, impulsado por el Estado nacional, confrontó -en sus dimensiones secularizadoras-, con algunos sectores de los grupos dirigentes locales, que limitaron el avance secularizador del Estado liberal cordobés. Si bien el estado no logró la laicización del espacio político y social, se generaron conflictos y tensiones, especialmente en temas referidos a la implementación de las llamadas leyes laicas, este conflicto no estuvo exento de acalorados debates.

En Córdoba, la Iglesia como institución, mantenía una fuerte influencia en la sociedad. La capital fue, desde el período colonial, el reducto más fuerte del catolicismo dentro de la Argentina. Con el pensamiento de la Iglesia Católica se identificaban importantes segmentos de las clases dominantes, celosas de sus orígenes eminentemente hispánicos, de los que heredaron un profundo fervor religioso, aunque perdieron espacio y poder con el ascenso del grupo liberal al gobierno de la provincia. El poder público comenzaba a actuar en áreas que antes eran de exclusiva responsabilidad de la Iglesia. En este sentido, tuvo lugar un conjunto de polémicas, debido a diversas medidas que los sucesivos gobiernos implementaron, a fin de modernizar las estructuras administrativas de la provincia. Estas apuntaban a delimitar el dominio que la Iglesia ejercía en algunos ámbitos: el registro de nacimientos y defunciones, la regulación de los matrimonios, el área educativa y los recursos de bienes de capellanías. La aprobación de las "leyes laicas" evidenció un deslizamiento de la concepción de un estado fundado en la unidad de la fe a la de un nuevo estado fundado en los principios de tolerancia y libertad religiosa.

Sin embargo, el gobierno provincial no secundó al gobierno nacional en la ley 1420 que propiciaba el carácter laico de la enseñanza. La ley provincial de educación común de 1884 sólo reconoció la gratuidad y obligatoriedad escolar, pero no reglamentó la laicidad de la educación pública, la Iglesia nombraba a los profesores de religión en las escuelas públicas 
hasta avanzadas las primeras décadas del siglo $\mathrm{XX} \cdot{ }^{17} \mathrm{El}$ obispo diocesano remitía la lista de candidatos al ministro de Justicia, Hacienda y Culto y éste procedía a la designación en el cargo de maestro de religión. ${ }^{18}$

El liberalismo pragmático del Partido Autonomista cordobés representó el inicio de un largo control político, ejercido por una fracción de la clase dominante que, después de 1880, tuvo una gran presencia en la vida nacional con el Partido Autonomista Nacional [PAN]. El partido, que giraba principalmente en torno de la figura del General Julio A. Roca, dominó la escena política, tanto nacional como cordobesa, hasta la reforma del sistema electoral en 1912.

Sin embargo, es importante resaltar que, desde la década del noventa al centenario, ninguna de las facciones que coexistían bajo el PAN logró un predominio estable y esto llevó a una feroz competencia por los espacios de poder. Los años del PAN en el poder no fueron años de dominio uniforme y sistemático, el contexto político implicó constantes realineamientos no sólo dentro del partido hegemónico, sino también entre fracciones de éste y de otros partidos políticos. La Argentina finisecular, lejos de estar dominada por un partido único, tuvo una turbulenta vida política en la que las alianzas temporales se hacían y rompían constantemente, según las circunstancias y conveniencias. La estabilidad política del orden conservador, advierte Botana, descansó en una notoria supremacía del poder ejecutivo y en una correlativa disminución del poder de los mandatarios provinciales y de los caudillos. El poder central mantuvo, a su vez, la supremacía sobre las situaciones provinciales mediante un ajustado sistema de premios y castigos, destinado a lograr un delicado equilibrio entre la necesidad de obtener el apoyo de los gobernadores y el deseo de evitar las repeticiones de las acciones sediciosas. Así, los gobernadores tuvieron un papel significativo pero subordinado en la coalición oficialista y fueron recompensados con posiciones de prestigio en el orden nacional. El castigo se concretaba a través de la intervención federal (Botana, 1994: 115). José Figueroa Alcorta asumió la primera magistratura en 1906, debido al fallecimiento del Presidente Manuel Quintana, ${ }^{19}$ para

\footnotetext{
${ }^{17}$ ACC. Carpeta Curia. Visitas Pastorales y Varios, 1887-1911. En 1912, el Director General de Escuelas de la Provincia de Córdoba solicitó al Obispo la designación de maestros para religión conforme a la ley de Educación, Art. 32 inciso 3 y 7 y 39.

${ }^{18}$ AAC. Fondo Zenón Bustos Obispo. Caja N ${ }^{\circ}$ 5. Enseñanza religiosa en las escuelas fiscales. f.2171.

${ }^{19}$ José Figuera Alcorta fue gobernador de Córdoba entre 1895 y 1898. En 1903, el PAN se dividió en roquistas y pellegrinistas, los hombres de la primera línea se reunieron en una convención de notables y
} 
limitar el poder "roquista", dispuso una serie de intervenciones provinciales. Córdoba, que era la llave de la dominación de Roca en el interior, tenía como gobernador a un fiel aliado, José Antonio Ortiz y Herrera. ${ }^{20}$ Los "figueroistas" cordobeses se organizaron en el partido Unión Provincial y el 14 de abril de 1909 provocaron un conflicto legislativo y forzaron la intervención nacional. El gobernador renunció el 3 de septiembre de 1909. El nuevo partido triunfó en las elecciones gubernamentales de 1909 y elevó al gobierno al "figueroista" Félix Garzón (1910-1913). Garzón era un hombre católico, cuya familia estaba fuertemente vinculada a la comunidad franciscana de Córdoba, su participación fue decisiva en la elección de Zenón Bustos y Ferreyra como Obispo de Córdoba en 1905.

La vigencia de este nuevo sistema electoral, reformado en 1912, permitió la integración de una importante masa de la población, hasta entonces excluida de toda participación política. Esta incorporación al sistema político estuvo acompañada de una integración más profunda en el campo social. La educación pública y obligatoria, la posterior instauración del servicio militar y los efectos de la prédica católica-nacionalista contribuyeron a la definitiva integración social de los inmigrantes.

El ascenso político del radicalismo a la gobernación provincial en 1915 no modificó sustancialmente las relaciones con la Iglesia. En el seno de este partido convivía una amplia corriente conservadora y católica liderada por Arturo M. Bas, entre otros. Gardenia Vidal (2000: 20) dice que el radicalismo cordobés surgió y se consolidó como resultado de una enorme mixtura de sus cuadros dirigenciales. "La presencia en sus filas de elementos conservadores y clericales fue una característica del partido desde sus orígenes. Alem y, más tarde, Yrigoyen promovieron la alianza con esos sectores primero para dar vida a la agrupación y luego para alcanzar la gobernación en noviembre de 1915”.

Por su parte, Marcela Ferrari (2001), al analizar el período radical, señala que Córdoba presentaba una particular singularidad, pues mientras la UCR era oficialismo a nivel nacional, en la provincia sólo dos gobiernos radicales llegaron al poder en los años que coincidieron con el comienzo de las presidencias yrigoyenistas. Estos fueron el de Eufrasio Loza y Julio C. Loza (1916-1919) y el de Enrique Martínez y José Antonio Ceballos (1928-

eligieron la candidatura Manuel Quintana y José Figuera Alcorta para presidente y vicepresidente, respectivamente.

${ }^{20}$ El 17/05/1907 asumió como gobernador de Córdoba. Ortiz y Herrera tenía amistad con Roca y el entonces presidente Figueroa Alcorta, en su deseo de limitar el poder del roquismo, envió una intervención a la provincia. 
1930). Durante el resto del período, el ejecutivo provincial estuvo en manos de miembros del Partido Demócrata, a quienes sindica como "Herederos de una tradición construida en tomo a notables y caudillos que nucleaban realidades regionales o locales, los demócratas formaban parte de aquellos grupos habituados a detentar el poder, aquella "aristocracia" que había operado como élite dominante y dirigente" (Ferrari, 2001: 131). Por su parte, la autora aclara que el primer radicalismo cordobés nutrió sus filas con parte de la elite tradicional marginada del poder político durante el período de gobierno de Marcos Juárez (1887-1890), representante del laicismo liberal. Ese sector de "aristocracia" católica cordobesa, cuyos ascendientes habían participado en el federalismo durante la primera mitad del siglo XIX, nunca apoyaron al "roquijuarismo".

\section{La debilidad institucional de la iglesia diocesana de Córdoba (1810-1858)}

"Se ve cómo piensa y ordena Roma lo que se hace en esta curia de Córdoba"

"El Progreso", 14/09/1881

La provincia de Córdoba pertenecía eclesiásticamente al obispado de Córdoba, circunscripción que también comprendía a la provincia de La Rioja. La diócesis estaba conformada por territorios muy heterogéneos, con características geográficas, demográficas, sociales y culturales muy diversas. La ciudad de Córdoba era la cabecera de la diócesis que llevaba el mismo nombre. La provincia gozaba de una posición mediterránea y marcadamente céntrica del territorio nacional, motivo por el cual se convirtió en el nudo de articulación de muy diversas regiones. Lo escarpado de la geografía hacía de la diócesis un mosaico poco integrado y con un deficiente control por parte del obispo.

\subsection{La debilidad institucional (1810-1858)}

La crisis del mundo colonial afectó profundamente al poder eclesiástico en la provincia. Desde el traslado del Obispo Rodríguez de Orellana en 1818, Córdoba no tuvo obispo titular, tanto el Pbro. Lic. Benito Lascano, como José Baigorri, promovidos a la sede 


\section{Mapa 5}

\section{La Diócesis de Córdoba en 1877}

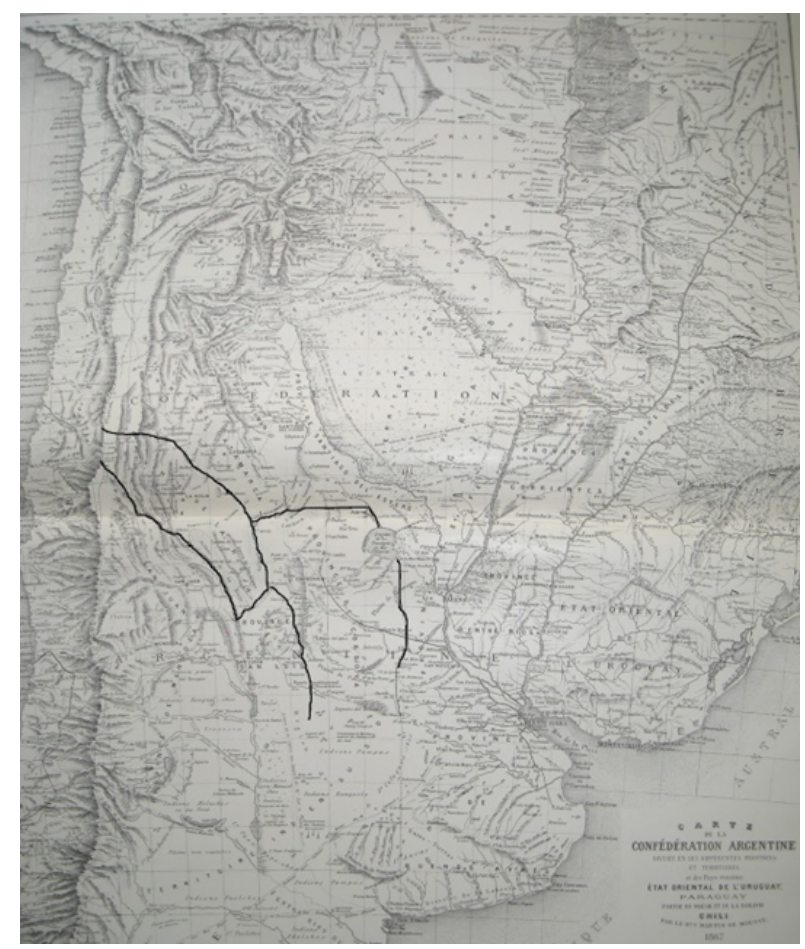

Fuente: Martin De Moussy (1869) (Carta de La Confederation Argentine)

mediterránea en 1836 y 1855, respectivamente, fallecieron antes de su preconización. De hecho, la diócesis, desde 1810, estuvo regida por el Cabildo Eclesiástico que nombraba provisores, los que cumplían las funciones de gobierno diocesano, debido a la permanente sede vacancia de la silla episcopal. La falta de una definición respecto al patronato favoreció que los Cabildos eclesiásticos ejercieran la prerrogativa de proponer a los gobiernos civiles los candidatos para ocupar sus sedes vacantes. Córdoba no era una excepción a la debilidad institucional de la Iglesia argentina. Santa Fe, Entre Ríos y Corrientes no tuvieron obispo hasta la creación de la diócesis del Litoral en 1860. Cuyo quedó sin obispo por más de ocho años, desde el fallecimiento de Monseñor Quiroga Sarmiento en 1852 hasta 1861, Salta fue gobernada por vicarios hasta 1862 (Di Stefano, 2000: 290-293). En la Tabla 5 puede observarse la sucesión de provisores y gobernadores de la sede vacante del obispado de Córdoba. 


\section{Tabla 5}

\begin{tabular}{|c|c|c|c|c|}
\hline \multicolumn{5}{|c|}{ Provisores que gobernaron la Diócesis de Córdoba (1810-1858) } \\
\hline \multirow{2}{*}{$\begin{array}{c}\text { Fecha de } \\
\text { Inicio }\end{array}$} & \multirow{2}{*}{$\begin{array}{c}\text { Fecha de } \\
\text { Finalización }\end{array}$} & \multirow[t]{2}{*}{ Prelado } & \multicolumn{2}{|c|}{ Tiempo } \\
\hline & & & Años & Meses \\
\hline $15 / 09 / 1810$ & Enero 1812 & VÁZQUEZ, José Gabriel & 1 & 3 \\
\hline $23 / 01 / 1815$ & $11 / 01 / 1816$ & CASTRO y CAREAGA, Juan Francisco & 1 & \\
\hline $16 / 01 / 1816$ & Febrero 1818 & LASCANO, Benito & 2 & 1 \\
\hline $13 / 02 / 1818$ & $17 / 02 / 1818$ & GUTIÉRREZ, Francisco Cándido & 0 & 1 \\
\hline $17 / 02 / 1818$ & $01 / 06 / 1818$ & DEÁN DEL CABILDO & 0 & 4 \\
\hline $20 / 06 / 1818$ & $18 / 06 / 1821$ & PAZ, Manuel Mariano de & 3 & 0 \\
\hline $30 / 07 / 1821$ & $31 / 08 / 1826$ & VÁZQUEZ, José Gabriel & 5 & 2 \\
\hline $31 / 08 / 1826$ & $18 / 03 / 1829$ & RODRÍGUEZ, Juan Justo & 2 & 7 \\
\hline $20 / 03 / 1829$ & Sin datos & LASCANO, Benito & 0 & 1 \\
\hline $01 / 05 / 1829$ & $11 / 06 / 1831$ & CASTRO BARROS, Pedro Ignacio & 2 & 1 \\
\hline $14 / 06 / 1831$ & $05 / 12 / 1831$ & LASCANO, Benito & 0 & 6 \\
\hline $05 / 12 / 1831$ & Desterrado & LASCANO, Benito, Vicario Apostólico & 0 & 0 \\
\hline $10 / 12 / 1831$ & 1834 & LÓPEZ CRESPO, Juan Antonio & 3 & $\mathrm{n} / \mathrm{c}$ \\
\hline $01 / 01 / 1835$ & $10 / 11 / 1835$ & ECHENIQUE, José Gabriel & 0 & 11 \\
\hline $17 / 12 / 1835$ & $30 / 07 / 1836$ & LASCANO, Benito (fallece) & 0 & 6 \\
\hline 1835 & 1837 & ALLENDE, José Domingo de & 2 & \\
\hline $25 / 04 / 1837$ & $15 / 09 / 1838$ & LÓPEZ COBO, Mariano & 1 & 5 \\
\hline $19 / 09 / 1838$ & $07 / 07 / 1841$ & MILLÁN, Bernardino Celestino (fallece) & 2 & 10 \\
\hline $28 / 07 / 1841$ & $21 / 10 / 1842$ & DE LA CERDA, José Bruno (fallece) & 1 & 4 \\
\hline Octubre de 1842 & $26 / 12 / 1842$ & LASCANO, Victoriano (fallece) & 0 & 2 \\
\hline $02 / 01 / 1843$ & Agosto/ 1848 & MARTIARENA, Gaspar & 5 & 7 \\
\hline $08 / 08 / 1848$ & $09 / 06 / 1858$ & BAIGORRI, José Gregorio (fallece) & 9 & 10 \\
\hline 1858 & $21 / 08 / 1859$ & RAMÍREZ DE ARELLANO, Eduardo & 1 & \\
\hline
\end{tabular}

La permanente sede vacancia de la silla episcopal, la falta de residencia fija del clero en los respectivos curatos de campaña y la estrecha vinculación de la organización eclesiástica con las autoridades civiles, las dejaron sujetas a los vaivenes de la vida política provincial. Algunos autores hablan de "iglesias rioplatenses" (Di Stefano, 2004) o de "provincias 
diócesis" (Ayrolo, 2007), haciendo clara referencia a la dependencia de las jurisdicciones eclesiásticas del poder civil y a la disgregación que existía entre ellas. Las sillas del cabildo eclesiásticos no se hallaban en su totalidad ocupadas. Valentina Ayrolo (2007: 204) señala que, entre 1848 y 1858, el cabildo eclesiástico estuvo constituido por dos dignidades (Arcediano y Chantre), un canónigo prebendado (Magistral), un tesorero, un racionero y un secretario capitular. A su vez, advierte que el Cabildo se llenaba y se vaciaba al ritmo de los enfrentamientos armados y de las luchas facciosas. Realidad que, sin duda, muestra una imagen clara de la debilidad institucional de la iglesia local.

Otra manifestación de la debilidad institucional de la iglesia fueron las escasas ordenaciones sacerdotales durante la primera mitad del siglo XIX. ${ }^{21}$ Cabe recordar que en 1838, el gobernador Quebracho López cerró el seminario Conciliar, y no volvió a abrir sus puertas hasta 1854. Las ordenaciones debieron realizarse en otras diócesis, o cuando se aprovechaba la visita de algún obispo a la región, como fue el caso del obispo Cienfuegos en 1829, quien realizó confirmaciones y ordenaciones. Las ordenaciones sacerdotales en la primera mitad del siglo fueron muy escasas.

Si bien no sabemos con precisión el número, gracias al legajo 23, referido a la concesión de dimisorias para órdenes, al legajo 24 tomo VII, que contiene los expedientes de ordenes entre 1845 y 1865 , la información contenida en los libros de títulos, las listas de los párrocos del Padre Liendo y los datos presentados por Valentina Ayrolo, hemos podido deducir que, entre 1810 y 1858, 41 postulantes accedieron a Ordenes. Ayrolo (2007: 195) señala que para el período que va de 1808 a 1852, del grupo de 52 clérigos que actuaron en Córdoba, 40 eran cordobeses. Durante una década -de 1815 a 1825-, prácticamente no hubo ordenaciones de clérigos cordobeses, exceptuando la de José Vicente Ramírez de Arellano en 1823. En 1829, Máximo Ferreyra Suárez y Eduardo Ramírez de Arellano recibieron las sagradas órdenes, Arellano de manos del Obispo Cienfuegos, quien, en la misma fecha, ordenó de menores a Eduardo Álvarez, quien posteriormente, en 1833, fue ordenado de presbítero por Benito Lascano, éste es el único ordenado en toda la década. A partir de 1840, hasta el advenimiento del Obispo José Vicente Ramírez de Arellano, en 1858, constatamos el otorgamiento de doce dimisorias para órdenes mayores. ${ }^{22}$ El legajo 24

\footnotetext{
${ }^{21}$ Cfr. BRUNO (1972: tomo XI).

${ }^{22}$ AAC. Leg. 23, TIV: Dimisorias para Ordenes, 1801-1911.
} 
tomo VII deja constancia de la ordenación, en Buenos Aires y en San Juan de Cuyo, de 24 presbíteros de la diócesis de Córdoba.

Si bien no tenemos datos precisos, varios autores señalan que el número de clérigos seculares durante la primera mitad del siglo XIX rondaría el medio centenar: Ayrolo (2005: 134) estima que en 1829 eran 59; Compañy (1955: 92) advierte que al hacerse cargo del obispado Eduardo Ramírez de Arellano (1859), el clero no alcanzaba a 50 individuos, el periódico "La Bandera Católica", del 11 de septiembre de 1858, informa que "el clero secular de la ciudad y de la campaña comprende solo cuarenta y cuatro individuos". Cayetano Bruno (1972: 137) señala que, en 1859, al asumir el obispado Ramírez de Arellano, los sacerdotes seculares eran 45 en la provincia de Córdoba, siete de los cuales estaban ya inútiles y nueve en La Rioja. Por lo tanto, para una provincia que, en 1857, contaba con trece curatos y, según registra el censo del Gobernador Guzmán, 137.079 habitantes, el clero secular era muy escaso, un promedio de uno cada 6.527 habitantes. Promedio que aumentaría si consideramos que no todos los sacerdotes tendrían la cura de almas y que la diócesis incluía además a la provincia de La Rioja. ${ }^{23}$ Sin embargo, lo reducido del grupo era inversamente proporcional a su importancia, se trataba de un grupo consolidado, estrechamente vinculado a la élite dirigente, cuyos miembros pertenecían al mismo sector socioeconómico, habían sido formados en las mismas aulas, compartían filiaciones familiares y negocios, tenían identidad, unidad de principios y objetivos (Ayrolo, 2007: 233).

En las partidas de bautismo o confirmación y en las declaraciones de testigos sobre la vida de los candidatos al estado clerical del período, es frecuente encontrar el calificativo de familia noble. En las décadas de 1830 y 1840, una de las preguntas que debían responder los testigos era si el candidato pertenecía "a los nobles". En 1848, Justa Prado, testigo de José Florentino Martínez, respondió que "pertenece al cuerpo de los nobles y así han corrido siempre todos sus antepasados por ambas líneas paterna y materna, y que en esto tiene pleno conocimiento por ser ella perteneciente a la misma estirpe". ${ }^{24}$ José Joaquín Amenábar, vecino de la ciudad de Córdoba, de cincuenta años, testigo "de vida y costumbres" de José Gregorio Ardiles, testimonia que "le consta que sean españoles,

\footnotetext{
${ }^{23}$ Vicaría Foránea: Famatina, Guandacol, Costa de Arauco, Tama, Los Llanos, Chilecito.

${ }^{24}$ AAC. Leg. 24, TVII (1845-1865). Expediente de Órdenes de José Florentino Martínez, sin foliar.
} 
limpios de sangres todos los mencionados. Le consta que son y siempre han sido tenidos por españoles nobles, y que conoció que hubo un sacerdote del orden de San Francisco, hermano del padre del pretendiente, que ha más, sabe que hubieron otros dos o tres sacerdotes de la misma familia". ${ }^{25}$ Podemos afirmar que un alto porcentaje de clérigos ordenados seculares pertenecían a familias "nobles". De los 33 clérigos ordenados entre 1830 y 1858, sólo dos, Roque Honesterosa ${ }^{26}$ y José Cardinali ${ }^{27}$ eran italianos y religiosos secularizados. Más adelante veremos que las familias tradicionales de la clase dirigente cordobesa tendrán hijos clérigos a lo largo de varias generaciones.

La figura del sacerdote en la sociedad cordobesa continuó siendo el espejo de la sociedad hasta bien avanzado el siglo XIX. Córdoba, como dijimos, recién experimentó el proceso de secularización en el último cuarto del siglo XIX, ya que no vivió la reforma eclesiástica impuesta por Rivadavia. Por lo tanto, podría hablarse de una sociedad de tipo antiguo, en la que sociedad, iglesia y estado no estaban morfo-genéticamente separadas (Peire, 2000: 208). Como señala Ayrolo (2007: 17), el modelo de sociedad y de estado propuesto por los sectores dirigentes de la primera mitad del siglo XIX se asentó más en el pasado que en el futuro, de manera tal que los hombres de la Iglesia "se convirtieron en los referentes de una sociedad cuyo imaginario era aún de antiguo régimen". Cabe destacar que en este tipo de sociedades era central el peso de las familias que componían la clase dirigente, formar parte del clero era también formar parte de la clase dominante, de la elite del poder. Ayrolo (2011: 108) dice que, entre 1821 y 1852, el clero secular participó activamente de la vida política provincial, 25 clérigos seculares ocuparon cargos en la Sala de Representantes. A su vez, Ana Inés Ferreyra (1994: 101) advierte que entre 1835 y 1852 el 13\% de los miembros de la elite dirigente cordobesa pertenecía al clero. Esta realidad coincide con la que analiza Roberto Di Stefano (2004: 21) para Buenos Aires, cuando dice que hablar de clero secular significa pensar, fundamentalmente, en la elite o, para usar un término de la época menos preciso aún, la "gente decente".

Nos interesa remarcar aquí que, hasta 1859, el clero secular era un grupo significativo pero relativamente pequeño y con frecuencia la política lo alejaba de la actividad pastoral. Además, el ejercicio del patronato por parte de los gobernadores significó, en algunos

\footnotetext{
${ }^{25}$ AAC. Leg. 24, TVII (1845-1865). Expediente de órdenes de José Gregorio Ardiles.

${ }^{26}$ AAC. Leg. 23, TIV. Dimisorias para Órdenes, 1801-1911.

${ }^{27}$ AAC. Leg. 24, TVII (1845-1865). Expedientes de Ordenes, Cardinali Fray José.
} 
casos, el destierro y la persecución política de algunos curas. El caso más conocido es el de Benito Lascano. ${ }^{28}$ También, Enrique Martínez Paz relata en su libro Formación Histórica de la Provincia de Córdoba, que, en 1841, el gobernador Quebracho López remitió a Rosas sacerdotes arrestados en calidad de procesados, se trataba del Deán Juan José Espinosa, el Canónigo Magistral Fernando Bulnes, el Canónigo José Gregorio Patiño, el Dr. Manuel Eduardo Álvarez, el Dr. Calixto del Corro, el Dr. Genaro Carranza, el Dr. Francisco Javier Granillo y el maestro Bartolomé Caldas, quienes sufrieron el destierro (Martínez Paz, 1983: 133). El futuro obispo de Córdoba, Manuel Eduardo Álvarez, debió abandonar su cargo de Cura Rector de la Catedral y establecerse en Achiras. El gobernador insistía ante el Provisor del obispado, José Bruno de la Cerda, para que se le iniciara una causa política. En este clima político, la vacancia en la atención de los curatos era frecuente, como también la falta de residencia de los pastores en sus parroquias. A modo de ejemplo, podemos señalar que el curato de Río Seco estuvo vacante durante cuatro años y dos meses, entre 1830 y 1834. Estas cuestiones ponen de manifiesto tanto la escasez de clero secular para la atención pastoral de los curatos de campaña, como la activa participación del clero en la vida política y social provincial. Silvia Romano (2010: 9) señala la participación activa de curas párrocos en la vida política en calidad de electores por departamentos o curatos, ellos fueron, en sus respectivas esferas de actuación, las máximas autoridades de las jurisdicciones rurales y tuvieron su cuota de influencia y poder local, participando, a su vez, de redes, grupos políticos y facciones. Advierte que para el período 1829-1855, sobre el total de 481 electores de los departamentos de campaña había 82 jueces de alzada, 94 curas (no especifica si regulares o seculares), 57 comandantes de milicias y 54 militares de diversos rangos. Algunos de ellos, sobre todo los curas, fueron electos por varios años consecutivos. Por ejemplo. Feliciano Centurión, cura párroco de Tulumba, fue elector por ese departamento en 14 elecciones entre 1831 y 1848; y Victoriano Lascano, cura párroco de Calamuchita, lo fue en nueve elecciones entre 1835 y 1841.

Otro síntoma de debilidad institucional fue la inmutabilidad de las jurisdicciones eclesiásticas. La diócesis no sufrió importantes modificaciones administrativas a lo largo del período 1810-1858. Los curatos no experimentaron cambios, salvo la división del de

\footnotetext{
${ }^{28}$ Para este tema, puede consultarse AYROLO y MAZZONI (2013).
} 
Río Tercero realizada en 1838, del cual se desmembró el nuevo curato de Tercero Abajo, cuya iglesia matriz se estableció en Villa Nueva.

En la Tabla 6 puede observarse el estancamiento del crecimiento parroquial en el período señalado. Hemos consignado el año de erección, el titular, las fechas de las primeras partidas, el nombre y el departamento en el que se encuentra la cabecera del curato. Puede observarse que todos los curatos, salvo el de Tercero Abajo, son anteriores a la revolución de 1810 .

\section{Tabla 6}

Fechas de inicio de libros parroquiales

\begin{tabular}{|c|c|c|c|c|c|c|c|}
\hline \multirow[t]{2}{*}{ Curato } & \multirow{2}{*}{$\begin{array}{l}\text { Fecha de } \\
\text { Erección }\end{array}$} & \multicolumn{4}{|c|}{ Fecha de Inicio Libros } & \multirow[t]{2}{*}{ Titular } & \multirow[t]{2}{*}{ Depto. } \\
\hline & & Bautismos & Matrim. & Confirm. & Defunciones & & \\
\hline Catedral & $28 / 08 / 1642$ & $28 / 08 / 1642$ & $4 / 11 / 1642$ & $06 / 01 / 1793$ & $06 / 03 / 1728$ & $\begin{array}{l}\text { Ntra. Sra. de } \\
\text { la Asunción }\end{array}$ & Capital \\
\hline $\begin{array}{l}\text { Villa del } \\
\text { Rosario }\end{array}$ & $10 / 05 / 1704$ & $10 / 05 / 1704$ & $7 / 01 / 1759$ & $17 / 08 / 1859$ & $21 / 11 / 1758$ & $\begin{array}{l}\text { Ntra. Sra. del } \\
\text { Rosario }\end{array}$ & $\begin{array}{l}\text { Río } \\
\text { Segundo }\end{array}$ \\
\hline Tulumba & $19 / 07 / 1749$ & $15 / 01 / 1765$ & $5 / 08 / 1762$ & $12 / 08 / 1870$ & $10 / 08 / 1780$ & $\begin{array}{l}\text { Ntra. Sra. del } \\
\text { Rosario }\end{array}$ & Tulumba \\
\hline Ischilín & $19 / 07 / 1749$ & $22 / 10 / 1793$ & $8 / 11 / 1793$ & $07 / 10 / 1877$ & $26 / 09 / 1793$ & $\begin{array}{l}\text { Ntra. Sra. del } \\
\text { Rosario }\end{array}$ & Ischilín \\
\hline Calamuchita & $01 / 01 / 1750$ & $01 / 01 / 1762$ & $29 / 05 / 1762$ & $21 / 03 / 1889$ & $\begin{array}{l}2^{\circ} \text { Libro } \\
6 / 01 / 1874 \\
\end{array}$ & San Agustín & Calamuchita \\
\hline $\begin{array}{l}\text { Pocho } \\
\text { (Salsacate) }\end{array}$ & $29 / 12 / 1765$ & $\begin{array}{l}1^{\circ} \text { libro no } \\
\text { existe }\end{array}$ & 1766 & 1886 & 1780 & $\begin{array}{l}\text { Ntra. Sra. del } \\
\text { Rosario }\end{array}$ & Pocho \\
\hline Río Seco & 1772 & $30 / 01 / 1753$ & $7 / 01 / 1810$ & $00 / 11 / 1892$ & $03 / 01 / 1826$ & $\begin{array}{l}\text { Ntra. Sra. del } \\
\text { Rosario }\end{array}$ & Río Seco \\
\hline Punilla & 1780 & $12 / 07 / 1780$ & $7 / 08 / 1780$ & $12 / 08 / 1813$ & $03 / 09 / 1780$ & $\begin{array}{l}\text { Ntra. Sra. del } \\
\text { Rosario }\end{array}$ & Punilla \\
\hline Río Cuarto & 1780 & $00 / 01 / 1747$ & $0 / 12 / 1746$ & $17 / 09 / 1814$ & $08 / 01 / 1747$ & $\begin{array}{l}\text { Inmaculada } \\
\text { Concepción }\end{array}$ & Río Cuarto \\
\hline $\begin{array}{l}\text { Capilla } \\
\text { Rodríguez } \\
\end{array}$ & 1776 & $00 / 00 / 1777$ & 1777 & $31 / 05 / 1898$ & $00 / 00 / 1777$ & $\begin{array}{l}\text { Inmaculada } \\
\text { Concepción } \\
\end{array}$ & $\begin{array}{l}\text { Tercero } \\
\text { Arriba } \\
\end{array}$ \\
\hline Anejos & 1781 & $18 / 11 / 1781$ & & $07 / 04 / 1875$ & $24 / 03 / 1782$ & $\begin{array}{l}\text { Ntra. Sra. de } \\
\text { las Mercedes }\end{array}$ & Santa María \\
\hline San Javier & 1784 & $21 / 07 / 1784$ & $21 / 07 / 1784$ & $02 / 07 / 1886$ & $27 / 07 / 1784$ & $\begin{array}{l}\text { San } \\
\text { Francisco } \\
\text { Javier }\end{array}$ & San Javier \\
\hline $\begin{array}{l}\text { Santa Rosa } \\
\text { Río Primero } \\
\end{array}$ & 1800 & $10 / 11 / 1800$ & --- & $07 / 06 / 1800$ & $22 / 11 / 1800$ & $\begin{array}{l}\text { Santa Rosa de } \\
\text { Lima }\end{array}$ & Río Primero \\
\hline $\begin{array}{l}\text { Tercero } \\
\text { Abajo }\end{array}$ & 1838 & $14 / 01 / 1838$ & $14 / 04 / 1842$ & $04 / 05 / 1873$ & $31 / 08 / 1847$ & $\begin{array}{l}\text { Ntra. Sra. del } \\
\text { Rosario }\end{array}$ & $\begin{array}{l}\text { Tercero } \\
\text { Abajo }\end{array}$ \\
\hline \multicolumn{8}{|c|}{$\begin{array}{l}\text { Fuentes: AAC. Datos parroquias. Respuesta circular 1824: Pregunta } n^{\circ} 1 \text { ¿Qué día, mes y año comienza cada libro?; } \\
\text { AAC. Compilación de datos relacionados con las parroquias de la arquidiócesis (1914-1960); AAC. Libro de Bautismos, } \\
\text { Matrimonios, Confirmaciones y Defunciones (Alta Gracia, San Javier, Santa Rosa de Río Primero, San Agustín); AAC. } \\
\text { Parroquias de Córdoba del Pbro. Ramón Liendo, Inédito; Anuario Eclesiástico de la Arquidiócesis Metropolitana de } \\
\text { Córdoba. Disponible en https://familyhistory.byu.edu }\end{array}$} \\
\hline
\end{tabular}


Junto a la inmovilidad del crecimiento de la estructura parroquial, la atención pastoral de los curatos de campaña era altamente deficiente, esta realidad la podemos constatar empíricamente, ya que cuando los obispos comenzaron a realizar sus giras pastorales dieron cuenta de una serie de deficiencias: deterioro material de las iglesias, descuido en los asentamientos de partidas en los libros parroquiales, escasa celebración de funciones litúrgicas, etc. También queda de manifiesto cuando los aspirantes a órdenes debían presentar las partidas de bautismo y confirmación a la curia, era muy frecuente que la autoridad competente recurriera a la citación de testigos para que confirmaran que el sacramento había sido administrado, esto se debe a que no se ha encontrado el asiento en los respectivos libros parroquiales. Por ejemplo, en los curatos de Tulumba, Villa del Rosario, Río Seco, Anejos, no quedaron asentadas las partidas de bautismo de José Florentino Martínez, ${ }^{29}$ Jerónimo Clara, ${ }^{30}$ Justino Juárez $^{31}$ y Felipe Cabanillas, ${ }^{32}$ entre otros sacerdotes. Por otra parte, la Tabla 6, nos muestra otro dato altamente significativo y es que el sacramento de la confirmación se haya administrado, después de 1810, sólo en dos ocasiones: la primera, en el curato de Río Cuarto, por el Obispo de Salta Nicolás Videla del Pino, en los meses de octubre a diciembre de 1814 y marzo de 1815, y, la segunda, en Punilla, en 1813, por el Obispo de Córdoba Rodrigo Antonio de Orellana, luego de su extrañamiento no se realizaron confirmaciones en el obispado hasta el año 1859 en que fue preconizado Ramírez de Arellano.

Otro de los aspectos que da cuenta de la debilidad institucional era el estado material de los templos. Según consta en los informes enviados a la curia en 1859, en la campaña, había 19 templos entre parroquiales y vice parroquiales, algunos de ellos, y muchas de sus capillas filiales, estaban en muy mal estado. El vicario de Río Cuarto envía un informe en 1858 señalando el estado de las capillas, San Bartolomé era una capilla pobrísima “con el

\footnotetext{
${ }^{29}$ AAC. Leg. 24, TVII. Expediente de órdenes José Florentino Martínez: no se encontraron las partidas de bautismo. Los testigos afirman que fue el 14/03/1824 en la Iglesia Parroquial Nuestra Señora del Rosario de Tulumba.

${ }^{30}$ AAC. Leg. 24, TVII. Expediente de órdenes Jerónimo Clara. No se encuentra la partida de confirmación. Los testigos afirman que la recibió en la Parroquia de Villa del Rosario por el obispo Cienfuegos en el año 1829.

${ }^{31}$ AAC. Leg. 24, TVII. Expediente de órdenes Justino Juárez. No se encuentra la partida. Los testigos afirman que fue confirmado en la estancia de sus abuelos, en Pozo del Tigre por el obispo Molina, cuando iba rumbo a Salta.

${ }^{32}$ AAC. Leg. 24, TVII. Expediente de órdenes de Felipe Cabanillas. Sin partida de confirmación. Los testigos afirman que la recibió en el Colegio de Huérfanas a fines de 1835.
} 
techo que amenaza caerse [... en la Tapa hay una antigua capilla derribada por los indios. ${ }^{33}$ Al asumir el obispado don José Vicente Ramírez de Arellano, vecinos de numerosas localidades solicitan el permiso para construir nuevas capillas o mejorar las existentes. Así, los vecinos de Los Molinos, curato de Calamuchita, en 1869, se dirigieron al obispo manifestándole la necesidad de edificar un templo "que pueda llamarse verdadera casa de Dios [...] pues la que actualmente existe de trece años a esta parte, es una pequeña y ruinosa pieza y por lo mismo no satisface las necesidades de la población”. El cura Adolfo Villafañe acompañó la petición e informó además que la antigua capilla, denominada de Soconcho, era efectivamente una "pieza ruinosa y sumamente reducida, próxima a desaparecer". Y además, señala que el patrono (el Sr. Astrada), había convertido la pieza contigua a la capilla en un establo, "la ha dedicado a pesebre de caballo, más antes, a depósito de frutos mercantiles". La nota finaliza señalando que para la reconstrucción de esa antigua capilla cuenta con cuarenta y tantas mil piezas de material cocido y que también sirve la puerta principal de la sacristía. ${ }^{34}$

En 1870, el cura de Tercero Abajo, Antonio Lima solicitó licencia para celebrar misa en Ballesteros, en una casa particular, porque "la capilla que allí hai está en ruinas". ${ }^{35}$ El cura de Anejos Sud informaba, en 1874, que había recorrido las capillas de su curato y "las Iglesias de San Antonio y Lagunilla [que] se encuentran sin cementerio y la primera estaba por caer”. En 1877, los vecinos del departamento de San Justo informan al obispado que la Iglesia parroquial, Nuestra Señora de la Concepción en la Villa del Tío, "según voz pública está empezando a caerse". ${ }^{36}$ En 1878, el cura y vicario de Minas, Olegario Villa, informaba al Obispo Manuel E. Álvarez que el oratorio de Pinas "acaba de venirse abajo, destruyéndose completamente" como consecuencia de las "quiebras" que tenía y de las copiosas lluvias, solamente se pudieron salvar las imágenes de la divina pastora y San Roque. El cura solicitaba al obispo autorización para levantar una subvención con el objeto de comprar los terrenos al patrono del oratorio y levantar una nueva capilla de carácter público, dada la necesidad de un templo en aquel lugar. ${ }^{37}$ En 1885, el cura de Chalacea, Luis Abriola, informaba al obispado que la capilla Nuestra Señora de las Mercedes en

\footnotetext{
${ }^{33}$ AAC. Carpeta Río Cuarto, s/f.

${ }^{34}$ AAC. Leg. 7. Capillas y cementerios, sin foliar (año 1869).

${ }^{35}$ AAC. Legajo Villanueva s/f. Nota de fecha 09/07/1870.

${ }^{36}$ AAC. Leg. 48. Curato de Chalacea, San Justo..., s/f.

${ }^{37}$ AAC. Curato del Tránsito, Salsacate, San Carlos y San Pedro, 1863-1887, s/f.
} 
Cañada de Luca estaba bajo amenaza de caerse, "cinco tirantes estaban salidos de la pared [...] y el techo se sostenía por fuerza de las alfajías”, por ese motivo retiró la Imagen de la Virgen y los ornamentos del lugar. ${ }^{38}$

Párrafos arriba señalábamos el descuido en los asentamientos de partidas en los libros parroquiales como otro rasgo de debilidad institucional. En 1878, el cura José Ametha y Planell, al hacerse cargo del curato de Pocho, envía una nota al gobernador del obispado en sede vacante, en la cual daba cuenta de que había tomado posesión del curato e informaba el estado de los libros. Señala "el notabilísimo descuido que ha habido en llevar los libros parroquiales [...] Hay un libro de óleos que desde el año 60 no se han firmado las partidas, el siguiente a éste que empieza en febrero del 63, excepto una que otra firma intercalada y el actual que corre hasta enero del 75, también carecen de las mismas. En los matrimoniales hay uno que desde junio de 1855, ya en época de mi antecesor y el actual desde septiembre del 76 se hallan en igual estado, el libro de defunciones que comienza en el año 53, de igual modo se encuentra desde diciembre de 1862 [...] tampoco hay en el archivo libro de fábrica, sólo existe uno que otro cuaderno que acredite algún que otro derecho de sepultura". Terminaba la nota preguntando ¿a quién pedir cuentas y en qué forma pedirlas? Y ¿cómo apreciar el saldo de cuentas de la administración de una época tan larga y tan oscura? ${ }^{39}$ Este no era sólo un problema del curato de Pocho, sino una realidad generalizada en los curatos de la campaña. El cura de Punilla señalaba en 1873 que "el archivo está pésimamente tenido, muchos de los que se dicen libros parroquiales no son sino un conjunto de hojas sueltas, sin folio, sin principio ni fin. Los libros de bautismo y matrimonio [...] están bien, al día y bien llevados; pero no hay libro de confirmaciones, ni de fábrica y el de defunciones aún está atrasado". " Otro ejemplo de muestra es la consulta que hizo el cura de Ischilín a la curia diocesana respecto del estado de los libros y de la determinación que debía tomar en caso de que se le solicitase alguna partida de matrimonio: "Faltando los libros parroquiales correspondientes a los matrimonios, todas las partidas correspondientes, desde el 4 de noviembre de 1868 al 30 de enero de 1877 , y estando cortadas las hojas en el libro, correspondiente desde 1862 a 1868, estando el tal

\footnotetext{
${ }^{38}$ AAC. Leg. 48. Curato de Chalacea..., s/f. Notal del 06/04/1885.

${ }^{39}$ AAC. Curato del Tránsito, Salsacate, San Carlos y San Pedro, 1863-1887, s/f.

${ }^{40}$ AAC. Caja Parroquias, Cosquín, f.77.
} 
libro con hojas en blanco [...]. También faltan algunas partidas de defunciones". ${ }^{41}$ Estos ejemplos nos permiten inferir que los párrocos no siempre cumplían con sus obligaciones, ni residían en los curatos asignados.

Finalmente, la debilidad institucional se muestra en la ausencia de visitas pastorales durante todo el período anterior a la preconización de Ramírez de Arellano. Luego del proceso revolucionario, y tras el destierro del Obispo Orellana, la diócesis no tuvo un obispo que hubiera ejercido el gobierno de manera efectiva. La sede vacancia permanente, junto a los derroteros de la vida política provincial y nacional, imposibilitaron el cumplimiento de la obligación canónica de los obispos de visitar periódicamente la diócesis a su cargo. Entre 1810 y 1858 no se realizaron visitas canónicas en la diócesis. Estas comenzaron a ser efectivas a partir de José Vicente Ramírez de Arellano, como veremos en el próximo apartado.

Sin embargo, pese a la debilidad institucional manifiesta, ¿la iglesia estaba presente en la campaña? ¿Cuál era la manera de garantizar esa presencia? Sin duda, la presencia de la religión y de la iglesia en la campaña dependía, en gran medida, de la participación de los fieles. Muchos templos y capillas tenían sus patronos laicos que disponían de ellas y muchos, aunque no todos (como se vio ut supra), velaban para que allí se realizaran las funciones religiosas. El libro de títulos de los años 1780 a 1859 registra el otorgamiento de permisos para edificar capillas y oratorios públicos a vecinos de diversos curatos de la provincia, a los que se les otorga el título de patronos. ${ }^{42}$ Tal era la costumbre, que el cura de Anejos, el 22 de mayo de 1874, informaba a la curia que de las diez iglesias del departamento "siete tienen Patrono y las otras medio Patrono, le cuento que en el archivo no existe inventario de ninguna Iglesia, ni libro de fábrica, por cuanto que ésta corre a cargo de los Patronos respectivos y sin noticia alguna al Párroco, ni por esto avanzaron a juzgar

\footnotetext{
${ }^{41}$ AAC. Caja 50-51, Curato de Ischilín.

42 AAC. Títulos de sacerdotes, 1780-1859. En 1837, se concede licencia al Sr. Carreño para edificar una capilla en el Paraje de Citón (f.111.v); en octubre de 1838, se concede licencia a Dn. Pedro Córdoba para edificar una capilla en el curato de Santa Rosa; en abril de 1840, se le otorgan licencias a Don Justo Sosa para edificar una capilla en el curato de Cosquín (f.112); en el mismo año, Don Diego Bustos obtiene licencias para edificar un capilla en el curato de la Punilla; en 1852, se le conceden licencias a Don Pantaleón Correa para edificar una capilla en el Puesto de Castro en el curato de Río Seco; en 1855, se le concede licencia a Juan Ferreira para edificar un oratorio público en el lugar llamado Los Talas en el curato de Pocho (f.112.v). El mismo año, el Sr. Toribio Junco recibe el permiso para edificar una capilla en Chalacea, curato de Santa Rosa de Río Primero. En 1857, Marcelino Berrotarán es autorizado a edificar un oratorio público en Las Peñas, curato de Río Cuarto, a todos se les expide el título de patronos.
} 
sobre buena o mal inversión que totalmente ignoro se hace en ellas". ${ }^{43}$ Esta cita nos remite a la realidad planteada por Roberto Di Stefano para Buenos Aires, donde señala que, a lo largo de la primera mitad del siglo XIX, las familias eran la iglesia. En el púlpito y la plaza, dice el autor "en cierta manera y en varios sentidos, las instituciones eclesiásticas coloniales pertenecían a la sociedad: habían nacido por su propia iniciativa y subsistían gracias a ella. No tenían existencia independiente de quienes las habían creado y las sostenían con recursos materiales y humanos" (Di Stefano, 2004: 43).

Con el correr del tiempo, y a medida que se lleva adelante el proceso de romanización y la consecuente centralización del gobierno eclesiástico, esta costumbre traerá no pocos conflictos entre feligreses y curas. A modo de ejemplo, presentamos la consulta remitida a la curia por Fray Luis Solís, del convento de Propaganda Fide de Río Cuarto, en 1861, respecto de los derechos del cura sobre la capilla de Tegua, en la cual señala que:

D. Juan Luis Molina. D Francisco Molina y D Bernardo Molina y muchos otros por ser desendentes de un Molina que levantó la capilla, se sienten patronos de la misma con todo lo que pertenece a dicha iglesia y por esto no quieren pagar los derechos de fábrica como prescribe el arancel y sostienen que yo como delegado del cura no puedo nombrar un mayordomo que atienda a la Iglesia, que la llabe debe siempre estar en manos de los Molina, y no puedo disponer de las cosas de la Iglesia como prescriben los sagrados cánones. ${ }^{44}$

Además del patronato laico, que sin duda generó no pocas dificultades y conflictos en las relaciones con los párrocos, conflictos que irán acentuándose a medida que la iglesia vaya centralizando más el gobierno, se afianza la figura del párroco como administrador y responsable de su curato; la escasez de clero conllevó que los fieles asumieran funciones y ejercieran cierto ministerio. Tal es el caso de los bautizadores, en cada curato existía un grupo de personas "bien formadas" que se encargaban de administrar el sacramento en ausencia del cura. Esto era tan frecuente que en los expedientes de órdenes consta quiénes fueron bautizados por ellos. De los 29 expedientes iniciados entre 1845 y 1859, más de 20 candidatos fueron bautizados por un seglar "facultado" por el cura. Roque Ríos fue bautizado, a los pocos días de nacer, por Torcuato Javier, facultado por el cura de Río Segundo, y a los tres meses de edad, el 7 de noviembre de 1852, recibió el óleo y la crisma

\footnotetext{
${ }^{43}$ AAC. Leg. 40. Cartas y notas de los Sres. Curas a los Sres. Obispos, 1842-1908, f.7.

${ }^{44}$ AAC. Leg. 46, TI. Curato de Río Cuarto, f.37.
} 
en la Catedral. Lo mismo podría decirse de Juan Correa, quien recibió el bautismo en la pieza oratorio de Nuestra Señora la Purísima de Citón de manos de Bernardino Correa, vecino facultado para ese menester y, luego de cuatro meses, el 8 de diciembre de 1850 fue oleado en la parroquia respectiva. Samuel Bustos fue bautizado por Rosario Villanueva, facultado por el cura de Tulumba y, luego de cuatro meses, el 14 de marzo de 1853 recibió el óleo y la crisma en la Iglesia Catedral, ${ }^{45}$ y así podríamos seguir...

Se supone que un mínimo porcentaje de personas es la que inicia el camino a las órdenes sagradas, por lo tanto no cabe duda de que el recurso a los bautizadores era una costumbre aquilatada. A estos testimonios, que dan crédito de la función de los bautizadores, podemos añadir las reiteradas consultas de curas relativas a la administración de los bautismos: en 1878, el párroco de Río Cuarto, Fray Ludovico Quaranta escribió a la secretaría del obispado para preguntar sobre el modo de proceder ante "la costumbre de bautizar bajo condición a todos los niños que hayan sido bautizados por personas seglares facultados para ello", ante la duda de si se había administrado bien el sacramento, el cura optaba por volver a bautizar, sub-condicionis. ${ }^{46}$ Como puede observarse, la práctica de los bautizadores fue muy frecuente hasta, al menos, fines del tercer cuarto del siglo XIX. A nuestro parecer, esta costumbre era, además de un indicio de la escasez de clero destinado a la atención de los curatos, una manifestación de la debilidad institucional de la iglesia diocesana, que debió delegar funciones centrales, como la administración de los bautismos, en manos de seglares. A su vez, este hecho revela una concepción de fondo y, de alguna manera, manifiesta la concepción de unanimidad que impregnaba la sociedad cordobesa de mediados del siglo XIX.

A la asunción de funciones propias del clero por parte de seglares, se suma la otra cara de la moneda, la asunción de funciones propias de seglares por parte del clero secular. En este período, en el que el proceso de secularización avanzaba muy lentamente, el clero secular cordobés tenía conductas propias del seculo, las mismas eran asumidas con aprobación por parte de la sociedad. La participación política del clero y la activa intervención en la administración civil de las pequeñas comunidades rurales, en calidad de

\footnotetext{
${ }^{45}$ AAC. Leg. 24, TVIII, 1860-1870.

${ }^{46}$ AAC. Leg. 46. Curato de Río Cuarto, documento 139.
} 
presidentes de comuna, concejales, etc., revela, a su vez, esa mutua imbricación de lo religioso y lo secular, con esferas que, paulatinamente, se delinean como diferenciadas.

Por otra parte, la decadencia material del templo daba cuenta de que la vida de la sociedad en la campaña no estaba centrada en los edificios religiosos, en la iglesia material, los ciudadanos, con frecuencia, celebraban los sacramentos fuera del templo, en sus propios hogares recibían el bautismo, el matrimonio y la unción. El templo se reducía al culto y éste consistía, particularmente, en la celebración de las fiestas patronales.

\section{El inicio del cambio: José Vicente Ramírez de Arellano (1859-1873)}

A partir del advenimiento de José Vicente Ramírez de Arellano ${ }^{47}$ finaliza una etapa que, como ya hemos señalado, se había caracterizado por la debilidad institucional, la autonomía de las iglesias locales, la estrecha simbiosis con los poderes civiles provinciales y el escaso control del Pastor sobre su territorio. La Diócesis comienza a organizarse institucionalmente a partir de 1858. La fragmentación de las jurisdicciones eclesiásticas fue más frecuente, y tuvo mayor impacto como mecanismo promovido por la Santa Sede para hacer más eficientes las administraciones diocesanas, que durante el período anterior, se habían caracterizado por una extensión territorial difícil de gobernar.

Al recibir el obispado, Ramírez de Arellano advierte el estado de precariedad y debilidad institucional en que se encontraba la diócesis: los curatos estaban mal servidos, el clero secular, que era muy escaso, se concentraba en la ciudad y el número de parroquias de campaña era reducido, muchos de sus templos -iglesias, capillas y oratorios-, se encontraban en mal estado y, como hemos señalado ut supra, varios al borde de la ruina.

\subsection{Erección de nuevos curatos}

A la división departamental llevada a cabo por el poder ejecutivo provincial, y descrita ut supra, le correspondió la subsiguiente división eclesiástica. El Obispo Ramírez de Arellano, en el auto del 18 de noviembre de 1859, dispuso la división de la parroquia de Anejos. ${ }^{48}$ Luego, procedió al desmembramiento del antiguo curato de Segundo Abajo y a

\footnotetext{
${ }^{47}$ José Vicente Ramírez de Arellano, elegido por Pío IX el 23 de diciembre de 1858. Tomó posesión de la sede el 22 de agosto de 1860 y murió el 31 de agosto de 1873.

${ }^{48}$ AAC. Libro de Notas, 1859-1873, f.2.
} 
los extensos curatos de Tulumba, Río Seco, Pocho, San Javier, Punilla y San Justo, ${ }^{49}$ creando los de Totoral, Sobremonte, Minas, San Alberto, Anejos Norte, Chalacea, Cruz del Eje y Unión (Fraile Muerto). El 12 de noviembre 1869, el obispo divide el antiguo curato de Calamuchita en dos, el nuevo, con sede en Río de los Sauces. ${ }^{50}$ La última parroquia creada por Ramírez de Arellano fue la Inmaculada Concepción de Pampayasta, por división del curato de Río Tercero Arriba, aunque fue suprimida al año siguiente (Bruno, 1972: 149). El diocesano se preocupó por hacer coincidir las jurisdicciones eclesiásticas con las civiles. Sin embargo, en algunas ocasiones, cuando la división civil no permitía la congrua sustentación de algún nuevo curato, la autoridad eclesiástica solicitaba modificar la jurisdicción departamental a fin de lograr la congrua sustentación para ambos curatos. ${ }^{51}$

Cada parroquia estaba formada por un extenso territorio, de muchas leguas, que comprendía diferentes poblaciones, "a más de la iglesia parroquial, en donde atiende y sirve el párroco, hay otras iglesias sucursales que atiende el mismo cura por sí solo o con algún sacerdote ayudante” (Bruno, 1972: 141). Sólo tres curatos, Río Cuarto, Villa Nueva y Fraile Muerto, se ubicaron en la región del sudeste, todavía con fronteras imprecisas, lindando con un extenso territorio ocupado por las naciones indígenas. La Tabla 7 muestra la creación de nuevos departamentos y curatos entre 1858 y 1871.

Esta política de expansión parroquial continuó y se afianzó luego de su fallecimiento. Durante la vacancia, el arcediano Gaspar Martiarena ocupó la sede, quien erigió la parroquia de Villa María, desmembrándola de Villa Nueva y la Parroquia de Jesús Nazareno, creando un nuevo curato con ese nombre, el cual fue suprimido en 1876.

El obispo dedicó gran parte de su gobierno a tomar conocimiento, de manera directa, del estado en que recibía la diócesis. Para ello, recorrió personalmente el territorio y realizó tres giras. En 1861, visitó el norte de la provincia de Córdoba, concretamente los curatos de Anejos Norte, San Francisco del Chañar (Sobremonte), Río Seco y Totoral. Al año siguiente, acompañado por tres sacerdotes jesuitas, estuvo seis meses en La Rioja. Entre 1866 y 1868, terminó de recorrer el este y sur de la provincia de Córdoba. Retomaremos este tema en el capítulo siguiente, en el cual presentamos a la diócesis de Córdoba a partir de las visitas pastorales y ad limina.

\footnotetext{
${ }^{49}$ AAC. Libro de Notas, 1859-1873, f.15.

${ }^{50}$ AAC. Leg. 2, TII. Cabildo Eclesiástico, s/f. Auto del 12/11/1869.

${ }^{51}$ Cfr. Expedientes de división de los curatos de Tulumba y Pocho. Leg. 2, TII (Cabildo eclesiástico), s/f.
} 
Tabla 7

\begin{tabular}{|c|c|c|c|c|c|c|c|}
\hline \multicolumn{8}{|c|}{ Creación de Departamentos y Curatos, 1858-1871 } \\
\hline \multicolumn{2}{|r|}{1838} & \multicolumn{2}{|r|}{$1858 / 1859$} & \multicolumn{2}{|r|}{1860} & \multicolumn{2}{|r|}{$1869 / 1870 / 1871$} \\
\hline 1 & Catedral & 1 & Catedral & 1 & Catedral & 1 & Catedral \\
\hline \multirow[t]{2}{*}{2} & \multirow[t]{2}{*}{ Villa del Rosario } & 2 & $\begin{array}{l}\text { Villa del } \\
\text { Rosario }\end{array}$ & 2 & $\begin{array}{l}\text { Villa del } \\
\text { Rosario }\end{array}$ & 2 & Villa del Rosario \\
\hline & & 3 & San Justo $^{4}$ & 3 & San Justo & 3 & San Justo \\
\hline \multirow[t]{2}{*}{3} & \multirow[t]{2}{*}{ Tulumba } & 4 & Tulumba & 4 & Tulumba & 4 & Tulumba \\
\hline & & 5 & Totoral $^{1}$ & 5 & Totoral & 5 & Totoral \\
\hline 4 & Ischilín & 6 & Ischilín & 6 & Ischilín & 6 & Ischilín \\
\hline \multirow[t]{2}{*}{5} & \multirow[t]{2}{*}{ Calamuchita } & \multirow[t]{2}{*}{7} & \multirow[t]{2}{*}{ Calamuchita } & \multirow[t]{2}{*}{7} & \multirow[t]{2}{*}{ Calamuchita } & 7 & Calamuchita \\
\hline & & & & & & 8 & Río de los Sauces ${ }^{7}$ \\
\hline \multirow[t]{2}{*}{6} & \multirow[t]{2}{*}{ Pocho (Salsacate) } & \multirow[t]{2}{*}{8} & \multirow[t]{2}{*}{ Pocho } & 8 & Pocho & 9 & Pocho \\
\hline & & & & 9 & $\operatorname{Minas}^{6}$ & 10 & Minas \\
\hline \multirow[t]{2}{*}{7} & \multirow[t]{2}{*}{ Río Seco } & 9 & Río Seco & 10 & Río Seco & 11 & Río Seco \\
\hline & & 10 & Sobremonte $^{1}$ & 11 & Sobremonte & 12 & Sobremonte \\
\hline \multirow[t]{2}{*}{8} & \multirow[t]{2}{*}{ Punilla } & \multirow[t]{2}{*}{11} & \multirow[t]{2}{*}{ Punilla } & 12 & Punilla & 13 & Punilla \\
\hline & & & & 13 & Cruz del Eje $\mathrm{E}^{3}$ & 14 & Cruz del Eje \\
\hline 9 & Río Cuarto & 12 & Río Cuarto & 14 & Río Cuarto & 15 & Río Cuarto \\
\hline \multirow[t]{3}{*}{10} & \multirow[t]{3}{*}{ Capilla Rodríguez } & \multirow[t]{3}{*}{13} & \multirow{3}{*}{$\begin{array}{c}\text { Río Tercero } \\
\text { Arriba }\end{array}$} & \multirow[t]{3}{*}{15} & Río Tercero & 16 & Río Tercero Arriba \\
\hline & & & & & Arriba & 17 & Jesús Nazareno $^{12}$ \\
\hline & & & & & & 18 & Pampayasta $^{10}$ \\
\hline 11 & Anejos & 14 & $\begin{array}{l}\text { Anejos } \\
\text { Norte }^{1}\end{array}$ & 16 & Anejos Norte & 19 & Anejos Norte \\
\hline & & 15 & Anejos Sur & 17 & Anejos Sur & 20 & Anejos Sur \\
\hline 12 & San Javier & 17 & San Javier & 18 & San Javier & 21 & San Javier \\
\hline & & & & & & 22 & El Tránsito ${ }^{9}$ \\
\hline & & 18 & San Alberto $^{2}$ & 19 & San Alberto & & \\
\hline & & & & & & 23 & San Alberto \\
\hline 13 & Santa Rosa Río & 19 & Santa Rosa & 20 & Santa Rosa & 24 & Santa Rosa \\
\hline & & & & & & 25 & Chalacea $^{8}$ \\
\hline 14 & Tercero Abajo & 20 & Tercero & 21 & Tercero & 26 & Tercero Abajo \\
\hline & & & Abajo & & Abajo & 27 & Villa María $^{11}$ \\
\hline & & & & 22 & Unión $^{5}$ & 28 & Bell Ville \\
\hline
\end{tabular}


1. Gobernador Fragueiro. Decreto del 12/11/1858. Eduardo Ramírez de Arellano, Gobernador del Obispado en sede vacante, Auto del 18/11/1858.

2. Gobernador Fragueiro. Decreto del 04/12/1858. Eduardo Ramírez de Arellano, Gobernador del Obispado en sede Vacante, Auto del 24/12/1858.

3. Gobernador Ferreyra. Decreto del 05/07/1856. Ramírez de Arellano, Obispo, Auto del 06/01/1860.

4. Gobernador Fragueiro. Decreto del 01/12/1859 (Boletín Oficial de Córdoba n ${ }^{\circ} 36$ 09/12/1859). Ramírez de Arellano, Obispo, Auto del 21/07/1860.

5. Gobernador Fragueiro. Decreto del 14/11/1860. Ramírez de Arellano, Obispo, Auto del 14/11/1860.

6. Gobernador Posse. Decreto del 14/06/1862. Ramírez de Arellano, Obispo, Auto del 09/07/1862 (AAC. Leg. 30, f.24).

7. Obispo Ramírez de Arellano, Auto del 12/11/1869 (AAC. Leg. 30, f.30/Leg. 2, TII, s/f).

8. Obispo Ramírez de Arellano, Auto del 31/05/1871 (AAC. Leg. 30, f.24).

9. Obispo Ramírez de Arellano. Se crea el 23/12/1870. Por el Auto del 15/06/1872 se suprime por incongruo. Los curatos de San Javier y San Alberto recuperan los límites que tenían antes de la creación de Tránsito (Leg. 2, TII. Expediente de junio de 1872, s/f).Vuelve a crearse en 1885 (AAC. Leg. 30, f.39).

10. Decreto del 07/01/1870. Obispo Ramírez de Arellano, Auto del 23/04/1870. Fue suprimido el $15 / 06 / 1872$.

11. Decreto de 1874. Gaspar Martiarena. Gobernador del Obispado en sede vacante, Auto del 10/11/1874 (AAC. Leg. 30, f.52).

12. Gaspar Martiarena. Gobernador del Obispado en sede vacante, Auto del 20/06/1873 (AAC. Leg. 30, s/f). Capilla Rodríguez (Punta de Agua y Salto). Pampayasta (Yucat y Chañares).

\subsection{La reforma del clero}

Otra de las preocupaciones del obispo fue el clero, tanto regular como secular. Las medidas destinadas a reformar el clero comenzaron con los regulares. Las antiguas órdenes religiosas, otrora dispersas y con sus templos semi-derruidos, comienzan a reformarse. A fines de la década de 1850, se restablece el convento de La Merced. ${ }^{52}$ En cuanto a los dominicos, en 1857, el padre Olegario Correa, concreta una disposición del capítulo provincial de 1855 e implanta la estricta observancia religiosa, que, posteriormente, adoptarán los restantes conventos dominicos argentinos. Uno de sus discípulos, formado en la austera disciplina y recia espiritualidad impuesta por el padre Correa a su obra restauradora, fue Fray Reginaldo Toro, quien sería futuro obispo de Córdoba.

Los frailes francisanos también retoman la vida en comunidad y regresan en 1853. A los jesuitas, que habían sido expulsados del territorio americano en 1767, se les devuelve la antigua Iglesia de la Compañía. Además del restablecimiento de la disciplina conventual, comenzó a regularse la formación en sus seminarios, los cuales se llenaron de nuevos candidatos. En pocos años, el clero regular adquirió vitalidad y el número de sus miembros aumentó de manera paulatina.

\footnotetext{
${ }^{52}$ Por decreto del Gobernador Roque Ferreyra del 30 de abril de 1857.
} 


\section{Mapa 6}

\section{Curatos de la provincia de Córdoba}

\section{8-1869}

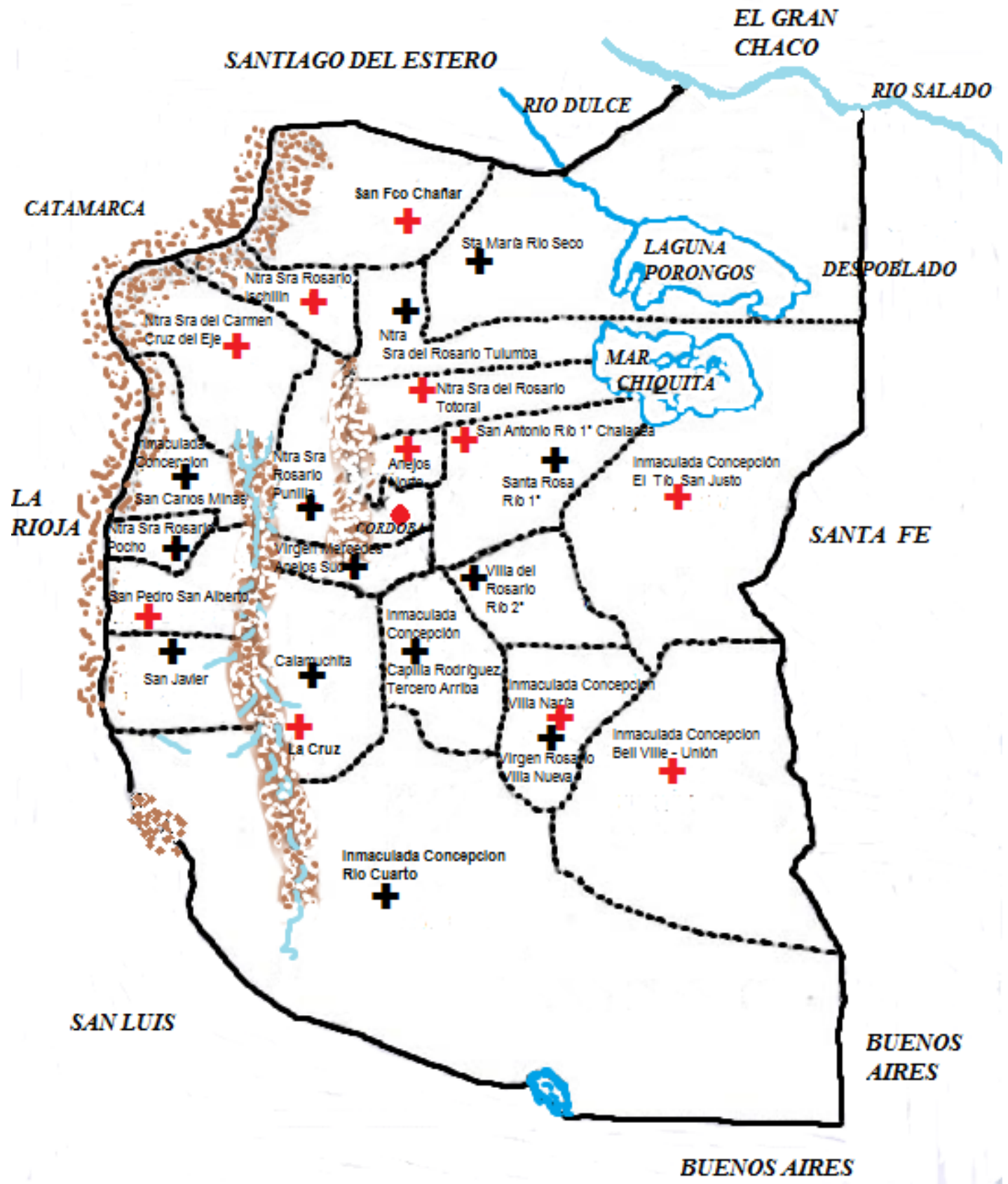

Referencias: Elaboración propia en base al mapa de Córdoba de 1871.

Curatos existentes hasta 1858

Curatos erigidos en la gestión del Obispo Ramírez de Arellano 
José Vicente Ramírez de Arellano, y los siguientes obispos, recurrieron al clero regular para buscar colaboración para llevar a cabo las misiones que comenzaron a realizarse con cierta periodicidad en la campaña. Éstas fueron encomendadas, hasta comienzos del siglo $\mathrm{XX}$, primordialmente, a los jesuitas, debido a su preparación teológica y pastoral. A fines del siglo, otras congregaciones, como los pasionistas, los misioneros de la Sagrada Familia y del Corazón de María colaboraron en la prédica de las misiones.

En cuanto al clero secular, en el decreto del 2 de diciembre de 1859, el obispo dispone que todos los curas de la diócesis envíen a la curia sus títulos y licencias. ${ }^{53}$ Un año después, el 27 de diciembre de 1860, emite un nuevo decreto con el mismo fin, destinado a la Vicaría de La Rioja. "En virtud y firmeza de mis propósitos de llevar a cabo la santa obra que me encomendó Dios y en descargo de mi conciencia he comenzado con el laudable objeto de reformar la disciplina eclesiástica con la debida parsimonia y dirección y establecer -en mi dilatada diócesis destituida por tan prolongado período del consuelo de un Pastor, una canónica administración y gobierno, hemos venido en mandar en precepto pastoral de obediencia lo siguiente: $1^{\circ}$ Todos los señores sacerdotes seculares residentes en la provincia de La Rioja, ya ejerzan o no la cura de almas, entregarán a nuestra Vicaría Foránea para que las remitan a nuestra secretaría las licencias con que ejercen su sagrado ministerio; $2^{\circ} \mathrm{Si}$ hubiere algún sacerdote en aquella provincia que no las haya obtenido lo manifestará nuestro Vicario foráneo para que informe acerca de su domicilio, instrucción, moralidad y determinar así lo más conveniente; $3^{\circ}$ Nuestra Vicaría foránea de La Rioja remitirá a esta secretaría como razón de circunstancia del nombre y número de curatos o parroquias de aquella provincia, de los sujetos que actualmente la desempeñan y de los que han recibido el correspondiente título con el fin de confirmar unos si hubiese lugar y extender el correspondiente a los que carezcan de documento tan necesario si así conviene por su idoneidad eclesiástica y buenas costumbres" ${ }^{54}$ El viario Foráneo Juan Vicente Brizuela informa que Francisco Aguilar, cura de Arauco, y el Sr. Coutiño eran los únicos párrocos que tenían, según ellos mismos aseguraban, competentes credenciales en la provincia de La Rioja y que formaban parte integral de la diócesis. ${ }^{55}$

\footnotetext{
${ }^{53}$ AAC. Libro de Notas, 1859-1873, f.12 y16.

${ }^{54}$ AAC. Libro de Notas, 1859-1873, f.25.

${ }^{55}$ AAC. Libro de Notas, 1859-1873, f.24.
} 
Este decreto ponía de manifiesto la urgente necesidad de conocer al clero que se desempeñaba en los espacios más alejados de la sede y afrontar las cuestiones disciplinares, a fin de evitar posibles abusos en el ejercicio del ministerio. Ante la falta de envío de las licencias y facultades del cura Aguilar, el prelado manifestó enérgicamente al vicario de La Rioja la necesidad de dar el más exacto cumplimiento a sus disposiciones y que "el sacerdocio se relance como debe, comenzando por obedecer con agrado los preceptos de su legítimo Pastor y no ejerciendo en sus respectivos ministerios más facultades que aquellas que se le hayan concedido en bien de las almas". 56 En 1860, el obispo concede un nuevo título para el ejercicio del ministerio, en los límites de su curato, a Martín Valdés, ocupado, interinamente, en Sobremonte hasta "que nos presente sus títulos de confesor y la licencia del Prelado el Diocesano de Salta a cuyo obispado pertenece, para residir fuera del territorio de su jurisdicción". ${ }^{57}$ Uno de los puntos centrales de la reforma iniciada estaba destinado a reforzar la unidad con el obispo y a centralizar el gobierno diocesano. Objetivos que estaban en consonancia con el proceso impulsado desde Roma.

Entre 1859 y 1877 se ordenaron como presbíteros seculares 29 candidatos; 23 diocesanos o domiciliarios de la diócesis de Córdoba (de los cuales dos eran extranjeros, oriundos de España); y 6 extra-diocesanos, dos de Paraná, uno de Salta, uno de Cuyo, uno de Tucumán y otro de Buenos Aires. Eleuterio Mercado, de la Diócesis de Cuyo, tío del Pbro. Pablo Cabrera, ejercerá, a partir de 1882 hasta su fallecimiento, el ministerio en la diócesis de Córdoba (Cfr. Tabla 1 del Anexo II)

En el gobierno del obispo Ramírez de Arellano, las ordenaciones tuvieron una tendencia de crecimiento sostenido, aumentaron considerablemente tanto las de presbíteros como las de clérigos minoristas, como se observa en la Tabla 7. Los minoristas suman un total de 31 (Cfr. Tabla 2 del Anexo II).

Algunos datos de los ordenandos nos permiten inferir el nuevo perfil del clero que se está delineando. El caso de Francisco Martínez del Val sugiere algunas lecturas interesantes. Era español, de la diócesis de Burgos, hijo legítimo de Manuel Martínez y Prudencia del Val, de 37 años de edad. En 1873, solicita, al obispo diocesano de Córdoba, ordenarse como clérigo secular domiciliario, luego de haber estado por el lapso de un año

\footnotetext{
${ }^{56}$ AAC. Libro de Notas, 1859-1873, f.26.

${ }^{57}$ AAC. Libro de Notas, 1859-1873, f.25.
} 


\section{Tabla 7}

\begin{tabular}{|c|c|c|}
\hline \multicolumn{3}{|c|}{$\begin{array}{l}\text { Ordenaciones del clero secular de Córdoba } \\
1859-1876\end{array}$} \\
\hline Años & Presbiterado & $\begin{array}{c}\text { Tonsura y Ordenes } \\
\text { Menores }\end{array}$ \\
\hline 1859-1861 & 1 & 3 \\
\hline $1862-1864$ & 2 & 4 \\
\hline $1865-1867$ & 3 & 11 \\
\hline $1868-1870$ & 3 & 4 \\
\hline $1871-1873$ & 7 & 8 \\
\hline $1874-1876$ & sede vacante 4 & 1 \\
\hline & Total 20 & Total \\
\hline
\end{tabular}

(1868) en el convento de San Francisco de Buenos Aires. Su primera petición fue denegada y no se le concedieron las dimisorias para la ordenación, las razones señaladas en el informe se refieren a la falta de estudios, a no haber concluido la carrera escolar y carecer de título. Al siguiente año, renueva la solicitud y vuelve a ser rechazada, esta vez, por carecer de patrimonio, no obstante lo cual, se remite la consulta al delegado apostólico en la Corte de Brasil. Si bien no conocemos la respuesta, en el libro de órdenes encontramos que recibió la ordenación presbiteral el 24 de marzo de 1874 e inmediatamente se lo destinó a la campaña con cura de almas, a uno de los curatos más pobres de la Diócesis, Anguyon en La Rioja; ${ }^{58}$ en 1881, lo encontramos como cura coadjutor en Villa del Rosario y luego pasó como cura y vicario interino a los curatos de Calamuchita e Ischilín. ${ }^{59}$ Este caso podría dar cuenta de que la necesidad de clérigos primaba por sobre las condiciones de idoneidad. Se perfila un nuevo tipo de cura destinado a la atención pastoral de las almas. El modelo remite a la figura del Cura de Ars, patrono de los párrocos. Volveremos a retomar este tema cuando analicemos el clero secular en la cuarta parte de la tesis.

Otra cuestión importante es analizar la distribución de estos individuos en el espacio territorial. Quedó dicho que en el período anterior la mayoría del clero se concentraba en la ciudad. El Obispo Ramírez de Arellano, según puede deducirse de los expedientes a órdenes, otorgó el título de coadjutor de párroco y, en menor número, se ordenó a título de

\footnotetext{
${ }^{58}$ AAC. Libro de Títulos (1859-1904), f.58,70,76,79. El primer nombramiento lleva la fecha del 26/08/1875.

${ }^{59}$ Libro 30 Licencias, f.155/AAC. Deán Funes, Libro de Bautismos n 1, f. 338, Bautismos 1884-1890, f.329.
} 
patrimonio o capellanía, esto le permitió disponer del clero para destinarlo a donde lo considerara de mayor utilidad, donde no fuera apetecible ir, por la pobreza del beneficio, la distancia de la ciudad, etc. No pudimos determinar si la disposición de enviar a los clérigos recién ordenados a la campaña a estaba destinada a mejorar su formación como "cura" o respondía sólo a una necesidad pastoral. Lo que sí podemos afirmar es que aquellos que recibieron como primer destino la ciudad eran hijos de familias muy tradicionales de Córdoba o La Rioja. Yaniz, Castellanos, Cabanillas, Luque, Gordillo y Díaz, pertenecían a las familias más granadas de la sociedad de entonces, en tanto a los curatos pobres de la campaña se envió a clérigos de origen extranjero, formados en el seminario, y/o hijos de familias humildes. León Gallioz era, según consta en su expediente a órdenes, natural de Thyl (Francia), de la parroquia de la diócesis de Maurrienn en Saboya. En el informe de solicitud de órdenes, relata brevemente su historia personal. En su tierra, ingresó al Instituto de la Sagrada Familia, allí recibió primera tonsura; en 1852, debido a las convulsiones de 1849 se trasladó a Estados Unidos en compañía del obispo Cretin, a cuyo lado permaneció hasta su fallecimiento, en 1858; en 1860, asuntos de familia lo obligaron a regresar a su país y pocos meses después, acompañando a su familia, se trasladó a Argentina; aquí se instaló en Santa Fe y consiguió trabajo en el colegio de Concepción del Uruguay en calidad de inspector; luego de unos años, pidió ser acogido en la diócesis de Córdoba e ingresó al seminario conciliar; en 1864, a los 38 años de edad, solicitó ser ordenado, adjuntó las letras dimisoriales necesarias para ser adscripto a la diócesis de Córdoba y el resto de la documentación pertinente, incluida la declaración del superior de la Sagrada Familia, que certificó que había sido desligado de los votos temporales que tenía. El Rector del seminario, Uladislao Castellano, adjuntó un informe favorable en el cual señalaba que "ha observado una conducta moral intachable observando el recogimiento propio del estado sacerdotal al que se ha mostrado ardientemente inclinado [...] se ha distinguido por el estudio asiduo que privadamente ha hecho particularmente de algunos tratados de la teología dogmática, de la moral y ha principiado el curso de teología de tercer año. Entre el 29 de abril y el 6 de junio de 1864, el Obispo Ramírez de Arellano le confirió todas las órdenes, hasta el presbiterado, bajo el título de coadjutor a párroco. No conocemos su primer destino, ya que no figura ni en el libro de títulos ni en el de licencias, ni aparece en 
los legajos de las parroquias, lo que encontramos es que en 1870 aparece como cura y vicario en Río Ceballos. ${ }^{60}$

De los siete curas destinados a la campaña cordobesa, dos tuvieron el mismo destino, el curato de Anejos, con cabecera en Alta Gracia, un curato muy cercano a la ciudad, que había sido Iglesia de la estancia jesuítica, poseía más de diez capillas y era congruo, es decir sus ingresos eran suficientes para el mantenimiento del párroco. Lo mismo puede decirse del curato de Anejos Norte, con cabecera en Jesús María, otra de las estancias jesuíticas, distante pocos kilómetros al norte de la ciudad capital.

Sin duda, con el advenimiento del Obispo Ramírez de Arellano, la iglesia de Córdoba comenzó a organizarse institucionalmente. Los ejes centrales del plan reformador fueron continuados por los siguientes obispos y podrían resumirse en los siguientes puntos:

a) Centralización y aumento del poder episcopal.

b) Reforma y disciplina del clero.

c) Consolidación de la presencia de la Iglesia en el espacio territorial, mediante las visitas canónicas, la creación de curatos, la reconstrucción y edificación de nuevos templos. Construyendo una teología de la Visibilidad.

d) Educación católica y religiosidad de los sectores populares.

e) Construcción de una nueva cristiandad, restaurando la mítica "civilización parroquial", con una concepción moderna.

\footnotetext{
${ }^{60}$ AAC. Leg. 24, TVII, 1845-1865, Expediente de Ordenes de León Gallioz. Libro de Títulos del Clero 18541904, f.37 y 38 .
} 


\section{CAPÍTULO 6}

\section{EL PODER ECLESIÁSTICO}

\section{La institucionalización de la Iglesia diocesana (1876-1904)}

Al Obispo Ramírez de Arellano lo sucedieron cinco obispos en el gobierno de la diócesis durante los años que dura esta investigación. Manuel Álvarez (1876-1878), Fray Mamerto Esquiú (1881-1883) y Fray Juan Capistrano Tissera (1884-1886), cada uno estuvo sólo dos años al frente de la diócesis. Luego se dan seis años de sede vacancia a cargo de provisores, Uladislao Castellano (1878-1880 y 1886-1888) y Jerónimo Clara (1883-1884), ambos miembros del cabildo eclesiástico y dignos representantes del clero secular cordobés. En 1888, Córdoba tuvo un obispo que gobernó durante 14 años, Fray Reginaldo Toro (1888-1902), a quien sucedió Fray Zenón Bustos con un gobierno efectivo de otros 14 años (1905-1919) y debido a una enfermedad que lo llevó a la muerte en 1925, se retiró del gobierno delegando el mismo en Monseñor José A Luque.

Sin duda, la reforma espiritual y disciplinaria llevada a cabo por los regulares en décadas anteriores (Di Stefano y Zanatta, 2000: 299-302), posibilitó el acceso de algunos de sus miembros a la sede episcopal provincial, pues la elección de obispos diocesanos del período analizado recayó en cuatro frailes, Mamerto Esquiú (O. M); Juan Capistrano Tissera (O. M.), Reginaldo Toro (O. P.) y Zenón Bustos y Ferreyra (O. M.), los dos últimos activos reformadores de sus respectivas órdenes.

La preocupación de todos ellos estuvo puesta en reorganizar la institución eclesiástica. Las líneas de acción estuvieron orientadas, fundamentalmente, en dos direcciones explícitamente señaladas por el obispo Álvarez al inicio de su gobierno: la necesidad de organizar la Iglesia y dotarla de una mayor institucionalización e impulsar la reforma pastoral. Para alcanzar el primer objetivo, en 1877 convocó a un Sínodo diocesano, que analizaremos más abajo. En cuanto al segundo, en su primera carta pastoral fijó estos propósitos evangelizadores: "mi primer cuidado será el cultivar la piedad y la ciencia en el clero. También considero un deber primordial el reanimar el espíritu católico de mis amados diocesanos, con la educación cristiana de los niños y el espíritu religioso de los fieles. Mi obligación y mis deseos son de atender hasta el último rincón del obispado" 
(Bruno, 1972: 165). Estas preocupaciones comunes a todos los obispos, se vieron teñidas por la realidad política y social del obispado y por los conflictos suscitados a nivel provincial y nacional con el estado liberal. Entre 1880 y 1890, las relaciones con el gobierno se convirtieron en un delicado y sensible punto.

\section{Los conflictos con el Estado (1880-1890)}

El proyecto de modernidad liberal de 1880, impulsado por el Estado nacional, implicó un proceso de cambio basado en la creencia del progreso indefinido, fundado en la capacidad transformadora de la ciencia y de la técnica, en la difusión de la enseñanza pública y en la secularización de las instituciones. Por sus dimensiones secularizadoras, confrontó con la jerarquía eclesiástica. La contienda entre ambos actores se centró en la implementación de las llamadas "leyes laicas", la definición de prerrogativas de ambas instituciones, Iglesia-Estado, no estuvo exenta de acalorados debates y conflictos. ${ }^{2}$

En 1880, cuando Fray Mamerto Esquiú fue nombrado obispo de Córdoba, Miguel Juárez Celman, miembro de la elite liberal cordobesa, asumía como gobernador de la provincia. Juárez Celman llevará a cabo una serie de medidas destinadas a excluir al clero de la instrucción pública, ${ }^{3}$ secularizar los registros de nacimientos, casamientos y defunciones, ${ }^{4}$ dejar la provisión de curatos a cargo de la autoridad civil, ${ }^{5}$ suprimir la Facultad de Teología de la universidad. Medidas que afectaron directamente a la Iglesia y a las relaciones entre las autoridades civiles y eclesiásticas. Esta progresiva laicización del estado apuntaba a

\footnotetext{
${ }^{1}$ Nos referimos, principalmente, a las leyes de Registro Civil (1884) y de matrimonio civil (1889), la secularización de los cementerios, la supresión de la Facultad de Teología de la Universidad de Córdoba y la educación. Córdoba no secundó el accionar del poder nacional planteado en la Ley 1420, que propiciaba el carácter laico, gratuito y obligatorio de la educación, sólo reconoció la gratuidad y obligatoriedad escolar, mediante la Ley de Instrucción Obligatoria de 1884 y en 1896 se sancionó la Ley de Educación Común.

${ }^{2}$ Para ampliar este tema, véase BRUNO (1976); AUZA (1981) y DI STEFANO y ZANATTA (2000).

${ }^{3}$ En 1884, comenzaría a funcionar la Escuela Normal con maestras protestantes extranjeras. En relación a este asunto, tuvo lugar la mayor crisis producida entre el Gobierno y la Iglesia y Córdoba fue el centro de la misma, la cual culminó con la expulsión del delegado apostólico Luis Mattera. El Vicario Capitular emitió dos pastorales exhortando a los fieles católicos a no enviar a sus hijas a las escuelas fiscales. El dictamen del procurador fiscal de Córdoba decretó la separación del Prelado del gobierno de la Diócesis, la suspensión de oficio y de beneficio en el coro de su Iglesia. El poder ejecutivo expidió, el 3 de junio de 1884, el decreto de suspensión. En este clima, se debatió la ley de educación común, pero Córdoba no aprobó la ley 1420 sancionada a nivel nacional.

${ }^{4}$ Ley de Registro Civil, promulgada para la ciudad en 1880 y para la provincia en 1889 .

${ }^{5}$ Decreto del presidente Roca del 31 de julio de 1886 sobre provisión de curatos: declara curas propietarios a los párrocos interinos de la capital y dispone que, en adelante, dichas parroquias se proveyeran por concurso, según lo establece el Concilio de Trento. El gobernador de Córdoba dictó un decreto similar al del gobierno nacional.
} 
desplazar a la Iglesia de algunos espacios que había ocupado hasta entonces, poniéndose en el centro del debate por el dominio del espacio público. La elite liberal procuró laicizar ese espacio y la Iglesia se vio obligada a reformular su lugar en la sociedad. La redefinición de los espacios de influencia de ambas instituciones se convirtió en un campo de fricción. No se trataba de un estado plenamente conformado, que desplazaba a una Iglesia débil, sino de un enfrentamiento, muchas veces en igualdad de condiciones, entre dos actores sociales protagónicos por la delimitación y ocupación de un espacio en construcción. La concepción de estado laico, al que aspiraba la elite liberal, no fue la de un estado neutral en cuestiones religiosas. Pretendía relegar a la Iglesia fuera de la vida pública, no reconociendo a la religión otro deber que el de contenerla en los límites de lo considerado por el gobierno civil como puramente espiritual y moral.

El avance del estado sobre cuestiones hasta el momento exclusivamente eclesiásticas generó conflictos que alcanzaron su punto de mayor virulencia en 1884, recordado por los católicos cordobeses como el año de la "persecución religiosa". Hemos abordado esta confrontación como un lente a través del cual acercarnos a las representaciones, actitudes y conductas de la jerarquía eclesiástica provincial. En la cuarta parte de la tesis volveremos sobre el tema para analizar las prácticas del clero parroquial en la implementación de las mismas. Aquí sólo presentamos la concepción de las relaciones con el estado, desde la mirada de los mismos actores, que, a nuestro parecer, permite matizar las apreciaciones de gran parte de la historiografía provincial, que presenta al clero provincial del último cuarto del siglo XIX como un sector hegemónico, homogéneo y combativo, que implementó una tenaz "resistencia", practicada con singular decisión, a fin de obstruir el avance liberal (Roitenburd, 2000 y 20001 y Vidal, 2001). Entre los autores que sostienen esta postura, Roitenburd (2000: 149) señala que la estrategia clerical se manifestó por su animadversión a las prácticas políticas modernas. La historiografía confesional muestra igualmente la existencia de un clero monolítico, un cuerpo colegiado que actuó en defensa de los intereses de la Iglesia católica contra los errores del liberalismo, presentando una versión triunfalista de la iglesia cordobesa frente al avance liberal (Bruno, 1981).

Resulta difícil pensar en la existencia de una doctrina católica que concibiera las relaciones entre la Iglesia y el Estado de manera única y unidireccional, por el contrario, sostenemos una mirada más acorde con la nueva historiografía (Mallimaci y Di Stefano, 
2001: 20; Cárdenas Ayala, 2008; Serrano, 2008), que admite la existencia de diversas posiciones frente al ideario liberal, que llevaron a la jerarquía a implementar estrategias que fueron desde la conciliación con el liberalismo dominante hasta el enfrentamiento a sus postulados.

Aquí nos detendremos a analizar la postura de los obispos diocesanos y gobernadores eclesiásticos del período. Advertimos tres posiciones, que agrupamos en función de la formación teológica y pastoral de los prelados. Los obispos formados en la tradición franciscana muestran una postura tendiente a mantener relaciones armoniosas con el estado, por las cuales acceden y negocian algunos requerimientos, sin ceder en las cuestiones de fondo, y reafirman con fuerza los derechos de los ciudadanos. Atribuimos esta actitud a su formación religiosa. No podemos olvidar que, como señala Silvano Benito Moya (2000: 393), en su libro Reformismo e Ilustración, la reforma más grande que se hizo en la universidad durante la regencia franciscana fue la apertura a las doctrinas regalistas y la ilustración. "El racionalismo, el conocimiento de los empiristas ingleses y enciclopedistas, abrieron nuevos caminos a la modernización". Esta apertura, sin duda, debe haber trascendido las fronteras de la universidad, derramándose sobre la formación del clero de la orden franciscana. Concretamente, los obispos Esquiú y Tissera coinciden en mantener la armonía con el estado, un estado que para ellos debía garantizar la libertad de las conciencias, respetar y defender la religión de la mayoría de los ciudadanos. En tanto, los provisores, Castellano y Clara, formados en el seminario diocesano, regenteado por los jesuitas, mantuvieron una línea más intransigente y de abierto enfrentamiento con el estado liberal, mientras Fray Reginaldo Toro, de la orden de los Predicadores, siguió, a nuestro parecer, la argumentación de Santo Tomás de Aquino, maestro de la Orden Dominica, revalorizado con la expansión del tomismo, luego del Vaticano I. Allí se afirma que el hombre, en tanto ciudadano, debe participar en el gobierno y elaboración de las leyes, y refuerza, a su vez, el concepto de "estado autónomo", dado que sus fines se diferencian de los de la Iglesia ("congregación de hombres": fines naturales / "congregación de fieles": fines espirituales). Estas convicciones se reflejan en las posiciones adoptadas por cada uno de ellos. 


\section{El gobierno de la diócesis}

\subsection{Los obispos franciscanos Esquiú y Tissera}

Fray Mamerto Esquiú era miembro de la generación de clérigos del $53 .{ }^{6}$ En su Catamarca natal, pronunció vario sermones, denominados "Patrióticos", en los cuales manifiesta su posición al respecto. En el discurso titulado "La Constitución Nacional", promulgado con motivo de la firma y promulgación de la carta magna, formula algunas de las líneas directrices de su pensamiento respecto de este tema y que luego reformulará en los sermones de 1856, 1862 y 1875 (Avellaneda, 1917; Cano, 1961). Tres son los conceptos que nos interesa plantear del pensamiento del fraile franciscano, que se vinculan directamente con su concepción de las relaciones entre autoridades civiles y eclesiásticas. El primero tiene relación con la función de la ley y el individuo en un estado republicano y democrático.

Que el individuo, el ciudadano no sea absorbido por la sociedad: que ante ella se presente vestido de su dignidad y derechos personales; que éstos queden libres de la sumisión a cualquier autoridad! (Esquiú, 1945 [1853]: 11).

La dignidad y el derecho del individuo no debe quedar sometido, el ciudadano debe resistirse ante el impulso tiránico de los gobiernos. Para evitar tanto la tiranía como la anarquía es necesaria la ley. Sin ley no hay progreso ni porvenir. La Constitución es esa ley que no cambia, que no debe ceder ante las conveniencias de los hombres, sino que debe ser fija, pues vela por el bien y los intereses de todos los ciudadanos. A esa ley, el ciudadano le debe sumisión.

La vida y la conservación del pueblo argentino dependen de que su Constitución sea fija, que no ceda al empuje de los hombres, que sea un ancla pesadísima a que esté asida esta nave [...] Me diréis, nosotros queremos progreso, libertad y porvenir y lo inmóvil es inerte, no vive. Pero señores, los principios no progresan y la ley en el orden es como el axioma en el orden científico: la ley es el resorte del progreso, y los medios no han de confundirse con los fines, libertad y no hay más libertad que la que existe según la ley (Esquiú, 1945 [1853]: 15).

Aunque el poder civil, el Estado, no proteja la religión, no impida la enseñanza del error, el ciudadano le debe obediencia, respeto y cumplimiento de sus leyes.

\footnotetext{
${ }^{6}$ Algunos textos sobre su vida y pensamiento, ORTIZ (1883); GONZÁLEZ (1905); AVELLANEDA (1917); CÓRDOBA (1926); GÁLVEZ (1931); CATURELLI (1953); CANO (1961); BAZÁN (1966); SANCHEZ DE LORIA PARODI (2002).
} 
Ante la ley es necesaria la sumisión, pronta la acción de la carta constitucional es vastísima y se halla en oposición casi a toda la actualidad de la república; es una savia que tiene que penetrar enmarañadas $\mathrm{y}$, multiplicadas fibras, que necesita mucho tiempo para vivificar totalmente el sistema [...] República Argentina! Noble Patria! ¡Cuarenta y tres años has gemido en el destierro! ¡Medio siglo te ha dominado tu eterno enemigo en sus dos fases de anarquía y despotismo i [...] Sumisión universal, que abrase todos los puntos de la ley sin exceptuar ninguno [...] ¿Y la Religión, me diréis, ¡y la conciencia? ¡Cómo entregaremos a lo temporal lo que es eterno? ¿Cómo hemos de obedecer a los hombres primeramente que a Dios? [...] Ya a nombre de esta Religión sublime y eterna os digo, católicos: obedeced, someteos, dad al Cesar lo que es del Cesar y a Dios lo que es de Dios. El poder civil protegía la Religión, impedía la enseñanza del error, alejaba con su vibrante espada al incircunciso profanador [...] ¿Niega ahora su decidida protección, deja al descubierto las avenidas del error, guarda su espada? Dejadle, someteos. Omnis anima súbdita sit sublimio oribus potestatibus, non solum propteriram, sed etiam propter conscientiam. ${ }^{7}$ Roma era pagana, era cruel, mataba a los cristianos, sin más delito que ser discípulo de Jesús, [...] y con todo eso el apóstol Pablo decía Civis Romanus sum ego [...] los cristianos obedecían, respetaban y defendían las leyes de su patria [...] La Religión quiere que obedezcáis, jamás ha explotado en favor suyo ni la rebelión ni la anarquía [...] Obedeced, señores, sin sumisión no hay ley; sin leyes no hay patria, no hay verdadera libertad, existen solo pasiones, desorden, anarquía, disolución, guerras y males de que Dios libre eternamente a la República Argentina (Esquiú, 1945 [1853]: 16-18).

Las definiciones son claras y contundentes y se repiten en varios sermones. Al estado y a la ley se le debe obediencia, sumisión y respeto. En el sermón, con motivo de la instalación de las autoridades federales en Catamarca, vuelve sobre estos temas relativos a la obediencia al estado y sus leyes. "Un gobierno, que en vez de cetro, tiene en su mano la carta de nuestros derechos y cuya persona se anonada ante la ley y sus deberes, cuya única base es la justicia, he ahí señores el inmenso beneficio de que os hablo" (Esquiú, 1945 [1853]: 20).

"Las bases del gobierno no son el apiñamiento de todas las personas, de todas las vidas, de todos los intereses que haría el trono de un dictador, sino las mismas garantías del ejercicio de nuestras facultades, el uso libre y cumplimiento de todos nuestros derechos, ese es el único camino para llegar al recinto de la autoridad [...] Nuestra organización consta de leyes y del poder público que las hace ejecutar. Respetad uno y otro, sofocando pasiones mezquinas de antipatías personales y de espíritu de partido" (Esquiú, 1945 [1853]: 26). En el sermón pronunciado en la catedral, en octubre de 1861, titulado "Preces por la Paz de la

\footnotetext{
7 “Toda alma se someta a las potestades superiores, no es sólo a causa de la ira, más aún por una cuestión de su propia conciencia”.
} 
República”, el obispo advierte que las consecuencias de la desobediencia a las autoridades legítimamente constituidas es el mal de la guerra. Y retoma la idea de que un ciudadano cristiano debe obediencia a la ley, a las instituciones y a la autoridad. "Tal es el espíritu de inobediencia a la autoridad pública, al magistrado y a las leyes, que se ha infiltrado en casi todos los ánimos, con solo suprimir el deber cristiano que todos tenemos de obedecer a los que nos mandan con autoridad legítima [...] como señala el apóstol Pedro cuando le dice a los romanos sed sumisos y obedientes a todos, sea el príncipe, sea a sus empleados y esto por causa de la obediencia que debéis a Dios (Petr II) o San Pablo, obedeced no solo por temor sino por deber de conciencia (Rom XIII). Pero en este estado de rebelión de las autoridades legítimas en que nos hallamos, con la piedad cristiana ha desaparecido igualmente todo patriotismo, desde que no se respetan las leyes, las instituciones, los representantes de la patria tan desgarrada y envilecida por sus propios hijos (Esquiú, 1945 [1861]: 26). La base y el fundamento de toda autoridad y de toda organización social viene de Dios, "Juzgad vosotros si la naturaleza, la ley, el modo de ser de la humanidad emanan de la cabeza de Rousseau, o de Dios, autor del universo [...] Juzgad, os digo, si es verdad tan grande como el universo: onmia in ipso constant, es aplicable, o no a la organización de un pueblo y si para darle su constitución os bastará el contrato social o deberéis fundaros sobre Dios, única base de la idea y de la realidad del derecho del deber, de la autoridad, de la obediencia, de las obligaciones que forman el alma de este pueblo" (Esquiú, 1945 [1875]: 59).

Con motivo de la asunción del primer gobernador federal en Catamarca, Octaviano Navarro, el discurso del Padre Esquiú giró en torno de la religión del estado. Sostiene que la constitución provincial reconoce la única religión que existe en la provincia $y$, en consecuencia, declara que es religión del gobierno, por la sencilla razón de que debe ser una entidad análoga al pueblo. La constitución no sólo afirma que el gobierno sostiene el culto, sino "que la Religión es la vida de los pueblos, es el primer elemento de orden y la obligación más fuerte del gobierno es protegerla, es respetarla" (Esquiú, 1945 [1856]: 36).

En 1875, en su célebre discurso sobre la reforma de la constitución, cuestiona dos puntos sostenidos por la elite liberal: $1^{\circ}$ ) que el cristianismo sea una cuestión exclusivamente privada, es decir una cuestión exclusivamente de la conciencia individual de los hombres, y $\left.2^{\circ}\right)$ que en el orden público no haya sujeto religioso. Con respecto al primer punto, 
argumentaba la necesidad del reconocimiento de la religión católica como única religión verdadera y la prescripción de no dar leyes ni actos administrativos contrarios a su doctrina y jurisdicción. En relación al segundo punto, sostenía que "si el orden público fuese mera abstracción me esforzaría, señores, por colocarme en esa región de lo abstracto y estudiar allí sus propios principios y relaciones, pero yo veo y no puedo dejar de ver que el orden público no es sino un agregado de los derechos, intereses y deberes de las conciencias privadas, elevado todo a una región más alta que la del individuo y la familia, pero siempre inferior a Dios [...] el orden público es al individuo lo que la circunferencia al centro, porque y todo él recae sobre el derecho y el deber de cada conciencia". ${ }^{8}$ Esta visión del espacio público disiente incluso con la posición católica-liberal encarnada por Estrada y compartida por otros miembros de la elite liberal católica provincial, ${ }^{9}$ quienes adherían a la idea que la Iglesia se emancipase de la tutela del Estado. Esquiú reprueba la separación entre Iglesia y Estado y sostiene la necesidad de la libertad de cultos basada en el respeto a la Iglesia y la convicción de que el estado no es sujeto de religión, pues la verdad religiosa no podía tener por sujeto la colectividad, sino al individuo, ya que el sentido religioso es una modalidad psicológica. Para Esquiú, un pueblo católico no podía prescindir de su ser católico cuando se trataba de su vida pública, de su organización política, de sus leyes y de su administración gubernativa. De donde se sigue que la separación de la Iglesia del Estado y la libertad de cultos con prescindencia de la religión en el orden político eran para Esquiú anticatólicas. El obispo entendía que "si la religión católica es declarada y profesada Religión del Estado de un modo sincero y no irrisorio, y a esto se agrega la libertad de cultos, tendríamos Religión en el Estado y tolerancia privada o pública de los demás cultos; tal modo de ser no está absolutamente prohibido por la Iglesia". ${ }^{10}$

Es interesante esta concepción que plantea la posibilidad de la religión católica para el Estado y libertad de cultos para la sociedad civil, mirada que se identificaba perfectamente con el ideario liberal en boga. Un estado católico que mantenía los derechos del Patronato y una sociedad que sostenía la tolerancia religiosa para todos los ciudadanos. Si el estado fuera verdaderamente católico no ejercería en nombre del patronato una acción despótica

\footnotetext{
${ }^{8}$ AAC. Fondo Esquiú. Sermón del 24 de octubre de 1875, f.75.

${ }^{9}$ Cfr. CAFFERATA, Juan F., “Dr. Tristán Achával Rodríguez, su centenario”, Buenos Aires, 1945. Discurso pronunciado en el Teatro Rivera Indarte de la Ciudad de Córdoba.

${ }^{10}$ Citado en Ibid., f.96.
} 
sobre la Iglesia, confiscando sus bienes, proscribiendo institutos religiosos, impidiendo la comunión de obediencia con el Pastor supremo de la Iglesia y pretendiendo coartar su jurisdicción divina, ese patronato lejos de provenir de la fe católica del Estado, proviene del espíritu contrario a ella [...] De aquí resulta que el único medio para liberar a la Iglesia de ese odioso despotismo es reconocerla sinceramente y prestar entera obediencia a este mandato de Jesucristo: Dad al Cesar lo que es del Cesar y a Dios lo que es de Dios" (Esquiú, 1945 [1875]: 65). Creo que aquí radica el núcleo del pensamiento del Obispo Esquiú.

Esquiú resuelve con un tono negociador los conflictos que se suscitaron con las autoridades civiles con motivo de la secularización de los cementerios en la Vicaría Foránea de La Rioja y en la localidad de Ballesteros, curato de Bell Ville. En ambas oportunidades, buscó soluciones de consenso y cedió al gobierno la administración del cementerio, sin renunciar a los derechos de la Iglesia católica sobre el mismo (Bruno, 1976: 186-187). El deseo de conciliar los derechos del gobierno civil con los de la Iglesia fue una idea fuerza en el Obispo Esquiú, que buscó armonizar la potestad civil con la eclesiástica, evitando, de ser posible, el conflicto entre ambas. Conducta que puso en práctica con motivo de un conflicto suscitado en algunos puntos de la diócesis por la administración de los cementerios.

En diciembre de 1882, Esquiú le comunica al Delegado Apostólico Mattera, que se trasladará a Bell Ville "a reclamar con suplicas la entrega del cementerio católico de que se ha apoderado violentamente la municipalidad del lugar", y le avisa su intención de demandar, ante tribunales competentes, a los autores de la violación y usurpación del cementerio sino consigue "la reparación por medio de la súplica". ${ }^{11} \mathrm{~A}$ los pocos días vuelve a escribir y comunica que ha "exigido solamente que la Municipalidad devuelva al párroco el cementerio y que una vez que se reconozca la jurisdicción eclesiástica en esa materia, la Municipalidad tendrá toda la intervención que desea". ${ }^{12}$ Dirigiéndose al gobernador delegado de La Rioja por un conflicto similar, le comunica que un cementerio católico es un lugar sagrado y su administración corresponde a la autoridad eclesiástica. Animado por

\footnotetext{
${ }^{11}$ Archivos Secretos Vaticanos [en adelante ASV]. Archivo Nunziatura del Brasile, Libro 63, fascículo 306, f.74.

${ }^{12}$ ASV. Archivo Nunziatura del Brasile. Libro 63, fasc. 306, f.77. Carta dirigida al Nuncio Mattera, fechada en La Rioja el 3 de enero de 1883.
} 
el deseo de conciliar los intereses con los deberes y de evitar todo conflicto, modificó el reglamento de los cementerios. ${ }^{13}$

Para el obispo, la vida política se basaba en la organización de la convivencia, tenía clara conciencia de que la virtud es fuente de solidaridad y de que el orden de la ley debía estar al servicio del orden de la amistad y la solidaridad. "Si bien las leyes tienen por objeto crear el orden de derecho, tienen por fin promover la amistad de los hombres" (González, 1914: 389). Esquiú señala al Delegado apostólico que, lamentablemente, este tipo de conflictos "pululan en toda los puntos de la diócesis", y considera que no son otra cosa que una forma particular de la gran cuestión entre el cristianismo y el naturalismo, cerraba la nota afirmando "creo que es llegado el caso de obrar suaviter et fortiter". ${ }^{14}$ El Prelado sostenía que con "el otro", caracterizado por el "liberalismo enemigo de la iglesia", se debía actuar con la caridad cristiana y la moderación. En este sentido, reprende a los responsables de la prensa católica por reproducir conceptos poco satisfactorios sobre autoridades civiles liberales. En sintonía con el pensamiento del Papa León XIII, proclamó la autonomía de las potestades civil y eclesiástica "libres y expeditas cada una de ellas en el desempeño de sus respectivas funciones; pero con este aditamento: que a las dos conviene y a todos los hombres interesa que entre las dos reinen la unión y la concordia". ${ }^{15}$ En medio de este conflicto, el obispo falleció en Pozo Suncho el 10 de enero de 1883.

Fray Capistrano Tissera, sucesor de Esquiú en la silla episcopal, mantuvo la misma línea de conducta, quizás sin la firmeza y decisión del primero. Heredó los conflictos iniciados en la gestión eclesiástica anterior. Al asumir el gobierno del obispado, envió una nota a los gobernadores de las dos provincias, en la cual explicitaba su preocupación por mantener la armonía entre ambas potestades.

No ignoráis Ilmo. Señores y amados hijos, que de la buena armonía entre las autoridades eclesiástica y civil, del mutuo acuerdo entre la Iglesia y el Estado emanan bienes fecundísimos, no solo para el acierto en el gobierno sino también para la prosperidad, paz y progreso moral y material y para la ventura y engrandecimiento de los pueblos. Es muy sabido que la religión, la piedad y la virtud hacen felices a las Naciones y especialmente a los pueblos de instituciones democráticas porque sólo la

\footnotetext{
${ }^{13}$ Cfr. BRUNO (1976, TXI: 187).

${ }^{14}$ ASV. Archivo Nunziatura del Brasile. Libro 63, fasc.306, f.75. Carta dirigida al Nuncio Mattera fechada en Bell Ville de diciembre a enero de 1882.

${ }^{15}$ León XIII Encíclica Arcanum Divinae Sapientiae (Sobre el matrimonio cristiano), 10-II-1880, en Enciclicas Pontificias, 1832-1965, Editorial Guadalupe, Buenos Aires, 1963. 2T. p. 445.
} 
religión, la piedad y la virtud dan a cada uno la conciencia de sus deberes y enseñan una sanción segura al sacrificio, a la abnegación y al heroísmo. La religión es la que consagra las leyes, unge a las autoridades supremas del Estado con el óleo de la veneración y el amor de los pueblos, les da una misión casi divina en dirigir sus destinos y los hace responsables de sus desgracias. Llamados a gobernar un pueblo eminentemente católico en su inmensa mayoría, esperamos, y os lo rogamos por amor a Jesucristo, que cooperéis hasta donde alcancen vuestras fuerzas a que la religión y la fe de nuestro mayores sea venerada y respetada porque creemos que la fe católica es la ancha base en que únicamente pueden descansar la unidad y la grandeza de nuestra Patria querida, después de tantos trastornos y sacrificios: como también creemos que solamente ella tiene medios morales para curar llagas e impedir que el cáncer de la corrupción invada el cuerpo social en estos tiempos aciagos [...].

[...] para alcanzar la verdadera grandeza de nuestra patria y la salvación de las almas, confiadas a nuestro cuidado pastoral: dos fines supremos, dos grandes intereses que Dios ha fijado al poder del Estado y a la Misión de sus Apóstoles. Nuestros votos y afectos, nuestras aspiraciones y propósitos son por la buena armonía y concordia de las dos potestades. Somos todos ministros de Dios para el bien, como dice el Apóstol, vosotros lleváis la espada y nosotros la cruz, símbolo de la redención y generación del mundo. Con esta cruz hemos salido, a pesar nuestro, de la dulce quietud de un claustro franciscano y esperamos que la cooperación de los poderes públicos de la Nación y de las dos provincias de nuestra diócesis nos la harán más llevadera: de lo contrario temeríamos sucumbir bajo su enorme peso antes de colocarla triunfante sobre las alturas del calvario [...].

[...] levantando en alto el símbolo de la salvación, de la fe y de la caridad, podremos, así confiamos, conjurar la tormenta y conducir a puerto seguro y tranquilo la nave de nuestra Iglesia, sin menoscabo de la del Estado. Quisiéramos que los poderes soberanos de la Nación y de las Provincias se persuadieran de una vez que el sagrado ministerio del apostolado de Cristo, esa misión salvadora que ejerce la Iglesia hace diez y nueve siglos, no solo no puede menoscabar en lo más minino la soberanía de los Estados y de los pueblos, sino que es la única base sobre la cual puede ser afianzada de una manera inconmovible [...].

[...] Deseamos pues que la calma, la paz y la buena armonía vuelvan a todos los espíritus y a todos los corazones, que la luz de la verdad ilumine todas las inteligencias y que animados todos por la caridad de Jesucristo obremos el bien y cumplamos la misión que Dios nuestro señor ha señalado a cada uno. ${ }^{16}$

Durante su gobierno, se estatuye el Registro Civil (1884), se debaten las leyes 1420 de educación laica, gratuita y obligatoria y la secularización de los cementerios. No le resultaron sencillas las gestiones con el gobierno. En una carta dirigida al Internuncio, le comunica, con cierto pesimismo, "Por lo que respecta a mi, creo hallarme en un terreno enteramente movedizo y voy tanteando para no caer" ${ }^{17}$ Con la creación del Registro Civil

\footnotetext{
${ }^{16}$ Pastoral del 21/09/1884. Publicad en El Eco de Córdoba el 27/09/1884.

${ }^{17}$ ASV. Nunziatura del Brasile. Libro 63, fasc.306, f.101. Carta a Mons. Mattera del 27 de abril de 1885.
} 
se sustituye el valor civil que tenían hasta entonces los libros parroquiales. La ordenanza municipal prescribía la obligación de los párrocos de suministrar a la oficina municipal copia de las actas de matrimonios, celebrados ante ellos, asentadas en sus libros. El Prelado se congratula con la iniciativa de establecer un registro administrativo para el mejor funcionamiento de la ciudad, pero no deja de cuestionar los artículos de la ley que equiparaban las uniones de otros credos -mahometanos, protestantes, judíos y racionalistas-, con el matrimonio católico. El tono de la nota es notablemente conciliador, finaliza la misma con un sincero deseo de llegar a una cordial inteligencia. Cumpliendo con el pedido, el obispo envía una circular a todo el clero parroquial de la diócesis, instando a cumplir con las obligaciones mencionadas:

Ha llegado a nuestra noticia por personas de autoridad, que algunos párrocos de esta diócesis al dirigir la palabra a los fieles, en la Iglesia, y aconsejarles usen del derecho de enrolarse en el Registro Cívico se han propasado al recomendar que les entreguen sus respectivas boletas. Hemos dudado algún tiempo de la exactitud de la noticia por referirse a una infracción de la ley, que todos debemos respetar y porque nuestro celoso y prudente clero parroquial, a Dios gracias, no está avezado a esta clase de transgresiones: pero se han repetido los avisos, y en vista del carácter de verdad que han revestido, hemos juzgado conveniente prevenir con tiempo el abuso a fin de que no se repitan tales exigencias ni se proclamen desde el pulpito enseñanzas que no estén en completa armonía con lo sagrado de nuestro ministerio y con los deberes de ciudadanos respetuosos de la ley. A los que profesamos y acatamos como fundamento de la sociedad el respeto a la ley y a la autoridad, no nos es lícito ni decoroso desvirtuarlas por mas que otros las violen y conculquen con frecuencia. Nos sería muy doloroso saber que se daba motivo para que la autoridad civil tomase alguna medida violenta, ante la cual no pudiéramos defender plena y justamente a los que la ocasionan, y por tanto esperamos confiados que esto no sucederá. ${ }^{18}$

En la última parte de este trabajo, veremos las prácticas del clero parroquial en relación a este conflicto.

La ley sobre la secularización de los cementerios obligaba al funcionario civil a anotar, en un libro especial, por duplicado, las defunciones. Además, exigía exhibir el boleto de inhumación expedido por el funcionario público y controlar a los encargados de cementerios para que no permitieran la inhumación de cadáveres sin la anotación del encargado del registro. La condición previa para acceder a la sepultura era la exigencia del boleto de registro de defunción y éste fue uno de los puntos más conflictivos en la

\footnotetext{
${ }^{18}$ AAC. Circular 12 de septiembre de 1884. El subrayado es nuestro.
} 
implementación de la ley en la mayoría de los curatos de campaña. ${ }^{19}$ La desinteligencia entre autoridades civiles y eclesiásticas respecto al uso y administración de los cementerios, evidencian conflictos por espacios de poder. Esta fue una de las primeras cuestiones en las que se evidencia la resistencia de la Iglesia y de la sociedad ante el avance secularizador del Estado. El cura párroco y el jefe político se convierten en actores claves en cada departamento. Los conflictos generados entre ambos ponen de manifiesto la preocupación del gobierno por controlar la actividad de los párrocos. El diocesano comunica al gobernador su interés por conciliar sus deberes de pastor con los deseos del gobierno y accede a trasladar a otros puntos a los referidos curas, ${ }^{20}$ antes de concluir, el pastor especifica que no ha tenido quejas de los feligreses y observa al gobernador que "la armonía y acuerdo que debe reinar entre ambos poderes, por su marcha regular en la esfera de acción que a cada uno corresponde, se reciente violentamente por la acción violenta del jefe político". ${ }^{21}$ El obispo diocesano falleció el 20 de setiembre de 1886, en el marco de estos conflictos, que serán heredados por sus sucesores.

\subsection{Provisores y gobernadores del obispado}

Para los Provisores Uladislao Castellano y Jerónimo Clara, los liberales y sus ideas eran un peligro para la doctrina y la acción católica, convirtiéndose, por lo tanto, en uno de los mayores males de la sociedad y enemigos de la Iglesia. En esta clave hay que mirar su firme oposición a todos sus postulados. Los campos en los que se dirime el enfrentamiento son diversos, destacan la prensa y la educación, la actuación de ambos prebendados es firme y decidida. El Vicario Capitular Uladislao Castellano publicó una pastoral, ${ }^{22}$ prohibiendo la lectura del diario "El Progreso", del seminario "La Carcajada" y del "El Interior". ${ }^{23}$ Los motivos de la prohibición fueron su espíritu manifiestamente hostil al catolicismo y "porque ha llamado a nuestra autoridad inferior a la del Gobierno, incitando después a los poderes civiles a anular aquella nuestra autoritativa declaración; lo que importa desconocer la independencia del poder eclesiástico y conduce a sistemas

\footnotetext{
19 AAC. Parroquias: Hay denuncias del curato de Bel Ville, Río Cuarto, Sampacho, Anejos Sud, Punilla, Quilino, Pocho y Villa María.

${ }^{20}$ Archivo Histórico de la Provincia de Córdoba [en adelante AHPC]. Gobierno 1886, T9.

${ }^{21}$ AHPC. Gobierno, 1886, T9. Nota al Gobernador Gregorio Gavier, Córdoba 17 de enero de 1884.

${ }^{22}$ AAC. Uladislao Castellano. Vicario Capitular: Pastoral del 15 de octubre de 1880.

${ }^{23}$ AAC. Auto del 30 de Octubre de 1880.
} 
reprobados por la iglesia como heréticos y depresivos de su autoridad". ${ }^{24}$ El conflicto con la prensa liberal fue sostenido a lo largo de varias décadas, por lo cual el prelado recomendaba la promoción de una buena prensa católica a fin de contrarrestar la acción de los periódicos adversos a la religión. El diario "El Progreso" hace una referencia a la actitud del gobernador del obispado y del secretario en la que advierte que: "D. Martín Yaniz y el Dr. Castellanos, Provisor y secretario del Obispado, han quedado solos en la Curia. Pueden llevar sus venganzas hasta donde quieran, pero la mitra no volverá. Bien sabemos que esta pastoral más que contra nosotros se vuelve contra el ilustrísimo Esquiú. Son los últimos ensayos [...] pero hoy con más malignidad porque lo que se proponen de esta vez es dividir al clero y prepararle una camarilla de oposición” (EP, 10/10/1880).

Los conflictos suscitados por la Pastoral tuvieron como tribuna a la prensa. "El Eco de Córdoba" y "El Progreso" discutían mediante sendos editoriales la cuestión. En el fragor del combate periodístico, salían algunos indicios sobre las divisiones del clero cordobés. En este sentido, "El Progreso" es el que desliza algunas afirmaciones como "fuimos partidarios de la candidatura para obispo del muy digno y virtuosísimo sacerdote Reverendo padre Esquiú [...], hemos herido la susceptibilidad de un círculo que quería al Dr. Castellanos para Obispo" (EP, 28/10/1880). La postura del provisor, tildada por "El Progreso" de oscurantista, medieval del siglo XIII y de ceguera ultramontana, era compartida por algunos miembros del cabildo eclesiástico y del clero secular, como Luis Tagle, Francisco Cesar, Rufino Núñez, Jacinto Ríos, Luis Falorni y Pablo Cabrera. También algunos curas de campaña, como Aquilino Ferreyra, cura de la Villa del Rosario, desde el púlpito recomendaba evitar la lectura del periódico. En tanto, las órdenes religiosas y otros miembros del clero secular, como Cabanillas, Brochero, Fierro, mantenían posiciones más conciliadoras con el gobierno y el liberalismo.

Cuatro años después, el Vicario Clara publicaba dos pastorales, en las cuales prohibía a los padres de familias católicas enviar a sus hijos a las escuelas fiscales, es bien sabido el efecto que tuvieron las mismas en el gobierno y en la sociedad. ${ }^{25}$ El gobierno nacional llegó a expulsar al delegado apostólico y a romper relaciones con la Santa Sede. Waldo Ansaldi (1997: 258) describe a Clara como un furibundo anti-liberal que en 1853 ya se

\footnotetext{
${ }^{24}$ AAC. Auto del Gobernador del Obispado declarando prohibido el diario El Interior, Córdoba 30 de octubre de 1880.

${ }^{25}$ Cfr. BRUNO (1981: TXII); AUZA (1981).
} 
había pronunciado en contra de las disposiciones de la Constitución Nacional en materia religiosa, enseñando a sus alumnos universitarios que el congreso constituyente no tenía facultades para legislar sobre el diezmo, fueros o declarar la tolerancia de cultos.

Las fuentes consultadas dan cuenta de miembros del clero que, sin alejarse de la ortodoxia católica, adoptaron discursos y prácticas diversas. Encontramos representantes de un tardío y quizá anacrónico reformismo eclesiástico de corte ilustrado, con ciertas reminiscencias galicanas o regalistas, sustentado por los frailes-obispos franciscanos, cuyo imaginario remitía a la república conservadora y católica, para quienes el Estado debía defender y amparar la religión católica. Los provisores y gobernadores aparecen como representantes del reformismo eclesiástico ultramontano y antiliberal, para quienes la relación Iglesia - Estado se concebía como la de dos entidades separadas, que se construyen como poderes autónomos con sus propias lógicas racionalizadoras. Proclamaban una Iglesia que defendiera su libertad frente al Estado y que adhiriera a la dependencia de Roma. Con un clero que defendiera esos derechos en todos los ámbitos de la sociedad: la Iglesia, la prensa, la política, que fuera el motor y ejerciera la dirección de la reforma. Podríamos decir que se trataba de un modelo vinculado a una concepción clerical de la sociedad, con reminiscencias medievales, pues entendía que "el poder espiritual institucionalizado en la jerarquía eclesiástica, poseía no sólo el derecho, sino también el deber de guiar a la entera sociedad en todas sus dimensiones. Desde esta óptica, el poder temporal deriva del poder espiritual, al que le está subordinado" (Fazio, 2009: 14).

Los primeros bregaron por mantener los espacios de inclusión mediante estrategias conciliadoras, la figura más emblemática fue Fray Mamerto Esquiú, embebido en una cultura política y en una vivencia cotidiana propias de la república conservadora y católica, en la que lo civil y lo religioso no eran lo mismo, sin embargo, en cierto modo, eran inseparables. Los segundos se opusieron, incluso tenazmente, a las medidas secularizadoras del gobierno. Más, ambas posturas buscaron mantener y aumentar la religiosidad de la población con formas y prácticas adaptadas a las nuevas sociedades más plurales. Encontramos una tercera posición vinculada al reformismo de corte liberal.

En 1881, cuando se anuncia el nombramiento de los miembros dignidades del cabildo eclesiástico, en favor de miembros del clero de postura intransigente (Clara, Vázquez, Juárez y Castellano), el diario liberal "El Progreso” anunciaba lacónicamente el "virtuoso, 
el viejo y católico clero de Córdoba, el que ha envejecido con servicios leales a la Iglesia y al Estado, el que jamás atentó contra la constitución y las leyes vigentes”, ha comenzado su ocaso. En abierta disidencia con los nombramientos, el periódico hace referencia a una decena de clérigos que podría haber ocupado esos cargos “idóneos, competentísimos y sin resistencia alguna ante la opinión y gobiernos de la Provincia y de la República” (EP, 18/02/1881) ¿Acaso no había en el católico y virtuoso clero de Córdoba otros hombres tan ilustrados como ellos que no hubieran atentado contra la libertad de prensa y la libertad de cultos? (EP, 19/02/1881).

\subsection{El dominico Fray Reginaldo Toro (1888-1904)}

El 25 de agosto de 1888, en un solemne acto en la Catedral de Córdoba, fray Reginaldo Toro tomaba posesión del obispado. ${ }^{26}$ Para suplir la vacancia de la sede metropolitana de Córdoba, el Senado de la Nación había presentado, el 27 de septiembre de 1887, una terna de candidatos, ${ }^{27}$ en la que figuraba, en primer lugar, Fray Reginaldo Toro de la Orden de los Predicadores. El Presidente de la Nación Miguel Juárez Celman elevaba su presentación a la Santa Sede y el Papa León XIII lo preconizaba Obispo de Córdoba en el consistorio del 1 de junio de 1888 , recibiendo a mediados del mismo mes las bulas pontificias. ${ }^{28}$

El obispo diocesano tomó una actitud "defensiva" frente a las disposiciones secularizadoras. A la creación del Registro Civil siguió la ley nacional de matrimonio civil, sancionada el 2 de noviembre de 1888, la cual establecía que los matrimonios que no se celebrasen con arreglo a las disposiciones del Código Civil no producirían efectos legales, lo que implicaba la obligación de realizar el matrimonio ante las autoridades o funcionarios públicos competentes para ello. Además, prohibía a todo sacerdote, bajo severas penas, la dispensación del sacramento sin tener a la vista los certificados de haberse verificado el Contrato civil. Esta ley alteró notablemente la situación establecida hasta ese momento, que suponía el reconocimiento de los efectos civiles del matrimonio religioso.

Ante este hecho, el obispo de Córdoba dirige una pastoral al clero y fieles de la diócesis en la que señala que no constituye un matrimonio verdadero, indisoluble, elevado la

\footnotetext{
${ }^{26}$ Para más datos sobre su biografía, véase GONZÁLEZ (1988).

${ }^{27}$ Diario de sesiones de la Cámara de Senadores (1887), 599. Integraban la terna dos religiosos y un secular: Fray Reginaldo Toro (O.P), David Luque (Pbro. Dr.) y Fray Juan B. González (O.F.M).

${ }^{28}$ AAC. Actas Capitulares (1878-1898), f.187-189.
} 
dignidad sacramental, "no es a los ojos del cristiano y de la Iglesia otra cosa que un reconocimiento público del Estado para vivir juntos y legalizar la descendencia de los dos, sin miramiento alguno a la fe, a las creencias o a la religión que profesan la inmensa mayoría de los hijos y ciudadanos de nuestro país. Así es que aunque dicha ley es una vejación para la Iglesia católica cuyos derechos y sacramentos desconoce y pospone -no altera absolutamente nada de lo que la Iglesia manda y determina sobre el Sacramento. El Estado no puede permitir y legalizar la unión de las personas, no puede imprimirle el sello sagrado del sacramento, no puede bendecir a los esposos ni a los hijos, ni alcanzarle gracias en el tiempo y en la eternidad". ${ }^{29}$

Las líneas directrices del documento están en conformidad con la pastoral colectiva firmada por los prelados argentinos en febrero de 1889. En marzo del mismo año, la curia diocesana envía una circular, a todos los párrocos de la diócesis, con instrucciones prácticas para que procedan, conforme a ellas, en la administración del sacramento del matrimonio y se eviten los inconvenientes a que la ley da lugar. ${ }^{30}$ Los puntos fundamentales del documento señalan: 1) La recomendación de explicar al pueblo la doctrina católica sobre el matrimonio, con una predicación preparada, prudente y acomodada a la inteligencia del pueblo cristiano. "Haga así comprender a todos que si se permite a los fieles el concurrir a declarar su consentimiento ante el oficial público, esto no importa celebrar verdadero matrimonio, sino solo cumplir un acto meramente civil, necesario ahora para que sus matrimonios tengan validez ante la ley". ${ }^{31}$ 2) La obligación de respetar a las autoridades y a las personas, cuidando de no ofender en lo más mínimo, ni suscitar odios personales. Prohibir, bajo pena de "suspensión", que se falte el respeto debido a tales funcionarios de cualquier clase que sean. 3) La petición a los fieles de ayudar "con oraciones fervientes a Dios que muda los corazones para que practiquen ayunos, la penitencia sacramental y la Santa Comunión en esta cuaresma, a fin de que no seamos vencidos por el mal, para que sean abolidas y revocadas esas leyes que nos deprimen". 32 La circular cierra con una recomendación clara y terminante, “como la misma ley, en su artículo 118, establece pena

\footnotetext{
${ }^{29}$ AAC. Pastoral del Ilmo. Rmo. Obispo de Córdoba D Fr. Reginaldo Toro, Buenos Aires, Imp. y Enc. del Colegio Pío de Artes y Oficios, Almagro, 1889.

${ }^{30}$ AAC. Leg. 53. Pastorales, Decretos y Edictos, 1834-1900, TI. Circular Obispado de Córdoba Marzo 28 de 1889.

${ }^{31}$ Ibid., punto 10.

${ }^{32}$ Fr Reginaldo Toro. Pastoral 1889. Ob. cit., p. 6 y ss.
} 
contra el sacerdote que proceda a la celebración de un matrimonio religioso, sin tener a la vista el acta que acredite haberse celebrado ya civilmente, será muy razonable que los párrocos se abstengan de autorizar matrimonios mientras no se les presente el acta civil". ${ }^{33}$ El prelado diocesano afirma que para evitar vejámenes y el desconocimiento de los derechos civiles, la Iglesia permite a los católicos que "se acomoden a ella en la práctica, con tal de que entiendan que ejecutan un acto meramente civil, que se apresuren cuanto antes a celebrar el matrimonio canónico, y no se tengan por casados mientras no hayan llenado este requisito" 34 .

El 19 de junio de 1889, a pocos meses de emitida la expresada circular, es apresado y encarcelado en La Rioja Monseñor Apolinario Argañarás, Canónigo Magistral de la Catedral, por haber celebrado algunos matrimonios sin tener a la vista las actas respectivas que acreditaban su previa celebración civil. El Obispo Toro eleva una protesta pública a las autoridades nacionales y de ambas provincias, al clero y a todos los diocesanos, por considerar el hecho un atentado que implica una grave injuria al sacerdocio, a la autoridad episcopal y a la disciplina de la Iglesia. Explica las circunstancias del caso: el hecho había sucedido durante las ceremonias de Semana Santa y no estaba constituida aún la oficina del Registro Civil ni había ningún funcionario público autorizado para celebrar el matrimonio civil. A continuación, advierte sobre la inconstitucionalidad de la aplicación de la pena.

Pero si estamos dispuestos a conservar un respeto en este sentido a esa ley, no lo estamos a reconocer su constitucionalidad, ni en el fondo ni en muchos de sus detalles. El artículo 118 que establece pena contra el sacerdote que proceda a la celebración de un matrimonio religioso sin tener a la vista el acta que acredite haberse celebrado ya civilmente, es a todas luces inconstitucional; porque se opone a la libertad de cultos que la Constitución Nacional reconoce, y porque pena un acto inocente, cual es la celebración del matrimonio ante un ministro de la religión, como una prescripción de ésta, sin pretensión de dar a este acto un valor que la ley le desconoce. Y si un acto de esta naturaleza fuera un delito, -siendo correlativos e inseparables en su ejecución el sacerdote y los contrayentes, estos serían tan criminales como aquél. ¡Sin embargo, la pena es solo para el sacerdote!

PROTESTAMOS: contra la intromisión de los tribunales civiles de La Rioja y de esta misma capital en una causa esencialmente eclesiástica. PROTESTAMOS: contra la violación de la inmunidad eclesiástica, que se ha perpetrado en el hecho de arrastrar a un sacerdote ante los tribunales laicos sin nuestra venia y allanamiento. PROTESTAMOS: contra el empeño de presentar como criminal y punible un acto

\footnotetext{
${ }^{33}$ AAC. Leg. 53. Ob. cit.

${ }^{34}$ AAC. Leg. 53. Pastorales, Decretos y Edictos, 1834-1900, TI.
} 
inocente, extraviando asi las ideas de la sociedad en tal delicada materia. PROTESTAMOS: contra el vejamen que se ha inferido al Canónigo Argañarás y en su persona a todo el clero (especialmente a nuestro venerable cabildo, del que es digno miembro) a nuestra autoridad y a la legislación de la Santa Iglesia.Y si los señores que han intervenido en este hecho quieren ser católicos, no es fuera de caso que les advirtamos que no está en nuestra mano impedir los efectos de las censuras eclesiásticas en que han podido incurrir, particularmente de excomunio lata esentenciae reservada de un modo especial al Romano Pontífice. ${ }^{35}$

El argumento esgrimido por el prelado es propio de un dominico tomista. Apela a la ley, a la justicia y a la libertad. Señala que la Carta Magna sostiene el derecho de los ciudadanos de ejercer libremente el culto; reivindica el carácter público - no estatal- del acto de celebrar un matrimonio ante un ministro de la religión, y, por último, apela a la igualdad de todos los ciudadanos ante la ley, al afirmar que si el acto fuera un delito, dado que lo ejecuta el sacerdote y los contrayentes, los últimos deberían también ser sancionados. Sin embargo, la pena era sólo para el sacerdote. Una sociedad democrática es una sociedad pluralista, en la que se debe respetar el principio de igualdad y no discriminación de los ciudadanos ante la ley, es un deber de justicia respetar los derechos de cada cual.

Fray Reginaldo Toro era un teólogo, durante años fue profesor y regente de estudios del convento Dominico de Córdoba y llegó a ser Maestro en Teología. Cuando era provincial de la Orden, conoció en Francia a Fray Ángel María Boisdron y lo invitó a venir a Argentina, el fraile aceptó y en 1876 llegó a nuestro país, en donde permaneció hasta su muerte en Tucumán (González, 2000: 112-113). En 1899, siendo Toro obispo diocesano, se inauguró en Córdoba un Estudio General unificado de las tres casas de estudio que había en la Provincia dominicana y el regente fue el Padre Boisdron. Es de suponer que coincidiría con las ideas político-teológicas de su hermano en religión, quien, según refiere Cynthia Folquer (2005: 171), se “definía como discípulo y seguidor de Lacordaire y se inspira en los pasos dados por este fraile francés". Recordemos que Lacordaire fue uno de los representantes del catolicismo liberal en Francia, fundador del periódico L'Avenir, órgano de defensa de la Iglesia de Francia. Las líneas directrices del periódico eran cristianismo y libertad, separación de la Iglesia y el Estado, renuncia de la ayuda estatal al clero, recuperación, por parte de la Iglesia, del nombramiento de obispos y lucha contra el monopolio escolar del Estado. Algunos discursos de Fray Reginaldo nos permiten señalar

\footnotetext{
${ }^{35}$ ACC. Leg. 53. Pastorales, Decretos y Edictos, 1834-1900, TI.
} 
las coincidencias al respecto. Tenemos aquí a un hombre más vinculado con el reformismo liberal, que, Ansaldi (1997: 266), además, señala como amigo de Juárez Celman.

Volviendo a la Protesta, el obispo la envía al Congreso de la Nación, acompañada con la firma de miles de feligreses, a fin de derogar el artículo 118. La petición logra, finalmente, la supresión del polémico artículo. De esta manera, quedan relativamente zanjados los conflictos entre Iglesia y Estado por el tema del matrimonio civil. En la última parte de la tesis, veremos cómo incidieron las leyes de secularización en las prácticas y en las relaciones entre curas, feligreses y autoridades políticas locales.

La laicización del Estado, en palabras de Roberto Di Stefano (2000: 347), permaneció inconclusa y duró poco, puesto que a finales de la década del 80 la voluntad de darla por concluida y restablecer la concordia era evidente. En Córdoba, ni el Estado ni la Iglesia de fines del siglo XIX eran instituciones totalmente consolidadas. Ambas vivieron una profunda crisis en los primeros decenios de la vida independiente. Podemos imaginar que esta mutua debilidad despertó en ambos actores una alta susceptibilidad hacia quien se consideraba ser su rival. Esta susceptibilidad recíproca no facilitó las relaciones. Con el triunfo de Juárez Celman en 1880 nació la dicotomía entre un Estado que no renunciaba a su proyecto ideal de sociedad liberal y que al no alcanzarlo lo daba por supuesto, y una sociedad que no renunciaba a sentirse y a reconocerse católica. Especie de esquizofrenia que, al extremarse, acabó por desembocar en un statu quo recíproco. De hecho, el gobierno provincial no secundó al gobierno nacional en la implementación de la ley 1420, que propiciaba el carácter laico de la enseñanza. La Ley Provincial de Educación Común de 1884 sólo reconoció la gratuidad y obligatoriedad escolar, pero no reglamentó la laicidad de la educación pública. La Iglesia nombraba a los profesores de religión en las escuelas fiscales hasta avanzadas las primeras décadas del siglo XX. ${ }^{36}$ El obispo diocesano remitía la lista de nombres a designar al ministro de Justicia, Hacienda y Culto y éste procedía al nombramiento en el cargo de maestros de religión. ${ }^{37}$

El decreto de provisión de curatos, sancionado por el Estado Nacional en 1886, también fue matizado en el orden provincial. Dicha disposición facultaba al gobierno - en su calidad

\footnotetext{
${ }^{36}$ ACC. Carpeta Curia Visitas Pastorales y Varios, 1887-1911. En 1912, el Director General de Escuelas de la provincia de Córdoba solicita al obispo la designación de maestros para religión, conforme a la ley de Educación, Art. 32 inciso 3 y 7 y 39.

${ }^{37}$ AAC. Fondo Zenón Bustos Obispo. Caja No 5. Enseñanza religiosa en las escuelas fiscales, f.2171.
} 
de Patrono de la Iglesia-, a que los curas interinos pasaran a ser curas propietarios, garantizando que no serían removidos sino en caso de sobrevenir causas legales. ${ }^{38} \mathrm{El}$ decreto provincial emitido por el gobernador Cárcano disponía que el gobierno, en su carácter de vice-patrono, delegaba la provisión de los curatos al obispo diocesano y no introducía innovaciones respecto al procedimiento que se utilizaba en conformidad a la ley 24 de la Recopilación de Indias. ${ }^{39}$ De manera tal que, en Córdoba, no se introdujeron modificaciones en el procedimiento utilizado para la provisión de los curatos y los interinatos continuaron siendo una herramienta que permitía al obispo disponer y organizar al clero según "las necesidades de la Iglesia". A su vez, la secularización de los cementerios fue un proceso lento y complejo, que finalizó en la segunda década del siglo XX, con la cesión de los cementerios parroquiales a las respectivas municipalidades, tema que abordaremos en la quinta parte de la tesis.

Con Reginaldo Toro finaliza un período y se inicia otro. El reformismo liberal católico, que luchó denodadamente por la defensa de los derechos de la iglesia frente al avance del Estado liberal y que bregó por mantener la catolicidad de la población, dio paso al reformismo social, que hunde sus raíces en las enseñanzas del León XIII y que deja de mirar al Estado para volcar su energía reformadora en la sociedad. Una sociedad a la que la iglesia había salido a buscar a fin de evitar que abandonara sus raíces cristianas. Los albores del siglo XX muestran una Iglesia que aspira a la conquista, cuyo objetivo era afianzar la militancia católica en orden a la reforma social. En palabras del Papa Pío X, Instaurare omnia in Christo (Restaurar en Cristo la vida social cristiana).

\subsection{La consolidación: Zenón Bustos y Ferreyra: Instaurare omnia in Christo (1905-1925)}

A la muerte de Fray Reginaldo Toro, ${ }^{40}$ Fray Zenón Bustos y Ferreyra (1905-1919), fraile franciscano, subió a la silla episcopal cordobesa. ${ }^{41}$ El nuevo obispo implementó su plan de gobierno dispuesto a imprimir, sin violencia, "el espíritu de Jesucristo en la sociedad transformada en sus nuevos ideales de progreso". Fue un hombre conservador que buscó

\footnotetext{
${ }^{38}$ Decreto Nacional del 31 de julio de 1886.

${ }^{39}$ AAC. Leg. 39. Decreto del 6 de Agosto de 1886.

${ }^{40}$ Fray Reginaldo Toro perteneció a la orden de Santo Domingo. Gobernó la diócesis de Córdoba entre 1889 y 1904.

${ }^{41}$ Zenón Bustos y Ferreyra fue elegido Obispo de Córdoba en 1905. En 1919, sufrió una enfermedad que le imposibilitó seguir en el ejercicio efectivo del gobierno de la diócesis, quedando ésta a cargo del Obispo Auxiliar José A. Luque. Bustos murió en 1925.
} 
fórmulas para armonizar la doctrina católica con las exigencias nuevas de la modernización, quiso "que el carro de la religión corriera parejo con el de la civilización".42 La postura de Zenón Bustos se encuadra en la línea pastoral propuesta en la encíclica Rerum Novarum de León XIII (1891), ${ }^{43}$ que marcó un nuevo rumbo en las relaciones entre Iglesia y modernidad. Atrás quedaba la actitud defensiva de Pío IX frente a las amenazas del mundo moderno.

Los lineamientos pastorales de fray Zenón Bustos estaban en sintonía con los propuestos por el Pontífice Pío X (1903-1914), cuya divisa fue Instaurare omnia in Christo, la restauración de la vida cristiana incluía, a sus ojos, una defensa de los derechos de la Iglesia y una labor positiva de reforma pastoral e institucional. Esta posición sintetiza las dos posturas que había asumido la Iglesia frente a la modernidad, la primera "de reacción”, porque intentó preservar la doctrina, la espiritualidad y las costumbres del clero y del pueblo cristiano, por este motivo la Iglesia se cerró sobre sí misma, y afirmarse como institución, la segunda “de acción”, porque la iglesia asumió el desafío de asomarse poco a poco a la modernidad y abrirse a sus requerimientos. En el primer proceso, la Iglesia tomó una actitud "defensiva" frente a la modernidad, adoptando un sistema destinado a proteger a los católicos de "los males" que presentaba el mundo moderno. Se trataba de una postura que llevó al aislamiento de los católicos. Fue un intento de conservar los modelos, los valores, las prácticas sociales y culturales católicas más arraigadas. ${ }^{44}$ El Pontífice León XIII (1878-1903) encarnó la tendencia a la "acción", a la apertura y al diálogo con la modernidad. El Papa era consciente de que los tiempos habían cambiado, ya no era

\footnotetext{
${ }^{42}$ Cfr. La Oración Fúnebre pronunciada por R. P. José Liqueno el día 11 de mayo en el funeral solemne que la Comunidad Franciscana de Córdoba celebró en homenaje a Fray Zenón Bustos y Ferreyra, Obispo diocesano de Córdoba.

${ }^{43}$ León XIII, a lo largo de su pontificado, elaboró un importante cuerpo de doctrina sobre la constitución de la República Cristiana y las normas de la vida en ella, adaptadas a las condiciones de la vida moderna. La preocupación del Pontífice radicaba en el modo de llevar adelante la cristianización y la espiritualización de la vida moderna, consideraba que el progreso de la civilización no se oponía a la Religión y a la existencia de la Iglesia y que era falsa aquella civilización que chocaba con la doctrina y las leyes de la Iglesia.

${ }^{44}$ HERVIEU-LÉGER (2005: 148) sostiene que las sociedades fundadas en la tradición combinaron diversas formas de tradicionalismos en el proceso de inclusión a la modernidad. El "tradicionalismo fundamental", que tiene por objetivo conservar los valores, los modelos de las prácticas sociales y culturales más arraigadas; que está al servicio de la permanencia, de lo que estima es constitutivo del hombre y de la relación social, según el código cultural del cual es producto y salvaguarda. El "tradicionalismo formal", exclusivo del precedente, utiliza formas que se mantienen pero cuyo contenido ha sido modificado, establece la continuidad de las apariencias y a la vez sirve a nuevos objetivos. El "pseudo-tradicionalismo" corresponde a una tradición remodelada que interviene durante los períodos en los que el movimiento se acelera y genera grandes trastornos, permite dar un sentido nuevo a lo inesperado, al cambio y dominarlo imponiéndole un aspecto conocido y tranquilizador.
} 
suficiente una actitud de condena, sino que era necesaria una propuesta que superara un tradicionalismo que no estaba abierto al cambio. Como advierte Etienne Fouilloux (2002:79), la Iglesia lleva adelante un modelo de sociedad antiliberal y antisocialista, se trata de un modelo integral, en cuanto que engloba todas las edades, todas las condiciones y todas las actividades humanas.

En Córdoba, el obispo diocesano planteó una línea de gobierno que asumía el desafío de construir una "modernidad católica". Para el pastor, la modernización no era necesariamente sinónimo de modernidad. La hostilidad contra el mundo moderno no implicaba ninguna postura en contra de la modernización, en tanto y en cuanto esta evitaba toda justificación ideológica. En un sermón predicado en 1904, expone claramente su postura:

El movimiento de progreso y civilización improvisado por la América, no puede negarse que coincide con el liberalismo que ha surgido también en sus clases intelectuales y pudientes por la fortuna. Pero esto no es causa ni ocasión de aquél, lo mismo podría levantarse poniendo la piedad y el amor a María como base [...] Aparecen juntos en el tiempo, pero el liberalismo no es causa de que se reconozcan efectos de esta civilización y progreso. Aquel es agente de la ruina y de la muerte, estos son manifestaciones de la vida; [...] Liberalismo es creer en la soberanía del pueblo con la supresión de Dios: y es muerte. Liberalismo es proclamar una moral independiente, del deleite y utilitaria: y es muerte. Liberalismo es erigir en dogma lo que dicen conquistas modernas, la supresión de toda sanción en la otra vida, y esto es lo mas desastroso en todas las obras del liberalismo. Liberalismo encarnado son las escuelas socialistas y anárquicas, y estas son las conductoras de la ruina, cuando aplicando sus principios sueltan sus huestes. ¿Cómo ha de ser el liberalismo el que ha edificado el progreso entre nosotros? [...] Progreso y civilización bien podrían haberse desarrollado en el ambiente de la fe, pero ésta con el liberalismo no se componen.

Es recurrente la idea de una Argentina católica y una América católica, mariana. Con motivo de la proclamación del dogma de la Inmaculada Concepción, Zenón Bustos afirma, en un discurso, "América es mariana [...] y ahora convertida en dogma, ofrece a la América la restauración segura contra las perturbaciones en los principios intelectuales, morales, sociales que traen conmovidos a los pueblos y sociedades en la perspectiva de un desastroso porvenir. A América le corresponde ponerse de pie, reconstruir sus tradiciones purísimas en la fe, en la moral y en los respetos a la autoridad". ${ }^{4}$

${ }^{45}$ Zenón Bustos, La Inmaculada Concepción de María en la moral, la sociedad y la intelectualidad de América latina. Sermón pronunciado en el $50^{\circ}$ Aniversario de la Declaración del Dogma, Convento de San Francisco, 1904, pp. 25 y 35. 
El recurso a la tradición y la religión fueron dos pilares sobre los que se apoyó un proyecto que intentó conciliar la modernidad y el progreso con la fe católica. Una sociedad moderna no implicaba, para el obispo, la negación de los dogmas de fe o el abandono de las tradiciones católicas, una auténtica sociedad libre, democrática y moderna debía apoyarse en los principios promovidos y sostenidos por el catolicismo. El prelado persiguió un proyecto de transformación cultural y social, que buscó insertarse en un discurso de cambio, al mismo tiempo que mantenía el control sobre la transmisión de los valores morales y sociales de las nuevas generaciones (Hervieu-Léger, 1997: 1). El problema de fondo a resolver era cómo transformar / mantener al catolicismo como el principio organizador de la sociedad civil (Bianchi, 1990).

Estas tendencias se vieron reflejadas en los editoriales de la "Revista Eclesiástica" de Buenos Aires. En 1905, señalaba que había que abandonar el sistema de "preservación”, que se tenía respecto de la educación cristiana, pues se trataba de un sistema que tendía al alejamiento del pueblo y que los católicos, aislándose del mundo, quedaban imposibilitados de ejercer su influencia en la sociedad. ${ }^{46}$ La publicación instaba a un cambio de estrategia, adoptando una actitud más ofensiva, que tendiera a la regeneración de la sociedad por medio de su cristianización. Para lo cual era preciso volver a colocar al católico -sacerdote y laico- en contacto con la sociedad, había que pasar de la retracción, del aislamiento, a la acción, impulsando la participación activa de los católicos en la sociedad. Se trataba, por lo tanto, de un ambicioso programa, que implicaba la necesidad de la acción de los católicos en la esfera individual y social, el objetivo era crear una conciencia cristiana que implicara un compromiso más radical de los creyentes, en defensa de los valores cristianos, en la vida privada y en la esfera pública.

Las relaciones entre Iglesia, Estado y sociedad sufrieron modificaciones en el marco de procesos complejos con ritmos diferentes. La laicización del Estado duró poco, a finales de la década del 80 podría darse por concluida, dice Di Stefano (2000: 347). Como advierte Semán (2007: 45), referenciando a Debbelaere, la secularización es un proceso que se realiza en planos diversos y que no hay correlaciones necesarias con lo que sucede en cada uno de ellos: lo que ocurre en el plano de la laicización, no se correlaciona directa y

\footnotetext{
${ }^{46}$ Era la publicación oficial de la Iglesia Argentina. Contenía una sección destinada a cada una de las diócesis. El obispado de Córdoba publicó sus datos en ella hasta 1924, fecha en la que creó su propio boletín eclesiástico.
} 
linealmente con lo que ocurre en un segundo plano, el de la participación eclesial -que se refiere a la reducción de la autoridad eclesial sobre sus fieles y el descenso del número de éstos-, o lo que acontece en un tercer plano, el del cambio religioso que implica, entre otras cosas, la pluralización y relativización de las creencias religiosas. En el caso cordobés, el plano de la laicización estatal fue eficaz, ¿cuál fue la estrategia del diocesano respecto a moderar la secularización de la sociedad?

\subsubsection{La cuestión social como inquietud compartida}

En el siglo XX, la penetración ideológica del socialismo y el anarquismo se constituyeron en el principal problema para los hombres de la dirigencia civil y eclesiástica. Las relaciones entre la Iglesia y el Estado transitaban causes de consenso y un modus vivendi armonioso. Las fiestas de fin de siglo, relanzadas en Río Cuarto con motivo de la bendición de la imagen del Cristo Redentor, muestran el clima de época, respecto de las relaciones entre autoridades civiles y religiosas, entre religión y patria. El último discurso a cargo del Dr. Juan José Vélez termina dirigiéndose "a las autoridades que con su presencia han impreso a estos homenajes el carácter de un desagravio oficial a Jesucristo; confirmando la unión en que el estado debe vivir con la Iglesia [...] y al pueblo, que se me presenta siempre cual abanderado, al pie de las derruidas almenas haciendo flamear las banderas de la religión y de la Patria". 47

Este binomio de Religión y Patria es una constante en los discursos, sermones religiosos y políticos, pues, pese al crecimiento económico, comenzaban a percibirse los desajustes sociales que afectaban a los sectores más vulnerables de la población. ¿Cuál era la solución a estos problemas? Para el obispo era principalmente una cuestión religiosa. En el sermón del 25 de mayo de 1910, ante la presencia del intendente municipal y otras autoridades civiles, expresa algunos conceptos al respecto. En el primer punto del sermón, advierte que los hombres de Mayo que forjaron la Patria poseían un eminente sentido religioso, pasa revista a cada uno de ellos y señala "la decadencia de aquel espíritu religioso con que actuaron nuestros padres. El pueblo argentino de hoy no tiene la intensidad religiosa de aquel pueblo glorioso que nos legó la nación. El liberalismo incrédulo difundiendo su

\footnotetext{
${ }^{47}$ IEA. Fiestas de fin de siglo. El pueblo de Río Cuarto a Jesucristo Redentor, Río Cuarto, Librería y Tip. La Minerva, Córdoba, 1901, p. 75.
} 
acción ha subido a un nivel asustador. Asustador señores porque tanto menos religión haya en el pueblo, tanto más cerca están del estado los horrores de la anarquía. El pueblo argentino será tanto más próspero y feliz, cuanto más consecuente se muestre en mantener la fe tradicional que guió a las victorias al pueblo de mayo". ${ }^{4}$

Pasa revista también a la religiosidad de los héroes de la independencia, Falucho, Cabral, San Martín y Belgrano. Señala como oscuros los años de las guerras civiles y las montoneras, dice que los constitucionales del 53 sancionaron la Carta Magna "en nombre de Dios, principio de toda unión, de toda fuerza y de toda institución” y se detiene en los últimos cuarenta años de crecimiento económico: "Señores, es una bendición de Dios esta inmensa actividad desplegada por los habitantes de este país, y la prosperidad que se ha alcanzado, sin que ni gobiernos, ni el pueblo, ni los sindicatos, ni el comercio, ni las industrias ni nadie haya sentido travas puestas por la religión en ninguno de los caminos que conducen a la prosperidad".

Explica los principios religiosos del trabajo, el ahorro, la obligación de hacer fructificar los talentos recibidos y concluye que no es refractaria al engrandecimiento material de los pueblos. El punto central del mensaje pastoral es marcar que si la religión desaparece del pueblo, desaparece un elemento fundamental de contención, “con el positivismo pronto desaparece en la conciencia la idea salvadora en la sociedad, la idea de esa mirada escrutadora que Dios ejerce sobre ella; desaparece llevándose consigo el más poderoso freno para mantener a los ciudadanos en los justos términos de sus derechos y deberes, el prestigio decisivo que la acompaña para evitar las grandes perturbaciones que de no tenérsele en cuenta se originan. No quedan otras fuerzas reguladoras que la acción policial y el veredicto de la censura pública, dejando fuera el gran mundo encubierto y misterioso, velo de las sombras, en que ellos no pueden mirar, sin sanción alguna. ¿Quién vela en ese mundo misterioso por la justicia, la moral y el orden suprimiéndose a Dios?". ${ }^{9}$ La respuesta para el obispo es el utilitarismo. Su lógica es certera, si la religión forma y modela las conciencias, y es el más poderos freno para mantener a los ciudadanos en los

\footnotetext{
${ }^{48}$ IEA. Zenón Bustos Obispo. Sermón Patrio, pronunciado en la catedral de Córdoba el 25 de mayo de 1910 , Tipología Los Principios, Córdoba, 1910, p. 5.

${ }^{49}$ IEA. Zenón Bustos Obispo. Sermón Patrio, pronunciado en la catedral de Córdoba el 25 de mayo de 1910 , Tipología Los Principios, Córdoba, 1910, p. 13.
} 
justo términos de sus derechos y deberes, formar las conciencias religiosas de los ciudadanos se convierte en un elemento importante para garantizar el orden social.

Desde esta óptica, la Iglesia, para el Estado, se convierte en una institución funcional a su proyecto, el efecto moralizador de la religión y las prácticas religiosas asistenciales fueron percibidos como elementos aptos para dar soluciones a las consecuencias sociales de la modernización. Era la única institución que poseía un poder de penetración social que superaba, incluso, el del propio Estado, capaz de llegar a los sectores sociales más desprotegidos y con capacidad de penetrar en las conciencias individuales. Esta convicción se puso de manifiesto cuando, en 1914, el comisario general del censo nacional en la provincia, Dr. Dutari Rodríguez, se dirigió al Obispo Zenón Bustos para requerir su colaboración en términos que evidenciaban el reconocimiento del rol que la Iglesia jugaba en la sociedad cordobesa, a la vez que ponía en evidencia las falencias del aparato estatal.

\begin{abstract}
Ahora bien la palabra que más llega a la conciencia y al corazón de nuestro pueblo, el consejo más escuchado, la propaganda más eficiente, es la que sale del labio del sacerdote católico y se propaga por su medio, llevando el convencimiento íntimo a todos los espíritus. Y esta es la propaganda que necesita una obra como la del censo para vencer los falsos prejuicios y las resistencias que suele levantar en la masa menos ilustrada del pueblo que tiene por norma recelar de toda medida administrativa, atribuyéndole siempre propósitos mezquinos y contrarios a sus propios intereses [...].
\end{abstract}

Las elites dirigentes civiles y eclesiásticas implementaron estrategias de control social a través de mensajes y discursos con un alto contenido moral y religioso. Llevaron a cabo políticas destinadas a la internalización de esos valores en vastos sectores de la población, llegando al ámbito familiar, laboral y de sociabilidad (Moreyra, 1998: 19). Se produce cierta simbiosis entre la Iglesia y el Estado, entre lo que la Iglesia aporta al Estado y lo que el Estado le proporciona a ella. El Estado reconocía la capacidad de comunicación y organización eclesiástica y requería su colaboración para asumir compromisos, cuya estructura administrativa burocrática era todavía incapaz de abordarlos eficazmente. El Estado concederá a la Iglesia diversas facilidades para el desarrollo de su labor pastoral, a condición de que se consolide la mentalidad de los sectores medios y evite la confrontación entre las clases sociales. Por lo tanto, el proyecto de transformación institucional de la Iglesia confraternizó con el proyecto de consolidación del Estado, que buscó articular religión, progreso y modernidad. 
Estas ideas están presentes en las directivas propuestas por el Obispo Bustos en su programática primera carta pastoral. Concebía a la Iglesia como un organismo vivo, que se movía en las condiciones concretas de tiempo y lugar, sin cambiar sus dogmas, su estructura íntima, debía adaptarse a las necesidades del momento y la contingencia de las cosas. ${ }^{50}$ No era una estructura atemporal que sólo se preocupaba por la dimensión espiritual de los hombres:

Si bien el objeto final de nuestra Santa Religión es la salvación de las almas, no debe olvidarse que [...] todo el que desee hacer una acción concreta, eficaz y práctica, deberá dirigirse al hombre concreto, al hombre de su tiempo, teniendo en cuenta sus ideales buenos o malos, sus maneras de pensar, sus vicios, sus virtudes, sus errores, su modo de concebir la vida, etc. Por otra parte, limitar la misión de la Iglesia a una finalidad escatológica o ultraterrestre es un error [...]. La Iglesia pues debe [...] tomar a su cargo la tutela de las clases proletarias, hasta alcanzar su emancipación del feudalismo industrialista y la posibilidad efectiva de que todos los hombres, hijos del mismo Padre que está en el cielo, participen proporcionalmente o según justicia social de todos los bienes de la sociedad moderna; en todos sus aspectos: material, moral, político y social. ${ }^{51}$

Estimaba que una sociedad moderna, signada por el progreso económico y material con un gobierno democrático, que respetara las libertades individuales y garantizara el orden, no se oponía a las enseñanzas del evangelio. Algunos términos que aparecen en su discurso, tales como progreso, civilización, democracia, ciudadanía, ciencia, libertad, nos permite sostener que el diocesano se propuso asumir todo aquello que la modernidad podía ofrecerle y construir un proyecto que articulara religión, tradición, progreso y modernidad. Para él, la ciencia moderna, la política, la economía y las artes, iluminadas por la fe, llevarían al auténtico y verdadero progreso, el lenguaje utilizado señala la distinción entre progreso y desarrollo integral. La sociedad debía alcanzar un desarrollo armónico que contemplara el ámbito material -crecimiento, desarrollo, progreso-, y el ámbito espiritual creencias, valores, normas morales-, en el cual la religión adquiría un rol protagónico:

En ésta, nuestra diócesis, la religión de nuestros mayores, la única religión que ofrece el augurio de orden y bienestar a todos los pueblos y en especial a los nacientes como los que se improvisan y crecen entre nosotros, sin la cual toda sociedad bien ordenada es imposible. $^{52}$

\footnotetext{
${ }^{50}$ AAC. Zenon Bustos y Ferreyra. Pastoral al inicio de su gobierno. Córdoba, 23 de noviembre de 1905.

${ }^{51}$ REOBA, sección Córdoba, año 1907, p. 283.

${ }^{52}$ AAC. Pastorales, Decretos y Edictos, 1834-1913. La Obra del Seminario, Pastoral del 08/06/1907.
} 
El concurso de las ciencias, junto a las inspiraciones de justicia y paz evangélicas, podrían hacer desaparecer el encono que dividía a los hombres entre proletarios y burgueses, la lucha entre obreros y capitalistas, entre ciencia y fe, entre destino terrenal y superior del hombre. Entendía que el conjunto de las ciencias no debía desdeñar el conocimiento teológico, pues la razón desamparada de la fe abría el paso al paganismo sin Dios, a un materialismo que para él era origen de los problemas que sufría la sociedad. A su vez, la Iglesia debía aprovecharse de los conocimientos y avances de las ciencias modernas, utilizando el discurso de la razón para dar respuestas a los cuestionamientos del mundo moderno, "conviene vencer por la razón y el poderío de la ciencia, a la razón que se resiste". ${ }^{53}$ Rescataba que el conocimiento que le otorgaban las ciencias sociales, pues era necesario para la explicación y solución de los problemas que convulsionaban a los sectores obreros.

Consideraba a la religión como un elemento identitario de la sociedad provincial. Era capaz de integrar a los nuevos sectores inmigrantes, en su gran mayoría católicos, con la sociedad criolla, también católica. Sobre esta premisa, impulsó un proceso de renovación con el que se propuso poner a la Iglesia y a la religión católica al servicio de una modernidad que se asentara sobre los valores cristianos. Para lograrlo, se dispuso a organizar la Iglesia diocesana e implementar un programa de acción católico-social que contemplaba dos dimensiones: una teleológica, que aspiraba a la implantación de los valores cristianos en la sociedad, y otra pragmática, que comprendía una acción orientada a la impugnación de las ideologías anti-cristianas y a la reparación de los desórdenes que de ellas dimanaban sobre el individuo, la familia, la escuela y la sociedad mediante una acción sistemática y organizada de los católicos, en torno a tres ejes fundamentales, lo social, lo religioso y lo político. ${ }^{54}$ Los ejemplos, propuestos como modelos a imitar, eran Alemania, Francia y Bélgica, países donde la cuestión social había mostrado características significativas por su radicalidad y donde los católicos se habían organizado y lanzado a la lucha, poniéndose a la "cabeza del movimiento democrático para enderezarlo, para encaminarlo al bien, y para convertir en reforma benéfica y fecunda las agitaciones

\footnotetext{
53 AAC. Fondo Zenón Bustos. Conferencia sobre las cualidades de la predicación al clero el día 2 de septiembre de 1918, Córdoba, Imprente Pereyra, 1918, p. 12.

${ }^{54}$ REOBA, 1909, pp. 812-813.
} 
informes que sacuden la sociedad con los hombres del nihilismo, anarquismo, socialismo". 55

\subsubsection{El orden social y la cuestión "del otro"}

La presencia en el escenario provincial de actores socialistas y anarquistas, aunque escasa y minoritaria (Duvjone, 2002a y b), ${ }^{56}$ puso en evidencia que la religión católica iba dejando de ser el universo de significados colectivos, en el cual, las experiencias cotidianas se relacionaban con un orden trascendente, inmutable, necesario y preexistente (HervieuLéger, 2005: 144). Estos nuevos actores, no sólo cuestionaban la religión como principio unificador de la vida de los grupos sociales, sino que también ponían en tensión el lugar de la tradición. Si entendemos la tradición como el conjunto de las representaciones, imágenes, saberes teóricos y prácticos, comportamientos, actitudes, etc., que un grupo o una sociedad acepta en nombre de la continuidad entre pasado y presente (Hervieu-Léger, 2005: 145), podemos inferir que amplios sectores sociales veían a las nuevas ideologías como perturbadoras del orden social. El recurso a la tradición católica supuso un elemento fundamental, utilizado por la jerarquía eclesiástica con el doble objetivo de consolidar la identidad católica y afianzar el mecanismo de transmisión de la creencia mediante una eficaz socialización religiosa y movilizar a los creyentes, impulsando una acción católica organizada, destinada a la re-catolización de la sociedad y el estado. En este sentido, cuando Pierre Bourdieu (1971) sostiene "que las autoridades religiosas al controlar y mantener el orden simbólico imponen, bajo la imposición disimulada un orden social y legitiman un orden político, es difícil no pensar en el rol de la Iglesia en la construcción del mito de la nación católica" (Zanatta, 1996).

La resistencia a los errores del socialismo fue una de las ideas directrices de la pastoral diocesana. El obispo veía en el socialismo una doctrina materialista que, a su entender, destruiría la sociedad, pues intentaba trasformar sus fundamentos, impugnar los derechos a la propiedad privada, socavar la autoridad, prometer una felicidad temporal, limitada a la vida terrenal, sin tener en cuenta los premios y penas de la vida eterna. Promesas que

\footnotetext{
${ }^{55}$ Los Principios [en adelante LP], 28/04/1894, col.1: "La verdadera democracia".

${ }^{56} \mathrm{El}$ autor sostiene que "la religiosidad de los trabajadores presentará un difícil escollo para la primera difusión del socialismo en la provincia”.
} 
llevarían a que las clases modestas, cansadas de la pobreza, se lanzaran a la revolución social. $^{57}$

Los aspectos fundamentales del socialismo y los puntos de fricción con la religión católica fueron vertidos en tres pastorales. ${ }^{58} \mathrm{El}$ diocesano advertía que, si bien, la bandera del socialismo era económica, pues propiciaba pan, techo y vestido para el proletariado y los pobres, el objetivo real de la doctrina era "suprimir el entero orden social cristiano que regía a la provincia", extinguir las creencias religiosas de cualquier credo, promover la rebelión contra el orden político, civil y religioso, despojar a los necesitados de su esperanza en la bienaventuranza, sumergiéndolos en el materialismo y confundiéndolos con promesas halagadoras de prosperidad temporal. ${ }^{59} \mathrm{Si}$ el materialismo fomentaba la lucha entre el capital y el trabajo, la religión, en cambio, daba sentido a las conductas sociales, se convertía en la fuente de moral que permitía la convivencia, la paz y la armonía social. Una sociedad sin religión sería una sociedad sin paz:

La impiedad cada día se presenta más audaz, extendiendo su acción descristianizando a todas las clases sociales y con pretensiones de infiltrar su odio satánico a Jesucristo, a su Iglesia, en todas las instituciones que afectan al individuo, a la familia, y a la sociedad, en la vida privada como en la pública dejándose sentir los efectos en su propaganda disolvente del orden moral establecido a costas de inmensos sacrificios. Esto debe estimular nuestro celo a luchar sin descanso por la causa de la fe y de la moral cristiana, oponiendo las doctrinas civilizadoras de la Iglesia a las formas convencionales del materialismo y positivismo, la luz de la verdad a las tinieblas del error, los ardores de la verdadera caridad a las frases frías y vanas de la beneficencia laica. ${ }^{60}$

Católicos y socialistas tenían su programa social, ambos procuraban defender las legítimas reivindicaciones del proletariado, mejorar la vivienda obrera, combatir las consecuencias del alcoholismo, regular las horas y condiciones de trabajo, velar por el descanso necesario, etc. Más, entre ambos, existía una diferencia fundamental, los primeros consideraban el mejoramiento material como un medio para alcanzar el progreso moral y la finalidad última trascendente del hombre, y los segundos negaban toda posibilidad de

\footnotetext{
${ }^{57}$ AAC. Zenón Bustos. Pastoral de Cuaresma, "El proletariado", p. 6.

${ }^{58}$ Zenón Bustos y Ferreyra. Pastoral sobre "El Socialismo" del 24 de febrero de 1914; Pastoral sobre "La revolución social" del 23 de noviembre de 1918; Pastoral de Cuaresma: "El proletariado antes y después de Jesucristo", Imprenta Ferreyra, Córdoba, 1919.

59 AAC. Fondo Zenón Bustos. Pastoral de Cuaresma: "El proletariado antes y después de Jesucristo", Imprenta Ferreyra, Córdoba, 1919.

${ }^{60}$ Sínodo Diocesano. Córdoba, $\mathrm{N}^{\circ} 188$.
} 
trascendencia, afanándose por alcanzar un bienestar exclusivamente terrenal. El humanismo materialista y ateo del socialismo se enfrentaba con el humanismo espiritual y trascendente del catolicismo. El obispo diocesano entendía que:

Las complicaciones de esos derechos [de los trabajadores] serán cada vez mas violentas a medida que la incredulidad crezca entre capitalistas y obreros. [...] Imposible una jurisprudencia reguladora, si se desconoce o se prescinde para formarla, la espiritualidad del alma, su inmortalidad, su albedrío [...]. ${ }^{61}$

Para el socialismo, los pobres no necesitaban obras de caridad, sino justicia. Las obras de caridad, como la limosna, serían, en realidad, un modo para que los ricos eludieran la instauración de la justicia y acallasen su conciencia, conservando su propia posición social y despojando a los pobres de sus derechos. El obispo diocesano sindicaba que el socialismo era una doctrina que pugnaba por "eliminar como inútil la ley de la caridad cristiana, acusar de indolencia a la Iglesia y no mirar por las condiciones económicas de los pobres". ${ }^{62}$ Por su parte, la iglesia entendía que siempre se darían situaciones de necesidad material, sufrimiento o soledad, en la que era indispensable la ayuda que demostrase el amor concreto al prójimo, por lo tanto, la caridad cristiana seguiría siendo un elemento constitutivo para lograr la paz social. El modelo de caridad cristiana, expuesto por el diocesano, remite al evangelio, a la parábola del buen samaritano, donde se presenta la caridad como una respuesta a la necesidad inmediata:

El desequilibrio de la fortuna es inevitable hoy y siempre habrá pobres que sufran sus privaciones $[\ldots]$ la economía siempre será impotente para suprimir el pauperismo, y la mecánica para suprimir el brazo del obrero. Sin curar el mal, podrán aliviar los dolores físicos de la pobreza, pero no podrán suavizar la pobreza y dolencia del espíritu. La filantropía acude con pan y con vestidos a los hambrientos y desnudos, pero es incapaz de enjugar las lágrimas que arranque de los ojos la desventura del corazón: es incapaz de descender a los abismos del espíritu a calmar las tempestades de las pasiones y anunciar la paz. ${ }^{63}$

\footnotetext{
${ }^{61}$ AAC. Pastorales, Decretos y Circulares, 1905-1920. Pastoral del 2 de mayo de 1905 al recibirse el gobierno de la diócesis, p. 17.

${ }^{62}$ Zenón Bustos y Ferreyra. Pastoral sobre "El Socialismo" del 24 de febrero de 1914.

${ }^{63}$ AAC. Pastorales, Decretos y Circulares, 1905-1920. Pastoral del 2 de mayo de 1905 al recibirse el gobierno de la diócesis, p. 17.
} 
En un clima en el que los socialistas utilizaban la acción y la agitación en la calle, unida a la difusión de sus principios ideológicos, la Iglesia utilizaba vías o instrumentos encaminados a preparar y conformar los pensamientos y conductas. Uno de ellos fue dar a conocer "los errores" de esta doctrina social materialista. En el círculo de estudios del clero, se preveían conferencias sobre los fundamentos doctrinarios del socialismo, sus manifestaciones intelectuales, religiosas y morales y su aplicación a la democracia, la legislación nacional, la instrucción, los obreros, los patrones y el capital y los inconvenientes resultantes de estos principios. ${ }^{64}$ Esta información debía ser transmitida a los obreros y al pueblo en general.

\begin{abstract}
Serán menos los prosélitos de la escuela socialista, o no los tendrá, cuando la actividad intelectual y el celo conservador de los hombres de representación, haya hecho conocer a las nuevas masas obreras, debidamente, los principios del liberalismo rojo que la informa, y el género de la acción que emplea para llegar a su fin: su fin es aniquilar al orden cristiano que actualmente rige, y todas las instituciones, que dentro de él se desenvuelven, siempre dentro del ambiente de la fe en lo sobrenatural, y después, ensayar una creación nueva, con los escombros producidos, toda material y puramente humana, sin religión alguna. ${ }^{65}$
\end{abstract}

En los discursos, se encuentra la afirmación reiterada de que la finalidad del socialismo era destruir la sociedad y transformar sus fundamentos, se proclaman como perjudiciales, injustos y subversivos los remedios postulados por quienes alientan la revolución social. Desde ese objetivo, se denuncian campañas desatadas contra la autoridad, el mal entendimiento y el uso de la libertad, que llevan a una práctica perturbadora del orden social.

Los conceptos vertidos revelan un discurso confrontativo, que revaloriza el rol de la religión católica como elemento de cohesión social y presenta al socialismo como enemigo de la Patria, la paz y el orden. Pastorales y otros escritos los sindican de "fuerzas peligrosas", "corrientes insanas que atentan contra el orden social", 66 "formidable enemigo", 67 "extranjeros, profesionales de perturbaciones obreras", ${ }^{6}$ que realizan una

\footnotetext{
${ }^{64}$ AAC. Círculo de Estudios del Clero, 1917-1918. Libro de Actas, f.3.

65 AAC. Zenón Bustos y Ferreyra. Pastoral recomendando los círculos de obreros. 28-11-1907. REOBA. Sección Córdoba, 1908, pp. 32-36.

${ }^{66}$ AAC. Fondo Zenón Bustos. Obispo Caja No 4. Visita canónica a la Parroquia NS de la Purísima Concepción de Río IV, f.1356.

${ }^{67}$ AAC. Zenón Bustos. Pastoral de Cuaresma: "El proletariado", p. 6.
} 
prédica "irreligiosa, inmoral, subversiva, anticlerical y anarquista", 69 con espíritu de “insubordinación y desorden". ${ }^{70}$ Los términos y expresiones con que el Obispo diocesano designa a estos adversarios, inducen a concluir que la jerarquía construyó una imagen "del enemigo", destinada a neutralizar la adhesión a las nuevas doctrinas y la necesidad de reforzar la identidad católica en la población.

La enseñanza eclesial se sintetiza en los siguientes postulados:

a) la igualdad de los hombres consiste en que todos son llamados a la misma dignidad de hijos de Dios;

b) en la sociedad civil hay varios órdenes, diversos en dignidad, derechos y potestad;

c) no es lícita la insurrección contra la autoridad;

d) el derecho de propiedad debe mantenerse intacto;

d) sólo se justifica la desobediencia a la autoridad cuando falta la conformidad entre el mandato de aquella y la del mismo Dios;

f) la abundancia de bienes terrestres no importa para la bienaventuranza eterna;

g) los males de la sociedad humana no pueden tener otro remedio que no sea la restauración de la vida e instituciones cristianas.

El obispo defendió y sostuvo con fuerza tres posiciones básicas, la primera es la indisoluble relación entre religión y moralidad, la segunda, los "grandes" beneficios sociales que se obtendrían de esa unión y la tercera, la educación religiosa como instrumento idóneo para inculcar modelos de conducta. Consideraba, y así lo expresaba, que la ignorancia de la Religión era uno de los principales obstáculos que el párroco debía sortear, pues las clases trabajadoras "ni pueden amar la Religión que ignoran. Ni pueden prestarse a modelar por ella sus actos si ignoran su santidad y pureza. ${ }^{71}$

Sobre estos principios se impulsó una acción pedagógica en los sectores populares que tuvo como elementos centrales la re-significación de la función del templo, la acción pastoral, litúrgica, sacramental y social del párroco y el impulso de las asociaciones parroquiales. En síntesis, se trataba de una nueva forma de llevar adelante la acción católica parroquial.

\footnotetext{
${ }^{68}$ REOBA. 1908, p. 141.

${ }^{69}$ REOBA. 1908, p. 144.

${ }^{70}$ AAC. Libro de Autos y Visitas Canónicas, 1885-1916, f.46.

${ }^{71}$ AAC. Libro 45, f.374.
} 


\section{Los instrumentos de la reforma: sínodos y visitas pastorales}

En el Capítulo 3, dedicado a las fuentes, señalábamos la importancia de los sínodos, pues al ser la Iglesia una organización fuertemente institucionalizada, las normas emanadas por los concilios debían ser llevadas a la práctica por los obispos mediante la celebración de sínodos diocesanos. Son asambleas eclesiásticas, destinadas a profundizar la vida religiosa de cada diócesis y legislar sobre los aspectos primordiales de la vida sacramental, la fe y la moral. Es por ello que el análisis de los mismos, nos permite abordar los lineamientos normativos de la Iglesia diocesana local.

En el primer apartado de este capítulo, señalábamos que el Obispo Álvarez había celebrado un Sínodo en 1877, que tomó los lineamientos del Concilio Ecuménico Vaticano I. El Sínodo se propuso "restablecer la disciplina eclesiástica, restaurar la sana doctrina, [...] para proveer por este medio el mejor gobierno de la diócesis y reformar las costumbres". El único estudio sobre esta asamblea lo realizaron Nelson Dellaferrera y José María Arancibia (1994). En 1906, casi treinta años después, se celebró en Córdoba un nuevo Sínodo para implementar en la diócesis las directivas del Concilio Plenario para América Latina, celebrado en Roma en 1898.

\subsection{Los Sínodos Diocesanos: su importancia}

\subsubsection{El Sínodo de 1877}

El Sínodo diocesano de 1877 fue el único sínodo realizado en el siglo XIX, convocado inmediatamente después del Concilio Vaticano I (1870)..$^{72}$ Estuvo destinado a marcar los rumbos que debía seguir el proceso de institucionalización eclesiástica.

La asamblea tenía como objetivo bajar las normativas del Concilio Vaticano I a la realidad diocesana, por ello, en sintonía con el Concilio el Sínodo declaró la necesidad de fijar las estrategias institucionales para "restablecer la disciplina eclesiástica, restaurar la sana doctrina, [...] para proveer por este medio el mejor gobierno de la diócesis y reformar las costumbres". ${ }^{73}$ Según José M. Arancibia y Nelson Dellaferrera (1983: 5), el Sínodo fue uno de los acontecimientos religiosos más importantes de la Argentina en las postrimerías del siglo pasado. En primer lugar porque se celebró después de 125 años en los que no se

\footnotetext{
${ }^{72}$ Para un análisis completo del sínodo, véase, ARANCIBIA y DELLAFERRERA (1983).

${ }^{73}$ AAC. Actas de las Sesiones del Sínodo diocesano de 1877, f.499.
} 
había convocado ningún sínodo. ${ }^{74}$ Tuvo una duración de 38 días y se aprobaron 107 constituciones. En segundo lugar, su importancia radica en los temas que se estudiaron y se definieron. Estos fueron, según el orden de su tratamiento: a) en las cuestiones relativas a los abusos en las celebraciones eucarísticas, el Sínodo manda el cumplimiento de las rúbricas del Misal Romano; b) la necesidad de contar con un catecismo completo y adaptado a las circunstancias de la diócesis, mientras no se contase con uno, mandaba a utilizar el de Astete. Dispone, además, la elaboración y publicación de un catecismo para la diócesis; c) regular el tiempo dedicado a la predicación y recordar la obligatoriedad de predicar los domingos y días festivos, además de señalar que la predicación debe realizarse para la gloria de Dios y la salvación de las almas; d) elaborar un reglamento para el seminario diocesano; e) reglamentar el pago de las primicias; ${ }^{75}$ f) la enseñanza de la doctrina cristiana, tanto en las escuelas como en las parroquias. ${ }^{76}$ En tercer lugar, su importancia también está dada por la alta concurrencia de miembros del clero. Asistió todo el cabildo eclesiástico, la curia diocesana, un alto porcentaje de párrocos $(68 \%)$ y miembros de las congregaciones religiosas.

El Sínodo dedicó una atención particular a los deberes parroquiales y a las parroquias, en este sentido recordó la obligatoriedad impuesta por el Concilio de Trento del deber de residencia en los curatos, residencia no sólo material, sino "activa y laboriosa". Establece la visita anual a cada vice-parroquia y la necesidad de velar para que las fiestas religiosas no degeneraran en espectáculos donde se diera rienda suelta a las "pasiones del juego y la embriaguez", si el párroco no podía combatir dichos males era conveniente suprimir las fiestas. Para conocer el estado material y los límites de cada curato, el Sínodo estableció que cada párroco enviase un informe con el detalle del número de capillas y su ubicación geográfica, a fin de que el obispo designara la iglesia que debía servir como parroquia y residencia del párroco.

\footnotetext{
74 El anterior había sido convocado por el Obispo Mercadillo en 1752.

${ }^{75}$ Hay que recordar que en 1854 habían sido suprimidos los diezmos. Poco a poco, éstos dejaron de cobrarse, pero los curas igual siguieron exigiendo el pago de primicias.

${ }^{76}$ En 1879, sale a la luz el Catecismo de la Doctrina Cristiana, aprobado por el Sínodo de 1877. Arancibia y Dellaferrera (1983: 28) señalan que el catecismo tuvo larga vigencia en la diócesis de Córdoba. El Sínodo de 1906 se publica en un apéndice y los obispos argentinos reunidos en Salta lo adoptan como compendio para la enseñanza de la doctrina ordenando su reimpresión, éste tuvo vigencia hasta la tercera conferencia episcopal de 1909, cuando se adopta el catecismo de San Pío X.
} 
Dedica un apartado a la conducta moral de los clérigos. Concretamente, sobre los ordenandos -aquellos que sin haber llegado al presbiterado poseen el estado clerical-, señala que deben evitar compañías y reuniones ajenas a su estado, vestir el hábito clerical, llevar abierta la tonsura y confesarse al menos una vez al mes. En cuanto a aquellos que hayan recibido el presbiterado, advierte la necesidad de que lleven una vida honesta y virtuosa, ya que "los sacerdotes son el espejo en el que todos se miran". Volveremos sobre las disposiciones del sínodo respecto al clero al delinear el perfil clerical (Parte 4: Cap. 7). En cuanto a los fieles, el Sínodo señala la obligatoriedad de asistir a la funciones y escuchar la predicación y a los padres el deber de enviar a sus hijos al catecismo.

Arancibia y Dellaferrera (1983: 48), sostienen el "carácter defensivo" de la legislación sinodal. "Pareciera que el mayor esfuerzo se vuelca en conservar, más que a impulsar la nueva misión que requieren los tiempos [...] el sínodo deja la impresión de una comunidad cristiana que esta como anclada en el tiempo. Una iglesia particular que resiste un cambio que entrevé pernicioso pero que no puede ubicar con claridad en el conjunto de un país que sufre la violencia de quienes quieren estructurarlo bajo otro signo. El pueblo sigue siendo cristiano pero la laicización de las instituciones será en este contexto un obstáculo grave que la iglesia superara con muchas dificultades".

Efectivamente, la relación de la Iglesia con los estados liberales y sus políticas laicistas dio lugar a una visión "ultramontana", que impulsó a los pontífices a una actitud defensiva frente a la modernidad. La Iglesia tendió a aislarse del mundo moderno, adoptó un sistema de educación destinado a proteger a los católicos de los males de la modernidad, viéndose a sí misma como una fortaleza asediada. La intransigencia y el aislamiento constituyeron un intento por conservar los modelos, los valores y las prácticas sociales y culturales católicas (Gallardo, 2010: 335).

\subsubsection{El Sínodo de 1906}

El Sínodo de $1906^{77}$ fue convocado por el recién electo Obispo diocesano Zenón Bustos y Ferreyra. El sínodo reunió a 37 padres sinodales, entre los que se encontraban 10 miembros de la curia, el vicario foráneo de La Rioja y 26 curas párrocos. El diagnóstico

\footnotetext{
${ }^{77}$ Sínodo Diocesano celebrado en Córdoba. Por el Ilmo. y Rvmo. Señor Obispo Don Fray Bustos y Ferreira. En el año del Señor MCMVI. Resoluciones y Apéndices, Córdoba, Tipografía La Industrial, 1907.
} 
sobre la cristiandad local fue similar al elaborado por el Concilio Plenario para América Latina [en adelante CPAL]. Recoge y aplica a la realidad diocesana los decretos de dicho concilio. Habían pasado casi treinta años del sínodo anterior y el contexto se había modificado sustancialmente. El carácter defensivo dio lugar a una actitud más ofensiva. La Iglesia diocesana se propuso salir a reconquistar la sociedad con el objetivo explícito de “instaurar el Reinado de Cristo". El lenguaje nos remite a nuevos conceptos, uno de ellos es el de "nueva cristiandad", que revela un marcado intento de reconquistar a la sociedad civil, mediante la puesta en marcha de un "catolicismo en movimiento". El sínodo diocesano elaboró un diagnóstico sobre la feligresía local y emitió disposiciones orientadas a dar solución a los problemas percibidos como más graves. Éstos podrían sintetizarse en dos cuestiones: la amenaza que suponía la actividad de aquellos considerados "enemigos de la fe", principalmente el socialismo, y la deficiente educación cristiana de amplios sectores sociales, que se manifestaba en una escasa práctica religiosa. Para los padres sinodales, un pueblo católico ignorante era proclive a verse atraído por las promesas del socialismo. Las disposiciones de la asamblea estuvieron orientadas a combatir a los enemigos de la fe y a reforzar la debilitada religiosidad popular. El sínodo se expidió en cuestiones relativas a la fe y a los peligros que atentaban contra ella; a la misión y función del clero parroquial y de las congregaciones religiosas; a la liturgia, los sacramentos, la predicación, la enseñanza del catecismo; la acción católica en relación a la educación, la prensa y las asociaciones laicales. En él se ven reflejadas las preocupaciones del obispo y el clero y las directivas pastorales que eran necesarias implementar.

Para paliar la ignorancia religiosa, el sínodo recomienda el catecismo; para alimentar la vida cristiana, reavivar el culto; para responder a los “errores" modernos, la instrucción católica de la niñez y juventud; y para salvaguardar a los fieles de la modernidad que se levantaba al margen de la Iglesia católica, crear instituciones católicas. Para vigorizar la religiosidad, el sínodo recomendaba una serie de puntos: fomentar el culto de la eucaristía y del sacrantísimo Corazón de Jesús, establecer en las parroquias asociaciones de fieles. Promover el culto público, porque, según el sínodo "el culto se le ha de tributar a Dios, no solo del individuo, sino también de las sociedades. Por tanto, consideraba necesario el reconocimiento a Dios por parte de la sociedad civil, a través del culto y la adoración". 78

\footnotetext{
${ }^{78}$ Sínodo Diocesano... ob. cit., punto 35.
} 
Estimular la práctica recurrente de sacramentos, en particular, la misa dominical y la confesión anual. También se le otorgaba suma importancia a la educación católica, en las escuelas y en las parroquias. Esta debía implementarse con la enseñanza del catecismo, la predicación y las clases de religión.

La institución eclesiástica es la que debe llevar adelante el proyecto, lo que implica capacitar al clero. Por consiguiente, los seminarios pasan a ser prioritarios; se debe aumentar el número de alumnos, pero sobre todo formarlos para llevar adelante dicho proyecto. Para ello, se insiste en la neo-escolástica como doctrina fundamental, en el derecho canónico como disciplina y en una espiritualidad ascética a la vez que sentimental. Si bien el sínodo constata la hostilidad del medio y la desfavorable correlación de fuerzas, consigna, con más fuerza aún, el convencimiento de que con la fe esa situación será superada. En sus documentos queda claro que el sujeto de la romanización es la institución eclesiástica y, por consiguiente, la convicción de que de su existencia vigorosa depende la consolidación del catolicismo en la sociedad provincial. En este marco, el sínodo plantea una lucha frene a las amenazas externas que afectan al catolicismo. Los enemigos son "los errores de nuestro tiempo": el ateísmo, el materialismo, el racionalismo, el naturalismo, el indiferentismo y, de modo especial, el liberalismo, el positivismo y el protestantismo. Estos errores se difunden en la prensa, las revistas y los libros y se infiltran en las novelas, cuya lectura se prohíbe. Se considera a la educación laica como una de las principales plataformas de difusión de los errores modernos y, por este motivo, es condenada. El sínodo propone edificar desde sus cimientos una sociedad nueva. El pilar del proyecto es la educación católica y, ante todo, la primaria. Por eso se manda a los párrocos a que la implanten y a los padres a que envíen a sus hijos a las escuelas parroquiales o a otras reconocidas como católicas. El sínodo comprueba, asimismo, la avidez que existe en el pueblo por informarse y leer. El problema que se plantea en este campo es cómo compaginar el fomento de la lectura con el control del contenido de lo que se lee. Para lograr este objetivo, se recomienda la creación de bibliotecas parroquiales públicas con "buena y sana” lectura. Así como fundar periódicos en cada diócesis. Por último, en el ámbito laboral, el peligro se materializaba en la acción del socialismo y los sindicatos. Para contrarrestar a ambos se insiste en la formación y difusión de los "círculos católicos de obreros". No obstante, esta institucionalización paralela de la sociedad civil la tienen que 
llevar adelante los laicos, la institución eclesiástica es la que ha de planificar, dirigir y controlar. Esto significa que, en última instancia, hay que revitalizar los seminarios para mejorar la instrucción de los futuros clérigos, si se quiere que el proyecto tenga éxito. Apuntalada la formación de los clérigos, se regulan los ejercicios espirituales y las conferencias teológico-litúrgicas, con vistas a su reavivamiento espiritual y su formación permanente.

La acción social debía orientarse a varios frentes, el fomento de la prensa católica, la constitución de asociaciones católicas con fines benéficos, asistenciales y mutualistas. La acción de la Iglesia en este campo fue presentada como una necesidad imperiosa, pues corría peligro de ser "arrebatada por la prédica de la escuela socialista y anarquista una parte considerable de la grey de Jesucristo". ${ }^{79}$

En el campo de la política, el sínodo sólo establecía "ser obligación de los católicos ejercer el derecho de sufragio, y que el hacerlo es, en todo caso, preferible a abstenerse de votar. En consecuencia, los encargados de la enseñanza de la doctrina cristiana, y en particular los párrocos y demás sacerdotes instruirán a los fieles sobre el deber que tienen de votar por el candidato católico, si lo hubiere, y si no, por el menos malo". 80

La difusión del espíritu del sínodo debía realizarse mediante la creación y mayor difusión de las asociaciones pías, como La Cofradía del Santísimo Sacramento, el Apostolado de la Oración y La Congregación de la Doctrina Cristiana. Sobre todo esta última, ya que la catequesis era el núcleo central de la propuesta sinodal, el sínodo insiste en la exigencia de utilizar el catecismo único y de crear escuelas de catecismo para los adultos que frecuentan el colegio nacional y la universidad, donde no se enseña religión.

Para contrarrestar la influencia de la prensa, las revistas y los libros erróneos, el sínodo propició la creación y propagación de medios de prensa católicos y la fundación de bibliotecas parroquiales, destinadas a paliar la ignorancia en materia religiosa. ${ }^{81}$ Para fortalecer la vida cristiana promovió la enseñanza del catecismo y propuso reavivar el culto, para dar una respuesta a la cuestión social impulsó la creación de instituciones católicas en el seno de las parroquias, destinadas a realizar actividades asistenciales, benéficas y sociales. El proyecto de renovación católica que se proponía estaría bajo la dirección del

\footnotetext{
${ }^{79}$ Sínodo Diocesano... ob. cit., puntos 243-246.

${ }^{80}$ Sínodo Diocesano... ob. cit., puntos 15-16.

${ }^{81}$ Sínodo Diocesano... ob.cit., Capítulo XXXVI: "De la prensa católica".
} 
clero. El seminario diocesano se convirtió en una institución clave, pues de allí saldrían sacerdotes formados para dar una respuesta católica a las demandas sociales. El sínodo propuso la reforma del plan de estudios, se incorporó el derecho canónico y algunas ciencias modernas y se instituyó una cátedra de cuestiones sociales "a fin de que el clero de la diócesis se halle habilitado para una eficaz actuación en esta clase de obras". ${ }^{82}$

Los presbíteros eran quienes debían planificar, dirigir y orientar la acción católica, lo cual significaba que no sólo había que revitalizar los seminarios para mejorar la instrucción de los futuros clérigos, sino que era necesario instaurar mecanismos para su formación permanente. En este campo, se regularon los ejercicios espirituales y las conferencias de moral y liturgia. ${ }^{83}$ El sínodo tuvo como prioridad promover instituciones católicas destinadas a penetrar en la conciencia popular y el modo considerado más eficaz para lograrlo fue la revitalización de la institución parroquial, poniendo énfasis en impulsar el afianzamiento de la religiosidad práctica de estos sectores sociales.

Estos dos sínodos marcan dos posturas de la iglesia local frente a la modernidad. La primera, remite a una mirada temerosa, a partir de la cual la iglesia se ve a sí misma como una fortaleza asediada por el avance secularizador y laicista del estado. Las medidas que se toman apuntan a un fortalecimiento interno, a una consolidación de las estructuras institucionales. En la segunda, se advierte la urgencia que tenía la Iglesia de adaptarse a las necesidades de la sociedad, en cuyo medio estaba llamada a realizar su actividad. Ello implicaba salir del aislamiento y penetrar en el mundo social, llevando el mensaje y los valores evangélicos.

Un aspecto central del sínodo estaba orientado a reactivar la debilitada vida parroquial a fin de organizar la acción católica y neutralizar la acción de los socialistas y librepensadores. La función del templo sobrepasará los objetivos de índole puramente espiritual, ejerciendo una función social de considerable importancia, la iglesia alcanzará un notable grado de presencia en las comunidades locales a través de la conformación de una red de parroquias, vice-parroquias y capillas. $^{84}$ La Iglesia se apoyó en el reconocimiento de la legitimidad social de la religión católica y, principalmente, en su

\footnotetext{
${ }^{82}$ Sínodo Diocesano... ob.cit., punto 245.

${ }^{83}$ Sínodo Diocesano... ob. cit., Capítulo XXX: "De los ejercicios espirituales” y Capítulo XXXI: "De las conferencias teológico-litúrgicas".

84 AAC. Fondo Zenón Bustos. Obispo. Caja No 5. "Reglas dadas a los párrocos de esta ciudad", Establecimiento Gráfico Los Principios, Córdoba, 1914.
} 
misión de socialización moral, para, desde allí, ocupar una posición institucional hegemónica y resguardar la posición católica dominante, tema que abordamos en el Capítulo 15 destinado a las prácticas pastorales.

Podría afirmarse que estas asambleas diocesanas marcan claramente el rumbo que el proyecto reformador debe seguir y muestran, de una manera bastante diáfana, las dos estrategias de acción. La primera de defensa y fortalecimiento hacia adentro y la segunda de conquista de la sociedad. Para llevar a la práctica las disposiciones, sin duda era importante conocer el estado de la diócesis y arbitrar los medios necesarios para orientar la vida parroquial hacia los objetivos sinodales. Una de las herramientas con la que cuentan los obispos fue, sin duda, la visita pastoral, que analizaremos a continuación.

\subsection{Las visitas pastorales: herramientas para el buen funcionamiento de la diócesis}

El objeto de análisis en este punto no es tanto la visita pastoral en sí misma, sino presentarla como una herramienta de la jerarquía en orden a la administración del poder pastoral, disciplinar y magisterial. En la tercera parte de la tesis, veremos el análisis detallado de las visitas como medios de control social del espacio y estrategias de territorialización religiosa. En la primera parte de este trabajo, hemos señalado la importancia del análisis de este tipo de documentos y las dificultades que presentan. Si bien en el archivo diocesano no existe un fondo que reúna las visitas del período, cuenta con dos libros que recogen los autos de las visitas, las fechas, los lugares y, en algunos casos, el visitador que las realizó. ${ }^{85}$ Para ello, hemos recogido y organizado la información fragmentaria y dispersa encontrada, a fin de tener una visión más acabada sobre la cantidad, el contenido y los lugares de las giras pastorales. Además, la consulta sistemática de los legajos y las cajas con documentación sobre las parroquias de Córdoba, nos ha permitido realizar una aproximación cualitativa y cuantitativa de las visitas realizadas y, en algunos casos, reconstruir el itinerario de la gira y las consideraciones del visitador.

Cabe advertir que la documentación más rica y completa se encuentra para el período de Fray Zenón Bustos, quien realizó dos giras, sobre las cuales hemos podido acceder a las pastorales de apertura y cierre, a los cuestionarios y a las disposiciones registradas en los

${ }^{85}$ ACC. Libro de Autos y Visitas Pastorales, 1885-1916; Libro de Notas Particulares del Sr Obispo. A partir del f.94 se encuentra el Libro abierto por el visitador de parroquias Filemón Cabanillas; AAC. Carpeta Curia, Visitas Pastorales y Varios, 1887-1929 y el Libro de Visita de Parroquias, 1916-1922. 
respectivos autos de cada visita. Contamos también con dos relatos o crónicas de visitas redactados de primera mano por Filemón Cabanillas, quien actuó como Secretario de Fray Capistrano Tissera (1885-1886), durante su visita, y como Visitador, siendo Obispo auxiliar de Córdoba (1901-1904), en la gestión del Obispo Fray Reginaldo Toro. Un vacío importante se genera al no haber podido localizar las visitas realizadas por Fray Reginaldo Toro, esto ha procurado salvarse con otras fuentes complementarias, como la serie de informes remitidos a la curia por los párrocos durante los años 1890-1893, en los cuales se informa sobre varios aspectos de la vida religiosa y el estado material del curato.

Para reconstruir la imagen de la diócesis que tenía el prelado, la parte más sustantiva de la visita es sin duda el auto del obispo, en el que se realizan las consideraciones relativas a la situación general del curato a nivel pastoral, económico, litúrgico, disciplinar, etc. Un segundo aspecto, no menor, es aquél que se relaciona con las respuestas de cada párroco a los cuestionarios de la visita, estas respuestas contienen una valiosa información sobre una diversidad considerable de temas. Estos autos, analizados en serie, nos brindan bastante luz sobre la realidad de cada curato, realidad que será contrastada con las normas emanadas de la curia.

Párrafos arriba, señalábamos que el primer obispo que retoma la práctica de la visita canónica fue Ramírez de Arellano. En el período de análisis que nos compete, la visita se abría mediante una comunicación del obispo a los párrocos $\mathrm{y}$, eventualmente, la publicación de una circular, a través de la cual se informaba al clero y a los fieles de la diócesis el inicio, los requerimientos y los frutos que se esperaban de la misma. A partir de 1906, durante la gestión de Zenón Bustos, comienzan a implementarse los cuestionarios previos a la visita, los cuales pueden consultarse en el Anexo III de este trabajo.

El Concilio de Trento estableció la obligación de los obispos de residir en sus diócesis y de visitarla personalmente o, en caso de legítimo impedimento, a través del vicario general o de otro visitador designado para esta tarea. El objetivo principal de estas visitas era “introducir la doctrina sana y católica y desterrar las herejías; mantener las buenas costumbres y corregir las malas; inflamar al pueblo con exhortaciones y consejos a la religión, paz e inocencia, y arreglar todas las demás cosas en utilidad de los fieles, según la prudencia de los visitadores, y como permitan el lugar, el tiempo y las circunstancias". ${ }^{86} \mathrm{El}$

\footnotetext{
${ }^{86}$ Sesión XXIV, De Reformatione, 11/11/1563, c 3.
} 
Concilio indicaba las visitas pastorales como una premisa de las periódicas visitas ad limina. Los sínodos locales se encargaron de impulsar esta práctica. A su vez, las visitas tenían entre sus fines implementar las normas.

Las visitas son una más de las medidas institucionales que llevarán a la transformación de Córdoba en una diócesis "romanizada". Valentina Ayrolo (2004) sostiene que, en la diócesis de Córdoba, la Iglesia colonial alcanzó su fin a mediados del siglo XIX y que, en ese momento, se abrió un proceso de transición, que permitió la homogeneización de la Iglesia que, lentamente, se perfiló como una Iglesia nacional alineada con Roma. De allí en más, la Iglesia cordobesa transformará su modus operandi al seguir básicamente dos premisas: la primera es la unión con Roma y la segunda es la defensa de algunas prerrogativas de origen colonial que la mantendrá en su rol de "garante del orden social". El sínodo dispuso la necesidad de la utilización del "ritual romano" y expresa claramente el motivo "siendo la Iglesia Romana la Madre y Maestra de todas las Iglesias, ningún ritual debe merecernos más respeto". ${ }^{87}$ En cuanto a la función de garante del orden social, el sínodo advertía a los párrocos que debían "celar contra los pecados públicos, implementando todos los medios que la prudencia y la caridad aconsejan, para cortar los escándalos, demandando para esto, si fuese necesario, el auxilio del brazo secular". ${ }^{88}$ Más adelante, la constitución onceaba señala que:

Siendo notorios los abusos y escándalos que se cometen en algunos puntos de la campaña con motivo de las fiestas religiosas que se celebran en ciertas capillas, en las cuales lejos de notarse un espíritu religioso en los concurrentes, se convierten por la malicia de algunos, en públicos escándalos, en donde se da rienda suelta a las pasiones del juego y de la embriaguez: el Sínodo para evitar estos funestos abusos ordena a los párrocos que empleen todo su celo a fin de cortar tamaños males, pidiendo si fuese necesario el auxilio a la autoridad civil [...] y si a pesar de estos esfuerzos los párrocos no pudieren evitar los escándalos públicos, el sínodo manda que se omitan o se interrumpan aquellas funciones en que tienen lugar males tan grandes. ${ }^{89}$

\footnotetext{
${ }^{87}$ AAC. Actas de las Sesiones del Sínodo Diocesano. Sesión Cuarta. Capítulo VIII: Se prescribe el uso del Ritual Romano en la administración de los sacramentos y se dan otras disposiciones relativas a esta materia.

88 AAC. Actas de las Sesiones del Sínodo Diocesano. Capítulo XVII: Disposiciones generales sobre parroquias, constitución $2^{\circ}$ f.529.

${ }^{89}$ AAC. Actas de las Sesiones del Sínodo Diocesano... f.534.
} 
Además, el sínodo presenta una serie de disposiciones relativas a las funciones del párroco en relación al cuidado material del templo, ${ }^{90}$ la administración de los sacramentos, el cuidado de los libros parroquiales, y el modo de hacer los asientos, las visitas frecuentes a las capillas dependientes "que los párrocos visiten por sí mismos las vice-parroquias durante uno o dos meses en el año, o que envíen a otro sacerdote cuando ellos se hallen impedidos". 91

Los obispos comenzaron a cumplir el deber canónico de la visita, venciendo los obstáculos de las distancias y de la precariedad de los medios de transporte, así como el deterioro de los caminos, la dificultad propia de territorios accidentados e inhóspitos, como lo son las sierras grandes en el oeste cordobés y la zona precordillerana riojana. En la realización de estas auténticas travesías, cumplimentando las visitas, fallecieron los Obispos Álvarez, Esquiú y Tissera.

El Concilio Plenario para América Latina (1899) dio un nuevo impulso a la práctica de las visitas canónicas. En el Título III, Cap. I, destinado al obispo, se advierte que: "no dejen los Obispos de visitar su propia diócesis personalmente, ó en caso de legítimo impedimento (Conc. Trid. sess. 24.), por medio de su vicario general ú otro visitador, ó por algunos eclesiásticos recomendables por su ciencia, piedad, destreza y madurez en el manejo de los negocios. En atención a la grande extensión de nuestras diócesis, y dada por otra parte la suma utilidad de la visita personal, practicada por el propio Obispo, hay que procurar con todo empeño que el Obispo llegue a su debido tiempo, aun a los lugares ya visitados por su delegado; y para lograrlo más fácilmente, dividir la diócesis en regiones, é ir visitando región por región, de modo que en determinado número de años quede visitada toda la diócesis". 92

Estas disposiciones regirán la práctica de la visita, así lo expresa el Obispo Zenón Bustos en la carta pastoral de cierre y apertura de las visitas de 1906 y 1912, respectivamente. "Dando cumplimiento a las disposiciones del Santo Concilio Plenario Latino Americano y persiguiendo los mismos intereses expresados en ellas, hemos practicado la santa visita

\footnotetext{
${ }^{90}$ AAC. Actas de las Sesiones del Sínodo Diocesano. Constituciones Sinodales. Capítulo I: Se recomienda el arreglo y el aseo de los templos.

91 AAC. Actas de las Sesiones del Sínodo Diocesano... Capítulo XVII: Disposiciones generales sobre parroquias, constitución $2^{\circ}$ f.529.

92 Actas y Decretos del CPAL. Celebrado en Roma el año del Señor MDCCCXCIX. 593 pp., Roma, Tipología Vaticana, 1906. Título III: De las personas eclesiásticas, Cap. I: De los Obispos, p. 117.
} 
terminada y nos disponemos a repetirla con los mismos propósitos. A esta función del obispado, une el Concilio ideales morales muy altos que deben promoverse en ella en bien del individuo, de la familia y de la sociedad. Aunque imponga sacrificios debe hacerla el obispo y debe repetirla con frecuencia". ${ }^{93}$ La pastoral continúa citando las disposiciones del Concilio en lo referente al objetivo de la visita, la facultad del obispo para arbitrar las medidas que considere necesarias para extirpar los abusos y la obligación de los párrocos de informar sobre el cumplimiento de los decretos de la visita en el lapso de un año. El Código de Derecho Canónico de 1917 establece con más precisión que "están los Obispos obligados a visitar la diócesis cada año, total o parcialmente, de suerte que por lo menos de cinco en cinco años la recorran toda" (CDC,1949: can. 343-346).

La visita tiene la función no sólo de vincular los diversos niveles de gobierno de la Iglesia (obispo visitador-párroco-feligreses), sino también las diversas realidades socioreligiosas de la diócesis de Córdoba. En el relato de las mismas, veremos que la visita del obispo reunía a feligreses, párrocos y autoridades civiles de regiones vecinas. El obispo advertía a los fieles que los párrocos "son la fuerza local que realiza en los curatos los ideales del programa de la visita: que son el evangelio viviente entre la porción de su feligreses. Hemos de pedirle a los fieles que rodeen de veneración y respeto a estos sus pastores, dispuestos como viven hasta el sacrificio a servir los intereses espirituales de todos los suyos [...] entregándoseles con todo su tiempo, su preparación intelectual y sus personas $[\ldots]$ inculcarles que estos sacerdotes son entre sus rebaños sal que condimenta las costumbres saludables y la luz que les marca los rumbos y caminos por donde conducir sus pasos en la vida espiritual". 94

Las visitas tenían, además, un carácter disciplinario, cuyo objetivo era reafirmar la autoridad episcopal y parroquial, llevar a la iglesia hacia un régimen más centralizado de gobierno, verificar el nivel de uniformidad, de decencia y de corrección de la liturgia y las prácticas religiosas. El visitador debía "conocer la marcha y estado de moralidad de cada parroquia, como la administración recta y verdaderamente ajustada a las leyes canónicas". 95

El objetivo de las visitas a las parroquias era la inspección directa de los aspectos materiales y espirituales de la vida parroquial y la conducta de fidelidad del clero y los

\footnotetext{
${ }^{93}$ Zenón Bustos, Carta Pastoral sobre la nueva Santa Visita de la Diócesis, REOBA, 1912, p. 1177.

${ }^{94}$ Ibid., p. 1178.

95 AAC. Libro de Notas particulares del Obispo, 1884-1903, f.102. Visita al Curato de Cruz del Eje.
} 
fieles. Por lo tanto, se realizaba la visitatio rerum y la visitatio hominum (las cosas materiales y los hombres). Entre las cosas materiales, el visitador examinaba los edificios (iglesia, capillas, cementerios), el mobiliario (sagrario, fuente bautismal, altares, reliquias, vasos sagrados) y el archivo parroquial. En cuanto a la visitatio hominum, trataba sobre los clérigos, titulares, vicarios y auxiliares. El visitador verificaba la condición canónica de los clérigos, investigaba sobre el modo de ejercer el ministerio parroquial (celebración de la misa, administración de los sacramentos, enseñanza de la doctrina y de la moral, obras de caridad y residencia). Además, recibía informaciones e interrogaba a testigos sobre el ejercicio de actividades incompatibles con el ministerio. También averiguaba respecto de su nivel intelectual. En cuanto al examen sobre la feligresía, se centraba, primordialmente, en la conducta moral, en particular, el concubinato, la embriaguez y el juego (Coulet, 1977: 31).

Las visitas suponían auténticas peregrinaciones por los valles y montañas, por caminos a menudo ásperos y casi inaccesibles, o por extensas llanuras, en algunos casos surcadas por líneas férreas, que hacían más ágil el trayecto. En la región serrana, las visitas se realizaron en coche de caballos y a lomo de cabalgadura. En las extensas llanuras del sudeste provincial, el tendido de las líneas férreas facilitó los traslados del obispo y su comitiva, el ferrocarril y las mensajerías constituyeron los medios de transporte habituales de la comitiva episcopal en la región.

De la lectura de las crónicas, se infiere que el desarrollo de la visita se hizo de acuerdo con normas bien establecidas. El obispo presidía la procesión, se dirigía a la entrada de la Iglesia, el cura párroco le daba la bienvenida en el pretil y le ofrecía adorar la cruz, luego, la procesión entraba solemnemente al templo. Habitualmente, se celebraba una misa de apertura, o el obispo decía una breve homilía dirigida a la concurrencia reunida. Se leía la pastoral de apertura de la "Santa Visita" y el edicto correspondiente. A continuación, o en otro momento, se pasaba revista al Sagrario, la pila bautismal, los óleos sagrados, las reliquias, la imágenes, los altares y el confesionario. En la sacristía, se revisaba la ropa, los manteles y los vasos sagrados. Luego, se inspeccionaban los libros, los inventarios y documentos del archivo y se visitaba el cementerio contiguo a la iglesia. Además, durante la visita se realizaba una misión, se administraban los sacramentos, en particular la confirmación, la comunión y la confesión. Se recibían denuncias sobre situaciones 
irregulares y de escándalo público, con el fin de regularizar "amancebamientos". En algunas oportunidades, el obispo enviaba a un delegado a visitar las capillas dependientes, cuando esto no era posible recibía informes de personas dignas de credibilidad. Durante la visita pastoral, el secretario del obispo elaboraba una crónica detallada a fin de reconstruir los movimientos e impresiones recibidas a lo largo de la visita.

En la tercera parte de la tesis, nos detendremos en las visitas como herramientas vinculadas al poder episcopal y al control del territorio. 


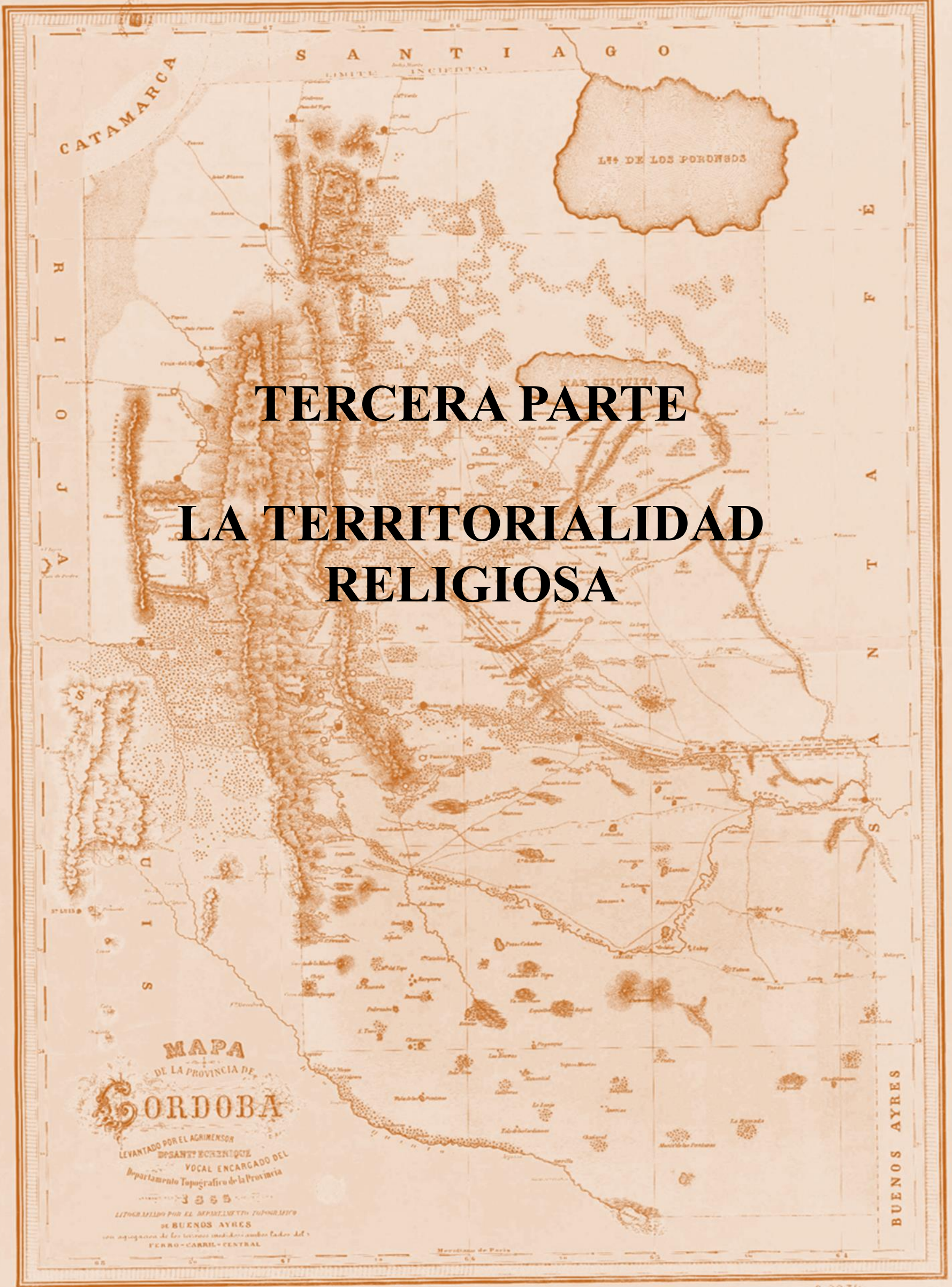




\section{CAPÍTULO 7}

\section{LA DIMENSIÓN ESPACIAL DEL HECHO RELIGIOSO}

Esta tercera parte de la tesis analiza las estrategias pastorales implementadas por la jerarquía eclesiástica, destinadas a asumir el desafío modernizador y adecuar las respuestas del catolicismo a las exigencias de una sociedad -que percibían- en tránsito hacia una posible desacralización. ¿En qué medida los obispos diocesanos articularon y resignificaron el espacio diocesano y parroquial, en función del proceso de modernización social? Una de las preocupaciones esenciales de este capítulo es abordar la dimensión material de la religión, tomando el territorio como un espacio de encuentro entre la religión y la sociedad. Nos interesa ver el impacto de la religión en el territorio. Para ello, se privilegia la dimensión material de la religión, pues como señalan varios autores (Le Bras, 1976; IognaPrat, 2005, 2006 y 2010; Restif, 2006 y 2013; Lawers, 2008; Provost, 2013; Turchini, 2013; Merdrignac y otros, 2013), los lugares de culto son indicadores de pertenencia religiosa visible en el espacio. Iglesias, capillas y cementerios nos permiten analizar la configuración territorial y social de la iglesia diocesana de Córdoba y acercarnos a la dimensión espacial de lo social y a las dimensiones socio-espaciales de la religión.

Dos categorías guían estas reflexiones, la de "espacialización eclesiástica", que se realiza a través de la creación de una red de lugares sagrados, ya sean parroquias, capillas, santuarios o cementerios, y la de "espiritualización", que hace referencia a los esfuerzos de la institución eclesiástica por establecer, en la tierra, una comunidad espiritual. Estos esfuerzos se reflejan en la necesidad de fijar un parentesco de lazos espirituales, que definan a las comunidades de fieles, como una forma de estructuración de las sociedades (Lawers, 2005: 269). En este primer capítulo, nos centraremos en el fenómeno de espacialización y territorialización y dejaremos para la última parte el proceso denominado de espiritualización, más vinculado a la creación de lazos sociales entre los miembros de la comunidad, si bien es necesario adelantar que en el estudio que nos convoca, la estrategia eclesiástica destinada a fortalecer los vínculos espirituales de las comunidades cristianas, se centrará en el templo y en la redefinición de la función de éstos en el espacio comunitario. El templo constituye, en el período analizado, el espacio de consolidación y fortalecimiento del vínculo religioso de las comunidades católicas. 
Para ello, tomaremos como referencia el debate de la historiografía europea respecto al término bífido de Iglesia material/comunidad, contenido/continente (Iogna-Prat, 2010). A la hora de abordar el problema sobre cómo se formó, dentro de una sociedad cristiana, la iglesia como institución nacional, se nos presenta una dificultad similar a la de los historiadores del viejo continente. La de diferenciar la iglesia edificio y la Iglesia institución, pues ambas tienden a confundirse, ya que la Iglesia es un término que da cuenta tanto del aspecto material, como del sociológico y espiritual. Pasemos a explicarlo. En el sistema de cristiandad, de unanimidad religiosa, que imperó con sus más y sus menos hasta mediados del siglo XIX, es difícil saber a qué nos referimos cuando hablamos de iglesia, porque iglesia era toda la sociedad de bautizados, por lo tanto, no existía diferenciación entre un término y otro (Di Stefano y Peire, 2004). La Iglesia era todo, tanto el edificio material como la comunidad, pero la fuerza del término está depositada en la comunidad más que en el edificio. De hecho, para pertenecer a la iglesia no era necesario pasar por el templo, es frecuente, muy frecuente, que sacramentos como el bautismo, el matrimonio, se celebraran en domicilios particulares, que el catecismo se impartiera en los hogares, el templo cumplía funciones subsidiarias y los fieles acudían a él una vez al año para cumplir con la Iglesia. Ya sea para las fiestas patronales o la pascua. Hasta mediados del siglo XIX, en Córdoba, la iglesia era la sociedad y la sociedad era la iglesia. La iglesia, como un todo social, era una institución que se imponía a toda la sociedad. El Obispo Bustos rememora esta imagen idílica. La cita que presentamos a continuación permite analizar este paso de una sociedad de unanimidad religiosa a una secularizada.

Cuando la religión en estos países navegaba en balsas de miel, aunque los sacerdotes fueran pocos hacían alcanzar su ministerio, siendo eficazmente ayudados en los muchos puntos que ellos no podían llegar, por la obra espontánea de los fieles. Hombre y mujeres tomaban el rol de sacerdotes y se mostraban empeñosos en cultivar y conservar sus creencias y transmitirlas a las generaciones nuevas. Aunque a los puntos demasiados distantes no llegase la palabra del prestigio sacerdotal, el párroco estaba tranquilo y seguro de que su presencia no era del todo indispensable, por la seguridad que tenía de que cada casa era un templo y que oficiaban, como lo haría el sacerdote, los jefes de familia. Todos se preocupaban de ser religiosos y en aparecer que lo eran aquellos que flaqueaban en sus creencias. En esas condiciones se comprende que no había tanta necesidad de recurrir a vuestra cooperación para aumentar el clero. Pero aquello ya pasó, quizá para no volver y hemos entrado en otra época diversa. Ya no se encuentra un sacerdote en cada individuo, sino que cada 
individuo de los tiempos presentes necesita del apostolado del sacerdote. Juzguemos por esto que no desconoceréis el deber de cooperar al aumento del clero. ${ }^{1}$

A medida que avanza el proceso de secularización, esta ecuación cambia. La iglesia ya no se identifica totalmente con la comunidad y para formar parte de ella comienza a ser necesario pasar por el templo. El templo, el edificio material, adquiere una función central, vinculada a la identidad católica. El cura sin templo fue comparado por el Obispo Bustos “al jefe de familia sin hogar donde reunir y trasmitir su espíritu a sus hijos". 2

La relación continente / contenido cambia. Iogna-Prat explica que el contenido de la Iglesia comunidad está sintetizado en los siete sacramentos, el inicio de la vida cristiana con el bautismo y el final de ella con la extremaunción. A partir del proceso de secularización europeo (el paso del período escolástico al absolutismo, a la modernidad sacralizada. El paso de la Iglesia al Estado). Según el autor hay una voluntad explícita de insertar los siete sacramentos dentro de la iglesia material. La Iglesia como institución se realiza a través de los sacramentos, esos sacramentos se administran en el templo. Aquí se ve el juego entre continente / contenido. El continente es la causa instrumental del contenido. De allí que se genere la metonimia entre el continente y el contenido. La iglesia como contenido significó iglesia como continente. Este proceso descripto para el espacio europeo tiene su correlación en el proceso de secularización que experimenta América durante la construcción del estado liberal. En el período independiente, el edificio, el templo, no representó el lugar central de la religión, una serie de circunstancias, entre otras la escasez de clero, llevó a que la religión en la campaña se refugiara fuera del templo, en las familias. A partir de la segunda mitad del siglo, el edificio sagrado se convirtió en un monumento emblemático, y, en el lugar por antonomasia de la religión, el continente pasó a ser la causa instrumental del contenido. Para ingresar en la Iglesia institución hay que pasar por la Iglesia templo.

En el paso del sistema de cristiandad a la Iglesia argentina romanizada, percibimos una voluntad explícita de centralizar la vida cristiana en el templo, como una respuesta a la laicización del estado y a la paulatina secularización de la sociedad. El Obispo Bustos lo señala cuando afirma que "sin el auxilio poderoso de los templos el trabajo de los padres de

\footnotetext{
${ }^{1}$ AAC. Carpeta Pastorales, 1900-1925. Zenón Bustos. Pastoral sobre el Seminario y la Necesidad de Clero, 1906.

${ }^{2}$ AAC. Libro de Autos y Visitas Pastorales, 1905-1916, f.369.
} 
familia por inculcar la fe religiosa y la moral cristiana en sus hijos, será impotente y de ordinario estéril en buenos resultados". Para el prelado, los niños criados "sin penetrar en el templo, por sus puertas", tenía consecuencias desastrosas para ellos y para la sociedad, era más grave que "criarlos sin hacerles conocer las puertas de la escuela", pues entendía que los disturbios sociales eran producidos por aquellos que tuvieron la desventura de no ver templos ni penetrar en ellos durante su niñez, ni la oportunidad de conocer la virtud civilizadora que ellos representan. ${ }^{3}$

Además, para ser miembro de la iglesia como institución comienza a ser necesario haber pasado por la Iglesia edificio. Uno, entre varios ejemplos, es la práctica de algunos sacramentos, el matrimonio, además de una acto sacramental, es, sin duda, un acto social por excelencia; durante la primera mitad del siglo XIX, era frecuente, como dijimos, que se celebrara en las casas particulares, en los propios domicilios, al igual que el bautismo; a partir de la primera década del siglo XX, los obispos comenzaron a limitar su celebración fuera del templo. Tal era la costumbre que la mayoría de las Iglesias no tenía pila bautismal. El Sínodo de 1877 señala que el santo sacramento del bautismo se administre con las ceremonias y ritos prescriptos y, para ello, manda "que en el término de un año desde la promulgación de estas constituciones, los párrocos coloquen en sus Iglesias parroquiales pilas decentes para el agua consagrada, y que administren siempre el santo bautismo con las solemnidades establecidas, aunque no haya pila bautismal: salvo en caso de necesidad verdadera". Respecto del matrimonio, el sínodo también es contundente, manda "que en adelante no se autorice el matrimonio, sino en la Iglesia, a menos que haya razones poderosas de proceder de otra manera". El templo comienza a ser el espacio central de la religiosidad, de manera tal que el sínodo también prohíbe "las novenas públicas que suelen hacerse en casas particulares en algunos puntos de la campaña" ${ }^{6}$

Esto nos llevó a pensar el problema sobre cómo las instituciones producen su espacio, es por ello que el análisis del espacio parroquial se enmarca en un campo más amplio, vinculado al análisis del espacio diocesano. A partir de los trabajos pioneros de Henry

\footnotetext{
${ }^{3}$ AAC. Pastorales, 1905-1927. Zenón Bustos, Pastoral del 4 de noviembre de 1911.

${ }^{4}$ AAC. Actas de Sesiones del Sínodo Diocesano celebrado en esta Santa Iglesia Catedral de Córdoba el año mil ochocientos setenta y siete, por el Ilmo. Obispo de la Diócesis Dr. Dn Manuel Eduardo Álvarez, Capítulo 9, Const. $1^{\circ}$, f. $19 \mathrm{v}$.

${ }^{5}$ Ibid., Capítulo 14, Const. $1^{\circ}$, f. 27.

${ }^{6}$ Ibid., Sección Quinta, Const. 10 , f.35.
} 
Lefebvre en los años de 1970, comienza a difundirse el uso de términos como espacio, espacialidad y espacial ente los geógrafos, antropólogos y sociólogos, estos conceptos y enfoques fueron adoptados más tarde por los historiadores. Los avances de los últimos años de la historiografía en el abordaje del espacio podrían agruparse, según Devroey y Lauwers (2007: 439), en función de tres grandes campos, el análisis de los territorios, de los poblamientos y de los espacios simbólicos.

Para elaborar este capítulo, centramos nuestro análisis en los territorios. La renovación de la historia política o institucional se abrió al campo de estudio de los "territorios" y la "territorialidad" en cuestiones vinculadas a la dominación y organización del territorio por parte de un poder particular, ya sea real, señorial, urbano, episcopal, etc. Uno de los aportes más sólidos de este tipo de abordajes está vinculado a los procesos de territorialización del poder. Estos estudios permitieron dar el paso de la idea de "territorio" como un espacio limitado, definido, controlado por el ejercicio de la autoridad, a la concepción de una pluralidad de "territorios". Entendiendo que el espacio jurisdiccional no es cerrado, sino que está permeado por los otros espacios. Los historiadores comenzaron a plantearse el problema relativo a la superposición compleja de espacios civil, parroquial, agrario o lingüístico, etc. (Lagrée, 1992). Por otro lado, el uso, por parte de los historiadores, de conceptos como centralidad, esfera de influencia, relaciones y redes sustituyeron a los enfoques basados en definiciones convencionales sobre el territorio.

El texto de Florian Mazel sobre el espacio de la diócesis, Episcopado presencia de la autoridad eclesiástica sobre el territorio (2008), analiza, justamente, la administración del territorio episcopal. Se trata de una reflexión teórica del espacio territorial episcopal como zona de dominación episcopal, de poder y de orden. El autor analiza la transformación de la diócesis en la unidad de base del gobierno de la Iglesia romana. La diócesis es la fuente del poder del papa reformador, que intenta tomar el control de la Cristiandad, creando o suprimiendo las diócesis. El papa nombra, enumera y coloca dentro de un mapa haciendo un corte territorial. También, la diócesis es la fuente de poder de cada obispo, que controla la circulación de la información y de actos litúrgicos y la implantación de cierta fiscalización. Estas prácticas administrativas surgen a partir de viajes para conocer la heterogeneidad del territorio, esos viajes son los que definen, en gran medida, la división de los territorios, dando lugar a la creación de nuevas entidades parroquiales, de esta manera, 
la cartografía de la "cristiandad local” empieza a densificarse. El artículo se encuadra en la historia social del poder, pues al autor le interesa analizar el poder episcopal en su dimensión territorial. El poder comprendido en un sentido amplio, que tiene relación con lo real y lo simbólico, con el poder personal o delegado. El poder que no se reduce a la figura del obispo, también de sus vicarios y funcionarios y del cura párroco. ¿Cuáles fueron las estrategias destinadas a afianzar ese anclaje territorial del poder eclesiástico?

\section{La precepción del espacio diocesano por parte de los obispos}

La percepción del espacio diocesano se modifica a lo largo del período que abarca la investigación. En los obispos del siglo XIX, encontramos esa actitud "defensiva” frente a la modernidad y a la consolidación del estado liberal. La postura de la jerarquía está orientada a implementar un sistema de educación cristiana destinado a proteger a los católicos de "los males" del mundo moderno, males que la autoridad eclesiástica identificaba con la indiferencia, la ignorancia religiosa, la impiedad. Las pastorales emitidas por la autoridad diocesana están en esta línea. Álvarez (1875 y 1876); Castellano (1879 y 1880); Esquiú (1881 y 1882); Tissera (1884); Toro (1892 y 1897) (REOBA, 1905: 364).

Así lo expresaba el Obispo Álvarez al inicio de su obispado "pero cuando observo toda incredulidad que caracteriza nuestro siglo, tantas blasfemias y desacatos que se cometen como por moda y despreocupación por los que se llaman librepensadores, tanta inmoralidad y corrupción y la turbulenta agitación que ella produjo [...] veo que entro a gobernar una nave combatida de todos lados por recias tempestades que amenazan echarla apique [...] Después de tantos trastornos políticos y de tanta licencia de las pasiones desencadenadas, necesariamente la disciplina de la Iglesia sufre grandes relajaciones y crece la dificultad en destruir y arrancar para edificar y plantar, en velar contra todos los errores y vicios que con tanto disimulo propagan los enemigos en las formas engañosas y fraudulentas para seducir a los incautos. Mi obligación es combatir esos errores y esos vicios donde quieran que se encuentren, trabajar en destruir el imperio, el demonio en las almas y restablecer el de Jesucristo".

Las directrices programáticas de su gestión fueron: 1) Cultivar la piedad y ciencia del clero (volveremos en la cuarta parte de la tesis sobre este tema). 2) Promover la educación cristina en los niños, a fin de combatir la ignorancia y la inmoralidad. 3) Fortalecer el 
espíritu católico en todo los diocesanos promoviendo conferencias católicas, ejercicios y misiones y otros medios a fin de "llevar la luz a las inteligencias ofuscadas por el error y la ignorancia. Hay mucha ignorancia en esas pobres gentes de la campaña que por las largas distancias y diseminado de su poblaciones carecen más de la instrucción religiosa necesaria para su moralidad, pero también hay en ellas excelentes disposiciones, fe, buena voluntad y respeto a la autoridad". 4) La paz y la tranquilidad sólo se alcanzarán si se vive la Ley de Dios, por lo tanto, es necesario vivir la caridad, el amor de unos con otros (Álvarez, 1975: 5-6).

El mensaje de esta pastoral está dirigido a una sociedad católica que se ha apartado por diversos motivos de sus prácticas religiosas. Los obispos y provisores mantienen las mismas directivas de gobierno: así, señala Castellano (1880), "vemos muchos que blasonan de católicos, viven olvidados de que para ellos han sido escritos los mandamientos de la Iglesia". En la misma sintonía, estaba el pensamiento de los Obispos Esquiú y Toro, "a nosotros que viajamos con El en la nave de la Iglesia, atravesando el mar tempestuosísimo de este mundo y que hoy nos hallamos a punto de naufragio [...] Debemos pues estar ciertos de que una grandísima parte del pueblo cristiano que hoy está sumergida en el sueño de una mortal indiferencia saldrá de su letargo" (Esquiú, 1881: 14). "Hoy nos vemos rodeados de muchos y graves errores", y la causa atribuida es la falta de fe, "vuestros errores nacen del poco conocimiento que tenéis, por vivir lejos de Dios que es la Sabiduría, por no practicar y no seguir las prácticas que el divino Jesús os enseñó" ( Toro, 1897: 5).

$\mathrm{Al}$ regreso de la visita ad limina de 1892, la primera que realizaba un obispo de Córdoba, Fray Reginaldo Toro comunicaba que, ante las preguntas del Pontífice sobre el estado de la fe, instrucción religiosa y piedad del pueblo de la diócesis, "con toda verdad y sin exageración alguna podía decirle sobre las virtudes de este pueblo católico casi entero" (Toro, 1892: 4).

La idea que expresan los obispos es la de un pueblo católico, la tradición católica heredada de sus antepasados, era aplicable a criollos e inmigrantes, sin embargo, en ambos casos se estaba sumido en la ignorancia y el abandono de las prácticas religiosas. La mirada sobre la diócesis es la de un todo católico, que está siendo inficionado por corrientes extrañas (masonería, anarquismo y socialismo), por lo tanto, era necesario volver a la religión, a la fe y a la tradición de los antepasados. 


\section{Conocer el territorio... Las visitas pastorales entre 1877 y 1904}

Entre las preocupaciones de los obispos diocesanos, se encontraba la de alcanzar, con la mayor prontitud posible, el conocimiento directo del estado material y espiritual del obispado. Para ello, dispusieron varias medias orientadas a tal fin, como la realización más asidua de las visitas pastorales y la solicitud, a los curas de campaña, de documentación pertinente para tal objeto. El Sínodo diocesano de 1877 estableció que cada párroco enviara un informe con el detalle del número de capillas y su ubicación geográfica, a fin de que el obispo designara la iglesia que debía servir como parroquia y residencia del párroco. ${ }^{7}$ Los informes fueron llegando a la curia y los obispos diocesanos comenzaron a recorrer la totalidad del territorio diocesano provincial, compuesto, en 1877, de 21 departamentos de campaña (jurisdicciones civiles) y 24 curatos (jurisdicciones eclesiásticas), ya que el departamento de Calamuchita comprendía los curatos de Santa Rosa y La Cruz; Tercero Abajo, Villa Nueva y Villa María, y Río Primero, Santa Rosa y Chalacea.

Como puede observarse en el Mapa 7, la provincia de Córdoba abarcaba una amplia circunscripción, formada por territorios heterogéneos, tanto desde el punto de vista social y cultural, como geográfico y económico. Lo escarpado de la geografía en la zona occidental serrana, las inmensas planicies del oriente, que conformaban la pampa húmeda agrícola y ganadera, y las llanuras o pampa seca con sus salitres al norte, hacían de la diócesis un mosaico poco integrado y con un deficiente control por parte del obispo. En cuanto a La Rioja, un informe enviado a la Nunciatura en 1883 señala que poseía extensos territorios, que ofrecían grandes dificultades a los párrocos "por ser en gran parte desiertos los trayectos que tienen que andar de montañas, y escabrosidades: incongruos por otra parte en razón de ser muy pobres los más de sus habitantes". 8

En la primera parte de este trabajo, hemos señalado la importancia del análisis de este tipo de documentos y las dificultades que presenta. Si bien en el archivo diocesano no existe un fondo que reúna las visitas del período, cuenta con dos libros que recogen los autos de las visitas, las fechas, los lugares y, en algunos casos, el visitador que la realiza.

\footnotetext{
${ }^{7}$ AAC. Actas del Sínodo... Capítulo 10, Cont. $1^{\circ}$.

${ }^{8}$ AAC. Copiador de Cartas. Secretaría del Obispado, 1882-1902, f.39 y ss.
} 


\section{Mapa 7}

\section{División eclesiástica de la provincia de Córdoba en 1877}

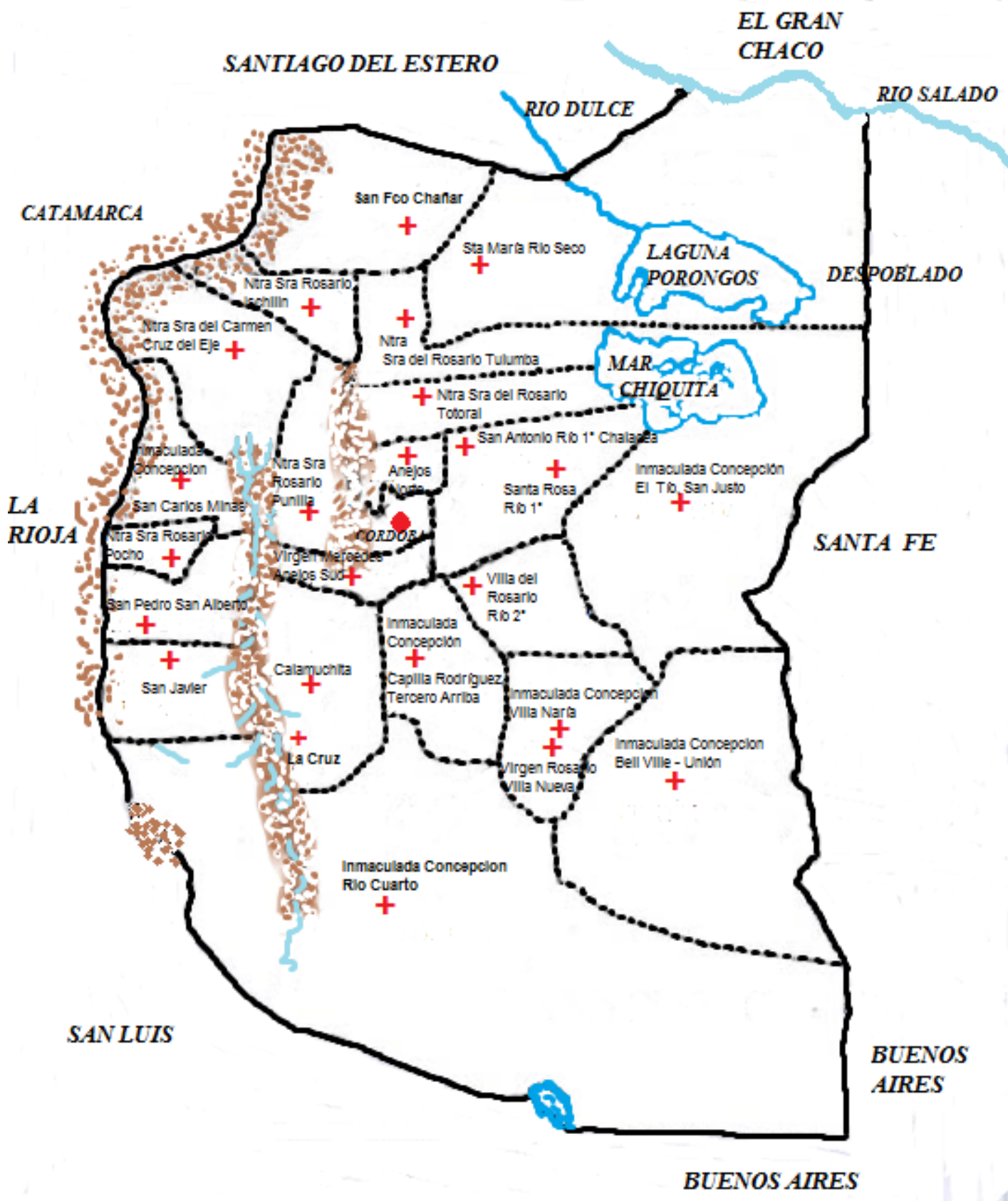

Fuente: Elaboración propia en base al Mapa Departamental de la provincia de Córdoba de 1871. 
No hemos encontrado documento alguno que acredite que el Obispo Toro abriese una visita canónica de manera formal, sí pudimos reconstruir sus desplazamientos y los de sus obispos auxiliares a partir de los libros de confirmaciones y la documentación de las parroquias, pero no se han encontrado los autos de visita. Por lo tanto, hemos registrado los lugares y las fechas de las visitas realizadas por el obispo y sus auxiliares, considerándolas como si fueran visitas canónicas. En algunos libros de confirmaciones, se deja constancia de las confirmaciones realizadas en el curato "durante la visita canónica", 9 por ende, no tenemos claro si formalmente se abrió o no una visita. El Obispo Zenón Bustos realizó dos giras pastorales por toda la provincia, además de visitar La Rioja, en los primeros años de su gestión episcopal, "la hemos recorrido por entero empleando de nueve a diez meses en las cuatro excursiones en que dividimos aquel vasto y penoso territorio". ${ }^{10}$

El texto de Angelo Turchini (2013), nos permitió pensar en una posible tipología de modelos parroquiales, vinculados a la estructuración socio-espacial de las comunidades locales. Por otro lado, el texto de Iogna-Prat y Zadora-Río (2005), nos ayudó a resolver el problema vinculado a la antigüedad de las Iglesias parroquiales, por un lado, y al resurgimiento/florecimiento, por el otro. Esta variable nos permite reflexionar en una jerarquía de iglesias rurales. Aquellas que tienen pila bautismal y derecho a bautizar y celebrar las grandes fiestas del calendario litúrgico y las que no lo tienen. Con la mirada puesta en las prácticas: ¿puede pensarse sólo un modelo común de parroquia emanado de la normativa jerárquica o podría sugerirse una multiplicidad de modelos regionales? ¿Cuáles son las características físicas de los límites de la parroquia? ¿Cuál es su valor simbólico? ¿Cómo y por qué se producen las múltiples anexiones y desmembramientos de los territorios parroquiales?

Hemos organizado el relato de las visitas, dividiendo el territorio, según un criterio demográfico y socio-cultural, en dos grandes regiones, los departamentos colonizadores y los de antigua colonización. La clasificación la hemos tomado del texto de Julio Rodríguez, Sinopsis Histórica de Córdoba (1907: 167), y del cual hemos tomado el Mapa que presentamos a continuación, Mapa 8. En tono más oscuro pueden observarse los departamentos llamados "colonizadores". Hemos intervenido el mapa delineando la región

\footnotetext{
${ }^{9}$ Santa Rosa Río, Libro de Confirmaciones 1890 f.1-81.

${ }^{10}$ AAC. Fondo Zenón Bustos. Obispo. Documentación varia, Caja N 2, f.719-720
} 


\section{Mapa 8}

\section{Departamentos colonizadores}

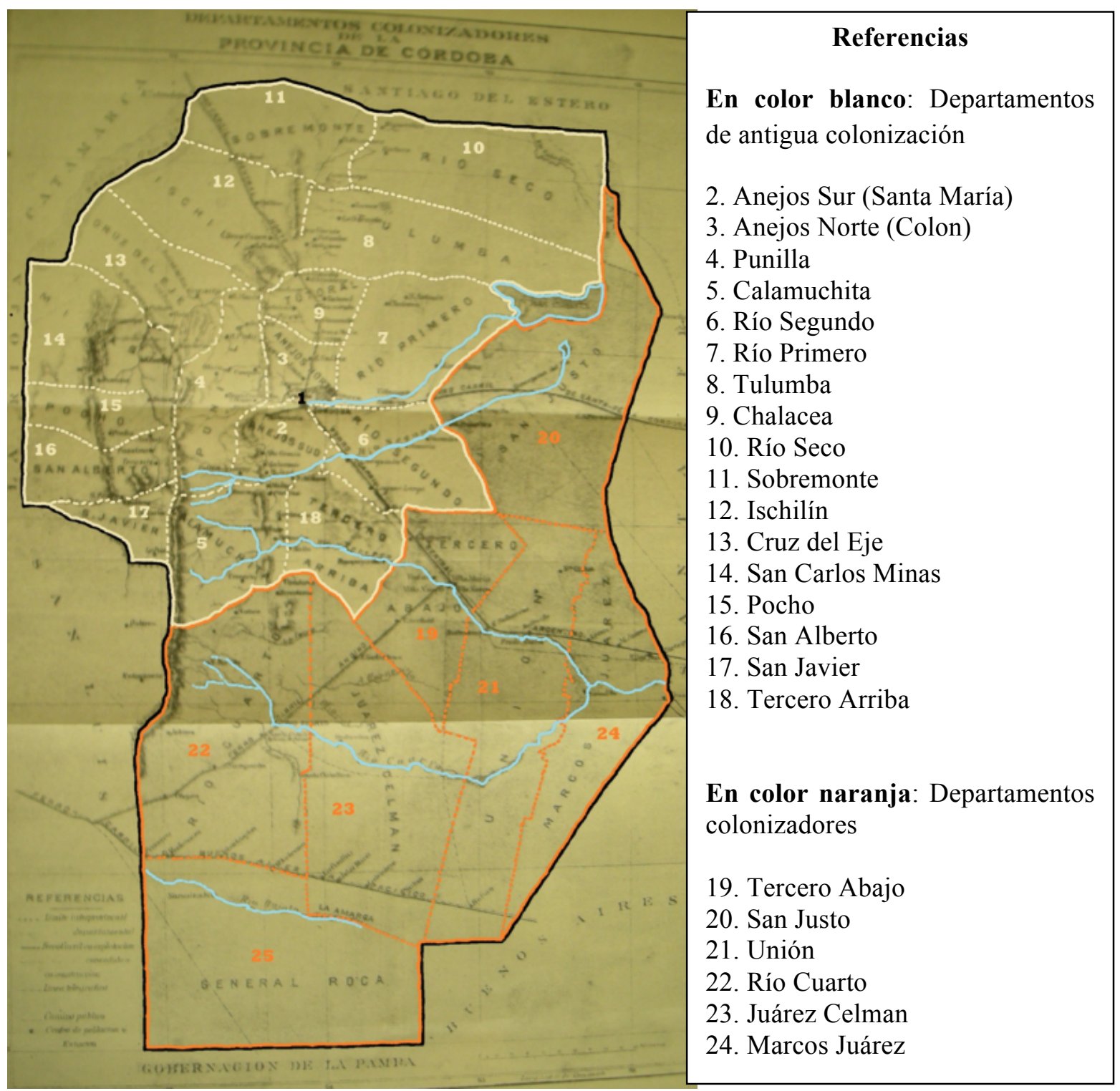

con color naranja. Nos interesa aclarar que los departamentos de Río Primero, Río Segundo y Tercero Arriba, si bien constituyen núcleos poblacionales de antigua data, y por ello se encuentran en la zona blanca, experimentaron, a lo largo del período analizado, un fuerte impacto inmigratorio. 
También, hemos elaborado el Gráfico 4, en el cual figura la fecha, el curato y los lugares visitados (capillas, colegios, hospitales, conventos). En el Gráfico 4, volcamos los datos de las visitas realizadas en la campaña cordobesa (omitiendo la provincia de La Rioja y las ciudades de Córdoba y Río Cuarto). Los Obispos Álvarez, Esquiú y Tissera realizaron las visitas personalmente, en tanto Fray Reginaldo Toro y Zenón Bustos contaron con obispos auxiliares como colaboradores en esta tarea. En las Tablas 3 y 4 del Anexo II puede consultarse el detalle. ${ }^{11}$

\section{Gráfico 4}

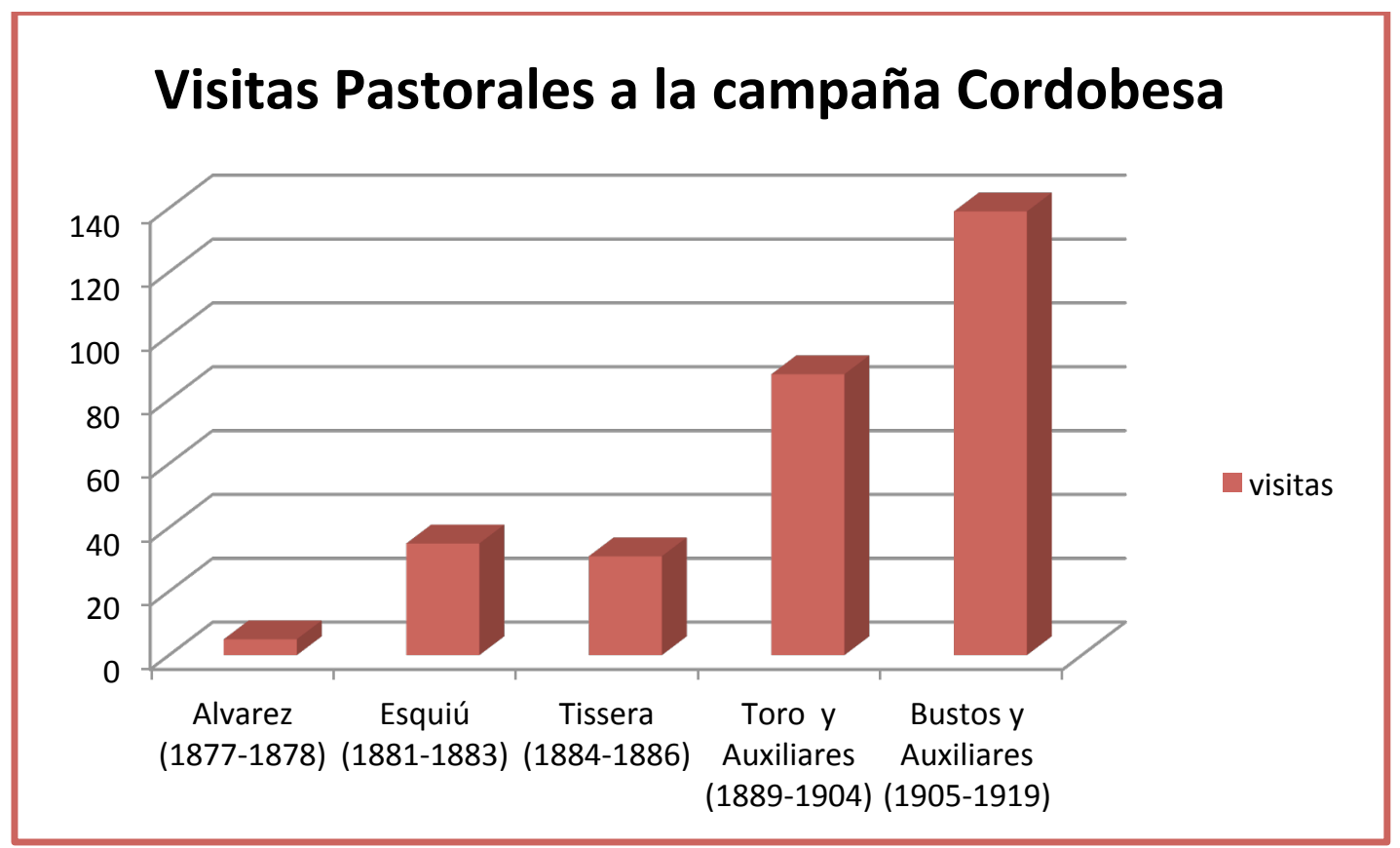

\subsection{Visitas pastorales a los departamentos de vieja colonización (1877-1887)}

En la segunda parte de la tesis, dijimos que hasta 1870 Córdoba era una provincia totalmente criolla y que en 1890 el porcentaje de extranjeros llegaba apenas al 10\% y que el $70 \%$ de población estaba establecida en el norte, el oeste serrano y el centro.

El centro, de mayor densidad de población, comprendía los curatos más congruos de la provincia. En el norte y el oeste, las condiciones socioeconómicas eran especialmente difíciles para sus habitantes, los curatos de estos departamentos estaban situados en zonas

\footnotetext{
${ }^{11}$ A las visitas realizadas por Fray Reginaldo Toro, accedimos de manera indirecta, a través de las cartas que envió al Ministro de Culto en las que le comunicaba sus desplazamientos, pero sin precisiones de fechas ni lugares específicos.
} 
geográficas de extensión diversa y escasamente pobladas, la población era de tradición criolla y el sentimiento religioso estaba arraigado, si bien la práctica, como veremos, no era habitual. En el oeste, una de las principales dificultades para la práctica religiosa eran las distancias extremas y los caminos escabrosos que tenían que recorrer para cumplir con las obligaciones y preceptos de la iglesia. A eso se sumaban otras dificultades, en la zona de tras las sierras, o sierras grandes, las pocas iglesias existentes carecían de albergues indispensables para que los feligreses pudieran pernoctar en los días de celebraciones religiosas. "Las iglesias no contaban con ni una sola habitación para los concurrentes, como tienen generalmente todas las iglesias rurales del obispado haciéndose así modestísimo el concurso de los fieles, y casi imposible". ${ }^{12}$ El cura que servía los curatos era por lo general uno solo, por lo tanto, debía multiplicar su acción a fin de llegar a todos sus fieles.

\subsubsection{Las visitas de los Obispos Álvarez y Esquiú}

En 1877, el obispo Álvarez realizó una gira pastoral en calidad de "visita" antes de la realización del sínodo, el objetivo era tomar conocimiento de manera directa de la realidad diocesana. No hemos encontrado relato alguno relativo a esta visita, sólo sabemos por Cayetano Bruno (1976: 164), que visitó, personalmente, acompañado por tres padres jesuitas, los curatos de Bell-Ville, Cruz del Eje, Totoral e Ischilín, administró el sacramento de la confirmación y realizó misiones. Dos años después, visitó La Rioja, allí recorrió los parajes de Guandacol y durante la gira enfermó y falleció el 24 de agosto de 1878.

Fray Mamerto Esquiú dedicó todo el año 1882 y el mes de enero del siguiente a visitar la diócesis. Comenzó su gira pastoral en los curatos del norte provincial: Tulumba, Río Seco y Quilino, celebró misiones y confirmaciones y recorrió los centros de población de dichos curatos. La información fue suministrada por los libros de confirmaciones, que nos permitió acercarnos a la movilización de las personas que implicaron estas visitas.

Como puede observarse en la Tabla 8 , las confirmaciones realizadas alcanzaron un número importante de feligreses. En el curato de Totoral, sumaron 4.683, es decir el 58\% de la población; en Ischilín, el 16\%; en Tulumba, el 24\% y en Villa del Rosario, el 14,63\%.

\footnotetext{
${ }^{12}$ AAC. Carpeta Curia. Visitas Pastorales y Varios, 1887-1911. Auto de Visita Canónica por la Sierra Grande e Iglesias del Valle de Calamuchita, 17 de enero de 1912.
} 
Tabla 8

\begin{tabular}{|c|c|c|c|c|c|}
\hline \multicolumn{6}{|c|}{$\begin{array}{c}\text { CONFIRMACIONES EN LOS CURATOS DE VIEJA COLONIZACION } \\
\text { Obispos Álvarez y Esquiú }\end{array}$} \\
\hline \multirow[t]{2}{*}{ Curato } & \multirow[t]{2}{*}{ Departamento } & \multirow{2}{*}{$\underset{\mathbf{k m}^{2}}{\text { Departamento }}$} & \multirow{2}{*}{$\begin{array}{l}\text { Población } \\
1879\end{array}$} & \multicolumn{2}{|c|}{$\begin{array}{c}\text { Confirmaciones } \\
\end{array}$} \\
\hline & & & & $\begin{array}{l}\text { Obispo Álvarez } \\
\text { (1876-1877) }\end{array}$ & $\begin{array}{l}\text { Obispo Esquiú } \\
(1880-1883)\end{array}$ \\
\hline Cruz del Eje & Cruz del Eje & $6.792,31$ & 14.381 & 784 & No hubo \\
\hline Totoral & $\begin{array}{l}\text { Totoral/ } \\
\text { Anejos Norte }\end{array}$ & $4.032,08$ & 8.001 & 3.254 & 1.429 \\
\hline Ischilín & Ischilín & $2.949,64$ & 15.367 & 2.520 & No hubo \\
\hline \multicolumn{6}{|l|}{ Quilino } \\
\hline Tulumba & Tulumba & $5.439,26$ & 8.208 & No hubo & 2.043 \\
\hline Río Seco & Río Seco & $25.274,97$ & 5.856 & \multicolumn{2}{|c|}{$\begin{array}{l}\text { No existe el libro de confirmaciones de } \\
\text { esos años }\end{array}$} \\
\hline $\begin{array}{l}\text { Villa del } \\
\text { Rosario }\end{array}$ & Río Segundo & $3.490,86$ & 14.349 & - & 2.128 \\
\hline Total & & & 66.162 & \multicolumn{2}{|c|}{12.158} \\
\hline $\begin{array}{l}\text { Fuentes: Mer } \\
\text { Córdoba, } 18 \\
\text { Confirmacion } \\
\text { Libro } 1,1860\end{array}$ & $\begin{array}{l}\text { Anual de la } \\
\text { AAC. Cruz }\end{array}$ & $\begin{array}{l}\text { cina de Estadís } \\
\text { Eje. Confirm } \\
\text {; Ischilín. Confi }\end{array}$ & $\begin{array}{l}\text { de la Prov } \\
\text { ones, Libro }\end{array}$ & $\begin{array}{c}\text { ncia de Córdoba, } \\
\text { 1, 1872-1877, } \\
\text { 1, f.1-280; Tulum }\end{array}$ & $\begin{array}{l}\text { blicación Oficial, } \\
\text { 81-309; Totoral. } \\
\text { Confirmaciones, }\end{array}$ \\
\hline
\end{tabular}

\subsubsection{La Visita del Obispo Tissera}

En 1885, el Obispo Tissera informó a los curas la fecha de apertura de la visita y solicitó que tuvieran dispuesto todo lo que por derecho debía ajustarse a su reconocimiento e inspección. "Conviene, pues, que tenga corrientes los libros parroquiales y los de las cofradías que existan en su curato, los inventarios de todas las capillas y oratorios públicos". ${ }^{13}$ En nota al Gobernador Gavier, le solicita la cooperación de las autoridades de campaña y le informa los motivos de la visita "lo que hace a la moralidad y pureza de costumbres, paz y tranquilidad social, aparte de otros bienes que la Iglesia propone". ${ }^{4}$ Finalmente, el obispo escribe una carta pastoral a todo el pueblo y a los fieles, donde anuncia la visita y explica los cometidos de la misma. Señala el propósito de "inspeccionar el templo de Dios en lo material y en lo espiritual, comprendiendo en estas palabras no solo

\footnotetext{
${ }^{13}$ AAC. Circular del 28/11/1885.

14 AAC. Correspondencia con las Autoridades Provinciales. Nota al Gobernador Gregorio Gavier del $28 / 11 / 1885$.
} 
la casa del Señor y el decoro de su santo servicio por el ministerio sacerdotal, sino también el templo espiritual que son las almas en que Dios es glorificado y servido".

La visita se realizaría en la catedral y cabildo eclesiástico, iglesias parroquiales, capillas, lugares píos, oratorios privados o domésticos, y personas eclesiásticas; las licencias concedidas para celebrar, predicar y confesar; los privilegios, gracias, o concesiones particulares a iglesias o personas; las cofradías, sus libros y estatutos; los monasterios de monjas y las congregaciones piadosas. Además de inspeccionar los templos, ornamentos y funciones sagradas, particularmente, le preocupaba conocer "el templo" de las almas de sus feligreses y el "templo" de las familias.

Para visitar esta iglesia, y este templo que son vuestras almas, es necesario que os acerquéis a vuestro Padre y Pastor, con la confianza de hijos y la docilidad, sinceridad y mansedumbre de las ovejas de Jesucristo, porque nuestra visita no será la de un juez con el aparato y estrépito de un tribunal, sino una filial entrevista de un padre con sus hijos, de un maestro con sus discípulos, de un médico con sus enfermos, de un amigo con sus amigos. Como a maestro nos manifestareis vuestras dudas, vuestras faltas de conocimiento en el lleno de vuestros deberes, y todo lo que ignoréis para alcanzar vuestra felicidad en esta y en la otra vida. Como a médico nos haréis conocer vuestras dolencias, llagas y miserias y flaquezas para que podamos aplicar a cada uno el remedio y el bálsamo saludable para devolver a todos la perfecta salud. [...] Como a Padre nos abriréis vuestro corazón, y nos pediréis con toda confianza lo que os haga falta $[\ldots]$.

Si, la familia es también un templo de Jesucristo [...] A este templo debe extenderse nuestra visita, para que sea digno de la morada de Dios [...] contamos con la buena voluntad, con la confianza y con el celo del honor de Dios y de la santa religión de todos nuestros amados diocesanos, ayudándonos a todos a remover los escándalos y los malos ejemplos, a cortar las disensiones y discordias, a devolver la paz y la gracia de Dios a su santa casa, en el hogar doméstico y que todos le alaben y glorifiquen con su vida, con sus labios, con sus corazones y con el cumplimiento de su divino servicio. $^{15}$

El 2 de diciembre de 1885 el obispo inició la gira visitando el curato de Anejos Sud. Iba acompañado por el Dr. Rosendo de la Lastra, el escribiente oficial de la curia, Dr. Ramón López, y el secretario de Cámara y Gobierno, Dr. Filemón Cabanillas, quien realizó un

${ }^{15}$ AAC. Carta Pastoral del 21/09/1885. Visita Canónica Fray Capistrano Tissera. 
detallado informe de la visita. ${ }^{16}$ La gira finalizó con la enfermedad y fallecimiento del prelado en el mes de septiembre de 1886. Para ello, contamos con una pormenorizada crónica de la gira pastoral por todo el oeste cordobés. Con los datos proporcionados, elaboramos una planilla con los lugares y fechas, que luego volcamos en un mapa con el objeto de presentar una visión cartográfica de los lugares y distancias recorridas. Estos relatos nos permiten además vislumbrar otras cuestiones que irán apareciendo, como la estructura de la visita, el ceremonial, las relaciones con las autoridades locales, el control sobre la población rural, etc.

El 6 de diciembre, segundo domingo de adviento, celebró la misa en la Iglesia de Alta Gracia y realizó confirmaciones de niños y adultos, luego se procedió a la inspección de la iglesia, altares, imágenes, reliquias, crismeras, óleos, sacristía, ornamentos, lienzos y vestidos de las imágenes. En fin, todos los útiles y enseres del culto. Fueron inspeccionadas las capillas que componían el curato y, por último, se dejó constancia de que habían sido muchos los escándalos "que se me han denunciado debido a la indagación prolija que he hecho a los pocos vecinos con que he hablado, y no es muy consolador el estado de moralidad de los feligreses en las pedanías mencionadas, debido sin duda a la falta de reprensión y castigos de ciertos vicios por parte de las autoridades”. El jefe político hizo comparecer, ante el visitador, a los autores de dichos escándalos y personas de mala vida, quienes después de "saludables consejos" dieron su promesa formal de componer su vida. Respecto a las casas de mercaderes, que "son el foco y la ocasión de los vicios de la ebriedad y del juego", el jefe político prometió castigar los excesos y vigilar la moral con la mayor severidad que le fuera posible, "a fin de evitar el mal ejemplo, y también para que el público no le atribuya negligencia en el cumplimiento de sus deberes como autoridad principal, encargada de la ley, de restablecer el orden y la moral pública donde quiera que sea perturbada".

La visita continuó en la vice-parroquia de la Candelaria de la Lagunilla, se inspeccionaron los útiles, ornamentos, sacristía y cementerio, se dio una serie de indicaciones, como la de quemar unas crismeras de plata que parecían haber servido en tiempo inmemorial, cuando la capilla era parroquia, y "estaban con oleos corrompidos y

\footnotetext{
${ }^{16}$ AAC. Libro Autos y Visitas Pastorales, 1886-1916, f.101-193.
} 
llenos de óxido hasta el punto de provocar el vomito al estómago más templado". ${ }^{17} \mathrm{El}$ cementerio tenía las paredes desmoronadas y había sido "consiguientemente invadido por las bestias no sirviendo ya para la sepultación de fieles”. Por ello, se ordenó la construcción de un nuevo cementerio que tuviese las condiciones prescriptas por el sínodo y "la independencia, de todo poder extraño que pudiera ofender la inmunidad de la Iglesia y los derechos del Párroco".

La última capilla, ubicada en la falda de Quiñones y dedicada a la Virgen del Carmen, estaba a cargo de un patrono y en perfectas condiciones de aseo. En esa capilla no había cementerio y a juicio del visitador no era necesario, pues se encontraba relativamente cerca de la parroquia de Alta Gracia, que tenía uno grande. En ese paraje no recibió ninguna denuncia de escándalo o amancebamiento.

El 25 de diciembre se dio por terminada la visita y el obispo mandó a publicar el auto respectivo con fecha 22 de diciembre. En dicho documento el prelado señala los aspectos más significativos de la visita y realiza diez observaciones. La primera, se refiere a la necesidad de implementar la enseñanza y explicación del catecismo a niños y adultos en los días festivos, "concediéndoles 41 días de indulgencia por cada vez que asistan a dicho ejercicio"; la segunda, a la necesidad de restablecer la Cofradía de la Merced; la tercera, hace referencia a la manera de llevar los libros parroquiales; la cuarta, señala que todas las capillas y oratorios tengan lo necesario para la celebración de las funciones y administración de los sacramentos, “con la decencia y el decoro conveniente, se prohíbe estrictamente llevar de una capilla a otra los ornamentos y útiles necesarios"; en la quinta, se vuelve sobre la cuestión de los libros, advirtiendo que "habiéndose notado muchos defectos e irregularidades insalvables en el modo de llevar los libros parroquiales de los anteriores curas por falta de inspección y vista del archivo, en adelante se remitan a nuestra secretaría los libros corrientes cada año en todo el mes de diciembre para su revisación"; en la sexta, se puntualiza que el libro de fábrica, "contenga las entradas y salidas y gastos de todas las capillas formando un solo cuerpo y una sola caja como lo ordena el sínodo diocesano"; la séptima observación se refiere a la función de los patronos de las capillas y a la necesidad de que tanto ellos como los feligreses tuvieran conocimiento de los deberes que les incumbían, para ello, el párroco debía explicarlos durante las misas solemnes, tanto

\footnotetext{
${ }^{17}$ AAC. Libro Autos y Visitas Pastorales, 1886-1916, f.115.
} 
en la parroquia como en las capillas; la octava, señalaba que el párroco "tenga la debida concordia con las autoridades civiles del departamento y se ponga de acuerdo con ellas, cuando el caso lo requiera, para cortar los escándalos y abusos que se descubriesen en su territorio. Encargándoles y recomendándoles a las mismas, de parte de la Santa Iglesia, presten su cooperación a tan grande obra como es la de ganar almas para Dios y contribuir al restablecimiento del orden y de la moral pública". La novena, ordenaba que se observase debidamente lo que el sínodo ordenaba sobre la residencia del párroco (Constitución $1^{\circ}$, Cap. V). Finalmente, se aprobaba y recomendaba la moralidad, actividad y celo del cura párroco y declaraba haber "quedado plenamente satisfecho y complacido de su saludable conducta en el desempeño del ministerio parroquial". ${ }^{18}$

El 25 de marzo del año siguiente, el obispo inició una nueva gira pastoral, pero esta vez por el noroeste provincial, visitando los curatos de Minas y Pocho, San Alberto, San Javier y Tránsito. El primer lugar de visita fue la capilla de La Higuera, perteneciente a Cruz del Eje, que quedaba de camino a San Carlos Minas. Allí se realizaron confirmaciones de unas 40 personas, aproximadamente. Luego, el obispo siguió viaje, en carruaje, hasta un lugar denominado "Rara Fortuna" perteneciente al curato de Minas, donde tenía su establecimiento Minero Mr. C. Treacher y Cía., que había enviado su carruaje al encuentro del Sr. Obispo y esperaba a la comitiva para ofrecerles un té en su casa.

Luego, siguieron viaje en los caballos preparados por "el activo y cumplido Sr Cura de Minas y la oficiosa voluntad del Sr Rosendo Leal, principal vecino del Curato”, que había preparado bajo sus costas la tropa que debía conducir al prelado y su comitiva a la capilla de Ciénaga del Coro, distante unas tres leguas de Rara Fortuna, "por un camino bastante áspero". Llegaron a destino “en medio de repiques, estruendos y vivas”. En el recibimiento, no se encontraba el Jefe político, pero el mandatario había enviado una nota al diocesano expresando su agradecimiento y dando la bienvenida al departamento. ${ }^{19}$

\footnotetext{
${ }^{18}$ AAC. Libro Autos y Visitas Pastorales, 1886-1916, f.125-148.

${ }^{19}$ AAC. Libro Autos y Visitas Pastorales, 1886-1916, f.127. La Nota dice fechada en Agua del Tala el 28 de marzo de 1886. Dice lo siguiente: "Dr Juan Capistrano Tissera y Capdevila: Frustrados mis deseos de ir personalmente a cumplimentar y recibir a VSI a la par de nuestro querido cura y Vicario, a causa de mi mala salud, apelo a esta para saludarlo cordialmente, manifestándoles mi sentimiento de respeto y amistad y deseando que el resultado y el fruto de su venida supere sus nobles y santas aspiraciones. Que la amistad y las atenciones de los habitantes de estos parajes, le hagan llevadera su venida a ellos, son los votos de su humilde servidor y feligrés que se honra saludando con la mas distinguida amistad. Firma Carlos M. Roque GP, Miguel a Echegaray Secretario.
} 
La visita fue acompañada de una misión, ${ }^{20}$ que comprendía pláticas, la administración del sacramento de la confirmación a aquellos que estaban preparados con la confesión. El relator advierte que era "pasmoso y bello ver llegar de todas direcciones numerosas familias que venían de largas distancias y escabrosos montes con el santo fin predicho".

La apertura de la visita fue un acto de gran solemnidad, consistió en una procesión formada por más de mil personas que se dirigió a la capilla cantando. Llegados a la puerta de la Iglesia, el párroco se acercó al obispo, le dio a besar la Cruz parroquial y le suministró el aspersorio y el incienso -como indica el ceremonial- para esos casos. Luego, se dirigió al altar, mientras se entonaba el canto del Te Deum y se adoraba de rodillas al Santísimo Sacramento. Se procedió a dar la bendición solemne y el diocesano dirigió al pueblo reunido unas breves palabras, explicó la pastoral que daba inicio a la visitas, deteniéndose particularmente en los puntos que señalan los deberes del obispo para con los fieles, prometió cumplirlos de la mejor manera posible y exhortó al cumplimiento de las obligaciones de los fieles para con su pastor, que el prelado puntualizó en la necesidad de la obediencia, fundamental para que pudieran sacar el fruto de la visita. A su término, el párroco leyó pausadamente la pastoral sobre la visita. A la lectura de la pastoral, le siguió la del edicto dado por el obispo para llevar a cabo la apertura de la visita, en el cual se explicaba que el objeto principal de las visitas era no sólo administrar el sacramento de la confirmación, sino también "instruir a los fieles en la sana doctrina, desterrados y purgados los errores, corregir las costumbres depravadas e inducir al pueblo con oportunas medidas a la práctica de la religión santa, a la paz y a la inocencia de vida por la observación de la ley de Dios". El obispo exhortaba y mandaba que si los fieles tenían "noticia de haberse introducido abusos, o evitado escándalos y pecados públicos que sirven de ruina espiritual al punto nos informéis denunciándolos con caridad cristiana para que podamos aplicarles los oportunos remedios. Y para que ninguno se tenga por escusado de prestar y ejecutar lo que en derecho se debe bajo pretexto de ignorancia". ${ }^{21}$

La gente seguía llegando y los sacerdotes se dedicaron a oír confesiones, mientras el obispo administraba la confirmación durante horas. En tanto, los agentes de policía, puestos

\footnotetext{
${ }^{20}$ Acompañaban al obispo, el Canónigo Honorario Rubén Márquez, el Padre Misionero Buenaventura, el Cura de Minas, don Vicente Ruiz, el Capellán de Coro Martínez y el Secretario de Cámara y Gobierno, Filemón Cabanillas.

${ }^{21}$ AAC. Libro Autos y Visitas Pastorales, 1886-1916, f.130. Edicto dado en Ciénaga del Coro en la apertura de la Visita Pastoral a este Curato de Minas a 31/03/1886.
} 
a disposición del prelado por el Jefe político, citaban y hacían ir "a las personas de mala vida, que eran denunciadas, para ponerlos en el camino de la salvación y cortar los escándalos". El obispo a gradece a las autoridades que le prestan toda su cooperación y a los vecinos que no dejan de denunciar a "cada rato escandalosos concubinatos hastiados tal vez de la depravación y corrupción de este pobre departamento en que afluyen con motivo de los trabajos mineros gentes de malas costumbres [...] La falta de visita pastoral de estas comarcas, desde tiempo inmemorial: la ninguna medida correccional de parte de las autoridades mirando con indiferencia todo, y por fin otras innumerables causas que concurren a dejar en la suma ignorancia a la niñez y en la corrupción espantosa del corazón de la mujer, perdiéndose todos los nobles sentimientos del pudor y del honor". ${ }^{22}$

Durante esos días, se regularizaron varios matrimonios y se pasó revista al templo y a los útiles y ornamentos del culto. Como en el caso anterior, el secretario en comisión realizó la visita a la capilla de Guasapampa, que como se ha indicado ut supra estaba prácticamente en ruinas. Tomó las denuncias sobre escándalos y personas de mala vida y señaló que "ha encontrado cierta distancia de los vecinos para con el cura, por su desinterés y falta de prontitud en el cumplimiento de sus deberes para con ellos". La visita se cerró con una alocución de despedida por parte del prelado diocesano, en la que pedía a los feligreses el apoyo de sus oraciones por el éxito de la visita.

De inmediato, partieron a su nuevo destino, el curato de San Carlos. Durante un largo trayecto fueron acompañados por una multitud de gente. Llegaron a "La Estancia", la casa del juez de paz de la Pedanía, donde permanecieron un día y dieron la confirmación a unas 76 personas. La llegada de la comitiva fue saludada por salvas y vivas, el Jefe político del departamento se encontraba acompañado de jóvenes armados con fusiles y toda la policía uniformada para hacer la guardia de honor al obispo. La capilla de Ninalquin, adonde se dirigían, distaba dos leguas del lugar de recibimiento. El secretario relata la inmensa cantidad de gente que concurría a confesarse y prepararse para la confirmación. El número aumentaba y los cuatro sacerdotes no daban abasto para oír tantas confesiones. En esas circunstancias, llegaron dos refuerzos, el cura de Pocho, Donato Latella, y el de Tránsito, Gabriel Brochero, quien ocupó un confesionario sin levantarse desde las 4 de la mañana hasta las 10 de la noche. El obispo, escoltado por el Jefe político del departamento, fue

\footnotetext{
${ }^{22}$ AAC. Libro de Autos y Visitas Pastorales, 1886-1916, f.134.
} 
saludado con una salva de fusilería por la guardia uniformada. En una procesión, encabezada por las escuelas del departamento, se dirigieron a la capilla. Al ingresar, cantaron el himno latino de acción de gracias Te Deum y el obispo procedió a impartir la bendición y a agradecer, mediante una breve alocución, a las autoridades y feligreses. La visita a la capilla de Ninalquin se extendió por cuatro días. Realizó la revista material del templo y de los útiles y ornamentos. Al igual que en otras oportunidades, desechó las casullas deterioradas y permitió que se siguieran utilizando hasta que por medio de limosnas se compraran unas nuevas. Se confirmaron más de 2.000 personas.

La capilla de San Carlos Minas, dedicada a la Purísima Concepción, estaba, según el secretario, por inhabilitarse por su deterioro material. Se procedió a la rutina de la visita, procesión compuesta por unas 300 personas hasta la puerta de la iglesia, donde esperaba un gran número de fieles, bendición y alocución del prelado. El obispo, esta vez, se alojó en la casa de un vecino acomodado. En la inspección, se descubrió la falta de partidas del libro de defunciones desde el año 1867 al año 1869, inclusive, advirtiéndose, a su vez, la disconformidad de las fórmulas utilizadas por los curas para los asientos de las partidas. El obispo se "ocupó de indagar la conducta del actual cura a varios sujetos de probidad y religiosidad, obteniendo de todos excelentes informes, por lo menos ninguna denuncia ni testimonio en contra, quedando completamente satisfecho de su conducta y desempeño del ministerio parroquial". ${ }^{23}$ Los útiles y ornamentos estaban en un estado lastimoso. Por este motivo, inició una suscripción destinada a colectar fondos para construir una nueva capilla en el terreno donado por un vecino acomodado. Ordenó que se colocara el auto general de la visita en todas las capillas y oratorios públicos del curato, documento que advertía que no había noticias de que el curato de Minas hubiese sido visitado y que, gracias a la visita, el obispo había tomado conocimiento directo de las necesidades que experimentaban. Las observaciones del auto de visita coinciden sustancialmente con los señalados para la visita del curato de Santa María. El auto se cierra aprobando y aplaudiendo la actividad y celo del párroco en el ejercicio de su ministerio. Agradeció al jefe político y demás autoridades por las atenciones recibidas. Como resultado de la visita al curato de Minas, se "arreglaron” 47

${ }^{23}$ AAC. Libro de Autos y Visitas Pastorales, 1886-1916, f.143. 
amancebados públicos, se confirmaron 10.800 personas, entre niños y adultos, se dieron 7.060 comuniones y 230 bautismos. $^{24}$

El día 16 se encaminaron hacia la capilla de Salsacate, donde permanecieron hasta el día 23. Dicha capilla había sido sede parroquial del antiguo curato de Tras la Sierra (que comprendía los curatos de San Javier, San Alberto, Tránsito, Pocho y Minas). Acompañaron al obispo y a su comitiva, a lo largo de las cuatro leguas que separaban ambas capillas, gran cantidad de gente y la guardia uniformada dispuesta por el Jefe del departamento. El secretario relata que apenas atravesaron el límite que separa a ambos departamentos "se dejaron ver gruesas columnas de gente encabezadas por el comandante Burgos, el comisario y demás empleados que salían al encuentro del Prelado. En la entrada de la Iglesia de Salsacate, esperaba un nutrido grupo personas, 'un mundo de gente', ${ }^{25}$ atraviesan seis arcos triunfales compuestos y colocados para la ocasión, hasta llegar al pretil de la capilla". Allí se desarrolló la ceremonia de apertura de la visita (adoración de la cruz, entrada al templo y breve alocución en la que se explica el objeto de la visita y se agradecen las manifestaciones de afecto, procesión, canto del Te Deum y lectura de la pastoral y edicto). Se administró la confirmación, se oyeron confesiones y se celebraron las funciones propias de la Semana Santa. Luego, se procedió a la revista del templo y el archivo, así como de los útiles y ornamentos.

Terminada la visita en Salsacate, el destino siguiente fue la capilla de Pocho. Parte de la comitiva fue acompañada por los principales vecinos de la zona. A mitad de camino, se detuvieron a almorzar en la estancia de Jovino Figueroa. Llegaron a la capilla, donde los esperaba una gran concurrencia, se había preparado un camino adornado con numerosos arcos triunfales. Se realizaron las ceremonias acostumbradas. Se pasó revista a la iglesia, sus vasos sagrados, útiles, imágenes y demás enseres. La capilla, dedicada a la Purísima, estaba limpia y en buen estado. Era la mejor de todas las que se habían visitado hasta ese momento. Por la tarde se realizaron confirmaciones. Se comisionó al cura de Minas para realizar la vista a la capilla de Las Palmas, distante cuatro leguas del lugar. Se trataba de una capilla bastante deteriorada, a la que se le había renovado el techo.

\footnotetext{
${ }^{24}$ AAC. Libro de Autos y Visitas Pastorales, 1886-1916, fs.147-148. Dado en Minas el 15/05/1886.

25 Compuesta por curas de Cruz del Eje, Rubén Márquez (Cgo. honorario), Tránsito, Gabriel Brochero, Minas, Vicente Ruiz, el misionero Padre Fray Buenaventura Escatllar y los presbíteros Domingo Martínez y Filemón Cabanillas.
} 
La visita a la capilla de Chancani, dedicada a la Virgen del Carmen, y ubicada al otro lado de la Sierra Alta, no estaba prevista, pero el pedido del jefe político y un importante número de pobladores hizo que el prelado aceptara la invitación para ir allí. La comitiva estuvo compuesta por el obispo, los sacerdotes, las autoridades departamentales y una importante cantidad de vecinos. Realizaron el descenso de la cuesta de Yaban. El obispo, montado en una mula, atravesó la sierra por un camino sinuoso, lleno de peligros y precipicios. Llegaron a la capilla cerca de las tres de la tarde, donde los esperaba una gran muchedumbre y se habían preparado los arcos triunfales. En los días siguientes, se oyeron confesiones, se celebraron confirmaciones y se regularizaron matrimonios. Se abrió la visita con la ceremonia prevista: procesión hasta la puerta del templo, entrega de la cruz, ingreso al templo y alocución del obispo. Inspección del estado material, útiles y ornamentos del templo y archivo parroquial. La visita tuvo como resultado la regularización de 53 matrimonios de amancebados, 7.774 confirmaciones, 5.930 comuniones y 440 bautismos. ${ }^{26}$ El 9 de mayo cerró la visita con un auto que consta de 18 artículos en los que se reiteran algunas de las disposiciones establecidas en los autos de las visitas a Cruz del Eje y Minas. El establecimiento de la enseñanza del catecismo, en la iglesia y las capillas, los domingos y días festivos, la lectura de las disposiciones del Sínodo durante las misas del domingo, la obligación de residencia en el curato y la prohibición de salir sin permiso previo. La limpieza y elementos necesarios para el culto en cada capilla, las visitas a cada una con la frecuencia que establece el sínodo y el cumplimiento de las constituciones sinodales respecto de los cementerios. Las observaciones respecto al modo de llevar los libros, la prolija anotación de los gastos de fábrica e inscripción de partidas y el nombramiento de patrones para cada capilla. Mantener las buenas relaciones con las autoridades y recurrir a su ayuda para combatir los pecados públicos y escándalos. ${ }^{27}$

El 11 de mayo la comitiva episcopal, acompañada por el jefe político y escoltada por la policía, llegó al paraje de Yerba Buena, curato de San Alberto, tres leguas antes de la iglesia parroquial de San Pedro. Durante el trayecto, se detuvieron en dos parajes a confirmar a 432 personas. Allí, lo esperaba el cura de San Javier, Facundo Bejaramo, provisoriamente a cargo del curato de San Alberto, el cura de San Martín (La Rioja), el jefe

\footnotetext{
${ }^{26}$ AAC. Libro Autos y Visitas Pastorales, 1886-1916, f.166.

${ }^{27}$ AAC. Libro de Autos y Visitas Pastorales, 1885-1916, fs.165-169.
} 
político de San Alberto y muchos vecinos principales de la Villa de San Pedro. A tres cuadras de la villa fueron recibidos con salvas de una compañía de Guardias Nacionales, que escoltaron el carruaje del obispo hasta las puertas de la iglesia, atravesando varios arcos triunfales, bajo una lluvia de vivas y flores. Luego de la alocución del prelado, se realizaron confirmaciones y se oyeron confesiones durante todo el día y parte de la noche. Al día siguiente, se dio inicio formal a la visita, realizando el acto de apertura, tal como lo prescribe el ritual, procesión solemne hasta el templo, adoración de la cruz, canto del Te Deum, canto de la oración Deus humilium visitator, lectura de la pastoral y del edicto de la visita y palabras alusivas del obispo. A continuación, la inspección correspondiente. Por la tarde, continuaron las confirmaciones y al día siguiente, se procedió a la inspección del archivo. Se recibieron las denuncias de conductas escandalosas y amancebamiento. La visita se clausuró el día 21 mediante el correspondiente auto. Esta dio como resultado la regularización de 27 casamientos de amancebados, 3.480 confirmaciones y 2.548 comuniones. $^{28}$ El obispo comisionó al cura de Minas, Vicente Ruiz, para hacer la inspección a la capilla de San Vicente, encontrándola limpia y en buen estado, con los ornamentos y vasos sagrados en condiciones.

El mismo día 21, la comitiva episcopal se dirigió a la villa de Dolores, curato de San Javier, ubicada en la otra ribera del río. Fue recibida con salvas y una guardia de honor, compuesta por los jóvenes principales, que acompañaron el carruaje hasta la casa donde se alojaría el obispo. Antes y después de la apertura de la visita, los sacerdotes se dedicaron a confesar y preparar a la gente para recibir el sacramento de la confirmación, en un solo día atendieron a 1.323 personas.

El 23 de mayo se realizó la visita a la Iglesia parroquial del curato, a unas tres horas de Villa Dolores. San Javier era el punto donde residía "la flor de la sociedad de los fieles de tras la sierra". El viaje lo hizo acompañado por el Jefe político y una gran cantidad de fieles. En el lugar, fueron recibidos por una multitud de gente y atravesaron una serie de arcos con inscripciones alusivas a la visita. Durante cuatro días se preparó a la gente para recibir la confirmación, se pasó revista al archivo parroquial, a la Iglesia y a todos los útiles y ornamentos. La visita se cerró según prescribe el ritual y el auto señala los puntos más

${ }^{28}$ AAC. Libro de Autos y Visitas Pastorales, 1885-1916, f.177. 
importantes a tenerse en cuenta. ${ }^{29}$ Durante la visita se realizaron más de 2.000 confirmaciones, se repartieron 6.000 comuniones y 55 parejas regularizaron su situación matrimonial. Clausurada la visita en el Curato de San Javier, la comitiva se dispuso a salir hacia Tránsito, pasando por la capilla de Las Rosas a celebrar confirmaciones.

En un paraje denominado El Pantanillo, límite con el curato de Tránsito, esperaban a la comitiva episcopal, el cura párroco, Gabriel Brochero, el jefe político, Guillermo Molina, y una nutrida concurrencia de gente y vecinos respetables. "Desde la altura saludan al prelado mediante una salva de fusilería, toda la comitiva del obispo se apeó de caballos blancos, dispuestos por el cura Borchero y el jefe político, ya que era imposible transitar con carruajes por esos lares". Luego de tres horas de cabalgata, llegaron a la Villa de Nono. Se realizaron confirmaciones, se oyeron confesiones $y$ se tomaron las denuncias correspondientes. Pasados tres días, se realizó la apertura de la visita tal como prescribe el pontifical y se procedió a la revista. Todos los ornamentos eran nuevos y en condiciones, la iglesia y la sacristía estaban limpias y en buen estado. Sus vasos sagrados, útiles, imágenes y ornamentos y el archivo parroquial estaban en perfectas condiciones. Durante la visita se celebró la fiesta del Sagrado Corazón de Jesús, realizando la procesión del Corpus. La visita a las capillas de Panaholma y Ambul, recientemente construidas, la realizó el secretario Cabanillas. La visita se clausuró el 24 de julio, con la lectura del auto y sin la presencia del obispo, que se encontraba imposibilitado de asistir debido a una enfermedad que lo llevaría prontamente a la muerte. El cura Brochero trasladó al obispo enfermo por la Cuesta de Copina, hasta la estancia de los Román, donde lo esperaba un carruaje para llevarlo a Córdoba. Fray Capistrano Tissera falleció el 20 de septiembre de 1886. El obispo, en la pastoral de febrero de 1886, nombró visitador delegado de La Rioja al Vicario General Uladislao Castellano, quien realizó la gira por la provincia. ${ }^{30}$

\subsubsection{Consideraciones sobre las Visitas Pastorales}

Nos hemos detenido en este pormenorizado relato de las visitas, a fin de dar una idea clara sobre el desarrollo de esta práctica pastoral, ya que es el único relato con el que contamos y que permite hacerse una idea de lo que suponían estos desplazamientos, tanto

\footnotetext{
${ }^{29}$ AAC. Libro de Autos y Visitas Pastorales, 1886-1916, f.184.

${ }^{30}$ AAC. Pastoral del Obispo Diocesano delegando un visitador a la Rioja, Tipografía La Prensa Católica, Córdoba, 1886.
} 
de prelados como de feligreses. Una apretada reflexión sobre las visitas del Obispo Tissera, nos lleva a considerar, por un lado, la importante movilización de gente que generaba la presencia del obispo. Las cifras de las confirmaciones dan cuenta del alto grado de aceptación de la religión católica en la región y, por el otro, la crónica refleja la armonía existente entre las autoridades civiles y las eclesiásticas.

Para tener una idea más acabada, en la Tabla 9, establecimos la relación entre el número de habitantes de los departamentos visitados y el número de confirmaciones realizadas, con el objeto de tener una idea aproximada del grado de adhesión de la población a la religión católica. Para los datos de población, hemos tomado la cantidad de habitantes de 1879 y del censo de 1895. Para las confirmaciones, como la crónica no menciona el número de éstas en el curato de Tránsito, hemos recurrido al libro de Confirmaciones, el cual tiene asentadas $6.344,{ }^{31}$ realizadas durante los días de la visita canónica. En cuanto al curato de San Javier, el relato tampoco da cuenta de todas las confirmaciones, en tanto en los Libros $2^{\circ}$ y $3^{\circ}$, se asientan 4.963 durante los días de la visita.

Tabla 9

\begin{tabular}{|c|c|c|c|c|}
\hline \multicolumn{5}{|c|}{ Gira Pastoral del Obispo Tissera, 1886} \\
\hline Curato & Departamento & $\begin{array}{c}\text { Población } \\
1879 \\
\text { en habitantes }\end{array}$ & $\begin{array}{l}\text { Población según } \\
\text { Censo de } 1895 \\
\text { en habitantes }\end{array}$ & $\begin{array}{c}\text { Confirmaciones } \\
1886\end{array}$ \\
\hline Minas & Minas & 9.387 & 7.563 & 10.800 \\
\hline Pocho & Pocho & 7.658 & 7.500 & 7.774 \\
\hline San Pedro & \multirow[t]{2}{*}{ San Alberto } & \multirow[t]{2}{*}{11.534} & \multirow[t]{2}{*}{14.143} & 3.480 \\
\hline Tránsito & & & & 6.344 \\
\hline San Javier & San Javier & 15.374 & 14.013 & 4.963 \\
\hline $\begin{array}{ll}\text { Villa } & \text { del } \\
\text { Rosario } & \end{array}$ & Río Segundo & & & 925 \\
\hline Totales & & 43.953 & 43.219 & 33.361 \\
\hline \multicolumn{5}{|c|}{$\begin{array}{l}\text { Fuentes: Memoria Anual de la Oficina de Estadística de la Provincia de Córdoba, Publicación Oficial, } \\
\text { Córdoba, 1881. AAC. El Tránsito, } 1^{\circ} \text { Libro de Confirmaciones, 1886, dadas por SS Ilma. Fr. Juan C. Tissera } \\
\text { y Cadevila desde el } 30 \text { de junio al } 22 \text { de julio de } 1886 \text {. AAC. Libro Autos y Visitas Pastorales, 1886-1916, } \\
\text { fs. } 101-193 \text {. AAC. San Javier, } 1^{\circ} \text { y } 2^{\circ} \text { Libro de Confirmaciones. }\end{array}$} \\
\hline
\end{tabular}

${ }^{31}$ AAC. El Tránsito, $1^{\circ}$ Libro de Confirmaciones 1886, dadas por SS Ilma. Fr. Juan C. Tissera y Cadevila desde el 30 de junio al 22 de julio de 1886. 
En la Tabla, las cifras son llamativas, pues en los curatos de Minas y Pocho fueron confirmadas más personas que habitantes, lo cual se explica por el desplazamiento de feligreses de curatos vecinos para recibir el sacramento. En San Alberto, la cifra es también muy alta, pues supera el 70\% de la población, en tanto en San Javier alcanza el 35\%.

La confirmación es un sacramento no necesario para la salvación eterna, se recibe una vez en la vida y quien lo recibe debe estar bautizado y en gracia, y si tiene uso de razón estar suficientemente instruido (CIC 786). El fin, como su nombre lo indica, es confirmar al cristiano. Esta condición nos permite inferir que muchos adultos se acercaron voluntariamente a recibirlo y decidieron hacer confirmar a sus hijos. La Tabla es elocuente, el alto porcentaje de confirmaciones $(77,19 \%)$, nos permite pensar que la población de la región tenía una fuerte identidad católica.

\subsection{Visitas a los departamentos de nueva colonización (1877-1887)}

Como señalábamos en la segunda parte, al lado de la Córdoba artesanal, radicalmente ganadera, criolla, tradicionalista, del norte y el oeste, se erigía, en el este y sur provincial, una nueva sociedad, fundada en la inmigración extranjera, el desarrollo de la economía agraria y la producción para la exportación ultramarina (Ferrero, 2003: 22). La superficie se fue ocupando de colonias y población italiana, que comenzaron a sembrar, alternativamente, maíz, trigo y lino, actividad agrícola que, en pocos años, redundaría en una notoria prosperidad económica.

En el mes de mayo de 1882, Fray Mamerto Esquiú comenzó su gira por el sudeste provincial. Visitó San Gerónimo de Fraile Muerto (posteriormente denominado Bel Ville), Cruz Alta y demás poblados y capillas existentes en la región. ${ }^{32}$ A mediados de mes, siguió por La Carlota y Villa Nueva. Estas localidades estaban en pleno crecimiento. El ferrocarril de Rosario a Córdoba ya pasaba por los pueblos de Bell Ville y Villa María. En el mes de julio, desde Bell Ville visitó Ballesteros y San Antonio de Litín. Durante el mes de septiembre visitó el este provincial, departamento de San Justo, celebró misiones y confirmaciones en Sacanta, El Tío, Arroyito, Las Cañas (actual curato de Laborde), Villa del Rosario, el Tránsito y oratorio de Peralta. Tras breves interrupciones para regresar a

\footnotetext{
${ }^{32}$ Realizó misiones en Tortugas, San José de la Esquina, Cañas, Saladillo, Fraile Muerto, Piquillín, Mercedes, la Carlota y Villa Nueva
} 
Córdoba o viajar a Buenos Aires, finalizó su gira visitando, en el mes de diciembre, la capilla Jesús Nazareno y Chañares (hoy James Craick), en el departamento de Río Segundo. Hacia fines del mes de diciembre, emprendió la gira a La Rioja, donde encontrará la muerte en el paraje de Pozo Suncho el 10 de enero de 1883 (Bruno, 1976: 182-185).

\section{Tabla 10}

\begin{tabular}{|c|c|c|c|c|c|}
\hline \multicolumn{6}{|c|}{$\begin{array}{c}\text { Confirmaciones en los Curatos de Nueva Colonización } \\
\text { Obispos Álvarez y Esquiú }\end{array}$} \\
\hline \multirow[t]{2}{*}{ Curato } & \multirow[t]{2}{*}{ Departamento } & \multirow{2}{*}{$\begin{array}{c}\text { Departamento } \\
\mathbf{k m}^{2}\end{array}$} & \multirow{2}{*}{$\begin{array}{c}\text { Población } \\
1879\end{array}$} & \multicolumn{2}{|c|}{ Confirmaciones } \\
\hline & & & & $\begin{array}{c}\text { Álvarez } \\
\text { 1874-1877 }\end{array}$ & $\begin{array}{l}\text { Esquiú } \\
1882\end{array}$ \\
\hline Villa Nueva & Tercero Abajo & 5.141 .590 & 8.464 & No hubo & 2.319 \\
\hline $\begin{array}{l}\text { Las Mercedes } \\
\text { La Carlota }\end{array}$ & Río Cuarto & 40.510 .317 & & \multicolumn{2}{|c|}{$\begin{array}{r}\text { no existe el libro de } \\
\text { confirmaciones de esos años }\end{array}$} \\
\hline $\begin{array}{l}\text { San Gerónimo } \\
\text { Bell Ville }\end{array}$ & \multirow[t]{2}{*}{ Unión } & \multirow[t]{2}{*}{18.401 .480} & \multirow[t]{2}{*}{6.596} & \multirow[t]{2}{*}{2.142} & \multirow[t]{2}{*}{3.346} \\
\hline $\begin{array}{l}\text { La Asunción } \\
\text { Cruz Alta }\end{array}$ & & & & & \\
\hline San Justo & San Justo & 17.102 .552 & 6.218 & & 4.587 \\
\hline TOTALES & & & 21.278 & & 12.395 \\
\hline
\end{tabular}

En este caso, los porcentajes de confirmaciones son también muy elevados. En el departamento de San Justo alcanzó al 73,7\% de la población y en el de Unión al 83,20\%.

El Mapa 9 grafica las visitas pastorales realizadas por los obispos Eduardo Alvarez, Mamerto Esquiú y Capistrano Tissera. La Tabla 3 que acompaña al mapa, ubicada en el Anexo II, indica las fechas y lugares visitados. En función de estos datos, volcamos la información en un mapa de época, contemporáneo a las visitas. Como puede observarse a simple vista, quien recorrió mayor cantidad de territorio provincial fue el Obispo Esquiú, llegando hasta La Carlota, el curato más austral en este período.

\subsubsection{Visita del Obispo Fray Reginaldo Toro y sus Obispos Auxiliares (1888-1904)}

El 25 de agosto de 1888, en un solemne acto en la Catedral de Córdoba, tomaba posesión del obispado fray Reginaldo Toro. ${ }^{33}$ Para suplir la vacancia de la sede

\footnotetext{
${ }^{33}$ Para saber más datos sobre su vida, véase GONZÁLEZ (1988 y 2000).
} 


\section{Mapa 9}

\section{Visitas Canónicas de los Obispos Alvarez, Esquiú y Tissera}

\section{4-1886}

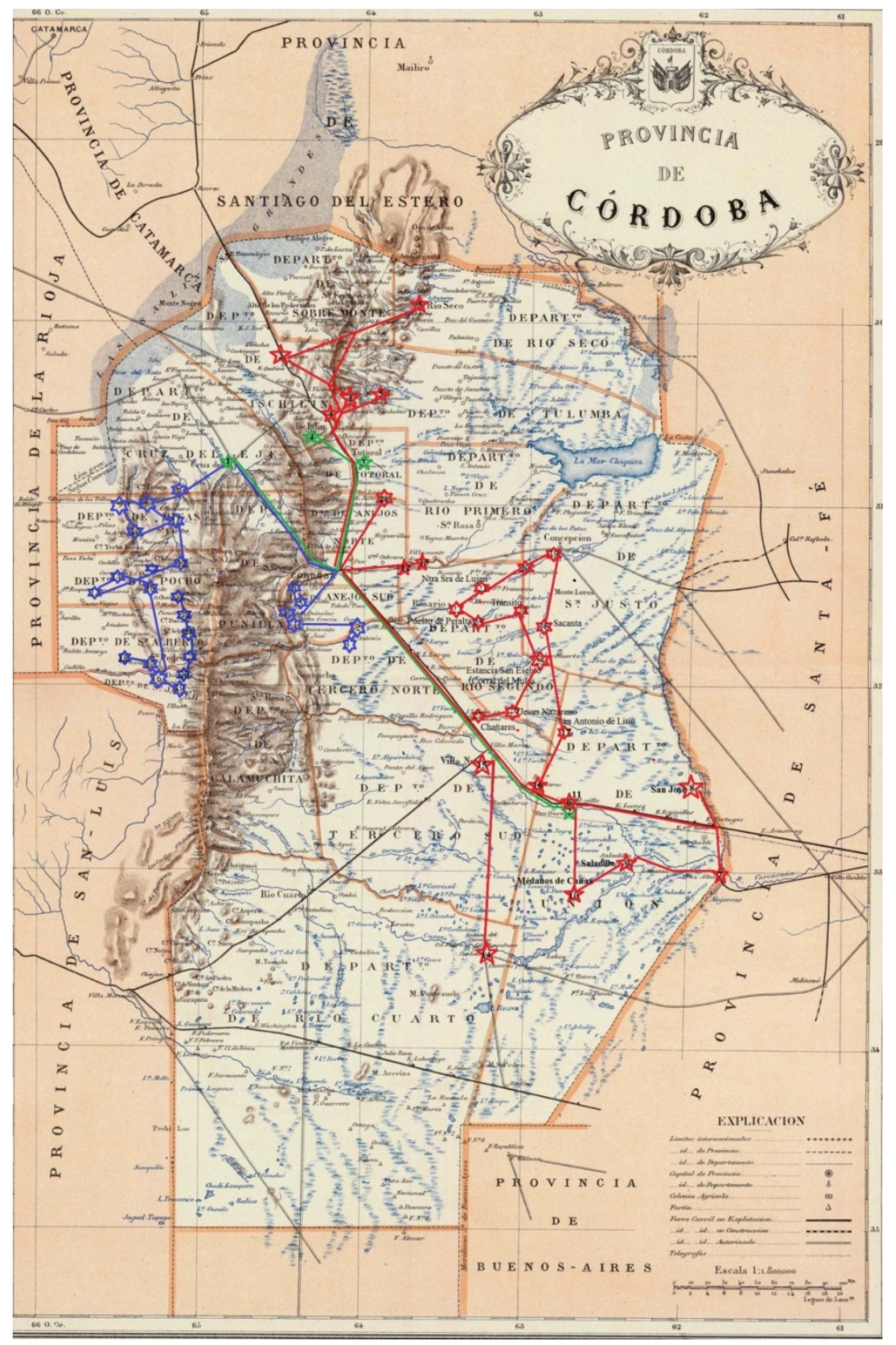

Fuente: Elaboración propia en base al mapa de Mariano Felipe Paz Soldán, 1888, Provincia de Córdoba, Félix Lajouane Editor, Buenos Aires.

Referencias: En color verde se señalan las visitas del Obispo Eduardo Álvarez; en rojo, las realizadas durante la gestión del Obispo Esquiú, y en azul, la de Fray Capitrano Tissera. 
metropolitana de Córdoba, el Senado de la Nación había presentado, el 27 de septiembre de 1887, una terna de candidatos, ${ }^{34}$ figurando en primer lugar, Fray Reginaldo Toro de la Orden de los Predicadores. Elevada su presentación a la Santa Sede por el Presidente Miguel Juárez Celman, el Papa León XIII lo preconizó obispo de Córdoba en el consistorio del $1^{\circ}$ de junio de 1888 , recibiendo las bulas pontificias a mediados del mismo mes. ${ }^{35}$

Luego de proveer el cabildo eclesiástico, comenzó sus giras pastorales. Lamentablemente, no hemos podido acceder a la documentación referida a sus visitas, ya que el libro de visitas canónicas correspondiente a los años 1886-1916 no contiene información de las mismas. No estamos seguros de que el obispo abriese una visita canónica de manera formal, no obstante constatamos sus desplazamientos por la diócesis y la realización de las misiones y confirmaciones. Para ello, reconstruimos dichas visitas en base a fuentes bibliográficas y otras fuentes primarias, como los libros de confirmaciones y la correspondencia con el gobierno nacional y provincial. De todas formas, dimos con un libro abierto por el Obispo Auxiliar, Monseñor Cabanillas, que recoge la crónica pormenorizada de las visitas hechas por él, siendo Obispo Auxiliar de Monseñor Toro, entre los años 1901 y 1903.

Volviendo a Fray Reginaldo Toro, en el mes diciembre, confirma en Villa Concepción ${ }^{36}$ y Bell Ville. ${ }^{37}$ La primera gira pastoral, la realizó por el departamento de Calamuchita y duró desde el 21 de marzo hasta el 7 de abril de 1889. El mismo obispo escribe: "dimos misiones, bien atendidas, en las capillas de Los Reartes, Santa Rosa y San Agustín" (Bruno, 237 y ss.). También administró confirmaciones en las capillas de Río de los Sauces y La Cruz. $^{38}$

La segunda gira comenzó el 27 de abril de 1889. El obispo, en compañía de los canónigos Aquilino Ferreyra y Luis F. Tagle, partió hacia Deán Funes, donde dieron "una muy satisfactoria misión". ${ }^{39}$ El 5 de mayo llegó a Cruz del Eje, bendijo la piedra fundamental del nuevo templo y celebró confirmaciones, ${ }^{40}$ y de allí continuó a Soto, La

\footnotetext{
${ }^{34}$ Diario de Sesiones de la Cámara de Senadores (1887), 599. Integraban la terna dos religiosos y un secular: Fray Reginaldo Toro (O.P), David Luque (Pbro. Dr.) y Fray Juan B. González (O.F.M).

35 AAC. Actas Capitulares, 1878-1898, fs.187-189.

${ }^{36}$ San Justo, Libro $2^{\circ}$ Confirmaciones, 1882-1888, f.209.

${ }^{37}$ Bell Ville, Libro $2^{\circ}$ Confirmaciones, 1888-1898, fs.2-45.

${ }^{38}$ Río de los Sauces, Libro $2^{\circ}$ Confirmaciones.

${ }^{39}$ Ischilín/Deán Funes, Confirmaciones, 1898, fs.1-23.

${ }^{40}$ Cruz del Eje, Libro $2^{\circ}$ Confirmaciones, 1886-1903, fs.96-160.
} 
Higuera, San Carlos, Salsacate y Villa del Tránsito, donde "dimos fin a esta visita con tres numerosas tandas de ejercicios en la casa edificada al efecto". En la segunda mitad del año, retomó las visitas pastorales, celebró confirmaciones en Villa del Rosario y dio misiones en Alta Gracia y Remedios. No pudo ir personalmente a La Rioja, aunque envió, en agosto, a su Vicario general, Monseñor Castellano (González, 2000: 123).

E1 7 de febrero de 1891, el prelado informó al ministro de Justica, Culto e Instrucción Pública de la Nación que había practicado la visita canónica personalmente y por medio de delegados, con toda la frecuencia que le había sido posible. Simultáneamente a la visita, se organizaron misiones, por lo que el obispo consideró que el fruto había sido satisfactorio. "En este orden, he puesto particular empeño, persuadido como estoy de que la conservación y aumento de la religión en el pueblo que es tan necesaria para el mantenimiento del mismo orden nacional, recibe un gran impulso con la frecuencia de las visitas canónicas y misiones". ${ }^{41}$ Señalaba que existían muchas dificultades para vencer, los gastos que ocasionaba esta práctica, las largas distancias, la extensión del territorio diocesano, la falta de clero, lo que hacía imposible estar en todos los puntos donde la presencia del obispo era de gran importancia para los fieles y súbditos de la Nación. A pesar de las dificultades mencionadas, el obispo informó que había visitado durante el año 1890 los curatos de La Cruz, Río de los Sauces, Río Segundo, Reducción, La Carlota, Tulumba, Chañar, Jesús María, Deán Funes, San Justo y la ciudad de La Rioja.

En su viaje a Roma con motivo de la visita ad limina de 1892, solicitó el nombramiento de dos obispos auxiliares, con el fin de contar con colaboradores para la atención pastoral de la diócesis. Fueron nombrados Mons. Uladislao Castellano, Auxiliar de Córdoba y Titular de Ankialo y Mons. Rosendo de la Lastra, Auxiliar de Córdoba y Titular de Miletópolis. El primero fue destinado como vicario general al sur de la provincia, con sede en Río Cuarto, y el segundo, como vicario foráneo a La Rioja. Ambos prelados colaboraron intensamente en la labor de visitar a las parroquias de sus respectivas jurisdicciones, en tanto Monseñor Toro atendió personalmente el centro y norte de la provincia.

En septiembre de 1893, encontramos a Fray Reginaldo Toro en Marcos Juárez, donde bendijo e inauguró la Iglesia parroquial Ntra. Sra. de la Asunción; un año después, en el

\footnotetext{
${ }^{41}$ AAC. Leg. 38. Comunicaciones con el Gobierno Nacional, 1814-1910.
} 
mes de agosto, recorrió Leones, Marcos Juárez y Roca. El periódico "Los Principios” informaba el acontecimiento de esta manera:

El 14 vino el obispo de Córdoba y de paso por Leones los vecinos de este pueblo le hicieron una espléndida recepción. En el andén no podía entrar ni una cuarta parte de la concurrencia así que los más estaban a lo largo de la línea, con las dos bandas de música y las cuatro escuelas con las banderas desplegadas. De allí se fue a la iglesia por medio de arcos y de un embanderamiento general de toda la villa. Esta ha sido una de las recepciones más preciosas que he presenciado en toda mi vida. Una cuadra antes de llegar a la Iglesia habían formado una columna de siete metros de altura, que tenía pendiente un hermoso escudo que contenía en letras doradas la siguiente inscripción "La municipalidad y el pueblo saludan al Eximo Obispo Diocesano en el primer aniversario de la colocación de su templo.

Ayer 15 pontificó el Sr obispo, y predicó el canónigo Márquez, haciéndose procesión del Corpus por la tarde, el 16 predicó el canónigo Ferreyra y, el 17 el Pbro. Viaggio. El departamento tiene como 25.000 habitantes, según el jefe político, el preceptor y el caballero Tiscornia. Se divide en 6 pedanías con 5 centros de población y 56 colonias. Tiene buenas autoridades, el jefe político es el Sr González; es una caballero cumplido y muy apreciado por todos, el intendente municipal es el Dr. Eleodoro Giménez con quien está el pueblo muy contento por su comportamiento. El preceptor es un excelente caballero. El cura es el Pbro. Elmiro Ruiz, párroco inmejorable, sentido trabajador que en once meses que lleva de cura ha gastado más de cinco mil pesos en adornar la Iglesia que esta como un relicario, advirtiendo que él no pide y sin pedir todos le dan, esta es la prueba concreta de que tienen confianza en él y lo aprecian. ${ }^{42}$

En 1895, Rosendo de la Lastra fue nombrado Obispo de Paraná y tres años después, en 1898, Uladislao Castellano fue preconizado Arzobispo de Buenos Aires, motivo por el cual, el Obispo Toro, en su viaje a Roma para asistir al Concilio Plenario para América Latina (1899), gestionó ante la Santa Sede el nombramiento de dos nuevos obispos auxiliares. Al año siguiente, la Santa Sede confirmó los nombramientos de Aquilino Ferreyra y Filemón Cabanillas como Obispos Auxiliares de Córdoba y Titulares de Amiso, el primero, y Circesio, el segundo. Monseñor Toro enfermó en 1902 y falleció el 24 de agosto de 1904 a los 75 años de edad.

2.2.2 Visita de Filemón Cabanillas a los curatos de vieja colonización, 1900-1903

Las visitas realizadas por el Visitador de parroquias y Obispo Auxiliar de Córdoba, Mons. Filemón Cabanillas, se encuentran registradas en el Libro de Notas particulares del

\footnotetext{
${ }^{42}$ Los Principios, 15/08/1894.
} 
Obispo, 1884-1903, a partir del folio 94, donde se deja constancia de la apertura del libro de la visita.

El prelado comenzó su gira en el curato de Calamuchita en el mes de abril de 1901, donde impartió, con toda solemnidad, la bendición de la nueva capilla de Amboy, viceparroquia del curato. Allí se encontraban dos padres jesuitas realizando una misión. Durante los diez días que duró la visita, "numerosa concurrencia participó de las funciones", se realizaron 1.900 comuniones, se regularizaron 10 matrimonios y se administraron 1.703 confirmaciones.

Luego, se dirigieron a la parroquia de San Agustín, donde se dio apertura a la misión y a la visita. Mientras los padres misioneros y el cura administraban sacramentos y predicaban, el Obispo Cabanillas "se ocupaba de inspeccionar todo lo perteneciente a la iglesia y útiles del culto". Como no pudo hacer personalmente la visita a las otras capillas del curato, se informó del estado material de las mismas valiéndose de "personas de reconocida piedad". Durante los diez días que duró la visita, comulgaron 1.890 fieles, se confirmaron 400 -la mayor parte niños-, y se celebraron 8 matrimonios. Para conmemorar la visita, se colocó una gran cruz de hierro en el atrio de la Iglesia, en honor a Jesús Redentor, como obsequio para el inicio del nuevo siglo. La ceremonia se realizó con toda solemnidad, el canto del Te Deum y la bendición papal.

El 22 de agosto se encontraba en el curato de Minas, donde realizó la visita a la viceparroquia de Guasapampa, recientemente reedificada, debido a que la iglesia parroquial de San Carlos estaba en construcción en un terreno que, aunque era propio de la iglesia por debida compra o donación, no estaba debidamente escriturado, con lo cual se corría grave peligro de que los antiguos dueños quisieran alegar dominio o propiedad de la iglesia. El auto, compuesto por cinco artículos, elogia la actividad y el celo del cura párroco, José Pío Angulo; prohíbe seguir la construcción de la parroquia en tanto no se solucionara la escritura del terreno; agradece y exhorta a las autoridades a seguir colaborando con el cura para velar por la moralidad pública; autoriza al párroco a utilizar los ornamentos y útiles del oratorio del Durazno, que se encuentra en ruinas, en la capilla de Guasapampa, y autoriza colocar, en la capilla de Ciénaga, una imagen del Crucificado, donada para el culto. ${ }^{43}$

\footnotetext{
${ }^{43}$ AAC. Notas particulares del Obispo... p. 109.
} 
A fines de julio y primeros días de agosto, se dirigió a los curatos de Cruz del Eje y Soto. La visita, acompañada de misión, duró diez días, se confirmaron más de 3.000 personas y se regularizaron 19 matrimonios "de pobres de mala vida" y comulgaron 5.000 personas. En el artículo quinto del auto, el obispo exhorta a las autoridades municipales, policiales y a los feligreses a prestar su auxilio y cooperación al párroco, en la esfera que les corresponda, en lo relativo a los pecados públicos y de escándalo "que tanto dañan a la moral y civilización cristianas, principalmente en los pueblos pequeños y nacientes". ${ }^{4}$

El obispo llegó a Cruz del Eje el 6 de agosto. La visita, acompañada de misión, tuvo los siguientes resultados, se regularizaron 29 matrimonios, de "parejas de mala vida", 1.011 niños se confirmaron, se distribuyeron más de 3.000 comuniones y se bautizaron más de 200 niños. "Se practicó la visita canónica del curato con la mayor prolijidad por medio de informes fidedignos sobre las capillas y personalmente en la parroquia, en que se bendijo la nave principal ya concluida”. La capilla de Media Naranja estaba todavía en construcción. El Oratorio de San Antonio estaba en "entredicho" por el abuso del que se llama patrono o propietario y la vice-parroquia de San Marcos estaba en regulares condiciones de aseo y ornamentación. Recomienda a los feligreses de la parroquia, y en especial a la sociedad San Vicente de Paul, para que "llevando el socorro material a los menesterosos, les presenten también el alimento del espíritu, inculcándoles las máximas de la moral y la religión que profesamos". 45

En marzo de 1902, visitó el curato de Punilla. Comenzó con las capillas de Dolores (vice-parroquia), Pinto, Cañada de Mercedes, Carreras de Pum Pum y San Roque y finalizó con la Iglesia parroquial de Cosquín, donde fue recibido solemnemente en la puerta de la Iglesia por el cura, según las prescripciones del ritual, dirigió unas palabras a los feligreses reunidos y a continuación visitó el tabernáculo, los vasos sagrados, el archivo, los ornamentos y útiles de la iglesia. Los resultados de la misión para el prelado fueron regulares, 2.000 comuniones, 28 matrimonios y 80 bautismos y 408 confirmaciones. Algunas de las dificultades que encontró el prelado para el mejor desempeño de la actividad pastoral del cura es que muchas de las capillas nos eran propiedad de la Iglesia y "se encuentran bajo el dominio de personas particulares ya con el nombre de patronos ya como

\footnotetext{
${ }^{44}$ AAC. Libro de Notas particulares del Obispo, 1884-1903, f.101.

${ }^{45}$ AAC. Libro de Notas particulares... f.103.
} 
propietarios". Por este motivo, ordenó al párroco, como se señaló ut supra, que a la brevedad adquiriera la propiedad tanto de templos como de cementerios. ${ }^{46}$ Otra de las cuestiones que queda expresamente manifestada en los respectivos autos es la preocupación porque se vele por la moral pública, para lo cual solicita el auxilio de las autoridades civiles, a fin de "cortar todos los escándalos y procurar la moralidad y arreglo de las costumbres sociales $\mathrm{y}$ domésticas y muy principalmente en lo que toca a los amancebamientos y "uniones criminales" que se deben cortar por el santo sacramento del matrimonio". 47

A continuación, el obispo se dirigió al curato de Chalacea, en el norte del departamento de Río Primero, donde dispuso el traslado de la sede de Monte del Rosario a San Antonio, pedanía de Timón Cruz, en el centro del curato, que será la residencia habitual del párroco. También estableció que debía colocarse una pila bautismal y trasladar el archivo parroquial. En el auto respectivo, exhorta a construir la capilla en Las Encrucijadas y recolectar limosnas para ese fin, advierte al párroco que debía, previamente, "recabar escritura pública de donación a propiedad, del terreno de cuatro cuadras cuadradas y del cementerio ubicados en la estancia del señor M. García" ${ }^{48}$ Además, indica que la capilla pública de Santa Rita, como las demás del curato, debe estar "bajo la administración libre y canónica del cura párroco, sin perjuicio de los derechos útiles y honorarios que el derecho concede al patrono (o sus herederos) que la edificó y dotó, dedicándose debidamente por el prelado al servicio público". ${ }^{49}$ Otro tema que comienza a aparecer en los autos es la prohibición de administrar sacramentos y celebrar misas en casas particulares, "aunque se le presenten las debidas licencias in scriptis, del ordinario de la diócesis". 50

La gira pastoral continuó y el 30 de agosto lo encontramos en el curato de Ischilín, donde ordena que la suma recolectada para construir un altar en honor al Sagrado Corazón de Jesús se invierta en la construcción de una sacristía al costado de la nave principal y que la imagen del Sagrado Corazón se coloque en el centro del altar principal y a los lados las imágenes de la Virgen del Rosario y la de San José; se autoriza a la patrona de la iglesia a recolectar limosna a tal efecto; ordena se coloque una pila bautismal en la Iglesia de Deán

\footnotetext{
${ }^{46}$ AAC. Libro de Notas particulares del Obispo, 1884-1903, f.112.

${ }^{47}$ AAC, Libro de Notas particulares.... f.114.

${ }^{48}$ AAC, Libro de Notas particulares.... f.116.

${ }^{49}$ AAC, Libro de Notas particulares... f.117.

${ }^{50}$ AAC, Libro de Notas particulares... f.117.
} 
Funes, que se ha constituido en parroquia en lugar de la antigua capilla de Ischilín; el oratorio de Avellaneda se encontraba clausurado por la muerte de la dueña y patrona. Respecto a los libros parroquiales, advierte que el párroco anterior no asentó las partidas para solucionar el problema, por ello ordena le remitan todos los apuntas y papeles para asentar y luego darlas a firmar por el cura respectivo, que se encontraba en otra parroquia. La visita continuó en el curato de Río Seco, donde ordenó se renovara la pila bautismal y menciona algunas condiciones que deben tener los bautizadores. Como en los autos anteriores, advierte sobre el peligro del concubinato, la embriaguez y la necesidad de velar por la moral pública.

\subsubsection{Visita de Filemón Cabanillas a los curatos de nueva colonización}

El 17 de agosto de 1902, el visitador pasó al curato de Marcos Juárez, donde realizó la visita a la iglesia parroquial y recibió informes del estado material y espiritual de las capillas dependientes. Advierte que "el cementerio de esta parroquia ha sido violentamente sustraído de la administración del párroco, quedando profanado y sin bendición, los feligreses privados de sepultura eclesiástica y sufragios que la Iglesia tiene destinados para honrar las cenizas de sus hijos fieles". En el auto, se ordena a los deudos próximos que conduzcan los restos al cementerio, den aviso inmediatamente al párroco para que bendiga la sepultura y haga el entierro en conformidad al ritual. Vuelve a recordar el deber de los oficiales municipales de "colaborar y no poner obstáculo alguno que prive a los fieles difuntos de tan sagrado derecho" y de colaborar con el párroco en la extirpación de los pecados públicos de escándalo que pervierten las costumbres sociales y la moral pública. ${ }^{51}$ Al día siguiente, 18 de agosto, se dirigió al curato de Bell Ville, donde realizó la visita a la Iglesia, el sagrario, vasos sagrados, útiles y archivo; felicitó por la prolijidad en el asentamiento de partidas y dejó constancia que había un saldo a favor de la fábrica de 700 pesos. Las capillas vice-parroquias del curato estaban bien asistidas por un teniente.

El 30 de octubre los encontramos de visita en los curatos de Bell Ville, Villa Nueva y Laboulaye, además de hacer las recomendaciones generales, se advierte una mayor preocupación por la enseñanza del catecismo a los niños y por combatir el concubinato. En Laboulaye, el obispo advierte "a todos y cada uno de los fieles que presumen casarse solo

\footnotetext{
${ }^{51}$ AAC. Notas particulares del Obispo, 1884-1903, f.119.
} 
civilmente y no reciben el sacramento como está ordenado, se hacen reos de grave pecado ante Dios y su conciencia, que pueden ser absueltos mientras permanezcan en tan deplorable estado de amancebamiento y concubinato". ${ }^{52}$ De Laboulaye continuó la visita a Sampacho y de allí al curato de la Anunciación en Arias. El artículo segundo del auto da las gracias a la comisión pro-templo por haber llevado a término la obra de construcción de la iglesia y declara que ha "cesado en su mandato debiendo el susodicho párroco hacerse cargo de su administración independiente y libre bajo todo concepto y plena responsabilidad". ${ }^{53}$ Advierte al párroco sobre la necesidad de velar por la enseñanza del catecismo, como lo señala el Concilio Plenario, la Asamblea de Obispos de Salta y las Constituciones del Sínodo diocesano de 1877. En San Francisco, administró el sacramento de la confirmación a 2.877 personas, 1.363 varones y 1.424 mujeres, 900 confesiones y 450 comuniones, en su mayoría confirmandos. De la crónica de la visita de Filemón Cabanillas, se desprenden algunas cuestiones interesantes, en primer lugar, la continua referencia a los decretos del Concilio Plenario para América Latina.

\subsubsection{Itinerarios de las Visitas del Obispo Toro y sus auxiliares}

Véase, Mapa 10.

\subsubsection{Obispo Zenón Bustos y Ferreyra: Visitas abiertas en el año 1905 y 1912}

El Obispo Fray Zenón Bustos y Ferreyra durante los catorce años que estuvo al frente de la diócesis realizó, por sí mismo, dos giras de visitas pastorales. La primera abierta en 1905 y la segunda en 1912. Para realizar esta tarea contó con la colaboración de dos obispos auxiliares. "La extensión tan amplia de este Obispado [...] comprueba la palpable necesidad de ser dotado con dos obispos auxiliares que compartiendo con el diocesano la tarea delicada de su apostolado pueda ser atendido conveniente y provechosamente". ${ }^{54}$ Monseñor Inocencio Dávila y José Anselmo Luque serán nombrados Obispos auxiliares y colaborarán con el diocesano en la tarea de las visitas pastorales.

\footnotetext{
${ }^{52}$ AAC. Notas particulares del Obispo, 1884-1903, f.134.

${ }^{53}$ AAC. Notas particulares del Obispo, 1884-1903, f.140.

${ }^{54}$ AAC. Fondo Zenón Bustos Obispo, Caja N 2, f.720.
} 


\section{Mapa 10}

\section{Visitas Pastorales del Obispo Toro y sus auxiliares}

\section{8-1904}

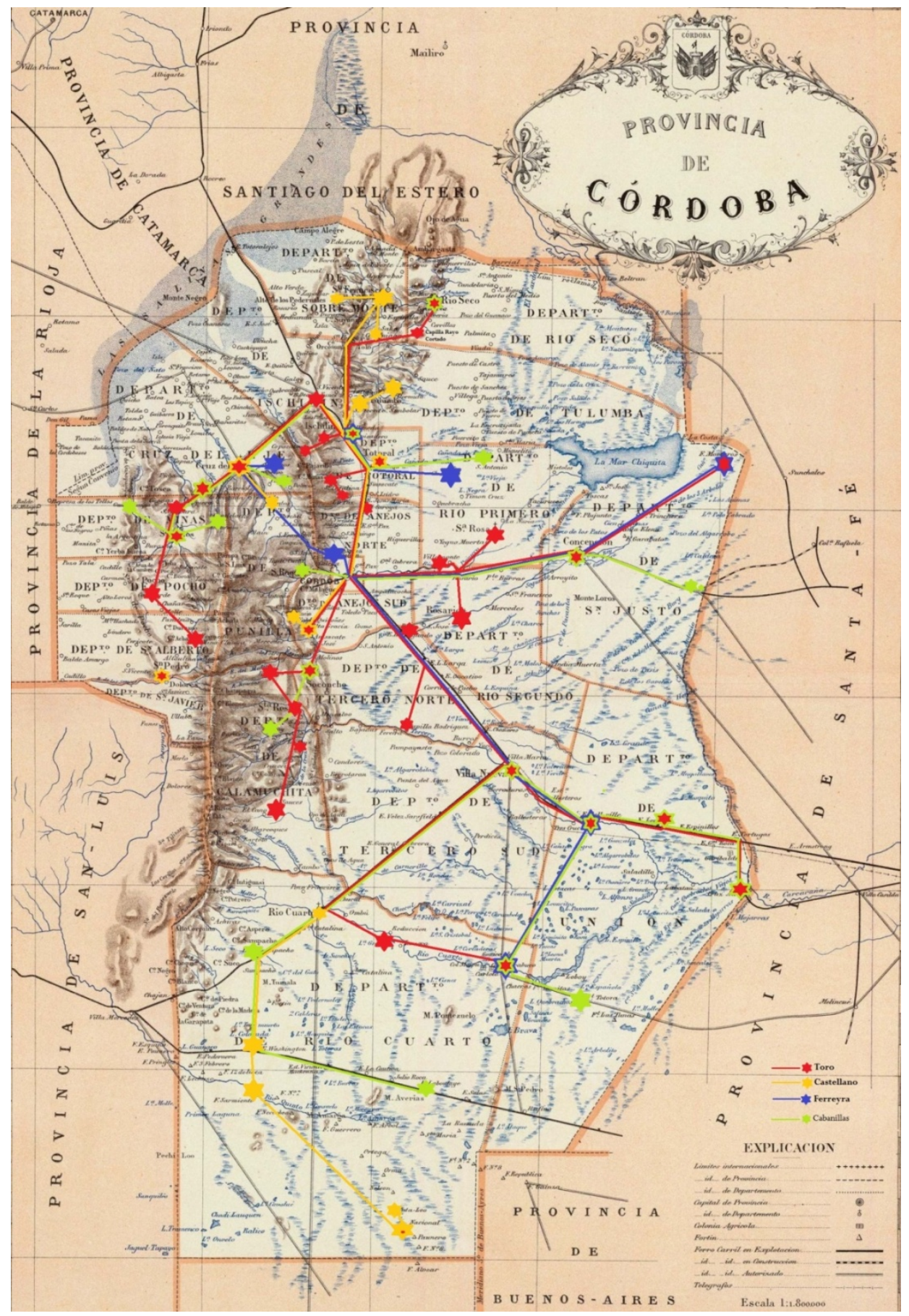

Fuente: Elaboración propia en base al mapa de Paz Soldán (1888).

Referencias: En color rojo, se señalan las visitas de Reginaldo Toro, el resto las de sus obispos auxiliares; en amarillo, Uladislao Castellano; en azul, Aquilino Ferreira; y en verde, Filemón Cabanillas. 
En su primera visita, pasó revista a un total de 64 establecimientos de la provincia de Córdoba entre parroquias, conventos y hospitales; ${ }^{55}$ en la segunda, inspeccionó, personalmente y a través de sus delegados, 65 establecimientos católicos, en su mayoría parroquias esparcidas en el amplio territorio diocesano ${ }^{56}$ (Cfr. Tabla 4 en el Anexo II). En la carta pastoral de cierre de la primera visita y apertura de la segunda deja constancia del trabajo pastoral que suponía esta práctica.

Mientras viajábamos de un lado a otro por el anchísimo campo de las dos provincias que componen la Diócesis, nuestro espíritu también giraba entre alternativas de luz y sombras, según alumbraban esperanzas de frutos saludables o temores de esterilidad en el ejercicio del ministerio. Que hayamos experimentado fatigas y penalidades al cruzar las extensas llanura de nuestras pampas, de las sierras escarpadas y selvas occidentales de nuestra provincia, los arenales y médanos, cuestas y regiones áridas de la Rioja entera, no vale la pena mencionarlo, habiendo tenido también a la vez la grata compensación, en todas partes, del afecto cordial de nuestros amados feligreses. ${ }^{57}$

Este breve extracto de la relación de la visita que realizó el Obispo Bustos a los curatos de las Sierras Grandes da una idea cierta de lo que significaban estos desplazamientos.

Salió de Córdoba el 16 de diciembre de 1912 [...]. Llegando a Santa María visitó esta población y al saber que se delineaba una nueva vía a la par, promovió la adquisición de un terreno para dotar a este pueblo de un templo. De aquí siguió parte en carruaje y parte a caballo, hasta completar la jornada para ese día, llegando a las Mercedes, casa del Dr. Julio Lezama, donde permaneció tres días impedido por las lluvias. De aquí a pesar del día lluvioso se siguió a caballo subiendo la altura hacia la Sierra Grande, llegando a la noche a la Mesada, que está al pie de ésta y tiene la capilla de Nuestra Señora del Valle. Aquí comenzó propiamente la misión permaneciendo 4 días. Trepando desde aquí por la escabrosa cuesta de los Gigantes a la pampa que corona la Sierra llegamos a la casa de Juan Bautista Pereyra pasando la lluvia en el camino [...] pasamos ese mismo día al borde contrario de la pampa, a la casa de Don José León Cuello, permaneciendo en esta por tres días la misión. Pasó de aquí a la estancia las Ensenadas donde la misión permaneció por tres días [...] se pasó a la estancia Trinidad permaneciendo en ésta la misión cinco días [...] De aquí nos trasladamos a la Ventana, estancia de don Tomás Domínguez donde permanecimos la tarde de un día y la mañana del otro [...]. Desde este punto hasta el cerro Champaqui era el caso de bajar la sierra cortando su altura rumbo al sudeste, bajando y subiendo sucesivamente cuestas empinadas hasta llegar a la noche del día en que salimos a la capilla de Yacanto, donde permanecimos dos días [...]. Aunque habíamos bajado durante todo un día la Sierra hasta la capilla mencionada tuvimos que continuar bajando casi todo un día más hacia el Sud, hasta ponernos en la Iglesia de Amboy, donde la misión fue muy animada

\footnotetext{
${ }^{55}$ AAC. Libro de Autos y Visitas Parroquiales, 1885-1916.

${ }^{56}$ AAC. Libro de Autos y Visitas, 1916-1922.

${ }^{57}$ REOBA, 1912, p. 1176; Pastoral del 27 de septiembre de 1912.
} 
durante 4 días. [...] Este era el punto más al Sud de la línea que se debía recorrer y desde donde tomamos rumbo al norte y fuimos a la iglesia de Santa Rosa [...] en esta iglesia permanecimos dos días y pasamos a la iglesia de los Reaertes, donde permanecimos otros dos días [...] Desde los Reartes nos dirigimos a la iglesia de Potrero de Garay [...] y desde aquí nos dirigimos a los Molinos [...] regresando desde este punto a la ciudad. [...] Duró toda la misión desde el 16 de diciembre al 18 de enero en que regresamos. ${ }^{58}$

Esta descripción nos da una idea de las dificultades que debían atravesar a la hora de realizar la visita. Era obligación del párroco organizar el desplazamiento del obispo y sus acompañantes, así como de supervisar el alojamiento apropiado, así lo expresó el cronista de la visita del Obispo Tissera al curato de Minas, "siguieron viaje en los caballos preparados por el Cura de Minas y Rosendo Leal, principal vecino del curato, quien había preparado a su costo la tropa que debía conducir al prelado y su comitiva a la capilla de Ciénaga del Coro". 59

La visita, a partir del Obispo Bustos, consta de dos cuerpos diferentes: un cuestionario que el párroco debía responder por escrito con anterioridad a la misma y el auto de la visita que contenía indicaciones y reflexiones del pastor luego de realizada la inspección. Para la primera visita, se diseñó un cuestionario que constaba de cuarenta y nueve preguntas, que abarcaban desde la inspección del conjunto de bienes y su administración, hasta lo relativo al personal, especialmente en cuanto al cumplimiento de sus deberes clericales, y en general, la detección y consiguiente corrección de eventuales irregularidades, abusos, errores o desórdenes. Los párrocos debían responder a dicho cuestionario "con toda verdad, claridad y precisión, confirmándolas con juramento". ${ }^{60}$ Más adelante, volveremos sobre las visitas canónicas realizadas por este obispo al analizar la mirada de la jerarquía sobre la diócesis a partir de los informes y autos de visitas, que nos permitirán detenernos en el análisis más cualitativo de las mismas. A continuación, presentamos la reconstrucción de los itinerarios de las visitas y su proyección sobre el mapa, a fin de dar una idea cartográfica de la dimensión espacial de esta práctica pastoral.

El Mapa 11 grafica las visitas pastorales realizadas por el Obispo Zenón Bustos y sus auxiliares. La Tabla 5 que acompaña el mapa ubicada en el Anexo II, indica las fechas y

\footnotetext{
${ }^{58}$ REOBA, 1912. Informe de la Visita practicada en la Sierra Grande por el Imo. Obispo Diocesano Doctor Fray Zenón Bustos, pp. 437-439.

${ }^{59}$ AAC. Libro Autos y Visitas Pastorales, 1886-1916, f.127.

${ }^{60}$ AAC. Parroquia del Pilar, s/f.
} 
lugares visitados. En función de estos datos, volcamos la información en un mapa encontrado en la curia, que muestra los curatos de la provincia en 1905.

\section{Mapa 11}

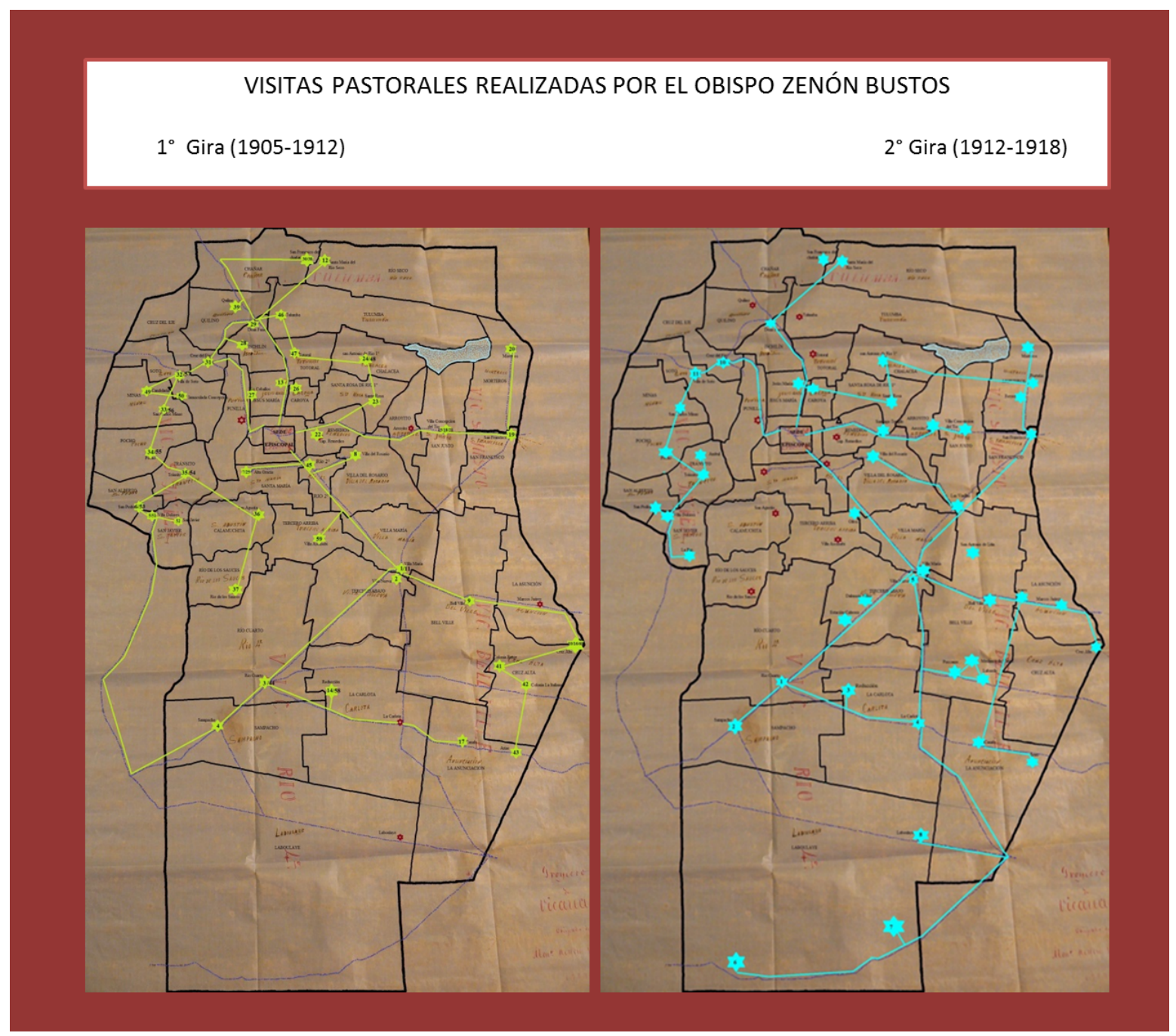

Fuente: Elaboración propia en base a un mapa a mano alzada del Archivo del Arzobispado de Córdoba, elaborado en 1905 para un proyecto de creación de vicarías foráneas.

\section{Lectura de conjunto de las visitas pastorales}

Esta aproximación a las visitas pastorales realizadas durante el período que abarca nuestra investigación, nos permite acercarnos a una de las estrategias planteadas por la jerarquía para llevar adelante la reforma eclesiástica planteada en el marco del proceso de romanización. Nos hemos detenido en un pormenorizado relato de la visita del Obispo 
Tissera, a fin de dar una idea acabada del desarrollo de esta práctica pastoral, ya que son escasos los relatos sobre visitas a los que hemos podido acceder. El relato, redactado por el secretario de la visita, permite darse cuenta del esfuerzo y el desgaste físico que suponían estos desplazamientos, tanto de prelados como de feligreses. Al presentar el volumen de las visitas realizadas, nos viene a la memoria el trabajo de José A. García de Cortázar (1994) sobre viajeros, peregrinos, mercaderes en la Europa medieval. Para el autor, el hombre medieval es un homo viator, un hombre que sigue un camino. El camino físico del viajero que se desplaza de un lugar a otro y el camino simbólico de quien hace de su vida una búsqueda de perfección o, cuando menos, de desasimiento respecto al mundo, concebido como simple tránsito, como mera vía, para la morada definitiva del cielo. Creemos, sin duda, que en el período analizado en este trabajo, el obispo fue un gran viajero, un viajero que se desplazaba con una pequeña comitiva, soportando las dificultades y exigencias del viaje por un motivo sobrenatural, la salvación de las almas que Dios le había confiado. Tres de los obispos emprendieron el viaje final de sus vidas, realizando las visitas canónicas. Esta figura de viajero itinerante está fuertemente vinculada al proceso de romanización y a la necesidad de ejercer un control efectivo sobre el territorio. Cuanto mayor sea el conocimiento por parte del prelado, y más cercana sea su figura a las feligresías, más eficaz sería la reforma.

En las visitas, el párroco aparece como un mediador entre el obispo y el pueblo, tanto en las primeras etapas de la visita, como en el ejercicio diario de sus funciones, él era el pastor del curato. Habitualmente valorado y respetado por las autoridades civiles y los jefes de familia, aparece como el organizador de la vida moral, civil y social de su comunidad, con un prestigio, en algunos casos, mayor que el jefe político. Estas características reaparecen con fuerza en la segunda mitad del siglo XIX y comienzos del XX.

Esta práctica permitió, a la jerarquía, fortalecer el contacto con los fieles y aspirar a convertir a cada templo en una institución bisagra entre la Iglesia y la sociedad, en un elemento primordial para la concreción del proyecto de re-catolización del Estado y la sociedad (Romero, 1999a: 47), en la construcción de una "nueva cristiandad" (Di Stefano y Zanatta, 2000). Se trataba de llevar adelante una política destinada a reconquistar el espacio rural, mediante la presencia activa del templo, con sus funciones y procesiones. Estas visitas dan cuenta del inicio del proceso reformador analizado, en el cual la Iglesia 
comienza a construir lo que Boutry (1995: 226) denomina una "teología de la visibilidad": "una visibilidad del culto y de la institución eclesial, entendida como manifestación histórica concreta y actual de la misión y de la centralidad de la iglesia sobre el espacio y la sociedad". La presencia del obispo y la celebración de la visita con toda pompa y solemnidad, según lo establecía el ritual, es, a nuestro entender, una clara manifestación de esta teología de la visibilidad. Era necesario hacer presente al obispo, personaje prácticamente desconocido para el pueblo cordobés del siglo XIX.

Por otra parte, las visitas nos permiten pensar la cuestión de la territorialidad de la Iglesia, una territorialidad entendida no sólo como la presencia material a través de los templos, que nos remiten a una presencia más estática, física y puntual, asentada en un espacio concreto, sino también como una territorialidad construida mediante una presencia itinerante. Es decir, mediante la capacidad que tenía la Iglesia de movilizar gente. El templo se convierte en un foco, en un centro de erradicación, a partir del cual se extiende la acción católica como fuerza centrífuga y centrípeta, pues al templo llegaban los feligreses de lugares apartados, pero también del templo salían misioneros a predicar la palabra de Dios e impartir los sacramentos. El complemento a las visitas fueron las misiones itinerantes que se celebraron en los rincones más apartados de cada curato.

Zenón Bustos compara los benéficos resultados de la visita canónica con "la lluvia frecuente en los arbustos y las selvas" y lamenta que haya dejado de hacerse por tanto años, privando al pueblo de sus ventajas. ${ }^{61} \mathrm{~A}$ fin de alcanzar un conocimiento personal de la provincia de La Rioja, en los primeros años de su episcopado, la recorrió de forma completa "empleando de nueve a diez meses en las cuatro excursiones en que dividimos aquel vasto y penoso territorio." Advierte sobre las ventajas de la buena marcha del espíritu y la disciplina que se descubre en las visitas canónicas y se lamenta de la imposibilidad de hacerla con la frecuencia anual o bi-anual que prescriben los cánones. ${ }^{62}$

Una apretada reflexión sobre las visitas de la segunda mitad del siglo XIX, nos lleva a considerar, por un lado, la importante movilización de gente que generaba la presencia del obispo. Las cifras de las confirmaciones dan cuenta del alto grado de aceptación de la religión católica en la región del norte y oeste, en tanto el número disminuye en los curatos

\footnotetext{
${ }^{61}$ AAC. Fondo Zenón Bustos Obispo, Documentación Varia, Caja N 2, fs.719-720.

${ }^{62}$ AAC. Fondo Zenón Bustos Obispo, Documentación Varia, Caja N 2, f.720.
} 
del este y del sur. Por otro lado, la crónica refleja cierta armonía y cooperación entre las autoridades civiles y las eclesiásticas. Esta visión relativamente armónica de las relaciones entre las autoridades no se condice con la realidad. En la segunda parte del trabajo, señalábamos que, en el período analizado, la iglesia y el estado son dos entidades que se conforman a nivel nacional. El proceso por el cual la iglesia transfiere al estado herramientas administrativas y elementos de control de la población (feligresía/ciudadanía) es complejo y con frecuencia conflictivo. Los registros de nacimientos, matrimonios y defunciones, llevados sólo por los curas párrocos, pasaron a la administración civil mediante un conflicto que retomaremos cuando analicemos las prácticas. El año 1884 fue conocido, como ya dijimos, por la prensa y la opinión pública cordobesa como el año de la “persecución religiosa". Las visitas dan cuenta del conflicto generado por la secularización de los cementerios a nivel de autoridades locales. Sin embargo, a través de los autos, no logra dimensionarse el grado de hostilidad que alcanzó en algunos curatos. En Punilla y La Rioja, por ejemplo, se iniciaron procesos penales contra el cura que casaba sin tener a la vista el boleto del registro civil, por este motivo el cura de Punilla fue condenado a un año de cárcel.

En general, la comitiva episcopal recibía la colaboración de las autoridades civiles, esto puede observarse, por ejemplo, en la utilización de la fuerza coercitiva del estado para combatir las "costumbres escandalosas". Aquí, el obispo desempeña un papel importante al ejercer la potestad de "perdonar" los pecados, "liberar" las conciencias y "arreglar" situaciones irregulares.

Por otro lado, el relato de las visitas permite advertir los signos claros de la debilidad institucional que aún vive la iglesia diocesana en el último cuarto del siglo XIX. Entre los signos tangibles, puede observarse el deterioro material de templos, capillas y cementerios. Esta realidad podría vincularse con el proceso descripto por la historiografía francesa medieval, cuando plantea el paso de un sistema de cristiandad, de unanimidad, de identidad entre la iglesia y la sociedad, a una secularización y paulatina diferenciación entre Iglesia y sociedad, entre contenido y continente. En un sistema de cristiandad, el templo cumple algunas funciones, pero no es determinante en la vida cristina. Se podría hablar de cristianos sin templos, o, para ser más precisos, de un cristianismo que está tan imbricado en la sociedad que el templo no es un espacio central en la vida del creyente. De hecho, 
algunos sacramentos como el bautismo y el matrimonio eran celebrados fuera del templo, en los propios hogares, los hogares eran concebidos como templos. El deterioro material de los templos de la campaña puede ser un indicio de que no constituían un espacio habitualmente frecuentado por las feligresías, ya que funciones que se comenzarán a ejercer dentro del templo, se realizaban fuera de él. En los hogares cristianos, se enseñaba el catecismo, se celebraban sacramentos, etc. Zenón Bustos dirá en 1906, en una pastoral sobre la catequesis, que "el padre y la madre tenían dentro del hogar cátedras levantadas en las que enseñaban el catecismo a sus hijos y domésticos. El catecismo era el evangelio que en ese templo se enseñaba y comentaba [...] manteniendo vivo y vigoroso el sentimiento religioso [...] Hoy las cátedras han desaparecido del hogar, esos templos se han cerrado" ${ }^{63}$ A medida que avanzamos en el siglo, la situación se revierte y el templo se convierte en una pieza fundamental, que garantiza la presencia de la iglesia en la sociedad.

Como señala Roberto Di Stefano, una iglesia que paulatinamente se parece cada vez menos a la sociedad. Es por ello que, a medida que se acentúa el proceso reformador, se hace necesario pasar por la iglesia material, por el templo, para formar parte de la iglesia comunidad. En este sentido, desde las últimas décadas del siglo XIX, comienza un proceso que se acentúa con el correr de los años, por el cual todos los sacramentos deben administrarse dentro del edificio, es decir en el marco de "la Iglesia material", del templo.

\footnotetext{
63 AAC. Fondo Zenón Bustos. Pastoral sobre "La enseñanza de la doctrina cristiana", Establecimiento Tipográfico Los Principios, Córdoba, 1906, pp. 6-7.
} 


\section{CAPITULO 8}

\section{La geografía eclesiástica de Córdoba}

El objetivo de este capítulo es presentar el estado de los curatos de la provincia a partir de la mirada de los párrocos y Obispos Reginaldo Toro y Zenón Bustos. Recién a partir del primero encontramos informes sistemáticos sobre la cuestión. Los informes son una fuente interesante, pues, de alguna manera, preparan la información que el obispo llevará a Roma para la primera visita ad limina que realice un obispo diocesano en Córdoba en 1892. A partir de estos informes, de los interrogatorios previos a las visitas pastorales, elaborados por el Obispo Bustos (1906-1912) y de los informes de sus visitas ad limina en 1908 y 1913, a los cuales pudimos acceder en los Archivos Secretos Vaticanos, intentamos presentar una cartografía eclesiástica que aspira a mostrar la dinámica pastoral, económica y social de cada curato, entre 1890 y 1925. La estructura del capítulo consta de dos partes, la primera, trata los informes de 1890-1893, y, la segunda, la situación de los curatos, organizados según regiones, entre 1905-1925, respetando la regionalización presentada previamente.

\section{El territorio diocesano provincial a la luz de los informes de los párrocos de 1890 a} 1893

A poco de asumir el obispado, Fray Reginaldo Toro dispuso el envío anual en el mes de diciembre de un informe relativo a la situación de cada curato. Dicho informe solicitaba datos referentes a trece puntos. ${ }^{1}$ De los 28 curatos existentes en la campaña cordobesa en

\footnotetext{
${ }^{1}$ AAC. Libro de Autos, 1876-1905, fs.120-121. El auto del 22/11/1890 solicita que se envíe a la curia en el mes de diciembre de cada año los siguientes datos:

1.-El número de capillas y oratorios y el estado material de las mismas y si hay alguna en construcción.

2.-Número aproximado de habitantes del curato. Cuántos de éstos cumplen el precepto de confesión y comunión anual.

3.-Cuál es el número aproximado de personas que frecuentan los sacramentos.

4.-Cofradías o congregaciones religiosas establecidas en el curato y el número de fieles alistados en ellas...

5.-Niños bautizados u oleados...

6.-Casamientos celebrados...

7.-Cuantos matrimonios pagaron derechos...

8.-Unciones o novenarios solemnes celebrados...

9.-Entradas de fábrica.

10.-Limosna en beneficio de las capillas...

11.-Si se pagan primicias y de que cosas y cuantos cumplen este deber.
} 
1890, hemos encontrado la respuesta a la circular, al menos en alguno de los tres años, de 19 curatos, la muestra, por lo tanto, responde a un $67 \%$ de las parroquias. La fuente tiene sus límites, pues las respuestas denotan que el cura algunas veces desconoce lo que se le pregunta, otras responde de manera ambigua. A la pregunta sobre el número de habitantes del curato y la cantidad de personas que cumplen el precepto pascual, algunos curas, como los de San Justo y Bell Ville, responden que "lo ignoran", y el de Ischilín que "algunos", respuestas que muestran, al menos, falta de conocimiento de sus feligreses. El análisis de algunas cifras puede resultar interesante.

Dividimos el contenido de la circular en dos grandes temas, Tabla 11, territorialidadreligiosidad, y Tabla 13, cuestiones económicas.

\section{Tabla 11}

\begin{tabular}{|c|c|c|c|c|c|c|c|}
\hline \multicolumn{8}{|c|}{ Territorialidad y religiosidad a través de los Informes parroquiales de 1890-1893 } \\
\hline Fuente & Curato & Año & $\begin{array}{l}N^{0} \text { de } \\
\text { Hab. }\end{array}$ & $\begin{array}{c}\text { Precepto } \\
\text { pascual }\end{array}$ & $\begin{array}{c}\text { Frecuentan } \\
\text { sacramentos }\end{array}$ & $\begin{array}{l}\mathbf{N}^{\mathbf{o}} \\
\text { Cap/ } \\
\text { Orat }\end{array}$ & $\begin{array}{l}\text { Funciones / } \\
\text { Novenarios }\end{array}$ \\
\hline $\begin{array}{l}\text { AAC. Parr. } \\
\text { Sobremonte }\end{array}$ & Chañar & 1893 & 9.000 & 300 & 80 & $3 \mathrm{c}$ & 1 (San Francisco) \\
\hline $\begin{array}{l}\text { AAC. Parr. } \\
\text { Río Seco }\end{array}$ & Río Seco & 1893 & 6.500 & 1.000 & $\begin{array}{l}100 \text { en cada } \\
\text { capilla }\end{array}$ & $3 \mathrm{c}$ & 4 \\
\hline $\begin{array}{l}\text { AAC. Leg. } \\
50\end{array}$ & Ischilín & 1893 & 6.000 & Algunos & No contesta & $4 \mathrm{c}$ & No contesta \\
\hline $\begin{array}{l}\text { AAC. Parr. } \\
\text { Quilino } \\
\text { f.100 y ss }\end{array}$ & Quilino & 1892 & 6.500 & $\begin{array}{l}\text { Tienen } \\
\text { obligación } \\
4.000 . \\
\text { Cumplen } \\
2.500\end{array}$ & $\begin{array}{l}\text { En la } \\
\text { parroquia } \\
\text { donde reside } \\
\text { el cura viven } \\
60 \text { personas, } \\
\text { de estas } 30 \\
\text { serán las que } \\
\text { comulguen } \\
\text { cada } 8 \text { días }\end{array}$ & $3 \mathrm{c}$ & $\begin{array}{l}3 \text { (Santo Patrón, } \\
\text { Animas, Ntra. Sra. } \\
\text { del Rosario) }\end{array}$ \\
\hline $\begin{array}{l}\text { AAC. Parr. } \\
\text { Cruz del Eje } \\
\text { fs. 201-202 }\end{array}$ & $\begin{array}{l}\text { Cruz del } \\
\text { Eje }\end{array}$ & 1893 & 7.000 & 4.630 & 260 & $\begin{array}{l}\mathrm{c} \\
1 \mathrm{co}\end{array}$ & $\begin{array}{l}3 \text { (Patrona, San } \\
\text { Marcos y del } \\
\text { Rosario) }\end{array}$ \\
\hline $\begin{array}{l}\text { AAC. Parr. } \\
\text { Minas } \\
\text { fs. } 300-301\end{array}$ & $\begin{array}{l}\text { San } \\
\text { Carlos } \\
\text { Minas }\end{array}$ & 1893 & 13.800 & $\begin{array}{l}\text { La mayor } \\
\text { parte }\end{array}$ & Muy pocos & $\begin{array}{l}4 \\
2 \text { or }\end{array}$ & $\begin{array}{l}32 \text { (novenarios en } \\
\text { todas las capillas y } \\
\text { oratorios) }\end{array}$ \\
\hline $\begin{array}{l}\text { AAC. Parr. } \\
\text { Pocho }\end{array}$ & $\begin{array}{l}\text { No se enví } \\
\text { del curato p }\end{array}$ & $\begin{array}{l}\text { in las } r \\
\text { or parte }\end{array}$ & $\begin{array}{l}\text { uestas de } \\
1 \text { párroco }\end{array}$ & cuestionari & Los vecinos e & & jas por la desatención \\
\hline AAC. Leg. 7 & $\begin{array}{l}\text { Río de los } \\
\text { Sauces }\end{array}$ & 1893 & 5.300 & 4.000 & 1.000 & 4 & 3 \\
\hline
\end{tabular}

12.-Cuántos cementerios existen, si están en buenas condiciones y administrados exclusivamente por el Párroco, y si hay cementerio para disidentes. En caso de no ser administrados por el Cura, si se observan los cánones en la sepultura de cadáveres.

13.- Observaciones. 


\begin{tabular}{|c|c|c|c|c|c|c|c|}
\hline $\begin{array}{l}\text { AAC. Parr. } \\
\text { Calamuchita }\end{array}$ & Sta Rosa & 1890 & 7.000 & 3.000 & 900 & 7 & 4 novenarios \\
\hline $\begin{array}{l}\text { AAC. Parr. } \\
\text { Punilla }\end{array}$ & Punilla & 1892 & 10.000 & 7.000 & Ibid. & 10 & $\begin{array}{l}4 \text { novenarios } \\
\text { solemnes }\end{array}$ \\
\hline $\begin{array}{l}\text { AAC. Parr. } \\
\text { Chalacea, s/f }\end{array}$ & Chalacea & 1892 & 7.000 & 2.300 & 2.300 & 3 & $\begin{array}{lll}2 \text { (Patrona y Las } \\
\text { Animas) }\end{array}$ \\
\hline $\begin{array}{l}\text { AAC. Parr. } \\
\text { Sta. Rosa }\end{array}$ & $\begin{array}{l}\text { Santa } \\
\text { Rosa Río } \\
\text { I }\end{array}$ & 1893 & 10.400 & 2.000 & 600 mensual & 4 & $\begin{array}{l}2 \text { (Santa Rosa y de } \\
\text { animas en el templo } \\
\text { parroquial) } \\
\text { En las capillas los } \\
\text { titulares }\end{array}$ \\
\hline $\begin{array}{l}\text { AAC. Río II } \\
\text { Abajo }\end{array}$ & $\begin{array}{l}\text { Villa del } \\
\text { Rosario }\end{array}$ & 1892 & 11.000 & Casi todos & Muchas & 3 & $\begin{array}{l}3 \text { (Las funciones de } \\
\text { las tres Iglesias }\end{array}$ \\
\hline $\begin{array}{l}\text { AAC. Parr. } \\
\text { Río II }\end{array}$ & $\begin{array}{l}\text { Central } \\
\text { Río II }\end{array}$ & 1892 & 5.344 & 1.000 & 350 & 2 & $\begin{array}{l}4 \text { (La Patrona, San } \\
\text { José } 2 \text { novenas de } \\
\text { Animas }\end{array}$ \\
\hline $\begin{array}{l}\text { AAC. Parr. } \\
\text { Río III }\end{array}$ & $\begin{array}{l}\text { Tercero } \\
\text { Arriba }\end{array}$ & 1893 & 4.500 & 1.500 & 150 & $\begin{array}{l}3 \\
1 \\
\end{array}$ & 4 \\
\hline $\begin{array}{l}\text { AAC. } \\
\text { Leg. } 49 \text { San } \\
\text { Francisco }\end{array}$ & $\begin{array}{l}\text { San } \\
\text { Francisco }\end{array}$ & 1893 & 10.000 & 900 & Pocas & 1 & 1 Patrono \\
\hline $\begin{array}{l}\text { AAC. Leg. } \\
49\end{array}$ & Morteros & 1893 & 800 & 50 & 20 & 2 & Triduo Pascual \\
\hline $\begin{array}{l}\text { AAC. Parr. } \\
\text { El Tío, f.135 }\end{array}$ & San Justo & 1892 & $\begin{array}{l}\text { Se } \\
\text { ignora }\end{array}$ & Se ignora & & 5 & No contesta \\
\hline $\begin{array}{l}\text { AAC. } \\
\text { Parroquias } \\
\text { Villa María, } \\
\text { f.174 }\end{array}$ & $\begin{array}{l}\text { Villa } \\
\text { María }\end{array}$ & 1892 & 5.000 & 2.265 & No contesta & 3 & $\begin{array}{l}3 \text { (Patrona, Corpus, } \\
\text { Animas, Dolores: } \\
\text { septenario rezado) }\end{array}$ \\
\hline Leg.52 & $\begin{array}{l}\text { Villa } \\
\text { Nueva }\end{array}$ & 1892 & 5.000 & 2.000 & 100 & 3 & $\begin{array}{l}6 \text { (Patrona Mes del } \\
\text { Rosario; Ntra Sra. del } \\
\text { Carmen, San José, } \\
\text { Sagrado Corazón, } \\
\text { Niño Dios; Animas, } \\
\text { Dolores: septeneario) }\end{array}$ \\
\hline $\begin{array}{l}\text { AAC. } \\
\text { Leg. } 52 \\
\text { Bel Ville }\end{array}$ & Bel Ville & 1893 & $\begin{array}{r}\text { Último } \\
\text { censo } \\
26.000\end{array}$ & Ignoro & Ignoro & 4 & $\begin{array}{l}6 \text { (Patrona, San José, } \\
\text { Corazón de Jesús, del } \\
\text { Niño, Animas) } \\
\text { Patronos capillas }\end{array}$ \\
\hline
\end{tabular}

Aquí observamos que en los curatos del norte (Chañar, Río Seco, Ischilín, Quilino y Tulumba), el porcentaje de cumplimiento anual con la iglesia oscilaba entre 3,3\% en Chañar, 15,3\% en Río Seco y 38,46\% en Quilino (al año siguiente, en 1892, el cura de Quilino informaba que el cumplimiento fue de 4.000 personas, alcanzando al $50 \%$ de la población).

En el oeste, el porcentaje era muy alto. El cura de Minas no dio cifras pero señaló que son la mayor parte; Calamuchita tenía el 52,85\%, Cruz del Eje el 62,5\%; Punilla el 70\% (el 
mismo cura señalaba que cumplían las $2 / 3$ partes de la población) y Río de los Sauces el $75,47 \%$. De San Alberto, no tenemos datos, ${ }^{2}$ pero la intensa labor evangelizadora del cura Brochero, y el funcionamiento de la casa de ejercicios de Tránsito, con al menos tres tandas por año para mujeres y tres para hombres y con asistencia promedio de 300 ejercitantes cada una, nos lleva a suponer que el cumplimiento con la Iglesia de la feligresía de ese curato era casi total. Además, si recordamos que en 1886, durante la visita canónica del Obispo Tissera, se confirmaron 7.774 personas en Soto y 9.820 en el departamento de San Alberto. Estos datos nos revelan que, en el oeste, el cumplimiento con la Iglesia era, en general, muy elevado.

La región del centro no la analizaremos, pues nuestro objetivo es comparar el noroeste y el sudeste. Pasamos entonces a los curatos del este y sudeste. El cura de San Justo "lo ignora”, en San Francisco 9\% y en Morteros 6,25\%. En tanto, en Villa María alcanza 45,3\% y Villa Nueva 40\%. Lamentablemente, no tenemos datos para el resto de los curatos, los mismos curas lo ignoran.

Es interesante la aclaración enviada por el cura de Cruz del Eje, en la que advirte que la población era de 6.500 habitantes y tenían obligación de cumplir 4.000. Esta acotación nos permite inferir que si a la población del resto de los curatos se le restaran los niños y ancianos que no están obligados a cumplir, el porcentaje de cumplimiento aumentaría, al menos un $30 \%$, pero ese dato no lo tenemos. Con los números enviados, estimamos las medias de cumplimiento y resultan en el norte $22 \%$, en el oeste $65 \%$, en el este (San Justo) 9\% y en el sudeste (Tercero Abajo) 43\%.

Las funciones que se celebraban en la iglesia matriz y en cada una de las capillas eran principalmente las fiestas patronales y la de ánimas. El cura de Ischilín envió una nota al obispado, en la que decía que haría los ejercicios en octubre porque ausentarse en septiembre sería un grave perjuicio para su feligresía, pues "tengo las funciones de las Mercedes y del Rosario, y es en el tiempo de las funciones que concurre la feligresía toda a desobligarse o a cumplir con la Iglesia". 3

Llama la atención que solamente el cura de Morteros informe que celebra el triduo pascual y los de Villa María y Villa Nueva las funciones del Niño Dios o Navidad. Sin

\footnotetext{
${ }^{2}$ Con motivo de la Causa de Canonización, se retiró de la consulta la documentación relativa al Cura Brochero.

${ }^{3}$ AAC. Leg. Ischilín, 1877-1899, s/f. Nota del 05/08/1882.
} 
embargo, otras fuentes dan cuenta de que esta celebración de pascua era habitual. Los periódicos relatan con frecuencia el impacto de estas celebraciones en la campaña. En 1881, el corresponsal de "El Progreso" hace una detallada crónica de las fiesta patronales de Villa del Rosario, departamento de Río Segundo, en ella advierte que la duración fue de tres días en los que predicaron sacerdotes invitados y en los días de procesión, "domingo y martes las imágenes eran seguidas por un séquito de tres mil almas". El relato termina apostillando "que el Dios de la bondad conserve siempre ardiente el sentimiento religioso de los habitantes de todos estos poblados, como el más puro consuelo en las angustias, como la mejor guía en los fugaces instantes de placer, como la higiene querida que purifica el alma hasta que el momento que llegue de rendirla en los altares del Dios Eterno". ${ }^{4}$

La función de ánimas era un festividad muy arraigada en la población, razón por la cual se celebraba en casi todos los curatos. Esta festividad tiene sin duda relación con el lugar que ocupaban los difuntos en la sociedad provincial, tema que veremos con más detenimiento en la quinta parte de la tesis, en el Capítulo 15, donde se tratan las prácticas devocionales en relación al proceso de secularización.

En el cuestionario, en el primer ítem, se solicitaba el número de capillas y oratorios; el estado material de las mismas y si había alguna en construcción. En función de estos datos, trasladamos la información al Mapa 12, de elaboración propia, en base al mapa de Paz Soldán de 1888, en el que, con líneas punteadas, marcamos las divisiones de los curatos que no coincidían con las departamentales, en rojo la cabecera del curato y en amarillo las capillas filiales con funciones parroquiales, que dependían, jurisdiccionalmente, del cura párroco, aunque estuvieran administradas por algún patrono seglar. No figuran las capillas particulares que no tenían dependencia del párroco.

Como hemos señalado en el Capítulo 7 de esta tercera parte, el proceso de reconstrucción de antiguas capillas y edificación de nuevas en 1890 ya llevaba algunos años. Y varias capillas, que en décadas anteriores habían quedado fuera de uso y semidestruidas, en estos años han sido puestas en valor e incorporadas al culto. El mapa nos presenta una densidad mayor de capillas en el norte, oeste y centro, en tanto en el este y el sur el proceso de expansión recién se esta iniciando.

${ }^{4}$ El Progreso, 10/10/1880. 


\section{Mapa 12}

\section{Curatos y capillas en la Provincia de Córdoba en 1893}

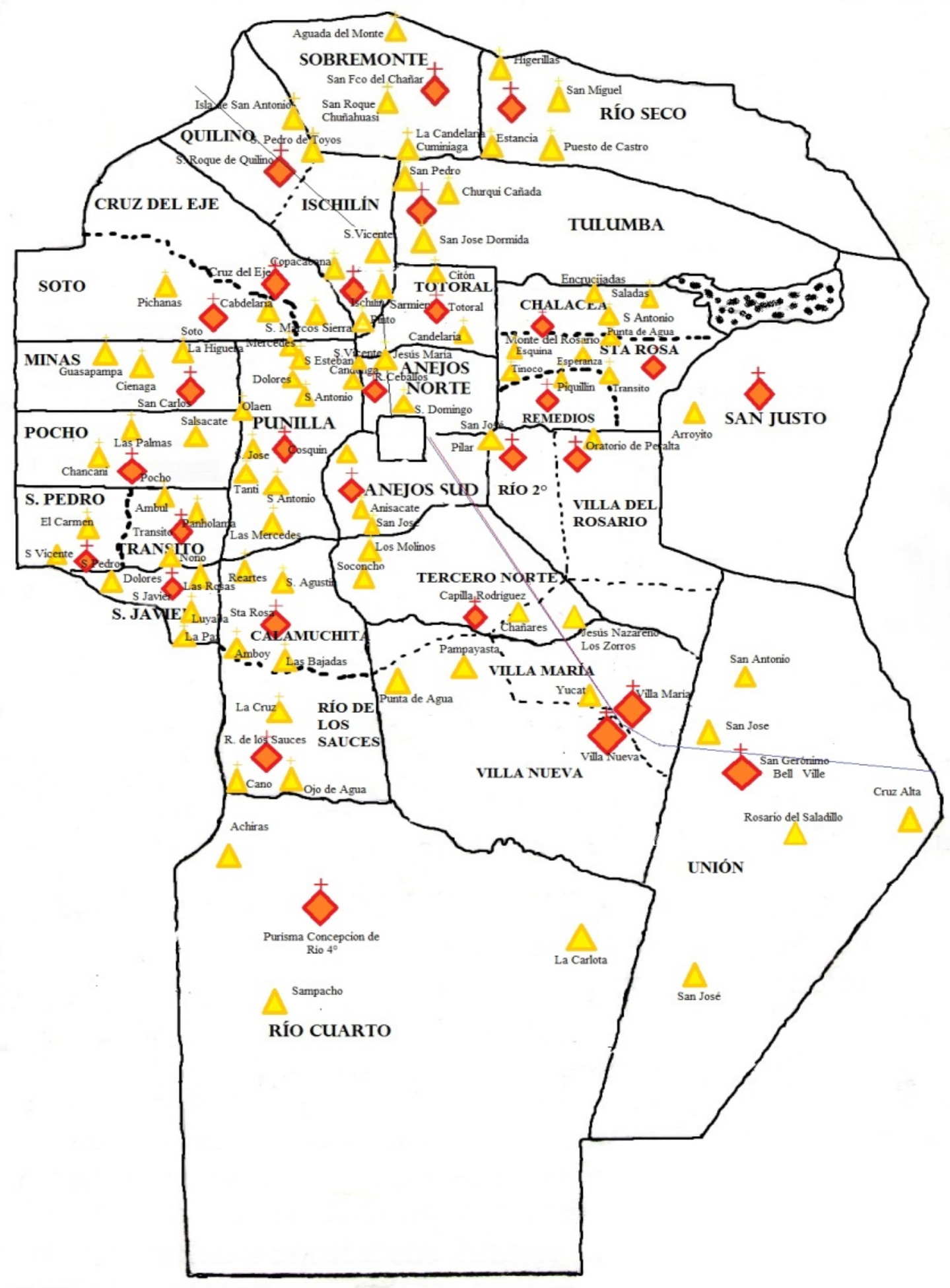




\section{La cuestión económica}

Elaborar un estado de la cuestión económica de cada curato es una tarea ardua, debido a la escasez de datos precisos que aparecen en las fuentes consultadas. El objetivo de este apartado es elaborar un cuadro de situación de las parroquias en orden a los ingresos. El dato más certero que tenemos es el ingreso de fábrica, pero lo que a nosotros no interesa es poder llegar a discernir la renta del beneficio, a fin de establecer el nivel de congrua sustentación para el párroco.

Las rentas parroquiales no eran fijas, sino "inciertas", como lo informan los párrocos. Las entradas se debían a la administración de sacramentos (bautismos y matrimonios), realización de funciones (misas, funerales y entierros), el cobro de primicias (muy exiguo y en vías de extinción) y la recepción de limosnas, donaciones o legados, etc.

La fábrica era el conjunto de ingresos y gastos que generaba el templo en lo relativo a su conservación, ornamentación, culto. La fábrica de las iglesias parroquiales era administrada, habitualmente, por el mayordomo de fábrica -si lo había-, y, con frecuencia, por el propio cura párroco. Independientemente de los ingresos eventuales (donaciones, legados o suscripciones voluntarias para un determinado fin), las principales fuentes de financiación de la fábrica eran el pago obligatorio según el arancel del porcentaje destinado a la fábrica por las celebraciones litúrgicas, la utilización velas y otros gastos.

Al patrimonio parroquial, se sumaba, en ocasiones, algún terreno u otro bien inmueble, que podía rentarse o ser enajenado para invertir el dinero en el mantenimiento o reconstrucción del templo. Los ingresos por derechos de estola se fijaban según el arancel eclesiástico. En 1891, el Obispo Toro envió al cabildo la consulta sobre la necesidad de reformar el arancel eclesiástico vigente en la diócesis. El obispo consideraba que "el antiguo ha caducado en parte y no se acomoda a la variedad de los tiempos y circunstancias presentes", habiéndose introducido alteraciones y cambios que ocasionaban la falta de uniformidad en la precepción de los montos correspondientes a los derechos de estola, "siendo algunos abusivos por cuanto no han sido ordenados por la autoridad competente y los que queremos desde luego interrumpir". ${ }^{5} \mathrm{El}$ apéndice del estudio preparatorio sobre el arancel señala algunas cuestiones de interés que ayudan a comprender el complejo

\footnotetext{
${ }^{5}$ AAC. Leg. 16. Arancel Eclesiástico de la Diócesis de Córdoba. Imprenta El Porvenir, Córdoba, 1891, p. 3.
} 
funcionamiento económico. Para la precepción de los derechos de estola, ${ }^{6}$ los fieles se dividían en tres categorías, pudientes, jornaleros y pobres. Los pobres abonarían lo que el criterio justo y caritativo del párroco estimase conveniente.

Tabla 12

\begin{tabular}{|c|c|c|c|c|c|c|c|}
\hline \multicolumn{8}{|c|}{ ARANCEL ECLESIÁSTICO 1891} \\
\hline & \multirow{3}{*}{\multicolumn{2}{|c|}{ FUNCIONES }} & \multicolumn{5}{|c|}{$\begin{array}{l}\text { ESTIPENDIOS (en pesos) } \\
\end{array}$} \\
\hline & & & \multicolumn{2}{|c|}{ MINISTROS } & \multicolumn{3}{|c|}{ FÁBRICA } \\
\hline & & & Oficiante & $\begin{array}{c}\text { Diáconos } \\
\text { (partibles) }\end{array}$ & Fábrica & $\begin{array}{c}\text { Por } \\
\text { c/vela } \\
\text { de } \\
\text { altar } \\
\end{array}$ & $\begin{array}{c}\text { Por c/ } \\
\text { vela de } \\
\text { mano/ } \\
\text { túmulo }\end{array}$ \\
\hline \multirow{12}{*}{$\begin{array}{l}\text { MISAS } \\
\text { REZADAS }\end{array}$} & \multicolumn{2}{|c|}{ Rezada s/gravamen } & 2 & & & & \\
\hline & \multicolumn{2}{|c|}{$\begin{array}{l}\text { Rezada c/ gravamen (altar, hora } \\
\text { fija, etc.) }\end{array}$} & 3 & & & & \\
\hline & \multirow{4}{*}{ A hora fija } & \begin{tabular}{l|l}
$10 \mathrm{a} 11 \mathrm{hs}$ \\
\cline { 2 - 3 }
\end{tabular} & 4 & & & & \\
\hline & & $11 \mathrm{a} 12 \mathrm{hs}$ & 4,5 & & & & \\
\hline & & $12 \mathrm{hs}$ & 5 & & & & \\
\hline & & $13 \mathrm{hs}$ & 6 & & & & \\
\hline & \multicolumn{2}{|c|}{$\begin{array}{l}\text { Misa de Purificación (pos- } \\
\text { partum) }\end{array}$} & 3 & & & 0,50 & 0,20 \\
\hline & \multicolumn{2}{|c|}{ Novenario de Misas } & 22,5 & & & & \\
\hline & \multicolumn{2}{|c|}{ Vigilia c/honras fúnebres } & 4 & & & & \\
\hline & \multicolumn{2}{|c|}{$\begin{array}{l}\text { Cuerpo presente y responso } \sin \\
\text { misa vigilia }\end{array}$} & 4 & & & & \\
\hline & \multicolumn{2}{|c|}{$\begin{array}{l}\text { Cuerpo presente con vigilia y } \\
\text { responso }\end{array}$} & 6 & & & 0,20 & \\
\hline & \multicolumn{2}{|c|}{30 misas Gregorianas } & $2,5^{\mathrm{c}} \%$ & & & & \\
\hline \multirow{5}{*}{$\begin{array}{l}\text { MISAS } \\
\text { CANTADAS }\end{array}$} & \multicolumn{2}{|c|}{ Sin diácono } & 5 & & 1 & 0,20 & 0,20 \\
\hline & \multicolumn{2}{|c|}{ Con diácono } & 6 & 4 & & & \\
\hline & \multirow{3}{*}{ Solemne } & Vísperas & 4 & 1,50 & \multirow{3}{*}{3} & \multirow{3}{*}{0,50} & \multirow{3}{*}{0,20} \\
\hline & & Misa & 8 & 3 & & & \\
\hline & & Procesión & 4 & 1,50 & & & \\
\hline \multirow[t]{6}{*}{ ENTIERROS } & \multirow{2}{*}{$\begin{array}{l}\text { Menor } \\
\text { rezado de } \\
\text { adultos }\end{array}$} & $\begin{array}{l}\text { Mayores de } 7 \text { y } \\
\text { menores de } 14 \text { años }\end{array}$ & 8 & & 2 & & \\
\hline & & Mayores de 14 años & 16 & & 4 & & \\
\hline & \multicolumn{2}{|c|}{ Menor rezado de párvulo } & 5 & & 2 & & \\
\hline & \multicolumn{2}{|c|}{ Cantado de párvulo } & 8 & & 2 & 0,20 & \\
\hline & \multicolumn{2}{|c|}{ Cantado menor solemne } & 20 & & 6 & 0,20 & \\
\hline & \multicolumn{2}{|c|}{ Cantado solemne } & 30 & 4 & 8 & 0,20 & \\
\hline \multirow{2}{*}{$\begin{array}{l}\text { MISAS DE } \\
\text { FUNERA- } \\
\text { LES* }\end{array}$} & \multicolumn{2}{|c|}{$\begin{array}{l}\begin{array}{l}\text { Cantada con vigilia, misa } \\
\text { responso }\end{array} \\
\end{array}$} & 12 & & 3 & 0,20 & \\
\hline & $\begin{array}{l}\text { Solemne } \\
\text { responso }\end{array}$ & on vigilia, misa $y$ & 15 & 6 & 4 & 0,50 & \\
\hline MATRIMO- & $\mathrm{c} / \mathrm{misa}$ & & 12 & & & 0,50 & \\
\hline NIO & $\mathrm{s} / \mathrm{misa}$ & & 10 & & 2 & 0,50 & \\
\hline
\end{tabular}

\footnotetext{
${ }^{6}$ Se denomina iura stolae, o derecho de estola a las contribuciones entregadas por los fieles de la parroquia con ocasión de la administración de los sacramentos (bautismo, funerales, matrimonios). Por la confesión estaba prohibido cobrar tasa alguna.
} 


\begin{tabular}{|c|c|c|c|c|c|c|}
\hline & \multicolumn{2}{|c|}{$\mathrm{Si}$ es jornalero c /misa } & 6 & & & \\
\hline & \multicolumn{2}{|c|}{ Si es jornalero s/misa } & 5 & 1 & & \\
\hline & \multicolumn{2}{|c|}{$\begin{array}{l}\text { Matrimonio a domicilio. Por c/ } \\
\text { legua sin cobrar por la vuelta }\end{array}$} & 2 & & & \\
\hline & \multicolumn{2}{|c|}{ Por registro de partidas } & 2 & & & \\
\hline \multirow[t]{6}{*}{$\begin{array}{l}\text { DERECHOS } \\
\text { DE } \\
\text { VICARÍA }\end{array}$} & \multicolumn{2}{|c|}{$\begin{array}{l}\text { Información de soltería y libertad } \\
\text { por extranjero o de extraña } \\
\text { diócesis }\end{array}$} & 10 & & & \\
\hline & \multicolumn{2}{|c|}{$\begin{array}{l}\text { Información de soltería y libertad } \\
\text { por extranjero o de extraña } \\
\text { diócesis Jornalero }\end{array}$} & 5 & & & \\
\hline & \multicolumn{2}{|c|}{$\begin{array}{lcc}\text { Información de } & \text { soltería } & y \\
\text { dispensas de impedimento } & \end{array}$} & 12 & & & \\
\hline & \multicolumn{2}{|c|}{$\begin{array}{lrrr}\text { Información } & \text { de } & \text { soltería } & \text { y } \\
\text { dispensas } & \text { de } & \text { impedimento } \\
\text { Jornalero } & & & \end{array}$} & 6 & & & \\
\hline & \multirow{2}{*}{$\begin{array}{l}\text { Certificación } \\
\text { partidas }\end{array}$} & Menos 5 años & 2 & & & \\
\hline & & $\begin{array}{ll}\text { Por } & \text { c/año } \\
\text { siguiente } & \end{array}$ & 0,20 & & & \\
\hline $\begin{array}{l}\text { BAUTISMOS } \\
\text { / ÓLEOS }\end{array}$ & \multicolumn{2}{|l|}{ Solemnes } & 1 & & 0,10 & \\
\hline
\end{tabular}

De la mayoría de las entradas, el cura debía deducir un porcentaje para la fábrica de la iglesia, ${ }^{7}$ que, según el arancel eclesiástico de 1891, no era fijo. El sueldo del sacristán lo fijaba el cura y se pagaba con la fábrica ${ }^{8}$ y el mayordomo de la fábrica cobraba el $10 \%$ de las entradas de fábrica. ${ }^{9}$ Las limosnas, donaciones o legados entraban directamente a la fábrica. Los ingresos del cura tenían relación directa con las entradas del curato.

Los informes de 1890-1893 son muy parcos en las cuestiones económicas. El cuestionario solicitaba información sobre el número de matrimonios y entierros y la cantidad de personas que pagaron los derechos. Nada nos dice respecto de las entradas por celebración de otras misas o atención de enfermos.

Para poder establecer una estimación de las rentas correspondientes al cura, seguiremos los siguientes criterios: a) cuando en la respuesta no se especifique el tipo de entierro,

\footnotetext{
${ }^{7}$ Se llama fábrica de la iglesia al conjunto de los ingresos y de los gastos que generaba una iglesia (templo), en su conservación, reparación, ornamentación, culto, salarios, etc. Su origen se remonta a fines del siglo V, cuando el Papa Gelasio I fijó una aportación a la fábrica (portio fabricae) consistente en la cuarta parte de las rentas eclesiásticas y de las oblaciones de los fieles (Cfr. Teruel Gregorio de Tejeda Manuel, Vocabulario básico de la historia de la Iglesia, Crítica, Barcelona, 1993, p. 206).

${ }^{8}$ AAC. Leg. 16. Arancel Eclesiástico de 1891, art. 31, p. 11.

${ }^{9}$ AAC. Leg. 16. Arancel Eclesiástico de 1891, art. 34, p. 11.
} 
tomaremos el arancel del entierro menor rezado que era $\$ 16$ para el cura más $\$ 4$ para la fábrica; b) en cuanto a los matrimonios, se tomará el casamiento -sin misa-, cuyo arancel era de \$10 para el cura y \$2 para la fábrica; c) en la tabla, incluimos una última columna, cuya información no se solicitaba en el cuestionario y que la denominamos "Entrada por Derechos de Estola”, en la que calculamos la estimación del dinero que anualmente percibía el cura en calidad de derechos de estola, aplicando los criterios arriba mencionados, por ejemplo, el cura de Río Segundo hizo 39 casamientos, de los cuales 30 pagaron derechos íntegros (calculamos 30 x $\$ 100=\$ 300$ ), y 87 entierros, de los cuales pagaron $22(22 \times \$ 16=\$ 353)$. Para estimar las entradas por misas, tomaremos la referencia de funciones y novenarios. El resultado de estos cálculos se colocó en la columna $n^{\circ} 9$. En el caso de que el cura especificara las rentas del beneficio, directamente se puso esa cifra.

Es necesario aclarar que no pretendemos realizar un análisis económico de los curatos, simplemente nos interesa llegar a una aproximación, con los datos que tenemos, respecto al ingreso que podía llegar a percibir el cura. Llama la atención que los curas de Villa María y Bell Ville no dejan constancia de la cantidad de entierros. El cura percibió un monto de \$720 sólo por matrimonios, suponemos que los entierros serían más numerosos. En cuanto al cura de Villa Nueva, dejó asentado que efectuó 113 entierros y que sólo 4 personas pagaron los derechos correspondientes, proporción que nos parece extraña. El cura de Villa del Rosario no contesta ni cantidad de entierros ni cuantos pagaron. Evidentemente, el monto mayor de entradas del cura se debía a casamientos y entierros, la renuencia a informar sobre este punto puede estar hablándonos de negligencia en el desempeño del ministerio, u omisión voluntaria, por motivos que desconocemos pero que imaginamos.

Las entradas anuales por derechos de estola varían significativamente según la región. En el este, en el departamento de San Justo, oscilaba entre el curato más pobre, con una entrada de \$440 anuales (Morteros), por ende \$36 mensuales, y el más rico con \$1.084 (San Francisco), con un promedio de $\$ 90,33$ mensuales. En el norte, el curato del Chañar tiene el menor ingreso, una media de \$28; le sigue Quilino, con una media mensual de \$70, y luego Río Seco con $\$ 80$. 


\begin{tabular}{|c|c|c|c|c|c|c|c|c|c|c|}
\hline \multicolumn{11}{|c|}{$\begin{array}{l}\text { Tabla 13 } \\
\text { Aproximación económica de los curatos a través de los Informes de los párrocos de 1890-1893 } \\
\text { Referencias: 1: Casamientos; 2: } \mathrm{N}^{\circ} \text { de personas que pagaron derechos; 3: Entierros; 4: } \mathrm{N}^{\circ} \text { de personas que pagaron derechos; 5: Novenarios; 6: } \\
\text { Entrada Fábrica (en pesos); 7: Limosna capillas (en pesos); 8: Primicias (en trigo y/o maíz); 9: Entrada de Derechos de Estola aproximados (en } \\
\text { pesos) }\end{array}$} \\
\hline Curato & Año & 1 & 2 & 3 & 4 & 5 & $\begin{array}{c}6 \\
\text { en } \$ \\
\end{array}$ & 7 & 8 & $\begin{array}{c}9 \\
\text { en } \$\end{array}$ \\
\hline Chañar & 1893 & 22 & 10 & 56 & 15 & 1 nov & 302,30 & & 3 & 342,50 \\
\hline Río Seco & 1893 & 47 & $\begin{array}{l}26 \text { íntegros } \\
25 \text { parte } \\
2 \text { gratis }\end{array}$ & 186 & 31 & 4 nov & 297,59 & & Se pagan & 971,00 \\
\hline Ischilín & 1893 & 15 & $\begin{array}{l}8 \text { Íntegros } \\
7 \text { lo que } \\
\text { puede o no } \\
\text { paga }\end{array}$ & $\mathrm{s} / \mathrm{d}$ & $\mathrm{s} / \mathrm{d}$ & $\mathrm{s} / \mathrm{d}$ & 150,00 & 0 & $\begin{array}{l}\text { No hay } \\
\text { primicias }\end{array}$ & \\
\hline Quilino & 1893 & 92 & 47 & $\begin{array}{l}\text { A nadie e } \\
\text { derechos } \\
\text { los intere } \\
\text { recomien } \\
\text { misa fune } \\
\text { no pasan } \\
\text { año y con } \\
\text { cantor sie } \\
\text { rezadas }\end{array}$ & $\begin{array}{l}\text { ijo } \\
\text { sino cuando } \\
\text { ados me } \\
\text { an alguna } \\
\text { aria y estas } \\
\text { e } 5 \text { o } 6 \text { al } \\
\text { o no tengo } \\
\text { apre son }\end{array}$ & $\begin{array}{l}3 \text { nov } \\
6 \text { misas } \\
\text { rezadas }\end{array}$ & 133,00 & Ninguna & $\begin{array}{l}6 \text { o } 7 \text { personas } \\
\text { maíz solamente }\end{array}$ & $\begin{array}{r}563,50 \\
833,00 \\
(10 \\
\text { informa } \\
\text { el cura) }\end{array}$ \\
\hline $\begin{array}{ll}\text { Cruz } & \text { del } \\
\text { Eje } & \end{array}$ & 1890 & 49 & $\begin{array}{l}6 \text { íntegros } \\
26 \text { la mitad } \\
17 \text { nada }\end{array}$ & 198 & 8 & $\begin{array}{l}4 \text { nov } \\
4 \text { funcion } \\
\text { de un día }\end{array}$ & 446,30 & $\begin{array}{r}2.607,00 \\
\text { para el } \\
\text { templo } \\
\text { parroquial } \\
\end{array}$ & 37 personas & 432,00 \\
\hline Minas & 1892 & 57 & $\begin{array}{l}2 \text { íntegros } \\
55 \text { la mitad } \\
\text { y gratis }\end{array}$ & $\begin{array}{l}367 \\
\text { párvulos } \\
175 \\
\text { adultos }\end{array}$ & $\begin{array}{l}\text { Párvulos } \\
\text { no pagan } \\
\text { 83íntegros } \\
\text { 92la mitad } \\
\text { y nada }\end{array}$ & $\begin{array}{l}32 \text { nov } \\
\text { (todas las } \\
\text { capillas y } \\
\text { oratorios) }\end{array}$ & 147,80 & $\begin{array}{l}\text { Del gobierno } \\
\text { nac. y prov. } \\
\text { construcción } \\
\text { del templo }\end{array}$ & 8 a 10 personas & $2.158,0$ \\
\hline $\begin{array}{l}\text { Río de los } \\
\text { Sauces }\end{array}$ & 1892 & 24 & 16 & 110 & 40 & 4 nov & 325,00 & 151,00 & $\begin{array}{l}\text { Todos los que } \\
\text { tienen cosechas }\end{array}$ & 800,00 \\
\hline Calamuchita & 1893 & 24 & 12 & $\begin{array}{l}\text { No } \\
\text { contesta }\end{array}$ & $\begin{array}{l}\text { No } \\
\text { contesta }\end{array}$ & 4 nov & 417,00 & 242,00 & & 210,00 \\
\hline Punilla & 1892 & 73 & 50 íntegros & $113 *$ & $\begin{array}{l}8 \text { adultos } \\
9 \text { párvulos } \\
\text { Los } \\
\text { pobres no } \\
\text { pagan } \\
\text { nunca }\end{array}$ & $\begin{array}{l}5 \text { nov } \\
\text { Solemnes }\end{array}$ & 222,00 & 293,00 & $\begin{array}{l}\text { Los pocos que } \\
\text { siembran }\end{array}$ & 812,50 \\
\hline Chalacea & 1892 & 20 & $\begin{array}{l}24 \text { íntegros } \\
6 \text { algo } \\
1 \text { nada }\end{array}$ & $61 * *$ & $\begin{array}{l}12 \\
\text { íntegros } \\
4 \text { (sólo } \\
\text { fábrica) } \\
45 \text { nada }\end{array}$ & 2 nov & 186,00 & $\begin{array}{l}\qquad 1.400,00 \\
\text { (invertido en } \\
\text { el palio } \\
\text { traído de } \\
\text { Europa) }\end{array}$ & & 477,00 \\
\hline $\begin{array}{l}\text { Santa Rosa } \\
\text { Río I }\end{array}$ & 1892 & 54 & $\begin{array}{l}20 \text { íntegros, } \\
28 \text { la mitad, } \\
5 \text { gratis }\end{array}$ & 102 & $\begin{array}{l}\text { (pagaron } \\
\text { una octava } \\
\text { parte del } \\
\text { total de } \\
\text { las } \\
\text { personas) }\end{array}$ & $\begin{array}{l}5 \text { nov con } \\
\text { funciones } \\
\text { solemnes } \\
\text { se percibe } \\
\$ 82 \text { por } \\
\text { cada uno }\end{array}$ & 500,00 & $\begin{array}{r}1.578,00 \\
\text { Igl. Párr. } \\
550,00 \\
\text { Cap. } \\
\text { Esperanza } \\
500,00 \\
\text { Cap. } \\
\text { Transito } \\
524,00\end{array}$ & $\begin{array}{l}\text { Todos los que } \\
\text { cosechan, salvo } \\
\text { dos o tres. Trigo } \\
\text { y maíz. }\end{array}$ & 842,00 \\
\hline Río & 1891 & 39 & (no & 87 & 22 & & & $2.830,50$ & personas & 652,00 \\
\hline
\end{tabular}




\begin{tabular}{|c|c|c|c|c|c|c|c|c|c|c|}
\hline Segundo & & & $\begin{array}{l}\text { todos } \\
\text { íntegros) }\end{array}$ & & & & & con limosnas & (maíz y trigo) & \\
\hline $\begin{array}{l}\text { Río II } \\
\text { Abajo } \\
\text { (Villa del } \\
\text { Rosario) }\end{array}$ & 1892 & 39 & $\begin{array}{l}\text { Casi todos } \\
\text { aunque no } \\
\text { íntegros }\end{array}$ & $\begin{array}{l}\text { No } \\
\text { contesta }\end{array}$ & $\begin{array}{l}\text { No } \\
\text { contesta }\end{array}$ & & & $\begin{array}{r}1.500,00 \\
\text { con limosnas }\end{array}$ & $\begin{array}{l}24 \text { personas } \\
\text { (12 fanegas de } \\
\text { trigo y otras } \\
\text { tantas de maíz) }\end{array}$ & 390,00 \\
\hline $\begin{array}{l}\text { Tercero } \\
\text { Arriba }\end{array}$ & 1893 & 26 & 26 & $\begin{array}{l}\text { No } \\
\text { contesta }\end{array}$ & $\begin{array}{l}\text { No } \\
\text { contesta }\end{array}$ & 5 & 660,00 & & $\begin{array}{l}\text { Maíz, trigo y } \\
\text { porotos } \\
\text { cumplen } 70\end{array}$ & \\
\hline $\begin{array}{l}\text { San } \\
\text { Francisco }\end{array}$ & 1893 & 37 & 30 & 58 & $\begin{array}{l}40 \\
\text { íntegros } \\
18 \mathrm{mitad}\end{array}$ & & 257,00 & $\begin{array}{r}3.250,00 \\
\text { (p/construir) }\end{array}$ & No se pagan & $1.084,0$ \\
\hline $\begin{array}{l}\text { San Pedro } \\
\text { Apóstol } \\
\text { Morteros }\end{array}$ & 1893 & 0 & 0 & 47 & $\begin{array}{l}20 \\
\text { íntegros } \\
15 \text { la } \\
\text { mitad } \\
12 \text { nada }\end{array}$ & & 56,00 & 0 & Nada & 440,00 \\
\hline San Justo & 1893 & 78 & $\begin{array}{l}40 \quad \text { (hay } \\
\text { algunos con } \\
\text { rebaja) }\end{array}$ & $\mathrm{s} /$ datos & 16 a 18 & & $\begin{array}{c}2.101,84 \\
\text { con } \\
\text { limosnas }\end{array}$ & $\begin{array}{l}\text { Permanente } \\
\text { pocas de } \\
\text { maíz y trigo }\end{array}$ & 688,00 & \\
\hline Villa María & 1893 & 29 & 26 & 113 & $\begin{array}{l}\text { No } \\
\text { contesta }\end{array}$ & & $\begin{array}{c}\text { Entradas } \\
804,36 \\
\text { Salidas: } \\
513,30\end{array}$ & $\begin{array}{l}\quad 44,00 \\
\text { Suscripción } \\
\text { compra } \\
\text { armonio: } \\
\quad 348,60\end{array}$ & $\begin{array}{l}\text { Parece que está } \\
\text { olvidado este } \\
\text { deber de los } \\
\text { fieles, sólo uno } \\
\text { ha pagado y fue } \\
\text { de maíz, la } \\
\text { cantidad de tres } \\
\text { almudes }\end{array}$ & \\
\hline Villa Nueva & 1890 & 7 & $1(\$ 2)$ & 110 & $\begin{array}{l}4 \\
\text { (Porque } \\
\text { son pobres } \\
\text { o porque } \\
\text { los } \\
\text { encarga- } \\
\text { dos del } \\
\text { cemente- } \\
\text { rio tienen } \\
\text { poco } \\
\text { cuidado } \\
\text { de cobrar } \\
\text { derechos) }\end{array}$ & & 670,00 & & $\begin{array}{l}3 \text { fanegas de } \\
\text { maíz }\end{array}$ & \\
\hline Bell Ville & 1892 & 101 & $\begin{array}{l}72 \quad \text { por lo } \\
\text { menos de } \\
\text { fábrica que } \\
\text { es por } \\
\text { donde } \\
\text { podemos } \\
\text { saberlo) }\end{array}$ & & 16 a 18 & $\begin{array}{l}\text { No } \\
\text { contesta }\end{array}$ & $1.214,44$ & $\begin{array}{l}537,00 \\
\text { (a beneficio } \\
\text { parroquial) }\end{array}$ & & 720,00 \\
\hline \multicolumn{11}{|c|}{$\begin{array}{l}\text { Fuente: AAC. Leg. 48, 49, } 50 \text { y 52. Caja Parroquias: Villa Concepción del Tío; Chalacea s/f.; Río II s/f; Punilla; Santa Rosa Calamuchita; Villa } \\
\text { María, fs. } 180-182, \text { f.135. } \\
\text { * El cura de Punilla advierte que el número de defunciones es sólo aproximado porque algunos no dan parte a la curia y otros se pierden o no se } \\
\text { apuntan por los encargados del cementerio por alguna circunstancia o descuido. } \\
\text { ** El Cura de Chalacea observa que "Las entradas de fábrica son pocos por varias razones: } 1^{\circ} \text { los casamientos que se celebran la mayor parte } \\
\text { en Santa Rosa por la oficina civil, } 2^{\circ} \text { los entierros de cadáver se practican también en Santa Rosa por el fanatismo de estos feligreses que allí } \\
\text { adonde han sido sepultados sus antepasados deben sepultarse todos de la familia. Las capillas son los cementerios de este curato siendo de } \\
\text { pocos años construidos no quieren ser sepultados en estos cementerios especialmente los ricos por cuyo motivo allí se pagan derechos de } \\
\text { sepultura, allí de funerales y allí de misas cuerpo presente. }\end{array}$} \\
\hline
\end{tabular}


En los curatos del oeste, la variación de la media mensual era similar, oscilaba entre $\$ 17,50$ en Calamuchita y \$66 en Río de los Sauces. No tenemos datos del curato de Pocho, pero por otras fuentes sabemos que eran escasas. El diario "El Progreso" relata que el cura del beneficio se "ha retirado de allí porque las dos o tres miserables capillas que atendía no le daban la congrua para vivir y de su propio y escaso peculio ha reparado la triste desolación en que estaba la iglesia de Soto" (EP, 26/01/1881).

En Bell Ville, al sur, los derechos de estola, sin contabilizar entierros, sumaban $\$ 720$.

Estas estimaciones dan remuneraciones muy bajas, si las comparamos con los sueldos vigentes en 1888 en la provincia de Córdoba. Pelliza presenta la tabla de salarios mensuales y jornaleros extranjeros de las provincias de Córdoba y La Rioja (1888: 22-31).

\section{Tabla 14}

Salarios mensuales y jornaleros extranjeros en la Provincia de Córdoba según Pelliza en 1888

\begin{tabular}{|c|c|c|c|c|c|}
\hline & & \multicolumn{2}{|c|}{ Córdoba } & \multicolumn{2}{|c|}{ La Rioja } \\
\hline PROFESION & PROFESION & $\begin{array}{c}\text { PAR } \\
\text { MOIS en \$ }\end{array}$ & $\begin{array}{c}\text { PAR } \\
\text { JOUR en \$ }\end{array}$ & $\begin{array}{c}\text { PAR } \\
\text { MOIS en \$ }\end{array}$ & $\begin{array}{c}\text { PAR } \\
\text { JOUR en } \$\end{array}$ \\
\hline \multirow[t]{2}{*}{ Agricultor } & AGRICULTEURS & 80 a 90 & & 80 a 100 & \\
\hline & MAçONS & & 10 a 15 & & 10 a $12 \frac{1 / 2}{2}$ \\
\hline Carpintero & \multicolumn{2}{|l|}{ CHARPENTIER } & 15 a 20 & & 11 a $12 \frac{1}{2}$ \\
\hline Cocineros & CUISINIERES & 60 a 75 & & & \\
\hline Cocineros & CULSINIERS & 150 a 200 & & & \\
\hline Curtidores & TANNEURS & 200 a 300 & & 75 a 125 & \\
\hline Que hace pastas & VERMICELLIERS & 200 a 300 & & & \\
\hline Herreros & \multicolumn{2}{|l|}{ FORGERONS } & 15 a 18 & & \\
\hline Hojalateros & \multicolumn{2}{|l|}{ FERBLANTIERS } & 10 a 15 & & \\
\hline Panaderos & \multicolumn{2}{|l|}{ BOULANGERS } & 6 a 10 & & \\
\hline Jardineros & JARDINIERS & 250 a 350 & & & \\
\hline Mecánicos & \multicolumn{2}{|l|}{ MECANICIENS } & 15 a 18 & & \\
\hline Colonos & $\begin{array}{l}\text { MENAGES DE } \\
\text { AGRICULTEURS } \\
\end{array}$ & 200 a 250 & & & \\
\hline \multirow[t]{2}{*}{ Molineros } & MEUNIERS & 250 a 300 & & 200 a 300 & \\
\hline & \multicolumn{2}{|l|}{ MANOEUVRES } & 7 a 9 & 125 a 175 & \\
\hline Picapedreros & \multicolumn{2}{|l|}{ TAILLEURS DE PIERRES } & 10 a 15 & & \\
\hline Aparceros & METAYEURS & 150 a 180 & & & \\
\hline Vitinicultores & VITICULTEUR & 150 a 200 & & & \\
\hline Bodegueros & VIGNERONS & 150 a 200 & & & \\
\hline
\end{tabular}


¿A qué categoría de asalariados podrían equipararse las rentas de cura de parroquia rural? Evidentemente estos números no reflejan la realidad.

Por otras fuentes sabemos cuánto podía llegar a percibir un capellán. En nota remitida al obispo diocesano desde colonia Porteña en 1898, el cura informaba que "ha cobrado solamente $\$ 1267$ que repartidos en 30 meses da $43 \$$ mensuales; mensualidad esta no conforme a la prometida en los 6 meses anteriores [...]. Su Ilma. el sueldo de $\$ 42$ en un campo no basta para pagar al panadero, el carnicero [...] y no creo que S.S. lo estimará un sueldo suficiente para un pobre cura de campo [...]". Adjunta la lista de los colonos y el aporte de cada uno. ${ }^{10}$

Si bien no hemos podido establecer con certeza las rentas del beneficio, en función de las entradas de fábrica informadas en los cuestionarios, hemos establecido una jerarquización económica de cada curato. La Tabla 15 indica el rango de entradas en pesos y el símbolo correspondiente que se utilizó para identificarlos en el mapa.

\section{Tabla 15}

\begin{tabular}{|l|l|l|l|l|l|l|l|l|l|}
\hline \multicolumn{10}{|c|}{ Jerarquización económica de los curatos según entradas de fábrica } \\
\hline $\begin{array}{l}\text { Entradas } \\
\text { en pesos }\end{array}$ & $0 /$ & $100 /$ & $200 /$ & $300 /$ & $400 /$ & $500 /$ & $1001 /$ & $1501 /$ & +2000 \\
\hline Cantidad & 1 & 4 & 299 & 399 & 499 & 1000 & 1500 & 2000 & \\
\hline $\begin{array}{l}\text { Símbolo } \\
\text { mapa }\end{array}$ & $*$ & 0 & $\#$ & $\cdots$ & 0 & + & $/$ & $=$ & \\
\hline
\end{tabular}

\section{La geografía eclesiástica a la luz de los informes y autos de las visitas canónicas} (1905-1925)

El informe del visitador de parroquias de 1903 nos da una idea de la situación de la campaña. Señala los curatos en que está dividida la diócesis y los curas párrocos que los atienden, muchos tienen varias capillas y oratorios que sirven de vice-parroquias por lo extenso de su territorio y dilatadas distancias en que se encuentran los núcleos de las poblaciones. $^{11}$

\footnotetext{
${ }^{10}$ AAC. Caja Parroquias: Porteña, f.15. Nota del 24/6/1898.

${ }^{11}$ AAC. Fondo Zenón Bustos Obispo, Caja No 3, f.944.
} 


\section{Mapa 13}

\section{Jerarquización económica de los curatos según entradas de fábrica}

1890-1893

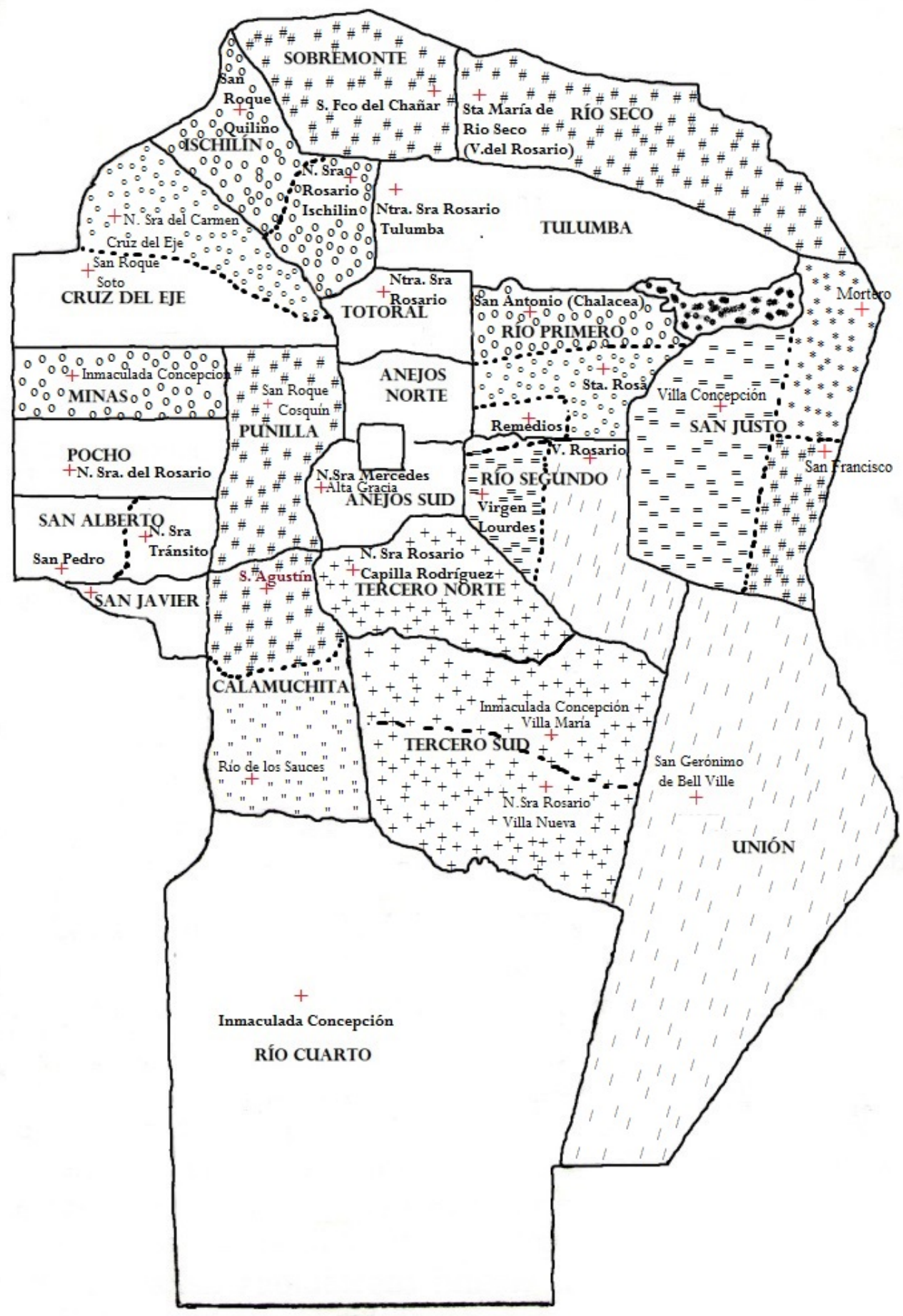

\section{Referencias:}

Mapa de base (Paz

Soldán 1887)

Entrada en pesos

0/99:

100/199:

200/299:

300/399:

400/499:

500/1000:

1001/1500:

$1501 / 2000$ :

Sin datos 
Al asumir el gobierno de la diócesis, Zenón Bustos se dirigió al clero parroquial para solicitar diversos datos de los curatos. "Veo que sin dominar el conjunto de la diócesis, por medio del conocimiento de los curatos que la forman, no será posible la unidad de plan en mi gobierno, ni la dirección podrá menos que adolecer de muchos defectos que contribuyen a hacer ineficientes las medidas que se tomen, útiles y también contraproducentes". ${ }^{12}$ Para ello, ordenó el envío de una serie de datos relacionados con cada realidad parroquial. ${ }^{13}$ La acción pastoral estuvo orientada a canalizar, a través de emprendimientos diversos, las necesidades específicas de cada región. El análisis de los autos de las visitas canónicas permite visualizar esta diversidad. La acción parroquial cristalizó en estrategias pastorales adecuadas a las realidades regionales y sociales diversas, que rescataron las especificidades propias de cada región. A través de los autos, el visitador impulsó iniciativas y procuró corregir desviaciones, en función de las necesidades puntuales de cada curato.

Los informes de los párrocos, aunque no siempre muy precisos, nos permiten acceder a su percepción respecto de la grey encomendada a su cuidado pastoral. Los autos de las visitas canónicas son una fuente adecuada para conocer quien dirige la diócesis, pues es precisamente a través de sus disposiciones de gobierno y de sus indicaciones donde se refleja su pensamiento, sus preocupaciones, sus planteamientos ante cuestiones puntuales, su celo pastoral, su unión con la Santa Sede, en una palabra, su concepción de iglesia particular encomendada a su cuidado.

El Obispo Zenón Bustos, al inicio de su gobierno, planteó la necesidad de conocer en profundidad, el territorio diocesano. "Veo que sin dominar el conjunto de la diócesis, por medio del conocimiento de los curatos que la forman, no será posible la unidad de plan en mi gobierno, ni la dirección podrá menos que adolecer de muchos defectos con que contribuyen a hacer ineficientes las medidas que se tomen, útiles y también

\footnotetext{
12 AAC. Pastorales, 1900-1925. Auto Episcopal del 13/06/1905.

${ }^{13}$ Los datos solicitados son los siguientes: 1) Los límites naturales del curato, si los tuviese, como ser sierras, ríos, arroyos, caminos públicos, líneas férreas o fronteras interprovinciales. 2) La extensión territorial en leguas cuadradas, aproximadamente, si es que no se pudiese precisar. 3) El número de iglesias y oratorios, expresando la mayor o menor importancia de cada uno de estos. 4) La totalidad de los habitantes que el curato pueda tener en número aproximado. 5) Las escuelas parroquiales que sostenga de mujeres o varones, las particulares y las fiscales sostenidas por el gobierno. 6) Los diversos pueblos dependientes de su jurisdicción espiritual, la importancia de cada uno de ellos, con el número de habitantes que la formen, en número aproximativo y la distancia que los separa entre sí. 7) Las capellanías o tenencias que contenga, y el número de sacerdotes que tenga actualmente o en carácter de simples residentes. El plano referido debe formarse en una cartulina o tela apropiada...
} 
contraproducentes". ${ }^{14}$ El diocesano ordenó a cada uno de los párrocos, que son los que conocen los lugares y datos relacionados con su curato, que elaboraran un plano o croquis, al estilo de una carta geográfica, de su curato respectivo, con un informe escrito que contuviera una serie de datos, limites, extensión territorial, iglesias, capillas y oratorios, la distancia que mediaba entre ellas y con la parroquia. Si bien no se han encontrado todas las respuestas, ya que de los 39 curatos existentes en la campaña en 1905, se obtuvieron 27, consideramos que el relevamiento es suficientemente representativo como para acceder a un conocimiento acabado del territorio diocesano provincial. Si a esta fuente, le añadimos las respuestas a las preguntas de los cuestionarios de las visitas canónicas de los años 1905, 1917 y $1924,{ }^{15}$ las respuestas a la circular de 1914, que solicitaba la fecha de erección, la cantidad de templos, la fecha de construcción y bendición, el titular, las dimensiones, su ubicación geográfica, la escritura de los edificios y terrenos donde se asentaban los templos, la casa parroquial, los cementerios y los colegios, tendremos una visión más acabada de la realidad diocesana provincial.

Para ordenar la exposición, agrupamos los curatos en orden a los departamentos de antigua y nueva colonización, según la tipología presentada por Julio Rodríguez.

La región correspondiente a los curatos de antigua colonización, la subdivimos en tres subregiones, la del norte, compuesta por Sobremonte, Río Seco, Ischilín y Tulumba; la del oeste, comprendida por Cruz del Eje, Punilla, Minas, Pocho, San Alberto, San Javier y Calamuchita, y la del centro, correspondiente a Totoral, Anejos Norte (Colón), Río Primero, Río Segundo y Anejos Sud (Santa María). En tanto la comprendida por los departamentos colonizadores, también la subdividimos en tres sub-regiones, la del este,

${ }^{14}$ AAC. Compilación de datos sobre las parroquias de la Arquidiócesis de Córdoba 1905-1960. Auto episcopal del 13/06/1905.

${ }^{15}$ CUESTIONARIO 1 (1905).

3) ¿Cuántas almas cuenta? ¿Hay en la parroquia no católicos? ¿Qué población no católica se calcula? ¿Tienen Templos? ¿Cuántos? ¿Dónde? ¿Por qué medios se procura su conversión?

CUESTIONARIO 2 (1917).

3) ¿Cuántas almas cuenta? ¿Hay en la parroquia no católicos? ¿Qué población no católica se calcula? ¿Tienen Templos? ¿Cuántos? ¿Dónde? ¿Por qué medios se procura su conversión?

45) ¿Qué número de fieles cumplen los preceptos de comunión y confesión pascual?

50) ¿Hay difusión de libros y periódicos malos?

CUESTIONARIO 3 (1924).

24) Misas.

26) Penitencia y Eucaristía.

31) Vicios Dominantes. 
comprendida por el departamento de San Justo, la del sudeste, por los de Tercero Abajo, Unión y Marcos Juárez, y la del sur, por Río Cuarto, Juárez Celman y Gral. Roca.

\section{Mapa 14}

\section{División de la provincia de Córdoba en Departamentos de Antigua Colonización y Colonizadores}

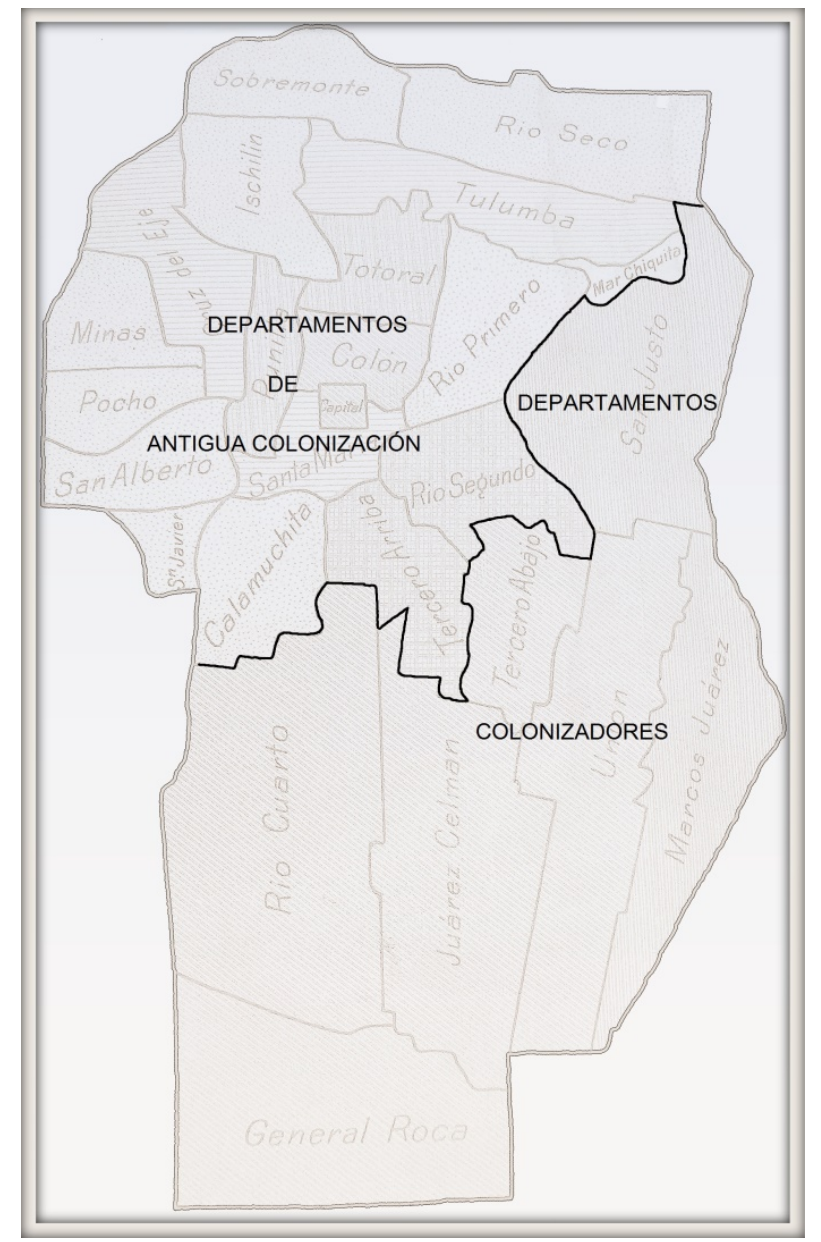

Siguiendo este criterio, hemos recurrido a la construcción de una tipología que permita agrupar las parroquias en función de las especificidades propias, teniendo en cuenta su ubicación geográfica y sus feligresías. ${ }^{16}$ Se trata un recurso metodológico que nos permite agrupar las parroquias de campaña en tres grandes categorías: a) las criollas de vieja colonización, b) las parroquias mixtas, y c) las inmigrantes de colonización reciente. Las primeras, se agrupan en las regiones del norte y el oeste, donde el porcentaje de extranjeros

\footnotetext{
${ }^{16}$ Tomamos los datos de población inmigrante correspondientes al año 1905 (Cfr. Río y Achával, 1904).
} 
oscilaba entre el 0,10\% y el 3\% en 1905. En las segundas, ubicadas en la región central, el porcentaje de extranjeros aumentaba y oscilaba entre el 0,4\% y el 6\%, exceptuando el departamento de Río Primero, cuyo porcentaje de extranjeros no alcanzaba el 1\% debido, entre otras razones, a que el curato de Chalacea era una zona de características similares al norte provincial y por lo tanto poco apetecida por la inmigración y a que la población más antigua ya estaba establecida en el antiguo curato de Santa Rosa, por ende, era un departamento con escasa disponibilidad de tierras. En las terceras, las parroquias de colonización reciente, el porcentaje de extranjeros oscilaba entre el $7 \%$ y el $45 \%$ y corresponden a las regiones del este, sudeste y sur.

\subsection{Parroquias rurales de vieja colonización en el noroeste provincial}

Mantienen de manera casi inalterable las características descriptas ut supra. Sólo añadiremos la precepción del prelado visitador, en relación a la religiosidad, al realizar las visitas, y una brevísima descripción del curato.

\section{El norte provincial}
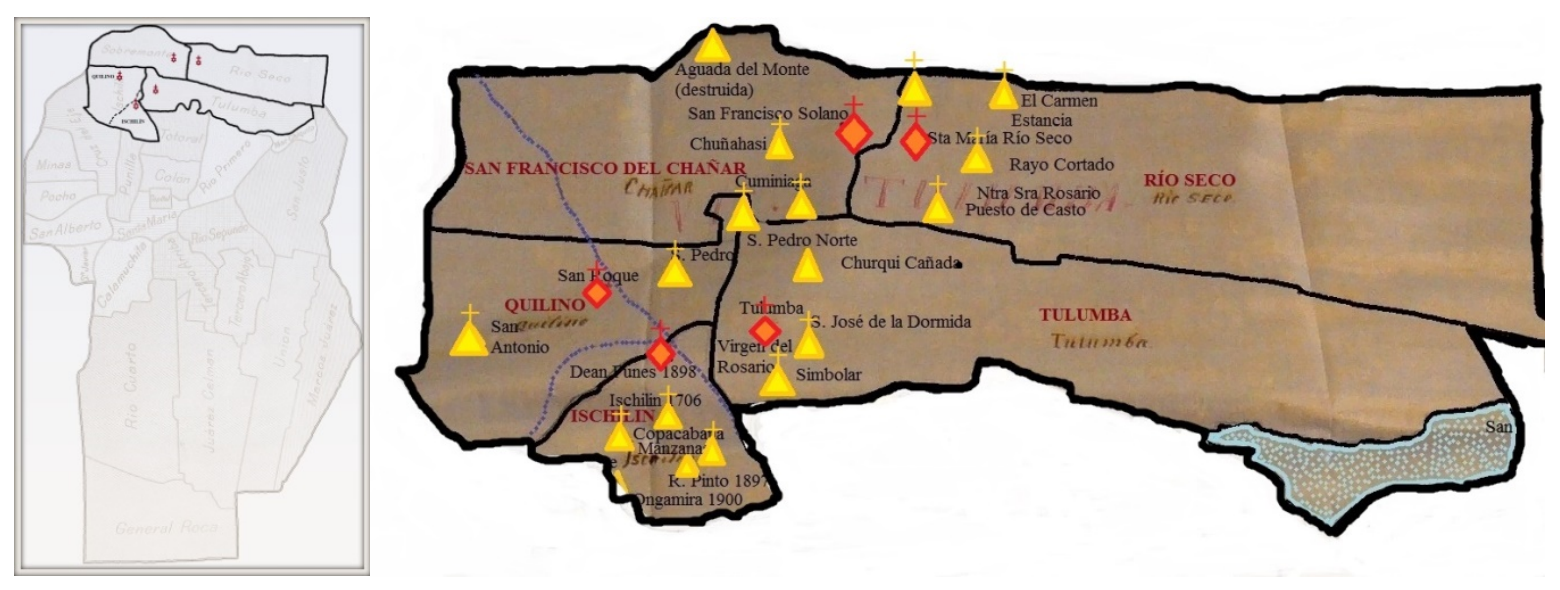

El curato de Sobremonte contaba, a estas alturas, con una gran iglesia parroquial en la villa, construida por iniciativa de Apolinario Argañarás en 1894 y concluida en 1900. El edificio tenía dos grande torres de $24 \mathrm{mts}$ de altura. La población se mantenía en las mismas proporciones y tenía dos de sus tres capillas en buen estado, la de Aguada del Monte estaba semi-derruida. La línea del Ferrocarril Central Córdoba atravesaba el curato por el oeste, 
allí la estación Tororalejos se encontraba en el límite con la provincia de Santiago del Estero, a una distancia de veinte leguas de la parroquia.

El informe de 1905, remitido por el Inspector de Parroquias Inocencio Dávila, señalaba que el curato de Tulumba tenía una extensión territorial de 150 leguas $^{2}$, seis templos, la iglesia parroquial y cinco capillas. Éstas distaban de la parroquia cuatro, quince, ocho y ocho y media leguas (Cfr. Anexo IV Dinámica Espacial Croquis Curato de Tulumba en 1905). La población total del curato era de 7.000 habitantes, los cuales se nucleaban de la siguiente manera: 400 en Villa de Tulumba,${ }^{17} 300$ en San José de la Dormida y 150 en San Pedro Norte. Churqui Cañada, Rosario del Saladillo y Simbolar eran caseríos de menos de 100 habitantes que tenían una pequeña capilla cada uno. El resto se distribuía en otros caseríos de menos de 100 habitantes y zonas rurales. Contaba con un solo sacerdote para la atención del curato y ninguna línea férrea atravesaba el territorio. La más cercana era el ramal norte del Ferrocraril Central Córdoba que tenía la estación Deán Funes en el curato vecino de Ischilín. Tres caminos atravesaban el curato y unían Villa de Tulumba con Deán Funes, San Pedro Norte con Quilino y el camino que de San José de la Dormida seguía a Río Seco y Santiago del Estero.

En el curato de Quilino, la población había aumentado considerablemente, en 1917 alcanzaba 7.000 habitantes distribuidos de la siguiente manera: en la Villa de Quilino 3.000, con toda la pedanía sumaba 4.000; San Pedro de Toyos tenía 250 habitantes en la aldea y 1.800 en la pedanía, existía una capilla dedicada a San Pedro; Isla de San Antonio era un poblado de 140 habitantes y unos 1.200 vivían en la pedanía. ${ }^{18}$ La población de la Estación San José era de 400 habitantes, aunque aumentaba a más de 1.000 en tiempos de extracción de sal. En 1906, el cura informaba que había unas 3.000 comuniones al año, en la semana santa comulgaban unas quinientas personas. Todos los domingos y días festivos se celebraban dos misas por la gran asistencia de gente. ${ }^{19}$

Ischilín, había trasladado, en 1902, la sede parroquial y la residencia del cura a Deán Funes, una villa poblada por 800 habitantes, la población estimada de todo el curato era de

\footnotetext{
${ }^{17}$ Este dato no coincide con el de Río y Achaval (1904), para quien la Villa de Tulumba tenía una población de 1.500 habitantes.

${ }^{18}$ AAC. Compilación de datos relacionados con las parroquias de la Arquidiócesis, 1905-1960.

${ }^{19}$ AAC. Parroquias: Quilino, f.122.
} 
6.000 habitantes. ${ }^{20}$ En 1903, se desprende la capilla de Santa Catalina que fue anexada al curato de Jesús María. ${ }^{21}$ En 1905, tenía una superficie de 190 leguas². Poseía cinco capillas $\mathrm{y}$ tres oratorios. ${ }^{22}$ Las distancias que separaban las capillas de la parroquia eran entre ocho y una legua y media. ${ }^{23}$ Los poblados, en razón de su importancia, eran Ischilín, punto céntrico del curato, Copacabana y Río Pinto, los cuales tenían 40 o 50 habitantes, sin embargo había bastante población en los contornos. ${ }^{24}$

En 1908, 1917 y 1926, el curato recibió las visitas pastorales correspondientes. En el cuestionario de la primera visita, el cura señala que la mayoría de la población era católica, y había "dos familias ortodoxas rusas, y cuatro protestantes, más unos hombres que se dicen convertidos al protestantismo, en total veinte personas". ${ }^{25}$ En Deán Funes, había un templo de Culto Evangélico, pero no tenían ninguna escuela. El cura párroco Guillermo Basso no tenía ningún teniente, aunque contaba con la ayuda de un sacerdote italiano, Félix Mattio, de sesenta años, capellán de las hermanas Eslavas. En la parroquia había otro sacerdote, Bernardo Tissera, hombre de 44 años, ex párroco del curato, que vivía en una casa de su propiedad y celebraba la misa en su casa. En cuanto a la moralidad, el cura decía que había muchas personas unidas sólo civilmente y amancebadas. "Para regularizarlas me sirvo hasta de la policía, del Jefe del Registro y de los cófrades, permito casarles de balde si no pueden pagar y lo hago, hasta gasto pagándoles trajes para la ceremonia". ${ }^{26}$ En 1925, el cura señala otro vicio dominante, "puedo informar que por desgracia tenemos una casa de prostitución a las orillas de la población. El diario que más circula entre las 'familias decentes' de esta población es nuestro conocido diario católico 'Los Principios'. 'El País' tiene también circulación en algún ambiente. Los libros y folletos circulantes, sobre todo en Deán Funes, contra la fe son los que a veces reparten los evangelistas". ${ }^{27}$

\footnotetext{
${ }^{20}$ AAC. Leg. 50, Ischilín. Respuesta al cuestionario de la Visita Canónica de 1906.

${ }^{21}$ AAC. Datos Parroquias, respuesta a la Circular de 1924.

22 AAC. Compilación de datos relacionados con las parroquias de la Arquidiócesis, 1905-1960. Ischilín 05/11/1905. AAC. Caja Deán Funes. Respuesta a la Circular del 16 de junio de 1913, f.42.

${ }^{23}$ Ischilín cuatro leguas, Copacabana ocho, Ongamira diez, Río Pinto ocho, Manzana seis, Avellaneda cinco y San Vicente una legua y media. El acceso a la capilla de Avellaneda era por ferrocarril y a las de Río Pinto y Manzana se llegaba hasta la estación y de allí dos leguas en carruaje. La Villa contaba con 1.000 habitantes y Estación Avellaneda con 150. Las demás iglesias y oratorios no tenían pueblos formados.

${ }^{24}$ AAC. Compilación... Ischilín.

${ }^{25}$ AAC. Caja Deán Funes. Respuesta al cuestionario de la Visita Canónica de 1908, f.45.

${ }^{26}$ AAC. Caja Deán Funes. Respuesta al cuestionario... 1908, f.45.

${ }^{27}$ AAC. Caja Deán Funes. Respuesta al cuestionario de la Visita Canónica de 1926.
} 
Los autos de visita definen a la población del curato como de índole industrial y comercial, cuyas aspiraciones tienden, principalmente, a la adquisición de fortuna. A esto se añade la venta de malos libros, periódicos y hojas que, diariamente, llegaban con los trenes y se depositaban en esa Villa. El párroco debía emplear mayor solicitud para neutralizar el daño de las malas lecturas en los fieles, por medio de una mayor vigilancia y una predicación más esmerada. Tomar con mayor interés la difusión de la prensa católica y en especial el diario "Los Principios". Un aspecto central del auto es el que se refiere al "cultivo religioso" del círculo de obreros existente en esa localidad. "Los obreros organizados y puestos por los estatutos bajo su dependencia espiritual, lo colocan en condiciones de comunicar con ellos con más frecuencia y con más intimidad, dándoles ventajas para hacer más eficaz sus enseñanzas". Advierte al párroco sobre la necesidad de velar por el mejoramiento de su clase, conduciéndolos al terreno práctico que señalan sus estatutos, creando la caja de ahorros, estableciendo los socorros mutuos, estimulándolos al trabajo regular, platicándoles la necesidad de ahorrar y la conveniencia de sustraerse a todo género de vicios y enseñándoles, por fin, a formar, regularizar y dignificar la propia familia. Para ello, aconseja la lectura de las encíclicas del Papa León XIII sobre este tema. "Empapándose de ellas y poniéndolas al alcance de los obreros para que las lean y asimilen su doctrina le habrá hecho todo el bien que se desea y los habrá precavido de participar del espíritu socialista". ${ }^{28}$

El segundo tema hace referencia a la formación de la niñez. Para lo cual, recomienda la enseñanza de la religión en todas las escuelas del curato, fiscales y particulares, así como a las diversas agrupaciones de niños. "La masa de la población escolar así reunida en centros concentra toda la niñez de su curato, lo que es igual a decir, que representan la feligresía del mañana". Por último, y para concretar esta idea, el obispo sugiere la fundación de un colegio de internado, de artes y oficios o de instrucción, pues entiende que es de gran provecho para el ministerio parroquial, cuando "este se dirige a los fieles constituidos en centros vinculados a los párrocos por otro título de dependencia además del vínculo espiritual". ${ }^{29}$ Se recomienda la pronta construcción y/o adquisición de una casa parroquial, para evitar que el cura se traslade de casa en casa alquilada con el archivo parroquial.

\footnotetext{
${ }^{28}$ Libro de Autos y Visitas Pastorales... f.206.

${ }^{29}$ Libro de Autos y Visitas Pastorales... f.206.
} 
El curato de Río Seco tenía una extensión de 55 leguas $^{2,}$ con 6.000 habitantes. En 1905, contaba con la Iglesia parroquial en Villa María y dos capillas. ${ }^{30}$

Exceptuando Quilino, las condiciones socioeconómicas de los feligreses de los curatos del norte eran especialmente difíciles, la tradición criolla y el profundo arraigo del sentimiento religioso se traducían en un fervor popular, que se manifestaba en procesiones y fiestas patronales, aunque la asistencia habitual de los fieles al templo era menos frecuente, sobre todo, en las zonas más alejadas de los centros de población. Se daba gran importancia a los sacramentos, en particular, el bautismo y la unción de los enfermos, ${ }^{31}$ aunque era frecuente la relajación de las prácticas religiosas. En su visita a los curatos del norte y del oeste, el prelado se congratulaba al observar la piedad y la fe manifestadas por los feligreses. ${ }^{32}$

Como dijimos, no resulta fácil realizar un balance de la realidad económica de los curatos de la región, ya que los datos que poseemos son fragmentarios e incompletos. Las entradas eran por "derechos de estola", cobro de primicias (muy exiguo y en vías de extinción), limosnas, donaciones o legados. En 1906, se estableció un nuevo arancel eclesiástico que regulaba los derechos de estola (Cfr. Tabla 6 en Anexo II).

Hemos podido realizar una estimación relativa de los ingresos durante los años 19051910, gracias a tres tipos de fuentes, la primera es un libro que recoge el movimiento económico y religioso de los curatos en ese período, ${ }^{33}$ uno de los datos que registra es la renta del beneficio y la renta de fábrica. Cuando se refiere a la renta del beneficio, entendemos que es el saldo de las entradas una vez deducidos los gastos, lo mismo respecto a la renta de fábrica. El segundo tipo de fuentes son las planillas que trimestralmente enviaron los párrocos a la curia, durante esos mismos años, en las que daban cuenta de una serie de datos vinculados al movimiento económico de su curato, relacionados con el envío del $3 \%$ de las entradas destinado como cuota para el seminario. ${ }^{34}$ En ellas se detallan los

\footnotetext{
${ }^{30}$ La Estancia, 3 leguas al sudeste; Candelaria, a 12, y la de Rayo Cortado, en construcción, a 5.

${ }^{31}$ Los reclamos de los feligreses al párroco para la atención de los enfermos eran muy frecuentes. Las denuncias hacen referencia al descuido del ministerio en relación a este aspecto (Cfr. AAC. Leg. 35, TVIII. Juicios Eclesiásticos, 1871-1905).

32 AAC. Carpeta Curia, Visitas Pastorales y Varios, 1887-1911; Auto de la Visita Canónica a la Iglesia parroquial de Ntra. Señora del Rosario del curato de Río Seco el 11 de octubre de 1910.

33 AAC. Libro Movimiento Religioso y Económico de la Diócesis, 1906-1912. El mismo contiene la información de las planillas trimestrales enviadas por cada parroquia y el ingreso económico que no figura en esas planillas. Entre los datos que releva se encuentra la Renta del Beneficio y la Renta de Fábrica.

${ }^{34}$ AAC. Fondo Seminario. Movimiento Religioso y Económico de los Curatos.
} 
ingresos por funerales, entierros, matrimonios, bautismos, misas, funciones, partidas, primicias, legados y donaciones y por cada uno de ellos se especifica el número, la renta, los derechos de fábrica, los gastos, el líquido y el 3\% destinado al seminario. Por último, en los cuestionarios de la visita canónica de 1906 y 1912 se pregunta: ¿cuáles son las rentas fijas del cura? Cuáles las inciertas? ¿Cuánto se cobra por los bautismos? ¿Cuánto por los matrimonios? ¿Cuánto por los funerales? Y ¿cuánto por otras funciones?

Trabajar estos datos supuso una labor muy compleja, pues, como dijimos, son incompletos $\mathrm{y}$, en algunos casos, poco claros los criterios de los párrocos para responder al requerimiento de la curia. Hemos procurado dejar de manifiesto los múltiples vacíos con los que nos encontramos. De todos modos, del cruzamiento de estas informaciones podemos inferir la posible rentabilidad de cada curato durante el quinquenio 1906-1910.

\section{Gráfico 5}

\section{Renta mensual del beneficio y la fábrica de los curatos del norte de la Provincia de Córdoba, 1906-1910}

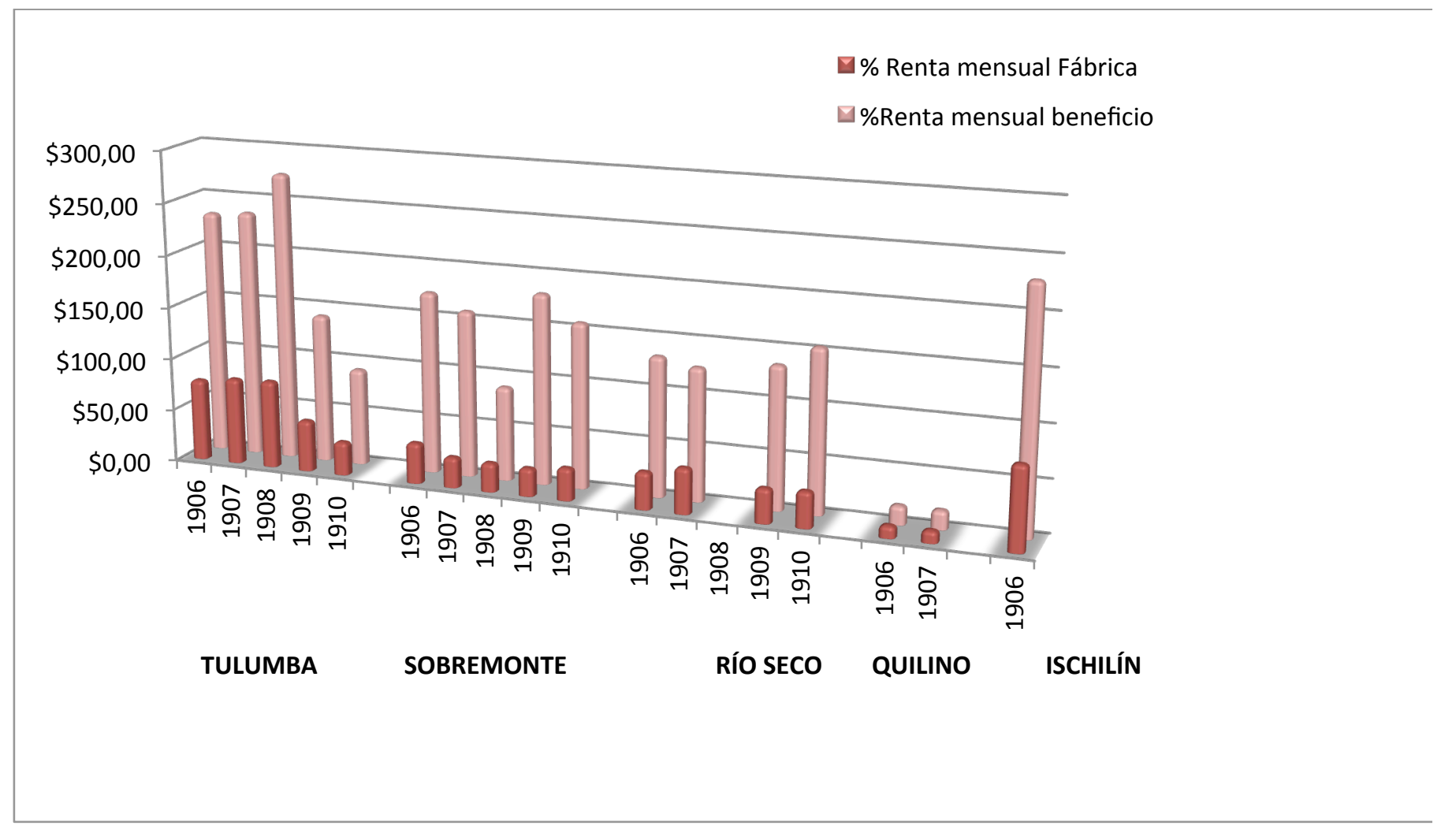


El Gráfico 5 nos permite inferir que el rango de rentabilidad mensual de los curatos del norte provincial era $\$ 78$ en el curato de Quilino y $\$ 274$ en el de Tulumba. En el lapso de cinco años, el promedio de la renta mensual del curato de Tulumba fue $\$ 195,23$, el de Sobremonte de $\$ 152$, el de Río Seco de $\$ 140,16$, el de Ischilín de $\$ 246,16$ y el de Quilino, que si bien tenemos datos incompletos, sería de $\$ 88,33$. La media estaría dando una suma de $\$ 164,37$ mensuales para los curatos del norte.

Como veremos a lo largo de este punto, la cuestión económica era un tema sensible, pues no siempre los curas llevaban los libros al día y con exactitud. Como puede observarse en el gráfico el cura de Quilino sólo informa sobre los años 1906 y 1907, y los informes son incompletos, ya que en 1907 envía únicamente los dos primeros trimestres. En el auto de la visita canónica, el prelado denuncia esta irregularidad, "declaramos el procedimiento incorrecto y reprobable del señor ex cura Miguel Salguero que aparece en los abusos cometidos en los libros y muy singularmente en el de matrimonios y en el de fábrica. La inspiración que aparece moviendo sus actos es el interés de lucro, que no le ha permitido renovar ninguno de los ornamentos sagrados de los viejos que encontró y menos adquirir otros, ni introducir mejora alguna en la parroquia, durante los cuatro años y tres meses durante los que la ha dirigido". 35

Para comprender el complejo funcionamiento económico de las parroquias, tomamos un caso testigo, el curato de Tulumba durante el año 1906. Presentamos dos tablas. La primera, construida con los datos económicos extraídos del libro sobre el movimiento económico, y la segunda, con las planillas destinadas a deducir el 3\% para el seminario. Hemos volcado los datos, tal cual estaban en las planillas, y hemos mantenido el concepto de lo solicitado (renta, derechos de fábrica, gastos, líquido), sólo agregamos la hilera correspondiente a la suma anual para facilitar la lectura del cuadro. La renta corresponde a lo percibido por arancel y donaciones, a esa cifra se le restan los derechos de fábrica y los gastos, el resultado de esas operaciones es el líquido. El 3\% de ese monto era lo que se destinaba al seminario. Puede observarse que las planillas tienen algunos errores, a modo de ejemplo, en el primer trimestre de 1906, el cura de Tulumba en lugar de restar los gastos, los suma. Ambas Tablas nos permiten alcanzar una idea más clara de cómo era la economía parroquial, cuáles eran los ingresos y egresos ordinarios de un curato.

\footnotetext{
${ }^{35}$ AAC. Libro de Autos, 1885-1916. Auto de la Visita al curato de Quilino, 29/07/1908, f.275.
} 


\section{Tabla 16}

\section{Renta del beneficio y fábrica del curato de Tulumba, quinquenio 1906-1910}

\begin{tabular}{|l|l|l|l|l|l|l|l|l|l|l|l|l|}
\hline TULUMBA & \multicolumn{5}{|c|}{ Renta del Beneficio } & \multicolumn{5}{|c|}{ Renta de Fábrica } \\
\hline Trimestres & $\mathbf{1}^{\circ}$ & $\mathbf{2}^{\circ}$ & $\mathbf{3}^{\circ}$ & $\mathbf{4}^{\circ}$ & $\begin{array}{l}\text { Total } \\
\text { Anual }\end{array}$ & $\begin{array}{l}\text { Total \% } \\
\text { mensual }\end{array}$ & $\mathbf{1}^{\circ}$ & $\mathbf{2}^{\circ}$ & $\mathbf{3}^{\circ}$ & $\mathbf{4}^{\circ}$ & $\begin{array}{l}\text { Total } \\
\text { Anual }\end{array}$ & $\begin{array}{l}\text { Total \% } \\
\text { mensual }\end{array}$ \\
\hline 1906 & $\$ 434$ & $\$ 685$ & $\$ 1066$ & $\$ 604$ & $\$ 2789$ & $\$ 232,41$ & $\$ 148$ & $\$ 195$ & $\$ 383$ & $\$ 208$ & $\$ 934$ & $\$ 77,83$ \\
\hline 1907 & $\$ 650$ & $\$ 903$ & $\$ 565$ & 0 & & $\$ 235,33$ & $\$ 202$ & $\$ 267$ & $\$ 272$ & 0 & & $\$ 82,33$ \\
\hline 1908 & $\$ 490$ & $\$ 951$ & $\$ 636$ & $\$ 397$ & $\$ 2474$ & $\$ 274,88$ & $\$ 231$ & $\$ 375$ & $\$ 234$ & $\$ 163$ & $\$ 1003$ & $\$ 83,58$ \\
\hline 1909 & $\$ 310$ & 0 & $\$ 683$ & $\$ 280$ & & $\$ 141,44$ & $\$ 148$ & 0 & $\$ 169$ & $\$ 123$ & & $\$ 48,80$ \\
\hline 1910 & $\$ 145$ & $\$ 495$ & 0 & $\$ 189$ & & $\$ 92,11$ & $\$ 69$ & $\$ 168$ & 0 & $\$ 49$ & & $\$ 31,77$ \\
\hline
\end{tabular}

Fuentes: AAC. Libro Movimiento Religioso y Económico de la Diócesis, 1906-1912. Caja Tulumba, Respuesta Cuestionario de la Visita Canónica del 05/10/1910. Pregunta 9.

\section{Tabla 17}

Movimiento económico de Tulumba, 1906

\begin{tabular}{|c|c|c|c|c|c|c|c|}
\hline \multirow[t]{2}{*}{ TULUMBA } & \multicolumn{6}{|c|}{ AÑO 1906} & \multirow[b]{2}{*}{$\begin{array}{c}3 \% \\
\text { SEMINARIO } \\
\text { en pesos }\end{array}$} \\
\hline & TRIMESTRES & $\mathbf{N}^{\circ}$ & $\begin{array}{l}\text { RENTA } \\
\text { en pesos }\end{array}$ & $\begin{array}{c}\text { FABRICA } \\
\text { en pesos }\end{array}$ & $\begin{array}{l}\text { GASTOS } \\
\text { en pesos }\end{array}$ & $\begin{array}{l}\text { LÍQUIDO } \\
\text { en pesos }\end{array}$ & \\
\hline \multirow{5}{*}{ FUNERALES } & $1^{\circ}$ & 7 & 235,00 & 102,00 & 45,00 & 178,00 & 5,34 \\
\hline & $2^{\circ}$ & 11 & 311,50 & 78,25 & 71,25 & 161,75 & 4,85 \\
\hline & $3^{\circ}$ & 19 & $1.010,00$ & 291,50 & 209,00 & 509,50 & 15.29 \\
\hline & $4^{\circ}$ & 12 & $\$ 330$ & $\$ 73$ & $\$ 72$ & $\$ 205$ & $\$ 6,15$ \\
\hline & ANUAL & 49 & $1.976,50$ & 544,75 & 397,50 & $1.054,25$ & 31,63 \\
\hline \multirow[t]{5}{*}{ ENTIERROS } & $1^{\circ}$ & 5 & 87,00 & 18,00 & 0 & 69,00 & 2,07 \\
\hline & $2^{\circ}$ & 5 & 100,00 & 20,00 & 0 & 80,00 & 2,40 \\
\hline & $3^{\circ}$ & 9 & 127,00 & 30,00 & 0 & 95,00 & 2,85 \\
\hline & $4^{\circ}$ & 8 & 121,00 & 25,00 & 0 & 95,00 & 2,85 \\
\hline & ANUAL & 27 & 435,00 & 93,00 & $\mathbf{0}$ & 339,00 & 10,17 \\
\hline \multirow[t]{5}{*}{ MATRIMONIOS } & $1^{\circ}$ & 11 & 84,00 & 13,00 & 0 & 71,00 & 2,13 \\
\hline & $2^{\circ}$ & 12 & 116,00 & 15,00 & 0 & 101,00 & 3,00 \\
\hline & $3^{\circ}$ & 20 & 150,00 & 25,00 & 0 & 125,00 & 3,76 \\
\hline & $4^{\circ}$ & 7 & 54,00 & 9,00 & 0 & 45,00 & 1,35 \\
\hline & ANUAL & 50 & 404,00 & 62,00 & $\mathbf{0}$ & 342,00 & 10,23 \\
\hline \multirow[t]{5}{*}{ BAUTISMOS } & $1^{\circ}$ & 32 & 32,00 & 0 & 0 & 32,00 & 3,60 \\
\hline & $2^{\circ}$ & 109 & 109,00 & 0 & 0 & 109,00 & 3,27 \\
\hline & $3^{\circ}$ & 118 & 118,00 & 0 & 0 & 118,00 & 3,54 \\
\hline & $4^{\circ}$ & 39 & 39,00 & 0 & 0 & 39,00 & 1,17 \\
\hline & ANUAL & 298 & 298,00 & 0 & $\mathbf{0}$ & 298,00 & 17,58 \\
\hline \multirow{2}{*}{$\begin{array}{l}\text { MISAS } \\
\text { CANTADAS }\end{array}$} & $1^{\circ}$ & 0 & 0 & 0 & 0 & 0 & 0 \\
\hline & $2^{\circ}$ & 23 & 347,00 & 78,50 & 8,00 & 155,10 & 4,55 \\
\hline
\end{tabular}




\begin{tabular}{|c|c|c|c|c|c|c|c|}
\hline & $3^{\circ}$ & 7 & 106,00 & 29,50 & 113,40 & 57,50 & 1,72 \\
\hline & $4^{\circ}$ & 9 & 260,00 & 90,00 & 19,00 & 35,00 & 1,05 \\
\hline & ANUAL & 39 & 713,00 & 198,00 & 140,00 & 247,60 & 7,32 \\
\hline \multirow{5}{*}{$\begin{array}{l}\text { MISAS } \\
\text { PAÑO }\end{array}$} & $1^{\circ}$ & 3 & 42,00 & 9,00 & 8,00 & 25,00 & 0,75 \\
\hline & $2^{\circ}$ & 0 & 0 & 0 & 0 & 0 & 0 \\
\hline & $3^{\circ}$ & 2 & 10,00 & 2,00 & 0 & 8,00 & 0,24 \\
\hline & $4^{\circ}$ & 2 & 25,00 & 7,00 & 5,50 & 12,00 & 3,60 \\
\hline & ANUAL & 7 & 77,00 & 18,00 & 13,50 & 45,00 & 4,59 \\
\hline \multirow{5}{*}{$\begin{array}{ll}\text { MISAS } & \text { DE } \\
\text { VIGILIA } & \end{array}$} & $1^{\circ}$ & 2 & 14,11 & 2,00 & 0 & 12,00 & 0,36 \\
\hline & $2^{\circ}$ & 4 & 28,00 & 4,00 & 0 & 24,00 & 0,72 \\
\hline & $3^{\circ}$ & 5 & 35,00 & 5,00 & 0 & 30,00 & 0,90 \\
\hline & $4^{\circ}$ & 3 & 27,00 & 3,00 & 0 & 18,00 & 0,54 \\
\hline & ANUAL & 14 & 104,11 & 14,00 & $\mathbf{0}$ & 84,00 & 2,52 \\
\hline \multirow[t]{5}{*}{ FUNCIONES } & $1^{\circ}$ & 0 & & & & & \\
\hline & $2^{\circ}$ & 0 & & & & & \\
\hline & $3^{\circ}$ & 0 & & & & & \\
\hline & $4^{\circ}$ & 0 & & & & & \\
\hline & ANUAL & 0 & & & & & \\
\hline PARTIDAS & ANUAL & 139 & 279,00 & 0 & 0 & & 8,30 \\
\hline PRIMICIAS & ANUAL & 0 & & & & & \\
\hline CERTIFICADOS & ANUAL & 31 & 31,00 & & & & \\
\hline $\begin{array}{l}\text { LEGADOS/ } \\
\text { DONACIONES }\end{array}$ & ANUAL & & 12,00 & & & & 12,00 \\
\hline TOTALES & & & $4.329,62$ & 929,00 & 691,40 & $2.709,22$ & 104,34 \\
\hline
\end{tabular}

Si al total de la renta, $\$ 4.329,62$, se le resta la fábrica $(\$ 929)$ y los gastos $(\$ 691,4)$, el líquido es de $\$ 2.709,22$ del cual se debe deducir 3\% destinado al seminario, $(\$ 104,34)$. Por lo tanto, la renta del beneficio destinada al cura sería de $\$ 2.604,88$ anuales. Si comparamos las cifras de esta planilla detallada con la renta del beneficio correspondiente al año 1906, presentada en la Tabla 16 (\$2.789), vemos que la variación es mínima. Por lo tanto, podemos concluir que el cura tenía una renta anual aproximada de $\$ 2.700$ que, dividido por los 12 meses del año, daría una suma de aproximadamente \$225.

La información de los cuestionarios de la visita canónica aporta algunos datos interesantes. El cura de Quilino responde, en 1906, que no tiene rentas fijas. "Las inciertas son administración sacramentos, funerales y misas cantadas. Por matrimonios se cobra 
según arancel y por funerales no hay nada fijo, de ordinario se cobra lo que los interesados ofrecen no pasando éstos de 10 a 50 pesos". 36

\section{La Región del Oeste}

La región se mantenía casi exactamente igual, el ramal del ferrocarril había implusado el crecimiento del curato de San Javier al sur y Cruz del Eje al Norte. ${ }^{37}$
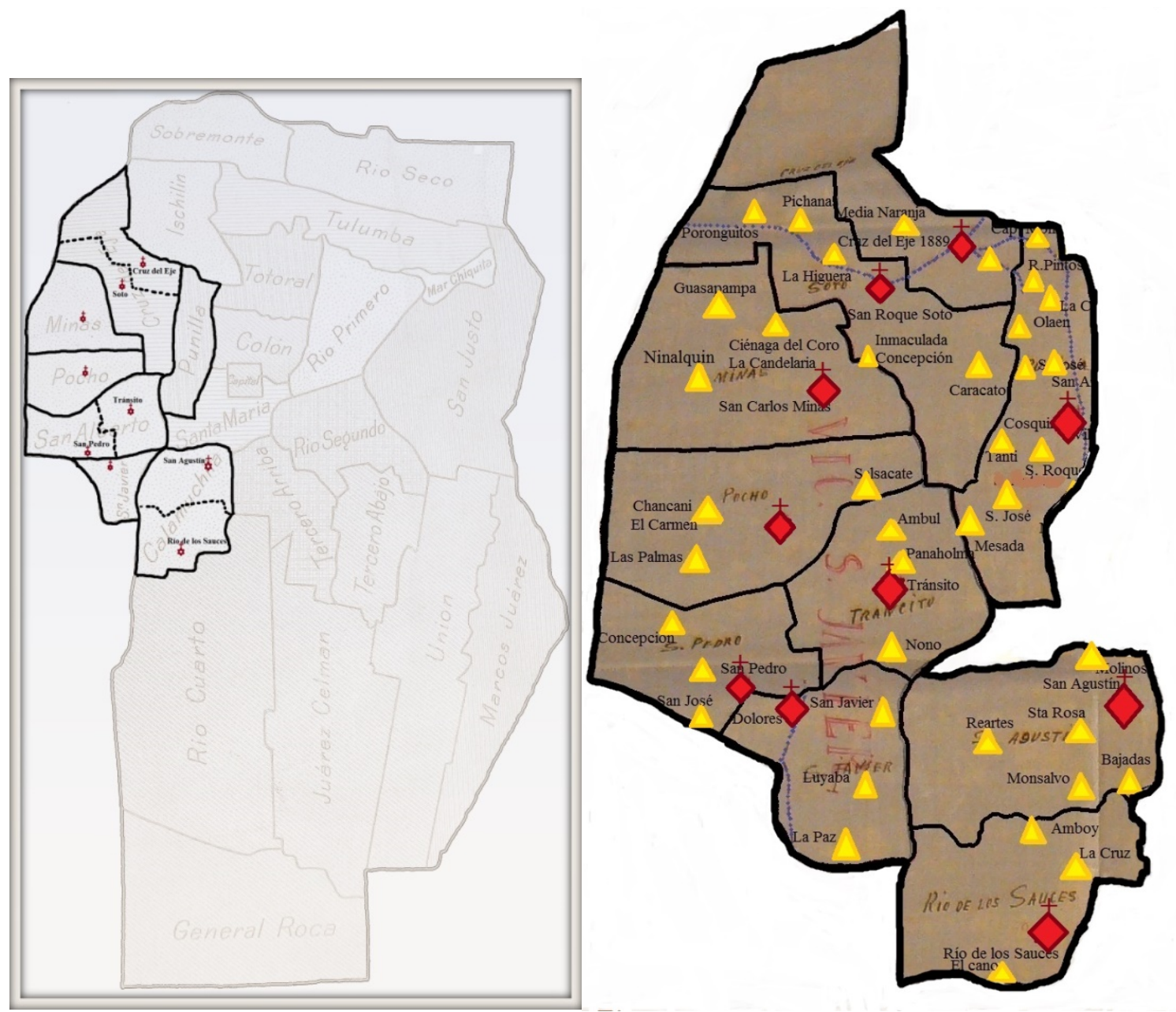

El curato de Punilla tenía una superficie de $2.455 \mathrm{~km}^{2}$ (Río y Achával, 1904: 531), o en palabras del párroco, 20 leguas de norte a sur. El curato era atendido por el párroco que residía en Cosquín y un ayudante, con residencia en Capilla del Monte, hospedado en una

\footnotetext{
${ }^{36}$ AAC. Leg. 50. Ischilín, Respuesta a la Pregunta no 9 del Cuestionario de la Visita Canónica.

${ }^{37}$ Esta región la integraban los departamentos de Punilla, Cruz del Eje, Minas, Pocho, San Alberto, Tránsito, San Javier y Calamuchita. Que comprendían, además de los curatos del mismo nombre, el de Soto en Cruz del Eje, Tránsito en San Alberto y Río de los Sauces en Calamuchita.
} 
casa particular. También vivían en el curato otros dos presbíteros, sin nombramiento pero con licencias, que colaboraban atendiendo alguna capilla. Durante la temporada veraniega residían temporalmente varios sacerdotes.

Había diecisiete iglesias, tres de propiedad particular, ocho oratorios, tres de ellos semipúblicos y los demás privados. ${ }^{38}$ La Iglesia parroquial estaba en Cosquín, dedicada a la Virgen del Rosario, aunque el patrono del pueblo tradicional era San Esteban protomártir, cuya fiesta se celebra el 16 de diciembre. ${ }^{39}$ En 1918, se estableció, como función patronal del pueblo, y para los años sucesivos, la de la Virgen del Rosario, el cuarto domingo de octubre. $^{40}$ El curato recibió la visita canónica en enero de 1911. La población, en ese momento, alcanzaba a 10.000 habitantes, la mayoría católicos, el cura calculaba unas 500 personas no católicas (protestantes y orientales). Los protestantes tenían una casa veraniega entre La Cumbre y San Esteban y en el verano aumentaban considerablemente. Además, tenían su templo y un colegio interno y externo, para ambos sexos, situado en Los Cocos.

La Villa había crecido y al obispo le preocupaba que la Iglesia hubiera quedado a una legua de donde se encontraba la mayor densidad de población. En 1908, el obispo amonestó la falta de celo del párroco por no terminar la edificación de la iglesia. Decía que el amplio templo construido con la cooperación de los poderes públicos y los esfuerzos individuales de la población estaba inconclusa, le "falta de una torre, del retoque del frente y de una nave de pavimentación, del pretel y de todo el ornato interior". ${ }^{41}$ De las palabras del auto se desprende cierta reconvención hacia el cura por la atención del ministerio. Esta indolencia se refleja también en la escasa documentación remitida a la curia sobre las cuestiones relativas a su curato.

El curato de Soto tenía, en 1905, una villa que alcanzaba una población de 1.000 habitantes y un solo cura atendía la parroquia y las cinco capillas del curato. La Iglesia, erigida en honor de San Roque, medía 32mts de largo por $7 \mathrm{mts}$ de ancho. El plano preveía tres naves, pero solo se construyeron la nave central y el crucero. La llegada del ferrocarril

\footnotetext{
${ }^{38}$ Una en San Antonio de Arredondo, muy poco poblada, en San Roque, también muy poco poblada, tenía dos capillas, la de San Roque y la de Tanti. El Rosario tenía una capilla en Cosquín y otra en San José. San Antonio de Punilla, que era la pedanía más poblada, tenía cuatro capillas y en la pedanía de Dolores, también muy poblada, había dos capillas (Cfr. AAC. Caja Cosquín, f.361 y ss).

${ }^{39}$ AAC. Caja Cosquín f.363.

${ }^{40}$ AAC. Caja Cosquín. Libro de los acontecimientos principales de la parroquia de Cosquín iniciado en el año $1917, \mathrm{~s} / \mathrm{f}$.

${ }^{41}$ Libro de Autos y Visitas Canónicas... f.213.
} 
en 1889 aumentó considerablemente la población de la Villa, que, según el censo municipal de 1925 llegó a 4.000 habitantes.

En 1890, llegó el ferrocarril a Serrezuela, ramal a La Rioja, pocos años después, la construcción del ramal a San Juan llenó la aldea de operarios. Este aumento de población llevó al cura Coto a construir allí una capilla que, en 1899, abrió sus puertas para la celebración de las primeras funciones religiosas y al año siguiente, durante la visita canónica de Monseñor Cabanillas, se bendijo el templo dedicado al Sagrado Corazón de Jesús. La capilla de Serrezuela distaba $50 \mathrm{~km}(8,5$ leguas) de la villa, estaba al pie de las sierras de Córdoba, con un población de unos 1.000 habitantes. $^{42}$

La capilla Nuestra Señora del Rosario de la Higuera distaba $24 \mathrm{~km}$ al sud de la villa de Soto, por el camino que lleva a Villa Dolores, tenía una población de 400 habitantes. Distaba de las líneas férreas unos $23 \mathrm{~km}$. En 1908, el cura párroco relataba que los caminos que unían la capilla con la villa eran intransitables y la mensajería era la única comunicación entre ambas. Al llegar a la cuesta de la Higuera, los pasajeros debían bajar del coche tirado por caballos y bajar la cuesta con bastones para no despeñarse. ${ }^{43}$ En 1925 , la Sociedad Minera del Plata instaló un gran obraje para la extracción de plata, cobre y estaño, a $10 \mathrm{~km}$ del pueblo, lo que atrajo a operarios de diversos lugares. Para el cura párroco, esta realidad había llevado a que aumentaran notablemente los vicios del juego y la bebida. La capilla de Pichanas, dedicada a Ntra. Sra. del Rosario, era un caserío de unas 300 personas, ubicado cerca de la estación Paso Viejo del Ferrocarril Central Argentino Norte, creada en 1890. El tendido de la línea ferroviaria seguía el trazado del viejo camino a San Juan. La capilla de Characato, levantada en 1895, quedaba a 14 leguas de la Villa, y la de Poronguitos a 16 leguas.

El auto de la visita canónica permite acercarnos a la percepción del obispo respecto de la atención del curato. El diocesano advierte que después de haber visitado la parroquia y capillas, le han llamado la atención varios aspectos relativos a la mala atención espiritual del curato, entre los que señala:

Nada halagador nos ha parecido el encontrar un numero inesperado de uniones ilícitas con el solo vínculo del matrimonio civil sin el matrimonio católico, en esta población

\footnotetext{
${ }^{42}$ BEDC, vol. II, N 10, Agosto 1925, p. 226.

${ }^{43}$ BEDC, vol. II, N 11, Septiembre 1925, p. 229.
} 
y en sus contornos de puros criollos casi en su totalidad y sin ser trabajada por el liberalismo, lo que sería de peor efecto si como muchos nos han dicho obedecía a la tirantez del párroco en exigir los derechos íntegros de casamiento con los pobres.

Iguales impresiones nos han causado el encontrar en el confesionario un número alarmante de niños grandes, hasta de veintitrés años sin hacer la primera confesión y poseídos de la más completa ignorancia en la doctrina en este mismo caso en que venían pregonando cumplir con este deber.

Nos ha llamado la atención así mismo la poca frecuencia de los sacramentos que hemos notado en la parroquia tanto mas que esto parece ser efecto de la falta de benignidad y caridad en el Párroco para tratar a los fieles que se acercan buscando la práctica de los sacramentos, conforme nos han hecho comprender por varias personas que prácticamente han experimentado este inconveniente.

En el curso de la Santa Visita hemos oído a personas de buen criterio sindicar al señor Cura de poseído de espíritu de lucro y mercantil y de guiar su ministerio con este criterio. Puede haber exageraciones en esto; pero algunos otros han agregado que su mano esta siempre cerrada para socorrer al pobre necesitado aun en el caso que se lo demanden. En tal caso los cánones que declaran ser de los pobres lo sobrantes de los frutos del beneficio, no estarían debidamente cumplimentados. ${ }^{44}$

El curato de San Carlos Minas, ubicado al oeste de la provincia, tenía, en 1905, una población de unos 7.500 habitantes, distribuidos en un territorio de $4.000 \mathrm{~km}^{2}$. La iglesia parroquial se encontraba en la villa de San Carlos y existían cuatro capillas antiguas. ${ }^{45}$ Estaba atendido por un solo sacerdote, quien no contaba con la ayuda de ningún ayudante. La población era enteramente católica. ${ }^{46} \mathrm{El}$ curato recibe la visita canónica en 1908 y 1917. El obispo destaca la religiosidad de la población y considera que se debe, en gran medida, a la influencia de la Casa de Ejercicios del Tránsito.

El curato de Pocho tenía, en 1905, una población de unos 7.500 habitantes, distribuidos en un territorio de $2.989 \mathrm{~km}^{2}$. La sede parroquial estaba en la localidad de Salsacate, una aldea de, aproximadamente, 500 habitantes. La Iglesia estaba dedicada a la Virgen del Rosario. Además de la parroquia, tenía siete capillas ubicadas en las pedanías de Salsacate, Chancani, Las Palmas y Pocho (Parroquia).

El departamento de San Alberto comprendía dos curatos, el Tránsito y San Alberto. Abarcaba una superficie de $3.700 \mathrm{~km}^{2}$ y contaba con un población de 10.082 habitantes,

\footnotetext{
${ }^{44}$ AAC. Carpeta Curia, Visitas Pastorales y Varios, Años 1887 a 1911; Auto de la visita Canónica al Curato de Soto, Parroquia de Soto y Chañar 21/03/1908.

${ }^{45}$ Ciénaga del Coro, distante de la parroquia 4,5 leguas; Sancacha a 3,5; Ninalquin a 1,5; y Guasapamapa a 4.

${ }^{46}$ AAC. Caja San Bartolomé. Respuesta al Cuestionario de la Visita Canónica de San Carlos Minas, $13 / 04 / 1917$.
} 
según lo estimado por Río y Achával (1904). En 1905, el curato del Tránsito abarcaba 130 leguas $^{2}$, en forma de polígono, las $3 / 4$ partes del territorio era montañoso, la población fue estimada por el párroco en 8.900 habitantes. ${ }^{47}$ La Iglesia parroquial se había comenzado a construir junto a la Casa de Ejercicios por iniciativa del cura José Gabriel Brochero. El curato contaba con cuatro capillas, algunas de las cuales se encontraban semiderruidas. La capilla de Panaholama, un "rancho viejo de paja hecho siglo y medio atrás", que distaba de la parroquia 2,5 leguas. La capilla de Nono estaba a una distancia de 2 leguas, la de Ciénaga de Allende a otras 2 y la de Ambul a 6. En el auto, el obispo dice que todas sus Iglesias estaban "ruinosas y desprovistas de todo". En 1908 y 1917, recibe otras dos visitas canónicas. El curato estaba atendido por un sacerdote estable, que tenía residencia en Villa del Tránsito. No había casa parroquial, motivo por el cual, el Obispo advierte sobre la necesidad de terminar la construcción del templo y edificar una casa digna para vivienda del párroco. ${ }^{48}$

El curato de San Javier estaba ubicado en el oeste provincial, los límites eclesiásticos coincidían con la demarcación civil: al norte con el departamento de San Alberto, al este con el de Calamuchita, al oeste y sur con la provincia de San Luis (límites definidos en el fallo arbitral del Gral. Roca en 1883). La superficie del curato era de 59,33 leguas ${ }^{2}$, o sea $1.483,47 \mathrm{~km}^{2}$. La población alcanzaba a unas 15.000 personas. La sede parroquial se encontraba en Villa Dolores y contaba con tres capillas y un oratorio. La capilla de las Rosas distaba 3 leguas de la parroquia, la de San Javier 5 y la de Luyaba 3,1/2 leguas de San Javier y 6 de Villa Dolores. La población de las villas y núcleos urbanos era la siguiente, Villa Dolores 2.500; San Javier 600; La Rosas 400 y Luyaba 200. En Los Romeros existía un oratorio en muy malas condiciones que amenazaba derruirse. ${ }^{49} \mathrm{El}$ titular de la Iglesia parroquial era San Francisco Javier. La distribución de la comunión de fue sumamente alta en 1906, 1907 y 1908, sobre todo en el segundo trimestre, que alcanzó 8.000 , lo que sería un 50\% de la población. Esto estaría indicando que, para la población, la fiesta más importante era la Semana Santa (que habitualmente cae en abril), más que la del Santo Patrono (el 3 de diciembre).

\footnotetext{
${ }^{47}$ AAC. Compilación de datos relacionados con las parroquias de la Arquidiócesis, 1905-1960. Respuesta del cura del Tránsito al auto del 13 de junio de 1905.

${ }^{48}$ AAC. Libro de Autos y Visitas... f.237.

${ }^{49}$ AAC. Compilación de datos relacionados con las parroquias de la Arquidiócesis, 1905-1960. Respuesta del párroco Gregorio Rodríguez al auto del 13 de junio de 1905.
} 
En 1926, faltaba terminar la Iglesia de La Paz, donde se había habilitado una parte de la iglesia en construcción para la celebración de los oficios religiosos. Esta feligresía estaba compuesta de unas 6.000 almas, aproximadamente. No había vicarios cooperadores ni otros eclesiásticos. El curato era atendido por el cura párroco, con residencia en Villa Dolores. Las fiestas patronales, San Francisco Javier, se celebraban los 3 de diciembre de cada año.

El informe enviado con las respuestas del cuestionario señala que "diariamente oyen misa 20 personas, y 300 personas los días de precepto o más. Los niños son bautizados ordinariamente dentro de los 8 días de su nacimiento. El párroco no sabe que haya niños sin bautismo en la parroquia, en caso de necesidad hay bautizadores nombrados por el párroco. En Pascua comulgan 900 personas, 600 mujeres y 300 hombres. Las comuniones diarias son 15 y 150 las semanales. La comunión en las fiestas principales se distribuye de esta forma: San Javier 300 comuniones en cada fiesta, que son Pascua, Corpus, San Francisco Javier, San Roque. En Luyaba se distribuían 900 comuniones; en la Paz 2000; en las Rosas 1900. Había años en los que por especiales circunstancias este número ha ascendido, llegando a 2.900 en La Paz y 2.700 en Las Rosas. El párroco estaba siempre dispuesto para la administración de los sacramentos, especialmente la penitencia y la eucaristía. Anualmente comulgan por primera vez 100 niños más o menos. Todos los años en la función patronal de cada pueblo, siendo el siguiente número global: 200 en San Javier, 200 en Luyaba, 350 en La Paz y 350 en Las Rosas". ${ }^{50}$ Los fieles tenían la costumbre de llevar el sacerdote a los enfermos. "Hay tres casos de concubinato en la parroquia, casos que el párroco espera poder legalizar, en esta materia se tiene especial preocupación quedando solo estos tres casos, en los que se ha tropezado con especiales dificultades. El vicio dominante es la embriaguez, el párroco cree que en su parroquia no circulan libros contrarios a la fe ni a la moral, además por la condición misma de los fieles, se lee poco".

El departamento de Calamuchita tenía $5.199 \mathrm{~km}^{2}$. Eclesiásticamente estaba dividido en dos curatos: Calamuchita, con su sede en San Agustín, y Río de los Sauces, con sede en La Cruz. El curato de Calamuchita comprendía las pedanías de Santa Rosa, Molinos, Monsalvo y Reartes. La sede parroquial, antiguamente, se encontraba en Santa Rosa, pero fue trasladada a San Agustín. El curato tenía, además, seis capillas. El otro curato, Río de los Sauces, estaba entendido por un solo sacerdote, que en 1908 cumplió 23 años al frente

\footnotetext{
${ }^{50}$ AAC. Caja San Javier, s/f. Respuesta al cuestionario de la Visita de 1926.
} 
del mismo. La residencia habitual del cura párroco era desde hacía 30 años la Iglesia de La Cruz, pero no estaba claro cuál era la sede del curato, ya que Río de los Sauces también lo era. El Obispo Zenón Bustos, en la visita canónica de 1908, nombró, de hecho y de derecho, la Iglesia Nuestra Señora de las Mercedes de la Cruz como sede parroquial y cabeza del curato. ${ }^{51}$ A su vez, señalaba que había observado "con satisfacción mientras hemos practicado la santa visita en esta Iglesia de la Cruz y Río de los Sauces, la fe religiosa de que se encuentran animados los fieles de este curato del Río de los Sauces. No tiene el párroco que trabajar en formar creencias en sus feligreses, su trabajo debe referirse a que esa fe sea práctica, haciendo que en todos ellos se formen y se mejoren en su relación con el tiempo que transcurre, los hábitos de observancia de los mandamientos de la ley de Dios y de la Iglesia y los hábitos de frecuentar los santos sacramentos". El Obispo observaba "la fe religiosa acompañada con la práctica de los sacramentos que hemos encontrado, no ha hecho comprender el trabajo empleado por el señor Cura Párroco en cultivar el espíritu de sus feligreses". ${ }^{52}$ A su vez, recomendaba la enseñanza de la doctrina a los niños y la utilización del catecismo aprobado por los obispos en Salta:

Propagar entre las familias el catecismo católico autorizado por la reunión de los Obispos en Salta, instruyendo a los padres de familia, en repetidas conferencias públicas sobre el uso práctico que deben hacer de él, empleándole en instruir a la familia los días festivos especialmente por vía de santificación de la fiesta, leyéndoles o haciéndoles leer con otras personas aquel punto de la doctrina en que se proponen instruirlos, repitiendo este punto hasta que lo hayan aprendido. Inculcándoles a los padres de familia que este libro del catecismo debe cuidarse y conservarse sin destruirlo, y como libro indispensable en la familia para la instrucción religiosa. Hágaseles comprender que en ese catecismo además de la doctrina han de encontrar el credo, los artículos, los mandamientos, los sacramentos, el padre nuestro y ave María; los días de fiesta que se deben guardar, el ayuno de todo el año como debe observarse sin dispensa o con ellas si se solicita, los misterios del Santo Rosario, la salve, las letanías y las aclamaciones etc. ${ }^{53}$

\footnotetext{
${ }^{51}$ AAC. Libro de Autos y Visitas... Auto visita canónica a Río de los Sauces (La Cruz) el 15 de mayo de 1908 , f.246.

${ }^{52}$ AAC. Libro de Autos y Visitas... Auto visita canónica a Río de los Sauces (La Cruz) el 15 de mayo de 1908 , f.246.

${ }^{53}$ AAC. Libro de Autos y Visitas... Auto visita canónica a Río de los Sauces (La Cruz) el 15 de mayo de 1908 , f.246.
} 


\section{Gráfico 6}

\section{Renta mensual del beneficio y la fábrica de los curatos del oeste de la Provincia de Córdoba, 1906-1910}

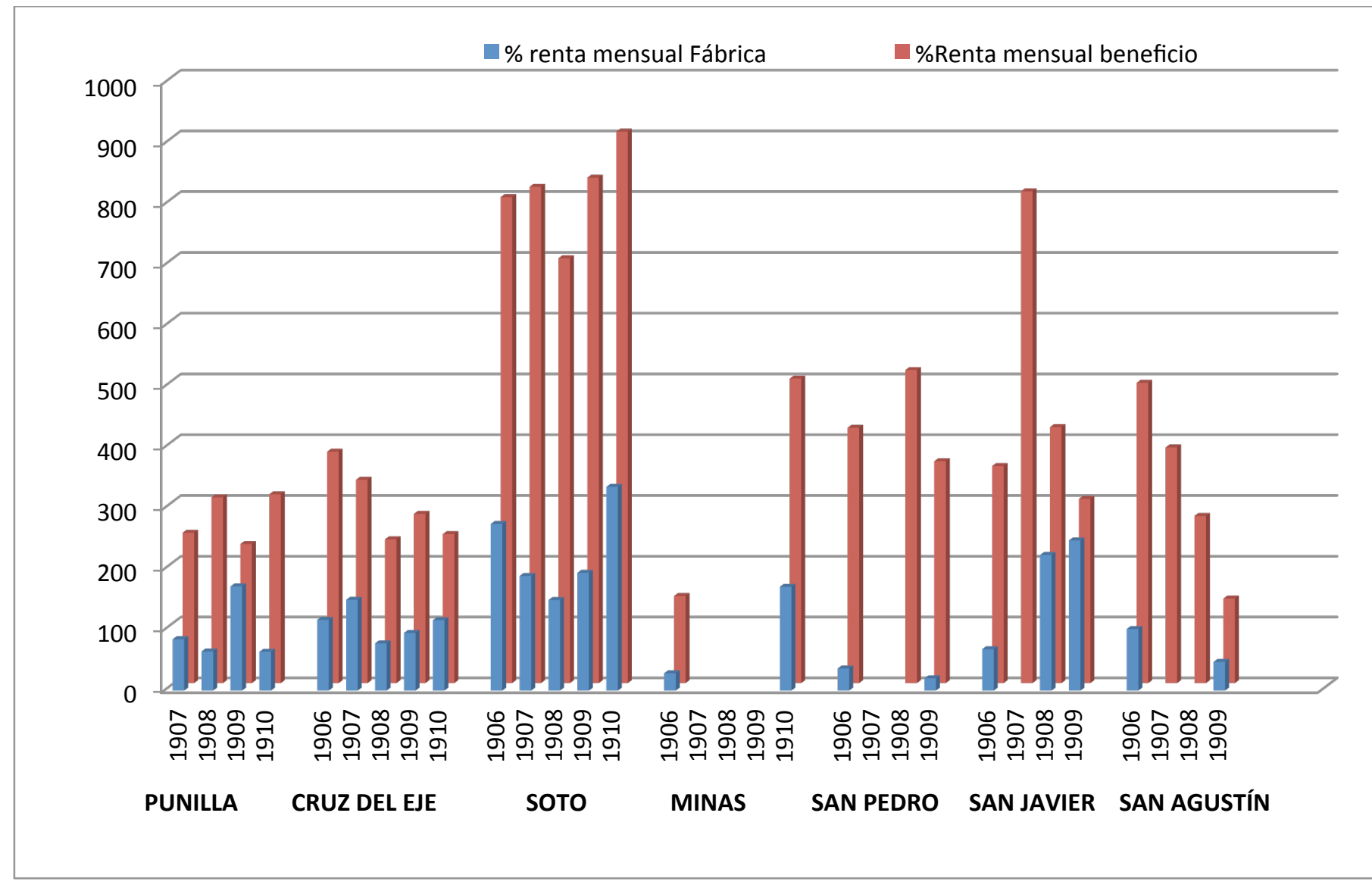

\subsubsection{Congruidad y sustentabilidad económica}

El Gráfico 6 nos muestra las diferencias de ingresos existentes entre los curatos del oeste (Cfr. Tablas 7 en Anexo II). Si bien los datos son incompletos, de todos modos, nos permiten sacar algunas conclusiones. A primera vista, el curato de mayor ingreso es Soto, cuya renta anual oscilaba entre $\$ 700$ y $\$ 900$. El otro dato significativo es la renuencia de los curas de Minas, San Pedro, San Agustín y Pocho a enviar datos. El cura de Pocho sólo envía los datos de tres trimestres del año 1907, cuyo renta era de \$409 y la fábrica de \$207.

\subsubsection{Consideraciones generales del obispo/visitador sobre la región del noroeste}

En cuanto a las apreciaciones del obispo durante las visitas, éste señala el arraigado sentimiento católico de los habitantes de la región. En Tulumba, dice que "hemos sentido el 
consuelo de ver que se conserva la fe religiosa en sus habitantes, sin los menoscabos y menguas producidos en diferentes puntos de nuestro Obispado por la acción del liberalismo, hemos podido observar que los tres últimos párrocos especialmente han continuado sus esfuerzos con recomendable celo a mantener viva e ilesa la fe y buenas costumbres". ${ }^{54}$ En las Sierras Grandes, "nos ha causado verdadero consuelo encontrar en toda aquella región inmaculada el patrimonio tradicional de la fe que sus mayores les legaron. No hemos encontrado ningún caso en que esta vacile o se viere rodeada por las nebulosidades de la incertidumbre. Esto hizo que bendijéramos varias veces aquella región de escabrosas faldas que se impusieron siempre a los propagandistas irreligiosos y no permitieron hasta ahora subir a sembrar sus ideas deletéreas". ${ }^{55}$ La misma impresión le causa la visita a los curatos de Calamuchita. Sin embargo, en todos remarca la falta de correspondencia entre creencia y práctica religiosa. Por ello, advierte que una de las aspiraciones de los párrocos debería ser promover actividades que coadyuven a "encarnar la religión teórica y práctica en los fieles que se le han encomendado, para infundir en todos ellos la piedad que los presenta como verdaderos católicos, para formar en ellos la práctica de los sacramentos y los hábitos de la vida cristiana, en el pueblo y muy principalmente en el seno del hogar, donde el cura debe vivir ayudando a los padres a formar cristianamente la familia; esta así debidamente formada es su principal triunfo, es la corona de su ministerio porque de aquí sale el pueblo con sus costumbres religiosas". ${ }^{56}$

En San Javier es más explícito cuando señala que el párroco no tiene que trabajar en "formar creencias en su feligreses, su trabajo debe referirse a que esa fe sea práctica, haciendo que en todos ellos se formen y se mejoren en su relación con el tiempo que transcurre, los hábitos de observancia de los mandamientos de la ley de Dios y de la Iglesia y los hábitos de frecuentar los santos sacramentos". ${ }^{57}$ Una de las principales dificultades para la práctica religiosa eran las distancias largas y escabrosas que tenían que recorrer para cumplir con las obligaciones y preceptos de la iglesia. ${ }^{58} \mathrm{~A}$ eso se sumaba que las iglesias

\footnotetext{
${ }_{55}^{54}$ AAC. Auto y Visita Canónica a Ntra. Señora del Rosario y Curato de Tulumba, 5 de octubre de 1910.

${ }^{55}$ AAC. Carpeta, Visitas Pastorales y Varios, 1887 a 1911. Auto de la Visita Canónica por la Sierra Grande e Iglesias del Valle de Calamuchita, 17 de enero de 1912.

${ }^{56}$ AAC. Carpeta Curia, Visitas Pastorales y Varios, 1887-1911. Auto de la Visita Canónica al Curato de Soto, Parroquia de Soto y Chañar, 21 de marzo de 1908.

${ }_{58}^{57}$ AAC. Carpeta Curia, Visitas Pastorales y Varios, 1887-1911.

${ }^{58}$ AAC. Carpeta, Visitas Pastorales y Varios, 1887-1911. Auto de visita Canónica por la Sierra Grande e Iglesias del Valle de Calamuchita, 17 de enero de 1912.
} 
existentes en las zonas serranas carecían de albergues indispensables para que los feligreses pudiesen pernoctar durante los días de las celebraciones religiosas. Las iglesias no contaban "ni una sola habitación para los concurrentes, como tienen generalmente todas las iglesias rurales del obispado haciéndose así modestísimo el concurso de los fieles, y casi imposible" ${ }^{59}$. Las estrategias pastorales sugeridas para atraer a los fieles al templo estaban relacionadas con el esplendor del culto en la funciones religiosas, "de modo que impresionen mejor a los fieles y sea más seguro el resultado de la piedad en ellos, ${ }^{60} \mathrm{a}$ fin de mantener viva e ilesa la fe y buenas costumbres". 61

Se recomienda a los párrocos rurales una acción permanente, como auténtico misionero, en todos los puntos de su curato, llevando los frutos de su celo a todas las personas, a todos los vecinos de cada iglesia y a todos los puntos donde haya agrupaciones. El objetivo era que no hubiese puntos en su curato en los que no se oyera la voz de la predicación, la enseñanza catequística y donde no abriese su confesionario para absolver los pecados y exhortar a los fieles al cultivo de las virtudes. Un punto importante tenía relación con el trabajo. El prelado señalaba que los párrocos debían sacar de la postración e inercia a "aquellas comarcas improductivas de criollos, asidas a la fe religiosa pero sin trabajar y sin cumplir la suprema ley que les impone el hacerlo durante seis días de la semana". ${ }^{62}$ Pero el sacerdote era uno solo y, por lo tanto, debía multiplicar su acción a fin de llegar a todos sus fieles y ampararlos contra todo mal espiritual. ${ }^{63}$

Las recomendaciones para las parroquias de estas zonas se centraron en: 1) aprovechar el arraigado sentimiento católico de la población y, mediante el esplendor del culto, incentivar la práctica religiosa, especialmente en las ceremonias de Semana Santa -por la que los fieles tienen tanta devoción-y las fiestas patronales. 2) Promover la enseñanza, eficaz y constante de la doctrina cristiana en la niñez, para ello se debía instituir donde no estuviera la Asociación de la Doctrina Cristiana y promover la utilización del catecismo aprobado por los obispos de Salta. 3) Realizar misiones en la parroquia y capillas del curato para celebrar con sacerdotes que le ayuden a la predicación y al confesonario. 4) Construir

\footnotetext{
${ }^{59}$ AAC. Carpeta, Visitas Pastorales y Varios, 1887-1911. Auto de visita Canónica por la Sierra Grande e Iglesias del Valle de Calamuchita, 17 de enero de 1912.

${ }^{60}$ AAC. Libro 45 Autos y Visitas Canónicas, f.41.

${ }^{61}$ AAC. Carpeta, Visitas Pastorales y Varios, 1887-1911. Auto y Visita Canónica a Ntra. Señora del Rosario y Curato de Tulumba, 5 de octubre de 1910.

${ }_{62}$ AAC. Zenón Bustos, Conferencia para párrocos del 29 de octubre de 1914.

${ }^{63}$ AAC. Zenón Bustos, Conferencia para párrocos del 29 de octubre de 1914.
} 
nuevos templos en las amplias zonas serranas, a fin de acortar las distancias y facilitar el cumplimientos de los preceptos eclesiásticos, edificar salones anejos a las parroquias, que permitan a los feligreses pernoctar allí, principalmente durante las ceremonias de Semana Santa. 5) Convertir a la parroquia en un foco de irradiación cristiana, que fomentara la constitución de las asociaciones de fieles como el Apostolado de la Oración. 6) Fomentar el trabajo durante los seis días de la semana, pues quien trabaja está menos expuesto al vicio y a las malas costumbres. Se concibe al trabajo como fuente de moralización.

\subsection{Parroquias de colonización mixta ubicadas en el centro de la provincia}

Esta región la integraban los departamentos de Totoral, Río Primero, Río Segundo, Tercero Arriba y Colón. Si bien el texto de Río y Achaval (1904) incluye el departamento de Tercero Abajo, nosotros, siguiendo Julio Rodríguez (1907), lo colocamos entre los departamentos colonizadores, dado que tiene el mismo comportamiento económico de los departamentos colonizadores de la región este.

Esta región comprendía en 1905, los curatos de Totoral, Chalacea, Santa Rosa de Río

Primero, Remedios, Villa del Rosario, Río Segundo, Jesús María y Colonia Caroya, Santa María, desmembrándose de ellos nuevos curatos, a lo largo del gobierno de Zenón Bustos. Si bien presentamos esta región y los curatos que la comprendían, como dijimos, no la analizaremos, debido a que nuestro objetivo central en esta tesis es realizar un análisis comparativo del noroeste y del sudeste. 


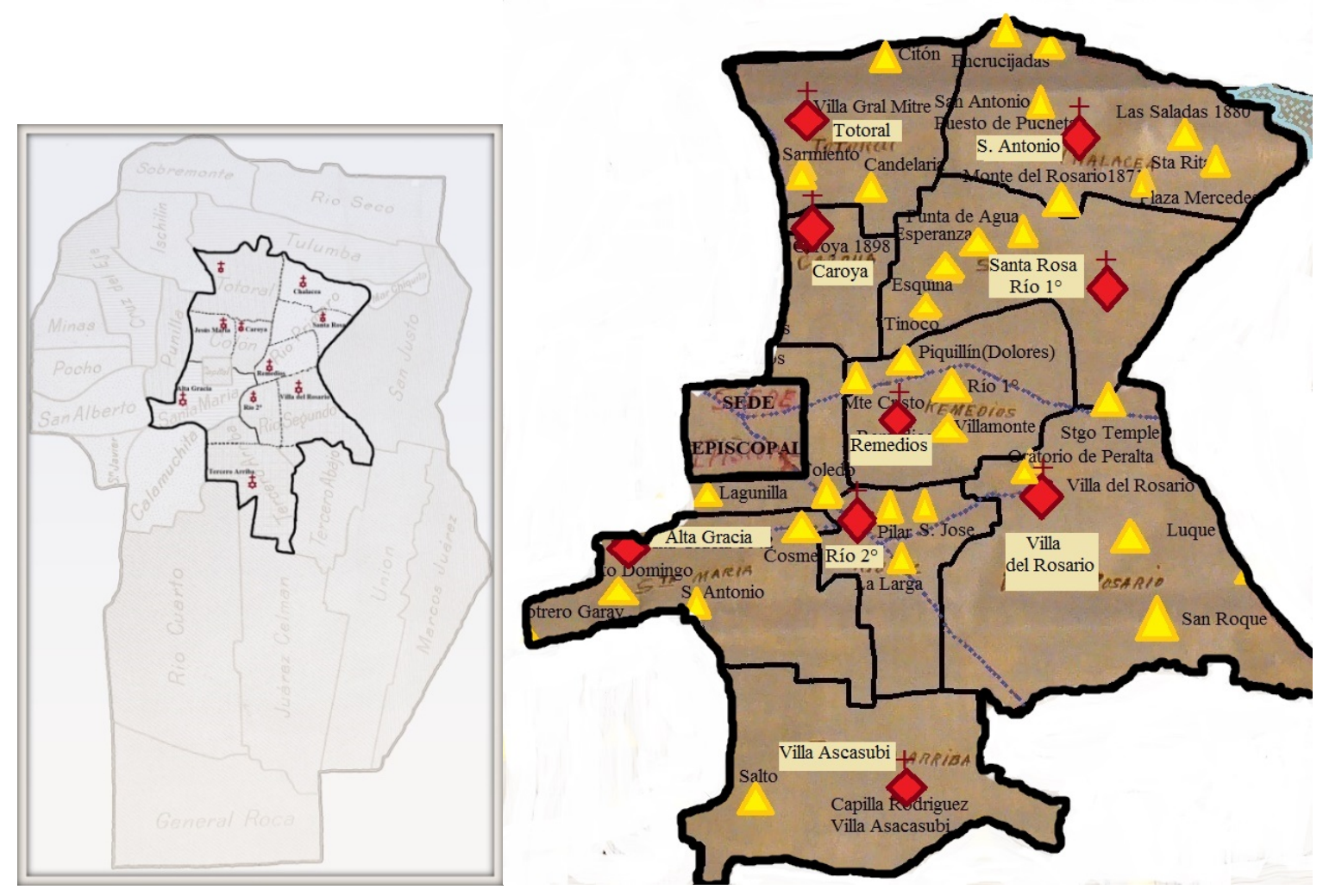

\subsection{Parroquias de colonización inmigrante del sudeste provincial}

Dividimos la región en tres sub zonas, el este, correspondiente al departamento de San Justo, el sudeste, con los departamentos Tercero Abajo, Unión y Marcos Juárez, y el sur, con Juárez Celman, Río Cuarto y Gral. Roca.

\section{El departamento de San Justo}

El curato de San Justo, erigido en 1860, es el más antiguo de la región. La cabecera se encontraba en Villa Concepción del Tío y la Iglesia parroquial fue reconstruida en 1884 por el cura y vicario Lorenzo Luz Cabrera, cuya titular era la Inmaculada Concepción. ${ }^{64}$ El curato tuvo varias modificaciones territoriales. El 18 de agosto de 1892 se desmembraron las pedanías Libertad y Juárez Celman, creándose los curatos de San Francisco y San Pedro (Morteros) ${ }^{65}$ En 1902, se desmembró la pedanía de Arroyito, erigiendo un nuevo curato, con sede en la Iglesia Nuestra Señora de las Mercedes. En 1917, se desprendió la pedanía

\footnotetext{
${ }^{64}$ AAC. Caja Villa Concepción del Tío.

${ }^{65}$ AAC. Caja Villa Concepción del Tío, fs.9-10.
} 
de Sacanta, conformando un nuevo curato con sede en Las Varillas. ${ }^{66}$ En 1925, se creó el curato de San Bartolomé que tomó parte del territorio de Villa Concepción y de Las Varillas. $^{67}$
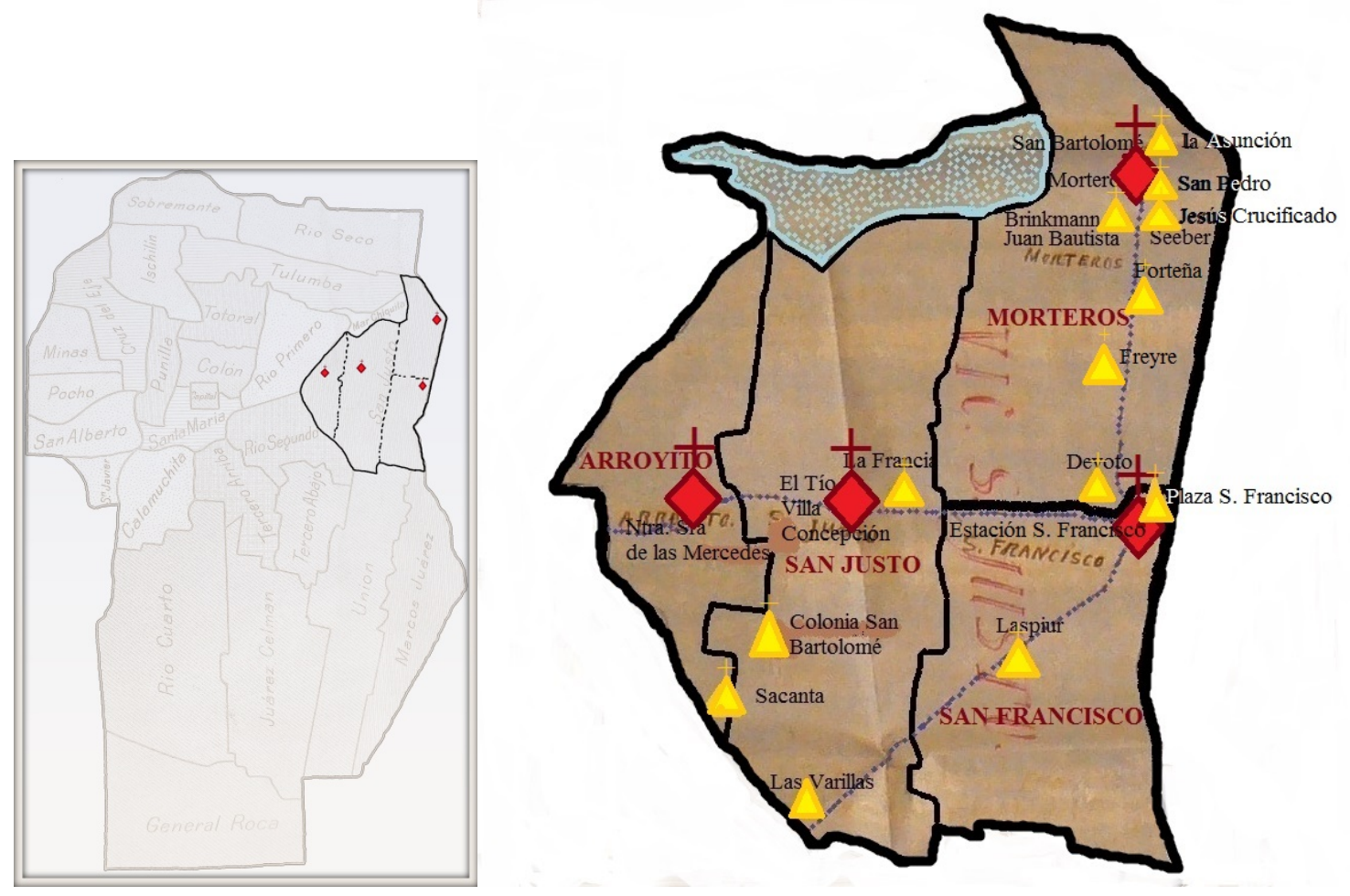

En 1917, tenía una población de 12.000 habitantes, en su mayoría católica. Entre los no católicos, se encontraban algunos mahometanos y protestantes que sumaban unas 40 personas, pero que no tenían templos ni escuelas. ${ }^{68}$ Había dos iglesias más, una en la estación La Francia, dedicada a la Virgen de las Mercedes, y la otra en la pedanía Sacanta, dedicada a San Agustín. Había también tres oratorios particulares, dos en Colonia San Bartolomé, uno propiedad de Bartolomé Amancio y el otro de Domingo, el tercero en

\footnotetext{
${ }^{66}$ Auto de creación del curato de Las Varillas del 30/07/1912. "Por cuanto el curato de villa Concepción del Tío resulta demasiado recargado para la atención de un solo cura, por la densidad de la población que aumenta día a día con la creación de nuevas colonias: oído el parecer del cabildo eclesiástico y del cura interesado, hemos resulto dividirlo tomando para formar el nuevo curato toda la pedanía de Sacanta y la parte que en ella entra la pedanía Concepción, que comprende las tres colonias de A Boero, BP de Córdoba y E Mayorga. El nuevo Curato se denominará del Rosario y la parroquia será la estación Las Varillas (Cfr. REOBA, 1912, p. 853).

${ }_{68}^{67}$ BEDC, vol. II, $\mathrm{N}^{\circ}$ 6, Abril de 1925.

${ }^{68}$ AAC. Caja Villa Concepción del Tío (San Justo), s/f. Respuesta al Cuestionario de la Visita Canónica, 23/04/1917.
} 
Colonia Impiria, propiedad de Juan Braudesco. Había dos capillas en construcción, una en Las Varillas, dedicada a la Virgen del Rosario, y la otra en Las Varas. ${ }^{69}$ En 1887 se había comenzado a construir un edificio para un colegio interno de niñas, el cual fue concluido 25 años después y encomendado a las Hermanas Mercedarias, quienes se hicieron cargo del mismo en el año $1910 .^{70}$

Respecto a la situación religiosa y económica del curato, debemos señalar que lamentablemente el cura no envió los datos pertinentes en las planillas, ni se registraron estos datos en el libro sobre el movimiento religioso y económico de los curatos, sólo sabemos que en 1905 y 1906 distribuyó 2.000 comuniones en el cuarto trimestre. En las respuestas al cuestionario de la visita canónica de 1917, el párroco señaló que más de la mitad de los hombres y una cuarta parte de las mujeres no cumplían con el precepto anual y que había muchos amancebados. En 1916, el cura Severiano Coronado informaba sobre el cumplimiento del auto de la visita canónica, en el que señalaba que se trabajaba para resolver dificultades que se oponían a la fundación del centro parroquial de acción católica social. Se habían predicado seis misiones en el curato, con no escasos resultados, y también se había logrado hacer clausurar tres casas de tolerancia e impedido la apertura de otras. En cuanto al trabajo social de la parroquia, el cura había establecido una cocina económica para pobres, "que cuenta con nueve meses de existencia y en la que diariamente se ha suministrado comida a diez y ocho familias pobres"; además, había abierto una escuela para niños pobres y proyectaba la fundación de un círculo católico de obreros. ${ }^{71}$ Respecto a la cuestión económica, el cura informó que las entradas eran de $\$ 100 \mathrm{~m} / \mathrm{n}$ y a veces de $\$ 200$.

Las fiestas patronales se celebraban el 8 de diciembre, pero en 1923 el Obispo auxiliar y Gobernador del obispado, José Luque dispuso el cambio de fecha para la celebración de las fiestas patronales: "Habiéndonos manifestado varios vecinos de respetabilidad por su piedad y dotes de buenos católicos los muchos e insuperables inconvenientes que tienen los feligreses para asistir a las fiestas de la Sma. Virgen patrona de este pueblo y obtener el fruto religioso que desean celebrándose en esta época de ocupaciones agrícolas que no

\footnotetext{
${ }^{69}$ AAC. Caja Villa Concepción del Tío. Respuesta al Cuestionario de la Visita Canónica, 1908.

${ }^{70}$ AAC. Caja Villa Concepción del Tío.

${ }^{71}$ AAC. Parroquias, Villa Concepción del Tío. Nota del 3 de octubre de 1916.
} 
pueden desentenderse, hemos dispuesto que todos los años se celebren dichas fiestas el día 24 de mayo dedicado a María Auxiliadora de todos los cristianos". ${ }^{72}$

El párroco Antonio Álvarez, al asumir sus funciones en 1920, envió un informe a la curia para referirse al "estado floreciente de la parroquia a nivel espiritual". En ese año, el curato comprendía cuatro capillas, San Antonio, San Bartolmé, La Francia y San Rafael. En cada uno de esos pueblos, existía una comisión pro-templo que pagaba $\$ 37$ al cura para tener una misa al mes. A su vez, informaba que en Balnearia, un pueblo de unas 4.000 almas, la comisión ofrecía pagar para tener una misa mensual y solicitaba al cura para dirigir la comisión que se encargaba de la construcción del templo. La capilla de San Rafael no pertenecía al obispado y el cura pensaba que no la entregaría, pues habían cambiado los dueños del campo donde estaba ubicada. ${ }^{73}$

El curato de San Francisco fue creado el 10 de agosto de 1892, desprendiéndose de Villa Concepción. Comprendía un territorio de 16 leguas de norte a sur por 7 leguas de este a oeste, en total unas 112 leguas ${ }^{2}$, según informa el cura párroco, Luis Jacinto Terzuolo, en 1905. El auto de creación señala que el nuevo curato comprendería unas 25 leguas ${ }^{2}$. La población total del curato la estimaba en 7.000 habitantes. La sede parroquial se encontraba en la estación San Francisco, con una población de 4.200 habitantes. Tenía varias capillas, la Plaza San Francisco, distante legua y media, nucleaba una población de 80 habitantes. La estación Devoto, con 450 habitantes, tenía una capilla dedicada a San José y distaba de la parroquia unas 4 leguas al oeste. La estación Freyre, 8 leguas al norte de la parroquia, estaba situada sobre el Ferrocarril Buenos Aires a Rosario -ramal a Morteros-, la capilla estaba dedicada a la Virgen del Rosario. Plaza Luxardo era una población de unas 40 personas, ubicada al noroeste del curato, que también tenía capilla, cuyo titular era San Roque, esta última no pertenecía al obispado aunque había sido bendecida y abierta al público por el Obispo Reginaldo Toro. Existían otros núcleos de población menores, como Quebracho Herrado y Santo Domingo que no tenían capillas, pero se proyectaba construirlas. El curato era atendido por tres sacerdotes, el párroco con residencia en San Francisco y dos tenientes, con residencia en Freyre y Devoto, respectivamente. ${ }^{74}$ El 7 de julio de 1911 se desmembró el pueblo de Freyre con sus respectivas colonias para formar

\footnotetext{
${ }_{72}$ AAC. Notas particulares del Obispo, 1884-1903, s/f., 1923.

${ }^{73}$ AAC. Caja Villa Concepción del Tío, fs.103-104.

${ }^{74}$ AAC. Compilación de datos sobre las parroquias... s/f., 29/06/1905.
} 
un nuevo curato. Las capillas de Devoto, Laspiur y Quebracho quedaron en el curato de San Francisco hasta 1925, cuando se crea el curato de Devoto.

En 1906, José Pío Cuesta informaba al obispado sobre cuestiones relativas al curato de San Francisco. En el informe señalaba que había estado con los capellanes en sus respectivas residencias. Advertía que la Iglesia de Devoto estaba bastante limpia y los ornamentos y demás útiles en orden. No así la de Freyre, que tanto Iglesia como sacristía eran una calamidad en cuanto a limpieza y orden. La enseñanza del catecismo era, según el capellán, "un desquicio", los niños no concurrían. El cura no sabía si eso sucedía porque la gente era muy despreocupada o porque el capellán no se preocupaba como debía. Respecto al estado moral del curato, señalaba que:

Todo le absorbe el deseo de medrar, todo se reduce a negocio, para estas gentes y en toda ocasión ya sea la más santa que uno puede hacer, no ven sino una cierta manera de negociar. Esto no hay para que decir de cuánto daño se causa. Debo advertir, que aunque hay sobrada indiferencia y mucha ignorancia, yo creía que esto sería peor, pues tenía desde tiempo ha, muy malos informes de este pueblo. Hay aquí un periódico malévolo dirigido, según me dicen, por el director de la Escuela Normal, pero como no siempre es fácil estinguir males, hay que ir despacio, para ver primero si uno simpatiza con estas gentes, que entonces ya es más fácil retirar lo que sea basura. ${ }^{75}$

El curato, durante este período, recibió cuatro visitas canónicas, 1907, 1915, 1917 y 1922. En el informe del cuestionario de la visita de 1915, la población había alcanzado el número de 15.000 y en la de 1917, llegó a 20.000 y una población no católica de 500 personas, sin templo ni escuelas. ${ }^{76}$

\section{Curato de Morteros}

El curato de Morteros, ubicado al noreste del departamento de San Justo, fue erigido el 10 de agosto de 1892, habiéndose desmembrado de Villa Concepción del Tío. La sede parroquial estaba en la iglesia de La Asunción, propiedad del fundador de la colonia Beiró. En 1899, la sede se trasladó a la Iglesia de San Bartolomé en la plaza del pueblo. ${ }^{77}$ El

\footnotetext{
${ }^{75}$ AAC. Leg. 49. San Francisco. Nota del 24/06/1906.

${ }^{76}$ AAC. Caja San Francisco, f.93.

77 AAC. Libro de Autos, 1876-1905, fs.179-180. El auto del 24/08/1899 dice lo siguiente: "Curato de Morteros tiene por parroquia la Capilla de la Asunción distante unas cuadras del pueblo. El nombramiento de parroquia le fue dado cuando no existía Iglesia en el centro. Que en la actualidad se ha construido una
} 
cuarto recibió tres visitas canónicas entre 1907 y 1925. ${ }^{78}$ Tenía una superficie de 22 leguas $^{2}$, la población, según lo informado por el cura párroco en los cuestionarios, era, en 1907, de 10.000 habitantes, sin saber la cantidad de no católicos. Había personas unidas sólo por el vínculo civil y también algunas que vivían en concubinato. El cura procuraba regularizar las uniones mediante visitas de personas piadosas.

La parroquia no tenía capellanías ni oratorios privados. Sin embargo, existía un considerable número de piezas destinadas para tal fin. El auto de la visita del obispo advierte que "las piezas que llevan el nombre de oratorios en diversos puntos de este curato no merecen tener el nombre de tales por no tener título canónico. Puede, sin embargo, si el cura lo creyere conveniente y prudente decir misa en ellos usando la licencia que tiene para celebrar en casas particulares siempre que fuese llamado por sus dueños y estos se comprometieran a reunir el acto de religiosidad, piedad y de actividad espiritual para los fieles que se congreguen: oyendo respetuosamente los sermones e instrucciones catequísticas, confesándose y comulgando y esto con ánimo de crear un derecho a favor de sus dueños en virtud de la costumbre que después quisieran". 79

El cura tenía, bajo su dependencia, un teniente en la colonia Porteña, y, en la colonia Vignaud, había dos padres Salesianos que se dedicaban a la enseñanza. En 1910, se estudió el proyecto de una nueva división de curatos en el departamento de San Justo, uno, formado los de Freyre y Porteña. Ambos resultaban congruos, por lo tanto, se procedió al desmembramiento y creación de los nuevos curatos. El Mapa 15 fue elaborado a partir de las respuestas a una circular de la curia enviada a las parroquias en 1924, en la cual se solicitaba lo siguiente: nombre del curato, fecha de fundacion según el Archivo Parroquial, fecha de comienzo de cada uno de los libros parroquiales: bautismos, matrimonios, confirmaciones y defunciones, pueblos que componen el curato, pedanía a la que pertenecían, si habían sufrido algún desmembramiento territorial y en qué fecha y si habían

dedicada al apóstol San Bartolomé con la piedad de los fieles que no podían sin gran dificultad llenar sus deberes religiosos por razón de la distancia y aislamiento de la capilla de la Asunción. Que el pueblo de Morteros ha crecido considerablemente. Que la capilla de San Bartolomé ha sido entregada enteramente con los terrenos adyacentes, por escritura pública al obispado. El diocesano ha designado un párroco con residencia fija. La Iglesia de San Bartolomé reúne los requisitos exigidos por Trento para ser erigida en parroquia. Se decide el traslado de la Parroquia de la Asunción a San Bartolomé”.

${ }_{78}^{78} 21 / 10 / 1907 ; 1915$ y 1917.

${ }^{79}$ AAC. Libro de Autos y Visitas, 1885-1916, f.83. 
tenido anexiones de territorios y en qué fecha. ${ }^{80} \mathrm{~A}$ la misma respondieron 49 de los 70 existentes a la fecha. Ademas, se recurrió a los autos de erección de los respectivos curatos, en los cuales se detallan los limites territoriales de los mismos. Estos datos se volcaron en un mapa provincial de 1924. En rojo se colocaron las sedes parroquiales y en amarillo las capillas e iglesias filiales.

\subsubsection{Rentabilidad económica de los curatos de San Justo}

$\mathrm{Al}$ analizar los números enviados por los curas sobre las rentas de fábrica y de beneficio, encontramos algunas cuestiones que nos llaman la atención. En primer término, las escasas entradas de la fábrica que tiene el curato de San Francisco, que no se corresponden con las del beneficio, o derechos de estola. En el auto de la visita canónica, el prelado advierte al cura que le llama poderosamente la atención que en el libro de fábrica no figure lo correspondiente a los entierros, cuando, sin embargo, están asentados en el libro de defunciones. Esta advertencia nos lleva a suponer que no siempre los curas eran tan honestos en las cuestiones económicas, ni pasaban a la fábrica de la Iglesia lo que establecía el arancel.

\footnotetext{
80 AAC. Compilación de datos relacionados con las parroquias de la arquidiócesis. Inicio del libro
} $31 / 05 / 1914$. 


\section{Mapa 15}

\section{Parroquias del Departamento de San Justo en 1925}

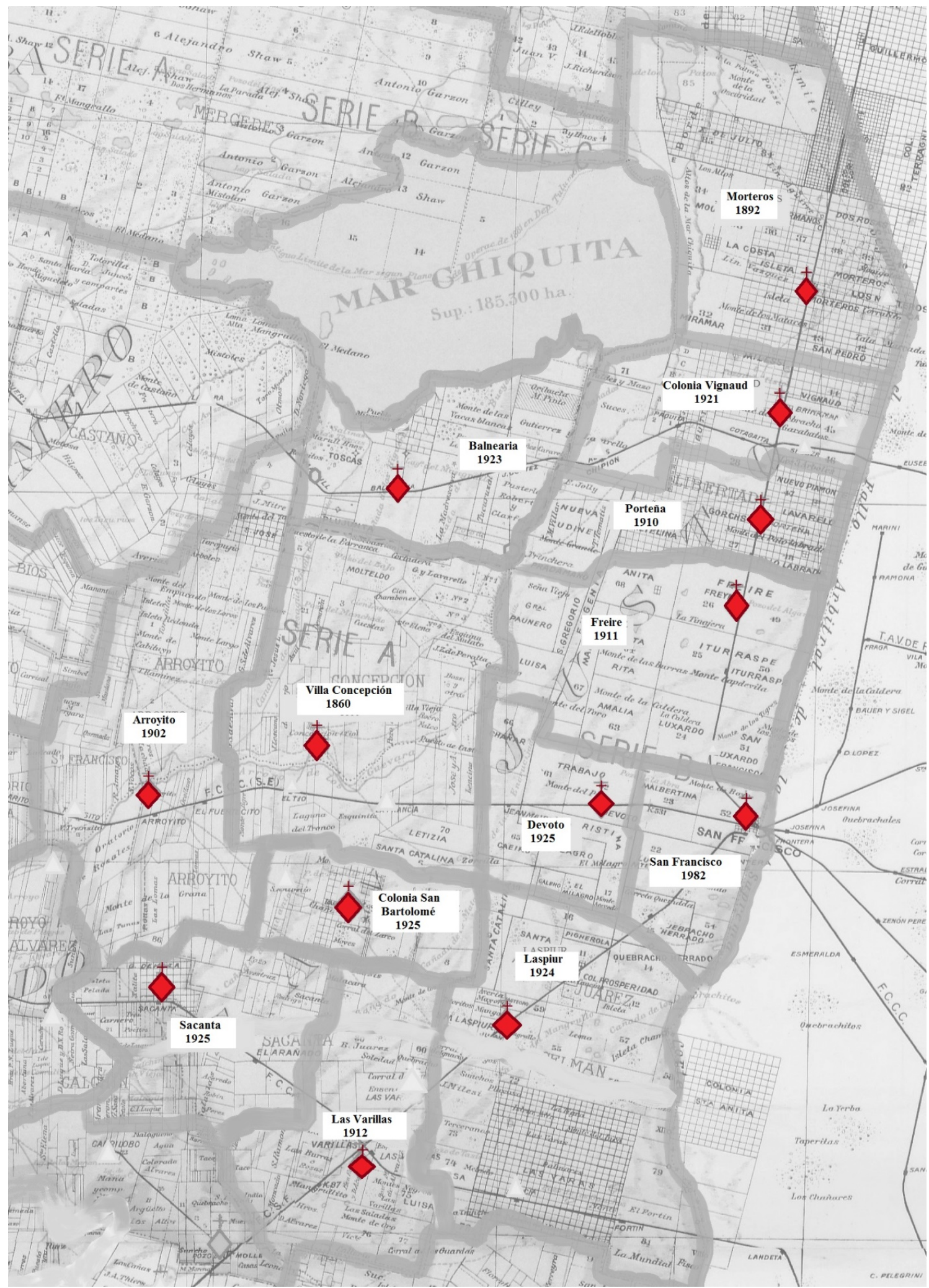




\section{Gráfico 7}

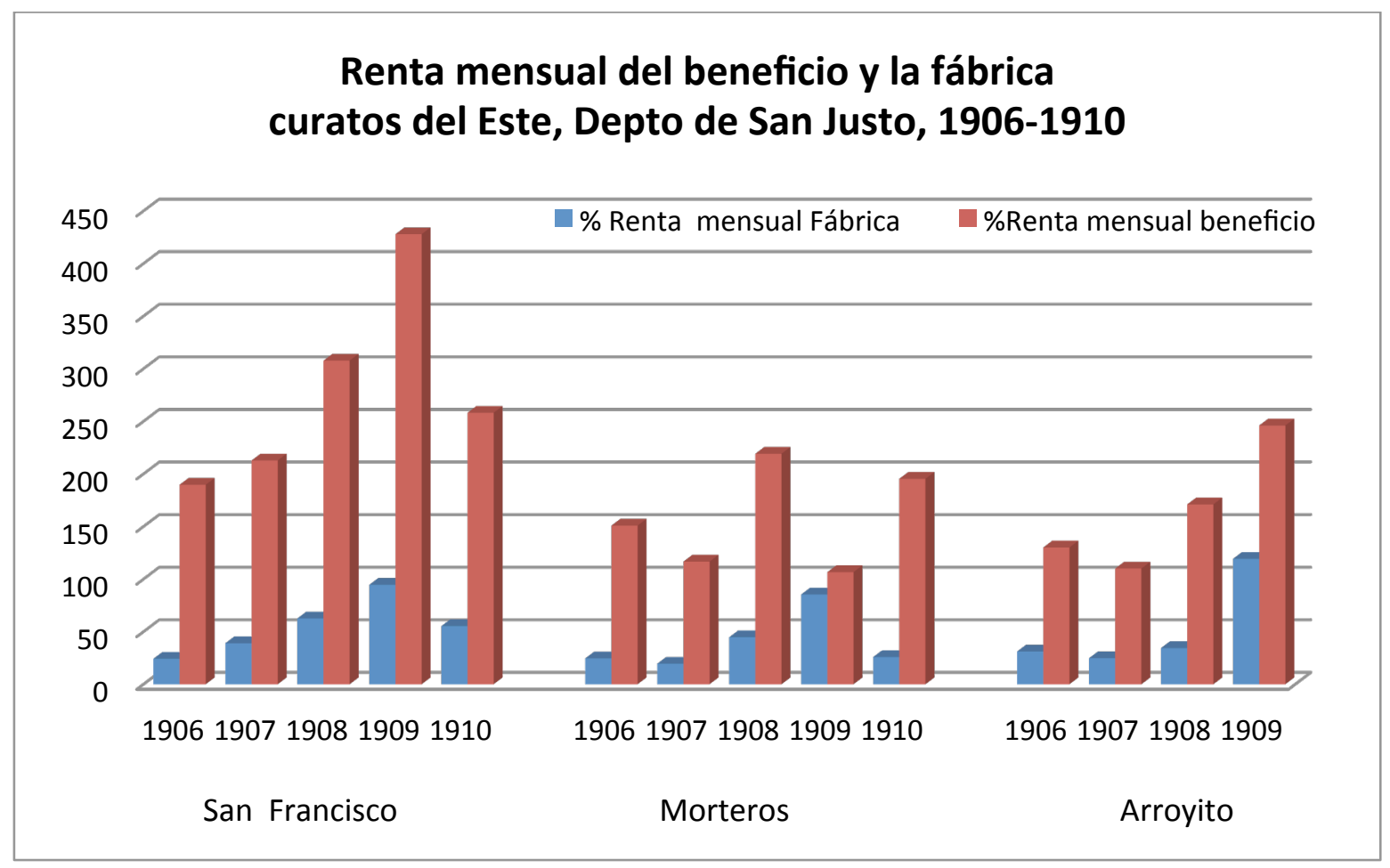

Departamentos de Tercero Abajo-Unión-Marcos Juárez

Curato de Villanueva

El Curato de Villanueva, fundado en 1838, era la cabecera del departamento de Tercero Abajo. El 10 de noviembre de 1874, Gaspar Martiarena, a la sazón Gobernador del Obispado, precede a la erección canónica del curato de Villa María, desmembrando la parte norte del departamento. El nuevo curato de Villa María comprendía las pedanías de Mojarras y Algodón, y a Villanueva se anexaron las pedanías de Pampayasta y Punta de Agua, que pertenecían al curato de Tercer Arriba. ${ }^{81}$ Villanueva tenía en 1906 una extensión aproximada de 15 leguas $^{2}$.

La feligresía era de 17.000 almas, la mayoría católica. ${ }^{82}$ En 1909 , contaba con varios templos. La Iglesia parroquial, dedicada a la Virgen del Rosario, estaba ubicada en la calle principal, frente a la plaza del pueblo, y una capilla pública, propiedad de la congregación de las Hermanas Terceras Franciscanas, y 9 capillas distribuidas en Dalmacio Vélez (300 habitantes), dedicada, una, a la Virgen de Luján, la de Punta de Agua a la Virgen del

\footnotetext{
${ }^{81}$ AAC. Leg. 30, s/f. División del curato de Villanueva y creación del Curato de Villa María.

${ }^{82}$ AAC. Leg. 48. Fraile Muerto (Bell Ville), Villa Nueva, f.485.
} 
Rosario, la de Perdices a la Virgen del Rosario, la de Pampayasta Sud a la Inmaculada Concepción, la de Palestina a la Virgen del Rosario, la de General Cabrera (1.200 habitantes) a San José, la de Deheza (1.000 habitantes) a la Asunción o Tránsito y la de Arroyo Cabral a San José. ${ }^{83}$ En 1919, los vecinos de la colonia Pasco construyeron una Iglesia y la donaron al obispado. ${ }^{84}$ A lo largo del período 1906-1925, sufrió varios desmembramientos para la erección de nuevos curatos: en 1910, el de Gral. Cabrera, en 1913, el de Dalmacio Vélez, y en 1923, el de Etruria.
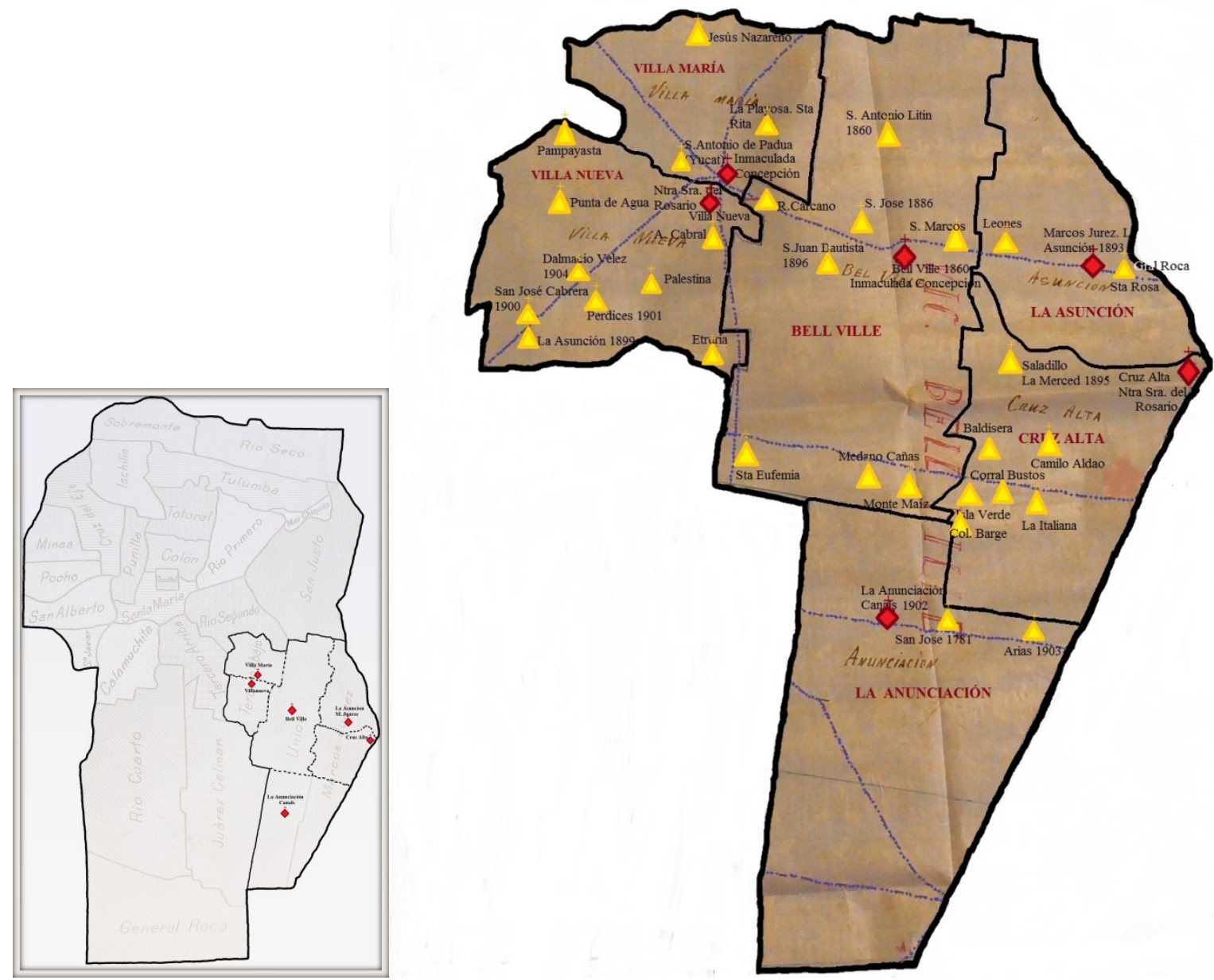

El curato estaba atendido por un párroco y un ayudante. Éste recibió la visita canónica el 24 de noviembre de 1905 y, en 1913, en el auto, el obispo dejaba expresa constancia de la

\footnotetext{
${ }^{83}$ AAC. Leg. 48. Fraile Muerto (Bell Ville), Villa Nueva, f.681.

${ }^{84}$ AAC. Parroquias: Villa Nueva, f.70.
} 
necesidad de la predicación y de la enseñanza de la doctrina en niños y adultos, ${ }^{85}$ y en la visita de 1913, señalaba la necesidad de que "con mayor frecuencia se promuevan los actos de culto en los pueblos de Sanabria, Ansonia y Laguna, procurando en esta estaciones lotes de terreno para hacer iglesias en cada uno de ellos". ${ }^{86}$ En 1914, en su visita a la nueva parroquia de Dalmacio Vélez, el obispo observaba que la acción parroquial debía orientarse y llegar a lograr "una piedad general de los fieles, en primer lugar por la santidad del ministro, que tiene esto como punto fijo de mira, la regularidad de vida de los feligreses y la salvación de las almas y en segundo lugar para que el culto pueda ser ayudado por los fieles a revestirse del debido esplendor. Desde luego se impone la conveniencia de formar una acción católica frecuente en todos los centros de población que tenga el curato, haya o no iglesia, las comisiones para la enseñanza del catecismo, la piedad por medio de la celebración frecuente de la santa misa, de la predicación ávida del evangelio y de la formación de asociaciones del Apostolado del Corazón de Jesús, de María y otras de este género. La comunión frecuente de los fieles tan interesadamente encomendada por el Santo Padre lo mismo que los niños de primera comunión y la frecuencia de sacramentos en general que merece una atención e interés especial en todas las parroquias". ${ }^{87}$

\section{Curato de Villa María}

El curato de Villa María ocupaba la parte norte del departamento de Tercero Abajo, con una superficie aproximada de 15 leguas $^{2}$ y 13.000 habitantes. Según el párroco, existían personas no católicas, pero no se podían calcular, ya que no era una población estable. Había protestantes (salvacionistas) y masones, los cuales tenían un local-salón en la villa, aunque, dice, "que no tienen adoradores no habiendo reunión porque están desorganizados". ${ }^{88}$ El párroco señalaba que era difícil la conversión porque, en general, era gente de mala fe, sin embargo, para ese fin, utilizaba hojas volantes, periódicos, opúsculos de apologética y conferencias públicas. La parroquia contaba con varios templos, el parroquial y una capilla dedicada a San Antonio, a cargo de las Hermanas Franciscanas, la de San Antonio en la pedanía de Yucat, la de Jesús Nazareno en la pedanía de Los Zorros,

\footnotetext{
${ }^{85}$ AAC. Libro de Autos de Visitas, 1885-1916, f.25. Fecha de la Visita 24/11/1905.

${ }^{86}$ AAC. Carpeta Curia, Visitas Pastorales y Varios, 1887-1929, s/f.

${ }^{87}$ AAC. Carpeta Curia, Visitas Pastorales y Varios, 1887-1929, s/f. Fecha de la Visita 06/05/1914.

${ }^{88}$ AAC. Cajas Parroquias: Villa María, f.169, sin fechar, respuesta al interrogatorio de la visita pastoral.
} 
la de la Virgen del Carmen en estación Algodón, la de San José en colonia Silvio Pellico, y la de las Mercedes a cargo de los Padres Mercedarios. El curato no tenía rentas fijas y para el cura las entradas "varían, hay meses en que las entradas llegan a 200 y meses a 350". El curato tenía una escuela parroquial y un colegio católico.

En el período sufrió algunos desmembramientos. En 1911, se creó el curato de Oliva y en 1913, el de la Playosa. ${ }^{89}$ El auto de la visita canónica de 1906 reflejaba la preocupación del obispo por evitar "el contagio irreligioso con que sus fieles se ven invadidos por numerosos agentes que la confluencia de los trenes le trae a la población”, animaba al cura a poner empeño en el "cultivo religioso que los pueblos como éste necesitan para iniciarse, incorporando en sus hábitos de la manera más conveniente la moralidad en las costumbres y la pureza de la fe en su doctrina y bien comprende que promueve los elementos mutuos de sociabilidad y de bienestar más indispensable". Para ello, un instrumento de la mayor eficacia sería animar a los fieles a asistir al templo para las funciones religiosas, el vía crucis y así influir para lograr "un saludable ambiente religioso y social". 90

El cura de La Playosa, parroquia desmembrada de Villa María, eleva una consulta a la curia a fin de ejercer el ministerio pastoral con mas eficacia. Señala que el curato tenía importantes núcleos de población pero que carecían de templo para celebrar los divinos oficios y, dada la necesidad de facilitar a los fieles el cumplimiento de sus deberes religiosos, consideraba necesario realizar las celebraciones en lugares adecuados y en puntos estratégicos de la campaña, donde los fieles pudieran concurrir fácilmente. Para ello, solicita el permiso oportuno, para binar los domingos y días festivos y para facultar a cualquier otro sacerdote que se encontrara en su jurisdicción para celebrar cuando fuese necesario. ${ }^{91}$ Para dar mayor realce a las funciones que se celebraban en la parroquia, pide permiso para realizar la exposición pública del Santísimo Sacramento en todas y cada una de las iglesias de su jurisdicción todos los domingos y fiestas de precepto del año, todo el mes de junio, durante los Novenarios del Sagrado Corazón de Jesús y las fiestas patronales de la parroquia, y de cada una de las capillas y sus respectivos novenarios, para celebrar la fiesta de Corpus Christi con procesión pública a la mañana o a la tarde, luego de las fiestas patronales de la parroquia y de cada una de las capillas. Todas estas solicitudes fueron

\footnotetext{
${ }^{89}$ AAC. Datos Parroquias, Villa María. Respuesta a la Circular de 1924.

${ }^{90}$ ACC. Libro de Autos y Visitas Pastorales, 1885-1916, f.29-30. Fecha de la Visita 26/10/1906.

91 AAC. Cartas Arzobispado 1910-1954 (citada por Nivello Mariana).
} 
concedidas desde el obispado, excepto la exposición del santísimo, que sólo se podía realizar en la parroquia Santa Teresa de Jesús por ser sede del curato.

\subsubsection{Sustentabilidad económica}

El curato de Villanueva, ubicado al frente de Villa María, en la ribera opuesta del río, tenía menores ingresos que este último. En el Gráfico 8 se observa la rentabilidad de cada curato.

\section{Gráfico 8}

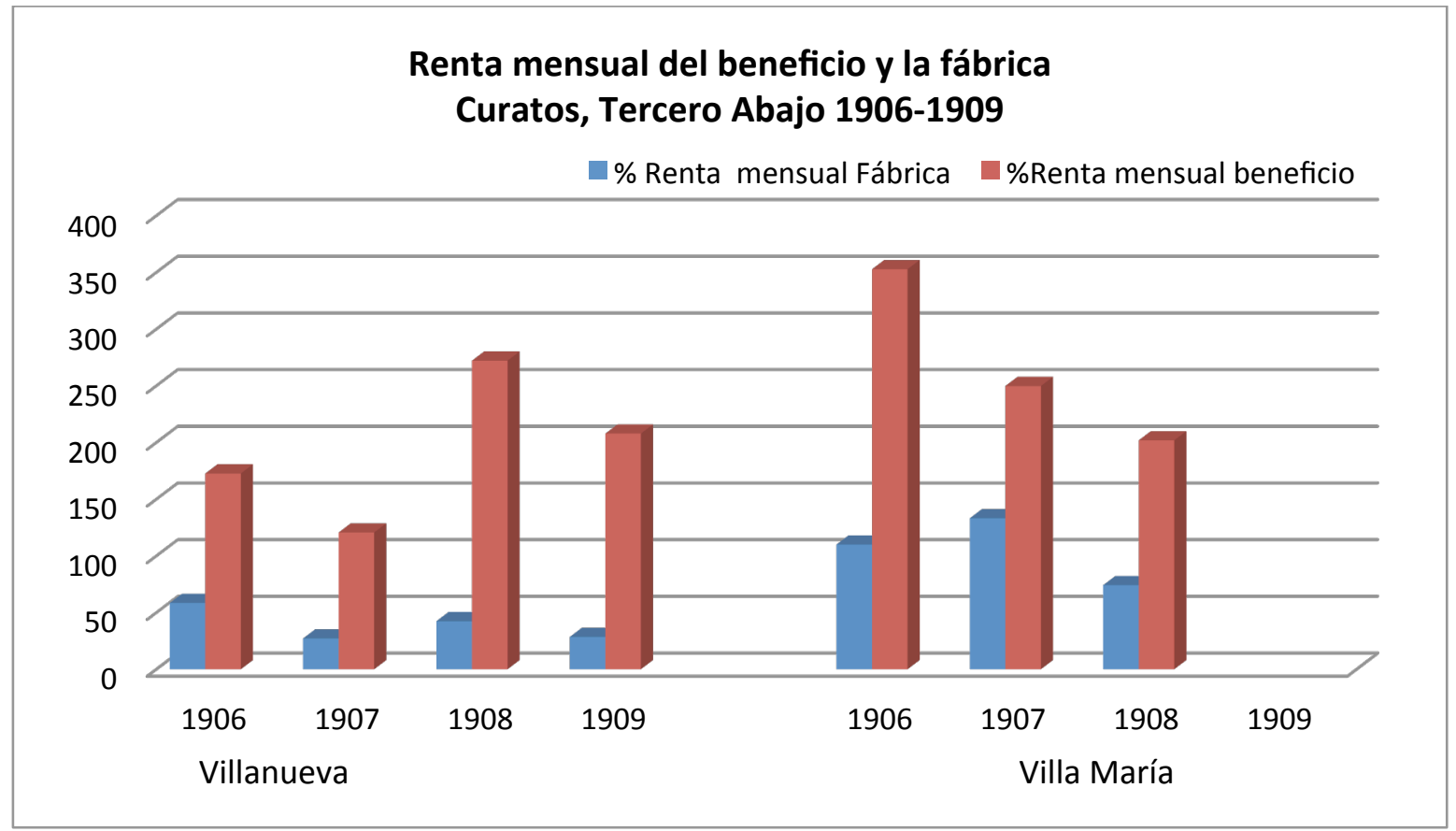

\section{Departamentos de Unión y Marcos Juárez}

El curato del Bell Ville es la cabecera del departamento de Unión, erigido en 1860. En el período que nos ocupa 1905-1925, estuvo atendido por el cura párroco Angulo y dos tenientes. En las respuestas al cuestionario de la visita de 1906, el cura advierte que la población alcanzaba el número de 34.000 habitantes, distribuidos, 9.000 en el municipio y 25.000 en la campaña. Ésta era católica casi en su totalidad, aunque la mayor parte no era practicante. Respecto a los no católicos, señalaba que "es muy difícil responder, diría imposible saber ni siquiera aproximadamente el número de habitantes no católicos de esta parroquia. Dado que no tenemos censo, ni es posible realizar el status animorum”. El cura 
predicaba los domingos y días festivos y tres veces a la semana durante la cuaresma. Se celebraba el mes del Rosario y de Mercedes. Entre los feligreses, había no católicos y abundaban las uniones civiles. Y entre las congregaciones y asociaciones, contaba con el Apostolado de la Oración, Conferencias Vicentinas, Congregación de la Doctrina Cristiana y una Sociedad Católica de Socorros Mutuos, no había círculo de obreros, pero el Apostolado ejercía una función mutualista. No tenía rentas, "pudiéndose calcular las eventuales en $\$ 365$ mensuales. Es un promedio aproximado porque varía mucho la renta en los diferentes meses del año". 92

El curato tenía cuatro iglesias, la parroquial, la de San Antonio de Litín, la de Ballesteros, dedicada a San José, y la de San Juan de Ballesteros al sur. Además, había tres oratorios privados, dos en la colonia de San Bartolomé y el tercero en la Colonia Impira.

La Iglesia parroquial se comenzó a construir en 1869 y se terminó en 1871. Si bien el curato lleva el nombre de San Gerónimo, la patrona es la Inmaculada, pues "el día siete de diciembre de mil ochocientos ochenta y cinco fue bendecida por el cura que suscribe la Imagen de la Purísima Concepción, Patrona Principal del Curato y colocada en la Iglesia Parroquial". 93 La capilla de Lítin quedaba a $30 \mathrm{~km}$ al norte de la parroquia, ubicada en el centro de la pedanía de Litín, que era muy poblada, su titular es San Antonio de Padua y vice-titular la Virgen del Carmen. Estaba edificada en un terreno de cuatro manzanas, donado por Samuel Ceballos. La Iglesia de Ballesteros tiene como patrono a San José, edificada en un terreno donado por Cayetano Allende y la de San Juan de Ballesteros o Ballesteros sud tenía a San Juan Bautista como su patrono. En cuanto a la población, la Villa de Bell Ville contaba con 6.000 habitantes, Ballesteros con 1.500 y San Juan de Ballesteros $600 . .^{94}$

En 1902, se desmembró parte de su territorio para formar el curato de la Anunciación con cabecera en Canals. En 1908, el cura Angulo dió la conformidad para la creación del curato de Villa Ascasubi, el cual contaría con seis pueblos: Monte Maíz, Médanos de Cañas, Liebres, Pascanas, Etruria y Santa Eufemia, dos iglesias habilitadas, dos concluidas,

\footnotetext{
92 AAC. Caja Bell Ville, s/f. Respuestas a los Cuestionarios de las Visitas Canónicas del 10/08/1906 y 21/11/1914.

${ }^{93}$ AAC. Caja Bell Ville, f.4.

${ }^{94}$ AAC. Leg. 52. Curato de Bell Ville, s/f. Nota del 15/05/1910.
} 
que aún no estaban bendecidas, y dos más en construcción. ${ }^{95}$ En 1913, se erigió el curato de Leones, en 1917 el de San Antonio de Litín y en 1918 el de San José de Ballesteros. En cuanto a la religiosidad de la población, el capellán de Litín informaba la "poca asistencia a misa y a la divina palabra, menos frecuencia todavía de sacramentos. El sagrario apenas se abre más que para los desposados y para renovar". 96

En agosto de 1906, recibió la visita canónica del Obispo Bustos. En el auto de la misma, el obispo manifestaba su preocupación porque el número de habitantes era superior al ministerio de los tres sacerdotes que atendían la parroquia, por lo tanto, éste se concentraba en los nucleos de población, en los que, lamentablemente, existían "los elementos disolventes" que llegaban de afuera. Quedaban sin atención más de trece estaciones de las diferentes líneas férreas que atravesaban el curato, que tenían un núcleo de población importante y las colonias. Para poder superar esta deficiencia solicitó a los curas que multiplicaran las obras populares que "sirven al pueblo de conducto por donde lleguen a los fieles las enseñanzas de la moral, la religión y la piedad, con mayor facilidad, como son las asociaciones, que por su índole, pondrán mayor concurrencia de auditorio bajo las instrucciones de su palabra". Para ello, el prelado insistía en el cultivo esmerado de la Sociedad Católica de Socorros Mutuos, la creación de la Sociedad de San Vicente de Paul y en comunicar un espíritu nuevo al Apostolado de la Oración.

Para aumentar la piedad del pueblo recomendaba la devoción al Smo. Sacramento, con prácticas eucarísticas, como la misa y la exposición de los jueves, la comunión frecuente y las primeras comuniones de niños, dándoles la importancia de mayor solemnidad. Teniendo la parroquia a la Inmaculada como patrona, el prelado insistía en fomentar las devociones marianas, como el rezo del rosario diario, en la parroquia y en cada familia, que se viviera el Mes de María. Otro punto central del auto es la recomendación de aumentar la predicación y las horas en el confesionario como "los dos recursos de la evangelización que, ejercidos con regularidad, más eficazmente acentúan la fe de los pueblos. Funcionando el púlpito y los confesionarios, la piedad se radica y florece en las poblaciones".97 Por último, respecto a la sustentabilidad económica, debemos decir que no hay datos, ya que los curas no enviaron ninguna planilla al obispado.

\footnotetext{
${ }^{95}$ AAC. Leg. 52. Curato de Bell Ville, s/f. Nota del 31/01/1908.

${ }^{96}$ AAC. Leg. 52. Curato de Bell Ville, s/f. Nota del 28/11/1908.

${ }^{97}$ AAC. Autos de Visitas, 1885-1916, f.52. Fecha de la visita 10/08/1906.
} 


\section{El curato de la Asunción, con asiento en Marcos Juárez}

El curato de La Asunción, con cabecera en Marcos Juárez, fue erigido el 10 de octubre de 1893. Abarcaba un amplio territorio que se desmembró para dar origen a nuevas parroquias, Leones e Isla Verde en 1913, Corral de Bustos en 1924 y Los Surgentes en 1926.

En 1905, tenía una población de 16.000 habitantes. Los centros más importantes eran la Villa de Marcos Juárez con 6.000 habitantes y Leones con 1.500. La iglesia matriz y cabecera del curato se había comenzado a construir bajo el impulso de una comisión protemplo y el cura párroco de Bell Ville era Eduardo Ferreyra. Al poco tiempo de haberse inaugurado, se erigió como cabecera del nuevo curato de La Asunción. El cura párroco, Elmiro Ruiz, impulsó la construcción de la casa parroquial. Además de la Iglesia parroquial, contaba con tres capillas, Ntra. Sra. del Rosario en Leones, Santa Rosa en Estación Roca, y San José al norte.

El departamento de Marcos Juárez fue uno de los que registró el mayor aumento de población de la provincia, los extranjeros llegaron a representar el $45 \%$ del total de sus habitantes (Río y Achaval, 1904: 34). La Villa era, a fines del siglo pasado, una colonia "gringa", integrada por italianos venidos del Piamonte y de las Marcas. Los italianos se agrupaban en dos sociedades, Unione e Benevolenza y Volere e Potere, fundadas en 1893 y 1897, respectivamente. Ambas se fusionaron en 1903, dando lugar a la Sociedad Italiana de Socorros Mutuos. También había una importante comunidad española, representada por la Casa de Comercio de la familia Lardizábal y la Sociedad Española de Socorros Mutuos. Los inmigrantes suizos-alemanes, a su vez, se nucleaban en la Sociedad Suiza de Marcos Juárez (Municipalidad de Marcos Juárez, 1987: 100).

La Iglesia parroquial tenía bajo su dependencia una infinidad de colonias agrícolas y nuevas poblaciones, en su mayoría de inmigrantes. En 1895, se desprende el territorio del sudoeste para formar el curato de Cruz Alta y en 1913 el oeste para formar el curato de Leones.

El cura párroco contaba con la colaboración de varios capellanes, que no siempre lograba someter a su jurisdicción y obediencia. En la visita canónica de 1907, el obispo señalaba que "la iglesia parroquial es cabeza y corazón de la feligresía, a ella le toca hacer las contribuciones que más aseguren los buenos resultados, proponerlos a otros y cuidar que 
las ejecuten colocada sobre la porción que se le ha confiado. Después de haber dado planes a sus capellanes, debe reunirse con ellos cada cuatro meses en un punto convenido a conferenciar el modo como se hubieron cumplido y a concertar otros nuevos para lo sucesivo con conocimiento necesario de cada punto". Otro de los puntos que preocupaban al prelado era la ignorancia de la religión por parte de los fieles. En este sentido, consideraba que era "el mayor enemigo del cura celoso y es por general el muro en que se estrellan sus mejores esfuerzos dirigidos a cultivar la religión. Ni pueden amar la Religión que ignoran. Ni pueden prestarse a modelar por ella sus actos desde que ignoran su santidad y pureza". Otro de los puntos, hacía referencia a poner los medios para evitar las uniones ilícitas, "el párroco que en esos fieles reconoce a sus ovejas, de cuyas almas debe responder a Dios si por prescindencia suya así muriesen no debe constituirse en observador pasivo de estos desordenes, por otra parte tan nocivos a la moral pública. Conviene que visite a esas almas acompañado de un seglar aceptable si así aconsejare la prudencia". ${ }^{98}$ La segunda visita realizada en 1914, deja constancia de la encomiable labor del párroco en el ejercicio de su ministerio, en particular la difusión de la buena prensa, mediante el boletín parroquial de la Familia Cristiana.

\section{Curato de Cruz Alta}

El curato de Cruz Alta, antigua posta de Cabeza de Tigre, fue erigido como tal en 1895, desmembrándose de Marcos Juárez. El cuestionario de la visita canónica de 1907 informaba que la parroquia tendría de 10.000 a 11.000 habitantes, distribuidos de la siguiente manera: Cruz Alta, 2.500; Camilo Aldao, 1.500; pueblo italiano, 200; estación Corral de Bustos, 150; estación Isla Verde, 250; El Progreso, 100; Los Matacos, 150; Baldicera, 50; El Saladillo, 150; colonia de Cruz Alta y Juárez Celman, 600; y colonia Elisa, 400. Según el cura, había una familia protestante y en Isla Verde, seis o siete familias holandesas de la misma religión, que no tenían escuela. También existían algunas logias masónicas, en Cruz Alta había una con 12 o 15 miembros principales, en Elisa con 6 o 7 y en Isla Verde con 5 o 6 . Tambien funcionaba una escuela particular, denominada "Instituto Rivadavia", dirigida por un masón. El párroco contaba con la colaboración de tres tenientes que atendían las capellanías, con residencia en Colonia Barge, Colonia

\footnotetext{
${ }^{98}$ AAC. Carpeta Curia, Visitas Pastorales y Varios, 1887-1929, s/f.
} 
Italiana e Isla Verde. En 1913, se desprende la pedanía de La Calera al sur para formar el curato de Isla Verde y en 1915 se erige la parroquia de Camilo Aldao. El curato recibió en 1904, 1906, 1912 y 1914 las visitas canónicas.

\section{Sustentabilidad económica}

La realidad económica de cada curato es muy difícil de determinar, ya que las planillas que se envían son incompletas y por otras fuentes sabemos las dificultades que tenían los párrocos para percibir los derechos de estola que les correspondían, debido a que los capellanes y/o ayudantes, con frecuencia, no se los remitían. Las quejas al respecto son permanentes. En el Gráfico 9, se vuelcan las respuestas enviadas y, como puede observarse, las entradas de la fábrica eran realmente exiguas.

\section{Gráfico 9}

Renta mensual del beneficio y la fábrica en los curatos del este, 1906-1909

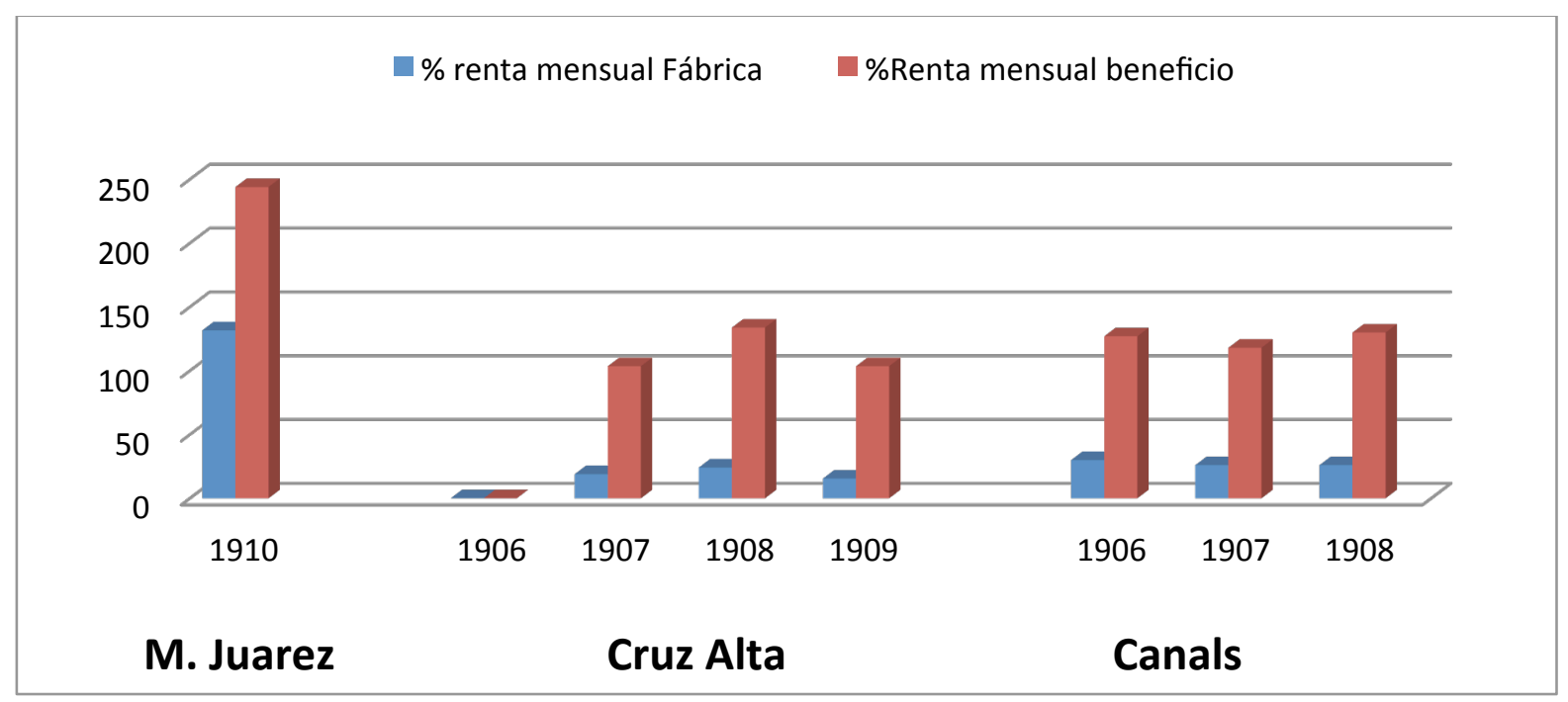

En el Mapa 16, presentamos los curatos existentes en 1925 en los departamentos mencionados y la fecha de su fundación. 


\section{Mapa 16}

Parroquias de los Departamentos de Tercero Abajo, Unión y Marcos Juárez en 1925

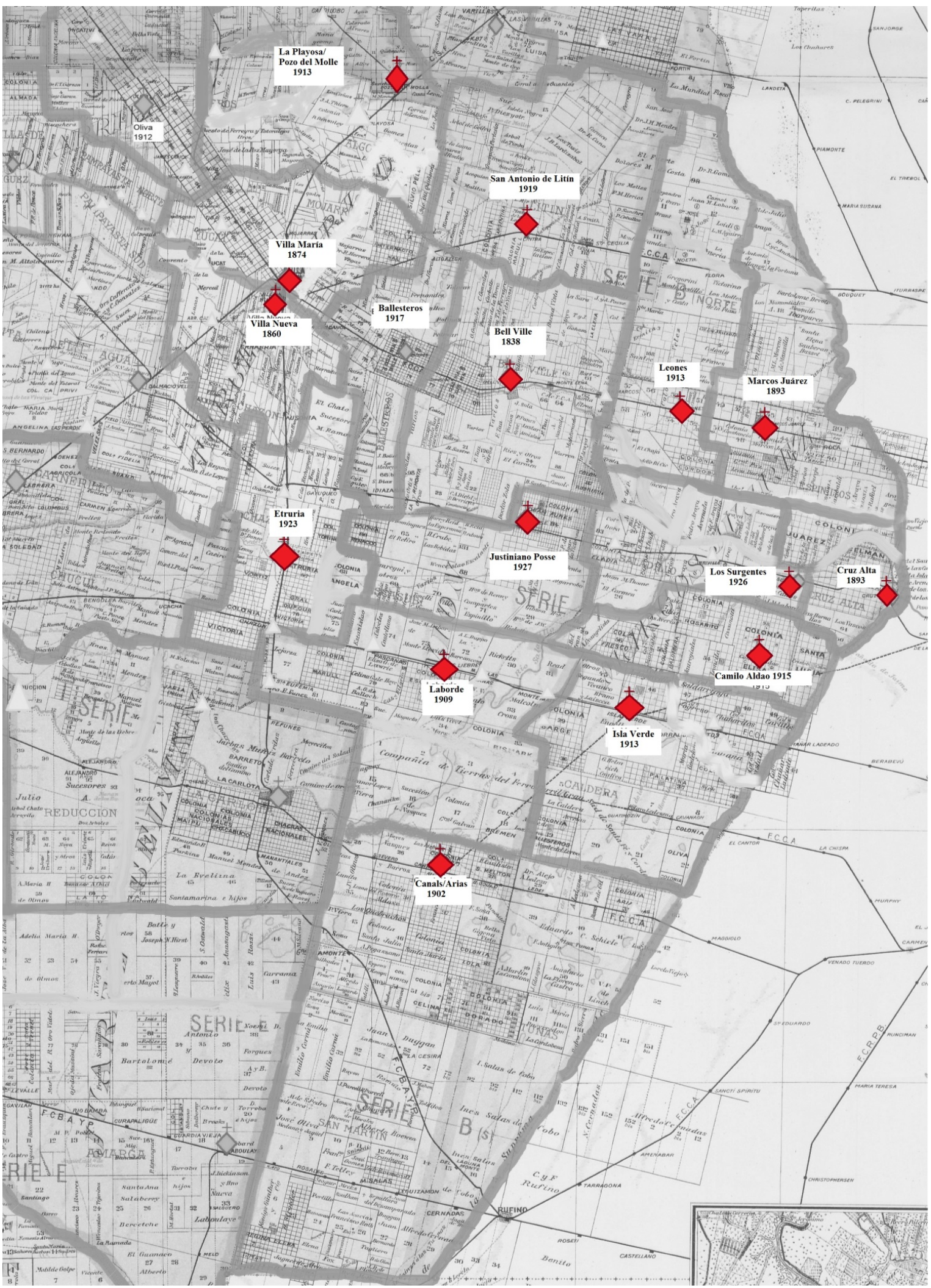




\section{Departamentos de Juárez Celman, Río Cuarto y Gral. Roca}

El curato de Río Curato estuvo encomendado hasta el año 1903 a los Franciscanos de Propaganda Fide, que tenían su convento en la Villa. A partir de esa fecha pasó a ser regenteado por el clero secular. El cuarto abarcaba un vasto territorio, del cual se fueron desmembrando partes para la erección de nuevos curatos.
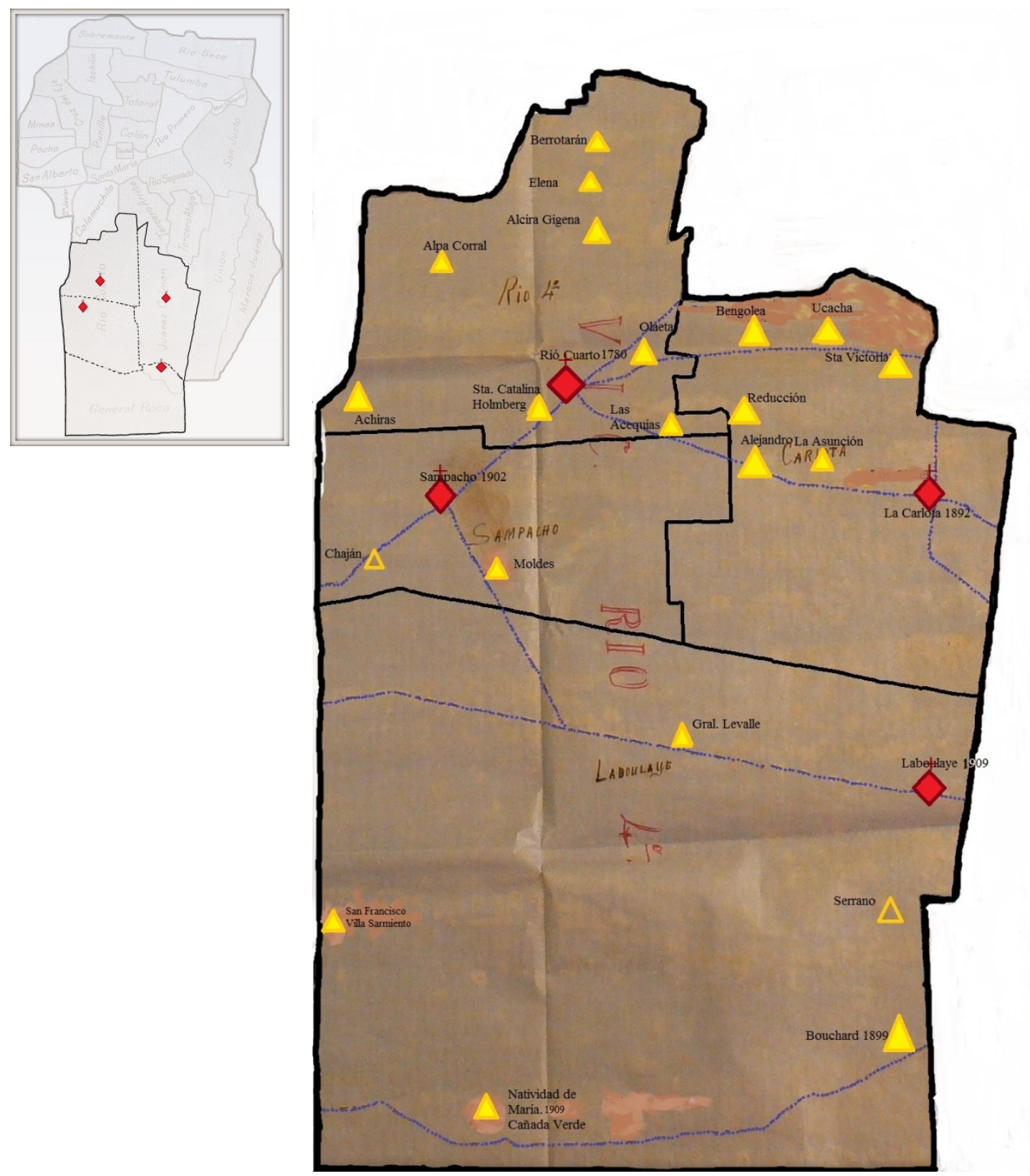
En 1892, se erigió La Carlota; en 1901, Laboulaye; en 1902, Sampacho; en 1909, Cañada Verde (Villa Huidobro); en 1910, Gral. Cabrera; en 1913, San José de Tegua (Alcira Gigena); 1924, Cnel. Moldes. La región recibió las visitas canónicas en 1906, 1909, 1912, 1913, 1914, 1917 y 1918. De esto se desprende que la región preocupaba a la jerarquía.

\section{Sustentabilidad económica}

En el Gráfico 10 se presentan las entradas de fábrica y las rentas del beneficio. Llama la atención la gran diferencia que presenta el curato de Laboulaye entre ambas entradas. La explicación la encontramos en la mala administración ejercida por el cura párroco Amancio Rodríguez, quien recibió una serie de denuncias por parte de los feligreses. Las mismas tenían relación con custiones morales y económicas.

En 1911, el ayudante de Laboulaye, Esteban Lobera, italiano, escribe al Internuncio apotólico la siguiente nota:

Quería transmitirle un suelto de "La Voz de las colonias de Laboulaye de fecha 8 de octubre de 1908 en que se decía que andan pocos feligreses a la iglesia porque el cura es muy inmoral y que la Iglesia no progresa porque hay malversación de fondos", pero como me pidio cinco pesos desiti: Si VE lo quiere con mucho gusto lo compro cueste lo que costare.

Voy a hablar de asuntos que se desarrollan en Jovita, pueblo puesto sobre el canal de Laboulaye a Villa Valeria. Un señor de Jovita llamado Juan M Larraburu, hombre muy honrado me dijo: he denunciado al Cura Rodríguez al Sr Obispo de Córdoba con cuatro hechos concretos y pidiéndole un emisario para interrogar a los testigos y poniéndole mi casa a su disposición. Todo es público, no solo hablan de estas cosas los hombres sino tambien las mujeres. Si V.E. no se preocupa no se a donde va a parar.

El dia 20 de julio de 1910 antes de nuestra llegada a Jovita las esquinas tenian un cartel con esta inscripción "Ojo al cura Rodríguez, que es un sodomitico". Últimamente muchos hombres de Santa Magdalena, estacion Jovita decretaron de echar al cura Rodríguez con una demostración hostil y quejas. Las causas son varias [...]. Lo echaron de Pasco, de Cañada Verde, de General Levalle y ahora de Santa Magadalena y tambien de unas estancias. Pobre Iglesia! Pobre Iglesia! Todo es verdad lo narrado hasta aquí, por ahora basta. ${ }^{99}$

\footnotetext{
99 ASV. Archivo Nunciatura Argentina, Nuncio Locatelli, Libro 17. Diócesis de Córdoba, fs. 177-179.
} Reclamos contra el párroco de Laboulaye. Carta del Pbro. Esteban Lovera al Internuncio, 19/02/1911. 


\section{Gráfico 10}

\section{Renta mensual del beneficio y la fábrica en los curatos del sur, 1906-1909}

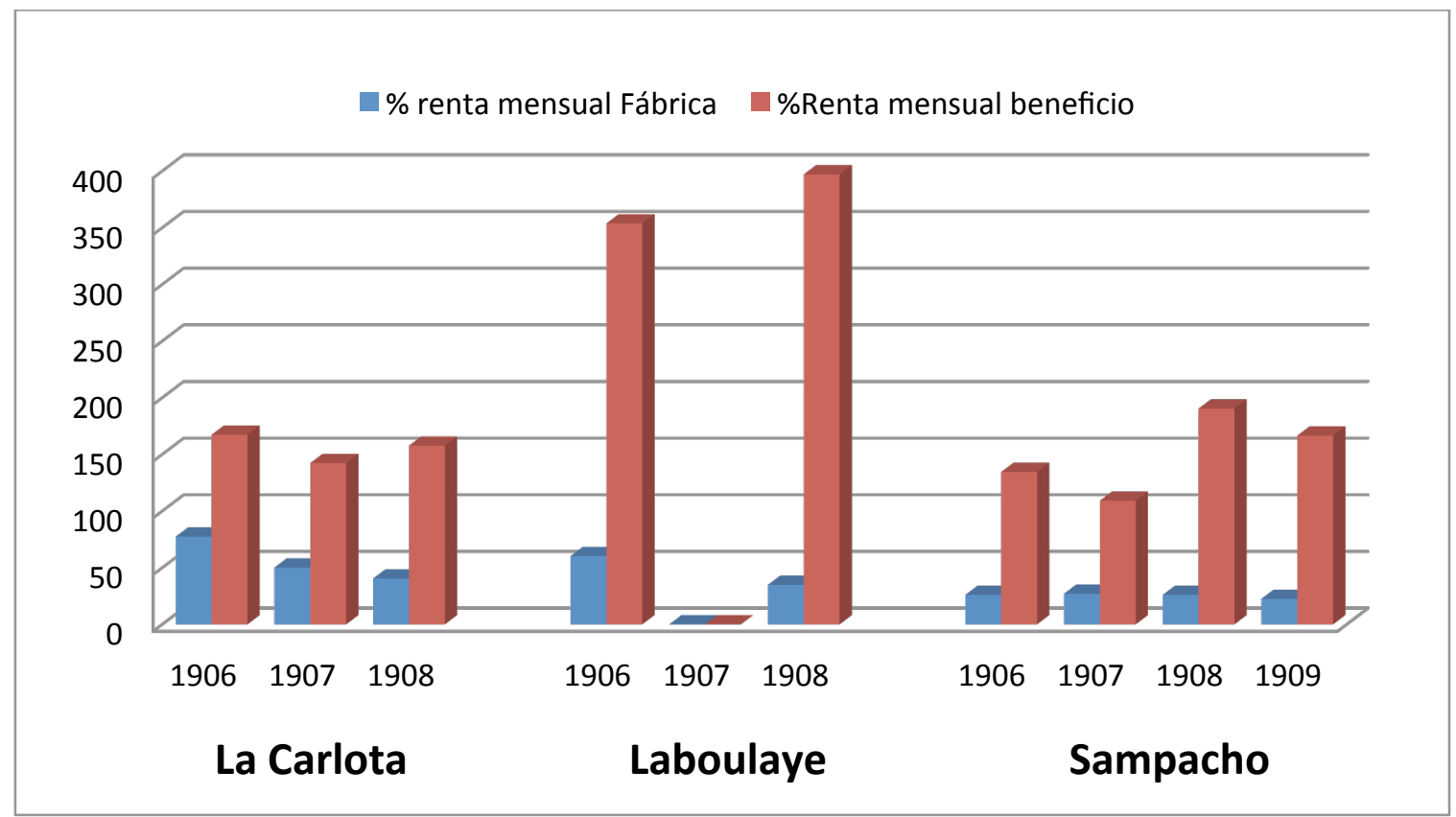

\subsubsection{Balance sobre la percepción de los curatos del sudeste}

De los autos de visita se desprende la opinión que el obispo se había formado sobre la realidad moral y religiosa de los curatos del sudeste. En 1906/1912, se insiste en la cuestión del templo, la necesidad de concluirlos, ampliarlos, etc. Las respuestas proporcionadas en los cuestionarios de la visita confirman la centralidad del cura en la vida social y religiosa de los poblados, ya que la exactitud de las anotaciones muestran cómo él era consciente no sólo de los sacramentos, funciones y enseñanza del catecismo, sino también de la conducta social, los pecados privados y públicos y de la moralidad de la población. La pregunta $\mathrm{n}^{\circ}$ 40 de la visita abierta en 1905 hace referencia al sacramento del matrimonio, se interroga si se procuraba que los novios se acercaran a los sacramentos, si en la parroquia había personas unidas solamente por el vínculo civil, y, en caso afirmativo, qué se hacía para que regularan su situación. Las respuestas a esta cuestión manifiestan, en general, un acabado conocimiento de sus feligresías. ${ }^{100}$ El cura de Villa Concepción del Tío, departamento de

\footnotetext{
${ }^{100}$ Un ejemplo esclarecedor, aunque corresponda a un curato de la periferia de la ciudad, es el informe enviado por el cura de San Gerónimo, quien adjunta, al cuestionario de la visita, una hoja suelta. En el listado, figuran los feligreses que vivían amancebados o no cumplían con el precepto pascual:

* Ramón Torres Casado vive amancebado Díaz Rodríguez Calle Santa Fe al frente de la empresa de tranvía.
} 
San Justo, Miguel Ludeña, responde que "se procura que se confiesen y comulguen y lo hacen siempre. Pocas parejas solo tres o cinco tengo noticias que viven amancebados. Procuro que ningún feligrés mío esté casado solo civilmente". ${ }^{101}$ En Cruz Alta, había “muchas personas casadas solo civilmente y aún sin esta unión”. ${ }^{102}$ La pregunta $n^{\circ} 4$ del cuestionario correspondiente a la visita abierta en 1912, dice “¿Qué población no católica se calcula? ¿Tiene templos? ¿Cuántos? ¿Cuántas escuelas tienen? ¿Por qué medios se procura su conversión?”. El Cura de Las Varillas, un curato que tiene una población de 7.000 a 8.000 habitantes, responde, concisamente, que "hay no católicos, unos protestantes $\mathrm{y}$ otros cismáticos de nacionalidad alemana, rusa y turca. No tengo datos fijos pero no serán más de cincuenta o sesenta". ${ }^{103}$ El cura de Villa María señala que había "salvacionistas", que tenían un local pequeño, y masones, con un salón más grande, pero no tenían demasiadas reuniones, pues a criterio del cura estaban desorganizados. Al cura le resultaba difícil lograr la conversión, pues entendía que eran "gente de mala fe en general". Sin embargo, señalaba que se procuraba la conversión mediante "hojas volantes, periódicos, entrega de opúsculos de apologética y conferencias públicas". 104 "Y el de

\footnotetext{
* Amancebados públicos Gregorio Tablada con Senaida Quintero Calle Colón No 1003

* José Carballo y Rosario Romero calle sin número

* Rudecinda Gonzáles y la hija, con Quintero (atrás al lado del cementerio)

* Petrona Barrera con NN

* Luis Bustos con Rosario N Calle Colón

* Lorenzo Molina con NN Cementerio

* Cirilo Sánchez con Petrona Paredes Cementerio

* Amancebados y adúltera públicamente: cabo Martínez con María de Gallardo

* Brígida Gallardo con empleado de policía

* Sofía Gallardo en casa non Santa calle Colón

* Manuela Tablada Cementerio

* Mercedes Capeto Cementerio

* No se confiesan ni oyen misa: Tomás Victorino Suárez, la vieja que ha vivido muchos años en mala vida murió [...] Pastora de Gigena y familia no se confiesa ni oyen misa. La familia Santilli

* Familia de Aguirre no se confiesan ni oyen misa

* José Carrizo y mujer no se confiesan ni oyen misa

* La vieja Santos Varela e hija no se confiesan

* La viuda de Villagra y el viejo Villagra

* José Barrera y familia

* José Santillán

* Domiciano Varela y familia Cementerio

* María Bracamonta de Lallana y familia

* La peonada del cementerio casi todos los que rodean el cementerio (Cfr. AAC. Carpeta San Gerónimo. Respuestas a las preguntas del cuestionario de la Visita Pastoral de 1906).

101 AAC. Caja Parroquias, Villa Concepción del Tío, f.124-127.

${ }^{102}$ AAC. Caja Parroquias, Cruz Alta, s/f.

${ }^{103}$ AAC. Caja Parroquias, Las Varillas, s/f.

${ }^{104}$ AAC. Parroquias Villa María, f.169, sin fechar.
} 


\section{Mapa 17}

\section{Parroquias de los Departamentos del sur en 1925}

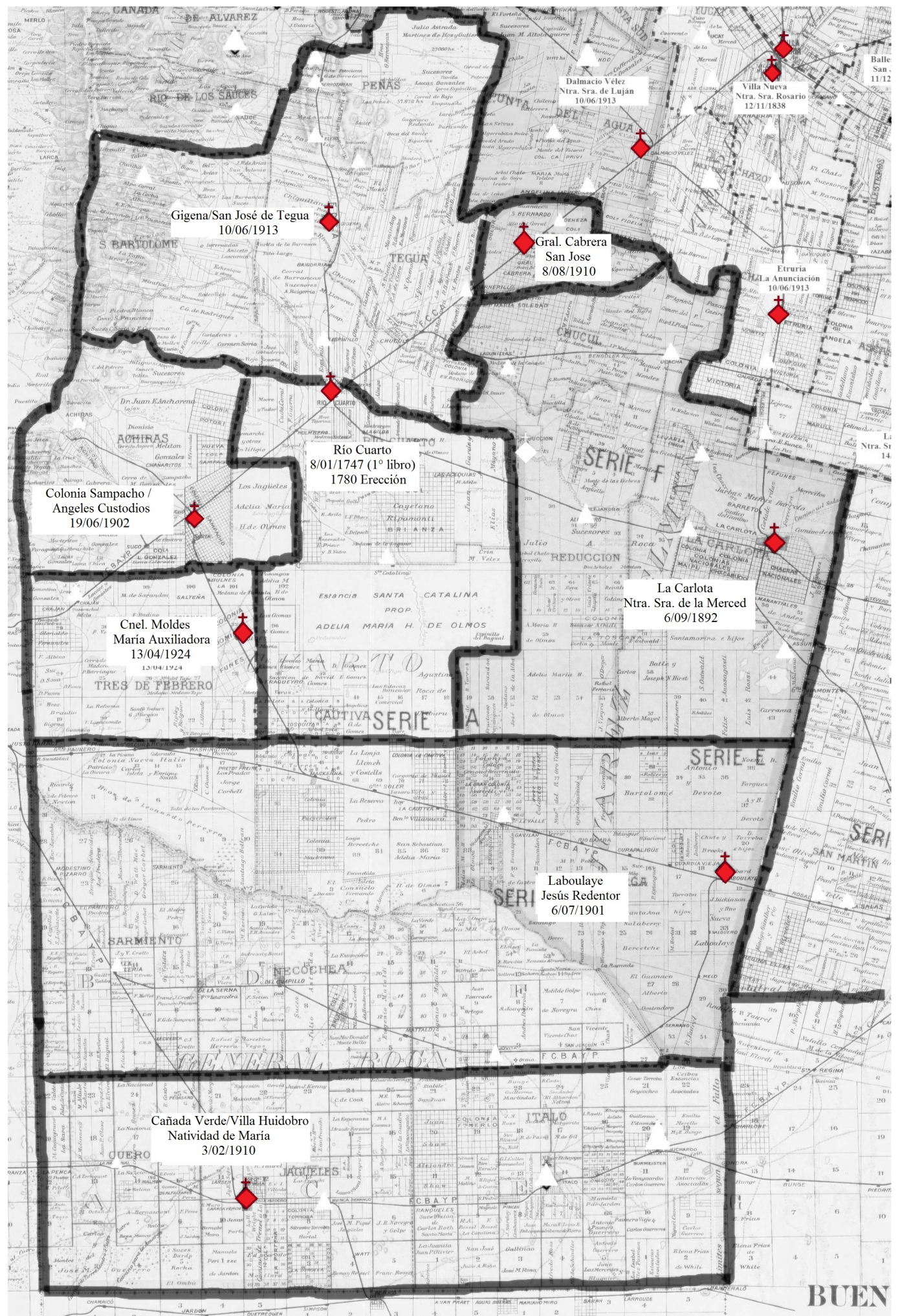


Villanueva responde que 'no católicos propiamente dichos, es decir refractarios' eran muy pocos". 105

Los curatos asentados sobre las líneas férreas corrían el peligro de la influencia de "los propagandistas de las malas ideas y doctrinas". Los párrocos previenen el sentimiento liberal de una parte considerable de la población y de la acción de los librepensadores que "agita impugnando el sentimiento religioso tradicional y saludable de la buena doctrina". El diocesano advierte en los autos que la facilidad de las comunicaciones permitía que su doctrina se irradiara y llegara a todos los centros poblados asentados a lo largo cada una de las líneas férreas. El obispo convoca, entonces, a los párrocos a trabajar para ganar, para la Iglesia, a "todos los que trabajan por marchitar la fe religiosa, las prácticas y observaciones de los mandamientos de Dios y de la Iglesia, como así mismo a los que hacen carrera de profesión de propagandistas, de perturbadores del orden social y encarnizados enemigos de las autoridades constituidas". Para lograrlo, cuentan con el templo que debe ser "el baluarte que la defiende de esos asaltos y los sacerdotes que la dirijan, los soldados que impugnen las malas doctrinas con las armas de la doctrina evangélica, predicando con ilustración, piedad y paciencia". ${ }^{106}$ El sentimiento católico que animaba a la población debía ser fomentado por el apostolado sacerdotal, exhortaba a los curas a realizar una labor de catequesis más incesante, teniendo en cuenta que hasta hacía relativamente poco tiempo "se creía y no se discutía, mientras que ahora se discute y no se cree ni practica". ${ }^{107}$

La población de estas regiones era en su mayoría católica, pero no siempre era practicante. ${ }^{108}$ Los mayores obstáculos para la práctica religiosa eran, para el diocesano, la difusión de las doctrinas anticatólicas, la ignorancia religiosa y la excesiva dedicación al trabajo que caracterizaba a los colonos.

"La ignorancia de la Religión en los fieles es el mayor enemigo del cura celoso y es por general el muro en que se estrellan sus mejores esfuerzos dirigidos a cultivar la religión. $\mathrm{Ni}$ pueden amar la Religión que ignoran. Ni pueden prestarse a modelar por ella sus actos desde que ignoran su santidad y pureza". ${ }^{109}$ Esa ignorancia debía ser neutralizada con la

\footnotetext{
${ }^{105}$ AAC. Leg. 48, Fraile Muerto (Bell Ville) Villa Nueva, f.485.

${ }^{106}$ AAC. Leg. 48, Fraile Muerto (Bell Ville) Villa Nueva, f.1357.

${ }^{107}$ AAC. Zenón Bustos Obispo. Documentación Varia, Caja No 4. Visita Canónica a la Parroquia NS de la Purísima Concepción de Río IV, f.1356.

${ }^{108}$ AAC. Carpeta Parroquias: Bell Ville, f.10.

${ }^{109}$ Libro 45, f.374.
} 
enseñanza de la doctrina, principalmente, en el seno familiar, el cura debía "encarecer a los padres y madres de la familia el deber que les incumbe de enseñar de diario en el hogar la doctrina a sus hijos y domésticos". 110 "De la familia cristianamente formada sale el pueblo con sus costumbres religiosas". 111

Al diocesano le preocupaba que, fruto de la ignorancia, muriesen enfermos sin la debida asistencia espiritual, motivo por el cual recomendaba a los párrocos enseñar e inculcar a los fieles, como un grave deber, “el de llamar al cura en casos de grave enfermedad y recibir los santos sacramentos de la confesión, comunión y extremaunción, y deben pensar sus deudos, desde que el caso se presente con caracteres de gravedad, sin evitar molestias, ni hacer economías para ir en busca del Cura debían explicar la importancia del recibir en esos casos los sacramentos y la gravedad de no recibirlos por culpa del enfermo o de los deudos. En el caso de que la muerte se apresurase o no pudieran llamar al confesor, el cura debía instruirlos acerca de la necesidad de realizar un acto de perfecta contrición". ${ }^{112}$

A partir de la segunda gira pastoral, las recomendaciones de los autos se orientan hacia el esfuerzo del cura por lograr la piedad popular. Para ello, debe contar con la ayuda de las asociaciones radicadas en la parroquia (Apostolado, Hijas de María), y fomentar la creación de centros catequísticos en todos los poblados. Además, la actividad del cura debe llegar a los colonos, fomentando las cajas rurales, los círculos de obreros o Josefinos, y las sociedades de socorro mutuo. La labor del cura debía llegar a todos su feligreses. No debía conformarse con la asistencia de los fieles al templo, "no debéis detenernos y quedar satisfechos con ver completo el templo en los días festivos, y concurridas las comuniones de Pascual Florida, que acreditan los feligreses su buena conciencia”, debía salir a buscar a aquellos miembros de su grey que no concurrían al templo, "de los remisos, de los que menos creen, menos practican los sacramentos y están más lejos del templo y del párroco". ${ }^{113}$ Señala que, si bien, ante las heridas de usura que sufrían los feligreses en las regiones cerealistas, los párrocos se levantaron con denuedo en su defensa, fundando las cajas rurales, era necesario que esa labor pastoral y social dejara de ser unilateral y se

\footnotetext{
${ }^{110}$ AAC. Carpeta Curia, Visitas Pastorales y Varios, 1887-1911. Auto de la Visita Pastoral a la parroquia de Canals.

${ }^{111}$ AAC. Carpeta Curia, Visitas Pastorales y Varios, 1887-1911.

112 AAC. Carpeta Curia, Visitas Pastorales y Varios, 1887-1911. Auto de la Visita Pastoral a la parroquia de San Antonio, 5 de Noviembre de 1907.

${ }^{113}$ AAC. Curia Visitas Pastorales y Varios. Auto de la Visita Canónica al curato de Dalmacio Vélez el 06/05/1914.
} 
ampliara, para llegar al mismo usurero, "los chacareros caen víctimas de la usura, pierden es verdad, arrebatada por ésta una considerable porción de su cosecha, pierden sus granos pero no la conciencia; mientras que el victimario usurero ha violado la moral y ha comprometido su alma. Se presentan al párroco dos víctimas que caen de un solo golpe en el campo, y no se ve ninguna razón que lo determine a salvar a una de ellas y abandonar a la otra. Siendo mucho más necesitado moralmente el victimario usurero, que la víctima de usura" (Zenón Bustos, 1914: 341).

En cuanto al colono, el cura debía velar para que el trabajo no incidiera en la mengua de sus prácticas religiosas, "la fertilidad de sus campos, el producto abundante que su tierra suministra a sus habitantes, les abre un horizonte iluminado por la prosperidad que promete en tiempos no muy lejanos, y con el estímulo de la codicia les hace entregar todas sus actividades y aficiones a la fortuna apetecida con mengua y descuido de sus prácticas religiosas, que no tendrán tiempo en las combinaciones para sus negocios". ${ }^{114}$ El párroco debía inculcar a sus fieles que el trabajo era un elemento de unión con Dios y la Iglesia, y no un impedimento para cumplir con las obligaciones religiosas, "en un pueblo agrícola como este, debe hacer llegar con preferencia la palabra alentadora del trabajo; como una de las escuelas de moral y de piedad religiosa mas ventajosa. El cultivo de la tierra la llama y la aparta fuera del concurso de los malos, muchas veces inficionados en los vicios, por la ociosidad. Solo esperan para ser religiosos, piadosos el cultivo de la palabra sacerdotal". ${ }^{115}$ Entendía que la palabra y la acción sacerdotal en relación al trabajo constituían un elemento clave en la constitución de la parroquia como núcleo religioso y social de las colonias.

La delimitación y división de parroquias que realiza el obispo, deriva de una concepción del espacio-tiempo adaptada a las prácticas de los fieles. El diocesano se propuso un doble objetivo, un movimiento de inclusión de las poblaciones dentro de la Iglesia y una mayor presencia de la Iglesia en el espacio territorial provincial.

\footnotetext{
${ }^{114}$ AAC. Curia Visitas Pastorales y Varios. Auto de la Visita Canónica al curato de Río Cuarto el 10 de septiembre de 1905.

${ }^{115}$ AAC. Curia Visitas Pastorales y Varios, 1877-1911. Auto de la Visita Canónica al curato de Sampacho el 10 de noviembre de 1905 .
} 
Tabla 18

\begin{tabular}{|c|c|c|c|c|c|c|c|c|c|c|}
\hline \multicolumn{11}{|c|}{ Jerarquización económica de los curatos según rentas del beneficio } \\
\hline \multicolumn{11}{|c|}{ 1905-1910 } \\
\hline $\begin{array}{l}\text { Entradas } \\
\text { en pesos }\end{array}$ & $80 / 99$ & $\begin{array}{l}100 / \\
119\end{array}$ & $\begin{array}{l}120 / \\
149 \\
\end{array}$ & $\begin{array}{l}150 / \\
179\end{array}$ & $\begin{array}{l}180 / \\
209\end{array}$ & $\begin{array}{l}210 / \\
229 \\
\end{array}$ & $\begin{array}{l}230 / \\
259 \\
\end{array}$ & $\begin{array}{l}260 / \\
289 \\
\end{array}$ & $\begin{array}{l}290 / \\
319 \\
\end{array}$ & Más de 320 \\
\hline Curatos & $\begin{array}{l}\text { Quilino } \\
\text { Punilla } \\
\text { Sta. María }\end{array}$ & $\begin{array}{l}\text { Cruz Eje } \\
\text { Minas } \\
\text { Cruz } \\
\text { Alta }\end{array}$ & $\begin{array}{l}\text { R. Seco } \\
\text { Ischilín } \\
\text { S. Pedro } \\
\text { S. Agustín } \\
\text { Morteros } \\
\text { Totoral } \\
3^{\circ} \text { Arriba } \\
\text { Sampacho }\end{array}$ & $\begin{array}{l}\text { Chañar } \\
\text { Pocho } \\
\text { S. Javier } \\
\text { Arroyito } \\
\text { Carlota } \\
\text { Río II }\end{array}$ & $\begin{array}{l}\text { Tulumba } \\
\text { Canals } \\
\text { V. Nueva } \\
\text { Sta.Rosa } \\
\text { Remedios } \\
\text { Chalacea }\end{array}$ & & $\begin{array}{l}\text { Marcos } \\
\text { Juárez }\end{array}$ & $\begin{array}{l}\text { San } \\
\text { Francisco } \\
\text { V. María }\end{array}$ & Soto & $\begin{array}{l}\text { Laboulaye } \\
\text { V. Rosario }\end{array}$ \\
\hline Cantidad & 3 & 3 & 7 & 6 & 6 & 0 & 1 & 2 & 1 & 2 \\
\hline $\begin{array}{l}\text { Símbolo } \\
\text { Mapa }\end{array}$ & $*$ & 66 & \# & / & + & & $>$ & $=$ & $\mathrm{O}$ & 1 \\
\hline
\end{tabular}


Mapa 18

Jerarquización económica de los curatos según rentas del beneficio, 1905-1910

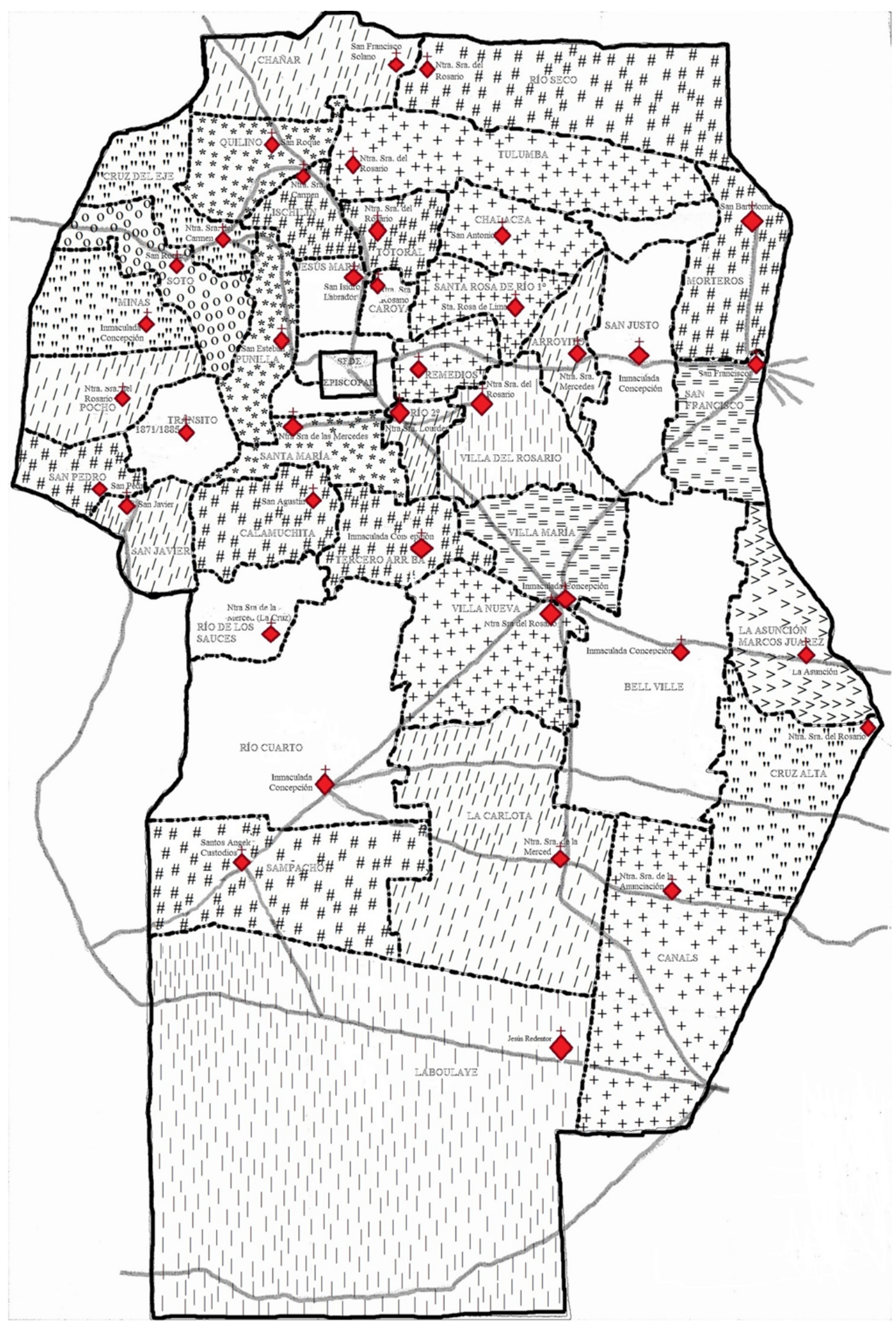




\section{CAPITULO 9}

\section{LA EXPANSION PARROQUIAL COMO FENOMENO DE TERRITORIALIZACION}

La parroquia rural adquirió, en la transición de los siglos XIX al XX, una importancia capilar en la campaña cordobesa, que excedió su función, pues pasó a ser una pieza clave de la administración eclesiástica. Como hemos señalado en el Capítulo 2, los estudios europeos han convertido a la parroquia en objeto de estudio de geógrafos, sociólogos y antropólogos, quienes se preocuparon por medir, delimitar y cartografiar los territorios parroquiales. En los últimos años, se sumaron los historiadores. Ejemplo de ello, es la obra colectiva de Bernard Merdrignac, Daniel Pichot, Louisa Plouchard y Georges Provost (2013), publicada por la Universidad de Rennes, cuyos artículos analizan la evolución y recomposición de la parroquia desde el medioevo hasta la actualidad. Los trabajos dan cuenta del protagonismo que esta institución fue adquiriendo en la vida local y su relación con los cambios de orden económico, social, religioso y cultural. Los estudios parten de la hipótesis de que la parroquia es una construcción medieval que desarrolla diversos modelos de funcionamiento. El trabajo retoma una preocupación actual, que es, justamente, el desmantelamiento que hoy experimenta el sistema espacial parroquial. Las contribuciones presentan una mirada de larga duración sobre el funcionamiento de las parroquias católicas del medioevo hasta el Concilio Vaticano II. En este recorrido, puede observarse el auge del modelo parroquial -que se consolida en Europa a partir del Concilio de Trento-, y el desmantelamiento de ese tejido, que siguió a la posguerra, dando por tierra el viejo patrón que afirmaba "una aldea, un campanario, una parroquia, un sacerdote" y destruyendo el esquema tradicional de "civilización parroquial" (Merdrignac at al, 2013: 7).

Si bien en nuestras provincias, este patrón no llegó a consolidarse, debido a la extensión del territorio y a la escasez de curas (Di Stefano, 2004; Ayrolo, 2007; Barral, 2007), nadie

pone en duda el papel de esta institución en la vida rural (Barral, 2007), reconociendo que, pese a los vaivenes de la política, fue una de las pocas instituciones de origen colonial que se mantiene hasta la actualidad. En el período que hemos analizado el modelo tridentinocolonial de parroquia territorial, se reconfigura y adquiere vitalidad, adaptándose a un 
nuevo contexto. El propósito de este capítulo es analizar la institución parroquial en el marco del proceso de romanización. Elegimos la parroquia como objeto de análisis, porque se trata de un espacio peculiar. Su importancia radica en que se trata de una institución de naturaleza local, que permite introducir, en la comunidad de fieles, novedades y transformaciones de orden superior a lo estrictamente religioso. El sociólogo de la religión Gabriel Le Bras (1976: 14), la denomina como el "centro de un país, la capital de una comunidad, la célula de una nación”. Si el propósito de la jerarquía era construir una nueva cristiandad, la institución sobre la cual gira toda la reforma es sin duda la parroquia, por su función de bisagra, vínculo estrecho entre la Iglesia y la comunidad.

La parroquia nos permite centrar la mirada en la continuidad de la Iglesia frente a los cambios, analizar el grado de consistencia y los signos de debilidad que manifiesta en la larga duración (siglo XIX), y detenernos en los cincuenta años que se ubican en la transición de dos siglos (1875-1925). Nos permite observar también la manera en que preserva su identidad pese al impacto de los cambios que coadyuvaron a su debilitamiento: los avatares políticos, el resabio de la anarquía, las montoneras y los malones en las décadas del 60 y el 70 y el laicismo, el anticlericalismo y la diversidad religiosa en los años siguientes. Pese a todo ello, veremos cómo la estructura parroquial mantuvo una estabilidad considerable en las coyunturas -demográficas, políticas, económicas, sociales y culturales-, que atravesó la provincia desde las reformas liberales hasta el primer tercio del siglo XX.

Las preguntas que nos hicimos fueron ¿cuáles son los motivos de la fortaleza y permanencia de esta institución? ¿Cuáles fueron y cómo variaron sus funciones a lo largo de contextos sociales y culturales diferentes? La hipótesis de la cual partimos es, justamente, que la vigencia, permanencia y fortaleza de esta institución milenaria tiene relación con su capacidad de poner en juego lo global con lo local, la capacidad de resignificar sus funciones a fin de adaptarse a las sociedades en cambio.

Las parroquias fueron y aún son el elemento básico de la administración eclesiástica, las fuentes nos permiten reconstruir su número aproximado, sus modificaciones territoriales, la ubicación de las sedes y sus cambios de lugar, sus titulares o patronos. Mediante una pormenorizada búsqueda de datos, pudimos reconstruir un tejido parroquial, que nos permitió hacer visible una red de templos que se densificó hasta cubrir gran parte del 
territorio provincial y que sirvió para situar y articular aldeas pequeñas o lugares que formaban un hábitat disperso.

Al elaborar esta base de datos, se presentaron algunas dificultades, por ejemplo, la cuestión de las denominaciones. Indistintamente se denomina a la parroquia por su titular o por su ubicación geográfica. Veamos un ejemplo, la parroquia de "San Antonio". La realidad es que existen varias cuyo titular era San Antonio, pero cuando aparece esta denominación a secas, los documentos referencian a la de Río Primero. A las otras, se las nombra con su característica toponímica, por ejemplo San Antonio de Litín, Isla Verde o Santiago Temple. Todas tienen como titular a San Antonio. Lo mismo sucede con "La Asunción", cuando se la menciona a secas, hace referencia a la parroquia de Marcos Juárez, en tanto al resto se las denomina con su lugar toponímico, El Tránsito, Estación Cabrera o Etruria. La Virgen de la Merced o Ntra. Sra. de las Mercedes es titular de más de 17 templos, pero es la parroquia de Alta Gracia la referencia por antonomasia.

Otra dificultad está relacionada con los cambios de sede parroquial, no siempre datados, que, en los documentos, aparece nombrada con el título de parroquia aquella iglesia que lo fue pero que ya no lo es, por ejemplo Santa Rosa de Calamuchita, antiguo curato erigido en 1762, tuvo como sede la Iglesia de Santa Rosa, pero no pudimos datar el cambio de sede a San Agustín, si bien suponemos que fue alrededor de 1890, dado que en los informes anuales de ese año se la nombra como Santa Rosa. O el curato de Ischilín, erigido en 1749, cuya sede estuvo, hasta 1898, en la aldea del mismo nombre y luego se trasladó a la Villa Deán Funes, sin embargo, cuando se la referencia se la sigue denominando Ischilín, aunque hablen de Deán Funes, es decir no se distinguen las matrices de las anejas, o, en términos más contemporáneos, de las filiales. Además, las parroquias no se mantuvieron inalterables, experimentaron modificaciones y cambios. Algunas se erigieron y luego se suprimieron por falta de congruidad (Jesús Nazareno); otras, con el tiempo, volvieron a erigirse (El Tránsito); en otros casos, el lugar se despobló, lo que provocó su consiguiente traslado de sede. En el caso de Morteros, la sede estuvo en la capilla de San Pedro, ésta estaba ubicada en la colonia La Asunción, a las afueras del pueblo; por su parte, la Iglesia de San Bartolomé se la traslada luego al pueblo de Morteros, igualmente la sede de San Antonio de Río Primero, que se traslada a Monte del Rosario por ser el lugar más céntrico del curato. 
También encontramos capillas que se desmembran y se anexan a otra iglesia matriz y, por supuesto, se encuentran las divisiones provocadas por el aumento del número de feligreses.

Vistas en conjunto, las parroquias de la campaña cordobesa eran muy extensas en términos de superficie y las iglesias, capillas dependientes y oratorios conformaron una red que articulaba los asentamientos dispersos en la campaña. Este fenómeno, que denominamos "espacialización religiosa", se realizó, fundamentalmente, mediante el aumento de iglesias en el territorio diocesano provincial. Se recuperaron para el culto antiguos templos deteriorados, que estuvieron fuera de uso, incluso clausurados por la autoridad eclesiástica debido a sus precarias condiciones materiales, se reconstruyeron y ampliaron antiguas capillas y oratorios y se edificaron nuevas iglesias, de grandes dimensiones, con el objetivo de afincar la religión católica en el territorio diocesano.

\section{La parroquia como marco de referencia de la campaña}

La presencia real de la iglesia en la campaña fue tangible a través de la existencia de templos. El templo acompañó el desarrollo de villas, aldeas y colonias. El cura era quizá la persona que más conocimiento tenía del espacio social del último tercio del siglo XIX. Así lo expresaba el cura de Tránsito, José Gabriel Brochero, "aunque no soy nadie, ni sepa nada, ni sea capaz de expresarme en forma elegante, conozco palmo a palmo y mejor que cualquier literato todas las sierras de Córdoba y he pasado en ellas los mejores años de mi vida, levantando templos y escuelas y luchando con las dificultades" (CEA, 1999: 545546). ${ }^{1}$ Realmente, el cura era el que conocía la jurisdicción de su curato. Cuando el gobierno nacional necesitó establecer los límites de la provincia de Córdoba con La Rioja en 1869, solicitó al obispo la ayuda para "obtener [información] de los párrocos, cuyos curatos son limítrofes de otras provincias. Cuáles son los límites de ese curato por la parte que linda con la Rioja especificando cuáles son las últimas poblaciones pertenecientes a esta provincia y cuál es el que se ha considerado y se considera como límite jurisdiccional. Enviar un informe con los datos que se puedan tener en el archivo parroquial como los que podrían suministrarle los colectores de primicias encargados de las capillas más distantes y otras personas conocedoras del curato principalmente las que tengan su poblaciones más

\footnotetext{
${ }^{1}$ Carta al Ingeniero y Diputado Nacional Francisco Seguí (Agosto de 1905).
} 
cercanas a la provincia indicada". 2 El cura de Minas, Pantaleón Abregu, envió la información solicitada a vuelta de correo, allí señalaba que "en la cabecera sur la línea que divide este curato de la Rioja y del curato de San Alberto es un punto denominado Balde de la Isla de Correa en la estancia de Don Fabián Murula, el punto que divide el curato de Pocho del curato de Minas". 3

El proceso de construcción de templos se aceleró a partir de la década del 70 y acompañó el establecimiento de las líneas férreas. La administración eclesiástica fue de la mano, y algunas veces un paso adelante, de la administración civil, ya que varios centros de población construyeron sus templos antes de tener oficinas estatales. Tal es el caso de Fraile Muerto, que sufrió una importante trasformación cuando se convirtió en terminal del ferrocarril en 1868. El cura párroco se abocó a la organización política del poblado, en 1869 creó la comuna de San Gerónimo, cuya acta de fundación deja constancia de que la primera presidencia le cupo a su fundador, el cura párroco Rubén Márquez. Además, el cura se ocupó de la construcción de un nuevo templo más espacioso y de la demarcación de terrenos, pertenecientes a la iglesia, para organizar lo que sería el centro de la villa, la plaza, la municipalidad, la alcaldía y la venta de los "terrenos de la virgen", a fin de fomentar el poblamiento. La antigua posta se convirtió en villa en los terrenos otrora donados a la iglesia.

Las crónicas de los corresponsales del periódico "El Progreso"4 en la campaña cordobesa entre 1868 y 1880 manifiestan, de manera reiterada, la ausencia del estado y el rol del cura y del templo en el mundo rural. E1 22 de octubre de 1868 comenzaron una serie de notas relativas a la situación de la campaña. El corresponsal del departamento de San Alberto advertía que el Gobierno “jamás se ocupa de la campaña”. Uno de los aspectos que destaca el cronista es la encomiable labor del cura en favor de la educación. "Es muy recomendable el celo y el patriotismo de nuestro cura párroco D. Francisco Aguirre, pues él ha costeado por tres años dos escuelas a sus expensas, una de varones y la otra de niñas". Además, el redactor señala que ha dado a los alumnos todo lo necesario, acción digna de

\footnotetext{
${ }^{2}$ AAC. Leg. Curato Tránsito, Salsacate, San Carlos y San Pedro, 1863-1887, s/f. Nota del 26/01/1869.

${ }^{3}$ AAC. Leg. Curato Tránsito, Salsacate, San Carlos y San Pedro, 1863-1887, s/f.

${ }^{4}$ El Progreso fue fundado en 1867 por Ramón Gil Navarro, quien defendió la causa del partido federal, cuyo caudillo era el "Chacho" Peñaloza. A partir de 1878, apoyó al Partido Autonomista y la política del futuro presidente Miguel Juárez Celman y la candidatura de Julio A. Roca en la provincia de Córdoba. El diario adquirió una orientación liberal. Dejó de aparecer a la muerte de su fundador en 1883.
} 
ser loada, puesto que “el Sr Cura jamás ha recibido un solo real de los fondos que el Departamento recolecta para fines de utilidad local". En una nota elevada por el cura de Sobremonte al Ministro de Hacienda provincial en 1874, solicita una subvención y le informa que la escuela parroquial de niñas, que "fundó el infrascripto con sus propios recursos bajo su exclusiva e inmediata dirección en la pedanía de Caminiaga”, funcionaba con regularidad. ${ }^{5}$

El 9 de junio de 1868, el periódico "El Eco" de Córdoba dedica una columna al cura de Villanueva, José C. Cevallos, en la que retrata la función del cura en la campaña, "los curas de campaña en nuestras apartadas y desiertas poblaciones, revisten el rol de médicos, de sacerdotes, de maestros de escuela y hasta de jueces con el carácter de amigables componedores, dirimiendo como en familia las cuestiones de sus feligreses". El 19 de octubre del mismo año, dedica una columna entera a la campaña y a sus párrocos, en ella vuelve sobre la inoperancia del gobierno, "a fuerza de mirar con indiferencia lo que pasa en la campaña, y a fuerza de olvidarla como si no fuera parte integrante de la familia cordobesa, dejamos de palpar las necesidades y de remediarlas a tiempo". Antes de cerrar la crónica, el autor sentencia:

Hoy la campaña abandonada por el Gobierno, sacrificada por Comandantes asesinos y ladrones, hundida en la ignorancia por falta de escuelas e incomunicada con la capital por falta de vías de públicas, hoy decimos, la campaña no tiene otro elemento de progreso que el celo y patriotismo de sus párrocos. Ellos fomentan las mejoras locales y la enseñanza, o realizando trabajos en favor del ornato y progreso de la localidad, o fundando escuelas, como las que vemos establecidas en los departamentos del oeste [...] Los párrocos es preciso decirlo, en obsequio de la justicia hacen las veces del Gobierno en los departamentos, ocupan el puesto de las Municipalidades en el fomento y adelanto de la localidad y son los médicos y los maestros de la escuela supliendo las faltas y indolencia de las autoridades. Los buenos párrocos llenan una misión santa y altamente civilizadora para el pueblo de la campaña. ${ }^{6}$

Un largo y minucioso relato describe los esfuerzos del cura de Calamuchita por dar realce a las fiestas patronales y hace la siguiente ponderación, "para nosotros las festividades religiosas de la campaña tienen altas tendencias civilizadoras, parte del principal objeto de culto religioso. Son las grandes ferias en que la población de la campaña diseminada en los inmensos campos, realiza una vez que otra siquiera el contacto, que trae

\footnotetext{
${ }^{5}$ Archivo Histórico de la Provincia de Córdoba [en adelante AHPC]. Gobierno 1874, T3, f.192.

${ }^{6}$ El Progreso, 19/10/1869, p. 1.
} 
la unión y la fraternidad [...] Sin esas grandes festividades la incomunicación haría el vacío en la sociedad de la campaña y el aislamiento fundando la ignorancia primero, trae en seguida el egoísmo y la falta de aspiraciones que constituyen el atraso en la indolencia para todo. Por eso es doblemente laudable en los párrocos la idea de enseñar el culto, logrando a la vez atraer los vecinos a un centro de reunión" (EP, 19/10/1869).

Las notas enviadas al gobierno provincial por los curas y obispos reflejan el rol y la función del cura. En 1873, el cura de Tercero Arriba eleva una consulta relativa a la redacción de los testamentos de los paisanos y señala: "Donde el gobierno no tiene ningún oficial para hacer dichos testamentos, es el cura quién los hace por ser persona más inteligente a estas cosas y mirar con más intereses ya por la paz y tranquilidad de las familias y por el bien de las almas". ${ }^{7}$ El diario "El Progreso" del 31 de enero de 1877, en la sección correspondencia, advierte que en la aldea de Remedios, "desconocida sin duda, va a ser en breve una aldea laboriosa y productiva. La escuela y la Iglesia esos dos agentes sublimes de civilización van a transformarla".

Otro indicador de la ausencia del estado en la campaña es el acalorado debate que se suscitó por la aplicación de la ley de matrimonio civil de 1889 (tema sobre el que volveremos en la quinta parte de la tesis al analizar las prácticas del clero), que puso de manifiesto las dificultades que tenían los párrocos para administrar el sacramento del matrimonio, justamente por la escasez de oficinas del registro civil. En 1891, el obispo fray Reginaldo Toro escribe al ministro de Justicia, Culto e Instrucción Pública de la Nación, en la que le solicita "que se aumenten las oficinas de registro, de modo que en vez de una sean varias en cada departamento, o que se suprima el artículo penal de la ley contra el sacerdote y lo reemplace con otro de pena pecuniaria contra los contrayentes infractores". ${ }^{8}$

Más arriba, decíamos que el templo acompañó el desarrollo de villas, aldeas y colonias. Con el surgimiento de pueblos a la vera del ferrocarril, se aceleró la construcción de nuevos templos. A modo de ejemplo, Pozo del Molle, fundado en 1904 sobre el ramal del ferrocarril que une San Francisco con Villa Nueva, estaba circundado de nueve colonias agrícolas, en las cuales vivían unas 50 familias extranjeras, en su mayoría italianas del Piamonte, y tres argentinas. ${ }^{9}$ En 1908, una de esas familias levantó una capilla en honor a la

\footnotetext{
${ }^{7}$ AHPC. Gobierno. Obispados y Otros. T2, f.199.

${ }^{8}$ AAC. Parroquias: Río Tercero, s/f.

${ }^{9}$ Anuario Estadístico de la Provincia de Córdoba, 1905.
} 
Virgen de la Divina Providencia. La misma fue bendecida por el cura de Villa del Rosario, Lindor Ferreyra. La familia también donó al gobierno provincial el terreno para el cementerio. El 30 de julio de 1907, el gobernador José A. Ortiz y Herrera decretó que, como en Pozo del Molle no existía comisión de fomento, ni municipalidad, ni otra autoridad civil de carácter permanente, confiaba la administración del cementerio a la autoridad eclesiástica.

\section{La expansión parroquial como fenómeno de territorialización}

En 1883, el vicario capitular en sede vacante envía, al Delegado Apostólico Monseñor Luis Matera, un informe sobre las parroquias de la diócesis de Córdoba, en el que observa que: "La provincia de Córdoba contiene veintiocho parroquias incluidas la de la capital y la de la ciudad de Río Cuarto. La de la capital, atendida por dos curas rectores con sus tenientes, alternativamente por semanas, contiene ella sola como 50.000 habitantes. La de Río Cuarto tiene un distrito de más de 100 millas de diámetro la atiende la comunidad religiosa de Misioneros Franciscanos. Las demás parroquias tienen en su mayor parte centros de población bastante numerosos y extensos territorios bastante poblados. Todas excepto dos, que tienen cura propio, son servidas por interinos". ${ }^{10}$

Entre 1877 y 1887 , el crecimiento parroquial fue escaso, sólo se crearon tres curatos, Quilino, Tránsito y Remedios, quizá el motivo de este estancamiento se deba, en parte, a que los obispos estuvieron al frente de la diócesis sólo por dos años cada uno. Una cartaedicto, emitida por el Vicario Capitular y Gobernador del Obispado Uladislao Castellano, con motivo del fallecimiento del Obispo Fray Juan Capistrano Tissera, señala que la vacancia es una "calamidad", pues "priva a la Diócesis de su Pastor, y los vicarios capitulares no pueden hacer el bien con la amplitud de los obispos”. El texto señala que "esta consideración adquiere mayor fuerza para nuestra diócesis cuyos tres últimos obispos han tenido tan corta duración, que los dos primeros no han igualado el tiempo de su gobierno ni siquiera al de las vacantes que les precedieron [...] no podemos dudar de que en tiempo tan limitado, mucho, muchísimo les quedara por hacer". ${ }^{11}$

\footnotetext{
${ }^{10}$ AAC. Copiador de cartas. Secretaría del Obispado, 1882-1904, fs.39-49.

${ }^{11}$ AAC. Parroquias: Río Primero, s/f. Carta edicto del 22/10/1886.
} 
El proceso de parroquialización tendrá un fuerte impulso durante los gobiernos de los próximos dos Obispos, Fray Reginaldo Toro y Fray Zenón Bustos. En la campaña, se crearon, durante la gestión del primero, 10 nuevas parroquias y durante la del segundo, 37 . Las Tablas que se presentan en el Anexo, muestran el proceso de desmembramiento y erección de parroquias entre los años 1877 y 1927, señalando las fechas de creación. Se tomaron tres años claves: 1877, fecha que da inicio a nuestra investigación; 1887, año de finalización de una etapa en la que los obispos duraron, como dijimos, escasos dos años cada uno (Álvarez, Esquiú y Tissera); 1904, que corresponde al final de la gestión del obispo Toro. En una Tabla aparte hemos colocado los datos correspondientes a la gestión de Fray Zenón Bustos (1905-1919) y de su obispo auxiliar Monseñor José A. Luque (19191927), quien asumió el gobierno de la diócesis después de la enfermedad del primero. La Tabla 19 recoge los datos de las Tablas 8 y 9 del Anexo II, a fin de mostrar el crecimiento parroquial según las regiones a lo largo del período.

\section{Tabla 19}

\begin{tabular}{|c|c|c|c|c|c|}
\hline \multicolumn{6}{|c|}{$\begin{array}{c}\text { Distribución regional } \\
\text { del crecimiento parroquial }\end{array}$} \\
\hline \multirow[t]{2}{*}{ Departamentos } & \multirow[t]{2}{*}{ Regiones } & \multicolumn{4}{|c|}{ Cantidad de Curatos } \\
\hline & & $\begin{array}{c}\text { Antes de } \\
1877\end{array}$ & 1887 & 1904 & 1927 \\
\hline \multirow{3}{*}{$\begin{array}{l}\text { Departamentos de antigua } \\
\text { colonización }\end{array}$} & Norte & 5 & 6 & 6 & 6 \\
\hline & Oeste & 8 & 11 & 11 & 13 \\
\hline & Centro & 6 & 7 & 9 & 13 \\
\hline \multirow[t]{3}{*}{ Departamentos colonizadores ${ }^{1}$} & Este & 4 & 4 & 10 & 30 \\
\hline & Sur & 1 & 1 & 3 & 8 \\
\hline & Totales & 24 & 29 & 39 & 70 \\
\hline
\end{tabular}

Los motivos que impulsaron este crecimiento están estrechamente relacionados con la necesidad de ejercer un mayor control sobre las feligresías, a fin de resguardar la fe religiosa que se veía en peligro por la acción de los librepensadores, el avance de nuevas ideologías, la "mala" prensa, etc. En el proyecto enviado al cabildo eclesiástico con motivo de la erección de los curatos de Porteña y Freyre en el departamento de San Justo, el obispo señalaba que: 
Las respectivas visitas sobre la llanura de esta provincia, colonizada por familias italianas en su mayor parte y cruzada por líneas férreas que entran y concentran sobre las estaciones elementos de propaganda activa contraria a la religión y el conocimiento adquirido de los sentimientos religiosos traídos y conservados por aquellas familias, me han determinado a ensayar la reducción de los extensos curatos de esos puntos a fin de aumentar la vigilancia sobre ellas, aumentando el apostolado con los sacerdotes a quienes sean confiados. Consagrándoles un ministerio más asiduo, conservarán mucho mejor su fe religiosa, los peligros de la propaganda contraria serán neutralizados, podremos esperar una generación creyente, modelada en los preceptos de la Iglesia y divinos. ${ }^{12}$

Esta reconstrucción del crecimiento parroquial en la mediana duración, la volcamos en el mapa de Río y Achával, que, si bien es de 1905, nos permite ver la evolución a lo largo de todo el período sobre una misma base cartográfica.

\section{Mapa 19}

\begin{tabular}{|cc|}
\hline \multicolumn{3}{|c|}{ Curatos de la Provincia de Córdoba } \\
1805 & 1925 \\
\hline
\end{tabular}

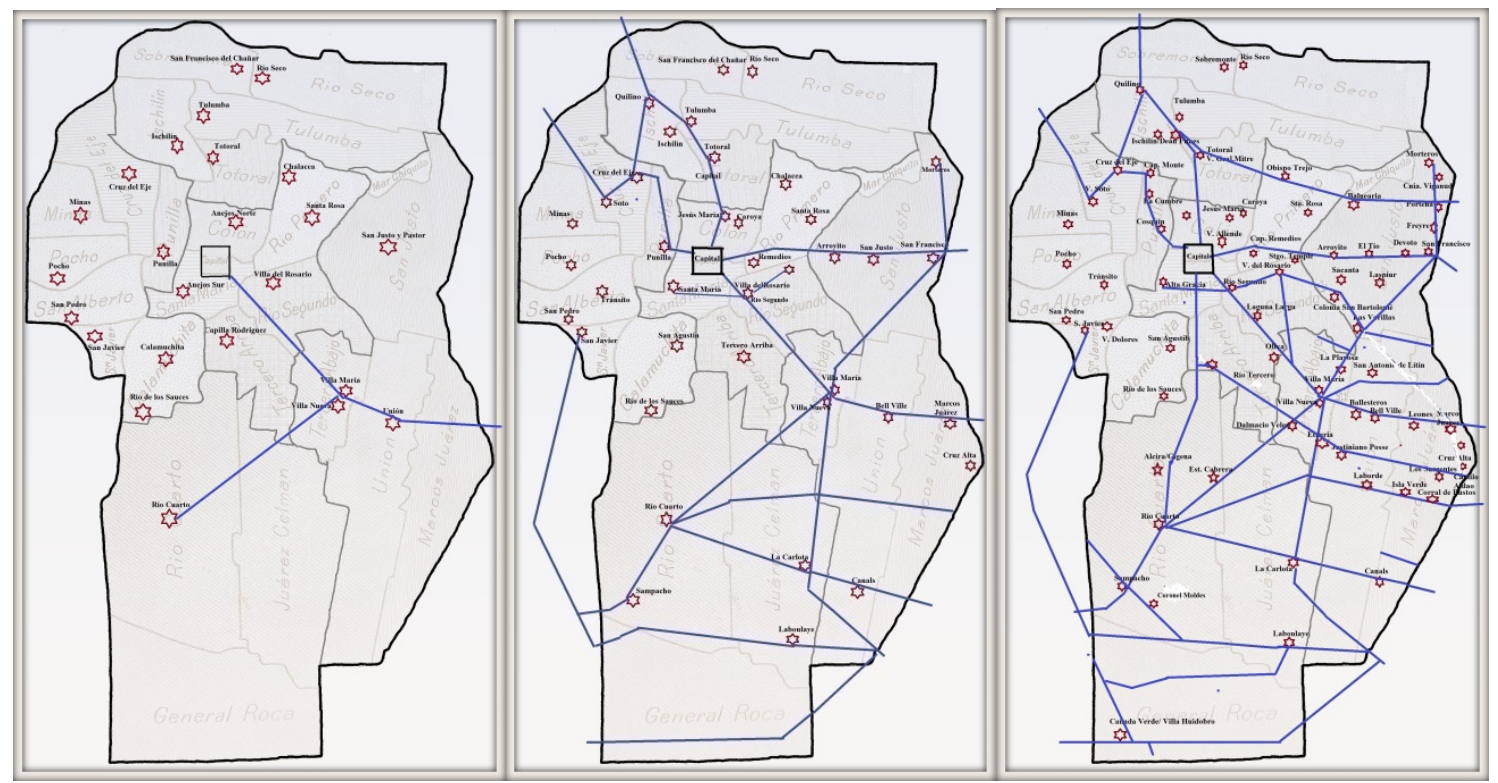

En el Archivo del Arzobispado, hemos encontrado una carpeta que contiene una compilación de datos relativos a las parroquias de la arquidiócesis, agrupados por el padre

${ }^{12}$ AAC. Leg. 10. Comunicaciones entre el Obispo y el Cabildo, 1908-1915, f.1205. 
Ramón Liendo. ${ }^{13}$ En ella se encuentra el único mapa que refleja la división eclesiástica provincial. Corresponde al año 1906 y está vinculado a un proyecto de creación de vicarías. Sobre ese original, de $1,50 \mathrm{~m} \times 1 \mathrm{~m}$, aproximadamente, realizado a mano alzada, hemos sobresaltado con color azul las líneas férreas que atravesaban la provincia, en celeste la laguna de Mar Chiquita y con negro las divisiones eclesiásticas numeradas cada una con su respectiva la iglesia parroquial marcada en rojo.

Reconstruir el entramado de templos supuso un trabajo complejo. En primer lugar, recurrimos a la consulta de fuentes que nos podían proporcionar información al respecto y realizamos una pequeña base de datos. La documentación más sustanciosa son los informes enviados por los curas a la curia. El Provisor en sede vacante, Uladislao Castellano, ordenó a los curas, mediante el auto del 3 de enero de 1879, enviar un informe detallado de la extensión de sus curatos, la ubicación topográfica de las capillas y todo "lo que pudiera ayudar al prelado a designar en cada curato de campaña una iglesia parroquial". ${ }^{14}$ En la circular se solicitaban los siguientes datos: la extensión de los curatos, el número de capillas, su titular, pedanía y departamento en el que se encontraba, distancia entre las capillas, dimensiones y estado material de cada una. ${ }^{15}$ Las respuestas que hemos encontrado, si bien son fragmentarias, nos han permitido un acercamiento a la situación de los curatos de campaña.

De 1890 a 1893, el Obispo Toro requirió el envío de un informe anual de cada curato. En el primer punto, se pedía el número de capillas y oratorios, el estado material de las mismas y si había alguna en construcción. ${ }^{16} \mathrm{Si}$ bien no todos los curatos respondieron cada año, contamos con la información de un $60 \%$ de los curatos existentes. En 1898, el obispado envió una nueva circular a todos los párrocos en la que solicitaba un informe sobre el estado de las iglesias y capillas del curato. En 1905, el Obispo Zenón Bustos solicitó una nueva información, en una circular volvió a pedir datos concisos sobre cada

\footnotetext{
${ }^{13}$ AAC. Compilación de datos relacionados con las parroquias de la arquidiócesis.

${ }^{14}$ AAC. Libro de Autos, 1876-1905, f.21.

${ }^{15}$ AAA. Parroquias: Punilla, f.361 y ss.

${ }^{16}$ AAC. Libro de Autos, 1876-1905, fs.120-121. Auto del 22/11/1890, determinado que: $1^{\circ}$ : todos los curas mandarán al final de cada año, comenzando por el presente, un informe detallado de su parroquia.
} 


\section{Mapa 20}

\section{Curatos de la Provincia de Córdoba en 1904}

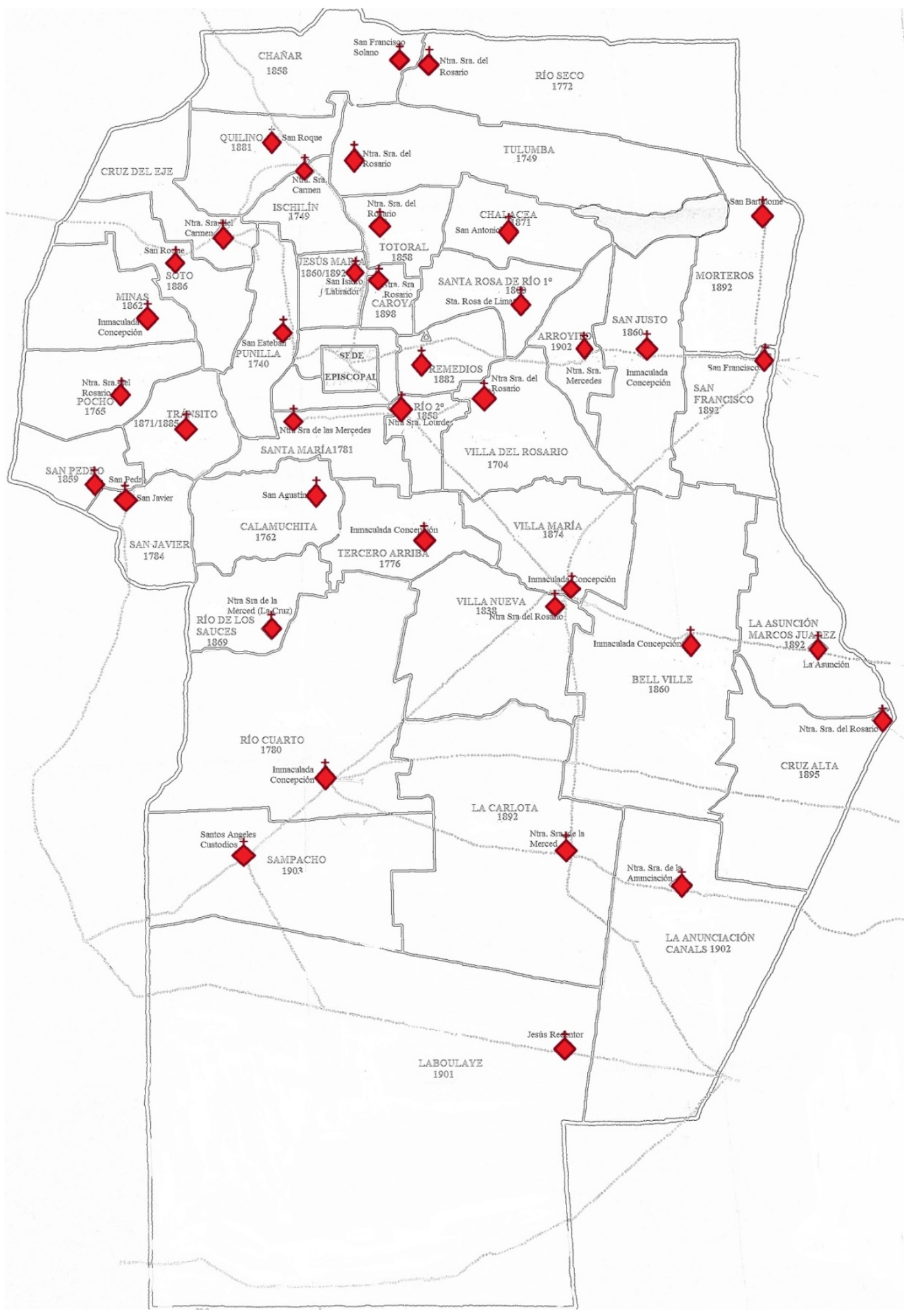

Fuente: Elaboración propia en base al mapa de Río y Achával (1904) 
curato: límites, fecha de erección, población, capillas, estado material y ubicación topográfica en un plano, etc. Finalmente, en 1924, en una nueva circular, se volvió a requerir datos más precisos, fecha de fundación según el Archivo Parroquial, fecha de comienzo de los libros de administración de sacramentos (bautismos, confirmaciones, matrimonios y defunciones), "qué día mes y año comienza cada libro", pueblos que componían el curato, pedanía y departamento en el que se ubicaban y desmembramientos y/o anexiones que tuvo y en qué fecha. ${ }^{17}$ Además se preguntaba si existía escritura de los terrenos e inmuebles de la parroquia. ${ }^{18}$

Los informes de la visita ad limina de 1892 dan cuenta del aumento progresivo de las parroquias. Reginaldo Toro informó a la Santa Sede que "hay numerosas villas y aldeas en todo el territorio de la Diócesis, sirviendo las más importantes para asiento de 37 parroquias más fuera de las que hay en las ciudades. ${ }^{19}$ Por lo tanto, 30 se asentaban en la campaña de la provincia de Córdoba. El obispo expresaba su deseo de crear nuevas parroquias, necesidad exigida por la extensión de los territorios y el crecimiento de la población, pero señalaba la falta de clero "indispensable para la ocupación de esos nuevos puestos". La mayor parte de las Iglesias mencionadas estaban provistas de los elementos necesarios para celebrar con decencia el culto, pero hay también muchas que se encontraban en suma pobreza, porque "son pobres los habitantes que las sostienen con sus limosnas". Las iglesias carecían de rentas propias, fuera de algunas que tenían unos pocos bienes. Para el sostenimiento, contaban con los derechos que la tasa diocesana asignaba a la fábrica y el mantenimiento del culto. El ingreso percibido por el desempeño de ciertas funciones parroquiales era siempre insuficiente para atender a todas las necesidades, de modo que para reparación de las iglesias, construcción y ornamentación de nuevas, "los párrocos se toman no pocas fatigas promoviendo suscripciones extraordinarias entre los fieles". ${ }^{20}$

El informe indicaba que las iglesias tenían los elementos para celebrar dignamente, y que la situación económica de muchas era precaria, ya que al estar ubicadas en regiones

\footnotetext{
17 AAC. Compilación de datos relacionados con las parroquias de la arquidiócesis. Inicio del libro 31/05/1914.

18 AAC. Compilación de datos relacionados con las parroquias de la arquidiócesis. Inicio del libro 31/05/1914.

${ }^{19}$ Existían dos parroquias rectorales en la ciudad de Córdoba, la Catedral y el Pilar, una en la ciudad de Río Cuarto y una matriz en la ciudad de La Rioja, que además contaba con siete curatos en la campaña (Famatina, San Blas de los Sauces, Vinchina y Guandacol, Chilecito, Costa de Arauco, Ullapes y Tama).

${ }^{20}$ Libro de Autos 1876-1905, f.143-158.
} 
muy pobres no contaban con las limosnas suficientes para su mantenimiento. Para reparar o construir nuevos templos se recurría a suscripciones voluntarias. ${ }^{21}$

El informe generado por la Sagrada Congregación Consistorial -cuyo secretario era el Cardenal De Lay-, sobre la visita ad limina de los obispos argentinos en 1913, señala, en las observaciones generales, que las 600 parroquias existentes en el territorio argentino resultaban muy pocas. Además, señalaba que no era fácil multiplicarlas, por un doble problema: la subsistencia del clero y la falta de clero. "Notase sin embargo un movimiento ascendente en la multiplicación de parroquias. Pero se comprende que la división parroquial en forma proporcionada no será posible por mucho tiempo. Solo queda el sistema de misiones y de multiplicación de capillas rurales, para atenderlas de cuando en cuando pero sistemáticamente". ${ }^{22}$

En las observaciones particulares a la diócesis de Córdoba, el informe señala lo que debería hacerse. "En cuanto a la multiplicación de parroquias hay que exigirla, recomendando la fundación de obras pro parroquias, máxime si se tiene en cuenta que los derechos parroquiales (únicas entradas) se reducen a bautismos, matrimonios y funerales, se han dado dos opiniones. La una es que el prelado sea autorizado para imponer un canon anual a cada parroquia, en proporción a sus entradas, que el Prelado reservaría para asegurar la subsistencia de las nuevas parroquias o de las más pobres. La otra, es que el Prelado sea autorizado a administrar directamente todas las parroquias, nombrando solo ecónomos no propiamente párrocos, fijando a estos una mensualidad y un tanto por ciento de las entradas. En ambos casos se constituiría una comisión administradora en que estuviesen representados los párrocos". Esta sugerencia no llegó implementarse en la diócesis.

El siguiente punto del informe sugiere que "en las parroquias rurales, en lugar de multiplicar las parroquias, muchas veces es más fácil fundar capillas, cada dos leguas por ejemplo, dentro de una misma parroquia, teniendo en cuenta los centros de población o de fácil acceso, reconcentrados así dos o tres sacerdotes en la Iglesia Matriz, los sábados y domingos irían a atender una o dos capillas, cada quince días o cada mes [...] De este modo se evita que quede un sacerdote solo regentando en medio del campo, embruteciéndose.

\footnotetext{
${ }^{21}$ Libro de Autos, 1876-1905, f.146.

${ }^{22}$ ASV. Nunciatura Argentina, Libro 62, f.103.
} 
Este es el sistema de misiones [...] que dio buenos resultados en Estados Unidos. Algo de eso se hace en Córdoba". ${ }^{23}$

La Tabla 20 y los Gráficos 11 y 12 presentan el aumento, entre 1875, 1905 y 1925, de capillas filiales. Estas cifras dan cuenta del proceso de expansión de los lugares sagrados en el período (Cfr. En el Anexo II, Tablas 8 y 9 sobre la evolución de las parroquias y capillas).

Tabla 20

Evolución de Templos, 1875-1925

\begin{tabular}{|c|c|c|c|c|c|c|}
\hline \multicolumn{7}{|c|}{ Parroquias, Iglesias y Capillas filiales* } \\
\hline \multirow[t]{2}{*}{ Departamentos } & \multicolumn{2}{|r|}{1875} & \multicolumn{2}{|r|}{1905} & \multicolumn{2}{|r|}{1925} \\
\hline & Parroquias & $\begin{array}{l}\text { Iglesias/Capillas } \\
\text { Filiales }\end{array}$ & Parroquias & $\begin{array}{l}\text { Iglesias/Capillas } \\
\text { Filiales }\end{array}$ & Parroquias & \begin{tabular}{|l} 
Iglesias/Capillas \\
Filiales
\end{tabular} \\
\hline $\begin{array}{l}\text { De Vieja } \\
\text { Colonización }\end{array}$ & 19 & 74 & 21 & 121 & 31 & 128 \\
\hline Colonizadores & 5 & 16 & 18 & 58 & 39 & 80 \\
\hline Totales & 24 & 90 & 39 & 179 & 70 & 208 \\
\hline $\begin{array}{l}\text { Total de } \\
\text { templos }\end{array}$ & & 114 & & 218 & & 278 \\
\hline \multicolumn{7}{|c|}{$\begin{array}{l}\text { Fuente: Respuestas a los cuestionarios de las Visitas Canónicas, Informes Diocesanos, Autos y Decretos } 1905 \text { - } \\
1925 \text { (Cfr. Tablas } 10 \text { a, b y c en Anexo II). } \\
\text { * No se ha tomado la Capital. Sólo hemos considerado iglesias o capillas que tenían funciones parroquiales } \\
\text { excluyendo las particulares, de colegios y conventos que no cumplían esa función. }\end{array}$} \\
\hline
\end{tabular}

Una mirada cartográfica del entramado parroquial nos permite observar que los nuevos curatos se establecieron en el centro y sureste provincial. En tanto, en los departamentos de vieja colonización el crecimiento fue disímil, el norte permaneció casi sin alteraciones en sus estructuras parroquiales, el oeste experimentó un crecimiento significativo en aquellos departamentos a los que llegó el ferrocarril, como Cruz del Eje y San Javier, y los departamentos del centro, Colón, Punilla, Río Primero, Río Segundo y Tercero Arriba, que tuvieron un ritmo propio y se vieron favorecidos por el tendido de las líneas férreas, y si bien tenían el mayor núcleo de población criolla, recibieron un fuerte impacto inmigratorio. Sin embargo, el mayor impulso de la jerarquía eclesiástica se focalizó en la zona de nueva colonización agrícola.

${ }^{23}$ ASV. Nunciatura Argentina, Libro 62, fs.114-116. 
Los Gráficos que presentamos a continuación muestran la evolución de los curatos y la creación de nuevas capillas a lo largo del período en estudio.

\section{Gráfico 11}

Evolución de curatos, 1875-1925

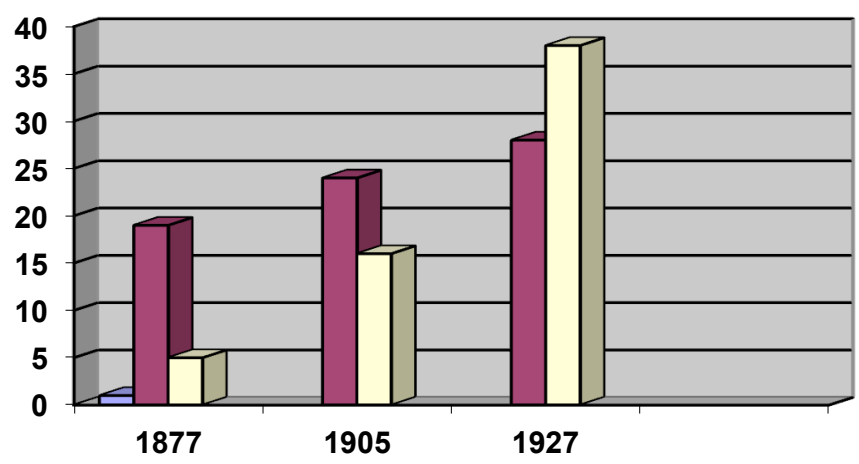

पVieja Colonización

口Nueva Colonización

Gráfico 12

Evolución de capillas, 1875-1925

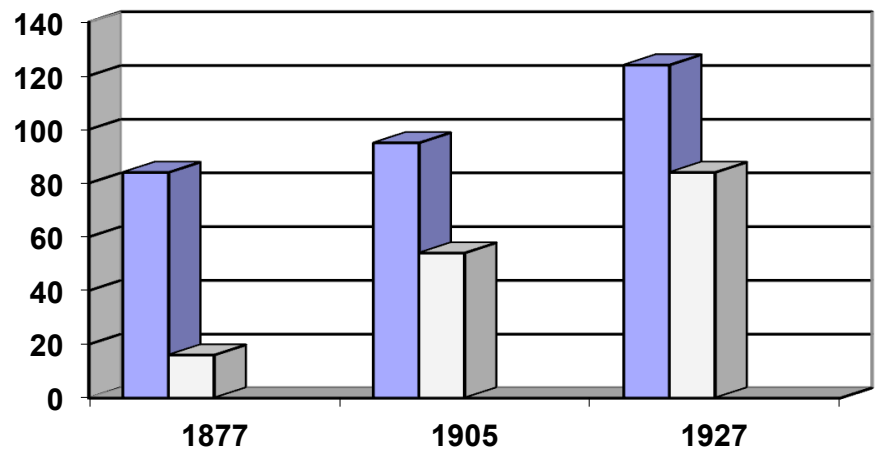

口Vieja Colonozación

口Nueva Colonización

Ahora, pasaremos a analizar la relación entre templos con funciones parroquiales, territorio y habitantes. Para ello, hemos diseñado las Tablas 21 y 22.

En 1875, existían, en los departamentos de vieja colonización, 93 templos sobre un total de 174.375 habitantes, lo que significaba un templo, con funciones parroquiales, cada 1.875,00 habitantes. Al finalizar el período de nuestro análisis, el mismo espacio contaba con 159 templos, con funciones parroquiales, y un total de 331.660 habitantes, lo que da un templo cada 2.085,91 habitantes. Como puede observarse, la proporción templo-habitante 
se mantiene casi sin variación. Esto significa que las autoridades diocesanas velaron, a través de los templos, para garantizar la presencia de la iglesia. La Iglesia aumentó la cantidad de templos, además los habitantes se nuclearon en centros poblados ligados a la extensión de las líneas férreas, a medida que esos centros se constituían en caseríos y aldeas, se construyeron oratorios y capillas destinados a atender a las nuevas poblaciones.

Tabla 21

\begin{tabular}{|c|c|c|c|c|c|c|c|}
\hline \multicolumn{8}{|c|}{$\begin{array}{l}\text { DEPARTAMENTOS DE VIEJA COLONIZACIÓN } \\
\text { POBLACION-TEMPLOS } 1879\end{array}$} \\
\hline \multirow[t]{2}{*}{ Departamento } & \multirow[t]{2}{*}{$\begin{array}{c}\text { Pedanías } \\
\mathbf{N}^{\circ}\end{array}$} & \multicolumn{2}{|c|}{\begin{tabular}{c|} 
Templos \\
No $^{\circ}$
\end{tabular}} & \multirow[t]{2}{*}{$\begin{array}{c}\text { Extensión } \\
\text { en km }^{2}\end{array}$} & \multirow[t]{2}{*}{$\begin{array}{c}\text { Población } \\
1879\end{array}$} & \multirow[t]{2}{*}{$\begin{array}{l}\text { Habitantes } \\
\text { por } \mathbf{k m}^{2}\end{array}$} & \multirow[t]{2}{*}{$\begin{array}{c}\text { Habitantes } \\
\text { - Templo }\end{array}$} \\
\hline & & \begin{tabular}{l|l}
$\mathbf{P}$ \\
\end{tabular} & $\mathbf{C}$ & & & & \\
\hline Anejos Sud & 7 & 1 & 3 & 3.815 .601 & 8.290 & 2,17 & $2.072,50$ \\
\hline Anejos Norte & 4 & 1 & 3 & 1.650 .721 & 7.434 & 4,50 & $1.858,50$ \\
\hline Punilla & 7 & 1 & 11 & 3.977 .967 & 7.905 & 1,99 & 658,75 \\
\hline Calamuchita & 7 & 2 & 5 & 5.631 .017 & 10.684 & 1.89 & $1.526,28$ \\
\hline Río Segundo & 9 & 1 & 4 & 3.490 .869 & 14.349 & 4.11 & $2.869,80$ \\
\hline Río Primero & 11 & 2 & 6 & 6.954 .677 & 17.036 & 2.45 & $2.129,50$ \\
\hline Tulumba & 5 & 1 & 6 & 5.439 .261 & 8.208 & 1.51 & $1.172,57$ \\
\hline Totoral & 4 & 1 & 3 & 4.032 .089 & 8.001 & 1,98 & $2.000,25$ \\
\hline Río Seco & 4 & 1 & 4 & 25.274 .974 & 5.856 & 0,23 & $1.171,20$ \\
\hline Sobremonte & 5 & 1 & 2 & 8.145 .361 & 7.096 & 0,87 & $2.365,33$ \\
\hline Ischilín & 6 & 1 & 5 & 2.949 .640 & 15.367 & 5.21 & $2.561,16$ \\
\hline Cruz del Eje & 4 & 1 & 6 & 6.792 .311 & 14.381 & 2.12 & $2.054,42$ \\
\hline Minas & 4 & 1 & 4 & 4.032 .089 & 9.387 & 2.33 & $2.346,75$ \\
\hline Pocho & 3 & 1 & 3 & 1.515 .416 & 7.658 & 5.05 & 1.914 .50 \\
\hline San Alberto & 6 & 1 & 4 & 3.490 .869 & 11.534 & 3.30 & $2.306,80$ \\
\hline San Javier & 5 & 1 & 2 & 4.410 .943 & 15.374 & 3.48 & 5124,66 \\
\hline Tercero Arriba & 6 & 1 & 3 & 4.952 .163 & 5.815 & 1.18 & $1.453,72$ \\
\hline TOTALES & 107 & 19 & 74 & 96.555 .968 & 174.375 & & $1.875,00$ \\
\hline $\begin{array}{l}\text { Fuente: Memoria A } \\
\text { AAC. Informes par }\end{array}$ & e la Oficin & & & Provincia de & DIIC & & oba 1881. \\
\hline
\end{tabular}

Los informes y planos enviados a la curia sobre las capillas de cada curato, muestran que, habitualmente, la distancia promedio que separaba a un templo de otro era de 4 a 6 leguas 
en los departamentos de mayor densidad de población, en tanto, en los departamentos de menor densidad de población, las distancias podían llegar de 12 a 15 leguas (Cfr. Croquis de los curatos de los departamentos del norte, oeste y centro de la provincia de Córdoba, en Anexo IV).

Tabla 22

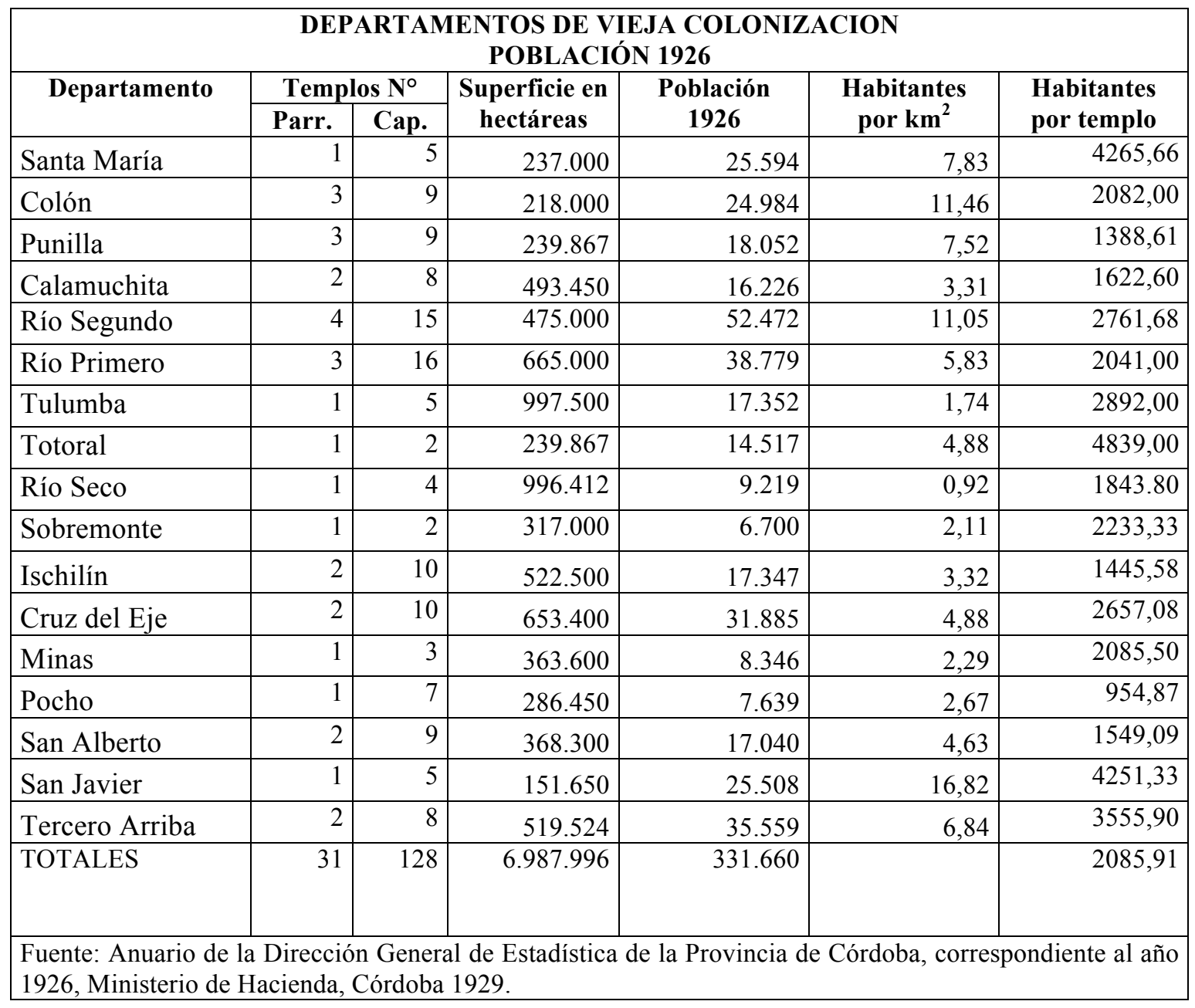

A continuación, analizaremos el proceso de expansión parroquial que experimentaron los departamentos colonizadores entre 1879 y 1926. En esta región, se observa que, en 1926, la relación templo-habitante aumentó casi en un 75\% respecto al año 1879 , esto significa que pese al aumento significativo de templos construidos en la región, éstos no resultaron suficientes en relación al aumento demográfico. Sin embargo, al desagregar los curatos, advertimos que Río Cuarto y General Roca, últimos en incorporarse a la actividad 
productiva, fueron los que menos templos, y por lo tanto, presencia religiosa tuvieron, mientras que en los departamentos de San Justo, Unión y Tercero Abajo el aumento poblacional fue acompañado por un proceso de expansión de la red parroquial. En 1879, la región tenía 21 templos y 36.296 habitantes, relación que da 1.910,31 habitantes por templo y, en 1926, la cantidad de templos aumentó un $60 \%$, sin embargo el aumento de la población fue tal que la proporción fue de un templo cada 3.532,13 habitantes. Como puede observarse en el Gráfico 13 la relación templo/habitante es más grave en 1926 que en 1879.

\section{Gráfico 13}

\section{$\mathbf{N}^{\circ}$ de habitanes por templo}

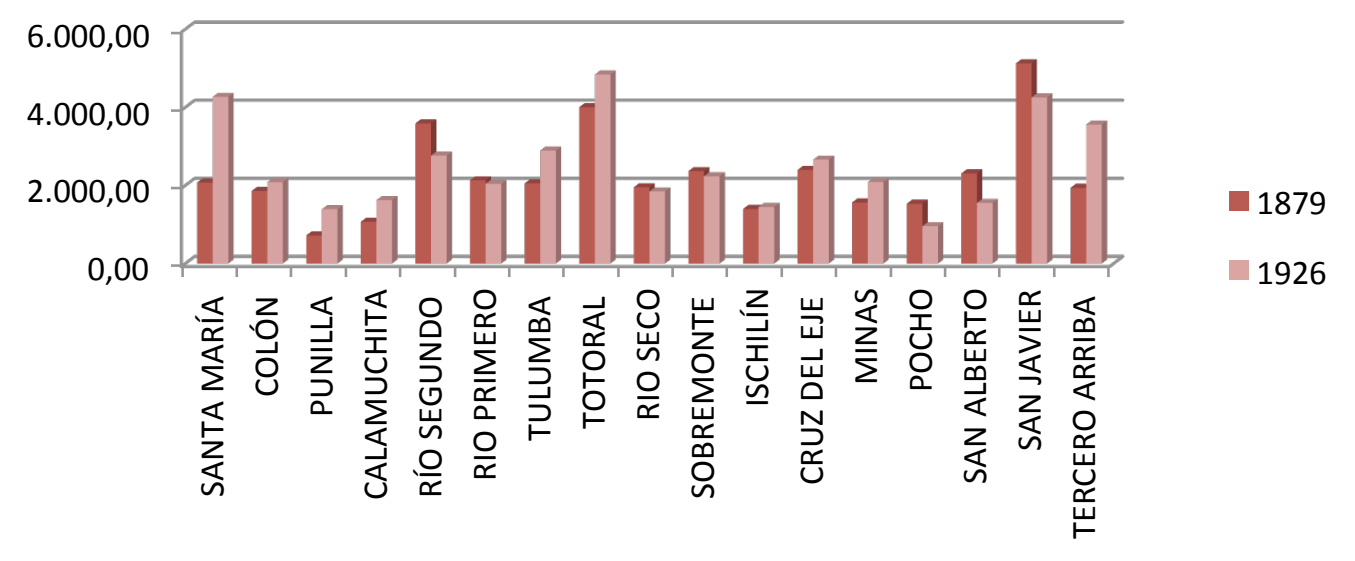

Tabla 23

\begin{tabular}{|c|c|c|c|c|c|c|c|c|}
\hline \multicolumn{9}{|c|}{$\begin{array}{l}\text { DEPARTAMENTOS COLONIZADORES } \\
\text { POBLACION } 1879\end{array}$} \\
\hline \multirow[t]{2}{*}{$\mathbf{N}^{\circ}$} & \multirow[t]{2}{*}{ Departamento } & \multirow{2}{*}{$\begin{array}{c}\text { Pedanías } \\
\text { N }^{\circ}\end{array}$} & \multicolumn{2}{|c|}{ Templos } & \multirow{2}{*}{$\begin{array}{c}\text { Extensión } \\
\text { en } \mathbf{k m}^{2}\end{array}$} & \multirow{2}{*}{$\begin{array}{c}\text { Población } \\
1879\end{array}$} & \multirow{2}{*}{$\begin{array}{c}\text { Habitantes } \\
\text { por } \mathbf{K m}^{2}\end{array}$} & \multirow{2}{*}{$\begin{array}{c}\text { Habitantes } \\
\text { por } \\
\text { Templo }\end{array}$} \\
\hline & & & Parr. & Cap. & & & & \\
\hline 12 & $\begin{array}{l}\text { Tercero } \\
\text { Abajo }\end{array}$ & 5 & 2 & 4 & 5.141 .590 & 8.464 & 1.64 & $2.116,00$ \\
\hline 13 & Río Cuarto & 5 & 1 & 5 & 40.510 .317 & 15.018 & 0.37 & $2.503,00$ \\
\hline 14 & San Justo & 4 & 1 & 3 & 17.102 .552 & 6.218 & 0.36 & $1.554,50$ \\
\hline 15 & Unión & 4 & 1 & 4 & 18.401 .480 & 6.596 & 0.36 & $1.634,75$ \\
\hline & TOTALES & 19 & 5 & 16 & 81.155 .939 & 36.296 & 0,44 & $1.910,31$ \\
\hline
\end{tabular}

Fuente: Memoria Anual de la Oficina de Estadística de la Provincia de Córdoba, Publicación Oficial, Córdoba, 1881. 
Tabla 24

\begin{tabular}{|c|c|c|c|c|c|c|}
\hline \multicolumn{7}{|c|}{$\begin{array}{l}\text { DEPARTAMENTOS COLONIZADORES } \\
\text { POBLACION-TEMPLOS } 1926\end{array}$} \\
\hline \multirow[t]{2}{*}{ Departamento } & \multicolumn{2}{|c|}{$\begin{array}{c}\mathrm{N}^{\circ} \\
\text { Templos }\end{array}$} & \multirow[t]{2}{*}{$\begin{array}{l}\text { Superficie en } \\
\text { hectáreas }\end{array}$} & \multirow[t]{2}{*}{$\begin{array}{l}\text { Población } \\
1926\end{array}$} & \multirow[t]{2}{*}{$\begin{array}{c}\text { Habitantes } \\
\text { por } \mathbf{k m}^{2}\end{array}$} & \multirow{2}{*}{$\begin{array}{c}\text { Habitantes } \\
\text { por } \\
\text { Templo }\end{array}$} \\
\hline & \begin{tabular}{l|l}
$\mathbf{P}$ \\
\end{tabular} & $\mathbf{C}$ & & & & \\
\hline Tercero Abajo & 4 & 23 & 487.104 & 44.121 & 9,06 & $1.634,11$ \\
\hline Río Cuarto & 5 & 3 & 1.843 .425 & 85.283 & 4,63 & $10.660,87$ \\
\hline San Justo* & 14 & 23 & 1.558 .800 & 82.914 & 5,32 & $2.240,91$ \\
\hline Unión & 5 & 12 & 1.365 .858 & 74.788 & 5,48 & $4.399,29$ \\
\hline Gral. Roca & 1 & 3 & 1.366 .271 & 35.150 & 2,57 & $8.787,50$ \\
\hline Marcos Juárez & 8 & 13 & 1.073 .437 & 68.180 & 6,35 & $3.246,66$ \\
\hline Juárez Celman & 2 & 8 & 1.251 .670 & 47.549 & 3,8 & $4.754,90$ \\
\hline TOTALES & 39 & 85 & 8.946 .565 & 437.985 & & $3.532,13$ \\
\hline
\end{tabular}

Los Gráficos muestran de una manera clara esta relación. En el Gráfico 14, puede observarse la evolución de curatos o parroquias, mientras que en el 15 se muestra el crecimiento de capillas y oratorios.

\section{Gráfico 14}

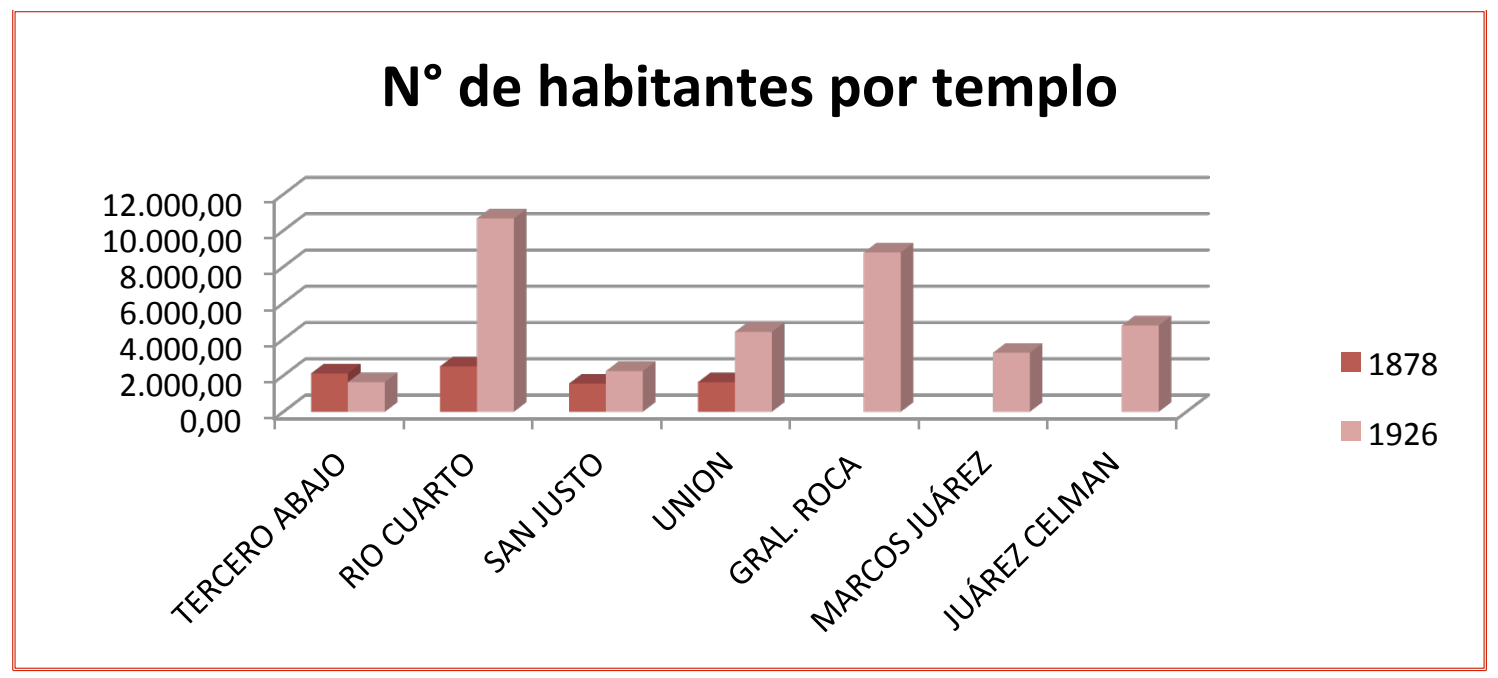




\section{Gráfico 15}

Evolución de parroquias por regiones, 1875-1925

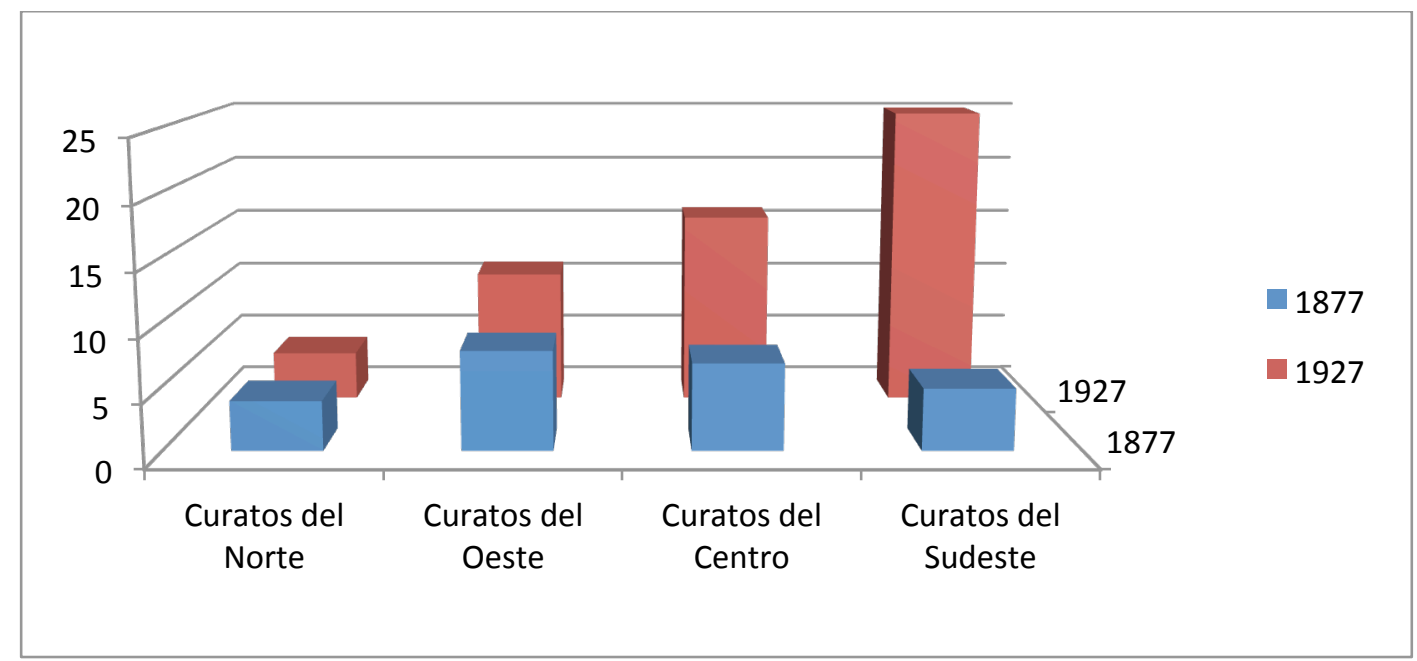

Gráfico 16

Evolución de capillas por regiones, 1875-1925

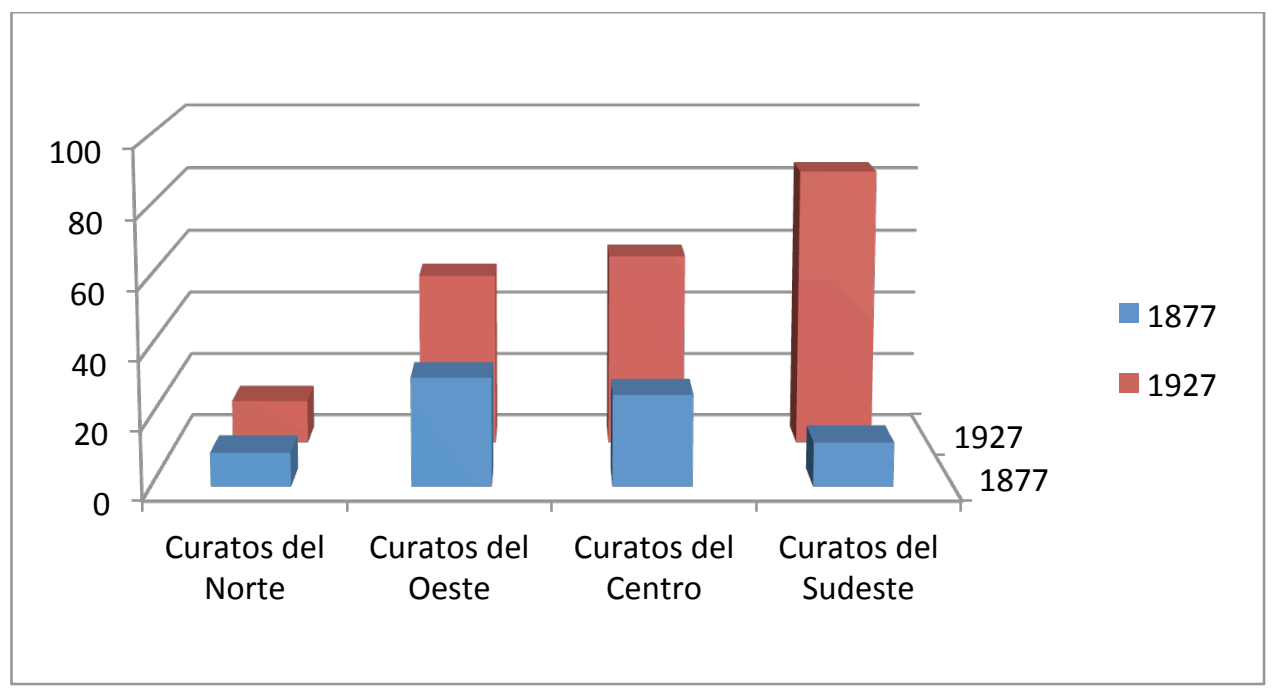

\subsection{La recuperación de antiguos templos para el culto}

Varias de las capillas que se señalan eran de origen colonial y, a la fecha, se encontraban muy deterioradas o, incluso, como afirman las fuentes, en ruinas. Durante el período, se inició la reparación de antiguas capillas o la reconstrucción de un nuevo templo en un lugar cercano al sitio. Un paneo de la situación de antiguas capillas establecidas en las diversas 
regiones de la provincia, nos muestra la precaria situación en que se encontraba la iglesia en la campaña.

En 1858, el párroco de Río Cuarto advierte el estado de deterioro de las 12 capillas de su curato. La del pueblo de Achiras era una capilla muy pequeña y pobre, bajo el título de Ntra. Sra. de las Mercedes, no poseía rentas ni temporalidades. La de San Bartolomé era una capilla u oratorio pobrísimo con el techo que amenazaba caerse. Tegua, "sin pueblo reunido", advierte el cura, tenía capilla en estado regular, bajo el título de Ntra. Sra. del Rosario, sin rentas ni temporalidades. El poblado de La Carlota tenía una capilla bajo el título de Ntra. Sra. de las Mercedes, al igual que el resto, no tenía rentas ni temporalidades. En Reducción, había una capilla bajo el título de Ntro. Señor de la Buena Muerte, era pobre y tampoco tenía rentas ni temporalidades. Otras pequeñas poblaciones no tenían capilla alguna, "San Fernando, dicho San Pacho, fuerte con pueblo de unas 300 almas, sin capilla y sin oratorio. Tres de Febrero, fuerte con pueblito, sin capilla y sin oratorio". El informe señala que no había clérigos seglares en todo el territorio, los que atendían la parroquia y las capillas eran los padres franciscanos. ${ }^{24}$

Si a estas citas, le agregamos las fechas de construcción de los templos, advertimos que, por estos años, la mayoría era del período colonial. La capilla de Tegua, construida en 1696, era de adobe y estaba ubicada en la estancia "El Tala” de Miguel Fernández Montiel. El Santuario de Reducción tiene sus orígenes en la primigenia reducción de indios pampas, en el paraje denominado El Espinillo, sobre la margen sur del Río Cuarto. Esta reducción estuvo a cargo de la Compañía de Jesús, su posterior restablecimiento como reducción a cargo de los Padres Franciscanos del Colegio de Propaganda Fide, tomó el nombre de San Francisco de Asís. La capilla de Achiras se levantó en 1770 y en 1830 fue trasladada a su emplazamiento actual, formaba parte del fuerte con asiento en el mismo lugar. San Bartolomé era una pequeña capilla ubicada al pie de las sierras, que comenzó a edificarse a fines de la década de $1850 .{ }^{25}$ El fuerte de San Fernando (San Pacho) tuvo una primera capilla que con el tiempo fue destruida por los indios. La capilla de la colonia Sampacho comenzó su construcción en 1879, pocos años después de la instalación de las primeras familias italianas. El resto de las capillas fue levantado por los padres franciscanos después

\footnotetext{
${ }^{24}$ AAC. Caja Parroquia Río Cuarto, s/f. Nota del 28 de agosto de 1858.

${ }^{25}$ INSTITUTO AGRARIO ARGENTINO, Reseña Histórica de Río Cuarto (Provincia de Córdoba), Buenos Aires, 1947, T. I, p. 138.
} 
de fundar, en 1856, el colegio de Propaganda Fide en Río Cuarto. Desde allí, atendieron toda la vasta zona sur de Córdoba. En 1879, el guardián del Convento de San Francisco, Fray Ludovico Quaranta, envía una carta al Provisor Castellano, en la que le informaba que estaba levantando limosnas para la terminación de una Iglesia que estaba construyendo en el pueblo de Reducción. ${ }^{26}$

Los obispos del período, en sus giras pastorales, advirtieron el deterioro material de las antiguas iglesias y capillas, muchas de las cuales se encontraban prácticamente en ruinas.

De la región oeste, tenemos algunos datos puntuales que dan una idea de la situación general. El cura Fernando Falorni, al hacerse cargo del curato de Ischilín en enero de 1877, advertía al secretario del obispado que el estado de la parroquia Ntra. Sra. del Rosario era "sucia e inmunda, desenladrillada en muchas partes, las puertas de la sacristía y de la Iglesia con pastos e inmundicias en sus umbrales, el pretil sin cerca, parte de los ornamentos estaban encima de los bancos ensuciados por las lechusas y murciélagos y los demás revueltos, ardidos y rotos entre la basura y polvo de los cajones". ${ }^{27}$ Esta descripción permite hacernos una idea del estado material del templo. Ischilín no era una excepción. En la visita canónica al curato de Punilla en 1885, el cura Lorenzo Luz de Cabrera le dice al prelado que "desde su advenimiento al Curato se había preocupado de regular los muchos defectos que encontró en estas pobres y casi abandonadas capillas". ${ }^{28}$

En 1882, el Obispo Tissera, durante la visita canónica al curato de Alta Gracia, se dirigió a la vice-parroquia de La Candelaria de la Lagunilla para realizar la visita y administrar las confirmaciones. El secretario la describe como "muy mal atendida en cuanto al aseo y seguridad, pues sus paredes son sin blanqueo, sus puertas sin buenas cerraduras, el albergue de los murciélagos en grande escala produciendo una desagradable impresión, la insoportable atmósfera que la llena y por fin los vestigios que se ven alrededor de los animales domésticos por la proximidad de los corrales y la falta de cerco que pudiera resguardarla, todo esto documenta la indolencia con que es atendida, [...] la invasión de animales y demás cosas que se oponen al aseo y decencia". 29

\footnotetext{
26 AAC. Parroquias: Remedios, f.317. Carta del 5 de noviembre de 1879 (está archivada en el lugar equivocado).

${ }^{27}$ AAC. Leg. 50, Ischilín, s/f.

${ }^{28}$ AAC. Libro de Autos, 1886-1916, f.115.

${ }^{29}$ AAC. Libro de Autos y Visitas Pastorales, 1886-1916, f.115.
} 
En el curato de San Alberto, las antiguas capillas y oratorios se encontraban, a la llegada del cura Brochero, en un estado de extremo deterioro. El cura fue rehaciendo todas las antiguas capillas de su curato y levantó nuevas. En 1871, lo encontramos reconstruyendo la capilla de San Vicente, un caserío de más de 100 habitantes ubicado al oeste de la sierra de Pocho, que tenía un "oratorio pajizo en estado ruinoso" (Cárcano, 1928: 47). Las capillas del Tránsito, Nono, Ambul y Panaholma, todas ellas, de adobe y techo de paja, fueron reconstruidas por el celoso párroco. Uno de sus biógrafos cuenta que el mismo cura construía los hornos de ladrillos, formaba el lozadal de barro, entremezclándoles el fiemo, se arremangaba la sotana y descalzo iba haciendo dar vuelta a la mula. Luego cortaba los ladrillos en el molde de madera (Aznar, 1950: 31).

La capilla Nuestra Señora de la Higuera del curato de Soto había sido construida en 1760 y se sostuvo en pie por poco más de un siglo, pasado ese tiempo comenzó a deteriorarse hasta quedar en ruinas. En 1879, comenzó a construirse, por iniciativa del cura Pretel, un nuevo templo a poca distancia del anterior y de mayores dimensiones, $25 \mathrm{~m}$ de largo por $8 \mathrm{~m}$ de ancho, el cual fue bendecido durante la misión de 1884 (Carole, 1925: 229).

El norte provincial no estaba exento de esta precariedad. El cura de Tulumba solicitó autorización a la curia para celebrar los oficios de Semana Santa en la vice-parroquia de San José de la Dormida, debido "al mal estado de la Iglesia parroquial de Tulumba". ${ }^{30}$ En el curato de Río Seco, se reconstruyeron antiguas capillas. En el auto de la visita canónica del Obispo Auxiliar Cabanillas, en 1903, se ordenó al cura demoler la parte vieja de la capilla de San Roque, de Rayo Cortado, y utilizar la otra parte para celebrar y administrar los sacramentos hasta que se edificara debidamente con los donativos de los vecinos". 31

En 1898, el obispado envió una circular a todos los párrocos en la que se solicitaba un informe sobre el estado de las iglesias y capillas del curato. Las respuestas a esta circular nos permiten conocer la realidad del sudeste. En el informe, el cura y vicario de Villanueva, Silvestre Ceballos, señalaba, entre otras cosas, que la Iglesia de la Villa de San Juan Bautista (antiguamente Esquina de Ballesteros) era de techo de paja y estaba en un estado más que regular, “[...] la iglesia de la guardia del Saladillo se había derrumbado y la que se

\footnotetext{
${ }^{30}$ AAC. Copiador de Cartas. Secretaría del Obispado, 1882-1904, f.255.

${ }^{31}$ AAC. Notas particulares del Obispo, 1884-1903, f.126.
} 
utilizaba para el desempeño del ministerio era la sacristía, pero tenía el techo de azotea en mal estado y era pequeña", otra de las capillas (de la cual no sabemos el titular, pues el documento está roto) se había derrumbado, por lo tanto, para el desempeño del ministerio utilizaba una pieza de 6 varas y estaba trabajando en una iglesia nueva. ${ }^{32}$ Estos son algunos de los tantos ejemplos que nos muestran el deterioro de los templos de la campaña cordobesa.

\subsection{La construcción de nuevas iglesias}

La reconstrucción de antiguos tempos y edificación de nuevos se realizaba, generalmente, por iniciativa de los fieles y/o preocupación pastoral de los párrocos. El edificio se levantaba con diversos recursos: suscripciones voluntarias de los vecinos, ayudas y subvenciones estatales, donaciones particulares. Tampoco se abandonó la práctica tradicional de que algún vecino acomodado lo construyera en su propiedad y lo donara luego al obispado, ni el celo de algún párroco que puso manos a la obra en la construcción de nuevos templos.

En 1872, José Gabriel Brochero, cura de San Alberto, se dirigió al intendente municipal de San Javier para informar que algunos vecinos de Las Rosas habían “donado un terreno para que se construya un templo de cal y piedra". El cura solicitó a la municipalidad ceder, a beneficio del referido templo, los $\$ 150$ de los $\$ 200$ que estaban destinados al presupuesto para la mejora del camino entre Las Rosas y San Javier, pues, señala, “es más importante en las presentes circunstancias Iglesia que camino [...] Camino hay, Iglesia no" (Conferencia Episcopal Argentina, 1999: 106).

En 1876, Juan Celayes, vecino de la Pedanía de Castaño, departamento de Río Primero, informaba al obispado que había construido una capilla en virtud de una promesa hecha a Santa Rita, para que su familia y vecindario rindiesen culto al Señor. La capilla fue edificada en su estancia y a su sola costa, medía 20 varas de largo por 6 de ancho, en material cocido, y estaba ubicada "en un lugar de frontera, muy distante de las iglesias pues la más cercana es la de las saladas, que dista como a 7 leguas, de suerte que la mayor parte del vecindario no puede cumplir con los deberes cristianos por temor a las invasiones de

\footnotetext{
${ }^{32}$ Carpeta Parroquias: Villanueva, f.1.
} 
indios, pues es espuesto dejar las habitaciones solas por esta razón".33 Don Juan se comprometía a mantener el edificio, costear los gastos y dotarlo de todo lo necesario para la celebración de las funciones litúrgicas y administración de los sacramentos. Solicitaba se le concediera el derecho de patronato sobre la capilla, para él y sus descendientes y con él, el derecho de costear un sacerdote, que "pagado por mí pueda ocuparse en doctrinar al vecindario". El obispado remitió la consulta sobre la necesidad de la capilla al cura de Chalacea, quien tenía jurisdicción parroquial y de quien dependería la futura capilla. El cura, Doroteo García de la Serna, respondió que consideraba que no era conveniente una nueva capilla, por la misma razón expuesta en la nota de solicitud, "el peligro de los indios", además opinaba que al cura no le sería posible ejercer el ministerio en un lugar tan retirado, alejado de los centros más poblados del curato, "sin embargo, en cumplimiento de mi deber lo haría cuantas veces sea necesario". El fiscal eclesiástico, Adolfo Luque, estudió el asunto e informó, el 6 de mayo de 1876, al provisor del obispado en sede vacante, Dr. Gaspar Martiarena, que se accediera a todo lo solicitado por el Sr. Celayes, "salvando siempre como es consiguiente los derechos parroquiales, tanto en el libre ejercicio de las funciones propias de su ministerio en el mencionado oratorio, cuanto en el cobro y administración de las entradas de fábrica, que es lo que es, y debe ser privativo del párroco según derecho, corresponde privativamente al párroco o beneficiado y de ninguna manera al patrono o fundador de dicha iglesia". ${ }^{34}$ Además, el fiscal consideraba pertinente y encomiable la cláusula impuesta por el fundador de costear un sacerdote a su expensas, "siempre que el sacerdote sea aprobado por el prelado y se limite al ejercicio de las funciones meramente sacerdotales a más de la que los señores párrocos quieran delegarle”. El provisor del obispado concede las licencias solicitadas, nombra patrón al Sr. Celaya y agrega la cláusula relativa a "donar a la Iglesia un área de terreno suficiente para el cementerio, casa parroquial y una escuela, cuya donación se hará por escritura pública. ${ }^{35}$ Esta capilla con el tiempo (más de 40 años) llegará a formar un curato propio.

El curato de Villa de Soto contaba con templos construidos en la colonia. La capilla de La Higuera a $24 \mathrm{~km}$ de la villa, por el camino hacia villa Dolores, había sido construida en el siglo XVII y figura en el empadronamiento ordenado en 1785 y enviado a la curia

\footnotetext{
33 AAC. Parroquias, Carpeta La Salada.

${ }^{34}$ Cita al Concilio de Trento, Sesión 25, Cap. 9.

${ }^{35}$ AAC. Parroquias, Carpeta La Salada.
} 
diocesana por el párroco Rodríguez. La capilla sufrió los asaltos de caciques levantados en armas durante la primera mitad del siglo XIX y las embestidas de los montoneros del Chacho Peñaloza. La capilla no se sostuvo en pie y la construcción cedió ante el persistente abandono, el aislamiento de La Higuera, las deficientes vías de comunicación y la pobreza de sus pobladores. En 1879, el cura Pretel, ayudante a la sazón del párroco de Villa de Soto, comenzó la reedificación de la capilla dedicada a la Santísima Virgen del Rosario, a 10mts de la antigua edificación, bendiciendo solemnemente la piedra fundamental. En la visita canónica del Obispo Tissera, en marzo de 1886, se deja asentado que "está inhabilitada la capilla y se trabajaba en la edificación de una nueva, espaciosa y más sólida que ya estaba por terminarse". ${ }^{36}$ Con la colaboración y trabajo de numerosos fieles, la empresa llegó a su término, inaugurándose, con una bendición solemne y una misión. La capilla era la propietaria de los $100 \mathrm{mts}$ de terreno circundante a la misma. Como era costumbre, los párrocos cedieron el mismo para levantar viviendas para los pobladores. Por eso, señala el párroco Juan Gustavo Carole, que la población de La Higuera estaba asentada en terrenos pertenecientes a la capilla. ${ }^{37}$

El Obispo Tissera en su visita al norte y oeste provincial, pasó revista del estado material de los templos. En el mes de abril de 1886, visitó la capilla de Guasapampa y observó que la antigua capilla estaba inutilizada y amenazaba ruina, motivo por el cual se estaba construyendo una nueva. Inspeccionó los ornamentos litúrgicos y concluyó que no eran aptos para la celebración del culto y que era necesario dotar a la nueva capilla de ornamentos dignos. La nueva capilla tendrá la imagen de la Virgen del Rosario en buen estado y adecuadamente vestida, vinajeras y cáliz de plata, dos crucifijos nuevos y uno muy roto que debió quemarse. ${ }^{38}$ La capilla de San Carlos Minas, dedicada a la Purísima Concepción, estaba a punto de inhabilitarse por su deterioro material. ${ }^{39}$

El interés de la jerarquía eclesiástica era, principalmente, la atención espiritual de los feligreses. Por ello, cuando los señores Ventura y Soto, vecinos del curato de Villa Nueva, escribieron al obispo para solicitar permiso para edificar una capilla en honor a San José, en el paraje denominado estación Vélez Sarsfield, distante 4 leguas de la capilla de Punta

\footnotetext{
${ }^{36}$ AAC. Libro Autos y Visitas Pastorales, 1886-1916, f.127.

${ }^{37}$ BEDC, vol. II, $\mathrm{n}^{\circ} 11$, septiembre de 1925, pp. 251-255.

${ }^{38}$ AAC. Libro Autos y Visitas Pastorales, 1886-1916, f.129.

${ }^{39}$ AAC. Libro Autos y Visitas Pastorales, 1886-1916, f.131.
} 
de Agua, 8 de la capilla Rodríguez y 7 de la de Villa Nueva, comprometiéndose a edificar un templo de más de 20 varas de fondo, con sacristía, casa para el cura y cementerio, y media cuadra de donación de terreno, se accedió al ofrecimiento. Entre los considerandos se encontraba la excesiva distancia de los pobladores de la zona de las mencionadas capillas y la consecuente dificultad para cumplir con la iglesia. ${ }^{40}$

En 1873, el cura de Chalacea informaba al obispo que había realizado una misión y confesado en la Pedanía de Castaño, en la capilla de La Salada, dedicada a la Purísima Concepción, pues "la gente en aquella frontera abandonada se encuentra totalmente privada de los auxilios de la religión". El cura, entonces, informó que al reflexionar sobre el abandono de aquella gente, le manifestó a José Piedras, hacendado del lugar, la preocupación por atender espiritualmente a esta población pobre y abandonada de la frontera norte, quien le contestó "que proporcionaría una pieza de las tantas que tiene con objeto que se administre en ellas los santos sacramentos, cuya pieza es de azotea muy decente de siete varas de luz". ${ }^{41}$ Con frecuencia, estas piezas prestadas y luego donadas, se convertían en templos provisorios y con el correr del tiempo se edificaban capillas.

En 1874, el cura de Tulumba solicitó ayuda al gobierno provincial para construir una iglesia dedicada a la Virgen del Pilar, debido a la pobreza del vecindario del paraje en el que se levantará el templo. ${ }^{42}$ En 1876, comenzó la construcción del templo de Río Seco, doce años después recibió una ayuda del gobierno provincial para su terminación. ${ }^{43}$ Lo mismo sucedió, en 1884, con la Iglesia parroquial de Río Segundo, cuatro años después, el gobierno le otorgó $\$ 300$ nacionales. ${ }^{44}$

En 1886, los miembros de la comisión directiva a cargo de los trabajos de la construcción de la capilla de San Carlos, departamento de Minas, solicitaron ayuda al gobierno provincial para "poder llevar adelante esta obra de primera necesidad para el estímulo del progreso atendiendo a las condiciones sociales y el estado intelectual de los habitantes, creemos pues es el mejor medio para formar la población de esta villa que será en adelante la primera semilla del progreso y el plantel de civilización y cultura de este

\footnotetext{
${ }^{40}$ AAC. Legajo Villanueva, s/f. Nota del 02/01/1879.

${ }^{41}$ AAC. Leg. 40, TIII. Cartas de los Sres. Curas a los Sres. Obispos, 1842-1908. Curato de Chalacea, Agosto 24 de 1873.

${ }^{42}$ AHPC. Gobierno 1873, f.204. Fecha 24/08/1874.

${ }^{43}$ AHPC. Gobierno 1888, T8, f.286.

${ }^{44}$ AHPC. Gobierno 1888, T8, f.276.
} 
pobre departamento". ${ }^{45}$ En 1886, comenzó la construcción del nuevo templo en Villa Nueva ${ }^{46}$ y en 1887 en Villa del Rosario. ${ }^{47}$ Ambas, con una subvención del gobierno. Ese mismo año, comenzó a construirse la capilla de San Pedro, en el departamento de San Alberto, con una ayuda del gobierno de $\$ 200$ mensuales. ${ }^{48}$ Como la Iglesia de Punilla quedó bajo el agua por la construcción del dique San Roque, el gobierno otorgó \$2.000 para levantar una nueva iglesia en el curato de Punilla. ${ }^{49}$ También en Dolores, departamento de Punilla, se reedificó la capilla, que estaba casi en ruinas, con una subvención del gobierno. ${ }^{50}$

En 1888, comenzó la construcción del nuevo templo de Villa María ${ }^{51}$ y la de una iglesia en Colonia Caroya, para lo cual el gobierno otorgó una ayuda de $\$ 300$ por una sola vez. ${ }^{52}$ También se edificó una nueva capilla en Puesto de Castro, curato de Río Seco, por estar en ruinas la antigua, ${ }^{53}$ en el mismo curato, el cura y vicario interino, Juan Pignolo (18831894), levantaron las capillas de La Estancia y Rayo Cortado. ${ }^{54}$

En 1889, se finalizó la construcción de la Iglesia de Cosquín, para ello, el gobierno concedió una ayuda de $\$ 400 .{ }^{55}$ En la visita canónica al curato de Chalacea, realizada en 1902, el obispo Filemón Cabanillas señalaba "la necesidad urgente de edificar una capilla en el lugar denominado Las Encrucijadas debido al aumento de población en aquellos parajes". ${ }^{56}$ Al año siguiente, en 1903, el prelado hizo la visita a la vice-parroquia de Gusapampa, recientemente reedificada, debido a que la iglesia parroquial de San Carlos Minas estaba en construcción. ${ }^{57}$ La misma fue inaugurada y bendecida el 23 de agosto de ese año. ${ }^{58}$ Zenón Bustos, en sus giras pastorales, también comprobó, entre otros aspectos, la insuficiencia de templos para la atención de los fieles. Advirtió, al cura de San Antonio de Litín, la conveniencia de construir un nuevo templo con capacidad para mayor número de

\footnotetext{
${ }^{45}$ AHPC. Gobierno, 1886, T7, f.152.

${ }^{46}$ AHPC. Gobierno, 1886, T7, f.156.

${ }^{47}$ AHPC. Gobierno, 1887, T8, f.108.

${ }^{48}$ AHPC. Gobierno, 1887, T8, f.114.

${ }^{49}$ AHPC. Gobierno, 1887, T8, f.119.

${ }^{50}$ AHPC, Gobierno, 1887, T8 f. 121

${ }^{51}$ AHPC. Gobierno, 1888, T8, f.289.

${ }^{52}$ AHPC. Gobierno, 1888, T8, f.297.

${ }^{53}$ AHPC. Gobierno, 1889, T9, f.281.

${ }^{54}$ La Voz del Interior, 28/03/1915. Pbro. Juan A Pignolo Aniversario de su ordenación.

${ }^{55}$ AHPC. Gobierno, 1889, T9, f.278.

${ }^{56}$ AAC. Libro de Notas particulares del Obispo, 1884-1903, f.115.

${ }^{57}$ AAC. Notas particulares del Obispo... p. 109.

${ }^{58}$ AAC. Respuesta al cuestionario de la Visita Canónica de 1917. Pregunta ${ }^{\circ} 11$.
} 
fieles y la urgencia de levantar la iglesia de Las Encrucijadas y reedificar la Iglesia derruida de la Cañada de Luca. ${ }^{59}$ Al párroco de Cruz del Eje, lo intimó a concluir la obra de ampliación del templo parroquial. ${ }^{60}$ En la visita a los curatos de las Sierras Grandes, determinó la construcción de, al menos, dos templos, debido a que "por encima de la sierra en una longitud de 25 o 30 leguas no tienen iglesias para el servicio religioso, viéndose obligados a bajar las altas y escarpadas faldas de las sierras para encontrarlas, ya sea al naciente ya al poniente, llevando sus hijos a grupa. Es pues una necesidad pensar en darles las dos iglesia que han señalado". ${ }^{61}$ También, sentencia al párroco de Sobremonte a realizar la compostura de las iglesias derruidas y a levantar la que faltaba en la Aguada del Norte. ${ }^{62}$ Al cura de Cruz Alta, lo anima a construir otra iglesia, y mientras esa iglesia se hiciera era urgente improvisarla, sirviéndose de una casa para celebrar el santo sacrificio, predicar y confesar, "sin esperar que el mal llegue a ser insalvable y a convertirse en una infección sumamente peligrosa para el resto de la población". 63

Como puede constatarse, ejemplos de este fenómeno son innumerables. En toda la provincia se construyeron nuevos edificios sagrados y se re-construyeron los antiguos, se amplió su capacidad y se renovaron los materiales. Muchas de las iglesias que conocemos hoy, se edificaron en esa época. Quizá lo que más llama la atención es la preocupación por levantar importantes iglesias en medio de la pampa. En 1891, el obispo Fray Reginaldo Toro informaba al ministro de Justicia, Culto e Instrucción Pública de la Nación que eran muchos los templos que se estaban construyendo en la diócesis, mencionaba los parroquiales de Tulumba, San Francisco del Chañar, Villa del Rosario, Villa Nueva, Villa María, Cruz del Eje, Colonia Caroya. Advertía que si esas obras no sumaban más recursos que las suscripciones populares, no sería posible llevarlas a término y solicitaba la protección y ayuda del gobierno. ${ }^{64}$

\footnotetext{
${ }^{59}$ AAC. Libro de Autos y Visitas Pastorales. Auto de la Visita Pastoral a la parroquia de San Antonio, 5 de noviembre de 1907.

${ }^{60}$ AAC. Libro de Autos y Visitas Pastorales. Auto de la Visita Canónica a Cruz del Eje, 22 de marzo de 1908.

${ }^{61}$ REOBA, 1912, p. 437. La visita se realizó del 16 de diciembre de 1912 al 18 de enero de 1913.

${ }^{62}$ AAC. Libro de Autos y Visitas Pastorales. Visita Canónica a la Parroquia de San Francisco Solano del Chañar, 24 de julio de 1908.

${ }^{63}$ AAC. Auto de la Visita Canónica a Cruz del Eje, 3 de agosto de 1913, f.389-391.

${ }^{64}$ AAC. Copiador de cartas. Secretaría del Obispado, 1882-1904, f.279. Nota del 07/02/1891.
} 
También contamos con abundante documentación sobre la dimensión material de los templos, proporciones, materiales, ornamentación, etc. ${ }^{65}$ En general, las iglesias que se construyeron a fines de siglo eran de grandes dimensiones, con una nave central y dos laterales. En 1890, se envía a la curia, para su aprobación, el plano de la nueva Iglesia parroquial de San Francisco, presupuestada en $\$ 24.000$ pesos nacionales. ${ }^{66}$ Sus medidas eran de $60 \mathrm{mts}$ por $18 \mathrm{mts}$; en 1889, se construyó la Iglesia de Cruz del Eje, cuyas dimensiones eran de 51,40mts por 21,40mts; en 1894, la iglesia de Villa del Rosario de $60,20 \mathrm{mts}$ por 24,20mts; Villa María de $52 \mathrm{mts}$ por $25 \mathrm{mts}$; Sampacho de $45 \mathrm{mts}$ por $11 \mathrm{mts}$; Bell Ville, en 1886, de $35 \mathrm{mts}$ por $14 \mathrm{mts}$, y podríamos agregar un largo etc.

¿Cuál era el móvil de la jerarquía eclesiástica? Los documentos pastorales nos dan algunos indicios al respecto. En primer lugar, el templo se levanta como un símbolo de civilidad. Su grandeza y monumentalidad manifiesta la presencia de la Iglesia, es decir, la vinculación de la religión con el progreso de cada comunidad es clara. En las respectivas solicitudes para la construcción de templos, por parte de los habitantes de cada comunidad, este concepto se manifiesta explícitamente. Además, los periódicos también expresan la relación entre el progreso de una localidad y la magnificencia de su templo.

Las solicitudes de feligreses enviadas al obispado y al ministerio de culto de la provincia para la construcción de templos son reiterativas. En los fundamentos de las mismas, están presentes diversas concepciones del templo. A modo de ejemplo, veamos la que los vecinos de Villa Concepción del Tío enviaron en noviembre de 1882 al Ministro Malbrán:

La erección de un suntuoso templo, en cualquier punto de la provincia, significaría siempre una prueba de bienestar y de adelanto moral y material, en departamentos fronterizos como el nuestro, significa a la vez estabilidad y confianza en el porvenir, siendo esto de vital importancia, para poblaciones que viven diariamente amenazadas por invasiones de indios y fluctuando entre permanecer con peligro para la vida para defender sus intereses o abandonar estos, a las depredaciones del salvage. El templo viene a cortar esta incertidumbre sirviendo como de garantía, para la estabilidad de los vecinos que quieran establecerse en puntos peligrosos. Convencidos de esta verdad desde el momento que nuestra capilla amenazó ruina, antes de permitir la destrucción del más fuerte vínculo que puede unir a un pueblo fronterizo y religioso y para cortar en su nacimiento la idea que surgió de llevar la Parroquia a otro punto más central por carecer en esta de capilla, lo que hubiera importado hacer retroceder la población del departamento y por consiguiente de la provincia los vecinos emprendieron la noble

\footnotetext{
${ }^{65}$ AAC. Compilación de datos relacionados con las Parroquias de la Arquidiócesis. Respuestas a Circulares de 1905, 1914 y 1924.

${ }^{66}$ AAC. Copiador de Cartas. Secretaría del Obispado, 1882-1904, f.185. Nota del 20/05/1890.
} 
tarea, de construir un nuevo templo, digno del rol que corresponde a esta localidad como Parroquia y cabeza del departamento. ${ }^{67}$

En esta cita, aparecen algunas cuestiones interesantes a tener en cuenta. En primer lugar, el templo es concebido como elemento de bienestar, progreso moral y material. Se lo señala como "el más fuerte vínculo que puede unir a un pueblo fronterizo y religioso". El templo, por ende, es concebido como un símbolo de unión, de lazo social. La Iglesia, con sus templos, procuraba organizar la vida en las comunidades rurales.

Los vecinos de Villa María, por ejemplo, al dirigirse al obispo, luego del fallecimiento de su párroco, Fortunato Gambini, agradecen "por haber hecho construir, a costa de grandes sacrificios, en el mismo lugar de la antigua capilla, un hermoso templo digno de figurar en muchas de las otras parroquias la más importante de la diócesis". ${ }^{68}$ Los vecinos de Arroyo Cabral donan al obispado un terreno frente a la plaza San Clemente, que mide unos 20mts de frente por $40 \mathrm{mts}$ de fondo, destinado al futuro templo; en la nota elevada al obispo, señalan que la "Iglesia es el faro luminoso que marca a las naciones la senda de su engrandecimiento". 69

El 28 de mayo de 1894, el Obispo Fray Reginaldo Toro, acompañado por el Ministro de Gobierno de la Provincia, Dr. Ferrer, y el Secretario del Obispado, visita San Francisco con el fin de bendecir la piedra fundamental del templo parroquial. En la estación, los esperaban un millar de personas, por lo cual el Ministro de Gobierno dio un breve discurso. Al día siguiente, domingo, el obispo bendijo la piedra fundamental del templo. Cerca de 10 matrimonios fueron padrinos del templo, entre los que se encontraban el gobernador de la provincia, el ministro de gobierno, el fundador de la colonia Bernardo Iturraspe, los señores Rafael y Tomás García Montaño y sus respectivas esposas. ${ }^{70}$ El diario "Los Principios" cubrió este acontecimiento. En 1907, el auto de la visita canónica del Obispo Zenón Bustos señalaba la urgencia de terminar la construcción del templo: "La terminación del templo es una de las primeras necesidades sentidas. La concurrencias atraída por las misiones que no pudo ser contenida en la parte que está hecha, han comprobado la necesidad de mayor espacio, la de invitar al concurso de todos para terminar la iglesia. Además de atender la

\footnotetext{
${ }^{67}$ AHPC. Gobierno, 1883, T8, f.84 (03/11/1882).

${ }^{68}$ AAC. Parroquias, Villa María. Nota del 9 de enero de 1925 de los vecinos de Villa María al Obispo.

${ }^{69}$ AAC. Leg. 48, f.481.

${ }^{70}$ Los Principios, 29 de mayo de 1894, col. 2.
} 
necesidad de los fieles del curato, el templo ofrecerá cuando esté concluido, un ejemplo de progreso y de cultura que hablan a favor de sus habitantes. Estén estos compuestos de argentinos o extranjeros, responderán al llamado porque lo mismo que en el viejo mundo, entre nosotros los templos se debieron a los esfuerzos de los particulares que expresaban su fe ayudando a levantarlos". ${ }^{71}$

Edificar el templo era un paso importante, sin embargo, para el desarrollo de una acción pastoral coordinada y eficaz era necesario que la Iglesia garantizara el control de los templos. En noviembre de 1908, los vecinos de Molles, localidad ubicada en las sierras grandes, elevaron una solicitud al obispo para obtener el permiso de construir un templo. La respuesta a tal petición fue negativa y entre los motivos de la denegación se encontraba justamente éste: el secretario del obispado señala que "aunque el deseo más vehemente de esta curia es que cada pequeño centro de población tuviera su Iglesia, pero en las actuales circunstancias en que por la escasez del clero, y pobreza de los lugares, un solo cura tiene que atender inmensos territorios, no es posible recargarlos con nuevas Iglesias, sin una necesidad muy apremiante, cuál sería la distancia considerable de las Iglesias ya existentes. El hecho de que algunos sacerdotes concurran allí a veranear es muy accidental para poder contar con la atención de la Iglesia". ${ }^{72}$

Por otra parte, en la cuarta parte de la tesis, también veremos los conflictos generados entre párrocos y patronos, entre capellanes y colonos, relacionados con la administración y control del templo. Estos conflictos motivaron que la jerarquía eclesiástica iniciara un reclamo sistemático de las escrituras de los terrenos en los que había templos. En 1905, el obispado envía una circular a todos los párrocos para que informaran sobre cuestiones relacionadas con sus curatos. En ella, se pregunta si los terrenos en los cuales se asientan los edificios sagrados están escriturados a favor del obispado. Así, constatamos que de los 197 templos diocesanos con funciones parroquiales existentes en 1905, el 52\% tenía escritura a nombre de la Iglesia, el 48\% no contesta sobre el tema, por lo tanto, no consta que la tuviera, y el $2 \%$ responde que los terrenos son antiguas donaciones sin escritura. ${ }^{73}$ En 1910, el presidente de la comisión de la Iglesia de Liebres elevó una nota al obispado

\footnotetext{
${ }^{71}$ AAC. Libro de Autos y Visitas Pastorales, 1885-1916, f.78.

${ }^{72}$ AAC. Notas de Secretaría, 1885-1913, f.119.

73 AAC. Compilación de datos relacionados con las Parroquias de la Arquidiócesis. Inicio del Libro $31 / 05 / 1914$.
} 
solicitando que dicha iglesia fuera erigida en la parroquia del nuevo curato del Carmen, el obispo responde que no será posible porque "aquella iglesia aún no está escriturada a favor de la diócesis, por tanto no se posible tratar por ahora ese asunto."74 En 1910, el obispo diocesano autorizó la construcción de una iglesia en Jovita, curato de Laboulaye, porque la comisión de la iglesia donaba un terreno en una ubicación central y "ellos se comprometen a construir por su cuenta la iglesia y casa parroquial entregando todo hecho". ${ }^{75}$ A medida que avanza el proceso de romanización, el clero toma el control y la dirección de la actividad parroquial, cuestión que analizaremos más adelante.

\section{Dificultades en el proceso de expansión parroquial}

\subsection{Territorios y jurisdicciones}

Las divisiones eclesiásticas, señalábamos ut supra, no eran cuestiones fijas, con frecuencia no coincidían totalmente con las jurisdicciones civiles. En 1892, Eduardo Ferreira, cura de Bell Ville, departamento de Unión, le informaba al obispo que no veía conveniente anexar Ballesteros a Villa Nueva por dos motivos. Primero, "porque perteneciendo ella a este departamento auguran las dificultades que siempre existen cuando la división de los curatos no concuerda con la división en lo civil. El otro motivo, porque este curato que abraza dos departamentos, exige una pronta división [...]. Cuando esta división se haga, es probable que se tomen las mismas líneas de la división civil y entonces este curato quedaría demasiado reducido sin la pedanía de Ballesteros, que es también la principal y la de demás fácil atención". ${ }^{76}$

A lo largo del trabajo, veremos que las jurisdicciones eclesiásticas se modificaron en función de diversas variables, una de ellas era la coincidencia con las demarcaciones civiles, más, la principal fue, sin duda, la congrua sustentación y la mejor atención de los fieles. En este sentido, hemos podido constatar que algunos curatos debieron ser suprimidos por incongruos, tal fue el caso de Jesús Nazareno, que se creó en 1874 y se suprimió en 1876, anexándolo al curato de Villa María. El curato de Tránsito, erigido en 1870 fue suprimido en junio de 1872 por incongruo y nuevamente creado en 1885. En 1885, el

\footnotetext{
${ }^{74}$ AAC. Notas de Secretaría, 1885-1913, f.128. Nota del 10/03/1910.

75 AAC. Notas de Secretaría, 1885-1913, f.138. Nota del Secretario del Obispado al Cura de Laboulaye del 19/03/1911.

${ }^{76}$ AAC. Leg. 52. Curato de Bell Ville, s/f. Nota del 25/01/1892.
} 
curato de San Agustín en Calamuchita fue suprimido por incongruo, "no pudiendo proporcionar al párroco ni una modesta subsistencia”. ${ }^{77}$ En 1891, el cura de Río Segundo, Luis Viaggio, informaba sobre la falta de congrua suficiente del curato, motivo por el cual se le anexó la parte sur de la pedanía Caseros, correspondiente al curato de Anejos. ${ }^{78}$

La capilla de Pampayasta dependía, en 1883, del curato de Villa Nueva, y para mejor atención de los fieles, dado que era menor la distancia que la separaba de Tercero Arriba, el cura, Fray Andrés Avelino López, pidió que fuera desmembrada y anexada al curato de Villa María. ${ }^{79}$ La solicitud volvió a reiterarse dos años después, produciéndose finalmente el traspaso. El cura de La Carlota, Juan Alonso, informó a la curia que, desde 1893, el cura de Bell Ville, Eduardo Ferreira, había cedido al curato de La Carlota la atención de las estaciones Santa Victoria y Santa Eufemia del Ferrocarril Villa María-Rufino y las estaciones Canals, Ledesma y Arias del Ferrocarril Buenos Aires-Rosario. Que para atender debidamente a esas estaciones, cercanas a su parroquia, había renunciado, a su vez, a favor del curato de Villa Nueva, las estaciones de Chucul, Cabrera y Gral. Deheza, 15 leguas más al sur. En 1902, se le quitó gran parte de su curato para formar el nuevo curato de Laboulaye y el cura Ferreyra le reclamó las estaciones cedidas en 1893, pues si el cura de Cruz Alta llera a reclamar las estaciones de Arias, Canals y Ledesma, pertenecientes a su curato, La Carlota quedaría totalmente incongruo, reducido a la parroquia y a Reducción. Por estos motivos, solicitó se le anexaran los territorios cedidos en $1893{ }^{80}$

En 1894, los vecinos de la colonia Freyre solicitaron a la curia la elevación de la capilla a parroquia. El informe enviado por el cura de San Francisco, Ambrosio Raynoldi, evaluando el pedido, muestra claramente las dificultades que se presentaban para elevar una capilla a parroquia. Una de ellas era la congrua sustentación del curato.

Sobre la solicitud de los vecinos de Freire para erigirse en parroquia a digo humildemente lo que sigue: 1- La colonia Freyre cuenta con poco más o menos tres leguas de largo de naciente a poniente y dos leguas y media de sur a norte es decir ocho leguas cuadradas. Linda al sur con la colonia Iturraspe, al poniente con la colonia Valtelina y al naciente con la provincia de Santa Fe, según verá en el croquis que se adjunta. Como resulta de la nota de los de Freyre pretenden éstos que para erigirla en parroquia se quiten a la parroquia de San Francisco las colonias de Iturraspe, Caldera y

\footnotetext{
${ }^{77}$ AAC. Libro de Autos, 1876-1905, f.67.

${ }^{78}$ AAC. Libro de Autos, 1876-1905, f.126.

${ }^{79}$ AAC. Leg. 48, Bell Ville, Villa Nueva s/f. La nota es del cura Antonio Lima del 23/05/1883.

${ }^{80}$ AAC. Leg. 52. Curato de Bell Ville, s/f. Nota del 21/06/1902.
} 
Valtelina y otras no todavía pobladas, a la de San Pedro se quiten los Potreros Lavardo y Suarez, la colonia Porteña y terrenos desocupados, a la parroquia de San Justo se quiten todos los terrenos de campo reduciéndola a dos leguas. La colonia Freyre tendría a lo menos dos mil almas y las demás ocho mil se quieren quitar a las tres parroquias San Francisco, San Pedro y San Justo.

El párroco de San Francisco expone las razones por las cuales considera inconveniente erigir a la colonia Freyre en parroquia, uno de ellos era que los ingresos de su curato quedarían reducidos "si llegara a quitarle las expresadas colonias, sería imposible la subsistencia de un cura". Además, la colonia Freyre pagaba al capellán \$140 mensuales, si a ese monto se le sumaba lo que percibiría por mitad de los bautismos, derechos de defunciones y misas libres de los habitantes de la colonia Freyre, "un sacerdote tendría más de lo necesario, pues tendría más congrua que el curato de San Francisco". Si se trasladara la sede parroquial de San Francisco a la estación Freyre, "los comerciantes que se obligaban por escritura a pagar la mensualidad al cura, con el traslado de la parroquia a la estación se negarían a hacerlo. Entonces ¿ante quién cobraría el cura la pensión ofrecida? ${ }^{81}$ La curia no dio lugar al pedido de los vecinos de Freyre y tuvieron que pasar más de 20 años para que se convirtiera en parroquia independiente.

En 1902, los curatos de Quilino y Deán Funes eran "del todo incongruos e incapaces de sostenerse por separado con la decencia y buen servicio que corresponde por carecer de la necesaria población y recursos [...] Pasa el archivo de ambos curatos a formar uno solo como lo fue antes de su desmembración". 82

En 1914, el cura de Villa del Rosario pidió al obispado la anexión de la capilla de la estación Sacanta a su curato, "porque aumentado el personal corriente, debían también aumentarse los medios. Lo contrario es dejarnos sin vida. La mejor parte de este curato es la estación Calchín. Villa del Rosario vive de los colonos. No sé para qué me han dejado aumentar los sacerdotes si me los habían de sitiar con hambre. El Arroyito no necesita porque no tiene más de una boca, no está como nosotros con seis bocas. Hagan lo que gusten pero no con mi opinión". 83

En 1923, ante el propósito del diocesano de desmembrar la pedanía de Cosme del curato de Alta Gracia y anexarla al de Río Segundo, el cura párroco, Bernardo Ferrony, informaba

\footnotetext{
${ }^{81}$ AAC. Leg. 49. San Francisco, s/f. Nota del 24/07/1894.

${ }^{82}$ AAC. Libro de Autos, 1876-1905, f.199.

${ }^{83}$ AAC. Parroquias: Villa del Rosario.
} 
a la curia que no encontraba motivos para dicho acto. Además, advertía que el curato de Santa María era casi en su totalidad serrano, que, salvo Alta Gracia, no había centros poblados de más de 400 habitantes, que Alta Gracia y alrededores eran lugares de veraneo, por lo tanto, era uno de los pocos casos en que las estaciones de tren que "son siempre lugares de aglomeración de población en este curato son desiertas”, la única pedanía llana, con actividad agrícola, era la de Cosme. Luego de una larga serie de razones por las cuales consideraba que no debía sustraerse la capilla de Cosme del curato, concluía que "si le sacamos a este curato la capilla de Cosme queda incongruo", pues las entradas generales del curato en 1922 sumaron $\$ 3.270$, de los cuales $\$ 1.690$ correspondían a la capilla de Cosme. $^{84}$

En otras oportunidades, el cura estaba de acuerdo con el desmembramiento de parte de su territorio y la creación de una nueva parroquia. José Pío Angulo, cura de Bel Ville, dio su conformidad para la creación del curato de Villa Ascasubi. El nuevo curato contaría con “seis pueblos de alguna importancia Monte Maíz, Médanos de Cañas, Liebres, Pascanas, Etruria y Santa Eufemia. Contaría con dos iglesia habilitadas, dos concluidas y que aún no se han bendecido y dos en construcción una de ellas para terminarse. Esa parte del curato está actualmente atendida por el Sr Francisco Ferrero, sacerdote celoso y laborioso" 85

En algunas otras ocasiones eran los mismos vecinos los que solicitaban el cambio de pertenencia de un curato a otro. Tal fue el caso de Tinoco, Tunas y Media Luna, poblados de la pedanía Esquina, pertenecientes al curato de Santa Rosa de Río Primero. Los vecinos solicitaban en 1896 pasar a depender del curato de Remedios. El motivo principal era la distancia, se encontraban a 13 leguas de Santa Rosa, en tanto, colindaban con la pedanía de Yegua Muerta, del curato de Remedios, del que los separaba sólo 5 leguas. Por este motivo, siempre recurrieron al cura de Remedios para la atención de enfermos y administración de los sacramentos. Manifestaban la conveniencia de que esos centros de población, con sus respectivas capillas, pasaran a depender del curato de Remedios y envían el croquis respectivo y la posible línea divisoria de ambos curatos. ${ }^{86}$

\footnotetext{
${ }^{84}$ AAC. Parroquias: Alta Gracia, f.28-36.

${ }^{85}$ AAC. Leg. 52. Curato de Bell Ville, s/f. Nota del 31/01/1908.

${ }^{86}$ AAC. Parroquias: Santa Rosa de Río Primero, s/f.
} 


\section{Plano de los curatos de Remedios y Santa Rosa de Río $1^{\circ}$ en 1905}

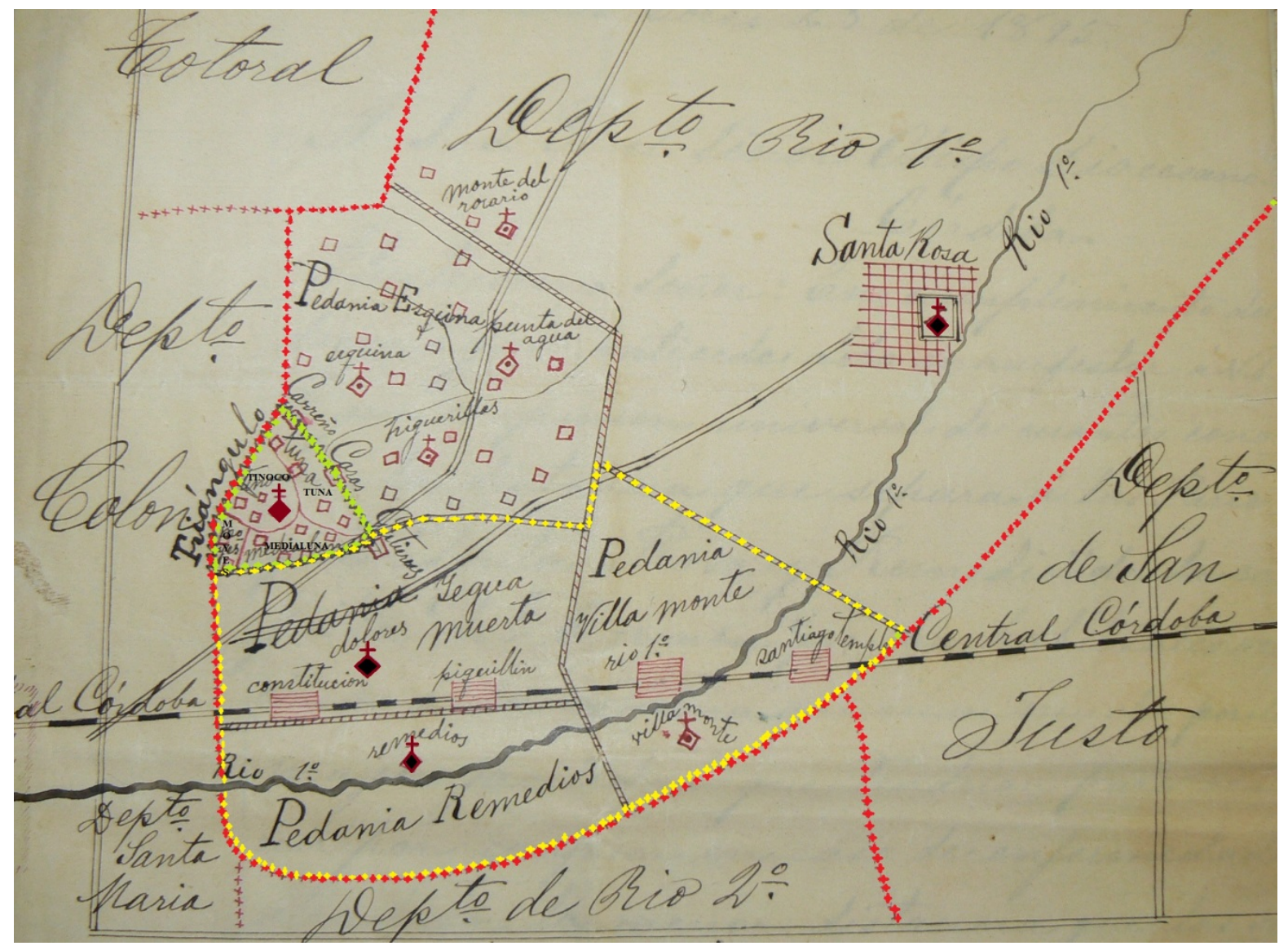

Fuente: AAC. Parroquias: Santa Rosa de Río $1^{\circ}$. En rojo, división departamental; en amarillo, límites del curato de Remedios; y en naranja, zona de litigio.

En 1893, los vecinos de la estación Chañares elevaron una nota al obispo en la que solicitaban que dicha estación, perteneciente al curato de Tercero Arriba, pasara a depender del curato de Villa María. Entre los considerandos, los vecinos invocaban como primer punto "la larga distancia que nos separa de la parroquia del Tercero Arriba y la difícil comunicación de viabilidad nos presenta muchos y casi siempre insuperables obstáculos para acudir al Sr Cura párroco Marcos Molina, en los momentos más supremos de la vida". 87

En 1892, la Comisión pro-templo de la Colonia San Francisco se dirigió al obispado para solicitar la creación de una parroquia:

\footnotetext{
${ }^{87}$ AAC. Leg. 2, T2, s/f. Nota elevada por los vecinos el 31 de enero de 1893 y remitida al cabildo. Expediente que determina anexar la pedanía de Chañares al Curato de Villa María.
} 
Tenemos el agrado de dirigir un croquis de las colonias que deberá de comprender la parroquia de San Francisco de Asís. Según nuestros cálculos, informes y detenidas reflexiones opinamos no poder acertar mejor: la parroquia de San Francisco de Asís comprendería 9 (nueve) colonias todas bien pobladas, las cuales una por otra tienen cuatro leguas cuadradas de superficie, subdivididas con un total de dos mil ochocientas ochenta concesiones y como es notorio por cada concesión entre chacra y campo se precisa por el trabajo no menos de tres personas tendremos entonces ocho mil seiscientas cuarenta (8.640) almas. De la misma manera echamos el cálculo sobre lo que se llamará Parroquia de Santo Domingo y pueblo de la Estación de San Francisco; las Colonias Francia, del Trabajo, Cristina, Quebracho Herrado y Luis A Sauye darían cuatro mil ochenta almas, (4.080), el pueblo Estación San Francisco se calcula hoy en tres mil habitantes (3.000), luego después viene una estación de terreno llamado Potrero de Iturraspe, al sudeste del pueblo, calculando en tres leguas cuadradas de superficie o sea doscientas cuarenta concesiones con setecientas veinte almas (720) de manera que tendríamos un total de ocho mil quinientas veinte almas (8.520) pero esta diferencia quedaría compensada con otras dos colonias al sud de Quebracho Herrado llamadas Prosperidad y Santa María, bastante extensas a cuatro o cinco leguas solo del pueblo La Estación San Francisco. ${ }^{88}$

En 1897, se desmembró la pedanía de Gral. Cabrera del curato de La Carlota para anexarla al curato de Villa Nueva. Además de la dificultad de los feligreses de acudir a La Carlota, otro motivo que aparece como determinante era la creación de una oficina del registro civil en la estación Las Perdices y "siendo a los pobres sumamente oneroso acudir a la Carlota por los matrimonios, sucede desgraciadamente que se quedan solo con el matrimonio civil, con gran daño espiritual y escandalo para mis feligreses", dice el cura de Villa Nueva. ${ }^{89}$

En 1917, los vecinos de San Bartolomé, capilla dependiente del curato de Las Varillas, solicitaban formar parte del curato de Villa Concepción del Tío. La razón principal que aducen era la dificultad de estar bien atendidos por el cura de Las Varillas, en razón de la distancia que separaba a ambos templos, a ello se sumaba el mal estado de los caminos, existiendo "cañadones que en el tiempo de las lluvias imposibilitan en tránsito", y, por lo tanto, resultaba imposible la atención de los enfermos. El obispo, atendiendo las reiteradas peticiones de los colonos y pareciéndole “justas las causas expuestas”, por el decreto del 19 de octubre de 1917, anexó esta capilla al curato del Tío. ${ }^{90}$

\footnotetext{
${ }^{88}$ AAC. Leg. 49. San Francisco.

${ }^{89}$ AAC. Leg. 2, T2 (Cabildo Eclesiástico). Expediente relativo al desmembramiento de la Pedanía Gral. Cabrera del curato de La Carlota agregándolo al curato de Villa Nueva. Nota del párroco de Villa Nueva del 05/09/1897.

90 AAC. Parroquias: San Bartolomé, f.16.
} 
Como señalábamos, la atención de los fieles era una de las principales variables a la hora de modificar las jurisdicciones eclesiásticas. En 1910, el obispo, a través de su secretario, consultó al cura de Morteros la conveniencia de anexar territorios que dependían del curato de Río Seco a su curato, "siendo imposible al cura de Río Seco atender la parte este de su curato, por la inmensa distancia de su parroquia y las grandes cañadas que se encuentran de por medio, el obispo desea agregar esa parte al curato de Morteros [...] el motivo es por la facilidad que a este cura presenta el Ferro-Carril Buenos Aires-Rosario que tiene las estaciones Ceres y Silva comprendidas en aquel territorio". 91

\subsection{Traslados de sedes}

Como puede observarse, las parroquias no eran una estructura rígida, pues se adaptaron a las necesidades de las diversas feligresías y, en función de ello, se modificaron los límites. También vemos traslados de Iglesias parroquiales a otras sedes más convenientes.

En 1896, el cura de la colonia San Francisco, solicitó permiso, como dijimos, para trasladar la parroquia, emplazada en la Plaza central, a la Estación San Francisco, donde se encontraba el mayor núcleo de población y existía una capilla dedicada a Santo Domingo. ${ }^{92}$ Ambas iglesias funcionaban como si cada una de ellas fuera parroquia. En 1904, el Obispo auxiliar y Gobernador del Obispado en sede vacante, Filemón Cabanillas, suprimió la parroquia de la Plaza, convirtiéndola en una capellanía dependiente de Santo Domingo. Esta decisión generó un conflicto con los vecinos de la Plaza, puesto que el cura residente allí presentó su renuncia, no estando dispuesto a depender del cura de la Estación. Los vecinos de la Estación escribieron al nuevo Obispo Zenón Bustos, en donde le solicitaban que la Plaza volviera a tener status de parroquia y fundamentaban su pedido al señalar que el pueblo existía desde antes de la creación de la estación, que en 1888 sus padres habían

\footnotetext{
${ }^{91}$ AAC. Notas de Secretaría, 1885-1913, f.133.

92 AAC. Leg. 49. San Francisco, s/f. Nota del 06/06/1896 informando la conveniencia del traslado. El cura Pablo Tríboli fue a Córdoba para "pedir permiso para trasladar la parroquia a la Estación San Francisco siendo que la Plaza no cuenta más, hay solamente una casa de negocio y todos se han trasladado a la Estación, había poco antes, pero ahora no hay más nada. Los días festivos la mayor parte de los colonos, sin quedarse a las funciones se van allá y si allí fuera la Parroquia, en el mismo tiempo que van a hacer su negocio, se aprovecharían de las misas, de las funciones, así el cura podría vivir todavía, lo que no puede en ésta. Ahora, si Ud. me permite llevar la parroquia a la Estación yo me podría ocupar de la iglesia de aquel pueblo [...] Ya he encontrado un galpón muy grande y bastante lindo, que puede convertir muy bien en capilla ya he encontrado también una casa para mí, el todo me cuesta 50 pesos de alquiler [...] En aquel pueblo me llaman por párroco y me quieren todos, menos uno".
} 
construido con sus ahorros la capilla dedicada a San Francisco de Asís, siendo una de las primeras que se edificaron en la región. En tanto, la Iglesia dedicada a Santo Domingo en la Estación se había comenzado a edificar en 1894 y continuaba en construcción. Además, advertían que la estación era una población floreciente y no tenía dificultades de congrua sustentación. ${ }^{93}$

En 1907, el cura de San Francisco envió a la curia un largo informe sobre la Plaza, en el que desestimaba la solicitud de los vecinos, entre otras cuestiones, decía que "los de la Plaza San Francisco me repiten que desean y expresan que le devuelvan la Parroquia allá o que por lo menos les envíen un cura. Yo siempre les digo que no hay, pero no hay quien les haga entender a esas gentes, buenas si se quiere, pero a su modo y sobre todo ignorantes en extremo. Tienen la idea de dejar sin arreglar la iglesia que hay y hacer otra nueva para hacer venir ellos un cura (como ellos llaman), naturalmente que este Sr Cura tendría por Obispo o superior a ellos. Hay que ver lo que son de caprichosos estas gentes porque lo que tienen es capricho y nada más, quieren sacerdote o cura para que se esté rascando toda la semana, porque en toda ella apenas si irá una que otra persona". ${ }^{44}$ Finalmente, la Plaza no fue elevada a parroquia, manteniéndose como capellanía dependiente.

En la visita canónica de 1903 al curato de Chalacea, departamento de Río Primero, el Obispo visitador, Filemón Cabanillas, dispuso el traslado de la sede parroquial de Monte del Rosario a San Antonio de Río Primero, por estar la capilla de Monte del Rosario situada en un extremo del curato, "teniendo que luchar el párroco con el gravísimo inconveniente de largas distancias, que muchas veces le imposibilitan el fiel cumplimiento de sus deberes principalmente en lo que respecta a la asistencia y sacramentación de los enfermos". San Antonio se encontraba en el centro del curato y tenía, en sus cercanías, "mucho vecindario, aunque en sus alrededores no tenga núcleo de población compacta”, sin embargo, es más central, presentaba más facilidades al párroco para el ejercicio de su ministerio. ${ }^{95}$

Los traslados de sede eran frecuentes. En los autos respectivos, el obispo señalaba la conveniencia de dicho cambio. El curato de Ischilín, erigido en 1793, tuvo la sede parroquial y la residencia del cura en Ischilín hasta el 31 de mayo de 1902, fecha en la que

\footnotetext{
${ }^{93}$ AAC. Leg. 49. San Francisco, s/f y sin fechar.

${ }_{94}$ AAC. Leg. 49. San Francisco, s/f. Fechada el 21/01/1907.

${ }^{95}$ AAC. Notas particulares del Obispo, 1884-1903, f.115.
} 
fue trasladada a Deán Funes. ${ }^{96}$ También se trasladó la cabecera del curato Colón, que pasó de Río Ceballos a Jesús María, la de Calamuchita de Santa Rosa a San Agustín y la de Río de los Sauces a La Cruz.

\section{Plano del Curato de Chalacea con sus sucesivas sedes parroquiales}

1905

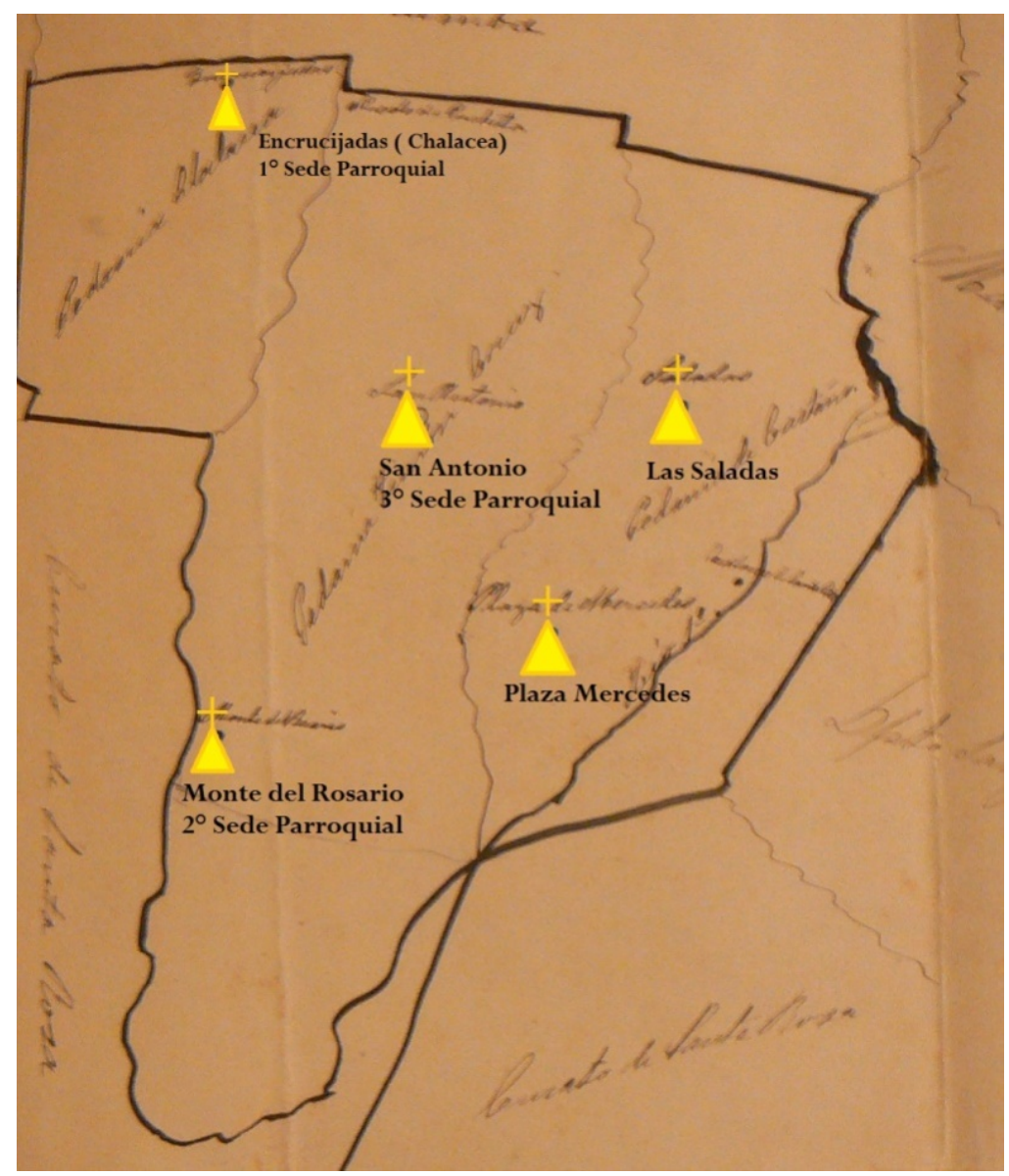

Fuente: AAC. Datos sobre las parroquias de Córdoba. Plano de Chalacea

El proceso de expansión parroquial no estuvo exento de dificultades, generadas, con frecuencia, como ya hemos señalado, por la incongruidad de los nuevos curatos. Una denuncia remitida a la Santa Sede por un cura italiano, capellán de General Roca, generó una serie de consultas por parte del Internuncio, Mons. Alberto Vassallo di Torregosa. Entre otras cuestiones, el cura planteaba la frecuente incongruidad de muchas de las

${ }^{96}$ AAC. Cajas Deán Funes. Respuesta a la Circular del 16 de junio de 1913. 
nuevas parroquias, que, según el denunciante, se creaban "sin fondos para el sustento del Párroco". Debido a tal denuncia, el Nuncio hizo una ronda de consultas, con el objeto de recabar información al respecto. Genaro Artavia (sacerdote franciscano) respondió sobre el punto, diciendo que, efectivamente, las parroquias se creaban generalmente por disgregación de algunas capillas, "mirando algo a la vida del sacerdote, pero se podía tener más cuidado en ello". Dice que el arancel no preveía nada sobre los fondos parroquiales y consideraba que, quizás, sería una buena medida a implementar, a la hora de aumentar el número de las parroquias. $^{97}$

A medida que crecía el núcleo de población, las capillas filiales pasaron a ser cabeceras de nuevas parroquias, en tanto, se construían nuevas capillas. Habitualmente, eran los vecinos los que solicitaban la elevación de la capilla a parroquia. ${ }^{98}$ El obispo diocesano recibía las solicitudes, consultaba al párroco del cual dependía la capilla, pedía un informe al inspector de parroquias, pasaba la consulta al cabildo y luego procedía a la creación mediante el auto respectivo. ${ }^{99}$

En el caso de las colonias, el que solicitaba permiso para construir capillas era, por lo general, el propietario o la comisión de culto de la respectiva colonia. En 1890, la colonia San Pedro, del departamento de San Justo, solicitó a la curia el permiso para "para levantar una regular capilla de tres naves en la plaza de la colonia de San Pedro que dista de la iglesia más cercana, que es san Francisco, nada menos que diez leguas”. Firmaba el propietario de la colonia y el presidente, secretario y vocales de la Comisión. ${ }^{100}$ La solicitud estaba acompañada de una carta aval del cura de San Francisco, Ambrosio Raynoldi. El

\footnotetext{
${ }^{97}$ ASV. Nunciatura Argentina Mons. Alberto Vassallo di Torregosa, 1916-1922, Libro 67, fs.481-482.

${ }^{98}$ AAC. Parroquias: Concepción del Tío. En 1910, los vecinos solicitaron se elevara la capilla de La Francia a parroquia. "Los que suscriben vecinos feligreses de esta Capilla vista la necesidad que tiene este pueblo de la instrucción religiosa y de la asistencia continua a la administración de los Santos Sacramentos; pedimos, respetuosamente, a Su Señoría Ilustrísima que se digne crear Parroquia esta Capilla de Nuestra Señora de las Mercedes y dictar nombramiento de cura y Vicario de la misma al reverendo Presbítero Señor Dn Juan D Saravia Caminos. Con la seguridad de que nuestras suplicas serán aceptadas lo más pronto que sea posible por el bien espiritual y temporal de nosotros y nuestros feligreses, damos las gracias". En el archivo, hemos encontrado una gran cantidad de solicitudes similares.

${ }^{99}$ El auto se redactaba en estos términos o similares: "Por cuanto los vecinos de la Colonia Caroya nos han presentado solicitud por escrito, pidiéndonos que desmembremos el Curato de Colon la parte de territorio que forma y ocupa la Colonia Caroya y que está perfectamente demarcada, y la constituyamos en un Curato y Vicaria hemos resuelto: $1^{\circ}$ Desmembrar toda la Colonia Caroya y erigirla en Curato y Vicaria independiente de Colón. $2^{\circ}$ Determinar que la iglesia parroquial sea la que está en el $n^{\circ} 15$ cuya titular será la Virgen de Montserrat. Se dará aviso a lo dispuesto en este auto a quienes corresponda" (AAC. Parroquias: Colonia Caroya. Auto del 29/04/1888).

${ }^{100}$ AAC. Leg. 49. San Francisco, s/f. Nota del 02/09/1890.
} 
diocesano la autorizó pocos días después y exigió que se escriturara en favor del Obispado. ${ }^{101} \mathrm{Al}$ tiempo, el cura envió a la curia los documentos públicos de la donación del terreno para la iglesia, la casa parroquial y el cementerio, realizada por los propietarios de la colonia, junto con otra donación de terreno para la construcción de un oratorio público en la colonia Freire, donde ya existía un pequeño oratorio, "pero si las cosechas darán buen resultado el actual oratorio servirá de presbiterio haciéndose a la brevedad posible". ${ }^{102}$ En 1893, el cura de San Francisco informaba que en Freyre el cementerio, la capilla, la habitación del sacerdote y el terreno pertenecían a varios dueños, como sería muy costoso para ellos ir a Córdoba a firmar la escritura de donación necesaria, solicitaba el envío del poder correspondiente, a fin de escriturar a favor del obispado ante el escribano público de San Francisco, Dn. Tomas García Montaño. En la nota, señalaba también que "la capilla es bastante grande y muy decente, y para la compra de todos los útiles y vasos sagrados me han encargado escriba, yo mismo, a Buenos Aires". ${ }^{103}$ Cuando los vecinos solicitan la transformación de la capilla de Freire en parroquia, el cura párroco se opone, como hemos señalado ut supra.

Lo mismo sucede en la colonia Devoto. La comisión para la edificación del templo envió la donación de dos solares de terrenos ubicados en la manzana 46 parte norte del pueblo de Devoto en favor de la Curia Eclesiástica de la Diócesis de Córdoba, realizada por los señores Fortunato Devoto y María V. de Devoto, propietarios de la Colonia. ${ }^{104}$ En 1907 , el cura de San Francisco informaba que había ido al pueblito y capilla de Luxardo, distante cinco leguas de la parroquia, tres y media de Devoto, a dos de la estación de ferrocarril y a cinco de Freyre, y que "la capilla ha sido levantada por los habitantes de esa colonia, no es pues particular. Esta bendecida con autorización del Sr Obispo y estuvieron por escriturar el terrenito a favor del Obispado". 105

No todas las solicitudes tuvieron el mismo éxito. En 1914, los vecinos de la viceparroquia de Monte del Rosario, pedanía de Timón Cruz, departamento de Río Primero, que había dejado de ser cabecera en 1902, escriben al obispado que: "Humildemente proponemos que para cumplir con nuestros deberes para con Dios como católicos creyentes

\footnotetext{
${ }^{101}$ AAC. Leg. 49. San Francisco, s/f. Nota del 09/09/1890.

${ }^{102}$ AAC. Leg. 49. San Francisco, s/f. Nota del 13/11/1890.

${ }^{103}$ AAC. Leg. 49. San Francisco, s/f. Nota del 29/04/1893.

${ }^{104}$ AAC. Leg. 49. San Francisco, s/f. Nota del 10/11/1898.

${ }^{105}$ AAC. Leg. 49. San Francisco, s/f. Nota del 22/01/1907.
} 
nos es forzoso sacrificar nuestros bienes temporales sin conseguir (muchas veces) el remedio para nuestras necesidades espirituales, por razón de que nuestro párroco reside en San Antonio, parroquia de este curato, la que dista de este vecindario unos $50 \mathrm{~km}$ lo que nos induce a solicitar de SSI la creación de un otro curato con cura estable en Monte del Rosario, por haber sido antes la parroquia del Curato (hoy San Antonio) y estar la iglesia ornamentada como cualquier otra de las parroquias de este departamento". ${ }^{106}$ Esta solicitud no fue concedida. De igual modo, los vecinos de San Pedro, curato de Morteros, se quejaban al obispado por el traslado de la sede parroquial a Morteros. San Pedro había sido una población floreciente, el visitador de parroquias informaba, en 1905, que "estaba muerta comercialmente", debido a su proximidad al pueblo de Morteros, estación terminal del Ferrocarril, "los vecinos se quejan amargamente por la manera como se les ha tratado por parte de la autoridad eclesiástica, al suprimir la parroquia y no dejarles siquiera un capellán, el cual prestaría importantísimos servicios a una dilatada zona poblada de colonos en su mayor parte propietarios". ${ }^{107}$

Lo que aquí nos interesa señalar es la preocupación de la jerarquía eclesiástica, no sólo por levantar templos, sino también por centralizar la administración parroquial, para lograrlo, un primer medio, fue acceder a la propiedad del terreno y del edificio mediante escritura pública; otro, fue combatir los abusos y hacer cumplir a los patronos de las iglesias sus obligaciones; y la tercera, fue quitarle poder a los patronos, sacando la jerarquía de parroquia a la Iglesia con patrón laico y trasladando la sede a una nueva iglesia en poder del obispado, como sucedió con la capilla Beiró, que durante años fue sede del curato de Morteros. La definición de la sede parroquial supuso una disputa entre los partidarios de la capilla de San Pedro y las pretensiones del dueño y patrono de la capilla La Asunción, el Sr. Beiró, fundador de la colonia del mismo nombre, sede del curato. El curato comprendía las poblaciones de Morteros, Brinkmann, Porteña y las demás colonias, a excepción de San Pedro, que funcionaba como una parroquia independiente. ${ }^{108}$ En 1894, el obispo le indicaba al cura de San Pedro que residiera en la sede parroquial en Morteros, Iglesia de La Asunción, propiedad del Sr. Beiró. El cura le respondió que sentía mucho "no poder condescender con los deseo de SSI de establecer como domicilio parroquial la capilla de

\footnotetext{
${ }^{106}$ AAC. Parroquias: Chalacea, f.67.

${ }^{107}$ AAC. Parroquias: Morteros. Informe del Visitador de Parroquias del 20/09/1905.

${ }^{108}$ AAC. Leg. 49. San Francisco. Nota del 29/07/1898.
} 
Morteros por los siguientes motivos: 1- La habitación del cura consiste en una sola pieza de cinco metros de largo con una cocinita. 2. La capilla se halla en una posición inaccesible a toda la población. 3- La población la cual se halla toda al poniente del Ferrocarril quiere que sea iglesia parroquial la capilla que da a aquel lado, que está en construcción y han declarado que nadie ira a la capilla del Sr Beiro si se eligiera iglesia Parroquial. 4- En San Pedro la Iglesia es bastante grande y el cura tiene tres buenas piezas y regular cocina y protestan que si el cura no residiera en San Pedro buscarían otro sacerdote antes que ir al oratorio del Sr Beiro. Para evitar enemistades y por los sobre exagerados motivos he resuelto establecerme en San Pedro hasta que se haga una buena Iglesia en donde existe toda la población y todo el comercio de Morteros". 109

Finalmente, en 1899, la parroquia fue erigida en la Iglesia de San Bartolomé en la plaza del pueblo. La decisión episcopal generó un conflicto con el patrono, pues Beiró reclamó con insistencia que su título es el de Patrono de una Iglesia parroquial y no de una simple capilla. Además, el obispo diocesano ordenó la prohibición de celebrar allí bajo pena de suspensión ad divinis.

El auto de erección del curato de San Bartolomé declaraba dos motivos para el traslado de la sede. El primero es que la capilla de la Asunción se encontraba distante unas cuadras del pueblo y que los feligreses no podrían cumplir "sin gran dificultad" sus deberes religiosos. Este motivo, sin duda, no era el real, pues, según el informe de 1905, la Iglesia de La Asunción distaba sólo 600mts de la nueva de San Bartolomé. El segundo motivo es, a nuestro parecer, el real, y tiene relación directa con el control del templo: "la capilla de San Bartolomé ha sido entregada enteramente con los terrenos adyacentes, por escritura pública al obispado. El diocesano ha designado un párroco con residencia fija. La Iglesia de San Bartolomé reúne los requisitos exigidos por Trento para ser erigida en parroquia. Se decide el traslado de la Parroquia de la Asunción a San Bartolomé”. ${ }^{110}$

El constructor de la capilla y fundador de la colonia reclamaba a la Internunciatura Apostólica que "el Obispo quiere que la Iglesia pase a propiedad del Obispado". El patrón acompañaba la nota de reclamo con la documentación relacionada al conflicto y le pide al Internuncio que interviniera ante la curia para que se aceptara su propuesta: "Suplico a

\footnotetext{
${ }^{109}$ AAC. Leg. 49. San Francisco. Nota del 05/09/1894.

${ }^{110}$ AAC. Libro de Autos, 1876-1905, f.179-180. Auto del 24/08/1899.
} 
Vuestra Excelencia tenga a bien prestar detenida atención a este asunto a fin de poder concluir con una situación insostenible y de desprestigio para la misma religión. Creo que su Señoría el Obispo de Córdoba no tendrá inconveniente en aceptar mi propuesta de transacción. Estaría dispuesto a recibirme otra vez de la propiedad de la Iglesia y sus anexos, para después escriturarla a una comunidad de religiosos italianos, cuya elección dejaría a la Excelencia Vuestra. Una comunidad de religiosos italianos podría hacer en Morteros un gran bien a la educación y casi diría a la civilización; pues todos los colonos de la colonia de Morteros, que he fundado, como también los que pueblan las demás colonias vecinales son italianos. [...] Los colonos pobladores de esta fértil región recibirán con mucha satisfacción a los religiosos italianos pues hace años una comisión de los más influyentes de ellos se me apersono insistiendo que hiciera diligencias a ese efecto, pues decían que los comprenderían bien en sus prácticas religiosas y tendrían educados e instruíos". ${ }^{111} \mathrm{El}$ asunto termina con una nota del obispo al Internuncio en el que solicita facultades para donar la Iglesia de Morteros y algunas hectáreas de terreno a los Padres Salesianos, quienes se instalaron en Colonia Viganud. Este conflicto da cuenta de la progresiva centralización eclesiástica y del control sobre los patronos y sus funciones por parte del obispo diocesano.

\subsection{Las propiedades eclesiásticas de cada curato}

La realidad diocesana daba cuenta de que muchas capillas construidas por particulares fueron donadas al obispado, con frecuencia testamentariamente pero sin mediar escritura pública, en otros casos, la propiedad nunca había sido donada, al propietario se lo nombraba patrono y se ocupaba de la dotación y administración del templo. Situación que generó no pocas dificultades. En la visita canónica de 1902 a la parroquia de Punilla, el visitador dejó sentado, en el auto, que "le ordenamos [al cura párroco] que lo más pronto que sea posible adquiera en propiedad, por escritura pública de donación las capillas, viceparroquias que están todavía en el dominio y administración de personas particulares, siéndole prohibido bendecir y dedicar al culto las que de nuevo fueran edificadas en el curato sin este requisito". ${ }^{12}$ Poco a poco, y no sin conflictos, el control de los templos fue

\footnotetext{
111 ASV. Nunziatura Argentina, Nuncio Locatelli, Libro 17, Diócesis de Córdoba, f.62-80.

${ }^{112}$ AAC. Libro de Notas particulares del Obispo, 1884-1903, f.112.
} 
pasando de las feligresías al clero, la jerarquía puso en marcha un engranaje destinado a lograr una administración más centralizada, disminuyendo el margen de acción y autonomía tanto de los párrocos como de los feligreses.

\subsection{Conflictos en la administración y control de templos}

La mayoría de las colonias y pueblos tenía su comisión administradora, la cual solía construir las Iglesias y controlar la actividad que allí se realizaba. Esto generó muchos conflictos con los curas, que llegaron a verdaderos enfrentamientos en los que tuvo que intervenir la curia eclesiástica.

En 1893, el cura de San Francisco elevó un largo informe a la curia en el cual relataba el accionar de la comisión pro-templo: "Lo que se llama Comisión de culto va contra lo dispuesto por el Sínodo Diocesano Capítulo IV, constitución primera, Capítulo XV, constitución novena y Capítulo XVI, constitución segunda, por ignorancia y por diferentes costumbres traídas de Europa que incurren en gravísimas faltas que expongo: 1. La Comisión (que no es Municipalidad ni autorizada por autoridad alguna) tiene bajo su jurisdicción y administración el Cementerio Público cuya donación fue hecha al Prelado Diocesano, hasta el grado de vender el terreno para sepulturas sin que el Cura Párroco sea siquiera consultado y los fondos resultantes de las ventas los administra sin pedir consejo ni dar cuenta al Cura Párroco. 2. Exigen que todos los derechos de fábrica como también las limosnas que en los días festivos se recogen en bolsa según costumbre de Italia pasen al fondo de la misma Comisión que los administra sin pedir consejo ni dar cuenta al Párroco. 3. En recompensa de las primicias, imposibles de recoger en esta localidad por varios motivos, la mayor parte de los fieles pagan un peso $\mathrm{m} / \mathrm{n}$ por concesión y esta primicia viene recogida de la Comisión que nada entrega al Párroco y como cosa propia administra sin dar cuenta al Párroco. En una palabra el Cura Párroco es un criado al cual no se debe ni siquiera consultar. Con esto no quiero decir que se abuse y se malgaste los fondos pero al Cura Párroco no puede proveer la Iglesia de las mas necesarias cosas como es un sacristán, crismera, ritual, manteles de hilo etc. etc. porque la Comisión gasta en otras cosas y dice que no tiene fondos. Como así se hace en las colonias de la Santa Fe y los capellanes de allí que pusieron sus reservas al prelado diocesano y así poner coto a estos desórdenes, fueron perseguidos como por ej. el de Susana que en estos días pasó a Rosario. Con todo 
desagrado elevo a V.S.I el presente informe de la gravedad a que hace referencia esta mi nota. La autoridad eclesiástica no reconoce dicha Comisión de culto y me ordena me haga cargo de la administración de la Iglesia y Cementerio según lo ordenado por el Prelado Diocesano. Sea esta la resolución que tomaría V.S.I juzgue más conveniente, cumpliré a la letra lo que me fuera ordenado, y creo que lo dispuesto por la Autoridad Eclesiástica será al momento acatado también por la Comisión que en su ignorancia obra mal aconsejada probablemente por personas de malos principios, pues los protestantes y masones abundan aquí". Firma Raynoldi.

Otro ejemplo lo encontramos en Colonia Caroya. Los colonos constituyeron una comisión pro-templo con el objetivo de edificar una capilla en la colonia. En 1884, enviaron una nota al obispado en la que informaban que "habiendo prometido a la Sma. Trinidad y al Patriarca San José la edificación de una capilla en uno de los lotes que es al centro de los que se han establecido los colonos con sus familias, el $n^{\circ} 25$ en distancia de la capilla de Caroya 64 cuadras, y es mas de legua y media. Han cumplido ya con la promesa, formando la capilla de siete metros de largo, cinco de ancho y cinco de alto, toda concluida; y están dispuestos a proveerla de lo necesario para la celebración del S. Sacrificio. Por lo tanto suplican a SSI se digne disponer por la colocación y su bendición, como oratorio y capilla pública; y lo esperan conseguir por favor y gracia particular de S.S Ilma. y que Dios Guarde”. Firmas: Francisco della Vedora, Jose Romanotti y Juan Bautista Vicentini. ${ }^{113}$

La curia diocesana envió al cura de Río Ceballos, Ambrosio Ramos, de quien dependía la colonia, a inspeccionar la capilla, pues en la curia no existía ningún antecedente sobre dicha fundación. El párroco informó que se apersonó para inspeccionar el local y a su juicio "no satisface a ninguna necesidad pública con la celebración del sacrificio de la misa en esta localidad". La construcción es muy pequeña, tiene sólo 6mts de largo, 3,50mts de ancho y alto y $3,35 \mathrm{mts}$ de costado. Tiene un pequeño alero o corredorcito. "Con el espacio que ocupa el Presbiterio y el que debe ocupar el confesionario, no queda local sino para muy pocas personas. Al frente de la puerta del edificio atraviesa una calle, no muy ancha y que es paso previo de caballos y carros y tendría que desalojar la concurrencia que más tendría que estar expuesta a la inclemencia de todos los elementos. No tiene una puerta de atrabieso donde el sacerdote pudiera entrar o salir con independencia de la multitud y

${ }^{113}$ AAC. Parroquias: Colonia Caroya, f.92. Nota fechada en Córdoba el 16 de octubre de 1884. 
menos local separado en donde se rebista el sacerdote o que haya sacristía”. Después de la descripción, el cura sostiene que a su parecer no existe ninguna necesidad, ya que en el pueblo de Caroya hay una capilla en funcionamiento y en Jesús María, otra, que aunque no pertenece al curato, está sobre la línea de éste y a pocas cuadras de distancia, y a la cual concurre toda la colonia cuando no hay sacerdote en la de Caroya. Con este informe, el obispado no dio lugar a la solicitud de los vecinos de Caroya de bendecir la nueva capilla, pero los colonos se siguieron reuniendo para rezar el rosario y realizar otras prácticas piadosas. De todos modos, la comisión no cejó en su cometido y continuó solicitando la aprobación de dicha capilla o la erección de una nueva que reuniera las condiciones necesarias.

\section{Primera capilla de Colonia Caroya dedicada a la virgen del Rosario}

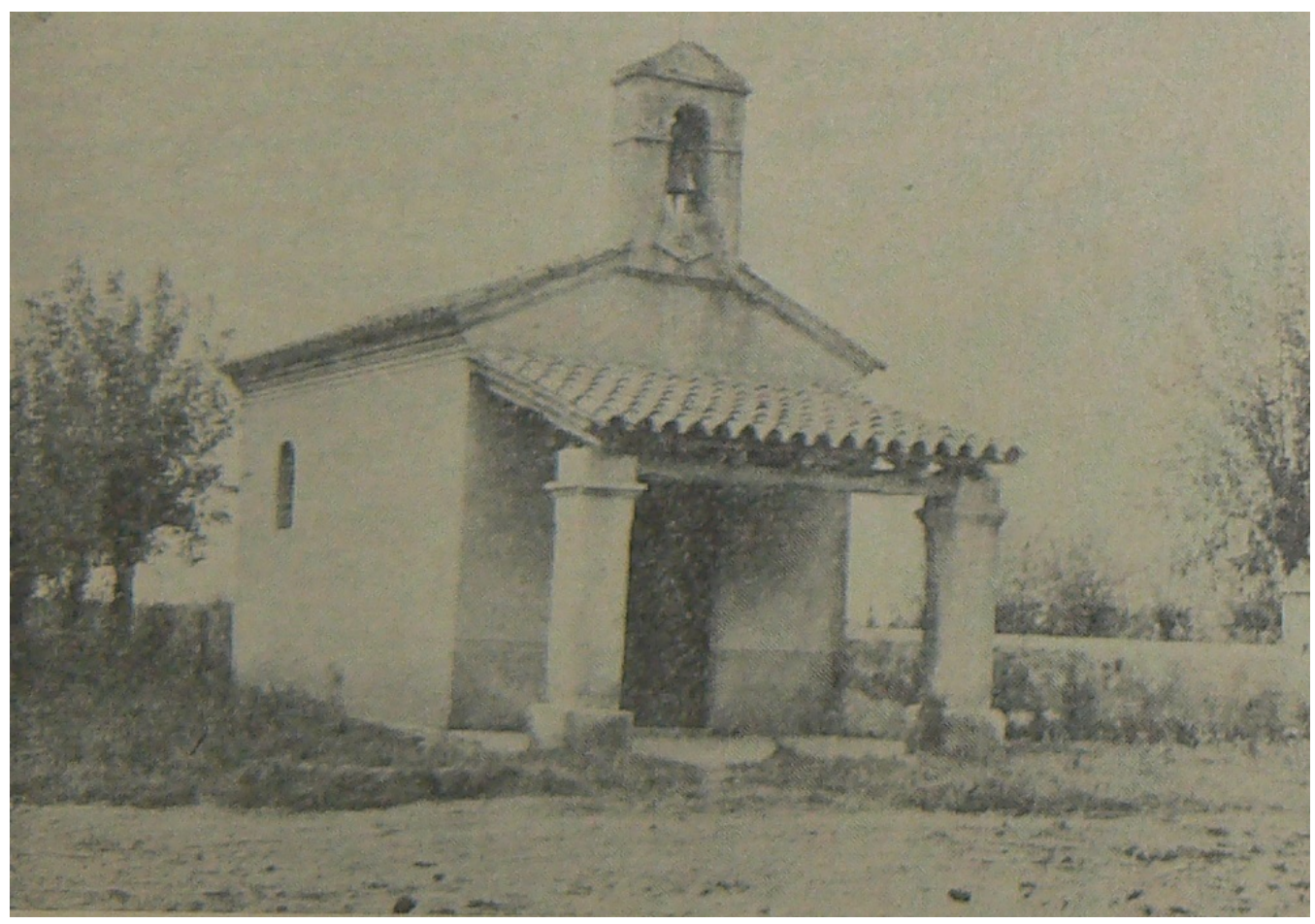

Fuente: Parroquia de Ntra. Señora de Montserrat, 1898-1948, Colonia Caroya.

Pocos años después, en 1896, se conformó la comisión pro-templo bajo la dirección del cura párroco Ambrosio Ramos y como vicepresidente el capellán de la colonia, José Bonoris. Dicha comisión inició las gestiones para la construcción de un templo adecuado. 
En 1897, el departamento de Colón se desmembró del curato de Jesús María, creándose un nuevo curato con cabecera en Río Ceballos. Los colonos de Caroya solicitaron al obispo la erección como curato independiente. El obispado consultó al párroco Ramos, quien señaló no ver dicha necesidad, pues la colonia contaba con un capellán con residencia permanente y era visitada cada dos meses por el cura párroco. A su juicio, el capellán desempeñaba un muy buen ministerio y contaba con todas las facultades que el cura párroco podía delegarle. Celebraba casamientos, entierros y todas las funciones necesarias para estimular la piedad de los fieles, atendía las confesiones de los enfermos y enseñaba la doctrina a los niños. Lo único que no hacía era los expedientes e informaciones matrimoniales, para lo cual los interesados debían ir a la parroquia para hacer los trámites, luego el párroco enviaba una nota al capellán para que hiciera la proclama y los casase. Advertía que por lo general los que se iban a casar eran "jóvenes y saben cabalgar lo mismo que los argentinos, y cuando esto no lo quieren hacer tienen el recurso de ir en tren a la Curia General de la ciudad". Dadas estas explicaciones, señalaba que no veía conveniente la elevación de Colonia Caroya a parroquia. ${ }^{114}$ Sin embargo, el obispo diocesano dispuso la erección de la Colonia en parroquia: "Por cuanto los vecinos de la Colonia Caroya nos han presentado solicitud por escrito, pidiéndonos que desmembremos el Curato de Colón la parte de Territorio que forma y ocupa la Colonia Caroya y que está perfectamente demarcada, y la constituyamos en un curato y vicaria. Hemos resuelto: $1^{\circ}$ Desmembrar toda la Colonia Caroya y erigirla en Curato y Vicaria independiente de Colón. $2^{\circ}$ Determinar que la Iglesia parroquial sea la que está en el no 15 cuya titular será la Virgen de Montserrat". ${ }^{115}$ Como párroco se nombró al capellán José Bonoris, ${ }^{116}$ quien falleció a los pocos meses, nombrándose cura a Félix Mattio. $^{117}$

Cuatro años después, el secretario y el tesorero de la comisión pro-templo, Sebastián Lepore y Domingo del Fabro, respectivamente, remitieron una nota al obispado en la que señalaban las desavenencias con el cura. Eran los únicos miembros que aún quedaban e informaban que la comisión había quedado sin presidente cuando la Colonia fue declarada parroquia (29/04/1898), ya que dicho cargo lo desempeñaba el cura Ambrosio Ramos;

\footnotetext{
${ }^{114}$ AAC. Parroquias: Colonia Caroya. Nota fechada el 15/06/1897.

115 AAC. Parroquias: Colonia Caroya. Auto de erección fechado el 29/04/1898

${ }^{116}$ Libro de Títulos, 1859-1904, f.105. Nombramiento fechado el 29/04/1898.

${ }^{117}$ Libro de Títulos, 1859-1904, f.106. Nombramiento fechado el 08/08/1898.
} 
además, con el fallecimiento del cura José Bonoris, quedó sin vice-presidente. Al nombrarse al cura Félix Mattio como nuevo párroco (08/08/1898), los vecinos trataron de reorganizar la comisión para la obra de la Iglesia "para que ella, dado su carácter, pudiese gozar de la mayor confianza posible entre los vecinos, se convino de acuerdo con el Señor Cura, de convocarlos a una asamblea general para que designasen las personas que debían constituir la nueva comisión de la que enseguida se pediría confirmación a V.S.Ilma. En efecto el pueblo se reunió y con aprobación del Señor Cura la Comisión quedo constituida". La cita de la larga nota enviada a la curia pone de manifiesto las diferencias entre el cura y la comisión: "Pero es el caso que por motivos que ignoramos, no pudo seguir la cooperación de aquel señor, mui al contrario, algunos aseguran que hasia propaganda en contra, por lo que se vio obligada a presentar su dimisión en masa, devolviendo a los suscritos los libros y demás documentos de la iglesia y a los cuales nosotros depositamos en manos del Señor Cura. Inmediatamente después de haber renunciado la mencionada comisión, el Señor Cura párroco según se publicó pidió a V.S.Ilma. el nombramiento de otra, la cual, hasta la fecha, no se ha constituido ni hecho cargo de los libros y demas papeles que le corresponden, a los cuales, como antes hemos dicho, habíamos depositado en manos del señor Cura, pero quien nos los devolvió declarando que no entendía porque habían sido llevados malamente, lo que constituye una gravísima ofensa a nuestro inolvidable párroco, don José Bonoris, que fue quién en su carácter de vice presidente de la comisión autorizo todo eso, y una calumnia a la vez para los suscriptos que como secretario y tesorero respectivamente, cooperábamos con ese venerable sacerdote. Las cuentas señor, fueron llevadas por los suscriptos bajo la dirección del Presbítero Bonoris, tienen el visto bueno de la comisión consultora y han sido aprobados sin observaciones ningunas por todo el pueblo que cuando se publicaron pudo examinarlas detalladamente durante meses enteros. Por tanto, a la vez que protestamos contra el agravio que se pretende inferir a nuestro difunto párroco de tan grata memoria, declaramos a V.S.Ima que podemos probar en cualquier momento y donde quiera, que esos libros fueran llevados con suma honradez. Ahora bien, pronto se cumplirá un año en que nos encontrabamos en esta angustiosa situación, que nos desconceptúa cada vez más ante los vecinos, porque todos suponen que dichos libros se encuentran en los condiciones manifestadas por el Señor Cura Mattio. El tesorero que suscribe $\mathrm{Sr}$ del Fabro, con el fin de que esto terminase de una vez, días 
pasados dirigió una nota al Señor Cura sobre el particular y contra lo que se esperaba dio por resultado a que dicho Señor manifestase a los vecinos que se le había dirigido un asunto injurio, y que se veía obligado a salir de la Colonia. Para que V.S.Ima puede juzgar del tema de dicho asunto, al cual no creemos ofensivo adjuntamosle copia de él. Si triste era nuestra situación antes que el tesorero dirigiese al Señor Cura la nota referida, ahora ha empeorado tanto que se ha hecho imposible, porque muchos vecinos creen que la desorganización actual de la Comisión para la Obra de la Iglesia es debida a los fraudes que se han cometido en los libros, y así que después de muchos años de inmensos sacrificios, relativamente hablando y de haber librado verdaderas batallas para levantar un templo, que no otro título merece el edificio construido, somos hoy motejados con el odioso título de defraudadores. Nuestros afanes por la construcción del edificio de la Iglesia, nunca nos hicieron concebir la idea de una recompensa, porque estábamos perfectamente convencidos que no hacíamos más que cumplir con nuestro deber, pero jamás nuestra mente pudo imaginarse que un día llegaríamos a ser cubiertos de calumnias. Ah, Señor, no es posible que sea este el galardón que hayamos podido merecer; no es posible que tanto afán y tanta labor sean premiados de esa manera, y por lo tanto no es posible que nuestros hogares inocentemente continúen por más tiempo hundidos en la deshonra. Por lo que pedimos la saludable intervención de V.S.Ima a fin de que esos libros después de una minuciosa revisión, nos sean recibidos en esa , o de lo contrario se nos autorice para depositarlos en la secretaria del Obispado, pues de otra manera nuestra situación nos obligaría a vindicar nuestro honor de alguna otra forma, y entonces muy a pesar nuestro deberíamos hacer ciertas declaraciones respecto al proceder del Señor Cura Mattio, que hablan muy poco a su favor, y aquí omitimos el carácter que esta reviste. Lo que no podemos abstenernos de manifestar a V.S. Ilma. es que la desmoralización cunde de una manera alarmante entre los vecinos de mayor valimiento y que mayor concurso han prestado. Rogamos pues a V.S.Ima que en las diversas ocasiones que nos ha honrado con sus visitas, y que aunque por breves instantes se dignó dirigirnos la palabra y por lo tanto su ilustrado criterio habrá podido apreciar nuestros sanos principios rogámosle interponga su indiscutible y paternal autoridad en este asunto y podamos al fin demostrar que durante nuestra permanencia en la Comisión siempre hemos tratado de cumplir leal y honradamente con nuestro deber". ${ }^{118}$

\footnotetext{
${ }^{118}$ AAC. Parroquias: Colonia Caroya, f.77. Nota fechada el 12/01/1900.
} 
Al cabo de algunos días, el intendente municipal envió al obispado una denuncia contra el cura, en la que señalaba que "el Ilustrísimo Señor Cura de la localidad, Don Félix Mattio en el sermón del Domingo próximo pasado se expresó de una manera ofensiva para con la Municipalidad de la Colonia, con el fin manifiesto de enajenarle el buen concepto que siempre ha tenido entre los vecinos. El suscrito no pudo impedir que el señor Cura se afilie a un bando político como tampoco el de hacer prosélitos desde el pulpito, como ha demostrado con hechos y palabras, pero si puede impedirle que desacredite a la Municipalidad que me cabe el honor de representar: por lo que ante todo y a fin de no abultar las cosas ya demasiado grandes, me dirijo a V.S.Ilma. a fin de que tome disposiciones del caso. Debo agregar que estoy dispuesto a probar si el caso se ofrece que esta Municipalidad jamás bajo ninguna forma ha tenido un acto hostil respecto al señor cura, muy al contrario". 119

El día 20 del mismo mes, el cura respondió ante el obispo, afirmando que el intendente municipal de la colonia había sido mal informado, pues en sus palabras nunca había hablado ni bien ni mal de la municipalidad, "únicamente el domingo pp. en un aviso dado al pueblo he dicho estas textuales palabras: 'Hai quien domina esta Municipalidad muy bien pero yo no permitiré nunca que haya quien venga a dominar mi Iglesia y nada más'. Todo el resto de la nota es completamente falsa como pueden atestiguar todos los colonos porque nunca me he puesto en política ocupándome exclusivamente de mi ministerio parroquial". 120

Simultáneamente, los vecinos de la colonia remitieron al obispado una nota a favor del tesorero de la comisión, Domingo del Fabro, denunciando al cura Mattio: "Los colonos que suscriben con el mas profundo sentimiento en el alma y el corazón herido nos presentamos humildemente a S.S. Ilma., para comunicarle la dolorosa e impresionante noticia siguiente: Nuestro estimado y digno vecino Don Domingo Del Fabro, quien como V.S.Ilma. ya sabe, estaba en desacuerdo con el Señor Párroco de esta localidad cuyo desacuerdo motivó el decreto de V.S.I de fecha 15 del corriente, y que el desgraciado Del Fabro en cumplimiento a lo ordenado por S.S.I. habría resuelto trasladarse a esa hoy mismo, no podrá ya hacerlo más porque ayer a las siete de la tarde y en plena calle fue

\footnotetext{
119 AAC. Parroquias: Colonia Caroya, f.78. Nota fechada el 16/01/1900.

${ }^{120}$ AAC. Parroquias: Colonia Caroya, f.79. Nota fechada el 20/01/1900.
} 
asesinado de un balazo que lo dejo inmóvil, sin conocer aún al asesino, a pesar de la actividad desplegada por la justicia para descubrirlo. Es creencia de los suscritos y también de la mayoría de los colonos que el Sermón hecho por el Señor Cura Párroco el domingo pasado durante la misa, haya influido en el asesinato de Del Fabro, porque el Sr Párroco desde el púlpito dijo más o menos estas palabras 'Sepan colonos de que por causa de tres personas, o sea tres lobos que hay en la Colonia yo tendré que ausentarme de aquí, pero les quiero prevenir que se guarden muy bien de esos lobos infernales porque son más dañinos que la peste bubónica, quieren interesarse en los asuntos del Párroco, pero se han equivocado mucho; yo no estoy dispuesto a dejarme gobernar, lo que debería ser es esto: que los empleados municipales cumplan con sus deberes y lo dejen al Párroco, que las maestras cumplan con sus deberes en su escuela y no se ocupen del Párroco, que me dejen tranquilo en la Iglesia porque aquí nadie manda sino yo, y no les tengo miedo, pero si es caso de hirme de la Colonia por culpa de los tres lobos protestantes que me hacen la guerra buscando firmas en contra mía, no tardaran mucho en sentir las consecuencias'. Estas fueron más o menos las expresiones, ahora bien: siendo Del Fabro el secretario Municipal y director de la escuela fiscal de la localidad, todos han entendido muy bien que los insultos del Párroco eran dirigidos (aunque indirectamente) a Del Fabro, señalado como uno de los principales lobos dañinos. De lo que resultó que apenas salida la gente de misa, dos personas ignorantes insultaron brutalmente a Del Fabro en plena calle, amenazándolo a palos y culpándolo de la hida del Párroco, cuyo insulto y ataque se apaciguaron luego por la intervención de varias personas. En la mañana de ayer tuvo lugar el bárbaro crimen y cruel asesinato del respetable Del Fabro que deja a la esposa y tres tiernos hijos desesperados en el solar y toda la colonia sumamente irritada e impresionada por la pérdida del hombre más ilustrado que tenía, quien se dedicaba totalmente y con perjuicio de sus intereses, a la educación de nuestros hijos y al engrandecimiento, bienestar y progreso de esta importante colonia. Como decíamos es opinión general aquí que el sermón del domingo pasado haya influido muchísimo y tal vez sea el principal motivo del bárbaro crimen cometido. Con esto creemos haber cumplido nuestro sagrado deber de poner en conocimiento de S.S.Ima lo que desgraciadamente ha sucedido en que se digne tomar las 
medidas conducentes a fin de salvar mayores consecuencias. Humildemente nos postramos a sus pies". ${ }^{121}$

El cura envió, a su vez, una nota al obispado en la que decía que estaba amenazado de muerte y que se retiraba a Jesús María, "habiendo sabido que su vida está amenazada por unos malos intencionados, y que por el miedo habiéndole vuelto el mal de corazón que antes ya sufría, presenta su renuncia indeclinable de dicha parroquia y como el peligro es grave se retira a Jesús María". ${ }^{122}$ Pocos días después, otro grupo de vecinos envió una nota al cura en defensa del párroco: "Los que suscriben vecinos de esta colonia con el mayor respeto nos presentamos a SS y exponemos: que teniendo conocimiento que nuestro señor Cura presbítero Félix Mattio ha resuelto retirase de esta parroquia sin saber la causa que lo induce nos vemos en la precisión de manifestar a S.S vea no aceptar lo solicitado por el laborioso y distinguido sacerdote, cuyas consecuencias serían muy perjudiciales para esta población. En la esperanza de obtener un favorable resultado con respeto saludamos con la mayor consideración nuestro prelado". ${ }^{123}$ En junio de 1900, los colonos solicitaron se nombrara a otro cura, dado que Mattio no estaba dispuesto a regresar a la colonia. "En vista de que tenemos el sentimiento de que nuestro Párroco Dn Félix Mattio no acepta volver a la parroquia por más que le aseguramos que nada habrá contra él, nos vemos en el caso de pedir a V.S.Ilma. se sirva nombrar otro que lo reemplace, si fuera posible, con uno que hablara italiano, permitiéndonos indicarle al Presbítero Latela (joven) o al que V.S.Ima. se sirva designar". ${ }^{124}$ Finalmente, gracias a las gestiones del Secretario del Obispado, Rubén Márquez, el cura Mattio regresó a la colonia. Los colonos agradecieron las gestiones y le aseguraron "que el retorno del Señor Mattio a esta parroquia será la mayor satisfacción de los colonos, y que la nueva comisión nombrada ayer le prestara su más decidido apoyo ayudándole en todo". ${ }^{125}$

Al cabo de siete meses, los miembros de la nueva comisión se quejaron de la conducta del cura Mattio. Aducían que no le gustaban las comisiones y obstaculizaba su trabajo y presentaron la renuncia. El obispado se las aceptó, agradeciendo sus servicios. ${ }^{126}$ Pasados

\footnotetext{
121 AAC. Parroquias: Colonia Caroya. Nota fechada el 19/01/1900.

122 AAC. Parroquias: Colonia Caroya. Nota sin fecha.

${ }^{123}$ AAC. Parroquias: Colonia Caroya. Nota fechada en el mes febrero de 1900, sin especificar el día.

${ }^{124}$ AAC. Parroquias: Colonia Caroya. Nota fechada el 03/06/1900.

${ }^{125}$ AAC. Parroquias: Colonia Caroya. Nota fechada el 04/06/1900.

${ }^{126}$ AAC. Parroquias: Colonia Caroya. Nota fechada en febrero de 1901.
} 
tres años, la comisión envía una nota al obispado en la que solicitaban se le ordenara al cura Mattio desalojar el sótano de la casa parroquial a fin de almacenar allí el vino recolectado. La respuesta del obispado fue firme. Respecto a las atribuciones y competencias de la comisión y del párroco, señalaba: "Vista la solicitud anterior elevada por el Presidente de la Comisión de la capilla o altar de San Antonio en la Iglesia Parroquial de la Colonia Caroya, pidiendo ordene al Cura Párroco el desalojo de la bodega de la casa parroquial para depositar la colecta de vinos oblados por los vecinos para la prosecución de los revoques de la misma iglesia parroquial, y considerando que según el informe del Cura párroco la iglesia mencionada, con esa casa parroquial y todas las demás dependencias de la misma, a su debido tiempo fue entregada en perpetua e incondicional donación al obispado, cual en derecho corresponde y, por tanto, es el Párroco el administrador exclusivo de todo cuanto en dicha donación este comprendido, siendo el único responsable de su conservación, -que la orden pedida por la comisión para que se mande al cura entregar un aparte del edificio correspondiente, como la precitada bodega, sería un verdadero despojo del derecho y justicia que le asiste para administrar los bienes eclesiásticos que están bajo su jurisdicción administrativa y exclusiva responsabilidad- que ninguna razón de conveniencia, ni de justicia tiene la comisión peticionante para opinar que no corresponde al párroco la posesión administrativa del local de la bodega, que para satisfacer la necesidad que actualmente se le presenta puede arbitrar medios que estén a su alcance, sin vulnerar derechos ajenos. Por estas consideraciones y deseando por nuestra parte obviar todo inconveniente que pudiera importar una intromisión ilegitima en el servicio y administración de la parroquia, que por todo derecho corresponde al cura y es quien debe responder por todos los bienes raíces y muebles de la misma, hemos venido en resolver y resolvemos: no hacer lugar a la petición de la mencionada comisión, quedando el párroco en su perfecto derecho de hacer con ella el arreglo que creyere conveniente para evitar todo desacuerdo y establecer la paz y armonía con sus feligreses", 127

La cuestión de la comisión pro-templo continuó siendo un problema y en junio y agosto de 1906 los colonos enviaron nuevamente una nota al obispo recientemente electo, Zenón Bustos, en la que resumían brevemente las dificultades que habían atravesado las

\footnotetext{
127 AAC. Parroquias: Colonia Caroya. Nota fechada el 10/02/1904 y firmada por Filemón Cabanillas,
} Gobernador del Obispado en Sede vacante. 
relaciones entre el cura y la comisión, llegando a la renuncia de todos sus miembros. Señalaban que la conducta del cura no era la que debía llevar un buen sacerdote, celoso del cumplimiento de sus deberes en bien de sus feligreses. "La prueba está, que a su llegada nomás aquí, se ha puesto de punta y completa discordia con la Comisión encargada de los trabajos del templo y al poco tiempo ésta tuvo forzosamente que renunciar indeclinablemente, porque el Sr. Mattio era y es contrario a tales comisiones. A fines de mayo del año 1900 sin motivos justificables, sin avisarlo a la población y sin ponerlo en conocimiento de ese Obispado, el Señor Mattio abandonó la parroquia brutalmente yéndose a vivir a Jesús María y dejando los registros parroquiales, los ornatos y alhajas pertenecientes a la Iglesia en poder de un señor de ninguna responsabilidad, que tenía de peón. A pocos días de tal desorden y a petición de algunas personas que pusieron el hecho a conocimiento de ese Obispado se presentó en esta el entonces Secretario Sr Rubén Márquez, quién lo aconsejó volver a la Parroquia abandonada, y al mismo tiempo dicho señor Márquez estableció aquí una nueva comisión para la prosecución de los trabajos del templo, la que fue confirmada por ese obispado con decreto del 4 de junio de 1900, esta comisión tampoco ha podido entenderse con el Sr Mattio, el cual en vez de animarla y ayudarla se puso en contra de ésta, para no seguir en continua discordia con dicho señor Cura y convencidos que al mismo le estorban las comisiones por ser contrario a ellas, presentaron la renuncia indeclinable en febrero de 1901, exponiendo en ella los motivos que obligaron a tal resolución. Así que, desde entonces no hay comisión alguna y así tampoco el Señor Mattio se ha ocupado absolutamente nada en favor de los trabajos del templo, así que van ocho años que él está aquí y son ocho años que dichos trabajos están paralizados y creemos que mientras él permanezca en ésta, seguirán en statu quo, porque nunca ni del púlpito ni en privado pronuncio la más mínima palabra animando el público al adelanto de la obra. Además debemos manifestar a S.S.Ilma. que el Señor Mattio ha comenzado a ser demasiado amante de la bebida, repitiéndose a causa de esto algunos hechos que contradicen de su decoro sacerdotal y menosprecian al sacerdote que los comete; especialmente en estos días de las Misiones habidas aquí, tuvimos que presenciar actos indecorosos que no detallamos por delicadeza, pero que S.S.Ilma. podrá tomar informes fidedignos de ellos al Cura de Jesús María Señor Frias y a los Reverendos Padres Misioneros que estuvieron aquí y fueron testigos oculares de estos últimos escándalos que 
denunciamos. En mérito a lo expuesto y otros datos que omitimos para que esta no sea tan extensa, humildemente pedimos a S.S. Ilma. se digne enviar a esta Parroquia al Señor Inspector de curatos para que compruebe los hechos que denunciamos y se adopten enseguida por S.S. Ilma. las medidas que estime convenientes. Con tal motivo nos complacemos saludar humilde y respetuosamente pidiéndole su apostólica bendición". ${ }^{128}$

Ante la denuncia, el obispado envió al Secretario de Cámara y Gobierno, Eduardo Ferreyra, para levantar información sobre el tema. ${ }^{129}$ El 17 de septiembre elevó un informe detallado sobre la cuestión. Allí comunicaba que por la carta enviada por el cura de Caroya resultaba innecesaria la información que se le ordenó realizar, sin embargo, como tenía ciertos antecedentes, consideró oportuno ir de todos modos al curato, aunque sin darle un carácter oficial a la visita. Así pasa a relatar los hechos observados: “Ayer pues, Domingo 16, nos trasladamos con el pro-secretario, con pretexto de paseo. Llegado a Jesús María, pasamos inmediatamente a la Colonia, llegando en momentos que se celebraba la misa mayor, y el Cura explicaba la doctrina a los adultos: el aspecto de la iglesia completamente llena de colonos, y la atención con que era escuchado el Cura nos hizo repentinamente cambiar nuestros prejuicios, porque allí se veía bien claro la acción de un Párroco que goza de toda una autoridad moral sobre los feligreses, y presuponía una labor larga y constante, de una parte, para conservar el espíritu religioso que allí se veía. Tratando de hablar a algunas personas tuvimos ocasión de conferenciar largamente mientras duraba la misa, con el secretario de la municipalidad, hombre educado y discreto, y al parecer muy digno: este señor nos manifestó que la colonia entera lloraba la salida anunciada del Cura, cuya conducta fue siempre irreprochable; que las faltas que se le atribuían eran exageradas por un grupo de ocho o diez personas cuyos nombres nos señaló; siendo los mismos que firman la denuncia de fecha 23 de agosto ppdo., y que estas faltas no son reconocidas ni tenidas en cuenta por el pueblo. En cambio, se me presentó el hijo del Sacristán, que es uno de los del grupo de enemigos, llevando una solicitud que andaba haciendo firmar, pidiendo que en caso de retiro del Cura actual, sea nombrado Cura de la Colonia, el señor (falta foto folio 43) folio 54 de los que han emprendido la guerra del cura. Mientras tanto, sus enemigos se valen de medios bajos de persecución: hemos constatado que se le ha

\footnotetext{
${ }^{128}$ AAC. Parroquias: Colonia Caroya. Nota fechada el 23/08/1906.

${ }^{129}$ AAC. Parroquias: Colonia Caroya. Nota fechada el 07/09/1906.
} 
violado la comunicación a esta Curia; pues ha recibido un sobre cerrado, copia exacta de la carta que él me ha escrito y adjunto, incluyendo, en esa copia, algunas palabras de mi carta dirigida a él, dándole cuenta de la misión que había recibido de VSSI. En una noche le han matado todos los canarios de la pajarera, que el Cura tenia grande estima. Y le arrojan pedacitos de carne al pozo, haciendo correr la voz de que esta envenenada, lo que el Cura cree. Anteriormente estos mismos enemigos acusaron al Cura de complicidad con un asesinato ocurrido en la colonia".

El 11 de noviembre de 1909, el sacristán de la parroquia, Santiago Lauro, envió una nota al obispado para informar que "el Sr Párroco don Félix Mattio se ausentó definitivamente de esta colonia, dejando las llaves de la Iglesia y casa parroquial, incluido el archivo del mismo. En consecuencia creo de urgente necesidad por múltiples razones que S.S.Ilma. se sirva proveer cuanto antes a llenar la vacante producida". ${ }^{130}$

Este es sólo un ejemplo entre tantos sobre las dificultades que encontraban los curas en relación al control del templo. Son infinitos los casos en los que las comisiones pro-templo, muchas veces propietarias del edificio, negaban las llaves al cura para la celebración del culto.

En 1901, Manuela de la Lastra, viuda de Funes, le escribió al Obispo Toro solicitándole autorización para construir un templo en Sta. Eufemia para la celebración de los divinos misterios situada en la parroquia de San Gerónimo, departamento de Unión, a 5 leguas o más de todas las capillas públicas existentes en esa parroquia. "Y deseando cooperar al mayor bien de las almas, hemos resuelto de común acuerdo con mis hijos, edificar un templo en nuestro terreno y en dicha población dotado de todo lo necesario para el culto y costear un sacerdote que celebre frecuentemente en él la Santa Misa, enseñe a los niños la doctrina Cristiana para lo cual presentaremos a V.S. Ilma. los planos oportunamente para que sean aprobados y fijaremos la asignación que de acuerdo con V. S. Ilma. fuere suficiente para el resto del templo. Ofrecemos dar el templo ya terminado a la Iglesia en la persona de V. Sria. juntamente con el terreno conveniente para que se edifique la casa en que ha de habitar el rector del templo. Por lo tanto, pido a V. Sria. la licencia necesaria para proveer a la construcción de dicho templo y solicito que el título y cargo de patrono que el derecho acuerda a los que edifican y fundan templos sin oficio ni beneficio se me

${ }^{130}$ AAC. Parroquias: Colonia Caroya. Nota fechada el 11/11/1909. 
confiera a mí en su defecto a mis hijos por orden de edad, mientras dicho templo no sea erigido en parroquia y en cuyo caso renuncio a todos los privilegios y prerrogativas que pudieran corresponderme". 131

El obispo concedió la licencia solicitada y una vez terminada la capilla comenzó a funcionar bajo la dependencia del cura de Bell Ville. En 1908, se sucedió una serie de conflictos entre la comisión pro-templo de Colonia Palestina y el párroco. La comisión no estaba dispuesta a entregar la iglesia al obispado. El cura informó que el día de San Juan se había negado a concurrir a las fiestas que se prepararon en Palestina, porque anticipadamente les había avisado que no iría si se incluían bailes populares en los programas de las fiestas, como estos bailes se incluyeron el cura no fue a la colonia a celebrar las funciones el día de la fiesta. Por este motivo, la comisión decidió no entregar las llaves de la iglesia. El cura acota que suponía que el conflicto generado fue adrede, utilizado como excusa para negarse a entregar el edificio al obispado como se les había solicitado. El domingo siguiente pidieron que fuera a decir misa y el párroco respondió que "mientras no hicieran la entrega del edificio a la diócesis no se dirían más misas, y acota que por la cantidad de 20 pesos les ha dicho misa todos los meses y lo seguiré haciendo si entregan la Iglesia". ${ }^{132}$

En 1914, en Oncativo sucedió otro altercado relacionado con el control del templo. El capellán Roque Di Stacio fue dejado cesante en el ejercicio del ministerio por la curia, el cura de Oliva, del cual dependía la capilla de Oncativo, Emilio Visca Caviglia, envió un representante a recibir la parroquia, la casa parroquial y el archivo. Al presentarse en el pueblo, la encargada de las llaves del templo se negó a entregárselas, aduciendo órdenes del juez de paz y de la comisión pro-templo, y de no dejar entrar a nadie, ni siquiera al cura. Uno de los miembros de la comisión era el Comisario Bernardo Rodríguez, en casa del cual solía alojarse el cura Di Stacio. Dicho comisario apoyaba al capellán y en algún momento había señalado de que en caso de que fuera removido "él armaría bochinque". El párroco de Oliva entiende que la actitud suponía un atropello por parte de la comisión y del juez de paz, ya que dicha comisión se había formado con el único fin de recolectar fondos para la construcción del templo. El cura señalaba que aún cuando hubiera tenido derechos

\footnotetext{
${ }^{131}$ AAC. Leg. 52. Curato de Bell Ville, s/f. Nota fechada el 06/05/1901.

${ }^{132}$ AAC. Leg. 48. Fraile Muerto/ Villa Nueva, f.615.
} 
sobre la capilla estos cesaron desde el momento en que fue puesta al servicio público, en 1911, y desde entonces se celebra misa sin interrupción. Entendía que los actos llevados adelante por el juez y la comisión implicaban un desconocimiento y una burla no sólo a la curia sino a la primera autoridad que representaba. No se trata de mantener allí un capellán sino de conservar en un puesto a un sacerdote que se había hecho indigno. "Dicha comisión y juez están al capricho de ese capellán cesante”. El párroco de Oliva solicitó a la curia que para evitar sucesivos abusos se escribiera un documento en el que se especificara, $1^{\circ}$ cuál era el fin de la comisión pro-templo y qué atribuciones tenía; $2^{\circ}$ en caso de que correspondiera la presidencia al cura, si los actos ejercidos sin su autorización eran válidos; $3^{\circ}$ si es reconocida y autorizada por la curia la comisión de Oncativo; $4^{\circ}$ si la referida comisión había rendido alguna vez cuenta de los fondos invertidos en la obra, de los colectados entre el pueblo y la colonia en diversas épocas, ya que en los dos años y cinco meses que el cura llevaba al frente de la parroquia no se había rendido cuenta de los fondos ni hubo ninguna reunión; $5^{\circ}$ si la acapilla de Oncativo había sido entregada por escrito a la Curia; $6^{\circ}$ si la comisión pro-templo tenía derecho a clausurar el templo y la casa parroquial; $7^{\circ}$ si había obrado correctamente negando la entrada al templo y a la casa parroquial a todos, inclusive al párroco. ${ }^{133}$

Los ejemplos aquí reseñados dan cuenta de las dificultades de los curas para el control de los templos y las medidas tomadas al respecto por la jerarquía. Estos conflictos motivaron que la jerarquía eclesiástica iniciara un reclamo sistemático de las escrituras de los terrenos en los que había templos. En 1905, el obispado envía una circular a todos los párrocos para que informaran sobre cuestiones relacionadas con sus curatos. En ella, se pregunta si los terrenos en los cuales se asientan los edificios sagrados están escriturados a favor del obispado. Así, constatamos que de los 197 templos diocesanos con funciones parroquiales existentes en 1905, el 52\% tenía escritura a nombre de la Iglesia, el $48 \%$ no contesta sobre el tema, por lo tanto, no consta que la tuviera, y el $2 \%$ responde que los terrenos son antiguas donaciones sin escritura. ${ }^{134}$ En 1910, el presidente de la comisión de la Iglesia de Liebres elevó una nota al obispado para solicitar que dicha iglesia fuera erigida en la parroquia del nuevo curato del Carmen, el obispo respondió que no sería

\footnotetext{
${ }^{133}$ AAC. Parroquias: Oliva, fs.138-140. Nota fechada el 08/08/1914.

134 AAC. Compilación de datos relacionados con las Parroquias de la Arquidiócesis. Inicio del Libro, 31/05/1914.
} 
posible porque "aquella iglesia aún no está escriturada a favor de la diócesis, por tanto no es posible tratar por ahora ese asunto". ${ }^{135}$ En 1910, el obispo diocesano autorizó la construcción de una iglesia en Jovita, curato de Laboulaye, porque la comisión de la iglesia donaba un terreno en una ubicación central y "ellos se comprometen a construir por su cuenta la iglesia y casa parroquial entregando todo hecho". ${ }^{136} \mathrm{~A}$ medida que el proceso de romanización avanza, el clero toma el control y la dirección de la actividad parroquial.

${ }^{135}$ AAC. Notas de Secretaría, 1885-1913, f.128. Nota del 10/03/1910.

${ }^{136}$ AAC. Notas de Secretaría, 1885-1913, f.138. Nota del Secretario del Obispado al Cura de Laboulaye del 19/03/1911. 


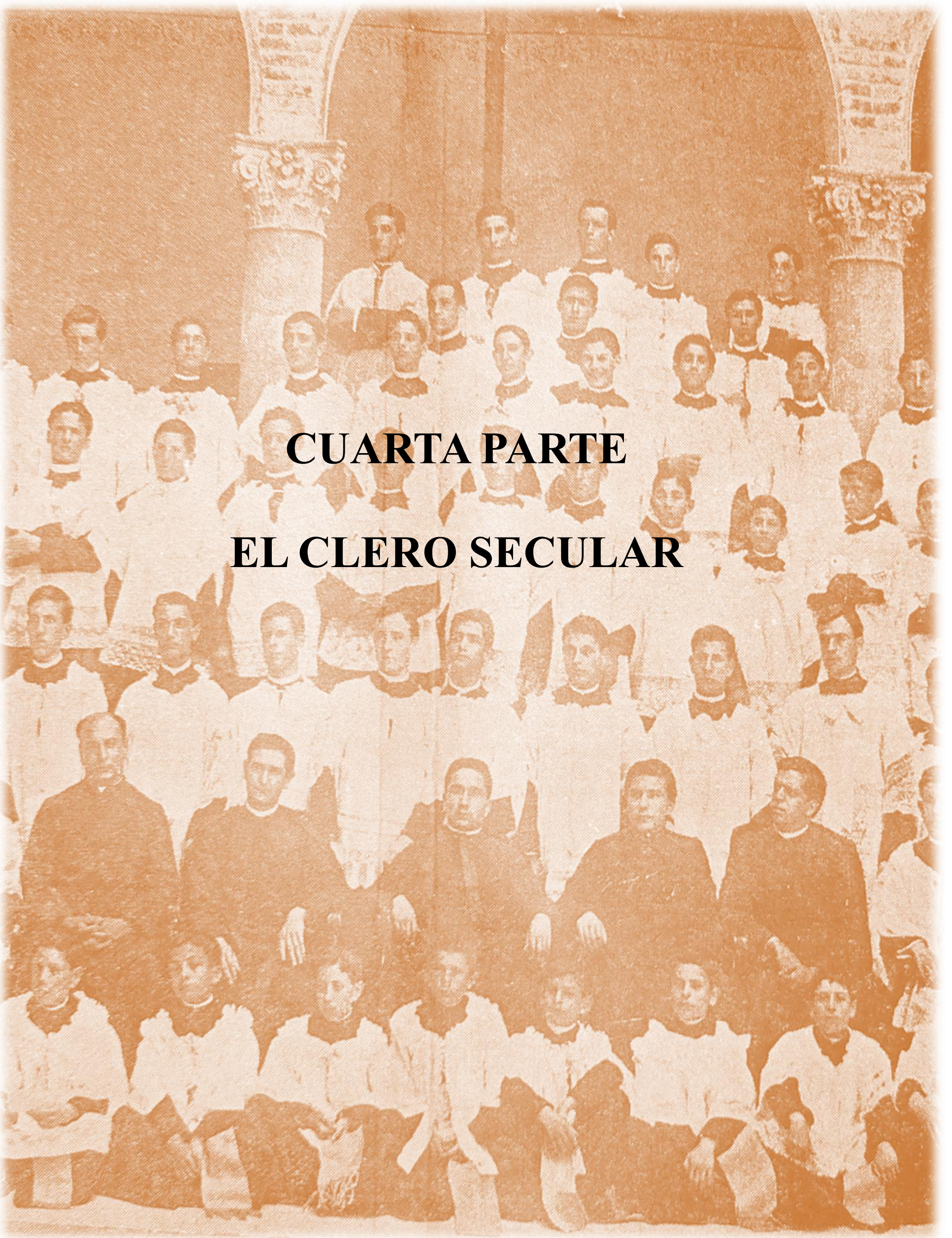




\section{CAPITULO 10}

\section{Un nuevo modelo de cura, distinto pero no distante de la feligresía}

En esta cuarta parte, presentamos una aproximación al clero como grupo social, sus formas de acción y organización, sus cambios y recomposiciones a lo largo de un período de profundos cambios sociales y económicos. Para ello, retomamos algunas de las consideraciones planteadas en la segunda aparte de la tesis respecto a la importancia que adquieren los actores. En una institución como la Iglesia, el clero secular es un actor central, por este motivo, además de utilizar el criterio de identificación socioprofesional (clero-secular-parroquial), privilegiamos, para su análisis, la dimensión relacional, considerando que sus acciones dependen del campo estratégico en el que se encuentren, como el marco geográfico o social, o sus relaciones de oposición o afinidad con otros actores (Guerra, 1993: 241). En este sentido, resulta de particular importancia el abordaje del clero y su relación con los diversos espacios regionales que conforman esta diócesis mediterránea.

Además, los grupos nos sólo se definen por sus propiedades relacionales, sino también por sus imágenes recíprocas y su capacidad de imponer una imagen de sí mismos a los otros (Reguera, 2007). Para ello, resulta de particular importancia analizar la composición y el capital relacional de esta "agrupación especial de carácter espiritual y jurisdiccional", un grupo de personas que tenían en común su adscripción al "orden sagrado", su incardinación en una diócesis y su dependencia de un obispo. Siguiendo estos lineamientos metodológicos, hemos abordado al clero como un "microcosmos social", un lugar donde desembocan individuos procedentes de muy diversos mundos sociales. Individuos que, unidos por el común denominador de su función, se estructuran y se sitúan en su interior (Benito Aguado, 1994: 44).

Como ya hemos señalado, en esta cuarta parte analizaremos cómo se estructura la composición del grupo, qué diferencias encontramos en el seno del mismo y cómo se pensaban esas diferencias y cómo se tradujeron en acciones concretas (Imízcoz, 1996). Pese a la existencia de obras generales, poco sabemos sobre estos actores en relación a su composición como grupo, orígenes sociales, carreras eclesiásticas, etc.

Manuel Gálvez (1944: 149) señala en su ensayo sobre Fray Mamerto Esquiú, que Córdoba, en 1881, por su población e importancia política, social e intelectual era la segunda ciudad de la república. Era una ciudad eclesiástica y conventual y todo lo que 
atañía a la religión ocupaba el primer lugar. El clero tenía una importancia decisiva y el sacerdote "era un personaje que no se mezclaba casi con el pueblo y que hasta gallardeaba cierta arrogancia, ya que fuera impropia hablar de orgullo o soberbia. Era un clero a la española: instruido en materia religiosa, más sin llegar a la sabiduría; dominador, hasta en cosas ajenas a la religión, como hacer la política; quisquilloso y celoso de su poder. No se distinguía por un excesivo amor a la caridad, ni por su espíritu evangélico. Gustaba el buen vivir relativo, de aquel que no es incompatible con una conducta arreglada. Harto preocupado de su poder sobre los fieles y los bienes materiales, era lógico que llegara a las rivalidades, a los chismes, a la politiquería”. Este modelo caricaturizado por Gálvez es combatido por la jerarquía, que busca imponer un perfil más acorde con las necesidades de la Iglesia y de la sociedad. Los sínodos, los autos de las visitas canónicas, las pastorales y los debates de la prensa en torno a la figura y misión del clero, nos permitieron modelizar el perfil clerical presente en la jerarquía y en la sociedad a lo largo del período.

\section{El perfil del clero deseado}

El perfil del clero está íntimamente vinculado a la función que se espera cumpla en la sociedad. Por este motivo, en este punto, hemos abordado el perfil delineado por la prensa, pues entendemos que ilustran el clero esperado por la sociedad de entonces. Un segundo punto aborda los documentos episcopales, con el objetivo de adentrarnos en la mirada de la jerarquía sobre el modelo clerical que se aspiraba a imponer. A partir de estos elementos, presentamos el perfil de cura deseado. La prensa no es ingenua respecto al tema, motivo por el cual consultamos dos diarios, el primero, de corte más liberal y anticlerical, "El Progreso", cuyo director era el Diputado Nacional Autonomista Ramón Gil Navarro, y el segundo, el periódico eclesiástico "El Eco de Córdoba", dirigido por el Pbro. Vélez. Por último, tomaremos algunas denuncias de las feligresías, que llevaron a la jerarquía a depurar conductas y tomar medidas destinadas a modelar al clero.

Contextualizamos este debate sobre el lugar y la función del clero en un período de transición, en el cual comienzan a perfilarse en Córdoba dos posturas ante el dualismo cristiano que postula la distinción de dos órdenes, el temporal y el espiritual. Estas posturas, llevadas a su extremo, se las identifica como clericalismo y laicismo. El primero sostiene que la distinción de ambos órdenes significa que la sociedad política debe ayudar a alcanzar la felicidad temporal, el cristiano sabe que por encima de esa 
felicidad esta la esperanza de una felicidad eterna. Por lo tanto, en orden a ese fin -la felicidad temporal y eterna-, el poder espiritual institucionalizado en la jerarquía eclesiástica, posee no sólo el derecho, sino también el deber de guiar a la entera sociedad en todas sus dimensiones. Desde esta postura, el poder temporal deriva del poder espiritual, al que está subordinado. Es el modelo de unanimidad religiosa, propia del Medioevo, en el cual el clero se convierte en el gozne sobre el cual gira el ordenamiento social. Se trata de una postura extrema, que, en el período analizado, tiene sus manifestaciones concretas. En tanto, el laicismo propone no ya una distinción entre ambos órdenes (temporal/espiritual), sino una radical separación, es una reacción a las actitudes clericales y su omnipresencia en la vida social. El laicismo vincula al clero con el orden espiritual, al que considera exclusivamente privado, un hecho de conciencia individual que no debe tener repercusiones públicas en el orden social. En esta postura, el orden temporal gozaría de una plena autonomía y no tendría necesidad alguna de referencia a un supuesto orden trascendente para organizar la vida de los hombres en sociedad (Fazio, 2009: 12).

Ambas posturas están presentes, con diversos grados de intensidad, en la Córdoba de fines del siglo XIX, atravesada por el proceso de modernización y el dilema de la modernidad. Si, como señalamos en el segundo capítulo, la modernidad se identifica con el proceso de secularización, podríamos plantear la secularización cordobesa -no tanto-, como un fenómeno de autonomía absoluta del hombre respecto de lo religioso, sino -más bien-, como un fenómeno de desclericalización, a través del redescubrimiento de la autonomía relativa de lo temporal. Lo que se comienza a cuestionar es el lugar que debe ocupar el clero en una sociedad que ingresa en la modernidad, su lugar deja de ser el todo social, se lo vincula al orden espiritual y social $\mathrm{y}$, en particular, se cuestiona su vinculación con la actividad política. Paralelamente a la desclericalización de la sociedad, se produce la clericalización de la Iglesia, se subordinan al clero las asociaciones seglares y la institución se organiza bajo la dirección del clero.

En este contexto, sostenemos que Córdoba, con avances, retrocesos y resistencias, construye una modernidad católica, que supone una secularización entendida no como una pérdida del sentido religioso, sino como una toma de conciencia de la distinción entre los órdenes temporal y espiritual y un reordenamiento del lugar y la función del clero en el nuevo concierto político y social provincial. 


\subsection{El clero en la prensa local}

A lo largo de los cincuenta años que abarca la investigación (1875-1925), encontramos cuatro posturas respecto de la función del clero en la sociedad: los católicos tradicionales, los católicos liberales, los católicos sociales y los anticlericales. Los católicos tradicionales partían del supuesto de que era necesaria la influencia del clero para la reconstrucción de la sociedad, tenían la convicción de que el orden social solamente podía recuperarse con un catolicismo integral, pensaban que la sociedad iba a la deriva y que el clero católico era la única fuerza capaz de evitar el cataclismo. La religión era vista como la solución a todos los males de la sociedad, con ella retornaría la fe, la caridad, la justicia, la paz en las familias, la concordia entre los pueblos y el progreso de las ciencias. "El Eco de Córdoba", órgano de difusión del catolicismo más tradicional, en un artículo sobre el liberalismo, sintetiza esta postura señalando:

$\mathrm{Y}$ esta es la diferencia fundamental que separa a los católicos de los liberales, aquellos son los hombres de la verdad y éstos son los hombres del error, aquellos son los hombres de la fe y éstos son los hombres de la duda, aquellos son los hombres de la afirmación y estos son los hombres de la negación. Y mientras recorren éstos el vasto campo de las negaciones que se extiende desde el liberalismo católico hasta el ateísmo....

Como se advierte en la cita, la postura es intransigente, planteaban un dilema de manera terminante, o se admitía la acción religiosa y social de la Iglesia, o se caería en la disolución social. Defendían un estado confesional y proponían un modelo de sociedad antiliberal y antisocialista. Su posición fue sumamente defensiva, consideraban que estas corrientes atacaban al clero porque así derribarían a la religión y con ella la “civilización cristiana". Estas ideas muestran una gran desconfianza en el proceso secularizador y una resistencia tenaz a ver disminuida la función y el poder del clero en la vida social. La función del clero era la propia de una sociedad de antiguo régimen, es decir que aún no había entrado en la modernidad, en la cual el clero estaba llamando a intervenir en todos los ámbitos de la vida política y social, al estilo de la sociedad colonial, es decir una sociedad clericalizada.

Los católicos liberales tenían otra mirada sobre la función del clero pregonada por los católicos intransigentes. Miraban al clero desde el supuesto de la libertad religiosa, la secularización y la autonomía de la vida pública. La propuesta era reconciliar la

\footnotetext{
${ }^{1}$ El Eco de Córdoba, "La Religión de la Patria": 11/1/1884; 12/01/1884; 18/01/1882; 19/01/1884; 20/01/1884; 31/01/1884; 07/02/1884; 08/02/1884; 10/02/1884; "Irreligión. Nihilismo y anarquía":
} 
Iglesia con el mundo moderno, salvando el principio de la libertad de conciencia y abogando por la separación de la Iglesia del estado, su consigna era "la Iglesia libre en el Estado libre", implicaba el respeto a la libertad de cultos y el reconocimiento de cierta autonomía de lo secular. En 1868, "El Progreso", un periódico de corte liberal, se pronuncia respecto de la cuestión del control de nacimientos, matrimonios $\mathrm{y}$ defunciones:

La autoridad civil no sabe cuándo nace un ciudadano, ignora cuando se contraen matrimonios y no tiene noticia cuando desaparece alguien de la sociedad para descender a la tumba. Cuando tiene que comprobar los derechos del ciudadano, cuando necesita saber la legalidad de un enlace, cuando llega el momento de repartir la herencia dejada por un padre a sus hijos, la autoridad civil tiene que ocurrir a otra autoridad para que ella le informe la verdad. La irregularidad de este proceder es palpitante, y no hay que hacer esfuerzo alguno para manifestar la conveniencia de que desaparezca. Dejando a la Iglesia todos los derechos que por la organización actual de la sociedad le corresponden, salvando sus prerrogativas, creemos que el mal que señalamos puede salvarse fácil y ventajosamente. Solo consiste en que la Municipalidad hará un registro civil en el que conste el nacimiento, casamientos y defunciones que tengan lugar. ¿Qué inconveniente puede haber para que después de practicados los actos religiosos se dé cuenta a la autoridad civil de ellos? ${ }^{2}$

El planteo es claro y está directamente vinculado con la diferenciación entre el orden temporal y el espiritual. La competencia del estado de velar y controlar a los ciudadanos, por lo tanto, es prerrogativa propia de un registro civil. Además, se aclara la intención de dejar a la Iglesia "todos los derechos que por la organización actual de la sociedad le corresponden, salvando sus prerrogativas". Para construir un estado moderno era plenamente necesaria la libertad e independencia de otros poderes, y uno de ellos era la Iglesia. Esta postura es mal interpretada por el sector más conservador. E1 diario "El Eco de Córdoba", en manos del clero más intransigente, los define como hombres que admiten el orden sobrenatural y la subordinación a él del orden natural, pero "pretenden separar en la práctica esos dos órdenes y que el espiritual no tenga injerencia en el temporal". 3 Aquí radica la preocupación, en la intención de "separar" en lugar de "diferenciar". Veían con preocupación la mirada de los liberales sobre el clero, al advertir que éstos entendían la acción sacerdotal sólo en el ámbito de lo espiritual; que la influencia y el poder del clero radicaban en su vivencia del evangelio, y que el

22/02/1884.

${ }^{2}$ El Progreso, 03/07/1868, p. 1.

${ }^{3}$ El Eco de Córdoba, "Qué es el liberalismo", 05/08/1883. 
modelo era un sacerdote espiritual y evangélico, testigo de la cruz con el ejemplo de su vida y sin apetencias de poder personal o temporal. Los liberales, frente al catolicismo intransigente e integrista de los tradicionales, proponían un catolicismo cristiano, evangélico y tolerante. La única influencia y poder del sacerdote debía consistir en visitar a los pobres y vivir el evangelio y la cruz proclamada por Cristo, sus funciones debían limitarse a lo espiritual y su lugar era el templo. ${ }^{4}$ La columna titulada "El sacerdocio lo que deber ser y lo que es según la práctica", publicada en "El Progreso" del $1^{\circ}$ al 21 de enero de 1879, plantea claramente el fenómeno de des-clericalización de la sociedad, que no significa en absoluto secularización en el sentido de pérdida de la religiosidad.

El periódico argumenta sobre los puntos centrales que manifiestan el cambio de lugar que parte de la sociedad espera del clero, señala "para nosotros y en nuestro caso no hay más diferencias entre el sacerdote y el creyente que las funcione especiales que a aquel le pertenecen en razón de su ministerio". El segundo punto hace referencia a la necesidad de no confundir al clero con la religión. "Así comprendemos nosotros la religión sin confundir lo que ella es en sí con lo que pueden ser sus encargados o ministros". En tercer lugar, señala que la religión, por inmejorable y útil que sea, "sin agentes, sin encargados que la enseñen, que la practiquen y que con la palabra y el ejemplo la arraiguen en la conciencia y en el alma de los individuos y de los pueblos, quedaría solo palabra escrita y sería del todo insuficiente para dispensar sus inmensos beneficios. De aquí sigue por una consecuencia precisa la necesidad del sacerdocio, de cuyo acertado y laborioso ministerio depende la realidad de las ventajas que la religión ofrece en bien de la sociedad y del hombre. Pero la existencia sólo del sacerdote y de su laboriosidad no es una garantía de la efectividad de los bienes que están llamados a desprenderse de los principios saludables de la religión puestos en acción, porque estos solo se producen cuando por la uniformidad de la enseñanza y de la práctica con aquellos principios, viene a ser el sacerdote la encarnación viva, patente, manifiesta de

\footnotetext{
${ }^{4}$ Entre octubre y diciembre de 1880 , los periódicos de Córdoba fueron protagonistas de un acalorado debate en torno a la Pastoral del Provisor Castellanos que condenaba a los periódicos El Progreso, La Carcajada y El Interior. El Eco de Córdoba y el semanario La Prensa Católica asumieron la defensa del provisor Castellano, con una postura tradicional integral que se manifestó en un marcado clericalismo. $E l$ Progreso, fundado y dirigido por Ramón Gil Navarro, defendía el catolicismo liberal, criticaba duramente al sector del clero que se nucleaba en torno a la figura de Castellanos a quienes denomina "la Cámara Oscura", en directa alusión al oscurantismo medieval. Resalta en cambio el perfil clerical de Mamerto Esquiú: "Ese humildísimo clérigo que tanto respeto tenía por la ley civil, consideraba al mismo ciudadano del estado miembro de la Iglesia de Cristo, no de la de vosotros [...]. El combina la virtud con la ilustración para dignificar al hombre, para destronar la barbarie y para engrandecer la república" ( $E l$ Progreso, 30/10/1880).
} 
ese pensamiento sublime en todas sus manifestaciones, o sea de la misma religión. Si por el contrario a pesar de todo, en la práctica y en la enseñanza del sacerdocio no se traduce la realidad de aquella idea, sino de sus pasiones, de sus vicios, de sus errores, entonces los resultados son [...] contrarios a los beneficios que su ministerio debiera producir. [...]. El clero ha de ser fiel a su misión [...]. Sin la acción del sacerdote la religión es letra muerta, sin resultados, sin aplicaciones" (EP, 01/01/1879). El periódico dedica varios días a esta columna, al día siguiente retoma el tema y añade un cuarto punto importante "esta es pues la misión del sacerdote hacer práctica en la enseñanza y con el ejemplo aquel bellísimo y sublime ideal de religión que se contiene en el evangelio. Para esto se necesita que sean agentes y encargados del Cristo y se subordinen por completo a las exigencias y al rol especial que les impone la ley fundamental del Maestro" (EP, 11/01/1879). La siguiente columna ahonda más en algunos puntos y concluye afirmando que "el sacerdocio cristiano para que responda a los fines de su institución, inspirándose en el espíritu del evangelio, debe abrazar con pureza los mismos fines que este abraza, teniendo como único objetivo a Dios y a sus semejantes para hacer que el uno con gratitud y amor sea adorado y el otro beneficiado y consolado con las máximas y doctrinas de esta religión de un Dios todo bondad y amor" (EP, 12 y $15 / 01 / 1879)$. Este extenso artículo manifiesta, de forma clara, el desplazamiento del lugar que el clero tenía y seguía ocupando en la sociedad provincial. Se reclama la necesidad de que se subordinen por completo a las exigencias y al rol que les impone el evangelio, el culto a Dios y el amor a los semejantes (EP, 16 y 17/01/1879).

El diario "El Progreso", a lo largo de sus páginas, presenta los rasgos del modelo de cura deseado, se trata de un clero al más puro estilo ilustrado. Consideraba a la Iglesia como el agente de civilización, por ello, la cruz, en medio del campo, era el primer "símbolo de civilización y progreso". En la campaña, un buen párroco era el eje principal de la sociedad, del progreso y del bienestar en todo sentido. ${ }^{6}$ La función del cura era múltiple, "los curas de campaña en nuestras apartadas y desiertas poblaciones revisten el rol de médicos, de sacerdotes, de maestros de escuela, y hasta de jueces, con el carácter de amigables componedores, dirimiendo como en familia, las cuestiones de sus feligreses". ${ }^{7}$ El cura de parroquias rurales llenaba los vacíos de un gobierno todavía

\footnotetext{
${ }^{5}$ El Progreso, 31/17/1877.

${ }^{6}$ El Progreso, 22/10/1868.

${ }^{7}$ El Progreso, 09/06/1869.
} 
ausente: "Hacen las veces de gobierno, en los departamentos ocupan los puestos de las municipalidades, supliendo las faltas e indolencias de las autoridades. Los buenos párrocos llenan una misión santa altamente civilizadora". 8 Quizá el ejemplo más paradigmático de este modelo lo haya encarnado el cura Brochero, un "ejemplo del verdadero sacerdote de Jesucristo". ${ }^{9}$ Este sacerdote, natural de Río Segundo, ordenado de presbítero el 4 de noviembre de 1866, fue nombrado párroco de San Alberto, cargo que desempeñó por casi cuarenta años (1869-1907), este curato abarcaba una gran extensión del oeste cordobés, donde la mayoría de sus 10.118 habitantes estaba signada por la pobreza. ${ }^{10}$ Allí, desarrolló una obra de gran envergadura, impulsó y gestionó obras de infraestructura, vías férreas, construyó acequias para el riego, delineó sesenta y seis caminos vecinales, proveyó a la población de molino, creó un colegio de niñas, una casa de ejercicio espirituales y evangelizó a la población, creó escuelas de beneficencia, procuró la enseñanza religiosa a las masas, combatió el vicio y la corrupción, vivió abnegadamente la pobreza evangélica, socorrió a los enfermos y bregó por el progreso material de su curato. Además de gestionar obras de todo tipo, el cura velaba por el bienestar espiritual de sus feligreses. Consideraba la práctica de ejercicios espirituales como una herramienta eficaz de conversión. En los primeros años de su gestión, organizaba grupos de hombres y mujeres, que con frecuencia superaban las 400 personas, para asistir a los ejercicios en la capital. La estrategia para reunirlos la relata el mismo cura:

"Preguntaba yo cuál era el hombre mas condenau, más borracho y ladrón de la comarca. En seguida, le escribía una cartita diciéndole que pensaba pasar dos días en su casa, decir misa, predicar y confesar, y que, por tanto avisase a sus amigos. iQue pucha! Yo sabía que, de esa manera, esa gente me iba a escuchar, porque si iba a una casa buena, esos pícaros no se iban a acercar. Ahí nomás les decía que me había costiau para hacerles bien, y que quería enseñarles el modo de salvarse, y que todos estaban condeaus y que bien podían ver ellos que yo no tenía ningún interés, porque ¿Qué podía importarme a mí que se los llevasen todos los diablos, sino fuera por Jesucristo? Y aquí sacaba el santo Cristo. Ahijuna, y se me echaban a llorar, que yo no sé cómo Dios me ponía esas cosas en el pico. Yo les decía: 'Bueno este sermón no vale nada. Mañana va

\footnotetext{
${ }^{8}$ El Progreso, 15/01/1873.

${ }^{9}$ El Progreso, 12/06/1877.

${ }^{10}$ Censo Nacional de 1869.
} 
a ser el bueno. Avisen a todas sus relaciones'. Ahí nomás empezaba a confesar. Un día que di la comunión a mucha gente, se me acerca una mujer y me dice:

- Padre, Fulano hace una hora que ha comulgau y ya está mamau como una cabra...

- Ahijuna, dije yo... Busqué al gaucho y le dije:

- Pero, hombre ¿cómo ha sido eso?

- Ah, padre, me contestó. Hacía 20 años que no comulgaba y de puro gusto me he mamau” (Díaz Cornejo, 2012: 72-73).

Luego de sus recorridos en busca de gente para asistir a los ejercicios, emprendía el largo y tortuoso camino de más de $150 \mathrm{~km}$ a lomo de cabalgadura por las altas cumbres, desafiando el frío, la lluvia y la nieve, pues los ejercicios se realizaban en invierno, dado que la gente de campo estaba más libre en esa época del año. Además, como la mayoría de los asistentes era pobre, el cura les daba todo lo que necesitaban y les allanaba las dificultades. Algunos relatos recogidos son un testimonio vivo de dichas odiseas. "El viaje se hacía más penoso cuando iban mujeres. Una vez, yendo el cura acompañando a una tanda de mujeres, subiendo la Pampa de Achala, casi a la mitad del camino les sorprendió una gran nevada al anochecer, lejos de todo rancho donde pudieran guarecerse y librarse del frío que, a más de mil metros de altura, es muy intenso y penetrante. Se vieron forzados a pasar la noche en la hendidura de una gran piedra donde se refugiaron. Por la mañana, las ejercitantes estaban medio tullidas de frío, el cura hizo fuego con algunos palos que desenterró de la nieve y cebó mate. Así, consiguió animarlas, hacerlas subir a los caballos y continuar la marcha" (Díaz Cornejo, 2012: 71).

"El Eco" de Córdoba relataba la llegada de estos contingentes a la ciudad de esta manera: "Ayer se notaba un movimiento extraordinario en la calle 9 de julio, en la cuadra que está la casa Municipal; los carros del tráfico y el gentío obstruían completamente el tránsito. ¡Qué había? La gente curiosa se agolpaba más y más [...] Salían 500 ejercitantes que se habían clausurado durante 9 días a hacer penitencia. La mayor parte eran vecinos de los departamentos de campaña. El señor cura Brochero, según sabemos, ha traído de su feligresía más de 200 individuos" (EE, 27/08/1874). De regreso a las sierras, hacía preparar la bienvenida en la parroquia, como una verdadera fiesta, los ejercitantes eran recibidos por sus familiares, entraban en el pueblo atravesando arcos de triunfo, preparados para la ocasión, mientras los cohetes retumbaban en el cielo azul serrano. 
El resultado de estos ejercicios los manifiesta la prensa del momento, "la influencia de los ejercicios se dejó sentir rápidamente, las cárceles comenzaron a aquedar vacías, se acabaron los crímenes y los robos, las poblaciones dejaron sus antiguos resabios de montoneras para entregarse al trabajo honrado" (LP, 11/02/1897). Otro testimonio contemporáneo dice que "con motivo de los ejercicios espirituales que hace tomar a todo ese paisanaje duro y redomón, aquella gente está hecha una seda. Los robos han cesado, las tropelías han minorado, las malas vidas han disminuido y, por fin, Pocho está completamente distinto de lo que era. Allí la gente no piensa, sino en la vida eterna y en practicar buenas obras para obtenerla" (Díaz Cornejo, 2012: 75).

En 1870, Ramón Cárcano (1885: 62), miembro de la élite liberal, lo caracterizaba, diciendo que Brochero era la personalidad más acabada del cura de campaña. "Tiene la vocación del sacerdocio y el sentimiento de su misión sagrada, abnegación de sí mismo, desprendimiento del mundo, amor al prójimo, rara resistencia y actividad en el trabajo, rudeza de vida, piedad en obra, virtud en acción, pensamiento en el cielo y penitencia en la tierra, he ahí las notas que al unísono resuenan en el diapasón de su alma".

El diario "Los Principios", con motivo de la inauguración de la casa de ejercicios, publica una larga crónica sobre la labor del cura Brochero en los departamentos del oeste. En ella, dice que "para suerte de estos departamentos vino de cura a San Alberto el presbítero Gabriel Brochero, hombre virtuoso, progresista, voluntad de hierro, emprendedor, que evangeliza a la vez que propone el engrandecimiento material del curato. [...] Cuando vino Brochero se encontró con que no imperaba más ley que la del facón, ni más medios para ganarse la vida que el pillaje. La familia no descansaba sobre los vínculos eternos del matrimonio, sino en uniones libres tan fáciles de formarse como de romperse. En fin el desorden era general y la inmoralidad reinaba en todas partes. Creyó entonces que era indispensable la instalación de una casa de Ejercicios. Con el apoyo de varios vecinos se decidió a acometer la obra. Tomó su mula, subió a la cumbre, bajó al valle, recorrió los llanos de La Rioja y parte de San Luis. Golpeó de puerta en puerta, de rancho en rancho, pidiendo limosnas de toda clase, dinero, animales, trabajo personal, y volvió arreando hacienda y trayendo infinitas promesas" (LP, 11/02/1897).

La función del cura en la campaña cordobesa de fines del siglo XIX es rememorada con motivo de la muerte del Obispo Inocencio Dávila, el "Boletín Eclesiástico del Obispado de Córdoba" publicó una reseña que contiene las características centrales del perfil deseado: 
La formación del sacerdote que necesitaban nuestras parroquias hace 30 años, abnegación hasta el sacrificio, celo ilimitado por la gloria de dios; una contextura de roble para resistir las fatigas que le imponían al párroco los largos y penosos viajes a lomo de mula por entre los breñales, guaridas del hombre anti-social antes que de las fieras. En seguida de ser ordenado sacerdote en noviembre de 1897, fue destinado a la dirección espiritual y civil de la parroquia de Tulumba, y decimos civil porque en aquella época era el párroco el director obligado de todo progreso material. Como el canónigo Brochero, debían ser los párrocos la fuerza civil que redujera al gaucho malo, el arquitecto que levantara iglesias y escuelas, el consejero de hombres y el preceptor de los niños. Solía referir ocasiones en que le era necesario mantenerse semanas enteras sobre el caballo, en interminables viajes para confesar enfermos. Estas virtudes de párroco que lo llevaron a la fundación de casi todas las iglesias de Tulumba.... ${ }^{11}$

En las notas presentadas ut supra aparecen algunos puntos significativos. La campaña se presenta como guarida del "hombre anti-social", del "gaucho malo" y, en este contexto, resalta al párroco como "director obligado de todo progreso material", “consejero de hombres y preceptor de niños". Estas notas, sumadas a las reseñadas por Cárcano, brindan una imagen del cura de campaña, un tipo ideal compartido por todos los actores sociales. Este tipo ideal se refuerza al remarcar las acciones clericales que se apartan de este modelo. Con motivo de una serie de denuncias al cura de Río de Los Sauces, departamento de Calamuchita, por mal desempeño de su ministerio, "El Progreso" señala:

El cura párroco para cumplir bien la religión, para hacer bien por las almas por cuyo rebaño es pastor no necesita de tales o cuales derechos, sino el necesario mantenimiento para el cuerpo. Jesucristo, la figura cuya aparición separa dos grandes edades: la edad de la barbarie y la edad de la civilización, ha revolucionado el orbe dando ejemplos al mundo con pobreza, amor y caridad. He ahí lo que los curas debieran imitar, si su ministerio fuese hijo de una vocación que emanase de lo más íntimo de su conciencia. ${ }^{12}$

Esta idea también está presente en la autoridad diocesana. De hecho, en el próximo capítulo veremos cómo comienza a ejercerse un mayor control sobre las vocaciones del sacerdocio, intentando garantizar "una auténtica vocación", que se adecuara al perfil deseado. Más allá de la veracidad de las denuncias expuestas, observamos que, hasta fines del siglo XIX, la prensa debatía el perfil del cura, analizaba y discutía el rol que debía asumir, aunque no negaba la importancia de su función social y espiritual. Sin embargo, aparecen cuestionamientos relacionados con su actividad en otros ámbitos de

\footnotetext{
${ }^{11}$ BEDC, vol. 7 n 6, junio 1930, p. 209.
} 
la vida social, en particular la política, como veremos en la quinta parte de la tesis, dedicada a las prácticas del clero.

A medida que avanza el siglo, algunos actores de perfil anticlerical cuestionan con más fuerza la figura y misión del clero, ahora sí, atribuyéndole una función netamente negativa y perjudicial en la sociedad. El diario "El Progreso" transcribe un suelto publicado en un diario de Buenos Aires titulado "Cuervos en acecho", ${ }^{13}$ relativo a la función del clero en la sociedad. El objetivo, señala el acápite del artículo, era llamar la atención al clero para que se "aperciba del rol que viene jugando ante la conciencia moderna con grave daño a la religión y a sus propios intereses por cuestiones de régimen de forma o de disciplina [...] Entendemos que la religión no debería quedarse rezagada en el camino rápido del progreso humano, y menos por cuestiones de mera forma; creemos si, por el contrario, que llevando en su manos el baluarte inalterable de su fe y de su moral, ella debiera presidir la marcha del mundo imprimiendo una fisonomía aún más hermosa a toda civilización". ${ }^{14}$ En esta introducción a la nota, el periódico no cuestiona la religión del estado ni el rol de la misma en el desarrollo de las sociedades modernas. Al contrario, afirma "que la religión no debería quedarse rezagada en el camino rápido del progreso humano". Pero cuestiona la forma, cuestiona la institución y caricaturiza el rol del fraile dispensador o ministro de sacramentos, presentándolo como un estorbo, algo inútil para la sociedad. Esta sentencia, de alguna manera, refleja un deslizamiento hacia una mentalidad que comienza a cuestionar la función del clero en el espacio público, otrora omnipresente en la sociedad cordobesa.

Hasta fines del siglo XIX, el clero aparece en la prensa liberal provincial, en general, vinculado al crecimiento y el desarrollo de las poblaciones rurales, y cuando se lo critica es porque se considera que se aparta de este modelo. "El Progreso" es muy duro

\footnotetext{
${ }^{12}$ El Progreso, 24/03/1870, p. 2.

${ }^{13}$ El suelto advertía lo siguiente: "CUERVOS EN ACECHO se necesita de estos sacudimientos populares para advertir los defectos de una organización social. En Francia, en medio de la tormenta revolucionaria fue cuando notó sus faltas y emprendió sus inmortales reformas. Nosotros, en pequeño, debemos fijarnos en los vicios que adolecemos. El sacudimiento político que esperimentamos, ha puesto en evidencia una monstruosidad de nuestras instituciones. Todos, estrangeros y nacionales, padres e hijos, magistrados y pueblo, ricos y pobres se ajitan por esta contienda, es que cada cual tiene afectos e intereses comprometidos. Sólo una clase o una casta social, pasa impasible en medio de esta tribulación general. Son los hombres de iglesia, para ellos no hay Patria, no existe familia, no contraen compromisos que liguen sus afectos e intereses con el mundo profano. Al vestir el hábito talar han muerto el corazón para todo sentimiento digno, solo vive en ellos el egoísmo, la avaricia. Se organizan sociedades de socorro, se provee las necesidades de los menesterosos, se hace todo lo que la civilización aconseja en favor de los que sufren, entre tanto ¿qué hace la Iglesia? Prepara los hisopos, el incienso, los catafalcos, las velas y los misales, para rogar a tanto por cabeza, sobre las fantásticas almas que ella forja en la imaginación de los incautos con objeto de tener una mina esplotable en la ignorancia humana. Sino qué servicio práctico han ofrecido los frailes a la sociedad que los alimenta?
} 
respecto a un sector del clero, más intransigente, ciertamente más político y más ultramontano, conformado por miembros del cabildo, la curia y algunos profesores del seminario. A este grupo lo denomina "la cámara oscura", sobre él carga con frecuencia, sindicándolo de oscurantista y opositor al progreso. Sin embargo, esa misma prensa rescata al clero parroquial, reivindicando su abnegación y proponiéndolo como mentor y promotor del progreso y la civilización.

La prensa se convierte en escenario de encarnizados combates periodísticos. Quizá por ello, el obispo Esquiú advierte que el clero era blanco de prevenciones, con un odio tan grande como implacable, y con cierta resignación se lamenta de la imagen que se quiere construir del clero: "si sois justos se os llama hipócritas; si celáis la gloria de Dios se os llama fanáticos. El sacerdocio cristiano ha dado al mundo verdadera civilización, y sin embargo sois al decir de ciertos hombres el foco de las tinieblas y de la ignorancia. Pero si vuestra ciencia y poder moral los deslumbra ya sois entonces monstruos y vampiros que a todo trance es preciso eliminar" (Esquiú, 1881).

Sin embargo, hay que señalar que, en Córdoba, la prensa radicalmente anticlerical tenía escasa difusión, ${ }^{15}$ y en "El Progreso", que tenía mayor circulación, no encontramos una postura tan hostil sobre la función del clero. Si bien, como dijimos $u t$ supra, aparecen artículos que cuestionan ciertas conductas y posturas de un clero más intransigente, para ese sector reducido, al que denominó "la cámara oscura", por lo general, esos agravios no alcanzaban al cura de campaña, salvo cuando no cumplía con sus deberes o abusaba del ejercicio del ministerio. En el Capítulo 7, veíamos que los artículos periodísticos destacaban la presencia de la Iglesia en la campaña, donde el clero y la religión eran percibidos como símbolos de civilización y progreso.

A inicios del siglo XX, la corriente de tinte anticlerical tiene mayor presencia en la sociedad cordobesa. El sudeste provincial comienza a ser objeto de la prédica socialista y anarquista. Los colonos de los departamentos de Marcos Juárez y Juárez Celman se sumaron a las movilizaciones agrarias. Los párrocos de Leones, Camilo Aldao y Cruz Alta denuncian conferencias públicas en las que se agraviaba al clero. En estas circunstancias, en 1912, el Obispo Bustos señalaba que el prestigio de los hombres de

\footnotetext{
${ }^{14}$ El Progreso, 21/07/1880, p. 1.

${ }^{15}$ Periódicos La Carcajada, La Libertad y El Mosquito. La Carcajada, periódico fuertemente crítico del gobierno autonomista, se fundó en 1871 y se editó regularmente hasta fines de siglo, luego siguió de manera más esporádica hasta 1905. Ese semanario joco-serio no tenía ningún tipo de subvención y contaba con 300 suscriptores, aproximadamente. El Progreso fue el principal referente autonomista, contaba con alrededor de 500 suscriptores. Creado en 1867 por Ramón Gil Navarro, se editó hasta su muerte en 1884 y de su redacción participaron jóvenes universitarios que se vincularon a ese partido. Este
} 
iglesia se encontraba en marcado descenso, "la clerofobia y los desafectos al sacerdocio abundan en el pueblo y abundan la indiferencia y falta de reconocimiento a nuestros sacrificios". ${ }^{16}$ La percepción de marginalidad que subyace en sus palabras puede ser vista como un indicador de los cambios que se producían. La sociedad de antaño aceptaba como natural la presencia del clero en todos los ámbitos de la vida provincial. En la nueva sociedad que se configuraba, algunos sectores criticaban y definían como clericalismo la injerencia del clero en la vida pública y propiciaban una sociedad más secularizada, en la que los campos se definieran y se separaran, reduciendo la presencia del clero sólo a las Iglesias y sacristías.

En este contexto, se hace más urgente la acción social del catolicismo. Para los católicos sociales, el perfil del sacerdote se asentaba en dos principios básicos, su protagonismo como pastor de su grey y su acción a favor del pueblo necesitado, debía ser virtuoso, ilustrado y abnegado, basar su influjo en la perfección moral y ser promotor de iniciativas sociales de carácter educativo, benéfico y de promoción social al servicio de las clases trabajadoras. Este modelo de sacerdote remitía a las figuras de pastor, padre, maestro y amigo. El nuevo cura no debía limitar su actividad a las funciones rituales, ni ser un cura de iglesia y sacristía, su lugar estaba fuera del templo, debía salir a buscar al pueblo donde éste se encontrara, en la escuela, en la prensa, en el hospital, en las familias y convocarlo a colaborar en las diversas congregaciones parroquiales. El párroco debía iniciar su ministerio en la iglesia:

Pero el campo de batalla se halla fuera, las primeras filas están tendidas en medio del pueblo y al pueblo debe ir: al pueblo doliente, para llevarle el consuelo de Jesús sacramentado; al pueblo gozoso para enseñarle a santificar las alegrías y compartirlas él mismo; al pueblo pobre para dirigirlo en la consecución de sus anhelos de acuerdo con el verdadero derecho y manifestarle el modelo de los modelos Jesucristo; al pueblo rico para indicarle hasta donde llega el derecho y cuál es el respeto que merece el prójimo, que es su hermano; al pueblo alejado para remover las cenizas en su corazón y renovar la fe casi apagada ya; y por último, al pueblo enemigo de la Iglesia para admirarlo con su ejemplo, para conmoverlo con su dulzura, para infundir respeto con su ciencia y para imponerle la justa veneración hacia el sacerdocio, cuando llegue a convertirlo y llevarlo hasta el trono de Jesucristo. ${ }^{17}$

Aparece un nuevo componente vinculado a la militancia católica en el campo social.

\footnotetext{
diario se presentaba como la voz "liberal" de Córdoba, llamado a polemizar con El Eco (Cucchi, 2014).

${ }^{16}$ AAC. Carpeta Pastorales, 1900-1925. Pastoral con motivo de la finalización de la primera gira pastoral y el inicio de la segunda, 27/10/1912, p. 9.
} 


\subsection{El clero parroquial en los escritos de los obispos}

El modelo esperado por la jerarquía queda reflejado en las pastorales y discursos. En ellos, hemos advertido que, al mencionar las defíciencias del clero, se ponen de manifiesto las preocupaciones de los obispos, pues, entendemos que cuando se insiste sobre un tema es, justamente, porque se reconoce una carencia al respecto, sino no habría necesidad de insistir tanto.

En las pastorales hay temas recurrentes. Al asumir el gobierno de la diócesis, el Obispo Álvarez, advierte que su "primer cuidado será cultivar la piedad y la ciencia del clero", de lo que se desprende la deficiencia de la formación en estos campos (Álvarez, 1875: 6). Envía una circular a los párrocos donde les solicita que no dejen vacíos en el ejercicio del ministerio. En ella deja explícito el modelo de cura parroquial que desea. El primer deber que debe tener un cura es el arreglo material de los templos, "el sagrado deber de conservar los templos y paramentos sagrados con el aseo y el decoro convenientes a las altas funciones a que están destinados". En segundo lugar, "deberá Ud. procurar por los medios que la prudencia aconseje que se enseñe el catecismo en todas las escuelas del curato, siendo Ud. el primero en dar el ejemplo, por lo menos, todos los domingos en su iglesia, cuidando sobre todo de cumplir este deber con los niños que se preparan para la primera comunión y con los ignorantes que deseen contraer matrimonio". En tercer lugar, les ruega, encarecidamente, el cumplimiento de la obligación impuesta por el Concilio de Trento de explicar el evangelio a sus feligreses los domingos y demás días de fiesta, en especial en cuaresma y adviento. La cuarta recomendación está destinada a la administración de los sacramentos, "principalmente en el artículo de la muerte para lo cual no debe omitir ningún sacrificio para proporcionar este bien a los feligreses. La quinta recomendación es la obligación de dar buen ejemplo, en particular "edificar a los fieles con su ejemplo, con este fin se llama su atención sobre las prescripciones de los sagrados cánones acerca de la vida y honestidad de los clérigos, de una manera especial sobre la prohibición de asistir a ciertos espectáculos impropios del carácter sacerdotal". Por sexta recomendación, señala que "en presencia de los funestos resultados que ha dado siempre la intervención de los párrocos en la política, manifiesto a Ud. que la voluntad del prelado es que se abstenga de toda participación en asuntos de esta naturaleza". A continuación, recuerda la obligación de sujetarse al arancel a la hora de percibir los emolumentos y derechos.

\footnotetext{
${ }^{17}$ REOBA, 1912, p. 419.
} 
Exhorta a tener arreglado, en orden y al día, el archivo parroquial "llevando con la mayor exactitud los libros de bautismos, matrimonios, defunciones y confirmaciones" y “cuenta prolija de las entradas y salidas pertenecientes a la fábrica de su iglesia". Por último, ordena hacer a la brevedad posible un inventario "prolijo de los ornamentos, vasos sagrados y demás objetos destinados al culto divino que se encuentran en cada una de las capillas de su curato y lo depositara en el archivo parroquial y enviara una copia esta secretaria". ${ }^{18}$ Estos puntos sintetizan un programa de gobierno diocesano que perdurará a lo largo de las cinco décadas estudiadas y se materializará en una serie de normativas y prácticas destinadas a modelar el clero diocesano.

Al asumir como Obispo, Fray Mamerto Esquiú dirige una primera pastoral al deán y cabildo eclesiástico, a los párrocos y al clero secular y regular, en la que sintetiza su mirada sobre el sacerdocio. ${ }^{19}$ Está fechada en la fiesta de Santo Tomás de Aquino (referente de la renovación teológica y espiritual del período). La pastoral es un esquema programático de su plan de gobierno, en el que considera al clero como indispensable cooperador del ministerio episcopal, "sin vosotros no puedo hacer mi oficio", por eso se dirige, primeramente, a aquellos sobre los que gira, como sobre sus propios ejes, "todo el lodo de las almas redimidas". El obispo hace referencia a que la alta dignidad del sacerdocio, a los ojos de todo cristiano, se debe a la triple potestad dada por Cristo, la de consagrar, enseñar y perdonar. Allí radica para él la fuerza del sacerdocio.

La primera virtud del sacerdote debe ser la caridad. "Amar hasta dar la vida por el prójimo esa es la medida". Al desarrollar las características del sacerdote como víctima consagrada al amor de Dios, el obispo advierte con fuerza a los hombres que "nadie, absolutamente nadie, puede estar en el sacerdocio ni venir a él por su propio bien, no digo temporal, de honor y comodidades y allegar dineros, lo que es horriblemente abominable, sino que ni aún por su propia y exclusiva santificación". El sacerdote debe ser santo, pero no es para eso el sacerdocio, sino para que esté consagrado al amor y a la obra de la santificación de los demás. De allí brotan sus deberes. El primero es, para el prelado, el ejemplo de vida:

Llevar el buen olor de Cristo en todo lugar, todo lo que Cristo ha mandado a anunciar debe ser práctica en la vida del sacerdote. Por ello es necesario un comportamiento que manifieste el amor a los enemigos, que huya de la corrupción

\footnotetext{
${ }^{18}$ AAC. Notas, 1873-1876, f.32.

${ }^{19}$ Pastoral del 04/03/1881.
} 
del siglo, que renuncie a la vanidad y a la ambición, que evite el ocio, que mortifique los sentidos, que sea limpio de corazón, que sea además penitente y ame la cruz de Cristo. Pero ese comportamiento no puede ser sólo una compostura externa, para alcanzar la fama y el buen nombre, debe ser interior. Debe brotar de un corazón que ama a Dios. Más para vivir con Cristo en Dios es necesario la huida del pecado y la oración. La oración es la clave de toda santidad y su olvido la causa de nuestros males (Esquiú, 1881:25).

El buen ejemplo es necesario pero no suficiente, debe seguir la predicación de la palabra de Dios, pero para que la predicación sea eficaz, debe estar precedida de la meditación y del estudio de las ciencias sagradas. "El estudio y la oración son el refugio seguro contra la disipación mundana y el ocio, causas las más generales de la perdición y la ruina de los sacerdotes", porque "la predicación de la palabra de Dios aprendida en el estudio y en la oración es pan desmenuzado que la caridad sacerdotal debe dar a los fieles. Por tanto peca mortalmente el párroco que de continuo o con interrupción sin causa grave dejase de realizar la predicación del evangelio".

Pero de nada vale el buen ejemplo y la predicación sin la continua y recta administración de los sacramentos, principalmente la penitencia y la eucaristía, decía el prelado, "dadme buenos confesores y os doy reformado el mundo cristiano". La pastoral cierra señalando que los sacerdotes deben ser "otros nuevos Cristos en el mundo", para ello, era fundamental, como también señala el Obispo Álvarez, vivir la caridad, "teniendo la caridad otras virtudes se vuelven naturales; el celo, la paciencia, la mansedumbre". Pero hay que querer vivirla. Querer importa la elección y la aplicación de medios conducentes a ella, "dadme una persona resuelta y os doy una santa". Si la caridad es fundamental en el desempeño del ministerio sacerdotal, el clero debía estar alerta frente a aquellos peligros que podían matar esta virtud. Para el prelado estos peligros se reducían a la triple concupiscencia: la lujuria, la avaricia y la soberbia. Para no caer en ellas, el obispo animaba a huir del ocio y la disipación mundana y de la cohabitación con personas que los sagrados cánones prohíben a los eclesiásticos, a dedicarse a la oración y a la plegaria y a practicar la mortificación de los sentidos como un medio que libera de la esclavitud de la lujuria.

Huir de la avaricia y la esclavitud de los ídolos, no solo negarse de negocio y ocupaciones prohibidas por los sagrados cánones, también de todo acto injusto que suele provocar en el hombre el amor al dinero, cuáles serían recibir mayor número de estipendios de misas de los que pueden celebrarse intra-bimestre o cobrar o hacer estipulaciones injustas sobre la tasa impuesta por el arancel eclesiástico. No solo huir de abominables rapiñas, sino guardaros del monstro de la avaricia que 
consiste en el amor desordenado de los bienes de este mundo que puede dominaros horriblemente sin que al parecer haya injusticia. En efecto si se procura o acepta el ministerio de párrocos y cura de almas [...] poniendo la mira principal en su emolumentos temporales aunque sea a título de asistencia necesaria; si en la misma percepción de derechos parroquiales, tan justos como sagrados no se hace lugar a la compasión, ni se ama el bien de las almas y el honor de Dios más que todas las riquezas de este mundo seríamos verdaderos avaros, y enemigos declarados de la caridad que es el mismo Dios (Esquiú, 1881: 27).

Finalmente, agradece la valiosa cooperación y advierte que "no os avergoncéis de respetar y ser sumisos a quién el mismo Espíritu Santo ha puesto para que rija esta porción de la Iglesia de Dios".

Estos pasajes de la pastoral muestran los abusos más frecuentes en los que incurría el clero diocesano y que todos los obispos procuraron extirpar. Veremos que fue una labor ardua que generó no pocas resistencias. Al final, aparece un punto central en el nuevo perfil del clero, la obediencia y sumisión al prelado, llama la atención que el diocesano señala que el clero no debe avergonzarse de respetar y ser sumiso al obispo. Esta breve frase sin duda está dando cuenta de un clero autónomo e independiente, con frecuencia díscolo a las disposiciones de sus prelados.

El Obispo Tissera (1885: 3 y 7-8), también dedica una pastoral al clero y a su función. Señala que el buen pastor conoce a sus ovejas y ellas lo conocen a él. Toma la parábola del evangelio para ejemplificar la misión del pastor. Las llama por su nombre, ellas lo siguen y obedecen, las cuenta una por una, las observa con cuidado para que no se extravíen o enfermen, las lleva a buenos pastos, las aparta de los lobos, barrancos y peligros, las mantiene limpias y hasta arriesga su propio bienestar y aún su vida por su bienestar. Define la labor de los pastores con algunas características puntuales: Padre y Pastor, al cual deben acercarse los fieles con la confianza de verdaderos hijos, con docilidad, mansedumbre y sinceridad. Debe ser un maestro con sus discípulos; un médico con sus enfermos y un amigo con sus amigos. Como maestro, los fieles deben manifestarle sus dudas; como médico, debe hacer conocer todas las dolencias, llagas y flaquezas, para poder aplicar el remedio; como padre, los fieles deben abrirle el corazón y pedir con toda confianza lo que les haga falta. Además, el cura era cooperador de Cristo en la predicación del evangelio, "con la sencillez del lenguaje que nos enseñó el divino maestro", y en la administración de los sacramentos, oyendo con "caridad y ternura de un padre en el tribunal de la penitencia" (Tissera, 1885: 17). Debían ser sacerdotes con un celo y una piedad encendida y fervorosa por la predicación de la 
palabra de Dios, la asidua y devota administración de los sacramentos, y el buen ejemplo de vida. ${ }^{20}$

En el documento de nombramiento de Moisés Quintero como cura y vicario excusador de San Blas de los Sauces, queda explícito el deber del párroco, el título señala que debe instruir a los fieles en la doctrina cristiana, explicar el evangelio los domingos y fiestas, administrar los sacramentos según la necesidad de los fieles, cumplir con los deberes impuestos por el Concilio de Trento y las constituciones sinodales de 1877, y llevar los libros parroquiales; en el fuero externo, debía "celar los pecados públicos con toda diligencia, piedad y esmero, pudiendo entender en causas judiciales hasta ponerlas en estado de sentencia, con excepción de las matrimoniales y criminales que quedan reservadas a nuestro vicario general [...] levantar informaciones de soltería". ${ }^{21}$ Para ejercer su ministerio se le otorgan las facultades correspondientes. ${ }^{22}$

En 1890, en los ejercicios del clero secular, el Obispo Reginaldo Toro predicaba una meditación sobre el sacerdocio. En ella vierte algunos rasgos del perfil deseado. La dignidad del sacerdocio es una institución Divina, "Jesucristo nos ha llamado, nos ha constituido sus apóstoles entre las gentes y nada en la tierra iguala esta dignidad -cómo mi padre me ha enviado a mí, así yo os envío a vosotros-, este maravilloso poder del sacerdocio católico se manifiesta sobre todo en el sagrado tribunal de la misericordia y más que todo en el santo y augusto sacrificio del altar [...]. Pero no de balde el sacerdote es general del ejército del señor, y columna que sostiene el universo vacilante, destinado como Elías [...] a hacer desaparecer las abominaciones de la impiedad, enviado para demoler, para destruir [...] para derribar el reino de satanás, destruir el pecado y edificar la virtud. He aquí las obras que corresponden al sacerdote de Dios y buen pastor. Su vida no es un lecho de rosas, su honor no consiste en la gloria de este mundo. [...] No os olvidéis que así mismo siendo ministros de Dios, también tenéis padres y pastores en la tierra, a quienes corresponden el gobierno y la dirección de la iglesia de Jesucristo y a quienes debemos obedecer y seguir, y muchas veces sacrificar y someter nuestro propio juicio y propia voluntad, esa propia voluntad, ese orgullo secreto, el más mortal enemigo del hombre. [...] La voz y la acción del sacerdote, la sal de la tierra, el guía, la luz y la fuerza que el señor envía a su pueblo, para que nadie ignore y nadie se pierda sino por su propia y deliberada voluntad. Predicad y exhortad como nos enseña el

\footnotetext{
20 AAC. Parroquias: Santa Rosa de Río $1^{\circ}$. Esquiú, Edicto con motivo de la Cuaresma, Córdoba, 21/02/1881.

${ }^{21}$ AAC. Parroquias: Santa Rosa de Río1 ${ }^{\circ}$, f.421. Título expedido el 14/06/1889 por el Obispo Toro.
} 
grande apóstol de las gentes, con toda paciencia y en toda caridad, y guardaos de lo falso e imprudente. Sacerdotes de Dios vivo, hermanos e hijos míos haced durante la tempestad lo que las ovejas hacen por instinto de conservación, aunque no como vosotros dotados con el don divino de la razón: reunirnos alrededor de nuestro pastor legítimo, padre y obispo, formando la falange de Dios". ${ }^{23}$

Esta larga cita sugiere algunos de los componentes del perfil que los obispos del período aspiraban para los curas párrocos de su diócesis. El primero era la piedad personal, el ejercicio del ministerio debía cimentarse en la oración, meditar la vida de Jesucristo, pues él era el modelo a imitar, el cura debía ser "otro Cristo" para el pueblo. Las imágenes a las que recurre el obispo con más frecuencia para ejemplificar la vida y la actividad del cura fueron la del "Pastor", que cuida y vela por su rebaño, se sacrifica por su bienestar, sale en busca de las ovejas descarriadas, y cura a las enfermas; la del "Maestro", que enseña con su palabra y su ejemplo, que advierte los errores y aconseja; y la del "Padre", que debía asumir los intereses del pueblo y, particularmente, los de la clase obrera y agrícola. La parroquia se asimila a una familia surcada por vínculos de solidaridad entre el párroco y los feligreses. ${ }^{24}$ Para lograr estas aspiraciones, el párroco, entre otras cosas, debía abandonar las actividades relacionadas con las contiendas políticas, que, para el diocesano, disgregaban y dividían las feligresías.

Este perfil de párroco, que se gestó a partir de la tercera década del siglo XIX, tomó, del modelo tridentino, el énfasis en el carácter sacerdotal que privilegiaba la función litúrgica y la administración de los sacramentos; del modelo ilustrado -que asumía la religión como instrumento civilizador y al párroco como agente del mismo-, incorporó la centralidad de la docencia, la predicación y la moral evangélica. ${ }^{25}$ A los rasgos mencionados, se añadieron la subordinación y obediencia a la autoridad eclesiástica, punto central de los lineamientos propuestos por Roma para la reforma del clero.

El Obispo Zenón Bustos, en una visita al curato de San Francisco, lo señalaba explícitamente:

Si la iglesia, única que puede salvar a la moderna sociedad, no realiza entre nosotros, con eficacia su acción en el orden social de acuerdo con las necesidades

\footnotetext{
${ }^{22}$ AAC, Parroquias: Santa Rosa de Río1 ${ }^{\circ}$, f.424.

${ }^{23}$ AAC. Leg. 30. Ejercicios del Clero de $1890 \mathrm{~s} / \mathrm{f}$.

${ }^{24}$ REOBA, 1912. "Misión del párroco", p. 417.

${ }^{25}$ Los Principios, 12/07/1894, al referirse a la misión del clero señalaba "Cristo llama a los curas, para que sean centinelas fieles, velen a fin de que el pueblo santo no sea puesto en peligro por el ataque de sus enemigos y no sufra detrimento".
} 
de la hora presente, es debido, más que a las oposición del enemigo a la falta de acción de sus hijos y a la falta de perfecta sumisión a sus indicaciones y directivas, no menos que a la mezquindad con que ofrecemos nuestros esfuerzos y sacrificios los que debiéramos en todo momento y en todos los campos, ser sus apóstoles celosos y abnegados. Pedimos pues al Sr. cura al terminar esta visita que por convicción de su necesidad y por obediencia tome el debido interés en esta obra que en todas partes es buena y santa, en ciudades como ésta reclama, por cierto, carácter de verdadera necesidad. ${ }^{26}$

El modelo al que se tiende es el de un cura distinto pero no distante de la sociedad, distinto porque su condición clerical marcaba diferencias con el mundo secular y éstas debían manifestarse en la conducta, el lenguaje y el modo de vestir. Pero esa distinción no significaba distanciamiento, debía estar al frente, dirigir y orientar el movimiento social católico. El cura se concibe como agente central en la movilización de los católicos. Al igual que en otros países europeos, en estos años, se constituye una cultura de "movilización católica", o, como señala de la Cueva Merino (2005: 44), comienza a incorporarse una "cultura de militancia católica". En una columna del diario "Los Principios" del 18 de mayo de 1905, titulada "La Acción Católica", se señala enfáticamente que debe estar bajo la dependencia de los obispos y critica a los demócratas cristianos que defienden la autonomía de la acción social. "Se inclinan ante la infalibilidad pero no ante la obediencia”. La Acción Católica debía estar sujeta a la jerarquía, el papa, los obispos, los párrocos. La función del cura párroco era fundamental para llegar a la sociedad, al pueblo cristiano. Para el Obispo Bustos, el catolicismo se encontraba en peligro y los clérigos debían salir en su defensa:

Es hora de militancia activa del sacerdocio, poniendo tesis contra tesis, para salvar la verdad contra el error, y marcar al pueblo la ruta práctica, que debe seguir: es hora de amparar las instituciones católicas defender su legitimidad, su acción saludable, benéfica y salvadora de la sociedad y de las almas y haciendo profundizar las raíces de éstas en la conciencia popular. ${ }^{27}$

Los obispos, en particular Zenón Bustos, estimularon al clero rural a dedicar horas diarias al estudio, por considerarlo indispensable para el buen desempeño de su ministerio parroquial. Su función le imponía alcanzar una formación adecuada a las exigencias de los tiempos, para ello debía dedicarse al estudio de manera seria y

\footnotetext{
${ }^{26}$ AAC. Parroquias: San Francisco. El subrayado es nuestro.

${ }^{27}$ AAC. Fondo Zenón Bustos. Caja No 4, f.1304. El subrayado es nuestro.
} 
sistemática. ${ }^{28}$ En la gira pastoral de 1905 , el diocesano señalaba a un párroco de campaña la necesidad de ocupar todo su tiempo en cuatro cosas: oración, estudio, confesionario y predicación. $^{29}$

\begin{abstract}
El ejercicio de este mismo ministerio, como es manifiesto, le reclama una reclusión relativa en su casa y el estudio consiguiente. El cura más prestigioso e influyente en el ánimo de sus feligreses es aquel que menos recorre las casas de familia y solo las visita reclamado por el ejercicio de su ministerio, manteniéndose recogido dentro de su casa, en estudio, oración lo restante del tiempo. [...] En las poblaciones rurales, el cura es por lo general, el consejero de los vecinos, el amigo más caracterizado a quién recurren por ideas para solucionar sus dudas, y si no está ilustrado nada podrá decir que sea acertado, ningún rumbo ventajoso podrá dar a los negocios consultados. Y para edificar a los suyos necesita además revestirse de toda la gravedad sacerdotal, ofrecer ejemplo de contracción a la piedad, a la prudencia, a la moderación, a la tolerancia de las groserías y torpezas de los pobres campesinos, con que tendrá que encontrarse con arta frecuencia. ${ }^{30}$
\end{abstract}

En 1910, el cura de Minas se excusa de rendir el examen de moral, justificando falta de tiempo para estudiar. El obispo diocesano, a través de su secretario, responde con firmeza que "si Ud. tuvo tiempo para escribir para la prensa poesías y cosas del todo alejadas al ministerio parroquial, no ha podio faltarle el necesario para estudiar lo que es esencialmente propio de ese ministerio por consiguiente me ordena decirle que ordena a Ud. que prepare su examen a la mayor brevedad posible". ${ }^{31}$

\title{
1.3 El clero según la feligresía
}

Sin duda, las denuncias de las feligresías suponen un indicador respecto de las conductas no deseadas del clero. Al tiempo que las manifestaciones de agradecimiento y /o solicitudes de permanencia en una determinada parroquia son indicadores del comportamiento aceptado. Más allá de la veracidad de las mismas.

En 1876, ante una denuncia contra el cura de Vinchina, Tristán Sotomayor, el vicario foráneo y visitador eclesiástico solicitó al jefe político levantar una información sumaria, con el fin de "arrancar como quien dice, las plantas nacidas de tan malas semillas que según voces fue pródigo en sembrar". Se le preguntó a varios testigos si conocían al cura,

\footnotetext{
${ }^{28}$ AAC. Libro de Autos y Visitas Parroquiales, 1885-1916. Auto de la visita al curato de San Pedro, 24/11/1905.

${ }_{29}$ AAC. Libro de Autos y Visitas Pastorales, 1885-1916. Auto de la visita pastoral a Canal y Arias, 02/09/1907.

${ }^{30}$ AAC. Libro de Autos y Visitas Parroquiales, 1885-1916. Auto de la visita a San Pedro, 24/11/1905.
} 
si tenían conocimiento de "que este sacerdote tuvo entonces comilonas i tertulias indecorosas a su carácter i ajenas a su misión"; si sabían o les constaba en qué casa tuvieron lugar dichos entretenimientos y cuál fue la conducta que observó en ellos el Pbro. Sotomayor. Cuatro testigos declararon y señalaron que tuvo banquete en la casa de Don Manuel Cienfuegos "i en seguida tertulia de vaile en casa de dicho ser Sienfiegos i a la del Señor Dn Juan Castillo y que le parecieron indecorosas a su carácter i ajenas a su misión". El siguiente testigo relata que un día fue a misa y después de celebrada,

pasó al cuarto del citado presbítero Don Tristan Sotomayor donde después del mate tomaron algunas copas de aguardiente / i que dicha piesa donde esto sucedió es el cuarto que se halla contiguo a la sacristía del oratorio del Distrito Cerro i que en seguida se redujo a tertulia en el mismo local que al efecto pidió el Sr. presbítero una guitarra con la que hizo cantar alguna tonada i canciones, ínterin se tomaba aguardiente, i que de por consiguiente la reunión de jente se puso un poco más alegre y que en seguida pasaron a casa del declarante, donde se almorzó i que enseguida se formo una tertulia sostenida con vino que tomábamos los participantes y que no recuerda si él tomaba este licor, i que si tomaba aguardiente, algunas copas, i que la sitada tertulia duro hasta las siete más o menos de la noche, en que el señor presbítero Sotomayor se retiró como hicieron los demás que asistían [...] que tales procedimientos a su modo de ver fueron indecorosos a su carácter i ajenos a su misión. ${ }^{32}$

Otro testigo acotó que había observado la "mala conducta por cuanto se embriagaba higual a los demás”. No sabemos la sanción impuesta al presbítero. Lo único que hemos podido constatar es que a partir de 1878 no fue ocupado en ningún curato de la diócesis, el último registro de licencias es de ese año. ${ }^{33}$

En 1876, se levantó una información sumaria contra el cura de Chalacea, debido a las reiteradas denuncias en su contra por parte de algunos feligreses. En la conclusión de la misma, el fiscal sentencia que ve la conveniencia de reemplazar al cura con otro sacerdote, fundado en que las cartas de denuncia daban fundamento a graves cargos y probaban, "cuanto menos, falta de tino y prudencia, condición indispensable en un Párroco para el buen resultado de su ministerio". El segundo fundamento es que "de hecho existe ya una desinteligencia muy pronunciada entre el mencionado párroco y sus feligreses $[\ldots]$ y si esto es así ¿qué utilidad puede haber en conservarlo al frente de esa feligresía ¿Tan es así esto que la Iglesia ha colocado entre las causas de renuncia, aún

\footnotetext{
${ }^{31}$ AAC. Notas de Secretaría, 1885-1913, f.135.

32 AAC. Leg. 35. Juicios Eclesiásticos, 1871-1905. Denuncia contra el presbítero Tristán Antonio Sotomayor, 19/10/1876.
} 
para el Obispado, el desacuerdo notable entre el Pastor y su rebaño [...]". ${ }^{34}$ Finalmente, el cura fue relevado de su puesto.

En 1881, un vecino de Calmuchita envía una denuncia al obispado contra el cura. En ella advierte que "no esquivo tampoco comparecer en juicio porque tengo la conciencia de ser verdad todo lo que ha sucedido y para asegurarlo juro ante SS Ilma. que no procedo con malicia ni por echos personales que no tengo en cuenta, sino que puedo morirme y temo mucho la confesión que haría tanto yo como mi familia". Los hechos denunciados fueron los siguientes:

Para la Sra. de Dn Asencio Gigena lo vinieron a ver para que la confesara, contesto que lo vieran al padre Calisto, y esa misma tarde se fue a la casa de negocio de Dn Pedro Luis Carranza para de hay ir al otro día a Amboy a decir misa habia carreras y llovió y ni aquí ni allí dijo misa: lo buscaron estando en la casa de Dn Pedro Luis Carranza para que confesase a Justino Ayala contesto que no podía montar a caballo mandado por el médico se murió sin confesión: lo buscaron dos veces para que confesara a Dña Norberta de Amboy no fue se murió sin confesión: se murió Sinforosa Flores sin confesión y preguntando porque no lo habían buscado al cura contestaron que como sabían que no habría de ir no lo vinieron a buscar: en lo de don Pedro Luis Carranza he asistido yo personalmente por carreras que tenían depositadas según decían por el cura cuando se fue por enfermo y lo encontré a primera con cuatro individuos más, con mi presencia se desasno y luego dejo a la tarde salio a las carreras y lo hizo correr uno de dos que decían que eran: en la noche dice Agapito Maldonado que volvió a jugar hasta que amaneció: después de tres días de esto vino con Dn Felis Rosa, venía a casar unos novios luego con don Pepe Lujan y estuvieron dos o tres días jugando de día y de noche, dijeron que Lujan había ganado treinta pesos. ${ }^{35}$

Las denuncias dieron inicio a una sumaria y luego a un juicio eclesiástico. Finalmente, el obispo le pidió la renuncia en junio de 1885. Los términos eran claros: "Debe cambiar la conducta, atender las necesidades del curato, apaciguar los ánimos a fin de desestimar las repetidas quejas, o resolver en vistas a la unanimidad de éstas renunciar al curato, no hubiese problema alguno de colocarlo en otro punto. Las quejas arrecian y no se decide a renunciar. Resistencia y malquerencia de los fieles a su persona. Es imposible desatender las continuas reclamaciones de los fieles". 36

En 1890, se suspendió al párroco de Tama del cargo de cura y vicario interino de ese beneficio, "debiendo Ud. abstenerse de ejercer actos parroquiales desde el momento de

\footnotetext{
${ }^{33}$ AAC. Libro de Licencias Ministeriales, 1859-1935, f.112.

${ }^{34}$ AAC. Leg. 34. Causas y Demandas de Curas y Seglares ante el Sr. Obispo, 1818-1884, TIV, 1873.

${ }^{35}$ AAC. Carpeta Parroquias: Santa Rosa de Calamuchita, f.9.

${ }^{36}$ AAC. Libro Notas particulares del Sr Obispo, 1884-1903, s/f. Nota del 03/05/1885.
} 
recibir la presente como así mismo del ministerio de la palabra". ${ }^{37}$ El motivo de tal disposición fue una serie de denuncias relativas al mal desempeño del ministerio en varios puntos, la asistencia a reuniones de baile, y el haber bailado en ellas, el excesivo cobro de estipendio sin sujetarse al arancel vigente; el haber realizado casamientos de extranjeros sin competente autorización. La advertencia era terminante, "procure no dar motivo alguno de queja y que se ajuste a las disposiciones vigentes en esta diócesis [...] Sabe bien que con poco que se desvíe el párroco escandaliza a los fieles pues él es el modelo para todos, cuide por consiguiente de no exhibirse jamás en reuniones que Ud. mismo tendría que reprobar de la catedra sagrada [...]. Si Ud. leyera con frecuencia el sínodo diocesano se persuadiría de la importancia que tienen estas observaciones". ${ }^{38}$

Las denuncias, ciertamente, favorecieron la posibilidad de modelar al clero en orden al perfil deseado. Para instalarlo fue necesario depurar algunas conductas y comportamientos que habían caracterizado al clero diocesano en las décadas anteriores (Ayrolo, 2007). El aseglaramiento, el amancebamiento, el abuso de la bebida, los juegos de naipes, las carreras de caballos y las riñas de gallos fueron prácticas ampliamente denunciadas y tenazmente combatidas por la jerarquía en las dos últimas décadas del siglo XIX. Respecto al amancebamiento, los obispos también eran firmes. Con frecuencia se recibían denuncias sobre estas cuestiones al respecto y exhortan a los párrocos, como señalamos ut supra, en la circular emitida por el Obispo Alvarez, a la obligatoriedad de dar buen ejemplo respecto de la vida y honestidad.

En 1899, la iglesia de Cruz Alta fue devorada por un incendio. Esta cuestión dio inicio a una causa judicial y la prensa dio una amplia cobertura al caso. El cura párroco Juan Pedro Alberti era napolitano y había llegado dos años antes a la diócesis. En 1897, se le concedieron licencias generales para el ejercicio del ministerio, primero se lo destinó a Olta (La Rioja) y, pasado el año, se lo nombró capellán de Cruz Alta. ${ }^{39}$ A los pocos meses de iniciarse en la gestión, se produjo el incendio. La prensa lo incriminó, “de él se dice que vivía con una señora que aparentaba ser su hermana pero en realidad era su concubina". Luego de pasar cuarenta días detenido en el departamento central de policía, envió una carta al obispo en la que relataba detalladamente los hechos. En ella, daba cuenta de la animosidad de algunos vecinos, de las denuncias anónimas contra su persona y su conducta moral, considerándose "víctima inocente de una barbaridad esperada y sin

\footnotetext{
${ }^{37}$ AAC. Copiador de Cartas. Secretaría del Obispado, 1882-1902. Nota del 21/11/1890.

${ }^{38}$ AAC. Copiador de Cartas. Secretaría del Obispado, 1882-1902. Denuncias del 03/06/1889.

${ }^{39}$ AAC. Libro Licencias Ministeriales, 1859-1932, f.273; Leg. 51. Cruz Alta s/f.
} 
nombre de los gauchos de Cruz Alta", a quienes atribuyó el incendio. ${ }^{40}$ El incidente dio lugar a que se le retiraran las licencias y se lo expulsara de la diócesis. Dos años después, el obispado de Paraná solicitó informes sobre dicho cura, "Se ha presentado en esta Curia el Pbro Juan Pedro Alberti, el Obispo me pide le escriba a ud. preguntándole si este sacerdote no es el mismo del que se ha hablado tanto en los periódicos de que vivía con aquella mujer cuando se incendió la iglesia de Cruz Alta? Dígnese informar acerca de su conducta". No conocemos la respuesta, pero el tono de la consulta denota preocupación por no dar lugar a un cura deshonesto en materia moral.

Los interrogatorios previos a las visitas canónicas comienzan a indagar la vida doméstica del cura. A partir de 1906, se pregunta ¿Quién vive con el cura? (Indicar el número de personas, nombre, apellido, conducta, edad, sexo, condición, profesión, grado de parentela con el cura). ${ }^{41}$ En general, las respuestas señalan que el cura vivía con algún pariente, generalmente la madre y/o la hermana. Entre el personal, se encontraba el sacristán, algún doméstico - generalmente una mujer mayor de buena conducta-, y algún chico que hacía las veces de mucamo y monaguillo. Sin embargo, llamaron nuestra atención algunas de las respuestas, por ejemplo, el cura de San Francisco responde que vivía con "un enjambre de personas de toda edad y sexo. Ninguna de ellas pariente del cura". Y el de Minas contesta que tiene un ama de llaves "llamada Valduina Díaz de 55 años de edad, hace quince años que lo acompaña. Un niño de crianza, Roque Lenzina, argentino. Un sacristán Reginaldo Guzmán y otra sirvienta María Ogaz de 27 años". ${ }^{42}$ Sin duda, la recavación de esta información estaba destinada a ordenar, controlar y velar por la vida honesta del clero.

Otra de las medidas vinculadas al nuevo modelo fue la imposición de llevar el traje talar. La sotana se convirtió en el signo identitario de los hombres de iglesia y en el símbolo de diferenciación entre el clero y el pueblo. En los primeros años del nuevo siglo, no llevar traje talar era inusual. El capellán de Cruz Alta, Juan Vozzi, respondía a una reconvención del obispo en relación al "mal efecto que produce en el público el presentarse un sacerdote tan solo vestido de sobretodo." El cura aclara el motivo de su proceder: "si yo he vestido así, ha sido no solamente por la comodidad que ofrece en los campos donde siempre vivimos cubiertos por una nube de polvo, sino así mismo porque ví que era práctica en los pueblos de campaña de Buenos Aires, y me incliné a creer que

\footnotetext{
${ }^{40}$ AAC. Leg. 51, s/f.

${ }^{41}$ AAC. Cuestionario Visita Canónica, 1906, pregunta $n^{\circ} 6$.

${ }^{42}$ AAC. Parroquias: Minas. Respuesta $n^{\circ} 6$ del Cuestionario de la Visita Canónica.
} 
ello no constituiría ni una falta ni una irreverencia". ${ }^{43}$ El traje talar no sólo se convertía en un símbolo de identidad sacerdotal, sino también cumplía la función de diferenciar, distinguir y eliminar definitivamente el aseglaramiento tan frecuente en el período precedente (Ayrolo, 2007). El obispo diocesano amonestó al capellán Faustino Nistal porque se había despojado del traje sacerdotal, presentándose públicamente de seglar. ${ }^{44}$ El modo de vestir llevaba implícito una manera de comportarse, inducía a identificar la conducta a la ortodoxia que establecían las disposiciones propias del estado clerical. El cura sin sotana era considerado un mal cura. Rosendo Liendo denuncia ante la curia a Domingo Arnedo por no llevar el traje sacerdotal. La sentencia del cura fue terminante, "si su vida no es como debe ser, yo no permito en la parroquia más escándalos que los de los seglares que ya son por demás". ${ }^{45}$ Por lo tanto, para los contemporáneos, el cura sin sotana incurría en una conducta escandalosa.

La bondad y delicadeza en el trato era otro punto importante. Como se ha manifestado, éste era uno de los temas que más preocupaba al Obispo Esquiú. El cura debía vivir en primer lugar la caridad. No son pocas las denuncias de los feligreses contra curas que no cumplían con sus expectativas. En 1879, los vecinos de Villa Nueva finalizaban el texto de su denuncia contra el cura, diciendo "Deseamos tener nosotros un sacerdote si es posible hijo de nuestro país, que por su ilustración, moralidad y como conocedor de nuestras costumbres pueda dirigir a su feligresía por la senda verdadera de los justos sabiendo que tiene que tratar y enseñar a personas que viven en lugares desiertos apartados de toda sociedad, que rara vez al año concurren a la Iglesia e ignoran por tanto la manera de conducirse en el templo, lo que les vale reconvenciones públicas, con toda terquedad y dureza, como las han recibido muchas veces del Cura Lima, quién carece por completo de paciencia, mansedumbre y bondad evangélica para expresarse con las personas de uno y otro sexo". 46

En los autos de visita canónica de Zenón Bustos, estos principios aparecen con fuerza. Recriminaba "la falta de benignidad y caridad en el Párroco para tratar a los fieles que se acercan buscando la práctica de los sacramentos", 47 sentencia que "para edificar a los suyos necesita además revestirse de toda la gravedad sacerdotal, ofrecer ejemplo de contracción a la piedad, a la prudencia, a la moderación, a la tolerancia de

\footnotetext{
${ }^{43}$ AAC. Parroquias: Morteros, 29/10/1903.

${ }^{44}$ AAC. Fondo Zenón Bustos, f.1692.

${ }^{45}$ AAC. Parroquias: Cruz Alta, 22/03/1907.

${ }^{46}$ AAC. Leg. 35. Juicios eclesiásticos. Denuncia y sumario al cura de Villa Nueva Pbro. Antonio Lima, 26 de septiembre de 1879 .
} 
las groserías y torpezas de los pobres campesinos, con que tendrá que encontrarse con arta frecuencia". ${ }^{48}$ Se advierte que el párroco debía ser "el ángel custodio de cada uno de sus feligreses y debe estar al lado de cada uno de ellos para ampararlos contra los peligros que comprometan su salvación. Esto significa el concepto del Redentor: Bonus Pastor". 49

Los debates de la prensa, los documentos episcopales y las denuncias de los feligreses nos permitieron construir la imagen y el perfil del modelo de clero parroquial deseado. A continuación, veremos cuál fue la formación destinada a modelar a este nuevo clero.

\section{La formación destinada a modelar el perfil de un clero romanizado}

En la introducción, decíamos que la jerarquía buscó la profesionalización del clero y llevó adelante un intento de crear un cliché, "una matriz de formación", a través del seminario, con la intención de lograr un clero más uniforme.

\subsection{El seminario conciliar}

El seminario Conciliar Ntra. Sra. de Loreto abrió sus puertas en 1853, siendo reconocido por el gobierno nacional en 1865, asignándosele una partida de dinero para la manutención del edificio, el pago del personal y becas para una decena de alumnos.

Por las aulas de este seminario diocesano de Córdoba, pasaron, entre 1853 y 1860, 132 alumnos, ${ }^{50}$ muchos de ellos externos, de los cuales, sólo una media decena ${ }^{51}$ recibió las órdenes mayores, ya que algunos de los que recibieron el presbiterado en esos años eran estudiantes de la universidad y no pasaron por las aulas del colegio eclesiástico. El libro de alumnos del seminario da cuenta de que se trataba de un colegio similar al colegio Montserrat, un lugar donde los hijos de las distinguidas familias cordobesas y de otras provincias argentinas compartían una etapa de su formación.

En 1860 comenzaron las reformas. Se estableció el reglamento que regirá a esa casa de estudios hasta $1913 .^{52}$ El mismo fue elaborado por Castellano y Cabanillas y proponía restablecer la disciplina eclesiástica y la formación de aquellos alumnos que

\footnotetext{
${ }^{47}$ AAC. Libro Visita de Parroquias, 1916-1922, f.13.

48 AAC. Carpeta Curia, Visitas Pastorales y Varios, 1887-1911. Auto de Visita a la Parroquia de San Pedro, 24/11/1905.

49 AAC. Carpeta Curia, Visitas Pastorales y Varios, 1887-1911. Auto de la Visita Canónica a Cruz del Eje, 22/03/1908.

${ }^{50}$ AAC. Fondo Seminario, Libro 3 Alumnos.

${ }^{51}$ AAC. Leg. 24. Expedientes de Ordenes, TVII, 1845-1865.
} 
dieran muestras claras de su vocación clerical. Las constituciones establecían que los alumnos que hubieran terminado el cuarto año de filosofía y no tuvieran la firme resolución o decidida inclinación al estado eclesiástico debían abandonar el colegio. ${ }^{53}$ Incluía una extensa normativa respecto a la distribución del tiempo, la vida de piedad, el estudio y el ocio de los seminaristas. El horario del establecimiento era exigente, las actividades diarias se iniciaban a las 5:30hs de la mañana y culminaban a las 21:45hs.

Una condición fundamental era el carácter interno de los alumnos, a los que no se les permitía, salvo caso de grave enfermedad o muerte de un familiar, dormir fuera del colegio. La necesidad de tener a las clases superiores en el mismo seminario era un anhelo de las autoridades diocesanas, ya que, por entonces, los alumnos asistían a clases en la Universidad: "Si alguna vez el colegio tuviere clases internas, se dará preeminencia a las de los estudios que en la Universidad se exigen antes de la Filosofía, y se establecerán bajo de las condiciones siguientes: $1^{\circ}$ No se admitirán alumnos externos y $2^{\circ}$ Las horas de las clases se uniformarán con las de la Universidad". 54

El carácter interno del alumnado implicó una disminución notable de seminaristas, de 60 que tenía en 1859 pasó a 30, sin embargo, lentamente, incrementó la matrícula. El seminario Conciliar se convirtió en un colegio especializado. Los estudios de Teología se dictaban en la universidad, pero, al estar el seminario a cargo del gobierno nacional, en 1862 se decidió pasar allí las cátedras de ciencias religiosas. Pasaje que se hizo efectivo dos años más tarde.

En el período que va de 1860 a 1877 , el seminario vio desfilar a más de un centenar de alumnos por sus aulas, de los cuales sólo llegaron a recibir las sagradas órdenes mayores -hasta el presbiterado-, 26 candidatos; 20 incardinados en la diócesis de Córdoba (de los cuales 2 eran extranjeros, oriundos de España) y 6 extra-diocesanos, 2 de Paraná, 1 de Salta, 1 de Cuyo, 1 de Tucumán y 1 de Buenos Aires. En cuanto a las órdenes menores, 47 seminaristas accedieron a ellas.

La década del 80 supuso un duro golpe para las finanzas del establecimiento y significó un cambio sustantivo en su funcionamiento interno. En 1881, el Presidente de la República, Julio A. Roca, estableció, por decreto, que las cátedras de teología y ciencias sagradas se retiraran de la Universidad y continuaran en el seminario conciliar de Córdoba bajo la dirección del obispo diocesano (Bruno, 1981: 53). De este modo, la

\footnotetext{
${ }^{52}$ Comenzará a utilizarse el previsto por la Sagrada Congregación para Seminario y Universidades.

${ }^{53}$ AAC. Fondo Seminario Conciliar. Exp. № 36, f.10.

${ }^{54}$ AAC. Fondo Seminario Conciliar. Exp. No 36, fs.20-23.
} 
formación del clero recaía, de manera exclusiva, en la institución conciliar, subvencionada por el Estado nacional, que pagaba los sueldos de las autoridades, los profesores y 12 becas para alumnos.

En 1884, se debate, en la Cámara de Diputados del Parlamento nacional, la supresión de partidas para los seminarios conciliares. El Diario "El Eco" de Córdoba, del 12 de octubre de ese año, informa que se había quitado del presupuesto la partida destinada al sostenimiento de los seminarios. ${ }^{55}$ Dos días después, publica un suelto titulado "Los seminarios sostenidos por el pueblo”. Allí advertía que, a pesar de esa decisión, los seminarios continuarían formando sacerdotes, destinados a mantener vivo $\mathrm{e}$ inextinguible el fuego sagrado del sentimiento religioso, pues personas influyentes de la ciudad de Córdoba se pondrían en campaña para obtener el dinero necesario para el sostenimiento del seminario diocesano. Además, informaba que algunos abogados dictarían cátedras y ayudarían, con una cuota mensual, al sostenimiento del establecimiento del clero. El diario animaba a la población a colaborar con dicho emprendimiento. ${ }^{56}$ Efectivamente, a partir del mes de octubre, el libro de cuentas del obispado deja de registrar la subvención del gobierno nacional, suspensión que duró hasta $1891 .{ }^{57}$ Con grandes penurias económicas, el seminario siguió su andadura en el vetusto edificio ubicado detrás de la catedral. Las finanzas comenzaron a mejorar y el estado nacional colaboró en ello. En el informe de la visita ad limina de 1892, el obispo menciona que "El gobierno de la nación paga mensualmente todo el cuerpo de directores y profesores y veinte becas para jóvenes pobres, fuera de esto percibe la pensión de los demás alumnos cuyas familias son pudientes a razón de 200 pesos anuales, pagando algunos algo menos por consideración de sus pocos haberes". 58

En 1894, el Obispo dominico Fray Reginaldo Toro proyectó la construcción de un nuevo edificio, para lo cual gestionó la donación de una manzana, sobre la actual avenida Vélez Sarsfield. El proyecto comenzó a hacerse realidad y, en 1895, el obispo bendijo la piedra fundamental. Doce años después, el nuevo edificio se terminaba de construir con la colaboración de un grupo de damas de la ciudad, las que, a solicitud del obispo, habían formado una comisión pro-seminario, para la búsqueda de fondos y becas de estudiantes.

\footnotetext{
${ }^{55}$ El Eco de Córdoba, Domingo 12 de octubre de 1884, Congreso Nacional, Cámara de Diputados, Presupuesto de Justicia y Culto.

${ }^{56}$ El Eco de Córdoba, 14 de octubre de 1884.

${ }^{57}$ AAC. Obispado y Seminario de Córdoba. Libro de Cuentas, 1878-1891.

${ }^{58}$ AAC. Libro de Autos, 1876-1905, f.149.
} 
El $1^{\circ}$ de marzo de 1908 se inauguró y se habilitó para su uso la mitad de la obra. En una pastoral, destinada a impulsar el aumento de alumnos para el seminario, expone la situación de la realidad clerical cordobesa. En respuesta a dicha pastoral, el cura de Camilo Aldao, español, sugiere al obispo algunas soluciones que dieron resultado a los obispos españoles de las regiones gallega, asturiana y vasca. Ellos, ante la escasez de clero, establecieron una carrera breve además de la larga. La más breve consta de tres años de latín, uno de humanidades, dos de filosofía y tres de teología dogmática y moral, un total de siete años de estudio. Con la peculiaridad que, para ambas carreras, se permite la enseñanza libre hasta filosofía y aún hasta teología, según las circunstancias. La teología siempre se enseña en el seminario. Además, permiten el externado de todos aquellos candidatos que no puedan pagar la pensión interna. Por lo regular, a los de la carrera breve no se los coloca más que de ayudantes, pudiendo llegar a ser curas, si ganasen el curato por concurso, cerrándoseles las puertas de las demás dignidades eclesiásticas. La carrera breve tenía la ventaja de exigir poco costo y además animaba más al candidato al ayudarlo en su inconstancia. La enseñanza libre hasta la filosofía abrevia el sacrificio de once años de internado en el seminario, además la enseñanza libre es más económica. El estudio más peligroso es el externado, es un gran medio de atraer a los pobres. Explica que en Santiago de Compostela se les permite ir de particulares pero siempre de negro, en otras diócesis se obliga a vestir manteo y sombrero eclesiástico desde filosofía inclusive. De modo tal que muchos padres, reconociendo que el seminario era un plantel de educación moral y religiosa, mandaban a sus hijos sin intención de hacerlos clérigos, pero resulta que los hijos le tomaban aprecio al seminario y terminaban ordenándose sacerdotes. El capellán de Camilo Aldao, José Figuera apostillaba que creía que los medios apuntados podrían dar resultado en Córdoba. ${ }^{59}$

En esta nueva etapa, el Obispo Zenón Bustos nombró una comisión de clérigos destinada a la revisión y actualización del plan de estudios y sugirió la redacción de un nuevo reglamento, a fin de imprimir a la enseñanza en el seminario una directriz más acorde con el espíritu de los tiempos. El seminario diocesano se convirtió en una institución clave para llevar adelante el proceso de renovación católica, ${ }^{60}$ aumentó el número de sus alumnos, y, sobre todo, el obispo se propuso involucrarlos y capacitarlos para llevarlo a cabo.

\footnotetext{
${ }^{59}$ AAC. Leg. 51. Cruz Alta, s/f. Nota del 06/08/1907.

${ }^{60}$ AAC. Pastorales, 1900-1923. Pastoral sobre el Seminario, 8 de junio de 1907.
} 
El informe elevado por el rector del seminario, Inocencio Dávila, sobre la marcha del instituto durante el año 1913, señala que el número de alumnos era el máximo que podía albergar el edificio y advertía que "en un tiempo no lejano este seminario podrá satisfacer las necesidades del clero cada día más sentida en esta vastísima diócesis, que con el aumento de su población y la multiplicación de sus pueblos, reclaman mayor número de sacerdotes". ${ }^{61}$ Según el rector, la marcha era satisfactoria, los alumnos vivían sin dificultad el reglamento, eran constantes y puntuales en las prácticas de piedad reglamentarias. En el orden intelectual, "este seminario en nada a desmerecido el de los años pasados. El plan de estudios se desarrolla con amplitud”. Además, todos los alumnos, sin excepción, colaboraron durante el año en la enseñanza de la doctrina en las parroquias de la ciudad. El prefecto de estudios, Horacio Ferreyra, adjunta su informe en el que destaca la preparación, dedicación y puntualidad de los profesores y solicita la incorporación y actualización de libros para la biblioteca, un museo de botánica, zoología y mineralogía y un gabinete de instrumentos de física. ${ }^{62}$

En 1916, el obispo envió a Roma la memoria sobre el funcionamiento del seminario, formulada de acuerdo al cuestionario de la Sagrada Congregación de Seminarios y Estudios Universitarios. ${ }^{63}$ Respecto a la sede, señala que tiene capacidad para 100 alumnos y “está completamente libre de la introducción de seculares y de personas extrañas al gremio de estudiantes". Además, posee una quinta a $8 \mathrm{~km}$ de la ciudad que provee de hortalizas, frutas, leche y otros elementos. Así mismo, cuenta con una estancia de 700 hectáreas en Los Molinos, donde los seminaristas pasan los meses de diciembre a marzo, luego de pasar 15 días de vacaciones con sus familias.

El crecimiento del número de alumnos fue progresivo. En 1892, el obispo informaba que los alumnos que vivían en el seminario eran $80 ;{ }^{64}$ en 1903 , el número se mantiene; ${ }^{65}$ en 1912, bajaron a $72,{ }^{66}$ y entre 1913 y 1916, ${ }^{67}$ aumentaron a 90 y 100, respectivamente;

\footnotetext{
${ }^{61}$ REOBA, 1914, p. 637.

${ }^{62}$ REOBA, 1914, p. 641.

${ }^{63}$ REOBA, 1916, pp. 476-478.

${ }^{64}$ AAC. Libro de Autos, 1876-1905, f.149. "Asisten ordinariamente 80 alumnos que viven en el seminario y cursan las siguientes materias: latín, idiomas nacional y francés, religión, historia sagrada, eclesiástica, griega, romana y del país, arte, oratoria, geografía, matemáticas, física, filosofía, teología dogmática y moral, derecho canónico y hermenéutica sagrada. Los alumnos viven bajo la buena disciplina y observan fielmente los reglamentos, son constantemente estimulados a la piedad y tienen su capilla interna donde se ejercitan en actos de religión haciendo el curso de ejercicios espirituales cada año".

${ }^{65}$ AAC. Leg. 1. Catedral, 1723-1900. Exp. No 85, fs.439-443. También, AAC. Zenón Bustos Obispo. Caja No 3, f.944.

${ }^{66}$ ASV. Congregaziones Concistoriales, relationes diocesis, $N^{\circ} 260$. Relación del Estado de la Diócesis de Córdoba en la República Argentina, 1913.
} 
en 1927, los alumnos llegaron a ser sacar. Sin embargo, la percepción que tenían las autoridades era que el clero no alcanzaba a satisfacer las necesidades.

\subsection{El Plan de Estudios}

El proceso de formación de este nuevo clero fue progresivo. El Sínodo de $1877,{ }^{68}$ disponía, en sintonía con el Concilio Vaticano I, la necesidad de fijar las estrategias institucionales para "restablecer la disciplina eclesiástica, restaurar la sana doctrina, [...] para proveer por este medio el mejor gobierno de la diócesis y reformar las costumbres". 69 Este sínodo enmarcaba una serie de medidas institucionales que llevarían a la transformación de la diócesis en una diócesis "romanizada". La reforma del seminario diocesano fue uno de sus objetivos. La asamblea dictó trece cláusulas, inspiradas en el Concilio de Trento, destinadas a mejorar el funcionamiento del instituto. Entre otros aspectos, dispuso no permitir la permanencia en el seminario de jóvenes que no manifestaran tendencia al estado eclesiástico y que no observaran una conducta regular y edificante. Se reguló también la vida de piedad que debían seguir los alumnos: asistir diariamente a misa, hacer oración mental, confesarse una vez a la semana, asistir mensualmente a un día de retiro y hacer una vez al año ocho días de ejercicios espirituales. ${ }^{70}$

El plan de estudios se estructuraba en dos años de estudios preparatorios, tres años de filosofía y cuatro de teología (Altamira, 1843: 333-334). Esta estructura pedagógica remite a la Ratio Studiorium Ignaciana, que preveía cinco años de estudios inferiores (ínfima, media, suprema, humanidades y retórica), es decir, tres años de gramática, uno de humanidades y uno de retórica. Los estudios superiores comprendían las carreras de Filosofía y Teología. La primera se extendía por un trienio, en el primer año se dictaba lógica y matemática; en el segundo, física y ética y, en el tercero, metafísica, psicología y matemática superior (al primer año solía llamársele Lógica, al segundo Física y al tercero Metafísica). La teología abarcaba cuatro años. La Ratio incluía, además, una

\footnotetext{
${ }^{67}$ REOBA, 1914, p. 637 y 1916, p. 477.

${ }^{68}$ Un análisis pormenorizado del Sínodo fue realizado por ARANCIBIA y DELLAFERRERA (1983: 548).

${ }^{69}$ AAC. Actas de las Sesiones del Sínodo Diocesano, celebrado en esta Santa Iglesia catedral de Córdoba, el año mil ochocientos setenta y siete por el Ilmo. Sr Obispo de esta diócesis Dr. Dn. Manuel Eduardo Álvarez, f.499; Sínodo Diocesano celebrado en Córdoba, por el Ilmo. y Rmo. Señor Obispo Don Fray Bustos y Ferreira, en el año del Señor MCMVI. Resoluciones y Apéndices. Apéndice "El Sínodo Diocesano de 1877", Córdoba, La Industrial, 1907, 265 pp.

${ }^{70}$ AAC. Sínodo Diocesano de 1906, p. 80.
} 
serie de prácticas de piedad, como la asistencia diaria a misa, oración, examen de conciencia, lectura y meditación de libros piadosos, frecuencia de sacramentos.

En 1905, el Obispo Bustos nombra una comisión destinada a reformar el Plan de Estudios. El rector del seminario informaba en 1906 que la comisión había formulado un plan de estudios que se había comenzado a implementar desde el comienzo de dicho año, pero que era imposible adoptarlo de manera integral debido al escaso número de profesores con que se contaba. Siguiendo dicho plan, las clases de primer año de teología sobre la Trinidad, Deo Trino, aumentaron a quince horas semanales, de once que tenía el plan anterior, las de segundo de once a trece: se establecieron dos clases semanales de canto y dos cursos de italiano para teólogos y filósofos con dos clases semanales cada uno. La reforma del plan continuó y, poco a poco, se incorporaron nuevas materias y se suprimieron otras. ${ }^{71}$ Se suprimió la enseñanza de la literatura en el segundo año de filosofía, reemplazándola por las asignaturas de Geología y Paleontología y se aumentaron las horas de estudio de Física. En 1912, se crea la cátedra permanente de Sociología, "para que el clero se ilustre en los estudios sociales y se asocie al movimiento práctico de las obras con que puede ayudar poderosamente a salvar situaciones penosas económicamente y a veces angustiosas para las creencias religiosas de los fieles cuya dirección espiritual se les confía". ${ }^{72}$ El nuevo obispo, en sintonía con el pensamiento de León XIII, consideraba necesario aprovechar los conocimientos y avances de las ciencias modernas y utilizar el discurso de la razón para dar respuestas a los cuestionamientos del mundo. Compartía la capacidad transformadora que el discurso de la modernidad liberal le otorgaba a la ciencia y a la técnica, rescataba el aporte de las ciencias sociales para la explicación y solución de los problemas que convulsionaban a los sectores obreros. Unía la racionalidad instrumental de la modernidad a las inspiraciones de justicia y paz evangélicas, a su entender, ambas, unidas, podían hacer desaparecer la lucha entre obreros y capitalistas. ${ }^{73}$

El seminario había implementado en 1914 un curso preparatorio para aquellos que ingresaban sin la preparación requerida. El curso de Humanidades duraba cuatro años, los alumnos cursaban latín dos horas diarias todos los años. Gramática castellana, aritmética, geografía, religión, historia argentina, aritmética razonada, retórica y poética, álgebra, francés e italiano, eran las materias que conformaban los estudios humanísticos.

\footnotetext{
71 AAC. Leg. 11. Seminario Conciliar de Córdoba, 1906-1909. Plan de Estudios del Seminario de Córdoba (Tabla 25) y Visitas Parroquiales, 1916-1922, p. 7. Auto de Visita al Seminario del 07/12/1916.

${ }^{72}$ REOBA, 1912, p. 439.
} 
Tabla 25

Plan de estudios del seminario Conciliar, 1906

\begin{tabular}{|c|c|c|}
\hline AÑO & MATERIA & HORAS SEMANALES \\
\hline \multicolumn{3}{|c|}{ HUMANIDADES } \\
\hline \multirow{5}{*}{$1^{\circ} \mathrm{AÑO}$} & Latín & 15 \\
\hline & Gramática castellana & 2 \\
\hline & Aritmética & 2 \\
\hline & Geografía & 2 \\
\hline & Historia Sagrada & 1 \\
\hline \multirow{6}{*}{$2^{\circ} \mathrm{AÑO}$} & Latín & 13 \\
\hline & Gramática castellana & 2 \\
\hline & Geografía & 2 \\
\hline & Historia Argentina & 2 \\
\hline & Aritmética & 2 \\
\hline & Historia Griega & 1 \\
\hline \multirow{5}{*}{$3^{\circ}$ AÑO } & Latín & 11 \\
\hline & Francés & 2 \\
\hline & Aritmética razonada & 3 \\
\hline & Historia Romana & 3 \\
\hline & Nociones de Literatura castellana & 2 \\
\hline \multirow{4}{*}{$4^{\circ}$ AÑO } & Retórica y Poética latina & 11 \\
\hline & Francés & 2 \\
\hline & Algebra & 4 \\
\hline & Literatura castellana & 2 \\
\hline \multicolumn{3}{|c|}{$\begin{array}{r}\text { FILOSOFÍA } \\
\end{array}$} \\
\hline \multirow{3}{*}{$\begin{array}{l}5^{\circ} \text { AÑO } \\
\left(1^{\circ} \text { de filosofía }\right)\end{array}$} & Lógica y Ontología & 8 \\
\hline & Geometría y Trigonometría & 5 \\
\hline & Historia de la Edad Media & 2 \\
\hline \multirow{4}{*}{$\begin{array}{l}6^{\circ} \text { AÑO } \\
\left(2^{\circ} \text { de filosofía }\right)\end{array}$} & Cosmología y Psicología & 5 \\
\hline & Física y Matemática elementales & 5 \\
\hline & Historia Natural & 3 \\
\hline & Historia Moderna & 2 \\
\hline \multirow{5}{*}{$\begin{array}{l}7^{\circ} \text { AÑO } \\
\left(3^{\circ} \text { de filosofía) }\right.\end{array}$} & Teodicea & 5 \\
\hline & Derecho Natural & 5 \\
\hline & Química & 2 \\
\hline & Astronomía & 2 \\
\hline & Historia Contemporánea & 1 \\
\hline \multicolumn{3}{|c|}{ TEOLOGIA } \\
\hline \multirow{4}{*}{$\begin{array}{l}8^{\circ} \text { AÑO } \\
\left(1^{\circ} \text { de Teología }\right)\end{array}$} & Teología Dogmática & 5 \\
\hline & Escritura Sagrada & 3 \\
\hline & Derecho Público & 5 \\
\hline & Historia Eclesiástica & 2 \\
\hline \multirow{4}{*}{$\begin{array}{l}9^{\circ} \text { AÑO } \\
\left(2^{\circ} \text { de Teología }\right)\end{array}$} & Teología Dogmática & 5 \\
\hline & Derecho Canónico & 5 \\
\hline & Sagrada Escritura & 3 \\
\hline & Historia Eclesiástica & 2 \\
\hline \multirow{4}{*}{$\begin{array}{l}10^{\circ} \text { AÑO } \\
\left(3^{\circ} \text { de Teología }\right)\end{array}$} & Teología Dogmática & 5 \\
\hline & Teología moral & 5 \\
\hline & Sagrada Escritura & 3 \\
\hline & Oratoria Sagrada & 2 \\
\hline \multirow{4}{*}{$\begin{array}{l}11^{\circ} \text { AÑ } \\
\left(4^{\circ} \text { de Teología }\right)\end{array}$} & Teología Dogmática & 5 \\
\hline & Teología moral & 5 \\
\hline & Sagrada Escritura & 3 \\
\hline & Oratoria Sagrada & 2 \\
\hline
\end{tabular}

${ }^{73}$ AAC. Fondo Zenón Bustos. Conferencia sobre las cualidades de la predicación, 02/09/1918. 
Los estudios de filosofía duraban tres años y las clases se dictaban en latín, siendo este idioma el que debían utilizar también los alumnos. El método era el propuesto por Santo Tomás de Aquino en la Suma. Los estudios filosóficos se completaban con las materias de religión, historia universal, historia de la literatura, sociología, geometría, historia natural, física, química, geología y paleontología. Los estudios superiores o teológicos duraban cuatro años, las clases se dictaban en latín y en plena conformidad con el método escolástico, se enseñaba teología dogmática, sagrada escritura, teología moral, derecho canónico, teología pastoral, historia de la iglesia, elocuencia sagrada, canto gregoriano y se enseñaba la manera de llevar los libros parroquiales. Los exámenes de los cursos de filosofía y teología eran en latín. Los profesores, en su mayoría, eran egresados del Pío Latinoamericano y la Universidad Gregoriana de Roma. $^{74}$

De esta manera, el obispo apuntaba a formar un clero más instruido y anhelaba que "venga al clero de este seminario un espíritu nuevo, más adentro de las aspiraciones de la Iglesia, más adentro de la médula del evangelio, más adentro del Sagrado Corazón de Jesús, con espíritu apostólico". ${ }^{75}$ Aquel seminarista que no diera muestras claras de vocación e idoneidad para el ejercicio del ministerio, no se lo admitiría a órdenes. Habiendo solicitado un alumno la primera tonsura y las ordenes menores, el rector del Seminario informaba que "este alumno da poco indicios de inclinación a la carrera eclesiástica, es negligente para los actos de piedad y en años anteriores se le ha notado marcada inclinación a amistades particulares sin que se haya constatado nada grave en su conducta". 76

El perfil del clero esperado era eminentemente pastoral y social, se asentaba en dos principios básicos, su protagonismo como pastor de su grey y su acción social a favor del pueblo necesitado. Debía ser un hombre virtuoso y abnegado, basar su influjo en la perfección moral y ser promotor de iniciativas sociales de carácter educativo, benéfico y asistencial al servicio de las clases trabajadoras. Como se ha indicado ut supra, este modelo de sacerdote remitía a las figuras de pastor, padre, maestro y amigo. El nuevo cura no debía limitar su actividad a las funciones rituales, ni ser un cura de iglesia y sacristía, su lugar estaba fuera del templo, por lo tanto, no debía esperar que la comunidad se acercara al templo, sino que debía salir a buscar al pueblo donde éste se

\footnotetext{
${ }^{74}$ REOBA, 1916, p. 178.

${ }^{75}$ Visitas Parroquiales, 1916-1922, p. 5.

${ }^{76}$ AAC. Fondo Monseñor Lafitte, f.260.
} 
encontrara. Por este motivo, a la formación académica impartida en el seminario, se sumó la necesidad de inculcar en los alumnos una espiritualidad que contemplase la formación ascética y sentimental, para lo cual se introdujeron una serie de devociones: eucarísticas, marianas, al Sagrado Corazón de Jesús, a San José y la práctica frecuente del Vía Crucis, entre otras. ${ }^{77}$

La dirección espiritual de los alumnos estaba a cargo de un religioso jesuita, quien atendía confesiones, predicaba las pláticas y los retiros mensuales y los ejercicios anuales, con el método ignaciano de seis días de duración. ${ }^{78}$ Los alumnos eran todos internos y no se admitía "a aquellos de quienes se sospecha no tienen vocación al sacerdocio", tampoco se admitían alumnos que hubieran sido rechazados por otros seminarios, no había alumnos de otras diócesis sino por excepción. En Roma cursaban dos alumnos del seminario. Se utilizaba el reglamento prescripto por Pío X en 1913 para los seminarios de Italia.

Entre 1875 y 1925, la institución estuvo regida por el clero secular. ${ }^{79}$ Tanto sus autoridades, rector, vicerrector, prefecto de estudios y profesores clérigos eran sacerdotes cordobeses, formados en el seminario conciliar y doctorados en la Universidad de Córdoba, unos, y en el Colegio Pío Latinoamericano en Roma y en la

77 AAC. Sínodo Diocesano... Capítulo XXVI del Seminario. Visitas Parroquiales, 1916-1922. Auto de Visita al Seminario del 07/12/1916.

${ }_{78}^{7 A C}$. Fondo Zenón Bustos. Caja N 2, fs.608-610. Informe del Rector del Seminario.

79 Rectores del Seminario: Uladislao Castellano (1860-1877); Juan Martín Yaniz (1877-1888); Aquilino Ferryra (1889-1894). Ferreyra se recibió de Bachiller de Teología en la Universidad de Córdoba, completó sus estudios en el Seminario de Loreto y se ordenó en 1854. Ocupó varios cargos en el Cabildo Eclesiástico de Córdoba hasta llegar a Deán. Fue preconizado Obispo Auxiliar de la Diócesis de Córdoba y titular de Amiso. José Anselmo Luque (1894-1905). Fue ordenado presbítero por el Obispo Esquiú en la catedral de Córdoba el 18/09/1881. Sirvió como cura vicario en los curatos de Remedios y Río II Abajo. Ocupó varias sillas del Cabildo Eclesiástico, llegando a la canonjía Teologal. El 19/02/1913 fue ordenado Obispo de Fornos y Auxiliar de Córdoba y Vicario General de la Diócesis. Luis Álvarez (1905-1908). Fue alumno del Pío Latinoamericano y de la Universidad Gregoriana de Roma. Fue ordenado sacerdote en 1894. Bernardino Maciel (31/07/1908 a 01/03/1909). Renunció por desavenencias con el cuerpo de profesores y el reglamento interno confeccionado por ellos. El rector saliente dio una nota a la prensa, explicando los motivos de su renuncia y anunciando su salida del obispado y su incorporación a la diócesis de Paraná. Al finalizar el gobierno del Obispo Bustos, Maciel regresó a Córdoba y el 07/06/1930 asumió el cargo de Deán del Cabildo Eclesiástico en reemplazo del fallecido Inocencio Dávila (AAC. Leg.38. Comunicaciones con el Gobierno Nacional, T4, 1898-1910, s/f. Nota del Obispo comunicando el nombramiento de Bernardino Maciel en reemplazo de Luis Álvarez. Diario La Patria, 16/03/1909 y BEDC, vol. VII, nº 7, julio 1930, p. 264). Inocencio Dávila (1909-1923). Fue ordenado presbítero en 1897. Se desempeñó como cura y vicario de Tulumba. Ocupó las sillas del Cabildo Eclesiástico hasta llegar a Deán en 1923. En 1914 fue nombrado Obispo de Ostracine in partibus infidelium y auxiliar de Córdoba. Carlos Vera Vallejo fue nombrado rector del seminario en 1923. Fue alumno del Pío Latinoamericano y de la Universidad Gregoriana. Recibió el presbiterado en Roma en 1915. Luego viajó a Bélgica a hacer experiencia en la organización del catolicismo social. 
Universidad Gregoriana, otros. En 1912, el 80\% del profesorado se había formado en Roma. $^{80}$

\subsection{La biblioteca del seminario}

Al asumir el obispado Zenón Bustos, advierte que en el seminario sólo "se encontraron algunos libros acomodados en una alacena sin orden ni concierto, que por ser tan pocos en número no se diría que existía una biblioteca". ${ }^{81}$ A partir de este pequeño grupo de libros, el obispo comenzó a formar una biblioteca que llegó a tener 2.500 volúmenes. "Siendo las materias canónicas de las que más se carecía y las que más se necesitaban para la instrucción del clero, se formó nuestra principal aspiración, la adquisición de libros de esta clase, habiéndose logrado hasta el presente reunir una considerable cantidad de las obras principales de este género, antiguas y modernas, hasta tener la última palabra de los escritores, compiladores de decretos de diversos géneros, canonistas del derecho en general, regularistas y moralistas". ${ }^{82}$ Además, el obispo, para "robustecer el intelecto del clero", se preocupó de "prepararle conocimientos de variada erudición, que pueden escoger, asimilarlas y esparcirlas después beneficiosamente sobre el pueblo [...] Se ha puesto también interés en reunir una buena cantidad de obras que traten materias relacionadas con la Argentina, de autores extranjeros y criollos y hasta la fecha ya son bastante numerosas las existentes que pueden ser consultadas en la biblioteca. Se seleccionan además revistas importantes como "La Religión" de Chile, el "Diario de Sesiones del Congreso", "El Boletín Oficial" también Nacional [...]. La suma total de volúmenes que forman por el momento la biblioteca es la de dos mil quinientos más o menos". ${ }^{83}$

\section{Seminaristas que accedieron a órdenes: cuando la necesidad prima sobre el ideal}

Algunos datos de los ordenandos a partir de 1875, nos permiten también inferir las características del nuevo perfil del clero que se delineaba. Los expedientes de órdenes dan cuenta de una serie de candidatos, algunos de ellos de origen inmigrante, que no

\footnotetext{
${ }^{80}$ Nos referimos a Ramón Gil Luque Ferreira, Rafael López Cabanillas, Antonio Álvarez, Carlos Echenique, Abel Bazán, David Luque, Horacio Ferreira, Froilán Ferreira, Vicente Ferreira, Alejo Ríos, Alejandro Miguens Parrado, Raymundo González, Juan Carlos Vera Vallejos, Audino Rodríguez, José Butler, Luis Álvarez, Juan Gómez.

${ }^{81}$ AAC. Fondo Zenón Bustos. Caja $\mathrm{N}^{\circ}$ 3, f.734.

${ }^{82}$ AAC. Fondo Zenón Bustos. Caja $N^{\circ} 3$, f.735.

${ }^{83}$ AAC. Fondo Zenón Bustos. Caja N 3, fs.737-738.
} 
reunían las condiciones intelectuales para acceder a las sagradas órdenes, sin embargo, su piedad y moralidad primaron a la hora de conceder el permiso para la ordenación.

A modo de ejemplo, presentamos el caso de Donato Latella, quien había iniciado sus estudios en el seminario de la Arquidiócesis de Acerenza y solicitó, en 1888, ser ordenado en Córdoba. El rector informa que "le es completamente desconocida la preparación científica del joven, pues en el establecimiento no había cursado ninguna materia en los pocos meses que había permanecido. Antes bien, por referencias de personas fidedignas, este joven no estaba preparado para recibir las sagradas órdenes". El tribunal examinador le confirió la calificación de regular y lo habilitó para recibir las sagradas ordenes hasta el presbiterado inclusive, concediéndosele "la ordenación extra tempora con dispensa de los intersticios y el título canónico por exigirlo así la necesidad de la Iglesia". ${ }^{84}$ En el caso de Francisco Magnoni, oriundo de La Rioja, era poseedor de una beca del seminario, había tenido dificultades para terminar su carrera eclesiástica "a causa de su poca aptitud para los estudios". Sin embargo, "como siempre se había mostrado un joven piadoso, celoso de su bien espiritual y deseoso de abrazar la carrera eclesiástica con el fin de salvar almas", también fue admitido a las órdenes sagradas. ${ }^{85}$ José López González, oriundo del curato de Río Segundo y establecido en la ciudad, según un testigo, "pertenece a la clase trabajadora y humilde". En el examen previo a recibir las órdenes, el tribunal advierte, en su dictamen, que "contestando éste con algún acierto muchas de las preguntas que se le hicieron en el espacio de una hora y cuarenta minutos que duró el examen, revelando en su desempeño estudio, si bien no tiene una preparación suficiente en esta ciencia tan vasta [...] En consecuencia el tribunal califica el examen de regular" y se lo admite a órdenes bajo el título de necesidad de la Iglesia. ${ }^{86}$

Estos casos, que no son los únicos, nos hacen pensar que la necesidad de clérigos primaba sobre las condiciones intelectuales de los candidatos. Estos casos muestran, por un lado, la urgencia de contar con clérigos para la atención de las nuevas poblaciones inmigrantes y, por el otro, cómo se forjó este nuevo perfil de clero diocesano compuesto por hombres piadosos, con una conducta moral recta, aunque no necesariamente doctos. Este nuevo tipo de cura estaba destinado a la atención pastoral de las almas, motivo por el cual sus cualidades principales debían ser la piedad, la ejemplaridad en la conducta moral y la abnegación en el ejercicio del ministerio. El modelo no sólo remite a la figura

\footnotetext{
${ }^{84}$ AAC. Leg. 24, TX, 1883-1889.

${ }^{85}$ ACC. Leg. 24, TXII, 1901-1909.

${ }^{86}$ AAC. Leg. 24, TX, 1883-1889.
} 
del Cura de Ars, patrono de los párrocos, ${ }^{87}$ sino también que está en sintonía con la realidad social diocesana. ${ }^{88}$ El rápido movimiento poblacional, fruto de la gran oleada inmigratoria, presionó sobre las estructuras administrativas eclesiásticas. El clero no era suficiente para satisfacer las necesidades espirituales de una diócesis, cuya población crecía a ritmos acelerados.

\section{Formación permanente del clero}

Una vez ordenados de presbíteros, el clero continuaba su formación mediante las conferencias de moral y liturgia, en las que se presentaba un caso pastoral que se ponía a debate entre los asistentes. Inmediatamente de asumir el obispado, Zenón Bustos, inspirándose en las disposiciones del Concilio Plenario, dispuso establecer las Conferencias de Teología, Moral y Liturgia, "disponemos que estas conferencias sean restablecidas en nuestro clero con los fines de mantener frescos los recuerdos de los estudios que cursaron en el Seminario, fomentarlo con nuevos estudios y ejercicios". ${ }^{89}$ El obispo se proponía brindar herramientas a los sacerdotes con cura de almas, a fin de ayudar en la labor del confesionario, por este motivo, las conferencias se centrarían en las materias morales. Para que fuera útil al ministerio, la metodología que se aplicaba era la del caso, con frecuencia extraído de situaciones de la vida real. ${ }^{90}$

Además, en 1909, el Obispo Bustos decretó la obligatoriedad -tal como se establecía en el Sínodo diocesano de 1906-, ${ }^{91}$ de que el clero joven (durante los primeros cinco años de ministerio), debía rendir examen ante los examinadores sinodales de Teología Dogmática, Moral y los decretos del Concilio Plenario. ${ }^{92}$ Los curas de campaña y de La Rioja deberían enviar por escrito la resolución de los mismos casos que presentaban en las conferencias.

\footnotetext{
${ }^{87}$ El Diario Los Principios del 10/10/1905 transcribe una nota, en la que relata que el Arzobispo de Buenos Aires, durante su permanencia en Roma, obtuvo de la Santa Sede que el nuevo Beato Juan Bautista Vianney, párroco de Ars, fuera el patrono de los curas de la capital. Para solemnizar el nombramiento tuvo lugar una gran celebración, con pontifical, en la Basílica menor del Socorro.

${ }^{88}$ El número de las colonias inmigrantes ascendió de 5 en 1877 a 268 en 1902, con un predominio del $75 \%$ de italianos.

${ }^{89}$ AAC. Libro Conferencias Eclesiásticas de Moral, Liturgia, Ascética y Teología Pastoral, f.1.

${ }^{90}$ El primer caso a resolver fue el siguiente: "Un párroco teniendo noticia de la gravedad de un feligrés, acude prontamente, le oye su confesión, le administra los sacramentos de la extremaunción y del viático y dándole la bendición in articulo mortis con indulgencia plenaria, en la formula prescripta por el Papa Benedicto XIV, lo deja y no se cuida más de él. La pregunta ¿Ha satisfecho el párroco los deberes que su ministerio le impone para con un feligrés gravemente enfermo o moribundo?

${ }^{91}$ Punto $\mathrm{n}^{\circ} 55$.

${ }^{92}$ REOBA, 1909, pp. 640-641. El Auto del 24/08/1909 establece el programa para cada año.
} 
En 1917, el obispo crea el Círculo de Estudios del Clero. En la primera conferencia dictada por el prelado diocesano, explica que dada la escasez de clero, resulta angustioso el hecho que se "viene produciendo de quedar vacantes los puestos de cura de almas y faltar sacerdotes en esta diócesis con quienes reemplazarlos. La mayor ilustración si bien no multiplica los individuos, multiplica evidentemente las aptitudes de ellos aumentando sus luces y proporcionándoles mayores recursos para extender a mayores distancias sobre el pueblo, los beneficios de las enseñanzas de su apostolado, valiéndose de la prensa, de la cátedra, del púlpito, del folleto y del libro en que puede llevar a derramar los beneficios de su instrucción sobre el mayor número de individuos y las más largas distancias". 93

La temprana reforma del seminario permitió que, en pocos años, el clero egresado del instituto se adecuara al perfil deseado por la jerarquía. Según los informes elevados a Roma, con motivo de las visitas ad limina de 1892, 1908 y 1913, el clero cordobés era escaso pero comparativamente mejor y más idóneo que el común del clero nacional. El Cardenal Secretario de la Sagrada Congregación del Concilio, en su informe sobre la visita de los obispos argentinos a Roma, en 1913, señalaba que el clero argentino era muy poco respetado, tenía poco ascendiente, salvo raras excepciones. Al referirse específicamente a Córdoba, señalaba que tenía "bastante clero del país, que es bastante bueno". ${ }^{94}$ El informe sobre el clero de Buenos Aires, elevado por el arzobispo, señala que para devolver a la Iglesia su prestigio y su influencia en la sociedad, se imponía "emprender la obra de una reforma radical en el clero y para llevarla a cabo se necesita tiempo, tino y constancia". ${ }^{95}$ El obispo de Córdoba, en cambio, informaba que tenía "un clero distinguido por su ilustración, moralidad y celo en el ejercicio de sus deberes. Los párrocos, casi sin excepción, son laboriosos y de muy recomendable contracción a extirpar los vicios de entre sus feligreses, y radicar la moral, la fe religiosa y la piedad en ellos". A los "muy pocos" miembros del clero diocesano que cometían delitos, se los penalizaba y se los mantenía alejados de todo empleo. ${ }^{96}$ El Obispo Zenón Bustos informaba que el clero de la diócesis era probis et honestis. ${ }^{97}$

En síntesis, podemos decir que, en términos generales, hacia la segunda década del siglo XX, el clero secular incardinado en la diócesis había abandonado prácticas de

\footnotetext{
${ }^{93}$ REOBA, 1917, pp. 757-758.

${ }^{94}$ ASV. Nunciatura Argentina, Libro 62, f.114.

95 ASV. Nunciatura Argentina, Libro 47, f.18.

${ }^{96}$ AAC. Libro 71, Visita ad limina, 06/11/1908, f.58.
} 
cincuenta años atrás, ya no frecuentaba las carreras, ni los juegos de naipes, ni las fondas, ni las riñas de gallos y no hay registro de clero concubinario, si bien existen algunas denuncias, la mayoría interpuestas a clero inmigrante, que, en general, no fueron comprobadas (sólo hemos detectado una denuncia de conducta indecorosa, a un cura criollo, de buena familia, pero que no fue ni investigado ni sancionado), lo habitual era que llevara sotana y cumpliera el deber de residencia en el curato.

Como corolario, compartimos la afirmación de John Lynch (1991: 71) cuando señala que en el período de cincuenta años, que va de 1860 a 1910, se observa un proceso de reforma y de evangelización renovada en el que los sacerdotes nuevos edificaron un catolicismo más fervoroso y se convirtieron en los líderes de una renovación espiritual y moral en el campo. El sacerdote, en muchos lugares, era el centro de la vida de las comunidades rurales. Era el proveedor de misas y sacramentos, una fuente de información y un medio de cultura rural.

En cuanto a su participación en la vida política, la repuesta al mandato del obispo no fue unívoca, ya que se trataba de modificar una tradición clerical de larga data. ${ }^{98}$ Sí puede decirse que supuso, al menos, una limitación y un control a la actividad del clero en este campo.

Por todo lo expuesto, podemos concluir que el seminario diocesano de Nuestra Señora de Loreto constituyó un instrumento clave en la difusión y consolidación del proceso de romanización en el territorio de la República Argentina. Como veremos más adelante, muchos de sus alumnos ocuparon altos cargos de gobierno y formación en varias de las diócesis argentinas en los años venideros. Buenos Aires, Córdoba, Paraná, Tucumán, Santiago del Estero, Catamarca, Río Cuarto, La Rioja y San Juan de Cuyo, contaron con obispos formados en el Seminario de Córdoba. Una vez caracterizado el perfil deseado del clero, nos adentraremos en la composición del grupo, cuántos y quiénes fueron sus miembros.

\footnotetext{
${ }^{97}$ ASV. Informe de la Visita ad limina de 1913. Congregaciones Consistoriales, Relaciones Diócesis, $\mathrm{N}^{\circ}$ $260,40$.

98 AAC. Zenón Bustos. Carta a Ramón Cárcano, 06/04/1917. "No es raro que los civiles no aprecien bastante la escasez del clero, cuando los mismos del clero, los apasionados por las bancas, hacen el papel de no comprenderlo".
} 


\section{Capítulo 11}

\section{La composición del clero secular}

\section{El clero existente en 1875}

Nos resultó sumamente arduo lograr una estimación del clero existente en la diócesis en 1875. No encontramos ninguna fuente (informes, cartas pastorales, notas de secretaría, etc.), que aportara este dato, por lo tanto, procedimos a reconstruir el grupo con las fuentes disponibles. Los expedientes y libros de órdenes, los libros de autos y las actas del cabildo, nos permitieron identificar al clero ordenado en la diócesis y los nombramientos que se realizaron. Sin embargo, en estas fuentes no pudimos rastrear al clero residente nacional o extranjero que ejercía su ministerio en el espacio diocesano y que accedía sólo a licencias ad libitum. Para suplir este vacío, recurrimos a la información que nos brindan los libros de títulos, la correspondencia entre obispos y arzobispos, las notas de secretaría, las notas del obispo, quejas y denuncias, juicios, correspondencia con el gobierno nacional y provincial y legajos de parroquias. De cada fuente, relevamos nombre y apellido, ocupación y la mayor cantidad de datos referidos al clero que actuaba en la diócesis en el año de referencia.

Identificamos así al clero que se desempeñaba en el gobierno y la administración de la diócesis (cabildo catedral y curia diocesana), en la formación (seminario) y en la cura de almas (vicarios y ayudantes), en algunos casos no pudimos saber cuál fue su desempeño, por lo que los ubicamos como de ministerio libre. Algunos compartían más de un campo de acción, sobre todo en relación al gobierno, administración y formación, de esta manera, incluimos estos tres rubros en un mismo campo, quedando conformados en esta tabla tres campos (gobierno; clero parroquial; otro). En cuanto a "la cura de almas", encontramos que algunos curatos estaban servidos por el clero regular, motivo por el cual incluimos a los religiosos que se desempeñaron en esa tarea. Otro dato significativo es la presencia de clérigos secularizados, es decir ordenados presbíteros en el marco de una orden religiosa y luego incorporados al clero secular. Por último, aparecen algunos clérigos regulares exclaustrados que continúan con el hábito de su orden, estos quedaron englobados en el campo de religiosos.

Los datos recogidos nos permiten concluir que la diócesis contaba, en 1875, con un número aproximado de 55 sacerdotes seculares ordenados e incardinados en la diócesis de Córdoba, denominados en las fuentes como “domiciliarios" (serían los diocesanos), 
a éstos se suma un número de clérigos seculares denominados "residentes" (serían extra-diocesanos) y otros llamados "residentes pero admitidos como domiciliarios" (vale decir, que funcionaban como si fueran diocesanos sin estar incardinados en la diócesis), para nuestro estudio los consideramos extra-diocesanos. Estas dos últimas categorías estaban constituidas por sacerdotes en su mayoría extranjeros.

\subsection{Distribución, funciones y cargos}

El año 1875 arroja un total de 83 clérigos seculares distribuidos como muestra la Tabla 26 (cfr. Tabla 11 en Anexo II).

Tabla 26

\begin{tabular}{|c|c|c|c|c|c|c|c|c|}
\hline \multicolumn{9}{|c|}{$\begin{array}{l}\text { Distribución del clero } \\
\text { Córdoba } 1875\end{array}$} \\
\hline Año 1875 & \multicolumn{3}{|c|}{ Diocesanos } & \multicolumn{3}{|c|}{ Extra-diocesanos } & \multirow{2}{*}{$\begin{array}{l}\text { Religiosos } \\
\text { al servicio } \\
\text { de curatos }\end{array}$} & \multirow[t]{2}{*}{ Total } \\
\hline Nacionalidad & Argent & Extranj & $\begin{array}{l}\text { No } \\
\text { consta }\end{array}$ & Argent & Extranj & $\begin{array}{l}\text { No } \\
\text { consta }\end{array}$ & & \\
\hline $\begin{array}{l}\text { Gobierno } \\
\text { Cabildo } \\
\text { Curia } \\
\text { Seminario }\end{array}$ & 21 & 1 & 1 & 0 & 0 & 0 & 0 & 23 \\
\hline Curatos & 21 & 4 & 1 & 1 & 20 & 3 & 4 & 54 \\
\hline Otro* & 4 & 1 & & & & 1 & & 6 \\
\hline TOTAL & 46 & 6 & 2 & 1 & 20 & 4 & 4 & 83 \\
\hline
\end{tabular}

Como puede observarse, las funciones de gobierno, administración y formación estaban cargo del clero diocesano argentino y cordobés. Sólo había un extranjero, en un puesto menor del coro de la catedral, se trataba de León Gallioz, oriundo de Thyl (Francia) y ordenado en la diócesis de Córdoba, que se desempeñaba como maestro de ceremonias en la catedral.

En cuanto al clero parroquial, vemos que en la ciudad de Córdoba el único curato que existía en aquél año era la Catedral, contaba con dos curas rectores diocesanos argentinos y un ayudante italiano que era el capellán del cementerio San Jerónimo. Los contabilizamos aquí, pues ninguno de los tres formaba parte del cabildo, la curia o el seminario. Como puede verse en la Tabla 26, la mayoría del clero diocesano argentino se concentraba en la ciudad. La Vicaría de La Rioja contaba con el cura rector de la Iglesia Matriz que era, a su vez, el Vicario Foráneo y visitador, y un ayudante. 
Pasemos ahora al clero parroquial de la campaña. Como se ha indicado en la segunda parte de la tesis, en 1875, los curatos de la campaña cordobesa eran veintitrés y los de La Rioja siete. Por regla general, estaban atendidos por un solo cura en calidad de Cura y Vicario, salvo algunas pocas excepciones, como los beneficios de Villa del Rosario y Calamuchita, que tenían Cura Propio. Quilino, Río de los Sauces, Sobremonte y Anejos Norte estaban a cargo de ex religiosos cordobeses secularizados. ${ }^{1}$ Los curatos de las regiones más alejadas y pobres estaban atendidos por extranjeros ( 3 diocesanos y 20 extra-diocesanos, entre los que también se encontraban religiosos secularizados), ${ }^{2}$ como sucedía también en toda la campaña riojana -salvo Chilecito-, y en los curatos del este cordobés -en aquel entonces zona de frontera-, Bell Ville, Villanueva, Villa María y Chalacea ${ }^{3}$ y las primeras colonias de inmigrantes -Sampacho y Caroya-, que estaban atendidas por curas italianos. $^{4}$

No tenemos datos del número de clérigos para otras diócesis argentinas. Sólo podemos afirmar que la diócesis de Buenos Aires tenía, en 1864, según Lynch (1991: 71), únicamente 35 sacerdotes seculares.

\subsection{Origen social}

Hasta 1875, el clero secular diocesano era mayoritariamente nativo y cordobés, como hemos visto en la segunda parte de la tesis, de familias acomodadas. Los extranjeros formados y ordenados en la diócesis eran sólo el 13\% (6 de 46). En la década del 70, sólo hemos registrado cuatro inmigrantes que, luego de transitar por un tiempo las aulas del seminario, recibieron la ordenación presbiteral: José María Mariño, según algunas fuentes era natural de Portugal y según otras de España (Santiago de Compostela), recibió las órdenes mayores hasta el presbiterado en 1870. Al año siguiente, se ordenó José Evaristo López Arcante, proveniente de la diócesis de Vitoria (España). Permaneció unos años ejerciendo el ministerio en la campaña como cura y vicario interino de Tulumba y en 1878 solicitó licencias para retirarse definitivamente de la diócesis. ${ }^{5}$ Le sigue Miguel Company, quien ingresó como alumno interno y estudiante

\footnotetext{
${ }^{1}$ Luis Tagle (Quilino); Eleodoro Fierro (Sobremonte); Francisco Pérez (Río de los Sauces); Nemesio Ibáñez (Anejos Norte). Todos ex mercedarios.

${ }^{2}$ Domingo Gherra, ex dominico (Santa Rosa de Calamuchita); Isidoro Anselmi, ex franciscano (Tercero Arriba); Tomás Gallo, ex francisano (Río Seco); Rafael Prisco, franciscano exclaustrado (administrador de Sobremonte).

${ }^{3}$ Doroteo García de la Serna, español (Bell Ville); Antonio Lima, portugués (Villa Nueva); RP Fr. Antonio Chiannea -O.F.M- (Italiano); Luis Abriola, italiano (Chalacea).

${ }^{4}$ Vicente Lorenzino (Sampacho) y Santiago Bonoris (Caroya).

${ }^{5}$ AAC. Leg. 30. Licencias Ministeriales, 1859-1932, f.109/AAC. Libro Nº 20. Títulos, 1859-1904, f.53.
} 
de $3^{\circ}$ año de Teología y Derecho. Había realizado estudios en Barcelona, luego se trasladó con su familia a Santa Fe y de allí pasó a Córdoba. Se ordenó de presbítero en 1874. Le sigue Bonifacio Gherica, cursó estudios de $3^{\circ}$ año de Teología en el Seminario Eclesiástico de Vitoria (España). Debido a la crisis en el país, se vio obligado (según relata en su solicitud a ordenes) "a buscar en alguna de las diócesis de Sud América la colocación necesaria para terminar mi carrera hasta recibir el sacerdocio a que desde mis tiernos años había aspirado". ${ }^{6}$ Llegó a la ciudad de Córdoba a fines de 1872 y el Obispo diocesano José Vicente Ramírez de Arellano, luego de visar sus credenciales e informes, lo admitió en el Seminario conciliar, en $3^{\circ}$ año de Teología, lo nombró su familiar y en 1873 le confirió la tonsura y las cuatro órdenes menores, en calidad de domiciliario de la diócesis, recibiendo también las ordenes mayores en 1874. León Gallioz, recibió todas las órdenes entre abril y junio de 1864 a la edad de 38 años. Era natural de Thyl (Francia), de la región de Saboya. Se había formado en el Instituto de los Hermanos de la Santa Familia, donde permaneció hasta 1852, cuando recibió la primera tonsura. Debido a las convulsiones sociales y políticas que comenzaron en 1849, se vio obligado a partir a Estados Unidos, en compañía del Obispo Cretin, con quien permaneció hasta 1858, año de su fallecimiento. En 1860, regresó a Francia y ahí decidió emigrar a Argentina con su familia. "Con el firme propósito de recibir las ordenes sagradas busqué para mi domicilio esta diócesis confiada a la solicitud pastoral de V.S. Ilma. de quien obtuve benévola acogida, ordenando se me hospedase en el seminario Conciliar de esta ciudad donde hasta ahora permanezco". ${ }^{7}$ La solicitud estaba acompañada de la documentación necesaria para las sagradas órdenes, entre las que figura haber quedado desligado de los votos temporales que había hecho al recibir la tonsura en el instituto de los Hermanos de la Sagrada Familia y los documentos relativos a su conducta. Una vez ordenado fue destinado al curato de San Javier, departamento de Calamuchita, como cura ayudante ${ }^{8}$.

Estos fueron los cinco clérigos extranjeros, formados y ordenados en el Seminario de Córdoba hasta 1875 , cuatro españoles y un francés.

\footnotetext{
${ }^{6}$ AAC. Leg. 24. Expedientes de Ordenes, 1860-1870, TVIII.

${ }^{7}$ AAC. Leg. 24. Expedientes de Ordenes, 1845-1865, TVII.

${ }^{8}$ AAC. Títulos, 1859-1904, f.59.
} 


\section{El clero propio: nativos e inmigrantes (1875-1925)}

A lo largo del período analizado, la composición del grupo varió, ya no encontraremos al clero secular, que nos presenta Ayrolo, cordobés en su mayoría y plenamente identificado con la elite dominante. Como veremos, el grupo se diversifica. Al interior del mismo, podemos distinguir dos grandes grupos: uno, en función de su incardinación en la diócesis el clero diocesano y extra-diocesano, que las fuentes denominan como "clero propio o domiciliario" (diocesano), compuesto por el clero formado y ordenado en la diócesis y por algunos religiosos secularizados. El otro grupo esta compuesto por el clero ordenado en la diócesis de origen, que ejerció el ministerio en Córdoba, las fuentes lo denominan "clero extraño o residente" de manera temporal o permanente (extra-diocesano). Además, encontramos otra categoría designada por las fuentes como "clero residente admitido como domiciliario", o "como si fuera propio", grupo muy pequeño, que en su mayoría era inmigrante. En relación a su origen, contamos con un clero nativo o "hijo del país" y un clero inmigrante.

No ha sido una tarea fácil determinar la cantidad de clérigos que ejercieron su ministerio a lo largo de los cincuenta años que corren entre 1875 y 1925 . Para el "clero propio" las fuentes son más accesibles, pues se cuenta con los expedientes, los libros de órdenes y las dimisorias del propio obispo para recibir órdenes fuera de la diócesis. A partir de estas fuentes, pudimos reconstruir, no sin dificultad, el clero propio o diocesano.

En cuanto al clero "extraño", inmigrante extra-diocesano, que ejerció el ministerio en el territorio diocesano, fue muy difícil de rastrear y, aún más, determinar su tiempo de permanencia. Para realizar esta ardua tarea, hemos seguido la propuesta de Giovanni Levi (1990: 48) que plantea en "La Herencia Inmaterial", "la reconstrucción de los acontecimientos y de las biografías deberá ser a menudo impresionista, alusiva y quizá imaginaria. De hecho me veré obligado a describir una pequeña población mediante indicaciones valiosas pero esporádicas, más que con una serie homogénea y confortable de datos: para cada personaje disponemos de fuentes específicas, raras veces congruentes con las que tienen de otros. Los problemas que se derivan de ello requieren un esfuerzo de imaginación por parte del lector". A partir de esta propuesta de trabajo, procuramos reconstruir, o al menos identificar, al clero secular extra diocesano inmigrante que ejerció el ministerio en la diócesis. Comenzaremos con el clero propio o diocesano. 


\subsection{Clero propio: cantidad}

La primera pregunta que nos hicimos fue referente a cuántos y quiénes eran los miembros del clero secular diocesano, y la segunda pregunta, cómo fue su distribución en el espacio diocesano.

Para reconstruir el clero propio y analizar su composición, hemos utilizado las fuentes que se referencian en la primera parte de la tesis (Cap. 3: punto 2).

Las autoridades diocesanas permanentemente denunciaban la escasez de clero y la necesidad de promover vocaciones para el seminario, a fin de poder contar con cantidad de "clero propio". Esta es una constante a lo largo de todo el período analizado. Los obispos son reincidentes en proclamar la escasez de clero.

La Tabla 27 sobre las ordenaciones presbiterales del clero secular de Córdoba y confeccionada con la información extraída de las fuentes arriba mencionadas, permitió establecer el número de ordenaciones de clérigos seculares diocesanos, tanto nativos como extranjeros. A continuación, presentamos los resultados.

Tabla 27

\begin{tabular}{|c|c|}
\hline \multicolumn{2}{|c|}{$\begin{array}{l}\text { Ordenaciones presbiterales del clero secular de Córdoba } \\
\qquad 1875-1925\end{array}$} \\
\hline Años & $\mathbf{N}^{\circ}$ Ordenaciones \\
\hline $1875-1879$ & 5 \\
\hline $1880-1884$ & 16 \\
\hline $1885-1889$ & 12 \\
\hline $1890-1894$ & 11 \\
\hline $1895-1899$ & 18 \\
\hline $1900-1904$ & 11 \\
\hline 1905-1909 & 23 \\
\hline $1910-1914$ & 15 \\
\hline 1915-1919 & 12 \\
\hline $1920-1925$ & 22 \\
\hline TOTALES & 145 \\
\hline \multicolumn{2}{|c|}{$\begin{array}{l}\text { Fuentes: AAC. Leg. 24. Expedientes de Ordenes/Libros } 23 \text { (Ordenes), } 24 \text { (Clero } \\
\text { secular de la diócesis de Córdoba)/Boletín del Obispado de Córdoba, 1924-1928. Para } \\
\text { ver las referencias nominales, véase Tabla } 12 \text { en Anexo II. } \\
\text { * Se ha trabajado con el clero secular diocesano, ordenado en la diócesis o fuera de ella. } \\
\text { No se ha considerado el clero ordenado en Córdoba domiciliario de otras diócesis. }\end{array}$} \\
\hline
\end{tabular}


Gráfico 17

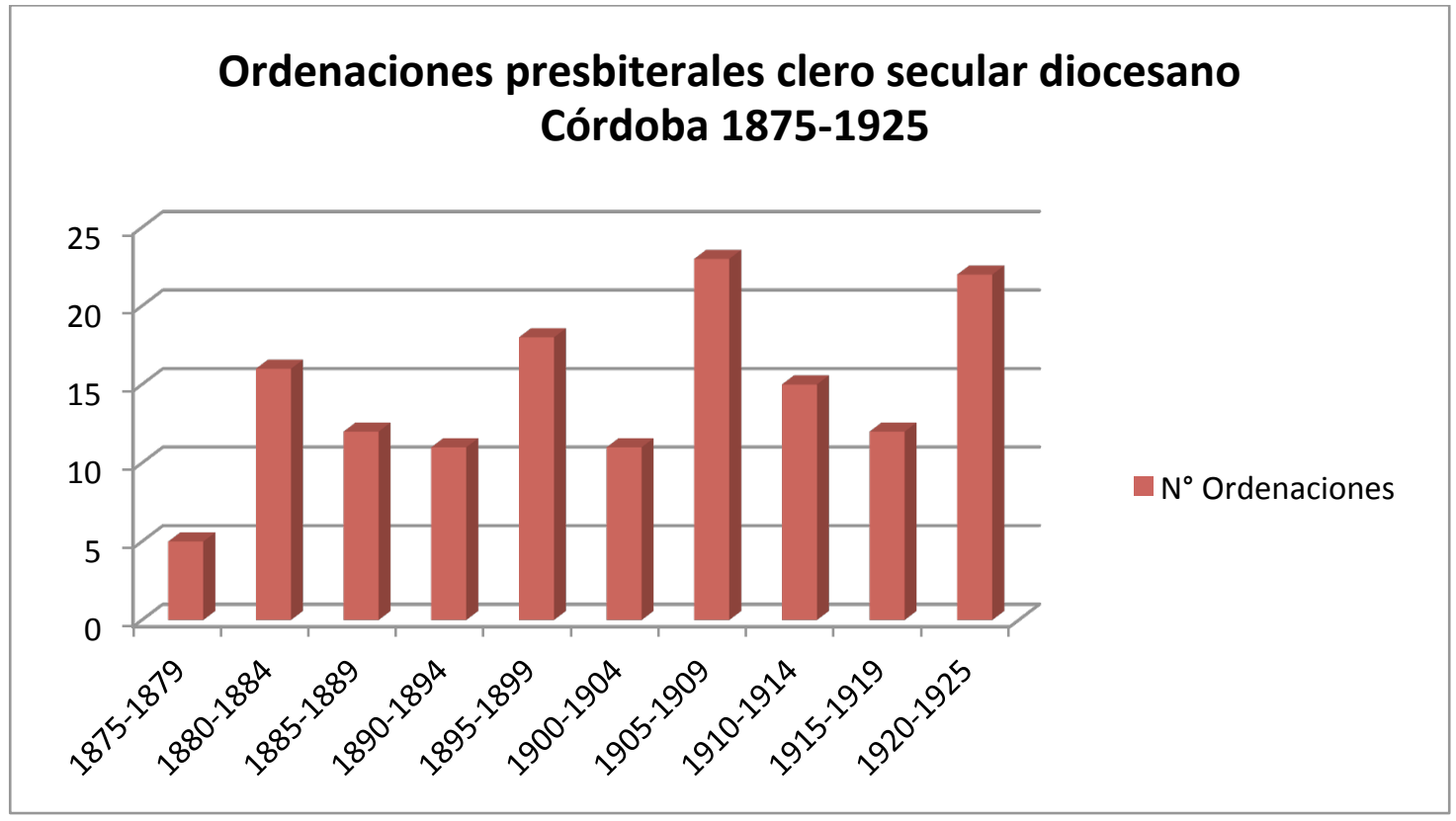

Las ordenaciones del clero, natural y/o domiciliario de la diócesis, e incardinado en la misma, alcanzaron el número de 145 entre 1875 y 1925. En función de su lugar de origen, establecimos una primera distinción entre nativos y extranjeros, estos últimos fueron sólo 30 a lo largo de estos cincuenta años de estudio, en tanto los argentinos alcanzaron el número de 115 .

Tabla 28

\begin{tabular}{|c|c|}
\hline \multicolumn{2}{|c|}{$\begin{array}{c}\text { Extranjeros ordenados y domiciliados en la diócesis. } \\
\text { Córdoba, 1875-1925 }\end{array}$} \\
\hline Años de las ordenaciones & Extranjeros \\
\hline $1875-1879$ & - \\
\hline $1880-1884$ & 2 \\
\hline $1885-1889$ & 2 \\
\hline $1890-1894$ & 4 \\
\hline $1895-1899$ & 6 \\
\hline $1900-1904$ & 3 \\
\hline $1905-1909$ & 6 \\
\hline $1910-1914$ & 3 \\
\hline $1915-1919$ & 2 \\
\hline $1920-1925$ & 2 \\
\hline Total & $\mathbf{3 0}$ \\
\hline \multicolumn{2}{|c|}{ Nota: Para ver las referencias nominales y las fuentes utilizadas, } \\
véase Tabla 12 en Anexo II.
\end{tabular}


Gráfico 18

\section{Ordenaciones Presbiterales segun nacionalidad}

1875-1925

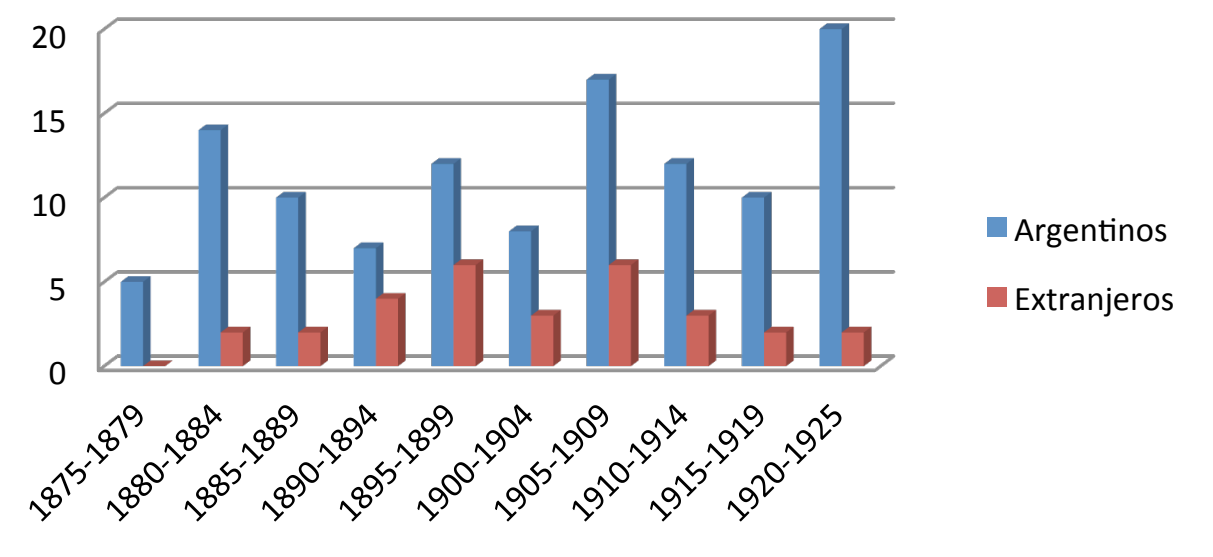

Como puede observarse en el Gráfico 18, el clero criollo fue numéricamente superior al extranjero. Lo que nos induce a establecer cierta diferencia en la tendencia que Roberto Di Stefano plantea para la diócesis de Buenos Aires, cuando señala que la carrera eclesiástica se convirtió progresivamente en patrimonio de sectores medios de origen inmigratorio, ya que a los vástagos de las familias notables no les interesaba ingresar en la carrera eclesiástica, por haber dejado de ser una opción apetecible y considerarla impropia de los nuevos tiempos (Di Stefano y Zanatta, 2000: 276). No sabemos cuál es la proporción para la diócesis de Buenos Aires, pero en Córdoba, al menos en este período, el ingreso a la carrera eclesiástica continuó siendo una opción significativa para los hijos de las familias notables. De los 145 sacerdotes diocesanos ordenados presbíteros entre 1875 y 1925, 115 eran argentinos, vale decir el 79,86\% del total. De éstos, 106 eran naturales del obispado de Córdoba, sólo 9 eran oriundos de otras provincias. En cuanto a los extranjeros, 30 fueron los que luego de haber pasado por las aulas del seminario se ordenaron sacerdotes de la diócesis, en términos porcentuales significó el 20,68\%. La Tabla 29 muestra el origen geográfico de los ordenandos. 
Tabla 29

\begin{tabular}{|c|c|c|c|c|c|c|c|}
\hline \multicolumn{8}{|c|}{$\begin{array}{l}\text { Origen geográfico del clero ordenado en la diócesis de Córdoba } \\
1875-1925\end{array}$} \\
\hline \multicolumn{4}{|c|}{ Argentinos } & \multicolumn{4}{|c|}{$\begin{array}{c}\text { Extranjeros } \\
\end{array}$} \\
\hline Cordobeses & Riojanos & Otros & $\begin{array}{l}\text { No } \\
\text { consta }\end{array}$ & Españoles & Italianos & Franceses & Otros \\
\hline 99 & 7 & 3 & 6 & 13 & 11 & 3 & 3 \\
\hline \multicolumn{4}{|c|}{115} & \multicolumn{4}{|c|}{30} \\
\hline \multicolumn{8}{|c|}{145} \\
\hline \multicolumn{8}{|c|}{$\begin{array}{l}\text { Fuentes: Leg. } 24 \text { (Expedientes); Libros: } 23 \text { (Ordenes); } 24 \text { (Registro del clero secular de la } \\
\text { diócesis); BEDO, 1924-1928. }\end{array}$} \\
\hline
\end{tabular}

Por lo tanto, sin ninguna duda podemos afirmar que en la Iglesia diocesana de Córdoba la carrera eclesiástica siguió siendo una opción significativa para sus habitantes y, como veremos más adelante, ser miembro del clero seguía otorgando prestigio y status social.

Esta hipótesis se refuerza si tenemos en cuenta que también ingresó al clero regular un importante número de miembros de familias patricias cordobesas. Las órdenes religiosas tuvieron en Córdoba un prestigio que se recuperó luego del período de crisis que atravesaron a mediados del siglo XIX y que dio como resultado la elección de cuatro obispos religiosos (Esquiú, Tissera, Toro y Bustos), los tres últimos residentes en Córdoba. Las ordenaciones del clero regular también fueron significativas, 119 candidatos aportados por las diversas congregaciones religiosas que tenían Seminario en Córdoba (franciscanos, dominicos, mercedarios, carmelitas, escolapios, salesianos y jesuitas) recibieron el presbiterado entre 1875-1925. No establecimos su procedencia geográfica, ya que no trabajamos sus expedientes a órdenes, pero los registros asentados en libro de órdenes nos permitieron realizar la comparación entre las ordenaciones de ambos cleros y verificar que ambas mantuvieron un equilibrio y una proporción análoga. Era frecuente que miembros de una misma familia ingresasen tanto al seminario, como al clero regular. ${ }^{9}$

\footnotetext{
${ }^{9}$ Ríos: Jacinto Roque (secular) y Fr. Francisco (franciscano); Chacón: Abdón (secular) y Fr. Agustín y Fr. Antonio (franciscanos); Amuchástegui: Ramón (secular) y Fr. Nicolás (franciscano); Ardiles: José Rafael (secular), Inocencio (escolapio) y Fr. Jeremías (mercedario); Buteler: Alfonso, Leopoldo, José y Benjamín (seculares) y Fr. Guillermo (dominico); Campos: Juan Carlos e Ignacio (seculares) y Fr. Ramón (mercedario); Castellano: Uladislao, Ramón y Félix (seculares) y Fr. Antonio (mercedario); Ferreira: Aquilino, Horacio, Vicente, Virgilio, Luis Lindor, Bruno, Andrés Avelino y Froilán (seculares), Avelino y Arnaldo (mercedarios) y Ramón (jesuita); Liendo: Rosendo y Ramón Amado (seculares) y Fr. Pedro Nolasco y Fr. Esteban (mercedarios); Ludueña: Miguel (secular) y Fr. Valentino, Fr. Ramón y Fr. Manuel
} 
En 1897, año en que se ordenó un número importante de clérigos, el diario "Los Principios" señalaba que "si no habría fe no habrá vocaciones religiosas y es precisamente este año cuando nuestra Iglesia los ha producido hasta ahora en número desconocido, pues entre los educandos en el seminario [fueron 9] y los conventos de regulares se han ordenado no menos de 24 jóvenes que constituirán mañana una falange en las milicias de Cristo [...]. Estos nuevos sacerdotes son una prueba mas de que la Córdoba del presente es digna de la del pasado, de la Córdoba tradicional y creyente que mereció con toda justicia ser llamada La Roma Americana" (LP, 23/12/1897).

Tabla 30

\begin{tabular}{|c|c|}
\hline \multicolumn{1}{|c|}{$\begin{array}{c}\text { Ordenaciones presbiterales del clero regular } \\
\text { Córdoba 1875-1925* }\end{array}$} \\
\hline Año & Clero regular \\
\hline $1875-1880$ & 15 \\
\hline $1881-1885$ & 8 \\
\hline $1886-1890$ & 18 \\
\hline $1891-1895$ & 30 \\
\hline $1896-1900$ & 11 \\
\hline $1901-1905$ & 10 \\
\hline $1906-1910$ & 12 \\
\hline $1911-1915$ & 10 \\
\hline $1916-1920$ & 10 \\
\hline $1921-1925$ & 130 \\
\hline Totales & \multicolumn{2}{|c|}{} \\
\hline $\begin{array}{l}\text { Fuentes: Ordenes, 1876-1925. } \\
\text { Nota: * Se ha trabajado con el clero regular ordenado en la diócesis, no se ha discriminado por } \\
\text { el origen geográfico de los ordenandos porque las fuentes no lo permitieron. }\end{array}$ \\
\hline
\end{tabular}

La suma de las ordenaciones al presbiterado de regulares y seculares es de 275 individuos a lo largo de todo el período. De éstos, el 52,72\% corresponde al clero secular y el 47,27\% al regular. No tenemos datos para otras diócesis argentinas en el mismo período. Como puede observarse, las ordenaciones del clero secular son levemente superiores a las del regular, lo que nos estaría indicando que las preferencias de ingreso a uno u otro clero eran equivalentes.

El clero diocesano no estaba formado sólo por aquellos alumnos del seminario que accedieron a órdenes. Cabe aclarar que algunos clérigos regulares solicitaron, luego de su ordenación, la secularización y, de esta manera, pasaron a formar parte del clero secular diocesano. Hemos identificado 17 regulares en esta situación, algunos se

(franciscanos); Taborda: Juan y Roque (seculares), Fr. Venancio (mercedario) y Fr. Josemaría (franciscano); Tissera: Luis (secular) y Fr. Capistrano y Fr. Bernardino (franciscanos); Varas: Ramón y Juan (seculares), Fr. Agustín (mercedario) y Juan J. (jesuita). 
desempeñaron como curas libres y a otros se les concedió la cura animorun, y fueron destinados a los curatos de la campaña (cfr. Tabla 13 en Anexo II). Más escasas fueron las incardinaciones de clero extra-diocesano.

También encontramos algunos pocos clérigos que, una vez ordenados, ingresaron en alguna orden religiosa, jesuitas y salesianos, y, en menor escala, hubo quienes se trasladaron a otras diócesis.

Esta es la estimación que hemos podido hacer del clero activo de la diócesis en el período de estudio. Además, por algunas fuentes, como el libro de registros del clero secular y los informes de las visitas ad limina, sabemos que el clero secular diocesano en actividad estaba compuesto, en 1905, por 114 individuos; ${ }^{10}$ en 1910 , por 117 , y en 1925 , por $129 .{ }^{11}$

\subsection{Carrera eclesiástica: nivel de perseverancia/deserciones}

Una vez resuelta la cantidad de clérigos, nos preguntamos cuál fue el porcentaje de alumnos que comenzaron la carrera, recibieron las primeras órdenes pero que no llegaron a finalizarla $y$, de esta manera, determinar cuál fue el nivel de perseverancia una vez iniciada la carrera clerical.

Como es bien sabido, la carrera clerical está compuesta de diversos escalones, el último es la ordenación en in sacris, el presbiterado y, eventualmente, el episcopado. San Isidoro de Sevilla en el siglo VII describe los diversos ministerios clericales, cuyos grados y denominaciones se mantuvieron por siglos: Ostiario, Salmista, Lector, Exorcista, Acólito, Subdiácono, Diácono, Presbítero y Obispo. La carrera comienza con la primera tonsura, que no es propiamente un orden, sino "una preparación para recibir las órdenes", la tonsura consagra al candidato a Dios con el corte del cabello -símbolo de lo que deberá ser en su vida-, abre la puerta para el sacramento del orden. El tonsurado queda convertido en "clérigo" e incardinado adscripto a una diócesis. Luego se confieren las llamadas órdenes menores, que podían recibirse juntas o separadas. Estas son cuatro, las dos primeras denominadas ostiariado y lectorado y las dos últimas llamadas exorcistado y acolitado. La tonsura y cuatro órdenes menores se conferían a

\footnotetext{
${ }^{10}$ ASV. Congregaciones Consistoriales, Relaciones Diócesis, № 260.

11 AAC. Registro del clero secular de la diócesis, 1905-1909, IEA, Nómina Completa del Clero de la Diócesis, Córdoba, 1927, 32 p.
} 
los alumnos de segundo y tercer año de Filosofía. ${ }^{12}$ Recibidas éstas, el candidato adquiere el status de clérigo minorista.

La segunda etapa de la carrera clerical establece la recepción de las llamadas órdenes mayores o sagradas, el subdiaconado, el diaconado y el presbiterado u-ordenación in sacris. La primera se confería en el tercer año de Teología, la segunda en el cuarto y el presbiterado a quienes hubieran aprobado todas las materias del último año. ${ }^{13}$ Todas las órdenes se recibían previo ejercicio espiritual ignaciano. Este largo recorrido estaba previsto realizarlo en diez años, tiempo que duraban los estudios eclesiásticos en el seminario conciliar de Córdoba. Entre las ordenaciones debía transcurrir un tiempo prudencial denominado intersticio. ${ }^{14}$ Sin embargo, con frecuencia, y sobre todo en la segunda mitad del siglo XIX, varios candidatos fueron ordenados con dispensa de los correspondientes intersticios, las causales fueron la edad avanzada del candidato, o las sede vacancias, o la necesidad de clero.

En el período analizado, la decisión de permanecer en el estado clerical, luego de la primera tonsura, es elevada, cerca del $70 \%$ de los clérigos que accedieron a las órdenes menores alcanzaron el presbiterado; los seculares lo hicieron en un $73 \%$ y los regulares en un $72,94 \%$.

Hemos detectado sólo 30 clérigos seculares que se iniciaron en la carrera eclesiástica pero no accedieron al presbiterado. Por lo tanto, las deserciones del clero secular se encontraban en el orden del 20,6\%. En cuanto al clero regular, el porcentaje era un poco mayor, alcanzando el 39,28\%. De todos modos, estos porcentajes son relativamente bajos si los comparamos con etapas anteriores. Realidad que podría estar dando cuenta de la progresiva especialización de los seminarios.

Como ya hemos indicado, el ingreso de los alumnos al seminario conciliar, a partir de 1875 , estaba supeditado a que tuvieran verdadera "inclinación al estado eclesiástico".

\footnotetext{
${ }^{12}$ REOBA, 1914, pp. 474-479. Informe del Seminario Conciliar elevado por el Obispo Zenón Bustos a la Sagrada Congregación de Seminarios y Universidades.

13 El Código de Derecho Canónico de 1917 establece que: "Nadie, sea secular o religioso, debe ser promovido a la primera tonsura antes de haber comenzado el curso teológico. No debe conferirse el subdiaconado si no es hacia el fin del tercer año del curso teológico; ni el diaconado antes de haber comenzado el cuarto año; ni el presbiterado si no es después de la mitad del mismo cuarto año. El curso teológico debe ser hecho no privadamente, sino en algún centro docente de los fundados para eso según el plan de estudios determinado en el canon. 1365" (CIC. 976). La edad legítima para acceder a las sagradas órdenes establecida por el Código: "No debe conferirse el subdiaconado antes de haber cumplido veintiún años de edad; ni el diaconado antes de haber cumplido los veintidós; ni el presbiterado antes de haber cumplido los veinticuatro" (CIC. 975).

14 "Las órdenes han de conferirse según orden de graduación entre ellas, de tal manera que están en absoluto prohibidas las ordenaciones por salto" (CIC. 977). "En las ordenaciones han de observarse los intersticios, durante los cuales deben los ordenados ejercitarse en las órdenes recibidas, en la forma que
} 
Tabla 31

\begin{tabular}{|c|c|c|}
\hline Tonsurados y Ordenes Menores en la diócesis de Córdoba, 1875-1925 \\
\hline Año & Clero secular & Clero regular \\
\hline $1876-1880$ & 15 & 11 \\
\hline $1881-1885$ & 16 & 16 \\
\hline $1886-189$ & 10 & 18 \\
\hline $1891-1895$ & 15 & 27 \\
\hline $1896-1900$ & 25 & 61 \\
\hline $1901-1905$ & 20 & 24 \\
\hline $1906-1910$ & 16 & 21 \\
\hline $1911-1915$ & 17 & 199 \\
\hline $1916-1920$ & 17 & \\
\hline $1921-1925$ & 24 & 17 \\
\hline Totales & 175 & \\
\hline Fuente: Libro de Órdenes. & & \\
\hline
\end{tabular}

Así lo estableció el sínodo diocesano celebrado ese año que, entre otras cuestiones, dispuso no permitir la permanencia en el seminario de jóvenes que "no manifestasen tendencias al estado eclesiástico y a los que no observasen una conducta regular y edificante". ${ }^{15}$ Esta podría ser una de las claves a la hora de analizar estos números. La carrera clerical era cada vez más especializada, cuando detectaban que los alumnos no tenían condiciones y/o vocación al sacerdocio solicitaban su retiro. En 1914, el rector del seminario destacaba el reducidísimo número de alumnos que abandonó sus estudios, señalaba que sólo fueron tres y por causas justificadas. ${ }^{16}$

Entre 1875 y 1925, los extranjeros ordenados minoristas llegaron a constituir sólo un $27,27 \%$ (en números reales fueron 41 de un total de 175 ordenados).

Como podemos observar, las ordenes menores también siguieron la tendencia de las mayores aunque se nota un leve descenso de los postulantes hijos del país y un leve aumento de los extranjeros. Esta tendencia no es, sin embargo, significativa, en este sentido sería muy bueno tener datos de otras diócesis argentinas para poder comparar. 
Tabla 32

\begin{tabular}{|c|c|c|c|c|c|c|c|}
\hline \multicolumn{8}{|c|}{$\begin{array}{c}\text { Alumnos del Seminario Diocesano } \\
\text { Tonsurados y Primeras Ordenes, 1875-1925 }\end{array}$} \\
\hline & \multicolumn{3}{|c|}{ Argentinos } & \multicolumn{4}{|c|}{ Extranjeros } \\
\hline Período & Total & $\begin{array}{c}\text { Cordobeses y } \\
\text { Riojanos }\end{array}$ & Otros & Total & Españoles & Italianos & Otros \\
\hline $1876-1880$ & 9 & 9 & 0 & 3 & 2 & - & 1 \\
\hline $1881-1885$ & 17 & 16 & 1 & 1 & - & 1 & - \\
\hline $1886-1890$ & 14 & 14 & - & 3 & 1 & 1 & 1 \\
\hline 1891-1895 & 7 & 7 & - & 4 & 2 & - & 2 \\
\hline $1896-1900$ & 16 & 14 & 2 & 8 & 6 & 1 & 1 \\
\hline 1901-1905 & 22 & 20 & 2 & 3 & 1 & 2 & - \\
\hline 1906-1910 & 18 & 16 & 2 & 4 & 1 & 3 & - \\
\hline 1911-1915 & 7 & 5 & 2 & 5 & - & 3 & 2 \\
\hline 1916-1920 & 14 & 14 & - & 3 & - & 2 & 1 \\
\hline $1921-1925$ & 9 & 9 & - & 6 & - & 5 & 1 \\
\hline Totales & \multicolumn{3}{|c|}{133} & \multicolumn{4}{|c|}{41} \\
\hline
\end{tabular}

\section{Gráfico 19}

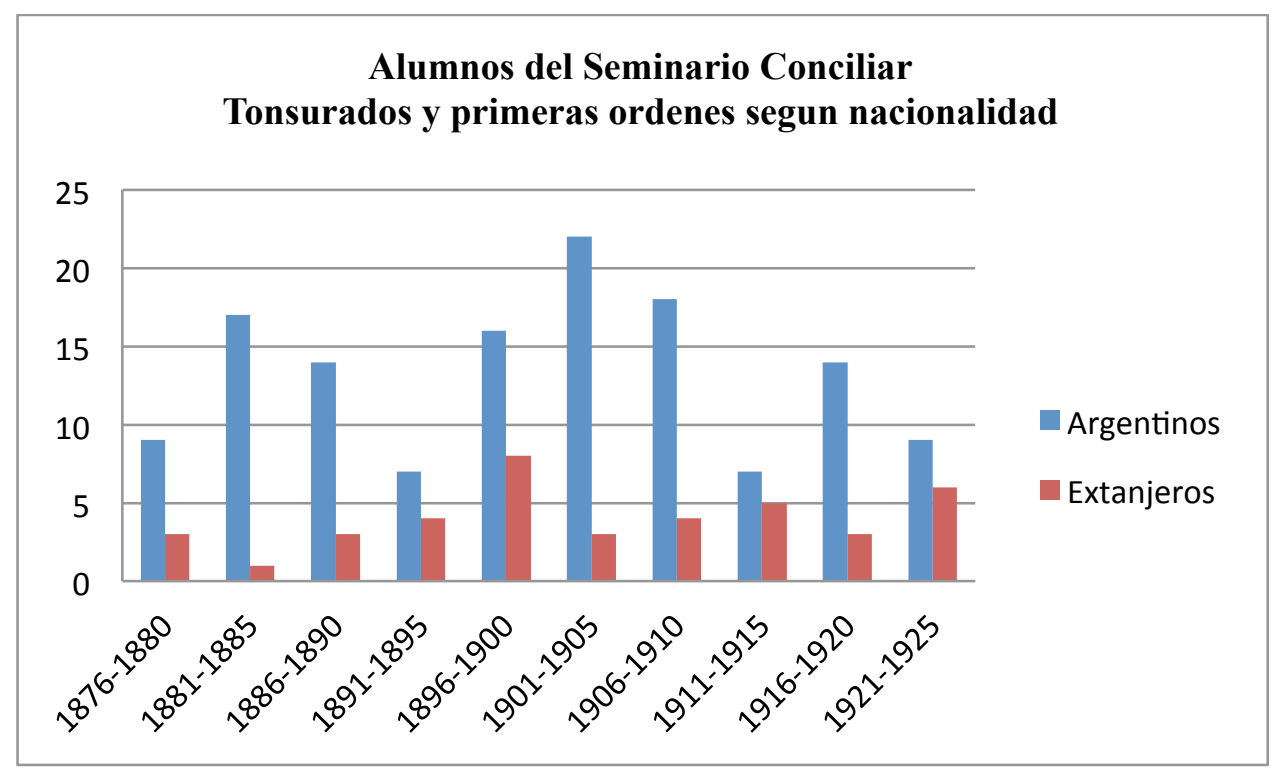

\subsection{Características socio-culturales}

En 1869, el diario "El Progreso" afirmaba que el seminario diocesano contaba con una buena cantidad de jóvenes de las familias más distinguidas. Esta afirmación no se condice con aquella creencia de que los jóvenes de las familias de la alta sociedad cordobesa ingresaban al seminario dominico o mercedario, en tanto los jóvenes de familias modestas lo hacían al seminario conciliar y al franciscano. 
Para ello, hemos analizado los títulos de ordenación a fin de verificar el status social de los aspirantes al sacerdocio. Comprobamos que de los 155 expedientes consultados, sólo siete clérigos solicitaron ordenarse a título de Congruo Patrimonio ${ }^{17}$ y tres a título de Capellanía, el resto no presentó título y fue ordenado a servicio y necesidad de la Iglesia. Por lo tanto, a partir de esta fuente, no nos fue posible establecer el nivel social de los postulantes al presbiterado. A esta dificultad, se agrega que, en este período, la declaración de testigos sobre vida y costumbres de los aspirantes a órdenes, ya no incluye la pregunta sobre si el candidato "corresponde a los nobles", el cuestionario se limita a indagar sobre las buenas costumbres y la frecuencia de los sacramentos, por ende, sólo en ocasiones muy puntuales se hace referencia al status social de la familia. Una de ellas es cuando se adjudica, en calidad de título de ordenación, una pía memoria fundada en favor de algún alumno del seminario. En la justificación se señala: "por contracción al estudio unida a su buena inteligencia lo han hecho dar un resultado satisfactorio [...] la notoria pobreza de su familia le adjudique en marzo la pía memoria". 18

Buscamos otros indicadores, indirectos pero sugerentes, para establecer el nivel sociocultural del clero secular nativo, el primero, tiene relación con la procedencia geográfica de los ordenandos. Esta variable nos podría develar cuáles fueron los grupos proveedores de vocaciones y cuáles las zonas geográficas de proveniencia. El siguiente indicador, relacionado ciertamente con la procedencia geográfica, se vincula con los grupos familiares que aportaron miembros al clero secular a lo largo de varias generaciones, $\mathrm{y}$, por último, identificar a qué familias pertenecían aquellos clérigos cordobeses que alcanzaron la cima de la carrera sacerdotal: el orden episcopal, quiénes ocuparon los cargos de gobierno (cabildo), administración (curia), y formación del clero (seminario).

\subsection{Grupos proveedores de vocaciones y zonas geográficas de proveniencia}

Una vez determinada la cantidad de clérigos seculares que accedió al presbiterado, procedimos a identificar el origen geográfico de los mismos, tarea que no ha sido para

\footnotetext{
${ }^{17}$ Nos referimos a José María Díaz, Jacinto Roque Ríos, Juan José Purcell, José Anselmo Luque, Samuel Bustos y Eduardo Ferreyra y Juan Martín Yaniz.

${ }^{18}$ Se trata de Belarmino Moyano a quien se le adjudica la Pía memoria fundada por el finado Don Mariano Vicente González, a favor de uno de los jóvenes del país que se educara en el seminario, la misma lleva la cláusula expresa de poder servir de título de órdenes a quien el Sr Rector del Seminario la adjudicara. El valor era de 3.000 pesos bolivianos (consistía en la donación de una casa cuyo el alquiler era de 20 pesos mensuales). Implicaba tres misas rezadas por mes aplicadas a las almas mencionadas.
} 
nada fácil, debido a que tanto el libro de órdenes como los expedientes no siempre registraron ese dato con precisión y sin error. Por lo tanto, hemos cotejado y complementado con otras fuentes alternativas, como correspondencia, notas de la curia, libros copiadores y legajos de parroquias. La Tabla 33 nos muestra el origen geográfico de los clérigos agrupados por regiones (cfr. Tabla 12 en Anexo II).

Tabla 33

\begin{tabular}{|c|c|c|}
\hline \multicolumn{3}{|c|}{$\begin{array}{r}\text { Zonas geográficas de proveniencia de los orde } \\
1875-1925\end{array}$} \\
\hline Región & Curatos & $\begin{array}{l}\text { Ordenes } \\
\text { Mayores }\end{array}$ \\
\hline Capital & $\begin{array}{l}\text { Catedral / Pilar / San Gerónimo /Gral. Paz /Alta Córdoba / } \\
\text { Nueva Córdoba }\end{array}$ & 18 \\
\hline Norte & Río Seco / Sobremonte / Tulumba / Ischilín / Quilino & 7 \\
\hline Oeste & $\begin{array}{l}\text { Cruz del Eje / Soto / Minas / Pocho / Tránsito / San Pedro / } \\
\text { Punilla / San Javier / San Agustín / Río de los Sauces }\end{array}$ & 7 \\
\hline Centro & $\begin{array}{l}\text { Totoral/ Chalacea / Santa Rosa / Jesús María / Caroya / } \\
\text { Remedios / Alta Gracia / Río Segundo / Villa del Rosario / } \\
\text { Tercero Arriba }\end{array}$ & 32 \\
\hline Este & $\begin{array}{l}\text { Morteros / San Francisco / San Justo / Arroyito / Villa } \\
\text { María / Villa Nueva / Bell Ville / Marcos Juárez / Cruz } \\
\text { Alta / Canals }\end{array}$ & 2 \\
\hline Sur & $\begin{array}{l}\text { Río Cuarto / Sampacho / La Carlota / Laboulaye / Gral. } \\
\text { Roca }\end{array}$ & 1 \\
\hline $\begin{array}{l}\text { Obispado de } \\
\text { Córdoba }\end{array}$ & Sin especificar lugar concreto & 31 \\
\hline La Rioja & $\begin{array}{l}\text { Ciudad / Chilecito / Famatina / Vinchina y Guandacol / } \\
\text { San Blas de los Sauces / Costa de Arauco / Los Llanos }\end{array}$ & 7 \\
\hline Otras provincias & San Juan, Santa Fe, Buenos Aires, La Plata & 4 \\
\hline Otros países & España, Italia, Irlanda, Francia, Portugal, Uruguay & 30 \\
\hline No consta & & 6 \\
\hline TOTAL & & 145 \\
\hline
\end{tabular}

Dos de las regiones que más candidatos proveyeron al clero fueron las del centro, en particular el curato de Villa del Rosario, departamento de Río Segundo, y la ciudad capital. Esto tiene su explicación, pues son curatos de antigua data y muchas de las familias más tradicionales de Córdoba estaban establecidas allí. Estos clérigos ocuparon las sillas del cabildo eclesiástico, las plazas de profesores del seminario y los curatos mejor ubicados y con rentas suficientes. Luego siguen, en orden de procedencia, las regiones del norte y el oeste y, por último, las del este y el sur. El clero de origen extranjero se ocupó principalmente en la atención de parroquias. 


\section{Familias proveedoras de vocaciones: el caso de los Ferreira ${ }^{19}$}

Nos detenemos ahora a analizar al grupo familiar que mayor cantidad de clérigos seculares proveyó a Córdoba, los Ferreira. Oriundos del departamento de Río Segundo, curato del Villa del Rosario, se trata de una familia de la aristocracia cordobesa, dedicada al comercio y al acopio de granos que, a mediados del siglo XIX, llegó a reunir una mediana fortuna. En este caso, podemos observar que han tenido clérigos a lo largo de todo el período analizado, abarcando varias generaciones. Así, podemos observar que para nuestro período de estudio, el primer obispo de la familia fue Aquilino Ferreira, ordenado presbítero en 1855 y consagrado obispo auxiliar de Córdoba en 1900, y, el último, Froilán Ferreira Reinafé, ordenado presbítero en 1913 y nombrado obispo de La Rioja en 1934.

Aquilino Ferreira nació el 4 de enero de 1824, hijo de don Francisco Froilán Ferreyra y de doña Eulalia Álvarez. Alumno del Colegio Seminario "Nuestra Señora de Loreto", el 28 de enero de 1855 recibió los grados en Teología por la Universidad de Córdoba y la ordenación in sacris. Fue cura propio del Beneficio de Río Segundo por más de 20 años, luego rector del seminario, provisor, vicario general de la diócesis, deán del cabildo eclesiástico y obispo. Su sobrino, Lindor Ferreira, hijo de Vidal Ferreira y Rosario Gómez, nació el 12 de abril de 1855 en Villa del Rosario, fue bautizado en la Iglesia de la Villa por Don Aquilino, siendo su padrino el presbítero José Gregorio Ardiles. En 1877, para acceder a las sagradas órdenes, presentó como testigos a los presbíteros Jacinto Roque Ríos (cuya madrina de Bautismo fue Josefa Ferreira), y Narciso González, hermano de Teresa González, madre de Bruno Ferreira. Bruno Ferreira nació en 1874, era hijo de Luis Ferreira y Teresa González, fue bautizado en la parroquia de Villa del Rosario por Don Aquilino. A los 20 años, en 1894, recibió las órdenes sagradas y presentó como testigos a los presbíteros Jacinto Correa y a Don Aquilino.

Nicandro Ferreira y Josefa Álvarez tuvieron tres hijos en el seminario conciliar, Nicandro, Avelino y Gil. Nicandro nació el $1^{\circ}$ de junio de 1871 y Avelino el 9 de noviembre de 1875. Ambos recibieron las primeras órdenes en 1888 y 1897, respectivamente. Avelino se ordenó de presbítero en 1899 y su hermano Gil terminó sus estudios en el Colegio Pío Latinoamericano y se ordenó en Roma. De regreso a la

\footnotetext{
${ }^{19}$ El apellido aparece en los documentos tanto con i latina como con y griega. Una misma persona es nominada de una $\mathrm{u}$ otra manera, incluso el mismo interesado escribe su nombre de una $\mathrm{u}$ otra forma. Por lo tanto, como criterio, hemos optado por elegir el de la auto-denominación. En los casos en que es
} 
diócesis, ocupó cargos en la vicaría foránea de La Rioja, en la curia diocesana, fue profesor y vicerrector del seminario y, en 1927, llegó ser vicario general y provisor del obispado.

Eduardo Ferreyra, hijo de Eleuterio Ferreyra y Dolores Pérez, cursó los últimos años como alumno externo de teología y derecho canónico en el seminario conciliar. A la edad de 30 años recibió todas las órdenes sagradas, bajo el título de congruo patrimonio por 3.107 pesos bolivianos. Durante 22 años ocupó el cargo de cura vicario en Bell Ville, pasando luego a la ciudad, donde se desempeñó como secretario del obispado y prebendado de ración en el cabildo.

En 1902, Ramón Ferreira, hijo de Ramón Ferreira y Eloísa Pérez, recibió la primera tonsura y cuatro órdenes menores, su padrino de confirmación fue Aquilino Ferreira, quien, para ese entonces, ocupaba el cargo de vicario general de la diócesis.

Horacio, Vicente y Froilán Ferreira, oriundos de la Villa del Rosario, terminaron sus estudios en el Colegio Pío Latinoamericano y recibieron las sagradas órdenes en Roma. Vicente nació el 10 de agosto de 1881 y estudió latín y humanidades en el seminario diocesano de Córdoba. En Roma, cursó filosofía y teología y a su regreso, en 1906, se incorporó al profesorado del seminario, dictando las cátedras de latín y retórica hasta 1911. A partir de esa fecha, enseñó filosofía durante doce años consecutivos, al cabo de los cuales fue nombrado vicario foráneo de La Rioja, cargo que desempeñó durante cuatro años. En 1927, fue nombrado profesor de teología dogmática, cuando lo sorprendió la muerte el $1^{\circ}$ de abril de 1930 . Por su parte, Horacio fue cura y vicario de Santa Rosa de Río Primero y le sucedió Francisco Ferreira, quien ocupó el cargo de cura y vicario de 1915 a 1952. Por último, Froilán, como ya hemos adelantado, llegó a ser obispo titular de La Rioja.

Los Ferreira, además, se vincularon matrimonialmente con los Luque, Álvarez, Liendo, López y otras familias tradicionales de Córdoba. En todas esas ramas, hay algún clérigo secular, como puede observarse en la Tabla 14 en Anexo II.

El caso Ferreira nos permite observar algunas cuestiones interesantes. En primer término, consideramos el inmenso capital relacional que detentaban. Pertenecían, por vínculos matrimoniales y de padrinazgo, al grupo dirigente cordobés. En la familia destacaron gobernadores, legisladores y hombres de la vida política, social y religiosa de la provincia mediterránea. 
Los Álvarez, relacionados con la familia Ferreira, también ocuparon el ejecutivo provincial. Juan Antonio Álvarez (1871-1874) y José Manuel Álvarez (1901-1904) fueron, respectivamente, gobernadores. En tanto, Manuel Eduardo, hermano del primero, accedió a la Mitra cordobesa, luego de haber transitado las sillas del cabildo eclesiástico. Durante la gestión del primero, la provincia inauguró la finalización del ramal del ferrocarril Córdoba-Rosario, el observatorio astronómico, se realizó la Exposición Universal, se organizó la inspección general de escuelas, el tendido de las líneas telegráficas al interior de la provincia y se inauguraron los trabajos del Ferrocarril Central Córdoba, que llegaría hasta Tucumán, y la instalación del tranvía en la ciudad. Luis Álvarez, ordenado sacerdote en 1898, se desempeñó como canónigo lectoral, profesor y rector del seminario diocesano.

Los Dávila, Porcel, Moyano, Centeno, Olmos, Rodríguez, Ríos, Ludueña, Argüello y Buteler también tuvieron, entre sus vástagos, clérigos, aunque en menor proporción que los Ferreira.

El clero perteneciente a estas familias ocupó distintas funciones de gobierno, obtuvo prebendas del cabildo eclesiástico, cargos en la curia diocesana y en el seminario, y estuvo al frente de los curatos de primer rango, suficientemente congruos, como los curatos rectorales de la Catedral y del Pilar, Vicaría de La Rioja, Remedios, Villa del Rosario, Santa Rosa de Río Primero, Bell Ville, San Francisco, Río Cuarto, etc. ${ }^{20}$

\section{Miembros del clero capitular}

El clero capitular era aquel formado por los integrantes del cabildo eclesiástico. Como bien sabemos, el cabildo era "un colegio de clérigos, instituido con el objeto de que tribute a Dios un culto más solemne en la iglesia, y tratándose del Cabildo catedral, para que de conformidad con los sagrado cánones, ayude a su obispo, como su senado y consejo, y mientras vaca la sede, le supla en el gobierno de la Diócesis" (CDC. 1917, parte I, sección II, cap. V, canon 391). O, como lo define Manuel Teruel Gregorio de Tejada, "es una corporación o colegio de beneficiados adscritos a una determinada iglesia, unidos por una tarea espiritual común: celebración solemne del culto divino en el coro capitular, por una comunidad temporal parcial: retribución de la mesa capitular,

\footnotetext{
${ }^{20}$ En 1883, solamente las dos parroquias de la ciudad, Catedral y El Pilar, y cuatro de la campaña fueron consideradas beneficios y se proveyeron mediante concurso (AAC. Copiador de Cartas. Secretaría del Obispado, 1882-1902, f.40). En 1906, el Obispo Bustos decretó la designación de ocho nuevos beneficios, dos sillas del coro capitular, la vicaría de La Rioja y los curatos de primer rango: Río Cuarto,
} 
su iglesia es una catedral (lugar de la cátedra o sede del obispo), el cabildo asume el calificativo de "catedral", si esta es metropolitana, el de metropolitano y si la iglesia no es catedral se llama colegial. Los hay completos, compuesto por tantos prebendados como prebendas, e incompletos, con solo los prebendados que pueden mantenerse decorosamente con las rentas disponibles. En sentido estricto, los miembros del cabildo son los canónigos, en sentido amplio lo forman, además, los titulares de las dignidades capitulares y los racioneros. Por disciplina canónica tanto unos como otros debían ser clérigos ya que gozaban de un beneficio, fijando cada estatuto particular el grado de las órdenes (Teruel Gregorio de Tejada, 1993: 31-32).

Por tanto, este órgano estaba compuesto por Dignidades, Canónigos y Beneficiarios, entre los que se distribuían los diversos oficios. Entre los primeros, se encontraban los de Deán, Arcedéan y Tesorero; los segundos, conformaban el cabildo de canónigos, quienes ocupaban las sillas, teologal, lectoral, magistral y de merced, cuando existía. Finalmente, el nivel inferior lo conformaban los racioneros y medio racioneros. Las funciones de cada oficio eran las siguientes. Al Deán le correspondía presidir el cabildo, y debía ser un estrecho colaborador del obispo. Era el responsable de la disciplina capitular y tenía bajo su cargo la dirección de los canónigos de la catedral y le correspondía, en ausencia del titular del obispado, presidir las reuniones del capítulo. En tanto, el Arcedeán presidía el coro junto al Deán, y, en ausencia de éste, asumía el gobierno capitular, sin embargo, esta dignidad, en el período analizado en este trabajo, era meramente honorífica. La tercera dignidad del cabildo era el Chantre, su misión era dirigir las actividades del coro de la catedral y organizar la ejecución del canto litúrgico. La Catedral de Córdoba dotó al cabildo de una canonjía que ayudaba al chantre en sus funciones. El Sochantre asumió con frecuencia estas funciones. El Tesorero era el encargado de la conservación de los bienes y objetos litúrgicos del cabildo. De él dependían los objetos religiosos y las reliquias, el vestuario de la catedral y tenía la responsabilidad de reparar el tesoro estropeado o deteriorado.

Por debajo de las dignidades se encontraba el Cabildo de canónigos, la misión de todos ellos era contribuir a la magnificencia del culto catedralicio mediante la asistencia diaria al coro, el rezo de las horas canónicas, la celebración de la misa y otras funciones litúrgicas. Especial mención merecen las llamadas canonjías de oficio, que fueron fundamentalmente cuatro: "Magistral", que era un experto en teología, encargado de la 
predicación en la catedral; "Doctoral", que era un perito en derecho canónico, encargado de defender al cabildo cuando fuese necesario; "Lectoral", que era un especialista en Sagradas Escrituras, encargado de explicar la Biblia y la doctrina católica en la catedral en días y horas determinadas; y el "Penitenciario", que era el confesor oficial de la catedral y especialista en teología moral. El resto eran canonjías simples y correspondían a los peldaños inferiores del cabildo, ocupados por los racioneros o medio-racioneros. Su misión era ayudar al cabildo de canónigos en el culto y administración de la catedral y su presencia era importante debido a la frecuente ausencia de dignidades y canónigos. Además de la jerarquía capitular, el cabildo contaba con un grupo de oficiales y servidores, tanto clérigos como laicos. Estos cargos menores comprendían las funciones de organista, sacristán, acólitos, notarios, maestro de ceremonias, etc.

En 1875, el cabildo comprendía 12 prebendas. En la visita ad limina de 1892, el Obispo Toro informaba que el coro de canónigos estaba compuesto por 11 prebendas, pues, en diciembre de 1878 , se había suprimido la de Sochantre $^{21}$ y eran las siguientes:

Dignidades: Deán, Arcedeán, Chantre y Tesorero. Canongías dichas de oficios, a saber: Magistral, Penitenciario y Teologal, dos racioneros diáconos y dos medio racioneros sub diáconos. Tiene además dos capellanes y un maestro de ceremonias, un Sacristán mayor, ecónomo y capilla de cantores. Todos estos beneficios son sostenidos por el gobierno de la Nación, así mismo lo es el Obispo y todos los empleados de la curia. ${ }^{22}$

La relación con los obispos diocesanos no siempre fue cordial. En 1905, Monseñor Bustos realiza la visita canónica a la institución capitular y en el auto de cierre de la visita advierte que "La última fecha en que aparecen las huellas de la visita canónica anterior, practicada en esta diócesis por el Ilmo. Moscoso Pérez y Oblitas la ponen en el año 1802 [...] Entre aquella fecha y esta en que la actual se practica, se encierran ciento tres años transcurridos sin que se hubiese repetido. En tan largo período, aunque solo hubiese actuado el tiempo con su acción demoledora, sobre las instituciones de esta Iglesia, era de esperarse que hubiera producido grandes desperfectos en ellas, cuando no lacerado dolorosamente, en puntos más sustanciales. Correspondía por tanto una revisación mas detenida, del largo proceso desenvuelto desde entonces hasta ahora, por esta Iglesia de Córdoba, debiendo ser ésta al presente, la materia de su visita. ¿Quién

\footnotetext{
${ }^{21}$ Obispado y Seminario de Córdoba. Libro de Cuenta, 1878-1891, f.1-4.

${ }^{22}$ Libro de Autos, 1876-1905, fs.143-158.
} 
abarca en tan pocos días la actuación tan variada y larga, que cabe en tan prolongado tiempo? Para plantearlo como correspondía un año de trabajo asiduo era poco. Por esto sin volver a tomar los hilos de la trama, buscando las roturas que pudieran haber desde aquella época, hemos concentrado nuestra inspección a las últimas manifestaciones de la actuación, de este tiempo de nuestro Venerable Cabildo". ${ }^{23}$

El obispo hace una serie de recomendaciones a los canónigos, entre las que se encuentra la de predicar y confesar "el púlpito y los confesionarios, para ser ocupados por el personal del cabildo. Los ocho confesionarios, indican que no fueron hechos para el Cura solo, sino que con la catedral que se hizo el cabildo para sí, en condición de poder ejercer los beneficios de su acción, simultáneamente rompiendo las cadenas de las culpas y derramando la gracia sacramental de la penitencia”. El púlpito se ha hecho para el cabildo "no es para el cura que hace sus homilías desde el altar [...] Lo han levantado para la enseñanza del pueblo, el deber del cabildo militante, con el Obispo, en la dirección de esta Iglesia de Córdoba. Las instituciones de las cátedras de los capítulos y de las sillas Obispales no han nacido sino en el pensamiento de la mejor y más eficaz conservación de la fe y de la religión práctica del catecismo. Donde están reclamando el culto de la adoración, con igual imperio, que el culto de la verdad por medio de la predicación y el culto de la Justicia y la santidad, en las conciencias por medio de los sacramentos".

La respuesta del deán, en ese entonces, Aquilino Ferreyra fue dura.

Dice SSI que el púlpito de la catedral permanece mudo. Sin temor de rectificarlo puedo afirmar que Mons. Bustos ha sido mal informado. Sin tomar cuenta las veces que se entre año con excepción de alguna práctica piadosa. En la catedral se dan ejercicios públicos todos los años, se predica en los domingos de adviento y cuaresma, todas las noches en el septenario de los Dolores de María y el lunes y jueves de la semana mayor. Se predica en todo el octavario de Corpus Cristi (exceptuando el primer día y en las fiestas del S. Corazón de Jesús, San Pedro y el tránsito de la Sma. Virgen, siendo los canónicos los predicadores muchísimas veces. ¿Podrá sustentarse con escrito la tesis de que los canónigos en virtud de su oficio estén obligados a confesar y predicar! Siendo que no. Ni el Concilio de Trento. Ni el Plenario de la A. L ni otro alguno, que yo sepa, ni nuestros estatutos vigentes imponen este deber a los canónigos. [...] Los canonistas y moralistas que he podido consultar no mencionan tal obligación como propia del oficio del canónigo. La administración del sacramento de la penitencia y el predicar o dar conferencias, son obligaciones de los que tienen cura de almas y de los canónigos penitenciario, Magistral o Teologal respectivamente [...]. Treinta años ha que tengo el honor de pertenecer a este $\mathrm{H}$ Cabildo. En tan prolongado lapso de tiempo he conocido y tratado con intimidad a varios canónigos que fueron nombrados en

\footnotetext{
${ }^{23}$ AAC. Fondo Zenón Bustos. Obispo. Documentación varia, Caja No 4. Exp. 13: Auto de la $1^{\text {a }}$ Visita Canónica a la Catedral - Observaciones del Venerable Cabildo, 1905-1906, f.1274.
} 
el primer tercio, si no ya en el primer cuarto del siglo pasado: todos estrictísimos en el cumplimiento de sus deberes y jamás oí decir a uno solo que se creyese obligado por su oficio a confesar y predicar y no es extraño que los discípulos pensemos de la misma manera. Si estamos pues, en la verdad, que se conserven las tradiciones de nuestros mayores y si en error que se nos ilustre. ${ }^{24}$

El obispo responde a las quejas y supuestos agravios, notificando el carácter de delegado de la Santa Sede en que se ha hecho esa visita y que los agravios no son tales. Que no es infundada la imposición a los capitulares de confesar y predicar en la misma Iglesia en carácter y que las observaciones formuladas e insertadas en el Libro Capitular resultan "como vindicación propia, y para no aparecer en la posteridad mal mirados, y quizá señalados como piedra de escándalo". ${ }^{25}$

\subsection{El beneficio capitular}

Antes de entrar en esta cuestión, es importante distinguir entre los bienes patrimoniales de los eclesiásticos y aquellos otros bienes y rentas de carácter beneficial, que no formaban parte del patrimonio personal del clérigo, sino de la iglesia como institución. El beneficio eclesiástico era una entidad jurídica, persona moral no colegiada, constituida a perpetuidad por la autoridad eclesiástica competente y que constaba de un oficio sagrado, o eclesiástico, y del derecho a percibir las rentas anejas por la dote de tal oficio, cosa esta última que constituye la llamada prebenda. Sería el fondo rentable adscrito a determinado oficio eclesiástico al que va unido de forma inseparable. Al ser el beneficio persona moral y estar ésta equiparada por el derecho canónico a un menor, el beneficio adquiere las obligaciones de tutor y administrador, en conformidad con las normas jurídicas pertinentes, de los bienes que constituyen su dote (Teruel Gregorio de Tejada, 1993: 19). El oficio eclesiástico, en sentido estricto, es el constituido de manera objetivamente estable, por ordenación divina o eclesiástica, que se debe conferir canónicamente y comporta una participación, al menos indirecta o complementaria, en la potestad eclesiástica, ya sea de orden ya de jurisdicción. Se obtiene pues con la provisión canónica que es la colación en propiedad, no en administración.

Si el que funda y dota el beneficio es la autoridad eclesiástica ordinaria, sobre el patrimonio de la iglesia, aquel es de derecho común y de libre provisión; si es un

\footnotetext{
${ }^{24}$ AAC. Fondo Zenón Bustos. Obispo. Documentación varia, Caja No 4. Exp. 13: Auto de la $1^{\text {a }}$ Visita Canónica a la Catedral - Observaciones del Venerable Cabildo, 1905-1906, fs.1284-1288.

${ }^{25}$ AAC. Fondo Zenón Bustos. Obispo. Documentación varia, Caja No 4. Exp. 13: Auto de la $1^{\text {a }}$ Visita
} 
particular o una corporación, es de derecho de patronato y corresponde al patrono laico o eclesiástico- la presentación del candidato. El fundador podía poner condiciones. Por ejemplo, que el beneficio se confiriese a clérigos de la propia familia.

Los beneficios son de dos tipos, aquellos que implican cargas eclesiásticas y disponibilidades pastorales, o de administración, de gobierno y/o jurisdicción llamados "beneficios curados" (con cura de almas) y los "beneficios simples" que implican obligaciones piadosas (oración, celebración de misas, etc.). Los beneficios fundados para el servicio general de la iglesia son "propios" y los instituidos para un servicio particular a personas o corporaciones son los "impropios" (como es el caso de las capellanías). En su mayoría, los beneficios eran vitalicios o perpetuos, por eso se denominaban "colados" o "inamovibles", cuyos titulares no podían ser desposeídos (salvo falta grave) y cuyos bienes o rentas eran susceptibles de amortización. El resto de los beneficios eran temporales o "amovibles", por lo tanto, sus titulares podían ser privados libremente (ad nutum), como en el caso de los conferidos por simple elección o aceptación para el oficio. Si la institución donde se prestaba el servicio era el cabildo, se denominaban capitulares, si era una parroquia, parroquiales. Además de las personas físicas, los destinatarios de un beneficio eran a veces personas jurídicas, como las fábricas de las iglesias. Cuando las rentas de un beneficio no alcanzaban el mínimo establecido por los sínodos para poder recibir las órdenes sagradas (congrua), éstos eran “incongruos” (Teruel Gregorio de Tejada, 1993: 24-29).

En el caso del beneficio capitular, su dotación estaba constituida por rentas de mayor o menor cuantía económica que recibía cada miembro del cabildo eclesiástico en función de su categoría jerárquica. En 1822, el gobierno de la provincia de Buenos Aires abolió los diezmos y "las atenciones a que estos eran destinados serán cubiertas por los fondos del estado". El cuerpo capitular quedó compuesto de cinco dignidades de presbíteros, cuatro canónigos, de los cuales dos serán diáconos y dos subdiáconos (Goyena, 1880: 161). Esta tendencia marcada por Buenos Aires se impuso a nivel nacional. Justo José de Urquiza determinó un presupuesto nacional para cubrir los gastos del clero, por el cual cada miembro del cabildo tenía una asignación del gobierno nacional. Esta práctica generó no pocos conflictos a la hora de designar candidatos para los diversos cargos, ya que el presupuesto de culto resultaba un instrumento de regalismo práctico y en el orden administrativo hizo de prelados y dignatarios

Canónica a la Catedral ... f.1291. 
eclesiásticos, otros tantos funcionarios y empleados públicos, dependientes del presidente de la república (Estrada, 1963: 88).

Tabla 34

\begin{tabular}{|c|c|c|c|c|}
\hline \multicolumn{5}{|c|}{ Presupuesto para el clero } \\
\hline \multirow[t]{2}{*}{ Cargo } & \multirow{2}{*}{$\begin{array}{c}\text { Monto } \\
\text { anual } \\
1856\end{array}$} & \multicolumn{3}{|c|}{ Asignación mensual } \\
\hline & & 1880 & 1890 & 1913 \\
\hline Obispos & 4.200 & 240 & 400 & 1.320 \\
\hline Vicarios & - & 50 & 50 & 1.880 \\
\hline Secretarios & & 24 & 40 & 1.385 \\
\hline Pro-secretarios & & & & 1.220 \\
\hline Deanes & 1.200 & 100 & 120 & 440 \\
\hline Arcedianos & 1.000 & 80 & 100 & 385 \\
\hline Chantres y tesoreros & 1.000 & 70 & 90 & \\
\hline $\begin{array}{l}\text { Canónigos: Magistrales, } \\
\text { Doctorales, Merced, } \\
\text { Penitenciarios }\end{array}$ & 900 & 70 & 90 & 330 \\
\hline Racioneros & $600 \%$ & 60 & 70 & 275 \\
\hline Medio racioneros & & 50 & 60 & 220 \\
\hline Secretarios capitulares & 240 & 24 & 40 & 154 \\
\hline Capellanes de coro & 500 & 25 & 40 & 264 \\
\hline Sacristanes Mayores & 500 & & & 132 \\
\hline So Chantres & 500 & & & \\
\hline $\begin{array}{l}\text { Gobernadores de } \\
\text { Obispado Sede Vacante }\end{array}$ & 1.000 & 100 & 120 & 2.660 \\
\hline
\end{tabular}

En 1883, el Obispo Fray Mamerto Esquiú, para evitar conflictos con el gobierno nacional, pide la exoneración del Deán Vázquez de Novoa, concediéndole una licencia por seis meses para asistir a las funciones y permite que se lo sustituya por otro capellán. ${ }^{26}$ En 1885, el Obispo de Córdoba, fray Capistrano Tissera, escribe al Ministro de Culto en referencia a la decisión del gobierno nacional de decidir la persona para ocupar la vacante en el coro del cabildo. El obispo se opone y advierte:

Yo debía esperar que el nombramientos de canónigos para este coro se hiciera sin demora y en conformidad a la nómina que tengo presentada. Ahora se me pide una modificación que, séame permitido decir, no puedo aceptar: $1^{\circ}$ porque no veo tantos méritos, en el nuevo candidato para tesorero, para que sea promovido pasando por los actuales canónigos Rectoral y Magistral, cuyas sillas han obtenido por oposición. $2^{\circ}$ porque llamar a un sacerdote sexagenario, que lleva treinta años de ministerio parroquial en nuestra dilatada campaña, y que ha sido durante dos años Provisor y Vicario General, llamarlo, digo, a ocupar una canonjía diaconal no

\footnotetext{
${ }^{26}$ AAC. Libro de Autos, 1876-1905, f.51. Auto del 10/04/1883.
} 
parece digno y no lo haré. Me creo pues obligado a insistir en mi posición y rogar a V.E y al Sr. Presidente tengan presente lo que me prometieron el día que presenté juramento, esto es, que para los nombramientos siempre serán atendidas mis indicaciones [...]. Así como V.E sabe quiénes son los buenos militares, así yo también debo saber quiénes son los buenos para los puestos eclesiásticos. No sé si V.E habrá tenido informes adversos del Sr. Ferreira, yo puedo asegurar como que lo conozco desde mi niñez a dicho Sr. que es un sacerdote dignísimo y que habiendo sido siempre prescindente en política, no puede ser hostil al gobierno. Digo más: el nombramiento de ese Sr. para la más alta silla vacante es un acto de Justicia que merecerá el aplauso, no solo del clero, sino del mismo pueblo. ${ }^{27}$

Conflictos de este tipo ya no se registran después de la década del 80. En 1898, el obispo diocesano mediante auto convoca a llenar la vacancia de la Canonjía lectoral por promoción de Filemón Cabanillas a la Dignidad de tesorero, llama a concurso de oposición a todos los sacerdotes con grado de licenciado o doctor. ${ }^{28}$ Se presentaron dos candidatos y el diocesano nombra a tres "replicantes" para cada uno. A la oposición de Samuel Bustos, el replicante fue Ramón Gil Luque; a la de Jacinto Correa, Carlos Echenique. "Las disertaciones fueron públicas en la catedral y fueron aprobadas ambas. Se procedió entonces a sortear quien ocuparía la silla, fue favorecido Jacinto Correa que renunció a favor de Samuel Bustos". ${ }^{29}$

El número de integrantes del Cabildo Catedral de Córdoba varió a lo largo del período y no siempre estuvieron todas las sillas provistas. Las prebendas capitulares se modificaron con el correr de los años. De las cinco previstas para 1856, se pasó a 11 en 1859: las Dignidades de Deán, Arcedeán y Chantre; Canonjías Teologal o Lectoral, Magistral, de Merced y Tesorero, dos canónigos prebendados de $2^{\circ}$ y $1^{\circ}$ ración y dos medio-racioneros. El cargo de SoChantre tuvo vigencia hasta fines de 1878, ya que a partir de 1879 no se registraron nombramientos hasta 1923, año en que se incorporó nuevamente. En 1876, se suprimió la Canonjía de Merced, que fue reemplazada por la Teologal. ${ }^{30}$ En 1884, se creó el beneficio de Penitenciario. ${ }^{31}$ En 1915, el gobierno nacional suprimió la asignación para el cargo de Tesorero, lo que implicó que el cargo quedara vacante. $^{32}$

\footnotetext{
${ }^{27}$ ASV. Nunziatura del Brasile. Libro 63, Fascículo 306, f.126.

${ }^{28}$ AAC. Libro de Autos, 1876-1905, f.169.

${ }^{29}$ AAC. Libro de Autos, 1876-1905, f.172.

${ }^{30}$ AAC. Notas, 1873-1879, f.41. Queda vacante en 1876 y se reemplaza por la Teologal (Nota del Obispo Álvarez al Ministro de Justicia, Culto e Instrucción Pública Dr. Leguizamón, 31/08/1876; Auto de creación del 27/12/1876).

${ }^{31}$ AAC. Notas particulares del Sr Obispo, 1884-1903, f.2.

${ }^{32}$ REOBA, 1917, p. 398. Informe sobre el Obispado.
} 
Reconstruir la composición del cabildo no ha resultado tarea fácil, dado que los cargos no siempre estuvieron ocupados y la promoción fue irregular, ésta podía ser por concurso, designación del prelado o en orden de antigüedad. Cuando se creó la silla de penitenciario, no se llamó a concurso para su provisión, por el contrario, el Obispo Tissera designó al prebendado de segunda ración -licenciado en derecho civil-, Domingo Castellano, previo examen ante tres examinadores, pese a carecer de título máximo en teología o derecho canónico. También hubo reorganizaciones internas. En 1895, el obispo dispuso reorganizar el cabildo y nombrar asistentes para las dignidades de Chantre, ocupada por Aquilino Ferreyra a la sazón de 72 años, la asistencia recayó en Juan Martín Yaniz. ${ }^{33}$ La silla teologal y lectoral en ocasiones se identificaban, quien ocupaba la canonjía lectoral ejercía las funciones de ambos cargos, al menos, durante el último cuarto del siglo XIX.

Los clérigos que formaron parte del cabildo durante 1875-1925 fueron 58, sin incluir los cargos menores, ni a los canónigos honorarios. Esto significa que, en relación a los números presentados ut supra (145 ordenaciones de presbíteros), un alto porcentaje del clero criollo formó parte del cabildo $(40 \%)$ y sólo un reducidísimo número de extranjeros tuvo acceso a alguna prebenda menor. ${ }^{34}$ La Tabla 35 permite observar la composición del cabildo a lo largo del período.

\section{Tabla 35}

\section{Miembros del Cabildo eclesiástico de Córdoba, 1875-1925}

\footnotetext{
${ }^{33}$ AAC. Libro de Autos, 1876-1905, f.165. Auto del 22/03/1895.

${ }^{34}$ Lucio Scorza (italiano de Cassaso) y José Pretel y Gómez (español), fueron nombrados canónigos medio racioneros, el 28/09/1881, el primero, y el 13/09/1904, el segundo.
} 


\begin{tabular}{|c|c|c|c|c|c|c|c|c|c|c|}
\hline \multirow[t]{2}{*}{$\begin{array}{l}\text { Apellido y } \\
\text { Nombre }\end{array}$} & \multicolumn{7}{|c|}{ Cabildo eclesiástico de Córdoba } & \multicolumn{3}{|c|}{$\begin{array}{c}\text { Mitra } \\
\text { Episcopal } \\
\end{array}$} \\
\hline & MR & $\mathrm{R}$ & $\mathrm{C}$ & $\mathrm{T}$ & $\begin{array}{l}\mathrm{C} \\
\mathrm{H}\end{array}$ & $\mathrm{A}$ & $\mathrm{D}$ & $\mathrm{A}$ & $\mathrm{T}$ & $\begin{array}{c}\mathrm{A} \\
\mathrm{r}\end{array}$ \\
\hline $\begin{array}{l}\text { MARTIARENA, } \\
\text { Gaspar }\end{array}$ & & & & & & & $\mathrm{X}$ & & & \\
\hline $\begin{array}{l}\text { VAZQUEZ DE } \\
\text { NOVOA, Andrés }\end{array}$ & & & $\mathrm{X}$ & $\mathrm{X}$ & $\mathrm{X}$ & & $\mathrm{X}$ & & & \\
\hline $\begin{array}{l}\text { CASTELLANOS, } \\
\text { Uladislao }\end{array}$ & $\mathrm{X}$ & $\mathrm{X}$ & $\mathrm{X}$ & & $\mathrm{X}$ & & $\mathrm{X}$ & $\mathrm{X}$ & $\mathrm{X}$ & $\mathrm{X}$ \\
\hline $\begin{array}{l}\text { FERREIRA, } \\
\text { Aquilino }\end{array}$ & & & $\mathrm{X}$ & $\mathrm{X}$ & $\mathrm{X}$ & & $\mathrm{X}$ & $\mathrm{X}$ & & \\
\hline $\begin{array}{l}\text { LUQUE, José } \\
\text { Anselmo }\end{array}$ & $\mathrm{X}$ & $\mathrm{X}$ & $\mathrm{X}$ & $\mathrm{X}$ & $\mathrm{X}$ & $\mathrm{X}$ & $\mathrm{X}$ & $\mathrm{X}$ & & \\
\hline $\begin{array}{l}\text { DAVILA, } \\
\text { Inocencio }\end{array}$ & & & & & & & $\mathrm{X}$ & $\mathrm{X}$ & $\mathrm{X}$ & \\
\hline $\begin{array}{l}\text { MACIEL, } \\
\text { Bernardino }\end{array}$ & & & & & & & $\mathrm{X}$ & & & \\
\hline $\begin{array}{l}\text { ANDRADE, } \\
\text { Manuel Victoriano }\end{array}$ & & & & & & $\mathrm{X}$ & & & & \\
\hline $\begin{array}{l}\text { ALVAREZ, } \\
\text { Manuel Eduardo }\end{array}$ & & & & & & $\mathrm{X}$ & & & & \\
\hline $\begin{array}{l}\text { CLARA, Pedro } \\
\text { Nolasco }\end{array}$ & & & & & $\mathrm{X}$ & $\mathrm{X}$ & & & $\mathrm{X}$ & \\
\hline $\begin{array}{l}\text { NUÑEZ BRAVO, } \\
\text { José Rufino }\end{array}$ & & $\mathrm{X}$ & & $\mathrm{X}$ & $\mathrm{X}$ & $\mathrm{X}$ & & & & \\
\hline $\begin{array}{l}\text { CLARA, Gerónimo } \\
\text { Emiliano }\end{array}$ & & & $\mathrm{X}$ & $\mathrm{X}$ & & $\mathrm{X}$ & & & & \\
\hline $\begin{array}{l}\text { DE LA LASTRA, } \\
\text { Rosendo }\end{array}$ & $\mathrm{X}$ & $\mathrm{X}$ & & & & $\mathrm{X}$ & & $\mathrm{X}$ & $\mathrm{X}$ & \\
\hline $\begin{array}{l}\text { YANIZ, Juan } \\
\text { Martín }\end{array}$ & $\mathrm{X}$ & & $\mathrm{X}$ & $\mathrm{X}$ & & $\mathrm{X}$ & & $\mathrm{X}$ & $\mathrm{X}$ & \\
\hline GALCERÁN José & $\mathrm{X}$ & $\mathrm{X}$ & & & $\mathrm{X}$ & & & & & \\
\hline $\begin{array}{l}\text { ARGAÑARÁS, } \\
\text { Apolinario }\end{array}$ & & & $\mathrm{X}$ & & $\mathrm{X}$ & & & & & \\
\hline TAGLE, Luis & $X$ & $\mathrm{X}$ & $\mathrm{X}$ & & $\mathrm{X}$ & & & & & \\
\hline $\begin{array}{l}\text { LEAL Luis } \\
\text { Rosendo }\end{array}$ & & & $\mathrm{X}$ & & $\mathrm{X}$ & & & & & \\
\hline ALVAREZ, Luis & & & $\mathrm{X}$ & & $\mathrm{X}$ & & & & & \\
\hline JUAREZ, Justino & & & $\mathrm{X}$ & $\mathrm{X}$ & & & & & & \\
\hline $\begin{array}{l}\text { CABANILLAS, } \\
\text { Filemón }\end{array}$ & $\mathrm{X}$ & $\mathrm{X}$ & $\mathrm{X}$ & $\mathrm{X}$ & & & & & & \\
\hline $\begin{array}{l}\text { GONZÁLEZ, } \\
\text { Narciso }\end{array}$ & $\mathrm{X}$ & $\mathrm{X}$ & $\mathrm{X}$ & $\mathrm{X}$ & & & & & & \\
\hline $\begin{array}{l}\text { MERCADO, } \\
\text { Eleuterio }\end{array}$ & & $\mathrm{X}$ & $\mathrm{X}$ & $\mathrm{X}$ & & & & & & \\
\hline BUSTOS Samuel & & & $\mathrm{X}$ & & & & & & & \\
\hline $\begin{array}{l}\text { MONTENEGRO, } \\
\text { Pedro }\end{array}$ & & & $\mathrm{X}$ & & & & & & & \\
\hline FIERRO, Eleodoro & & & $\mathrm{X}$ & & & & & & & \\
\hline $\begin{array}{l}\text { CASTELLANO, } \\
\text { Domingo }\end{array}$ & & $\mathrm{X}$ & $\mathrm{X}$ & & & & & & & \\
\hline $\begin{array}{l}\text { ECHENIQUE, } \\
\text { Carlos }\end{array}$ & & & $X$ & & & & $X$ & $X$ & & \\
\hline MARTINEZ, José & & $X$ & $\mathrm{X}$ & & & & & & & \\
\hline $\begin{array}{l}\text { RODRIGUEZ, } \\
\text { Juan A }\end{array}$ & & $\mathrm{X}$ & $\mathrm{X}$ & & & & & & & \\
\hline LÓPEZ, Norberto & & & $\mathrm{X}$ & & & & & & & \\
\hline VELEZ, José & & $X$ & & & & & & & & \\
\hline
\end{tabular}




\begin{tabular}{|l|c|c|c|c|c|c|c|c|c|c|}
\hline María & & & & & & & & & & \\
\hline $\begin{array}{l}\text { GARCÍA } \\
\text { COLMENA, } \\
\text { Andrés }\end{array}$ & $\mathrm{X}$ & $\mathrm{X}$ & & & & & & & & \\
\hline $\begin{array}{l}\text { FERREYRA, } \\
\text { Eduardo }\end{array}$ & $\mathrm{X}$ & $\mathrm{X}$ & & & & & & & & \\
\hline $\begin{array}{l}\text { MOYANO, Juan } \\
\text { Trifón }\end{array}$ & $\mathrm{X}$ & $\mathrm{X}$ & & & & & $\mathrm{X}$ & & & \\
\hline $\begin{array}{l}\text { LÓPEZ } \\
\text { CABANILLAS, } \\
\text { Rafael }\end{array}$ & $\mathrm{X}$ & $\mathrm{X}$ & & & & & & & & \\
\hline $\begin{array}{l}\text { ESQUIVEL, } \\
\text { Nemesio }\end{array}$ & $\mathrm{X}$ & & $\mathrm{X}$ & & & & & & & \\
\hline LUQUE, Tomás & $\mathrm{X}$ & & & & & & & & & \\
\hline $\begin{array}{l}\text { PRETEL Y } \\
\text { GOMEZ, José J }\end{array}$ & $\mathrm{X}$ & & & & & & & & & \\
\hline $\begin{array}{l}\text { BROCHERO, José } \\
\text { Gabriel }\end{array}$ & $\mathrm{X}$ & & $\mathrm{X}$ & & & & & & & \\
\hline $\begin{array}{l}\text { SOTOMAYOR } \\
\text { TRISTAN }\end{array}$ & $\mathrm{X}$ & & & & & & & & & \\
\hline $\begin{array}{l}\text { FERREYRA, } \\
\text { Bruno }\end{array}$ & $\mathrm{X}$ & & & & & & & & & \\
\hline $\begin{array}{l}\text { MARQUEZ, } \\
\text { Rubén }\end{array}$ & & & $\mathrm{X}$ & & & & & & & \\
\hline $\begin{array}{l}\text { GARCÍA DE LA } \\
\text { SERNA Doroteo }\end{array}$ & & & $\mathrm{X}$ & & & & & & & \\
\hline BULA, Juan & & & $\mathrm{X}$ & & & & & & & \\
\hline $\begin{array}{l}\text { RAMOS, } \\
\text { Ambrosio }\end{array}$ & & $\mathrm{X}$ & & & & & & & \\
\hline LUQUE, Adolfo & & & $\mathrm{X}$ & & & & & & & \\
\hline
\end{tabular}

Abreviaturas: MR (medio racionero); R (racionero); C (Canónigos); $\mathrm{T}$ (tesorero), $\mathrm{CH}$ (Chantre); D (Deán); OA ( Obispo Auxiliar); OT (obispo Titular); AR (Arzobispo)

\subsection{Clérigos que accedieron a la mitra episcopal}

Además, un grupo importante de este clero capitular alcanzó la silla episcopal. Entre 1895 y 1934, trece fueron los clérigos cordobeses, miembros de estas familias tradicionales, que llegaron a obispos. Así, las diócesis de Buenos Aires, Córdoba, Paraná, Tucumán, Santiago del Estero, Catamarca, Río Cuarto, La Rioja y San Juan de Cuyo, contaron con obispos cordobeses y otros formados en el Seminario diocesano de Córdoba, como Rizzo y Patrón, quien fuera obispo de Salta. También añadimos a Alfonso Buteler, cordobés, alumno del Pío Latinoamericano y ordenado en 1915 en Roma y preconizado en 1940 obispo de Mendoza. 
Tabla 36

\begin{tabular}{|c|c|c|}
\hline \multicolumn{3}{|c|}{ Presbíteros cordobeses que accedieron a la Mitra Episcopal } \\
\hline Apellido y Nombre & Año & Cargo \\
\hline ÁLVAREZ, Manuel Eduardo & 1876 & Obispo Titular de Córdoba \\
\hline TISSERA, Fray Capistrano & 1881 & Obispo Titular de Córdoba \\
\hline \multirow[t]{2}{*}{ CASTELLANOS, Uladislao } & $24 / 09 / 1892$ & Obispo Titular de Ankialo y Auxiliar de Córdoba \\
\hline & $29 / 11 / 1895$ & Arzobispo de Buenos Aires \\
\hline \multirow{2}{*}{$\begin{array}{l}\text { DE LA LASTRA GORDILLO, } \\
\text { Rosendo }\end{array}$} & $01 / 10 / 1892$ & $\begin{array}{l}\text { Obispo Titular de Miletópolis y Auxiliar de } \\
\text { Córdoba }\end{array}$ \\
\hline & 25/03/1898 & Obispo Titular de Paraná \\
\hline FERREIRA, Aquilino & $04 / 06 / 1899$ & Obispo Auxiliar de Córdoba y Titular de Amiso \\
\hline CABANILLAS, Filemón & $16 / 11 / 1899$ & Obispo Auxiliar de Córdoba y Titular de Circesio \\
\hline BUSTOS, Zenón (OMF) & $05 / 04 / 1905$ & Obispo Titular de Córdoba \\
\hline ECHENIQUE, Carlos & $10 / 12 / 1914$ & Obispo Auxiliar de Tucumán \\
\hline YAÑIZ, Juan Martín & $08 / 05 / 1910$ & Obispo Titular de Santiago del Estero \\
\hline BAZÁN y BUSTOS, Abel & $07 / 02 / 1910$ & Obispo Titular de Paraná \\
\hline LUQUE, José Anselmo & $25 / 05 / 1914$ & Obispo Auxiliar de Córdoba \\
\hline DÁVILA y MATOS, Inocencio & $\begin{array}{c}25 / 05 / 1914 \\
7 / 07 / 1927 \\
\end{array}$ & $\begin{array}{l}\text { Obispo Auxiliar de Córdoba } \\
\text { Obispo Titular de Catamarca }\end{array}$ \\
\hline \multirow[t]{2}{*}{ BUTELER, Leopoldo } & $8 / 01 / 1831$ & Obispo Auxiliar de Córdoba y Titular de Tino \\
\hline & $13 / 09 / 1934$ & Obispo Titular de Río Cuarto \\
\hline FERREIRA REINAFÉ, Froilán & $13 / 09 / 1934$ & Obispo Titular de La Rioja \\
\hline $\begin{array}{l}\text { RODRÍGUEZ OLMOS, } \\
\text { Audino }\end{array}$ & $07 / 07 / 1927$ & Obispo Titular de Santiago del Estero \\
\hline BUTELER, Alfonso María & $11 / 10 / 1940$ & Obispo Titular de Mendoza y Neuquén \\
\hline
\end{tabular}

Esta realidad nos lleva a pensar algunas cuestiones vinculadas al proceso de romanización. En primer lugar, nos preguntamos si Córdoba no fue para Roma el pivote a través del cual llevar a cabo la reforma de la iglesia argentina. La llegada de un sacerdote cordobés, como Uladislao Castellano, al arzobispado de Buenos Aires es un claro indicio del interés de Roma por poner en puestos claves a sacerdotes formados en el espíritu de la reforma. La tendencia continuó y los sacerdotes cordobeses que accedieron a la mitra episcopal, en diversas diócesis argentinas, superaron la docena. Todos ellos pertenecientes a familias tradicionales.

Los ítems presentados ut supra nos llevan a pensar el peso que seguían teniendo las familias tradicionales de Córdoba, incluso en el ámbito eclesiástico. ${ }^{35}$ Ana Inés Ferreyra

\footnotetext{
${ }^{35}$ Cfr. Los trabajos de ROMANO y AYROLO (s/f); FERREYRA (1992); FERRARI (2001).
} 
señala que, en el período $1835-1852$, el $13 \%$ de los miembros de la elite dirigente cordobesa (analiza los cargos de elector, legislador, funcionario del ejecutivo y judicial), pertenecía al clero (Ferreyra, 1992: 101). De ello, puede inferirse que el poder eclesiástico estaba íntimamente vinculado al político y que, sin duda, los miembros del clero que ocuparon cargos políticos formaron parte de esa elite. En nuestro período, las familias "patricias" (antiguas y prestigiosas) siguieron aportando miembros al clero secular, algunos de los cuales estaban vinculados al mundo de la política partidaria, como veremos mas adelante, otros se desempeñaron en los más altos cargos y funciones eclesiásticas.

Los vínculos familiares tuvieron un peso significativo en las carreras eclesiásticas del clero nativo. Las influencias iban desde la elección de la familia de enviar un hijo a estudiar al Colegio Pío Latinoamericano hasta la designación en puestos de gobierno diocesano o ministerio parroquial. En este sentido, es sumamente clara la nota enviada por el cura Leopoldo Buteler, párroco de Marcos Juárez, al secretario de la curia, informando: "Por las ocupaciones de estos días he olvidado comunicar ha SS.Ilm. y a usted que creo que para el caso será indiferente, que de acuerdo con mis padres hemos resuelto mandar a mis hermanos seminaristas a terminar sus estudios en Roma aprovechando una media pensión que he conseguido. Según creo, por noticias recibidas la partida debe ser el 25 de septiembre y por consiguiente en estos días debe salir mi hermano del seminario. Espero pues que de la curia se le harán las recomendaciones y documentos que para estos casos se requieren". 36

Llama la atención el tono imperativo de la misiva. El cura comunica una decisión tomada por la familia a sólo unos días de anticipación de la partida, no hay consulta previa al obispo, ni siquiera se le da opción de opinar al respecto. En una aspecto tan central, como la formación del clero, las familias de la elite mantuvieron un importante poder de decisión sobre las carreras eclesiásticas de sus miembros.

\section{El clero parroquial}

\subsection{La provisión de curatos}

El cañamazo sobre el cual se sustentaba la reforma eclesiástica era sin duda el clero parroquial, aquel que estaba en permanente contacto con la sociedad y del cual nos ocuparemos con más profundidad más adelante. A lo largo de los años analizados, las

\footnotetext{
${ }^{36}$ AAC. Cajas Parroquias: Marcos Juárez, f.141. Nota del 31/08/1909.
} 
fuentes son reiterativas en la idea de que el clero era muy escaso y no alcanzaba a cubrir las necesidades espirituales de la población. Como señala Di Stefano para Buenos Ares, el problema no radicaba tanto en la cantidad de clérigos sino en la distribución de los mismos y en la escasa disponibilidad de clero para ocupar los curatos de la campaña menos favorecidos. Para salvar esta situación los obispos nombraban párrocos amovibles ad mutum. El Obispo Toro informaba en la vista ad limina de 1892 que "de conformidad a la costumbre que hemos encontrado vigente en la diócesis, haremos los nombramientos de Párrocos en forma interina, amovibles ad mutum". ${ }^{37}$ La práctica de proveer los curatos sin recurrir a concursos, requisito establecido por el Concilio de Trento, ${ }^{38}$-que obligaba a todos los candidatos a párrocos a probar sus aptitudes para el desempeño del cargo por medio de un examen-, ${ }^{39}$ fue una medida tomada, entre otros motivos, para paliar la escasez del clero y la dificultad de hallar sacerdotes extranjeros medianamente aptos para el ejercicio del ministerio. Esta designación significaba que la mayoría de las parroquias era provista directamente por el prelado, lo que garantizaba cierta movilidad y la posibilidad de remover fácilmente del cargo. No se llamaba a concurso y por lo tanto no se otorgaba el título de cura propietario, quienes estuvieron al frente de los curatos recibieron el título de vicarios interinos o excusadores. ${ }^{40}$ Remover a un cura colado, es decir que había accedido al curato por concurso, era jurídicamente muy complicado, debía iniciársele un juicio de destitución. En 1882, el cura de Chilecito, Pedro Anglada, fue denunciado por promover disturbios políticos. El obispo procedió a su remoción. Las causas de esta medida fueron, según el prelado, "no estar en condiciones de cumplir su ministerio por estar turbada la buena inteligencia entre él y su feligresía, aunque ninguna culpa tenga, aunque abunde en méritos, es llegado el caso de separarlo de ahi, tanto por el bien de su feligresía, como por el de el mismo". El cura solicitó un juicio justo, “¿pero si me remueve sin juicio previo? ¿Cómo se vindica mi conducta, que es de la seguridad del ministerio parroquial?". La respuesta del prelado fue contundente: "Si se tratara de un beneficio por colación habría que pedir juicio y

\footnotetext{
${ }^{37}$ AAC. Libro 39, Autos, 1876-1905, fs.153-159, Visita ad limina 1892.

38 AAC. Copiador de cartas. Secretaría del Obispado, 1882-1902, f.39 y ss. Informe sobre la Diócesis 1883, Provisión de Curatos.

${ }^{39}$ Los concursos de méritos eran exámenes abiertos a los clérigos que deseaban obtener un beneficio. Trento los estableció como forma de probar la idoneidad intelectual y moral de los futuros párrocos. En consecuencia, los concurso eran una forma de proveer parroquias como de comprobar la capacidad y valía de los aspirantes (Cfr. Martín Riego, "Los concursos de Parroquia en la archidiócesis de Sevilla 1611-1926", Caja Sur, 1999, p. 17).

${ }^{40}$ Entre 1875 y 1925 no se nombró ningún cura propio (Cfr. AAC. Libros 20 y 21: Títulos del clero).
} 
entretanto darle un coadjutor, pero tratándose de provisión interina no es el caso de la coadjutoría ni necesario juicio porque no hay derecho adquirido al beneficio". 41

La práctica relativa a la provisión de curatos está claramente descripta en el informe que el Provisor del Obispado, Jerónimo Clara, envía al Nuncio Mattera en 1883. Advierte que ninguna de las parroquias de la diócesis se hallaba vacante y que desde tiempo inmemorial los prelados eran los encargados de proveerlas oportunamente. Acto seguido, explica detalladamente el procedimiento seguido:

La regla de proveerlos puede decir no consiste más que en mandar cuanto antes se hace posible un sacerdote que reemplace interinamente al cura saliente, o halle la vacante, ocasionada por muerte, renuncia o remoción del que antes servía el curato. Son tantos, tan frecuentes e inesperados los casos de vacantes de curato en esta dilatada diócesis principalmente en la Provincia de la Rioja, por lo incongruo y peligroso del servicio de ellos, que por todas partes, siendo tan diminuto el clero secular del país para ocupar esos destinos, que en lo general se hace imposible la observancia de las "prescripciones" del Tridentino respecto a la forma de proveerlos; pues hasta difícil es muchas veces hallar un sacerdote "medianamente" apto para llenar las mayores y más frecuentes necesidades, que a cada paso se presentan con extrema exigencia. No por esto se cree legítimamente establecida esta práctica; pues jamás los Prelados la han considerado tal; y si se han visto en la necesidad de adoptarla, como una necesidad de circunstancias, cada vez que se hace indispensable proveer de Cura a las Parroquias casi instantáneamente. Esta es la causa por que nada se sigue las prescripciones conciliares de Tridentino. Además harta irregularidad y falta de formas en proveer las parroquias sin duda de las frecuentes y muy ruidosas conmemoraciones y trastornos políticos, por que ha atravesado desde el año 1810 nuestra República Argentina: trastornos y sacudimientos que ha ocasionado larguísimas y frecuentes vacantes de la Silla Episcopal. Desde entonces habiendo sido víctima de la revolución contra la Corona Española el último de los Obispos Españoles que llego a ocupar la silla de esta Diócesis, se produjo una vacante de más de cuarenta años y que llego hasta 1859 , con la ligera interrupción de un Vicariato apostólico que duró muy pocos años entre el año 30 al 36.

Más al ocupar la silla episcopal de esta diócesis en el año 1859 el Ilmo. Sr Obispo diocesano Dr. Don Vicente Ramírez de Arellano, habiendo inmediatamente con facultad apostólica nombrado Examinadores Sinodales, por falta de Sínodo Diocesano, procedió a poner algunos curatos en concurso, conforme a las disposiciones del Tridentino.

Lo que tuvo muy buen resultado nombrándose como se hizo de este modo cuatro curas propios para la campaña y los dos del curato rectoral de la ciudad. Mas luego vinieron a trastornar de nuevo al país, los disturbios políticos y esta, sin duda, sería la causa de no volver a adoptar esa práctica para la provisión de otros curatos hasta que murió en 1873. En seguida desde esa fecha los dos obispos que han ocupado la silla episcopal solo han sido cada uno por el espacio de dos años: razón por la que no habrán podido entrar a arreglar la provisión de curatos en la forma prescripta por el tridentino. ${ }^{42}$

\footnotetext{
${ }^{41}$ AAC. Libro de Títulos, 1859-1904, f.71.

${ }^{42}$ AAC. Copiador de Notas. Secretaría del Obispado, 1882-1902, fs.41-43.
} 
En el informe de la visita ad limina, el obispo también expresaba su deseo de crear nuevas parroquias, pero señalaba la falta de clero "indispensable para la ocupación de esos nuevos puestos". En 1905, con motivo de la construcción del edificio del seminario, el Obispo Bustos emite un auto donde vuelve a advertir sobre la escasez de clero. ${ }^{43}$ Los puntos centrales son retomados en el informe correspondiente a la la visita ad limina de 1905, en el que se señala que su número alcanza a 114 y que los alumnos del seminario eran 70. En el informe generado por la Sagrada Congregación Consistorial sobre la visita ad limina de los obispos argentinos en 1913, el tema vuelve a hacerse presente, dice que "es poco, no muy instruido, su actividad muy limitada; el espíritu de sacrificio bastante alejado de él; sin espíritu de unión”, sin embargo, al referirse a la diócesis de Córdoba, advierte que "hay bastante clero del país, que es bastante bueno". 44 A lo largo de estas páginas, veremos la paulatina voluntad de los obispos diocesanos de controlar más al clero, disponiendo de él según "las necesidades de la Iglesia".

\subsection{El clero diocesano parroquial de origen inmigrante}

Otro sector que forma parte del clero propio fue el grupo de origen inmigrante, aquellos que estudiaron y se ordenaron en el seminario diocesano. Párrafos arriba, señalábamos que fueron 30 los extranjeros que llegaron al presbiterado. Las fuentes consultadas nos proporcionaron escasos datos sobre el origen social de los mismos. De las cartas de solicitud de los aspirantes a recibir las órdenes enviadas al obispo y de los informes del rector del seminario que las acompañan, pudimos extraer algunos indicios. Por ejemplo, Luis Galeano era hijo de Rosario Ligaró, lavandera, proveniente de la Diócesis de Messina (Italia). A los 17 años se confirmó en la Iglesia de Giardini, su villa natal. En 1879, con 24 años, ingresó al seminario diocesano, luego de haber pasado por las aulas del seminario de la Merced.

Eugenio Ghérica escribe al obispo diciendo que después de haber cursado tercer año de Sagrada Teología en el Seminario Eclesiástico de Vittoria, "me vi obligado por el lamentable estado de mi país a buscar en alguna de las diócesis de Sud América la

\footnotetext{
${ }^{43}$ Zenón Bustos. Obispo. Auto Episcopal sobre el Seminario diocesano y la necesidad de clero, 1907.

${ }^{44}$ ASV. Nunziatura Argentina. Libro 62, Visita ad limina. Obispos Argentinos, 1913. Observaciones y recomendaciones de la visita ad limina. Smo Card Le Loi Segretario della S.C Concistoriale, 27 de marzo de 1913, f.101.
} 
colocación necesaria para terminar mi carrera hasta recibir el sacerdocio, a que, desde mis tiernos años había aspirado". 45

Francisco Martínez del Val, español, de la diócesis de Burgos, hijo legítimo de Manuel Martínez y Prudencia del Val, en 1873, a los 37 años de edad solicitó, al diocesano de Córdoba, ordenarse como clérigo secular domiciliario, luego de haber estado, por el lapso del año 1868, en el convento de San Francisco de Buenos Aires. No se le concedieron las dimisorias para la ordenación, las razones señaladas en el informe son por falta de estudios, no haber concluido la carrera escolar y carecer de título. Al año siguiente, renovó la solicitud y volvió a ser rechazada por carecer de patrimonio, no obstante lo cual, se remitió la consulta al delegado apostólico en la Corte de Brasil. ${ }^{46} \mathrm{Si}$ bien no conocemos la respuesta, suponemos que fue positiva, dado que se le concedieron las dimisorias para recibir las órdenes mayores el 24 de marzo de 1874, ${ }^{47}$ estando el obispado en sede vacante.

Francisco Magnoni, italiano, proveniente de La Rioja, fue poseedor de una beca del seminario. El rector informaba que "ocupaba una de las becas destinadas para dicha provincia y es ayudado en sus gastos particulares por el Señor Abel Bazán, Ministro de la Suprema Corte Nacional". ${ }^{48}$ Había tenido que luchar con dificultades para terminar su carrera eclesiástica, "a causa de su poca aptitud para los estudios". Sin embargo, "como siempre se había mostrado un joven piadoso, celoso de su bien espiritual y deseoso de abrazar la carrera eclesiástica con el fin de salvar almas", fue admitido a las órdenes sagradas.

También de la indagación a testigos, sobre vita et moribus de los aspirantes, a veces, se desprende la condición social de los extranjeros. Así, por ejemplo, Vicente Jorba, español, de la provincia de Barcelona, de 30 años de edad, comerciante, domiciliado en la localidad de Río Cuarto, responde a la indagatoria, señalando que Juan Erviti y Erasum, aspirante a recibir órdenes, era español y fue su dependiente en la casa de negocios en Río Cuarto. Como empleado tuvo una conducta irreprochable y "le consta pertenece a una familia intachable, que aunque no conoce a la madre, conoció al padre y a tres hermanos, personas todas muy bien".49

\footnotetext{
${ }^{45}$ AAC. Leg. 24. TVIII, 1860-1870.

${ }^{46}$ AAC. Leg. 24. TIX, 1873-1880. Martínez del Val.

${ }^{47}$ AAC. Libro 20, Títulos del Clero, 1854-1904, f.56. Se le conceden las dimisorias para acceder a las Ordenes Mayores el 24/03/1874.

${ }^{48}$ ACC. Leg. 24. TXII, 1901-1909.

${ }^{49}$ AAC. Leg. 24. TXI, 1890-1894.
} 
Estos primeros indicios nos inducen a pensar que se trataba de familias modestas, que llegaban a Córdoba en busca de un mejor porvenir. Evidentemente, éste no fue el único motivo para emprender un viaje más allá del océano. El caso de Valentín Mabrés, español, oriundo de la Diócesis de Vich (Barcelona), es interesante por dos razones. La primera es que fue un inmigrante que llegó a Córdoba, a Villa del Rosario, y allí contrajo matrimonio con Dolores Luque, miembro de una de las familias más tradicionales de la provincia, hija de Evaristo Luque y Josefa Álvarez, oriundos de Villa del Rosario. La segunda es que ingresó en el seminario Conciliar de Loreto en 1896, cuando enviudó a la edad de 53 años. A fines de ese año, recibió el subdiaconado y, en abril de 1897 , las sagradas órdenes del diaconado y presbiterado. ${ }^{50}$

Valentín era hijo de Vicente Mabrés y María Josefa Carner. Su padre era agricultor y su madre, hija de un industrial fabricante de telas de algodón. Valentín recibió una esmerada educación, primero, en su pueblo natal, y luego en Tarragona, donde obtuvo el título de profesor de enseñanza primaria y secundaria. Desde sus primeros años, manifestó una marcada inclinación hacia el estado eclesiástico, "a cuyo efecto hizo los correspondientes estudios en algunos Colegios de las Escuelas Pías y en los Seminarios Conciliares de Tarragona y Barcelona, habiéndosele conferido la Primera Tonsura en el año $1861 " .51$

María Josefa Carner Maciá enviudó a los 34 años, quedando a cargo de tres hijos pequeños, Jaime, Rosa y Valentín de apenas 4 años. Rosa pertenecía al grupo de las familias notables de Igualada. ${ }^{52}$ Según consta en su testamento, ${ }^{53}$ a su hijo Valentín legó la cantidad de 2.000 libras catalanas, pagaderas al cumplir éste los 25 años o antes si contrajera matrimonio o, "si tuviera voluntad de pasar a América antes de la muerte de la otorgante y le fuesen costeados por ésta los gastos de su viaje, se entendería rebajado el legado de las 2000 libras a la cantidad que quede, deducido el importe del referido viaje". El valor de la libra catalana era equivalente a 20 sueldos de la época.

Los motivos que llevaron a Valentín Mabrés a viajar a América, como puede deducirse de lo expuesto, no fueron de tipo económico. Valentín decide viajar a Argentina motivado por las disertaciones de Domingo F. Sarmiento en la ciudad de

\footnotetext{
${ }^{50}$ AAC. Leg. 24. TXII, 1895-1900. Expedientes de Ordenes.

${ }^{51}$ AAC. Leg. 24. TXII, 1895-1900. Datos extraídos de la solicitud elevada por Valentín Mabrés, en junio de 1869, al Obispo de Córdoba, para continuar sus estudios eclesiásticos en el Seminario Mayor Ntra. Sra. de Loreto de Córdoba.

${ }^{52}$ Igualada es una comarca de la Anoia, región de Cataluña. Se caracteriza por una importante actividad económica, dividida entre la agricultura, la industria textil y del cuero.

53 Testamento fechado el 11/10/1865, a la edad de 51 años.
} 
Barcelona. Allí, el educador dictó una serie de conferencias sobre la educación en Argentina y la necesidad de educadores para el desarrollo del progreso y la civilización. Estas palabras calaron hondo en su corazón. Varios años después, su madre dejó, como dijimos, legado en su testamento el dinero era para que Valentín pudiera "realizar su sueño, ese sueño loco, contagiado por ese loco americano que pasó hace tiempo por Barcelona alborotando a las buenas gentes con eso de la educación. Que es un maestro, dicen, ese tal Sarmiento, y que es inteligente y arrollador, eso salta a la vista". "Es feo, madre, le contó Valentín, pero su inteligencia y su palabra atrapan, demuelen, obligan. Me han dicho que allá, en su país, la Argentina, todo está por hacerse, y yo quiero hacerlo". 54

Una vez llegado a Argentina, comenzó a desarrollar su vocación de educador en diferentes centros urbanos. Fue profesor de diversas asignaturas en los Colegios Nacionales de Buenos Aires y Mendoza y desempeñó el cargo de Vice-Rector en Santiago del Estero. En Mendoza, comenzó su tarea de visitas de inspección y asesoramiento a escuelas de esa provincia. ${ }^{55}$ Finalmente, escogió el medio rural para desempeñar su tarea y se afincó en la provincia de Córdoba, en la Real Villa del Rosario. En 1869, se ofreció al gobierno de la provincia para inspeccionar, gratuitamente, las escuelas de la zona y fundó la Escuela San José de Calasanz, haciéndose cargo de la dirección de la misma. A fines de 1870, su ofrecimiento fue aceptado por el gobierno que lo nombró inspector de las escuelas públicas de los Departamentos Río Segundo, Río Primero y San Justo. En cumplimiento de sus funciones de inspector, visitó las escuelas de dichos Departamentos e informó al Inspector General de Escuelas de la Provincia sobre los resultados obtenidos. En 1871, a los 28 años, contrajo matrimonio. En la celebración, participó el Gobernador de la Provincia, Dr. Juan Antonio Álvarez, pariente de la novia. El matrimonio tuvo siete hijos: Valentín, el primogénito, nació el 21 de abril de 1872 y fue seguido por Josefa de los Dolores, Aurelia Rosa, Rodolfo Vicente, Josefa Ceferina del Pilar, Enrique Vicente y Celina.

Dejamos aquí a Valentín Mabrés, pues simplemente nos interesa mostrarlo como el caso de un inmigrante, cuyos motivos para salir de su terruño no fueron exclusivamente económicos, además logra establecerse e insertarse en las familias de la élite cordobesa e ingresar al sacerdocio tardíamente, luego de haber desplegado una copiosa labor educacional.

\footnotetext{
${ }^{54}$ César Ostilio MABRES, Memorias de un Olvido. Valentín Mabrés. Carné, educador, Córdoba, 1999.

${ }^{55}$ Los Principios, 20/10/1901. Nota necrológica de Valentín Mabrés, escrita por el Pbro. Pablo Cabrera.
} 
Volviendo al grupo de clérigos de origen extranjero, ordenados en el seminario diocesano, podemos sostener que se los ocupó, principalmente, en las parroquias de campaña. En 1903, Paulino Colabianchi ingresa en el seminario diocesano, suponemos que era sobrino de Valeriano, dado que, en el informe, el rector del seminario señala que traía documentos y buenas recomendaciones del seminario de Frascati (Italia). Y añadía, "ha gozado de muy buena estimación, de la confianza de sus superiores y del cariño de sus compañeros". ${ }^{56}$ Paulino fue ordenado en 1907 y destinado como cura y vicario de Villa María, cargo que ejerció durante más de 20 años. Valeriano Colabianchi, italiano, fue cura y vicario de Quilino, originario de Frascati (Italia). Suponemos, como dijimos, aunque no tenemos certeza, de que era tío de Paulino, quien en 1903, era, según los feligreses de su curato, "un sacerdote anciano i virtuosisimo, activo i tanto desprendido, en su escasez y pobreza, que hemos tenido en diversas ocasiones, [que] cubrir sus necesidades más primarias de su vida". ${ }^{57}$

Donato La Tella, italiano, proveniente de la Villa de Calvere, Arquidiócesis de Acerenza, ingresó en el Seminario Conciliar. En el informe de primera tonsura, el rector, Uladislao Castellano, señala que "el joven Donato Latella fue alumno de este seminario Conciliar desde 1881 a 1883 inclusive [...], habiéndose trasladado a Europa a principios de 1884 por disposición de sus padres". 58 En 1888, ingresa nuevamente al seminario y recibe las órdenes. El Rector Juan Yaniz informa que "le es completamente desconocida la preparación científica del joven Latella, pues en el establecimiento no ha cursado ninguna materia en los pocos meses que ha permanecido. Antes bien, por referencias de personas fidedignas este joven no está preparado para recibir las sagradas ordenes". El Tribunal examinador le confirió la calificación de regular y fue admitido a las primeras órdenes, con el título de servicio a la Iglesia. Ese mismo año, en el mes de noviembre, fue ordenado presbítero, "extra témpora, con dispensa de los intersticios y el título canónico, por exigirlo así la necesidad de la Iglesia". ${ }^{59}$ Fue destinado al curato de San Jerónimo en Bell Ville y luego como cura y vicario a Las Varillas. ${ }^{60}$

\footnotetext{
${ }^{56}$ AAC. Leg. 24. TXII, 1901-1909.

${ }^{57}$ ASV. Nunziatura Argentina, Antonio Sabatucci, 1900-1906, Libro 9, f.172.

${ }^{58}$ AAA. Leg. 24. TX, 1883-1889.

${ }^{59}$ AAC. Leg. 24. TX, 1883-1889.

${ }^{60}$ AAC. Libro 20, f.109 y Libro 21, f.22. No hemos podido confirmar, pero es muy probable que Donato Latella haya sido sobrino de otro Donato La Tella, que también provenía de Frascati y que arribó a la diócesis en 1878. Se le concedieron licencias por dos años para celebrar misas en los templos de la ciudad, luego se lo nombró cura-vicario de Río Seco, donde permaneció seis años, pasando a luego a Salsacate.
} 
Carlos Borello, originario de la diócesis de Cúneo (Italia), en el informe que eleva el Rector del seminario, Luis Álvarez, advierte que los documentos y letras comendaticias del rector del seminario de Cúneo eran muy favorables y "las pruebas que hasta aquí ha dado de su comportamiento, en nada desdicen de la buena reputación y estima que ha sido tenido por los superiores de Italia". Fue ordenado en 1908 y, al poco tiempo, destinado como cura y vicario de Colonia Caroya, permaneció pocos años y luego se lo destinó a San Francisco, cargo que desempeñó por más de treinta años.

Luis Della Casa, italiano, de la diócesis de Utinensis, de la región del Véneto, ingresó al seminario conciliar en 1903 y fue ordenado, a los 29 años de edad, bajo el título de servicio a la Iglesia. El informe del rector del seminario señala que "el seminarista ha observado siempre una conducta moral intachable, frecuenta los sacramentos de la Penitencia y Comunión, y tiene suficiente piedad y exacta observancia de la disciplina del establecimiento". ${ }^{61}$ Nada dice de su preparación científica.

Estos datos muestran, por un lado, la urgente necesidad de contar con clérigos de habla italiana para la atención de las nuevas poblaciones y, por el otro, que se está forjando un nuevo perfil de clero diocesano, compuesto de hombres piadosos, con una conducta moral recta, aunque no necesariamente doctos. El modelo que se está mirando es el del Cura de Ars, patrono de los párrocos. En esta instancia, podemos advertir que la mayoría de los clérigos de origen extranjero, ordenados en la diócesis, alcanzaron el cargo de cura y vicario interino en curatos rurales. Ninguno llegó a ocupar cargos en el gobierno de la diócesis.

\footnotetext{
${ }^{61}$ AAC. Leg. 24. TXIII, 1901-1909.
} 


\section{Capítulo 12}

\section{Clero secular inmigrante extra diocesano}

El presente capítulo aspira a comprender la complejidad del fenómeno de inmigración clerical desde una perspectiva regional que permita, al menos, matizar algunas miradas generalizadoras, que han pasado por alto las especificidades propias de cada espacio. Suele afirmarse que "el clero inmigratorio agudizó los problemas que ya tenía el clero criollo", 1 esta aseveración parte de la base de un clero nativo con profundas deficiencias en el orden disciplinar, moral y espiritual. Si bien esta realidad podría ser ajustada para el espacio porteño, pampeano bonaerense y santafecino, ${ }^{2}$ en Córdoba el clero nativo, a la llegada del clero inmigrante, ya había sido reformado y era bastante idóneo.

El aporte de los estudios migratorios para la comprensión del proceso de secularización, los cambios culturales y las nuevas actitudes de los inmigrantes europeos que arribaron a la Argentina (Devoto, 1990: 183), recuperaron la figura del cura y su función en las sociedades de destino. Si bien Oscar Álvarez Gila (2001: 559576) señalaba, hace casi una década, la carencia de una reflexión historiográfica profunda sobre las actividades que desarrolló la Iglesia en los diversos países americanos con respecto a los inmigrantes, cada vez son más numerosos los trabajos que abordan esta cuestión. El asociacionismo religioso ${ }^{3}$ y la religiosidad popular han sido algunos de los temas preferidos, en ellos, el clero, si bien está presente, no es el objeto central de estudio. En cuanto a la función del clero, los estudios han priorizado la acción del clero regular y las congregaciones religiosas, ${ }^{4}$ quizá por haber sido estas las principales encargadas de la atención del inmigrante (salesianos, scalabrinianos, Propaganda Fidei, etc.), dejando en un segundo plano al clero secular. ${ }^{5}$

Fernando Devoto (1990: 186) señala la evolución que ha experimentado el abordaje de esta temática. En la década de 1960, los científicos sociales recuperaban la imagen, bastante difundida en los ambientes eclesiásticos contemporáneos a la inmigración de masas, de que "en América se pierde la fe". Los nuevos enfoques de los estudios sobre la inmigración italiana, con su énfasis en las continuidades de la experiencia migratoria,

\footnotetext{
${ }^{1}$ AUZA (1990: 107); DI STEFANO y ZANATTA (2000: 321); CEVA (2000: 23).

${ }^{2}$ Cfr. los trabajos de Néstor AUZA y Edgardo STOFFEL en Bibliografía.

${ }^{3}$ Uno de los trabajo pioneros sobre el tema es el de ROSOLI (1992: 77-100).

${ }^{4}$ AUZA (1990: 105-136); BERNASCONI (2005).
} 
entre el antes y el después, con su interés por las redes de sociabilidad parentales y aldeanas, con su preocupación por recuperar la dimensión de lo cotidiano, han hecho emerger una nueva imagen que rescata la figura del clero inmigrante a partir de la lógica y de la significación de esas experiencias en su singularidad, hemos podido revertir el preconcepto de que el clero inmigrante era malo. Como diría Jaques Revel (1995), “esas migajas de experiencias, dan acceso a lógicas sociales y simbólicas" que permiten la reconstrucción de la totalidad desde cada una de sus partes.

\section{Cantidad y tiempo de permanencia}

Responder a la pregunta sobre cuántos y quiénes fueron los individuos que conformaron el clero inmigrante destinado al servicio de las parroquias, no fue tarea sencilla. Los Obispos Álvarez, Esquiú y Tissera gobernaron la diócesis por un período de dos a tres años cada uno, demasiado breve como para organizar administrativamente el obispado. Reginaldo Toro estuvo al frente de la diócesis por doce años, pero tampoco dejó ningún registro de estos clérigos. Recién en 1905, Zenón Bustos, al asumir el gobierno del obispado, llevó a cabo un ordenamiento administrativo, que incluyó el registro del clero secular extranjero. Estos registros suman la cantidad de 124 clérigos.

Tabla 37

\begin{tabular}{|c|c|c|c|c|c|}
\hline \multicolumn{6}{|c|}{ Clero extranjero oficialmente registrado entre 1875 y 1925} \\
\hline \multirow{2}{*}{$\begin{array}{c}\text { Fecha de } \\
\text { arribo }\end{array}$} & \multirow[t]{2}{*}{ Cantidad } & \multicolumn{4}{|c|}{$\begin{array}{l}\text { Procedencia } \\
\end{array}$} \\
\hline & & Españoles & Italianos & Otros & Totales \\
\hline Antes de 1875 & 9 & 2 & 7 & 0 & 9 \\
\hline $1875 / 1879$ & 1 & 0 & 1 & 0 & \multirow{5}{*}{21} \\
\hline $1880 / 1884$ & 1 & 0 & 1 & 0 & \\
\hline $1885 / 1889$ & 7 & 2 & 4 & 1 & \\
\hline $1890 / 1894$ & 5 & 3 & 1 & 1 & \\
\hline $1895 / 1899$ & 7 & 4 & 3 & 0 & \\
\hline $1900 / 1904$ & 16 & 6 & 10 & $\mathbf{0}$ & \multirow{3}{*}{66} \\
\hline $1905 / 1909$ & 23 & 7 & 13 & 3 & \\
\hline $1910 / 1914$ & 27 & 12 & 15 & $\mathbf{0}$ & \\
\hline $1915 / 1919$ & 6 & 1 & 5 & 0 & \multirow{3}{*}{28} \\
\hline 1920/1924 & 17 & 8 & 8 & 1 & \\
\hline 1925/1929 & 5 & 2 & 3 & 0 & \\
\hline Totales & 124 & 47 & 71 & 6 & 124 \\
\hline $\begin{array}{l}\text { Fuente: AAC. I } \\
\text { 1905-1909; Lib } \\
\text { f. } 947 \text { y ss. }\end{array}$ & $\begin{array}{l}\text { 25. Registro c } \\
\text { Registro de }\end{array}$ & cerdotes extr & cesanos; Libr & $\begin{array}{l}\text { Registro sac } \\
\text { do Zenón } B\end{array}$ & $\begin{array}{l}\text { es seculares } \\
\text { Caja } N^{\circ} 3 \text {, }\end{array}$ \\
\hline
\end{tabular}

${ }^{5}$ STOFELL (1991: 222-223); PAZOS (1997: 543-567); ÁLVAREZ GILA (1998: 557-587; 2001); CEVA (2000: 22-31). 
Observamos que los años que van del comienzo del siglo XX a la primera guerra mundial son los que experimentaron el mayor aumento en el arribo de clérigos, fenómeno que se corresponde con la experiencia inmigratoria general.

En cuanto a su procedencia, advertimos que fue diversificada; sin embargo, se destacan dos grupos, los piamonteses y los granadinos. Esta constatación, nos llevó a indagar al respecto. Así, pudimos identificar los nombres y ocupaciones que tuvieron en la diócesis y procuramos seguir sus trayectorias individuales. El análisis, muy limitado y provisorio, nos permite sostener que, dentro de estos grupos, en especial el piamontés, se encontraban los curas que promovieron a cargos estables, como era el de párroco, y a puestos más expectantes, como dignidades del cabildo eclesiástico. Sólo uno de ellos llegó a ser canónigo honorario del cabildo eclesiástico. Juan Cinotto, piamontés, de la diócesis de Turín, párroco de la Colonia Sampacho, durante cuarenta años, desde 1905 hasta su fallecimiento, en 1946. En 1930, recibió el nombramiento de canónigo honorario de la Catedral en reconocimiento de la labor realizada. ${ }^{6}$

La idoneidad se confirma con el testimonio de algunos párrocos. En 1910, el cura de Marcos Juárez advertía que del Piamonte habían llegado "los mejores sacerdotes extranjeros, haciéndose acreedores a la confianza [del Obispo] en la atención de las parroquias". ${ }^{7}$ Seguramente, esta particularidad se debía a que la vida religiosa, en esa diócesis italiana, había conocido un importante crecimiento en la segunda mitad del siglo XIX. Figuras significativas marcaron su impronta y dejaron sentir su influencia en varios ámbitos de la vida social: Don Orione, impulsó las obras de Caridad con los enfermos y desahuciados; Juan Bautista Scalabrini, obispo de Piacenza, impulsó la ayuda a los inmigrantes; Juan Bosco promovió la educación de la juventud marginada por la pobreza; Paolo Manna despertó la conciencia misionera en el clero, fundando la Unión Misional. En el catolicismo piamontés, la parroquia fue el centro de instrucción religiosa, de educación social y de acciones caritativas. El renacimiento religioso del norte italiano contrastaba con la indiferencia, el abandono y la ignorancia de otras regiones. Franco Molinari y Luigi Mezzardi (1979: 837-838) señalan que el centro y el sur mantenían un fuerte indiferentismo religioso, se trataba de zonas campesinas en las que se hallaban muy difundidos el anti-clericalismo y la ignorancia religiosa. La formación del clero era insuficiente y adolecía de grandes lagunas.

\footnotetext{
${ }^{6}$ AAC. Libro de Registro de Sacerdotes Extra-Diocesanos, f.23.
} 
Tabla 38

\begin{tabular}{|c|c|c|c|}
\hline \multicolumn{4}{|c|}{$\begin{array}{c}\text { Clero secular extranjero } \\
\text { que ejerció su ministerio en la diócesis entre 1875-1925 } \\
\text { según regiones de origen de procedencia }\end{array}$} \\
\hline \multicolumn{2}{|c|}{ ESPAÑA } & \multicolumn{2}{|c|}{ ITALIA } \\
\hline Procedencia & Cantidad & Procedencia & Cantidad \\
\hline Andalucía & 11 & Piamonte & 19 \\
\hline Asturias & 2 & Apullia & 1 \\
\hline Baleares & 7 & Basilicata & 1 \\
\hline Castilla-La Mancha & 1 & Calabria & 3 \\
\hline Castilla-León & 6 & Campaña & 2 \\
\hline Cataluña & 2 & Emilia Romaña & 1 \\
\hline Galicia & 3 & Lacio & 1 \\
\hline La Rioja & 1 & Las Marcas & 5 \\
\hline Alicante & 2 & Liguria & 2 \\
\hline País Vasco & 1 & Lombardía & 2 \\
\hline & & Sicilia & 4 \\
\hline & & Toscana & 4 \\
\hline & & Triveneto & 3 \\
\hline Sin identificar & 11 & Sin identificar & 27 \\
\hline Total & 47 & Total & 75 \\
\hline
\end{tabular}

No sorprende que el clero secular que llegó a Córdoba, proveniente del Piamonte, Lombardía o Liguria, haya destacado por su celo y dedicación al ministerio. El obispo los ocupó en la región de las colonias, un espacio con aldeas y villas con gran dinamismo económico y social, en donde el fenómeno de la modernización avanzaba acompañado de un acentuado cambio en las mentalidades.

Sin embargo, el registro analizado es incompleto, pues al consultar los libros de nombramientos y títulos, advertimos la presencia de clérigos seculares que ejercieron el ministerio parroquial sin estar consignados en el registro de clero extra diocesano anteriormente citado. También, al cruzar estos datos con el libro de licencias, comprobamos la existencia de clérigos inmigrantes que ejercieron el ministerio con cura de almas, sin tener ningún nombramiento, solamente con las licencias habilitantes para celebrar, confesar y/o ejercer el ministerio.

\footnotetext{
${ }^{7}$ AAC. Parroquias, Marcos Juárez, f.51. Diciembre 16 de 1910.
} 
Los datos proporcionados por estas fuentes, nos permiten constatar la presencia de 213 clérigos inmigrantes ejerciendo el ministerio en la diócesis. Estas fuentes nos amplían considerablemente el registro anterior.

Tabla 39

\begin{tabular}{|c|c|c|c|c|}
\hline \multicolumn{5}{|c|}{$\begin{array}{l}\text { Clero secular extra diocesano inmigrante } \\
\text { que ejerció el ministerio parroquial en la diócesis de Córdoba } \\
\text { entre } 1875 \text { y } 1925\end{array}$} \\
\hline \multirow[t]{2}{*}{ Fecha arribo* } & \multirow{2}{*}{$\begin{array}{c}\text { Cantidad } \\
\text { Total }\end{array}$} & \multicolumn{3}{|c|}{ Procedencia } \\
\hline & & Españoles & Italianos & Otros \\
\hline Antes de 1875 & 26 & 12 & 11 & 3 \\
\hline $1875 / 18880$ & 17 & 6 & 8 & 3 \\
\hline $1881 / 1885$ & 9 & 4 & 4 & 1 \\
\hline $1886 / 1890$ & 13 & 3 & 6 & 4 \\
\hline $1891 / 1895$ & 12 & 3 & 7 & 2 \\
\hline $1896 / 1900$ & 24 & 6 & 16 & 2 \\
\hline 1901/1905 & 31 & 9 & 20 & 2 \\
\hline 1906/1910 & 31 & 9 & 19 & 3 \\
\hline 1911/1915 & 23 & 11 & 12 & $\mathbf{0}$ \\
\hline $1916 / 1920$ & 4 & 1 & 2 & 1 \\
\hline $1921 / 1925$ & 23 & 10 & 10 & 3 \\
\hline Totales & 213 & 74 & 115 & 24 \\
\hline \multicolumn{5}{|c|}{$\begin{array}{l}\text { Fuentes: AAC. Libro de Registro de sacerdotes extra-diocesanos; Libro de Registro de } \\
\text { sacerdotes seculares, 1905-1909; Libro de Registro de firmas sacerdotes y religiosos, } \\
\text { 1910. Fondo Zenón Bustos, Caja N 3, f.947 y ss. Libro de Títulos, 1859-1925; Libros } \\
\text { de Licencias Ministeriales, 1859-1932; Cajas y Legajos de Parroquias. } \\
\text { Nota: *Cuando no estaba explícita la fecha de arribo se tomó el año de concesión de } \\
\text { las primeras licencias. }\end{array}$} \\
\hline
\end{tabular}

Como puede observarse, el número de clérigos inmigrantes se eleva casi al doble con la incorporación de estas fuentes, las cuales nos permiten un acercamiento más real y dinámico.

Para poder saber la cantidad de clérigos extranjeros que actuaron en la diócesis al menos durante cada quinquenio, procedimos a tomar, además de los arribos, las salidas o fallecimientos. Cuando la fecha de salida no estaba explicitada, consideramos el año del último registro del cura (en las licencias; nombramientos; o libros parroquiales). 
Tabla 40

\begin{tabular}{|c|c|c|c|c|}
\hline que eje & $\begin{array}{l}\text { de clero } \\
\text { el minist }\end{array}$ & $\begin{array}{l}\text { ar extra di } \\
\text { arroquial } \\
\text { e } 1875 \text { y } 1\end{array}$ & $\begin{array}{l}\text { no inmig } \\
\text { diócesis d }\end{array}$ & \\
\hline Fecha & Cantidad & & rocedencis & \\
\hline $\begin{array}{c}\text { fallecimiento } \\
\text { salida* }\end{array}$ & & Españoles & Italianos & Otros \\
\hline Antes de 1875 & 10 & 6 & 3 & 1 \\
\hline $1875 / 1880$ & 11 & 7 & 2 & 2 \\
\hline $1881 / 1885$ & 14 & 9 & 3 & 2 \\
\hline $1886 / 1890$ & 8 & 3 & 2 & 3 \\
\hline $1891 / 1895$ & 19 & 5 & 10 & 4 \\
\hline $1896 / 1900$ & 17 & 2 & 12 & 3 \\
\hline $1901 / 1905$ & 20 & 4 & 14 & 2 \\
\hline $1906 / 1910$ & 23 & 10 & 11 & 2 \\
\hline 1911/1915 & 20 & 12 & 8 & 0 \\
\hline $1916 / 1920$ & 15 & 6 & 8 & 1 \\
\hline $1921 / 1925$ & 22 & 4 & 15 & 3 \\
\hline Totales & 179 & 68 & 88 & 23 \\
\hline $\begin{array}{l}\text { Fuentes: AAC. I } \\
\text { sacerdotes secul } \\
\text { 1910; Fondo Zer } \\
\text { de Licencias Mir } \\
\text { Nota: *Cuando } 1 \\
\text { las últimas licen }\end{array}$ & $\begin{array}{l}\text { o de Regist } \\
\text { 1905-190 } \\
\text { Bustos, Caj } \\
\text { riales, } 185 \\
\text { staba explíc }\end{array}$ & $\begin{array}{l}\text { acerdotes ex } \\
\text { ro de Regis } \\
3 \text {, f.947 y ss } \\
\text {; Cajas y Le } \\
\text { fecha de sal }\end{array}$ & $\begin{array}{l}\text { ocesanos; I } \\
\text { firmas sac } \\
\text { de Títulos } \\
\text { de Parroqu } \\
\text { consignó e }\end{array}$ & $\begin{array}{l}\text { Registro de } \\
\text { y religiosos, } \\
\text { 925; Libros } \\
\text { novación de }\end{array}$ \\
\hline
\end{tabular}

Comparando los ingresos y las salidas/fallecimientos, podemos observar que la presencia de clérigos seculares inmigrantes por quinquenio osciló entre 16 y 44 individuos. A partir del quinquenio 1896-1900, el aumento fue progresivo, los años correspondientes a la gran guerra registran un escaso ingreso de clero y, a partir de 1921, una mayor cantidad de salidas.

Tabla 41

\begin{tabular}{|c|c|c|c|}
\hline \multicolumn{5}{|c|}{ Arribos y Salidas del clero secular extra diocesano inmigrante } \\
que ejerció el ministerio parroquial en la diócesis de Córdoba entre 1875 y 1925 \\
\hline & Arribos & Salidas & Diferencia \\
\hline Existencia & 26 & 10 & 16 \\
\hline $1875-1880$ & 17 & 11 & 22 \\
\hline $1881-1885$ & 9 & 14 & 17 \\
\hline $1886-1890$ & 13 & 8 & 22 \\
\hline $1891-1895$ & 12 & 19 & 15 \\
\hline $1896-1900$ & 24 & 17 & 22 \\
\hline $1901-1905$ & $\mathbf{3 1}$ & 20 & 33 \\
\hline $1906-1910$ & $\mathbf{3 1}$ & 23 & 41 \\
\hline $1911-1915$ & $\mathbf{2 3}$ & 20 & 44 \\
\hline $1916-1920$ & 4 & 15 & 33 \\
\hline $1921-1925$ & 23 & 22 & 34 \\
\hline TOTALES & 213 & 179 & \\
\hline
\end{tabular}


Una vez determinada la cantidad, procedimos a identificar el tiempo de permanencia. Para poder establecer un corte, tomamos como fecha límite el año 1925, de esta manera, a aquellos que permanecieron en la diócesis por más tiempo no se les consideran los años posteriores a esa fecha. Por ejemplo, Juan Cinotto llegó en 1902 y falleció en su parroquia en 1946. El tiempo de permanencia que aparece en la Tabla 42 es 23 años (1902-1925), aunque su permanencia real haya sido de 44 años.

Tabla 42

\begin{tabular}{|c|c|c|c|c|c|c|c|c|c|c|c|c|}
\hline \multicolumn{13}{|c|}{$\begin{array}{c}\text { Clero extra diocesano inmigrante } \\
\text { Años de permanencia }\end{array}$} \\
\hline Años & $0-1$ & $2-5$ & $6-10$ & $\begin{array}{l}11- \\
15\end{array}$ & $\begin{array}{l}16- \\
20\end{array}$ & $\begin{array}{l}21- \\
25\end{array}$ & $\begin{array}{l}26- \\
30\end{array}$ & $\begin{array}{l}31- \\
35\end{array}$ & $\begin{array}{l}36- \\
40\end{array}$ & +40 & $\mathrm{n} / \mathrm{c}$ & Total \\
\hline Antes 1875 & 4 & 5 & 4 & 3 & 4 & 0 & 4 & 1 & 0 & 1 & 0 & 26 \\
\hline $1875-1880$ & 5 & 2 & 2 & 4 & 1 & 2 & 0 & 0 & 0 & 0 & 1 & 17 \\
\hline $1881-1885$ & 3 & 1 & 0 & 1 & 0 & 0 & 3 & 0 & 0 & 0 & 1 & 9 \\
\hline 1886-1890 & 2 & 7 & 0 & 2 & 1 & 0 & 0 & 1 & 0 & 0 & 0 & 13 \\
\hline 1891-1895 & 7 & 1 & 0 & 1 & 0 & 1 & 2 & 0 & 0 & 0 & 1 & 12 \\
\hline 1896-1900 & 10 & 6 & 3 & 2 & 0 & 2 & 1 & 0 & 0 & 0 & 0 & 24 \\
\hline 1901-1905 & 7 & 3 & 9 & 6 & 1 & 3 & 2 & 0 & 0 & 0 & 0 & 31 \\
\hline 1906-1910 & 7 & 10 & 4 & 3 & 4 & 3 & 0 & 0 & 0 & 0 & 0 & 31 \\
\hline 1911-1915 & 3 & 5 & 4 & 6 & 3 & 1 & 0 & 0 & 0 & 0 & 1 & 23 \\
\hline 1916-1920 & 1 & 1 & 2 & 0 & 0 & 0 & 0 & 0 & 0 & 0 & 0 & 4 \\
\hline 1921-1925 & 11 & 12 & 0 & 0 & 0 & 0 & 0 & 0 & 0 & 0 & 0 & 23 \\
\hline TOTALES & 60 & 53 & 28 & 28 & 14 & 12 & 12 & 2 & 0 & 1 & 3 & 213 \\
\hline
\end{tabular}

\section{Gráfico $\mathrm{N}^{\circ} 20$}

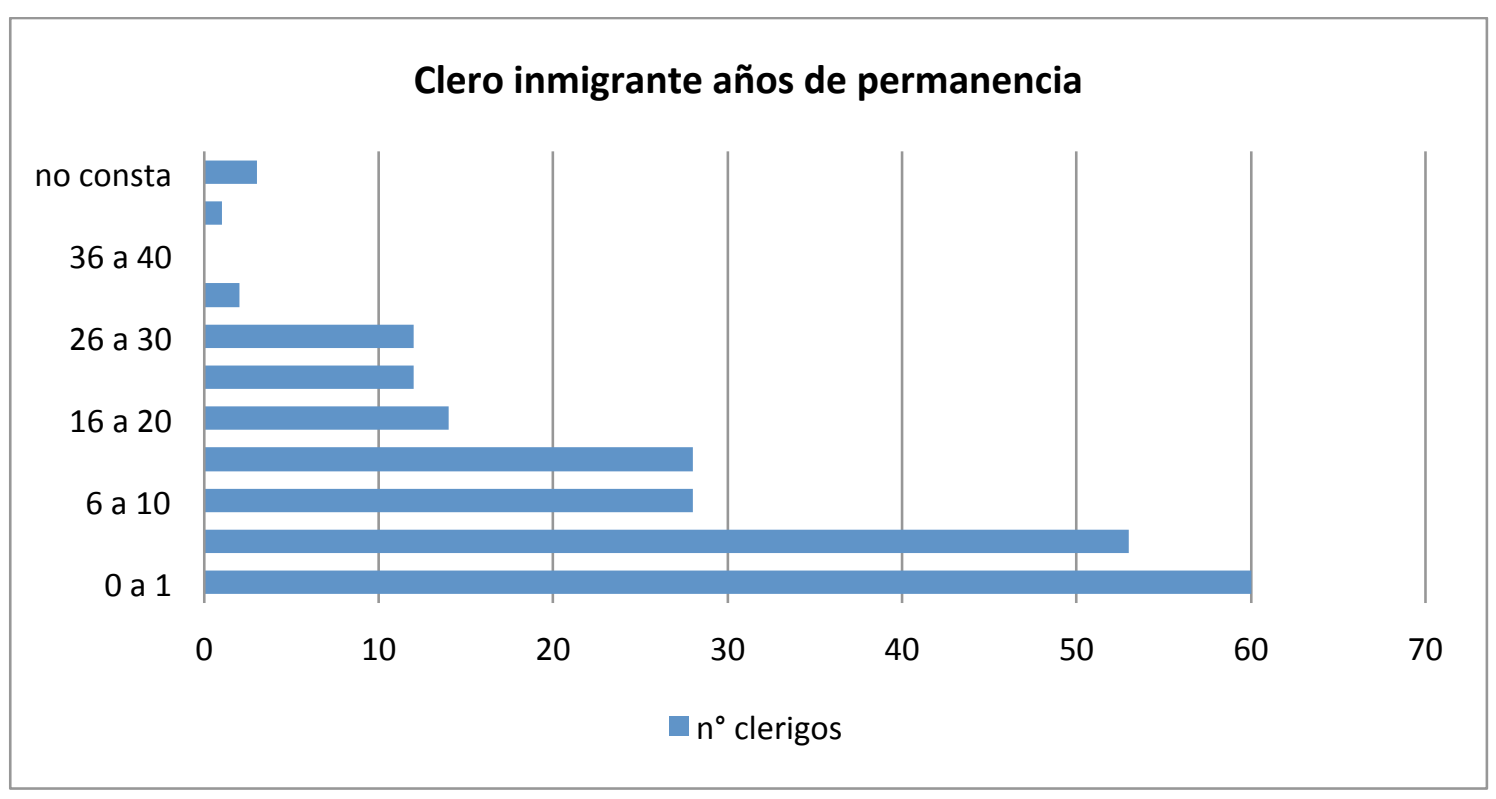


El gráfico muestra claramente que la mayor cantidad de clero permaneció entre $0 \mathrm{y}$ un año y entre 2 y 5 años. En el Gráfico 21 podemos observar los años de permanencia por quinquenio.

\section{Gráfico 21}

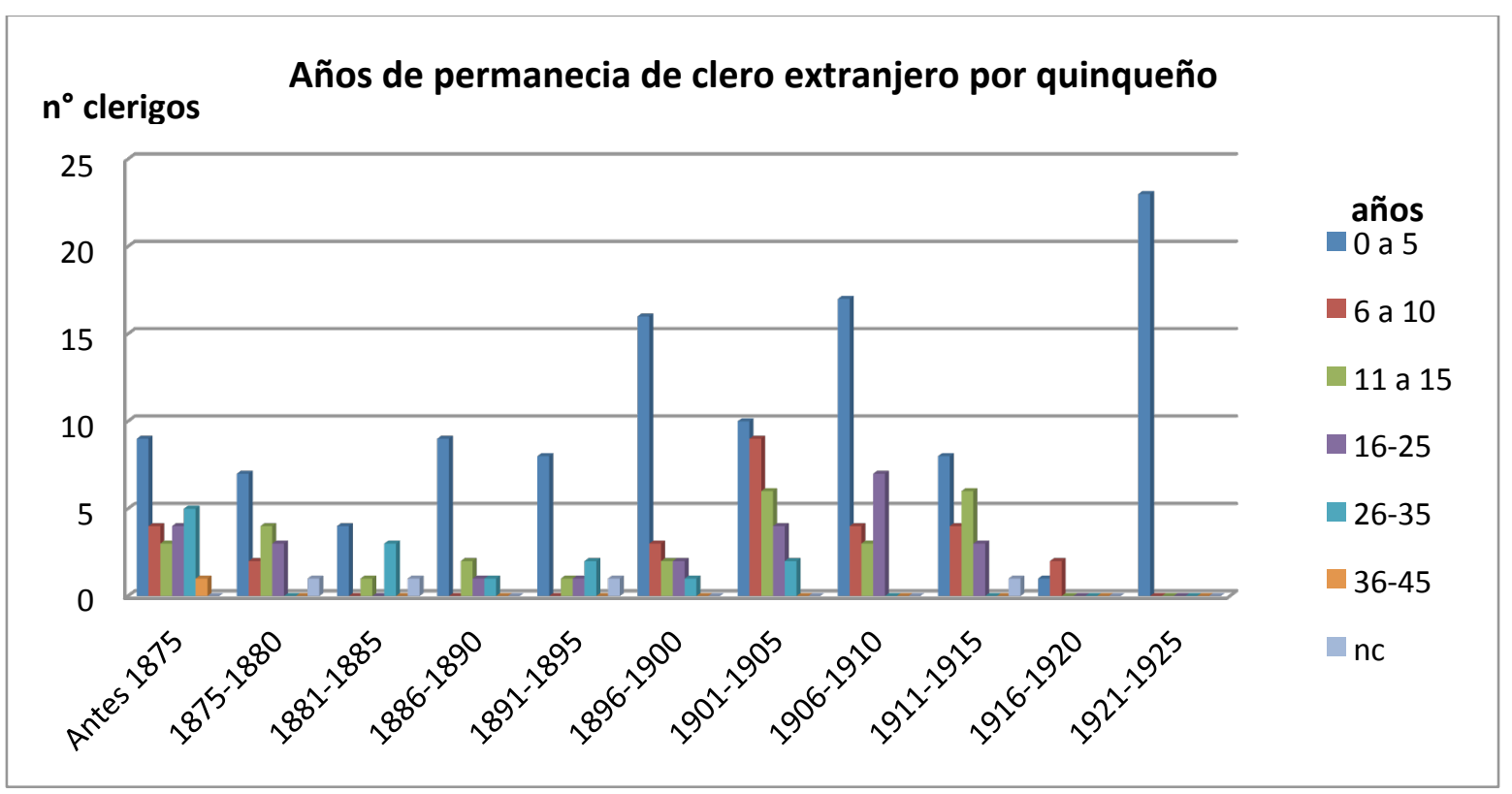

\section{Criollos e inmigrantes: su distribución en el espacio diocesano}

Una vez presentados estos tres sectores del clero, nos interesa indagar respecto a su distribución en el espacio diocesano. La diócesis de Córdoba, en el período analizado, incluía, como dijimos, a la provincia de La Rioja en calidad de Vicaría Foránea, con ocho curatos dependientes. ${ }^{8}$

Para analizar la distribución del clero en el espacio, tomaremos dos regiones contrapuestas, la del este y la del norte, que fueron presentadas en la segunda parte de esta tesis. Cada uno de estos espacios incluía varios curatos de diversa jerarquía en función de su población e ingresos. El norte provincial prácticamente no experimentó el proceso inmigratorio. La fundación de los curatos son de antigua data y la presencia de clero nativo en algunos curatos de raigambre histórica y social fue permanente, como el caso de San Francisco del Chañar. A medida que avanzamos en el período, comienzan a adquirir mayor relevancia los curatos del este provincial, pues, con el aporte de la

\footnotetext{
${ }^{8}$ En 1903, la Vicaria Foránea de La Rioja comprendía los curatos de Famatina, Chilecito, Castro Barros, Tama, Olta, San Blas de los Sauces, Ullapes, Vinchina y Guandacol (AAC. Leg. 1. Catedral. Exp. № 85, fs.439-443. También, AAC. Zenón Bustos. Obispo. Caja No 3).
} 
inmigración europea, esos departamentos alcanzaron mayor índice de crecimiento poblacional y económico, mientras las zonas serranas decrecieron.

El curato de Tulumba tuvo 4 párrocos a lo largo del período 1875-1925. Evaristo López Arcante, diocesano español; Andrés García Colmena, español ordenado en el seminario diocesano; y los Dávila, Inocencio, quien rigió el curato por 10 años, y José María, su sobrino, cuyo ministerio se extendió de 1908 a 1956. El curato de Totoral, en cambio, estuvo regido por 8 párrocos cordobeses, destacándose Domingo Luque, quien se mantuvo por 11 años; Samuel Bustos, 16 y Moisés García, 11. En el curato de San Francisco del Chañar, departamento de Sobremonte, 13 fueron los curas y vicarios cordobeses y 4 extranjeros, dos españoles y dos italianos.

Los curatos de Ischilín y Quilino tuvieron 7 curas párrocos argentinos, dos españoles, formados en el seminario, y 5 inmigrantes, tres italianos y dos españoles. ${ }^{9}$

La presencia y permanencia en el cargo de párrocos, en su mayoría argentinos y en menor media españoles, responde, en primer lugar, a que muchas familias tradicionales de Córdoba tenían sus intereses económicos y propiedades en estos departamentos. Por ello, con frecuencia, el cura era uno de sus miembros. Es el caso, por ejemplo, de Samuel Bustos, miembro de una familia afincada en Totoral, hijo de José Bustos y Anastasia Ramallo, fue uno de los pocos clérigos que se ordenaron a título de patrimonio. ${ }^{10}$ Rigió el curato por 16 años. Lo mismo puede decirse de Pedro Montenegro, hijo de Eleodoro Montenegro y Eduviges Olmos, quién estuvo como cura y vicario cerca de 8 años.

\section{Tabla 43}

\footnotetext{
9 José María (Lindor) Ramallo, argentino, rigió el curato de Ischilín entre 1878 y 1883; Sixto Pereyra, argentino, entre 1884 y 1888; Francisco Martínez del Vall, español, formado en el seminario, entre 1884 y 1889; Alberto Allegro, italiano, de la diócesis de Colta (Canónigo Honorario de aquella Catedral), entre 1889 y 1890; Luis Ramírez y Aparicio, español, de la diócesis de Calahorra; Casto Aparicio, argentino, entre 1890 y 1899; Bernardino Tissera, argentino, entre 1899 y 1913; Guillermo Basso, italiano, de la diócesis de Cesena, Emilia Romagna, entre 1917 y 1926. En cuanto a Quilino, estuvo a cargo de Francisco Pérez, argentino, entre 1880 y 1882; Sofonías Oviedo, argentino, entre 1882 y 1899; Juan Herrera Cortés, argentino, 1898 y 1899; Francisco Cravero, español, entre 1900 y 1902; Valeriano Colabianchi, italiano, entre 1902 y 1903; Miguel Salguero, entre 1903 y 1907; José María Blanch, español, formado en el seminario (proveniente de Palma de Mallorca y domiciliado en la ciudad de Río Cuarto desde 1887), entre 1907 y 1926.

${ }^{10}$ AAC. Leg. 24, TIX, 1873-1880.
} 


\begin{tabular}{|c|c|c|c|c|c|c|c|}
\hline \multicolumn{8}{|c|}{ Párrocos de los curatos del norte entre 1875 y 1925} \\
\hline \multirow[t]{3}{*}{ Departamentos } & \multirow[t]{3}{*}{ Curatos } & \multirow[t]{3}{*}{ Creación } & \multirow[t]{3}{*}{$\begin{array}{l}\text { Párrocos } \\
\text { Regulares }\end{array}$} & \multicolumn{4}{|c|}{$\begin{array}{c}\text { Párrocos seculares } \\
\text { ( cura y vicario, excusador, ecónomo, } \\
\text { administrador) }\end{array}$} \\
\hline & & & & \multicolumn{2}{|c|}{ Diocesanos } & \multicolumn{2}{|c|}{ Extra-diocesanos } \\
\hline & & & & $\begin{array}{l}\text { Argen } \\
\text {-tinos }\end{array}$ & $\begin{array}{c}\text { Extran- } \\
\text { jeros } \\
\text { Alumnos } \\
\text { Seminario }\end{array}$ & $\begin{array}{c}\text { Inmigrantes } \\
\text { europeos }\end{array}$ & $\begin{array}{c}\text { No } \\
\text { consta }\end{array}$ \\
\hline Tulumba & Tulumba & $19 / 07 / 1749$ & 0 & 2 & 1 & 1 & 0 \\
\hline Río Seco & Río Seco & 1772 & 2 & 5 & 5 & 3 & 1 \\
\hline \multirow[t]{2}{*}{ Ischilín } & Ischilín/ & $19 / 07 / 1849$ & 0 & 5 & 1 & 4 & 1 \\
\hline & Quilino & 1860 & 0 & 4 & 1 & 2 & 2 \\
\hline Totoral & Totoral & $\begin{array}{l}18 / 11 / 1858 \\
\end{array}$ & 0 & 8 & 0 & 0 & 0 \\
\hline \multirow[t]{2}{*}{ Sobremonte } & $\begin{array}{l}\text { S. Fran. }{ }^{\text {co }} \\
\text { delChañar }\end{array}$ & $18 / 11 / 1858$ & 2 & 13 & 9 & 3 & 1 \\
\hline & & & 4 & 37 & 17 & 13 & 6 \\
\hline
\end{tabular}

En cuanto a la región del oeste, la realidad fue similar. El curato de Cruz del Eje estuvo regido por 4 curas cordobeses, formados en el seminario, y sólo un español, que se desempeñó como administrador temporario. ${ }^{11}$ El curato de Soto, tuvo como curas y vicarios a 2 argentinos y 3 extranjeros. ${ }^{12}$ El curato de Minas era uno de los más pobres del oeste cordobés, estuvo regido por 12 curas, tres argentinos, uno ex-religioso dominico y nueve inmigrantes, uno de ellos formado en el seminario diocesano. ${ }^{13}$ En tanto en el curato de Pocho, durante el período analizado pasaron 20 curas-vicarios y 4 interinos o provisorios.

El departamento de San Alberto contó con dos curatos, el de San Pedro y el Tránsito. El primero tuvo a José Gabriel Brochero como cura y vicario por 16 años, al crearse el Tránsito, se constituye en cura y vicario del nuevo curato por 13 años más, luego de una

\footnotetext{
${ }^{11}$ Rubén Márquez ocupó el cargo de cura y vicario por un total de 18 años, entre 1860 y 1867 y 1877 y 1888, en los 10 años intermedios estuvo José María Ramallo, también cordobés, formado en el seminario. El período lo completan Rufino Polanco (1888-1914), natural de Tulumba, y José Félix Díaz. El español Ulpiano García estuvo un año como interino mientras se desempeñaba como cura excusador de Punilla (1915).

${ }^{12}$ Juan Baigorri Mota lo rigió por 6 años entre 1886 y 1892, era un religioso franciscano secularizado (secularización concedida en 1884 por la Sagrada Congregación para la disciplina de los regulares); Juan Morandini, italiano, estuvo como cura a cargo durante un interinato de un año y medio (1893-1895); Juan Coto, español, domiciliario de la diócesis de Cuyo, residente en Córdoba, fue párroco por 17 años (18951912); Alberto Molina, cordobés, alumno del seminario conciliar estuvo como párroco 8 años; y Juan Carole, francés, rigió el curato por 6 años (1920-1926).

${ }^{13}$ Olegario Villar, español (1877-1882); Juan José Bataglia, italiano (sin nombramiento, 1882-1884); Vicente Ruiz (1884-1886), se ordenó como dominico en 1869 (no tenemos constancia de su secularización); Juan Morandini, italiano (1895-1896); José Pío Angulo, diocesano cordobés (18961905); José Ghersi, italiano (1905-1905); Emilio García Morón, español (1906-1907); Juan Ramón Varas, diocesano cordobés (1907-1912); Emilio Pichotino, italiano (1913-1915); Teodoro Sierra Álvarez, español (1915-1917); Luis Pauli, italiano, diocesano formado en el seminario (1917-1923); Ignacio Campos, diocesano cordobés (1923-1927).
} 
ausencia de 4 años, vuelve a hacerse cargo por 5 años, hasta su fallecimiento. Un total de 34 años al frente de la parroquia. Lo sucede en el cargo Domingo Acevedo, quien regirá el curato por 36 años, con cabecera en San Pedro. Durante el período analizado estuvo regido por 3 curas párrocos, Facundo Bejaramo, 5 años; José Martínez, 4 años; y José Moyano Centeno, 25 años.

\section{Tabla 44}

\begin{tabular}{|c|c|c|c|c|c|c|c|c|}
\hline \multicolumn{9}{|c|}{ Párrocos de los curatos del Oeste entre 1875 y 1925} \\
\hline \multirow[t]{3}{*}{$\begin{array}{l}\text { Departamen- } \\
\quad \text { tos }\end{array}$} & \multirow[t]{3}{*}{ Curatos } & \multirow[t]{3}{*}{ Creación } & \multirow{3}{*}{$\begin{array}{c}\text { Párrocos } \\
\text { Regulares y ex- } \\
\text { regulares } \\
\text { (secularizados) }\end{array}$} & \multicolumn{5}{|c|}{$\begin{array}{c}\text { Párrocos seculares } \\
\text { (cura y vicario, excusador, ecónomo, administrador) }\end{array}$} \\
\hline & & & & \multicolumn{2}{|r|}{ Diocesanos } & \multicolumn{3}{|c|}{ Extra-diocesanos } \\
\hline & & & & Argentinos & $\begin{array}{c}\text { Extranjeros } \\
\text { Alumnos Seminario }\end{array}$ & $\begin{array}{l}\text { Inmigrantes } \\
\text { europeos }\end{array}$ & Argentinos & $\begin{array}{l}\text { No } \\
\text { consta }\end{array}$ \\
\hline \multirow[t]{2}{*}{ Cruz del Eje } & Cruz del Eje & 1860 & & 4 & & & - & - \\
\hline & Soto & 1886 & & 2 & 1 & 3 & - & - \\
\hline Minas & Minas & 1862 & & 3 & 1 & 8 & - & - \\
\hline Pocho & Pocho & 1765 & 1 & 4 & 1 & 7 & - & - \\
\hline \multirow[t]{2}{*}{ San Alberto } & San Pedro & 1859 & & 2 & - & - & & - \\
\hline & Tránsito & 1885 & & 4 & - & - & & - \\
\hline \multirow[t]{3}{*}{ Punilla } & Punilla & 1780 & 1 & 3 & 1 & 2 & & - \\
\hline & $\begin{array}{l}\text { Capilla del } \\
\text { Monte }\end{array}$ & 1914 & & 2 & - & - & & - \\
\hline & La Cumbre & 1924 & & 1 & - & - & - & - \\
\hline San Javier & $\begin{array}{l}\text { San Francisco } \\
\text { Javier }\end{array}$ & & & 2 & 1 & 1 & 1 & \\
\hline \multirow[t]{2}{*}{ Calamuchita } & San Agustín & 1750 & & 5 & - & 1 & 1 & \\
\hline & $\begin{array}{l}\text { La Cruz/Río de } \\
\text { los Sauces }\end{array}$ & 1870 & 2 & 2 & - & 2 & - & - \\
\hline TOTALES & & & 4 & 34 & 5 & 24 & 2 & - \\
\hline
\end{tabular}

La región del este/sur se logró con la "Campaña del desierto" y, durante el período que abarca este trabajo, se desarrolló el proceso de poblamiento. La corriente inmigratoria ocupó las extensas tierras de pastaje y de tránsito que, en el este de la provincia, habían contado, hasta entonces, con la menor densidad de habitantes, como se presentó en la tercera parte de la tesis. Recordamos aquí que el porcentaje de inmigrantes italianos alcanzó en 1902 el 75\% de la población radicada en estos departamentos (Terzaga, 1963: 101).

Como señalamos en el capítulo anterior, este movimiento poblacional presionó sobre las estructuras administrativas eclesiásticas, ya que el clero diocesano no era suficiente para satisfacer las necesidades espirituales de la diócesis, motivo por el cual se recurrió al clero inmigrante. Aquí nos preguntamos ¿cómo fue la distribución del clero secular en esos espacios? ¿Adónde fueron destinados y a qué cargos accedieron los curas 
inmigrantes? Para acercarnos al tema, hemos identificamos la cantidad, permanencia y procedencia de los párrocos en cada curato (hemos incluido en la categoría párrocos a los curas y vicarios -propios e interinos-, excusadores y administradores), para más adelante quedará el análisis de los ayudantes, tenientes y capellanes, que sin duda son más difíciles de identificar.

\section{Tabla 45}

\begin{tabular}{|c|c|c|c|c|c|c|c|c|}
\hline \multicolumn{9}{|c|}{ Párrocos de los curatos del centro entre 1875 y 1925} \\
\hline \multirow[t]{3}{*}{ Departamentos } & \multirow[t]{3}{*}{ Curatos } & \multirow[t]{3}{*}{ Creación } & \multirow{3}{*}{$\begin{array}{c}\text { Párrocos } \\
\text { Regulares y } \\
\text { ex-regulares } \\
\text { secularizados }\end{array}$} & \multicolumn{5}{|c|}{$\begin{array}{c}\text { Párrocos seculares } \\
\text { ( cura y vicario, excusador, ecónomo, administrador) }\end{array}$} \\
\hline & & & & \multicolumn{2}{|c|}{ Diocesanos } & \multicolumn{3}{|c|}{ Extra-diocesanos } \\
\hline & & & & Argentinos & $\begin{array}{c}\text { Extranjeros } \\
\text { Alumnos Seminario }\end{array}$ & $\begin{array}{l}\text { Inmigrantes } \\
\text { europeos }\end{array}$ & argentinos & \begin{tabular}{|l|l} 
No \\
consta
\end{tabular} \\
\hline \multirow[t]{3}{*}{ Colón } & $\begin{array}{l}\text { Anejos } \\
\text { Norte/Jesús } \\
\text { María }\end{array}$ & $18 / 11 / 1858$ & & 1 & 1 & 1 & - & - \\
\hline & $\begin{array}{l}\text { Colonia } \\
\text { Caroya }\end{array}$ & $29 / 04 / 1898$ & - & - & 2 & 4 & - & - \\
\hline & $\begin{array}{l}\text { Villa } \\
\text { Allende/Calera }\end{array}$ & $04 / 02 / 1914$ & - & 1 & 1 & & & \\
\hline Santa María & $\begin{array}{l}\text { Anejos/ } \\
\text { Altagracia }\end{array}$ & $18 / 11 / 1781$ & - & 4 & 2 & 4 & - & - \\
\hline \multirow{3}{*}{ Río Primero } & Santa Rosa & $10 / 11 / 1800$ & & 5 & - & - & - & - \\
\hline & Remedios & $24 / 07 / 1882$ & 1 & 6 & 1 & $\begin{array}{c}2 \\
\text { (interinatos de } \\
\text { ocho y diez } \\
\text { meses) }\end{array}$ & - & - \\
\hline & $\begin{array}{l}\text { Chalacea- } \\
\text { Obispo Trejo }\end{array}$ & $31 / 05 / 1871$ & 1 & 5 & - & 2 & - & - \\
\hline \multirow[t]{3}{*}{ Río Segundo } & $\begin{array}{l}\text { Villa del } \\
\text { Rosario }\end{array}$ & $10 / 05 / 1704$ & - & 3 & - & - & - & - \\
\hline & $\begin{array}{l}\text { Central Río } \\
\text { Segundo }\end{array}$ & $30 / 3 / 1888$ & - & 3 & 1 & 3 & - & - \\
\hline & $\begin{array}{l}\text { Santiago } \\
\text { Temple }\end{array}$ & $26 / 02 / 1914$ & & 2 & - & 3 & - & - \\
\hline \multirow[t]{4}{*}{$\begin{array}{l}\text { Río Tercero } \\
\text { Arriba }\end{array}$} & $\begin{array}{l}\text { Capilla } \\
\text { Rodríguez/ }\end{array}$ & $00 / 00 / 1780$ & 1 & 2 & - & $\begin{array}{l}1 \text { ( interinato } \\
\text { tres meses) }\end{array}$ & - & - \\
\hline & Oliva & $05 / 03 / 1912$ & - & - & 1 & - & - & - \\
\hline & $\begin{array}{l}\text { Dalmacio } \\
\text { Vélez/Herna- } \\
\text { ndo }\end{array}$ & $10 / 06 / 1913$ & 1 & - & - & - & - & - \\
\hline & & & 4 & 32 & 9 & 16 & & \\
\hline
\end{tabular}

La región de los departamentos colonizadores, como hemos dicho, creció considerablemente. De 4 curatos que tenía en 1877, San Justo, Villanueva, Bell Ville y Río Cuarto, pasó a 29 en 1927. En las cabeceras y curatos más antiguos, el obispo puso a curas argentinos, tal el caso de Villa Concepción del Tío (San Justo), Bell Ville (Unión), donde prácticamente todos los curas vicarios fueron cordobeses, salvo dos 
españoles. ${ }^{14}$ El curato de Río Cuarto estuvo a cargo, hasta 1900, del convento franciscano de Propaganda Fidei. A partir de esa fecha, estuvo regido por curas cordobeses. En los curatos de creación más reciente, se desempeñaron, por lo general, curas inmigrantes, de origen italiano. La Tabla 46 nos permite ver que en la región se ocuparon 40 curas extranjeros, 11 de ellos formados en el seminario diocesano y 37 inmigrantes frente a 33 argentinos. Estos últimos se concentraron en el departamento de San Justo. Esta mirada estática de la distribución del clero vamos a complejizarla unos puntos más adelante, cuando nos refiramos a las relaciones y el ejercicio del misterio, ahora sólo nos interesa mostrar su distribución. Nos preguntamos a qué respondía esta distribución geográfica del clero, pero a esta altura de la investigación sólo podemos aventurar que estuvo estrechamente vinculada a la política eclesiástica a nivel central (Roma) y diocesana local.

\section{Políticas de incorporación del clero inmigrante}

Durante el último tercio del siglo XIX, las políticas de incorporación de clero foráneo fueron bastante erráticas. Los sacerdotes seculares que arribaron a la diócesis traían licencias "ilimitadas", cuyo destino era Sud América. ${ }^{15}$ Se trataba de permisos suficientemente imprecisos, que habilitaban al clero a desplazarse en busca de una mejor colocación. Para admitir a un sacerdote de otra diócesis, sólo bastaba la presentación de las licencias del propio ordinario y la admisión por parte del prelado de la diócesis de destino. ${ }^{16}$ Esto facilitó el desplazamiento de curas sin demasiada supervisión por parte de las autoridades eclesiásticas.

A comienzos del siglo XX, esta práctica comenzó a cambiar y la emigración de clérigos europeos estuvo cada vez más controlada por la Santa Sede y los obispos locales. Pío X reformó la curia romana y creó, en 1913, la primera oficina para la emigración. El Vaticano comenzó a exigir una serie de requisitos para el traslado, entre los que se encontraba la autorización del obispo propio, el prescripto pontificio y la admisión en la diócesis de destino. ${ }^{17}$

\footnotetext{
${ }^{14}$ Doroteo García de la Serna, a cargo del curato de Bell Ville entre 1876 y 1879, y Severiano Coronado en Villa Concepción del Tío (San Justo), como cura excusador, entre 1915 y 1920.

${ }^{15}$ Cf. AAC. Libro 25. Entre 1874 y 1899, la mayoría de los sacerdotes que arribó a la diócesis de Córdoba lo hizo con licencias ilimitadas con destino a Sud América, Buenos Aires o sin especificar.

${ }^{16}$ AAC. Leg. 47. Morteros, 08/06/1905.

${ }^{17}$ El decreto de la Congregación Consistorial del 25 de marzo de 1914 establecía, en su artículo primero, que ningún sacerdote podía emigrar sin tener un certificado de buena conducta. Quienes obtuvieran dicho certificado debían obtener la promesa de recibir algún oficio eclesiástico en el lugar de destino. Por su parte, los obispos no debían recibir ningún sacerdote sin antes asegurarse de que se trata de un sacerdote
} 
Tabla 46

Párrocos de los curatos del sudeste entre 1875 y 1925

\begin{tabular}{|c|c|c|c|c|c|c|c|}
\hline \multirow[t]{3}{*}{ Departamentos } & \multirow[t]{3}{*}{ Curatos } & \multirow[t]{3}{*}{ Creación } & \multirow{3}{*}{$\begin{array}{c}\text { Párrocos } \\
\text { regulares } \\
y \\
\text { secularizados }\end{array}$} & \multicolumn{4}{|c|}{$\begin{array}{c}\text { Párrocos seculares } \\
\text { (cura y vicario, excusador y administrador) }\end{array}$} \\
\hline & & & & \multicolumn{2}{|c|}{ Diocesanos } & \multicolumn{2}{|c|}{ Extra-diocesanos } \\
\hline & & & & Argen. & $\begin{array}{c}\text { Extranjeros } \\
\text { (Alumnos } \\
\text { Seminario) }\end{array}$ & $\begin{array}{c}\text { Extranjeros } \\
\text { Inmigrantes } \\
\text { europeos }\end{array}$ & $\begin{array}{l}\text { No } \\
\text { consta }\end{array}$ \\
\hline \multirow[t]{12}{*}{ San Justo } & $\begin{array}{l}\text { San Justo/V. } \\
\text { Concepción }\end{array}$ & $21 / 08 / 1860$ & \multirow{12}{*}{1} & \multirow{12}{*}{15} & \multirow{12}{*}{ 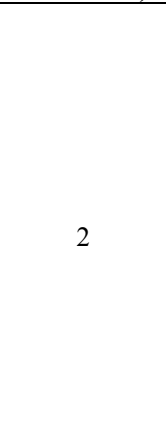 } & \multirow{12}{*}{19} & \multirow{12}{*}{1} \\
\hline & S. Francisco & $10 / 08 / 1892$ & & & & & \\
\hline & Morteros & $10 / 08 / 1892$ & & & & & \\
\hline & Arroyito & $13 / 02 / 1902$ & & & & & \\
\hline & Porteña & $17 / 12 / 1910$ & & & & & \\
\hline & Las Varillas & $20 / 07 / 1912$ & & & & & \\
\hline & Vignaud & $27 / 10 / 1921$ & & & & & \\
\hline & Balnearia & $4 / 12 / 1923$ & & & & & \\
\hline & Etruria & $15 / 09 / 923$ & & & & & \\
\hline & San Bartolomé & $16 / 02 / 1925$ & & & & & \\
\hline & Sacanta & $17 / 02 / 1925$ & & & & & \\
\hline & Devoto & $04 / 03 / 1925$ & & & & & \\
\hline \multirow[t]{4}{*}{ Unión } & Bell Ville & $16 / 01 / 1860$ & \multirow{4}{*}{0} & \multirow{4}{*}{5} & \multirow{4}{*}{1} & \multirow{4}{*}{6} & \multirow{4}{*}{2} \\
\hline & Canals/Arias & $27 / 06 / 1902$ & & & & & \\
\hline & S. Antonio Litín & $11 / 12 / 1917$ & & & & & \\
\hline & Ballesteros & $11 / 12 / 1917$ & & & & & \\
\hline \multirow[t]{6}{*}{ Marcos Juárez } & Marcos Juárez & $10 / 10 / 1893$ & \multirow{6}{*}{3} & \multirow{6}{*}{5} & \multirow{6}{*}{7} & \multirow{6}{*}{4} & \multirow{6}{*}{0} \\
\hline & Cruz Alta & $28 / 09 / 1895$ & & & & & \\
\hline & Leones & $03 / 06 / 1913$ & & & & & \\
\hline & Isla Verde & $02 / 06 / 1913$ & & & & & \\
\hline & C. Aldao & $17 / 12 / 1915$ & & & & & \\
\hline & Surgentes & $08 / 06 / 1926$ & & & & & \\
\hline \multirow[t]{4}{*}{ Tercero Abajo } & Villa Nueva & $14 / 01 / 1838$ & 1 & 3 & 1 & 2 & \\
\hline & $\begin{array}{l}\text { La Playora/Pozo } \\
\text { del Molle }\end{array}$ & $11 / 05 / 1913$ & - & - & - & 1 & \\
\hline & Etruria & $15 / 11 / 1923$ & - & - & - & 1 & - \\
\hline & Villa María & $15 / 11 / 1874$ & 2 & 1 & 1 & - & - \\
\hline Juárez Celman & La Carlota & $8 / 09 / 1892$ & 0 & 1 & 0 & 3 & 0 \\
\hline & Gral. Cabrera & $14 / 08 / 1910$ & & & & 3 & 0 \\
\hline Río Cuarto & Río Cuarto & $10 / 07 / 1749$ & & & & & \\
\hline & Sampacho & 1902 & & & & & \\
\hline & S. José Gigena & 1913 & Convento & & & & \\
\hline & Moldes & 1924 & & 3 & 0 & 1 & 0 \\
\hline Gral. Roca & Laboulaye & $26 / 07 / 1901$ & & & & & \\
\hline & Cañada Verde & $14 / 08 / 1909$ & & & & & \\
\hline & & & 7 & 33 & 11 & 37 & 3 \\
\hline
\end{tabular}

En 1914, se fundó, en Roma, el Pontificio Collegio per la Emigracione Italiana, que se orientaba a los emigrantes italianos en América (Ceva, 2000: 24). A su vez, el nuevo Código de Derecho Canónico, de 1917, regulaba la disciplina del clero y normalizaba la

digno. Los obispos del sacerdote emigrante debían comprobar que dicho sacerdote perteneciera a su diócesis por un título canónico que por sus cualidades podía ser recomendado. Dadas estas condiciones restaba poseer el documento escrito del obispo americano, prometiendo recibir y dar colocación al clérigo que emigraba (Cfr. La Civilta Cattolica, n 56, vol. II, Roma, 1914, pp. 366-369). 
adscripción de los clérigos a las diócesis, prohibiendo la existencia de clero vago. ${ }^{18} \mathrm{La}$ Santa Sede también comienza a exigir a los obispos que verifiquen la idoneidad del clero que emigra. En 1882, el delegado Apostólico Mons. Mattera ordena al Obispo Esquiú que "salvo pocas excepciones que deban hacerse, se exija a los sacerdotes europeos que vienen a esta diócesis además de las letras testimoniales el que tomen ejercicios espirituales antes de ser habilitados para predicar y oír confesiones". ${ }^{19}$

En el informe de la Visita ad limina de 1908, el Obispo Bustos señalaba la necesidad de multiplicar las parroquias y advertía que "a falta de clero criollo, tendremos que acudir al extranjero, escogiéndolo con las cautelas necesarias y mientras nuestro seminario no pueda llenar estos claros". ${ }^{20}$ El clero extranjero era, por lo tanto, un recurso ante situaciones de extrema necesidad. El obispo no contaba con clero suficiente para la atención de las numerosas colonias que se establecían en el sudeste provincial.

La política eclesiástica fue reticente a nombrar, en carácter de cura párroco, a "clero extraño”. El auto del 6 de mayo de 1906 lo expresa claramente:

Resolvemos que los interinatos sean servidos exclusivamente por los sacerdotes de la diócesis. [...] Los sacerdotes de extraña diócesis cuya piedad y celo los haga acreedores de nuestra confianza, podrán ocupar sus ratos en calidad de excusadores, que son completamente amovibles, y por su buen porte hubieren de permanecer más de una año, sus títulos serán renovados el $1^{\circ}$ de enero de cada año. ${ }^{21}$

Sólo aquellos sacerdotes cuya piedad y celo los hiciera acreedores de la confianza episcopal podían aspirar a un puesto más expectante. El clero inmigrante estuvo, por lo tanto, destinado a servir en calidad de capellanes o ayudantes y de párrocos en aquellos curatos a los que no aspiraba el clero diocesano.

En el informe de la Visita de 1908, el Obispo Bustos señala claramente: "La parte del clero extranjero que hemos hallado incorporado al nuestro a nuestra llegada lo hemos separado casi en su totalidad, salvando las pocas excepciones honrosas, por alejar de nuestros fieles los ejemplos incorrectos que les ofrecían en varias formas. Empleando medidas no menos caritativas que eficaces los hemos devuelto a sus respectivos

\footnotetext{
${ }^{18}$ Código de Derecho Canónico, Parte Primera, Título I, La B.A.C, Madrid, 1941, pp. 48-50.

${ }^{19}$ AAC. Libro de Notas, 1876-1892, f.265. Nota fecha del 26/07/1882.

20 AAC. Libro 99. Informe presentado a SS Pío X Por el Ilmo. Sr. Obispo de Córdoba Zenón Bustos y Ferreyra en su Visita ad limina practicada en el mes de noviembre de 1908, f.55.

${ }^{21}$ AAC. Leg. 2. Cabildo Eclesiástico de Córdoba, TII, f.333.
} 
prelados, aunque a muchos de ellos, después que habían impreso hondas huellas de perturbación moral".22

En este sentido, la política diocesana hacia el clero inmigrante fue reticente a otorgar títulos. Antes de hacer un nombramiento, el obispo se aseguraba la idoneidad de los aspirantes. De los 213 clérigos que identificamos que ejercieron el ministerio parroquial, 52 lo hicieron sólo con licencias ministeriales. Una nota enviada por un cura inmigrante al obispo, en la que le solicitaba su nombramiento, refleja claramente la política implementada, "como no puedo menos que poner mis documentos en regla pues dentro de dos meses expira el permiso de mi ordinario le agradeceré muchísimo se digne decirme con toda claridad si puedo o no contar con ser admitido aquí, ya que en caso negativo tentaría de nuevo en Buenos Aires por si allí tuvieran a bien prorrogarme la admisión [...] Espero que V.E que me prorrogará la admisión por aquí el tiempo que me fuese conveniente, pues confieso nuevamente que este clima me sienta muy bien". La respuesta del prelado fue breve, "no puedo darle admisión por falta de colocación adecuada y por otros compromisos pendientes, no tengo inconvenientes en que siga con sus licencias como las tiene hoy". ${ }^{23}$

El análisis del libro de licencias ministeriales nos permitió hacer un rastreo de la trayectoria personal de estos clérigos que se ocuparon, temporal y provisoriamente, en la diócesis. Por lo pronto, lo que podemos señalar es la tendencia a conceder licencias para celebrar la misa durante unos meses (tres o seis), al cabo de ese tiempo, se renovaban por la misma cantidad de tiempo o un año, al cabo de ese lapso se ampliaban y se prorrogaban por uno o dos años más, luego de haber chequeado la idoneidad del cura si se le concedía título o se le retiraban las licencias. Un ejemplo es el caso de José de Diego, italiano, de la diócesis de Cassaso (Calabria). Llegó al obispado en 1887, se le otorgaron licencias por dos años (1887 a 1889), en 1896 se le renovaron por un año y a partir de 1913 por dos años (1915, 1917 y 1919). Ese año se le vencieron y ya no le fueron renovadas. Un caso similar fue el de Blas Sarti, también italiano, de la diócesis de Mossa. Llegó a Córdoba en 1910, se le otorgaron licencias para celebrar y confesar por tres meses, luego se le renovaron cada año (1911, 1912 y 1913), y en el último se le concedieron por tres años para el ejercicio del ministerio hasta 1916, renovándoselas por tres años más.

\footnotetext{
${ }^{22}$ AAC. Libro 71, f.54. Informe de la Visita ad limina del 06/08/1908.

${ }^{23}$ AAC. Fondo Monseñor Lafite, f.289.
} 
El otorgamiento de títulos también tenía su lógica, pues el clero inmigrante debía recorrer un cierto camino. Comenzaba a ejercer el ministerio en curatos pobres de La Rioja, el norte de Córdoba o como ayudantes en colonias de inmigrantes. En función de su desempeño, pasaba a curatos de mayor categoría. Por ejemplo, Ambrosio Raynoldi, italiano, llegó a la diócesis en 1871, en febrero se le concedieron licencias para celebrar por el término de cuatro meses, al cabo de los cuales le fueron renovadas por un año; pasado ese tiempo, le volvieron a ser renovadas por tiempo indeterminado. ${ }^{24}$ En noviembre de 1871 , lo encontramos como párroco de uno de los curatos más pobres y extensos de la diócesis, Vinchina, y como administrador, hasta que se proveyera, de Guandacol en La Rioja. Desde allí, escribió al secretario del obispado para solicitar se lo trasladara a otro curato. La carta es sumamente interesante, pues da cuenta de la difícil situación de estas regiones, la pobreza de las parroquias, las penurias que debían pasar y los pasos que debían seguir para ascender en la carrera eclesiástica:

Cuando acepté el cargo honroso de cura y vicario de los dos departamentos de Vinchina y Guandacol no conociendo la localidad no podía juzgar del pesado oficio que aceptaba. Estos dos departamentos tienen una extensión de cerca de 70 leguas de largo y unas 20 de ancho, ocupando los abitanes y con la mayor parte a enormes distancias. Es imposible que un cura, no muy acostumbrado a tan largos galopes pueda consiensusamente atender y cumplir con sus deberes sin perjudicar su salud, de manera que a poco tiempo será inútil. Esto sucede a mi, no tanto creo por las fatigas, cuanto por los vientos norte y la falta de todos los medios de honrada subsistencia. Dos confesiones me hicieron dar siete días y cuatro noches de galope y a consecuencias de ella tuve un ataque apoplético del cual he salido felizmente contra la esperancia de todos lo que me rodeaban, pero en tres meses no he todavia podido reemplazar las fuerzas perdidas. La pobreza en estos lugares es tanta que me hace imposible poder pedir ayudante, pues confieso la verdad que si no gastara la plata que me llego de Europa, con los réditos de estos dos curatos no alcanzaría a vivir. Esta pobreza es originada por las desvastaciones de la Montoneras por una parte, y por otra influyo la imprudente conducta de algunos de mis predecesores. He tomado mucho afecto a mis feligreses, todos que trato como hijos, pues ellos mismos, ninguno exeptuado me quieren como padre, y por ello no quisiera dejarlos, pero creo sea mi ingrato deber decirle a Ud. que muy pronto acabarán mis fuerzas si permanezco en estos lugares. Si V.S. tuviera disponible un curato más proporcionado a mis fuerzas, en la provincia de Córdoba, que me parece más favorable a mi salud, y como yo no sea un ser indigno o del todo inútil, suplico tenga $\mathrm{Ud}$. la bondad de tenerme en consideracion pues hasta que la benigna autoridad crea oportuno ocuparme no rehusaré prestar mis débiles servicios. No busco un curato rico no de grande descanso, pues como a Ud. vera noto, mi vida es laboriosa ni amo guardar plata, lo que yo quisiera si es posible es conseguir un curato al cual pueda atender perfectamente siendo más reducida su extensión. En el caso que mis defectos, bien que involuntarios, me hagan indigno ante Ud. de ocupar ningún curato, suplico me de licencia para volver a Córdoba, en el Pueblo

\footnotetext{
${ }^{24}$ AAC. Libro 30. Licencias Ministeriales, 1859-1932, fs.66, 67, 70, 75.
} 
Nuevo cuando V.S. haya provisto a otro cura en estos departamentos. [...]. No es una formal renuncia, pues como hijo de la obediencia jamás he renunciado ni renunciaré a los cargos que me fueron confiados [...] también estoy pronto a quedarme con la certidumbre que deberé dejar la vida por las ocupaciones superiores a mis fuerzas si esta es la determinación de la venerable superioridad quedando satisfecha mi conciencia en el manifestar humildemente mi verdadero estado. $^{25}$

Al cabo de cinco años, pasó a desempeñarse como cura y vicario en varios curatos de Córdoba, Punilla, Remedios, San Justo y San Pedro en las colonias. ${ }^{26}$ En 1900, solicitó licencias para viajar a Europa y salió de la diócesis. El obispado de Paraná envió a la curia un acuse de recibo de las licencias de Raynoldi y advertía que "debo manifestarle que dicho señor ha aceptado un cargo en una capellanía en una colonia italiana en esta ciudad y no piensa por ahora ir a Europa. ${ }^{27}$

A Olegario Villar y Pastor, español, en agosto de 1874, se le concedieron licencias para celebrar, predicar y confesar por tres meses y luego se le prorrogaron por el tiempo que permaneciera en la diócesis, renovándose cada dos años. ${ }^{28}$ En diciembre, se lo nombró cura interino de Tama (La Rioja), donde permaneció por tres años, en 1877 se lo nombró cura y vicario de Minas, luego de cinco años pasó a Río Seco y después de nueve años fue nombrado cura y vicario de Tercero Arriba. ${ }^{29}$

Félix Mattio, italiano, de la diócesis de Rívoli, llegó a Córdoba en 1878, recomendado por el Cardenal Rampolla, ex alumno del Seminario de San Pedro y San Pablo en Roma (Propaganda Fidei). Se le concedieron licencias para celebrar, confesar y predicar por dos años, las cuales fueron renovadas sucesivamente. En 1892, se lo nombró cura y vicario interino de Chilecito (La Rioja), con todas las facultades para el ejercicio del ministerio, en 1898, con el mismo cargo, se trasladó a Famatina, otro curato de La Rioja, y, al año siguiente pasó, a Córdoba, donde se desempeñó como cura y vicario de Colonia Caroya y luego de San Vicente (ciudad).

Juan Morandini, italiano, llegó al obispado en 1883, se le concedieron licencias generales para el ejercicio del ministerio por el lapso de dos años y se lo nombró cura y vicario de Tama en La Rioja, siete años después fue nombrado cura y vicario en San Blas de los Sauces (La Rioja), pasados tres años se lo destinó como cura de Soto en el

\footnotetext{
${ }^{25}$ AAC. Nombramiento de Curas, 1777-1904, s/f. Nota del 18/11/1871.

${ }^{26}$ AAC. Libro de Títulos, 1859-1904, fs.54, 63, 76, 95, 99 y 101.

${ }^{27}$ AAC. Leg. 43. Comunicaciones de Arzobispos y Obispos, 1859-1907, s/f. Nota del 31/03/1900.

${ }^{28}$ AAC. Libro 30. Licencias Ministeriales, 1859-1932, fs.86, 94, 108. Fechas de renovación: 19/08/1874, 21/09/1876 y 22/8/1878.

${ }^{29}$ AAC. Libro de Títulos, 1859-1904, fs.58, 64, 75, 79, 53.
} 
norte cordobés, dos años después se lo nombró en el curato vecino de Minas, en el que permaneció por dos años más, luego pasó como cura y vicario de San Pedro de Morteros, en 1912, lo encontramos como capellán de la Colonia Brinckman. ${ }^{30}$ Las licencias fueron renovadas, al principio, cada dos años y, luego, a voluntad del obispo hasta 1913, en que se le renovaron por un año. ${ }^{31}$ A partir de esa fecha, ya no tenemos rastros Morandini, ${ }^{32}$ suponemos que salió de la diócesis.

En los albores del siglo XX, la lógica seguía siendo la misma. Emilio Pichottino llegó a Córdoba en 1902, proveniente de Turín. Poseía el Prescripto de la Sagrada Congregación, fechado en 1902, renovado en 1919 hasta 1922 y vigente hasta 1930. En 1902, se lo destinó como cura y vicario a Ullpes (La Rioja), nueve años después pasó a Minas, en el oeste cordobés, donde permaneció nueve años, y luego fue designado como ayudante (vicario cooperador) del curato de Santa Rosa y luego de Río Segundo. ${ }^{33}$

Otro caso es el de Teodoro Sierra Alvarez, español, oriundo de la diócesis de León, quien arribó a Argentina en posesión de licencias sin término para la Arquidiócesis de Buenos Aires y el Prescripto de la Sagrada Congregación, fechado en 1900. En 1902, se trasladó a Córdoba, se le conceden licencias generales por tres meses, pasado ese tiempo se lo nombró cura de Río Seco, donde permaneció cuatro años, luego se lo nombró cura y vicario interino de Vinchina (La Rioja) y al año siguiente pasó a Famatina en la misma provincia, permaneció en el cargo ocho años y fue trasladado al curato de Minas, donde ejerció el ministerio por dos años, pasado ese tiempo se lo nombró ayudante de la catedral en 1920. En 1927, se lo distinguió como capellán de Coro de la Catedral. ${ }^{34}$

Al fallecer Fortunato Gambini, cura italiano, capellán de Villa María con residencia en San Antonio de Litín, del cual hablaremos más adelante, el cura párroco, Pablo Cicerón Colabianchi, escribió al secretario de la curia para señalar que "en las condiciones que se encuentra esa parroquia podría servir como ascenso para otros

\footnotetext{
${ }^{30}$ AAC. Títulos 1859-1904, fs.77, 95, 98, 102, 104.

${ }^{31}$ AAC. Libro 30. Licencias Ministeriales, 1859-1932, fs.190, 237, 257, 269, 271, 300, 315, 317, 318, 355.

${ }^{32}$ AAC. Libro 24. Registro de Sacerdotes Seculares, 1905-1909, f.120.

${ }^{33}$ AAC. Libro de Títulos, 1859-1904, f.111; Libro de Títulos, 1905-1927, f.23 y 42. AAC. Libro 24. Registro Sacerdotes Seculares, 1905-1909, f.78.

${ }^{34}$ AAC. Libro 30. Licencias Ministeriales, 1859-1932, fs.350, 375, 378, 385; Libro de Títulos, 18591904, f.111 y Títulos, 1905-1927, fs.8, 33, 36. AAC. Libro 25. Registro de Sacerdotes Extra Diocesanos, f. 91; Registro Sacerdotes Seculares, 1905-1909, f.36.
} 
colegas que desean salir de la Rioja [...] No te parece?". ${ }^{35}$ La nota refleja un modus operandi, los curatos de La Rioja eran sin duda el primer escalón para incorporarse al clero diocesano de Córdoba. Podríamos decir que eran una prueba de fuego que no todos los curas lograban superar. De hecho de los 168 clérigos inmigrantes que recibieron nombramientos para ejercer el ministerio en Córdoba, 90 comenzaron en La Rioja, 42 en los departamentos del norte y el resto como ayudantes o capellanes en la colonias.

En cuanto a los 52 clérigos que ejercieron solamente con licencias, 10 corresponden a licencias otorgadas en 1923-1925, es decir eran curas que todavía estaban en los primeros años de prueba. Los otros 42, que ejercieron sólo con licencias, los encontramos, fundamentalmente, en la zona de las colonias y no alcanzaron a estar en la diócesis más de cinco años. Sólo encontramos el caso de Santiago Bonoris, italiano, de la diócesis de Ultinensis, que llegó a la provincia en 1880 y se retiró en 1904, se le concedieron licencias para celebrar, predicar y confesar (la fecha de retiro es estimada). Era hermano de José Bonoris, cura de Caroya, a quien acompañó como ayudante sin tener nombramiento de tal. También aparece el caso de Genaro Tartagalia, a quien en 1886 se le concedieron licencias por tiempo indeterminado y permaneció en la diócesis hasta al menos 1902, en que lo encontramos como capellán de Perdices.

Estos casos nos hablan de una carrera de tipo meritocrática. Se comenzaba como ayudante, teniente o capellán, se accedía al cargo estable de cura interino en algún curato pobre, en general de La Rioja, y luego se pasaba a Córdoba, para cubrir curatos vacantes.

El clero inmigrante con frecuencia mantenía más relación con la nunciatura que con el obispo de la diócesis que lo acogía. El caso de Ricardo P., ${ }^{36}$ italiano, de la diócesis de Camerino, nos muestra la fluidez de la comunicación del clero inmigrante con la nunciatura. En 1905, se desempeñaba como capellán en Camilo Aldao, por ello recibió varias denuncias del ministerio por mal desempeño. En enero de 1908, lo encontramos en Buenos Aires, donde había sido admitido en la casa de la Misión de San Vicente de Paul, a petición de Mons. Locatelli, Internuncio Apostólico, con el fin de trabajar, mediante retiro y silencio, en su rehabilitación. El visitador le informa al internuncio que el Pbro. Ricardo P. "ha demostrado buena voluntad y ha desempeñado su oficio, sino con éxito por tener poca actitud para la educación y formación de la juventud, por

\footnotetext{
${ }^{35}$ AAC. Parroquias: Villa María, f.122. Nota del 17/12/1924.
} 
lo menos con celo y exactitud. Se ha consagrado además al repaso de la Teología moral bajo la dirección de un sacerdote de la misión. Que de ese punto de vista de la moralidad, su conducta ha sido ejemplar, no habiendo cosa alguna que reprocharle, ni hecho alguno que pueda dar lugar a la más mínima sospecha. Que en cuanto a la piedad ha sido regular y fiel en cumplir con los ejercicios espirituales que previamente se le señalaron, habiendo rezado cada día el santo breviario, hecho diariamente la comunión y acercándose semanalmente al sacramento de la penitencia. Dicho sacerdote tiene y manifiesta deseo vehemente de verse cuanto antes rehabilitado". ${ }^{37}$ En 1909, escribe a la Nunciatura argentina e informa que estaba, provisoriamente, en la parroquia de Jesús María como ayudante del párroco de Colón. Pero en una situación crítica y delicada, ya que no contaba con "documentos formales para ser recibido", por lo tanto, la Curia de Córdoba, debido al decreto del Santo Oficio del mes de octubre, le exigía los papeles correspondientes. En octubre de 1908, había recibido licencias generales para el ejercicio del ministerio por el lapso de tres meses. En el mes de enero de 1909, se le concedió una prórroga de seis meses. En el mes de diciembre de 1910, lo encontramos en Monte Maíz, atendiendo la colonia italiana de Bargés, compuesta de unos 200 colonos italianos y 20 argentinos. En una nota al nuncio, advierte que la mayor parte de los padres y madres de familia no comprende el castellano y habla puro italiano, que tiene mucho trabajo y que los colonos cumplen con sus deberes religiosos. Ante la negativa del ordinario diocesano de extender la licencia de permanencia en la diócesis por no haber presentado los papeles respectivos, el presbítero solicita al Nuncio que intercediera en lo relativo a la regularización de su situación. La Sagrada Congregación da la facultad al Internuncio Apostólico para conceder la licencia. Con este aval, suponemos que se autoriza su permanencia, ya que en 1911, se lo nombra cura y vicario interino de Vinchina y Guandacol en La Rioja. En 1913, el obispo diocesano le otorga el certificado de buena conducta para regresar a Italia por motivos de salud y, al año siguiente, en 1914, lo encontramos en La Rioja como cura y vicario de San Blas de los Sauces. A mediados de ese mismo año, se traslada a Pocho, curato del noroeste de Córdoba, donde permanece hasta 1921. En los tres años de estancia en ese curato recibe algunas denuncias por participación en política, por lo que se lo traslada y se lo nombra Cura amovible de Freyre, cargo que mantendrá hasta 1956.

\footnotetext{
${ }^{36}$ ASV. Archivo Nunciatura Argentina, Gestión Mons. Locatelli, 1907-1916. Libro 47, fs.202-233.

${ }^{37}$ ASV. Archivo Nunciatura Argentina, Gestión Mons. Locatelli, 1907-1916, Libro 47, f.233.
} 
Los obispos diocesanos no incorporaban al clero extranjero sin antes probar su idoneidad. Por este motivo, algunos curas obtuvieron sólo licencias para celebrar, confesar y predicar. Estas fueron renovadas, incluso por tiempo indeterminado. La reserva de la jerarquía para incorporar clero inmigrante también se manifestó en la restricción para conceder incardinaciones, incluso a los que llevaban muchos años en la diócesis. Según consta en las fuentes, algunos curas "eran considerados como de la diócesis", ${ }^{38}$ aunque por derecho siguieran perteneciendo a su diócesis de origen. Juan Pignolo, por ejemplo, sacerdote italiano, proveniente de Turín, donde se había ordenado en 1868, se trasladó a Córdoba en 1874, donde se desempeñó en varios curatos. En 1908, le escribía al obispo solicitando su incardinación:

\begin{abstract}
Me permito esponerle con el debido respeto que vivo en esta república hace más de 30 años y 24 en esta diócesis. Que además hace muchos años que disfruto de la ciudadanía argentina: así que como ciudadano pertenezco de lleno a esta Nación. No así en el orden eclesiástico, que a pesar de tantos años no estoy incorporado, es decir, incardinado, a este obispado, lo que presenta una anomalía: ciudadano en lo civil y extranjero en lo eclesiástico. ${ }^{39}$
\end{abstract}

El diario "La Voz del Interior" publicó en 1915 un artículo con motivo del $47^{\circ}$ Aniversario de su ordenación sacerdotal. Antes de llegar a Córdoba, fundó en Buenos Aires la Sociedad Juventud Católica (1881). Allí prestó servicios de enseñanza de latín, castellano, italiano, francés, retórica y filosofía. Militó largos años en las filas del partido radical. Fue dos veces capellán de hospitales y cinco, ayudante de cura y cura suplente. Finalmente, en 1883, fue nombrado cura y vicario de Río Seco, cargo que desempeñó tan sólo un año y medio. Fue escritor y editor del almanaque social argentino, publicación que salía anualmente. Falleció en 1926 a los 82 años de edad. ${ }^{40}$ Por su perfil, podemos decir que fue un cura instruido, pero, sin embargo, no logró incorporarse, formal y jurídicamente, al clero de la diócesis.

La cita nos lleva a otras cuestiones que son importantes dejar planteadas. ¿Cómo y hasta qué punto el clero de origen inmigratorio logró insertarse en las estructuras eclesiásticas locales? ¿Cuál fue el grado de inclusión en las comunidades de campaña? ¿Cómo se vincularon entre sí y con el clero nativo? ¿Podemos hablar en Córdoba de un

\footnotetext{
38 AAC. Libro 24. Registro de Sacerdotes Seculares, 1905-1909, f.15. Es el caso, por ejemplo, de Eleuterio Mercado, sacerdote de la diócesis de San Juan de Cuyo, pero considerado de la diócesis de Córdoba.

${ }^{39}$ AAC. Leg. 42. Notas al Obispo. Febrero de 1908.

${ }^{40}$ BEDC, vol. 3, No 7, julio de 1926.
} 
proceso de italianización de la iglesia? o ¿Tendríamos que hablar de la argentinización del clero italiano?

\section{Ocupación del clero inmigrante: relaciones sociales y meritocracia}

En el mundo clerical, como en cualquier comunidad, un condicionante importante para acceder a puestos de mayor jerarquía fueron las recomendaciones y las relaciones, éstas constituían la carta de presentación, sin ellas era más difícil el ingreso y encontrar colocación rentada. Beatriz Moreyra (2001a) señala que para comprender la experiencia social se requiere primero la identificación de los actores sociales, cuyas experiencias no son uniformes, sino que varían de acuerdo a su posición social. Quienes lograron establecer su red de relaciones, ocupar un lugar preeminente en el espacio diocesano e insertarse en la elite clerical local fueron los clérigos "celosos, abnegados con verdadero espíritu sacerdotal". Este pequeño sector llegó a ocupar algunas prebendas en el cabildo eclesiástico y participó de los espacios de sociabilidad clerical. Juan Cinotto llegó a Canónigo Honorario de la Catedral, los españoles Teodoro Sierra Álvarez y Lorenzo Fernández Gobeo alcanzaron el cargo de capellanes de Coro, Modesto Cobejaus y Ulpiano García fueron socios del círculo de estudios del clero, institución que reunía lo más selecto del clero diocesano. ${ }^{41}$

Muy pocos fueron los extranjeros que llegaron a ocupar algún cargo en el cabildo, por ahora sólo hemos registrado tres, un número más representativo se desempeñó como párroco. Un informe del visitador de parroquias de 1903, indica que 11 de las 43 parroquias de Córdoba tenían al frente un cura inmigrante, 4 en las zonas más pobres del norte y oeste provincial: Sobremonte, Soto, Río Seco y Alta Gracia, y el resto en espacios de nueva colonización, Colonia Caroya, Cruz Alta, Canals, Morteros, Arroyito, San Francisco, Carlota y Villa Nueva. En La Rioja, 5 de los 9 curatos estaban a cargo de un inmigrante. De manera tal que el $30,70 \%$ de los cargos de cura y vicario estaba en manos de clero extra-diocesano. ${ }^{42}$ Tendencia que irá en aumento con la elevación a parroquias de capillas establecidas en las colonias inmigrantes. Aquellos clérigos que llegaron a la diócesis con buenas referencias accedieron rápidamente a puestos estables.

Juan Cinotto arribó a Argentina en 1901, proveniente de la diócesis de Turín, fue nombrado Secretario del Internuncio Apostólico Monseñor Sabatucci, en 1904 se trasladó a Córdoba y recibió el nombramiento de capellán de Devoto, luego de Colonia

\footnotetext{
${ }^{41}$ AAC. Libro 35. Actas del Círculo de Estudios del Clero, 1917-1918. Libro 36. Registro de Socios.

${ }^{42}$ AAC. Legajo 1. Exp. No 85, fs.439-443. También, AAC. Zenón Bustos. Obispo. Caja No 3.
} 
Sampacho y al año se le concedió el título de cura y vicario, cargo que desempeñó hasta su fallecimiento en 1946. Félix Mattio y Juan Pignolo llegaron en 1878 provenientes de Italia, de las diócesis de Rivaroli y Turín, respectivamente. El primero tenía recomendaciones del Cardenal Rampolla, se lo nombró cura y vicario de Famatina y luego de Caroya. ${ }^{43}$ Al segundo, se le concedió el mismo título en Río Seco. ${ }^{44}$ Esteban Lovera, sacerdote secularizado de la congregación salesiana, estuvo dos años como familiar del Internuncio Sabatucci, quien seis meses antes de marcharse a Italia lo ocupó en la diócesis de Córdoba. ${ }^{45}$ Guillermo Bosso, recomendado por el Cardenal Di Lay, fue recibido en la diócesis y el obispo le dio ocupación provisoria pese a ser sacerdote secularizado. Bustos se había impuesto la norma de no recibir curas secularizados, sin embargo se dirige al Cardenal señalando que "no por esto dejaré de ayudarle hasta que se ocupe definitivamente". 46

En 1908, el párroco de Bell Ville le pide al obispo iniciar las gestiones convenientes para contar como ayudante con el Pbro. Arturo Boletti, "de quién tengo muy buenos informes, sacerdote de cuarenta años de edad, ayudante de la parroquia de Moncaglieri, diócesis de Turín". ${ }^{77}$ Pío Angulo informaba al obispo que el Pbro. Juan C. Carole, residente en San Luis, le ofrecía los servicios de su ministerio, tenía muy buenas referencias de un padre misionero y del obispo de Santa Fe. Con esos datos consideraba viable darle colocación en Ballesteros. ${ }^{48}$ Lindor Ferreyra, párroco de la Villa del Rosario, se había enterado de un castellano de Salamanca que había pasado a Chile y quiso quedarse en la Argentina, "quiere venirse conmigo". 49

Si bien las relaciones sociales jugaron un papel importante, es necesario destacar que no fueron suficientes para mantener el status social, cuando el comportamiento no se adecuaba al perfil de clérigo deseado, las autoridades diocesanas no dudaban en aplicar medidas coercitivas. A Modesto Cobejaus se le retiraron las licencias para el ejercicio del ministerio. Ocupaba el cargo de cura y vicario interino de Pocho cuando recibió una serie de denuncias en la que se lo acusaba de participación política y concubinato. ${ }^{50} \mathrm{El}$ sacerdote escribió a la Internunciatura apostólica para solicitarle que el Nuncio interpusiera sus oficios ante el diocesano, presentándose de la siguiente manera:

\footnotetext{
${ }^{43}$ AAC. Libro de Títulos, 1859-1904, fs.55 y 105.

${ }^{44}$ AAC. Parroquias, Río Seco, s/f.

${ }^{45}$ ASV. Nunziatura Argentina, Nuncio Locatelli, Libro 17, Diócesis de Córdoba, f.258.

${ }^{46}$ AAC. Fondo Zenón Bustos. Correspondencia sin clasificar.

${ }^{47}$ AAC. Leg. 52. Bell Ville, 31/01/1908.

${ }^{48}$ AAC. Leg. 52. Curato de Bell Ville, 1910.

${ }^{49}$ AAC. Parroquias: Villa del Rosario, 1910.
} 
Sacerdote español de cincuenta años de edad y veintisiete en el ministerio parroquial, diez de ellos practicado en este obispado, habiéndole el venerado diocesano retirado sus licencias ministeriales por causas sin duda que él mismo juzgará justas y razonables y de las que aún implícitamente ignoro: ante semejante situación además de humillante y vergonzosa con mi salud a más de un año quebrantada y preso de constantes sufrimientos morales $[\ldots] .{ }^{51}$

Si bien no pudimos constatar los oficios del Nuncio, podemos señalar que en 1918 el cura salió del obispado.

\section{5. ¿Cadenas migratorias clericales?}

Cuando un extranjero alcanzaba el título de párroco intentaba colocar a parientes o paisanos en puestos de su parroquia. En agosto de 1892, llegó, proveniente de la diócesis de Granada, Juan Alonso Prado con licencia de su prelado, se le concedieron licencias generales para predicar, celebrar y confesar. Durante unos meses se desempeñó como ayudante del cura del Pilar, ${ }^{52}$ al cabo de los cuales se lo nombró cura y vicario interino de Ntra. Sra. de las Mercedes en La Carlota, un curato de creación reciente, ${ }^{53}$ una vez establecido, comenzó a emigrar su familia. Su hermano Antonio ingresó al seminario conciliar en 1893, el obispo de Granada le concedió las dimisorias para recibir las órdenes de manos “de algún obispo de la República Argentina”. Recibió la primera tonsura y las cuatro órdenes menores, en 1895, un año después, el subdiaconado, y, finalmente en 1897, el presbiterado. Una vez ordenado se lo destinó como teniente cura de Villa Nueva, al poco tiempo falleció el párroco y los vecinos solicitaron al obispo el nombramiento de Alonso como cura y vicario. ${ }^{54}$ En abril de 1899, Juan envía una carta al secretario del obispado solicitando viajar a España:

Monseñor Aquilino Ferreira: Querido Señor

Por carta hemos recibido en estos días de España y por noticias de mi pariente Puenteduras, sabemos, que los intereses que dejamos allí estan hechos un bochinche, se creen que nos hemos muerto, o, que estamos en vísperas y para nada nos tienen en cuanta, ni nos han mandado, hasta ahora un medio de los arrendamientos, en vista de todo esto, de las circunstancias de la baja del oro, estadía de mi pariente Puentedura y otros de menos cuantía, espero S.S me de licencia para pasar a España por tres o cuatro meses, esperando a primeros de junio en compañía de mi hermano Eloy, creo que no me negaran esta primera licencia que en 7 años pido y espero me las den con todo el bombo que se pueda: mi

\footnotetext{
${ }^{50}$ AAC. Caja parroquias: Salsacate, f.171.

${ }^{51}$ ASV. Nunciatura Apostólica Argentina, Libro 67, f.514.

${ }^{52}$ El 10/08/1892 aparece la primera mención como ministro en una partida de bautismo.

${ }^{53}$ AAC. Libro 30. Licencias Ministeriales, 1859-1932, f.254; Libro de Títulos, 1859-1904, f.97.

${ }^{54}$ AAC. Leg. 48, fs.27-33. Notas del 17/08/1898.
} 
pariente y la vista de Antonio, son los encargados que dejo para velar por mi curato. Juan Alonso.

En marzo de 1898, había llegado su primo Plácido Puentedura Alonso y se le concedieron licencias generales. ${ }^{55}$ Hasta tanto recibiera un nombramiento, acompañaba a su primo Juan en el curato de La Carlota, como se deduce de la nota enviada al obispo. Un año y medio después, en diciembre de 1899, lo encontramos en La Rioja, se lo nombró cura y vicario de San Blas de los Sauces y al año siguiente pasó como cura a Vinchina. ${ }^{56}$ Permaneció dos años más en La Rioja y en 1902 se lo nombró cura-vicario de Quilino. ${ }^{57}$ En 1907, lo encontramos como capellán en Villa del Rosario, desde allí le escribe una nota al secretario del obispado donde le comunica su estado de salud quebrantado y la necesidad del traslado a otro punto, debido a las dificultades que se presentaban en las relaciones con el cura párroco: "Desde el día que SS me mandó a esta Villa me propuse con todo empeño evitar todo motivo de desacuerdo y disgusto con el Sr Cura y hasta la fecha lo he conseguido Gracias a Dios. No tengo motivo de queja con el señor cura ni creo que él este descontento con mis servicios pues siempre he procurado hacer su gusto y voluntad en todo, pero ya no me lo permiten mis pocas fuerzas ni mi salud delicada. Creo justo SS que venga otro a ejercitarse en la virtud de la paciencia y la resignación, ya que es de todo punto de vista imposible la permanencia en esta por largo tiempo". ${ }^{58}$ El traslado se concretó y pasó, sin nombramiento, como capellán de Gral. Cabrera, dependiente de Villa Nueva, curato atendido en ese entonces por su primo Antonio, hermano de Juan. ${ }^{59}$ En 1908, Antonio envía a la curia la noticia de su deceso y solicita se le envíe otro capellán". "Como lo había previsto dejo de existir el Sr Puentedura el 25 a las 9 de la noche. Como ud. comprenderá me deja completamente manco y le reitero mi pedido último de mandar el primer gringo bueno que se le presente. Sé que Orlando no quiere ir a Cabrera mientras no le den en propiedad aquellos pueblos. De mi parte, Sr. puede mandarlo en tal carácter contando con Carnerillos Cabrera y Deheza de mi curato y se le pueden anexionar dos estaciones del Ferrocarril pertenecientes al curato de la Carlota". 60

\footnotetext{
${ }_{55}$ AAC. Libro 30. Licencias Ministeriales, 1859-1932, f.275.

${ }^{56}$ AAC. Libro de Títulos, 1859-1904, f.108.

${ }^{57}$ AAC. Libro de Títulos, 1859-1904, f.111.

${ }_{58}^{5}$ AAC. Parroquia de Villa del Rosario, f.61. Nota del 05/10/1907.

59 Antonio Alonso Prado recibió el presbiterado de manos del Obipo Fray Reginaldo Toro el 21/11/1897 (Cfr. Libro de Órdenes, 1876-1925, f.48).

${ }^{60}$ AAC. Leg. 48. Fraile Muerto (Bell Ville) Villa Nueva, s/f. Nota del 22/03/1905.
} 
Luego del viaje a España de Juan, en 1899, arribó a la diócesis, procedente de Granada, otro primo de Alonso, Domingo Arnedo, en diciembre de 1899 se lo nombró teniente cura de la Catedral, ${ }^{61}$ en marzo de 1903 pasó en calidad de cura vicario a Cruz Alta. ${ }^{62}$ Al poco tiempo de establecerse, colocó como capellanes de la colonia a Camilo Aldao, dependiente de su curato, a otro primo granadino, Lorenzo Villaescusa, y a un paisano español, salamanquino, llamado Antonio Resquejo.

Al año de desempeñarse como cura de Cruz Alta, Arnedo recibió una serie de denuncias por mal desempeño, motivo por las cuales temía ser removido de su puesto. Así, escribió a su primo Antonio solicitándole un puesto de "sirviente", en caso de que esto sucediera. En la nota señala lo siguiente:

Te agradeceré me dijeras si es posible que rumores son ellos porque te confieso francamente que no adivino que pueda ser, asegurándote bajo mi palabra de honor y de sacerdote que no descubriré tu nombre para nada. Pues, de una parte no pienso pedir explicaciones a nadie y de otra quiero ajustar mi conducta con arreglo a la importancia de esas calumnias. Si puedo asegurarte que jamás de sacerdote que estima el hábito que viste soy correcto y caballero en todos mis actos y no he cometido acción alguna que me pueda avergonzar, sin que deje de adivinar el fin que persiguen mis enemigos: $\mathrm{Si}$ el objeto de ellos es que yo abandone este curato, porque temen que les haga sombra y no transija en alguna picardía, estoy dispuesto a dejarlo pues no puedo consentir en manera alguna se manche la reputación y el buen nombre de personas inocentes. Si llegara este caso te pediré un puesto de sirviente. Espero querido primo que no me ocultaras nada y que me hablaras con la franqueza que sabes hacerlo conmigo. Te quiere siempre mucho tu primo Domingo. ${ }^{63}$

Las denuncias referidas hacían referencia al juego de naipes por dinero. ${ }^{64} \mathrm{La}$ respuesta de la curia no se hizo esperar. El secretario del obispado le comunicó que el obispo "le dio la orden de pasarle una nota exonerándole del cargo que interinamente desempeña. Pero creyendo que para Ud. es en todo caso más conveniente presentar su renuncia le supliqué me permitiera escribirle". ${ }^{65}$

\footnotetext{
${ }^{61}$ AAC. Libro de Títulos, 1859-1904, f.107.

${ }^{62}$ AAC. Libro de Títulos, 1859-1904, f.112.

${ }^{63}$ AAC. Leg. 48. Fraile Muerto (Bell Ville) Villa Nueva.

${ }^{64}$ AAC. Leg. 51. Cruz Alta. "Teniendo conocimiento de que le son necesarios los datos que justifiquen la conducta observada por el cura de esta localidad Señor Domingo Arnedo, me permito manifestar a SS que el día 14 de julio ppdo. encontré al dicho señor Arnedo jugando dinero a los naipes en el café y hotel de Don Pedro Lepori, juntamente con los Señores Rufino Aragon y Carlos [ilegible] José Reinado y Julio del Viso, acto que presenciaron varias otras personas. Tengo también conocimiento que en la casa del $\mathrm{Sr}$ Cura se reúnen con este mismo objeto, no habiéndolo yo presenciado. Igualmente sé que se reunieron el día 16 del corriente por la noche con idéntico propósito en casa de Ramón Aragon, Rufino Aragon, José Reinado y Julio del Viso, y el Sr Cura en cuya jugada los ganadores fueron el Sr Cura y Julio del Viso, según informes que tengo perdió 40 pesos Rufino Aragón, Sin otro motivo y quedando a su ordenes", firma Manuel Ortiz.

${ }^{65}$ AAC. Leg. 51. Cruz Alta, Nota de fecha del 03/11/1906.
} 
Los vínculos de solidaridad se refuerzan más allá del Atlántico. Juan regresó a España, no conocemos la fecha cierta, el último registro data de 1905. Antonio estuvo 11 años en la diócesis, en 1911 solicitó una licencia ya que pensaba retirarse a la diócesis de Santiago del Estero, "donde se me presenta una oportunidad de mejorar un poquito de nuestra triste situación de curas rurales". ${ }^{66}$ Arnedo renunció a su cargo y no sabemos su paradero, suponemos que acompañaría a sus primos Alonso. En 1911 se le concedieron licencias para ausentarse a Rosario. ${ }^{67}$

Los clérigos establecidos en América traían a sus parientes con inclinación al sacerdocio, tal es el caso de Enrique Ferroni, sacerdote nacido en 1835 en Suiza. Ingresó al seminario de Como en Italia, donde en 1859 recibió el presbiterado. En 1865 se trasladó a América, estableciéndose por un breve período en Buenos Aires, luego pasó a Corrientes, donde permaneció cinco años, al cabo de los cuales regresó a Buenos Aires y el obispo de La Plata lo ocupó como teniente cura de Chascomús (provincia de Buenos Aires), desempeñándose como cura en San Miguel del Monte y Lobos, donde falleció en 1914 (Kufman, 1999: 30). Un pariente suyo, suponemos que un sobrino, hijo de Vicenzo Ferroni y Magdalena Muchietti, llamado Bernardo, también natural de la provincia del Tesino (Suiza), parroquia de Arossio, luego de realizar el curso de ingreso en el seminario italiano, se trasladó a América a la edad de 24 años. En 1889, solicita ingresar al seminario diocesano de Córdoba y fue admitido. En el informe a primeras ordenes, el rector señala que "el alumno de este seminario Bernardo Ferroni ingresó a mediados del año próximo pasado, presentando oportunamente el certificado de haber hecho en julio los cursos preparatorios y algunos tratados de los que aquí se estudian en segundo año. En virtud de esto y en atención de su edad se le permitió ingresar en el curso de 3 año de filosofía y preparar al mismo tiempo privadamente las materias restantes correspondientes al segundo año, de todo lo cual tiene ha rendido los exámenes con plena aprobación del tribunal respectivo, cursando actualmente el primer año de teología. Su conducta y aplicación satisfacen plenamente a los superiores". ${ }^{68}$ En 1901 fue ordenado presbítero y se desempeñó como cura párroco de Alta Gracia.

\footnotetext{
${ }^{66}$ AAC. Villanueva, f.9. Nota del 20/07/1911.

${ }^{67}$ AAC. Libro 30. Licencias Ministeriales, 1859-1932, f.342.

${ }^{68}$ AAC. Leg. 24. TXIII, 1895-1900. Informe del rector Castellano del 19/07/1898.
} 


\section{Movilidad del clero inmigrante}

Un rasgo del clero inmigrante fue su movilidad. Fueron numerosos los clérigos que llegaron para probar suerte y luego de un par de años se retiraron a otras diócesis para buscar nuevas oportunidades. Como señalamos ut supra, Antonio Alonso fue cura de Villa Nueva desde 1898 hasta 1911, fecha en la que se retiró a la diócesis de Santiago del Estero. En la nota enviada a la curia, explicitaba el motivo: "Donde se me presta la oportunidad de mejorar un poquito nuestra triste situación de curas rurales". ${ }^{69}$

La precariedad de los cargos conllevaba, a su vez, inestabilidad. En 1900, el teniente de la catedral informaba al obispo que el cura "daba por terminado el compromiso que tenia y le daba las gracias por sus servicios y conocimientos", pues con motivo de la división del curato no contaba con entradas suficientes para pagar a un teniente. ${ }^{70}$ Situaciones que implicaban la búsqueda de un nuevo puesto laboral. Luis García Insúa se dirigió al obispo para solicitar se lo ocupara en algún cargo, pues sino intentaría incorporarse a la diócesis de Buenos Aires o viajar a España, según le conviniese. ${ }^{71}$ El capellán Serafín Fraiz, del curato de Bell Ville, comunicaba a la curia su decisión de alzar sus escasos bienes para trasladarlos a Córdoba o a Jesús María, ${ }^{72}$ el motivo aducido era que los feligreses de San Antonio se habían comprometido con una mensualidad y no habían hecho nada al respecto. “¿Qué hacer? Yo del aire no he de vivir". 73

Los feligreses de Brinkmann escribían a la curia para comunicar que el capellán, Antonio Terrazas, el día de la Ascensión del año 1900 no celebró misa, actitud que despertó la indignación pública y ese mismo día a la una de la tarde "cargó un baúl y un fardo en un coche, y hasta hoy no se le ha visto más, sin avisar a nadie y según versiones de algunos, parece que se ha ido a la Colonia Palencia, de Santa Fe". ${ }^{74}$

El cura de Morteros, José Russo, puso en conocimiento de la curia que a la plaza de Brinkmann había llegado de la provincia de Santa Fe un sacerdote desconocido, "Ignoro si ese sacerdote esta habilitado o suspenso por el Diocesano de Santa Fe y mucho menos si estará habilitado por el prelado de Córdoba". ${ }^{75}$

\footnotetext{
${ }^{69}$ AAC. Caja Parroquias: Villa Nueva, 11/07/1911.

${ }^{70}$ AAC. Leg. 42. Notas al Obispo, 17/12/1900.

${ }^{71}$ AAC. Leg. 42. Notas al Obispo, 14/09/1900.

${ }^{72}$ AAC. Leg. 52. Bell Ville, 16/10/1908.

${ }^{73}$ AAC. Leg. 52. Bell Ville, 16/10/1908.

${ }^{74}$ AAC. Leg. 47. Morteros.

${ }^{75}$ AAC. Leg. 47. Morteros.
} 
El capellán de Gral. Roca, Domingo Ugo [Ugolini], italiano, se había marchado del curato con el dinero de una suscripción que había levantado a fin de comprar una imagen de la virgen. El párroco escribe a la curia informando que tenía conocimiento de que tal capellán estaba en Sunchales, provincia de Santa Fe, y solicitaba a la curia solucionar el conflicto con la curia de Santa Fe, pidiéndole la devolución del dinero o la entrega de la Imagen. ${ }^{76}$

En 1899, el cura de Villa del Tránsito solicita un ayudante. El obispado le otorga el título de ayudante de cura y capellán de las Hermanas Esclavas al Pbro. Cayetano Cagnina. ${ }^{77}$ En carta enviada a la curia, el párroco advierte que no se puso de acuerdo con el nuevo ayudante, ya que las "escasas entradas del curato no me permiten pagar un estipendio mayor de 40 pesos mensuales y dejar las misas libres", a la vez, las Hermanas no podían pagar más de 50 mensuales dando casa y comida, el cura Cagnina "dijo que con esta propuesta a él no le conviene quedarse y que se vuelve a Córdoba donde ganaba mucho más y con menos trabajo". ${ }^{78}$

Las experiencias recogidas en las fuentes dan cuenta de un clero subalterno relativamente numeroso que mantuvo una considerable autonomía de la autoridad diocesana, tanto parroquial como episcopal, se movía de un lado al otro de la diócesis en busca de mejores cargos. Los curas inmigrantes conformaron un grupo diferenciado, heterogéneo y plural, que tejió lazos en el nuevo espacio de inserción. Fueron diversos en sus comportamientos, aspiraciones, estrategias y trayectorias.

La jerarquía no siempre logró imponer el modelo clerical deseado y quizá una estrategia de resistencia fue el alto grado de movilidad que caracterizó a este sector del

\footnotetext{
${ }^{76}$ AAC. Caja Parroquias, La Asunción Marcos Juárez, f.29.v. Nota del 28/09/1910.

77 Cayetano Cagnina era italiano, provenía de la diócesis de Caltanissetta (Sicilia). En 1898 se le otorgaron licencias para celebrar. En 1903 fue nombrado cura y vicario de San Blas de los Sauces en La Rioja. Cinco años después lo encontramos en San Marcos Sierra, curato de Cruz del Eje, sin ejercer el ministerio sacerdotal. El cura informa al obispado que "por lo que he podido notar las veces que lo he visto, es que su estado de salud es muy delicado. El médico que lo visito en San Marcos, me dijo que 'jamás ha visto un caso igual de neurastenia, esta consumido'. Varias veces le he invitado a oír misa y comulgar pero me contestaba siempre que no podía llegar a la Iglesia. Creo que sería una obra de caridad permitirle la celebración de la santa misa en casa ya que no puede llegar al templo, pero así cuando él lo pide, una vez dispuso de reconciliarse para celebrar en casa. Referente a la pobreza si juzgamos por el traje que le he visto no puede ser ya más indecente, jamás he visto un sacerdote ni tan pobre ni tan asqueroso! No conozco la participación que tiene en los bienes de la cuñada. Si tiene parte, nada absolutamente nada tiene, y si tiene parte nada tendrá este año porque el granizo les ha llevado la mayor parte de la cosecha" (AAC. Parroquias, Cruz del Eje). En 1918 lo encontramos como ayudante del curato de San Francisco. El cura lo califica como un hombre enfermo por muchos años de grave neurastenia. Acusado de vivir mal con la cognorta (cuñada). Se está reponiendo en lo físico (Nota del Párroco Rufino Polanco al Secretario del Obispo sobre salud cura Italiano Cayetano Cagnina). En 1922 lo encontramos como teniente en Devoto (AAC. Parroquias: San Francisco, f.114). Muere el 29/07/1953.

${ }^{78}$ AAC. Caja Parroquias: Cura Brochero. Nota del 25/07/1900.
} 
clero. Los motivos que generaron los desplazamientos fueron variados, algunos por voluntad propia, otros por suspensión de licencias, o cuestiones económicas relativas al monto de las remuneraciones, o por el cobro de estipendios, o por conflictos originados con sus propias feligresías o con los curas de quienes dependían.

\section{De capellanes a párrocos, una aspiración del clero inmigrante}

Una de las motivaciones que llevaba al clero inmigrante a hacerse cargo de las capillas de las colonias era la esperanza de que en un espacio breve de tiempo la capilla fuera elevada a la categoría de parroquia. El departamento de San Justo fue el primero en experimentar el proceso de colonización del este cordobés, como una expansión del fenómeno santafesino.

A los pueblos que crecían y sobre todo aquellos que tenían colonias, les convenía tener sacerdotes permanentes, pues los colonos iban a misa los domingos y en ese día hacían sus compras. Por ese motivo, los comerciantes eran los que más se empeñaban en convertir a la capilla en parroquia y con este objetivo insistían hasta conseguirlo de la curia. Un informe elevado a Roma sentencia que las autoridades y vecinos de las colonias "llegado el capellán le llenan la cabeza de ilusiones para que se haga parroquia y entonces vienen las divisiones entre el Párroco y el Capellán de esa población. Este es un mal grande". ${ }^{79}$ La documentación deja constancia de las reiteradas quejas de los párrocos, porque los capellanes trabajaban a sus espaldas para conseguir que las capillas fueran elevadas a la categoría de parroquias. ${ }^{80}$

Con frecuencia los capellanes eran contratados por las comisiones pro-templo de las colonias, o por los mismos fundadores, situación que generaba no pocos conflictos con los curas párrocos. Luis Abriola, italiano, cura de Cruz Alta, se quejaba de la conducta de unos de los capellanes con residencia en su curato y suplicaba al obispado que interviniera, pues "dicho señor [el capellán de Colonia Elisa] se le ha puesto, valiéndose de la protección del Sr. Aldao, de no dar cuenta a mí de entradas y ni de partidas porque espera será nombrado Cura a petición del mismo Aldao". ${ }^{81}$ Tampoco cumplía con la obligación de dar cuenta de las partidas correspondientes a la administración de los sacramentos. José Russo, cura de Morteros, se quejaba al obispado por la conducta de los capellanes de Brinkmann y colonia Porteña, "para ellos no hay informaciones, ni

\footnotetext{
${ }^{79}$ ASV. Nunciatura Argentina, Mons Alberto Vassallo di Torregosa, 1916-1922. Libro 67, f.482.

80 AAC. Leg. 47. Morteros, 1898. Nota del Párroco de Morteros Juan Morandini quejándose de los capellanes de Brinkmann y Porteña.
} 
proclamas, ni confesión sacramental antes de casar a los contrayentes. De ahí la continua polémica que debo a menudo sostener con los feligreses del porque yo les pido estas istorias! [...]. Ya van 18 meses que por voluntad de mi prelado estoy en este curato; y los capellanes de Porteña y Brinkmann ni siquiera me han presentado una sola partida de matrimonio o de bautismo; a pesar de pedir repetidas veces con insistencia para el asiento de las partidas en los libros parroquiales; a mi juicio esta negación tiene su origen en que los capellanes no tomaron los apuntes para no pagarle al cura algún pequeño derecho, y además porque se creen no estar sujetos al cura" ${ }^{82}$

Los conflictos entre capellanes y curas eran muy frecuentes. El motivo, no pocas veces, radicaba en el cobro de los derechos parroquiales, pero éste no era el único, algunos no estaban dispuestos a someterse a la autoridad del cura. Fue el caso de Francisco Cravero, quien luego de haber sido expulsado de la capellanía Colonia Vignaud se presentó en Brinkmann "gritando a los cuatro vientos y por todas las fondas y boliches de que él era capellán de la capilla de Seeber”. El párroco de Morteros, José Russo, informaba del hecho a la curia:

\begin{abstract}
Me reconocí el deber, como cura titular de amonestar con una carta a ese presunto capellán diciéndole a que presentara los títulos que lo acreditaban como capellán y no haciéndolo quedaría suspendido ad divinis. Hasta la fecha no se ha presentado y además dice a todo el mundo que él no reconoce ninguna autoridad de cura porque es capellán por orden del Obispo! De lo arriba expresado comprenderá el señor secretario, la malicia y la ignorancia del tal sujeto que a mi parecer esa venerable Curia debiera inmediatamente suspenderlo y hacerle salir de la diócesis porque de otro modo (en unos días más) el objeto de escándalo, la manzana de la discordia y la crítica y severa murmuración contra el cura, contra el sacerdocio y el mismo Señor Obispo. ${ }^{83}$
\end{abstract}

Cravero desafía al párroco diciéndole "yo seguiré estando aquí, Ud. es cura de Morteros y nada tiene que ver conmigo, yo estoy en Seever la que no pertenece a la Plaza de Morteros. Atiéndase Ud. la parroquia de Morteros y déjese de molestar a los demás!". ${ }^{84}$ Russo amonestó a Cravero en presencia del comisario y del juez de paz y le exigió que mostrara el título expedido por la curia de Córdoba que lo acreditaba como capellán de Seeber y -según el párroco- en lugar de exhibir el papel, presentó a "un jovencito paisano suyo que a la vez dijo que él era presente cuando el señor secretario

\footnotetext{
${ }^{81}$ AAC. Leg. 50. Cruz Alta, 12/05/1900.

${ }^{82}$ AAC. Leg. 47. Morteros, 06/01/1900. El subrayado es nuestro.

${ }^{83}$ AAC. Leg. 47. Morteros.

${ }^{84}$ AAC. Leg. 47. Morteros, 16/06/1901.
} 
le dio el título". ${ }^{85}$ El párroco le recuerda que él no sólo era cura de Morteros sino también de todas las demás colonias que formaban el curato de Morteros y en presencia de la autoridad civil y la política de la colonia Brinkmmann, le informa:

Quede Ud. Señor Cravero, suspenso ad divinis por ser ud. un intruso en casa ajena un sacerdote arrogante que abusa y falsea descaradamente las disposiciones de la Curia, queriendo comprometer al Sr secretario. Quedará Ud suspenso ad divinis no solamente por la capilla que ud fue de Seever sino de todas las colonias que forman este curato de mi cargo, hasta tanto el Ilmo Señor Obispo disponga otra cosa en favor de ud. Al mismo tiempo que pondré un aviso en la puerta de la capilla de Brikmann para que el pueblito sepa que Ud. no podrá decir misa. ${ }^{86}$

El suspendido capellán se retira de Brinkmann y pocos años después regresa, dedicándose a dirigir los trabajos para concluir la capilla de Seeber, con la esperanza de ser nombrado su capellán. El párroco comunica al obispado el hecho y sugiere expulsarlo mediante la intervención, el cura entiende que de otra manera "no solamente no se irá de Brinkmann, sino que a pesar de la suspensión in sacris, apenas concluida y arreglada la capilla, empezará a decir misas". ${ }^{87}$ El conflicto llegó a su término cuando el capellán sancionado salió de Brinkmann para dirigirse a Freyre en compañía del capellán de esa estación. ${ }^{88}$

La autonomía de los capellanes es una de las denuncias más frecuentes por parte de los curas. El cura de Oliva, Enrique Visca Caviglia, refiriéndose al capellán de Oncativo, señalaba: "Este sujeto envalentonado con la protección de cierto elemento y al darse cuenta de la falta de apoyo de los superiores hacia el Cura párroco ha levantado con todo descaro bandera de independencia declarándose capellán y escudándose maliciosamente en el inciso d del art. 38 del Sínodo pisoteando el inciso g del mismo artículo". ${ }^{89}$ Informa que pese a haberle pedido su retiro, el sacerdote "aun permanece en

\footnotetext{
${ }^{85}$ AAC. Leg. 47. Morteros, 26/06/1901.

${ }^{86}$ AAC. Leg. 47. Morteros, 06/06/1901.

${ }^{87}$ AAC. Leg. 47. Morteros, 26/06/1901.

${ }^{88}$ AAC. Leg. 47. Morteros, 15/07/1908.

${ }^{89}$ AAC. Fondo Zenón Bustos, f.1266, 10/12/1918. [Sínodo Diocesano Art 38: Son deberes del capellán a) Representar al cura en su capilla y cumplir con las obligaciones propias de aquél, a saber: predicar los domingos, y días festivos, enseñar la doctrina a los niños y adultos, rezar el rosario por la noche, confesar, asistir a los enfermos, etc. b) Enviar mensualmente a la parroquia las anotaciones de bautismos, matrimonios, defunciones. c) Llevar libros de cuentas e invertir en su iglesia los ingresos que a ella le correspondieren, como también las limosnas que recibiere; mas no podrá hacer ningún gasto que exceda de cincuenta pesos sin permiso del párroco, ni endeudar a la iglesia en ningún caso, ni por ninguna cantidad. d) Rendir cuenta al párroco, cada seis meses, de los ingresos que hubiere tenido y de las sumas invertidas en la iglesia. e) Ayudar al párroco siempre que éste así lo dispusiese, en la fiesta del titular y en los oficios de Semana Santa, la cual no podrá celebrar en su capilla sin permiso de aquel. f) Suplir al párroco en la parroquia cuando éste esté ausente de ella y a falta de otros tenientes que lo reemplacen, sin
} 
su puesto sin querer rendir cuenta desde hace casi cinco meses y sin facultades, pues las parroquiales se las he retirado por completo hace ya más de mes y medio. Su actuación perniciosa a los intereses y unidad parroquial está bien definida y está en conocimiento, por lo menos en gran parte y desde mucho tiempo atrás, del Ismo Vicario General". ${ }^{90}$

Las quejas del párroco de Morteros, Gerardo Perrucci, ante la conducta del capellán de Porteña se dejaban oír en el obispado. En primer lugar, denuncia que dicho clérigo no había entregado a la parroquia los derechos parroquiales y de fábrica correspondiente; en segundo lugar, denuncia los "desaires que yo no debo sufrir por la dignidad que invisto". Los desaires hacían referencia a la invitación de sacerdotes de otras parroquias para las fiestas patronales, haciendo caso omiso del cura, denuncia al capellán "por no sujetarse al cura de la parroquia" y cierra la nota afirmando que "ya cansado de tanto batallar inútilmente con ese señor, estaba determinado a pedirle la renuncia y retirarle las facultades que le he dado". ${ }^{91}$

Ya se ve que los conflictos entre párrocos y capellanes eran harto frecuentes. En 1907, el cura Laureano Ríos solicita capellán para Porteña y, de ser posible, para el resto de las capillas, lo que le preocupaba era mantener relaciones armónicas con dichos capellanes. Pregunta al secretario, “¿Que tal es Latella, irá a conducirse bien? Quiero que me hable antes de que venga, que trate de llevarse en armonía que yo es lo que deseo, porque si no hemos de andar en armonía no deseo que venga”. El párroco Ríos había suspendido las misas en las capillas porque, según su parecer, no convenía, pues "las tales capillas son para negocio, ponen un boliche y hacen un cuarto de dos metros y ya está la capilla, ni altar ni nada y uno tiene que ir porque pagan". ${ }^{92}$ El párroco de San Francisco, Julián Pío Cuestas, en 1907, comunicaba al obispo que el capellán, Antonio Resquejo, no estaba dispuesto a entregar las llaves y los objetos de la capilla de Freyre. Señalaba que había creído conveniente "no usar los medios violentos para exigir la entrega". Luego de realizar una explicación del caso, dice: "Lo ocurrido me hace tomar la firme resolución de declarar ante VS que desde hoy renuncio indeclinablemente a tener atención de capellanes. SS independientemente de mí les dará las facultades y

cambiar empero de residencia. g) Formar por último una sola persona moral con el cura, lo mismo que sus tenientes inmediatos, procurando siempre excitar en el pueblo el amor al propio párroco, siendo la conducta contraria una de las principales causas por las cuales puede ser destituido].

${ }^{90}$ AAC. Fondo Zenón Bustos, f.1266, 10/12/1918.

${ }^{91}$ AAC. Leg. 47. Morteros, 29/05/1905.

${ }^{92}$ AAC. Leg. 47. Morteros, 02/07/1907. 
ejercerá sobre ellos la vigilancia que crea conveniente. Yo no quiero ni derechos sobre ellos ni lo que ellos hagan, ni obligación alguna para con ellos". 93

Los conflictos entre párroco y capellanes no siempre tuvieron soluciones pacíficas. En algunas oportunidades, el párroco hizo valer su autoridad recurriendo a la autoridad pública.

\section{8. ¿Capellanes con dependencia de párrocos o curas particulares?}

El sistema de capellanías en Córdoba funcionaba de manera diferente al empleado por el Obispo de Santa Fe, Mons. Gelabert y Crespo, quien para facilitar el trabajo pastoral y la posibilidad de remoción del cargo, si era conveniente, les concedió una dependencia directa del obispo, obviando la mediación del párroco y los autorizó a llevar sus propios registros de los sacramentos que administraban y a usufructuar de los beneficios que la capellanía producía. En la práctica, las convirtió en vice-parroquias con la misma obligación que la parroquia, pero sin conceder el cargo de párroco o vice párroco. De manera tal que resultase más viable la remoción del capellán si era necesario (Stoffel, 1991).

En Córdoba, las capellanías tenían dependencia directa del cura párroco, quien percibía un porcentaje, rondaba el 50\%, de las entradas de las mismas. Esta realidad generó no pocos conflictos entre capellanes y párrocos. Además, los administradores de las colonias hacían valer su calidad de propietarios de la iglesia y pretendían el derecho de controlar la actividad del capellán. En 1893, la situación del cura de Freyre, Francisco Guida, da cuenta de esta realidad. El cura de San Francisco, Ambrosio Reynoldi, de quien dependía la colonia Freyre, escribía al Obispo Toro, para informarle que:

\footnotetext{
Es indudable que mucha falta hace en Freire un sacerdote para la misa festiva, pero es cierto también que durante la semana casi nunca hay una aplicación de misas. Dejo emitir mi opinión si convenga o no el señor Francisco Guida para la colonia Freire en calidad de Capellán puesto que V.S. Ilma. el Obispo Castellano está bien impuesto y si por acaso V.S.I accede ruego me indique las condiciones tanto respecto a la capilla y propietarios de ella y respecto al cementerio como también respecto al mismo señor Guida. No obstante creo mi deber poner en vista a V.S.I que los propietarios de la capilla como también el Sr Francisco Guida están firmes en la opinión que el Prelado Diocesano no puede mandar sobre capillas particulares y que por tanto pueden en ella celebrar etc. cualquier sacerdote hasta imposición al mismo ordinario. ${ }^{94}$
}

\footnotetext{
93 AAC. Caja Parroquias: Freyre, fs.130-131. Nota del 20/08/1907.

${ }^{94}$ AAC. Leg. 49. San Francisco, Nota del 12/08/1893.
} 
La sentencia al respecto es clara, al afirmar que "los a propietarios de la capilla como también el Sr Francisco Guida están firmes en la opinión que el Prelado Diocesano no puede mandar sobre capillas particulares y que por tanto pueden en ella celebrar". Además, el cura informaba que el capellán se consideraba “exento de la jurisdicción del Prelado Diocesano, celebra en oratorio particular, hace casamientos, administra bautismos y confiesa etc. etc. sin la autorización necesaria de V.S. Los propietarios de la capilla de Freire "se creen en derecho de tener un cura pagado por ellos sin que el Prelado diocesano intervenga, pues el sacerdote por ellos admitido en esa capilla, administra cualquier sacramento", por este motivo la comisión no donaba el cementerio al obispado. ${ }^{95}$

Esta situación desencadenará una decisión de la curia respecto a la necesidad de reglamentar estas situaciones irregulares. Poco tiempo después, la curia ordenó al cura Raynoldi que comunicara al cura Guida tres cuestiones, la primera, que remitiera sus papeles o documentos dimisoriales al obispado, a fin de que se le otorgasen las facultades convenientes; la segunda, se refiere a que la comisión de Freire no podía hacer contrato por tiempo determinado con el Pbro. Guida porque sería "restringir las facultades del Prelado, quién puede en tiempo, por causas y motivos que tenga, suspender a cualquier sacerdote que está en la Diócesis"; la tercera, señala al párroco que advirtiera a Guida que todos los derechos parroquiales eran del cura y que el párroco le sostendría el sueldo mensual que le sería asignado. Y le especificara sus deberes como capellán: enseñar la doctrina los días festivos, celebrar la misa y atender las confesiones de enfermos. El párroco cumple con lo mandado pero advierte que la comisión de Freire no se quiso informar del paradero del cura Guida. El sabe que lleva más de un mes en Freire "en donde funciona como Cura sin haberse visto con el suscrito, ni haberle ni siquiera comunicado las facultades que le fueron otorgadas". Además, advierte a la curia que dicha comisión no cumplió con el deber de entregar al prelado el cementerio, la Iglesia y sus adyacencias. Señala que no sólo no se pagan los derechos parroquiales, tampoco se han entregado los apuntes necesarios para registrar las partidas en los libros parroquiales, como esta prescripto. ${ }^{96}$

Un mes después la situación continuaba y nuevamente el cura Raynoldi informa que el Pbro. Guida seguía celebrando misas en casas particulares de las Colonias, bautizaba y administraba todos los sacramentos y, a su vez, comunica que la comisión de Freire

\footnotetext{
95 AAC. Leg. 49. San Francisco, Nota del 02/02/1894.

${ }^{96}$ AAC. Leg. 49. San Francisco, Nota del 04/04/1894.
} 
“en el caso que saliera el Pbro. Francisco Guida han tratado con otro presbítero cuyo nombre no he podido averiguar". 97

Ante esta situación, el secretario de la curia pide información reservada a un vecino de Freyre, quien responde que: "En ocasión de su carta de ayer debo decirle que Don Fco Guida hace un mes se fue a córdoba. De donde volvió siguiendo tranquilamente a decir misa en la Iglesia y en las capillas de los colonos. El domingo pasado según me han informado los vecinos de Freire ha dicho misa y sigue estando todavía en Freire. Respecto a otro clérigo que quiera irse a Freire nada he podido averiguar. Este informe es particular que se lo remito a Ud., pues yo no quiero intervenir en lo que no me pertenece no soy ninguna autoridad para que tenga que hacerse público". ${ }^{98}$ Cabe señalar que Francisco Guida fue uno de esos clérigos que no obtuvo ni licencias ni nombramiento alguno de la curia y, por lo que hemos podido rastrear, su permanencia en la diócesis no alcanzó al año.

La situación en Camilo Aldao nos proporciona otro ejemplo. La administración de la colonia argumentó que era la propietaria de la capilla, ya que la había construido y le pertenecía el terreno. El administrador, aduciendo mala conducta del capellán, le retiró las llaves del templo y lo expulsó de la colonia. ${ }^{99}$

La iglesia de Cruz Alta se había incendiado en 1899. El pueblo acusó al cura de dicha catástrofe y se le inició un juicio civil. En 1900, el nuevo cura, Luis Abriola, escribió al Obispo diocesano Reginaldo Toro advirtiéndole la situación del curato y el conflicto generado con la comisión pro-templo:

Aquí se está siempre sin Iglesia y sin esperanza alguna de que pueda ser refaccionada, porque la Comisión nombrada ad Hoc, con 2.695 pesos que tiene en su poder no quiere ni renunciar al cargo, ni moverse para hacer algo. No ha sido posible ni reunir la comisión, ni las principales personas del pueblo porque todos están dominados de la falsa idea de que siendo la Iglesia de propiedad del Obispado, toca a él proporcionar los fondos para la refacción, tanto más en cuanto que ha sido un representante de el quien ha incendiado la iglesia y que tanto se ha trabajado para hacerlo declarar inocente. Está también el pueblo obstinado en no dar para la Iglesia por varias causas, la primera por la indiferencia en las cosas que atañen a la religión; la segunda, por el bajo precio de los cereales y tercero, por una estafa cometida por un tal Carlos A Flores Pinto ex juez de esta población. Este buen señor encargado para recolectar algunos fondos de haber reunido unos $300 \mathrm{o}$ 400 pesos se fue de aquí llevando el dinero. En cuanto a mí no puede dejar de manifestar a S.S Ilma. que mi vida aquí es insostenible porque no quieren pagar defunciones, habiéndose la comisión de fomento imposesionado de la llave del

\footnotetext{
${ }^{97}$ AAC. Leg. 49. San Francisco, Nota del 04/04/1894.

98 AAC. Leg. 49. San Francisco, s/f.

${ }^{99}$ AAC. Parroquias: Camilo Aldao.
} 
cementerio y no hay casamientos y los que hay se casan solamente por civil, no hay entrada ninguna y condecir que no hay aplicación de misas creo haber manifestado todo. Así están las cosas en esta Parroquia y por cuyo motivo he dispuesto irme a establecer o en la Colonia Italiana o en la de Progreso. Pero suplico a S.S. Ilma. que se digne ordenar al capellán de Elisa que cumpla con su deber en dar cuenta tanto de las partidas de los sacramentos a registrarse en los libros parroquiales, como también de las entradas reteniéndose para él la mitad, teniendo en cuenta que él recibe una buena mensualidad y cosa segura mientras yo debo contentarme de eventualidades tan escasas en este tiempo. Ahora, dicho señor se lo ha puesto, valiéndose de la protección del $\mathrm{Sr}$ Aldao, de no dar cuenta a mí de entradas y ni de partidas porque espera ser nombrado Cura a petición del mismo Aldao, no obstante de ser inválido, pues por sus afecciones reumáticas casi no sale de la cama. Pocos son los días que dice misa y nunca abre la boca en la Iglesia, ni enseña doctrina a las criaturas, pero así gusta al Sr Aldao y así será. Esto se lo refiero, porque así me lo han referido. Yo no voy a establecerme en la Elisa porque he comprendido de una carta de el Sr Aldao, que el capellán será nombrado cura y no otro porque otro no ha de hacer lo que ordena. En la esperanza de que SS se dignara mandarme al respecto las órdenes e instrucciones convenientes. ${ }^{100}$

La nota del cura señala cuestiones que se reiteran en el ejercicio del ministerio en la zona de las colonias, como las relaciones conflictivas entre las comisiones pro-templo y el cura; las dificultades en las relaciones entre los curas párrocos y los capellanes; la movilidad del clero, que se traslada de un lugar a otro, y el intento por parte del párroco de subordinar a su autoridad y control al capellán, a la comisión pro-templo, o al fundador de la colonia. El poder pastoral del párroco entra en conflicto con poderes locales diversos, razón por la cual, desde la curia, se profundizan las medidas destinadas a garantizar la autoridad parroquial.

Las reiteradas situaciones de este tipo llevaron a la curia a exigir, de manera sistemática, los títulos de propiedad de los terrenos donde había iglesias edificadas o capillas y a prohibir la construcción de nuevos templos sin la previa donación de los terrenos. Para aquellas iglesias que estuvieran en manos de particulares, se gestionaba la donación o compra respectiva. ${ }^{101}$ De esta manera, se intentaba suprimir las capellanías, o neutralizar la autonomía de su funcionamiento, poniéndolas bajo la dependencia del párroco. Respetando estas condiciones, se levantaron numerosos templos. Las colonias construían su iglesia $\mathrm{y}$ con frecuencia gestionaban su propio capellán, comprometiéndose a pagarle un sueldo mensual. Así, los vecinos de San Pedro de Morteros se dirigieron al obispo para solicitarle accediera al nombramiento de un sacerdote que se encontraba en Italia desocupado. Respecto de su buena conducta y

\footnotetext{
${ }^{100}$ AAC. Leg. 51. Cruz Alta. Nota del 12/05/1900.

${ }^{101}$ AAC. Pastorales, Edictos y Circulares. Circular enviada a los párrocos solicitando datos sobre títulos de propiedad de Iglesias y terrenos, 1906.
} 
capacidad -decían-, constaba de los necesarios documentos y, a su vez, "varios vecinos de ésta lo conocen personalmente". ${ }^{102}$

El hecho de que el capellán dependiera de una subvención de la feligresía generó serias dificultades, pues el cura terminaba dependiendo de la voluntad de los fieles. Así lo señalaba el cura de Morteros, Manuel López, en una nota de 1905 que envió al obispo, señalando que era necesario evitar que "sigan siendo viles instrumentos de las personas que contribuyen para formar la cuota mensual que perciben en calidad de retribución". ${ }^{103}$ El problema era de antigua data. Diez años antes, el cura de la Asunción, Elmiro Ruiz, enviaba una carta al obispado en la que señalaba que el capellán de Cruz Alta no "sirve para nada, no puedo conseguir que venga aquí, ni me hace juicio, ni cumple de ninguna manera, yo creo que no tiene más obispo que José María Aldao y Dios el dinero. Cuesta muchísimo el poder vigilarlo". ${ }^{104}$ José María Aldao era el fundador de la Colonia, quien contrataba a los capellanes para el servicio religioso de la misma.

Brinkmann tenía una capilla construida por el fundador de la Colonia. Su viuda donó la capilla y el terreno a la curia diocesana, pero siguió manteniendo con una mensualidad al capellán. En 1900, el capellán Antonio Terrazas comunicó su renuncia al obispo debido a que la viuda de Brinkmann no le pagaba la mensualidad acordada. "La Señora viuda de Brinkmann me ha suspendido la mensualidad [...] que me pasaba para mi sostenimiento sin motivo ni causa alguna y tan solo con el objeto de hacerme abandonar por necesidad esta Iglesia, así a lo menos lo creo yo, pues de otro modo no me puedo explicar la causa de retirarme la pensión conque ayudaba a mi sostenimiento. Ha habido quién me ha dicho que la Sra Viuda de Brinkmann se ha dirigido a S.S Ilma solicitando que sea yo retirado de esta Iglesia y reemplazado por un otro sacerdote". ${ }^{105}$ Cuando el cura no respondía a las expectativas de la comunidad era práctica frecuente la suspensión de la mensualidad, forzando su salida del curato.

La dependencia económica del cura de la comunidad que lo subvencionaba implicaba, de alguna manera, el control sobre sus actividades. En 1903, el Visitador de Parroquias elevó un informe al obispado en el que advertía que en las colonias "por regla general había un capellán que en principio estaba bajo la jurisdicción del Párroco,

${ }^{102}$ AAC. Leg. 47. Morteros, Carta del Presidente de la Comisión pro Templo de San Pedro al Secretario del Obispado, Eduardo Ferreyra, 05/06/1906.

${ }^{103}$ AAC. Leg. 47. Morteros, 1905.

${ }^{104}$ AAC. Caja Parroquias: Marcos Juárez. Nota del 05/08/1898, f.18.

105 AAC. Leg. 47, s/f. 
pero en la práctica los colonos que subvencionan esos capellanes se convierten en jueces y prelados de la parte del curato en que se encuentra la tal capellanía independiente". ${ }^{106}$

La feligresía de Gral. Roca, ante el conflicto suscitado entre el capellán Luis Sarti y el párroco de Marcos Juárez, Leopoldo Buteler, escribió al obispado para pedir la no destitución de su capellán y deslizó el argumento que si la resolución final era retirar al capellán, “declinará de seguir prestando su cooperación en los asuntos relacionados con el sostenimiento de la subvención mensual, dado que está en sus derechos, es decir, la población al hacer sus sacrificios para el mantenimiento de la religión católica al más alto nivel, le asiste el derecho de tener sus autoridades religiosas a su placer". ${ }^{107}$

Los vecinos de Devoto, curato de San Francisco, escribieron al obispo para solicitarle que dejara permanecer al frente de la colonia al presbítero Domingo Losmo, "pues si no fuera del agrado del pueblo y los colonos, no lo hubiéramos pedido ni hubiera permanecido entre nosotros los nueve años y meses que esta en ésta colonia y además si no observara buena conducta y faltara al cumplimiento de sus obligaciones, seriamos los primeros en ponerlo en conocimiento de vuestra excelencia". ${ }^{108}$

La ausencia de una reglamentación especial, que determinase las relaciones que debían existir entre los capellanes que servían en las capillas de las colonias, los feligreses y los curas, era un obstáculo para el buen funcionamiento de las relaciones. Con el fin de subsanarlo, en 1905 se redactó un reglamento destinado a tal fin. Sus artículos establecían: $1^{\circ} \mathrm{El}$ capellán es ayudante del cura y está sujeto a su jurisdicción en el ejercicio mismo del ministerio que debe prestar a los interesados. $2^{\circ}$ El capellán recibirá su sueldo directamente de la secretaría del obispado, las comisiones que los soliciten depositarán lo correspondiente a un año o semestre adelantado. $3^{\circ}$ El capellán está obligado a asistir a la parroquia, a la fiesta del Titular y a los oficios de Semana Santa, los que no podrá celebrar en su capilla.

Además, se estipulaba la firma de un contrato entre los colonos y el capellán que establecía las mutuas obligaciones y compromisos. ${ }^{109}$ El contrato, firmado por los miembros de la comisión de la capilla de la Colonia Bergés y el capellán Luis Della Casa en abril de 1905, estipulaba la obligación de la comisión de abonar al capellán la

\footnotetext{
${ }^{106}$ AAC. Leg. 1, 1723-1900, Exp. № 85, f.440. También, AAC. Fondo Zenón Bustos. Obispo. Caja ํㅜ 3, f.944.

${ }^{107}$ AAC. Fondo Zenón Bustos, f.1116.

${ }^{108}$ AAC. Parroquias: Devoto, 02/07/1915.

${ }^{109}$ AAC. Carpeta Pastorales, 1900-1925, 20/10/1905.
} 
suma mensual de 90 pesos nacionales a pagar el último día de cada mes, asumir los gastos de edificación y reparación de la capilla, reunirse en asamblea cada vez que el capellán o el presidente lo requiriera. Por parte del capellán, tenía derecho a ausentarse seis días al mes, previo aviso a los fieles y con el compromiso de estar presente los días domingo de precepto y para la celebración de las fiestas patronales. También correspondía al capellán la dirección, administración, vigilancia y cuidado de la capilla, la casa de la capellanía y los enseres de culto. ${ }^{110} \mathrm{Si}$ bien los contratos se firmaron, no siempre se cumplieron, Generoso Tartagalia, capellán de la colonia La Italiana, dependiente del curato de Cruz Alta, informaba a la curia su situación:

Es come un año y medio que estoy de capellán en la Italiana, curato de Cruz Alta, con permiso de su Ilustrisima comunicado al Sr. ex cura Arnedo: ahora siendo cambiada la situación que tenía, a razón de la competencia del pueblo Corral de Bustos y que está cerca como una legua, donde los negociantes y colonos se están mudando y también la razón por ser la mayor parte protestantes francmasónicos, me encuentro como cinco meses sin sovencion, siendo terminada la contrata recién en noviembre, me prometieron 60 pesos pero hasta la fecha no me dan nada y parece que me están burlando. ${ }^{111}$

Las frecuentes irregularidades y conflictos que se establecieron en el "mundo de las capellanías de las colonias", determinó la reglamentación de una serie de medidas por parte del obispado, en primer lugar, se exigió el envío a la curia, por adelantado, de seis meses a un año de la subvención o mensualidad prevista para el capellán; en segundo lugar, reglamentar las relaciones entre capellanes y feligreses mediante la firma de contratos que determinasen las funciones de cada parte; y finalmente, sustituir el nombramiento de capellanes por el de ayudantes o tenientes con residencia estable en un determinado pueblo o colonia y bajo la jurisdicción de un párroco. Estas medidas pusieron fin a la dependencia económica de los capellanes de sus feligreses, pues el teniente o ayudante era un empleado del párroco y era él a quien le correspondía pagar un sueldo mensual a sus ayudantes. Además, tendieron a regular las relaciones con sus párrocos y poner fin a ese modus vivendi autónomo e indisciplinado. El cura de Marcos Juárez informaba al obispo sobre la conducta de estos capellanes: "El mal de estos capellanes creo que es este: que se han credo un modus vivendi confuso en el cual solo reconocen en el cura una prescindencia muy lejana como para ir solamente muy de

\footnotetext{
${ }^{110}$ AAC. Cruz Alta, 11/04/1905.

${ }^{111}$ AAC. Cruz Alta, La Italiana, 28/04/1903.
} 
cuando en cuando en calidad de inspector hasta cierto punto no más". ${ }^{112}$ En 1909, refiriéndose al capellán de general Roca, sentencia que tenía un genio terrible y que prácticamente es muy poca la dependencia que reconoce a la Parroquia. De modo que es muy difícil conocer cómo manda esa parte del curato". 113

Estas medidas centralizadoras también generaron sus inconvenientes. Por lo pronto, los colonos no siempre estuvieron de acuerdo con el sacerdotes designado por la curia para su atención espiritual. En 1904, el cura de Morteros, Gerardo Perrucci, escribía al obispado para explicar la actitud de la colonia ante su llegada: "En cuanto el efecto de mí llegada a esta población debo decirle con toda franqueza que no ha sido para mí la más favorable, pues aunque los colonos han quedado conformes, no así los argentinos que aquí son las autoridades. -Pues- ni después que yo les he pasado nota oficial de mi toma de posesión se han dignado visitarme-. También los colonos el primer día festivo, se mostraron medio descontentos en oírme dirigirles la palabra en castellano, pero en la fiesta subsiguiente de todos los santos al oírme predicar en Italiano primero y después conversar con algunos en Piamontés, me mostraron el propio contento y satisfacción visitándome casi todos". 114

Finalmente, el Sínodo diocesano de 1906, después de recoger informes sobre la experiencia de los capellanes y las capellanías, estableció, en el capítulo cuarto, la reglamentación relativa a capellanes y tenientes. Señala que el capellán era un teniente cura con residencia en alguna de las capillas de la parroquia. La retribución corría por cuenta del pueblo que lo solicitaba, empero el cura debía cederle parte de los derechos que él percibía, cuando la pensión no fuera congrua. Eran deberes del capellán, representar al cura en su capilla y cumplir con la obligación de predicar los domingos y días festivos, enseñar la doctrina a los niños y adultos, rezar el rosario por la noche, confesar, asistir a los enfermos, etc.; enviar mensualmente a la parroquia las anotaciones de bautismos, matrimonios, defunciones; llevar libros de cuentas e invertir en su iglesia los ingresos que a ella le correspondieren; no podía hacer ningún gasto que excediera la suma de cincuenta pesos sin permiso del párroco y tenía obligación de rendir cuentas al párroco cada seis meses; era su obligación ayudar al párroco siempre que éste así lo dispusiese en la fiesta del titular y en los oficios de Semana Santa y suplir al párroco en

\footnotetext{
112 AAC. Cajas Parroquias: Marcos Juárez, f.42. Nota del 24/07/1909.

113 AAC. Caja Parroquias: La Asunción de Marcos Juárez, f.140.

${ }^{114}$ AAC. Leg. 47. Morteros, 01/11/1904.
} 
la parroquia cuando se ausentase si no había otros tenientes que lo reemplazaran. La falta de unión con el párroco era una de las causales de destitución. ${ }^{115}$

\section{Motivos para emigrar}

Poco sabemos de la condición social de los curas inmigrantes que llegaron a la diócesis de Córdoba. Algunos indicadores nos hacen suponer que la mayoría era de un sector social poco acomodado. Entre los motivos que algunos expresaron para ser admitidos en la diócesis, figuran la falta de ocupación en la diócesis de origen y cuestiones de salud o familiares, ninguno hace mención a cuestiones económicas, que, como se ha visto, pareciera ser uno de los móviles más frecuentes.

Francisco Fernández, natural de Adorgam, de 44 años, residente en Buenos Aires, capellán interino de la Iglesia San Nicolás de Bari, gozaba de poca salud y deseaba "salir al campo, y trabajar con mas libertad en la viña del señor". ${ }^{116}$ Pedro Villanueva Cáceres y Manuel Fernández Hidalgo, presbíteros de la parroquia de Poibuena y de la diócesis de Astorga, exponían al obispo su deseo de ejercer el ministerio en Argentina, ${ }^{117}$ ambos curas salieron de su diócesis sin esperar la respuesta de admisión. Faustino Nistal, cura español residente en Córdoba, que era quien los había conectado, informa el hecho al obispo y señala que "la conducta como sacerdotes es buena, solo si desconfío que siendo párrocos dejen lo seguro por lo dudoso y se me hace bengan por plata y esto a mí no me gusta (es una suposición mía) SS me dirá lo que debo comunicarles". ${ }^{118}$ En el caso de Narciso Oleña, de 30 años, llevaba cinco años de sacerdote y cinco de carrera parroquial en la diócesis de Gerona, decía que el motivo de su traslado era que había muerto su madre y que estaba libre para el ejercicio del ministerio. Deseaba ser admitido en la diócesis de Córdoba, especificando que la certificación de su conducta moral y religiosa era "del todo limpia". ${ }^{119}$ José María Chavarría era más explícito, en su relación, dejaba constancia que tenía 41 años, había sido vicario in caite desde 1888 hasta 1892, y que luego había conseguido ser párroco en Villadisente, cargo que desempeñaba hasta la fecha. Tenía una paga de 1.200 pesetas y una feligresía de 150 vecinos, se trataba de una rivera parroquial buena pero no de las

\footnotetext{
115 Sínodo Diocesano celebrado en Córdoba por el Iltmo. y Rmo. Señor Obispo Don Fray Bustos y Ferreira, en el año del Señor MCMVI, Resoluciones y Apéndices, Córdoba, Tip. "La Industrial”, 1907. Cap. VI: De los capellanes y tenientes, puntos 31-45.

116 AAC. Fondo Zenón Bustos, 04/09/1905 (sin catalogar).

${ }^{117}$ AAC. Fondo Zenon Bustos, 30/09/905 (s/c).

${ }^{118}$ AAC. Fondo Zenón Bustos, s/c).

${ }^{119}$ AAC. Fondo Zenón Bustos, Gerona, 02/11/1905 (s/c).
} 
mejores. El motivo de su traslado era familiar, vivía con tres hermanas que había logrado finalmente casar, y "sus maridos me disgustan a cada paso", antes de cerrar su nota, dice que "casi en iguales circunstancias esta otro párroco de mi edad y muy digno, por abusar de él su familia se irá de gana". ${ }^{120}$

\section{Imágenes y representaciones ${ }^{121}$}

La política eclesiástica pone de manifiesto una imagen más bien negativa del clero foráneo. En unos borradores, en los que el Obispo Bustos apuntó las dificultades que encontró al hacerse cargo del gobierno, encontramos una explicitación muy significativa: "lo que viene es lo peor, lo bueno se coloca en su país y no emigra. No sé si con alguna excepción, los resultados prácticos son funestos. Son mercaderes y dejan de ser apóstoles. Son extranjeros y no tienen el calor impulsivo del patriotismo: sus esfuerzos en bien del país y del rebaño, tienen que ser mucho menores que los de un hijo del país". ${ }^{122}$ Consideraba negativo el servicio que prestaba el clero inmigrante, ${ }^{123}$ sin embargo, su presencia se imponía por necesidad, a "pesar de su colaboración insuficiente y perjudicial en muchos casos". ${ }^{124}$

La mirada del diocesano sobre el cura inmigrante no refleja la figura idealizada del europeo que aportaba hábitos civilizadores, por el contrario, destaca la imagen de extranjeros portadores de prácticas disgregantes. En este contexto, el clero nativo adquiere cualidades, también idealizadas, de ser portador de un ethos nacional y católico. La percepción que la clerecía tenía del clero se insertó en un esquema binario, criollo y extranjero aparecen como términos opuestos, el calificativo de "bueno" se asocia al clero propio y el de "malo" al extranjero.

En 1923, el párroco de Villa Concepción del Tío solicitaba al obispo un teniente y especifica: "yo quiero y necesito un buen teniente, uno criollo [...]. De no ser de éstos [...], no me animaría a recibir a nadie," ${ }^{25}$ El cura de Morteros pide un "italiano y bueno" para capellán de San Pedro; el de Villa del Rosario solicita "un gringo bueno";

\footnotetext{
${ }^{120}$ AAC. Fondo Zenón Bustos, Villadisente, 19/09/1905 (s/c).

121 Tomamos el concepto de representación, según el cual los individuos organizan los esquemas de percepción y de apreciación a partir de los cuales clasifican, juzgan y actúan. No nos detendremos en la representación como forma de exhibición del ser social o del poder político expresado mediante signos, símbolos o ritos (Cfr. CHARTIER, 1996: 29).

${ }^{122}$ AAC. Fondo Zenón Bustos (sin clasificar). Autos, Pláticas y Estudios. "Problemas fundamentales del obispado a mi llegada de obispo", p.168.

${ }^{123}$ AAC. Zenón Bustos. Carta del obispo al diputado nacional Luis Agote, 20/07/1910.

${ }^{124}$ AAC. Zenón Bustos. Carta del obispo al senador nacional Justiniano Posse, 05/08/1910.

${ }^{125}$ AAC. Parroquias: Concepción del Tío, 29/06/1923. El subrayado es nuestro.
} 
el inspector de parroquias advierte que el cura de Caroya, Luis Viaggio, era un "italiano bueno". ${ }^{126}$ Estas maneras de decir, en cierto modo, ratifican la mirada negativa sobre el clero inmigrante, dado que es necesario especificar cuando alguno constituía una excepción. Laureano Ríos, párroco de Morteros, al renunciar a su curato advierte a la curia que "lo único que sentiría es que mi reemplazante fuera italiano pues creo que lejos de adelantar destruiría lo que se ha hecho [...]". ${ }^{127}$

La figura del criollo se contrapone al "extranjero", que es presentado como sacerdote ignorante, "ocioso, jugador, torpe, y grosero en el lenguaje y en sus maneras, no raras veces tramposo" y sin otro afán ni otro ideal que el dinero, pocos eran los sacerdotes inmigrantes "bien preparados, celosos, laboriosos y de conducta edificante". ${ }^{128}$ Sin embargo, los comportamientos del clero nos permiten distinguir, al menos, dos grandes perfiles. El primero, contempla ese universo clerical inmigrante díscolo, indisciplinado y móvil que, pese a ser poco numeroso -no alcanzó el 20\%-, constituyó la preocupación de la jerarquía y generó las imágenes y representaciones negativas que se le adjudican al clero inmigrante. El segundo, comprende aquellos curas que se establecieron y permanecieron en la diócesis, ocuparon sus puestos en la campaña, incluso promovieron a párrocos. Son curas que no han concitado aún el interés de los historiadores, de los cuales sabemos muy poco y, al no ser problemáticos, tampoco han dejado demasiados registros.

\section{1 "Ignorante, ocioso, jugador, avaro y mercader"}

El estudio de las trayectorias de los curas inmigrantes permite identificar un estereotipo que cuenta con toda una tradición de acervo popular, la figura del sacerdote mercenario, mero expendedor de sacramentos, de vida errante y fuera del control de la jerarquía (Alvarez Gila, 2001: 563). Este perfil estuvo presente entre los sacerdotes que llegaron a Córdoba. Hemos localizado algunos curas sindicados de avaros y ambiciosos. Son numerosas las cartas y notas de párrocos y feligreses enviadas al obispo que vierten esta imagen. Elmiro Ruiz, cura de Marcos Juárez, denunciaba en 1901 la conducta de los capellanes italianos Alberti y Rastelli, los cuales, en lugar de aplicarse a sus funciones pastorales, llevaban una vida amancebada y no cumplían con su ministerio.

\footnotetext{
${ }^{126}$ AAC. Leg. 1. Exp. No 85, f.443.

127 AAC. Leg. 47. Morteros, Carta del Cura de Morteros al Obispo, 25/11/1907.

${ }^{128}$ ASV. Nunciatura Argentina, $\mathrm{N}^{\circ}$ 47, f.17.
} 
Para el párroco, tenían "menos fe que esos que gritan por la calle mueran los frailes". ${ }^{129}$ El cura de San Antonio de Litín se refería al capellán de Leones afirmando que se había propuesto "hacer la América por fas o por nefas". ${ }^{130}$ Los colonos de Marcos Juárez solicitaban la separación del capellán de Cruz Alta, porque "ellos buscaban era un verdadero sacerdote, Ministro de Dios y no un explotador ni un mercader". En palabras de los colonos, el cura se ocupaba: "[...] en dar dinero en interés, con usura a los colonos, en hacer sociedades comerciales, en explotar chacras y en comprar y vender frutos del país". Ocupado en esos negocios desatendía las funciones, celebraba la misa sin devotos y a la madrugada, no enseñaba la doctrina ni realizaba las novenas y fiestas patronales. ${ }^{131}$ En una carta confidencial enviada por el cura de La Asunción (Marcos Juárez) al obispo, éste le informa que los vecinos solicitan capellán y aclara que debido a la situación particular y a la heterogeneidad de la población (católicos, protestantes, masones, argentinos e italianos), era necesario un sacerdote santo, lo mejor que tenga la diócesis. Puntualiza que "en la Provincia de Santa Fe ai varios napolitanos que quieren venir, pero son borrachos, no quieren saber nada con el Cura ni con el Obispo, solo con los \$200 de subvención y nada más, los sacerdotes extranjeros solo sirven para hacer perder la Fe y como creo que V.S no estará dispuesto a mandar un Argentino asi es que creo muy difícil la tal capellanía". 132

Las acusaciones más frecuentes hacían referencia a un excesivo afán de lucro, vida mundana, frecuentación de fondas y boliches, participación en carreras de caballos y juegos de naipes, conducta moral indecorosa, a las que se sumaba el incumplimiento de los deberes propios del ministerio, dejaban cerradas las iglesias, desde el lunes hasta el sábado, y ellos se iban a farrear a los almacenes. ${ }^{133}$

Elmiro Ruiz, párroco de Marcos Juárez, señalaba que el capellán de Leones “solo se ocupa de llenar el sótano de vino y jamones; sembrar cebolla, lechuga, rábano [...] solo la media hora de la misa se ve la puerta de la iglesia abierta y siempre a la quinta". ${ }^{134}$ Este perfil clerical se caracteriza, también, por una gran movilidad, algunos capellanes, en el corto período de dos años, habían pasado por varias colonias, incluso por varias provincias. Los vecinos de Brinkmann advertían que Antonio Terrazas había cargado "un baúl y un fardo en un coche, y hasta hoy no se le ha visto más, sin avisar a nadie

\footnotetext{
${ }^{129}$ AAC. Parroquias: Leones, s/f.

${ }^{130}$ AAC. Parroquias: San Antonio de Litín, f.3, 11/05/1918.

131 AAC. Leg. 35. Juicios Eclesiásticos, 1871-1905, 26 de Septiembre de 1891.

132 AAC. Caja Parroquias: Marcos Juárez, fs.16-18

${ }^{133}$ AAC. Leg. 47. Morteros.
} 
[...] parece que se ha ido a la Colonia Palencia, de Santa Fe". ${ }^{135}$ Como hemos advertido, esta movilidad facilitaba que el clero escapara del control eclesiástico y de las medidas disciplinares.

En síntesis, se trató de un clero subalterno, que mantuvo una considerable autonomía de la autoridad diocesana, tanto parroquial como episcopal, y que se movía de un lado a otro de la diócesis aspirando a mejores cargos, como señalamos ut supra, este pequeño porcentaje de clérigos se concentra entre los curas que recibieron licencias para el ejercicios del ministerio de uno a cuatro años, y luego se retiraron de la diócesis, en busca de nuevos horizontes. Las prácticas de este grupo inducen a pensar en un clero escasamente cualificado y sin una vocación sacerdotal muy definida. De todos modos, su importancia, en términos cuantitativos, es escasa, 36 curas inmigrantes tuvieron observaciones sobre su conducta, lo que significó un 19,25\%, del total, de los cuales 13 fueron suspendidos ad divinis y expulsados de la diócesis.

10.2 "Digno, celoso, prudente y de buen espíritu sacerdotal: merecedor en consecuencia de toda benevolencia y consideración"

Este perfil de cura inmigrante fue el que logró insertarse en la diócesis y del que menos conocimiento tenemos. La abundancia de fuentes que remiten a los "malos curas" puede distorsionar $\mathrm{o}$, al menos opacar, la presencia y actividad de clérigos inmigrantes que no se encuadraban en esta categoría. Sin embargo, el fenómeno de la inmigración clerical puede ser visto en términos muy diferentes si se intenta aprehenderlo a través de las estrategias individuales y las trayectorias biográficas particulares (Revel, 1996: 12). Si bien hay que señalar que las referencias a "buenos curas inmigrantes" son más escasas, por lo tanto, resulta difícil reconstruir las trayectorias del clero de campaña que no generó conflictos.

En el mundo clerical, como en cualquier comunidad, un condicionante importante para acceder a puestos de mayor jerarquía fueron, como dijimos, las recomendaciones y las relaciones. Estas constituían la carta de presentación, sin ellas era difícil el ingreso y encontrar una colocación rentada. Quienes lograron establecer su red de relaciones, ocupar un lugar preeminente en el espacio diocesano e insertarse en la elite clerical local, fueron aquellos clérigos que llegaron a la diócesis con buenas referencias, recomendaciones y, además, reunían los rasgos del perfil clerical deseado por el obispo.

${ }^{134}$ AAC. Parroquias: Leones, s/f, 1901. 
Algunos de los casos los mencionamos ut supra, cuando hicimos referencia a las relaciones meritocráticas, como Juan Cinotto, Félix Mattio, Juan Pignolo, Juan Alonso Prado, Guillermo Bosso.

¿Quiénes fueron los curas que lograron promover a párrocos? Como ya hemos dicho, la mayoría de ellos provenía del norte de Italia, eran piamonteses, varios de la diócesis de Turín, como Juan Cinotto, Juan Pignolo, Fortunato Gambini, Angel Botta, José Di Giorgini, Atilio Gaino, etc., y del sur de España, en particular Granada.

En 1910, el cura de Marcos Juárez decía que del Piamonte habían llegado "los mejores sacerdotes extranjeros, haciéndose acreedores a la confianza [del Obispo] en la atención de las parroquias". ${ }^{136}$ Esta particularidad respondía, como hemos advertido al comienzo de este capítulo, a que la vida religiosa en esa diócesis había tenido un importante crecimiento en la segunda mitad del siglo XIX. Algunos de esos curas, casi anónimos, aparecieron casi por casualidad entre nuestras fuentes.

Fortunato Gambini era un cura italiano, proveniente de la diócesis de Pescia, región de la Toscana, que llegó en 1901 con la documentación correspondiente. ${ }^{137}$ El prescripto de la Sagrada Congregación y licencias ilimitadas de su obispo para permanecer en la diócesis. En Córdoba, se le otorgaron licencias para el ejercicio del ministerio por un año y luego fueron renovadas cada dos hasta 1924, año en que falleció. En 1902 fue destinado como capellán del curato de Tercero Abajo, con residencia en Chañares, donde permaneció hasta 1909, luego pidió trasladarse al curato de Bell Ville, pues el cura le prometió colocación en la capilla de San Antonio de Litín. ${ }^{138}$ Se lo nombró ayudante de Bell Ville, con residencia en San Antonio de Litín, y cuando en 1917 ésta fue erigida en parroquia independiente fue nombrado párroco de la misma. Durante los años que estuvo a cargo desarrolló una labor encomiable. Con motivo de su fallecimiento, el cura de Villa María se trasladó a Litín e informó al obispado lo siguiente:

1. El señor Gambini tiene hermanos y hermanas en Italia. En Córdoba vive una sobrina carnal, casada con un comerciante Sr Aldaccini dueño del almacén de Santo Domingo. Los dos estuvieron presentes en el entierro del malogrado sacerdote.

\footnotetext{
${ }^{135}$ AAC. Leg. 47. Morteros.

${ }^{136}$ AAC. Parroquias: Marcos Juárez, f.51, 16/12/1910.

${ }^{137}$ AAC. Libro 24. Registro de Sacerdotes Seculares, 1905-1909, f.104.

${ }^{138}$ AAC. Parroquias: Villa María, f.76. Nota del 20/11/1909.
} 
2. El Pbro. Gambini ha muerto pobre. Es su gloria. No tenía más que unos $\$ 900$ que apenas alcanzaran para cubrir los gastos de entierro y las cuentas del almacén. No tenía ningún bien inmueble. Tenía depositado en el banco $\$ 80$. La casa parroquial tenia los muebles necesarios, ropa blanca etc. No había hecho testamento. Los sobrinos se llevaron todos los documentos y las cosas íntimas del finado y también el cáliz y una casulla perteneciente al mismo según declaración de varios testigos. Por medio del Juez hice hacer el inventario de lo que había a fin de que se inicie el juicio sucesorio si es que vale la pena. Trate de defender lo más que pude lo que pertenece a la Iglesia para que no fuera inventariado, la tarea no fue difícil pues los parientes son personas discretas. El sábado estuve nuevamente allá para entregar la parroquia al padre Muguerza. Hemos hecho un prolijo inventario que hemos firmado los dos. La Iglesia de Litín ha sido levantada por el Pbro. Gambini y se encuentra en muy buenas condiciones. No falta nada. Tiene una buena y abundante ornamentación. Todos los ahorros del finado fueron invertidos en la construcción del templo y de la casa parroquial que está en muy buenas condiciones. Tiene siete piezas, galería, jardín, aljibe etc. etc. todo muy bueno y decente. ${ }^{139}$

"El Boletín Eclesiástico" le dedicó una nota necrológica en la que señalaba que "falleció en su sede parroquial el digno y celoso Párroco de San Antonio de Litín. Duelo intenso, verdadero y espontaneo que han exteriorizado no sólo sus actuales feligreses sino los que participaron de su solicitud apostólica en los 16 años que llevaba entre nosotros, es el mejor testimonio de su vida sacerdotal consagrada por entero al servicio de Dios y de las almas". ${ }^{140}$ A poco tiempo de su fallecimiento, los vecinos de Litín se dirigieron al obispado para solicitar un nuevo cura, refiriéndose a Gambini, lo invocaban como "su querido párroco y bienhechor [...] cuyo recuerdo en esta villa quedará imperecedero, por su carácter sincero y bondadoso y por haber hecho construir, a costa de grandes sacrificios, en el mismo lugar de la antigua capilla, un hermoso templo digno de figurar en muchas de las otras parroquias más importantes de la diócesis". ${ }^{141}$ Gambini es sólo un ejemplo de una multiplicidad de curas inmigrantes, ocupados en diversas parroquias de la diócesis, que ejercieron su ministerio con caridad y abnegación. Ellos merecieron la confianza y aprobación del obispo diocesano y el respeto de los curas criollos. ${ }^{142}$

\footnotetext{
${ }^{139}$ AAC. Parroquias: Villa María, f.122. Nota del 01/12/1924.

${ }^{140}$ BEDC, vol. $1, \mathrm{~N}^{\circ} 11,15 / 09 / 1924$.

${ }^{141}$ AAC. Parroquias: Villa María, f.124. Nota del 19/01/1925.

${ }^{142}$ Podríamos mencionar, entre otros, a Luis Pedro Taulaigo (francés), quien llegó a la diócesis en 1886 y fue nombrado ayudante de Bel Ville y luego cura y vicario interino de Villa Nueva, cargo que ejerció hasta su muerte en 1900; Antonio Lamonaca (italiano), de la diócesis de San Severo (Puglia), llegó en 1909 y a los pocos meses fue nombrado cura y vicario de San Vicente, cargo que desempeñó hasta su fallecimiento en 1922; Antonio Trías (español), de la diócesis de Mallorca, llegó a la diócesis en 1905, se desempeñó como capellán de Camilo Aldao, en 1911 fue nombrado cura y vicario de Cruz Alta y en 1924 de Corral de Bustos, regresando a España, donde falleció en 1959.
} 

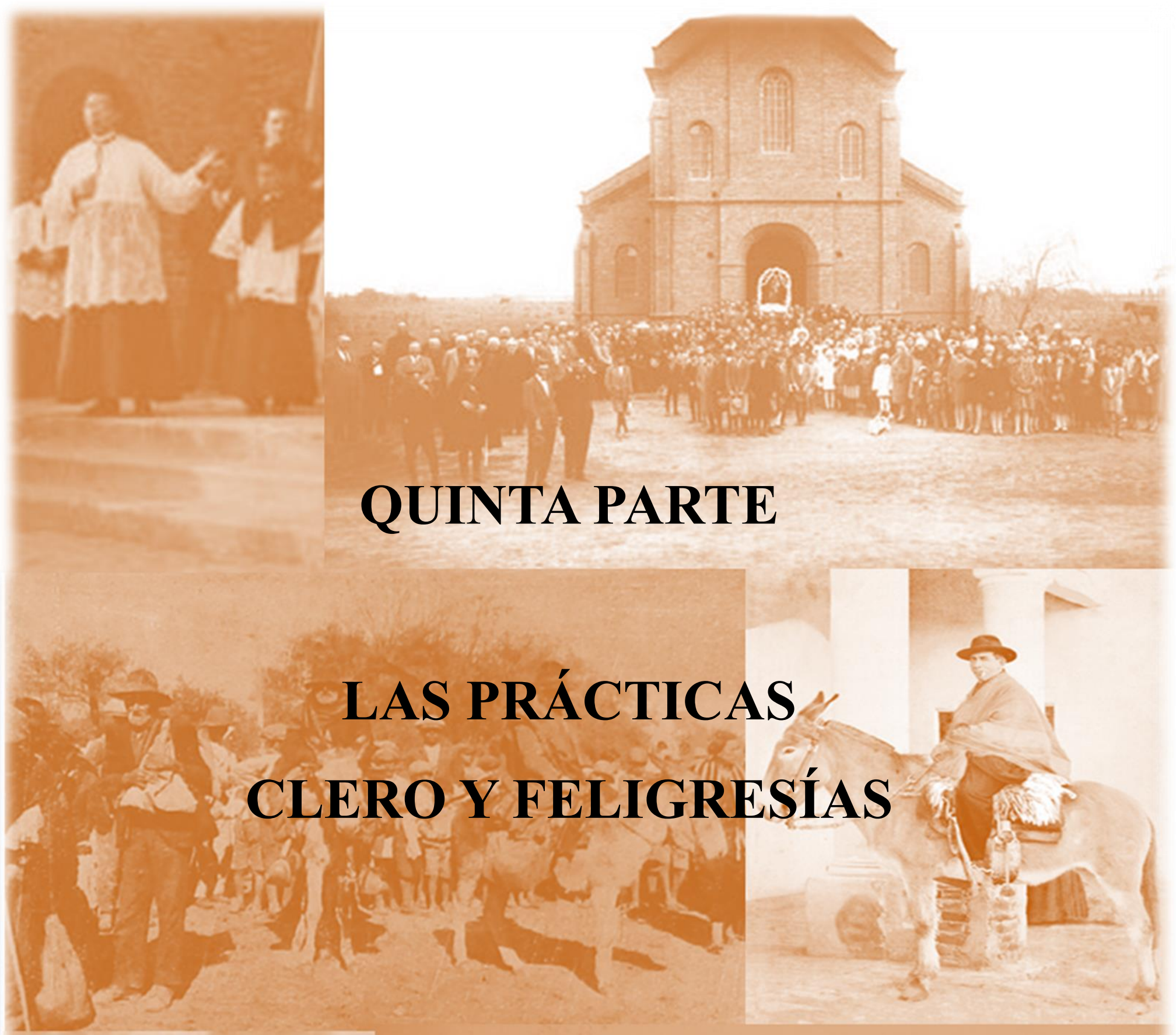


\section{CAPITULO 13}

\section{Clero y feligresías frente al avance secularizador del estado}

La laicización establece relaciones de nuevo tipo entre el estado y la religión católica, pues ésta deja de ser fundamento de aquél, para quedar en él comprendida. Se asume el catolicismo como religión nacional porque se reconoce como religión del pueblo soberano. El sistema político liberal consagró la igualdad ante la ley y esto implicó reajustar la posición de la Iglesia que mantenía funciones jurisdiccionales, privilegios y fueros (Serrano, 2008: 20; Cárdenas Ayala, 2008: 92). En el capítulo 6 de la segunda parte, abordamos las relaciones entre Iglesia y Estado en el marco del proceso de secularización, desde la mirada de los mismos actores, y analizamos cuál debía ser el lugar de la Iglesia y la religión en el proyecto liberal de la segunda mitad del siglo XIX. Modelizamos la visión de los obispos y provisores, reconociendo tres posturas vinculadas a diversas corrientes de pensamiento: el reformismo ilustrado de raíz galicana, sostenido por los Obispos franciscanos Esquiú y Tissera; el reformismo ultramontano de raíz conservadora, más intransigente respecto de la modernidad, propiciado por los Provisores Castellano y Clara; y el reformismo católico de raíz liberal, vinculado al Obispo dominico Fray Reginaldo Toro. En este capítulo, nos acercaremos a la dinámica del clero parroquial y las feligresías a lo largo del conflicto por la implementación de las llamadas "leyes laicas".

El enfrentamiento evidenció la concepción de un nuevo estado fundado en los principios de tolerancia y libertad religiosa, en el que la homogeneidad confesional había dejado de ser considerada la base de la lealtad cívica y de la existencia política, la religión dejaba de ser el elemento estructurante de la sociedad. Estos conceptos, "tolerancia" y "libertad religiosa" significaban cosas diferentes para cada sector. Para los liberales, implicaba la privatización de lo religioso y la disminución de la centralidad de la religión católica en la sociedad, equiparándola al resto de los cultos; el estado, más allá de las convicciones personales de quienes lo componían, reivindicaba para sí el ejercicio de los derechos patronales $^{1}$ y no estaba dispuesto a abandonarlo en momentos en que intentaba consolidar

\footnotetext{
${ }^{1}$ La Constitución de 1853 establece como atribución del Congreso Nacional la de "arreglar el ejercicio del Patronato en toda la Nación" (art 67, inci.19) y como función del poder ejecutivo la de "ejercer los derechos del Patronato Nacional en la presentación del obispo para las iglesias catedrales, a propuesta en terna del senado" y la de conceder el pase o retener los decretos de los concilios, las bulas, los breves y rescriptos
} 
su poder. Por caso, el texto de la sentencia de la causa criminal seguida contra el cura Correa por administrar el matrimonio sin acatar la ley civil evidencia esta concepción. El fiscal señala que:

Siendo innegable la preeminencia consignada en la Constitución Nacional a favor del culto Católico Apostólico Romano al establecer la libertad de todos los cultos no puede sostenerse con su texto que la Iglesia católica constituye un poder político en nuestra organización, con potestad de dictar leyes de carácter civil como son las que estatuyen el régimen de matrimonio civil [...] que la iglesia no es considerada por la Constitución Nacional como poder político, de existencia necesaria e independiente en nuestra organización como sostiene el apelante. ${ }^{2}$

La Iglesia, por lo tanto, no era ni podía ser un poder político del Estado argentino, ni tampoco era un poder político de existencia necesaria e independiente de ese Estado. ¿Qué lugar debía ocupar entonces la Iglesia? Sin duda la aspiración de las autoridades civiles era supeditarla al poder estatal. Se pensaba en una Nación Católica - porque el catolicismo era la religión del pueblo soberano- y en una Iglesia sobre la que el estado ejerciera sus derechos patronales. Pero, en esa Nación Católica, la sociedad civil no tenía por qué serlo, la religión, por ende, podía ser privatizada, circunscribiéndose a las conciencias individuales. De esta manera, el fiscal de la causa esgrime:

Pero si la Nación es católica en su conjunto, individualidades de su seno podrían no serlo -el art. 14- responde a los propósitos de libertad e igualdad garantiendo a todos los habitantes de la nación el derecho de profesar libremente su culto. [...] La ley no niega los sacramentos de la Iglesia, no desconoce el derecho individual de rendir cultos, no prohíbe y al contrario reconoce la aspiración legítima de interponer su grandiosa consagración hasta en el acto mismo de la inscripción en el registro civil según el libre albedrío de la conciencia del creyente. Ante tales seguridades y garantías la ley ha podido determinar la forma civil de la obligación entre los contrayentes -las consecuencias puramente civiles de ese acto y la forma de comprobación para la seguridad de sus efectos- y esto que a los efectos puramente civiles debe ejecutar todo contrayente -no excluye en la misma ley las ceremonias religiosas que satisfaciendo las aspiraciones de la conciencia en el creyente más

papales en acuerdo de la Suprema Corte. En 1966, se suscribió un acuerdo entre la Santa Sede y la República Argentina. Dicho acuerdo suprime el patronato en Argentina, "el artículo $1^{\circ}$. Reconoce y garantiza la Iglesia, por parte del Estado Nacional, el libre y pleno ejercicio de su poder espiritual, el libre y público ejercicio de su culto, así como de su jurisdicción en el ámbito de su competencia". Dicho Acuerdo fue aprobado por la ley 17.032 del 23 de noviembre de 1966 y ratificado en enero de 1967.

${ }^{2}$ AHPC. Crimen $2^{\circ}$ Capital. Leg. 4, Exp. 1, 1889. 
fervoroso y sincero, da testimonio de la verdad de nuestras garantías constitucionales que aseguran para todos la libertad de profesar libremente su culto".3

En el Capítulo 6, señalábamos que más allá de las diferencias, la posición de los obispos respondía a la búsqueda de una modalidad de inserción de la Iglesia en la nación, que garantizase a la sociedad el derecho de informar con su fe católica la vida social. Por su parte, el gobierno provincial, identificado con el ideario liberal, reivindicaba para sí los espacios ocupados hasta entonces por la Iglesia, en particular aquellos que afectaban directamente la constitución de los individuos en tanto ciudadanos. Espacios que signaban los hitos más importantes de la vida de una persona, el nacimiento, la educación, el matrimonio y la muerte. La cuestión estaba presente en la prensa desde una década atrás. El diario "El Progreso", en su edición del 9 de julio de 1869, dedica una larga nota al tema. Allí se expresa claramente el fondo de la cuestión y se reclama al Estado que cumpla con los deberes que le incumben con los ciudadanos:

El bautismo, el casamiento y la muerte de los individuos de la sociedad, entrañan los más altos y estables intereses y derechos civiles, y sin embargo la autoridad civil no toma nota en ninguna de sus oficinas del nacimiento de un ciudadano, de su casamiento y de su muerte, no hay razón alguna para ello, sino la costumbre, que se hace ley, causando perjuicios graves. La autoridad eclesiástica es la que se encarga de hacer establecer la constancia de los tres actos más graves y serios de la vida del hombre. Muy santo y muy bueno. Lo religioso y la creencia precediendo el bautismo, el casamiento y la muerte de un cristiano, está en su puesto de madre, y ejerciendo sus deberes y derechos incuestionables. Pero la autoridad civil tiene que cumplir con sus deberes después que la Iglesia ha cumplido con los suyos. Y hay que advertir que la Iglesia y la religión al sentar las partidas de bautismo, casamiento, y defunciones, termina todo lo que a ellas corresponde. Pero las acciones y derechos que esos tres actos producen en la sociedad, pertenecen a la autoridad civil, pues ante ella se discuten y ventilan posteriormente. Es claro pues, que la autoridad civil debe tener constancia fidedigna de sus actos después que la religión y la Iglesia han tomado nota de ellos a los efectos consiguientes. Las oficinas de los párrocos no son las de la autoridad civil, y aunque no fuera sino la ventaja de una doble constancia de esos actos que tan altos y graves intereses entrañan, sería ya suficiente motivo para que se estableciese otra ofician civil en la que se hiciese el registro de nacimientos, casamientos y defunciones [...]. Como hemos dicho antes la autoridad civil no ejerce ningún derecho de inspeccionar sobre las oficinas y libros de los párrocos. Y si es verdad que están perfectamente servidas en la capital, no sucede lo mismo en la campaña donde sacristanes y muchachos que ayudan misa, sientan las partidas en cuadernos o papeles sueltos [...]. Una Partida mal sentada, perdida u omitida puede

\footnotetext{
${ }^{3}$ AHPC. Crimen $2^{\circ}$ Capital. Leg. 4, Exp. 1, 1889, f.181.
} 
traer y ha traído ya las más serias complicaciones y pleitos con perjuicios de los más valiosos y sagrados intereses $[\ldots]{ }^{4}$

Al día siguiente, el periódico publica otra larga nota en la que señala las consecuencias civiles de cada uno de estos actos: "el niño que nace, es en ese mismo instante heredero de sus padres, adquiere el derecho de llamarse ciudadano del país, bajo cuya bandera nace y ve la luz primera. Por nacer en Córdoba, por ejemplo, ha conquistado el derecho de ser mas tarde uno de su representantes". Luego describe los derechos adquiridos con el matrimonio y la muerte de un ciudadano. El artículo finaliza preguntando ¿cuál es la autoridad que debe dar a cada uno su derecho? ¿Cuál es la que entiende en caso de disconformidad? Simplemente, la autoridad civil.

La cita expuesta muestra con claridad cómo se perfila en la opinión pública la necesidad de diferenciar las esferas política y religiosa y de definir los espacios de competencias de cada institución. Esta tendencia se consolida con el correr de los años. En junio de 1870, "El Progreso" analiza la ausencia del estado en el registro de defunciones y señala "que el estado religioso es defectuoso y debe ser reemplazado por el estado civil [...] A la iglesia pertenece bendecir a los hombres y apartarlos del mal camino y dirigirles por la senda del Señor, más la autoridad civil tiene el supremo deber de registrar los datos de la vida para mayor bien de la sociedad. Cada uno sus atribuciones. Al sacerdote el cuidado del alma, al funcionario civil el cuidado de los intereses sociales". A partir de la década del 80 , la elite liberal se propuso desplazar a la Iglesia y a la religión hacia un espacio menos central de la vida pública, situando la vida religiosa dentro de la esfera privada.

En consonancia con lo afirmado por Sol Serrano (2008: 22) para el caso chileno, podemos afirmar que el catolicismo cordobés si bien aceptó el retiro de lo público como sinónimo de estatal, se resistió tenazmente a ser relegado al ámbito de las sacristías y de la vida doméstica. Apeló a mantener una presencia activa en la esfera pública moderna, en ese espacio que no es estatal, pero que tampoco es privado, en un sentido intimista o doméstico, que se ha denominado sociedad civil.

El clero no resignará el lugar que tenía en la sociedad y hará uso del mismo para mantener su influencia sobre la población. El alegato del fiscal de la causa seguida al cura de Punilla da cuenta de esto cuando afirma que la gente sencilla de campo estaba

\footnotetext{
${ }^{4}$ El Progreso, 09/07/1869.
} 
"habituada a respetar como verdades infalibles los consejos, opiniones y pláticas de los párrocos, influenciados y sumisos a ellos en su mayor parte". 5

En 1884, sumidos en pleno conflicto con el estado, los católicos, dirigidos por el clero, bregaban por ejercer los derechos que el liberalismo amparaba -la autonomía del individuo y de sus libertades-, para defenderse y afianzarse en la sociedad civil. La eficacia de la acción católica dependía de la capacidad de los católicos de valerse, según sus posibilidades, de los derechos civiles que las constituciones ofrecían a todos los ciudadanos, entre los que se encontraba la facultad de influir en la cosa pública. Fundan asociaciones civiles, dirigidas por clérigos, y las inscribían en las parroquias. Una de ellas fue la Sociedad Juventud Católica, con sede en la ciudad capital y ramificaciones en todas las parroquias de la campaña. "El Eco de Córdoba", en los números de septiembre y octubre de 1884, da cuenta de la constitución de estas asociaciones y de la resistencia a su formación por parte de las autoridades civiles en algunos departamentos de la campaña. Este diario, órgano afín al catolicismo, sentencia "con un descaro que indigna y una impavidez que asombra impidieron acto tan perfectamente ajustado a la ley, tan expresamente garantizado por la constitución, tan conforme a los primeros derechos y a las primeras garantías de que le es lícito usar a un ciudadano en un país libre". ${ }^{6}$

La nueva racionalidad, el espíritu de tolerancia como valor público, la pluralidad de formas políticas y religiosas, parecían amenazar la esencial unidad de vida y fe postulada por el catolicismo, propio de un estado confesional, sin embargo, paradójicamente, la modernidad le otorgó las herramientas necesarias para que el catolicismo cordobés lograra afianzar su identidad y aumentar su relevancia, en unión con la Iglesia universal de Roma, impulsando un proyecto que aspiraba a mantener la adhesión de la gran mayoría de la población. El comentario de "El Eco" refleja claramente la estrategia eclesiástica:

Ay de los ciegos instrumentos del poder. Por la fuerza invencible del derecho van a saber que a un ciudadano de un estado libre e independiente le es lícito asociarse para fines útiles y mucho más para fines santos y que para impedirlo es impotente por más que lo contrario se crea, el derecho brutal de la fuerza, que impedirá un acto pero que no sojuzgará una conciencia cristiana. Adelante, la campaña responde a la capital de la provincia y los católicos de la una van a probar a los católicos de la primera que los han de acompañar en las pericias de la lucha que empieza y en pos de la cual surgirá y

\footnotetext{
${ }^{5}$ AHPC. Crimen $2^{\circ}$ Capital. Leg. 4, Exp. 1, año 1889. Texto de la sentencia de la causa criminal seguida contra el Cura Correa por casar sin acatar la ley de matrimonio civil.

${ }^{6}$ El Eco de Córdoba, 09/09/1884.
} 
se asegurará la libertad religiosa que los apóstatas y los sectarios atropellan ahora con inaudito descaro. ${ }^{7}$

La Iglesia perdió la batalla por mantenerse como religión del Estado, pero cimentó una nueva inserción en la sociedad permeada por la diversidad cultural y religiosa. Es, justamente, en este período (1860-1920), cuando la iglesia de Córdoba se construye como una organización territorial, a la vez que expande y consolida el vínculo entre la institución y los fieles. No cabe duda de que es un período en el que el estado se seculariza, la sociedad se hace más plural y la cristianización se expande (Serrano 2008).

\section{La actitud del clero parroquial frente a las políticas secularizadoras}

\subsection{Registro Civil y secularización de los Cementerios}

El proyecto reformista eclesiástico cordobés tuvo figuras del clero que respondían a distintas concepciones respecto a la relación de la Iglesia con el Estado. Unos estaban vinculados a una concepción reformista con reminiscencias ilustradas que proponían la armonía con el Estado en la construcción de una Iglesia nacional, buscando el apoyo de las autoridades civiles en beneficio de las iniciativas eclesiásticas y velando por evitar confrontaciones. Los otros, más en sintonía con una visión ultramontana, sostenían la necesidad de separación de las esferas religiosa y civil y la construcción de una Iglesia autónoma del Estado, que veía como intromisión las decisiones relativas a la secularización de algunas prácticas que, hasta el momento, habían sido prerrogativas exclusivas de la Iglesia. Estas concepciones derivaron en la adopción de prácticas diversas frente al avance secularizador del estado provincial, si bien todas ellas se mantuvieron dentro de la ortodoxia católica.

El Gobernador Miguel Juárez Celman intentará excluir al clero de la instrucción pública, ${ }^{8}$ secularizar los registros de nacimientos, casamientos y defunciones, ${ }^{9}$ dejar la

\footnotetext{
${ }^{7}$ El Eco de Córdoba, 10/09/1884.

${ }^{8}$ En 1884 comenzaría a funcionar la Escuela Normal con maestras protestantes extranjeras En relación a este asunto, tuvo lugar la mayor crisis producida entre el Gobierno y la Iglesia y Córdoba fue el centro de la misma, la cual culminó con la expulsión del delegado apostólico Luis Mattera. El Vicario Capitular emitió dos pastorales exhortando a los fieles católicos a no enviar a sus hijas a las escuelas fiscales. El dictamen del procurador fiscal de Córdoba decretó la separación del Prelado del gobierno de la Diócesis, la suspensión de oficio y de beneficio en el coro de su Iglesia. El Poder Ejecutivo expidió el 3 de junio de 1884 el decreto de suspensión. En este clima, se debatió la ley de educación común. Córdoba no aprobó la ley 1420, sancionada a nivel nacional.
} 
provisión de curatos a cargo de la autoridad civil, ${ }^{10}$ y suprimir la facultad de teología de la universidad.

Hemos visto cómo el Obispo Esquiú buscó armonizar la potestad civil con la eclesiástica, evitando, de ser posible, el conflicto entre ambas. Conducta que puso en práctica en el conflicto suscitado por la administración de los cementerios. El obispo debió negociar con la Municipalidad de Bell Ville, Ballesteros y La Rioja capital, a fin de garantizar la propiedad de los mismos para la iglesia, cediendo su administración a las autoridades civiles. Dirigiéndose al gobernador delegado de La Rioja, le comunica que un cementerio católico es un lugar sagrado y su administración corresponde a la autoridad eclesiástica; pero su deseo de conciliar intereses con deberes y de evitar todo conflicto, le llevó a modificar el reglamento de cementerios (Bruno, 1976: TXI: 187). Fray Capistrano Tissera heredó los conflictos iniciados en la gestión eclesiástica anterior. Durante su gobierno, se estatuye el Registro Civil (1884), se debate la Ley 1420 de educación laica, gratuita y obligatoria y la de secularización de los cementerios. Con la creación del Registro Civil se sustituía el valor civil que hasta entonces tenían los libros parroquiales. La ordenanza municipal prescribía la obligación de los párrocos de suministrar a la oficina municipal copia de las actas de matrimonios celebrados ante ellos y asentados en sus libros. El incumplimiento sistemático de los curas a este requerimiento gubernamental motivó reclamos de parte del jefe de la Oficina del Registro al obispo diocesano, solicitando que instara al clero a cumplir con esa oficina pública. Hemos analizado la respuesta del prelado y el envío de una circular a todo el clero parroquial de la diócesis en la que instaba a cumplir con los requerimientos del gobierno:

Ha llegado a nuestra noticia por personas de autoridad, que algunos párrocos de esta diócesis al dirigir la palabra a los fieles, en la Iglesia, y aconsejarles usen del derecho de enrolarse en el Registro Cívico se han propasado a recomendar que les entreguen sus respectivas boletas. Hemos dudado algún tiempo de la exactitud de la noticia por referirse a una infracción de la ley, que todos debemos respetar y porque nuestro celoso y prudente clero parroquial, a Dios gracias, no está avezado a esta clase de transgresiones: pero se han repetido los avisos, y en vista del carácter de verdad que

\footnotetext{
${ }^{9}$ Ley de Registro Civil promulgada para la ciudad en 1880 y para la provincia en 1889.

${ }^{10}$ Decreto del Presidente Julio A. Roca del 31 de julio de 1886 sobre provisión de curatos: declara curas propietarios a los párrocos interinos de la capital y dispone que en adelante dichas parroquias se provean por concurso según lo establece el Concilio de Trento. El gobernador de Córdoba dictó un decreto similar al del gobierno nacional.
} 
han revestido, hemos juzgado conveniente prevenir con tiempo el abuso a fin de que no se repitan tales exigencias ni se proclamen desde el pulpito enseñanzas que no estén en completa armonía con lo sagrado de nuestro ministerio y con los deberes de ciudadanos respetuosos de la ley. A los que profesamos y acatamos como fundamento de la sociedad el respeto a la ley y a la autoridad, no nos es lícito ni decoroso desvirtuarlas por mas que otros las violen y conculquen con frecuencia. Nos sería muy doloroso saber que se daba motivo para que la autoridad civil tomase alguna medida violenta, ante la cual no pudiéramos defender plena y justamente a los que la ocasionan, y por tanto esperamos confiados que esto no sucederá. ${ }^{11}$

La reconvención episcopal tuvo poco eco en los curas de la campaña cordobesa. La obligación impuesta por el gobierno a los ciudadanos de anotarse en el Registro Civil siguió siendo resistida por algunos curas párrocos, quienes, desde el púlpito, desestimaban los alcances y la necesidad de la misma y se negaban a enviar copia de las actas de matrimonio a dicha oficina. Incluso antes de la creación del Registro Civil, la oficina de estadística comenzó a exigir a los curas párrocos el envío de planillas trimestrales con los datos contenidos en los libros parroquiales. Las excusas de éstos de no poder cumplir con esta exigencia eran reiteradas. Los motivos argumentados fueron la falta de tiempo para realizar esa tarea considerada por el clero un trabajo de carácter enteramente civil, que no justificaba el descuido de las funciones del cargo parroquial, de por sí más importantes; a esta primera dificultad, se le sumaba el deficiente e inexacto registro de los libros parroquiales. El cura de Cosquín, al hacerse cargo de la parroquia, expresaba que el archivo estaba pésimamente tenido y muchos de los libros parroquiales no eran sino "un conjunto de hojas sueltas, sin folio, sin principio ni fin. Los libros de bautismo y matrimonio [...] están bien, al día y bien llevados; pero no hay libro de confirmaciones ni de fábrica y el de defunciones aún está atrasado". ${ }^{12}$ El cura vicario interino de Bell Ville, Eduardo R. Ferreira, informaba a la curia que el funcionario civil le exigía, además de la remisión de los estados mensuales de los libros parroquiales, poner a disposición, para la consulta, el archivo parroquial, a fin de constatar la exactitud de los datos, a lo que el párroco respondió que "no habiendo recibido, al respecto instrucciones del obispo, no reconocía ningún derecho a la intromisión del Gobierno en una oficina que es puramente eclesiástica. Y que ni graciosamente (puedo) suministrar estos datos, pues he suprimido, por este año, el escribiente y yo llevaré mis apuntes en

\footnotetext{
${ }^{11}$ AAC. Circular 12 de septiembre de 1884. El subrayado es nuestro.

${ }^{12}$ AAC. Cajas Parroquias: Cosquín, f.77.
} 
los libros como y cuando Dios me ayude". ${ }^{13}$ Esta actitud remisa de los párrocos con el gobierno no sólo se debía, a nuestro parecer, a dificultades reales, como el mal estado de los libros o la falta de tiempo para ejecutar esa tarea, sino que está, sin duda, latente la resistencia ante la intromisión del poder civil en asuntos considerados estrictamente eclesiásticos.

La ley obligaba al funcionario civil a anotar, en un libro especial, por duplicado, las defunciones. Además, exigía exhibir el boleto de inhumación expedido por el funcionario público y controlar a los encargados de los cementerios para que no permitieran la inhumación de cadáveres sin la anotación del encargado del registro. La condición previa para acceder a la sepultura era la exigencia del boleto de registro de defunción y éste fue uno de los puntos más conflictivos en la implementación de la ley en la mayoría de los curatos de campaña. ${ }^{14}$ La desinteligencia entre autoridades civiles y eclesiásticas respecto al uso y administración de los cementerios tienen varias aristas y evidencian conflictos por el control de espacios de poder. Esta fue una de las primeras cuestiones en las que se evidencia la resistencia de la Iglesia y de la sociedad ante el avance secularizador del Estado. El cura párroco y el jefe político se convierten en actores claves en cada departamento. Los conflictos generados entre ambos ponen de manifiesto la preocupación del gobierno por controlar la actividad de los párrocos.

El Gobernador Gregorio Gavier solicitó al Obispo Tissera la remoción de algunos curas por hostilizar a las autoridades constituidas, ${ }^{15}$ a fin de favorecer la armonía y buena inteligencia con el poder ejecutivo provincial con la convicción de que esta decisión podría llevar grandes bienes a la Iglesia y al Estado. ${ }^{16}$ Concretamente, los curas de Quilino, Pbro. Sofonías Oviedo; de Pocho, Pbro. José Chaneton; y de Tercero Abajo, Pbro. Eleuterio Mercado, fueron removidos a pedido del poder ejecutivo bajo los cargos de "hostilización a las autoridades", desacato y prácticas subversivas. El cura Mercado se negó a entregar las llaves del cementerio al jefe político, razón por la cual fue expulsado del curato. El diocesano comunicó al gobernador su interés por conciliar sus

\footnotetext{
${ }^{13}$ AAC. Cajas Parroquias: Bell Ville, 1890, s/f.

14 AAC. Parroquias: Hay denuncias de los jefes del registro contra los curas de Bel Ville, Río Cuarto, Sampacho, Anejos Sud, Punilla, Quilino, Pocho, Villa María por no acatar la ley y sepultar sin solicitar el boleto respectivo.

${ }^{15}$ AHPC. Gobierno, 1886, T9. Nota del Obispo al Gobernador de 22 de enero de 1885.

${ }^{16}$ AHPC. Gobierno, 1886, T9. Nota al Gobernador Gregorio Gavier, Córdoba, 17 de enero de 1884.
} 
deberes de Pastor con los deseos del gobierno, "para mantener con la autoridad política la armonía de que tantas pruebas he dado a VE, usaré de facultades que me son propias para trasladar a otro punto al expresado cura párroco [...] Descanse VE en esta seguridad con que quedaron satisfechas las exigencias del Gobierno". ${ }^{17}$ Sin embargo, el obispo expresó en la nota que no había tenido quejas de la conducta del cura y sutilmente advertía su disconformidad con la actuación del jefe político expulsando al párroco: "la armonía y acuerdo que debe reinar entre ambos poderes, por su marcha regular en la esfera de acción que a cada uno corresponde, se reciente violentamente por la acción violenta del jefe político". ${ }^{18}$

En 1889, la autoridad civil del departamento de Santa María solicitaba al cura José López González una partida de defunción; el cura se negó a entregarla, aduciendo que no le correspondía hacer el trabajo del oficial del registro, ya que no era empleado del gobierno y además se negó a entregar la llave del cementerio mientras no se le pagasen los derechos correspondientes. El funcionario del registro civil recurrió a la fuerza pública y forzó el cementerio. Este conflicto motivó una denuncia del juez pedáneo al Ministro de Gobierno, Justicia y Culto Eleazar Garzón contra el cura de Alta Gracia. El Fiscal de Gobierno y Tierra pública, Dr. Julio Rodríguez, estudió el caso realizando un análisis pormenorizado de los cementerios. Señaló que era una institución debida exclusivamente al cristianismo, concebida como cosa sagrada $y$, como tal, sujeta a la legislación religiosa. Habilitada la Iglesia católica por las instituciones civiles (art. 33, inc. $4^{\circ}$, C.C.), con la personería jurídica que la hacía capaz de adquirir y reconocer en algunos de sus bienes el carácter de sagrados o religiosos, sometidos a la legislación eclesiástica, una vez consagrados, estos quedaban necesariamente exentos de la potestad civil, no sólo en lo que afecta a su naturaleza misma, sino también en cuanto a los usos al que son destinados. Por lo tanto, el "Estado no puede tener ningún interés en ejercer autoridad sobre cosas que por sus destinaciones están en cierto modo espiritualizadas”. Los cementerios religiosos, y en especial los católicos, no son ni pueden ser meras creaciones higiénicas. El fiscal define que:

\footnotetext{
${ }^{17}$ AHPC. Gobierno, 1886, T9.

${ }^{18}$ AHPC. Gobierno, 1886, T9. Nota al Gobernador Gregorio Gavier, Córdoba, 17 de enero de 1884.
} 
Los cementerios consagrados suponen un vínculo religioso que une a los vivos con los muertos; suponen la fe religiosa; la esperanza en una vida futura que se realizará más allá de la tumba; la seguridad religiosa también de que nuestros despojos mortales, los restos de nuestros muertos queridos, habrán de animarse de nuevo en un día, que sólo pueden entrever las miradas de la fe. Son por esto los cementerios objeto de piadosa veneración. Es por esto que el Estado, se ha limitado siempre a munir con la sanción de sus leyes esa veneración religiosa, que sin infundirla él, la encontraba en todas partes adherida a la conciencia de sus súbditos. ${ }^{19}$

Finalmente, el fiscal aconseja al ministro la necesidad de hacer comprender a los jefes políticos y a los encargados del Registro Civil que por ley no tienen ninguna atribución que los autorice a violar los cementerios católicos y que la solución a este tipo de conflictos sería la construcción de cementerios profanos o civiles, en cuya administración sólo interviniera el poder civil, y dejar a salvo el derecho de cada uno de depositar los restos de sus deudos en el cementerio que prefieran, civiles o religiosos.

Esta imagen del cementerio remite sin lugar a dudas a la creación de vínculos espirituales en una sociedad dada, lo que en la primera parte señalábamos como el proceso de espiritualización religiosa, esa fuerza de los vínculos espirituales que unen a los miembros de una comunidad católica. En 1890, el cura de Chalacea observaba en un informe remitido a la curia, en la que se quejaba de que sus feligreses no pagaban los derechos de sepultura porque enterraban a sus deudos en el curato vecino de Santa Rosa, "los entierros de cadáver se practican en Santa Rosa por el fanatismo de estos feligreses que allí adonde han sido sepultados sus antepasados deben sepultarse todos de la familia [...] allí se pagan derechos de sepultura, allí de funerales y allí de misas cuerpo presente". ${ }^{20}$

Esa integración de los muertos en el mundo de los vivos, donde se desvanecen las diferencias entre el espacio de los vivos y el espacio de los muertos sigue estando presente, aunque, como veremos, hay un claro deslizamiento hacia una concepción más moderna y desacralizada del cementerio. La iglesia comienza a sacralizar el cadáver individual y a desacralizar el lugar común de los muertos. Waldo Ansaldi (1997: 254) señala que el "día de los fieles difuntos, el 2 de noviembre, era una manifestación de sociabilidad que combinaba de manera notable sacralidad y profanidad. Ese día, la familia del(os) muerto(s) concurría al cementerio, llevaba flores y coronas que se depositaban en las tumbas, pero

\footnotetext{
19 AAC. Leg. 39. Comunicaciones con el Gobierno Provincial, 1760-1910, T4, s/f. Inicio del Expediente 05/12/1889.

${ }^{20}$ AAC. Caja Parroquias, Obispo Trejo (Chalacea). Informe anual de 1892.
} 
también viandas y bebidas que se ingerían junto a ellas, compartiéndolas simbólicamente deudos y finados. Vendedores ambulantes ofrecían unas y otras a los imprevisores. Incluso, no faltaba la guitarra y el canto". Esto nos habla de una sociedad católica preocupada por el destino eterno de los miembros de cada familia. Esto se condice con las prácticas relativas al bien morir. Si bien los cementerios pasan a la administración civil, los pobladores siguieron solicitando a los curas la realización de responsos para sus deudos, la administración de los ritos funerarios, incluida la bendición de la sepultura. Los ritos podían realizarse en la iglesia o en el mismo predio del cementerio. La secularización de los cementerios fue, sin duda, un paso en el proceso de laicización del estado, pero no necesariamente en el proceso de secularización de la sociedad. Al secularizar los cementerios, se crean, en un espacio profano a cargo de la administración civil, lugares sagrados (las tumbas benditas). Durante la visita canónica al curato de Soto, en 1902, el Obispo Auxiliar Monseñor Cabanillas, dejó constancia, en el artículo tercero del auto, que "habiéndose quitado al párroco, por la Municipalidad, la propiedad y administración del cementerio de esta parroquia, quedando por tanto profanado y sin bendición, ordenamos que en cada caso que ocurra, bendiga la sepultura y haga los oficios correspondientes a los fieles que murieren en comunión con la Iglesia". En el artículo siguiente, exhortaba a la feligresía a que "por ningún pretexto, o doctrina o disposición contraria quieran omitir el mandato de la iglesia de hacer que sus deudos sean sepultados en tierra sagrada con los ritos y oficios que para honrar las cenizas de sus hijos fieles tiene ordenado la Iglesia. Debiendo para tal efecto, dar oportuno aviso al párroco, por medio del boleto de sepultura, según es de práctica en todo el obispado".

A lo largo de estos años, puede observarse como se adecua la Iglesia, por obligación o necesidad, a las nuevas prácticas funerarias, más acordes con las sociedades modernas. La solidaridad entre vivos y muertos ya no está sólo en el recuerdo de los restos de los deudos para el consuelo de los vivos, sino en la responsabilidad de los vivos en contribuir a la salvación eterna de los muertos. El obispo ordenaba al cura que "bendiga la sepultura y haga los oficios correspondientes a los fieles que murieren en comunión con la Iglesia”. Aquí estamos en presencia de un vínculo moderno, ligado a la veneración del recuerdo del difunto en una tumba propia. Esta individuación no implica necesariamente descristianización, es, sin embargo, una clara manifestación de la privatización de lo 
religioso que se está operando. Antes, el cuerpo importaba poco mientras estuviera sepultado en campo santo. Ahora, lo importante es bendecir la tumba individual y garantizar los oficios fúnebres. El campo santo cede el paso a la sepultura individual, bendecida, en un espacio profano. El cura de Villa Concepción del Tío informa al obispado que existe un cementerio en Balnearia que no lo han bendecido, porque los vecinos no lo quieren entregar a la Iglesia y que "piden muchos la bendición de sepulturas, ¿podré bendecir sepulturas según piden muchas personas buenas que tienen miembros de la familia en ese cementerio?". ${ }^{21}$ La preocupación del clero es dar sepultura eclesiástica. Esto queda reflejado en el auto de la visita canónica de 1902 al curato de Punilla, donde se deja constancia de que el libro de defunciones no contiene las partidas correspondientes porque los cementerios estaban en poder de las municipalidades:

Cuyos empleados o encargados del registro civil no advierten a los deudos la obligación que, como católicos, les incumbe de dar parte a los párrocos para que se les den sepultura eclesiástica. Que esta obligación que atañe a dichos empleados como a todos los fieles es un derecho inalienable que no puede ser anulado o despreciado por ninguna ley civil en un pueblo católico, tanto más que por la constitución y leyes fundamentales que nos rigen, la religión católica es la religión del Estado, cuyo gobierno le debe la más decidida protección y sostenimiento. Que la falta de cumplimiento de tan sagrado deber trae consigo la profanación del cementerio haciéndole perder la bendición de la Iglesia y demás bienes que corresponden a los fieles que en él se inhuman, quedando en las mismas condiciones de infieles y herejes destituidos de las limosnas y sufragios que en caso contrario tendrían de la iglesia nuestra madre. ${ }^{22}$

La importancia y necesidad de brindarle las honras fúnebres al individuo y bendecir su propia sepultura acentúa, como señala la cita, lo que era considerado un derecho inalienable de cualquier ser humano, el de recibir la bendición de la Iglesia y los demás bienes que corresponden a los fieles, ya que de no recibirla "quedan los difuntos en las mismas condiciones de infieles y herejes destituidos de las limosnas y sufragios" previstos por la Iglesia. El derecho a los ritos de la muerte supuso también un campo de fricción. Aquí la sociedad se enfrentó a las autoridades municipales que quisieron impedir el paso del cadáver por el templo. El Concejo Deliberante de Marcos Juárez, el 3 de agosto de 1898 sancionaba una ordenanza de seis artículos que reglamentaba la conducción de cadáveres a

\footnotetext{
${ }^{21}$ AAC. Caja de Parroquias: Villa Concepción del Tío, s/f.

${ }^{22}$ AAC. Libro de Notas particulares del Obispo, 1884-1903, f.111.
} 
los cementerios y la entrada de los mismos en la iglesia. El primero prescribía que quedaba absolutamente prohibido la conducción y entrada de cadáveres en la Iglesia de la Villa. El segundo establecía que cuando alguno quisiera celebrar una misa de cuerpo presente, debía pedir permiso a la Municipalidad, que podía concederlo o denegarlo previo informe del médico municipal, en el caso de concederse el permiso debía ser por escrito con un sello de diez pesos. El tercero prohibía la conducción de cadáveres en carruajes de alquiler destinado a pasajeros, jardineras o carros de servicio público, como los que reparten bebidas o comestibles. El cuarto establecía que cuando se condujesen cadáveres al cementerio en vehículos no autorizados no podía circular por las calles principales de la villa. El quinto establecía que debía conducirse el cadáver de la casa mortuoria al cementerio por el camino más corto. Y el último artículo estipulaba una multa de cincuenta pesos para los infractores. ${ }^{23}$ La ordenanza causó estupor en la población. El cura informaba al obispado que "el pueblo está indignado con la Municipalidad, ha habido personas que han llevado al finado a otros pueblos". ${ }^{24}$ Prohibir la conducción y entrada de cadáveres en la villa era ir contra un sentimiento profundo de la población, que, con tal de otorgarle los ritos fúnebres a sus muertos, era capaz de ir a otros pueblos.

La preocupación era justamente ésa, no dejar a ningún fiel católico morir y ser sepultado como hereje o infiel y garantizarle las limosnas y sufragios necesarios para dar el salto a la vida eterna. De allí que el morir sacramentado sea en una preocupación para la jerarquía y, a la vez, sea uno de los primeros motivos de denuncia de las feligresías a la hora de pedir la destitución, cambio o permanencia del cura o argumento para edificar un templo. Lo que indica la importancia que la población le otorgaba al tema. Los feligreses de Salsacate, por ejemplo, solicitaron la remoción del cura. El primer cargo de la denuncia era justamente que "se ha negado en reiteradas veces a prestar el auxilio de confesión a enfermos que han fallecido sin recibir tal beneficio". ${ }^{25}$ En una nota posterior, señalaban, puntualmente, el nombre de una veintena de fallecidos sin asistencia espiritual. ${ }^{26}$ Cinco años después, volvieron a denunciar a otro cura y entre los argumentos presentados afirmaban que había fallecido en la localidad la Sra. Ernestina Oropel sin que el cura le prestara los debidos

\footnotetext{
${ }^{23}$ AAC. Cajas Parroquias: La Asunción de Marcos Juárez, f.30.

${ }^{24}$ AAC. Cajas Parroquias: La Asunción de Marcos Juárez, f.51.

${ }^{25}$ AAC. Caja Parroquias: Salsacate, f.175. Nota del 16/11/1913.

${ }^{26}$ AAC. Caja Parroquias: Salsacate, f.184. Nota del 24/02/1914.
} 
auxilios más allá de que la madre de la víctima se lo había requerido varias veces. ${ }^{27}$ En tanto, los feligreses de San Agustín, al argumentar la necesidad de que no se retirara al cura Martínez, señalan, entre otras cuestiones, que “jamás para él se encuentran obstáculos de ningún género en el cumplimiento sagrado de sus deberes; los calores impetuosos del verano como los crudos frios del invierno no son un obstáculo ni mucho menos para trasladarse a cualquier rincón donde necesiten sus auxilios. Parece que todo esto retempla su alma virtuosa, llena de méritos al abandonar su casa y correr al través de tortuosos caminos para auxiliar al pobre moribundo que lleno de angustias aspira los auxilios de la religión". 28

El jefe político y los vecinos de Balnearia solicitaron permiso para la construcción de un templo para "tantos católicos que solo deseamos fe y auxilios espirituales en trance de muerte". ${ }^{29}$ La recepción de los sacramentos en el trance de la muerte era una cuestión de suma importancia para la población de la campaña cordobesa, de tal modo, que, en algunas oportunidades, el cura incluso llegó a negar este servicio a personas que llevaban una vida alejada de la religión a modo de castigo ejemplificador, con el fin de lograr que otros miembros de su feligresía cambiasen su conducta y se pusiesen a bien con Dios. Tal fue la conducta del cura Abriola, de Chalacea, curato ubicado al norte del departamento de Río Primero, en su informe al obispado señalaba que:

Que habiendo encontrado muerto el día de Pentecostés, en su casa, al individuo Pedro Vivanco, y habiendo este vivido en una continua borrachera sin haber jamás cumplido con los preceptos de la Iglesia y sin haber jamás pisado los umbrales de la casa de Dios para oir misa los días festivos, o al menos en otros días, ha tenido a bien negarle la sepultura en el cementerio, prefiriendo que se sepulte provisoriamente al lado de afuera hasta esperar la decisión de V.S.I. Debo añadir que hace la fecha de cuatro o cinco años que tubo este individuo una enfermedad que casi le causo la muerte y que entonces y con grandes esfuerzos se consiguió hacerle confesar y administrarle la eucaristía y la extremaunción. Algunos días antes de morir sentíase muy mal y que veía aproximarse la muerte, según el mismo decía y sin embargo de tener presente la proporcion de confesarse y conseguir los auxilios de la religión no se ha servido de ellos. En sus borracheras que sabía tomar cotidianamente en las casas de negocios no dejaba de ablar algo contra la religion y los religiosos. Por estos motivos y para escarmiento de varios otros que viven del mismos modo y despreciando la práctica de

\footnotetext{
${ }^{27}$ AAC. Caja Parroquias: Salsacate, f.229. Nota de denuncia del 08/04/1819.

${ }^{28}$ AAC. Cajas Parroquias: San Agustín, f.15.v.

${ }^{29}$ AAC. Cajas Parroquias: Balnearia. Nota del 17/04/1922.
} 
los actos de la religión se ha visto el esponente en la dura necesidad de servirse de esta medida, siempre dispuesto sin embargo a rectificar $[\ldots] .{ }^{30}$

La bendición de la tumba individual y la celebración de los ritos fúnebres cobran importancia en tanto el cementerio deja de ser una preocupación para el clero. En este contexto, se inscribe la reflexión del cura de Villa Concepción del Tío, Antonio Álvarez, cuando, en 1920, informa al obispado que "la Municipalidad pretendía administrar el cementerio parroquial", y advierte que "al cura solo le da gastos, $25 \$$ mensuales a un empleado que recibe los muertos y le indica el lugar de sepultura y las refacciones que cada momento requieren las tapias viejas que se están cayendo. Es una verdadera carga gratuita para el cura porque nadie paga derechos y es imposible cobrar. Deseo que este, si es posible, se lo entregue a la municipalidad". ${ }^{31}$

La cuestión de los cementerios fue un largo conflicto que culminó con la promulgación de la Ley de Municipalidades $n^{\circ}$ 3373, sancionada en 1926, que, en su artículo 136, disponía que el cuidado y administración del cementerio es una obligación de las autoridades civiles, e incluye lo producido por los cementerios como una fuente de recursos para las Municipalidades. Lo que había comenzado como un serio conflicto en la década del 80, incluso antes, cuarenta años después se convierte en un simple trámite administrativo, que ya no afecta "los derechos de la Iglesia".

Es interesante analizar, a modo de ejemplo, el caso de Leones. En 1904, el cura de Leones, capellanía dependiente de Marcos Juárez, solicitó al jefe político del departamento la administración del cementerio local por no existir autoridad municipal. El permiso le fue otorgado con la condición de "que no impida la inhumación de cadáveres de personas disidentes, pudiendo bendecir en cada caso los nichos de los que hayan pertenecido a la religión católica, si así lo solicitaren, por lo que evitarían conflictos que en lo sucesivo pudieran sobrevenir". Como el cementerio era propiedad del vecindario, que lo había construido de su peculio particular, la entrega se realizaba al sólo efecto de la administración, es decir, podía percibir los derechos de sepultura, pero no tenía permitido la venta de nichos ni la percepción del valor de aquellos vendidos que estuvieran impagos. Además, dicha administración eclesiástica concluiría al momento de crearse la Comisión

\footnotetext{
${ }^{30}$ AAC. Cajas Parroquias: Obispo Trejo (Chalacea), f.71. Nota del 21/04/1888.

${ }^{31}$ AAC. Cajas Parroquias: Villa Concepción del Tío, f.103-104.
} 
Municipal. En 1913, la capellanía de Leones fue erigida en parroquia independiente y se nombró cura al que hasta ese momento era el capellán, Antonio Mosso, sacerdote italiano, de la diócesis de Turín. En julio de 1915, se creó la Comisión Municipal y el primer presidente, José Tricarico envió una nota al cura para solicitarle le hiciera entrega de las llaves del cementerio, anunciándole que pasaría a ser administrado por dicha Comisión. El cura se negó a entregarlas y la Comisión tomó posesión del cementerio con el auxilio de la fuerza pública. ${ }^{32}$

El enfrentamiento entre la Municipalidad y el cura se manifestó en una serie de hechos concretos. Uno de ellos tuvo relación con las prácticas mortuorias. El cura Mosso protestó por el incumplimiento de la promesa formal del intendente de "no hacer efectivo los impuestos de la entrada de cadáveres a la Iglesia para las misas de Cuerpo Presente". El Intendente Infante y su Concejo dispusieron un impuesto de $\$ 100$ para exhumar el féretro que se llevaba a la Iglesia. El cura reaccionó desde el púlpito y la prensa, en el boletín "La Familia Cristiana", llamó al intendente a revisar el artículo 65 de la Ordenanza Municipal que prohíbe la entrada de cadáveres a la Iglesia, considerándolo inconstitucional y violatorio de los derechos de los católicos y restrictivo de la libertad de conciencia. Calificó la acción como una agresión de "dos o tres masones con manía anticlerical".

El 25 de abril de 1918 publicó que "después de haber puesto mano a todos los recursos de la prudencia $[\ldots]$ y haber esperado inútilmente una solución pacífica $[\ldots]$, he entablado pleito en contra del Municipio de Leones, demandándolo ante el Juez de Primera Instancia en Córdoba". El 28 de febrero el sacerdote responsabilizó al Municipio por la epidemia de carbunclo, una enfermedad infecciosa transmitida por insectos, por la cantidad de moscas, existentes al no ser enterrados o incinerados los cadáveres de los animales muertos. El pueblo denunciaba que se había transformado en un verdadero foco de infección. Cerró la nota advirtiendo que "los señores del Municipio que ven un peligro para la higiene en la entrada de los cadáveres a la Iglesia y la prohíben, no ven el peligro grandísimo que entraña para la salud pública la putrefacción de animales muertos de peste; y la venta de carne en las carnicerías en tiempo de epidemia, no habiendo inspección médico-veterinaria [...]. Es vivamente comentada por todo el vecindario la inacción en que se encuentra la municipalidad desde los tres primeros meses de su funcionamiento. A excepción de tapiar

\footnotetext{
${ }^{32}$ AAC. Parroquias: Leones, fs.41-43.
} 
una parte del cementerio, no ha hecho otra cosa que cobrar. Siendo lamentable la condición en que se encuentran las calles a cuyo arreglo se habría podido proveer, con poco gas aprovechando la gran crisis y los muchos pobres desocupados que andan inútilmente en busca de trabajo. [...] que se acuerden que delante de la Iglesia y propiamente en el paso que da al Templo, por las calles que vienen del norte, existe una planta que dificulta la llegada a la Iglesia y es un foco de verdadera infección". ${ }^{33}$

Entre 1920 y 1926, los curas firmaron convenios con las autoridades civiles de sus respectivos curatos, en los cuales figuran las bases de la cesión de los cementerios eclesiásticos a la administración civil ${ }^{34}$ El intendente de Río Primero es muy claro al respecto, al señalar, en nota enviada al obispo, que la municipalidad no estaba en contra de la Iglesia y que no deseaba quitarle nada de lo que justamente le correspondiera, sino que deseaba cuidar, como se merece, un sitio sagrado, "además [decía], en todo los pueblos que existe Municipalidad, está a cargo de ella la administración y cuidado de los cementerios, citando el de la culta y Católica Villa del Rosario". ${ }^{35}$

Los puntos centrales de dichos convenios estipulaban el permiso otorgado por la curia a la municipalidad de enajenar sitios para construir panteones y nichos con el fin de solventar los gastos del cementerio; la municipalidad no podrá permitir la inhumación de cadáveres en la parte destinada a los católicos, que, según las leyes eclesiásticas, no puedan ser sepultados en lugar sagrado, a cuyo efecto el cementerio conservará siempre una sección no bendecida; tampoco permitirá la inhumación de cadáveres sin previa presentación del boleto del cura o su ayudante; el cura párroco tendrá la dirección espiritual canónica del cementerio, pudiendo, en consecuencia, practicar en él los oficios religiosos que estimara convenientes. ${ }^{36}$ En el convenio entre la municipalidad y el cura de Arroyito, por caso, se establecía que la parroquia disponía de dos solares en el cementerio, además de especificar que la municipalidad emitirá los permisos de inhumación por triplicado, a fin de entregar a la parroquia una copia para que llevara sus propios registros, que el párroco podía celebrar

\footnotetext{
${ }^{33} \mathrm{http}$ ://parroquia-leones-historiaparroquial.blogspot.com.ar/2010/02/historia-parroquial_26.html

34 AAC. Cajas Parroquias: Remedios, 26/02/1926; Deán Funes, 03/04/1921, f.141 y ss.

${ }^{35}$ AAC. Cajas Parroquias: Remedios, f.34.

${ }^{36}$ AAC. Cajas Parroquias: Villa Concepción del Tío, f.139-142.
} 
libremente los oficios religiosos en los cementerios y que al efecto de facilitar las funciones religiosas, la municipalidad entregaría al párroco una copia de la llave. ${ }^{37}$

\subsection{Morir sacramentado}

Una de las mayores preocupaciones de la jerarquía era velar para que ningún feligrés católico muriera sin la debida atención espiritual. En 1876, el Obispo Álvarez envía una circular sobre el ministerio parroquial que en su cuarto punto señala que "siendo tantas las ventajas que reportan a las almas de la participación de los santos sacramentos, principalmente en el artículo de la muerte, se recomienda vivir las prescripciones de la iglesia a este respecto, a fin de que ningún sacrificio omita para proporcionar este bien a sus feligreses" ${ }^{38}$ Los cuestionarios remitidos a los párrocos con motivo de las visitas canónicas son cada vez más explícitos. En 1906, en el número 37 se pregunta: ¿El cura y el teniente están prontos siempre para asistir a los enfermos? ¿Qué medidas toma el cura para promover la frecuencia de los santos sacramentos? ¿Se procura que los enfermos cumplan con la Iglesia en el tiempo pascual?

Las respuestas dan cuenta de la solicitud del cura y algunas incluyen las prácticas de las feligresías. El cura de Morteros responde que el cura y su ayudante estaban prontos para asistir a los enfermos. "Se procura que no mueran al menos sin confesión, ya que el cumplimiento pascual es algo que apenas se frecuenta por una pequeña parte de la población". ${ }^{39}$ El cura de Río Segundo advierte que está "pronto siempre, a cualquier hora del día o de la noche. Predica con frecuencia se procura que los enfermos cumplan con el precepto pascual". ${ }^{40}$ El cura de San Francisco señala que "con puntualidad se atiende a los enfermos" ${ }^{41}$ El cura de San Javier dice que "los fieles tenían la costumbre de llevar el sacerdote a los enfermos". ${ }^{42}$ El cura de Jesús María responde que "asiste a todas las confesiones, tanto en mi curato como en el vecino, siempre que me lo demanden. Las medidas tomadas para promover la frecuencia de sacramentos son facilitarles los medios, hacerles una limosna, mando a las vicentinas hagan una visita, hagan una caridad,

\footnotetext{
${ }^{37}$ AAC. Cajas Parroquias: Arroyito. Acta Convenio por la Administración del Cementerio, f.25.

${ }^{38}$ AAC. Leg. 53. Pastorales, 1854-1913, s/f. Circular del 31/12/1876.

${ }^{39}$ AAC. Cajas de Parroquias: Morteros, s/f. Respuesta al Cuestionario de la Visita fechado el 25/08/1915.

${ }^{40}$ AAC. Cajas Parroquias: Río II, f.117. Respuesta al Cuestionario de la Visita fechado el 02/02/1910.

${ }^{41}$ AAC. Cajas Parroquias: San Francisco, s/f. Respuesta al Cuestionario de la Visita fechado el 05/10/1907.

${ }^{42}$ AAC. Cajas Parroquias: San Javier, s/f. Respuesta al Cuestionario de la Visita de 1926.
} 
abriéndome por estos medios el camino para poder llegar hasta ellos y convencerlos. Se exhorta en público y en particular se les habla de cumplimiento pascual" ${ }^{43}$

Morir sacramentado no era sólo una preocupación del clero y la jerarquía, las feligresías destacan esta cuestión a la hora de denunciar a un cura por incumplimiento de sus deberes de párroco o a la hora de solicitar se deje sin efecto alguna remoción, destacando la atención a los enfermos y moribundos como ejemplos del buen desempeño de sus funciones. Es así cómo en 1879 los vecinos de Santa Rosa solicitan la remoción del cura Bula, aduciendo que están cansados de soportar, más de 17 años, sus "abusos y las faltas como cura", entre las causales de dicha solicitud se expresa que "no confiesa a todo aquel que no tiene caballos suficientes para que lo lleven en volantas, previniendo que es la única manera que sale de confesión fuera de la villa, de consiguiente mueren sin auxilios". ${ }^{44} \mathrm{O}$ en 1882, los vecinos de Río Segundo sacan un suelto en el diario "La Voz del Interior", en donde denuncian que el cura había negado la unción y pedían su destitución. El cura eleva una nota de protesta a la curia y relata lo sucedido. Dice que llegó un muchacho a buscarlo para que atendiera a su padre gravemente herido, el presbítero tomó lo necesario para darle la comunión y la unción y siguió al muchacho. "Ni bien llegue allí rodee a todo aquel inmenso pueblo que rodeaba al herido, de que tuviera a bien retirarse para darme lugar a que lo confesara. Al instante quede solo con el paciente y como no había silla en la que poderme sentar porque el herido estaba en un catre en medio de un patio. Pedí una silla la cual me fue dada al instante ¿Cuál fue mi sorpresa cuando, una vez sentado en la cabecera del paciente veo que el pobre desgraciado estaba completamente enlicorado y que no atinaba en contestarle?". El cura reprendió a los presentes y les explicó que debía suspender el sacramento de la penitencia al igual que el de la unción y recomendó que trataran de refrescarlo y una vez que logaran hacerlo volver a su entero juicio lo llamaran, él estaba dispuesto a volver a cualquier hora y se retiró del lugar. Los parientes salieron inmediatamente a buscar a un franciscano que estaba de paso por la Villa, quien tampoco lo pudo confesar ni dar la absolución por el mismo motivo de ebriedad. Al poco rato, el herido murió sin haber podido recibir los sacramentos, el cura les negó a los deudos la misa de

\footnotetext{
${ }^{43}$ AAC. Cajas Parroquias: Jesús María, s/f. Respuesta al Cuestionario de la Visita fechado en agosto de 1915.

${ }^{44}$ AAC. Leg. 48. Chalacea, Santa Rosa, San Justo, s/f. Nota sin fechar del año 1879 de los vecinos de Santa Rosa.
} 
cuerpo presente y el entierro. ${ }^{45}$ Conducta que motivó la denuncia de los vecinos por el comportamiento del cura. En 1921 o 1922, los feligreses de La Playosa elevan una solicitud al obispado, en la que piden un cura permanente, entre los argumentos señalan "los innumerables trastornos que nos ocasiona la atención debida de los moribundos, para la asistencia de los cuales, tenemos que recorrer grandes distancias sin conseguir muchas veces lo que deseamos y tener que resignarnos a la pena de ver morir nuestros deudos, sin poder proporcionarles la necesaria ayuda cristiana, indispensable para poder morir reconciliados con nuestro Dios". 46

Ahora bien, el morir sacramentado no era sólo un vínculo de solidaridad con los moribundos, sino también un ejemplo para los vivos. "La Familia Cristiana", revista parroquial de Marcos Juárez, dirigida por el párroco Leopoldo Buteler, que se distribuía en toda la región, en enero de 1916, sacaba una breve nota sobre el fallecimiento de Antonio Quinteros, un vecino acomodado de la zona. "Ha muerto en la paz del Señor, con la tranquilidad del justo, después de haber recibido todos los auxilios de la sacrosanta religión". La nota reseñaba brevemente la vida de este vecino, destacando las obras que había hecho en beneficio de la religión, como celebrar misiones religiosas en su estancia de Villa Argentina, facilitar de forma permanente un salón para la enseñanza del catecismo, poner a disposición de la catequista un carruaje, etc. La nota culmina señalando que "el párroco hace votos para que estos bellos ejemplos de nobleza y generosidad en favor de la religión sean lecciones provechosas para los que quedan vivos". 47

Es claro que la iglesia ya no mira tan sólo hacia la otra vida, sino a los que quedan aquí abajo, su preocupación se orientaba a movilizar a los católicos a realizar obras concretas para la expansión y el afianzamiento del catolicismo.

\section{La ley de matrimonio civil}

A la creación del Registro Civil, le siguió la ley nacional de matrimonio civil, sancionada el 2 de noviembre de 1888, que establecía que los matrimonios que no se celebrasen con arreglo a las disposiciones del Código Civil no producirían efectos legales; desde ese momento, sólo los matrimonios realizados ante las autoridades o funcionarios

\footnotetext{
${ }^{45}$ AAC. Cajas Parroquias: Central Río II, fs.31-34.

${ }^{46}$ AAC. Cajas Parroquias: La Playosa. Nota sin fecha, fue contestada el 20/10/1922.

${ }^{47}$ AAC. Caja Parroquias: La Asunción, Marcos Juárez, f.182.v.
} 
públicos competentes producirían efectos civiles. Esta ley alteró notablemente la situación establecida hasta ese momento, pues suponía el reconocimiento de los efectos civiles del matrimonio religioso, prohibía, bajo severas penas, a todo sacerdote la dispensa del sacramento sin tener a la vista los certificados de haberse verificado el contrato civil. Ante este hecho, el obispo de Córdoba dirigió una pastoral al clero y a los fieles de la diócesis, en la que señalaba que no constituía un matrimonio verdadero, indisoluble, elevado a la dignidad sacramental, "no es a los ojos del cristiano y de la Iglesia otra cosa que un reconocimiento público del Estado para vivir juntos y legalizar la descendencia de los dos, sin miramiento alguno a la fe, a las creencias o a la religión que profesan la inmensa mayoría de los hijos y ciudadanos de nuestro país. Así es que aunque dicha ley es una vejación para la Iglesia católica cuyos derechos y sacramentos desconoce y pospone -no altera absolutamente nada de lo que la Iglesia manda y determina sobre el Sacramento. El Estado no puede permitir y legalizar la unión de las personas, no puede imprimirle el sello sagrado del sacramento, no puede bendecir a los esposos ni a los hijos, ni alcanzarle gracias en el tiempo y en la eternidad". ${ }^{4}$

Las líneas directrices del documento están en conformidad con la pastoral colectiva firmada por los prelados argentinos en febrero de 1889 y la Encíclica Arcanum Divinae Sapientiae de León XIII, donde expresamente señala: "Y no se le ocurra a nadie aducir aquella decantada distinción de los regalistas entre el contrato nupcial y el sacramento, inventada con el propósito de adjudicar al poder y arbitrio de los príncipes la jurisdicción sobre el contrato, reservando a la Iglesia la del sacramento. Dicha distinción o, mejor dicho, partición, no puede probarse, siendo cosa demostrada que en el matrimonio cristiano el contrato es inseparable del sacramento". Algunos puntos más abajo, esclarece que la Iglesia no ignora ni niega que el sacramento del matrimonio, encaminado también a la conservación y al incremento de la sociedad humana, tiene parentesco y vinculación con cosas humanas, consecuencias indudables del matrimonio, pero que caen del lado de lo civil y respecto de las cuales con justa competencia legislan y entienden los gobernantes del Estado (León XIII, 1880: 12-21).

\footnotetext{
${ }^{48}$ AAC. Pastoral del Ilmo. Rmo. Obispo de Córdoba D Fr. Reginaldo Toro, Buenos Aires, Imp. y Enc. del Colegio Pío de Artes y Oficios, Almagro, 1889.
} 
En marzo de 1889, la curia diocesana envía una circular a todos los párrocos de la diócesis con instrucciones prácticas sobre cómo proceder conforme a ellas para la administración del sacramento del matrimonio y se eviten los inconvenientes a los que la ley da lugar. ${ }^{49}$ Los puntos fundamentales del documento señalan: 1) La recomendación de explicar al pueblo la doctrina católica sobre el matrimonio, con una predicación preparada, prudente y acomodada a la inteligencia del pueblo cristiano. "Haga así comprender a todos que si se permite a los fieles el concurrir a declarar su consentimiento ante el oficial público, esto no importa celebrar verdadero matrimonio, sino solo cumplir un acto meramente civil, necesario ahora para que sus matrimonios tengan validez ante la ley". ${ }^{50} 2$ ) La obligación de respetar a las autoridades y a las personas, cuidando de no ofender en lo más mínimo ni suscitar odios personales. Prohibir bajo pena de "suspensión" que se falte el respeto debido a tales funcionarios de cualquier clase que sean. 3) La petición a los fieles de ayudar "con oraciones fervientes a Dios que muda los corazones para que practiquen ayunos, la penitencia sacramental y la Santa Comunión en esta cuaresma, a fin de que no seamos vencidos por el mal, para que sean abolidas y revocadas esas leyes que nos deprimen". ${ }^{51}$ La circular cierra con una recomendación clara y terminante, "como la misma ley en su artículo 118 establece pena contra el sacerdote que proceda a la celebración de un matrimonio religioso, sin tener a la vista el acta que acredite haberse celebrado ya civilmente, "será muy razonable que los párrocos se abstengan de autorizar matrimonios mientras no se les presente el acta civil". 52

El prelado diocesano advierte que por las circunstancias que se viven, y para evitar "vejámenes", la Iglesia permite y tolera que los católicos "se acomoden a la ley en la práctica, con tal de que entiendan que ejecutan un acto meramente civil, y que se apresuren cuanto antes a celebrar el matrimonio canónico, y no se tengan por casados mientras no hayan llenado este requisito". 53

Además, la sanción de la ley de matrimonio civil exigía a los oficiales del Registro confrontar los datos con los libros parroquiales, éstos deberían ponerse a su disposición

\footnotetext{
${ }^{49}$ AAC. Leg. 53. Pastorales, Edictos y Decretos, 1834-1900, TI. Circular Obispado de Córdoba Marzo 28 de 1889.

${ }^{50}$ AAC. Leg. 53. Pastorales, Edictos y Decretos, 1834-1900, TI. Circular Obispado de Córdoba Marzo 28 de 1889 , punto 10 .

${ }^{51}$ ACC. Fray Reginaldo Toro. Obispo. Pastoral, 1889, p. 6 y ss.

52 AAC. Leg. 53. Pastorales, Edictos y Decretos, 1834-1900, TI.

${ }^{53}$ AAC. Leg. 53. Pastorales, Edictos y Decretos, 1834-1900, TI.
} 
para comprobar la exactitud de los datos suministrados por los párrocos. ${ }^{54}$ La reticencia del gobierno y la desconfianza hacia el clero eran evidentes. Por otra parte, llegó a la curia una notable cantidad de consultas de los párrocos sobre el modo de proceder frente a esta obligación, ya que percibían que la intención del gobierno era convertir los registros parroquiales en oficinas auxiliares del Registro Civil y a los curas en empleados dependientes de los jefes inspectores y jueces de paz. El promotor fiscal del obispado, Ramón Gil Luque, informaba al clero sobre la práctica a seguir y advertía que esas disposiciones eran, a su juicio, demasiado absurdas, onerosas e injuriosas, por lo tanto, "si por bonus pacis se pueden acatar; únicamente se puede encargar a los curas que permitan que un escribiente de la oficina civil tome los datos que quiera de los libros parroquiales, pero con la precaución de que esto no sea ocasión para que los libros sean llevados fuera del lugar del archivo parroquial". 55

Jacinto Correa, cura de Punilla, Miguel Salguero, cura de Alta Gracia, Rafael López, cura de Anejos Sud y Alejo Torres, cura de Calamuchita, se opusieron tenazmente a la implementación de las referidas leyes laicas, en particular, la del matrimonio civil. Desde el púlpito, predicaban desestimando la necesidad de casarse por el registro civil y desplegaron una persistente oposición a la misma. Por ello, fueron detenidos y acusados de desacato, el caso más notable fue el de Jacinto Correa. En la indagatoria, todos los testigos coincidieron en afirmar que, en las pláticas, oyeron que "casándose por el civil él no los casaría". Gabriel Martínez, de 28 años, dijo al juez que "no se celebró matrimonio civil porque el cura le dijo que si se casaba por lo civil él no lo casaba por la Iglesia, también me dijo que después de casarme podía venir a ver al juez". ${ }^{56}$ El cura Correa estaba convencido de que el matrimonio era un sacramento que sólo le competía administrarlo a la Iglesia, razón por la cual, la autoridad civil no tenía atribuciones en el asunto. En la audiencia ante el tribunal, el sacerdote confesó “que había cometido muchísimas más infracciones que las constatadas en el sumario, que en el mismo recinto de la prisión había casado con prescindencia de la ley civil, y que allí en la misma presencia del juez casaría si se le presentaran personas a pedírselo y que cuando recobrase su libertad seguiría casando en la misma forma". ${ }^{57}$ Rafael

\footnotetext{
${ }^{54}$ Ley de Registro Civil, arts. 38-39.

${ }^{55}$ AAC. Curato de Bell Ville, s/f.

${ }^{56}$ AHP. Crimen $2^{\circ}$ Capital. Legajo 4. Expedientes Judiciales. Exp. 1, 1889, f.47.

${ }^{57}$ AHP. Crimen $2^{\circ}$ Capital. Leg. 4. Expedientes Judiciales. Exp. 1, 1889, f.49.
} 
López Cabanillas, cura de Anejos Sud, procedió de manera análoga. Consultado por el juez de paz, le dijo que él casaba sin sujetarse a la ley civil, "que los jueces de la campaña no entienden la ley y han de ser los curas los que han de hacer los dos matrimonios, por consiguiente yo casaré por el religioso como tengo dicho, si me meten preso sufriremos, que hemos de hacer...". ${ }^{58}$ Esta actitud le valió algunos días de arresto. ${ }^{59}$ Miguel Salguero, cura de Villa María, fue apercibido por el juez por la misma falta. El funcionario se trasladó a Villa María para constatar personalmente las irregularidades y luego solicitó al obispo diocesano que ordenara al cura que pusiera los libros de registro a su disposición a fin de verificar si se habían practicado algunos matrimonios en vigencia de la ley de matrimonio civil. ${ }^{60}$ El canónigo magistral del coro de la catedral fue remitido preso a La Rioja. Se le siguió un sumario por haber celebrado algunos matrimonios sin tener a la vista las actas respectivas que acreditaban su previa celebración civil. El prebendado cordobés había sido enviado a La Rioja a ayudar al vicario foráneo en tareas del ministerio durante la Semana Santa. Gracias a las diligencias del obispo diocesano la causa se detuvo y fue puesto en libertad.

Para las autoridades eclesiásticas, la ley penalizaba un acto estrictamente de culto, la administración del sacramento del matrimonio. Por lo tanto, la pena era injusta e inconstitucional, violaba la tolerancia religiosa y la libertad de cultos. Además, sólo penalizaba al sacerdote, cuando, en estricta justicia, quienes violaban la ley eran los mismos contrayentes que no cumplían con el requisito previo de anotarse en el registro. Las autoridades civiles veían con preocupación la acción del clero dado el predicamento que tenían sobre los pobladores de la campaña. La sentencia del Juicio a Correa era clara:

Estos hechos y estas declaraciones ponen de manifiesto que no es el celo mesurado y juiciosos del sacerdote honrado por el ejercicio de su ministerio el que lleva a violar la lei, pues que hace venir personas hasta su prisión para casarlos sin una razón necesaria por lo menos aparente que justifique ese proceder en el que debe mirarse solo el placer

\footnotetext{
${ }^{58}$ AAC. Leg. 53, s/f. "El Señor Cura López ha casado en la capilla de Altagracia por el matrimonio religioso y sin observar la ley de matrimonio civil vigente, al Señor Tristán Garay, vecino de la Pedanía Reartes, Departamento de Calamuchita, con la viuda Senavia Echenique de Oviedo, domiciliada en una estancia de la Pedanía de Potrero de Garay, Departamento de anejos Sud".

59 AAC. Leg. 39. Comunicaciones con el Gobierno Provincial, 1876-1910, s/f. Informe del Juzgado de Instrucción al Obispo Reginaldo Toro con fecha 5 de diciembre de 1889.

${ }^{60}$ AAC. Leg. 39. Comunicaciones con el Gobierno Provincial, 1876-1910.
} 
de violar la lei, sino una índole perversa y una corrupción total de la dignificación personal producen una voluntad inquebrantable y bien conciente de llevar a cabo un acto cualquiera sean los medios a emplearse, porque solo así se explica la reiteración de las infracciones, las amenazas y falsedades a sus feligreses, las declaraciones irrespetuosas hechas al tribunal, la falta de obediencia y acatamiento a las instrucciones del Ilmo. Sr. Obispo que corren publicadas y por fin el hecho de que en Córdoba donde el clero goza de justo buen nombre se produzcan esta clase de juicios. ${ }^{61}$

¿Quiénes fueron los curas que se opusieron con tanta firmeza a las leyes laicas? Dos de ellos, Jacinto Correa y Rafael López Cabanillas, eran sacerdotes que hacía poco que habían regresado de terminar sus estudios en Roma, en el Colegio Pío Latinoamericano, formando parte del primer contingente de seminaristas que salió de Córdoba rumbo a Roma en 1875 (Altamira, 1943: 341), apenas cinco años después que Cavour propuso el estado italiano laico con capital en Roma y Pío IX cedió contra su voluntad los Estados Vaticanos. Conocida es la postura de Pío IX respecto al liberalismo, es por tanto viable suponer que esta línea de conducta estuviera influenciada por la experiencia vivida en la ciudad eterna.

El oficial del Registro Civil, al presentar el informe del primer año de funcionamiento, justifica la escasa representatividad de los números, invocando "las creencias religiosas tan arraigadas en el vecindario de nuestra Provincia y muy especialmente la guerra tenaz que con motivo del matrimonio civil, se viene haciendo por los representantes de la Iglesia a toda nuestra institución". ${ }^{62}$ El gobierno provincial tenía la mira puesta en los párrocos y ante las denuncias de los jefes políticos procedió al apercibimiento de los curas, llegando, incluso, como hemos mencionado ut supra, a iniciarles proceso penal, como al párroco de Punilla, Jacinto Correa, y a apercibir a más de una docena de curas.

En 1890, el juzgado de instrucción de la provincia solicitó al Obispo Toro le informara si, como se había denunciado en Villa María, se habían "practicado algunos matrimonios después del diez y ocho de julio del ppdo." y le enviara la legalización de las copias mencionadas o impartiera las órdenes del caso a fin de que se pusieran a su disposición los libros de registro de dicha parroquia a los fines de constatar si se había infringido la ley. ${ }^{63}$ En 1891, los vecinos de Villa Sarmiento, departamento de Gral. Roca, enviaron una nota al

\footnotetext{
${ }^{61}$ AHPC. Crimen $2^{\circ}$ Capital. Leg. 4. Expedientes Judiciales. Exp. 1, 1889, f.117.

${ }^{62}$ AHPC. Gobierno, 1891, tomo 10. Memoria del Registro Civil.

${ }^{63}$ AAC. Leg. 39. Comunicaciones con el Gobierno Provincial, 1876-1910. Juzgado de Instrucción.
} 
obispo en la que informaban cumplir con un deber de conciencia al decir que eran "de todo punto inciertos y calumniosos los cargos hechos ante el Sr Gobernador de la Provincia por el Jefe de esta Oficina del Registro Civil, contra el respetable padre misionero Fray Ludovico Quaranta, cura de este departamento, sobre pretendidas transgresiones de la ley civil". En efecto, el cargo fue formulado por Barrales, ciudadano chileno que se desempeñaba como jefe de la oficina del Registro Civil, contra lo estatuido por la ley, "en nuestro concepto, por su calidad de extranjero, carece de todo fundamento por cuanto los matrimonios a que se refiere fueron celebrados con anterioridad a la vigencia de la ley de matrimonio civil por el padre Rossetti, que residía entre nosotros como maestro de escuela, y que fue suspendido en funciones eclesiásticas por orden de SS Ilma., entendemos que es un deber de conciencia, como lo dejamos dicho, llevar estos hechos a conocimiento de SS Ilma. para que se digne ponerlos en el de el Exmo. Sor Gobernador a fin de que Barrales que auxiliado por las autoridades locales mendiga firmas que justifiquen su conducta. No terminaremos sin manifestar a su Ilma. que las trabas de todo género creadas por Barrales para entorpecer la acción de las personas que necesitan acudir a su oficina, a fin de percibir las remuneraciones prohibidas por la ley, hacen odiosos a las conciencias católicas, el cumplimiento de la ley Civil". ${ }^{64}$

Las denuncias contra los curas que casan sin cumplir con las prescripciones de la ley civil continuaron entre 1905 y 1906. En total fueron denunciados más de 10 curas. El jefe de la oficina del Registro Civil del departamento de Río Primero señalaba que el cura de Remedios celebró matrimonios contra la ley de matrimonio civil. "Algunos señores curas de campaña han iniciado una activa propaganda entre sus feligreses para inducirlos a prescindir de la misma, llegando algunos hasta oponerse en forma tan irregular como inusitada a fin de que los que debían celebrar algún acto concurrieron a las oficinas del registro civil. Por los antecedentes en algunos curatos de campaña no solo se prescinde de la ley del registro civil si no que aún se la violenta e infringe deliberadamente y a sabiendas como lo ha hecho el cura de Colonia La Italiana, La Paz, y el de Capilla Remedios [...] Actos cuya gravedad es notoria porque tienden a sacar del medio legal los actos más

\footnotetext{
${ }^{64}$ AHPC. Gobierno, 1891, Tomo 9.
} 
trascendentales de la vida civil el nacimiento, el matrimonio y la muerte y colocándolos fuera de la sanción y del reconocimiento de las leyes". ${ }^{65}$

El obispo recabó información, los curas comunicaron que no había existido intencionalidad de violar la ley, porque circunstancias puntuales llevaron a celebrar esos matrimonios. Un cura había celebrado el matrimonio in articulis mortis, otro, debido a la distancia en que se encontraba la oficina del registro, los contrayentes tenían que hacer más de 12 leguas para llevar el boleto, motivo por el cual el cura los casó y les recomendó dirigirse luego al registro. A modo de ejemplo, el teniente cura de San Justo envía, en 1916, una consulta al obispado en la cual señalaba que:

Como en mis salidas habituales al campo me encuentro no pocas veces con amancebados que desean ponerse a bien con Dios y no pueden ponerse antes en condiciones legales o por falta de recursos, o por no tener facilidades para llegar hasta el registro civil y no me atrevo a proceder por haber sido hace muy poco denunciado por el jefe del registro por haber procedido de buena fe a un matrimonio que el mismo día se presentaron a la oficina a celebrar su matrimonio civil. ${ }^{66}$

Como se observa, algunos curas se opusieron tenazmente a la ley mediante la prédica y la práctica, otros no opusieron resistencias y colaboraron con ella, enviando las planillas y cumpliendo con lo dispuesto por el Estado, y otros buscaron la manera de salvar los inconvenientes y facilitar el acceso del sacramento a sus feligresías.

Nos interesa presentar un caso particular, en el que un cura párroco pone en tensión, o de alguna manera cuestiona, las prácticas administrativas eclesiásticas referidas a la administración del sacramento del matrimonio. El cura de Guandacol, Pablo Boy, envía, en 1884, un expediente matrimonial a la Vicaría Foránea de La Rioja, en el que adjunta una nota en la que solicita se le concediera permiso para dispensar impedimentos. En ella, señala que el expediente matrimonial pertenece a Martín Alarcón, joven pobre, que ni aún tiene para trabajar. Su mala vida con la pretendiente la declaran testigos cuasi oculares. Las causales por las cuales se solicita la dispensa de impedimento, para el cura, eran buenas y estaban bien justificadas. A continuación, el capellán solicitó al vicario foráneo le concediera las facultades necesarias para dispensar impedimentos de $1^{\circ}$ y $2^{\circ}$ grado, "al

\footnotetext{
${ }^{65}$ AAC. Leg. 39. Comunicaciones con el Gobierno. Nota del 02/04/1906.

${ }^{66}$ AAC. Cajas Parroquias: San Justo, f.97. Nota del 08/02/1916.
} 
pedir esta facultad no me asiste el mezquino interés del dinero, sino facilitar a muchos infelices que tal vez ni se casan por ciertas difíciles circunstancias", y señala algunas de ellas. La primera, son las largas distancias, entre 10 y 20 leguas, que muchos feligreses deben hacer para salir a buscar al cura, sin saber en qué capilla encontrarlo. La segunda, es la necesidad de "proveerse de cabalgaduras para novios, testigos y padres de aquellos". La tercera, es la pobreza de los pretendientes para el pago de sus derechos matrimoniales. La cuarta, tener estos gastos sólo para que se levanten las informaciones necesarias y recién después, regresar para efectuar el matrimonio y poder vivir cristianamente. Luego de enumerar las dificultades, el cura se pregunta: “¿No parece necesario, en estos casos Sr. Vicario, que la Iglesia nuestra Madre fuese cruel, en no revestir a los curas de suficientes facultades para no gravar en tanto a sus feligreses en campañas tan dilatadas como éstas? ¡Cuándo la iglesia se persuadirá de estas necesidades!" Y continúa, "no es mi ánimo reprobarla en sus sabias disposiciones administrativas, sino que creo no sabe lo que son estas enormes, desiertas y dilatadas campañas, pero ni aún los señores Obispos, puesto que dos de esos ilustrísimos y celosos Prelados al atreverse a visitarlas, al salir de sus sedes, han quedado exánimes en ellas. Al hacer estas observaciones no siento animo de crítica contra nadie, solo procedo teniendo a la vista un mandato de Ntro. Sr. Jesucristo: La mies es mucha y los operarios pocos, rogad al señor de la mies que envíe operarios. Entiendo que los que somos operarios no podemos estar maniatados para segar la mies. Maniatados para suspender todo impedimento al que en el acto pretende salir de la infelicidad de la culpa en que se encuentra y que al solo pensar en las mil molestias por las que tiene que atravesar, los gastos pecuniarios, los fríos glaciales en invierno, los sofocantes, asfixiantes y excesivos calores del verano, las crecidas de los ríos, teniendo que marchar con frecuencia por dentro de sus cauces pantanosos, sin poder salir a las márgenes por sus elevados barrancos [...] Es mi humilde modo de pensar protestando de no querer más, ni amar más que a mi Madre Santísima la Iglesia Católica, creo con todo que en la crisis en que atraviesa y atravesamos debe ella aflojar un tanto la cuerda para que los católicos tibios apostaten en materia de matrimonios católicos, porque el matrimonio civil les es más cómodo, con fe o sin ella no les grava más que presentarse al juez del Registro, y en materia de interés, en el siglo del positivismo, irán al juez porque nuestra religión o la que profesan los gravan con idas y venidas, con recursos al Prelado fuera del cura, costándoles mas i pérdidas de 
tiempo; paralización de sus trabajos [...] en fin creo que si estos obstáculos continúan, no solo no se casarán sino que muchos católicos desertarán del catolicismo...".67

El fiscal eclesiástico dictaminó que la nota del cura estaba concebida en términos de lo más irrespetuoso, no sólo para SSI, sino también para la Iglesia. Contiene términos y conceptos falsos e injuriosos para la sabiduría y fines que siempre guían a la Iglesia en el establecimiento y conservación de la disciplina eclesiástica. Sugiere al prelado enviar una notificación al cura reprobando los conceptos emitidos, los modos descomedidos con que los hizo y apercibiéndolo sobre la manifestación de las ideas que expresa. Advierte además que no sería prudente conceder ni una sola de las facultades que solicita y respecto al expediente matrimonial sugiere conceder la dispensa del impedimento. ${ }^{68}$

Más allá de la reacción de la curia, esta cita nos permite pensar, al menos, dos problemas. El primero sobre las dificultades que tenían los feligreses y los párrocos en cumplir con algunas de las prácticas administrativas del sacramento del matrimonio. El segundo, cómo se afianza la tendencia centralizadora del gobierno eclesiástico en las figuras de los obispos y sus auxiliares.

También encontramos curas, como José Gabriel Brochero (Tránsito), Vicente Luz de Cabrera (Chalacea), Rufino Polanco (Cruz del Eje), Alejo Torres (Calamuchita), que, en sus respectivos curatos, procuraron cumplir con la ley del matrimonio civil, mientras, de forma simultánea, intentaban que entre sus feligreses no hubiera ninguna pareja que viviera amancebada o unida sólo por el contrato civil. La consigna era velar para que los feligreses siguieran contrayendo matrimonio religioso.

El resultado de esta cruzada fue, sin duda, desigual, ya que las medidas secularizadoras respecto del matrimonio civil tuvieron un efecto disímil en la práctica religiosa de las poblaciones de las villas, colonias y pueblos de la campaña, al menos durante las primeras décadas de su implementación. Los informes recogidos por el Internuncio Locatelli, para los años 1907-1910, y enviados a la Sagrada Congregación Consistorial en 1911, permiten acercarnos al tema y elaborar alguna explicación. Como puede observarse en la Tabla 47 las diferencias departamentales son significativas.

\footnotetext{
${ }^{67}$ AAC. Leg. 35. Juicios Eclesiásticos, 1871-1905, TVIII. Nota del 01/10/1884.

${ }^{68}$ AAC. Leg. 35. Juicios Eclesiásticos, 1871-1905, TVIII. Nota del 14/10/1884.
} 


\section{Tabla 47}

Matrimonio civil y religioso entre 1907 y 1910

\begin{tabular}{|c|c|c|c|c|c|c|c|c|c|c|}
\hline \multirow[t]{2}{*}{ Departamento/Año } & \multicolumn{2}{|c|}{1907} & \multicolumn{2}{|c|}{1908} & \multicolumn{2}{|c|}{1909} & \multicolumn{2}{|c|}{1910} & \multicolumn{2}{|c|}{ Totales } \\
\hline & Civil & Relig. & Civil & Relig. & Civil & Relig. & Civil & Relig. & Civil & Relig \\
\hline Santa María & 49 & 52 & 45 & 51 & 44 & 41 & 65 & 59 & 203 & 203 \\
\hline Colón ${ }^{1}$ & 109 & 87 & 97 & 74 & 99 & 80 & 80 & 86 & 385 & 327 \\
\hline Río Primero $^{2}$ & 172 & 139 & 172 & 152 & 126 & 89 & 148 & 134 & 618 & 514 \\
\hline Río Segundo $^{3}$ & 157 & 151 & 200 & 201 & 186 & 148 & 179 & 144 & 722 & 644 \\
\hline Tercero Arriba & 166 & 20 & 137 & 20 & 148 & 27 & 147 & 31 & 598 & 98 \\
\hline Calamuchita $^{4}$ & 58 & 69 & 69 & 57 & 71 & 68 & 73 & 68 & 271 & 262 \\
\hline San Javier & 99 & - & 110 & - & 88 & - & 104 & - & 401 & \\
\hline San Alberto ${ }^{5}$ & 87 & 48 & 67 & 77 & 74 & 86 & 86 & 85 & 314 & 296 \\
\hline Pocho & 30 & 35 & 22 & 16 & 19 & 17 & 17 & 20 & 88 & 88 \\
\hline Minas $^{6}$ & 33 & 33 & 24 & 29 & 40 & 41 & 32 & 47 & 129 & 150 \\
\hline Punilla & 48 & 49 & 43 & 49 & 56 & 98 & 65 & 56 & 212 & 252 \\
\hline Cruz del Eje $^{7}$ & 155 & 226 & 124 & 128 & 142 & 131 & 128 & 110 & 549 & 595 \\
\hline Ischilín $^{8}$ & 100 & 137 & 64 & 38 & 79 & 41 & 108 & 58 & 351 & 225 \\
\hline Totoral & 17 & 25 & 62 & 53 & 31 & 25 & 44 & 41 & 154 & 144 \\
\hline Tulumba & 54 & 53 & 70 & 63 & 62 & 68 & 61 & 59 & 247 & 243 \\
\hline Río Seco & 38 & 34 & 41 & 44 & 39 & 37 & 35 & 38 & 153 & 153 \\
\hline Sobremonte & 48 & 47 & 28 & 29 & 33 & 32 & 30 & 31 & 139 & 139 \\
\hline San Justo $^{9}$ & 381 & 353 & 418 & 348 & 456 & 400 & 412 & 347 & 1.667 & 1.448 \\
\hline Marcos Juárez ${ }^{10}$ & 189 & 117 & 220 & 155 & 218 & 163 & 290 & 155 & 917 & 590 \\
\hline Unión $^{11}$ & 281 & 200 & 329 & 178 & 283 & 158 & 290 & 98 & 1.183 & 634 \\
\hline Tercero Abajo $^{12}$ & 247 & 197 & 276 & 215 & 226 & 260 & 268 & 268 & 1.017 & 940 \\
\hline Río Cuarto $^{13}$ & 335 & 230 & 362 & 245 & 425 & 295 & 454 & 308 & 1.576 & 1.078 \\
\hline Juárez Celman ${ }^{14}$ & 132 & 133 & 206 & 185 & 256 & 159 & 269 & 172 & 863 & 649 \\
\hline Gral. Roca $^{15}$ & 87 & - & 107 & - & 99 & - & 116 & - & 409 & \\
\hline
\end{tabular}

Fuentes: ASV. Fondo Nunciatura Argentina, Libro 31. Matrimonio Religioso, fs.55, 85-89; AAC. Libro 28, Movimiento Religioso de los Curatos, 1906-1910. Curato de Soto, Libro 1 de Matrimonios y Libro 2 de Matrimonios, 1900-1905, f.2; San Agustín, Matrimonios, Libro 16, 1905-1911, f. 29-100; La Cruz, Matrimonios, Libro 2, 1890-1908, f.173-188 y Libro 3, 1908-1920, f.148; San Carlos Minas, Matrimonios, Libro 4, 1905-1932, fs.16-88; Bell Ville, Matrimonios, Libro 8, 1905-1909, fs.194-434 y Libro 9, 1910-1918, fs.48-98.

Notas: ${ }^{1}$ Comprende los curatos de Colón y Caroya

${ }^{2}$ Comprende los curatos de Remedios, Santa Rosa y Chalacea. Este último no envía datos

${ }^{3}$ Comprende los curatos de Villa del Rosario, Río Segundo y Parte de Oliva

${ }^{4}$ Comprende los curatos de San Agustín y Río de los Sauces. Sin datos sobre matrimonios religiosos en estas planillas. Se extrajeron los datos de Libros de Matrimonios

${ }^{5}$ Comprende los curatos de San Pedro y Tránsito

${ }^{6}$ Sin datos sobre matrimonios religiosos en estas planillas. Se extrajeron los datos del Libro de Matrimonios

${ }^{7}$ Comprende los curatos de Cruz del Eje y Soto. Este último no envía los datos sobre matrimonios religiosos.

Tomamos los datos de los Libros de Matrimonios ํ2 (1900-1905) y N³ (1905-1912)

${ }^{8}$ Comprende los curatos de Ischilín (Deán Funes) y Quilino no envía datos. Sólo pudimos acceder a los matrimonios de 1907 (Planillas 3\% seminario) 49 matrimonios

${ }^{9}$ Comprende los curatos de San Justo, Arroyito, San Francisco, Morteros y Freyre. Este último no envía datos sobre matrimonios religiosos y San Justo manda la cifra total por los cuatro años

${ }^{10}$ Comprende los curatos de Cruz Alta y La Asunción

${ }^{11}$ No se envían datos sobre los matrimonios religiosos. Se tomaron del Libro de Matrimonios

${ }^{12}$ Comprende los curatos de Villanueva, Villa María y parte de Oliva

${ }^{13}$ Comprende los curatos de Río Cuarto, Sampacho y parte de Laboulaye

${ }^{14}$ Comprende los curatos de La Carlota y Laboulaye, que también ocupa parte de Gral. Roca y Río Cuarto

${ }^{15}$ El curato Cañada Verde (Natividad) ocupa parte del departamento de Gral. Roca 
En los departamentos de vieja colonización, Santa María, San Alberto, Pocho, Tulumba, Totoral, Río Seco, Sobremonte, Punilla, se observa una paridad entre el vínculo civil y el religioso, además las respuestas a los cuestionarios de las visitas canónicas confirman los datos de la Tabla. El cura de Minas afirmaba en 1917 que "no hay matrimonios con sólo vínculo civil"69 y el cura de San Agustín (Calamuchita) advertía que "Hay pocas uniones civiles, que se procuran regularizar". ${ }^{70}$ En cuanto al curato de San Javier, el cura señalaba que en 1926 había tres casos de concubinato en la parroquia y que esperaba regularizar. ${ }^{71}$ Según estos indicadores, la sociedad seguía manteniendo una fuerte impronta católica y el avance secularizador del estado no incidía con fuerza en las prácticas religiosas de la población.

El Gráfico 22 muestra de manera comparativa los datos de los matrimonios civiles y religiosos entre 1907 y 1910. Aclaramos que del departamento de Ischilín (Deán Funes) se obtuvieron los datos completos del curato de Deán Funes, pero no de Quilino, en este caso sólo accedimos al año 1907. Este vacío intentamos suplirlo con algunas apreciaciones cualitativas de los curas respectivos.

\section{Gráfico 22}

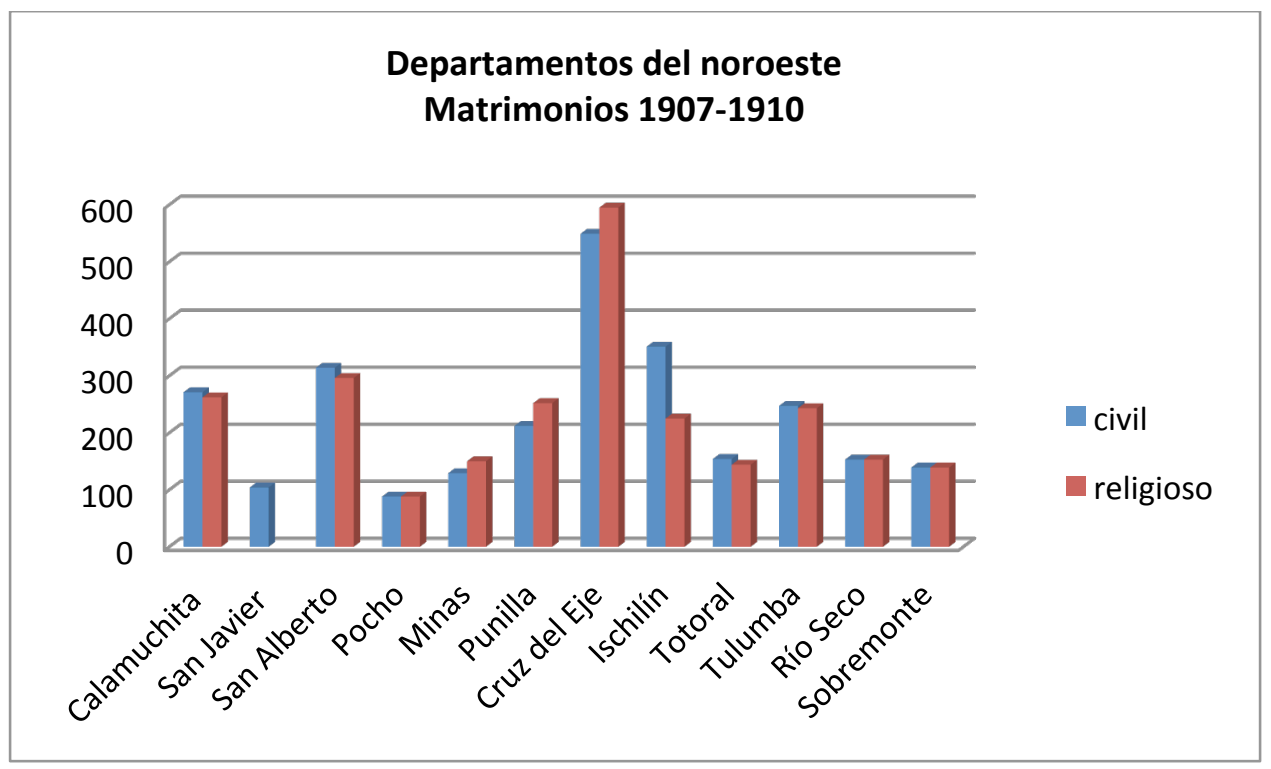

\footnotetext{
${ }^{69}$ AAC. Caja Parroquias: Minas. Cuestionario de la Visita, 13/04/1917, respuesta a la pregunta $\mathrm{n}^{\circ} 40$.

${ }^{70}$ AAC. Caja Parroquias: San Agustín. Cuestionario de la Visita, 02/02/1914, respuesta a la pregunta $n^{\circ} 40$, f.272.v.

${ }^{71}$ AAC. Cajas Parroquias: San Javier. Cuestionario de la Visita, 20/08/1926, f.95.
} 
En cuanto a los departamentos colonizadores de la región del este y del sur, el relevamiento de datos cualitativos indica una preocupación por los curas respecto de la cantidad de uniones civiles. La pregunta $n^{\circ} 40$ del cuestionario de las visitas canónicas señala que: ¿Para la celebración del matrimonio, se usa la fórmula aprobada por los Obispos reunidos en Salta? ¿Se procura que los novios se acerquen a los Santos Sacramentos? ¿Hay en la parroquia personas unidas por el solo vínculo civil? ¿Qué se hace para que regularicen dicha situación?

Las respuestas de los curatos del departamento de San Justo reflejan una percepción de que había mucha gente que no se casaba por la iglesia. El cura de San Francisco responde que "las uniones ilícitas son la plaga de estos pueblos", 72 diez años después, responde que "hay por desgracia no pocas personas unidas solamente por lo civil y aunque el Párroco hace cuánto le sugiere su celo y renuncia a sus derechos estas aumentan en Balnearia y La Francia". ${ }^{73}$ El cura de Morteros señala que en su curato "hay personas unidas solo por el vínculo civil y otras sin este también, procurándose regularizar su unión mediante visitas de personas piadosas". ${ }^{74}$ El de San Justo responde "Afirmativamente, se procura que se confiesen y comulguen y lo hacen siempre. Pocas parejas solo tres o cinco tengo noticias que viven amancebados. Procuro que ningún feligrés mío este casado solo civilmente". ${ }^{75} \mathrm{El}$ cura de Arroyito informa que las malas uniones son pocas y se regularizan frecuentemente por diferentes medios, en especial por la acción de las Vicentinas. ${ }^{76}$ El de Las Varillas señala en 1912 que "varios matrimonios unidos solo por el vínculo civil, aunque se toman muchos empeños para que se casen por la iglesia", doce años después, el cura especifica que el número de matrimonios civiles alcanza a un 5\% de la población del curato, si la población era de unas 12.000 personas, hablamos de 600 personas, aproximadamente. ${ }^{77}$

Las respuestas de los curas de los departamentos de Tercero Abajo, Unión y Marcos Juárez, dan cuenta de mayores dificultades respecto de la administración del matrimonio

\footnotetext{
${ }^{72}$ AAC. Leg. 49. San Francisco. Cuestionario de la Visita Canónica, 05/10/1907, respuesta a pregunta $n^{\circ} 40$.

73 AAC. Parroquias: Villa Concepción del Tío (San Justo). Cuestionario de la Visita Canónica, 23/04/1917, respuesta a pregunta $n^{\circ} 40$.

${ }_{75}$ AAC. Leg. 47. Morteros. Cuestionario de la Visita Canónica, 25/08/1915, respuesta a pregunta $n^{\circ} 40$.

75 AAC. Cajas Parroquias: Villa Concepción del Tío, f.124-127. Cuestionario de la Visita Canónica, $18 / 09 / 1913$, respuesta a pregunta $n^{\circ} 40$.

${ }^{76}$ AAC. Cajas Parroquias: Arroyito. Cuestionario de la Visita Canónica, 14/06/1920, respuesta a pregunta ${ }^{\circ}$ 40.

77 AAC. Cajas Parroquias: Las Varillas. Cuestionario de la Visita Canónica, 01/09/1912 y 05/09/1924, respuesta a pregunta $n^{\circ} 40$.
} 
religioso en sus curatos. El cura de Leones sostiene "de todas las maneras posibles se procura que los novios se acerquen a los santos sacramentos. Desgraciadamente hay varios que se resisten bajo un pretexto u otro". ${ }^{78}$ El de Cruz Alta informaba que "hay muchas personas casadas solo civilmente y aún sin esta unión".79

Las misiones realizadas en los curatos también fueron una ocasión para regularizar matrimonios. El impreso que se difundió con motivo de una misión en la capilla de Cosme señalaba que la Santa Misión era una oportunidad para que se arreglaran muchos matrimonios que siempre suele haber en malas condiciones. "A tal fin no solo invitamos a casarse a los que estén en esas condiciones, sino que también pedimos a las personas de buena voluntad que animen y ayuden a los que conozcan que necesitan este sacramento, a fin de que nadie quede así en toda la pedanía, después de la Misión”. ${ }^{80}$ El Gráfico 21 muestra la evolución de los matrimonios civiles y religiosos en la región de los departamentos colonizadores entre 1907 y 1910.

\section{Gráfico 23}

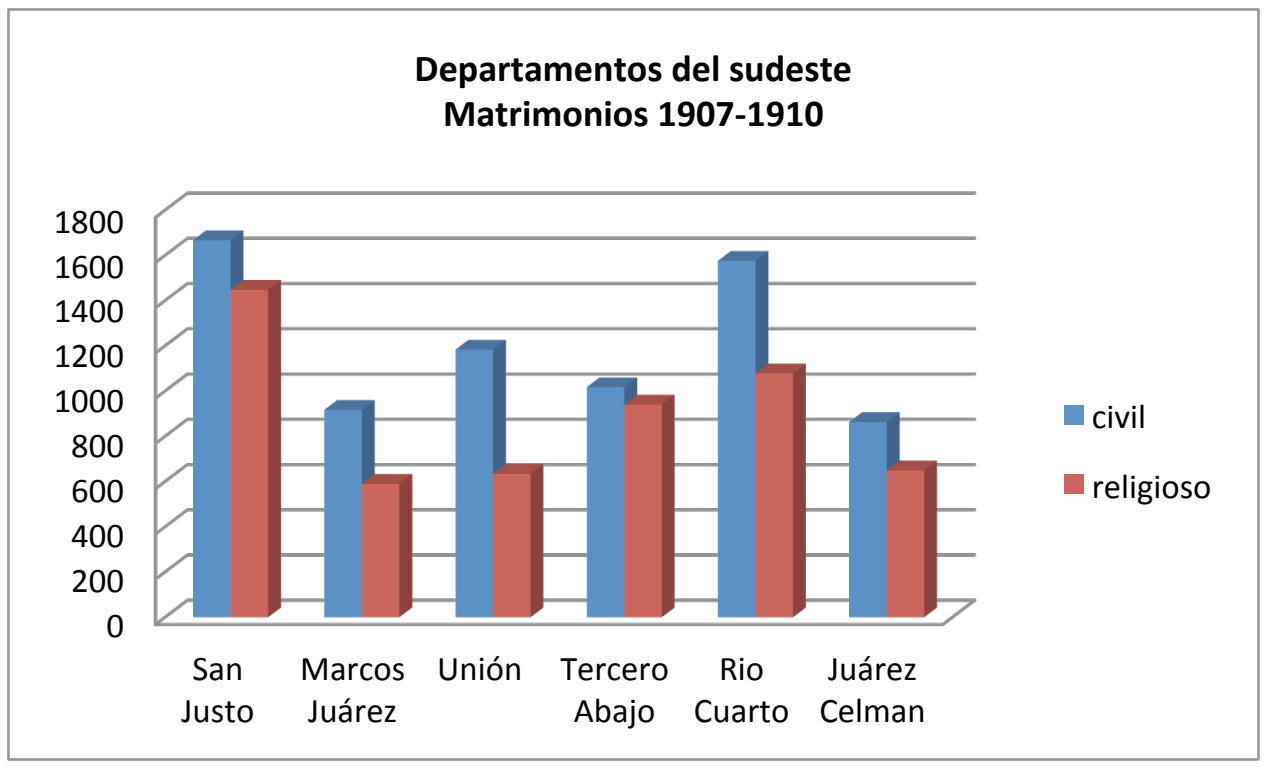

\footnotetext{
${ }^{78}$ AAC. Cajas Parroquias: Leones. Cuestionario de la Visita Canónica, 17/08/1915, respuesta a pregunta $n^{\circ}$ 40 .

${ }^{79}$ AAC. Cajas Parroquias: Cruz Alta. Cuestionario de la Visita Canónica, 24/10/1907, respuesta a pregunta ${ }^{\circ}$ 40.

${ }^{80}$ AAC. Cajas Parroquias: Alta Gracia, f.40.
} 
En el cuestionario de la visita canónica al curato de Bell Ville, departamento de Unión, el cura contesta que "desgraciadamente hay no pocas uniones civiles". ${ }^{81}$ En 1918, el cura de la parroquia de San Antonio de Litín, ubicada al norte de dicho departamento, publicaba una hojita con avisos para sus feligreses, en la cual advertía que "vivir unidos solo civilmente es un pecado mortal. El cristiano debe casarse por la iglesia porque el matrimonio es un sacramento. Se advierte que las personas casadas solo civilmente no pueden ser padrinos ni madrinas de bautismo". 82

Cabe señalar que este largo conflicto relativo a la secularización del matrimonio y de la muerte no supuso necesariamente la pérdida de la religión católica en la sociedad, pues si bien con el gobierno liberal el catolicismo pasaba a ser una opción más, continuó siendo una opción que acompañó la vida y la muerte de gran parte de la población de la campaña cordobesa.

La secularización de los cementerios fue sin duda un paso en el proceso de laicización del estado, pero no necesariamente en el proceso de secularización de la sociedad. La secularización, señala Sol Serrano, "hay que comprenderla dentro de un fenómeno más estructural, que es el paso de una sociedad en que la solidaridad de los vivos y los muertos consiste en que cada uno salve su alma, y que ese paso tan incierto por el purgatorio sea lo más corto posible, a una sociedad donde esos vínculos se concentran en la inserción en esta vida para incorporarse a la sociedad. La sociedad no es menos religiosa, lo que cambia son las prácticas en este contexto. No es lo mismo pertenecer a una cofradía con indulgencias que formar una escuela técnica para niños vulnerables, con sus diferencias en ambos casos, la sociedad actuó por un sentido religioso y lo practicaron en distinta forma durante el siglo XIX". ${ }^{83}$

\footnotetext{
${ }^{81}$ AAC. Cajas Parroquias: Bell Ville. Cuestionario de la Visita Canónica, 10/08/1906 y 21/11/1914, respuesta a pregunta $\mathrm{n}^{\circ} 40$.

${ }^{82}$ AAC. Cajas Parroquias: San Antonio de Litín, f.42.

${ }^{83}$ Entrevista a Sol Serrano, Ricardo Solis para "El Mercurio".
} 


\section{CAPITULO 14}

\section{El lugar del clero parroquial:}

entre la secularización de la política y la secularización de la sociedad

\section{La política un campo de disputa. Obispos, clero parroquial y feligresías}

\subsection{Los curas y los procesos revolucionarios de la década de 1870}

La política también fue un campo que se secularizó. Los obispos del período procuraron distanciar al clero de las actividades que no fueran estrictamente pastorales. Las denuncias sobre la participación del clero en política son tempranas. A partir de la década de 1860 existían en Córdoba dos partidos políticos, el Nacionalista, que lideró la organización nacional entre 1862 y 1868 bajo el liderazgo de Bartolomé Mitre; y el Autonomista, que defendía las prerrogativas provinciales frente al gobierno nacional. Liliana Chaves (1997: 144-145) señala que la política cordobesa de la década de 1870 era facciosa y tenía prácticas clientelares. Entre 1874 y 1877 se conformó "una alianza inestable", que llevó al grupo liberal al gobierno. Esta estaba compuesta, según la autora, por tres facciones o grupos, uno vinculado al Partido Nacionalista, cercanos a Nicolás Avellaneda y representados por la figura de Clímaco de la Peña; otro era un sector del Autonomismo liderado por Filemón Posse y el último era el grupo Autonomista organizado en torno de la Figuera de Antonio del Viso. Algunos curas también participaron activamente en diversos sectores políticos.

En 1872, los vecinos del Chañar elevaron una serie de denuncias contra el cura Fierro. ${ }^{1}$

Si el presbítero Fierro no se ocupa de los deveres de su ministerio, en cambio se ocupa y demasiado de la política que tiene siempre divididos en partidos a los vecinos de nuestra villa, pero no se ocupa como su SS podría suponerse para templar las fracciones políticas sino por el contrario poniéndose al frente de uno de los vandos con su espíritu joven y fogoso, para atizar la lucha y causar disturvios, como lo hemos visto hacer últimamente, en la elección municipal haciéndose nombrar presidente de la corporación y como le vimos también cuando la revolución de Santiago comunicando partes falsos bajo el seudónimo de (Grio?) a los diarios de esta capital y como finalmente lo hemos visto en las mesas electorales cuando la elección del actual gobernador presentándose a la mesa de Caminiaga, acaudillando un partido pretendiendo enredar la elección y llegar hasta el acceso de pretender arrebatar las actas de la elección practicada en aquel punto. No es su SS una mezquina pacion una enemistad personal con el presbítero Fierro lo que nos impulsa a dar este paso, los nombres que van al pie de esta solicitud y el número de ellos son una garantía de lo

\footnotetext{
${ }^{1}$ Para más datos sobre su vida, véase KASSLATTER (1999).
} 
contrario, no es tampoco ya que hablamos de partidos políticos, la pacion de partido lo que nos mueve, los que firmamos pertenecemos a diferentes vandos, es un deber de conciencia, es el interés que nos inspira la educación religiosa de nuestros hijos y de las masas de nuestro departamento lo que nos mueve a presentarnos ante VSS. ${ }^{2}$

El provisor y viario general vio conveniente "hacerle bajar al Pbro Fierro, i aconsejarle que en vista de la denuncia hecha contra él, de las personas más notables de aquella localidad, le convendría hacer su renuncia, puesto que sería imposible con estos obstáculos prestar el servicio que con buen fruto debe desempeñar un Cura coadyuvado por sus feligreses, mientras que su salida de este modo, sería más honrosa i sin escándalo". ${ }^{3}$ Sin embargo, el cura no renunció. Se le inició un juico civil y eclesiástico por su actuación en las elecciones a gobernador del año 1872. Las denuncias se hicieron públicas en la prensa y el 21 de julio de 1873 el diario "El Progreso" publicó algunos extractos del juicio, declaraciones testimoniales y el memorándum del jurado que se presentó el día de la audiencia, donde se expusieron siete hechos probados de dicha participación. En 1873, el periódico informó, a lo largo del año, sobre la cuestión del cura Fierro y su vinculación con las actividades políticas en el departamento del Chañar. "Todos acusan al cura Fierro y dicen que es él quien dirige la política” (EP, 26/11/1873). En vista de ello, el gobierno provincial solicitó al obispo la destitución del cura para garantizar la paz y la tranquilidad pública del departamento.

Eleodoro Fierro era cordobés, militaba en las filas del Partido Autonomista, liderado a nivel nacional por Adolfo Alsina y opuesto a las fuerzas de Mitre. En su carácter de cura influyente en la sociedad, apoyó una invasión armada organizada por José Antonio Urquizo residente en San Francisco del Chañar- a Sumampa, provincia de Santiago del Estero, contra el gobernador nacionalista de dicha provincia, Luis Farías. Por este motivo se le inició un juicio de sedición. Farías solicitó al gobernador de Córdoba, en ese momento Juan Antonio Álvarez, que hiciera "alejar de aquel departamento fronterizo al Cura Fierro [...] informando a su vez que el Cura se había trasladado al departamento a prestar por sí mismo los elementos para la realización de planes anárquicos" (Kasslatter, 1999: 25).

\footnotetext{
${ }^{2}$ AAC. Leg. 35. Juicios Eclesiásticos, 1871-1905, TVIII. Contra el cura Eleodoro Fierro de Chañar (Julio 26 de 1872).

${ }^{3}$ AAC. Leg. 35. Juicios Eclesiásticos, 1871-1905, TVIII. Contra el cura Eleodoro Fierro de Chañar (Julio 26 de 1872).

${ }^{4}$ El Progreso, 02/01/1873; 19/02/1873; 01/03/1873; 16/03/1873; 18/05/1873; 20/05/1873; 21/07/1873; 22/07/1873; 27/07/1873; 22/10/1873;26/10/1873; 31/10/1873; 09/11/1873; 26/11/1873.
} 
En las elecciones de abril de 1874, que convalidaron la presidencia de Nicolás Avellaneda a nivel nacional, el cura Fierro fue elector provincial por el departamento de Sobremonte. Bartolomé Mitre, opositor a la candidatura de Avellaneda, no aceptó la derrota electoral y optó por la revolución armada. En el interior, contaba con el apoyo de San Juan y Santiago del Estero. 5

Su vinculación con la política le trajo serias desavenencias con la jerarquía eclesiástica. Renunció al curato de Chañar y, en enero de 1879, se lo nombró rector interino de la Catedral. Nombramiento que generó algunas controversias periodísticas que enfrentaba al cura Fierro con algunos sacerdotes redactores del diario "El Eco". 6 El cura Fierro inició una demanda por agravios en la curia contra Tagle y Falorni, sacerdotes redactores de "El Eco". 7

Finalmente, el 19 de septiembre de 1879 el Provisor y Gobernador del Obispado, Uladislao Castellano, le solicitó la renuncia como cura rector menos antiguo de la catedral, aduciendo "razones que obran en su conciencia". El cura Fierro publicó la nota en "El Progreso" y respondió a la misma con una carta dirigida al secretario del obispado en la que protestaba por la medida adoptada, considerándola falta de fundamento, infamatoria contra su persona y atentatoria contra su subsistencia. ${ }^{8}$ Según el diario, la resolución tomada contra el cura no era compartida por el deán del Cabildo, Gaspar Martiarena, el Arce deán, Dr. Nuñez Bravo y otros miembros del cabildo y del clero. ${ }^{9}$ La decisión del gobernador y provisor dividió las aguas en la sociedad cordobesa y en el clero, manifestándose unos y otros a favor o en contra de tal decisión. En las páginas de la prensa, a lo largo de los meses entre septiembre y diciembre, las intervenciones, las notas y las cartas de detractores y las respuestas del cura Fierro o de alguno de sus defensores fueron reiteradas.

Algunos clérigos firmaron un manifiesto en el que aprobaban la conducta del provisor de destituir al cura rector de la catedral por motivos de conciencia, y muchos otros no firmaron dicha declaración, lo que les valió ser tildados por "El Eco" de rebeldes a la autoridad. Entre esos "rebeldes" se encontraba el futuro obispo de Córdoba, el franciscano Juan C. Tissera.

\footnotetext{
${ }^{5}$ Para conocer el desarrollo de la revolución de 1874 en Córdoba, consúltese DAGHERO (2014).

${ }^{6}$ Cfr. El Progreso, 21/01/1879. Carta del cura Fierro defendiéndose de las acusaciones del Cgo. Vélez y El Eco. El Progreso, 26/01/1879. Tercera carta del cura Fierro. El Progreso, 28/01/1879. Demanda del cura Fierro contra el Cgo. Vélez ante el Provisor del Obispado. El Progreso, 29/01/1879. Cuarta carta del cura Fierro. El Progreso, 02/02/1879. Demanda del cura Fierro contra los presbíteros Luis Tagle y Fernando Falorni, por calumnias e injurias.

${ }^{7}$ AAC. Leg. 35. Juicios Eclesiásticos, 1871-1905, TVIII.

${ }^{8}$ El Progreso, 30/09/1879.

${ }^{9}$ El Progreso, 04/10/1879.
} 
Este episodio muestra claramente las divisiones existentes en el seno del clero secular cordobés, divididos por la militancia en ambos partidos, autonomista y nacionalista.

\subsection{El caso del cura Pablo Lynch}

Pero el cura Fierro no fue el único liberal autonomista. En apoyo de la candidatura de Avellaneda, encontramos al Pbro. Pablo Lynch, a quien se lo acusó de haber participado en la ciudad de La Rioja en los sucesos revolucionarios de 1874, donde repartió medallas y escapularios a los revolucionarios y amenazó al gobernador de que si no renunciaba estallaría la revolución. Por este motivo se le inició una investigación sumaria. El fiscal eclesiástico elevó un informe al provisor y gobernador del obispado en el que señalaba que a su regreso de la campaña:

Se ha impuesto de varios documentos publicados en el mes ppdo. en los diarios de esta ciudad, procedentes de personas respetables de la Provincia de la Rioja y en todos ellos ha visto con gran sentimiento, se atribuyen al Pbro. Pablo Lynch, clérigo domiciliado de esta diócesis, una participación directa e inmediata en los sangrientos sucesos que tuvieron lugar el veinte y nueve de enero del corriente año, en dicha provincia; y como hechos de esta naturaleza a ser ciertos, son directamente opuestos a la misión divina del sacerdote católico, y como tal severamente prohibidos y penados por los sagrados cánones, es altamente conveniente, no solo a los intereses de la Religión, sino también al buen nombre del clero todo de esta diócesis, que sean esclarecidos a la mayor brevedad posible. En cumplimiento de los deberes de mi oficio, vengo a hacer de los mencionados hechos, la más formal denuncia y pedir ordene al ordinario de la Rioja levantar un sumario. ${ }^{10}$

Se levantó un sumario, pero los testigos no aportaron suficientes datos, según declaró ante el vicario foráneo de La Rioja, Lorenzo Torres, vecino de la ciudad. Cuando se le preguntó si "sabe que el mencionado Linch haya tenido parte en el movimiento revolucionario que estayó en esta ciudad el día veinte y nueve de enero del corriente año, responde que no sabe, que solo si sabía del interés que este sacerdote tenía era de pacificar los partidos políticos que se disputaban a fin de sofocar el movimiento que se temió por uno u otro partido". La siguiente pregunta apuntó a averiguar si la participación que se dice tuvo Lynch en el movimiento revolucionario había sido pública en el pueblo, el testigo respondió que no sabía, que sólo sabía que el gobierno de la provincia lo buscó después del movimiento y no lo encontró. La siguiente pregunta hizo referencia a si tenía conocimiento del lugar donde se encontraba el

\footnotetext{
${ }^{10}$ AAC. Leg. 35, Juicios Eclesiásticos, 1871-1905, TVIII. Nota del 30/07/1872.
} 
cura Lynch en la noche de la revolución, el testigo contestó que no sabía, que sólo sabía que paraba en el convento de la Merced. El siguiente testigo fue Lorenzo Antonio Blanco, también vecino de la ciudad. Declaró que “oyó decir de pública voz que el expresado Linch había tomado parte en el movimiento revolucionario que estayó en esta ciudad el día veinte y nueve de enero [...], pero que no le consta". Ante la siguiente pregunta, señaló que no le constaba que hubiese tomado parte en la revolución, y, ante la última, "oyó decir que la noche de la Revolución se halló el clérigo Linch en Casa de Dña Genobeba Herrera, madre del Coronel Barros”. Luego de estos testimonios, se remitió el sumario a la curia diocesana. El fiscal lo consideró incompleto y defectuoso y, por ello, solicitó al vicario foráneo la ampliación del mismo. Éste respondió que "la política que ha habido en esta y que hasta hoy hay síntomas de ella, me hacen abstenerme como me abstengo de encargarme nuevamente de la reforma del Sumario. Quiero, Sor. tranquilidad, porque encargarme de esto, puede traerme más tarde un compromiso que turbe mi tranquilidad". Se excusa ante el vicario y se comisiona al cura Francisco Cuesta para que continúe la indagatoria.

El cura llamó a nuevos testigos, entre los que se encontraba un tal Natal Luna. Ante la indagatoria, respondió que conocía al Pbro. Lynch personalmente porque lo había visto en el mes de enero en la ciudad. Que sabía y le constaba, por haberlo escuchado del mismo Lynch, que venía mandado por el Dr. Avellaneda a reconciliar al Dr. Gordillo con el coronel Olegario Gordillo, en la desavenencia en la que se estaba últimamente sobre la conveniencia de candidatos para presidente de la República. También le constaba que Lynch, mientras estuvo en La Rioja, se ocupó de frecuentar el Club Avellanedista, donde entusiasmaba a las masas con discursos en favor de ese partido, para cuyo objeto, Lynch, después de asegurar que las balas no afectarían a quienes llevaran los objetos que él les daría, procedió a repartir dinero, medallas y rosarios y esto lo sabe por habérselo dicho uno de los cabecillas de dicho club, Víctor Herrera, con quien él tenía bastante relación. Además, testificó que sabía y le constaba que salió ocultamente de la ciudad con Ramón Bravo después del 29 de enero, disfrazado con un traje de gaucho, con la cara especialmente cubierta, y que esto lo sabía por José Agüero, quien lo encontró en el camino. Finalmente, el testigo añadió que Lynch, por orden de Torres, ofreció al Gobernador Gordillo la cantidad de quinientas onzas de oro con la condición de que el gobernador renunciara, caso contrario estallaría la revolución, la misma que tuvo lugar en la noche del mismo día. 
A continuación se le tomó declaración al guardián del convento de San Francisco, Fray Gerardo Molina, quien contestó que conoció a Lynch hace algunos años atrás en Córdoba, que sabía que había estado en la ciudad en enero, que sabía también, por un compañero de viaje de Lynch llamado Loria, que había venido a la ciudad a trabajar en los asuntos electorales. Que se hospedó en el convento de La Merced y que allí tuvo reuniones políticas con los cabecillas de los partidos electorales, lo mismo que en casa del coronel Gordillo, y que Lynch había repartido medallas y rosarios a los soldados y que salió a escondidas de La Rioja después de haber estallado la revolución.

El siguiente testigo, Jacinto Rincón, conocía a Lynch por haber asistido a algunas pláticas suyas en el convento de La Merced, confirmaba gran parte de las respuestas que dieron los otros testigos mencionados más arriba y añadía que había oído a los partidarios de MitreAlsina que Lynch había venido a la ciudad y se ocupaba especialmente de asuntos políticos. Confirmó que se alojó en el convento de La Merced y que allí había recibido a muchos sujetos que se ocupaban de las elecciones.

Otro testigo, Eliseo Moreno, testificó de forma similar, agregando que sabía que Lynch había salido de la ciudad hacia el Chañar oculto, lugar donde se batieron las fuerzas del coronel Gordillo y del gobernador.

Continuó el Prior del Convento de Santo Domingo, Fray Laurencio Torres, cuyas respuestas fueron muy similares a las de los anteriores, agregando que había oído que había tenido reuniones en el convento de La Merced con la Junta que se llama -populacho. Siguieron pasando más testigos, entre ellos, el Ministro de Gobierno, Nicolás Carrizo, quien afirmó que conocía personalmente a Lynch, que le constaba que estuvo en la ciudad de La Rioja en el mes de enero, que él mismo le dijo que "no trajo otro objeto que armonizar el partido electoral, que entonces se encontraba en desacuerdo con el gobernador de la Provincia”. Que fue a visitar a Lynch al convento de La Merced y que no vio ninguna reunión de juntas que se ocuparan de cuestiones electorales, que había oído que repartió rosarios y medallas e ignoraba con quién y cómo salió de la ciudad.

Terminada la información sumaria, el Pbro. Cuestas envió las declaraciones testimoniales: "Los datos recogidos y que remito a esa curia habrá lo suficiente para llegar al fin a que se haya propuesto el inicio de esta información, no es posible penetrar más al fondo de asunto a donde recién se encuentra despejada la incógnita, porque aquellas personas que han estado en 
los secretos mas íntimos, me dicen que estarán en el deber de ser consecuentes a los de su partido y por consiguiente se ven en el caso de negar su deposición".

El fiscal, Adolfo Luque consideró insuficiente la información suministrada y devolvió el sumario a La Rioja y solicitó un mayor esclarecimiento en los siguientes puntos: 1) Cuándo y en qué circunstancias se repartieron medallas a los revolucionarios, si esto lo realizó inmediatamente antes de estallar la revolución; 2) Si era verdad que el Sr. Lynch había amenazado al gobernador con que estallaría la revolución si no renunciaba, ofreciéndole, al mismo tiempo, dinero para ello; y 3) En qué casa se encontraba el Sr. Lynch en la noche de la revolución.

Recibido nuevamente el sumario, el vicario foráneo de La Rioja procedió a tomar declaración sobre esos tres puntos. La revolución ya había pasado, se había depuesto al gobernador y el bando de los revolucionarios ocupaba a la sazón el gobierno provincial. El primer testigo fue Aurelio Carreño, quien oyó decir que, en la tarde, pocas horas antes del estallido de la revolución, Lynch repartió medallas. Sobre la segunda cuestión, respondió que oyó decir, a una persona muy respetable, que Lynch se había presentado ante el gobernador para hacerle algunas propuestas, entre ellas, que se abstuviera de participar en las próximas elecciones y que si no podía mantenerse neutral renunciase al mando ofreciéndole para ello una cierta cantidad de pesos, por lo cual el gobernador se irritó y le contestó que debajo del hábito había un hombre como él y que tenía la autoridad suficiente como para quitarle la vida, Lynch, a su vez, no se quedó atrás y le contestó que a los dos o tres días podía verse colgado de un álamo. Respecto a la tercera cuestión, señaló que a las once de la noche lo vio en la casa del coronel Nicolás Barros, quien se encontraba de tertulia con varios señores respetables de la ciudad y a la madrugada estalló la revolución.

El declarante Nicolás Barros se abstuvo de dar detalles y señaló que el cura no había repartido medallas a los revolucionarios, simplemente que el 26 o 27 de enero había entregado en el Convento de La Merced algunos obsequios -medallas y rosarios- a las señoras que habían ido a escuchar sus pláticas. Que la misión del cura Lynch era reconciliar al gobernador con el coronel de las fuerzas nacionales, Olegario Garrido, que se había quedado en la ciudad a pedido del gobernador y que en ese ínterin estalló la revolución. A la segunda cuestión, respondió que no sabía ni le constaba que el cura Lynch hubiera hecho propuesta alguna al gobierno y mucho menos ninguna imposición. Que sabía y le constaba 
que en Buenos Aires se había abierto un sumario con el fin de esclarecer los hechos sucedidos en la provincia y en la que figuraban todas las personas que tuvieron participación en los hechos y que la Honorable Cámara Legislativa de la provincia había declarado, en una minuta, al ex-gobernador Pedro Gordillo que los hechos sangrientos que tuvieron lugar en la provincia él era el único culpable de ellos por su participación oficial que había puesto al servicio de uno de los bandos políticos. Respecto a la tercera cuestión, que a medida que avanzaba las horas del día, y viendo que podía acontecer un hecho de armas, el cura Lynch, como otras personas, buscó garantizar su vida y se refugió en la casa del declarante, donde pasó la noche. Que, en la madrugada, al escuchar tres tiros de armas, fue a tomar su puesto en el cuartel general, que queda a pocos metros de su casa, mientras que Lynch seguía durmiendo en su casa. Luego, pasó al convento de La Merced y el tres de febrero a la noche salió para Córdoba.

Luego fue el turno de Ramón Molina, jefe de policía, quien eximió al cura Lynch de toda participación activa en los hechos, efectivamente, lo vio repartiendo medallas y rosarios, aunque exhortando a la religión. Sobre la segunda cuestión, respondió que se habían formado dos comisiones, una de sacerdotes, en la que se encontraba Lynch y los padres dominicos, y otra de ciudadanos y miembros de la legislatura, de la cual formaba parte, con el objeto de mediar con el gobernador a fin de evitar los hechos de armas. Que el gobernador tomó a mal las pretensiones de dichas comisiones, que no surtieron efecto y que fracasaron en su intento de mediación. Ante la tercera pregunta, señaló que esa noche, él mismo se encontraba con Lynch y otros ciudadanos respetables en la casa del Sr. Barros, hasta las once de la noche, y que luego se retiró a dormir a su casa y en la madrugada lo sorprendieron las balas de fusilería en la plaza. Por último, dijo que, como vicepresidente del Comité Avellaneda, mantuvo muchas conferencias con Lynch, y otros señores, pero nunca se habló de revolución.

Luego testificó el Juez federal Mardoqueo Molina. Dijo haber oído que el padre Lynch había repartido medallas y rosarios a la gente del pueblo y que antes como ahora lo consideraba un acto de piedad o misión evangélica. Deslindó responsabilidades políticas por parte del cura y señaló que su misión era conciliar al ex gobernador con el coronel Gordillo, jefe de las fuerzas nacionales. Ante la tercera pregunta, respondió que pasó la noche en la casa del coronel Barros. Todos los testigos protegieron la figura del cura Lynch y justificaron 
su participación en los hechos, otorgándole un matiz evangélico y conciliador. Terminada la declaratoria de testigos, el expediente fue enviado a la curia diocesana.

El fiscal, luego de haber estudiado con "atención y prolijidad el sumario instruido", declaró que, a su juicio, estaba suficientemente constatado que el Pbro. Lynch se había excedido "en mucho, de la moderación prescripta a su estado por los Sagrados Cánones y mui especialmente por el Santo Concilio de Trento en las ses. 23 cap. $1^{\circ}$. Por tanto:

su conducta ha sido, como es natural universalmente censurada y gran parte de la prensa argentina le ha atribuido o supuesto complicado en la revolución que estalló en dicha ciudad durante su permanencia en ella. Hai pues en el sumario cargos mui graves contra el Sor Linch aunque es verdad que desvirtuados en parte por algunas otras declaraciones que son un tanto favorables. Tengo por consiguiente que el sumario hai merito bastante para tomar declaración al presente reo y seguidamente por todos los tramites de derecho. Sin embargo, también juzgo se podría adoptarse otro medio legal que conduciría a evitar el escándalo y la morosidad indispensable, a un juicio que versa sobre hechos acaecidos en esta provincia, y al mismo tiempo en esta última medida daría el resultado deseado que es evitar la repetición de actos de este género. Imponer al presunto reo, por vía de consecución unos ejercicios espirituales por quince días en una casa de religiosas, haciendo uso para eso su Sria. de la facultad que le concede el Concilio de Trento en la ses 24 cap. 10 de ref. ${ }^{11}$

Si bien el dictamen señalaba la conveniencia de evitar "el escándalo y morosidad de un juicio" y la "repetición de actos de este género", impone una sanción, a nuestro parecer bastante liviana, en relación al hecho denunciado. La sanción consistió únicamente en la realización de ejercicios espirituales por quince días. Finalmente, el sumario prescribió por falta de mérito. Es evidente que los tiempos políticos habían cambiado, sin duda la conciliación propuesta por Avellaneda también alcanzó a los hombres de iglesia. Este ejemplo es interesante para dar cuenta del grado de participación política que tuvieron algunos clérigos cordobeses. A tal punto, que la autoridad eclesiástica no logró morigerar la participación del clero en lo sucesos políticos de la diócesis.

\subsection{El caso del cura Luis Tagle}

Luis Tagle, cura de Quilino en 1876, tuvo una serie de denuncias por desempeñar actividades políticas. El Juez de Quilino, Ignacio Peña, elevó una nota al jefe político del departamento de Quilino, en la que advertía que, desde hacía un tiempo, la población de

\footnotetext{
${ }^{11}$ AAC. Leg. 35. Juicios Eclesiásticos, 1871-1905, TVIII.
} 
Quilino se encontraba en "un estado casi revolucionario por los trabajos políticos e incesantes del Cura de esta departamento Don Luis Tagle, de tal manera que no solamente va siendo imposible mantener el orden con los medios limitados que puede disponer un Juez, sino que mi seguridad está gravemente comprometida sino se toman medidas de otra naturaleza que impidan con energía y prontitud llegar a sus últimas consecuencias los sucesos que con tanto celo dirige el Presbítero Tagle". Las acusaciones remitían a pláticas en la capilla contra el juez. A partir de la denuncia, se dio inicio al sumario. A tal efecto, se presentaron varios testigos a declarar.

El primer testigo fue el Juez de Copacabana, Rosendo Ordoñez, vecino de la Pedanía de Copacabana, departamento de Ischilín, viudo, de veinticinco años de edad. Declaró que "le consta que el Pbro. Tagle se ocupaba activamente de la política diciéndole al declarante que habían de ganar las elecciones para Gobernador de la Provincia por la razón o por la fuerza a favor de la candidatura del Señor Dr. Posse, que él estaba dispuesto a gastar plata en este sentido. Que las mesas de Ischilín y de Quilino sino podía ganar las elecciones legalmente la interrumpiría por la fuerza. Que había oído que sabe que se le puso una multa de veinticinco pesos por haber calumniado de ladrón a Don Nicolás Cabreras".

El testigo siguiente fue Eufracio Valles, vecino de Quilino, peón, no sabía firmar, que dijo "que estando el declarante en misa en la Capilla, le oyó decir en la plática al cura en ese día que a ese que le llaman Juez don Ignacio Peña, no le debían respetar, porque por nuestra constitución ya había dejado de ser juez, y que al mismo tiempo decía que debíamos proteger a la comisión y sostenerla que era la que les hacia los bienes: que había oído decir en otras ocasiones había predicado el Cura contra el Comandante Don Francisco Monje, diciendo que era cuerpo de gente, cabeza de caballo y sable susio, también dice que ha oído que en otra platica predicada en Quilino insultó a una familia diciendo que era una pluma que vendía a su hija por dos reales y dijo quién era, nombrándola por el apodo que era conocida Cielito”.

La siguiente testigo fue Eloísa Agüero, mayor de edad, soltera y vecina de Quilino: "Dijo que estando ella en la plática a que se refiere la declaración le oyó decir al Cura en la plática que estaba toda la jente sublevada por ese que le dicen juez, que no era juez, sino uno que les quería hacer mal a ellos y al Cura y que era un estúpido, y que reputasen a la Comisión y que le ayudaba en todo lo que pudieran y que era la que les hacía bienes que estas fueron las 
únicas palabras que pudo entender, y que no decía más el Cura porque el local no lo permitía". 12

El Obispo Álvarez fue tajante respecto de este tema. Páginas arriba, señalábamos el contenido de la circular remitida a los párrocos, en la que advertía que, debido a los funestos resultados que ha dado siempre la intervención de los párrocos en política, "la voluntad del prelado es que se abstenga de toda participación en asuntos de esta naturaleza". ${ }^{13}$ Pero, como vemos, esta exhortación no tuvo los resultados esperados.

En 1877, el vice-gobernador Antonio del Viso asumió la gobernación de Córdoba, luego del fallecimiento de Clímaco de la Peña, quien desempeñaba la primera magistratura provincial. Mientras tanto, a nivel nacional, Roca preparaba su candidatura presidencial, de esta manera, el autonomismo logró, por primera vez, la gobernación de la mano de del Viso, y el nacionalismo, que había detentado el poder local hasta ese momento, en la figura de De la Peña, pasó a la oposición. Desde este nuevo lugar, se sumó a la política nacional de Conciliación de los partidos promulgada por Avellaneda con la esperanza de no perder el protagonismo político a nivel provincial. Dicha Conciliación aspiraba a lograr un acuerdo entre las dirigencias políticas del conjunto de las provincias respecto del candidato a la sucesión presidencial. Paula Alonso (2000: 12) afirma que con la llegada de del Viso al gobierno, la provincia quedó bajo la influencia directa de Roca, Juárez Celman y su círculo político, quienes tejieron un entramado tal de relaciones que no dio cabida a la oposición. Con excepción del conflicto religioso, que exacerbó las pasiones en la provincia, la lucha partidaria quedó prácticamente reducida a las tensiones dentro de las facciones del PAN.

En 1879, el diario "El Progreso", en el fragor de la discusión sobre la deposición del cura Fierro como rector de la catedral, denunció un plan, a su entender planificado, de la denominada "Cámara Oscura", destinado a neutralizar a los curas párrocos simpatizantes del partido autonomista liberal. El diario señalaba que "parece que hay un plan estudiado contra los sacerdotes de la ciudad y de la campaña que simpatizan con el grande y noble partido Autonomista [...] Las denuncias sin motivo y sin fundamento que se dirigen a la capital de los curas de campaña son todo un plan preconcebido”. A continuación, relataron las denuncias contra el Pbro. Francisco Pérez, cura de Sobremonte, por el sólo hecho de ser

\footnotetext{
${ }^{12}$ AAC. Leg. 35. Juicios Eclesiásticos, 1871-1905, TVIII. Juicio contra el cura de Quilino Luis Tagle, 1876.

${ }^{13}$ AAC, Notas, 1873-1876, f.32.
} 
presidente del Club Autonomista de la localidad; a la denuncia respondieron más de cincuenta vecinos, quienes elevaron un nota al obispado en la que advertían que los enemigos del cura "entre otras asquerosas calumnias aparece la cínica, torpe y audaz de que dicho señor Párroco con motivo de una manifestación en favor del general Roca que tuvo lugar en esta población el sábado 15 por la noche, había salido recorriendo las calles y la plaza de ésta a la cabeza de los manifestantes, ente los caballos y el chusmaje completamente ebrio dando gritos y mueras a varios particulares golpeando a las puertas de las casas en medio de los mayores insultos”. Decían que dicha denuncia estaba fundada en sin razones e injusticias y es "la más vil venganza, dado que dicho Sr. Cura se encontraba en su casa durante la manifestación". Advierten que sus enemigos deseaban la salida del cura y para lograrlo seguirán levantando falsos testimonios. ${ }^{14}$

En el mes de diciembre de 1879, el secretario del obispado le dirigió una nota al Pbro. Fierro, comunicándole, de parte del Provisor Castellano, que desde el día de la fecha, 13 de diciembre, y hasta nueva disposición "se le retiran a Ud. las facultades de celebrar, confesar y predicar". El fundamento de la medida fue "atraer a Ud. al buen camino", advirtiéndole que durante más de dos meses "ha venido publicando en la prensa, casi diariamente, artículos altamente injuriosos a la autoridad y a la conciencia del Prelado, con evidente tendencia de sublevar contra éste la opinión del clero y del pueblo [...]. La continuación de Ud. en el ejercicio del ministerio sin haber moderado su conducta es ya un escándalo para los verdaderos católicos y el prelado no puede mirar con indiferencia esto". ${ }^{15}$ El cura Fierro respondió a la nota solicitando se lo escuchara y se le iniciara juicio a fin de comprobar fehacientemente su culpabilidad si ésta existiese, "sería bueno que antes de llevarse a efecto una medida tan dura y estrema se me juzgara o se escucharan al menos mis descargos”. La respuesta no se hizo esperar, el provisor contestó escuetamente "debo desde ya manifestarle que no estoy dispuesto a entrar en juicio ni nada que se le parezca, el escándalo está dado y necesita una reparación [...]. La suspensión esta impuesta y queda en vigor hasta nueva disposición". ${ }^{16}$

En 1881, el Presidente de la República, Julio A. Roca, lo nombró, junto con el Pbro. José Galcerán y La Torre, canónigos de la Iglesia catedral de Córdoba. Tal designación

\footnotetext{
${ }^{14}$ El Progreso, 29/11/1879.

${ }^{15}$ El Progreso, 13/12/1879.

${ }^{16}$ El Progreso, 13/12/1879.
} 
provocó un entredicho con el Obispo diocesano recién electo, Fray Mamerto Esquiú, y gran repercusión en la prensa local (EP, 27/08/1881). Con el paso del tiempo, el cura Fierro se alejó del partido Autonomista, hasta convertirse en un férreo opositor. Se vinculó a Leandro N. Alem e Hipólito Irigoyen, fundó en Córdoba la Unión Cívica Radical y ostentó el cargo de presidente. Hombre enérgico y conspirador, participó en varias revueltas y revoluciones durante los años 1891 y 1905, por lo que en más de una ocasión fue llevado a la cárcel. En 1910, viajó a Europa y en agosto del año siguiente falleció en Turín.

\section{El clero y la política en los albores del siglo XX (1880-1905)}

Las elecciones de 1880 llevaban las fórmulas de Miguel Juárez Celman-Tristán Malbrán, por el partido Liberal Autonomista, y Cayetano Lozano-Felipe Díaz, por la oposición liberal nacionalista, como candidatos a la primera magistratura cordobesa. El clima pre-electoral era tenso y las dos facciones se disputaban en la prensa, en las calles y, como veremos, también en el púlpito.

Laura Cucchi (2007) describe muy bien el clima de época: "conforme avanza el año 79 y previendo que no sería tan fácil neutralizar a la oposición -para unos-, ni vencer al candidato oficial -para los otros-, ambos sectores del liberalismo empiezan a tomar otra serie de medidas para deslegitimarse mutuamente y ganar cada uno más adhesiones en la provincia. De allí en más todos los esfuerzos estarán dedicados a preparar las elecciones para gobernador y para las cámaras nacionales. Pero como se teme que la cuestión electoral no pueda resolverse de manera pacífica (ya por el fraude y la violencia que se espera por parte del gobierno; ya por los rumores de planes de alzamiento de la oposición en caso de verse derrotada), tanto autonomistas como nacionalistas se preparan también para un conflicto armado que empieza a parecer inevitable. El clima de tensión existente en la provincia se ve agravado al momento en que se establecen las mesas de inscripción, donde se producen una y otra vez enfrentamientos entre ambos sectores. El sector oficialista manifiesta que los disturbios tienen lugar en razón de la incapacidad de la oposición de presentar un número superior de potenciales votantes que el autonomismo. En virtud de esto, lo que se sospecha es que los nacionalistas declararán nula la elección, alegando que se les ha privado de la inscripción, y usarán eso de excusa para provocar un levantamiento armado". 
Otro sector importante del clero se encolumnaba en las filas del partido liberal nacionalista y, desde la redacción de "Pueblo Libre", López Cabanillas y Angulo escribían solicitando el apoyo a la candidatura de Lozano-Díaz. El diario "El Progreso" denunciaba que, en la Villa del Rosario, el cura Aquilino Ferreira predicaba desde el púlpito que "antes de la elección de electores para gobernador, que votasen por el elector Lozano, porque era religioso, y que no votasen por el Dr. Juárez, porque no sabía oír misa y era masón” (EP, 26/02/1880). A medida que las leyes secularizadoras se sancionaban, la oposición del clero al partido liberal se hacía cada vez más importante, aunque varios clérigos siguieron en las filas del PAN. En enero 1885, con motivo de la visita del Ministro Eduardo Wilde a la provincia, se hizo una recepción en su honor. El Obispo Tissera informó al Nuncio Mattera, a la sazón en Montevideo, sobre la cuestión y señalaba: "Ya sabrá S.E. Rvdma. que aquí estuvo el Mitro Wilde, que el pueblo ha observado una actitud digna con excepción de algunos, entre ellos el Prebendado Galcerán y el Cura Rector Tagle, quienes concurrieron a la recepción, si bien, según he sido informado después, no estuvieron presentes a los blasfemos discursos que se pronunciaron en esa noche: hecha esa excepción [...] ni una sola persona decente se arrimó al porteño cortejo". ${ }^{17}$

Al pensar quiénes fueron estos curas díscolos con la autoridad diocesana, que participaron activamente en la política local, descubrimos que varios de ellos no se habían formado en el seminario local, ya que en su mayoría eran sacerdotes religiosos secularizados. Eleodoro Fierro era oriundo de San Francisco del Chañar, su padre, Manuel Fierro, había sido propietario rural. Por otro lado, era sobrino de Juan de la Rosa Fierro, sacerdote mercedario ordenado en 1824. Eleodoro nació el 4 de julio de 1840, estudió en el seminario mercedario de Córdoba y el 19 de septiembre de 1862 fue ordenado de presbítero en la capilla privada del obispado por Ramírez de Arellano. ${ }^{18}$ El 30 de agosto de 1866 se lo nombró cura y vicario interino de San Francisco del Chañar. No tenemos la fecha de secularización, pero el expediente a órdenes tiene la carátula de secularización. ${ }^{19}$ En cuanto a Luis Tagle, también mercedario, recibió el presbiterado el 21 de mayo de 1864 de manos del Obispo Ramírez de Arellano. En 1868, se lo nombró cura y vicario de Ischilín, cargo que desempeñaría hasta

\footnotetext{
17 ASV. Nunciatura del Brasil, Libro 63, Fascículo 306, f.101. Carta de Mons. Tissera al Nuncio Luis Mattera, 05/01/1885.

${ }^{18}$ AAC. Títulos del Clero, 1854-1904, f.32.

${ }^{19}$ En el Leg. 24, TVII, 1845-1865, sólo está la caratula, no se encuentra en el expediente.
} 
1876, cuando presentó su renuncia. ${ }^{20}$ En 1885, ingresó al cabildo eclesiástico con el cargo de medio racionero, alcanzando, en 1904, el de Chantre. ${ }^{21}$ Luis Viaggio era italiano, sacerdote exclaustrado de la Orden de Santo Domingo, natural de Aderno, diócesis de Catascia. En 1884, se le concedió el prescripto de secularización perpetua y fue incardinado en Córdoba, el expediente señala que poseía suficiente patrimonio. ${ }^{22}$ En 1882, se lo nombró ayudante de Colonia Caroya, luego, en 1889, se desempeñó como cura y vicario interino del curato central de Río Segundo, en 1894, fue cura de Chalacea y en 1895, de Cruz Alta, donde, en 1896, firmó su última partida.

No tenemos demasiados datos sobre Pablo Lynch, sólo sabemos que era extranjero, que no pertenecía al clero secular diocesano, ya que no fue alumno del seminario conciliar ni recibió las órdenes en Córdoba. Entre 1857 y 1863, fue cura párroco de Anejos Sur (Alta Gracia); cuando renunció al curato, el obispo solicitó al guardián del Convento Franciscano otro padre para su reemplazo, explicando que la escasez de clero le impedía proveer ese beneficio con un secular. En 1869, se lo encuentra en la ciudad de Córdoba al frente de un colegio de mujeres, fundado por él y al que el obispo manda cerrar en 1869, bajo pena de suspensión in sacris. ${ }^{23}$ La nota del secretario del obispado fue contundente, "tengo orden del Obispo de decir a Ud. que en el término de tres días, disuelva Ud. ese colegio de mujeres, especie de monasterio que ud. ha formado". ${ }^{24} \mathrm{El}$ cura Lynch cumplió con lo indicado y así lo comunicó al obispado. En 1877, lo encontramos como cura sin oficio, residente en la ciudad. Todos estos datos nos hacen suponer que podría tratarse de un clérigo, exclaustrado o secularizado, si bien no tenemos certeza al respecto. Su vínculo con el convento de La Merced de la ciudad de La Rioja, en los acontecimientos de 1874, inducen a pensar que, al igual que el cura Fierro, podría ser ex mercedario.

La convulsionada vida política cordobesa de fines del siglo XIX, con las sucesivas revoluciones radicales, también tuvo su impacto en la vida de la campaña y dividió a los feligreses en apoyo o rechazo a los radicales o conservadores. Como vimos, el cura, actor de suma importancia en la campaña, no siempre se mantuvo ajeno o neutral a los conflictos

\footnotetext{
${ }^{20}$ AAC. Libro de Notas, 1876-1892, f.417/Leg. 51. Ischilín, s/f.

21 AAC. Leg. 38. Comunicaciones con el Gobierno Nacional, 1898-1910, TIV. Fecha del nombramiento, 08/06/1904, Decreto del Poder Ejecutivo, 14/06/1904.

${ }^{22}$ AAC. Nombramiento de Curas, 1777-1904, s/f.

${ }^{23}$ AAC. Juicios Eclesiásticos, 1870. Nota del cura informando que ha cumplido la orden, 09/11/1869.

${ }^{24}$ AAC. Leg. 35. Juicios Eclesiásticos, 1870, TVII. Nota del Obispado, 03/11/1869.
} 
políticos. El templo tenía un valor simbólico significativo y su atrio servía para la celebración de los actos electorales. En 1890, se celebró en Río Segundo un mitin radical. El cura era por entonces el Pbro. Luis Viaggio, italiano, fraile secularizado de la Orden de Santo Domingo. Ese día, el cura había salido para la atención de enfermos y a su regreso fue increpado por unos vecinos respecto a por qué había permitido a la población hacer replicar las campanas del templo a la hora del mitin. El cura respondió que "no podía oponerse a todo un pueblo que le pedía replicar la campana para esa manifestación". Esa noche fue profanada la iglesia,

forzaron la torre, se llevaron las campanas bendecidas y dejaron una inscripción en la pared de la sacristía que decía "mueran los frailes, las campanas no son para cosas políticas". ${ }^{25} \mathrm{La}$ feligresía de Río Segundo, como las de todos los curatos, estaba dividida políticamente, radicales y conservadores disputaban en todos los espacios posibles.

\section{El clero y la política y la norma vs la costumbre (1906-1925)}

A nivel normativo, el Concilio Plenario para América Latina [CPLA], dispuso la no participación del clero en contiendas políticas. ${ }^{26}$ El Concilio señala "absténgase el clero prudentemente de las contiendas políticas y civiles sobre las cuales sin salir de los límites de la ley y la doctrina cristiana, puede haber diversas opiniones; y no se mezcle en partidos políticos, no sea que nuestra santa Religión que debe ser superior a todos los intereses humanos y unir los ánimos de todos los ciudadanos, con el vínculo de la caridad y benevolencia, parezca que falta a su misión y se haga sospechoso su saludable ministerio. Absténganse, pues los sacerdotes de tratar o discutir estos asuntos en público, ya sea en el templo ya sea fuera del templo, ya sea y con más razón en el púlpito. Esto no ha de entenderse como si el sacerdote hubiera de guardar perpetuo silencio acerca de la gravísima obligación que tiene todo ciudadano de trabajar siempre y en todas partes, aún en los asuntos públicos, conforme al dictamen de su conciencia y ante Dios, por el mayor bien de la religión, de la Patria y del Estado, pero una vez declarada la obligación general, no favorezca el sacerdote a ningún partido más que a otro, salvo que uno de ellos sea abiertamente hostil a la religión". ${ }^{27}$

\footnotetext{
25 AAC. Cajas Parroquias: Río Segundo, f.100.Nota del 01/09/1890.

${ }^{26}$ Concilio Plenario para América Latina, Roma, Tipografía Vaticana, 1906. Título VIII, Cap. V, No 656.

${ }^{27}$ CPLA. Cit. VIII, Cap. V, No 656.
} 
El diocesano considera sabia y trascendente esa disposición del Concilio Plenario, y muy aplicable a los "momentos actuales en que estamos palpando de una manera harto dolorosa el menoscabo que sufre la Religión y la piedad de los fieles, así como el desprestigio en que va quedando la sotana por la imprudente intromisión de los clérigos en las contiendas cívicas" 28 .

El Sínodo diocesano de 1906 ratificó la decisión del Plenario, "aunque los sacerdotes deben dar el ejemplo depositando su voto en las urnas, sin embargo se les prohíbe en absoluto afiliarse a ningún partido político, mientras no exista el católico y mayor razón, acaudillar las masas en las contiendas políticas, como así mismo hacer desde el púlpito alusiones de esta índole". ${ }^{29}$

No obstante, a pesar de las anteriores disposiciones muchos sacerdotes no tuvieron reparo alguno en inmiscuirse en asuntos de este género, precisamente en el momento en que menos convenía tomar parte activa en nuestros partidos que se caracterizan por su prescindencia de programas católicos o anti religiosos. ${ }^{30}$

Finalmente, en el informe elevado con motivo de la visita ad limina de 1913, el obispo dejaba constancia, en latín, de que los clérigos no estaban implicados en cuestiones políticas de manera excesiva, sí existían dos canónigos que participaban en candidaturas políticas de dos partidos e, incluso, había dos clérigos senadores. ${ }^{31}$ Quizá esta primera afirmación sea demasiado positiva, pues la realidad da cuenta de varios clérigos que actuaban de manera explícita en política y otros tantos más implícitamente.

En 1913, los vecinos de Salsacate solicitaron al obispado la remoción del cura vicario Modesto Caubejans, advirtiendo que era "público y notorio que el cura toma participación activísima en política, al estremo de esteriorizar sus vehementes ideas partidistas desde el púlpito anatematizando e injuriando a los feligreses que no piensan como él. Estos procederes

\footnotetext{
${ }^{28}$ AAC. Fondo Zenón Bustos. Caja Nº 1 f.143.

${ }^{29}$ Sínodo diocesano celebrado en Córdoba, Resoluciones y Apéndices, Córdoba, Tip. "La Industrial”, 1907, Cap. II, $\mathrm{N}^{\mathrm{o}} 17$.

30 AAC. Fondo Zenón Bustos. Obispo. Carpeta $\mathrm{N}^{\circ} 1$, f.143. Prescripciones canónicas vigentes sobre la intromisión de los clérigos en las contiendas políticas y La Voz del Interior, 27/11/1915. Transcribe el auto del 15 de noviembre.

31 ASV. Congregaciones Concistoriales, Relaciones de las Diócesis, No 260, p. 48. "Ex clero nemoinmo dicerebus politicis implicatur. Sunttamen duo canonicis un factionibus politicis favent. Sun tetiam senatores. Ignoraturan de anima bene provideant. Qua erit Episcopus quid agendum in casu? El clero no está excesivamente enredado en cuestiones políticas. Sin embargo hay dos canónigos favorecen a dos partidos políticos, son ellos senadores, ignorantes para cuidar bien de su alma. Que debe hacer el Obispo en estos casos?
} 
políticos del cura son bien conocidos en todo el pueblo de Salsacate y lleva [...] sus enconos políticos hasta el mismo seno de la familia, donde esparce la cizaña de la discordia destruyendo la paz y la concordia [...]. Los compromiso políticos que mantiene lo distraen de sus altos y delicados deberes espirituales al estremo de abandonarlos". ${ }^{32}$

El mismo año, se denuncia, ante la nunciatura, al canónigo Luis Leal, ente otras acusaciones, se encuentra su activa participación política. El Nuncio solicita un informe detallado, el cual confirma que "ha trabajado activamente para hacerse elegir diputado y después para sacar triunfantes a los candidatos del gobierno, siendo él el único jefe de su partido en el departamento y dirigiendo personalmente todos los actos de las elecciones. Sus enemigos políticos propalan que durante las elecciones llevaba armas, pero de esto no tengo informe fidedigno". ${ }^{33}$

En 1914, el obispo volvió a recordar al clero reunido en las Conferencias de Párrocos que ningún clérigo debía declararse por alguno de los partidos militantes, tampoco podía ser candidato a cargos nacionales, provinciales o comunales. Consideraba que estas actividades separaban al clero de su misión y dividían a las feligresías, provocando enfrentamientos a nivel de la religiosidad. Sin embargo, las elecciones de 1915, que llevaron al radicalismo a la gobernación provincial, resultaron un campo de batalla entre clérigos de diversos partidos.

Gardenia Vidal (1994; 1995; 1996; 2000a y b) ha reflexionado en sus trabajos sobre la vida política cordobesa entre 1912 y 1930. En ellos, señala la trascendencia de las elecciones de 1912, en las que se aplicó la reciente Ley Sáenz Peña, que establecía el voto masculino, universal, secreto y obligatorio. La Unión Cívica Radical salió de la abstención y se presentó en las elecciones con Julián Amenábar Peralta como candidato a gobernador. La campaña fue violenta y azarosa, surcada de acusaciones de fraude. Ante la presencia radical, fuerzas conservadoras e independientes se unieron en la llamada "Concentración", una coalición que propuso un programa de gobierno más amplio, en el que se comprometía a garantizar la libertad de sufragio y la autonomía provincial. En noviembre de 1912, las elecciones dieron el triunfo a la fórmula de la Concentración Popular, cuya fórmula estaba

\footnotetext{
${ }^{32}$ AAC. Caja Parroquias: Salsacate, f.165. Nota enviada al obispo firmada por vecinos de Salsacate, marzo de 1913.

${ }^{33}$ ASV. Archivo Nunciatura Argentina, Nuncio Locatelli. Libro 17. Diócesis de Córdoba, Investigación pedida por el Internuncio a Carlos Etchenique, f.273 y ss.
} 
compuesta por Ramón J. Cárcano, gobernador, y Félix Garzón Maceda, vicegobernador. La Concentración, expresión del heterogéneo conservadurismo cordobés, no era un partido sino una unión de fuerzas políticas dispersas que auspiciaba una fórmula para la renovación del poder ejecutivo provincial (Vidal, 1996).

En 1913, las fuerzas conservadores se organizaron y conformaron el Partido Demócrata. Ramón J. Cárcano había percibido la necesidad de darle forma a las fuerzas conservadoras dispersas. El nuevo partido era orgánico y contaba con una plataforma, un programa y estaba adaptado al nuevo contexto de competencia electoral. De esta manera, desaparecía, formalmente, el Partido Autonomista Nacional y nacía uno nuevo de la fusión de las distintas fuerzas conservadoras.

Las elecciones del 14 de noviembre de 1915 consagró la llegada, por primera vez, del radicalismo al poder ejecutivo provincial, a través de la fórmula Eufracio Loza-Julio C. Borda, que derrotó, por más de tres mil votos de diferencia, a los candidatos demócratas Juan E. Cafferatta-Eloy Igarzábal (Vidal, 1996).

La prensa local dio cuenta de la actividad política partidaria del clero. El cura de Minas, Rosendo Leal, militaba en el partido Demócrata, en apoyo de la candidatura de Cafferatta (LVI, 03/11/1915). Ramón Varas, cura de Remedios, había dirigido una proclama al pueblo para solicitar el voto, pues había sido proclamado candidato a elector por ese partido. En el mismo departamento de Río Primero, el cura Rafael Ardiles era candidato por el radicalismo, correligionarios suyos eran Pastor Islas y Ramón Amuchástegui, cura de San Antonio (LP, 2/11/1915). El primero era candidato a senador provincial por el departamento de Río Seco. Las disputas entre clérigos de signos políticos opuestos traspasaban las cuestiones meramente partidarias. Pocos días antes de las elecciones, el periódico anunciaba que "el Pbro. Ardiles, candidato radical por Río $1^{\circ}$ debió decir misa en Piquillín. Temeroso el padre Varas de que su colega sirviera a los radicales antes que a Dios, se ha marchado a Villa del Rosario llevándose las llaves del templo" (LP, $31 / 10 / 1915)$.

El cura Saravia Caminos fue el candidato del partido Demócrata en el departamento de Calamuchita. El diario "La Opinión” del 29 de octubre de 1915 replica el enfrentamiento clerical y narra el siguiente hecho: "El clérigo Islas fue a Mansalvo el domingo último y asistió a una reunión radical. El buen señor subió a una mesa, dejó a un lado el bastón de 
sauce que lleva siempre a la diestra y dirigiéndose a los correligionarios les dijo estas palabras: Mis amigos, no hagáis caso de lo que pueda decir el cura Saravia, que no es mas que un simple cura de Calamuchita. En cambio yo digo la verdad y me debéis oir y hacer caso, porque soy miembro del cabildo eclesiástico de Córdoba, pertenezco a la curia y al obispado y tengo más autoridad que ningún cura de campaña”.

Radicales y demócratas disputaban votos palmo a palmo. El comité radical de Villa María acusó al cura Paulino Colabianchi de hacer proselitismo político a favor de los demócratas, sirviéndose del periódico "Vita Coloniale". El cura respondió ante el obispo que "ante todo niego que haya trabajado en política en el ejercicio de mi ministerio". Aclara que "hace mas de un año que hace propaganda del periódico italiano, católico, cuya predicha moral y religiosa y patriótica es muy útil para los colonos que trabajan en nuestras campañas, mi decisión para apoyar dicho periódico responde a un concepto eminentemente moral y social y no a fines políticos". En los últimos tiempos, "Vita Coloniale" había hecho propaganda por una determinada candidatura, pero eso no había dependido del cura. Si los radicales consideraban eso una "culpa", podían dirigirse a la dirección de "Vita Coloniale" para que les diera las consabidas explicaciones. "Respecto al cargo que yo invité al cochero Olguin a que votara por los carcanistas, diciéndole que los radicales son masones, le manifiesto que no conozco a ese cochero ni podría haberme expresado nunca en una forma tan chabacana. Solamente a un inconsciente se le podría ocurrir hablar de carcanismo y radicales masones". 34

En noviembre de 1915, el obispado recibe una denuncia en la que se afirma que el cura de Porteña, Jacinto Terzuolo, hizo un sermón político. El cura respondió a la acusación y afirmó que, efectivamente, habló en la iglesia (no desde el púlpito), de los candidatos rivales del partido radical, de la siguiente forma:

Después de encarecer la obligación de todo ciudadano argentino de tomar parte en las elecciones de las autoridades que han de regir los destinos de la provincia, pase a decir que esta vez a Dios gracias, la conciencia del ciudadano cristiana no se veía como en otras ocasiones en apuros por la elección del menos malo entre los malos, porque ahora se trataba de hacerlo del mejor entre los buenos, pues ambas partes son bonísimos y muy cristianos. De mi parte en vista de la brillante actuación del Dr. Cafferata en el congreso a favor del obrero, trabajador y colonos, no dudaría un instante en votar su candidatura si no fuera extranjero (a pesar de mis 32 años de residencia en esta tierra),

\footnotetext{
${ }^{34}$ AAC. Cajas Parroquias: Villa María, fs.317-318.
} 
como lo sois casi todos vosotros y por tanto inhabilitado para el voto. Hago esta manifestación para que los pocos votantes que hay se den cuenta del gran acto a realizarse. Por lo demás cada cual seguirá el dictamen de su conciencia o simpatía que a mi, en ello no me va ni me viene. Cada cual se arregle con el que vote. En fin, no es este el lugar propio para internarse en los laberintos de la política, ni yo tampoco me he metido en ella asi que hago punto y... basta. Vayamos a nuestro evangelio de hoy...

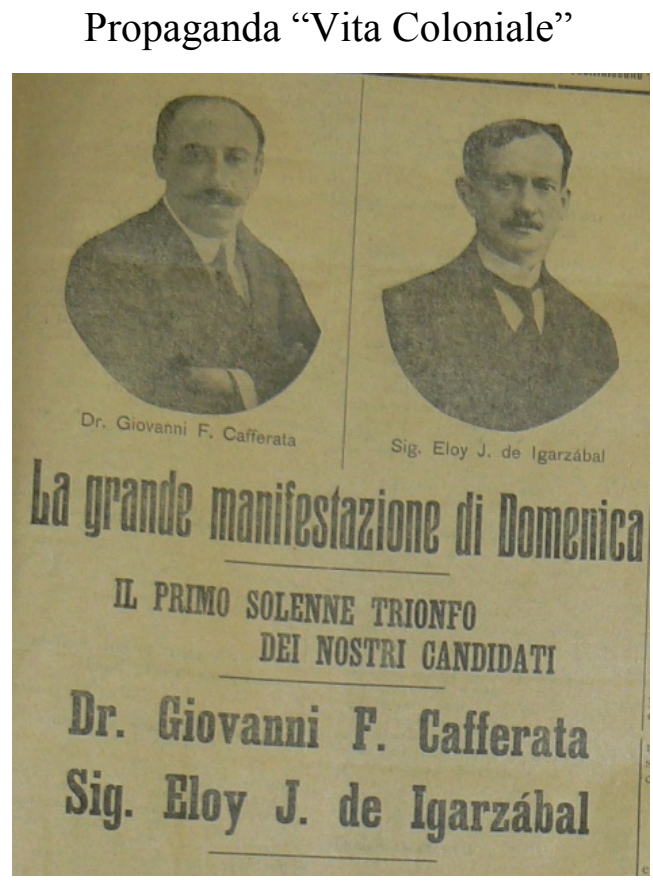

Fuente: $15 / 01 / 1915$

El 15 de noviembre de 1915, en pleno fragor electoral, el obispo prohibió al clero la participación en política. ${ }^{35}$ Antes de hacer público el auto, consultó el tema y pidió opinión al fiscal eclesiástico, Vicente Álvarez, quien respondió lo siguiente:

\footnotetext{
${ }^{35}$ El auto Prohíbe: $1^{\circ}$ Que se presten los sacerdotes a concurrir con frecuencia a cualquier comité o dirección de partidos políticos. $2^{\circ}$ Asistir a reuniones o manifestaciones populares con idénticos fines. Y bajo pena de suspensión ipso-facto, incurrenda prohibimos: $1^{\circ}$ Aceptar o permitir que se proclame su nombre para ningún puesto civil o político, sin permiso escrito, en cada caso, debiendo entenderse además que este permiso queda retirado en el mismo momento que haga mal uso de él, por parte del sacerdote favorecido incurriendo en faltas de circunspección, gravedad y compostura que comprometan la posición y el decoro sacerdotal. $2^{\circ}$ Salir los sacerdotes solos o acompañados en delegaciones de propaganda política. $3^{\circ}$ Acaudillar masas animadas con fines políticos. $4^{\circ}$ Firmar invitaciones o manifiestos al pueblo, de este mismo carácter. $5^{\circ}$ Dar su nombre a un partido o sostener públicamente un candidato por la prensa, circulares u otros medios de propaganda. $6^{\circ}$ Los sacerdotes que actualmente ejercen puestos políticos quedan comprendidos en todas estas prohibiciones y pena de suspensión indicada durante el ejercicio de su mandato, debiendo renunciar sus puestos en el caso de que se sientan presionados por el partido, a comprometer la moderación sacerdotal en aquellas manifestaciones.
} 
[...] siguiendo las indicaciones de los Sagrados Cánones del CP Americano en los artículos 656, queda vedada a los clérigos toda intromisión en la política como igualmente afiliarse a ningún partido político mientras en el país no haya un partido de principios neta y exclusivamente católico. En consecuencia ningún clérigo se debe declarar privada o públicamente por ninguno de los partidos militantes a fin de no hacerse odioso a los afiliados a otros partidos y con esto inutilizar, en parte al menos, la benéfica influencia de su sagrado ministerio, el cual se debe a todos y se cierne en una esfera superior a todas las apasiones humanas, y por su propia naturaleza como dice el CP está llamado a ser vínculo de unión y no elemento de discordia entre los fieles. Por la misma razón el clérigo no debe permitir presentarse ni que se le presente como candidato a ningún comicio, nacional, provincial o comunal; máxime cuando al presente la organización de las elecciones reclama muchas clases de manejos, dispendios y distracciones ajenas a su carácter sagrado y a las funciones de su ministerio $[\ldots]$.

[...] bástese decir que aunque muy sabio en su resolución [el auto del 15 de noviembre] e inspirado en el fin nobilísimo de evitar los muchos males que trae consigo la intromisión de algunos clérigos en las contiendas cívicas a la hora presente, es de temer que resulte ineficaz en la práctica, mientras V.S.I no los reconvenga primero paternalmente y después, si es necesario, imponiéndoles algún castigo saludable, a fin de que se abstengan de salir en giras de propaganda, de acuadillar las masas, como dice nuestro Sínodo y de hablar y obrar con la imprudencia de quién está cegado por la exaltación partidista. Cuando V. S. I. por un acto de benevolencia y de confianza en la corrección de su procederes, les concedió el permiso necesario para desempeñar cargos electivos no intentó de ninguna manera (pues no estaba en sus facultades) dispensarles de la prohibición del Concilio Plenario, dándoles amplia libertad para encarar la propaganda en cualquier forma con evidente menoscabo del respeto debido al Sacerdote y a su sagrado ministerio. Es cuanto creo del caso informar a V.S.I respetando siempre su más ilustrado criterio. ${ }^{36}$

Los fundamentos del auto del 15 de noviembre de 1915 fueron el ardor, la impetuosidad y el apasionamiento con que se desarrollaban las contiendas partidistas y las consecuentes discordias entre los feligreses afiliados a distintos partidos se acrecentaban si el cura tomaba parte en alguno y la causa primordial era que estas cuestiones provocaban disminución de la influencia del sacerdote y su ministerio en las comunidades cristianas. Además, señalaba el auto previo a la prohibición, publicado el 14 de octubre, que "la actuación del sacerdote no está en armonía con estos movimientos, ${ }^{37}$ por no avenirse en ellos las cualidades de pacífica bondad, mansedumbre y recogimiento propia de su carácter". Como corolario, señala la manifiesta necesidad del obispado "de sacerdotes que ejerciten el ministerio sagrado, en la provisión de parroquias vacantes, en el confesionario y

\footnotetext{
${ }^{36}$ AAC. Zenón Bustos. Obispo, Carpeta 1, f.143.

${ }^{37}$ Se refiere a la actividad política partidaria.
} 
en el púlpito". 38 El auto cierra con la siguiente advertencia episcopal "creyendo que tutelamos las consideraciones y respetos debido al personal del clero de nuestra Diócesis, y, contribuimos a tonificar su autoridad moral y la de su sagrado ministerio alejándolo de la actuación agitada y peligrosa que llevan consigo las cargos políticos, hacemos saber y declaramos el presente Auto, no concederemos en adelante, nuevos permisos a los miembros de nuestro clero para aceptar diputaciones, senadurías ni otros cargos políticos, a no ser enteramente transitorios, ni municipales ni otros asimilables, ni para prorrogar los cargos actualmente ejercidos por algunos". ${ }^{39}$ La normativa era clara, pero la tradición y la costumbre tuvieron un peso, incluso más fuerte, que la norma. Algunos curas consideraban esta actividad digna y respetable y se sentían orientados a ella. En una carta abierta, dirigida al Pbro. Ardiles, publicada en el diario "Los Principios" el 13 de marzo de 1915, el cura de Bel Ville, José Angulo, lo felicitaba. El diario publicó lo siguiente: “El Sr Pbro. José E Angulo, que había sido elector en el colegio electoral que designó Gobernador al Dr. Cárcano dirigió la siguiente carta abierta al Pbro. Ardiles, candidato radical a diputado en la próximas elecciones.

Mi buen Amigo:

Ahí va esta que espero te de alcance en alguna parte mientras recorres la inmensa extensión que comprende la circunscripción electoral, porque has sido proclamado candidato a diputado provincial. Confío en tu triunfo por lo que respecta al departamento de Río $1^{\circ}$. Pero antes de pronunciarme franca y decididamente en forma pública en pro de tu candidatura, deseando satisfacer sentimientos íntimos de mi alma y aportar siquiera un grano de arena a tu victoria, quiero prevenir apreciaciones erróneas y aclarar conceptos.

A no pocos causa extrañeza ver a quienes propiciaran la fórmula Cárcano - Garzón Maceda, frente a la del partido radical, verles propiciando candidatos surgidos de este partido, como has surgido tú y como ha surgido el Dr. Borda. Hay que distinguir entre los que se afiliaron a la Concentración y los que actuaron en carácter independiente en la elección de gobernador y vice a que me he referido.

Desparecería esa extrañeza si se tuviera en cuenta que el ciudadano que aporta el contingente de su voto y de su propaganda a determinados candidatos sin estar afiliado a ninguno de los partidos militantes, lo hace libre e independiente y con el derecho a propiciar en cada caso particular al candidato que juzgue conveniente cualquiera sea su procedencia, no viniendo de partidos extremos como el socialista por ejemplo.

\footnotetext{
${ }^{38}$ AAC. Fondo Zenón Bustos, Auto del 14 de octubre de 1915.

${ }^{39}$ AAC. Fondo Zenón Bustos. Auto del 14 de octubre de 1915.
} 
Yo pues al adherirme a la fórmula Cárcano - Garzón Maceda, en carácter plenamente independiente, al hacer votar antes a Cafferata - Igarzabal, [...], lo mismo que al propiciar tu gran candidatura y la prestigiosa del Dr. Borda, me encuentro en el mismo sitio, me encuentro en el campo independiente y gozaré de independencia hasta que llegue el día venturoso que se organice un partido católico con su bandera propia.

[...] soy consecuente con mi propio criterio que procuro conformar en las normas de conciencia que los Sumos Pontífices tienen dadas a los católicos en estos casos. Y cuanto por lo mismo que los católicos no estamos por nuestra fatal organización en condiciones de levantar candidaturas de las filas militantes, no se presentan a la lucha comicial candidatos dignos de los votos de los católicos, me atengo a términos relativos y consulto los casos difíciles.

Con lo que precede mi amigo he querido desvanecer prejuicios que flotan en el ambiente a fin de que esta modesta carta no se considere descalificada por la nota de veleidad o inconsistencia que por una torpe confusión pudiera atribuirse al autor.

Y Bien mi amigo tú te encuentras en situaciones excepcionales respecto a Río $1^{\circ}[\ldots]$ y yo que soy hijo del departamento bato palmas a tu candidatura.

Al encarecer los sumos Pontífices y con ellos los obispos que los católicos vayamos a los terrenos de los comicios, indudablemente quieren que vaya a desempeñar funciones públicas ciudadanos cuyo lema sea "pro aris et fosis" por la religión y por la Patria, que sean denodados defensores de la causa católica. Ese es tu lema y tal serias tú si te incorporaras a la cámara de diputados [...].

Para ti mi amigo tu investidura sacerdotal es motivo de prestigio decisivo para aquel departamento eminentemente católico, a menos que las policías electorales y los jueces "forcen" la máquina y lleven al máximo los abusos y sustraigan los ciudadanos sus libretas. El Río $1^{\circ}$ no solo tiene un altísimo concepto del sacerdote católico y de su misión augusta, sino que se ha acostumbrado. ${ }^{40}$

La carta de apoyo del cura Angulo no fue la única, el cura de Arroyito, Ramón Liendo, el vicario foráneo de La Rioja, Manuel López, publicaron sendas cartas en el periódico. Ramón Liendo escribió el 18 de marzo de 1915 una larga carta en la cual vertió elogiosos conceptos a su "excondiscípulo y amigo", entre los párrafos, se destaca el siguiente: “cuando hace pocos días viajando tu y yo tuve la ocasión de estrechar tu mano y expresarte con satisfacción intima mi franca adhesión a tu candidatura para diputado provincial, sentí el placer de oírte frases como esta: 'si el voto libre de mis electores me lleva al recinto de las leyes, tendré oportunidad de decir a mis conciudadanos que vine allí, para hacer que impere en mi provincia y en mi patria el espíritu de nuestra sabia y gran constitución, y por ella, en ella y con ella triunfen los santos principios de nuestro viejo partido Radical. [...] Nuestro pueblo

\footnotetext{
${ }^{40}$ Los Principios, 13/03/1915.
} 
siente hambre de justicia y de verdad', te oí decir y pude verte enseguida mezclado con un grupo de obreros, tus futuros electores, y con esa amabilidad que es patrimonio de los grandes hombres y de la virtud probada acariciar entre tus manos la mano encallecida y temblorosa de ese pueblo hambriento de justicia". Luego, al igual que la carta del cura Angulo, hace una reseña de sus derroteros políticos donde asevera que "no estábamos ni estamos con ningún partido (los católicos queremos un partido propio, como lo tienen ya con mucho honor otras naciones), ni en contra de ninguno, como hoy éramos pues independientes. No fuimos invasores de fueros, porque éramos, a pesar de nuestra investidura ciudadanos $[\ldots]$. Y bien mi amigo, yo no podré votar tu candidatura no me pertenece $[. .$.$] yo$ daré gustoso mi voto en pro de otra simpática candidatura, la de nuestro correligionario en la fe, Dr. Julio C. Borda, para diputado Nacional. [...] Día llegará tal vez que será de unión para los católicos argentinos y entonces no teniendo como hoy que mezclar nuestro sufragios con quienes ni en política ni en religión piensan como nosotros". 41

Estas cartas muestran, sin duda, un pensamiento bastante generalizado en un sector del clero cordobés. Pero el obispo diocesano mantiene firme su decisión de evitar la participación del clero en política. El 25 de octubre de 1915 emite un decreto por el cual llama la atención del Pbro. Ardiles: "por la información de la prensa local y por la de diferentes personas, la propaganda activa en política desplegada por el Pbro. Rafael Ardiles, la cual le tiene ocupado casi todo el tiempo, recorriendo algunos departamentos con abandono de los deberes propios de la capellanía que se le ha confiado, en menoscabo del prestigio de la sotana, del ministerio sacerdotal y no sin desagrado de algunos sacerdotes de su gremio ordenamos por el presente decreto su permanencia estable en el puesto de su capellanía o la dimisión de éste". ${ }^{2}$

La participación del clero en política era una cuestión compleja. Había un importante sector del clero que, encabezados por Monseñor Carlos Echenique, propuso la creación de un partido católico cordobés. Éste se inspiraba en la actuación del clero alemán y la creación del Centrum, partido católico, que se opuso a las fuerzas liberales, en el cual el clero tuvo un protagonismo fundamental, ocupó bancas en las diversas cámaras, tuvo un papel activo en el periodismo militante y desarrolló una intensa actividad social con los obreros y los campesinos (Kannengieser, s/f). La cuestión del partido católico enfrentó al obispo con el

\footnotetext{
${ }^{41}$ AAC. Caja Zenón Bustos, f.

${ }^{42}$ AAC. Fondo Zenón Bustos, Caja N 5, f.2070.
} 
clero secular y generó una denuncia del clero que fue elevada a Roma. El punto central del enfrentamiento radicó en la oposición del obispo a dar su consentimiento a este tipo de iniciativas. Roma inició una investigación sobre el tema y solicitó información al obispo de Paraná. El informe señalaba que los antecedentes de dicho partido habían sido publicados en el periódico "El Pueblo Católico". Se trataba de una agrupación importante de católicos, a cuya cabeza se encontraba Mons. Carlos Echenique y el Pbro. Pablo Cabrera, y cuya base era la antigua Sociedad Juventud Católica, su presidente, vicepresidente y miembros de la Junta directiva. En 1912, conformaron una Comisión que invitaba a votar una lista de candidatos católicos con independencia partidaria. Un grupo de clérigos informaba al obispo que "Atendiendo a las diversas instrucciones de la Santa Sede y del Episcopado recomendando la acción conjunta del clero y del pueblo católico, para obtener el triunfo amplio de la ideas y doctrinas católicas en todo terreno [...] haya en el Congreso Nacional representantes genuinos de nuestro credo religioso, hemos resuelto constituirnos en comisión para formular una lista de sinceros creyentes, tomándolos de los diversos candidatos proclamados, sin tener en cuenta para nada diversos partidos a que pertenecen porque como sacerdotes nos esta absolutamente prohibido enrolarnos en partido alguno [...]”. Firman el comunicado los canónigos Luis Álvarez, Francisco Cesar, José Martínez, Rafael López Cabanillas, Bruno Ferreira y el presbítero pastor Isla. ${ }^{43}$ Además, la comisión redacta una nota para enviarla a los posibles votantes. En dicha nota, encabezada con un "Mi estimado amigo", se explica que con la nueva ley electoral ha llegado el momento de hacer valer la superioridad del número a favor de los católicos: "ha llegado el momento en que los católicos que no hemos podido aun congregarnos en un partido único, hagamos uso de nuestros derechos y cumplamos nuestro deber de concurrir a las urnas para votar por los candidatos que son fieles representes de nuestras tradiciones". Luego de explicar el modus operandi, termina diciendo "si ud. tiene un amigo de toda confianza a quien pueda dirigirme yo desde aquí con toda reserva, avísemelo enseguida para enviarle las instrucciones y los datos [...]". 44

Paralelamente, se publica un panfleto titulado "Católicos en las elecciones nacionales. Graves deberes del momento. Católicos a Votar”. La circular fundamenta la obligación de votar, hace un llamado a todo los católicos de la provincia para que votaran a los siguientes

\footnotetext{
${ }^{43}$ AAC. Fondo Zenón Bustos, Caja N ${ }^{\circ}$ 5. Nota de marzo de 1912.

${ }^{44}$ AAC. Fondo Zenón Bustos, Caja N 5, f.2997. Nota del 07/03/1912.
} 
candidatos a diputados nacionales: Juan Cafferata, Manuel E. Río, Eloy de Igarzábal, Arturo Bas, Pedro Funes Lastra y J. Vaca Narvaja. El obispo diocesano reflexiona sobre el asunto y en un papel borrador, hizo las siguientes indicaciones:

- 'Un grupo del clero autor del manifiesto ¿no es política esto?

- Inician la lucha religiosa en el país excluyendo a los muchos buenos que están en las listas consagradas por partidos sanos en sus ideas como son los dos principales militantes.

- Una de las listas formadas por el gobierno no católico y protector del clero ¿Cómo no ha de despertar animosidad este comportamiento?

- ¿Se quiere cambiar la situación en unas horas? Es temeridad, lo óptimo es enemigo de lo bueno.

- ¿No serán clérigos empleados?"45

A partir del manifiesto y las cartas publicadas, el obispo preparó una conferencia. En ella, explicó la situación de la diócesis, la escasez de clero para servir las parroquias, los curatos vacantes que había y los curatos nuevos que estaban por crearse, esta realidad conformaba una barrera salvadora que obligaba al clero a dedicarse a su labor primordial. "Rota esa barrera para que pasen las sotanas, el número de sacerdotes en la legislatura sería numeroso. Los llevarían de uno y otro partido. Sería teocrática y repudiada solo por esta razón por el pueblo liberal y criticada ácidamente por los civiles excluidos de esos puestos ocupados por los que debieran ocuparse de pregonar la religión y la moral al pueblo. El Obispado va a pura perdida, los debates ardientes que a menudo se encienden en las cámaras llegan a ser borrascosos y arrasan al sacerdote, al ministerio que representa y a veces a la misma religión". 46

Pese a la postura del obispo diocesano, la idea del partido católico continuó siendo impulsada por sectores del clero. La Comisión encomendó a Mons. Echenique que solicitara el aval del obispo, para conformar un partido que llevara el nombre de partido católico, quien, de manera informal, puso al tanto al prelado de dichas gestiones. El obispo se alegró de que los católicos se unieran, pero no se pronunció sobre el partido. Ante la insistencia de que pusiera por escrito su anuencia, Monseñor Bustos envió una nota, en la cual señalaba que

\footnotetext{
${ }^{45}$ AAC. Fondo Zenón Bustos, Caja N 5, f.2999.

${ }^{46}$ AAC. Fondo Zenón Bustos, Caja N 5, f.3005.
} 
"la oportunidad de formar un partido, creía que era asunto que debían resolver los obispos reunidos y no cada uno por separado". Con lo cual, los promotores desistieron de seguir adelante con la empresa. ${ }^{47}$

Fracasado el intento de un partido católico, los católicos se incorporaron a los partidos existentes y los políticos, tanto radicales como demócratas, aspiraban a llevar curas en sus listas. En 1917, Miguel A. Cárcano, ${ }^{48}$ en una carta reservada, solicitó al Diocesano la autorización para que el cura Saravia Caminos del departamento de Calamuchita aceptara la candidatura a senador provincial; entre los argumentos esgrimidos, afirmaba la dificultad de "encontrar un candidato que una todas las voluntades, y cualquier nombre que se mencione produce la división y anarquía que nos llevaría a la derrota. Es por eso que sin esperar la contestación y consentimiento del Señor Saravia y del diocesano, ha sido forzoso votarlo como candidato, corriendo la contingencia de su no incorporación. [...] A las clases más conservadoras del país, empezando por el clero, conviene tener en la legislatura, hombres que equilibren las exageraciones de los gobiernos o partidos exaltados, mucho más como en este caso en que no solo se agranda la influencia de un partido conservador sino la influencia serena y decisiva del diocesano, que es una garantía para todos". ${ }^{49}$ La respuesta del prelado fue firme, sostenía que si levantaba la prohibición:

La puerta queda abierta para que pasen todas las sotanas adictas a los diversos partidos políticos [...] esta facilidad para adquirir bancas pronto nos llevaría a la composición de una cámara teocrática con la protesta general de los civiles y el perjuicio del ministerio sacerdotal, por el abandono que de él harían los incorporados a los puestos legislativos. ${ }^{50}$

La consulta del político y la respuesta del prelado nos permiten inferir que si bien el obispo bregaba por separar la acción religiosa-social de la acción cívico-política del clero, la religión y la política, en este período, seguían aún profundamente imbricadas. El interés de los partidos por contar con clérigos entre sus candidatos pone de manifiesto el carácter católico y tradicional de la sociedad y la influencia que aún ejercía el clero en ella; la oposición de la jerarquía y de otros sectores a esta práctica refleja, a su vez, el gradual avance

\footnotetext{
${ }^{47}$ ASV. Archivo Nunciatura Argentina, 17. Internunciatura Mons. Locatelli, 1907-1916, Diócesis, Córdoba, fs. $345-350$.

${ }^{48}$ Pertenece a una familia de políticos cordobeses. Su padre, Ramón Cárcano fue gobernador en 1913. Miguel Ángel fue diputado nacional por la provincia de Córdoba en 1929-1931-1934.

${ }^{49}$ AAC. Fondo Zenón Bustos. Obispo. Documentación varia, Caja N 1, f.2288.

${ }^{50}$ AAC. Zenón Bustos, Carta Cárcano.
} 
del proceso de secularización. En enero de 1918, el Dr. Rafael Núñez, referente del Partido Demócrata, candidato a la gobernación para el período $1919-1922,{ }^{51}$ solicita al obispo diocesano la autorización para que el Pbro. Luis Rosendo Leal sea candidato a Diputado Nacional por el Partido Demócrata Progresista. Las razones aducidas en la nota señala que el cura Leal no ejercía la cura de almas en una parroquia, además era un importante exponente de la cultura e lustración del clero de Córdoba y defensor de los derechos eclesiásticos. Señala también que el cura Leal, dentro del Partido Demócrata, representaba la tendencia conservadora más sana y eficaz del partido. ${ }^{52}$

La repuesta del obispo fue clara y firme "me veo en la violencia de no complacer su pedido. Por otra parte mi estimado Dr. abriendo la puerta para uno en la barrera esta quedaría destruida y habría que abrirla para todos quedando anulado el Auto totalmente y la misma autoridad que lo dictara". ${ }^{53}$ Acto seguido remite otra carta al cura Leal en la que expresa conceptos similares. ${ }^{54}$ Pocos días después, el obispo realizó su visita pastoral a las Mesadas, donde se entera que, por denuncias políticas, habían apresado a Monseñor Leal. Desde allí escribe al Obispo Auxiliar Mons. Luque solicitando pasara el tema al fiscal para que estudiara el caso y apostilla: "Sin haber producido nada bueno las sotanas en las bancas en favor de la Iglesia, ahora le tocan a ésta los vejámenes. La humillación y vejamen que se hecha sobre sus ministros cae directamente sobre ella. Las represalias de lo que llaman política no reconocen barreras ni fueros que las contengan. Atropellan lo mismo a lo sagrado que a cualquier otra cosa cuando se ven estorbados en sus miras". ${ }^{55}$

Con fecha 18 de febrero llega al obispado la notificación telegráfica de los hechos acaecidos en Ciénaga del Coro, departamento de Minas, que llevaron al Pbro. Leal al encarcelamiento. El presidente del comité radical denunciaba al cura Leal y solicitaba "garantías personales para correligionarios y familias. Pedimos que constate excomuniones a católicos por parte de Leal. Balazos de intimidación en Ciénaga. Cura de San Carlos quemando estruendos en reuniones políticas. Del grupo encabezado por sacerdotes salen

\footnotetext{
51 Fue dos veces diputado provincial, presidente de la Cámara de Diputados, ministro de Hacienda del gobernador Ramón J. Cárcano, diputado nacional y gobernador de Córdoba (1919-1921), candidato a vicepresidente de la Nación en 1922 y senador nacional hasta 1924, año de su fallecimiento. Los comicios del 17 de noviembre de 1918 le dieron el triunfo a la fórmula demócrata Rafael Núñez - Dr. Jerónimo del Barco.

${ }^{52}$ AAC. Zenón Bustos, Caja N ${ }^{\circ}$ 7, f.3166. Carta del 26/01/1918.

${ }^{53}$ AAC. Zenón Bustos, Caja N ${ }^{\circ}$ 7, f.3167. Carta del 05/02/1918.

${ }^{54}$ AAC. Zenón Bustos, Caja N ${ }^{\circ}$ 7, f.3168. Carta del 05/02/1918.

${ }^{55}$ AAC. Zenón Bustos, Caja N ${ }^{\circ}$ 7, f.3169. Carta del 11/02/1918.
} 
matones fanáticos, desafiando señoras, partidarios, errando tajos para implantar el terror. Hay tres concretos" ${ }^{56}$ El obispo recibe la notificación del Poder Ejecutivo Provincial, en la que se adjunta el telegrama del encargado de la construcción del camino de Ciénaga del Coro a Sumampa, con fecha 23 de febrero, donde relata los hechos acontecidos: "El Canónigo Luis Rosendo Leal al frente de una pandilla de individuos se presentó al lugar donde se ejecutaban los trabajos, con pilchas de paisano sobre sus hábitos sacerdotales, desmotándose de su cabalgadura con actitud hostil, faltando el respeto al encargado, al negarle el consentimiento para repartir prospectos despectivos de las autoridades del país, procedió a amenazar a capataces y peones sembrando el terror entre aquella gente, a quién amenazó con su influencia divina de matarlos, quemarlos y esparcir sus cenizas por las regiones etéreas si no se presentaban a su campamento político". ${ }^{57}$ El cura Leal publicó en el diario "Los Principios" que "toda esa grita es completamente falsa y calumniosa como lo demostraré en breve". ${ }^{58}$ A su vez, el obispo diocesano comunicaba al cura Leal que si bien tenía la convicción de que los hechos no habrían ocurrido en la forma que se relata, le solicitaba le enviara una relación exacta de los hechos mencionados y de la forma en que se produjeron con el objeto de deslindar responsabilidades. ${ }^{59}$

Paralelamente, llega a la curia una carta anónima, firmada por "un católico", en la que se adjuntaba la nota periodística donde se relataba la gira proselitista de Monseñor Leal por el curato de Cruz del Eje y Minas, en ella se protesta y se denuncia dicha conducta: "como creyente que soy me avergüenzan dichas crónicas [...] los frailes y clérigos que como Leal practican la religión de Cristo solamente como un modus vivendi son indignos de ocupar puestos directivos, no solamente en cuestiones de conciencia sino hasta en los asuntos de la vida real. Un clérigo que actúa tan descarada y apasionadamente en política, no puede jamás cumplir los preceptos divinos, desde que en política no hay honestidad, no hay caridad, no hay verdad, no hay nada!". ${ }^{60}$

En el mes de julio, el obispo volvió a escribirle a Leal comunicándole que se había enterado, por la prensa local, que había sido designado candidato a vicegobernador de la provincia por un comité del partido demócrata. Aprovechaba, entonces, a recordarle las

\footnotetext{
${ }^{56}$ AAC. Zenón Bustos, Caja N 7, f.3176. Telegrama del 18/02/1918.

${ }^{57}$ AAC. Zenón Bustos, Caja N 7, f.3180. Telegrama del 23/02/1918.

${ }^{58}$ Los Principios, 25/02/1918.

${ }^{59}$ AAC. Zenón Bustos, Caja N ${ }^{\circ}$ 7, f.3183. Nota del 23/02/1918.

${ }^{60}$ AAC. Zenón Bustos, Caja N 7, f.3194. Nota del 25/03/1918.
} 
disposiciones eclesiásticas vigentes y concluía diciéndole: "me permito anticiparle que mantengo en todo y sin excepción aquellas disposiciones". ${ }^{61}$ El 26 de julio el cura Leal solicitó, por nota, permiso formal para aceptar dicha candidatura ${ }^{62}$ y el 27 el obispo le respondió denegándosela. ${ }^{63}$ Finalmente, el cura declinó su candidatura por no haber obtenido el permiso del obispo diocesano. El diario "El Pueblo" de Río Cuarto sentenciaba que la prohibición al clero de no aceptar ninguna candidatura sin el permiso expreso estaba "en pugna con nuestras instituciones y los verdaderos intereses del país y de la iglesia católica en la Argentina" (EP, 22/02/1918). Esta afirmación da cuenta de la tensión entre las posturas asumidas por los diversos sectores de la sociedad.

El clero era escaso en relación al aumento demográfico de la población, por lo tanto era de capital importancia restringir la labor del párroco a la predicación, la administración de los sacramentos y la promoción de la acción social católica, dejando otro tipo de actividades, particularmente las políticas, bajo la responsabilidad de los laicos. Esta tarea tuvo, por parte de algunos sectores del clero, bastante resistencia. La tradición político clerical cordobesa tenía su peso y, si bien, como advierte Ayrolo (2011: 113), la presencia y participación de clérigos en política comenzó a ser cuestionada a mediados del siglo XIX, el ejercicio de la política moderna ya se había instalado como una práctica corriente, el clero ya no tenía más espacio en las bancas de diputados sino como resabio nostálgico de otros tiempos. Lo cierto es que en 1917 y 1919 aún era posible encontrar clérigos que ocupaban bancas en las cámaras provinciales como diputados y senadores, en las comunas municipales y como electores o apoyando diversas candidaturas.

Las elecciones presidenciales de 1919 también dieron ocasión a varias denuncias por la participación política del clero. Los vecinos de Salsacate enviaron una nota al obispado para informar que el cura Ricardo Pulcinelli apoyaba y hacía proselitismo político a favor del oficialismo, afirmaban que había tomado directa participación, hecho reuniones con dirigentes radicales en la casa parroquial y "allí se operaban los trabajos preliminares para las contiendas electorales viéndose pegados hasta en la Iglesia -hacia afuera- papeles de propaganda". La denuncia señalaba, además, que, en vísperas de los comicios de noviembre, el sacerdote celebró una función religiosa en casa de "uno de los más conspicuos caudillos

\footnotetext{
${ }^{61}$ AAC. Zenón Bustos, Caja N ${ }^{\circ}$ 7, f.3186. Nota del 22/07/1918.

${ }^{62}$ AAC. Zenón Bustos, Caja N 7, f.3192. Nota del 26/07/1918.

${ }^{63}$ AAC. Zenón Bustos, Caja N 7, f.3191. Nota del 27/07/1918.
} 
radicales para cooperar por ese medio a la reunión de electores". ${ }^{64}$ Los obispos procuraron distanciar al clero de las actividades que no fueran estrictamente pastorales.

\section{Secularización de la sociedad: el clero frente a librepensadores, socialistas, anarquistas y masones}

A media que avanza el siglo, los intereses de la sociedad ya no eran exclusivamente católicos, sectores de la población se fueron diversificando y manifestando su disidencia con el clero. En la campaña, el mundo de las colonias agrarias, en particular los departamentos de Marcos Juárez y Juárez Celman, comenzó a ser inficionado por el anarquismo, el socialismo y las logias masónicas, convirtiéndose en una preocupación del obispo diocesano y el clero. El título de un editorial del diario católico "Los Principios" es sumamente sugestiva "El enemigo avanza"; allí se sostiene que "la anarquía, el socialismo, el masonismo, el liberalismo sectario, no son más que matices diversos de una misma grande y funesta filosofía: la filosofía materialista". ${ }^{65}$

El cura José Benard, párroco de Tercero Arriba, en una conferencia dictada para el clero diocesano, luego de enumerar las fuerzas que, a su entender, trabajaban en favor de la "descristianización" de los habitantes de Córdoba, los vislumbra como "un gigante Goliat que se presenta a provocarnos en nuestro campo", motivo por el cual, "la hora presente exige al ministerio pastoral un completo sacrificio", pues entendía que, hasta el momento, el ministerio parroquial no había sido eficaz en la lucha por neutralizar los efectos nocivos de esas corrientes. Veía como una necesidad urgente, para ser más eficaces los esfuerzos del ministerio parroquial, "cambiar de método" buscando "combinaciones más apropiadas y directas para detener el avance". ${ }^{66}$ Esta cita nos permite pensar algunas cuestiones relativas a su concepción sobre la sociedad. En primer lugar, cabe preguntarse qué entendía el presbítero al referirse a la provocación del socialismo, en "nuestro campo", entendemos que se trata de una cuestión que remite a un tema complejo como es el dominio del espacio público. El socialismo ganaba el espacio público mediante la propaganda escrita, las conferencias callejeras y la actividad de sus centros, este fenómeno, que se extendía del este

\footnotetext{
${ }^{64}$ AAC. Cajas Parroquias: Salsacate, f.229. Denuncia del 08/04/1919.

${ }^{65}$ Los Principios, 09/04/1919, col. 1, p. 1.

${ }^{66}$ AAC. Fondo Zenón Bustos. Obispo. Documentación varia, Caja No 1, f.136. Carta del Pbro. José Benard al Obispo Zenón Bustos, enero de 1919.
} 
hacia el sur, preocupó al clero de Córdoba. Los llamados de atención respecto al cuidado que debían prestar los párrocos a "la acción disolvente de los centros iniciadores del socialismo y anarquismo" son recurrentes. ${ }^{67}$ En segundo lugar, es interesante preguntarnos hasta qué punto el socialismo supuso una amenaza para la Iglesia diocesana. Los trabajos de Alejandro Dujovne sobre el socialismo cordobés arrojan luz sobre esta cuestión. El autor sostiene que la composición mayoritariamente extranjera y el carácter marcadamente anticlerical del partido socialista eran dos de sus principales características. Si bien los inmigrantes europeos aportaron ideología, organización y propaganda al socialismo cordobés, su presencia numérica fue escasa. La escasez de militantes socialistas, unido a la religiosidad de los trabajadores, presentará -según el autor-, un difícil escollo para la primera difusión de socialismo. En 1918, la federación socialista local tenía quince centros y 414 afiliados, en 1921, pasó a tener diez centros y 333 afiliados, en 1923, ocho centros y 211 afiliados (Dujovne2002a). Estas dos cuestiones: la religiosidad de los trabajadores y el escaso número de afiliados a los centros socialistas ponen de manifiesto que el socialismo y el anarquismo en Córdoba no se convirtieron en una alternativa atrayente para los trabajadores y que gran parte de la sociedad criolla e inmigrante se identificaba con el universo de creencias, conductas, sensibilidades y prácticas católicas. Sin embargo, el discurso eclesiástico muestra una excesiva preocupación por el impacto de estas ideologías en la sociedad provincial. Las alertas son permanentes y alarmantes.

\subsection{El socialismo y el anarquismo en el discurso eclesiástico}

Los discursos eclesiásticos sobre el socialismo y el anarquismo nos permiten acercarnos a las concepciones que los sustentaban. Dichas concepciones orientaban las prácticas instrumentadas por el clero para desarrollar su labor religiosa, asistencial y social.

El obispo veía en el socialismo una doctrina materialista que, a su entender, destruiría la sociedad, ya que intentaba trasformar sus fundamentos, impugnar los derechos de la propiedad privada, socavar la autoridad, prometer una felicidad temporal, limitada al tiempo presente, sin tener en cuenta los premios y penas de la vida eterna; llevando a que la gente de clase modesta, cansada de la pobreza se lanzara a la revolución social. ${ }^{68}$

\footnotetext{
${ }^{67}$ AAC. Libro 45, f.21.

${ }^{68}$ AAC. Zenón Bustos. Pastoral de Cuaresma. El proletariado... p. 6.
} 
Los conceptos fundamentales del socialismo y los puntos de fricción con la religión católica fueron vertidos en tres pastorales. ${ }^{69}$ Desde el punto de vista doctrinal, la diferencia fundamental radicaba en que el materialismo que propugnaba se oponía directamente a la concepción cristiana y trascendente del hombre y la sociedad. El diocesano advertía que, si bien, la bandera que presentaba el socialismo era económica, pues propiciaba pan, techo y vestido para el proletariado y los pobres, el objetivo real de la doctrina era "suprimir el entero orden social cristiano que regía a la provincia", extinguir las creencias religiosas de cualquier credo, promover la rebelión contra el orden político, civil y religioso, despojar a los necesitados de sus esperanzas en la bienaventuranza, sumergiéndolos en el materialismo y confundiéndolos con promesas halagadoras de prosperidad temporal. ${ }^{70}$

Para el diocesano, esta concepción materialista fomentaba la conflictividad social, la lucha entre el trabajo y el capital. La problemática social tendría su origen en la expulsión de la religión de las leyes, del espacio público, de la escuela, de la cátedra, de la familia, de la sociedad civil. ${ }^{71}$ Desde este punto de vista, la religión daba sentido a las conductas sociales, se convertía en la fuente de moral que permitía la convivencia, la paz y la armonía social. Una sociedad sin religión sería una sociedad sin paz:

La impiedad cada día se presenta más audaz, extendiendo su acción descristianizando a todas las clases sociales y con pretensiones de infiltrar su odio satánico a Jesucristo a su Iglesia, en todas las instituciones que afectan al individuo, a la familia, y a la sociedad, en la vida privada como en la pública dejándose sentir los efectos en su propaganda disolvente del orden moral establecido a costas de inmensos sacrificios. Esto debe estimular nuestro celo a luchar sin descanso por la causa de la fe y de la moral cristiana, oponiendo las doctrinas civilizadoras de la Iglesia a las formas convencionales del materialismo y positivismo, la luz de la verdad a las tinieblas del error, los ardores de la verdadera caridad a las frases frías y vanas de la beneficencia laica. ${ }^{72}$

Católicos y socialistas tenían su programa social, ambos procuraban defender las legítimas reivindicaciones del proletariado, mejorar la vivienda obrera, combatir las consecuencias del alcoholismo, regular las horas y condiciones de trabajo, velar por el

\footnotetext{
${ }^{69}$ AAC. Zenón Bustos y Ferreyra. Pastoral sobre el Socialismo del 24 de febrero de 1914. Pastoral sobre "La revolución social", 23 de noviembre de 1918. Pastoral de Cuaresma. El proletariado antes y después de Jesucristo, Córdoba, Imprenta Ferreyra, 1919.

${ }^{70}$ AAC. Fondo Zenón Bustos. Pastoral de Cuaresma. El proletariado antes y después de Jesucristo, Córdoba, Imprenta Ferreyra, 1919.

${ }^{71}$ AAC. Zenón Bustos y Ferreyra: La Revolución Social, Pastoral del 23 de noviembre de 1918.

${ }^{72}$ Sínodo Diocesano de Córdoba, № 188.
} 
descanso necesario, etc. Más, entre ambos, existía una diferencia fundamental, los primeros consideraban el mejoramiento material como un medio para alcanzar el progreso moral y la finalidad última trascendente del hombre, y los segundos negaban toda posibilidad de trascendencia, afanándose por alcanzar un bienestar exclusivamente terrenal. El humanismo materialista y ateo del socialismo se enfrentaba con el humanismo espiritual y trascendente del catolicismo. El obispo diocesano entendía que:

Las complicaciones de esos derechos [de los trabajadores] serán cada vez mas violentas a medida que la incredulidad crezca entre capitalistas y obreros. [...] Imposible una jurisprudencia reguladora, si se desconoce o se prescinde para formarla, la espiritualidad del alma, su inmortalidad, su albedrío [... $]^{73}$

Para el socialismo, los pobres no necesitaban obras de caridad, sino de justicia. Las obras de caridad, como la limosna, serían, en realidad, un modo para que los ricos eludieran la instauración de la justicia y acallasen su conciencia, conservando su propia posición social y despojando a los pobres de sus derechos. El obispo diocesano sindicaba que el socialismo era una doctrina que pugnaba por "eliminar como inútil la ley de la caridad cristiana, acusar de indolencia a la Iglesia y no mirar por las condiciones económicas de los pobres". ${ }^{74}$ Por su parte, la Iglesia entendía que siempre se darían situaciones de necesidad material, sufrimiento o soledad en la que era indispensable la ayuda que demostrase el amor concreto al prójimo, por lo tanto, la caridad cristiana seguiría siendo un elemento constitutivo para lograr la paz social. El modelo de caridad cristiana expuesto por el diocesano remite al evangelio, a la parábola del buen samaritano, donde se presenta la caridad como una respuesta a la necesidad inmediata:

El desequilibrio de la fortuna es inevitable hoy y siempre habrá pobres que sufran sus privaciones, [...] la economía siempre será impotente para suprimir el pauperismo, y la mecánica para suprimir el brazo del obrero. Sin curar el mal, podrán aliviar los dolores físicos de la pobreza, pero no podrán suavizar la pobreza y dolencia del espíritu. La filantropía acude con pan y con vestidos a los hambrientos y desnudos, pero es incapaz de enjugar las lágrimas que arranque de los ojos la desventura del corazón: es incapaz de descender a los abismos del espíritu a calmar las tempestades

\footnotetext{
${ }^{73}$ AAC. Pastorales, Decretos y Circulares, 1905-1920. Pastoral del 2 de mayo de 1905 al recibirse el gobierno de la diócesis, p. 17.

${ }^{74}$ AAC. Zenón Bustos y Ferreyra. Pastoral sobre el Socialismo del 24 de febrero de 1914.
} 
de las pasiones y anunciar la paz. ${ }^{75}$

La estrategia del Obispo Bustos estaba orientada a dar a conocer al clero y al pueblo los errores de esta doctrina social materialista. En el círculo de estudios del clero se preveían conferencias sobre los fundamentos doctrinarios del socialismo, sus manifestaciones intelectuales, religiosas y morales. La aplicación del socialismo a la democracia, la legislación nacional, la instrucción, los obreros, los patrones, el capital y los inconvenientes resultantes de estos principios. ${ }^{76}$ Esta información debía ser transmitida a los obreros y al pueblo en general.

Serán menos los prosélitos de la escuela socialista, o no los tendrá, cuando la actividad intelectual y el celo conservador de los hombres de representación, haya hecho conocer a las nuevas masas obreras, debidamente, los principios del liberalismo rojo que la informa, y el género de la acción que emplea para llegar a su fin: su fin es aniquilar al orden cristiano que actualmente rige, y todas las instituciones, que dentro de él se desenvuelven, siempre dentro del ambiente de la fe en lo sobrenatural, y después, ensayar una creación nueva, con los escombros producidos, toda material y puramente humana, sin religión alguna. ${ }^{77}$

Pastorales y otros escritos los sindican de "fuerzas peligrosas", "corrientes insanas que atentan contra el orden social", "formidable enemigo", 78 "extranjeros, profesionales de perturbaciones obreras", 79 que realizan una prédica "irreligiosa, inmoral, subversiva, anticlerical y anarquista", ${ }^{80}$ con espíritu de "insubordinación y desorden". ${ }^{81}$ Los términos y expresiones con que el obispo diocesano designaba a estos adversarios, inducen a concluir que la jerarquía construyó una imagen "del enemigo" destinada a neutralizar la adhesión de la población a las nuevas doctrinas. Los conceptos vertidos revelan un discurso confrontativo que revaloriza el rol de la religión católica como elemento de orden y cohesión social y presenta al socialismo como enemigo de la patria y del orden social. Denota una necesidad de reforzar la propia identidad católica, frente a la amenaza que

\footnotetext{
${ }^{75}$ AAC. Pastorales, Decretos y Circulares, 1905-1920. Pastoral del 2 de mayo de 1905 al recibirse el gobierno de la diócesis, p. 17.

${ }^{76}$ AAC. Círculo de Estudios del Clero, 1917-1918. Libro de Actas.

77 AAC. Zenón Bustos y Ferreyra. Pastoral recomendando los círculos de obreros, 28/11/1907. REOBA, Sección Córdoba, 1908, pp. 32-36.

${ }^{78}$ AAC. Zenón Bustos. Pastoral de Cuaresma. El proletariado... p. 6.

${ }^{79}$ REOBA, 1908, p. 141.

${ }^{80}$ REOBA, 1908, p. 144.

${ }^{81}$ AAC. Libro de Autos y Visitas Canónicas, 1885-1916, f.46.
} 
suponía el socialismo. Esta identidad, de alguna manera, se construyó a instancias de marcar las diferencias con el otro.

Las denuncias sobre actividades socialistas y/o anarquistas en la campaña son escasas. En 1908, el cura de Bell Ville informaba que en conferencias pronunciadas por los anarquistas en la plaza pública, "se ha atacado y ultrajado torpísima y escandalosamente a la religión católica, al sacerdocio, a las congregaciones religiosas habiéndose establecido paralelos entre estas y los peores centros de corrupción". ${ }^{82}$

\subsection{Las logias masónicas}

En este contexto, la actividad de las logias masónicas se inscribía en el marco de elementos de disolución de la cohesión y el orden social cristiano. ${ }^{83}$ Poco sabemos del accionar concreto de estas agrupaciones, tenemos constancia de su existencia a través de noticias esporádicas recogidas por los diarios, algunas denuncias de los párrocos enviadas a la curia diocesana y escasas retractaciones in articulis mortis de miembros de logias locales. $^{84}$

En Villa María, tres días después de las elecciones municipales de diciembre de 1895, el juez de paz ordenó un allanamiento y registro del templo a partir de denuncias recibidas porque en el templo "existen vestigios de preparación para amparar gente armada en las elecciones del domingo pasado". El hecho se produjo al medio día, cuando el cura Bernardino Maciel estaba en Córdoba. Se presentó el subcomisario en el templo con dos gendarmes y la orden de allanamiento. El padre del cura, Pastor Maciel, lo atendió y rechazó la orden diciendo que él no era el representante de la iglesia y que no tenía potestad para

\footnotetext{
${ }^{82}$ AAC. Leg. 52. Curato de Bell Ville. Nota del 12/10/1909.

${ }^{83}$ AAC. Zenón Bustos. Obispo. Caja No 3, fs.1024-1032.

${ }^{84}$ Eduardo Gamound de la ciudad de Río IV era miembro Honorario de la Logia República, tercer gran Consejero Suplente de la Logia Voltaire, primer diácono de la Logia Emilio Zola y Hermano de la Logia Los Cinco Manuel Benet Bofill, natural de España, de 42 años, casado y de profesión empleado según consta en el diploma de incorporación otorgado por El Supremo Consejo y Grande Oriente del rito azul de la República Argentina, era Maestro de la Logia No 36 de los Hermanos Unidos de la Ciudad de Villa María; Carlos Corazzi natural de Italia, de 39 años de edad, iniciado en la Logia Emilio Zola el 10 de Julio de 1903; el Comandante Álvarez de la ciudad de Río IV abjuró de la secta masónica a la que pertenecía e hizo profesión de fe antes de morir; Clodomiro Corvalán quién el 10 de noviembre de 1917 in artículo mortis y ante escribano público se retractó formalmente de sus errores como miembro de la masonería y declaró que quiere morir en el seno de la Iglesia como católico confesando todo cuanto ella enseña y promete, en adelante, si Dios nuestro Señor le concede vivir que será conforme y en todo ajustado a sus leyes y doctrina ${ }^{84}$ Conocemos únicamente aquellos que antes de morir han hecho profesión de fe dejando constancia de su pertenencia a estas sectas secretas.
} 
autorizar el registro. Sin embargo, le dijo al subcomisario, no tenía inconveniente en dejarlo pasar como particular, más no como autoridad pública. En estas condiciones ingresaron al templo, recorrieron el coro, la nave y las dependencias de la sacristía y no encontraron nada.

La reflexión del cura Maciel sobre el acontecimiento era "que de las declaraciones del Juez y de los testigos, se desprende que se allanó el templo con pretextos risibles para la gente seria, con el único objeto de inferir vejamen al templo, pues todo partió de la masonería, como lo puedo comprobar". ${ }^{85}$ El día de la elección se hacía propaganda en la prensa de que en el templo había gente armada y que salieron dos tiros, cosa falsa y calumniosa. Luego, el cura pasa a relatar otro hecho sindicado como grave: "La noche antes del día del allanamiento le comunicaron a mi padre que esa misma noche iban a asaltar el templo, todo obra de masones apoyados por el sub-comisario. Inmediatamente mi padre con varios vecinos y hermanos míos se pusieron a la expectativa en ronda oculta toda la noche, mientras se organizaba esta vigilancia particular en momentos en que el templo estaba solo vigilado por mi oficial de albañilería que habita un cuarto de la torre, sintió que golpeaban las puertas del templo, diciéndole desde abajo que abriera, cosa que no hizo. Uno de los hombres, que era el sub-comisario, le dijo que se presentara a la policía al día siguiente. Apostilla el cura "si el asalto no se realizó fue porque apercibieron los movimientos de defensa ¿cuál sería el fin de ellos? Bien puede ser que se cumplieran las amenazas que me hacen los masones de quemar las muñecas, así llaman a las imágenes, o bien pudiera ser que quisieran esconder armas para hacer aparecer a la iglesia como arsenal que es lo que quieren, para tener pretexto de vejar a su antojo". A continuación, dice que "en las elecciones del próximo 24 no se que camino tomar, si dejo las puertas del templo abiertas para que se cercioren que no hay nada adentro hay peligro de que cometan toda clase de profanaciones, si las mantengo cerradas, sospecharán o protestarán que hay gente armada. [...] Las autoridades policiales no valen un clavo". ${ }^{86}$

En 1907, el cura de Bell Ville, José Pío Angulo, informaba a la curia que, en Ballesteros, “en la misma casa en que tenía lugar una fiesta oficialmente masónica, llamada por las logias 'casamiento o reconocimiento conyugal masónico' fue quemada la cruz conmemorativa de la misión que se dio el año pasado en el pueblo de Ballesteros en que se

\footnotetext{
${ }^{85}$ AAC. Cajas Parroquias, Villa María, f. 52 y ss. Nota fechada el 12/12/1895

${ }^{86}$ AAC. Cajas Parroquias: Villa María, f.53v.
} 
ha perpetrado el delito. La Cruz estaba en la fachada de la iglesia adherida a la pared". El juez tomó cartas en el asunto y detuvo a cuatro individuos, instruyendo el sumario correspondiente. Estos restituyeron la cruz y pusieron otra similar en el mismo lugar y solicitaron al cura que no iniciara ninguna acción judicial. El cura pidió instrucciones al obispo. $^{87}$

En 1906, el cura de Villa Nueva, Antonio Alonso, consultaba a la curia sobre la existencia en el vecino pueblo de Villa María de un subcomité de librepensamiento "que sustenta doctrinas radicalmente impías como esta proposición (p. ej.) la enseñanza del catecismo constituye un peligro social". El cura deseaba saber qué actitud tomar respecto a aquellos individuos que hubieran corroborado públicamente con sus firmas dichas doctrinas y se presentaran para desempeñar algún acto oficial de la Iglesia, a saber: padrinos, testigos, miembros de comisiones para erección de iglesias, etc. ${ }^{88}$

El diario "Los Principios”, en las elecciones de 1910, recogía que en Marcos Juárez ganó el "partido oficialista, a cargo de la municipalidad guiado y sostenido por la masonería y casi identificado con ella". ${ }^{89}$ El párroco de Cruz Alta denunció ante el obispo al juez de paz por haber fundado una logia masónica que "arrastró a más de ese elemento pervertido y mal sano que no faltan por desgracia en estos pueblos de campaña, a algunos bolicheros, panaderos y carniceros, los que por miedo a las persecuciones y multas que sus negativas pudieran acarrearles en sus negocios e industrias formaron un reducido número de afiliados sin conciencia en su mayoría, de los perversos fines de esa sociedad". 90

El congreso de libre pensamiento celebrado en Buenos Aires del 20 al 23 de septiembre de 1906 había llegado a conclusiones que preocupaban a la jerarquía eclesiástica local. Entre otras cuestiones, sostenía la negación de la existencia del pontificado como poder político internacional por ser contrario a la soberanía popular; el monopolio completo del Estado laico de la instrucción pública; la prohibición de las procesiones religiosas en los actos públicos; la abolición del juramento religioso en todos los actos públicos; la supresión de las órdenes monásticas; la supresión en el calendario del Estado de todas las fiestas religiosas; la supresión de todos los privilegios o exenciones a favor de los individuos que

\footnotetext{
${ }^{87}$ AAC. Leg. 52. Curato de Bell Ville. Nota del 07/09/1907.

${ }^{88}$ AAC. Leg. 48. Villa Nueva, f.523. Nota del 27/03/1906.

${ }^{89}$ Los Principios, 07/04/1910, p. 3.

${ }^{90}$ AAC. Leg. 35. Juicios Eclesiásticos, TVIII, 1904.
} 
tienen como medio de vivir el ejercicio de algún ministerio religioso; el divorcio por mutua voluntad; la sustitución de las hermanas de la caridad en los hospitales por enfermeras laicas y diplomadas; la prohibición de hacer testamento a favor de las instituciones religiosas; el servicio obligatorio de los seminaristas; la separación de la Iglesia del Estado; la aplicación del artículo constitucional prohibiendo la admisión de nuevas comunidades religiosas; la enseñanza del catecismo era vista como un peligro social y las donaciones de tierras públicas a las instituciones religiosas como contrarias al bienestar general; y, como colofón final, el catolicismo era considerado la principal causa del estado lánguido en que se encontraba América Latina. ${ }^{91}$

A medida que avanza la segunda década del siglo XX, la preocupación aumentaba. Con motivo de la reforma universitaria, durante las manifestaciones de 1918 se apedreó el palacio episcopal, se insultó al clero y a la iglesia a tal punto que el obispo diocesano, en una pastoral titulada "La revolución social", manifestó su deseo de hacer llegar a los fieles una voz de alerta, llamando a tomar el puesto que a cada cual le correspondiera en defensa de los principios que integraban la civilización cristiana y la religión católica, agredidas fuertemente por la revolución social que:

Tomará la faz aterradora de la bestia apocalíptica, que en todas las épocas del mundo ha trabajado por destruirla y hoy mas todavía. Con los esfuerzos con los que ha logrado separarla del consejo de los gobiernos y del recinto en el que se hacen las leyes, baja ahora a separarla de las masas del pueblo y de los individuos que las forman dejándolas despojadas de los atributos de obediencia y respeto a la autoridad [...] su soplo sobre las masas es revoltoso y las han tornado anárquicas [...] miró sobre Córdoba y descubrió el gran fondo de piedad que la caracteriza, su ardor por el culto católico, las grandes corrientes que rodean frecuentemente el Tabernáculo y se alimentan con el pan eucarístico, miró, se estremeció de envidia ante estas manifestaciones y levantó la guerra apasionada contra ellas a una parte de la juventud para combatirlas. ${ }^{92}$

En este clima de turbulencia, el obispo cordobés de Santiago del Estero, Juan Martín Yáñez, escribe a Monseñor Bustos una breve carta en la cual pueden percibirse los niveles de alarma:

\footnotetext{
${ }_{91}^{9}$ AAC. Fondo Zenón Bustos. Caja Nº 4, f.1303.

${ }^{9}$ AAC. Fondo Zenón Bustos. Caja No 4. "La Revolución Social”, Pastoral del 23 de noviembre de 1918, Córdoba, Tip. Los Principios, 1918, 16 pp.
} 


\begin{abstract}
Venerado Hermano:
[...] si bien separados por el espacio, nuestras almas están unidas en Jesucristo por la caridad, las alegrías y las tristezas que nos son comunes [...]. Tengo mi corazón apenado, y nada leo con más interés que los escándalos que la impiedad está dando en la católica Córdoba, para lamentarlos y llorarlos. Innumerables son los mártires que la Iglesia venera, y mártires son solo los que derraman su sangre por la fe sino los que padecen persecuciones por la justicia, en cuyo número encuentro a V.S. Ilma. Y a todos los verdaderos católicos de Córdoba. Más de 50 años hace que la masonería viene trabajando por descristianizar a Córdoba y si no dio los escándalos que se presenciaron hoy fue porque no contaba con la protección de las autoridades civiles. A V.S Ilma. Que gobierna con celo y sabiduría su ilustre diócesis le ha tocado ser víctima de los sectarios $[\ldots] .^{93}$
\end{abstract}

La imagen del martirio, sin duda, exalta la figura del prelado y le da un tinte épico, de cruzada, al combate con los "sectarios masones". Este es justamente el tono con el que se perciben los ataques contra el clero. La Iglesia se ve a sí misma como protagonista de una cruzada contra la impiedad, que avanza sobre la sociedad, urbana y rural provincial. El combate es de tal magnitud que exige llegar hasta el martirio, es decir, ser capaz de "dar la vida por la causa", que no significa solamente el derramamiento de sangre, sino sufrir la persecución. Estos conceptos aportan dramatismo y fuerza a la imagen construida del enemigo.

El prelado en las visitas animaba a los párrocos a reforzar y multiplicar el ministerio "para atajar las numerosas corrientes de propaganda insana que invaden a las poblaciones y promover asiduamente las prácticas y costumbres religiosas que nos legaron nuestros mayores, no se nos oculta que mientras mayores son los peligros que amenazan menoscabar las prácticas de la religión, mayores deben ser la contracción y resortes que se pongan en juego". 94

El clero era consciente de que mientras el pueblo fuera religioso no se haría socialista, la población era cristiana por tradición. Los censos de 1895 y 1914 dan un altísimo porcentaje de población católica. En los albores del siglo XX, la provincia de Córdoba tenía el 99,8\% de católicos, frente a un $0,2 \%$ de otras religiones (Río y Achával, 1904). Esa creencia no se traducía en el cumplimiento de los deberes cristianos, ni en una religiosidad acorde a ellas. En el auto de la visita pastoral a Capilla Rodríguez, departamento de Tercero Arriba, el prelado afirmaba que en muchos feligreses "comienza a posesionarse el grave descuido de

\footnotetext{
${ }^{93}$ AAC. Fondo Zenón Bustos. Caja N ${ }^{\circ} 2$, fs.433-434. Nota fechada en Santiago del Estero el 07/11/1918.

${ }^{94}$ AAC. Fondo Zenón Bustos. Caja No 4, f.1303.
} 
no cumplir con el precepto anual de la confesión y comunión. Es el comienzo de una enfermedad infecciosa que cundirá generalizándose de pocos a muchos con desedificación de los buenos y amarga inquietud del pastor. Conviene buscar y encontrar un arte nuevo para curar este mal". 95

En las visitas pastorales, se constató que el estado general de la feligresía, en lo religioso y moral, era deficiente. Las razones obedecían a causas diversas. En el norte, las dificultades para cumplir con los preceptos de la iglesia se debían a las excesivas distancias, a la deficiencia de los caminos y a cierta apatía o abandono de los habitantes, incluso a la negligencia de algún párroco, que no percibía un problema de fe o incredulidad. El prelado, en el auto de visita a la parroquia de Soto, decía: "Nos ha llamado la atención [...] la poca frecuencia de los sacramentos que hemos notado en la parroquia tanto más que esto parece ser efecto de la falta de benignidad y caridad en el Párroco para tratar a los fieles que se acercan buscando la práctica de los sacramentos". 96 El este y sur suponían una preocupación para el diocesano debido a la influencia y a la acción de "la propaganda impía", la población se caracterizaba por una mayor ignorancia religiosa y por el desconocimiento u olvido de los preceptos de la Iglesia, en relación a las regiones del norte y el oeste. El obispo entendía que la feligresía de San Francisco vivía en un "ambiente de indiferentismo, una población completamente materializada en sus ideas e inspiraciones". 97 El párroco de Bell Ville informaba en 1915 que casi la totalidad de la población era católica, si bien la mayor parte no eran prácticos, ${ }^{98}$ y en Porteña había muchos "malos cristianos". 99 El indiferentismo, incluso la apatía, de los fieles en cumplir con sus obligaciones con la iglesia, y la renuencia de algunos párrocos a cumplir con su ministerio sacerdotal, eran inconvenientes frecuentes Las palabras del delegado del gobernador diocesano, expresadas en el auto de la visita canónica al curato de San Francisco, son elocuentes:

Si la iglesia, única que puede salvar a la moderna sociedad, no realiza entre nosotros, con eficacia su acción en el orden social de acuerdo con las necesidades de la hora presente, es debido, más que a las oposición del enemigo a la falta de acción de sus

\footnotetext{
95 AAC. Parroquias: Capilla Rodríguez. Visita Canónica, 09/05/1909.

96 AAC. Carpeta Curia, Visitas Pastorales y Varios, 1887-1911.

97 AAC. Parroquias: San Francisco. Auto de la Visita Canónica de 1922, f.117.

${ }^{98}$ AAC. Parroquias: Bell Ville. Respuesta al cuestionario de la Visita Canónica, noviembre de 1914, f.1910.

99 AAC. Parroquias: Porteña. Respuesta al cuestionario de la Visita Canónica, junio de 1915, f.121.
} 
hijos y a la falta de perfecta sumisión a sus indicaciones y directivas, no menos que a la mezquindad con que ofrecemos nuestros esfuerzos y sacrificios los que debiéramos en todo momento y en todos los campos, ser sus apóstoles celosos y abnegados. Pedimos pues al Sr. cura al terminar esta visita que por convicción de su necesidad y por obediencia tome el debido interés en esta obra que en todas partes es buena y santa, en ciudades como ésta reclama, por cierto, carácter de verdadera necesidad. ${ }^{100}$

La restauración de la práctica religiosa en el ámbito urbano-rural de pueblos, villas y colonias sería una de las metas del gobierno diocesano, para ello se propuso organizar y dirigir la "acción católica", en el marco de las iglesias parroquiales, cuestión que analizaremos en el próximo capítulo, adelantamos que el objetivo principal de la misma apuntará a formar núcleos de católicos comprometidos -dirigidos y orientados por el clero parroquial-, dispuestos a colaborar con la "restauración cristiana de la sociedad". Para ello, se resignificó la función de la parroquia en relación a las exigencias y necesidades planteadas por el nuevo contexto social en el marco del proceso de modernización.

El obispo defendió y sostuvo con fuerza tres posiciones básicas, la indisoluble relación entre religión y moralidad, los "grandes" beneficios sociales que de esa unión se obtendrían, y la educación religiosa como instrumento idóneo para inculcar modelos de conducta, pues entendía que la ignorancia de la religión era uno de los principales obstáculos que el párroco debía sortear, ya que las clases trabajadoras "ni pueden amar la Religión que ignoran. Ni pueden prestarse a modelar por ella sus actos si ignoran su santidad y pureza". ${ }^{101}$

Sobre estos principios, impulsó una acción pedagógica en los sectores populares que se apoyó en la función del templo, la acción del párroco y las asociaciones parroquiales, cuyos contenidos básicos se sintetizan en los siguiente postulados: a) la igualdad de los hombres consiste en que todos son llamados a la misma dignidad de hijos de Dios; b) en la sociedad civil hay varios ordenes, diversos en dignidad, derechos y potestad; c) no es lícita la insurrección contra la autoridad; d) el derecho de propiedad debe mantenerse intacto; d) sólo se justifica la desobediencia a la autoridad cuando falta la conformidad entre el mandato de aquella y la del mismo Dios; f) la abundancia de bienes terrestres no importa

\footnotetext{
${ }^{100}$ AAC. Parroquias: San Francisco. Respuesta al cuestionario de la Visita Canónica de 1922, f.117. El subrayado es nuestro.

${ }^{101}$ AAC. Libro 45, f.374.
} 
para la bienaventuranza eterna; g) los males de la sociedad humana no pueden tener otro remedio que no sea la restauración de la vida e instituciones cristianas.

\section{El clero frente a la celebración del XX de Septiembre}

La fiesta del XX de Septiembre fue, sin duda, un punto de difícil resolución para los curas párrocos de los departamentos colonizadores. Los obispos diocesanos fueron muy claros respecto a la significatividad de la fecha.

En 1882, el Obispo Esquiú señalaba que "hacía doce años que el obispo de Roma vivía prisionero en el Vaticano, sitiado de todo poder enemigo, la fuerza, la astucia, la hipocresía, un odio a muerte y el peligro hasta las demostraciones del amor y veneración de los fieles. Pío IX vivió así durante siete años y cuatro meses y León XIII, su prodigioso sucesor, vive así hace ya cuatro años". Ante esta realidad, el obispo convocaba a los fieles de la diócesis a una triple acción: "protesta, oración y socorro. Todos los católicos debemos este triple obsequio a nuestro común Padre, el vicario de Jesucristo en la Tierra". ${ }^{102}$

Para los italianos era una verdadera fiesta cívica y la celebraban como tal. En algunas ocasiones, las comisiones solicitaban la celebración de la misa en el marco de dichos festejos. En 1894, el cura de San Francisco escribía al obispado para informar que había llegado a sus manos un "manifiesto de los vecinos de Colonia Porteña perteneciente al curato de San Pedro, en el cual se dice que el Veinte de Septiembre con grandes fiestas se solemnizara la Caída del Poder Temporal del Papa y se bendecirá la nueva iglesia [...] ignoro quien bendecirá dicha Iglesia". ${ }^{103}$

Unos años antes, en noviembre de 1881, la sección noticias del periódico "La Prensa católica", publicaba la noticia de que el capellán de Colonia Sampacho, Vicente Lozino, había sido participado como promotor de las fiestas del XX de Septiembre celebradas en la colonia. El cura solicitaba al obispado la vindicación por lo que consideraba una infamia. "Esta infamia Señor mancha mi conducta y empaña mi fe. Por cuya razón suplico se digne hacer levantar una sumaria información para que aparezca la verdad y quede a salvo mi reputación. V.S. Ilustrísima no desconoce que esos hechos denigran la conducta de un sacerdote, y declaro ante Dios y ante los hombres que nunca he participado de las ideas

\footnotetext{
102 AAC. Caja Parroquias: Santa Rosa de Río 1. Fray Mamerto Esquiú, Carta del 01/01/1882.

${ }^{103}$ AAC. Leg. 49. San Francisco. Nota del 05/09/1894.
} 
italianas y siempre he sido adicto a la causa del rey de Nápoles y a la Santa sede de quién soy hijo obediente y sumiso". ${ }^{104}$ El obispo nombró en comisión al cura del sagrario de la catedral, Gregorio Ardiles, a fin de que se trasladara a Sampacho para verificar los hechos denunciados.

El primer testigo fue Amadeo Miranda, argentino, casado, oriundo de Salta y administrador de la colonia. Informó que ignoraba que el cura Lozino hubiera sido el promotor de la fiesta del XX de Septiembre. Que lo único que sabía es que ese día fue invitado a un almuerzo en casa del colono José Pistoletti y con ese motivo concurrió el día citado a las 12 del medio día. Allí estaban reunidos unos ocho colonos que también habían sido invitados por el mismo motivo, había hijos del país, tiroleses e italianos. Que no vio ni estuvo allí el Pbro. Lozino y cree que ni siquiera fue invitado. En cuanto a la participación de dicho cura en la fiesta, sólo sabe que como a las siete de la tarde del mismo día concurrió a la casa del declarante una comitiva de veinte colonos, entre los que se encontraba el cura y un sobrino suyo llamado Francisco Sogarno, quien le expresó, en nombre de los colonos, su agradecimiento por los honrosos conceptos vertidos por el declarante en el almuerzo, sobre la honradez, la común unión y laboriosidad ejemplar de los colonos, invitándolo a tomar un café a su casa a la que concurrió. Ante la pregunta relativa a si el Pbro. Lozino dijo algún discurso en la fiesta de ese día, si se hizo mención al Soberano Pontífice, o se ha encomiado el despojo de Roma practicado por las tropas de Víctor Manuel, rey de Italia. El testigo declaró no escucho hablar palabra alguna sobre el Soberano Pontífice ni sobre la ocupación de Roma de las tropas italianas. A continuación declaró como testigo José Pisoletti, italiano, casado, domiciliado en la colonia, afirmo que sabe y le consta que el padre Lozino no ha sido promotor de la fiesta italiana y que no ha oído a Lozino decir discurso alguno, que los únicos pronunciados fueron los del señor administrador, en todo los demás la declaración es coincidente con la anterior. Luego declaró el médico, Luis Charelli, italiano soltero, residente en la colonia. Que sabe y le consta que el Pbr. Lozino no participo ni fue promotor de fiesta alguna. Que su participación se redujo a haber acompañado a los colonos a la casa del administrador y compartir un café en casa de su sobrino con otros colonos y que no dijo ningún discurso. El fiscal eclesiástico considera infundado los cargos hechos contra el cura Lozino.

${ }^{104}$ AAC. Leg. 35. Juicios Eclesiásticos, 1871-1905, TVIII. 
En 1897, Fray Reginaldo Toro dedica un Auto a este tema, en donde refleja su mirada sobre la celebración del XX de Septiembre. "El próximo 20 de septiembre se repetirán con amargura de nuestro corazón las manifestaciones de odio, que un año tras otro se vienen haciendo por los enemigos de Dios y de su Cristo contra el supremo jerarca de la Iglesia Católica, obedeciendo la consigna de los sectarios factores mantenedores del funesto estado de cosas creado el año 70 en Italia con la ocupación de la Roma de los Papas. Y si la masonería sigue invocando a lo que ella denomina 'Genio de la Humanidad' a fin de que todos los hermanos hagan el último esfuerzo para disgregar las piedras del Vaticano y construir con ellas el templo de la razón emancipada, sería una cobardía, una ingratitud, y aún más una perfidia el que los hijos de la Iglesia presenciemos silenciosos e indiferentes ataques, insultos y calumnias que en el día mencionado dirigirán contra el Pontífice Romano [...]. Triste, muy triste, hijos en J.C. es la condición de estos tiempos. La Iglesia de Dios vive encadenada por las potestades civiles, las potestades civiles se hallan dominadas por la masonería, y la masonería es esclava de Lucifer; y si las piedras del Vaticano no han sido hasta ahora removidas para levantar con ellas el templo de satanás, [...] Por tanto, amados hermanos e hijos apresurémonos a formar parte de los elegidos de Dios, procuremos fortalecernos en la fe; y aumentando nuestras fuerzas procuremos abreviar los días de tribulación que pesan sobre la Iglesia y su augusto Pastor. Formemos un ejército aguerrido y disciplinado, que pelando las batallas del señor nos haga merecer la victoria [...] Cómo buenos cruzados debemos añadir a la acción la oración [...]. Los días 18, 19 y 20 se celebrarán un triduo de desagravios y de plegarias por el Sumo Pontífice en todas las Iglesias y capillas públicas de nuestra diócesis [...]. El domingo 19 se hará una devota peregrinación al Santuario de Nuestra Señora del Milagro". ${ }^{105}$ El obispo cierra el auto concediendo cuarenta días de indulgencia por la asistencia a las celebraciones mencionadas.

El 12 de septiembre de 1906, el Obispo Zenón Bustos publica un nuevo auto con motivo del "aniversario sacrílego de la ocupación de Roma", en el que ordena a "los católicos de la diócesis se abstengan de tomar participación alguna en las fiestas que los enemigos del Pontificado so pretexto de patriotismo suelen hacer en esta ocasión". 106

\footnotetext{
105 AAC. Caja Parroquias: Santa Rosa de Río 1, Fray Reginaldo Toro, Auto sobre el XX de septiembre, 15/09/1897.

${ }^{106}$ AAC. Fondo Zenón Bustos. Documentación varia, Caja N 5, f.1937.
} 
Al año siguiente, publica otro auto, de contenido similar al anterior, y vuelve a recordar que los católicos se abstengan de participar "en las fiestas de los enemigos del Pontificado". El auto dispone: “ $1{ }^{\circ}$ ) que en todas las Iglesias y capillas públicas de esta ciudad se celebre en los días 18, 19 y 20 un triduo de desagravio que consistirá en la exposición pública o privada del Santísimo Sacramento, rezo del rosario y las letanías". ${ }^{107}$ Los curas párrocos de los pueblos y las colonias italianas, en ocasiones, se encontraban con cuestiones de difícil solución, pues sus feligreses celebraban esta fiesta cívica y solicitaban la presencia del cura.

En 1894, el cura de San Francisco, elevó un informe a la curia, en el cual dice haber tomado conocimiento y haber pasado por su manos un manifiesto de los vecinos de Colonia Porteña, perteneciente al curato de San Pedro, "en el cual se dice que el Veinte de septiembre, con grandes fiestas se solemnizará la caída del Poder Temporal del Papa y se bendecirá la nueva iglesia”. El cura señala que nada sabe al respecto y que ignora quién bendecirá dicha Iglesia. ${ }^{108}$

El médico de Camilo Aldao, curato de Cruz Alta, Domingo Scasso elevó a la curia un informe detallado de la conducta del capellán Resquejo y del párroco Domingo Arnedo. Primero, ocupó el cargo de capellán provisoriamente y luego de manera efectiva, porque el nuevo capellán no cumplía con su deber. Entre las acusaciones se encontraba su participación en las fiestas del XX de Septiembre. "Es el primer año Ilmo Sr Obispo, que las fiestas del 20 de septiembre han adquirido en este pueblo el carácter de tales. Debido sin duda a la ignorancia y recelo de las gentes, esas fiestas que duraron tres días se convirtieron en real entusiasmo al ver que el Sr. Capellán fue a rezar una misa bien pagada en los galpones improvisados para el objeto en medio del campo y donde concurrieron no menos de 3000 personas. El Sr. Capellán después de la misa asistió al baile como lo había hecho ya en otras ocasiones". Con motivo de la denuncia, el inspector de parroquias, Pbro. Manuel López, se trasladó al lugar y confirmó los hechos denunciados, “que ha dicho misa de campaña en las fiestas celebradas por los italianos el 20 se septiembre, festejando la toma de la ciudad eterna. Si bien este cargo parece no pudiera ser cierto, es sin embargo un hecho aunque vergonzoso puesto que ha sido presenciado por toda la colonia la cual en su mayor parte asistió porque se celebraba el santo sacrificio de la misa". ${ }^{109}$ En 1913, el cura

\footnotetext{
${ }^{107}$ REOBA, septiembre de 1907. Zenón Bustos, Auto del 15/09/1907.

${ }^{108}$ AAC. Leg. 49. San Francisco, s/f. Nota del 05/09/1894.

${ }^{109}$ AAC. Cajas Parroquias: Cruz Alta. Informe del inspector de parroquias del 29/05/1905.
} 
de Bell Ville, Fortunato Gambini, denunció a la curia que el cura Donato Latella "celebró misa en Corral de Guardia, en circunstancias muy impropias, pues festejaban la fecha sacrílega del XX de septiembre". ${ }^{110}$

La parroquia de Dalmacio Vélez, erigida en 1914, fue encomendada a los Padres Trinitarios. Los vecinos de Hernando, jurisdicción perteneciente a dicha parroquia, presentaron una queja al obispo diocesano Zenón Bustos por las actitudes de los padres con las sociedades italianas en relación a los festejos del XX de septiembre: "Desde hace años los modestos italianos de la colonia de Hernando, nos vemos vituperados por los Padres trinitarios de Dalmasio Vélez [...] se permiten insultar cuando la colectividad italiana hace en ocasiones Fiestas Patrias [...]. En ocasión de la fiesta del XX de septiembre que universalmente es solemnizada, estos señores padres persisten en su costumbre de elevar públicamente con largas conferencias el vituperio a nuestra sociedad (como sucedió en el momento de la misa que se ofreció el 11 del corriente) protestando porque el comité profiesta XX de septiembre en su programa alude históricamente al héroe de la astronomía Galileo Galilei. El mismo comité nombró una comisión honorifica en su mayor parte de colonos y los mencionados padres sean permitido visitarlos chacra por chacra, haciendo una propaganda subversiva a los festejos aludidos. Llegando su poco tino a apersonarse a nuestro médico Dr. Víctor Porta, presidente del comité de festejos, exigiendo la renuncia del cargo, y no pudiendo conseguir su intento, quisieron trazarle los limites sobre el discurso en conmemoración de la próxima fiesta [...]. Esos señores padres creen formar el descontento entre los mismos socios de una sociedad italiana más católicos que los mismos padres trinitarios". 111 El boletín parroquial que se distribuía en la zona, llamado "El Cruzado", había publicado una breve nota titulada "Guerra a las sacrílegas bananales del XX de septiembre". La nota era un llamado para evitar la realización de dichas fiestas, en este sentido vale la pena trascribir un breve párrafo en el que es posible valorar el tono combativo y militante del texto:

Hasta cuando hemos de permitir los católicos que todos los años se vea en esta fecha tan cínicamente ultrajada en nuestra presencia la majestad augusta del Romano Pontífice?

\footnotetext{
${ }^{110}$ AAC. Carpeta Curia. Vistas Pastorales y varios, 1912-1916, s/f.

111 AAC. Caja Parroquias: Dalmasio Vélez, sin fechar, fs.60-61.
} 
Pero está en nuestra mano el estorbarlo?

Sin duda ninguna.

Retiremos los católicos nuestro concurso, hagamos propaganda, toda la propaganda posible entre nuestros correligionarios argentinos e italianos para boicotear estas sacrílegas fiestas, y ellas desaparecerán de nuestro suelo.

No, no cuenta en nuestras poblaciones la masonería con tantos elementos que basten ellos solos, sin el auxilio de los católicos, para festejar los sacrílegos atentados del 20 que Septiembre conmemora.

Madres de familias, vosotras de que católicas os preciáis en vuestras manos está el ver suprimidos lo impíos festejos.

Prohibid, estorbad, impedid a todo trance que tomen parte en los bailes, en los conciertos, en las manifestaciones todas del 20 de Septiembre vuestras hijas, esas hijas a quienes con tanto esmero habéis instruido en la religión católica que tan ultrajada contemplamos todos los años en ese infausto aniversario.

Con solo eso desaparecerán de nuestro pueblo los festejos del 20 de Septiembre.

Procurarlo con todo empeño, es un deber, un serio deber religioso. ${ }^{112}$

Para el clero italiano, las fiestas del XX de septiembre, principalmente, suponían, con frecuencia, un problema en la relación con sus feligresías. En 1910, Domingo Lupo, capellán de Colonia Freyre, ante una notificación del prelado por una denuncia recibida sobre su participación en las fiestas del XX de septiembre, respondió con una nota que nos permite, al menos, vislumbrar el problema:

Me es grato decirle que yo nunca contribuí a los festejos del XX septiembre, no solo eso, sino he tenido sermones contrarios a la fiesta en la capilla a mi cargo. Yo soy italiano, no dejo de ser católico, y si no hostigo a quienes tienen creencias contrarias a las mías en cosa de religión, ni tampoco los ayudo. Estuve socio de la Sociedad italiana cuyo objeto es el mutuo socorro y no festejar el XX de septiembre, ahora no soy más porque he creído mi deber retirarme de una sociedad en la cual me respetaban como socio, y no como sacerdote, y tan es verdad, que estos mismísimos jefes me hacen guerra sin cuartel y para desprestigiarme dicen que me invitan a cantar el Te Deum el día mismo del XX de Septiembre [...] Pero si supiera si es uno de los socios que me denunció ante el $\mathrm{Sr}$ obispo, le aseguro que quien acabaría este asunto es el juez, tanto estoy seguro de lo que le acierto. Si V.S tuviera la amabilidad de decirme quién me denunció, me haría un favor, pues podría pegar en la cara a mis denunciantes, con el mismo papel que me denunciaron. ${ }^{113}$

La respuesta del capellán llevó al secretario del obispado a pedir informes a algunos vecinos respetables de la colonia. Francisco Battista responde "en cuanto a las informaciones reservadas que S.I. Ilma. me pide referente a la conducta de nuestro sr cura, le diré con toda franqueza que aquí es muy querido por todo el vecindario y siempre se

\footnotetext{
${ }^{112}$ AAC. Cajas Parroquias: Dalmasio Vélez, sin fechar, f.60.

${ }^{113}$ AAC. Cajas Parroquias: Freyre. Nota del 04/08/1910.
} 
portó muy bien con todos y trabajó mucho para fundar una sociedad de socorro católica, para unir las fuerzas, pero a consecuencia de los males anticlericales no pudo conseguir nada. Yo he tenido el honor de acompañarlo por cuatro años como presidente de la comisión pro- templo desde el día de su llegada a ésta, hasta la creación de la parroquia, he tenido bastante tiempo para conocerlo, así que puedo asegurarle que ese cura se merece aprecio [...]. Los denigradores del cura son cobardes que usan el arma del anónimo para criticarlo, estos individuos son nada más que cuatro o cinco que nunca pisan ni el umbral de la puerta de la Iglesia, sirven nada más que para calumniar y despreciar al cura y a los que van a la iglesia [...]. Me permito agregar todavía una consideración, al trasladar a dicho cura a otra parte, no le rebaje, que los anticlericales cantarían victoria y los feligreses pasaríamos un bochorno". ${ }^{114} \mathrm{El}$ cura envió una nota a la curia en la que solicitaba que lo "sumariasen, tan seguro estoy de mi conducta". 115

Está claro que el XX de septiembre suponía un problema para los párrocos de las comunidades italianas. Sus feligreses con frecuencia festejaban estas fiestas liberales y solicitaban al cura la bendición de las banderas italianas. Para el capellán de Baldisera, la disyuntiva era seria, negarse al petitorio supondría la enemistad con gran parte de su feligresía y bendecirlas significaba una afrenta para la iglesia. ¿Cómo resolver el conflicto? El cura accedió a bendecir las banderas italianas fuera del templo y se negó a celebrar la misa en dicha ocasión.

Para cerrar este capítulo, podemos decir que la secularizaron de la sociedad encontró al clero en posiciones diversas. En el campo político, la tradición de su participación en la vida política provincial pesó mucho y generó resistencias a la imposición del obispo de no hacerlo. En cuanto a la secularización de la sociedad y la emergencia de actores socialistas y anarquistas, los dispositivos de la jerarquía, en concordancia con la elite dirigente, estuvieron dirigidos a hacer frente al avance de ideologías seculares percibidas como perturbadoras del orden social. Las medidas se centraron en la conservación de los valores, los modelos y las prácticas sociales y culturales que estaban arraigadas. Puso en vigencia y resignificó la tradición. El discurso eclesiástico estuvo destinado a reforzar la dimensión comunitaria y emocional de los católicos. Presentar a la masonería y el socialismo como

\footnotetext{
114 AAC. Parroquias: Freyre, f.139.

115 AAC. Parroquias: Freyre, f.143.
} 
peligros del orden social cristiano implicaba la construcción de una imagen acabada "del enemigo", que llevaba a reforzar la propia identidad religiosa. La jerarquía puso en práctica los dispositivos del tradicionalismo fundamental, descriptos por Hervieu-Léger (1977: 4), según el cual se pusieron en funcionamiento cuatro lógicas: una lógica comunitaria, que se refiere a la delimitación social del grupo religioso y a la definición formal de las pertenencias; una lógica emocional, que concierne a la producción del sentimiento colectivo de la pertenencia (el sentimiento de formar un nosotros); una lógica ética, que pone en juego la definición de los valores compartidos en el seno del grupo, valores transformados en normas de comportamiento; y una lógica cultural, que reúne los saberes constitutivos de la memoria común, a la vez histórica y legendaria del grupo. 


\section{CAPITULO 15}

\section{Las nuevas prácticas pastorales: estrategias de cristianización de la vida moderna y de modernización de la vida cristiana}

\section{El poder pastoral: la parroquia como núcleo de la vida religiosa en la campaña}

El modelo de parroquia que surge a partir de la segunda mitad del siglo XIX y se consolida en los albores del XX, poco tiene que ver con el anterior, propio de sociedades de unanimidad religiosa, en las cuales tenía mucho peso la preparación para la otra vida, los ritos de la muerte, la vida penitente y la idea de pasar por esta vida para ganar la eterna. En estas sociedades, las cofradías y hermandades inscriptas en los templos reunían fieles con vista a facilitar el tránsito a la otra vida, rogar la ayuda de los santos ante las calamidades de esta vida, pestes, malas cosechas, enfermedades, etc. Procesiones, rogativas y novenarios, formaban parte de las prácticas religiosas que buscaban el amparo divino ante las necesidades y penurias temporales (Di Stefano, 2002a: 33; Martínez, 2011).

La omnipresencia de la muerte, provocada por una infinidad de causas, que iban de los malones y la guerra, a las grescas violentas; de los partos y enfermedades, a las pestes y sequías; obligaba a prepararse para una buena muerte, de allí que los testamentos revelen las disposiciones en torno a ella. Los entierros y funerales, las honras y pompas fúnebres, el lugar de sepultura, las misas gregorianas, los novenarios, las honras de aniversario, demostraban el vínculo de esa sociedad con sus muertos. Como advierte Di Stefano (2002a: 37) al describir las cofradías: "La ayuda se extendía asimismo a las necesidades de la muerte, que en la sociedad católica colonial no eran pocas. El imaginario religioso contemplaba fundamentalmente tres espacios de la muerte, el infierno, el purgatorio y el paraíso, y tres categorías de fieles correspectivas: los de la Iglesia militante, aun inmersos en la experiencia terrena; los de la Iglesia purgante, que debían purificarse para ser admitidos en el Cielo; y los de la Iglesia triunfante, que gozaban de la contemplación de Dios. Estas consideraciones representaban una cuestión central en la vida de las personas, más importante incluso que las enfermedades y la asistencia médica. La muerte era considerada menos como punto de llegada de la experiencia vital que como pasaje a otras condiciones de existencia, un tránsito en el que los hombres necesitaban más que nunca de los demás". 
En la tercera parte de la tesis, vimos que, durante la primera mitad del siglo XIX, el templo, en la campaña cordobesa, no tenía una significación de importancia en la vida de las personas, se acudía a él pocas veces al año (fiestas patronales) e incluso pocas veces en la vida. El bautismo era administrado con mucha frecuencia por bautizadores seglares, muchos de quienes contraían matrimonio lo hacían en domicilios particulares, quizá la presencia en el templo era frecuente a la hora de las honras y ritos fúnebres, al final de la existencia, como un rito de pasaje a la otra vida. La enseñanza religiosa solía impartirse en el seno de cada familia, el cura no siempre cumplía el deber de residencia, predicaba poco, en circunstancias especiales y la enseñanza del catecismo no estaba en absoluto regulada ni era sistemática. De hecho, muchos templos de la campaña estaban en la segunda mitad del siglo XIX en ruinas. ¿Por dónde pasaba entonces la vida parroquial en la campaña? Poco sabemos de ello, daría la impresión que casi no existía. Valentina Ayrolo (2007: 138) advierte que la falta de sacerdotes que cumplieran sus funciones era usual y que los feligreses sentían que sus vidas quedaban a merced de la naturaleza. La ausencia del sacerdote dejaba sin cubrir etapas importantes de la vida, como el ingreso a la pubertad y a la adultez, cambios marcados por la comunión y la confirmación. Sin sacerdotes que bendijeran cada una de estas etapas, los cambios en la vida de los fieles se vivían con marcada inquietud. María Elena Barral (2007: 16) en cambio, rescata a la parroquia como una institución activa y vigente para el período tardo colonial. Señala que, en la campaña bonaerense colonial, el templo, con su campanario, atrio y cementerio -e instituciones como las cofradías - fueron elementos simbólicos de gran presencia para la formación de un sentimiento de pertenencia a la localidad y de identidad. Roberto Di Stefano (2004: 193212) nos habla de una institución desmantelada que comienza a institucionalizarse sobre la base de un programa civilizador e ilustrado que tendría también sus resistencias. De todos modos, el papel real de la parroquia durante los cincuenta años que van de 1825 a 1875 aún no ha sido objeto de estudio.

Nosotros advertimos que, a partir de la segunda mitad del siglo XIX, la parroquia comienza a organizarse para dar respuestas a una sociedad que es cada vez más plural, que mira al individuo inserto en el mundo moderno, que debe velar por consolidar los vínculos y lazos sociales en el marco de la diversidad de creencias. En el Capítulo 13, vimos cómo las prácticas de la muerte se resignifican en el contexto de sociedades modernas, en las 
cuales el individuo es el centro de referencia; las antiguas hermandades y cofradías no desaparecen, no obstante dan paso a nuevas asociaciones vinculadas al apostolado seglar (Apostolado de la Oración); la promoción social de los más indigentes (Las Conferencias Vicentinas); la dignidad del trabajador (Círculos de Obreros y Liga Social); enseñanza de la doctrina (Congregación de la Doctrina Cristiana) y la Unión Popular Católica, entre otras. Estas asociaciones estaban orientadas a llevar a cabo la acción católica, es decir la acción de los católicos en las sociedades modernas.

La parroquia representa una estructura espacial que toma consistencia en función de diversas variables, se presenta como el lugar legítimo y necesario de la administración de sacramentos; el lugar destinado a la participación de los fieles en el culto; la organización de las feligresías en orden al trabajo; un espacio de socialización y recreación, la ocupación simbólica del espacio público. La parroquia se convierte entonces en una institución que, por voluntad del obispo, apunta a encuadrar a los fieles mediante la creación de un espacio-tiempo adaptado a las prácticas de los fieles, se busca llevar la parroquia a los fieles y de acercar a los feligreses a la parroquia. Se trata de imprimirle una función de doble dimensión: la inclusión de las poblaciones dentro de la Iglesia y la expansión de la iglesia fuera del templo, a los espacios públicos: calles, plazas y campos. Este modelo se conformó paulatinamente y no sin resistencias.

$\mathrm{Al}$ asumir el gobierno de la diócesis en 1876, Eduardo Alvarez envía, como dijimos, una circular sobre las orientaciones pastorales para la atención de los curatos. El documento delinea los puntos centrales que, a su parecer, debían cuidar los párrocos para ser eficaces en su ministerio: "siendo grandes los bienes que se derivan del buen arreglo de las parroquias, nada ha preocupado tanto al actual prelado diocesano desde que asumió el gobierno de esta Iglesia como el deseo de exitar el celo de los párrocos a fin de que no dejen vacíos en el cumplimiento de sus sagrados deberes". El primer punto hacía referencia al deber de los párrocos de mantener limpios los templos y objetos sagrados "con el aseo y decoro convenientes a las altas funciones que están destinados"; el segundo punto se refería a la necesidad de enseñar el catecismo en todas las escuelas del curato, "siendo Ud. el primero en dar ejemplo, enseñándolo, por los menos, todos los domingos en su Iglesia, mirando sobre todo a los niños que se preparan para la comunión y a los ignorantes que deseen contraer matrimonio"; el tercer punto recordaba el deber consignado en el Concilio 
de Trento de explicar a los feligreses el Santo Evangelio todos los domingos y días de fiesta y con mayor frecuencia en los tiempos de adviento y cuaresma; el cuarto punto, como hemos señalado, se refería a la atención de moribundos; el quinto, hacía referencia directa al ejemplo de vida y honorabilidad que debían dar los clérigos, sobre todo aquel que tenía la cura de almas, con mayor responsabilidad de edificar a sus feligreses. Por lo tanto, recuerda la prohibición de asistir a ciertos espectáculos y entretenimientos impropios del carácter sacerdotal. ${ }^{1}$ En esta circular, de alguna manera, están invocados algunos de los elementos sobre los que se edificará el nuevo concepto de parroquia: conducta ejemplar y edificación de los fieles; enseñanza de la doctrina; predicación; administración de los sacramentos; y centralidad del templo. A estos puntos, se agregarán algunos otros, como la centralización del gobierno; la creación de nuevas asociaciones parroquiales con un compromiso más militante por parte de sus miembros; la realización de un apostolado más masivo, valiéndose no sólo de la predicación y la enseñanza del catecismo, sino también de medios de esparcimiento modernos como proyecciones cinematográficas y "buena prensa". La ocupación real y simbólica del espacio público, como plazas y calles, mediante la organización de misiones ambulantes, procesiones, primeras comuniones masivas, etc.

Uno de los puntos centrales del nuevo modelo de parroquia fue sin duda el compromiso militante de sus miembros. La iglesia llamaba a los católicos a comportarse como tales en todos los espacios. En 1922, el cura de Villa Concepción del Tío se dirige a los miembros de la Comisión pro-templo de Balnearia para amonestarlos por la conducta asumida frente a la creación de un prostíbulo en las afueras del pueblo. La carta es un reflejo del poder pastoral que ejerce el cura y la responsabilidad exigida a los católico comprometidos, "los acontecimientos a los que me refiero son la instalación de un prostíbulo y la próxima apertura de otro nuevo foco de perversión del mismo género, como si uno solo no bastara para corromper el organismo social de un pueblo! [...] Digo que algunos miembros de la comisión pro templo [...] miembros a la vez de la comisión de fomento, pudiendo hacer mayoría en el seno del Consejo cuando el proyecto del prostíbulo fue presentado y dar su voto en contra, lo dieron a favor o se abstuvieron de votar, lo cual está muy en pugna con el carácter de miembros de la Comisión pro-templo, lo mismo que se oponen diametralmente a los fines moralizadores de la Iglesia, con los resultados deplorables de la prostitución. Yo

\footnotetext{
${ }^{1}$ AAC. Leg. 53, s/f. Circular del 31/12/1876.
} 
no puedo aprobar la actitud de quien por no sentirse perturbado en su bienestar personal, permanezca impasible ante el avance de los escándalos [...] Los miembros de la comisión pro templo tuvieron sin duda conocimiento de que debía instalarse el prostíbulo y no comunicaron al párroco para haber emprendido la campaña en contra, en tiempo oportuno, yo creía que formábamos una sola fila, pero ahora veo que ustedes o nunca estuvieron del lado del párroco o si estuvieron ahora desertaron". 2 Por estas conductas, el cura retiró al capellán permanente que residía en el pueblo y dependía económicamente de dicha comisión y sujeta a su persona la atención espiritual del mismo.

En la tercera parte de la tesis, vimos la centralidad que adquiría el templo en el proyecto de institucionalización de la Iglesia diocesana de Córdoba. En la cuarta parte, presentamos cómo se delineó un nuevo perfil de clero en orden a la acción de la iglesia en una sociedad cada vez más plural. En la quinta, analizamos el lugar del clero en la sociedad que se seculariza, la resistencia de algunos clérigos a retirarse de la actividad política partidaria y el llamado de los obispos diocesanos a un compromiso pastoral y social de mayor envergadura. En este capítulo, veremos cómo se delinea y se lleva a la práctica el instrumento adecuado para llegar con el mensaje cristiano a la sociedad: la resignificación de la parroquia.

\section{La consolidación de un nuevo modelo de parroquia}

"La Revista Eclesiástica del Obispado de Buenos Aires" dedica varios editoriales a explicar y redefinir el tipo de parroquia que "los nuevos tiempos necesitan". El acápite del artículo dice: "Restaurar cristianamente la sociedad, quiere decir restaurar la vida parroquial":

La labor que cada pastor de almas despliegue en pro de la resurrección de aquella familia que se llama parroquia, será la más meritoria, la más saludable, la más eficaz. Pero a los esfuerzos reconstructores del párroco debe añadirse la cooperación de todo católico, de toda la familia católica [...] es necesario que junto a la actividad religiosa y espiritual del párroco, florezca una acción moral y social que inspire y conforme aquella, siempre obediente y fiel. [...] los tiempos ya muy diferentes piden y exigen providencias nuevas, adecuadas y eficaces. De esta realidad deben estar todos convencidos; este hecho debe existir en la conciencia de cada uno, sea del párroco

\footnotetext{
${ }^{2}$ AAC. Parroquias: Balnearia. Nota del 16/12/1922.
} 
como de todo fiel, de manera que a los confines más extendidos del error responda un campo más amplio de saludables actividades". 3

El objetivo principal del Obispo Zenón Bustos fue consolidar la parroquia como centro pastoral y renovar las formas de participación. Era responsabilidad del cura acercar a todos los que se hubiesen alejado de la Iglesia por la acción de "la nueva propaganda" (entiéndase el socialismo) y formar centros parroquiales destinados a fines religiosos, benéficos, sociales y asistenciales. ${ }^{4}$ La función de la parroquia sobrepasaba los objetivos de índole puramente espiritual, ella debía ejercer una función social más relevante.

El concepto de parroquia que se desprende de las fuentes analizadas es amplio. Remite a la creación de vínculos de solidaridad entre el párroco y los feligreses y a una participación más activa de los seglares en la acción católica parroquial, siempre bajo la dirección del cura. A través de la parroquia, la Iglesia alcanzará un notable grado de influencia en amplios sectores de las comunidades locales en las que se insertaba. La vida parroquial se convertirá en el elemento primordial en orden a la restauración social cristiana. ${ }^{5}$ Aparece como una institución estrechamente ligada a la comunidad, socialmente heterogénea que combina la devoción con la acción colectiva y, a su vez, estará fuertemente controlada por el clero. Se sitúa, de esta manera, entre lo privado y lo público, lo espiritual y lo temporal, la familia y la comunidad, la jerarquía y los fieles laicos.

La acción parroquial se organizó sobre la base de dos pilares fundamentales: la acción del clero y la actividad de los laicos. Su motor debía ser el clero. En palabras del obispo, “el alma, el cerebro que combina y estudia el movimiento religioso en beneficio de sus feligreses, es el cura". ${ }^{6}$ El párroco era quien tenía el discernimiento necesario sobre lo más conducente a la vida espiritual de sus fieles, era, por lo tanto, el iniciador del movimiento y quien debía dirigirlo. Sus funciones fueron claramente definidas por el diocesano:

El lugar del sacerdote es la Iglesia, es su sede, es lo que podría llamarse la base de sus operaciones; y el párroco ante el Sagrario debe iniciar su ministerio cada día, al pie de los altares, orar por su pueblo dentro de su iglesia, cultivar sobrenaturalmente las almas infundiendo la gracia por medio de los sacramentos; pero el campo de batalla se

\footnotetext{
${ }^{3}$ REOBA, 1912, p. 419.

${ }^{4}$ AAC. Fondo Zenón Bustos y Ferreyra. Pastoral sobre el Socialismo del 24 de febrero de 1914.

${ }^{5}$ REOBA, 1912, p. 417.

${ }^{6}$ AAC. Libro de Autos y Visitas Pastorales, 1885-1916. Auto de la Visita a San Pedro, 24/11/1905.
} 
halla fuera, las primeras filas están tendidas en medio del pueblo y al pueblo debe ir: al pueblo doliente, para llevarle el consuelo de Jesús sacramentado; al pueblo gozoso para enseñarle a santificar las alegrías y compartirlas él mismo; al pueblo pobre para dirigirlo en la consecución de sus anhelos de acuerdo con el verdadero derecho y manifestarle el modelo de los modelos Jesucristo; al pueblo rico para indicarle hasta donde llega el derecho y cual es el respeto que merece el prójimo, que es su hermano; al pueblo alejado para remover las cenizas en su corazón y renovar la fe casi apagada ya; y por último, al pueblo enemigo de la Iglesia para admirarlo con su ejemplo, para conmoverlo con su dulzura, para infundir respeto con su ciencia y para imponerle la justa veneración hacia el sacerdocio, cuando llegue a convertirlo y llevarlo hasta el trono de Jesucristo. ${ }^{7}$

La labor del párroco se extendía, por lo tanto, a toda la sociedad, condensada en la parcela de su propia parroquia, iba más allá del pueblo católico, el cura debía velar por toda la comunidad. El objetivo fue "hacer de cada parroquia una fortaleza por su acción decidida y franca y de cada sacerdote un adalid, un soldado armado en las luchas del Señor para derribar al enemigo declarado". ${ }^{8}$ El desafío del gobierno diocesano consistió en "trabajar en la renovación de la mentalidad católica, para preparar las victorias del porvenir".

Las almas corren atribuladas ante los peligros de la fe; en tales circunstancias para nadie es hora de consejos solamente, es hora de militancia activa del sacerdocio, poniendo tesis contra tesis, para salvar la verdad contra el error, y marcar al pueblo la ruta práctica, que debe seguir: es hora de amparar las instituciones católicas, defender su legitimidad, su acción saludable, benéfica y salvadora de la sociedad y de las almas y haciendo profundizar las raíces de éstas en la conciencia popular. ${ }^{9}$

En la diócesis, se llevó a cabo un proceso de acelerado crecimiento parroquial, pues era de primordial importancia adaptar la organización y la estructura eclesiástica a la realidad social provincial, la manifestación inmediata fue el aumento significativo del número de parroquias existentes y el impulso de la acción católica parroquial (Cfr. Capítulo 9).

El estudio de las estructuras institucionales eclesiásticas nos impone, a su vez, analizar la acción, intención y pensamientos de los actores involucrados en ellas. La acción pastoral se centró en la organización de la acción católica parroquial, la cual consistió en reunir a los católicos alrededor de un centro común de doctrina, de organización social y de propaganda

\footnotetext{
${ }^{7}$ REOBA, 1912, p. 419.

${ }^{8}$ Reverendo Padre José M. Liqueno, “Oración fúnebre pronunciado el día 11 de mayo en el funeral solemne que la comunidad franciscana de Córdoba celebró en homenaje al Iltrmo. y Rmo. Fray Zenón Bustos Ferreira, obispo diocesano de Córdoba”, Talleres Gráficos Cubas Madueño, Córdoba, 1925.

${ }^{9}$ AAC. Fondo Zenón Bustos. Caja No 4, f.1304.
} 
activa, apto para contrarrestar la propaganda adversa, en particular socialista, y llegar con su acción a los sectores populares. El objetivo del obispo fue "buscar los caminos prácticos para devolver la fe y sus copiosos beneficios al pueblo”. El camino escogido privilegió el "ministerio pastoral de los párrocos, activa y celosamente ejercitado". ${ }^{10}$ La parroquia con su templo fue concebida como una alternativa educativa, una escuela de religión, tendiente a regular y modelar las conductas sociales mediante una práctica pedagógica sistemática fundada en tres pilares: la resistencia a las ideologías laicas, ateas o agnósticas; la inculcación de ideas; y la orientación práctica de modelos de conducta que promovieran soluciones católicas a los problemas sociales, algo que naturalmente significaba mejorar la cultura y la moralidad de las clases trabajadoras y también llegar a la mentalidad, a fin de hacer conocer, asumir y ejecutar las ventajas de las fórmulas cristianas para la reconstrucción social. La actividad parroquial se convirtió en el elemento central del proceso de renovación católica y de socialización de los sectores populares más expuestos a la acción de la propaganda socialista. En la segunda parte, hemos visto cómo la parroquia se expande sobre el territorio provincial mediante la construcción de nuevas iglesias y capillas. Ahora veremos cómo el clero patrocinó ciertas devociones y sus correspondientes peregrinaciones, organizó misiones, promovió una serie de actividades económicosociales, asistenciales y recreativas vinculadas a la parroquia.

La parroquia se consolidó como centro de irradiación cristiana, a través del cual se procuró llegar a amplios sectores de la población y ganar la ocupación material y simbólica del espacio público: plazas y calles de villas, colonias y pueblos rurales que fueron testigos de multitudinarias procesiones y ceremonias masivas. Los campos vieron protegidos sus sembrados con cruces y pequeñas capillitas. Los templos, concebidos como centros de irradiación moral, educativa y religiosa, trascienden las fronteras locales para ejercer una influencia a nivel regional.

En las visitas pastorales, el Obispo Bustos animaba a los párrocos a crear, en los sectores indigentes de sus curatos, templos y/o centros religiosos para que los fieles concurrieran a recibir la instrucción y los sacramentos, ${ }^{11}$ y donde los feligreses pudieran verse y

\footnotetext{
${ }^{10}$ Fray Zenón Bustos y Ferreyra, Pastoral al inicio de su gobierno, Córdoba, 23 de noviembre de 1905, Diario Los Principios, 03/05/1905; AAC. Pastorales, Edictos y Circulares, 1905-1925; REOBA, Sección Córdoba, 1905.

${ }^{11}$ AAC Autos y visitas parroquiales 1885-1916. Folio22
} 
comunicarse y se les pudiera inculcar sentimientos de respeto hacía sí mismos y su propia dignidad. ${ }^{12}$ El cuestionario de la visita de 1924 , en la pregunta $\mathrm{n}^{\circ} 1$, solicita que el cura señale la importancia de los pueblos, villas y estaciones de ferrocarril, si tienen iglesias y si no las tienen dónde cumplen estos feligreses sus deberes católicos. ${ }^{13}$ La labor del cura debía ir más allá del pueblo católico, se extendía a toda la sociedad, además de velar por la comunidad que tenía encomendada como pastor. Los vínculos a establecer con los fieles debían ser similares a los de un padre de familia que se preocupa por sus hijos, que vela por sus necesidades, los acompaña en el dolor y comparte con ellos las alegrías. El cura debía conocer a todos sus feligreses e intensificar su acción pastoral en aquellas poblaciones más expuestas a la pobreza, la ignorancia y la acción de los centros de propaganda socialista.

La parroquia aparece como una institución estrechamente ligada a la comunidad, era socialmente heterogénea, sus actividades combinaban la devoción con la acción colectiva, benéfica y social. Se sitúa de esta manera entre lo privado y lo público, lo espiritual y lo temporal, la familia y la comunidad, la jerarquía y los fieles laicos. Se trataba de una política destinada a reconquistar el espacio público, otorgándole una simbología sacra, mediante la celebración de funciones, procesiones y actividades sociales, culturales y recreativas.

\section{La acción católica parroquial: reforzar la identidad católica y fomentar la militancia}

El eje sobre el cual se estructuró la reactivación de la vida parroquial fue la "acción católica”, entendida no como la institución que nacerá en la década de 1930, sino como la acción general de los católicos organizados alrededor de la figura del párroco y la parroquia.

La vida parroquial se convirtió en el elemento primordial en orden a la renovación social cristiana. ${ }^{14}$ El templo será el lugar por antonomasia de la vida cristiana; allí el fiel se incorpora mediante el bautismo a la comunidad católica, allí recibe -junto a su familia-, su primera formación religiosa, allí asiste a la misa dominical, es miembro de alguna

\footnotetext{
${ }^{12}$ AAC. Libro de Autos y Visitas Pastorales, 1895-1916. Visita Canónica al Curato de San Vicente, febrero 17 de 1906, f.369.

${ }^{13}$ AAC. Caja Parroquias: Sobremonte, 1926. BEDC, enero 1925, pp. 16-24.

${ }^{14}$ REOBA, 1912, p. 417.
} 
asociación, contrae matrimonio cristiano y, finalmente, su cadáver recibe las últimas bendiciones antes de ser sepultado. Ser cristiano se identificará con ir al templo, participar en las ceremonias religiosas y desarrollar luego, cada uno en su lugar, una intensa militancia destinada a sumar voluntades en pro de la renovación católica y social. En ese contexto, se organizó la acción católica, con un modus operandi jerárquico, cuyos “capitanes eran el Papa, los obispos, los párrocos y el clero". ${ }^{15}$ En esta nueva organización, los seglares están llamados a colaborar, en esta empresa, en carácter de auxiliares, a ser lazos de unión entre el párroco y el pueblo. El fin era dar soluciones católicas a los conflictos sociales, reunir a los católicos alrededor de un centro común de doctrina, de organización social y de propaganda activa, para oponerse, con energía, a la propaganda adversa. ${ }^{16}$ Y luego, llegar a las grandes masas del pueblo y a la sociedad en un sentido global. Ese era el objetivo principal del cine-teatro de Alta Gracia. Al decir del cura, "allí convergía todo el movimiento social católico del pueblo". ${ }^{17}$

La formación franciscana del Obispo Bustos lo llevó a concebir la labor de los laicos en la iglesia como una prolongación de la espiritualidad de la orden en la vida secular como ejemplo de las terceras órdenes. León XIII había actualizado la regla de la Tercera Orden Franciscana mediante la bula Misericors Dei Filius del 30 de mayo de 1883, a fin de dotarla de actualidad y adecuarla a las necesidades del mundo moderno. Dicho papa consideraba a la Tercera Orden como la "única Orden”, capaz de hacer frente a la cuestión social: "cuando hablo de reforma social, pienso especialmente en la Tercera Orden de San Francisco" o "la Tercera Orden de San Francisco organizada para la acción social es capaz de dar frutos maravillosos". El diocesano hizo propia la recomendación del Concilio Plenario de 1899 que exhortaba a todos los Obispos a esforzarse para "que los fieles conozcan el Orden Tercero y aprendan a estimarlo: dictad vuestras providencias para que los Curas enseñen a menudo lo que es, cómo está al alcance de todos, en cuántos privilegios abunda para la salvación de las almas, y cuánto provecho promete al individuo y a la sociedad". ${ }^{18}$ A su vez, impulsó, la erección de cofradías en las parroquias, como las del

\footnotetext{
${ }^{15}$ AAC. Fondo Zenón Bustos, f.3536.

${ }^{16}$ REOBA, 1908, p. 1030.

${ }^{17}$ AAC. Caja Parroquias: Alta Gracia. Informe al recibir la parroquia.

18 Concilio Plenario para América Latina, Título XI: "Del celo por el bien de las almas y de la caridad cristiana", Cap. IV: "De las hermandades piadosas”. Disponible en: multimedios.org/docs/d000021/p000015. $\underline{\mathrm{htm}}$
} 
Santísimo Sacramento, de la Doctrina Cristiana, del Sagrado Corazón de Jesús y muy especialmente el Apostolado de la Oración, las Conferencias de San Vicente de Paul y las Obras piadosas de la Propagación de la Fe.

El auto de erección de la extinta cofradía del Santísimo Sacramento da una clara idea de la función a la que estaban llamados los laicos. El obispo remarca la importancia de la cofradía y su misión en la sociedad de entonces:

Nació entre nosotros en la época colonial, y sin dificultad y firmeza pudo incorporar y mantener entre sus miembros a la parte más significativa y de significación del pueblo. Los caballeros y damas de mayor espectabilidad lo mismo que los representantes de la justicia y del poder dieron sus nombres a este piadoso gremio; para ejemplo del pueblo inferior y satisfacción propia, eran los primeros en acudir y rodear en los templos, los tabernáculos y en seguir al Señor cuando salía para los enfermos o en procesiones públicas $[\ldots]$ expresaban entonces con estas manifestaciones del culto los sentimientos de la fe religiosa que alimentaban [...]. Es poderosísimo el prestigio del ejemplo que parte de la alta sociedad y de los representantes de los poderes públicos: atrae fuertemente a los inferiores alejados, vigoriza fuertemente el sentimiento religioso en el pueblo, y despierta poderosamente la fe adormecida. En aquella época no era tan necesaria la presencia de la clase caracterizada, en estos cultos como es hoy, que el oscurecimiento de las creencias desciende y comienza a producir estragos en las capas medianas e inferiores de la sociedad. Allá obedecían a un sentimiento de su piedad; ahora cumplirán con el sagrado deber de edificar a los demás. Y cuán necesario es mostrarse en las filas militantes a los creyentes prácticos hoy! Antes se hería la fe con negar e impugnar uno que otro dogma, más ahora la agresión directa es a todos, y la guerra desplegada en su contra, lleva el propósito de estirparla radicalmente, llegándose a afirmar por sus jefes, que no hay nada absolutamente sobrenatural. Tal situación impone la medida de llamar a la vida militante de la piedad a la cofradía del Smo. Sacramento. Queremos que se reconstituya llamando a su seno a nuevos y numerosos adeptos que se acerquen y rodeen a Jesús sacramentado, haciéndole una corona iluminada por la fe en el dogma de las maravillas del Omnipotente y presentándoles a los demás un alto ejemplo de sus creencias. ${ }^{19}$

Esta institución de origen colonial se resignifica y adquiere funciones adecuadas a la realidad social presente. El obispo advierte que antes obedecían a un sentimiento de su piedad, ahora “cumplirán con el sagrado deber de edificar a los demás. Y cuán necesario es mostrarse en las filas militantes a los creyentes prácticos hoy!”. El corazón de la acción católica en los albores del siglo XX es sin duda la militancia activa en todo los campos sociales. El boletín parroquial de la parroquia de Río Cuarto es muy claro al respecto: "trabajar en la parroquia, he aquí uno de los graves deberes de los católicos, trabajar como

${ }^{19}$ AAC. Pastorales, Edictos y Circulares. Auto Episcopal, "Sobre la reconstitución de la Cofradía del Santísimo Sacramento en la catedral", 05/05/1906. 
el buen soldado que pone a disposición de su general todas las propias fuerzas, con perfecto espíritu de disciplina, porque el secreto de la victoria está en la unión firme de las ideas y en la obediencia sumisa de las órdenes superiores". ${ }^{20}$

La parroquia siempre fue un elemento central de la tradición católica. En esta coyuntura histórica, renovó sus formas de participación con el objetivo de llegar con mayor eficacia a una sociedad que se había transformado. Recurriendo a la conceptualización de HervieuLéger (2005: 148), la tradición se pone al servicio de la modernidad, se mantienen las formas, aunque el contenido se haya modificado, se establece la continuidad de las apariencias y se sirve a nuevos objetivos, pues bajo el aparente mantenimiento de formas y funciones, la naturaleza, los componentes y el papel de las parroquias experimentan transformaciones esenciales. La preocupación del diocesano se centraba en el rol que debía desempeñar en cada comunidad. Pare él era necesario "hacer de cada parroquia una fortaleza por su acción decidida y franca y de cada sacerdote un adalid, un soldado armado en las luchas del Señor para derribar al enemigo declarado". ${ }^{21}$ La política eclesiástica refleja la preocupación por adaptar las estructuras institucionales, impulsar la organización y administración de las jurisdicciones eclesiásticas, convertir a la parroquia en una institución bisagra entre la iglesia y la sociedad. Se propuso reconfigurar la anquilosada estructura parroquial, adaptándola a las necesidades y exigencias de una sociedad que se modificaba a ritmos acelerados.

Una de esas trasformaciones estaba vinculada a la concepción de la acción social católica. El Dr. Cafferata, diputado católico cordobés, en su discurso en el primer Congreso Eucarístico Nacional de 1917 afirmaba: "La acción social es la misión más importante del apostolado moderno. Hay que ir al pueblo para adoctrinarlo y para mejorarlo; para llevarle con el sustento material el alimento del espíritu. Es el deber de todo católico" (Moreyra et al, 1998: 312).

"La Revista Eclesiástica" señala que la parroquia albergaba en su seno a varios grupos de personas, los católicos prácticos sinceros, los católicos a medias, los indiferentes, aquellos que no se acuerdan de su catolicismo sino en una que otra circunstancia y

\footnotetext{
${ }^{20}$ AHRC. Boletín Parroquial: "La semana católica", Año VII, n 347, p. 9. Parroquia de Río Cuarto, 05/12/1926.

${ }^{21}$ Reverendo Padre José M. Liqueno, "Oración fúnebre pronunciado el día 11 de mayo en el funeral solemne que la comunidad franciscana de Córdoba celebró en homenaje al Iltmo. y Rmo. Fray Zenón Bustos Ferreira, obispo diocesano de Córdoba”, Talleres Gráficos Cubas Madueño, Córdoba, 1925.
} 
finalmente los que son ajenos a toda idea religiosa. Los esfuerzos del pastor debían dirigirse a conservar el primer grupo, perfeccionarlo y aumentar progresivamente su número a costa de los demás. ${ }^{22}$

El boletín parroquial de Río Cuarto señalaba que la acción parroquial tenía por objetivo "hacer vivir a los hombres en la iglesia y hacerlos católicos en la mente, en el corazón y en las costumbres", como señala Fouilloux (2002: 77), se trataba de un proyecto integral, no integrista, en cuanto englobaba todas las edades, todas las condiciones y actividades humanas. El boletín advertía la necesidad de que en la parroquia estuvieran engastadas todas las asociaciones y que los hombres católicos formaran con las asociaciones un lazo de unión entre el párroco y la masa del pueblo, el objetivo era ayudar al párroco en "la obra de penetración de las conciencias para atraerlas a la parroquia, para amaestrarlas en la vida de la fe y formar así el verdadero rebaño de Jesucristo". ${ }^{23}$

Estas pautas episcopales fueron tomadas por los párrocos. En 1924, el cura de Alta Gracia, con motivo de hacerse cargo del curato, elevó un informe al obispado, en el que detallaba su estrategia pastoral y su plan de acción. Dicho plan plasmaba los puntos centrales de la reforma: la centralización de la actividad parroquial bajo la dirección del párroco, el control y limitación de la autonomía de las asociaciones parroquiales, la religiosidad popular y el catolicismo social. El cura describía su plan general de acción para vigorizar la vida parroquial, espiritual y material del curato y para poner las cosas en orden y someter a las asociaciones a su rol correspondiente: "En lo moral me propuse: $1^{\circ}$ Reivindicar la parroquia y el párroco el derecho canónico de centralización y alta dirección de todo el movimiento religioso a efectuarse en ella; $2^{\circ}$ Reducir las asociaciones parroquiales a las más indispensables, reorganizarlas, dotarlas y confiarles su respectiva misión, compartiendo con ellas las múltiples actividades del ministerio, tanto en la sede parroquial como en el resto de la parroquia si fuera posible; $3^{\circ}$ Fomentar la piedad en todas partes y por todos los medios posibles en cada caso y lugar; $4^{\circ}$ Dejar en libertad de acción a las instituciones independientes de la parroquia, secundándolas en sus iniciativas mientras no estorben el plan parroquial. En lo material: $1^{\circ}$ habilitar el obraje, viejo edificio abandonado, inconcluso y antihigiénico para instalar allí una casa de ejercicios de acuerdo

\footnotetext{
${ }^{22}$ REOBA, 1906, p. 440.

${ }^{23}$ AMRC. Boletín Parroquial La Semana Católica, Año VII, N 347, 05/12/1926, p. 6.
} 
con el destino otorgado por el donante [...], la enseñanza de la doctrina a los niños; la sede de las instituciones parroquiales; y la centralización de todo el movimiento social católico del pueblo. $2^{\circ}$ Refaccionar la iglesia parroquial. $3^{\circ}$ Construir un baptisterio. $4^{\circ}$ Construir un cementerio y una casa parroquial con capacidad para cuatro o cinco personas, fundar un colegio católico; acondicionar cada una de las capillas, etc. En 1932, el cura daba cuenta de la ejecución del plan previsto y señalaba algunas consideraciones de interés. Advertía que había trabajado tenazmente en disciplinar la parroquia, unificando, en manos del párroco, la dirección de los feligreses y del movimiento religioso, a fin de llevar a la práctica su primer propósito en el orden moral, pero se lamentaba de haber encontrado resistencias que le impidieron "conseguir esa subordinación que el derecho impone y que inspira la Acción Católica en todo el mundo".

A su vez, redujo las asociaciones parroquiales a tres, que eran el Círculo de Obreros, el Apostolado de la Oración y la Cofradía de Nuestra Sra. de las Mercedes, todas ellas ramificadas estaban en cada una de las capillas. Impulsó la religiosidad de sus feligreses, celebrando misiones, novenarios, misas y fiestas patronales en la parroquia y las capillas. También construyó la casa de ejercicios espirituales en el antiguo obraje con una capacidad para 80 personas, realizándose varias tandas en los cuatro años de funcionamiento. Creó una escuela parroquial incorporada al Consejo Provincial de Educación, con siete maestras, una por grado, y más de un centenar de niños. Por último, en consonancia con el catolicismo social en boga, se instaló un cine-teatro con biógrafo (cine) semanal, con todo lo necesario para festivales y actos públicos. ${ }^{24} \mathrm{~A}$ continuación, veamos cómo este programa o modelo se organizó y desplegó en el tiempo.

\subsection{La organización de la acción católica}

En 1914, Zenón Bustos envió a los párrocos unas orientaciones para organizar la "Acción Católica" 25 en las parroquias. Estableció un consejo diocesano, cuyo fin era dirigir y desenvolver en toda la diócesis la Acción Católica y Social por medio de la propaganda y creación de diversos organismos que la impulsaran y fomentaran. A su vez, se promovió la constitución de juntas parroquiales y otorgó a la junta diocesana el ejercicio del patronato

\footnotetext{
${ }^{24}$ AAC. Cajas Parroquias: Alta Gracia, fs.60-63.

${ }^{25}$ No se refiere a la institución fundada en 1931 con el nombre de Acción Católica, sino a la acción que deben desarrollar los católicos.
} 
sobre aquellas obras que sus fundadores pusieran bajo su cuidado, autorizando, a la vez, la posibilidad de aplicar donativos, legados o herencias que se le entregasen para establecer obras, sociedades o fundaciones nuevas o para mejorar las que ya existían.

Ese mismo año, el obispo convocó a los católicos de Córdoba a salir del templo y desarrollar una participación activa en la sociedad. Señalaba que los objetivos de esta acción se orientaban a las siguientes direcciones: recordar las preferencias de Jesucristo y de su Iglesia en favor de las necesidades corporales de los pobres, defender la necesidad de la caridad cristiana y su acción social para devolver la armonía a la sociedad, acercar a la iglesia a todos los que se hubiesen alejado de ella por la acción de la propaganda socialista, formar centros parroquiales de acción religiosa, benéfica y social.

Como dijimos, estableció un consejo diocesano destinado a dirigir e impulsar la acción católica y promover la constitución de juntas parroquiales. El consejo estaba presidido por el obispo y lo componían el párroco respectivo, sacerdotes, religiosos y seglares, en representación de las obras de propaganda y de acción social. Este debía reunirse con el obispo dos veces al año, la primera quincena de junio y la segunda de noviembre. En dichas reuniones se daría cuenta de las tareas de cada una de las juntas parroquiales. La comisión ejecutiva se dividía en tres secciones, la religiosa, la benéfica y la social, que si bien podían actuar por separado, estaban sometidas a un criterio de unidad.

Las juntas parroquiales estaban presididas por el párroco y los feligreses designados por éste con el título de vocales. Todos los feligreses de la parroquia eran considerados asociados en concepto de cooperadores. A fin de extender su acción a todas las clases sociales, la junta debía designar una representación de las diferentes profesiones y oficios. El sostenimiento dependía de una suscripción única. La cuota voluntaria variaba entre veinte centavos a un peso por mes. La junta, al igual que la comisión ejecutiva, se organizaba en tres secciones, en función de la acción que le correspondía desarrollar. La sección destinada a la acción religiosa, debía ocuparse de secundar al párroco en lo referente al culto, fomentar la enseñanza y propaganda de la religión y combatir toda enseñanza contraria a ella; la sección de acción benéfica debía socorrer la pobreza de los feligreses y la sección de acción social se proponía mejorar las condiciones morales y materiales de los obreros. ${ }^{26}$

${ }^{26}$ AAC. Reglas dadas a los Párrocos de esta ciudad por el Ilmo. Obispo Diocesano Mons. Zenón Bustos para 
El proyecto respondía a una triple necesidad: dar solución a algunos de los problemas percibidos por la jerarquía en relación a los desajustes sociales que afectaban a los sectores más desprotegidos; revertir la escasa participación y compromiso de los laicos en la iglesia; y orientarse a combatir la relajación de la práctica religiosa de la población. Un modo de ampliar la irradiación espiritual de las parroquias, era salir del templo, tratar de llegar a toda la comunidad y a cada familia creyente. Estas fueron las consignas de los boletines parroquiales. El objetivo era lograr que la enseñanza de la religión y de la moral llegara a quienes no concurrieran al templo y estimular a practicar las obras de misericordia en favor de los pobres. ${ }^{27}$ Ahora pasaremos a analizar detalladamente cómo se instrumentaron estas actividades en las diversas parroquias de la diócesis.

\subsection{Las actividades parroquiales}

\subsubsection{Los boletines}

Las hojas parroquiales surgieron como respuesta a la difusión de la "mala prensa". Al inicio de su gestión episcopal, Zenón Bustos advertía la necesidad de llegar a las familias y para lograrlo animaba a los párrocos a llegar a su feligresía mediante boletines u hojas parroquiales.

En 1906, el cura de Bell Ville informaba que en su curato había "cuatro periódicos malos" y que su hoja parroquial hacía mucho bien y tenía una especie de sucursal en Villa María. ${ }^{28}$ En diciembre de 1912, comenzó a salir la hoja parroquial de Cruz Alta, "El Santísimo Rosario", aparecía todos los domingos y su suscripción costaba 0,25cts al mes. Impulsada por el cura Antonio Trías, se trataba de cuatro páginas que contenían un artículo de fondo con temas doctrinales, una sección destinada a la explicación de las fiestas litúrgicas, una sección informativa sobre la atención del despacho y la biblioteca parroquial, los horarios de misa, catecismo y funciones religiosas en la parroquia y capillas del curato. Como nota curiosa, seguramente destinada a aumentar el número de suscriptores, se promovía algún concurso que incluía premios. Tampoco faltaba la página destinada a los avisos tarifados. ${ }^{29}$ En abril de 1913, el cura de Cruz Alta, Antonio Trias, comunica al

el mejor desenvolvimiento de la Acción Católica de las Parroquias, pp. 6-9.

${ }^{27}$ REOBA, Sección Obispado de Córdoba, Buenos Aires, 1915, p. 227.

${ }^{28}$ AAC. Leg. 52, Curato de Bell Ville, s/f.

${ }^{29}$ AAC. Parroquias: Cruz Alta. "El Santísimo Rosario", Hoja Parroquial de Cruz Alta, Año I, enero 26, № 9, 
obispado que "El Santísimo Rosario" pasaría a llamarse "La Familia Cristiana” y sería el órgano de las parroquias de Cruz Alta, Marcos Juárez en Córdoba y Artega y San José del Esquina en Santa Fe. ${ }^{30}$

En 1914, el obispo nombró una comisión conformada por los curas José Pío Angulo, Pablo Cabrera y Genaro de Artavia para que estudiaran la posibilidad de fundar una revista para las parroquias de la ciudad. ${ }^{31}$ El boletín nació con la idea de llegar al núcleo familiar con "buena y sólida doctrina”. Se proponía ser un vínculo de comunicación entre la feligresía y la parroquia, destinado a los miembros de cada comunidad parroquial para formarlos en los principios y valores básicos del cristianismo. La publicación debía estar precedida por la oración al titular o patrono de la parroquia y debía contener un breve pasaje del evangelio, acompañado de un comentario con consideraciones y resoluciones prácticas.

Contaría con siete secciones: una sección doctrinal que, básicamente, debía contener el catecismo explicado. Una sección social en la que se explicarían los principios generales y los errores en la cuestión social: la historia del movimiento social y la respuesta de la iglesia a esta cuestión, las soluciones propuestas, inspiradas en el evangelio, traducidas en obras sociales como, círculos de obreros, patronatos, cajas rurales, cooperativas agrícolas, cooperativas de consumo, sindicatos, escuelas dominicales y nocturnas, cajas dotales, granjas agrícolas, salas de lectura, bibliotecas circulantes, ligas para la defensa del clero, contra la inmoralidad pública etc. La sección beneficencia destinada a dar información y promocionar las obras de caridad, la labor de las Conferencias Vicentinas, las terceras órdenes, orfelinatos, hospitales, consultorios gratuitos para niños y madres pobres, comedores de pobres y de obreros, patronatos de sirvientes y sirvientas. La sección apologética debía tratar sobre cuestiones de actualidad, según los principios católicos, presentar las doctrinas y errores del socialismo, el anarquismo, el liberalismo, el modernismo y el protestantismo. Incluía explicaciones sobre la Iglesia, la defensa de sus derechos, el pontificado romano, la jerarquía eclesiástica, los sacerdotes y las órdenes religiosas, la relación con las autoridades civiles, las elecciones y el divorcio. La sección histórica comprendía la historia sagrada, antiguo y nuevo testamento, la historia eclesiástica

\footnotetext{
Febrero 2, 1913.

${ }^{30}$ AAC. Parroquias: Cruz Alta. Nota del 29/04/1913.

${ }^{31}$ AAC. Zenón Bustos. Autos y Decretos, 1905-1919, f. 2040.
} 
argentina, las ceremonias y ritos católicos. La sección variedades debía recoger experiencias de la propia vida parroquial y lecturas que estimulasen el mejoramiento de la vida espiritual de los feligreses mediante pensamientos escogidos, anécdotas edificantes, historias piadosas, poesías selectas, novelas cortas y cuentos. La última sección era la parroquial, en la cual se reproducían las pastorales y las disposiciones de la curia local y romana y se informaba del movimiento religioso, matrimonios, defunciones, comuniones, horarios de misa, avisos de funciones parroquiales, advertencias de los párrocos, etc. Al finalizar cada sección se sugerían una serie de libros que los fieles podían consultar. ${ }^{32}$

La iniciativa no llegó a concretarse en la ciudad capital, de todos modos fue asumida por seis párrocos de los departamentos del este: Marcos Juárez, Bell Ville, Villa María, Villa Nueva, Río Segundo y Cruz Alta, quienes fundaron la revista católica de la diócesis denominada "Nuestra Causa". La misma se distribuía en las parroquias, iglesias y capillas de la zona. El director fue el Pbro. Ardiles y colaboraron los curas Colabianchi (Villa María), Borello (San Francisco), Caviglia (Canals), Salgueiro (Cañada Verde) y Buteler (Marcos Juárez). A los pocos años de andar, las dificultades para su continuación se hicieron presentes. El cura de Villa María, Paulino Colabianchi, se quejaba al obispo por las premuras económicas y solicitaba que intercediera para que se suscribieran a ella las parroquias de la ciudad, sostenía:

Que no había ciudad en la República donde los curas de la misma no se preocupen de tener una revista parroquial que es el mas poderoso auxiliar de propaganda católica, solamente la ciudad de Córdoba es reacia a esta acción primordial de celo y propaganda. Las seis parroquias de la ciudad no tienen ninguna revista, ni están adheridas a ninguna de las que se publican en las parroquias de campaña. En este sentido Córdoba non docet. ${ }^{33}$

A partir de 1920 varios de los curatos contaban con su propio boletín, o repartían el que se editaba en alguna parroquia vecina. En 1921, Juan Carole, cura de Soto, sostenía una revista quincenal, de ocho páginas, denominada "El hogar cristiano", que circulaba dentro y fuera del departamento. ${ }^{34}$ En Santa Rosa, el órgano parroquial fue la revista "Santa Rosa". 35 En varios curatos se repartían, a la salida del templo, hojas sueltas y boletines como "El

\footnotetext{
${ }^{32}$ REOBA, Sección Obispado de Córdoba, Buenos Aires, 1915, pp. 227-228.

${ }^{33}$ AAC. Fondo Zenón Bustos, f.830.

${ }^{34}$ Los Principios, 11 de enero de 1921, p. 3.

${ }^{35}$ AAC. Parroquias: Santa Rosa de Río 1 ${ }^{\circ}$. Respuesta al Cuestionario de la Visita Canónica, 1916, f.288.
} 
sembrador" ${ }^{36}$ y “El Santísimo Rosario", fundado por el cura de Cruz Alta, el Pbro. Antonio Trias, quien también fundó el periódico católico "La Verdad," que pervivió durante quince años. ${ }^{37}$ Por otro lado, circulaban el boletín "La Cruz" y el "Descanso Dominical". ${ }^{38}$ En Deán Funes se entregaban cien copias semanales de "El Cruzado". En 1920, la parroquia de Río Cuarto editaba un boletín denominado "La Semana Católica", que comenzó siendo un impreso de cuatro páginas y tres años más tarde alcanzaba veinte. Sus notas reflejaban un perfil doctrinal pedagógico que respondía a las directivas dadas por el prelado diocesano en 1914. ${ }^{39}$ En 1922, el congreso de la Unión Popular Católica Argentina, realizado en Córdoba, encarecía la fundación de revistas y hojas parroquiales como medio de unión entre sus adherentes y como uno de los mejores instrumentos para producir la vida parroquial. $^{40}$

Estos medios estaban destinados a contrarrestar la difusión de las "malas lecturas" y fomentar "las buenas". En el auto de la visita al curato de Sobremonte en 1924, se lee: "nos permitimos recordar al señor cura, que siendo él el padre espiritual de una gran familia de todos los fieles de la parroquia, no ha de contentarse con alimentar a sus hijos con el pan de la doctrina angélica, sino que también ha de vigilar a fin de evitar, en cuanto es posible, que se amengüe su fe a causa de las lecturas malsanas, que se infiltran por todas partes. En la respuesta al número 31 del cuestionario dice el señor cura que quedan como unos diez suscriptores a la Voz del Interior (Pasquín de Córdoba) y que cuatro son buenos cristianos y que lo reciben por asuntos políticos. ¿No sería posible persuadir a estos buenos cristianos que primero está su conciencia y el bien espiritual de sus familias, que todos los intereses de la política? No perdone pues medios el señor cura para restarle propaganda a la impiedad. Entre gente que aún no está contagiada por el virus ponzoñoso del indiferentismo moderno. Nos parece no ha de ser tan difícil conseguir el bien que de ella se desea". ${ }^{4}$

En 1924 se crea el Boletín Eclesiástico de la Diócesis de Córdoba. El decreto señala que el objetivo del mismo no era sólo de acicate y estímulo, sino, primordialmente, "un medio de información, un medio para sugerir y dar a conocer iniciativas de las entidades y

\footnotetext{
${ }^{36}$ AAC. Parroquias: Quilino, f.129.

${ }^{37}$ AAC. Parroquias: Arroyito, f.46.

${ }^{38}$ AAC. Parroquias: Salsacate (Pocho), f.292.

${ }^{39}$ AHMRC. "La Semana Católica", 1922-1933.

${ }^{40}$ AAC. Actas del Congreso UPCA, 1922. Conclusión de la Segunda Sesión.

${ }^{41}$ AAC. Caja Sobremonte, f.286.
} 
corporaciones católicas y las obras de celo realizadas por los párrocos y demás sacerdotes del clero secular y regular". ${ }^{42}$ El decreto concretaba una resolución del Sínodo Diocesano de 1906 que sugería la edición de un boletín eclesiástico, "donde se publiquen los documentos oficiales de la diócesis y otros asuntos de importancia relacionados con la disciplina, la religión y las ciencias". ${ }^{43}$ Se constituyó en el órgano oficial de la curia diocesana, salía con una periodicidad bimensual, era administrado por el Pbro. Domingo Bonaparte y el Pbro. Juan Taborda, secretario de redacción. Mediante el boletín, la Iglesia diocesana construyó una red de información y de relaciones destinada a impulsar y consolidar la acción católica.

La prensa periódica, en general, y la publicación de boletines parroquiales, en particular, constituyeron un canal de adoctrinamiento de las clases populares y una fuente para generar y ganar a la opinión pública. Hojas, folletos y boletines se constituyeron en un género más popular, en los que junto con los horarios de las funciones religiosas, podían encontrarse noticias de las asociaciones católicas y artículos doctrinales. Estos se constituyeron, de alguna manera, en auténticos púlpitos diseñados para difundir los ideales cristianos. Pese a la escasez de recursos y a las dificultades financieras, surgió una importante cantidad de publicaciones parroquiales que se distribuían semanalmente a los fieles de cada curato. Estas procuraban ser el vínculo de unión entre los fieles y un medio para que la voz del pastor llegase a todos los ámbitos de su grey. ${ }^{44}$

El Prelado Bustos, en los cuestionarios de su segunda gira pastoral, solicitaba información respecto a la difusión de prensa católica. En la pregunta $n^{\circ} 50$, se planteaba ¿Hay difusión de libros y periódicos malos? ¿Qué se hace para contrarrestar ese mal? ¿Se fomenta la buena prensa? ¿Qué cooperación se presta a la prensa católica de la diócesis? ${ }^{45}$

Es difícil medir la eficacia que estos medios prestaron al proyecto católico, sin embargo pueden deducirse algunos indicios de las críticas que despertaban en "los adversarios". En 1913, los vecinos de Cruz Alta elevaron una denuncia a la curia por el contenido publicado en "El Santísimo Rosario". En ella, se presentan como vecinos nacionales y extranjeros y solicitan al obispo que "suspenda su licencia al semanario que bajo el epígrafe del

\footnotetext{
${ }^{42}$ AAC. Decretos y Edictos, 1920-1925, f.68-69.

43 AAC. Sínodo Diocesano de 1906.

${ }^{44}$ BEDC, Enero de 1926. Órgano de la parroquia de Calamuchita.

${ }^{45}$ AAC. Parroquias: Santa Rosa de Río $1^{\circ}$. Cuestionario de la Visita Pastoral, 12/01/1917.
} 
Santísimo Rosario y bajo la dirección del cura y vicario, se publica en esta localidad, que en vez de circunscribirse a llenar su misión de hoja parroquial y ocuparse de cosas que a la iglesia atañen, se ocupa de denigrar a vecinos. Los denunciantes relatan que dicho boletín arremete contra el Sr. Guillermo Moore debido a la adhesión que hizo a la liga de librepensamiento de Rosario en pro de la separación de la Iglesia del Estado". ${ }^{46}$ Lo mismo sucedió con "El Cruzado" y la campaña contra las fiestas del XX de septiembre analizadas en el capítulo anterior. Estas denuncias alertan sobre la incidencia de estas hojas parroquiales en el seno de comunidades relativamente pequeñas.

\subsubsection{La prensa católica en Marcos Juárez}

La importancia de la prensa como medio del apostolado moderno estaba clara. El cura de Marcos Juárez, en la editorial de la revista parroquial "La Familia Cristiana", reconocía los esfuerzos de la Iglesia cordobesa en la construcción de templos, si bien consideraba que esta iniciativa no era suficiente, ya que era necesario combatir ideas y las ideas no se combatían sólo con piedras: "Nosotros, cuando ellos hacen rotativas, les contestamos levantando Iglesias, amontonando piedras ¿Es posible combatir piedras contra ideas?”. Efectivamente, levantar edificios y conservarlos para los pueblos era importante, pero primero había que conservar los pueblos para los edificios y sin prensa eso no era posible. Sin periódico católico, la Iglesia quedaría sin pueblo. ${ }^{47}$ Estaban convencidos de que el combate era desigual: "no tenemos armas iguales, usamos fechas y espadas para combatir a nuestros enemigos. Estamos completamente indefensos para los combates modernos". ${ }^{48}$ Este era el sentir de la jerarquía y de los curas párrocos y, en ese sentido, pusieron manos a la obra.

\subsubsection{1 "La Familia Cristiana" vs "La Patria degli Italiani” y "La Vanguardia"}

"La Patria degli Italiani" era un periódico, sindicado por el Internuncio Apostólico Locatelli, como el "máximo órgano liberal de la colonia italiana", ${ }^{49}$ difusor de las ideas masónicas, y sectario respecto de la Iglesia católica. El periódico circulaba en las colonias

\footnotetext{
${ }^{46}$ AAC. Parroquias: Cruz Alta, fs.146-48. Nota de febrero de 1913.

${ }^{47}$ La Familia Cristiana, 20/07/1915.

${ }^{48}$ La Familia Cristiana, 02/12/1914 (cit. en Costa, 2004: 31).

${ }^{49}$ ASV. Secretaría de Estado. Nunciatura Argentina, 1907, N²52, f.10.
} 
del sudeste cordobés y el oeste santafesino y los párrocos veían con preocupación cómo influía en sus feligreses. Uno de los temas sobre el que se giraba con frecuencia eran las fiestas garibaldinas y los festejos del XX de Septiembre. En 1913, los curas párrocos de la región suscribieron una circular, en la cual señalaban el sectarismo de "La Patria degli Italiani" y sus ataques a la iglesia católica y a sus instituciones, en particular al Papa y a la Santa Sede, advirtiendo que "Es notorio, por otra parte que las tres principales provincias argentinas, Buenos Aires, Santa Fe y Córdoba, abrigan en su seno un número inmenso de italiano católicos a quienes lenta pero eficazmente se está propinando el veneno de la descristianización". ${ }^{50}$

Respecto de la acción mancomunada de los párrocos, Ignacio Costa (2004: 22), en su reseña sobre Monseñor Buteler, señalaba que los párrocos de las provincias de Buenos Aires, Santa Fe y Córdoba "eran conscientes de que no podían continuar con los brazos cruzados viendo al enemigo entrar en su redil, atrapar en él a su presa y marcharse tranquilo como si no hubiera quien vaya a disputársela". Por este motivo, pusieron manos a la obra, a fin de contrarrestar el impacto de "La Patria degli Italiani", y decidieron darle mayor difusión a la revista parroquial de Cruz Alta, fundada el año anterior por el cura Antonio Trias. Esta se transformó en una nueva publicación, de mayor tirada y circulación, que se denominó "La Familia Cristiana", cuyo director responsable fue el cura de Marcos Juárez, Leopoldo Buteler. Era el boletín parroquial de La Asunción (Marcos Juárez) y Cruz Alta, parroquias de la diócesis de Córdoba, y San José de la Esquina y Artega de la diócesis de Santa Fe.

En 1913, los curas decidieron visitar a todos los hogares italianos de las respectivas parroquias, invitando a suscribirse a "La Familia Cristiana". "Que no quede un solo italiano a quien no lleguen nuestras visitas, nuestras cartas, nuestros discursos y nuestras instancias [...] que arrojen de sus casas el diario enemigo de Dios, enemigo del Papa, enemigo de la religión, enemigo del nombre cristiano y de la Patria". ${ }^{51}$ La estrategia fue eficaz, pues la revista creció exponencialmente. Comenzó con ocho páginas, en agosto alcanzó a doce y un año después, dieciséis. De 300 suscriptores pasaron a 800 . Y lo que había comenzado como el boletín de una sola parroquia paso a serlo de ocho. Se distribuía en todas las

\footnotetext{
${ }^{50}$ La Familia Cristiana, 11/12/1913.

${ }^{51}$ La Familia Cristiana, diciembre de 1913 (cit. en Costa, 2004: 22).
} 
parroquias de los departamentos de Unión y Marcos Juárez. El cura de Arroyito, departamento de San Justo, informaba que, en su parroquia, se distribuía, en 1914, "La Familia Cristiana". ${ }^{52}$ En ese mismo año, el radio de influencia se amplió aún más, llegando hasta los curatos de Bell Ville y Tercero Arriba. La tirada alcanzaba 1.200 ejemplares. En 1917, se sumaron las parroquias de Arequito (Santa Fe), Oliva y Oncativo, departamento de Río II. En 1920, alcanzó Ballesteros, Sanabria, Palestina, Colazo, Dalmasio Vélez, Hernando, Cañada de Luca y Las Perdices (Costa, 2004: 30-32).

El boletín fue, sin duda, no sólo un elemento de unión entre los párrocos de la región, sino también una estrategia destinada a mancomunar esfuerzos y unir a las fuerzas católicas disgregadas. Allí se daban cita los intereses de las familias cristianas y de las asociaciones cristianas. Los editoriales de la revista definieron la misión de la misma. "La Familia Cristiana" era, para los párrocos, un medio eficaz de evangelización y catequesis, se convirtió en una escuela. El católico debía recurrir diariamente a la escuela de la buena prensa y allí saciar su hambre de información, ilustrar su inteligencia respecto de la historia maravillosa de la Iglesia, aprender sus deberes para con la Patria. La revista imponía "la ruta firme y segura a las convicciones de nuestros amados feligreses". ${ }^{53}$ Era la herramienta adecuada para la evangelización del siglo XX: "El estampido del cañón era baladí comparado con la influencia decisiva de esas armas de papel”. El redactor continúa diciendo:

Cada hoja es el apóstol de una idea [...] ¡Y qué apóstol! Vedlo con que firmeza descansa doblado sobre la mesa, esperando que llegue su hora. No se mueve si no lo mueven. No habla si no le preguntan. Si no lo tocan permanecerá días y días, sin cansarse, sin retroceder, guardando como un tesoro su semilla [...] Pero nos llegamos a él, lo desdoblamos y aparecen sus plantas hermosas, tentadoras, llenas de insinuaciones y atractivos, con su prosa ligera y sugestiva, sus nocivas insinuaciones, sus títulos de gruesos caracteres que atraen y seducen [...] Dirigimos a él sus ojos, nos entregamos a sus lecturas, nos abismamos en el laberinto de su fraseología [...] Ya somos suyos. ${ }^{54}$

Uno de los temas recurrentes de "La Familia Cristiana" era el combate al socialismo y a las ideas difundidas en el periódico "La Vanguardia”, que, según relatan los párrocos, tenía

\footnotetext{
${ }^{52}$ AAC. Parroquias: Arroyito, f.46.

${ }^{53}$ La Familia Cristiana, 03/12/1914 (cit. en Costa, 2004: 30).

${ }^{54}$ La Familia Cristiana, 20/07/1915 (cit. en Costa, 2004: 31).
} 
cierta difusión en la zona. ${ }^{55}$ De forma directa y sencilla, el boletín llegaba a los feligreses advirtiendo contra esta doctrina: "Hoy, en cambio, ha venido la cultura moderna y ha dicho al pobre: lo que te cuentan los curas son todas mentiras: sufre, trabaja, muere de cansancio; una vez muerto todo habrá terminado. ¿Qué otra contestación dará el pobre que un rugido de rabia?" 56 [...] "que no vengan después a decirnos que los católicos somos individuos retrógrados, oscurantistas y todo ese vocabulario que de puro viejo ya está gastado". ${ }^{57} \mathrm{El}$ editorialista respondía que el catolicismo era el amigo más fiel de la instrucción y de la ciencia, porque en todos los países del mundo florecían a su amparo grandes escuelas y universidades. Afirmaba que la religión nunca había sido enemiga de la verdadera ciencia. Las preguntas que dejamos planteadas son dos ¿es posible medir el impacto de la prensa católica y los boletines parroquiales en las feligresías? ¿Supusieron un cambio de conducta y un acercamiento a la iglesia institucional? No estamos en condiciones de responderlas, lo que si podemos afirmar que si unimos esta estrategia con las otras desplegadas, todas ellas en su conjunto tuvieron un impacto en la conducta de las feligresías. Para ejemplificarlo presentaremos al final de este capítulo el caso de la colonia Sampacho.

\subsubsection{La acción religiosa}

Las orientaciones de la curia diocesana en relación al impulso de la acción religiosa de las parroquias se centraron en dos aspectos, la instrucción religiosa y la difusión de prácticas destinadas a acrecentar la religiosidad popular. Las estrategias para lograr este objetivo fueron señaladas por el diocesano en los autos de las visitas pastorales del período. Los párrocos y tenientes debían preocuparse por el ejercicio asiduo de la predicación, la enseñanza del catecismo, la celebración de funciones litúrgicas y la realización de misiones anuales en cada uno de sus curatos. El incremento de la religiosidad del pueblo se

\footnotetext{
${ }^{55}$ AAC. Leg. 52. Bell Ville. Nota del Cura de Bell Ville Pío Angulo al Secretario del Obispado, 1909. "Las funciones de Ballesteros me dejan muy decepcionado. Sabe Ud. cuantos varones comulgaron? Cinco. Total de comuniones 50; matrimonio 1. Por eso mismo, he resuelto dar una misión en septiembre o agosto. Aquí hay mucho progreso, pues a 4 periódicos malos y a la escuela anarquista de Abdón se nos agrega la escuela mixta normal. Mi hermano que me atendía el periódico en lo que podía no lo hará en adelante ni puede figurar como director por haberse ocupado en los tribunales. Mi pobre hoja bien atendida podría hacer mucho bien, y tendría una especie de sucursal en Villa María [...]. José Pío Angulo”.

${ }^{56}$ La Familia Cristiana, 08/01/1914 (cit. en Costa, 2004: 33).

${ }^{57}$ La Familia Cristiana, 10/10/1918 (cit. en Costa, 2004: 35).
} 
alcanzaría estableciendo centros y asociaciones piadosas que facilitasen y proporcionasen la ocasión de recibir los sacramentos y practicar los actos propios del culto religioso. ${ }^{58}$

Las visitas canónicas realizadas por el Obispo Bustos en los primeros años de su gestión reflejan la escasa participación de los fieles en las ceremonias religiosas. En 1909, durante la visita pastoral a Capilla Rodríguez, departamento de Tercero Arriba, el prelado observaba que en muchos feligreses comenzaba a imponerse el grave descuido de no cumplir con el precepto anual de la confesión y comunión. En el auto, señalaba que era "el comienzo de una enfermedad infecciosa que cundirá generalizándose de pocos a muchos. Conviene buscar y encontrar un arte nuevo para curar este mal". ${ }^{59}$ Anima a los párrocos a reforzar y multiplicar el ministerio y promover asiduamente "las prácticas y costumbres religiosas que nos legaron nuestros mayores, no se nos oculta que mientras mayores son los peligros que amenazan menoscabar las prácticas de la religión, mayores deben ser la contracción y resortes que se pongan en juego". 60

En la visita pastoral al curato de San Pedro de Morteros, departamento de San Justo, el obispo señalaba:

En cuanto a distribuciones religiosas para el pueblo, es de desear mayor animación y aún el aumento de estas, en la parroquia y en las otras iglesias del curato, dado el espíritu de frialdad religiosa y del liberalismo que la época actual trata de imponer en todas partes, estas deben aumentar y mejorárselas en las ceremonias piadosas, de modo que impresionen mejor a los fieles y sea más seguro el resultado de la piedad en ellos. $^{61}$

Las estrategias pastorales sugeridas para atraer a los fieles al templo estaban relacionadas con el esplendor del culto en la funciones religiosas, "de modo que impresionen mejor a los fieles y sea mas seguro el resultado de la piedad en ellos", 62 a fin "de mantener tener viva e ilesa la fe y buenas costumbres". 63

\footnotetext{
${ }^{58}$ ACC. Libro de Autos y Visitas Pastorales, 1885-1916. Visita Canónica al Curato de Arroyito, Octubre 26 de 1907.

59 AAC. Parroquias: Capilla Rodríguez. Visita Canónica 9 de Mayo de 1909.

${ }^{60}$ AAC. Parroquias: Capilla Rodríguez. Visita Canónica 9 de Mayo de 1909.

${ }^{61}$ AAC. Libro de Autos y Visitas Pastorales. Auto de la Visita a San Pedro, Noviembre 24 de 1905.

${ }^{62}$ AAC. Libro 45. Autos y Visitas Canónicas, f.41.

${ }^{63}$ AAC. Carpeta Curia, Visitas Pastorales y Varios, 1887 a 1911. Auto y Visita Canónica a Ntra. Señora del Rosario y Curato de Tulumba, 5 de octubre de 1910.
} 
Las disposiciones del obispo buscaban restablecer las fiestas patronales y la Semana Santa "con todo su esplendor", así como la organización de jornadas eucarísticas y procesiones, pues este tipo de eventos religiosos impresionaban al pueblo y generaban un profundo impacto. ${ }^{64}$ En la Catedral, se restableció la Cofradía del Santísimo Sacramento destinada a promover la piedad eucarística con el objetivo de replicar sus fines en todas las parroquias de la diócesis. ${ }^{65}$ En 1911, se publicaba un folleto titulado Procesional Eucarístico, donde se establecía una serie de prácticas devotas para las procesiones del Santísimo Sacramento en las calles. ${ }^{66}$

La religiosidad invadió las calles y las devociones a Jesucristo se multiplicaron, las fiestas de fin de siglo en el pueblo de Río Cuarto así lo demostraron. El objetivo estaba cumplido, el folleto conmemorativo decía: "han abierto grandes brechas en los corazones creyentes y no creyentes donde yace depositada la semilla augusta de la fe" ${ }^{67}$ Las fiestas duraron tres días, el punto central fue la entronización de una imagen monumental de Jesucristo en la iglesia matriz. Se celebró un triduo de misas solemnes acompañadas con orquesta; la procesión nocturna por las calles acompañaba la imagen a la luz de las antorchas y, finalmente, a la mañana siguiente, la bendición y colocación de la imagen con un solemne Te Deum.

Las expresiones de los sermones y discursos fueron todos en la misma línea "el siglo que muere ha desconocido a Jesucristo". El siglo XIX se presenta como el siglo de la incredulidad, de la racionalidad y el cientificismo, que presentó a Jesucristo como la perfección ideal de la humanidad, pero negando su condición divina; la inspiración de los evangelios y la explicación de los milagros como fenómenos naturales, "el pueblo nunca fue filósofo ni lo será jamás, y por esto despreciando a tales críticas y a tales filósofos, perseveró firme en la fe de sus padres que es la fe católica". ${ }^{68}$ Siguiendo el curso del siglo, primero se lo presentó como revolucionario, que llamó a la rebelión de los oprimidos y lanzó anatemas contra los opresores, precursor de los enemigos del derecho de propiedad, un hombre extraordinario al que se le debía respeto y admiración, pero al que se le negaba su carácter de hijo de Dios, y la Iglesia que fundó para continuar su obra de redentora. Luego, aparece la imagen de un Cristo sentimental, presentado por Ernesto Renán, un genio, un gran utopista, pero que nunca había

\footnotetext{
${ }^{64}$ AAC. Leg. 7. Carpeta $\mathrm{N}^{\circ} 37$.

${ }^{65}$ AAC. Fondo Zenón Bustos. Caja No 5, fs.1952-1953.

${ }^{66}$ IEA. Pablo Cabrera, "E1 Procesional Eucarístico”, Imprenta y Casa Editora Domici, Córdoba, 24/09/1911.

${ }^{67}$ IEA. "Fiestas de fin de siglo. El pueblo de Río Cuarto a Jesucristo Redentor", Río Cuarto Librería y Tip. La Minerva, Córdoba, 1901, p. 3.

${ }^{68}$ Ibid., p. 4.
} 
osado declararse hijo de Dios. El siglo XIX reconoció a Cristo, pero presentó una imagen relativizada, adecuada a intereses y ambiciones, y, en todos los casos, negando el orden sobrenatural y divino. "Jamás la fe en Jesucristo ha manifestado tan grande poder de expansión como en este siglo, y no solo de expansión, sino también de resistencia". ${ }^{69} \mathrm{El}$ siglo XIX fue un siglo incrédulo, "no basta con reconocer a Cristo también hay que adorarlo". Fue un siglo de negaciones, "sea el XX, el siglo de las afirmaciones, de las verdades sobre Cristo, cuya presencia en el sacramento del Altar es el compendio de todas las figuras, ritos y revelaciones". "Cristo vence, Cristo reina, Cristo impera". "Nosotros en el nuevo siglo seremos los apóstoles de su divinidad, heraldos de su fe, soldados de su Iglesia y discípulos de su magisterio". 70

Estas fiestas muestran un giro en las relaciones entre autoridades civiles y religiosas y dan cuenta del lugar que comenzará a ocupar la religión como elemento de identidad nacional. Patria y religión comienzan a ser conceptos que aparecen indisolublemente unidos. El último discurso a cargo del Dr. Juan José Vélez termina dirigiéndose "a las autoridades que con su presencia han impreso a estos homenajes, el carácter de un desagravio oficial a Jesucristo; confirmando la unión en que el estado debe vivir con la Iglesia [...] y al pueblo, que se me presenta siempre cual abanderado, al pie de las derruidas almenas haciendo flamear las banderas de la religión y de la Patria".71

Una de las asociaciones destinada a fomentar los actos de piedad eucarística fue el Apostolado de la Oración. Hay un fenómeno masivo de expansión y en poco tiempo se estableció en las parroquias de la provincia. Esta asociación estaba orientada a ser de gran ayuda para el párroco en el florecimiento de la piedad parroquial, "un poderoso resorte en manos del cura que le asegure el poder mantener incólume el depósito de la piedad y de la fe de su feligresía". ${ }^{72}$ ¿Cuántos centros y cuántos socios había? ¿Qué impacto tenía en las respectivas comunidades? Es una pregunta difícil de responder, pues si bien la curia pedía información, no todos los párrocos la envían y algunos envían parte y no completa. Una de las preguntas del cuestionario de las visitas canónicas se refería a este tema ¿Hay cofradías en la iglesia parroquial o fuera de ella? ¿Cuántas y como se llaman? ¿Hay Círculo de Obreros?

\footnotetext{
${ }^{69}$ Ibid., p. 15.

${ }^{70}$ Ibid., p. 19.

${ }^{71}$ Ibid., p. 75.

${ }^{72}$ AAC. Libro de Autos y Visitas Canónicas, 1885-1916. Visita Curato de Santa Rosa de Río $1^{\circ}$, f.88.
} 
¿Quién es su director? ¿Hay Conferencia de San Vicente de Paúl y otras asociaciones católicas? Entre 1905 y 1912, también se enviaron unas planillas relativas al movimiento religioso parroquial para que los curas las completaran. Entre los datos que se solicitaban esta la información sobre el apostolado y la cantidad de socios. Sin embargo, no todos los curas respondieron. En 1905, sólo ocho de los treinta y nueve curatos de la campaña cordobesa informaban que tenían establecido el Apostolado de la Oración; en 1910, respondieron 26 y 13 no respondieron; ${ }^{73}$ cerca del $50 \%$ contaba con esta institución establecida en iglesias y capillas dependientes. ${ }^{74}$ El número de socios también fue significativo, principalmente en algunos curatos. En el oeste, el curato de Calamuchita tenía, en 1893, 228 socios; en 1905, 300 y en 1910, 1.550. San Javier tenía, en 1910, 300 socios. En 1905 se creó en Minas y contó con 118 socios y en 1910 alcanzó el número de 601. En Cruz del Eje, comenzó con 75 socios y cuatro años más tarde, eran 445. En el norte, Sobremonte alcanzó a tener, en 1910, 582 socios; Río Seco, 190 y Tulumba, 150. En el este, departamento de San Justo, Morteros tenía 263 socios; San Francisco, 480; Villa Concepción, 370 y Arroyito, 100. En Tercero Abajo, Villa María tenía 200 y Villa Nueva, 325 socios. $^{75}$ El total de miembros del Apostolado de la Oración en la campaña, sin contar las ciudades de Córdoba y Río Cuarto, superaba los 3.000 socios. Además del Apostolado, comenzaron a crecer las Congregaciones del Sagrado Corazón de Jesús y del Inmaculado Corazón de María, las Conferencias Vicentinas y las congregaciones propias de cada curato, Cofradías del Rosario, del Carmen, del Niño Jesús de Praga, la Pía Unión de San Antonio, etc.

El obispo fomentaba en los párrocos la necesidad de cultivar la piedad en las personas que formaban parte de las asociaciones fundadas en las parroquias, y de inspirarles la convicción de que desempeñaran el rol de propagandistas y cooperadores del ministerio parroquial. En la década de 1920, la imagen de apatía e indiferencia religiosa del pueblo es infrecuente en el discurso eclesiástico. Los autos de las visitas pastorales realizadas entre 1915 y 1925 son optimistas en este campo. En 1917, Zenón Bustos visita el curato de Canals y en el auto señala que le es "muy satisfactorio dejar constancia de la buena

\footnotetext{
${ }^{73}$ Bell Ville, Caroya, Colón, Ischilín, Pocho, Quilino, Río II, Río IV, Río de los Sauces, San Alberto, Soto, Tránsito y Villa del Rosario, no envían ningún dato.

${ }_{75}^{74}$ AAC. Libro sobre Movimiento Religioso en las Parroquias, 1905-1912.

${ }^{75}$ Libro 28. Movimiento Religioso de los Curatos.
} 
impresión que llevamos de la acción desarrollada por el Señor cura que con caridad desempeña la alta misión de su sagrado ministerio, la vida religiosa de los diversos pueblo que hemos visitado comprendido en esta parroquia si bien es cierto que no la hemos encontrado todavía debidamente cimentada, sin embargo, reconocemos lo mucho que ha ganado en estos últimos tiempos. El sacerdote, que antes era mirado con recelo y desconfianza en estos pueblos y para muchos objeto de burla y desprecio, hoy lo vemos respetado por todos, como también encontramos frecuentadas las Iglesias, en otra hora desiertas, por gran número de fieles que concurren para cumplir con los preceptos de la Santa Misa en los días festivos y a recibir los sacramentos de la confesión y comunión y no dudamos que en el porvenir ira mejorando más y más cada día dada la solicitud y celo con que trabaja el señor cura". 76

La visita al curato de Morteros tiene el mismo tono optimista que el Prelado, Mons. Luque, señala en el auto en el cual dice que un "halagüeño porvenir, siendo ya aunque lento, real y positivo el resurgimiento de la piedad exteriorizada en la mayor concurrencia al templo y más frecuencia de sacramentos". ${ }^{77}$ Lo mismo sucedió en la visita al curato de Río Seco, donde en el auto también se deja constancia "de las buenas impresiones que hemos recibido al examinar la labor del cura en el desempeño fiel de su santo y sagrado ministerio", luego pasa a detallar las actividades desarrolladas por el cura, atenta y pronta atención a los enfermos, la constancia en la predicación los domingos, días festivos y novenarios, las visitas periódicas a las capillas, la solicitud en la instrucción religiosa, y el cuidado material del templo y las capillas. Labor que redunda en beneficio de los fieles y en una mayor asistencia al templo. ${ }^{78}$ Lo mismo sucede en la visita al curato de Porteña realizada por el Obispo Bustos el 28 de octubre de 1917. Allí señala que le ha impresionado “gratamente, gratísimamente", las mejoras en el templo, en particular el atrio y la torre que hablan del espíritu parroquial y de progreso que animan al cura y a su acción eficiente". 79

En la visita canónica de 1922 al curato de San Francisco, el Obispo visitador, José A. Luque, dice en el auto que le es "muy satisfactorio dejar constancia de la buena impresión que hemos recogido en estos días de la marcha general de la parroquia, y de los progresos

\footnotetext{
${ }^{76}$ AAC. Libro Visita de Parroquias, 1916-1922, fs.42-44. Fecha de la visita, del 16 al 24/09/1917.

${ }^{77}$ AAC. Libro Visita de Parroquias, 1916-1922, f 39. Fecha de la visita, 23/08/1917.

${ }^{78}$ AAC. Libro Visita de Parroquias, 1916-1922, fs.57-58. Fecha de la visita, del 11 al 15/10/1917.

${ }^{79}$ AAC. Libro Visita de Parroquias, 1916-1922, f.61. Fecha de la visita, 28/10/1817.
} 
que hemos encontrado tanto en el orden moral y religioso como en el orden material, debido sin duda en gran parte al celo y decidida voluntad con que el Sr cura trata en lo posible de cumplir con sus deberes de párroco y a la influencia que propicia a ejercer el primer colegio católico de niñas existente en esta ciudad. El notable aumento de comuniones en la parroquia, el mayor concurso del pueblo que se acerca a cumplir el precepto de la misa en los días domingos y festivos y la asistencia de niños a la doctrina, creciente cada día según los informes recogidos, son verdaderos testimonios del mejoramiento espiritual y el progreso religioso de esta feligresía que comienza a experimentar la influencia salvadora de los principios cristianos que irradian en el alma la vida espiritual para exteriorizarse después en la moral de las costumbres". ${ }^{80}$

El culto adquiere un carácter popular y se advierte la concurrencia masiva de fieles a las ceremonias religiosas. La religiosidad asume dimensiones masivas y se promueven prácticas devocionales en todos los templos, la devoción a Jesús Sacramentado y la práctica de ejercicios piadosos, como el Vía Crucis, todos los viernes, el rezo del Rosario durante el mes de octubre, el mes de María y la novena a la Inmaculada Concepción. Particular importancia adquieren los actos de devoción eucarística, como las procesiones de Corpus Christi por las calles de la ciudad y de las villas.

En el mes de mayo de 1922, se celebraron, en toda la diócesis, las Jornadas Eucarísticas en la catedral y en las iglesias de la ciudad, en adhesión al Congreso Eucarístico Internacional, celebrado en Roma. La función de la Catedral estuvo destinada a los hombres, a la que asistieron más de dos mil, y la de señoras tuvo lugar en San Francisco con una asistencia aún mayor. ${ }^{81}$ Las iglesias de la ciudad se unieron a la celebración con misas y actos de adoración al Jesús Sacramentado. Con motivo de la celebración del Congreso Eucarístico en Roma y de la celebración de la fiesta de Corpus Christi se organizó en la diócesis un programa de actos eucarísticos. ${ }^{82}$ La respuesta a esta convocatoria fue multitudinaria, las celebraciones

\footnotetext{
${ }^{80}$ AAC. Parroquias: San Francisco, f.117. Fecha de la Visita del 18 al 22/12/1922.

${ }^{81}$ Los Principios, 29 de mayo de 1922.

${ }^{82}$ Los Principios, viernes 12 de mayo de 1922, p. 1. "El programa podría condensarse en una gran jornada eucarística para señores el día 28 en la Iglesia Catedral, previo un triduo de conferencias como reparación al acto. Una velada eucarística para la noche del 28 de mayo. Programas particulares en las diversas iglesias. Adoración continua en el Templo de San Francisco, que consiste en un triduo de preparación para la 'jornada eucarística de señoras' del día 28 en dicho templo".
} 
se desarrollaron simultáneamente en distintos templos de la ciudad. ${ }^{83}$ Miles de hombres asistieron a la celebración eucarística en la catedral metropolitana.

La pléyade de católicos asistentes a la jornada eucarística y que así se unen en espíritu a la gran asamblea internacional que se celebra en Roma [...] está diciendo claramente que la fe vive en Córdoba encendida en multitud de hogares bajo la mirada vigilante de nuestras mujeres, esposas, madres e hijas [...]. Desde las 7.30 las naves de la catedral se hallaban concurridísimas de hombres cristianos de todas las clases, condiciones y edades dispuestos asistir a la jornada eucarística que comenzó a las 8.30 con el santo sacrificio de la misa. ${ }^{84}$

Distintos puntos del interior de la provincia se unieron a la celebración. En Colonia Vignaud comulgaron alrededor de 600 personas, de las cuales la mayoría eran hombres. "El acto fue altamente edificante, dando una prueba conmovedora de la fe viril" ${ }^{85}$ La religión sale de las paredes del templo, movilizaciones y procesiones religiosas cruzan las calles de la ciudad y villas de la campaña. Algunas reúnen importantes contingentes pertenecientes a los sectores populares e inmigrantes. En la parroquia de Alta Córdoba se celebraron las fiestas josefinas. Las dos asociaciones de hombres que funcionan en la parroquia, la de San José y la Juventud Católica, llevaron más de ciento cincuenta de sus asociados, “cosa jamás vista en este barrio eminentemente obrero y por ello poco favorable a parecidos espectáculos". ${ }^{86}$

A partir de estas fechas, la festividad de Corpus se convirtió en una conmemoración de carácter multitudinario, el boletín parroquial de Río Cuarto describe, diez años después, con detalle, la preparación para dichas fiestas y anuncia que serán presididas por el obispo: "El jueves de la semana venidera se celebrará la clásica festividad del CORPUS CHRISTI, urge entonces que las instituciones piadosas y los católicos todos empecemos desde ya a organizarnos para celebrar con todo el esplendor posible el día de la Sagrada Eucaristía [...]. Urge que todos nos organicemos a saber, los cuatro organismos de la Acción católica, las asociaciones del Apostolado, Hijas de María, Tercera Orden de San Francisco y personas

\footnotetext{
${ }^{83}$ Los principios, Jueves 25 de mayo de 1922. "Las celebraciones eucarísticas se desarrollaron en La Catedral, la Compañía de Jesús, la Merced, la Iglesia del Carmen, la Parroquia de San Vicente, el Templo de las Adoratrices, el Buen Pastor, el Pilar, San Roque y San Francisco".

${ }^{84}$ Los Principios, 29 de mayo de 1922.

${ }^{85}$ Los Principios, Sábado 20 de mayo de 1922, p. 9.

${ }^{86}$ Los Principios, Martes 9 de mayo de 1922, p. 7.
} 
particulares, prepararan los sitiales para la procesión de ese día, los colegios católicos prepararán los cánticos $\left[\ldots\right.$. ]" ${ }^{87}$

Cuatro son los cambios que observamos en relación a la religiosidad, el primero es un deslizamiento de una religiosidad individual, radicada en el espacio privado, con escasa participación en el templo y en la vida parroquial, hacia una religiosidad popular, que se desborda en las calles con procesiones eucarísticas, devociones populares, fiestas patronales. El segundo deslizamiento tiene relación con la participación masculina. La religión deja de concebirse como una cuestión femenina, se advierte una participación activa del hombre en las asociaciones eclesiásticas parroquiales. El tercer deslizamiento tiene vinculación con la incorporación de sectores populares (obreros y trabajadores rurales), a través de las asociaciones de Josefinos y los círculos de obreros. El cuarto giro está vinculado con la determinación de disminuir la participación de los colonos italianos en la fiesta cívica del 20 de septiembre, como vimos en el capítulo anterior.

\subsubsection{La predicación}

El informe sobre la diócesis enviado a la Santa Sede en 1908 reconocía que la predicación era un medio poderoso que contribuía a la formación, conservación y perseverancia del pueblo, pero que se encontraba "falseado, desnaturalizado y quebrantado". Señalaba que la predicación era frondosa y redundante, pero que faltaban las ideas, las enseñanzas que instruyesen al pueblo en sus deberes, les corrigiesen sus defectos y les impulsasen a la práctica de la virtud. El contenido y los temas tampoco se adecuaban a las necesidades espirituales, con frecuencia eran políticos, históricos, sociales o patrióticos, y no siempre eran comprendidos por la gente que asistía a las funciones, generalmente "mujeres y pobres gente del pueblo". 88

La ausencia de predicación era muy frecuente. A modo de ejemplo, en la catedral, la misa de los días domingos se celebraba en horas tempranas de la mañana y no se decía homilía. La décima disposición del auto de la visita del año 1906 intimaba al párroco a cumplir con gravísima obligación de predicar el Evangelio al pueblo de la parroquia en los días festivos. ${ }^{89}$ Esto sucedía en la catedral, que contaba con personal suficiente para realizar

\footnotetext{
${ }^{87}$ AHRC. La Semana Católica, parroquia de Río Cuarto, 04/06/1933. Año XIV, N 606, p. 2.

${ }^{88}$ ASV. Fondo Nunciatura Argentina, 47, f.23.

${ }^{89}$ AAC. Libro de Autos y Visitas Parroquiales, 1885-1916, f.19.
} 
esta actividad, un cura rector, un teniente y los capellanes de coro. En las parroquias rurales, que contaban con un solo sacerdote, que, además de las funciones de la parroquia, debía atender las capillas y salir al campo cuando lo requería la atención espiritual de los enfermos, la práctica de la predicación frecuente era aún más problemática. En 1905, sólo nueve de los cuarenta y tres curatos existentes tenían un teniente o ayudante. ${ }^{90}$

Los párrocos debían responder al cuestionario de las visitas canónicas, indicando si se predicaba en los días festivos y en otras ocasiones. El balance que se obtiene de la primera gira de las visitas pastorales (1906-1913), es que si bien los curas informaban que predicaban, las denuncias de las feligresías y las disposiciones manifestadas por el obispo en los diversos autos de la visita dan cuenta de las deficiencias en el cumplimiento de ese deber ministerial. Los fieles de los curatos de Soto, Minas, Río Primero, San Francisco, Bell Ville, Porteña elevaron quejas a la curia en las que denunciaban la falta de predicación y el carácter político de los sermones de los respectivos párrocos.

En la visita canónica al curato de Cruz del Eje, el obispo solicita al párroco que "llene con celo el deber de la predicación impuesta por el tridentino a los párrocos todo los domingos y días festivos, palabra necesaria, indispensable a los fieles, como que es el alimento espiritual sin el cual fácilmente sucumben". ${ }^{91}$ El control respecto a la predicación fue un punto importante del gobierno diocesano.

En 1918, el obispo dictó una conferencia al clero diocesano sobre el alcance y las cualidades que debía tener la predicación. Advertía que su ausencia acarreaba la indiferencia y la decadencia en las prácticas religiosas. La predicación tenía que ser sencilla, simple, clara, natural y sin artificios. La materia de la predicación debía ser el evangelio, el cura debía desechar especulaciones filosóficas o políticas. Las características de un buen orador no radicaban en la erudición y la oratoria, en primer lugar se exigía al clero una conducta moral ejemplar, una vida de piedad fervorosa y sólida y una práctica frecuente de oración y meditación de las escrituras. La Biblia debía ser el libro más meditado y del cual se extrajeran para los fieles ejemplos concretos. La predicación debía ser una manera de "popularizar la teología llevándola al pueblo". 92 El párroco de San

\footnotetext{
${ }^{90}$ AAC. Leg. 1. Exp. No 85, f.444-448.

${ }^{91}$ AAC. Libro de Autos y Visitas Parroquiales, 1885-1916. Auto de la Visita Canónica a Cruz del Eje, 22 de marzo de 1908.

92 AAC. Conferencia al Clero sobre las Cualidades de la Predicación, Imp. Ferreyra, Córdoba, 2 de
} 
Vicente, Antonio Lamonaca, sostenía que la predicación sistemática era una estrategia pastoral de suma eficacia, "se puede resistir a la predicación de ocho días, de diez, pero no a la predicación de una cuaresma entera".93

En la segunda gira pastoral (1915-1922), los autos de las visitas canónicas son optimistas al respecto. Resaltan que los párrocos predican con constancia y regularidad los domingos, días festivos y durante las novenas. La pregunta 38 del interrogatorio de la visita se refiere al tema: ¿Se predica en los días festivos? ¿Quién? ¿Hay además otros sermones en cuaresma? ¿Cuántos? ¿Hay mes de María? Las respuestas son todas afirmativas. El cura de Villa María, Paulino Colabianchi, responde que se predica todos los días festivos, en la primera misa, el cura, y en la segunda, el teniente, y en cuaresma, todos los miércoles y viernes de cada semana había sermones. Además, se predicaban ejercicios espirituales para el pueblo, del septenario de Dolores al miércoles Santo, y en el mes de María, a diario. ${ }^{94}$ Responden 27 curatos. Todas las respuestas señalan que se predica los domingos y días festivos. En algunas ocasiones se especifica que también se predican novenarios íntegros durante varias festividades del año. Se vive el Mes de María, o el mes del Rosario. Durante la cuaresma se predicaba al menos dos veces a la semana. ${ }^{95}$

\subsubsection{Enseñanza de la Doctrina Cristiana}

Uno de los pilares en los que se apoyó la política eclesiástica del Obispo Bustos fue formar en los rudimentos de la religión católica a niños y adultos. La enseñanza del catecismo tenía un doble objetivo, se presentaba como un dique de contención ante el avance de las nuevas doctrinas socialistas y anarquistas y se convertía en una estrategia a mediano plazo, destinada a impulsar la práctica religiosa en vastos estratos de la población, otorgando a la religión un papel central en la vida cotidiana. Se trataba de una medida destinada a vigorizar a la Iglesia e inculcar a los niños las bases para un comportamiento futuro de acuerdo a los valores cristianos. Consideraba la enseñanza religiosa como una

septiembre de 1818.

${ }_{93}^{93}$ AAC. Parroquias: San Vicente, f.85.

${ }^{94}$ AAC. Parroquias: Villa María, fs.171-172.

95 AAC. Respuestas a la pregunta 38 del interrogatorio de la visita canónica: San Justo, Arroyito, San Francisco Morteros, Freyre; Bell Ville, Las Varillas, San Antonio de Litín; Ballesteros, Villa María, Villanueva, Marcos Juárez, Cruz Alta, Leones, Santa Rosa de Río $1^{\circ}$, Chalacea, Río $2^{\circ}$; Santa María, Jesús María, Punilla, San Javier, San Agustín, Río de los Sauces, Cruz del Eje, Ischilín, Quilino, San Carlos Minas. 
necesidad de individuo y del sostenimiento de las instituciones sociales, particularmente importante en "esta hora de rebelión y de desorden".

Falta al pueblo y ella es la que debe tenerse pacífica sede en el corazón de los fieles para que pueda destellar luces sobre sus futuros destinos y alumbrar sus pasos con la moral práctica y manifestaciones públicas al verdadero Dios. Y por lo general falta, y es necesario que ella viva, se radique en el corazón y sirva de principio permanente de inspiraciones salvadoras del individuo y de la sociedad. ${ }^{96}$

Al inicio de su mandato, el obispo publicó una carta pastoral referida a la enseñanza de la Doctrina Cristiana, en la cual recomendaba establecer, en las parroquias, las homilías dominicales y, en días de fiesta, la catequesis para niños y adultos, y sostenía la necesidad de que la enseñanza penetrara en el "espíritu y la práctica el pueblo", haciéndose popular. ${ }^{97}$ En la concepción episcopal, la doctrina cristiana, encarnada en el pueblo, ayudaría a mantener la armonía social; como contrapartida, su ignorancia facilitaría la anarquía y el desorden, tal como lo expresa:

Prepara la unión y concordia populares, sin derramar los gérmenes disolventes esparcidos por las demás doctrinas contradictorias o expuestas a cambios, que luego entrega a las masas a la marea de las agitaciones populares. [...] tarde o temprano la mutabilidad de las doctrinas en las que se educa al pueblo, se convierten en peste moral del mismo. Instruyéndolo civilmente en estas doctrinas tendremos un pueblo en ciertas horas idealista, materialista en otras, o socialista o anarquista o escéptico, según el catecismo que se le puso en sus manos: los hijos contradecirán a los padres y los padres a los hijos iniciándose la anarquía en el hogar que se derramará después al pueblo y subirá inevitablemente a la altura de los poderes públicos. ${ }^{98}$

Nuevamente se advierte el carácter moralizador atribuido a la doctrina cristiana. A ella dedicará firmes esfuerzos por el rol que desempeña la enseñanza del catecismo en la conservación de la fe. El obispo pide a los curas la formación de centros de doctrina, oratorios dominicales, advirtiéndoles que estaba dispuesto a impulsar esas obras, convencido de que encarnaban "eficaces bienes para la religión y la moral popular". 99

Para el obispo, el lugar privilegiado para recibir los rudimentos de la vida cristiana contenidos en el catecismo debía ser el hogar, pero observaba en los padres de familia una

\footnotetext{
${ }^{96}$ AAC. Autos y Visitas Pastorales, 1885-1916, f.15.

${ }_{97}$ AAC. Carpeta Pastorales, Edictos y Circulares, s/f. Pastoral del 7 de julio de 1906.

${ }^{98}$ AAC. Carpeta Pastorales, Edictos y Circulares. Pastoral del 7 de julio de 1906, p. 4.

${ }^{99}$ Los Principios, 03/05/1905.
} 
marcada desidia e indolencia para cumplir con ese deber. ${ }^{100}$ Para suplir esa falencia la parroquia asumió un rol primordial en la formación cristiana de los niños. En 1906, se creó el Centro Diocesano de la Doctrina Cristiana. ${ }^{101}$ El presidente debía organizar la enseñanza de la doctrina en las parroquias, vice-parroquias y oratorios, contando con el número de congregantes activos. El secretario de cada centro parroquial debía llevar un libro de actas, un registro de los congregantes, donde especificaría nombre, apellido y domicilio, y anotar en el libro el número de niños y niñas que asistían a la doctrina. Cada socio catequista debía informar semanalmente la asistencia de alumnos y llegar un cuarto de hora antes de comenzar la clase. El texto del catecismo fue el aprobado por la Conferencia de Obispos de Salta de $1902 .{ }^{102}$ El movimiento catequístico rápidamente se expandió por toda la ciudad y en algunos puntos de la campaña. Uno de los principales problemas para instalar los centros de enseñanza radicaba en la falta de personal idóneo. Los curas se dedicaron a formar grupos de catequistas seglares, primordialmente mujeres, que asumieran esa tarea pedagógica. ${ }^{103}$ La enseñanza se realizaba los domingos y feriados, durante una hora y media antes o después de la celebración de la misa. La educación culminaba luego de dos años con la celebración de la primera comunión. La Iglesia advierte con claridad la importancia de la socialización primaria, recomienda al párroco especial dedicación en esta tarea. La ceremonia de la primera comunión comienza a tomar un relieve particular, debe tratarse de "una función que quede grabada en la mente de los niños". En Río Cuarto, se instauró la "fiesta angélica", se trataba de una fiesta religiosa dedicada a todos los niños, sin distinción de “clase, edad o religión”. Se celebraba la misa donde los niños tomaban su primera comunión, luego se repartían masas, caramelos y otros dulces y un número de rifa, luego se realizaba una procesión con cánticos y plegarias, en la que cada centro catequístico llevaba sus estandartes. En general, asistía un promedio de tres mil chicos. Al finalizar, se efectuaba el sorteo de los regalos. ${ }^{104}$

Entre 1905 y 1912, la curia diocesana llevó un registro del movimiento religioso de las parroquias. En él se consignaban los datos referidos a la enseñanza del catecismo y las primeras comuniones. El registro revela la importancia que tenía para el diocesano esta

\footnotetext{
${ }^{100}$ AAC. Pastorales, Edictos y Circulares. Auto sobre la Enseñanza del Catecismo, 7 de abril de 1912.

${ }^{101}$ AAC. Libro de Actas, Centro Diocesano Doctrina Cristiana, f.2.

${ }^{102}$ AAC. REOBA, Sección Córdoba, 1905, f.245-249.

${ }^{103}$ AAC. Pastorales, Edictos y Circulares. Auto sobre la Enseñanza del Catecismo, 7 de abril de 1912.

${ }^{104}$ AHFRC. Memoria de la Conferencia Vicentina Santa Rosa de Viterbo, 1918, f.10.
} 
actividad. En 1906, quince parroquias rurales envían sus planillas, en las que se suman sólo 986 niños que tomaron la primera comunión; en 1910, también quince parroquias rurales informan la cantidad consignada que asciende a 2.117 chicos. ${ }^{105}$

En 1906, de las 45 parroquias existentes en la provincia, sólo dos tenían instalada la Congregación para la Doctrina Cristiana, con un total de 17 socios; en 1912, pudimos constatar la existencia de centros en 18 parroquias con un total de 273 socios dedicados a la enseñanza del catecismo a niños. El 29 de agosto de 1924 la curia envió una nueva circular a todos los párrocos de la diócesis en la que solicitaba que informaran respecto al número de centros de doctrina instituidos en sus parroquias. Si bien las respuestas son incompletas y fragmentarias, dan cuenta de la existencia de numerosos centros, parroquias, capillas, oratorios, colegios y escuelas fiscales que tenían establecido un centro de doctrina. Los autos de la segunda gira pastoral, dejan constancia de esta realidad.

En Río Cuarto, funcionaban en 26 centros catequísticos, la mayoría a cargo de la Conferencia Vicentina de Santa Rosa de Viterbo, con un promedio anual de 250 niños en primeras comuniones.

\subsubsection{El rol de las familias en la enseñanza del catecismo}

La ignorancia debía ser neutralizada con la enseñanza de la doctrina principalmente en el seno familiar. El cura debía "encarecer a los padres y madres de la familia el deber que les incumbe de enseñar de diario en el hogar la doctrina a sus hijos y domésticos". ${ }^{106}$ De la familia cristianamente formada "sale el pueblo con sus costumbres religiosas". ${ }^{107}$

La acción de los padres cristianos era un punto clave para consolidar los valores en la familia y la sociedad. En octubre de 1923, la región del este realizó las primeras asambleas regionales de padres cristianos, organizadas por la parroquia de Colonia Vignaud. El objetivo era la concreción de reuniones inter-parroquiales -entre las parroquias de Freire, Porteña, Morteros, Suardi y Vignaud-, de padres de familia, a fin de hacerles tomar conciencia sobre su responsabilidad como padres cristianos. Reflexionar sobre el compromiso contraído ante Dios y la iglesia de custodiar la fe y la pureza de costumbres en

\footnotetext{
105 AAC. Libro Movimiento Religioso de Parroquias, 1905-1912.

${ }^{106}$ AAC. Carpeta Curia, Visitas Pastorales y Varios, 1887-1911. Auto de la Visita Pastoral a la Parroquia de Canals.

${ }^{107}$ AAC. Carpeta Curia, Visitas Pastorales y Varios, 1887-1911.
} 
sus hijos y que al conocer las dificultades que existían para la formación y educación cristiana de los mismos, decidían reunirse bajo la guía de los pastores de la iglesia con el fin de estudiar y buscar medidas conducentes a la feliz realización de tan magna tarea. El llamado de los párrocos fue firme:

No toleréis que los impíos se crean con derecho a escupir en la frente de vuestros hijos el veneno de la inmoralidad y de las falsas doctrinas, mientras blasfeman de vuestro mas sagrado tesoro: la Fe. Vean ellos que los padres católicos de estas colonias, forman legión, que están organizados y dispuestos a la lucha, y que siendo así nadie podrá ofender impunemente sus creencias ni manchar con inmunda bava la pureza de sus familias. ${ }^{108}$

Los temas del congreso abordaban la misión de los padres cristianos, el estado moral, religioso y social de las familias de las colonias, las causas del relajamiento del espíritu cristiano; la vida parroquial como medio de formación del criterio y del carácter cristiano; los peligros de la juventud en las colonias, vigilancia, educación cristiana, obra de preservación -centros catequísticos, centros de círculos de jóvenes, etc.-; blasfemias y profanación de los días festivos y el espíritu de asociación como medio de defensa contra los ataques del enemigo; el carácter de las asociaciones. El congreso duró cuatro días, el programa iniciaba cada día a las 7 hs de la mañana con una misa general y concluía por la tarde luego de las sesiones de trabajo que comenzaban a las 14:30hs. El último día se celebró solemnemente la fiesta de la Virgen del Rosario, con una jornada eucarística, misa pontifical, rezo del Te Deum y procesión.

En síntesis, la acción religiosa de las parroquias combinó la formación doctrinal, primordialmente de niños, las funciones litúrgicas y las fiestas religiosas, como instrumentos de socialización del pueblo. La pedagogía eclesiástica se orientó a forjar un imaginario colectivo en el cual la religión jugaba un papel central en la configuración societal. La inculcación de valores religiosos y morales garantizaría una sociedad menos conflictiva.

${ }^{108}$ AAC. Fondo Zenón Bustos, fs.410-411. 


\subsubsection{La acción benéfica y asistencial}

Para el diocesano, la pobreza y la miseria iban unidas a la decadencia moral y religiosa. El prelado identificaba la indigencia con la depreciación moral, por lo tanto consideraba que al aligerar los problemas materiales de los sectores más vulnerables, disminuiría la situación de pecado - de vida desordenada. De allí la responsabilidad de la Iglesia en proporcionar asistencia material a los más necesitados. La solución de situaciones de indigencia garantizaría una conducta moral cristiana. ${ }^{109}$

Gran parte de la acción benéfica que desarrollaba la Iglesia en Córdoba era llevada a cabo por la acción de las diversas congregaciones religiosas, tanto en el campo educativo como en el asistencial. En el período que nos ocupa, se instalaron, en la diócesis, congregaciones femeninas y masculinas dedicadas a la asistencia y a la caridad. ${ }^{110}$ No nos detendremos aquí en la beneficencia llevada a cabo por las congregaciones religiosas, sino que centraremos nuestra atención en la actividad benéfica impulsada desde las parroquias.

La acción benéfica asistencial continuó en manos de las Conferencias Vicentinas. Al inicio del gobierno del obispo Bustos, estaban establecidas ocho Conferencias en la ciudad capital, ${ }^{111}$ una en Río Cuarto ${ }^{112}$ y seis en curatos de campaña. ${ }^{113}$ El obispo impulsó la

creación de nueve conferencias más en la ciudad y cuatro en la campaña. ${ }^{114} \mathrm{La}$ actividad de esta institución se caracterizaba por la asistencia a los pobres y realización de visitas domiciliarias y estaba a cargo de asilos, colegios, comedores y talleres. Cada conferencia se asentaba en un templo y se regía por una junta directiva.

\subsubsection{Acción Social}

La acción social parroquial se centró en la vigorización de asociaciones con orientación mutualista y de socorros mutuos como los círculos de obreros católicos, las asociaciones de Josefinos y las cajas rurales.

\footnotetext{
${ }^{109}$ AAC. Parroquias: El Pilar, f.24.

${ }^{110}$ Concepcionistas Italianas (Asilo y Colegio de Niñas Pobres, 1899); Salesianos (1904); Lazaristas (1913); Concepcionistas Españolas (Atención del Hospital, 1913); Hermanas del Huerto (Hospital San Roque, 1899); Hermanas de la Sagrada Familia (Asilo del Rosario y Asilo Maternal, 1911); RP Escolapios (Colegios, 1905); RP Benedictinos Alemanes (Instituto Técnico Agrícola Luis María Robles, 1924).

111 Ntra. Sra. de Copacabana, Purísima Concepción, María del Pilar, Ntra. Sra. del Rosario, Ntra. Sra. del Valle, María de la Merced.

112 "Santa Rosa de Viterbo".

${ }^{113}$ Río II, Villa Dolores, Totoral, Jesús María, Cruz del Eje, Sta. Rosa de Río I, Cosquín.

${ }^{114}$ Bell Ville, Villa María; Quilino, Huerta Grande.
} 
La acción del círculo era de tipo mutualista y social, orientándose, primordialmente, a controlar los espacios de ocio y diversión de los obreros (Gardenia Vidal: 2010 y 2011). En 1917, el obispo nombró a Monseñor Dávila visitador de cofradías y círculos de obreros, a fin de darles mayor impulso, "invitándolas a salir del retraimiento en que están detenidas y desplegar la acción beneficiosa de sus mejores tiempos". Destacaba su función de contención, de barrera y defensa del patrimonio de la fe religiosa y de la moral individual y colectiva frente al peligro en que se encontraba "constituido actualmente el proletariado y la masa de menoscabar su fe y aun perderla solicitando activamente a plegarse a creencias opuestas y adversas a sus prácticas tradicionales y fe de sus mayores por los agentes de venenosas enseñanzas". ${ }^{115}$ Los propósitos de la designación apuntaban a animar a esas instituciones, fomentar el mutualismo y la protección recíproca y promover el trabajo honesto y profesional, como escuela individual y colectiva.

En cuanto al círculo de obreros, en 1905 existía uno solo en la ciudad capital con 122 socios, en 1907 los curatos de Calamuchita, Cruz del Eje, Sampacho, San Javier y Santa María constituyeron sus círculos con 49, 11, 115, 70 y 180 socios, respectivamente, en 1908 se crearon círculos en Punilla, Remedios y Río Cuarto, con 19, 94 y108 socios, respectivamente; y en 1910 se creó el círculo en Villa María con 250 miembros. Los Josefinos era otra asociación similar al círculo que también funcionaba en algunos curatos. Sumando los miembros de todos los círculos, sin incluir los de la ciudad de Córdoba, en 1910, alcanzaron un total de 1.038 socios. ${ }^{116} \mathrm{Si}$ comparamos estas cifras con las del partido socialista las diferencias son grandes. En el capítulo anterior, señalábamos que Alejandro Dujovne sostenía que, en 1918, la federación socialista cordobesa tenía quince centros y 414 afiliados, en 1921 pasó a tener diez centros y 333 afiliados, y en 1929 ocho centros y 211 afiliados.

La preocupación mayor del diocesano radicaba en contrarrestar la influencia de los socialistas en los sectores obreros. El sudeste provincial era visto como particularmente vulnerable a la influencia de las nuevas ideologías. El objetivo de los círculos se sintetizaba en la siguiente frase del Obispo Luque, pronunciada al inaugurarse la sede del Círculo de Córdoba, "reafirmar en la conducta del hombre trabajador el culto a Dios y a la Patria, el

\footnotetext{
115 AAC. Fondo Zenón Bustos, f.2095.

${ }^{116}$ Libro sobre el Movimiento Religioso de los Curatos.
} 
respeto a las instituciones y su adhesión a la paz social". ${ }^{117}$ En 1911, convocó a los curas de la región este y sur de la diócesis a participar de las conferencias sobre cuestiones sociales, animándolos a llevar consigo alguna persona seglar, capaz de aportar ideas y luces. ${ }^{118}$ El obispo promovió las asociaciones para cultivos, cría de ganados, socorros mutuos, pues suponían una ayuda para alcanzar el pan cotidiano y a la vez despertar en los trabajadores una mayor actividad de trabajo y un acercamiento a la religión.

\section{El "Comitato Parrocchiale" de Sampacho}

En 1878, 45 familias italianas, originarias de Trento y Tirol, llegaron a la frontera sur de la provincia de Córdoba y se asentaron en los parajes donde había sido levantado el antiguo fuerte de San Fernando (1785), más de cien años atrás. Se trataba de una iniciativa del gobierno nacional, destinada a instalar una colonia agrícola, con el objetivo de colonizar estas tierras, recientemente ganadas a la frontera con el indígena. ${ }^{119}$ Se les dieron los pasajes pagos y la manutención gratuita por dos años. A cada familia se le adjudicó 30has y los elementos necesarios para construir su casa y labrar la tierra, una yunta de bueyes, una vaca, un caballo, un arado y otros utensilios. ${ }^{120}$ Dos sacerdotes, Vicente Lozino y Luis Sciarelli acompañaban a estas familias.

La rigurosidad de la vida rural y diversas vicisitudes, coadyuvaron a que, transcurridos unos pocos años, el contingente se redujera a tan sólo 30 familias, que, con los años, se amplió con nuevos contingentes. En el informe de 1881, remitido por el comisario Amadeo Miranda a la oficina de tierras y colonias, se señalaba que la colonia contaba, a la fecha, con 223 familias, de las cuales 153 eran italianas, 73 argentinas, 2 francesas, 1 española, 1 inglesa y 1 oriental. En total, sumaban 1.175 individuos. El terreno de la colonia era de siete leguas. En los lotes urbanos había 59 edificios entre los cuales no se señala el templo (Peyret, 1973: 529). Sin embargo, con el arribo de los primeros colonos, se construyó una capilla de condiciones muy precarias, sus paredes eran de adobe y el techo de madera y paja.

\footnotetext{
${ }^{117}$ BEDC, 1926, p. 294.

${ }^{118}$ AAC. Auto Episcopal, 11 de julio de 1911.

119 Por el decreto del poder ejecutivo de la provincia de Córdoba de fecha 23/11/1875, se nombra una comisión encargada de practicar el reconocimiento de los campos fiscales, conocidos con el nombre de Sampacho, con el fin de que se signe el lugar adecuado para el establecimiento de un colonia.

${ }^{120}$ INSTITUTO AGRARIO ARGENTINO (1947, TI: 191-192).
} 
En 1896, el Pbro. Lozino solicitó al obispo de Córdoba, Fray Reginaldo Toro, la autorización para construir una nueva capilla, debido a que la capilla en uso estaba a punto punto de derribarse y le informaba que disponía de 40.000 ladrillos para ello y de un vagón vagón de cal. El diocesano concedió el permiso, con la condición de que el terreno, donde donde se levantase el nuevo templo, fuese donado a la diócesis. ${ }^{121}$ El nuevo templo se erigió frente a la plaza principal y estaba bajo la advocación de los Ángeles custodios. Dos años más tarde, en septiembre de 1898, se procedió a la bendición solemne y colocación de las campanas. En 1902, esta iglesia fue erigida en parroquia y se nombró al Pbro. Juan A. Rodríguez como párroco, quien la sirvió hasta julio de 1905, fecha en que asumió el nuevo párroco, Juan Cinotto, joven sacerdote de origen italiano. ${ }^{122}$ A la llegada de Cinotto, proveniente de Turín, el pueblo era un activo centro comercial de 2.200 habitantes, con una floreciente colonia agrícola. La actividad principal era la exportación de cereales y la estación del ferrocarril era la más importante cargadora de maíz de la provincia (Río y Achával, 2004: 649).

La actividad del cura Cinotto estuvo orientada a lograr el arraigo de las prácticas religiosas en los colonos y a mejorar sus condiciones de vida y de trabajo. Le preocupaba favorecer el mantenimiento y desarrollo de la religión y de la moral, a fin de contrarrestar la propaganda y la adscripción de los colonos al socialismo. Paradójicamente en Córdoba, la adscripción al socialismo arraigó más en la campaña que en la ciudad (Dujovne, 2002a). La jerarquía eclesiástica veía con preocupación la penetración de las doctrinas materialistas en las poblaciones del sudeste provincial, donde los colonos, con frecuencia, sufrían los abusos de un sistema de arrendamientos injusto, que beneficiaba a los empresarios que subarrendaban la tierra en pequeñas parcelas a inmigrantes italianos. "La Revista Eclesiástica", en una nota editorial de 1907, advertía que "el subarrendador, que por otra parte suele ser el cacique del pueblo, o alguno de sus allegados, se cuida bien de esquilmar a los colonos, no dejándoles más que lo preciso para que continúen matándose para vivir". ${ }^{123}$

En 1925, Atilio Gallioz, cura párroco de la Porteña, curato vecino a Sampacho, advertía al secretario del obispado de esta situación, al señalar que "todo el curato tiene como los

\footnotetext{
${ }^{121}$ Carta del 14 de mayo de 1896.

${ }^{122}$ BDRC, octubre/diciembre 2001, pp. 23-32.

${ }^{123}$ REOBA, 1907, p. 287.
} 
demás de esta zona su importancia agrícola. Es de lamentar que los pactos agrícolas para arrendatarios, en general, son desastrosos para los pobres que no salvan sus gastos la cosecha no es más que abundante". ${ }^{124}$

Otro de los problemas centrales del agricultor era acceder al crédito necesario para adquirir herramientas, mantener a la familia hasta la venta del grano y comprar semillas cuando la cosecha fuera mala. Beatriz Moreyra (1992: 331-332), en su trabajo sobre la producción agropecuaria cordobesa, señala que la obtención del crédito presentaba serias dificultades. El crédito agrario era una colocación poco tentadora para los capitalistas, ya que el ciclo de producción imponía la concesión de créditos a plazos más extensos. Las características de la actividad, sujeta a numerosos e imprevistos riesgos climáticos, y el escaso margen de beneficios del agricultor impedía fijar altos intereses. La ausencia de un crédito agrícola determinaba que las necesidades del capital fueran atendidas, en su gran mayoría, en forma no institucional y, en una mínima proporción, por una deficiente ayuda oficial. Las fuentes de crédito fueron durante muchos años los comerciantes de campaña, los consignatarios, o bien los terratenientes. Quienes cobraban impuesto excesivo y le creaban al colono una situación de dependencia en lo que respecta a la colocación de los productos.

En este contexto, el párroco se convirtió en una pieza clave para mostrar, de manera práctica, que la reforma social cristiana era el medio más adecuado para "hacer reinar la justicia en el mundo del trabajo". ${ }^{25}$ La predicación y la acción pastoral, en relación al trabajo, fueron herramientas pastorales del cura de Sampacho. El obispo diocesano, en el auto de la visita canónica de 1905, animaba al párroco a predicar sobre el valor y el sentido cristiano del trabajo: "En un pueblo agrícola como este, debe hacer llegar con preferencia la palabra alentadora del trabajo; como una de las escuelas de moral y de piedad religiosa más ventajosa. El cultivo de la tierra los llama y los aparta fuera del concurso de los malos, muchas veces inficionados en los vicios, por la ociosidad. Solo esperan para ser religiosos, piadosos, el cultivo de la palabra sacerdotal". ${ }^{126}$

\footnotetext{
${ }^{124}$ AAC. Cajas de Parroquias: Porteña, f.87.

${ }^{125}$ REOBA, 1907, p. 288.

126 AAC. Carpeta Curia, Visitas Pastorales y Varios, 1887-1911. Auto Visita Canónica al Curato de Sampacho, 10 de noviembre de 1905.
} 
La predicación y la acción pastoral se orientaron a convertir el trabajo en un vínculo de unión con Dios y con la Iglesia, y no un impedimento para cumplir con las obligaciones religiosas. Con este objetivo, el cura Cinotto impulsó iniciativas destinadas a lograr mejores condiciones laborales, como cooperativas de consumo, de maquinaria agrícola, de pequeños créditos y de seguros. Iniciativas que fueron concebidas como herramientas adecuadas para la evangelización de la campaña. ${ }^{127}$

En octubre de 1907, creó el Comité Parroquial. ${ }^{128}$ Se trataba de una cooperativa. La fundación se inspiraba en el Comitato Parrocchiale italiano, cuya finalidad se orientaba a hacer de cada parroquia un centro de vida religiosa y de trabajo cristiano (Rocca, 1899: 28). El fin secundario se orientaba al auxilio mutuo. El Comité contaba con diferentes secciones: un seguro contra el granizo, una caja rural, una cooperativa de consumo, con los ramos de almacén, tienda, zapatería, frutería, compra de cereales, panadería, lechería, carnicería, en provecho de los socios; para participar de esos beneficios, había que estar inscripto en el Comité parroquial como socio activo. Las obligaciones de los miembros estaban establecidas en los estatutos. En función de cada categoría, activos, participantes u honorarios, variaban las responsabilidades. Los miembros activos debían recibir los sacramentos al menos una vez al mes, participar en las ceremonias y funciones religiosas, dar buen ejemplo a los demás, y cumplir con todas las prácticas devotas que el párroco les encomendase. Los miembros participantes y honorarios ayudaban en las limosnas y colaboraban en las obras que se realizaran. ${ }^{129}$

El Comité de Sampacho inició sus actividades con 130 socios de "buena voluntad" y 115 socios activos, ${ }^{130} \mathrm{y}$, tres años después, llegó a 170 activos. Al segundo año de funcionamiento, se creó la Sociedad de Ayuda Mutua contra el Granizo, que al tercer año, ya contaba con un capital de 4.000 pesos. La sección Cooperativa de Consumo se organizó con el concurso de accionistas. Comenzó con 400 acciones y cada acción valía $\$ 15,00$, un monto al alcance de todos los colonos. Al poco tiempo de iniciar sus actividades, compró un terreno, se edificaron galpones para almacenar el cereal y se instaló un salón social

\footnotetext{
${ }^{127}$ REOBA, “Acción católica y clero", 1907, p. 287.

${ }^{128}$ REOBA, 1907, p. 995.

${ }^{129}$ ASV. Nunciatura Argentina, Libro 51: Cajas Rurales, Cooperativas, Comités Parroquiales, f.95 y ss.

${ }^{130}$ REOBA, Sección Córdoba, 1907, p. 995.
} 
recreativo, con una biblioteca popular. ${ }^{131}$ En julio de 1911, el padre Cinotto incorporó al Comité la primera caja rural argentina. ${ }^{132}$ Fue concebida como una sociedad destinada al beneficio de los colonos, a fin de facilitarles la práctica del ahorro y del crédito, medios seguros con los que el trabajador podía mejorar su situación económica y su condición social: "Persiguiendo el bien de las clases trabajadoras la caja se propone fomentar y propagar en ellos el ahorro porque es este el único camino que lleva al obrero a la formación de un capital propio. La caja proporciona colocación lucrativa hasta las más pequeñas cantidades. Las sumas depositadas en la caja de ahorro pueden retirarse a voluntad del depositante". ${ }^{133}$

Como se ha visto, la posibilidad de que los trabajadores agrícolas pudieran acceder al crédito otorgado por la caja rural, solucionaba uno de los inconvenientes que sufría el agricultor. Cinotto señalaba que en Sampacho "una gran mayoría de agricultores se ve obligada a quemar los frutos apenas cosechados para poder pagar el arrendamiento de trilladoras etc., pues bien: la caja rural facilitará el dinero para que paguen a todos los acreedores y puedan así conservar los frutos cosechados para venderlos más tarde a buen precio". ${ }^{134}$

En 1910, el capital ascendía a más de 4.000 pesos y estaba colocado a interés en beneficio de la institución. Ese mismo año, luego de tres años de sequía y de muy malas cosechas, la situación de los agricultores era alarmante. El párroco, para ayudar a los colonos, promovió la compra de una trilladora, que se utilizó para levantar la cosecha de los socios del Comité, lo cual abarató notablemente el costo que implicaba contratar maquinarias para realizar esa actividad. ${ }^{135}$

Para las fiestas de pascua de ese año, es decir entre marzo y abril de 1910, el cura Cinotto informaba al Internuncio Locatelli que el "Señor ha bendecido la obra y se obtuvo una muy buena cosecha, lo que podrá salvar a los colonos de la miseria. El salón social y la casa rural estaban llenos de granos de los socios que esperaban ser bien

\footnotetext{
${ }^{131}$ ASV. Nunciatura Argentina, Libro 51, pp. 76 y ss.

${ }^{132}$ El cura Cinotto se inspiró en la Caja Rural Santa Lucía, cooperativa católica de ahorro y crédito mutuo, fundada por los sacerdotes Damián y Camacho en Uruguay.

${ }^{133}$ ASV. Nunciatura Apostólica Argentina, f.21.

${ }^{134}$ ASV. Nunciatura Argentina, Libro 51, Cajas Rurales, Cooperativas, Comités Parroquiales.

${ }^{135}$ Cinotto señala que algunos comerciantes habían hecho un trust y cobraban $\$ 1,80$ el quintal. La trilladora adquirida por la Caja rural obligó a los socios del trust a bajar el precio de la trilla de $\$ 1,80$ a $\$ 1,30$ (ASV. Nunciatura Argentina, Libro 51, Cajas... f.78. Carta de Giovanni Cinotto al Internuncio Mons. Locatelli).
} 
vendidos. La venta del cereal dará muchos ánimos a los socios" ${ }^{136}$ En 1915, se realizó la primera operación de cereales de la caja rural de Sampacho, con 400 toneladas de grano, 106 de lino, 699 de alfalfa y 350 de cebada.

El Comité también extendía su actividad al ámbito cultural. En este campo, organizó conferencias, cuyo objetivo central era contrarrestar la acción del socialismo y el anarquismo. En 1911, José Serralunga Langhi, abogado y sociólogo católico italiano, recorrió la Argentina para hablar sobre religión y civismo. Tema de gran importancia para los italianos católicos, pues los anarquistas predicaban que el Estado Vaticano se oponía a la Patria Italiana. ${ }^{137}$

En este contexto, las fiestas del XX de septiembre no constituyeron un evento conflictivo entre la Iglesia católica y las comunidades italianas, como sucedió en otros espacios diocesanos. ${ }^{138}$ El cura Cinotto, en lugar de combatirlas, se empeñó en fomentar la festividad de la patrona del pueblo, la Virgen de La Consolata. En vez de aplicar una estrategia de confrontación, implementó una de superación, opacar el XX de septiembre con las festividades de La Consolata.

Una manera de vincular a los colonos con la parroquia era fomentar la devoción a la Virgen María bajo la advocación de La Consolata, patrona de la región del Piamonte. El 20 de junio de 1906, se celebró, por primera vez, el triduo en honor a la Virgen, presidido por un cuadro de la imagen donado a la iglesia por un vecino de la colonia, y a la que asistieron unos pocos feligreses. Las fiestas de La Consolata fueron in crescendo. En 1908, comenzaron los novenarios, predicados en español e italiano. Dos años después, tuvo lugar la primera procesión, con una imagen realizada en Italia, por encargo de un feligrés, Juan Fasano, y donada a la Iglesia. La estatua, que pesaba 100 kilos, fue llevada en andas por más de cuarenta hombres por las calles de la colonia, con la asistencia de 5.000 participantes en la procesión. Esta festividad adquirió particular relevancia no sólo en la colonia Sampacho, sino también en las zonas aledañas. En 1908, la asistencia a las fiestas

\footnotetext{
${ }^{136}$ ASV. Nunciatura Argentina, Libro 51, Cajas rurales... f.78. Carta de Giovanni Cinotto, en italiano, al Internuncio Locatelli.

${ }^{137}$ BDRC, enero/marzo 2002, p. 21.

${ }^{138} \mathrm{La}$ jerarquía eclesiástica combatió tenazmente la fiesta del XX de septiembre, considerándola atea y contraria a la Iglesia (Cfr. Auto sobre el XX de septiembre de 1898; Pastoral de 1899; Auto Episcopal de 1902; Auto Episcopal de 1905). En los curatos de Cruz Alta y Villa María la conmemoración provocó divisiones y conflictos entre párrocos y feligreses. En relación a Sampacho, no hemos encontrado referencias a su conmemoración, de alguna manera el cura Cinotto convirtió el día de La Consolata en la festividad más importante de la comunidad italiana de Sampacho, relativizando el XX de septiembre.
} 
ya era numerosa. Los informes parroquiales enviados a la curia dan cuenta de un número importante de feligreses y forasteros que asistían a la celebración. En 1912, "la iglesia se encuentra estrecha para contener a todos los fieles llegados de los pueblos vecinos". ${ }^{139}$ 1913, la asistencia a las fiestas de La Consolata fue de 8.000 fieles. ${ }^{140}$ La devoción a la Virgen de La Consolata se extendió año a año. Por decreto del mes de abril de 1915, el Papa Benedicto XV nombró a La Consolata Patrona de Sampacho. La población con limosnas para la construcción de un nuevo templo en honor a la Virgen. Se institucionalizaron las fiestas patronales, la devoción a la Eucaristía y al Sagrado Corazón. Pocos años después, el cura sostenía que el día de la Patrona se había convertido en una fiesta no sólo para la comunidad de Sampacho, sino para toda la comarca. ${ }^{141}$ El padre Juan Cinotto, promotor de esta iniciativa, comentaba años después que, en veinticinco años, fueron más de 20.000 los parroquianos que asistieron y participaron de las actividades parroquiales.

Los socios del comité fueron activos propagadores de la religión católica. Los informes parroquiales enviados a la curia dan cuenta de un número importante de feligreses que frecuentaban los sacramentos y participaban de las asociaciones parroquiales. El comité debía facilitar el acercamiento del párroco a la comunidad y a las actividades parroquiales. Sus miembros debían inculcar, con el ejemplo personal, la observancia de las fiestas religiosas a sus familiares y dependientes. ${ }^{142}$

En la Tabla 48, hemos volcado los datos referidos al movimiento religioso de la parroquia en el quinquenio 1906-1910. ${ }^{143}$ Esto nos ha permitido constatar, de una manera empírica y cuantitativa, la relación de la feligresía con la parroquia. En un pueblo de 2.200 habitantes, el número de comuniones era alto.

Estos datos anuales, agrupados por trimestres, muestran que en el segundo trimestre, fiesta de La Consolata, es cuando aumenta el número de comuniones. Si bien no contamos con datos continuos, podemos decir que, en las respuestas a los cuestionarios

\footnotetext{
${ }^{139}$ BDRC, octubre/diciembre 2001, p. 27. Transcripción de las palabras expresadas por el Padre Cinotto en el Libro de Actas, Memoriales de la Parroquia.

${ }^{140}$ REOBA, Sección Córdoba, 1913, p. 40.

${ }^{141}$ REOBA, Sección Córdoba, 1918, p. 496.

${ }^{142}$ ASV. Nunciatura Argentina, Libro 51, Estatutos del Comité Parroquial de Sampacho, Córdoba, Establecimiento La Industrial, 1907, f.56 y ss.

${ }^{143}$ AAC. Libro Movimiento Económico y Religioso de las Parroquias.
} 
de las visitas canónicas, el cura señala que en el mes de junio de 1920 se repartieron 4.500 comuniones y en 1930 se duplicaron a 8.250 .

\section{Tabla 48}

\begin{tabular}{|c|c|c|c|}
\hline \multicolumn{4}{|c|}{ Comuniones en Sampacho } \\
\hline $\begin{array}{c}\text { Año/ } \\
\text { Trimestre }\end{array}$ & Comuniones & $\begin{array}{c}\text { Año/ } \\
\text { Trimestre }\end{array}$ & Comuniones \\
\hline $1906 / 1^{\circ}$ & 238 & $1908 / 3^{\circ}$ & 165 \\
\hline $1906 / 2^{\circ}$ & 942 & $1908 / 4^{\circ}$ & 291 \\
\hline $1906 / 3^{\circ}$ & 334 & $1909 / 1^{\circ}$ & 288 \\
\hline $1906 / 4^{\circ}$ & 245 & $1909 / 2^{\circ}$ & 1880 \\
\hline $1907 / 1^{\circ}$ & 641 & $1909 / 3^{\circ}$ & 315 \\
\hline $1907 / 2^{\circ}$ & 1371 & $1909 / 4^{\circ}$ & 0 \\
\hline $1907 / 3^{\circ}$ & 0 & $1910 / 1^{\circ}$ & 925 \\
\hline $1907 / 4^{\circ}$ & 1685 & $1910 / 2^{\circ}$ & 1780 \\
\hline $1908 / 1^{\circ}$ & 194 & $1910 / 3^{\circ}$ & 937 \\
\hline $1908 / 2^{\circ}$ & 1832 & $1910 / 4^{\circ}$ & 491 \\
\hline
\end{tabular}

Fuente: Movimiento religioso de los curatos.

\section{Gráfico 24}

\section{Comuniones en Sampacho}

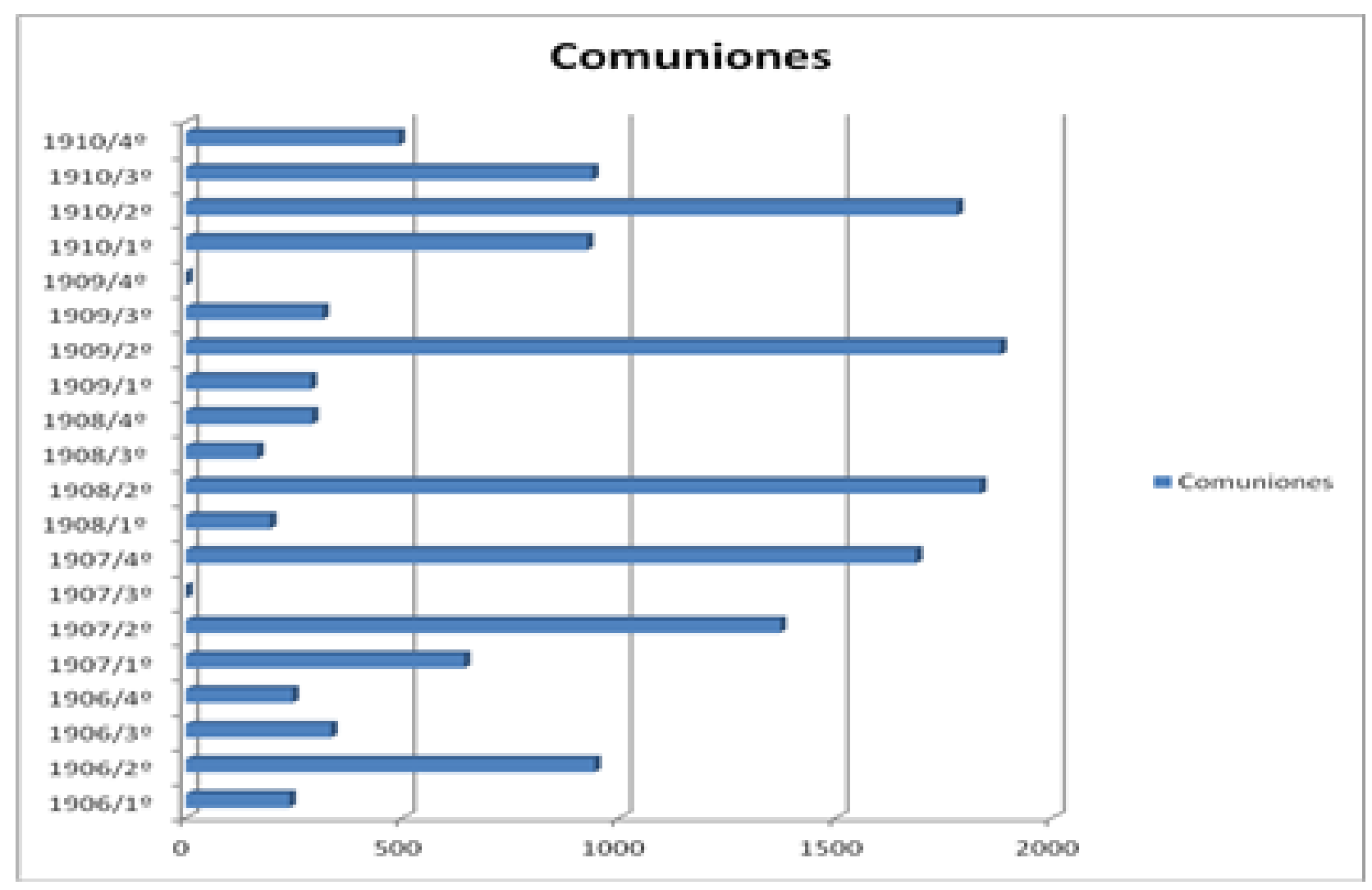


Finalmente, en las respuestas para el cuestionario de la visita pastoral de 1933, el cura Cinotto deja constancia de que cumplían el precepto pascual unas 9.000 personas, las comuniones diarias eran de 20 o 30, cuando más comulgaban era en la fiesta patronal de La Consolata, en el mes de junio, en la que lo hacían no sólo mujeres, sino también hombres y jóvenes. El total de comuniones durante el año oscilaba entre 18.000 y $20.000 .^{144}$

Otro indicador interesante, que nos permite establecer la vinculación de la comunidad con la parroquia, es el número de personas que participaban en las asociaciones parroquiales. En el quinquenio 1906-1910, había dos asociaciones, una, de varones, el “comité parroquial”, al cual nos referiremos más adelante, y, otra, de mujeres, el “apostolado de la oración”. No deja de ser interesante constatar que cerca de 400 personas formaban parte, de manera activa, de las asociaciones parroquiales. Si a estas personas le sumamos la asistencia al catecismo de niños y adultos la cifra se duplica.

Tabla 49

Asociaciones parroquiales

\begin{tabular}{|c|r|r|}
\hline Año & Comitato/socios & Apostolado/socios \\
\hline 1906 & s/d & 130 \\
\hline 1907 & 115 & 172 \\
\hline 1908 & 115 & $\mathrm{~s} / \mathrm{d}$ \\
\hline 1909 & 140 & 200 \\
\hline 1910 & 170 & 250 \\
\hline
\end{tabular}

Fuente: Movimiento religosos de los curatos

El cura Cinotto convirtió la parroquia en un centro de irradiación religiosa y promoción social de la población. La obra religiosa y social le valió la condecoración del Vaticano, otorgándosele la medalla al mérito por la labor desarrollada en bien de la comunidad parroquial.

La actividad del cura de Sampacho, nos permite ver, al menos, que la Iglesia asumió estrategias destinadas a consolidar el lazo social en las zonas de nueva colonización y en el caso de Sampacho, la religión actuó como un fuerte vínculo de integración social.

\footnotetext{
${ }^{144}$ BDRC, octubre/diciembre 2001, pp. 26-27.
} 


\section{Gráfico 25}

Participación en asociaciones parroquiales

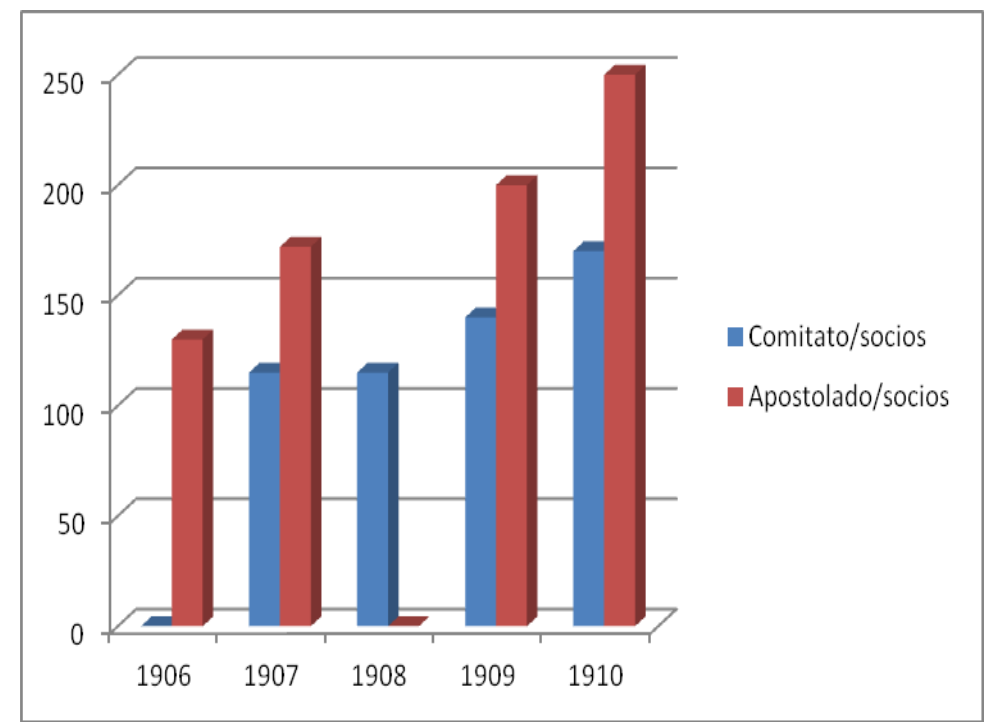

Tabla 50

Asistencia al catecismo

\begin{tabular}{|l|r|r|}
\hline \multirow{2}{*}{ Año } & \multicolumn{2}{|c|}{ Catecismo } \\
\cline { 2 - 4 } & Asistencia media niños & \multicolumn{1}{c|}{ Asistencia media adultos } \\
\hline 1906 & 130 & 45 \\
\hline 1907 & 110 & 40 \\
\hline 1908 & 290 & 110 \\
\hline 1909 & 170 & 90 \\
\hline 1910 & 180 & 90 \\
\hline
\end{tabular}

Fuente: Movimiento Religioso de los curatos 


\section{Gráfico 26}

Asistencia al catecismo

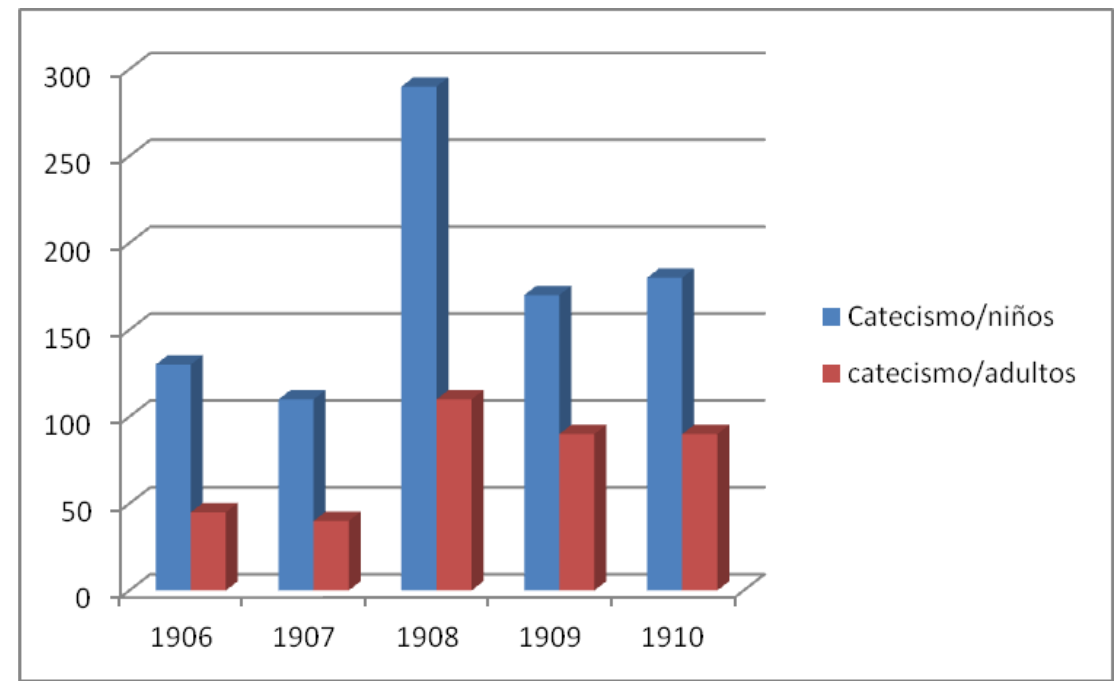

\section{La parroquia como espacio de militancia católica: la UPCA}

La Iglesia percibe que era necesario que los laicos asumieran su responsabilidad moral frente a los avances del anarquismo y del socialismo. Tanto el Sínodo diocesano de 1906, como los distintos congresos católicos, las pastorales, la prensa e, incluso, los discursos de intelectuales y políticos católicos, insisten en que los desórdenes sociales se deben a un problema moral. Corresponde entonces a los laicos actuar con mayor eficacia frente a los elementos disgregantes que nacían en esta nueva sociedad cordobesa. Comienza entonces a tomar cuerpo la idea de unificar las organizaciones católicas ${ }^{145}$ y de crear instituciones formadas por laicos que, bajo la tutela y la orientación de la jerarquía, actuaran en la vida social. El fiel debía encauzar su actividad como católico a través de las líneas jerárquicas (Gallego, 2002: 256). Loris Zanatta caracteriza esta transformación como un proceso de clericalización de la vida católica (Di Stefano y Zanatta, 2000: 359 y ss).

Párrafos arriba vimos cómo en 1914 se concreta el primer intento de unificar las organizaciones católicas en Córdoba mediante la organización de una acción católica

\footnotetext{
${ }^{145}$ El mismo Sínodo dedica el capítulo XXXVII a las Asociaciones Católicas. El art. 247 dispone: "De acuerdo con lo dispuesto por los Prelados Argentinos en las Reuniones de Salta (1902) y Buenos Aires (1905) sobre la confederación de las asociaciones católicas, el Sínodo desea la pronta realización de una obra tan importante y trascendental para los intereses católicos de la República, y recomienda encarecidamente a los párrocos que le presten su decidida cooperación, a fin de ver cuanto antes convertida en hecho obra tan vivamente anhelada".
} 
parroquial más centralizada y más unificada. En 1918, se realiza el primer Congreso Católico Diocesano que toma una serie de medidas sobre la formación y la acción de los católicos cordobeses y se procede a la federación de asociaciones católicas. ${ }^{146}$ A la inauguración y primera sesión pública asisten 374 congresales. ${ }^{147}$ Las siete sesiones privadas tuvieron una asistencia de 589 delegados, representantes de comunidades religiosas, de varones y mujeres, asociaciones y congregaciones piadosas, círculos de obreros, escuelas, colegios y asociaciones semejantes de la diócesis. ${ }^{148}$ Vecinos de otras poblaciones hicieron llegar sus adhesiones. ${ }^{149}$

La federación de asociaciones católicas tenía por objeto unificar y robustecer la acción para la propaganda, defensa e implantación de los principios religiosos, morales y sociales del catolicismo, sin perjuicio de los fines propios y directos de las sociedades que la constituían. ${ }^{150}$ En la aprobación provisoria de los estatutos, el obispo señalaba que el fin era promover y desarrollar la obra social católica entre personas de ambos sexos, con entera prescindencia de la política y acción de los partidos militantes. ${ }^{151}$ Durante los cinco días de sesiones, se trataron, entre otros temas, la constitución de la federación y sus estatutos, la relación de la federación con las parroquias y las instituciones federadas, con la presencia de diversos oradores para cada tema. La sesión de la federación de asociaciones católicas y

${ }^{146}$ AAC. Serie Libros. Sociedad Juventud Católica, 1918.
${ }^{147}$ Los Principios, 11/10/1918.
${ }^{148}$ AAC. Serie Libros. Juventud Católica, 1918, f.18 y ss.

149 AAC. Serie Libros. Sociedad Juventud Católica, 1918. Actas del Congreso Católico, f.4. Primera sesión privada: se da lectura por secretaría de una nota, firmada por un mil cuatrocientos vecinos de colonia Caroya, adhiriéndose al congreso y sus resoluciones; otra nota del Dpto. de $3^{\circ}$ arriba suscripta por trescientos veinte y dos vecinos y una de Varilla firmada por vecinos caracterizados.

${ }^{150}$ La Federación, de acuerdo con las normas contenidas en la encíclica Il fermo propósito de SS Pío X, se propuso:

a) Instruir al pueblo para formar su conciencia católica.

b) Sostener la libertad de enseñanza de acuerdo a las doctrina de la Iglesia y de la Constitución del estado.

c) Fomentar la instrucción religiosa en las escuelas oficiales, fundar bibliotecas e institutos educacionales católicos y prestar ayuda a los ya existentes.

d) Proteger y difundir la buena prensa.

e) Repartir al pueblo libros, revistas, periódicos y hojas volantes de sana doctrina.

f) Organizar periódicamente conferencias populares y veladas para familias.

g) Cooperar a la creación de cursos apologéticos y círculos de estudios en sociedades de jóvenes a fin de fomentar oradores propagandistas.

h) Estimular en los católicos el espíritu de asociación y de solidaridad cristianas.

i) Fundar en los centros urbanos, escuelas profesionales y otras instituciones que tiendan a mejorar la condición moral y económica de las clases obreras.

j) Velar porque rija la justicia y el criterio católico y jurídico en las leyes del país, y promover el buen servicio profesional y defensa jurídica de las corporaciones y particulares federados.

${ }^{151}$ Ibid., f.43. 
la buena prensa estuvo a cargo del relator Dutari Rodríguez, presidente del diario católico "Los Principios"; Miguel Ángel Pucheta, estudiante universitario y presidente de la Asociación Juventud Católica, quien disertó sobre las conferencias populares para estudiantes; y el Dr. Juan Cafferatta abordó el tema de la acción social católica. Las resoluciones de la sesión fueron las siguientes:

$1^{\circ}$ Que la Federación Católica preste a los círculos de Obreros, Cajas Rurales y demás instituciones de acción social existentes en la diócesis de Córdoba, su ayuda moral y material dentro de los medios que estime convenientes la junta directiva.

$2^{\text {a }}$ La junta directiva procederá a contratar en el país o en el extranjero, para la dirección de las Obras, personas que estén al cabo de las cuestiones sociales, las que serán costeadas con el peculio de la federación.

Una vez finalizado el Congreso, la Federación y el Consejo Superior del mismo quedaron constituidos. ${ }^{152}$ La creación de la federación de asociaciones católicas, de 1918, facilitó el camino para la implementación de una nueva asociación en Córdoba, destinada a centralizar la acción de los católicos, impulsada por el episcopado argentino, en sintonía con la Santa Sede, bajo el nombre de Unión Popular Católica Argentina.

\subsection{La Unión Popular Católica Argentina}

La tendencia a organizar, unificar y movilizar las fuerzas católicas se concretó en la iniciativa promovida por la Santa Sede, y asumida por los obispos argentinos, de crear la Unión Popular Católica Argentina [en adelante UPCA], cuyo fin era justamente organizar las fuerzas católicas y movilizarlas para llevar adelante el proceso de recristianización de la sociedad, ya que los movimientos y asociaciones católicas, múltiples y dispersos, no garantizaban la eficacia del combate contra los enemigos de la Iglesia: los movimientos anarquistas y socialistas, las asociaciones de librepensamiento, los masones y los protestantes. Más allá del éxito o fracaso de esta organización, nos detenemos a analizarla, pues consideramos que en ella cristalizan las tendencias del pensamiento social católico del primer cuarto del siglo XX. Con ella, la jerarquía pretendió dirigir las fuerzas católicas hacia la acción social, propiciar la colaboración activa del laicado, como forma de

\footnotetext{
${ }^{152}$ El Consejo Superior estuvo formado por el Dr. Juan F. Caferratta, el Dr. Antonio Nores, el Dr. Nemesio González, el Dr. Clodomiro Ferreyra y el Sr. Igarzábal, el Dr. Bass, Mons. Inocencio Dávila y el Dr. Néstor Pizarro.
} 
participación con el apostolado jerárquico de la Iglesia en el marco parroquial, y orientar la función del clérigo hacia una labor de asesoramiento y dirección de los asuntos sociales y espirituales, alejándolo de las cuestiones políticas.

En la pastoral de 1919, ${ }^{153}$ el arzobispo de Buenos Aires y los obispos sufragáneos comunicaban la decisión de crear una gran organización nacional denominada Unión Popular Católica Argentina, cuya finalidad declararon "prescindente en absoluto de toda intervención en la política y orientada por entero a consignar el éxito de los propósitos del catolicismo social [...]. Siguiendo los fieles las inspiraciones de sus párrocos, los párrocos las de sus obispos, los obispos las del Papa y el Papa las de Dios es incontrastable el ejército de la Iglesia e indudable su victoria". ${ }^{154}$

Esta iniciativa se inspiró en un doble objetivo, el ordenamiento de las asociaciones piadosas existentes, asimilándolas a la UPCA, y el deseo de adaptar la realidad a una concepción teórica importada y verticalista. Esta decisión originó una serie de resistencias y, según algunos autores, terminó fracasando (Auza, 1984: 47 y 1987: t.1; Di Stefano y Zanatta, 2000: 359).

\subsection{Creación de la UPCA en Córdoba}

El Obispo de Córdoba, Zenón Bustos, participó en las reuniones preliminares a la sanción del estatuto definitivo de la UPCA. El 25 de junio de 1919, dos meses después de la creación de la UPCA en Buenos Aires, el prelado procedió a constituir el Consejo y la Junta Diocesana, ${ }^{155}$ otorgando todas las facultades necesarias a la Federación de Asociaciones Católicas para formar centros parroquiales, primero, en las parroquias urbanas de la capital y, después, en las restantes de la campaña, con especial interés en la zona sur este de la provincia. ${ }^{156}$

El objetivo de esta institución fue unir las fuerzas católicas de todo el país para dedicarse a trabajar en el terreno moral, religioso y social. La idea es que este proyecto uniría en gran

\footnotetext{
${ }^{153}$ Pastoral Colectiva del 25 de abril de 1919.

154 REBA, 1919. Dado en el Palacio Arzobispal de Buenos Aires a veintiocho días del mes de abril de mil novecientos diez y nueve. Firmado por Mariano Antonio Arzobispo de Buenos Aires; Pablo Obispo de Tucumán; Juan Obispo de Santa Fe; Juan Nepomuceno Obispo de La Plata; Zenón Obispo de Córdoba; Juan Martín Obispo de Santiago del Estero; Abel Obispo de Paraná; Luis Maria Obispo de Corrientes; osé Américo Obispo de San Juan; Juan Gregorio Obispo de Salta.

${ }^{155}$ AAC. Zenón Bustos Obispo. Caja No 1, f.302. Córdoba, 25 de junio de 1919.

${ }^{156}$ AAC. Zenón Bustos Obispo. Documentación Varia, Caja No 5. Autos y Decretos, 1905-1919.
} 
forma el apostolado seglar a fin de consagrarlo a mejorar la moral del país; la UPCA debería esforzarse, por tanto, en educar la conciencia de los católicos en orden, principalmente, a la restauración cristina de la sociedad, a la defensa de la iglesia y al mejoramiento de las clases populares. ${ }^{157}$ El obispo, en una nota, definía a la UPCA como:

Una fuerza nueva que entra a actuar en el ministerio parroquial, es la creación del apostolado laico que se inicia para extenderse sobre toda la extensión vasta del país entero. Pone al párroco en comunicación intima con el pueblo y al pueblo con el párroco y por medio de éste con la Iglesia. ${ }^{158}$

Del 29 de abril a los primeros días de octubre de 1919, el obispo diocesano se ocupó de fundar, personalmente, los diversos centros de la UPCA. Inició una gira por la provincia para dejar constituidas las Juntas Parroquiales de la Unión Popular para hombres, las Ligas de Damas Católicas y las Ligas de la Juventud Católica. ${ }^{159}$ Toda esta actividad fundacional se suspendió a principios de octubre porque el 10 de octubre de 1919, cuando el diocesano, dando una conferencia en el templo de San Francisco para preparar la fundación de la Unión Popular, sufrió un ataque cerebral, que lo obligó a retirarse del gobierno de la diócesis. Dos años después, el Obispo auxiliar Monseñor Dávila retomó la obra comenzada por su predecesor y, mediante cartas y visitas, procuró el establecimiento de las juntas parroquiales en todos los curatos. ${ }^{160}$

En el transcurso de 1921-1922, cada una de las parroquias envió a la Junta Diocesana el acta de fundación y las planillas de socios, éstas, a su vez, se remitían al Secretariado nacional. Razón por la cual nos ha resultado imposible acceder a documentos que no quedaron en la ciudad. De manera inferencial, a través de las cartas recogidas en el libro copiador de la UPCA de Córdoba y de la consulta del libro de actas, hemos podido establecer algunas relaciones y reconstruir algunos hechos del itinerario de esta institución.

\footnotetext{
${ }^{157}$ AAC. Libro Esquemas de Conferencias Obra de la UPCA.

${ }^{158}$ AAC. Libro Esquemas de Conferencias Obra de la UPCA.

${ }^{159}$ AAC. Zenón Bustos Obispo. Carpeta Nº 1, UPCA, fs.300-333.

${ }^{160}$ AAC. Copiador de Cartas, UPCA, f.1. Primera Circular a todos los Curatos. Se dirige a los curas párrocos de San Francisco, Pozo del Molle; Sobremonte, San Agustín, Capilla del Monte; Arroyito, Canals, Marcos Juárez; Cruz del Eje, Alta Gracia, Bel Ville; Río 1; Playoba, La Carlota; San Pedro; Monte del Rosario; Tulumba; Salsacate; Deán Funes, Laborde; Colonia Caroya; Río Seco, Santa Rosa; Cosquín.
} 
El 22 de octubre de 1920 quedó establecida la primera Junta Diocesana de la UPCA en Córdoba con sus ligas Económico Social; de la Juventud y de Damas. ${ }^{161}$ La mayoría de sus miembros fue un activo participante del primer Congreso Católico Diocesano en 1918. El decreto de fundación da cuenta de las autoridades, presidente, vice y vocales de la Junta Diocesana y de las respectivas ligas. ${ }^{162}$ A continuación, se procedió a la creación de las respectivas juntas parroquiales.

Una publicación periódica de la UPCA define a las juntas parroquiales como "el estado mayor de los católicos de la parroquia porque en él están representadas las instituciones y elementos mejor dispuestos a servir con su trabajo a la causa de Dios y del pueblo". A continuación, se pregunta ¿para qué es la Junta Parroquial? Y, sintéticamente, expone:

a) Para cristianizar la parroquia.

b) Para facilitar y fomentar las relaciones entre el párroco y los feligreses.

c) Para organizar, orientar, secundar, impulsar, coordinar o dirigir todo movimiento o iniciativa que pueda favorecer los intereses espirituales, sociales, patrióticos o económicos del pueblo.

d) Para estudiar el estado espiritual, moral, económico, social de la parroquia y luego tomar las necesidades de la población o para hacer más eficaz la acción católica en esa localidad. ${ }^{163}$

El informe del secretariado nacional, correspondiente al primer trimestre de 1922, advertía que el número de socios con que contaba la UPCA era de 6.456 socios activos y 2.485 socios adherentes, repartidos en 584 grupos y 77 juntas parroquiales. ${ }^{164}$ Es altamente

\footnotetext{
${ }^{161}$ Se constituye el 13 de Noviembre de 1922 (Cfr. AAC. Libro de Actas de la UPCA, f.3).

162 AAC. Libro Decretos y Edictos, 1920-1925, f.8. Junta diocesana: Asesor eclesiástico, Monseñor Inocencio Dávila; Presidente, Néstor Pizarro; Vocales: Dr. Antonio Nores, Dr. Clemente Villada, Sr. Segundo Dutari Rodríguez, Dr. Ernesto Aliaga Tejerina, Ing. Baltasar Ferrer, Sr. Abraham Castellanos y Jacinto Ortiz de Guinea.

Primera Junta Diocesana de la Liga de Damas Católicas Argentinas: Asesor Eclesiástico, Provisor Monseñor David Luque; Presidenta, Sta. Eugenia Deheza García Montaña; Vocales: Sta. Pilar Nores de Rivero, Sra. Pastora V. de Olmos, Sra. Aída C. de Colazo Rodríguez, Sra. Rosa A. de Soria, Hortensia C. de Vera, Amelia F. de Prado y Renaida L. de Páez de la Torre.

Junta Diocesana de la Liga de la Juventud Católica: Asesor Eclesiástico, Canónigo Vicente Álvarez; Presidente, Dr. Luis Martínez Villada; Vocales: Dr. Clodomiro Ferreyra, Dr. Néstor A. Pizarro, Dr. Miguel A. Pucheta, Sr. Rodolfo Martínez Espinosa, Sr. Carlos Melo, Sr. Manuel Villada Achával y Sr. Ricardo López de la Torre.

${ }^{163}$ Boletín mensual de la UPCA. Secretariado Nacional, Año IV, N 45, 30 de noviembre 1923.

${ }^{164}$ ANH. Fondo Enrique Udaondo.
} 
significativo que de las 77 juntas parroquiales existentes en el país, 45 correspondieran a la diócesis de Córdoba.

Tabla 51

Juntas parroquiales de la UPCA en Córdoba

\begin{tabular}{|c|c|c|}
\hline Parroquia & $\begin{array}{c}\text { Acta de } \\
\text { Fundación }\end{array}$ & Presidente \\
\hline 1. Río IV & IV-1919 & Pbro. Francisco Ferreyra \\
\hline 2. Villa María & IV-1919 & Pbro. Pablo Colabianchi \\
\hline 3. Villa Dolores & IV-1919 & Pbro. Gregorio S. Rodríguez \\
\hline 4.Concepción del Tío & IV-1919 & Pbro. Severiano Coronado \\
\hline 5. Canals & IV-1919 & Pbro. Francisco Leoncini \\
\hline 6. Villa Nueva & IV-1919 & Pbro. José Buteler \\
\hline 7. Camilo Aldao & IV-1919 & Pbro. Antonio Llabres \\
\hline 8. Leones & IV-1919 & Pbro. Antonio Mosso \\
\hline 9. Santiago Temple & IV-1919 & Pbro. José Pérez Bueno \\
\hline 10. Varillas & IV-1919 & Pbro. Donato Latella \\
\hline 11. Soto & X- 1919 & Sr. F. Castro Gómez \\
\hline 12. Punilla & IV-1919 & Pbro. Teótimo Peralta \\
\hline 13. La Cruz & IV-1919 & Pbro. Gerardo Centurión \\
\hline 14. Cruz del Eje & V-1919/IX-1921 & Don Felipe H. Anabi \\
\hline 15. Isla Verde & 22-IX-1921 & Pbro. Javier de Bella \\
\hline 16. Marcos Juárez & 20 mayo 1920 & Pbro. Leopoldo Buteler \\
\hline 17. San Francisco & Mayo de 1920 & Don Anselmo Ceballos \\
\hline 18. Tulumba & 22-IX-1921 & Don Elías Bustamante \\
\hline 19. Cañada Verde & Mayo 1919 & Pbro. Guillermo Salgueiro \\
\hline 20. Deán Funes & 20-XII-1921 & E. Miguel Quinteros \\
\hline 21. Villa del Rosario & $\mathrm{X}-1921$ & \\
\hline 22. Villa Dolores & XII-1921 & \\
\hline 23. Salsacate & $17 / \mathrm{I} / 1922$ & Don Luis (ilegible) \\
\hline 24. Sobremonte & Febrero 1922 & O. P. Don Bustos \\
\hline 25. Colonia Caroya & Febrero 1922 & Pbro. Leandro Buela \\
\hline 26. San Carlos & Febrero de 1922 & \\
\hline 27. Arroyito & 22-IX-1921 & Pbro. Ramón B. Liendo \\
\hline 28. Río Seco & Abril 1922 & Guillermo Novillo \\
\hline 29. Santa Rosa & Octubre 1921 & Don Juan G. Dávila \\
\hline 30. Monte del Rosario & Abril de 1922 & \\
\hline 31. La Carlota & Mayo de 1922 & Pbro. Juan B. Tassi \\
\hline 32. Cosquín & Abril 1922 & S. V. Sarfield \\
\hline 33. Capuchinos ciudad & $25-X I-1922$ & \\
\hline 34. Chañar & & Pbro. Gerardo Nis \\
\hline 35. Río $1^{\circ}$ & & Don Ramón Cuestas \\
\hline 36. Alta gracia & Noviembre 1919 & Don Fermín B. Ferreira \\
\hline 37. La Playoba & Noviembre 1919 & Don Rafael Luque \\
\hline 38. Pozo del Molle & & Don Julián Nobrega \\
\hline 39. La Carlota & & Don Claudio Gelos \\
\hline 40. San Pedro & & Don Ricardo Girordia \\
\hline 41. Monte el Rosario & & Don José Abdaín Ardiles \\
\hline
\end{tabular}




\begin{tabular}{|l|l|l|}
\hline 42. Laborde & & Pbro. Amadeo Carcavale \\
\hline 43. San Carlos & 14-II-1922 & Sr. Ramón Arias \\
\hline 44. Capilla del Monte & & Pbro. Arturo Gómez \\
\hline 45. Quilino & IX-1921 & \\
\hline $\begin{array}{l}\text { Fuentes: AAC. Libro copiador de Cartas de la UPCA; Libro de Actas de la } \\
\text { UPCA; Fondo Zenón Bustos (recuerdos). }\end{array}$
\end{tabular}

En Buenos Aires, esta tentativa de la jerarquía eclesiástica de organizar, unificar y someter a su autoridad un mundo católico que se encontraba todavía desarticulado, a menudo litigioso y celoso de su propia autonomía, generó ciertas resistencias (Auza, 1984 y 1987; Di Stefano y Zanatta, 2000: 359). En el caso de Córdoba, en cambio, encontramos, por parte de las organizaciones católicas, una alta adhesión y un apoyo explícito a la acción de la UPCA. ${ }^{165}$ Esto quizá se deba a la presencia activa de la Iglesia en la vida y sociedad cordobesa, que ya desarrollaba una acción sistemática en todo el territorio diocesano. La prensa insta a los católicos a apoyar esta iniciativa:

La unión hace la fuerza, repetimos. Frente al peligro de las huestes organizadas de la revolución social, no formar en las filas de las asociaciones católicas significa una deserción, acaso una verdadera y formal traición. "Quién no está conmigo está contra mí" ha dicho Cristo, repudiando por igual a los enemigos como a los neutrales e indiferentes. Debemos pues [...] unirnos con devoción y sinceridad bajo la disciplina de los obispos, como ellos están unidos con Roma y con su clero diocesano en unidad de la fe y de la verdadera disciplina. La UPCA, obra del episcopado de nuestro país, tiene como fin primario congregar, unificar y disciplinar todas las fuerzas católicas del país para lanzarlas a la acción católica social, como medio de precaver y evitar, en cuanto ello sea posible, la subversión del orden social, que trepida en estos momentos amenazando derruir todas las instituciones básicas de la sociedad, la religión, la Patria y la autoridad. ${ }^{166}$

Con gran expectativa comienza el trabajo de la UPCA en la diócesis. En el terreno religioso, lleva a cabo numerosas jornadas eucarísticas, con motivo de la celebración del Congreso Eucarístico en Roma y de la fiesta de Corpus Christi. El programa de los actos fue intenso ${ }^{167}$ y la respuesta a esta convocatoria fue multitudinaria. Las celebraciones se

${ }^{165}$ AAC. Libro Copiador de Cartas de la UPCA. Adhieren a la fundación de la UPCA: la Orden Tercera Franciscana (f.40); la Asociación Católica Artesanos de San José (f.56); la Cofradía del Santísimo (f.57); la Congregación de María Inmaculada y San Luis Gonzaga (f.61); la Hermanad de San Pedro (f.113); Centro Católico de Estudiantes (f.114). AAC. Libro de Actas de la UPCA, Adhesión de La Cofradía de Ntra. Señora del Rosario de Santo Domingo con una cuota de \$10 y de los Josefinos (f.10).

${ }^{166}$ Los Principios, 19/10/1922. Nota editorial.

${ }^{167}$ Los Principios, 12/05/1922, p. 1. El programa podría condensarse en una gran jornada eucarística para señores el día 28 en la Iglesia Catedral, previo un triduo de conferencias como reparación al acto. Una velada 
desarrollaron simultáneamente en distintos templos de la ciudad ${ }^{168}$ y de la campaña. Miles de hombres esperaban en la catedral metropolitana el comienzo de la celebración eucarística.

Al mismo tiempo en los diversos templos, multitud de señoras y niñas de todas clases sociales se acercaban al banquete eucarístico, en la catedral más de dos mil hombres gustaban el pan de los ángeles. [...] La pléyade de católicos asistentes a la jornada eucarística y que así se unen en espíritu a la gran asamblea internacional que se celebra en Roma [...] está diciendo claramente que la fe vive en Córdoba encendida en multitud de hogares bajo la mirada vigilante de nuestras mujeres, esposas, madres e hijas [...] Desde las 7.30 las naves de la catedral se hallaban concurridísimas de hombres cristianos de todas las clases, condiciones y edades dispuestos a asistir a la jornada eucarística que comenzó a las 8.30 con el santo sacrificio de la misa [...]. ${ }^{169}$

A la celebración, se unieron los distintos puntos del interior de la provincia, "Los Principios" recogía de esta manera el eco de los festejos en Colonia Vignaud y Porteña:

En la mañana del domingo se iniciaron los festejos con una jornada eucarística, recibiendo la comunión alrededor de seiscientas personas, de las cuales la mayoría eran hombres. El acto fue altamente edificante, dando una prueba conmovedora de la fe viril y ardiente de los pobladores de aquella colonia, en su mayoría formada por familias italianas de origen piamontés. A las diez se cantó la misa solemne, asistiendo de medio pontifical Monseñor Dávila. Las tres amplias naves del suntuoso templo se vieron colmadas de concurrentes. Después de la Misa se organizó la procesión de San José, concurriendo la cofradía Josefina, la UPCA, la congregación de María Auxiliadora, los colegios de varones y niñas de los padres y hermanas de Don Bosco y todo el pueblo, formando una columna de tres cuadras que recorrió las calles alrededor de la plaza $[\ldots] .{ }^{170}$

La UPCA organizó un Congreso Diocesano ${ }^{171}$ que se realizó en Córdoba el 7, 8, 9 y 10 de diciembre de 1922. El diario "Los Principios" hizo notar la presencia de representantes católicos de toda la provincia. ${ }^{172}$ Los temas que trataron hicieron referencia a la formación, organización y acción de la UPCA. ${ }^{173}$ Entre las actividades más destacadas, cabe mencionar

eucarística para la noche del 28 de mayo. Programas particulares en las diversas iglesias. Adoración continua en el Templo de San Francisco, que consiste en un triduo de preparación para la "jornada eucarística de señoras" del día 28 en dicho templo.

${ }^{168}$ Los Principios, 25/05/1922. Las celebraciones eucarísticas se desarrollaron en La Catedral, la Compañía de Jesús, la Merced, la Iglesia del Carmen, la Parroquia de San Vicente, el Templo de las Adoratrices, el Buen Pastor, el Pilar, San Roque y San Francisco.

${ }^{169}$ Los Principios, 29/05/1922.

${ }^{170}$ Los Principios, 20/05/1922, p. 9.

${ }^{171}$ AAC. Libro de Actas de la UPCA, f.3.

${ }^{172}$ Los Principios, 12/12/1922.

${ }^{173}$ AAC. Copiador de Cartas de la UPCA, f.76; Libro de Actas de la UPCA, fs.11-12. 
la gran colecta destinada a recaudar fondos asignados a las obras sociales. Finalmente, luego de una corta existencia, la UPCA se disuelve (1919-1931), y dio lugar a una nueva institución, la Acción Católica Argentina [en adelante ACA]. Las cartas intercambiadas entre el presidente, Luis Bidone, y el vicepresidente, Enrique Udaondo, de la UPCA, con motivo de la disolución de la misma y la creación de la ACA, permiten observar la continuidad entre ambas instituciones:

\section{Sr. Enrique Udaondo:}

Bs As

De mi mayor aprecio:

En este momento, sábado 24 a las 19 hs. me llega una nota del arzobispado de Bs. As. en la que me comunica que, la autoridad eclesiástica en resolución del 19 del corriente aceptó la renuncia de los miembros de la Junta Nacional de la UPCA y que los miembros de la nueva Junta de La Acción Católica Argentina, nombrados en la misma fecha se harán cargo de la institución el lunes próximo 26.

Atenciones que la premura del plazo me impiden resolver me ponen en el caso de estar ausente en el acto de entrega y rogarle que me represente en su carácter de vicepresidente quiera hacer las veces y presentar a todos y a cada uno de los miembros de la nueva Junta a la vez que el testimonio de mi mayor consideración y votos de mejor éxito en la tarea que se les ha encomendado.

Firmado Pedro Bidone

Sr Dn. Enrique Udaondo:

Mar del Plata enero 29/931

\footnotetext{
Temas del Congreso de la UPCA.

$1^{\circ}$ La UPCA como institución. Su autoridad, sus finalidades.

$2^{\circ} \mathrm{La}$ UPCA en el orden parroquial, en el orden diocesano, en el orden nacional.

$3^{\circ}$ Deberes de los católicos ante la UPCA y sus finalidades.

$4^{\circ}$ La UPCA y la Mujer. Organizaciones femeninas.

$5^{\circ}$ La UPCA y la Juventud. Centros de Jóvenes, sus finalidades. Medios de propagar y multiplicar dichos centros, delegados permanentes en los pueblos.

6 a Congresos Regionales y Diocesanos de la UPCA y de la Juventud. Su Conveniencia y utilidad como medio de propaganda y afianzamiento de la Obra.

$7^{\circ}$ Los Congresos Regionales Diocesanos de la UPCA y de la Juventud como medio de unificar la acción parroquial en orden a la acción social católica.

$8^{\circ} \mathrm{La}$ UPCA en el orden económico social. Su acción a desarrollar a favor de las clases proletarias.

$9^{\circ}$ La UPCA y los institutos docentes católicos.

$10^{\circ}$ La Eucaristía y la obra social católica. ${ }^{173}$

Podían participar del congreso:

$1^{\circ}$ Las juntas parroquiales con el asesor y 4 delegados.

$2^{\circ}$ Las Juntas de Jóvenes católicos con 4 delegados de cada junta.

$3^{\circ}$ Las asociaciones adheridas a la UPCA con 2 delegados.

$4^{\circ}$ Las parroquias con el párroco y 2 delegados.

$5^{\circ}$ Los pueblos o centros de población que no sean parroquia y no tengan juntas locales de la UPCA, con 2 delegados designados por el párroco.

$6^{\circ}$ La Liga de Damas Católicas e instituciones adheridas a la misma.
} 
Bs As

Estimado Señor y Amigo

He recibido su carta del 27 del corriente en la que se sirve comunicarme la forma en que se ha realizado la entrega de la UPCA a la nueva Junta de la ACA atención que le agradezco.

La actitud final de la autoridad eclesiástica ha estado en perfecta concordancia con sus antecedentes ya que ni siquiera ha querido tener la atención de consultar a los miembros de la Junta de la UPCA sobre la comodidad que para ellos pudiera importar la fecha a fijarse para la transmisión tomándose con toda desconsideración la toma de posesión de la nueva Junta.

Pero sea por Dios, que los que nos suceden cuenten con el apoyo que a nosotros nos ha faltado y que su actuación tenga el mayor éxito para bien de nuestra santa causa.

Creo que nosotros podemos retirarnos tranquilos con la conciencia de haber hecho el bien que hemos podido y por lo que a mí me toca me considero recompensado con los buenos amigos y compañeros de Junta, gracias a quienes he podido hacer obra eficaz. Con el afecto me despido atte, su amigo Pedro Bidone. ${ }^{174}$

Si bien la jerarquía eclesiástica priorizó la agrupación y actuación de los laicos en materia social, no dejó de impulsar la acción de los católicos en la vida política. Luego de un proceso complejo, lleno de idas y vueltas, que hemos presentado en el Capítulo 13, se abandonó la idea de crear un partido católico, prefiriendo alentar la participación de los católicos en los partidos existentes, cuyas plataformas no se opusieran a la doctrina de la iglesia. A través de la actividad legislativa, los católicos desarrollan todo un programa social, sancionando una serie de leyes en pro de la clase obrera. Sería fatigoso nombrar a quienes desde la actividad política promovieron los principios cristianos en el período que nos ocupa. Legisladores nacionales, como Arturo M. Bass ${ }^{175}$ y Juan Cafferata, ${ }^{176}$ y provinciales, como Segundo Dutari Rodríguez, ${ }^{177}$ Félix Garzón Maceda, ${ }^{178}$ Lisandro

\footnotetext{
${ }^{174}$ ANH. Fondo Enrique Udaondo.

175 Arturo M. Bass fue diputado nacional por Córdoba (1912-1916), reelecto en 1920. Entre sus iniciativas legales, figuran la creación de la Caja Nacional de Ahorro Postal, la de Jubilaciones ferroviarias, las jubilaciones bancarias y los accidentes ferroviarios, entre otras.

${ }^{176}$ Juan F. Cafferata fue presidente de la Cámara de Diputados de la Nación (1932-34). En su obra legislativa se destaca la ley para la construcción de casas para obreros.

177 Segundo Dutari Rodríguez fue vicepresidente del Concejo Deliberante Municipal de Córdoba; senador provincial; convencional diputado constituyente de la reforma de la constitución; director en la provincia del tercer Censo Nacional. En el diario Los Principios (19/03/1921), declara que: "La cuestión social constituye una de las pasiones de mi vida, como que milito en las filas de los círculos obreros desde su fundación en la Argentina, hacen 25 años, habiendo sido presidente de Córdoba, comprando como tal la magnífica casa que posee y asistido en el carácter de delegado a todos los congresos nacionales celebrados por esa institución en Buenos Aires, Córdoba, Catamarca, Santa Fe, la Plata, etc.”.

178 Félix Garzón Maceda fue diputado y senador provincial. En la legislatura cordobesa, propuso la construcción de casas para obreros (1906-1911).
} 
Novillo Saravia, ${ }^{179}$ Antonio Nores, ${ }^{180}$ Néstor Pizarro, ${ }^{181}$ etc. Los debates parlamentarios promovidos por los católicos privilegiaban la cuestión social y proponían reformas a fin de mejorar la condición del obrero. Muchas de las cuales cristalizaron en leyes. La ley del descanso dominical; leyes y medidas destinadas a mejorar la condición moral y material de las clases trabajadoras; atención y mejoramiento de la salud pública; reglamentación del trabajo en las fábricas y talleres especialmente de la mujer y el niño; formación moral e intelectual de la niñez abandonada; estímulo de la enseñanza particular, etc. ${ }^{182}$

El campo político era un campo de acción en el que los católicos se manejaban con cierta autonomía de la autoridad eclesiástica. A fines de 1919, el obispo diocesano expresaba su pesadumbre ante la dificultad de encontrar hombres dispuestos a sacar adelante las obras sociales mientras la política atraía a gran número de católicos cordobeses.

Acaba el Obispo de llamar a los católicos a formar parte en la Obra Social; y ellos toman otro rumbo; y se van al campo de la política ¿les dará como ellos piensan mayor prestigio que aquello? ¿Siendo los mismos iniciadores de la obra social que luego iban a trabajar en política comprometiendo los frutos de esta obra y su propia existencia? Si no aparece el acatamiento al prelado: no hay disciplina, habrá anarquía [...]. La política y la obra social no son cosas que se excluyan, se dan la mano y se confunden en su finalidad, mirando ambas a la doctrina de Cristo [...]. Pero siendo pocos los agentes para acometer las dos, debe hacerse la de mayor beneficio al mayor número y más reclamada. ${ }^{183}$

La militancia católica, en el campo social-religioso, se consolidó, paulatinamente, a través del fortalecimiento de la institución parroquial. Esta implicó una suerte de ocupación territorial y presencia activa en las diversas comunidades. Desde las parroquias, se organizó el control de la militancia de los católicos en las cuestiones sociales, la presencia institucional y disciplinada de la Iglesia en ese terreno, la preocupación por las formas de la devoción y la liturgia, y un combate sistemático contra quienes eran definidos como enemigos de ese proyecto.

\footnotetext{
${ }^{179}$ Lisandro Novillo Saravia fue convencional en la Convención Reformadora de 1923 y una gran defensor de la libertad de enseñanza frente al proyecto de enseñanza laica.

${ }^{180}$ Antonio Nores fue senador provincial (1910-1015).

${ }^{181}$ Néstor Pizarro fue legislador provincial y diputado nacional (1936-1940).

${ }^{182}$ Cfr. MOREYRA, REMEDI y ROGGIO (1998).

${ }^{183}$ AAC. Fondo Zenón Bustos, Caja No 3, fs.1024-1032. Borradores sobre diversos temas.
} 
Para llevar a cabo este proyecto de renovación católica, la Iglesia consideró necesario optar por una redefinición de los roles de sus miembros, la función del párroco se caracterizó por una intensa acción pastoral, de cánones clásicos, y por una batalla librada en aspectos relacionados con la formación doctrinal, alejándolo progresivamente de la acción política partidaria. El laicado católico se constituyó en un auténtico actor eclesial y social que de la mano de la jerarquía comenzó a movilizarse en la búsqueda de soluciones católicas para la llamada cuestión social. La jerarquía procuró encuadrar a los seglares en asociaciones y movimientos que los motivaran a un compromiso cristiano más activo. No nos referimos a las asociaciones de "perfección cristiana" o "asociaciones piadosas" que existían desde mucho antes. Los creadores de un incipiente apostolado seglar trataron de comunicar a la Iglesia local el espíritu que surgía de la Iglesia Universal, sintetizado en la expresión "la hora de los seglares" y que tuvo como resultado la creación de la Unión Popular y luego de la Acción Católica. La UPCA supuso, y allí radica nuestro interés, un antecedente significativo de un modo de insertar al laicado en las estructuras eclesiásticas parroquiales, que si bien en esta etapa no se consolida, logrará hacerlo en la década siguiente bajo la égida de la Acción Católica Argentina. 


\section{Conclusiones}

En este trabajo, mostramos cómo la Iglesia Católica diocesana de Córdoba fue un actor fundamental de la formación política y social de la provincia. Sabiéndose portadora de una experiencia que trascendía las fronteras de una cultura nacional, se instituyó como reproductora de valores universales, instaurando un programa cultural específico, que aspiró, entre otras cosas, a la consolidación de un sistema cultural y social de matriz católica, que podríamos denominar proyecto integral orientado a construir una "nueva cristiandad" o una "nación católica".

El clero parroquial de campaña fue uno de los agentes fundamentales del proceso y la parroquia el gozne o la bisagra sobre los cuales la Iglesia organizó su poder pastoral en el territorio, restableciendo y consolidando sus vínculos con la sociedad, estimulando a sus feligreses a un mayor compromiso en pro de una militancia en la causa católica, e impulsando una pastoral litúrgica, sacramentaria y devocional, destinada a las multitudes.

El primer paso de este largo y complejo proceso consistió en reorganizar una institución debilitada que había sufrido los vaivenes de la anarquía, las guerras civiles, la sede-vacancia de la silla episcopal y la escasez de su clero. Este proceso de institucionalización fue analizado en tres tiempos: 1) la fragilidad (1875-1888); 2) el fortalecimiento (1889-1904); y 3) la consolidación (1905-1925). En el transcurso de la investigación, vimos la necesidad de introducir y hacer referencia, a modo de antecedente, a un período que escapa a nuestro análisis (1859-1874), por considerarlo el punto de partida, el arranque o el inicio del cambio. El proceso de institucionalización de la iglesia diocesana debió abordar dos cuestiones vinculadas al proceso de secularización: la laicización del estado y la pluralidad religiosa-social, ambas realidades ponían en tensión la hegemonía que otrora habían ejercido la religión y sus ministros y discutían el lugar que debían ocupar en una sociedad en vías de modernización.

Para analizar este proceso de institucionalización tomamos tres variables amplias: $1^{\circ}$ ) la territorialización eclesiástica; $2^{\circ}$ ) el clero secular como actor político, social y religioso de cambio; y $3^{\circ}$ ) el poder pastoral parroquial.

Con la primera variable, analizamos el territorio como espacio de proyección de la institución. Si la Iglesia aspiraba a construir una "nueva cristiandad”, debía garantizar 
una presencia real y efectiva en el territorio y promover la adecuación de las conductas de los feligreses a los principios morales y creencias católicas. Para hacer operativa esta variable, trabajamos dos indicadores: el primero, vinculado a la territorialización del poder, la presencia del obispo en el territorio a través de las visitas pastorales, y, el segundo, la transformación de la diócesis, tomando los curatos/parroquias como unidades de base del gobierno de la Iglesia romanizada.

La primera variable permitió analizar el espacio territorial como zona de dominación episcopal, de poder y de orden. A partir de este indicador, pudimos observar cómo cada obispo buscó controlar la circulación de la información, los actos litúrgicos, la moral pública y privada de las feligresías. Estas prácticas administrativas surgieron a partir de la realización de viajes para conocer la heterogeneidad del territorio diocesano y esos viajes fueron, en gran medida, los que definieron la división de los territorios, dando lugar a la creación de nuevas parroquias, con la consecuente densificación de la cartografía eclesiástica parroquial.

La dimensión territorial del poder episcopal fue analizada en un sentido amplio, es decir, el poder vinculado con lo real y lo simbólico, con el poder personal y delegado, entendiendo que dicho poder no se reducía a la figura del obispo, sino que continuaba en sus vicarios, funcionarios y, en particular, en el cura párroco.

La reconstrucción de los itinerarios de las visitas y su proyección en mapas de época, permitió elaborar una cartografía de la dimensión espacial de esta práctica pastoral. A su vez, el análisis de los autos, las crónicas de las visitas y el poder determinar el volumen de sacramentos administrados, permitió visualizar, por un lado, la importante movilización de personas que generaba la presencia del obispo. Las cifras de las confirmaciones dan cuenta del alto grado de aceptación de la religión católica en la región del norte y oeste, de antigua colonización, en tanto el número disminuye en los curatos del este y del sur, de nueva colonización. Por otro lado, dichas crónicas reflejan las relaciones, a nivel local, entre el poder civil y el eclesiástico. Relaciones complejas que experimentaron cambios a lo largo del período de estudio y en relación a las regiones analizadas. Relaciones que iban de la armonía y cooperación al conflicto y/o abierto enfrentamiento.

El relato de las visitas realizadas entre 1876 y 1888, en el período que denominamos de "fragilidad", permite advertir los signos claros de la debilidad institucional que aún están presentes en la iglesia diocesana. Entre los signos tangibles, puede observarse el deterioro material de los templos de campaña, lo cual es un claro indicio de que no 
constituían un espacio habitualmente frecuentado por las feligresías. Muchas de las funciones que a partir de este período comenzaron a realizarse dentro del templo, se hacían fuera de él. En los hogares se enseñaba el catecismo, se celebraban bautismos, casamientos, misas, etc. A partir de la tercera parte de siglo XIX, se acelera un proceso por el cual todos los sacramentos comienzan a administrarse dentro del edificio, es decir en el marco de "la Iglesia material". Esta diferenciación entre iglesia comunidad e iglesia material es, además, un indicio claro del proceso de secularización. Para pertenecer a la iglesia comunidad es necesario pasar por la iglesia material, es decir, el templo parroquial.

El segundo indicador, vinculado al primero, hace referencia a la transformación de la diócesis. A la concepción de los curatos/parroquias como unidades de base del gobierno de la Iglesia romanizada. A media que avanza el proceso de romanización, la presencia y el control episcopal en los territorios es mayor. Para garantizar el "buen gobierno" y la mejor atención de las feligresías, la jerarquía, por iniciativa propia o por solicitud de los fieles, procedió a realizar divisiones eclesiásticas y a erigir nuevos curatos. El análisis de los cuestionarios de las visitas y los informes parroquiales confirma la centralidad del cura en la vida social y religiosa de los poblados. Con frecuencia, la exactitud de sus anotaciones muestra hasta qué punto era consciente de su rol, no sólo como "ministro de lo sagrado", administrador de sacramentos, funciones y enseñanza del catecismo, sino también de garante de la conducta social y moralidad de la población.

Por ultimo un tercer indicador de la presencia de la iglesia diocesana en el territorio, que se desprende de las políticas anteriores, son los templos con funciones parroquiales distribuidos en el espacio diocesano. Para lograr esa presencia, primero había que ocupar el territorio. Un medio para lograrlo era impulsar la construcción de templos en cada comunidad cristiana. Mediante una reconstrucción minuciosa del entramado de iglesias, capillas y oratorios, observamos cómo a lo largo de los 50 años que abarca nuestra investigación, el número de templos en la campaña se triplicó, las parroquias pasaron de 24 a 70 y las capillas dependientes con funciones parroquiales ( $\sin$ contar los oratorios privados) de 90 a 201. El objetivo de la jerarquía de contar con un templo cada cuatro leguas no llegó a cumplirse en todos los departamentos. En los de antigua colonización, el aumento de templos fue proporcional al aumento de la población. En 1875 existían 88 templos con funciones parroquiales sobre un total de 174.375 habitantes, lo que significó un templo cada 1.981,53 habitantes; en 1925, en el mismo espacio, había 159 templos y un total de 331.660 habitantes, lo que implicó la relación 
de un templo cada 2.085,91 habitantes. Como puede observarse, la proporción templohabitante se mantuvo casi sin variación.

En 1875, la región comprendida por los departamento colonizadores tenía 21 templos y 36.296 habitantes, guarismo que supuso 1.910 habitantes por templo; en 1925, la cantidad de templos aumentó en un $60 \%$, sin embargo, el aumento de la población fue tal que la proporción fue de un templo cada 3.532,13 habitantes, es decir la relación templo-habitante aumentó casi en un 75\% respecto del año 1875 , esto significa que pese al aumento significativo de templos construidos en la región, éstos no resultaron suficientes para satisfacer las necesidades religiosas debidas al aumento demográfico, producto de la llegada masiva de inmigrantes, sobre todo españoles e italianos. No sólo analizamos la cantidad de templos, sino también el rol de los mismos en las diversas comunidades.

En la primera mitad del siglo XIX, el templo, en la campaña cordobesa, no tenía demasiada importancia en la vida de las personas, se acudía a él pocas veces al año (fiestas patronales) e, incluso, pocas veces en la vida. El bautismo era administrado con mucha frecuencia por bautizadores seglares; muchos de los que contraían matrimonio, lo hacían en domicilios particulares; quizás la presencia en el templo era frecuente al final de la existencia, a la hora de las honras y los ritos fúnebres, como un rito de pasaje a la otra vida; la enseñanza religiosa solía impartirse en el seno de cada familia; el cura no siempre cumplía con el deber de residencia, predicaba poco, en circunstancias especiales, y la enseñanza del catecismo no estaba en absoluto regulada ni era sistemática. De hecho, muchos templos de la campaña, en la segunda mitad del siglo XIX, estaban en ruinas. ¿Por dónde pasaba entonces la vida parroquial en la campaña? Poco sabemos de ello, daría la impresión de que casi no existía. Valentina Ayrolo (2007: 138) señala que la falta de sacerdotes que cumplieran sus funciones era usual y que los feligreses sentían que sus vidas quedaban a merced de la naturaleza. La ausencia del sacerdote dejaba sin cubrir etapas importantes de la vida, como el ingreso a la pubertad y la adultez, cambios marcados por la comunión y la confirmación. Sin sacerdotes que bendijeran cada una de estas etapas, los cambios en la vida de los fieles se vivían con marcada inquietud.

Al analizar la estructuración, restructuración y expansión del tejido parroquial, pudimos demostrar que la parroquia adquiere un nuevo rol, vinculado a una pertenencia identitaria. En el dimensionamiento del espacio, sobre todo en el sudeste cordobés, el templo parroquiano deja de ocupar un lugar central alrededor del cual se establecen 
nuevos pobladores. La Iglesia, edificio, se impone en el paisaje y busca convertirse en el lugar de congregación y de control de los hombres. La densificación de la red parroquial, la residencia habitual del cura en el lugar y las periódicas visitas pastorales permitieron el afianzamiento y la presencia de la iglesia diocesana en las nuevas regiones incorporadas al proceso productivo. La Iglesia se proyecta sobre el espacio y busca hacer más visible su poder. La dimensión material de la religión se plasma en el territorio, los templos son lugares de encuentro entre la religión y la sociedad. Los obispos diocesanos articularon y resignificaron el espacio diocesano y parroquial en función del proceso de modernización social.

La segunda variable analiza el clero secular como actor político, social y religioso. El análisis de las numerosas fuentes consultadas ha permitido establecer algunas consideraciones generales y otras más específicas. En primer lugar, nos interesa destacar que la carrera eclesiástica, tanto secular como regular, a diferencia de la diócesis de Buenos Aires, continuó siendo una opción para las familias de la alta sociedad cordobesa. Hay familias que tienen miembros en el clero desde tiempo inmemorial y por supuesto a lo largo del período que abarca esta tesis. Los ejemplos más significativos los encontramos en los grupos familiares de los Ferreira, Luque, Álvarez, Buteler, Cabanillas, Castellano, etc. Sus miembros clérigos ocuparon puestos en el cabildo eclesiástico, la curia diocesana y el seminario y desempeñaron el ministerio parroquial en los curatos de más antigua data, donde ocuparon los cargos por extensos períodos y se sucedieron entre sí, en particular de tíos a sobrinos. En este grupo de clérigos, se encuentran todos aquellos que estudiaron en el Colegio Pío Latinoamericano y se ordenaron en Roma.

Los extranjeros ordenados en la diócesis se desempeñaron como clero parroquial de campaña. Las autoridades diocesanas permitieron ordenaciones de candidatos que, por los informes contenidos en los expedientes de órdenes, eran piadosos y cumplían con la disciplina del colegio, aunque no siempre los resultados académicos fueran óptimos. El clero de habla italiana era necesario para la atención pastoral de las colonias inmigrantes, por este motivo se privilegió la vida de piedad y la actividad pastoral a la excelencia académica en la formación del futuro pastor de almas.

En cuanto al clero inmigrante, la política eclesiástica fue reticente a nombrar en carácter de cura párroco a "clero extraño". Muchos de ellos ejercieron su ministerio con licencias o permisos temporales y renovables. Los primeros años de permanencia estuvieron en la diócesis como ayudantes o capellanes de párrocos argentinos o 
destinados a los pobres curatos de La Rioja o del norte de Córdoba. Sólo aquellos sacerdotes, cuya piedad y celo los hiciera acreedores de la confianza episcopal, podían aspirar a un cargo de párroco en un curato de mayor categoría. Los puestos disponibles para el clero extranjero fueron, en términos generales, aquellos destinos no apetecidos por el clero local, es decir las parroquias más pobres e incongruas de la provincia de La Rioja, las capellanías y nuevas parroquias de las colonias del sudeste.

En este sentido, podemos afirmar que la iglesia diocesana implementó políticas destinadas a disciplinar al clero en orden a las pautas romanizadoras. Entre las medidas disciplinares, la jerarquía condicionó la permanencia del clero extranjero a la idoneidad requerida para el ejercicio del ministerio y promovió la subordinación de los capellanes a los párrocos. En función de dicha condición, se concedieron títulos y cargos. La ocupación principal fue la de capellanes, tenientes y curas de parroquias poco apetecidas por el clero criollo. Sólo aquellos que se adecuaron al perfil clerical deseado por el diocesano, se incorporaron, sin mayores inconvenientes, a la estructura eclesiástica local. La reserva de la jerarquía para incorporar clero inmigrante se manifestó también en la reticencia a la incardinación. Por más que llevara años ejerciendo el ministerio, continuaba siendo clero extra-diocesano, como dicen algunos documentos, se lo consideraba "como si" fuera de la diócesis.

Más allá de la categoría profesional que caracteriza al clero como "ministros de lo sagrado" (Taylor, 1999: 113-139), consideramos que el clero secular se constituyó como un grupo social complejo, con marcadas diferencias en su interior. Se trató de un actor social profundamente imbricado con la sociedad provincial, que participó activamente de los procesos políticos, económicos y de las transformaciones sociales que experimentó la diócesis en el período de entre siglos.

En el clero extranjero, la carrera fue meritocrática, al menos para acceder al cargo de cura párroco en los curatos de la provincia de Córdoba, esto sin detrimento de la importancia que tuvieron las relaciones y recomendaciones a la hora de aceptar y/o designar a curas extranjeros.

El abordaje de la inmigración clerical desde una perspectiva regional nos permitió, al menos, matizar algunas miradas generalizadoras que pasaron por alto las especificidades propias de cada espacio. La concepción de que "el clero inmigratorio agudizó los problemas que ya tenía el clero criollo", en Córdoba, el clero nativo, a la llegada masiva del clero inmigrante (1900-1914), ya había sido reformado y era bastante idóneo. El segundo presupuesto que reconsideramos es aquel que afirma que el 
aporte de clero extranjero fue "insuficiente y perjudicial". El análisis de las trayectorias individuales nos permitió delinear una imagen diferente del clero inmigrante, rescatando la actuación de más de un $50 \%$ de clérigos que permanecieron muchos años en la diócesis y colaboraron activamente con el proyecto modernizador diocesano. La contribución del clero inmigrante al proceso de renovación católica fue significativa. Las estrategias pastorales realizadas por algunos curas piamonteses fueron la punta de lanza de la labor pastoral de la región del sudeste. Implementaron una pastoral novedosa para el clero local, en estrecha relación con los postulados del catolicismo social europeo, como se analizó en el caso del cura Cinotto de la colonia Sampacho.

Los curas inmigrantes constituyeron un colectivo diferenciado, heterogéneo y plural, desarticulado, complejo y, en general, poco cualificado. Su principal característica fue, precisamente, la diversidad. Algunos, debido a su escasa calificación, contribuyeron a la construcción de una imagen negativa del clero gringo, al cual se lo veía como mercader, oportunista y aventurero. Sin embargo, esta percepción no se adecua enteramente a la realidad y responde a la conducta de un $19 \%$ del clero inmigrante -el que fue observado, sancionado o suspendido. Por otra parte, establecer los años de permanencia en la diócesis, hizo que pudiéramos comprobar que el clero inmigrante, que se identifica con esta imagen negativa, fue el que permaneció menos de cinco años en el territorio diocesano y se corresponde con el $28 \%$ del clero extranjero que llegó a Córdoba.

Otro de los presupuestos que pusimos en tensión fue la afirmación de que la Iglesia argentina se italianizó. Pese a la presencia de clero extranjero, no podemos sostener que la iglesia diocesana de Córdoba se haya italianizado, ya que los cargos de gobierno (cabildo) y administración diocesana permanecieron en manos del clero argentino y cordobés.

La tercera variable analiza el poder pastoral parroquial en el contexto secularizador. Para ello, centramos la mirada en las complejas relaciones entre clero-feligresíasautoridades locales. El abordaje se efectúa a partir del análisis de las prácticas. La redefinición del espacio parroquial permitió a la iglesia fortalecer el contacto con los fieles, convirtiendo a la parroquia en una institución bisagra entre la Iglesia y la sociedad. Las parroquias fueron instrumento y vehículo para la consolidación del cristianismo. Ellas tuvieron un rol social polivalente, como ámbitos de fuerte contenido espiritual, de circulación de discursos y prácticas religiosas, como espacios de sociabilidad, alianzas y definición de identidades grupales, apoyo material y solidaridad 
entre los fieles y lugar privilegiado de formación del laicado que dará sus frutos en el renacimiento católico de los ' 30 .

En la investigación indagamos sobre la naturaleza de este espacio, los cambios que experimentó y cómo se redefinió a lo largo del período considerado. Procedimos al estudio de las estructuras institucionales eclesiásticas conjuntamente con la acción, intención y pensamiento de los actores responsables de ellas, concibiendo que el estudio de la Iglesia y la religión es la historia de las experiencias vividas y, a la vez, la historia de los discursos, las imágenes y las representaciones, pues no hay práctica ni estructura que no sea producida por las representaciones, contradictorias y enfrentadas, por las cuales los individuos y los grupos dan sentido al mundo que les es propio.

El análisis minucioso del proceso de institucionalización y transformación de la Iglesia diocesana cordobesa, nos permitió demostrar la asombrosa capacidad que mostró la Iglesia católica para sobrevivir y mantenerse influyente en la vida social y espiritual de las personas. La religión no se volvió socialmente irrelevante en la modernidad, como sostienen algunas tesis radicales de la teoría de la secularización, sino que encontró nuevas significaciones sociales. Un ejemplo de ello fue sin duda el proceso que llevó a la secularización de los cementerios, pues si bien los cementerios pasaron a la administración civil, los pobladores siguieron solicitando a los curas la realización de responsos para sus deudos, la administración de los ritos funerarios, incluida la bendición de la sepultura. La secularización de los cementerios fue, sin duda, un paso en el proceso de laicización del estado, pero no necesariamente en el proceso de secularización de la sociedad. A lo largo de estos años, puede observarse cómo la iglesia se adecuó a nuevas prácticas funerarias, más acordes con las sociedades modernas. La solidaridad entre vivos y muertos ya no está sólo en el recuerdo, sino en la responsabilidad de los vivos de contribuir a la salvación eterna de los muertos. El cura debía bendecir la sepultura y hacer los oficios correspondientes a los fieles que murieran en comunión con la Iglesia. Aquí estamos en presencia de un vínculo moderno, ligado a la veneración del recuerdo del difunto en una tumba propia. Esta individuación no implicó necesariamente descristianización, fue, sin embargo, una clara manifestación del proceso de privatización de lo religioso. Antes, el cuerpo importaba poco mientras estuviera sepultado en campo santo. Ahora, lo importante es bendecir la tumba individual y garantizar los oficios fúnebres. El campo santo cede el paso a la sepultura individual, bendecida, en un espacio profano. 
Aquí advertimos que, a partir de la segunda mitad del siglo XIX, la parroquia comenzó a organizarse para dar respuestas a una sociedad que era cada vez más plural, que miraba al individuo inserto en el mundo moderno, que debía velar por consolidar los vínculos y lazos sociales en el marco de la diversidad de creencias. Las prácticas de la muerte se resignificaron en el contexto de sociedades modernas, en las cuales el individuo era el centro de referencia; las antiguas hermandades y cofradías si bien no desaparecieron, dieron paso a nuevas asociaciones vinculadas al apostolado seglar (Apostolado de la Oración); la promoción social de los más indigentes (Las Conferencias Vicentinas); la dignidad del trabajador (Círculos de Obreros y Liga Social); enseñanza de la doctrina (Congregación de la Doctrina Cristiana) y la Unión Popular Católica, entre otras. Estas asociaciones estaban orientadas a llevar a cabo la acción católica, es decir, la acción de los católicos en las sociedades modernas.

La parroquia representó una estructura espacial que tomó consistencia en función de diversas variables, se presentaba como el lugar legítimo y necesario de la administración de sacramentos; el lugar destinado a la participación de los fieles en el culto; la organización de las feligresías en orden al trabajo; un espacio de socialización y recreación, la ocupación simbólica del espacio público. La parroquia se convirtió entonces en una institución que, por voluntad del obispo, apuntó a encuadrar a los fieles mediante la creación de un espacio-tiempo adaptado a las prácticas de fieles, se buscó llevar la parroquia a los fieles y de acercar los feligreses a la parroquia. Se trató de imprimirle una función de doble dimensión: la inclusión de las poblaciones dentro de la Iglesia y la expansión de la iglesia fuera del templo, a los espacios públicos: calles, plazas y campos. Este modelo se conformó paulatinamente y no sin resistencias.

Al analizar el lugar del clero en la sociedad que se seculariza, observamos la resistencia de algunos clérigos a retirarse de la actividad política partidaria y el llamado de los obispos diocesanos a un compromiso pastoral y social de mayor envergadura. El clero era escaso en relación al aumento demográfico de la población, por lo tanto, era de capital importancia restringir la labor del párroco a la predicación, la administración de los sacramentos y la promoción de la acción social católica, dejando otro tipo de actividades, particularmente las políticas, bajo la responsabilidad de los laicos. La tradición política clerical cordobesa tenía su peso y, si bien, como advierte Ayrolo (2011: 113), la presencia y participación de clérigos en política comenzó a ser cuestionada a mediados del siglo XIX, el ejercicio de la política moderna ya se había instalado como una práctica corriente, el clero ya no tenía más espacio en las bancas de 
diputados sino como resabio nostálgico de otros tiempos. Lo cierto es que en 1917 y 1919 aún era posible encontrar clérigos que ocupaban bancas en las cámaras provinciales como diputados y senadores, como concejales en las comunas municipales, como electores o apoyando diversas candidaturas.

El trabajo de investigación aquí presentado viene a llenar un vacío en la historiografía provincial y, a nuestro parecer, revierte la tendencia de considerar al catolicismo de fines del siglo XIX y comienzos del XX como una historia de fracasos y crisis, producto de la fuerza reaccionaria del catolicismo y de la fuerza ineludible de la modernidad hacia el progreso. 


\section{FUENTES}

\section{FUENTES INEDITAS}

\section{ARCHIVO DEL ARZOBISPADO DE CÓRDOBA [AAC]}

- Legajo $N^{\circ}$ 2. Cabildo Eclesiástico de Córdoba, Tomos 3 y 4

- Legajo $\mathrm{N}^{\circ}$ 7. Fundación y Creación de Oratorios, Capillas y Cementerios, 1727-1905

- Legajo N 14. Santa Sede, 1645-1907, Tomo 2

- Legajo No 11. Seminario Conciliar de Córdoba, 1620-1910, Tomo 4

- Legajo N 16. Sínodos y Aranceles Eclesiásticos, 1699-1907, Tomo 2

- Legajo $N^{\circ} 23$. Dimisorias para Ordenes, 1801-1911, Tomo 4

- Legajo 24 Expedientes de Ordenes: (1680-1908), Tomo VII: 1845-1865; Tomo VIII: 1860-1870; Tomo IX: 1873-1880; Tomo X: 1883-1889; Tomo XI: 1890-1894; Tomo XII: 1895-1900; Tomo XIII: 1895-1900; Tomo XIII bis

- Legajo N²6: Nombramiento de Curas, 1777-1904

- Legajo No 28: Movimiento Religioso de los Curatos, 1905-1910

- Legajo N³4: Quejas y Denuncias. Curas, Tomo 4

- Legajo N 37: Juicios Criminales, 1699-1871, Tomo 8

- Legajo $N^{\circ}$ 38: Comunicaciones con el Gobierno Nacional, 1814-1910, Tomos 3 y 4

- Legajo No 39: Comunicaciones con el Gobierno Provincial, 1760-1910, Tomos 3 y 4

- Legajo $N^{\circ}$ 40: Cartas y Notas de los Sres. Curas a los Sres. Obispos, 1773-1908, Tomos 3

y 4

- Legajo No 42: Cartas del Sr. Obispo, Sr. Vicario y Sr. Secretario, 1795-1912, Tomos 3 y 4

- Legajo N 43: Comunicaciones de Arzobispos y Obispos, 1859-1905

- Legajo N 46: Curato de Río Cuarto, 1838-1910, Tomo 2

- Legajo No 47: Curato de San Pedro Morteros, 1890-1910

- Legajo No 48: Curato de Fraile Muerto, 1847-1910

- Legajo No 49: Curato de San Francisco, 18991910

- Legajo No 50: Curato de Ischilín, 1859-1910

- Legajo N 51: Curato de Cruz Alta, 1894-1910

- Legajo No 52: Curato de Bell Ville, 1861-1910

- Legajo N 53: Pastorales, Decretos y Edictos, 1834-1913, Tomo 2

\section{LIBROS}

- Registro de Sacerdotes Seculares, 1905-1909

- Registro de Sacerdotes Extra Diocesanos, 1921-1928

- Curato del Tránsito, Salsacate, San Carlos y San Pedro, 1868-1887

- Curato de Chalacea y San Justo, 1875-1887

- Autos y Edictos, 1905-1920

- Decretos y Edictos, 1920-1925

- Libro de Autos y Visitas Pastorales, 1885-1916

- Libro de Visitas Pastorales, 1914-1922

- Notas de Secretaría, 1885-1913

- Copiador de Cartas, Secretaría del Obispado, 1882-1903

- Notas Particulares del Sr. Obispo, 1884-1903

- Comunicaciones con Prelados y Eclesiásticos, 1908-1923 
- Comunicaciones con el Gobierno Nacional, 1911-1925

- Comunicaciones con las Autoridades y Seglares, 1908-1924

- Obispado y Seminario de Córdoba, Libro de Cuentas, 1878-1891

- Registro de Comunidades de Religiosos y Religiosas y Asociaciones Piadosas, 1918

- Libro de Actas: Centro Diocesano de la Doctrina Cristina, 19061907

- Círculo de Estudios del Clero, Registro de Socios, 1917

- Círculo de Estudios del Clero, 1917-1918

- Libro de Actas, Conferencias Eclesiástica Moral y Liturgia, 1905-1912

- Sínodo Diocesano de Córdoba, 1906

- Cofradía del Ssmo. Sacramento, Libro de Actas, 1906

- Libro de Actas de la U.P.C.A., 1920-1928

- Obispado y Seminario de Córdoba. Libro de Cuentas, 1878-1891

- Compilación de Datos relacionados con las Parroquias de la Arquidiócesis

ARCHIVO DEL SEMINARIO CONCILIAR NTRA. SEÑORA DE LORETO QUE SE ENCUENTRA EN EL ARCHIVO DEL ARZOBISPADO DE CORDOBA

- Clasificación de Exámenes desde 1920

- Libro de Premios, Conducta y Estudios desde 1909

- Libro de Pensionistas desde 1915

- Libro de Caja desde 1917

CAJAS PARROQUIAS DE CORDOBA

CURIA, VISITAS PASTORALES Y VARIOS, AÑOS 1887 A 1918

FONDO ZENÓN BUSTOS (6 cajas)

FONDO FRANCISCANO ZENÓN BUSTOS (3 Cajas)

DATOS PARROQUIAS

ARCHIVOS SECRETOS VATICANOS [ASV]

- Archivo Nunciatura Apostólica en Argentina 1159

- Congregación Consistorial. Relaciones Diócesis

- Congregaciones del Concilio 1169-1140

- Visita Apostólica 1154-1154 4

- Congregaciones de la Visita Apostólica a Roma 1117-1144-1145

- Secretaría de Estado: República Argentina

ARCHIVO NUNCIATURA DEL BRASIL

- Gestión Roncetti-Aiuti, 1876-1878

- Libro 61. Secularizaciones, fascículo 291

- Libro 62, fascículo 298

- Libro 63. Gobierno, fascículo 306: Fray Mamerto Esquiú y Capistrano Tissera 
ARCHIVO NUNCIATURA ARGENTINA 1159

- Libro 2. Diócesis de Córdoba, fascículo 4: Córdoba y Gobierno; fasc. 5: Mons. Cabanilla. Administrador Obispado; fasc. 6: Solicitud del Deán; fasc. 9: Provista Chiessa Vacante: Zenón Bustos; fasc.12: Los Principios; fasc. 13 Varios: - Obispo Reginaldo Toro; Nómina Clero secular; Denuncias vs clero; Pbro. Cravero; Informe

- Libro 9. Sacerdotes extranjeros en Argentina, fasc. 1: Italianos en Argentina; fasc. 44: Colabianchi

- Libro 10. Sectas Heterodoxas en Argentina

- Libro 11. Colegio Pío Latinoamericano

- Libro 17. Obispo clero, fasc. 2: Seminario de Córdoba; fasc. 3: Sacerdote Luigi Terzuolo; fasc. 18: Acusaciones contra Bustos; fasc. 15: Sacerdote Domingo Ugo situación en la diócesis; fasc. 20: Reclamos contra Párroco de Laboulaye; fasc. 23: Asociaciones rurales; fasc. 34: Acusación Luis Leal; fasc. 40: Denuncias vs Obispo; fasc. 41: Participación clero política

- Libro 26. Procesos Canónicos. Mons. Juan Martín Yaniz; Mons. Abel Bazán; Mons. José A. Luque; Mons. Inocencio Dávila; Mons. Carlos Echenique

- Libro 30. Diócesis, fasc. 2: Colegio Pío Latinoamericano

- Libro 31. Diócesis, fasc. 1: Matrimonios Religiosos. Estadísticas comparadas; fasc. 15: Informe Diócesis de Córdoba; fasc. 20: Estadísticas

- Libro 47. Emigración, fasc. 1: Conducta clero extranjero; fasc. 2: Admisión del clero extranjero; fasc. 3: Relación con el clero secular

- Libro 50. Acción Católica, fasc. 3: Asociaciones católicas

- Libro 51. Acción Católica, fasc. 1: Cajas rurales, Comités parroquiales

- Libro 54. Anticlericalismo, fasc. 1: Campañas y demostraciones; ClemenceauMartineche y Maurri; 2. Diarios Anticlericales; 3. Congreso Científico Internacional

- Libro 62. Internunciaturas. 1. Visitas ad limina. Obispos Argentinos 1913

- Libro 63. Gestión Mons. Locatelli, 1907-1916. 3. Informe política religiosa. Nueva política eclesiástica favorable a la Iglesia. Denuncias

- Libro 67. Gestión Mons. Vassallo di Torregrosa, 1916-1922. 4. Cuestión S.C. para seminarios. 3. Pío latinoamericano

- Libro 74. Congregaciones Romanas. 4. Relación secreta. Visita ad limina

- Libro 75. Clero extranjero en Argentina

- Libro 76. Anticlericalismo, fasc. 6: Desordenes y manifestaciones anticlericales Universidad de Córdoba

- Libro 77. Publicaciones. Primer Congreso Católico Diocesano Discurso Zenón Bustos 1918

CONGREGACIONES DE ASUNTOS ECLESIASTICOS EXTRORDINARIOSARGENINA (1878-1903)

192/9 Noticias. Política Religiosa de la Argentina. Obispo de Córdoba Capistrano Tissera 207/11 Córdoba. El nuevo Obispo de Córdoba Reginaldo Toro

208/11 Córdoba

209/11 Córdoba. Educación

214/13 Córdoba 1889. Matrimonio civil

216/13 Córdoba 1889 
220/15 Córdoba 1891. Denuncia contra el Obispo Diocesano que le prohíbe ejercer el ministerio y lo suspende ad divinis

223/15 Córdoba 1892. Reginaldo Toro grados académicos en el Seminario

224/15 Córdoba 1892. Petición de Pide obispo auxiliar

227/16 Causas. Deplorable estado del clero

264/29 Córdoba 1898. Sobre la situación religiosa en Argentina, su clero y sus obispos especialmente de Córdoba. Reginaldo Toro

278/32 Córdoba 1899. Sobre el clero de Córdoba

CONGREGACIONES DE ASUNTOS ECLESIASTICOS EXTRORDINARIOSARGENINA (1903-1922)

Diócesis de Córdoba

Facultades

Asuntos diversos

Necesidad de Clero

SECRETARIA DE ESTADO 1848-1913 (1089-I)

251 (1-2) 1881 América (Brasil, Perú, Chile, Bolivia, Argentina)

251 1884-1885 No 61119 República Argentina: Controversia Clero-Gobierno. Ruptura relaciones

$2511885 \mathrm{~N}^{\mathrm{o}} 64479$ Conflictos políticos-religiosos. Leyes contra la Iglesia

SECRETARIA DE ESTADO (1089-I-II)

251 Nunciatura Rio de Janeiro

279 Affari de América

CONGREGACIONES CONCISTORIALES.

RELACIONES: DIOCESIS

No 260 Diócesis de Córdoba. Relación Visita ad limina 1913

ARCHIVO HISTÓRICO PROVINCIAL DE CÓRDOBA [AHPC]

FONDO GOBIERNO

1870 T.2 Obispado y otros

1871 T.2 Solicitud subsidios

T.5 Obispado

1872 T.3 Construcción Iglesia Carlota; Achiras

T.6 Cura Río Cuarto Subsidio

1873 T.2 Obispado

T.3 Cura Eleodoro Fierro

T.4 Vecinos Molinos construcción capilla

1874 T.3 Obispado y curas

T4. Solicitudes subsidios construcción Iglesias

1875 T4. Subsidios capillas

T.5 Obispado

1876 T.2 Colonia Sampacho

T.4 Solitudes subsidios capillas 
1877 T. 1 Ministerio de Justica, Culto e Instrucción Pública

T.4 Colonia Sampacho

T.6 Arreglo capilla Río 1\% Solicitudes varias

1878 T.1. Ministerio Culto

T.2 Ley de Capellanías

T.5 Obispado

T.9 Comisión pro-Templo Villa Gral. Belgrano

T.10 Colonias

1879 T.5 Estadísticas obispado

T.9 Solicitudes pro templos

1880 T.1 Ministerio Justicia y Culto

T.4 Obispado

T.5 Colonias

T.10 Solicitudes vecinos construcción iglesias

1881 T.5 Obispado

1882 T.1 Ministerio Justicia y Culto

T.5 Obispado

T.7 Solicitudes construcción iglesias

1883 T.1 Colonias: Carlota, Sampacho, Caroya. Ministerio de Gobierno, Justicia y Culto

T.7 Solicitudes varias

T.8 Actividades eclesiásticas

T.9 Subsidios construcción Iglesia Río Seco

1884 T.1 Ministerio de Culto

T.5 Estadísticas Municipalidades

T.9 Colonias

1885 T.1 Ministerio

T.9 Autoridades religiosas

T.10 Estatutos diversas sociedades / Colonias

1886 T.7 Obispado

T.8 Departamento Topográfico Estadísticas

T.9 Solicitudes

T.13 Colonias. La Carlota

1887 T.8 Municipalidades / Autoridades religiosas / La colonización

T.13 Solicitudes diversas

T.15 Informes colonias

1888 T.8 Autoridades religiosas

T.6 Estadísticas

T.9 Colonias

T.14 Jefaturas políticas

1889 T.6 Estadísticas

T.9 Autoridades y asuntos religiosos

T.10 Censo General de la Provincia

T.11 Estatutos de sociedades

T.12 Pueblos fundados en la Carlota

T.17 Jefaturas políticas

1890 T.6 Estadísticas 
T.9 Autoridades religiosas

T.10 Diversos asuntos. Registro Civil

T.13-14 Jefaturas políticas

1891 T.9 Autoridades religiosas

T.10 Memoria Registro Civil

T.12/13 Jefaturas políticas

1892 T. 8 Solicitudes

T.10 Oficina estadística

T.12 Registro civil

T.14 Autoridades religiosas

T.15-16 Jefaturas políticas

1893 T.3 Autoridades eclesiásticas

T8 Solicitudes varias

T.10 Oficina estadística

T.14 Marcos Juárez Iglesia

T. 16-17 Jefaturas políticas

1894 T.5 Construcción Templos

T.11 Estadísticas

T.17 Autoridades religiosas

T.19-20 Jefaturas políticas

1895 T.10 Solicitudes

T.15 Estatutos sociedades

T.16 Autoridades religiosas

T.18-19 Jefaturas políticas

T.22 Diversos asuntos de la campaña

1896 T.12 Autoridades religiosas

T.17 Colonias

T.20 Jefaturas políticas

1897 T.3 Elecciones

T.14 Solicitudes

T.13 Elección senadores y diputados

T.14 Solicitudes

T.17 Justicia y Culto

T.18-19 Jefaturas políticas

1898 T.2 Solicitudes varias

T.7 Obispado

T.10 Ministerio de Justicia y Culto

T.15-16 Jefaturas políticas

1899 T.1-2 Jefaturas políticas

T.3 Registro civil

T.7 Obispado

T.8 Ministerio de Culto

T.10 Solicitudes varias

1900 T.1-2 Jefaturas políticas

T.5 Ministerio de Justicia y Culto

T.6 Obispado 
T.15 Solicitudes

T.16 Solicitud subsidio templo Villa Ascasubi

1901 T.1-2 Jefaturas políticas

T.5 Solicitudes

T.10 Culto

1902 T.1-2 Jefaturas políticas

T.3 Solicitudes

JUZGADO $1^{\circ}$ NOMINACIÓN CIVIL 18831926

1892 Leg.1, Exp. 4: Eleodoro Fierro

1901 Leg. 31, Exp. 6: Eleodoro Fierro

1883 Leg. 3, Exp. 1: Rosendo Leal

1886 Leg. 7, Exp. 2: Rosendo Leal

1903 Leg. 27, Exp. 1: Correa Jacinto

1887 Leg. 19, Exp.: Pbro. Domingo Guerra

1898 Leg. 9, Exp.11: Pbro. Domingo Guerra: testamento

1902 Leg. 30, Exp. 11: Pbro. Domingo Guerra: testamento

CIVIL $2^{\circ} 1883-1926$

1876 Leg. 373, Exp. 8: Tagle ofrece caución por su hermano el Pbro. Luis Tagle

1879 Leg. 403, Exp. 2: Calderón por calumnia Juan Chacón

1886 Leg. 484, Exp. 10: Martínez Injurias Pbro. Torres

CRIMEN GENERAL

1871 Capital, Leg. 329, Exp. 9: Sumario contra autores sustracción de actas elección de la capilla de Rodríguez

1872 Leg. 330, Exp. 9: Argeñarás Antonio por Injurias al Cura Eleodoro Fierro

1873 Leg. 3432, Exp. 15: EL Progreso por artículo injurioso contra el Pbro Eleodoro Fierro

$19022^{\circ}$ Nominación, Leg.13, Exp. 1: Ludueña violación

$19042^{\circ}$ Nominación, Leg. 5, Exp. 14: Molina Ramón desacato

CRIMEN $2^{\circ}$ CAPITAL

1890 Leg. 7, Exp. 5: Dn. Elías Carranza contra el Cura de Quilino S. Oviedo. Injurias

1891 Leg. 4, Exp. 1: Cura párroco Depto. de Punilla Dn. Jacinto A. Correa. Infracciones a la Ley de Matrimonio Civil

1892 Leg. 1, Exp. 7: José Pérez

1899 Leg. 7, Exp. 4: Alberti Pedro Presbítero (incendio Iglesia de Cruz Alta)

CRIMEN $1^{\circ}$ NOMINACION 1906-1914

1909 Leg. 9, Exp. 2: Injurias y calumnias a José Pío Angulo

CRIMEN $2^{\circ}$ NOMINACION

1898 Leg. 4, Exp. 16: Falso matrimonio

1899 Leg. 7, Exp. 4: Presbítero Pedro Alberti solicita excarcelación bajo fianza 
JUZGADOS DE PAZ LEGOS

Campaña 1 1870-1902

ARCHIVO MUNICIPAL DE RIO CUARTO [AMRC]

Periódicos

ARCHIVO HISTÓRICO CONVENTO SAN FRANCISCO SOLANO DE RÍO CUARTO [ACSF]

Asociaciones religiosas: Memorias, reglamentos, estatutos y boletines

Cajas 66 y 67, 1901-1929: Comandancia de Frontera Río Cuarto. Notas. Laboulaye. Parroquia. Documentos históricos.

Caja 68, Laboulaye. Parroquia, 90 años

Caja 120, Curato de Tegua. Datos Históricos

ARCHIVO HISTÓRICO INSPECTORIAL SALESIANO DE CORDOBA [ASC]

- Caja 1. 5.1.3 Inspectoría Rosario. Notizie Cronistoriche: Escual y templo del Sagrado Corazón de Jesús. Colonia Vignaud-Estación Brickmann. Prov. de Córdoba -Argentina-

- Colonia Vignaud, Congreso de Padres Cristianos 1925

ACADEMIA NACIONAL DE LA HISTORIA

- Fondo Enrique Udaondo

- Documentos Relativos a la UPCA. Correspondencia 1919-1931

\section{FUENTES EDITAS}

DOCUMENTOS PONTIFICIOS: https://w2.vatican.va

- Pío IX, Etsi Multa. Sobre los ataques a la Iglesia en los diferentes países (21/11/1873)

- Pío IX, Cuanta Cura y Syllabus (12/1864). Condenas al Liberalismo

- León XIII, Aeterni Patris (04/08/1879). Sobre la restauración de la filosofía cristiana conforme a la doctrina de Santo Tomás de Aquino

- León XIII, Arcanum Divinae Sapientiae. Sobre la familia (10/02/1880)

- León XIII, Diuturnum Illud. Sobre la autoridad política (29/06/1881)

- León XIII, Humanus Genus. Sobre la masonería (20/04/1884)

- León XIII, Immortale Dei. Sobre la constitución cristiana del Estado (01/11/1885)

- León XIII, Quamquam Pluries. Sobre la devoción a San José (15/08/1889)

- León XIII, Rerum Novarum. Sobre el mundo moderno (15/05/1891)

- Pío X, Il Fermo Proposito. Sobre el establecimiento y desarrollo de la Acción Católica $(11 / 06 / 1905)$

- Benedicto XV, Maximum Illud. Sobre la propagación de la fe católica en el mundo $(30 / 11 / 1919)$

- Pío XI, Rerum Ecclesiae. Sobre la actividad misionera de la Iglesia (26/02/1926)

- Concilio Plenario de la América Latina, Actas y Decretos, Traducción oficial (Roma, Tipografía Vaticana, 1906), 593pp.

- Pío IX, Carta autógrafa, 1875 
DOCUMENTOS EPISCOPALES

- Ramírez de Arellano, Pastoral. Sobre la Cuaresma, 1873

----- Circular. Sobre el Seminario Conciliar, 1873

- Álvarez, Manuel E., Disposiciones Eclesiásticas sobre las Prácticas de Piedad, 1875

----- Consagración de la Diócesis al Sagrado Corazón de Jesús, 1876

----- Pastoral, al hacerse cargo de la Diócesis, 1876

----- Pastoral de Convocatoria Sínodo, 1876

----- Edicto. A los fieles cristianos sobre la Cuaresma, 1877

- Martiarena, Gaspar, Vicario Capitular y Gobernador, Pastoral sobre la cuaresma, 1878

- Castellano, Uladislao, Provisor y Gobernador del Obispado, Carta edicto sobre la Cuaresma, 1879

----- Manifiesto sobre Escritos del cura Fierro, 1879

----- Carta Pastoral por el Jubileo Universal León XIII, 1880

----- Carta edicto sobre la Cuaresma, 1880

----- Auto. Prohibiendo el Diario El Interior, 1880

- Esquiú, Fray Mamerto, Obispo, Jubileo por el Tercer Aniversario de la Muerte de Pío IX, León XIII, 1881

----- Pastoral, al hacerse cargo de la diócesis, 1881

----- Agradecimiento a León XIII de los fieles de Córdoba, 1882

----- Pastoral. Sobre el Tercer Aniversario de la Muerte de Pío IX, 1882

----- Edicto. Con motivo de sequía y epidemias, 1882

----- Acción de gracias por el beneficio de las lluvias, 1884

----- Pastoral. Día de Expiación, 1888

- Clara, Gerónimo, Pastoral, 1882

----- Edicto Circular. Sobre sepultura eclesiástica, 1883

----- Edicto. Indulgencia Fiesta y Mes del Rosario, 1883

----- Edicto. Dispensa del Ayuno Cuadragesimal, 1883

----- Secretaría del Obispado, Circular Triduo Fiesta Natividad de la Virgen, 1883

----- Edicto. Sobre la Sociedad Juventud Católica, 1883

----- Breve sobre su Santidad León XIII, 1883

----- Pastoral para impedir la propagación del error y el vicio que se difunden por medio de escritos y libros anticatólicos, 1884

----- Carta Pastoral sobre Escuela normal de niñas regidas por maestras protestantes, 1884

----- Circular. Asistencia escuelas regidas por maestras protestantes, 1884

----- Provisor y Gobernador del Obispado por delegación del vicario capitular, Edicto

----- Carta edicto sobre el fallecimiento de Fray Capistrano Tissera, 1887

----- Preces Públicas. Rogativas por lluvias, 1887

- Tissera Juan Capistrano, Obispo, Carta edicto sobre el mes del Rosario, 1884

----- Carta edicto sobre la Cuaresma, 1885

----- Pastoral. Apertura de la Visita Canónica, 1885

----- Pastoral. Con motivo de un sacrilegio, 1886

----- Carta edicto. Sobre la Cuaresma, 1886

----- Pastoral Jubileo de León XIII, 1886

----- Carta Edicto a los católicos de Villa Nueva, 1886

----- Pastoral. Delegando un visitador a la Rioja, 1886

----- Carta Edicto sobre cuaresma y el cumplimiento con la Iglesia, 1887 
- Clara Gerónimo, Carta edicto sobre el Fallecimiento de Fray Capistrano Tissera, 1887

----- Preces Públicas. Rogativas por lluvias, 1887

- Castellano, Uladislao, Vicario Capitular, Pastoral. Día de Expiación, 1888

- Toro, Fray Reginaldo, Obispo, Pastoral, 1889

----- Circular. Solicitud informes curatos, 1890

----- Pastoral. Tercer Centenario San Luis Gonzaga, 1892

----- Pastoral. Visita ad limina, 1891

----- Pastoral. Coronación Virgen del Rosario, 1892

----- Pastoral. Indulgencia porciúncula, 1892

----- Pastoral. Regreso de Roma, 1892

---- Pastoral. Cuaresma, 1893

----- Pastoral. Penitencia. Pecado, 1895

----- Pastoral. Cuaresma y Tiempos presentes, 1897

----- Auto Episcopal. Sobre el XX de septiembre, 1897

----- Auto Episcopal. Liberalismo en Marcos Juárez, 1897

----- Pastoral. Pedido informes curatos, $\mathrm{N}^{\mathrm{o}}$ de iglesias y oratorios, 1898

----- Auto Episcopal. XX de septiembre, 1899

---- Pastoral, 1900

----- Auto episcopal. XX de septiembre, 1902

----- Auto episcopal. Sobre el ayuno, 1902

----- Pastoral. Fiestas del Aniversario Coronación Virgen del Rosario, 1902

----- Pastoral. Jubileo de León XIII, 1903

----- Pastoral. Jubileo de Pío IX, 1903

----- Edicto sobre cuaresma, 1903

- Cabanillas, Filemón, Obispo auxiliar y Gobernador delegado, Auto Quincuagésimo Aniversario Inmaculada Concepción, 1904

- Bustos, Zenón, La Inmaculada Concepción de María en la moral, la sociedad y la intelectualidad de América Latina. Sermón pronunciado en el 50 aniversario de la declaración del Dogma, Convento de San Francisco, Est. Gráficos La Moderna, Córdoba, 1904

- Bustos Zenón, Obispo, Pastoral. Sobre la doctrina cristiana, 1905

----- Edicto al recibir el gobierno de la Diócesis, 1905

----- Auto episcopal. Sobre el 20 de Septiembre, 1905

----- Auto episcopal. Adoración Smo. Sacramento, 1906

----- Carta Circular. Sobre el seminario diocesano y la necesidad de clero, 1906

----- Programa Actos Sínodo diocesano, 1906

----- Edicto. Centenario de Santo Toribio, 1906

----- Auto Episcopal. Sobre el seminario diocesano y la necesidad de clero, 1907

----- Pastoral. Sobre el templo. Lugar y comportamiento, 1907

----- Circular. Sobre la prensa católica. Los Principios, 1907

----- Auto. Sobre el Santuario de Reducción, 1907

----- Reglamento uso de campanas, 1907

----- Pastoral. Sobre el Círculo de Obreros, 1907

----- Auto. Sobre el Ayuno, 1908

----- Pastoral. Regreso Roma y Palestina, 1909

----- Auto. Arreglo contabilidad cofradías y asociaciones, 1909 
----- Pastoral. Sobre la Universidad católica, 1909

----- Auto. Sobre el ayuno, 1910

----- Pastoral sobre Semana Santa, 1910

----- Auto. Sobre el Centenario, 1910

---- Sermón Patrio, pronunciado en la catedral de Córdoba el 25/05/1910. Tipología los Principios, Córdoba, 1910

----- Pastoral. Sobre el Tercer Centenario San Francisco Solano, 1910

----- Auto. Sobre Acción Católica: Conferencias sociales para el clero del sud este. Asociaciones campesinas, 1911

----- Pastoral. Sobre Cristo de Reducción, 1911

----- Pastoral. Sobre la necesidad de templos en la ciudad, 1911

----- Auto. Sobre la enseñanza del catecismo, 1912

----- Enseñanza popular del Catecismo. Padres de familia. Ayudar a párrocos. Métodos nuevos, 1912

----- Auto. Sobre la Obra Social, 1912

----- Pastoral. Fin de visita canónica. Anuncio apertura de nueva visita, 1912

----- Pastoral. Constantino Batalla sobre el puente Milvio, 1913

----- Pastoral. Jubileo Universal. Su promulgación en Córdoba, 1913

----- Auto. Sobre colaboración con el censo, 1913

----- Pastoral. Fray Mamerto Esquiú, 1914

----- Pastoral. Ordenando plegarias por la Paz Europea, 1914

----- Pastoral. Sobre el socialismo, 1914

----- Pastoral. Sobre la Paz, 1916

----- Pastoral. Sobre cuaresma, 1916

----- Pastoral. 25 aniversario Coronación Virgen del Milagro, 1917

----- Pastoral. Sobre agitación anti-religiosa en Córdoba, 1918

----- Conferencia al Clero sobre La Revolución Social, 1918

----- Pastoral sobre las cualidades de la Predicación, 1918

----- Pastoral sobre Cuaresma, 1918

----- Auto. Sobre la obra de la propagación de la Fe, 1918

----- Pastoral. Del proletariado antes y después de Jesucristo, 1919

----- Pastoral. Sobre situación social, 1919

----- Discurso Inaugural leído en el Seminario de Córdoba, 1919

----- Auto. Retiro del Gobierno de la Diócesis, 1919

- Luque, José Anselmo, Gobernador Delegado, Auto. Ayuno y abstinencia, 1920

ASOCIACIONES RELIGIOSAS: MEMORIAS, ESTATUTOS Y REGLAMENTOS

- Sociedad San Vicente de Paul. Bodas de Plata Conferencias de Señoritas Santa Rosa de Viterbo

----- Conferencias de Señoras. Memorias, 1918/1921, 1931/1934

----- Conferencia Consejo General. Memorias, 1926, 1927 y 1934

----- Asilo de San José, Río Cuarto. Reglamento

- Sociedad de Beneficencia, Río Cuarto. Estatutos y Reglamento. Bodas de Oro

- Sociedad Damas Misericordia, Río Cuarto. Memorias, 1924/1927. Estatutos

- Círculo Católico de Obreros. Estatutos, 1911. Reglamento. Panteón Social.

- Pía Unión Hijas de María Inmaculada. Iglesia Parroquial de Río Cuarto. Estatutos 
- Cofradía Buena Muerte de Reducción. Estatutos 1917. Parroquia de La Carlota

- Sociedad Católica de Señoras Solteras. Estatutos y Programa

- Cofradía Ntra. Señora del Carmen. Estatutos

- Cofradía del Sagrado Corazón de Jesús, Iglesia catedral

- Congregación de la Doctrina Cristiana

PUBLICACIONES OFICIALES

- Memoria oficial de la Oficina de Estadística de Córdoba, Publicación oficial, 1880

- Dirección General de Estadística de la Provincia de Córdoba, Imprenta y Casa Editora Domenici, 1900, 1901, 1902, 1903, 1904, 1905, 1910, 1926

- Anuario Estadístico, 1904

REVISTAS

- La Civilta Cattolica, vol. II, n 56, Roma, 1914

- Boletín Eclesiástico de la Diócesis de Córdoba, 1924-1935 [BEDC]

- Revista Eclesiástica del Obispado de Buenos Aires, 1901-1924 [REOBA]

BOLETINES PARROQUIALES

- "El Santísimo Rosario", Parroquia de Cruz Alta, 1911-1913

- "La Familia Cristiana", Parroquias de Marcos Juárez, Cruz Alta, Arteaga y Esquina, 1913-1925

- "La Semana Católica”, Parroquia de Río Cuarto, 1922-1933

- "El Cruzado", Parroquia de Dalmacio Vélez

- "El Heraldo" de Reducción, 1930-1940

- "Boletín mensual de la UPCA", Secretariado nacional, 1919-1925

- “Acción Franciscana”, 1920-1933

PERIÓDICOS

- "El Progreso", 1868-1881

- "El Eco", 1880-1890

- "Los Principios", 1894-1925

- "La Voz del Interior”, 1900-1925

- "El Pueblo" de Río Cuarto, 1893/1897-1915-1919

- "El Tribuno" de Río Cuarto, 1897

- "Vita Coloniale", 1920-130 
BIBLIOGRAFIA

- AA.VV. (1999), El Cura Brochero. Cartas y Sermones, Conferencia Episcopal Argentina, Buenos Aires.

- AA.VV. (2002), De las cofradías a las organizaciones de la sociedad civil. Historia de la iniciativa asociativa en Argentina 1776-1990, Gadis, Buenos Aires.

- AA.VV. (1994), Historia general de la Iglesia en América Latina, Tomo IX, Cono Sur (Argentina, Chile Uruguay y Paraguay) Cehila-Ediciones Sígeme, Salamanca.

- AA.VV. (2008), Civitatis Mariae. Historia de la Diócesis de Villa María, 500 años de fe a la vera del río de Nuestra Señora. Galeón Editorial, Córdoba.

- AA.VV. (1897), Marcos Juárez, cien años de historia... Municipalidad de Marcos Juárez, Córdoba.

- AA.VV. (1999), "El Cura Brochero. Cartas y Sermones", Conferencia Episcopal Argentina, Buenos Aires.

- ACEVEDO (1928), "El cura Brochero 50 años después de su obra en San Alberto”, A. Biffignandi, Córdoba.

- AGUIRRE SALVADOR, Rodolfo (2004), "Los límites de la carrera eclesiástica en el Arzobispado de México (1730-1747)", en Carrera, Linaje y Patronazgo. Clérigos y juristas en Nueva España, Chile y Perú (siglos XVI-XVIII), UNAM, México.

---- (2008), "El clero secular en Nueva España. Balance historiográfico y perspectivas de investigación", Anuario CEH, n 7, Córdoba.

---- (2010), "Historia social de la Iglesia y la religiosidad novohispanas. Tendencias historiográficas", Fronteras de la Historia, vol. 15, Colombia.

- AGULLA, Juan Carlos (1968), Eclipse de una aristocracia. Una investigación sobre las élites dirigentes de la ciudad de Córdoba, Libera, Córdoba.

- AGULHON, Maurice (1994), "Clase obrera y sociabilidad antes de 1848”, en Historia Vagabunda, Instituto Mora, México.

- AIRIAU, Paul (2004), "La formation sacerdotale source 1'anticlericalim au XIXe siècle", en Christian Sorrell (dir.), L'anticléricalisme croyant (1860-1914). Jalons pour une histoire, Université de Savoie, Chambéry.

----- (2006) "La formation sacerdotale en France au XIXe siècle", Archives de Sciences Sociales des Religions, $\mathrm{n}^{\circ} 133$.

- ALBERDI, Juan Bautista (1887), Obras completas, Imprenta La Tribuna Nacional, Buenos Aires.

- ALDEA, Quintín (1987), Iglesia y sociedad en la España del siglo XX. Catolicismo social (1909-1940), Consejo Superior de Investigaciones Científicas / Centro de Estudios Históricos / Departamento Enrique Flores, Madrid.

- ALDEA, Quintín y CARDENAS, Eduardo (1987), Manual de Historia de la Iglesia. La Iglesia del siglo XX en España, Portugal y América Latina, Herder, Barcelona. T. X.

- ALONSO, Paula (2000a), Entre la revolución y las urnas. Los orígenes de la Unión Cívica Radical y la política argentina en los años 90, Sudamericana, Buenos Aires.

----- (2000b), "El Partido Autonomista Nacional y las provincias de Córdoba y el litoral, 1880-1886”, I Jornadas de Historia Regional Comparada, Porto Alegre, 23-25 de agosto. 
- ALTAMIRA, Luis Roberto (1943), El Seminario Conciliar de Nuestra Señora de Loreto. Colegio Mayor de la Universidad de Córdoba, Imprenta de la Universidad, Córdoba.

----- (1948), "El Deán Funes, filósofo y soldado de la Revolución de Mayo", Revista de la Universidad Nacional de Córdoba, $\mathrm{n}^{\mathrm{o}}$ 2, Año 35.

- ALVAREZ GILA, Oscar (1998), "Relación entre clero e inmigración vasca en Argentina, razones y formas", Hispania Sacra, n 50 .

----- (2001), "La emigración del clero secular europeo a Hispanoamérica (siglos XIX y XX), causas y reacciones", Hispania Sacra, n 53.

- ANDRÉS-GALLEGO, José (1995), "Historia religiosa en España”, Anuario de Historia de la Iglesia, vol. 4, Universidad de Navarra.

----- (1996), "Historia cultural e historia religiosa", en Ignacio Olabarri y Francisco J. Capistegui (coords.), La nueva historia cultural, la influencia del posestructuralismo y el auge de la interdisciplinariedad, Editorial de la Universidad Complutense, Madrid.

---- (2002), “Algunas claves para entender el papel de la Iglesia en el mundo Moderno", Prohistoria, Año VI, nº 6.

- ANSALDI, Waldo (1997a), "Lo sagrado y lo secular-profano en la sociabilidad en la Córdoba de la modernización provinciana, 1880-1914", Cuadernos de Historia, $\mathrm{n}^{\circ}{ }^{1 \text {, }}$ Córdoba.

---- (1997b), "Ritos, ceremonias sacras y meas. Acerca de la sociabilidad cordobesa en los comienzos de la modernización provinciana", Anuario del IEHS, n 12.

----- (2000), La industrialización fallida. Córdoba 1880-1914, Ferreyra Editor, Córdoba.

- ARANCIBIA, José María y DELLAFERRERA, Nelson (1983), "Un Sínodo diocesano en el siglo XIX. Córdoba", Teología, no 41, UCA.

- ARCONDO, Aníbal (1969), "Tierra y política de tierras de Córdoba", Revista de Economía y Estadística, ${ }^{\circ} 2$ y 3, Córdoba.

---- (1972), Población y mano de obra agrícola, Córdoba, 1880-1914, Universidad Nacional de Córdoba, Córdoba.

---- (1975), La agricultura en Córdoba: 1870-1880, Dirección General de Publicaciones, Córdoba.

----- (1980), “El conflicto agrario argentino de 1912. Ensayo de interpretación”, Desarrollo Económico, vol. 20, $\mathrm{n}^{\circ} 79$.

- ARMUS, Diego (2000), "Mirando a los italianos. Algunas imágenes esbozadas por la elite en tiempos de la inmigración masiva", en Fernando Devoto y Gianfausto Rosoli (eds.), La inmigración italiana en la Argentina, Biblos, Buenos Aires.

- AUBERT, Roger (1988), "Pío X. El Papa de la Reforma Conservadora", en Hubert Jedin (coord.), Manual de Historia de la Iglesia, Herder, Barcelona. T. VIII.

- AURELL, Jaume y PEREZ LOPEZ, Pablo (2006), "La historia religiosa y su dimensión sociológica", en Católicos entre dos guerras. La historia religiosa en España en los años 20 y 30, Biblioteca Nueva, Madrid.

- AUZA, Néstor T. (1981), Católicos y Liberales en la generación del 80, ECA, Buenos Aires.

----- (1984), Corrientes sociales del catolicismo argentino, Claretiana, Buenos Aires.

---- (1987), Aciertos y fracasos sociales del catolicismo argentino, Guadalupe, Buenos Aires. Tomos I-II-III.

---- (1990), "La Iglesia argentina y la evangelización de la inmigración”, Estudios Migratorios Latinoamericanos, $\mathrm{n}^{\circ} 14$. 
---- (1994), “Una aproximación a la relación entre clero, población e inmigración en la provincia de Santa Fe", en Iglesia e Inmigración en la Argentina, T. II, CEMLA, Buenos Aires.

---- (2001), "La experiencia pastoral con las colectividades extranjeras en Buenos Aires, 1900-1961", en Iglesia e Inmigración en la Argentina, T. IV, CEMLA, Buenos Aires.

- AVEllanedA, Félix (1917), Fray Mamerto Esquiú. Datos Biográficos, Talleres Tipográficos de Stella, Catamarca.

- AYROLO, Valentina (1996), "Una nueva lectura de los informes de la misión Mussi: la Santa Sede y la Iglesia de las Provincias Unidas", Boletín del Instituto de Historia Argentina y Americana "Dr. Emilio Ravignani”, n 14, Buenos Aires.

---- (2001), "Cura de almas. Aproximación al clero secular de la diócesis de Córdoba del Tucumán en la primera mitad del siglo XIX”, Anuario del IEHS, nº 16.

----- (2004), "La participación política del clero como expresión de una Iglesia en transición (1820-1880)", Jornadas de Investigadores del Departamento de Historia, Mar del Plata (Inédito).

----- (2006), "Entre los fieles y Dios, hombres. Observaciones acerca del clero secular de la Diócesis de Córdoba en las primeras décadas del siglo XIX", en Estudios sobre el clero Iberoamericano, entre la Independencia y el Estado Nación, CEPHIA Editorial de la Universidad Nacional de Salta, Salta.

---- (2007), Funcionarios de Dios y de la República. Clero y política en la experiencia de las autonomías provinciales, Biblos, Buenos Aires.

----- (2009), "Reflexiones sobre el proceso de 'secularización' a través del 'morir y ser enterrado’. Córdoba del Tucumán en el siglo XIX”, Dimensión Antropológica, vol. 46.

---- (2011), "La carrera política del clero. Aproximación al perfil político-clerical de algunos hombres del XIX. El caso de los de Córdoba", en Marcela Ferrari (comp.), Dossier: "Acerca de los políticos y los procesos de profesionalización de la política", PolHis, Boletín Bibliográfico Electrónico del Programa Buenos Aires de Historia Política.

- AYROLO, Valentina, BARRAL, María Elena y DI STEFANO, Roberto (2012), Catolicismo y secularización en la Argentina, primera mitad del siglo XIX, Buenos Aires, Biblos.

- AYROLO, Valentina y BARRAL, María Elena (2012), "El clero rural, sus formas de intervención social y su politización (las Diócesis de Buenos Aires y Córdoba en la primera mitad del siglo XIX)", Anuario de Estudios Americanos, vol. 69, n 1.

- AYROLO, Valentina y FERRARI, Marcela (2005), "Algunas notas sobre la política en el oeste cordobés entre los siglos XIX y XX. El caso del cura José Gabriel Brochero", Cuadernos de Historia, $\mathrm{n}^{\circ}$ 7, Córdoba.

- AYROLO, Valentina y MAZZONI, Laura (2013), "De familiar a obispo de Córdoba. La trayectoria política de Benito Lascano como ejemplo de ascenso en la carrera eclesiástica, 1800-1836", Anuario de la Escuela de Historia Virtual, vol. 4.

- AZNAR, Antonio SJ (1950), El Cura Brochero. En su apostolado sacerdotal, su vida espiritual y legendaria en heroísmos, Ediciones Paulinas, Buenos Aires.

- BADA ELIAS, Joan (1994), "Iglesia y Sociedad en el Antiguo régimen: el clero secular" en Enrique Martínez Ruiz y Vicente Suárez Grimon (eds.), Iglesia y Sociedad en el Antiguo Régimen, III Reunión Científica Asociación Española de Historia Moderna, vol. I, Universidad de las Palmas de Gran Canaria. 
- BAUTISTA GARCÍA, Cecilia (2005), "Hacia la romanización de la Iglesia mexicana a fines del siglo XIX", Historia Mexicana, IV.

----- (2012), Las disyuntivas del estado y de la Iglesia en la consolidación del orden liberal, México, 1856-1910, Colegio de México / Universidad Michoacana de San Nicolás de Hidalgo, México.

- BARAGLI, Matteo (2011), "Visite pastorali in terra di mezzadria: il clero e le popolazioni contadine nella Toscana d'inizio '900”, AMMENTU - Bollettino Storico, Archivistico e Consolare del Mediterraneo (ABSAC).

- BARRAL, María Elena (2006), "Ministerio parroquial, conflictividad y politización: algunos cambios y permanencias en el clero rural de Buenos Aires luego de la revolución de independencia", en Valentina Ayrolo (coord.), Estudios sobre el clero Iberoamericano, entre la Independencia y el Estado Nación, CEPHIA Editorial de la Universidad Nacional de Salta, Salta.

---- (2007), De sotanas por la Pampa. Religión y sociedad en el Buenos Aires rural tardocolonial, Prometeo, Buenos Aires.

---- (2009), "De mediadores componedores a intermediarios banderizos: el clero rural de Buenos Aires y la 'paz común' en las primeras décadas del siglo XIX”, Anuario del IEHS, $\mathrm{n}^{\circ} 23$.

- BARREIRO MALLON, Baudilio (1988), "Sínodos, Pastorales y Expedientes de Ordenes: tres indicadores de religiosidad en el noroeste de la península", en León C. Álvarez Santaló (coord.), La religiosidad popular, Anthropos, Sevilla.

- BARRIO GOZALO, Maximiliano (1990), "El bajo clero en la España del siglo XVIII. Estado de la cuestión, problemas y direcciones de la investigación actual" en Actas del Coloquio Internacional Carlos III y su siglo, Universidad Complutense, Madrid, vol. I. ---- (2002), "Sociología del alto clero en la España del siglo Ilustrado", Manuscrit, 20.

- BASTIAN, Jean-Pierre (1990), Protestantes, liberales y francmasones. Sociedades de ideas y modernidad en América Latina, siglo XIX, Cehila-FCE, México.

----- (1998), "La lucha por la modernidad religiosa y la secularización de la cultura en México durante el siglo XIX”, en Manuel Ramos Medina (comp.), Memoria del I Coloquio de Historia de la Iglesia en el siglo XIX, Centro de Estudios de Historia de México, Condumex, México.

----- (2004) [2001], “Aprender a descentrar la mirada sobre la modernidad religiosa", en (coord.), La modernidad religiosa: Europa y América Latina en perspectiva comparada, FCE, México.

- BAUBEROT, Jean (2004a) "Sécularisation et laïcisation. Une trame décisive. L'histoire religieuse en France et en Espagne”, Actes (reunidas y presentadas por Benoît Pellistrandi), Casa de Velázquez, Madrid.

----- (2004b) "Los umbrales de la laicización en la Europa Latina y la recomposición de lo religioso en la modernidad tardía", en Jean-Pierre Bastian (coord.), La Modernidad religiosa: Europa latina y América Latina en perspectiva comparada, FCE, México.

- BAZAN, Armando (1979), Historia de La Rioja, Plus Ultra, Buenos Aires.

----- (1996), Esquiú. Apóstol y ciudadano, Emecé, Buenos Aires.

- BAZAN, Armando y BUSTOS, Abel (1922), Biografía del Cgo. Hon. Dr. David Luque, Cofundador del Instituto Esclavas del Corazón de Jesús, Buenos Aires. 
- BEATO, Guillermo (1993), "Los grupos sociales dominantes en Córdoba", en (comp.), Grupos sociales dominantes. México y Argentina (siglos XIX-XX), Universidad Nacional de Córdoba, Córdoba.

- BENITEZ BAREA, Avelina (2001), El bajo clero rural en el Antiguo Régimen (Medina Sidonia siglo XVIII), Publicaciones de la Universidad de Cádiz, Cádiz.

- BENITO AGUADO, María Teresa (1994), "Clero e historia social: nuevas perspectivas de estudio", en Enrique Martínez Ruiz y Vicente Suárez Grimón (eds.), Iglesia y Sociedad en el Antiguo Régimen, III Reunión Científica Asociación Española de Historia Moderna, vol. I.

- BENITO MOYA, Silvano (2000), Reformismo e Ilustración, los Borbones en la Universidad de Córdoba, CEH, Córdoba.

---- (2005) "Filosofía, Teología y Cánones en el Río de la Plata", en Josep-Ignasi Saranyana (dir.) y Carmen-José Alejos Grau (coord.), Teología en América Latina, Iberoamericana-Vervuert, Madrid- Frankfurt, vol. II/1.

---- (2013), La cultura teológica de las elites letradas" ¿Especulación teórica o pragmatismo en el Tucumán de mediados del siglo XVIII?, Consejo Superior de Investigaciones Científicas - Centro de Ciencias Humanas y Sociales - Instituto de Historia, Madrid. vol. 65.

- BERGER, Peter y LUCKMANN, Thomas (2001), La construcción social de la realidad, Amorrortu, Buenos Aires.

- BERNASCONI, Alicia (2005) "De Pergamino a la Boca en veinte años: los scalabrinianos y la asistencia a los inmigrantes italianos, 1940-1961", en X Jornadas Interescuelas / Departamentos de Historia, Rosario, 20-23 de septiembre.

- BERTONI, Lilia Ana (2009), “¿Estado confesional o estado laico? La disputa entre librepensadores y católicos en el cambio del siglo XIX al XX", en Lilia Ana Bertoni y Luciano de Privitellio (comps.), Conflictos en Democracia. La vida política argentina entre dos siglos, Siglo XXI, Buenos Aires.

- BERTRAND, Michel (2000), "Los modos relacionales de las élites hispanoamericanas coloniales. Enfoques y posturas", Anuario del IEHS, n 15.

----- (2002), "Historia social y análisis micro histórico", Cuadernos Digitales, vol. 6, n 17, Universidad de Costa Rica.

- BERZAL DE LA ROSA, Enrique (2004) "Biografía y prosopografía en la historia de la Iglesia española contemporánea", en L'Histoire religieuse en France et en Espagne, Casa de Velásquez, Madrid.

BIANCHI, Susana (1988), La Iglesia Católica y el Estado peronista, Colección "Conflictos y Procesos de la Historia Argentina Contemporánea", CEAL, Buenos Aires.

----- (1990), "La lglesia católica en los orígenes del peronismo", Anuario del IEHS, no 5.

----- (1994), "Catolicismo y peronismo: la religión como campo de conflicto (Argentina, 1945-1955)", Boletín Americanista, Año XXXIV, no 44.

- BIDERBOST, Pablo y UTRERA, Lucas (2004), "Los Círculos Católicos de Obreros: una mirada desde la sociología organizacional", en Marcela B. González (ed.), Poder político y estrategias sociales (Córdoba, 1900-1950), Universidad Católica de Córdoba, Córdoba.

- BISCHOFF, Efraín (1981), El Cura Brochero, Plus Ultra, Buenos Aires.

----- (1995) [1977], Historia de Córdoba, Plus Ultra, Buenos Aires.

- BJERG, María y OTERO, Hernán (comp.), Inmigración y redes sociales en la Argentina moderna, Tandil, IEHS-CEMLA. 
- BLACKBOURN, David (1991), "The Catholic Church in Europe since the French Revolution", Comparative Studies in Society and History, 33 (4).

- BLANCARTE, Roberto (comp.) (2008), Los retos de la laicidad y la secularización en el mundo contemporáneo, Colegio de México, México.

---- (2012), "Religión y sociología, cuatro décadas alrededor del concepto de secularización", Estudios Sociológicos, vol. XXX, número extraordinario.

----- (2015), “¿Por qué la religión volvió a un mundo secularizado?”, Estudios Sociológicos, vol. XXXIII, $\mathrm{n}^{\circ} 99$.

- BLANCO, Jessica (2005), "Modernidad conservadora y cultura política: Acción Católica de Córdoba (1931-1941)", Trabajo Final de Licenciatura en Historia (FFyH-UNC) (Inédito).

----- (2008), Modernidad conservadora y cultura política. La Acción Católica Argentina (1931-1941), Editorial de la Facultad de Filosofía y Humanidades, Universidad Nacional de Córdoba, Córdoba.

---- (2012), "La Juventud Obrera Católica y la política: entre la lealtad peronista y la identidad católica", Prohistoria, vol. 17.

- BOTANA, Natalio (1998), El Orden Conservador. La politica argentina entre 1880 y 1916, Sudamericana, Buenos Aires.

- BOTANA, Natalio y GALLO, Ezequiel (1997), De la República posible a la República verdadera (1889-1910), Espasa Calpe, Buenos Aires.

- BOUDON, Jacques Oliver (1996), L'épiscopat français à l'époque concordataire (18021905): origines, formation, nomination, Editions du Cerf, Paris.

- BOUDON, Olivier, CARON, Jean-Claude y JON, Jean-Claude (2001), Religion et culture en Europe au 19e siecle (1800-1914), Armand Colin, Paris.

- BOURDIEU, Pierre (1971), "Génesis y estructura del campo religioso", Revue Française de Sociologie, XII.

----- (1997), "La ilusión biográfica”, en Razones Prácticas, Anagrama, Barcelona.

----- (1999), ¿Qué significa hablar? Economía de los intercambios lingüísticos, Akal, Madrid.

- BOURDIEU, Pierre y SAINT-MARTIN, Monique de (1982), "La Sagrada Familia. El episcopado francés en el campo del poder", Actes de la Recherche en Sciences Sociales, ${ }^{\circ}$ 44-45.

- BOUTRY, Philippe (1986a), La vie quotidienne du prêtre français au XIXe siècle 18011905, Hachette, Paris.

---- (1986b), "Restauration de l'Église romaine et renouveau du catholicisme italien durant le premier XIXe siècle, à travers la récente historiographie italienne", Mélanges de l'Ecole Française de Rome, Moyen-Age, Temps modernes, t. 98, n 2.

---- (1986c), Prêtres et Paroisses au pays du Curé d'Ars, Le Cerf/Histoire, Paris.

---- (1997), "El Cura" en El Hombre romántico, Alianza, Madrid.

---- (2004), "Paroisses et clergé paroissial en France”, en L'Histoire religieuse en France et en Espagne, Casa de Velásquez, Madrid.

----- (2008), "La doctrina cristiana frente al mundo moderno" en Alain Corbin (dir.), Historia del cristianismo, Ariel, Barcelona. 
- BRAVO LOZANO, Jesús (1994), “Cura rico, cura pobre” en Enrique Martínez Ruiz y Vicente Suárez Grimón (eds.), Iglesia y Sociedad en el Antiguo Régimen, III Reunión Científica Asociación Española de Historia Moderna, vol. I, Universidad de las Palmas de Gran Canaria.

- BREÑA, Roberto (2010), "El liberalismo (hispánico) como categoría de análisis histórico. Algunas tensiones con la historia de los conceptos y con la historia de los lenguajes políticos", en Elías Palti (org.), Mito y realidad de la cultura política latinoamericana, Prometeo, Buenos Aires.

---- (2011), "El primer liberalismo español y su proyección hispanoamericana”, en Ivan Jaksic y Eduardo Posada Carbó (eds.), Liberalismo y poder. Latinoamérica en el siglo XIX, FCE, México.

- BRUNO, Cayetano (1972), Historia de la Iglesia Argentina, Editorial Don Bosco, Buenos Aires, T.VIII.

---- (1974), T. IX.

---- (1975), T. X.

---- (1976), Historia de la Iglesia Argentina, Editorial Don Bosco, Buenos Aires. T. XI, Segunda parte: "Las diócesis de las provincias interiores".

---- (1981), T. XIII.

- BURGUIÉRE, André (2009), La escuela de los Annales. Una historia intelectual. Publicaciones de la Universidad de Valencia, Valencia.

- BURKE, Peter (1993), La revolución historiográfica francesa. La Escuela de los Annales: 1929-1989, Gedisa, Barcelona.

- BURMEISTER, Hermann (1973), Viaje por los Estados del Plata, en Carlos S. A. Segreti, "Córdoba ciudad y Provincia (siglo XVI-XX). Según relatos de viajeros y otros testimonios, Junta Provincial de Historia de Córdoba, Córdoba.

- BUSTOS, Zenón (1915), "La misión de los Curas", Revista de Derecho, Historia y Letras, año XVII, Buenos Aires.

- CABRERA, Miguel Ángel (2001), Historia, Lenguaje y Teoría de la Sociedad, Universidad de Valencia, Valencia.

- CABRERA, Pablo (1916), Universitarios de Córdoba. Los del Congreso de Tucumán, Biblioteca del Primer Centenario de la Universidad Nacional de Córdoba, Córdoba.

- CAFFERATA, Juan F. (1945), Dr. Tristán Achával Rodríguez, su centenario, Buenos Aires. Discurso pronunciado en el Teatro Rivera Indarte de la Ciudad de Córdoba.

- CAIMARI, Lila (1995), Perón y la Iglesia Católica. Religión, Estado y Sociedad en la Argentina, 1943-1955, Ariel, Buenos Aires.

- CALDARONE, Alicia y FERRARI, Marcela (1988), "La incorporación de la tierra pública al dominio privado. El caso de Córdoba entre 1855 y 1880”, Tesis de Licenciatura, Universidad Nacional de Córdoba, Córdoba.

- CALVIMONTE, Luis (2001), Las misiones de Esquiú en los curatos de Tulumba, Ischilín y Río Seco, Editorial Trejo, Córdoba.

- CALVO, Nancy (2001), "Cuando se trata de la civilización del clero. Principios y motivaciones del debate sobre la reforma eclesiástica porteña de 1822", Boletín del Instituto de Historia Argentina y Americana "Dr. Emilio Ravignani”, no 24.

----- (2006), "Los unos y los otros. Católicos, herejes, protestantes y extranjeros. Los alcances de la tolerancia religiosa en las primeras décadas del s.XIX”, Anuario IHES, n⿳2 21. 
- CANDAR, Gilles (2000), "Le statut de la biographie. Essai de chronologie", Correspondances, $\mathrm{n}^{\circ}$ 61, IRMC.

- CANDAU CHACÓN, María Luisa (1993), La carrera eclesiástica en el siglo XVII, Universidad de Sevilla, Sevilla.

- CANEVARO, Alfredo (1995), "La storia religiosa contemporanea in Italia (1980-1993)", Anuario de Historia de la Iglesia, $\mathrm{n}^{\circ} 4$, Universidad de Navarra.

- CANO, Luis (1961), Fray Mamerto Esquiú Obispo de Córdoba (Argentina), Convento Franciscano, Catamarca.

- CANOBBIO, Elizabetta (1999), "Visite Pastorali nel medioevo italiano: temi di indagine es elaboracione dei dati", en Cecilia Nubola y Angelo Turchini (eds.), Fonti ecclessiastiche per la storia sociale e religiosa d'Europa: XVI-VIII séculos, Societa Editrice Il Mulino, Bologna.

- CARBIA, Rómulo (1914), Historia Eclesiástica del Río de la Plata, Alfa y Omega, Buenos Aires.

---- (1945), La Revolución de Mayo y la Iglesia: contribución histórica al estudio de la cuestión del Patronato Nacional, Huarpes, Buenso Aires.

- CÁRCANO, Ramón (1885), Perfiles Contemporáneos. José Gabriel Brochero cura de San Alberto, Imprenta de El Interior, Córdoba. T. I.

----- (1928), "José Gabriel Brochero cura de San Alberto", en Domingo Acevedo, El Cura Brochero. 50 años después de su obra en San Alberto, A. Biffignandi, Córdoba.

- CARCEL ORTI (2003), Historia de la Iglesia. La Iglesia en la época contemporánea, Ediciones Palabra, Madrid.

- CARDENAS AYALA, Elisa (2007), "Hacia una historia comparada de la secularización en América latina", en Guillermo Palacios (coord.), Ensayos sobre la nueva historia política de América latina, siglo XIX, Colegio de México, México.

----- (2008), "La construcción de un orden laico en América Hispánica. Ensayo de interpretación sobre el siglo XIX", en Roberto Blancarte (coord.), Los retos de la laicidad y la secularización en el mundo contemporáneo, El Colegio de México, México.

- CARETTA, Gabriela (1999), "Con el poder de las palabras y los hechos. El clero colonial de Salta entre 1770 y 1820", en Sara Mata (comp.), Persistencias y cambios: Salta y el Noroeste argentino, 1770-1840, Prohistoria y Manuel Suárez Editor, Rosario.

----- (2006), "El clero secular de Salta entre la colonia y la revolución", Actas del Primer Congreso Argentino "Gral. Martín Miguel de Güemes", Municipalidad de Salta, Salta.

- CARETTA, Gabriela y AYROLO, Valentina (2003), "Oficiar y gobernar. Apuntes sobre la participación política del clero secular de Salta y Córdoba en la pos-revolución”, Revista Andes. Antropología e Historia, $\mathrm{n}^{\circ} 14$.

----- (2008), "Clérigos seculares del Tucumán entre la colonia y la independencia (17761810)", en Rodolfo Aguirre y Lucrecia Enríquez (coords.), La iglesia Hispanoamericana de la colonia a la república, Editorial Plaza y Valdés-Ediciones Universidad Católica, México.

- CARETTA, Gabriela y MARCHIONNI, Marcelo (2000), "Entre la ciudadanía y la feligresía. Una cuestión de poder en Salta a principios del siglo XIX", Revista Andes. Antropología e Historia, $\mathrm{n}^{\mathrm{o}} 11$.

- CARMONA FERNANDEZ, F. J. (dir.) (2010), Historia del Cristianismo, Editorial Trotta / Universidad de Granda, España. 
- CAROLE, Juan (1925), "Ensayo histórico del Curato de Soto", Boletín Eclesiástico de la Diócesis de Córdoba, vol. II, n 10.

- CARREGAL PUGA, Joaquín (1981), “Aproximaciones a una lectura social de la historia eclesiástica argentina”, Revista Mexicana de Sociología, Año XLIII, vol. XLIII.

- CASANOVA, José (2006), "Rethinking Secularization: A Global Comparative Perspective", The Hedgehog Review, vol. 8, n 1-2.

- CASTELLANO, Uladislao (1891), La milagrosa imagen de Nuestra Señora del Rosario que se venera en el convento de predicadores en la ciudad de Córdoba, Est. Tip. La Minerva, Córdoba.

CATURELLI, Alberto [1953] (1971), Fray Mamerto Esquiú. Vida y Pensamiento, Teuco, Córdoba.

- CELTON, Dora (1996), "Migraciones en la provincia de Córdoba a fines del siglo XIX", Jornadas de Historia de Córdoba entre 1830 y 1950, Junta Provincial de Historia de Córdoba, Córdoba.

- CERUTTI, Simona (1995), "La construction des catégories sociales", en Jean Boutier y Dominique Juliá (dirs.), Passés recomposés. Champs et chantiers de l'histoire, Autrement, Paris.

- CEVA, Mariela (2000), "La Acción Pastoral de los inmigrantes", Todo es Historia, n 401.

- CUCCHI, Laura (2012), "Desacuerdo y oposición política en Córdoba a fines de la década de 1870", Estudios Sociales, n 42.

----- (2014a), "La política como administración. El surgimiento y consolidación del Juarismo en la provincia de Córdoba, Argentina (1877-1883)", Historia y Sociedad, Universidad Nacional de Colombia.

----- (2014b), "Estado, Iglesia y partidos en los inicios del poder autonomista en Córdoba, Argentina (1877-1880)", Iberoamericana, XIV, n 54.

- CHACON JIMÉNEZ, Francisco (2008), "La revisión de la tradición: prácticas y discurso en la nueva historia social", Historia Social, n 60, Valencia.

- CHARLE, Christopher (2006) "A prosopografia ou biografia coletiva: balanco e perspectivas”, en Flávio M. Heinz (org.), Por outra história das elites, Editora FGV, Río de Janeiro.

- CHARTIER, Roger (1995), Espacio público, crítica y desacralización en el siglo XVIII. Los orígenes culturales de la revolución francesa, Gedisa, Barcelona.

---- (1996a), Escribir las prácticas, Manantial, Buenos Aires.

----- (1996b), "La Historia hoy en día: dudas, desafíos, propuestas" en Francisco J. Capistegui Gorasurreta e Ignacio Olábarri Cortázar (coords), La nueva historia cultural, la influencia del posestructuralismo y el auge de la interdisciplinariedad, Editorial Universidad Complutense, Madrid.

- CHAVES, Liliana (1997), Tradiciones y rupturas de la élite política cordobesa (18701880). La clave conservadora de la modernización politica, Ferreyra Editor, Córdoba.

----- (2005), Sufragio y representación política bajo el régimen oligárquico en Córdoba, 1890-1912. Las élites y el debate sobre las instituciones de la igualdad y el pluralismo políticos, Ferreyra Editor, Córdoba.

- CHIARAMONTE, José C. (1997), Ciudades, provincias, estados: orígenes de la Nación Argentina (1800-1846), Ariel Historia, Buenos Aires. 
- CHIFFOLEAU, Jacques (2011), La religion flamboyante. France, 1320-1520, Points, Paris [1984].

- CHUFFART-DOMONT, Elisabeth (1991), Le clergé séculier du diocèse d'Amiens de 1802 à 1905, D.E.A. d'Histoire, Université de Picardie.

- CÓDIGO DE DERECHO CANÓNICO y Legislación complementaria (1949), Texto bilingüe comentado por profesores de la Pontificia Universidad de Salamanca, Biblioteca Autores Cristianos, Madrid, ( $3^{\circ}$ ed.).

- COMPAÑY, Francisco (1955), El Vicario Clara. Sus ideales, sus trabajos, su lucha. Argentina Cristiana, Córdoba.

- CONFERENCIA EPISCOPAL ARGENTINA [CEA] (1999), El Cura Brochero, cartas y sermones, Conferencia Episcopal Argentina, Buenos Aires.

- CONNAUGHTON, Brian (1995), "La sacralización de lo cívico. La imagen religiosa en el discurso cívico-patriótico del México independiente. Puebla (1827-1853)”, en Brian Connaughton, Álvaro Matute Aguirre y Evelia María del Socorro Trejo Estrada (eds.), Estado, Iglesia y Sociedad en México. Siglo XIX, UNAM y Grupo Editorial Miguel Ángel Porrúa, México.

----- (2007), “La nueva historia política y la religiosidad ¿un anacronismo en la transición? en Guillermo Palacios (coord.), Ensayos sobre la nueva historia política de América Latina, siglo XIX, El Colegio de México, México.

- CONNAUGHTON, Brian F. y Andrés LIRA GONZÁLEZ (1996), Las fuentes eclesiásticas para la historia social de Méjico, Universidad Autónoma Metropolitana / Instituto Mora, México.

- CONVERSO, Félix (1993a), La lenta formación de capitales. Familias, comercio y poder en Córdoba, 1850-1880, Junta Provincial de Historia de Córdoba, Córdoba.

-----, (1993b), "Los procedimientos empleados por el sector mercantil para abordar el poder político. El caso de Córdoba, primera mitad del siglo XIX”, en Guillermo Beato (comp.), Grupos sociales dominantes. México y Argentina (siglos XIX-XX), Universidad Nacional de Córdoba, Córdoba.

---- (1997), “Los negocios y la política. Las redes mercantiles y el poder”, Junta Provincial de Historia de Córdoba, Córdoba, $n^{\circ} 16$.

---- (2001) Un mercado en expansión, Córdoba 1870-1914, Centro de Estudios Históricos "Prof. Carlos S. A. Segreti", Córdoba.

---- (2004), Las crisis en el mercado rural, Córdoba del Centenario a la "Gran Depresión”, Centro de Estudios Históricos "Prof. Carlos S. A. Segreti”, Córdoba.

- CORBIN, Alain (dir.) (2008), Historia del Cristianismo, Ariel, Barcelona.

- CORDOBA, Fray Luis (1926), El Padre Esquiú, Córdoba.

- CORTES CONDE, Roberto (1979), El Progreso Argentino, 1880-1914, Sudamericana, Buenos Aires.

- CORTES PEÑA, Antonio Luis (1996), "Domínguez Ortiz y la Historia social de la Iglesia", Manuscrits, $\mathrm{n}^{\circ} 14$.

----- (2006), Historia del Cristianismo, Editorial Trotta, Madrid. Vol. III.

- CORTÉS PEÑA, Antonio Luis, LOPEZ, Miguel Luis y MUÑOZ Guadalupe (eds.) (2007), La Iglesia española en la Edad Moderna. Balance historiográfico y perspectivas, Abada Editores, Madrid. 
- COSTA, Ignacio Miguel (1996), "Leopoldo Buteler, un evangelizador del siglo XX", Quarto Rio, Revista de la Junta Municipal de Historia. Año $1, \mathrm{n}^{\circ} 1$.

----- (2004), Monseñor Leopoldo Buteler, vida y obra del primer Obispo de la Diócesis de la Villa de la Concepción de Río Cuarto, Ediciones ICALA, Río Cuarto.

- COULET, Noël (1977), "Les visites Pastorales", en Leopold Genicot (dir.), Tipologie des sources du Moyen Age Occiental. Fas. 23 A-IV.1, Lovain, Bélgique.

- CUENCA TORIBIO, José Manuel (1976), Sociología de una elite de poder de España e Hispanoamérica contemporáneas. La jerarquía eclesiástica (1789-1966), Ediciones Escudero, Madrid.

- CURSENTE, Benoît y MOUSNIER, Mireille (dirs.) (2005), Les territoires du médiéviste, Presses Universitaires de Rennes, Rennes.

- DAINVILLE-BARBICHE, Ségolène de (2005), Devenir curé à Paris, Institutions et carrières ecclésiastiques (1695-1789), PUF, Paris.

- DAGHERO, Sergio (2014), "Las facciones y las armas. La Revolución de 1874 en Córdoba y Cuyo", Coordenadas, n 1, Río Cuarto.

- DE ESTRADA, Santiago (1963), Nuestras relaciones con la Iglesia. Hacia un concordato entre la Sede Apostólica y el Estado Argentino, Theoría, Buenos Aires.

- DE IMICOZ, José María (1996), "Comunidad, red social y elites. Un análisis de la vertebración social en el Antiguo Régimen", en (dir.), Elites, poder y red social. Las elites del País Vasco y Navarra en la Edad Moderna, Universidad del País Vasco, Bilbao.

- DE IMÍCOZ, José María y GARCÍA DEL SER, María Victoria (2008), "Alto clero vasco y navarro en la monarquía hispánica del siglo XVIII: bases familiares, económicas del parentesco y patronazgo" en Rodolfo Aguirre y Lucrecia Enríquez (coords.), Iglesia Hispanoamericana: de la Colonia a la República, UNAM/ Pontificia Universidad Católica de Chile, México.

- DE MOUSSY, Martín (1869), Description geographique et statistique de la Confederation Argentine. ATLAS, Imprimerie Adolphe, Paris (Carta de Córdoba y San Luis Plancha XII).

- DE ROSA, Gabriele (1987), Tempo religioso e tempo storico. Saggi e noti di storia sociale e religiosa dal medioevo all éta contemporánea, Edizioni di Historia e Letteratura, Roma.

- DE VEDIA Y MITRE, Mariano (1909), El Deán Funes en la Historia Argentina, Biblioteca del Instituto de Enseñanza General, Buenos Aires.

---- (1954), El Deán Funes, Kraft, Buenos Aires.

- DE LA CUEVA MERINO, Julio (2005), "Clericalismo y movilización católica durante la Restauración”, en Ángel Luis López Villaverde, Alfonso Botti y Julio De La Cueva Merino (coords.), Clericalismo y asociacionismo católico en España, de la Restauración a la Transición: un siglo entre el palio y el consiliario, Ediciones de la Universidad de CastillaLa Mancha, Cuenca.

----- (2015), "Conflictiva secularización: sobre sociología, religión e historia", Historia Contemporánea, $\mathrm{n}^{\circ} 51$.

- DE LA CUEVA MERINO, Julio y MONTERO, Feliciano (2007), La secularización conflictiva, España (1898-1931), Editorial Biblioteca Nueva, Madrid. 
- DE LA CUEVA MERINO, Julio y LÓPEZ VILLAVERDE, Ángel Luis (2005), “A modo de introducción. Reflexiones en torno al clericalismo y al asociacionismo católico" en Clericalismo y asociacionismo católico en España de la Restauración a la Transición, Ediciones de la Universidad de Castilla-La Mancha, Cuenca.

- DEL FORNO, Evangelina (1996), Pregonero del Amor. Brochero es historia, San Pablo, Buenos Aires.

- DEDIEU, Jean-Pierre (1989), L'administration de la l'Inquisition de Toledo XVI ${ }^{e-}-X V I I I^{e}$ siècles, Casa de Velázquez, Madrid.

- DELGADO, Reynaldo (1937), Biografía del RP José León Torres, Imprenta La Guttemberg, Córdoba.

- DELLAFERRERA, Nelson (1994), "El Concilio Plenario Latinoamericano y los sínodos argentinos de principios del siglo XX", Anuario Argentino de Derecho Canónico, vol. I, Buenos Aires.

----- (1996a), "El tribunal eclesiástico de Córdoba en la segunda mitad del siglo XIX", Revista de Historia del Derecho, $\mathrm{n}^{\circ} 24$, Buenos Aires.

----- (1996b), "Los provisores de Córdoba", Cuadernos de Historia, nº 6, Córdoba.

----- (1997), "Ministros y auxiliares de la justicia eclesiástica en Córdoba (1688-1888)", Revista de Historia del Derecho, $\mathrm{n}^{\circ}$ 25, Buenos Aires.

---- (1999), "La Iglesia diocesana: las instituciones", en Nueva Historia de la Nación Argentina, Planeta, Buenos Aires. t. II: Segunda Parte (1600-1810): La Argentina en los siglos XVII y XVIII.

- DELUMEAU, Jean (1973), El catolicismo de Lutero a Voltaire, Labor, Barcelona. ---- (1977), La reforma, Labor, Barcelona.

- DEMÉLAS, Marie-Danielle e Yves SAINT-GEOURS (1988), Jerusalén y Babilonia: Religión y Política en el Ecuador, 1780-1880, Biblioteca de Ciencias Sociales, vol. 21, Corporación Editora Nacional, Quito.

- DEPARTAMENTO GENERAL DE INMIGRACION (1894), Noticias útiles para los inmigrantes, trabajadores y capitalistas, Provincia de Córdoba, Publicación gratuita en español, francés inglés, alemán e italiano, $\mathrm{n}^{\circ}$ 2, Establecimiento Gráfico de Ganche, Weibeek y Tarti, Buenos Aires.

- DE ROUX, Rodolfo R. (2014), "La romanización de la Iglesia católica en América Latina: una estrategia de larga duración”, Pro-Posições, vol. 25, $\mathrm{n}^{\circ}$ 1, Campinas.

- DEVOTO, Fernando (1990), "Catolicismo y anticlericalismo en un barrio italiano de Buenos Aires (La Boca) en la segunda mitad del siglo XIX", Estudios Migratorios Latinoamericanos, $\mathrm{n}^{\mathrm{O}} 14$.

----- (2002), Nacionalismo, fascismo y tradicionalismo en la Argentina moderna. Una Historia, Siglo XXI, Buenos Aires.

- DEVROEY, Jean-Pierre y LAUWERS, Michel (2007), “L'espace des historiens médiévistes: quelques remarques en guise de conclusion", Construction de l'espace au Moyen Âge: pratiques et représentations, XXXVIIe Congrès de la SHMES.

- DIAZ ALEJANDRO, Carlos F. (2002), Ensayos sobre la historia económica Argentina, Amorrortu, Buenos Aires. 
- MÉHU, Didier (2001), Resención de Michel Lauwers, "Recherches sur la fonction sociale de l'Église dans 1'Occident médiéval: sacralisation de l'espace, modèles de sainteté, commémoration des morts (IXe-XIIIe siècle)", Dossier pour l'Habilitation à Diriger des Recherches, présenté à l'Université de Nice, en Chronique, Revue Historique, 2001/4, n 620.

- DI STEFANO, Roberto (1997-1998), “Abundancia de clérigos, escasez de párrocos: las contradicciones del reclutamiento del clero secular en el Río de la Plata (1770-1840)", Boletín del Instituto de Historia Argentina y Americana "Dr. Emilio Ravignani”, Tercera Serie, $n^{0} 16 / 17$.

---- (2000a), "De la cristiandad colonial a la Iglesia Nacional. Perspectivas de investigación en historia religiosa de los siglos XVIII-XIX”, Revista Andes. Antropología e Historia, $\mathrm{n}^{\mathrm{o}} 11$.

----- (2000b), "Pastores de rústicos rebaños. Cura de almas y mundo rural en la cultura ilustrada rioplatense", Boletín del Instituto de Historia Argentina y Americana "Dr. Emilio Ravignani", Tercera Serie, $\mathrm{n}^{\mathrm{o}} 22$.

----- (2002a), "El origen del movimiento asociativo. De las cofradías coloniales al auge mutualista", en De las cofradias a las organizaciones de la sociedad civil. Historia de la iniciativa asociativa en Argentina, 1776-1990, Gedisa, Buenos Aires.

---- (2002b), "De la teología a la Historia: un siglo de lecturas retrospectivas del catolicismo argentino", Prohistoria, Año VI, no 6.

---- (2004), El Púlpito y la Plaza. Clero, sociedad y política de la Monarquía Católica a la Republica Rosista, Siglo XXI Editores, Buenos Aires.

----- (2006), "El clero de Buenos Aires en la primera mitad del siglo XIX", en Valentina Ayrolo (coord.), Estudios sobre el clero Iberoamericano, entre la Independencia y el Estado Nación, CEPHIA Editorial de la Universidad Nacional de Salta, Salta.

----- (2008a), "Disidencia religiosa y secularización en el siglo XIX iberoamericano. Cuestiones conceptuales y metodológicas", Projeto Historia, no 37.

---- (2008b), "La renovación de los estudios sobre el clero secular en la Argentina: de las reformas borbónicas a la Iglesia romana", Anuario, n ${ }^{\circ}$, Centro de Estudios Históricos "Prof. Carlos S. A. Segreti". Dossier: "La historiografía sobre el clero americano, visiones, enfoques y relecturas", Córdoba.

----- (2008c), "Los estudios sobre el clero secular en la historiografía reciente", en Gabriela Caretta e Isabel Zacca (coords.), Para una Historia de la Iglesia. Itinerarios y estudios de caso, CEPIHA Editorial de a Universidad Nacional de Salta, Salta.

---- (2010), Ovejas negras. Historia de los anticlericales argentinos, Sudamericana, Buenos Aires.

---- (2011a), “El Pacto Laico Argentino 1880-1920), Revista PolHis, n 8.

---- (2011a), "Por una historia de la secularización y de la laicidad en la Argentina", Quinto Sol, vol. 15, $\mathrm{n}^{\mathrm{o}} 1$.

- DI STEFANO, Roberto y PEIRE, Jaime (2004), "De la sociedad barroca a la ilustrada: aspectos económicos del proceso de secularización en el Río de la Plata", Andes. Antropología e Historia, $\mathrm{n}^{\mathrm{o}} 15$.

- DI STÉFANO, Roberto y ZANATTA, Loris (2000), Historia de la Iglesia Argentina. Desde la Conquista a finales del siglo XX, Grijalabo Mondadori, Buenos Aires. 
- DOBBELAERE, Karel (1994), Secularización: un concepto multi-dimensional, Universidad Iberoamericana, México.

- DOMÍNGUEZ ORTIZ, Antonio (1970), La sociedad española en el siglo XVII, Instituto "Balmes" de Sociología, Madrid. Tomo II.

- DONINI, Antonio (1985), Religión y sociedad. Reflexiones sociológicas sobre clericalismo, laicismo, laicidad, Docencia, Buenos Aires.

- DOSSE, François (2003), Michel de Certau. El caminante herido, Universidad Iberoamericana, México.

----- (2007), El arte de la Biografía, Universidad Iberoamericana, México.

- DOUGLAS, Mary (1996), Cómo piensan las instituciones, Alianza, Madrid.

- DUBY, Georges (1992), Los tres órdenes o lo imaginario del feudalismo, Taurus, Barcelona.

- DUJOVNE, Alejandro (2002a) "El partido socialista en la provincia de Córdoba: 18951936. Aproximaciones para su historia política", Segundas Jornadas de Historia de las Izquierdas, UBA, Buenos Aires, 11 al 13 de diciembre.

----- (2002b), "El partido socialista de la provincia de Córdoba, 1933-1936: la construcción de una identidad", IV Jornadas de Historia de Córdoba, IV Jornadas Municipales de Historia de Córdoba, Junta Provincial de Historia, Córdoba.

---- (2003) "El partido socialista de la provincia de Córdoba, 1933-1936: una lectura política desde el periódico Tribuna Socialista", Publicación de la Maestría en Partidos Políticos y del Archivo de la Palabra del CEA-UNC, Serie Voces y Argumentos, Documentos de Trabajo, Ferreyra Editor, Córdoba.

----- (2004) "El partido socialista de Córdoba y la Reforma Universitaria, 1917-1948”, en Marcela González (ed.), Poder Político y Estrategias Sociales, Córdoba 1900-1950, EDUCC, Editorial de la Universidad Católica de Córdoba, Córdoba.

- DUPRONT, Alphonse (2005), Du sacré: croisades et pèlerinages, images et langages, Gallimard, Paris.

- DUSSEL, Enrique (1983), Historia General de la Iglesia en América Latina, SíguemeCehila, Salamanca, T.I/1.

----- (1990) "Tensiones en el espacio religioso: masones. Liberales y protestantes en la obra de Mariano Soler", en Jean-Pierre Bastian (comp.), Protestantes, liberales y francmasones. Sociedades de ideas y modernidad en América Latina, siglo XIX, CehilaFCE, México.

- ENRIQUEZ, Lucrecia (2005), De Colonial a Nacional. La carrera eclesiástica del clero secular entre 1650 y 1810, Instituto Panamericano de Geografía e Historia, México.

- ESQUIÚ, Fray Mamerto (1945), Patria, Libertad, Constitución, Editorial Difusión, Buenos Aires.

---- (1968), Sermones patrióticos, Eudeba, Buenos Aires.

- FARÍAS, Inés (2001), Convento San Francisco Solano. Instituciones y obras (18561957), Ediciones de Divulgación del Archivo Histórico del Convento San francisco Solano de Río Cuarto, Río Cuarto (Córdoba).

- FARRELL, Gerardo (1992), Iglesia y pueblo en Argentina. Historia de 500 años de evangelización, Editorial Patria Grande, Buenos Aires. 
- FASSI, Juan B. (1931), "Noticias históricas sobre Reducción”, El Heraldo de Reducción, Año 7, $\mathrm{n}^{\mathrm{0}}$ 7, Reducción (Córdoba).

----- (1935), "El antiguo curato de Río Cuarto y la nueva diócesis", El Heraldo de Reducción, Año IX, no 11, Reducción (Córdoba).

- FAZIO, Mariano (2009), De Benedicto XV a Benedicto XVI, Rialp, Madrid.

----- (2010), Evangelio y culturas en América Latina. Evangelización, liberalismo, liberación, Promesa, San José de Costa Rica.

- FEBVRE, Lucien, (2010) [1927], Martín Lutero. Un destino, FCE, México.

---- (1942), La religion de Rabelais, Le problema de l'incroyance au XVIe, Albin Michel, Paris.

----- (1995) [1957], Au coeur religieux du XVIe siècle, Éditions de l'EHESS, Paris.

- FERRARI, Marcela (2001), "Las elites políticas provinciales en tiempos de gobiernos radicales. El caso Córdoba (Argentina), 1916-1930", Anuario del IHES, nº 16.

---- (2006)", "Dirigentes políticos cordobeses nos tempos da república verdadeira, 19161930. Una aproximacao prosopografica”, en Flávio Heinz (org.), Por outra história das elites, Editora FGV, Río de Janeiro.

- FERRERO, Roberto (1972), "La Revolución Radical de 1905 en Córdoba”, Todo es Historia, $\mathrm{n}^{\circ} 58$.

---- (1978), La colonización agraria en Córdoba, Junta Provincial de Historia de Córdoba, Córdoba.

----- (1999), Breve historia de Córdoba (1528-1995), Alción Editora, Córdoba.

----- (2003), La 'pampa gringa' cordobesa. Emergencia e idiosincrasia de las clases medias rurales, Ediciones del Corredor Austral, Córdoba.

- FERREYRA, Ana Inés (1994), Elite dirigente y vida cotidiana en Córdoba, 1835-1852, Centro de Estudios Históricos "Prof. Carlos S. A. Segreti”, Córdoba.

----- (2001), "Universidad y política a comienzos del siglo XX. El impacto de la cuestión social”, Revista de la Junta Provincial de Historia de Córdoba, Córdoba.

- FOLQUER, Cynthia (2005), "Somos hombres y yo más que ninguno. Los escritos autobiográficos de Fray Angel María Boisdron, 1845-1924”, Actas de las Segundas Jornadas de la Orden Dominicana en Argentina, UNSTA, Tucumán.

----- (2012), Viajeras hacia el fondo del alma. Sociabilidad, política y religiosidad en las Dominicas de Tucumán, Argentina, 1886-1911, Tesis Doctoral Universidad de Barcelona.

- FONTANA, Josep (2001), La historia de los hombres, Crítica, Barcelona.

- FORSTER, Marc (2001), Catholic Revival in the Age of the Baroque-Religious Identitity in Southwest Germany, 1550-1750, Camridge University Press, Cambridge.

- FOUILLOUX, Étienne (2002), "Iglesia Católica y mundo moderno. Siglos XIX y XX", en Religión y Sociedad en España (siglos XIX y XX). Colección Casa de Velásquez, Madrid, vol. 77.

---- (2004), "Nouvelle theologie et theologie nouvelle (1930-1960)", en L'histoire religieuse en France et en Espagne, Casa de Velázquez, Madrid.

- FURLONG, Guillermo (1939), Bio-Bibliografía del Deán Funes, UNC, Instituto de Estudios Americanistas, Córdoba.

---- (1945a), Monseñor Pablo Cabrera, su personalidad, su obra, su gloria. Prólogo de Enrique Martínez Paz, Editorial Huarpes, Buenos Aires. 
---- (1945b), "La historiografía eclesiástica argentina desde 1536 a 1943”, Archivum, Revista de la Junta de Historia Eclesiástica Argentina, Buenos Aires, $1^{\circ}$ tomo.

- GALLARDO, Milagros (en prensa), "Orígenes sociales, vínculos relacionales y trayectorias individuales del clero secular cordobés (1877-1927)", Revista Andes, Salta.

---- (2008a), "La implementación de las leyes laicas. Una mirada sobre los discursos y las prácticas del clero. Córdoba 1880-1890", en Lucrecia Enríquez y Rodolfo Aguirre (coords.), La Iglesia hispanoamericana de la colonia a la República, Ediciones del Instituto de Investigaciones sobre Universidad y Educación (UNAM) y Universidad Católica de Chile, México.

----- (2008b), “Una aproximación a la producción biográfica del clero secular cordobés”, en Beatriz Moreyra y Silvia Mallo (coords.), Miradas sobre la historia social Argentina en los comienzos del siglo XX, Centro de Estudios Históricos "Prof. Carlos S. A. Segreti" y Centro de Estudios de Historia Americana Colonial, Córdoba.

---- (2008c), "Iglesia, modernidad y cuestión social. La acción católica parroquial. Córdoba, 1905-1925”, en Beatriz Moreyra y Silvia Mallo (coords.), Pensar y construir los grupos sociales, Centro de Estudios Históricos "Prof. Carlos S. A. Segreti” y Centro de Estudios de Historia Americana Colonial, Córdoba.

---- (2008d), Dossier "La historiografía sobre el clero americano: visiones, enfoques y relecturas", Anuario del $\mathrm{CEH}, \mathrm{n}^{\circ} 7$, Córdoba.

---- (2010) "El clero secular inmigrante en la Argentina del cambio de siglos. Políticas y representaciones eclesiásticas (Córdoba, 1875-1925)", Revista Mêtis, vol. 10, n⿳ 17, Universidade de Caxias do Sul (Brasil).

----- (2012), "Políticas y representaciones eclesiásticas (Córdoba, 1875-1925)", Revista In Itinere, vol. $2, \mathrm{n}^{\mathrm{o}} 1$.

----- (2012) "Los lugares sagrados: santuarios, parroquias y capillas, su función en la ocupación territorial y en las transformaciones socio-espaciales del sudeste cordobés", en Hugo Cancino, Rogelio de la Mora V., Lenà Medeiros de Menezes y Silvano G. A. Benito Moya (eds.), Miradas desde la historia social y la historia intelectual. América Latina en sus culturas: de los procesos independistas a la globalización, Centro de Estudios Históricos "Prof. Carlos S. A. Segreti", Facultad de Filosofía y Humanidades, Universidad Católica de Córdoba, Universidad Veracruzana e Instituto de Investigaciones HistóricoSociales, Córdoba.

----- (2013), "Fray Zenón Bustos y Ferreyra. Renovación y tradición en las formas de evangelización franciscana (Córdoba, 1880-1905)", Revista Brasileira de História das Religiões e das Religiosidades, vol. V, nº 15.

----- (2014), "Redes eclesiásticas y redes políticas: la candidatura de Fray Zenón Bustos y Ferreyra como obispo de Córdoba, Argentina (1905-1925)", Revista Mêtis, Universidade de Caxias do Sul (Brasil).

- GALlARDO, Milagros y MARTINS, Patricia (2014), "La formación del clero en América. Los colegios seminarios de Córdoba (Argentina) y São Paulo (Brasil) en la segunda mitad del siglo XIX. Una perspectiva comparada", en Elianne Deckman Fleck y Andrea Reguera (coords.), Variaciones en la comparación. Procesos, instituciones y memorias en la historia de Brasil, Uruguay y Argentina. Siglos XVIII-XXI, Ediciones del CESAL UNCPBA, Tandil.

- GALLO, Ezequiel (2004), La pampa gringa, Edhasa, Buenos Aires. 
- GALVEZ, Manuel (1917), La sombra del convento, Agencia General de Librería y Publicaciones, Buenos Aires. ---- (1944), Vida de Fray Mamerto Esquiú, Club de Lectores, Buenos Aires.

- GANSTER, Paul (1992), "Religiosos" en Louisa Schell Hoberman y Susan Migden Socolow, Ciudades y sociedad en Latinoamérica colonia, FCE, Buenos Aires.

- GARCIA DE CORTAZAR, José Ángel (1994), El Hombre Medieval como "Homo Viator": Peregrinos y Viajeros, Universidad de Cantabria.

----- (2012), Historia religiosa del occidente medieval, Akal, Madrid.

- GARCÍA JORDÁN, Pilar (1988), "Estado moderno, Iglesia y secularización en el Perú contemporáneo (1821-1919)", Estudios y Debates, no 2.

- GARCIA AGUILERA (1892), Apuntes Biográficos del Dr. David Luque, Córdoba.

- GERBOT, Paul (1982), Europa cultural y religiosa de 1815 a nuestro días, Nueva Clío La historia y sus problemas, Labor, Barcelona.

- GICQUEL, Samuel (2008), Prêtres de Bretagne au XIX siècle, PUR, Rennes.

- GINZBURG, Carlo (1994), "Indicios. Raíces de un paradigma de inferencias indiciales", en Mitos, emblemas, indicios. Morfología e historia, Gedisa, Barcelona.

----- (1999), El queso y los gusanos. El cosmos, según un molinero del siglo XVI, Muchnik, Barcelona.

- GONZÁLEZ, Mamerto (1905), Fray Mamerto Esquiú y Medina, Córdoba. Vol. I.

---- (1906), Fray Mamerto Esquiú y Medina. Vida Pública, Córdoba. Vol. II.

----- (1914), Fray Mamerto Esquiú, La Moderna, Buenos Aires.

- GONZÁLEZ, Marcela (1994), "Elite social, universidad y dirigencia”, Studia, nº 4, Córdoba.

---- (1999), "Estado y Sociedad. Imágenes del proceso de modernización en la provincia de Córdoba, 1855-1904", en Carlos S. A. Segreti. In Memoriam. Historia e Historias, Centro de Estudios Históricos "Profesor Carlos S. A. Segreti", Córdoba. T. II.

- GONZÁLEZ, Rubén O. P. (1988), Monseñor Fray Reginaldo Toro, Obispo de Córdoba (Argentina) 1939-1904, El Liberal, Córdoba.

---- (2000), Los Dominicos en Argentina. Biografías, UNSTA, San Miguel de Tucumán.

- GOYENA, Juan (1880), Digesto eclesiástico argentino. Recopilación de leyes, decretos, bulas, pastorales, constituciones, etc. Que se refieren a la Iglesia Nacional (1810-1880), Imprenta Especial de Obras, Buenos Aires.

- GRENON, Pedro (1960), Libro de las Mercedes, Publicación Oficial, Córdoba.

- GUERRA, François-Xavier (1992), Modernidad e independencias, FCE, México.

----- (1993), “El renacer de la historia política: razones y propuestas”, en José Andrés Gallego (dir.) New History, Nouvelle Histoire: Hacia una nueva historia, Actas, Madrid.

----- (2000), "El análisis de los grupos sociales: balance historiográfico y debate crítico", Anuario del IEHS, n 15.

- GUERREAU, Alain (1986), “Organisation et contrôle de l'espace: les rapports de l'État et de l'Église à la fin du Moyen Âge", en Jean-Philippe Genet y Bernard Vincent (eds.), État et Église dans la genèse de l'État moderne, Casa de Velázquez, Madrid.

- HERVIEU-LÉGER, Danièle (1997), "La transmisión religiosa en la modernidad: elementos para la construcción de un objeto de investigación”, Revista Social Compass. Revue internationale de sociologie de la religion, vol. 44.

---- (2005), La Religión Hilo de la Memoria, Herder, Barcelona. 
- HILAIRE, Yves-Marie (1971), “Chronique: sociologie et histoire religieuses contemporaines en France", Revue du Nord, t. 53, nº 208.

---- (2000), "Charles de la Tour d'Auvergne, eveque d'Arras, et la reconstitution d'un clerge diocesain (1802-1851)", Société et religion en France et aux Pays-Bas, XVe-XIXe siècles, Mélanges en l'honneur d'André Lottin, Artois Presses Université, Arras.

- HOGAN, J. L. (1959), "Fray Reginaldo Toro O. P., un católico ilustre de Córdoba", en Álbum del VI Congreso Eucarístico Nacional, Córdoba.

- HUTCHINSON, Thomas J. (1973), "Buenos Aires y otras provincias argentinas", en Carlos S. A. Segreti, "Córdoba, ciudad y provincia (siglo XVI-XX). Según relatos de viajeros y otros testimonios, Junta Provincial de Historia de Córdoba, Córdoba.

- IBARGUREN, Carlos (Inédito), Los Antepasados. A lo largo y más allá de la Historia Argentina, Tomo VI, "Los Argañaraz y Murguía”.

----- (1977) [1955], La historia que he vivido, Ediciones Dictio, Buenos Aires.

- IGGERS, Georg (1998), La Ciencia Histórica en el siglo XX. Tendencias actuales, Idea Universitaria, Barcelona.

- INSTITUTO AGRARIO ARGENTINO (1947), Reseña General Histórica, Geográfica y Económica del Departamento de Río Cuarto (Provincia de Córdoba), Buenos Aires.

- IOGNA-PRAT, Dominique (2006), La maison de Dieu. Une histoire monumentale de l'Eglise au Moyen Âge (800-1200), Seuil, Paris.

---- (2010), Iglesia y Sociedad en la Edad Media, UNAM, Instituto de Investigaciones Históricas, México.

----- (2016), La Invención social de la Edad Media, Miño y Dávila, Buenos Aires.

- IOGNA-PRAT y SCHMITT, Jean-Claude (2002), "Una historiografía en medio del vado" (Une historiographie au milieu du gué). 30 años de Historia medieval en Francia.

- IOGNA-PRAT, Dominique y ZADORA-RIO, Elisabeth (2005), "Formation et transformations des territoires paroissiaux", Médiévales: langue, textes, histoire, $\mathrm{n}^{\circ} 49$, Paris.

- ISERN, Juan (1936), La formación del clero secular de Buenos Aires y la Compañía de Jesús, Editorial San Miguel, Buenos Aires.

- JEDIN, Hubert (1988), Manual de Historia de la Iglesia, Herder, Barcelona. T. VIII.

- JULIA, Dominique (1966), "Le clergé paroissial dans le diocèse de Reims à la fin du XVIIIe siècle", Revue d'Histoire Moderne et Contemporaine, t. XIII.

----- (1970), "Problèmes d'histoire religieuse: regards nouveaux sur la période moderne", Recherches de Science Religieuse, t. 58.

---- (1979), "La religión. Historia religiosa", en Jacques Le Goff y Pierre Nora (eds.), Hacer la Historia, Laia, Barcelona.

----- (1985), "L'éducation des ecclésiastiques aux XVIIe et XVIIIe siècles", en Problèmes de l'histoire de l'éducation. Actes des séminaires organisés par l'École française de Rome et l'Università di Roma - la Sapienza, École Française de Rome, Roma.

---- (1995), “El sacerdote”, en Michel Vovelle (dir.), El Hombre de la Ilustración, Alianza, Madrid.

----- (2000a), "Sources nouvelles, sources revisitées. Le traitement des sources dans 1'historiographie religieuse de XX siècle", Revue d'Histoire de l'Eglise de France, t. 86.

---- (2000b), "Une anthropologie religieuse du Jubilé: l'année sainte d'Alphonse Dupront", Revue d'Histoire de l'Église de France, t. 86 (en colaboración con Ph. Boutry). 
- JULIA, Dominique, GADILLE, Jacques y VENARD, Marc (1969), "Pour un répertoire des visites pastorales", Revue d'Histoire de l'Église de France, t. 55.

- KASSlATTER, Alejandra (1999), El Cura Fierro. Paladín de Justicia y Libertad, Narvaja Editor, Córdoba.

- KOCKA, Jürgen (1989), Historia Social. Concepto. Desarrollo. Problemas, Alfa, Estudios Alemanes, Barcelona.

----- (2000), "Burguesía y sociedad burguesa en el siglo XIX. Modelos europeos y peculiaridades alemanas", en Josep M. Fradera y Jesús Millán (eds.), Las burguesías europeas del siglo XIX. Sociedad civil, politica y cultura, Universidad de Valencia.

- KHOLER, Oskar (1978), "El plan mundial de León XIII. Objetivos y métodos", en Hubert Jedin (ed.), Manual de Historia de la Iglesia, Herder, Barcelona. T. VIII.

- LAGRÉE, Michel (1992), Religion et culture en Bretagne, 1850-1950, Fayard, Paris.

----- (1999), "Historia religiosa, historia cultural", en Jean-Pierre Rioux y Jean-François Sirinelli (comps.), Para una historia cultural, Taurus, Madrid.

----- (2002), Religión et Modernité. France XIXe -XXe siècles, Presses Universitarires de Rennes, Rennes.

----- (2004), "Religión et monde moderne", en L'Histoire religieuse en France et en Espagne, Casa de Velásquez, Madrid.

- LAGRÉE, Michel y BOUDON, Jacques-Olivier (1997), "L'épiscopat français à l'époque concordataire, 1802-1905”, Annales de Bretagne et des Pays de l'Ouest, vol. 104, no 2.

- LAGRÉE, Michel, GREMION, Catherine y LEVILLAIN, Philippe (1987), "Les lieutenants de Dieu. Les évêques de France et de la République", Annales, vol. 42, no 1.

- LANGLOIS, Claude (1987) "Trente ans d'histoire religieuse. Suggestions pour une future enquête. Thirty Years of Religious History", Archives de sciences sociales des religions, $\mathrm{n}^{\circ}$ 63/1. $N^{\circ}$ du trentenaire. Les sciences sociales des religions aujourd'hui: jalons et questions.

- LANGUE, Frédérique (2000), "Las élites en América española. De la historia de las prácticas a la práctica de la historia", Anuario del IEHS, $\mathrm{n}^{\circ} 15$.

- LAUNAY, Marcel (1986), Le bon prêtre: le clergé rural au XIXe siècle, Aubier, Paris.

----- (2003), Les séminaires français aux XIXe et XXe siècles, Cerf, Paris.

---- (2009), Le ciel et la terre. L'Église au village (XIXe siècle), Cerf, Paris.

----- (2010), "El clero francés en tiempos del Cura de Ars", Anuario de Historia de la Iglesia, vol. 19.

- LAUWERS, Michel (2005), Naissance du cimetière: lieux sacrés et terre des morts dans l"Occident medieval, Aubier, Paris.

---- (2008), “Territorium non facere diocesim'. Conflits, limites et représentation territoriale du diocèse, Ve-XIIIe siècle", en Florian Mazel (coord.), L'espace du diocèse. Genèse d'un territoire dans l'Occident médiéval (Ve-XIIIe siècle), PUR, Rennes.

- LAVRIN, Asunción (2005), "Los hombres de Dios", Revista de Estudios Históricos, vol. $2, \mathrm{n}^{\mathrm{o}} 1$.

- LE BRAS, Gabriel (1937), "Pour l'étude de la paroisse rurale", Revue d'Histoire de l'Église de France, $\mathrm{n}^{\circ} 101$.

---- (1955-1956), Etudes de sociologie religieuse, T. I: Sociologie de la pratique religieuse dans les campagnes françaises; T. II: De la morphologie à la typologie, PUF, Paris.

----- (1976), L'Église et le village, Flammarion, Paris. 
- LE GOFF, Jacques (1983), Tiempo, trabajo y cultura en el Occidente medieval, Taurus, Madrid.

----- (1995), Pensar la Historia, Altaza, Barcelona.

---- (1996), Entrevista en la Revista Label France, no 24.

- LEAL, Luis R. (1914), Datos biográficos de los obispos de Córdoba del Tucumán, Córdoba.

- LEMAÎTRE, Nicole (1988), Le rourgue flamboyant. Le clergé et les fideles du diócesis de Rodez, 1417-1563, Cerf, Paris.

---- (2002), Histoire des curés, Fayard, Paris.

- LEPETIT, Bernard (1995), "Histoire des pratiques, pratique de l'histoire", en Les formes de l'expérience. Une autre histoire sociale, Albin Michel, Paris.

----- (1996), "De l'échelle en histoire", en Jacques Revel (dir.), Jeux d'échelles. La microanalyse à l'expérience, Gallimard-Le Seuil, Paris.

- LEVI, Giovanni (1989), "Les usages de la biographie", Annales, $\mathrm{n}^{\circ} 6$.

---- (1990), La herencia inmaterial, Nerea, Madrid.

- LIDA, Miranda (2006), Dos ciudades y un Deán. Biografía de Gregorio Funes, 17491829, Eudeba, Buenos Aires.

---- (2007a), "La Iglesia católica en las más recientes historiografías de México y Argentina. Religión, modernidad y secularización", Historia Mexicana, vol. LVI.

----- (2007b), "Por una historia social del catolicismo argentino (1880-1980)", $1^{\circ}$ Jornadas de Historia social, Córdoba, 30 y 31 de mayo y 1 de junio del 2007.

----- (2007c), "Secularización: doctrina, teoría y mito. Un debate desde la historia sobre un viejo tópico de la sociología", Cuadernos de Historia, $\mathrm{n}^{\circ} 9$, Córdoba.

- LOBATO, Mirta y SURIANO, Juan (2000), Atlas Histórico de la Argentina, Nueva Historia Argentina, Sudamericana, Buenos Aires.

- LORIGA, Sabina (1996), "La biographie comme problème", en Jacques Revel (dir.), Jeux d'échelles. La micro-analyse à l'expérience, Gallimard/Le Seuil, Paris.

- LOUZAO VILLAR, Joseba (2008), "La recomposición religiosa en la modernidad: un marco conceptual para comprender el enfrentamiento entre laicidad y confesionalidad en la España contemporánea", Hispania Sacra, LX, n 121.

- LUQUE ALCAIDE, Elisa (2003), "La restauración de la vida católica en América Latina en la segunda mitad del siglo XIX", Anuario de Historia de la Iglesia, ${ }^{\circ} 12$, Pamplona.

----- (2012), Iglesia en América Latina (siglo XIX). Renovación y continuidad en tiempos de cambio, EUNSA, Pamplona.

- LUQUE COLOMBRES, Carlos (1977), "Martínez Paz Historiador" en Homenaje al Doctor Martínez Paz, Facultad de Filosofía y Humanidades, UNC.

- LYNCH, John (1991), "La Iglesia Católica en América Latina, 1830-1930", en Leslie Bethell, (comp.), Historia de América Latina, Barcelona, Crítica, Tomo 8. Cap. 2.

- MAJEUR, Jean-Marie (1995), "L'historiographie française en histoire religieuse conternporaine", Anuario de Historia de la Iglesia, vol. 4, Universidad de Navarra. Dossier "Historia Religiosa en Europa 1980-1993".

- MALDONADO, Jorge y MOYANO ALIAGA, Alejandro, "Los universitarios y el poder político en Córdoba. 1900-1950", en Jornadas de Historia de Córdoba entre 1830 y 1950, Junta Provincial de Historia de Córdoba. 
- MALLIMACI, Fortunato (1988a), "Movimientos laicales y sociedad en el período de entreguerras. La experiencia de la Acción Católica en Argentina", Cristianismo y Sociedad, $\mathrm{n}^{\mathrm{o}} 108$, México.

----- (1988b), El catolicismo integral en la Argentina (1930-1943), Biblos, Buenos Aires.

---- (1993), "Los estudios sobre la relación catolicismo, Estado y sociedad en la Argentina: conflictos y tendencias actuales", en Ciencias sociales y religión en el Cono Sur, CEAL, Buenos Aires.

----- (2008), Modernidad, Religión y Memoria, Colihue-Centro Franco Argentino, Buenos Aires.

- MALLIMACI, Fortunato y DI STEFANO, Roberto (2001), Religión e imaginario social, Manantial, Buenos Aires.

- MARTÍNEZ, Ana Teresa (2007), Pierre Bourdieu. Razones y lecciones de una práctica sociológica, Manantial, Buenos Aires.

- MARTÍNEZ, Ignacio (2013a), "Una Nación para la Iglesia Argentina”, Academia Nacional de la Historia, Buenos Aires.

----- (2013b), "La circulación de noticias ultramontanas en el Río de la Plata tras la instalación de la primera nunciatura en la América Ibérica (1830-1842)", Historia Crítica, Bogotá.

- MARTINEZ DE SÁNCHEZ, Ana María (2000), La cofradía del Carmen en la Iglesia de Santa Teresa de Córdoba, Prosopis, Córdoba.

----- (2006), Cofradías y obras pías en Córdoba del Tucumán, EDUCC, Córdoba.

----- (2007), Los jesuitas. Sus cofradias y congregaciones, EDUCC, Córdoba.

----- (2011), Formas de vida cotidiana en Córdoba (1573-1810). Espacio, tiempo y sociedad, Centro de Investigaciones y Estudios sobre Cultura y Sociedad, Córdoba.

- MARTINEZ PAZ, Enrique (1936), Elogio de Mons. Pablo Cabrera, Junta de Historia y Numismática Americana Filial Córdoba.

----- (1937), El sentido político moderno de la historia, Instituto de Estudios Americanistas, Universidad Nacional de Córdoba, Córdoba.

---- (1946), “Córdoba (1810-1862)", en Academia Nacional de la Historia, Historia de la Nación Argentina, Historia de las Provincias, El Ateneo, Buenos Aires, vol. IX.

----- (1950), El deán Funes. Un apóstol de la libertad, Pronsato Impresores, Córdoba.

----- (1983), La Formación Histórica de la Provincia de Córdoba, Instituto de Estudios Americanistas, Universidad Nacional de Córdoba, Córdoba.

- MATUTE, Álvaro, TREJO, Evelia y CONNAUGHTON, Brian (1995), Estado, Iglesia y Sociedad en México siglo XIX, UNAM, México.

- MAYORDOMO, Alejandro (1995), Socialización, educación social y clase populares, Estudios Históricos, Universidad de Valencia.

- MAZEL, Florian (2008), “Cujus dominus, ejus episcopatus? Pouvoirs seigneuriaux et territoires diocésains (Xe-XIIIe siècle)", en (dir.), L'espace du diocèse. Genèse d'un territoire dans l'Occident médiéval (Ve-XIIIe siècle), PUR, Rennes.

- MELO, Carlos (1967), "Córdoba entre 1862 y 1930", en Historia Argentina Contemporánea, 1862-1930, Academia Nacional de la Historia, El Ateneo, Buenos Aires. Vol. IV. $1^{\text {a }}$ sección.

- MERDRIGNAC, Bernard, PICHOT, Daniel, PLOUCHART, Louisa y PROVOST, Georges (dir.) (2013), La paroisse, communauté et territoire. Constitution et recomposition du maillage paroissial, PUR, Rennes. 
- METZER, Marcel (1994), Les Sacramentaires. Typologie des Sources du Moyen Age Occidental, Brepols-Turnhout, Belgium. Fasc. 70.

- MEYER, Jean (1991), Historia de los cristianos en América Latina siglos XIX y XX, Vuelta, México.

- MOLINARI, Franco y MEZZARDI, Luigi (1979), "El catolicismo italiano", en Hubert Jedin (dir.), Manual de Historia de la Iglesia, Herder, Barcelona. T. IX.

- MONTERO, Feliciano (2004), "La historiografía española entre la historia eclesiástica y la religiosa", en René Remond, Javier Tusell, Benoît Pellistrandi y Susana Sueiro (coords.), Hacer la Historia del siglo XX, Casa de Velázquez, Madrid.

- MONTERO, Feliciano, GARCÍA, Ángel, LÓPEZ VILLAVERDE, Luis y SÁNCHEZ JIMÉNEZ, José (2005), "Transición política, transición religiosa" en Clericalismo y asociacionismo católico en España, de la Restauración a la Transición: un siglo entre el palio y el consiliario, Ediciones de la Universidad de Castilla-La Mancha, Cuenca.

- MORELLO, Gustavo (2003), Cristianismo y Revolución. Los origenes intelectuales de la guerrilla en la Argentina, EDUCC, Córdoba.

- MOREYRA, Beatriz (1992), "Crecimiento demográfico y expansión económica en el espacio pampeano cordobés durante el modelo primario-exportador (1880-1930)", Cuaderno, $\mathrm{n}^{\mathrm{0}} 4$, Centro de Estudios Históricos "Prof. Carlos S. A. Segreti", Córdoba.

---- (1996), "Historia social: problemáticas, perspectivas y desafíos contemporáneos", Investigaciones y Ensayos, ${ }^{\circ} 46$.

----- (1999), "La política social en Córdoba (1914-1930): ¿ruptura o continuidad?”, en Carlos S. A. Segreti. In Memoriam. Historia e Historias, Centro de Estudios Históricos "Prof. Carlos S. A. Segreti", Córdoba. T. II.

----, (2001a), "La historiografía argentina del siglo XX: una mirada cuasi secular", en $L a$ Escritura de la Historia. Una mirada sobre las prácticas y discursos de los historiadores de Córdoba (Argentina), Centro de Estudios Históricos "Prof. Carlos S. A. Segreti", Córdoba.

-----, (2001b), "La política social: caridades, estado y sociedad civil. Córdoba (19001930)", en Beatriz Moreyra y otros, Estado, Mercado y Sociedad, Córdoba 1820-1950, Centro de Estudios Históricos "Prof. Carlos S. A. Segreti", Córdoba. T. I y II.

-----, (2002), "Renovación y tradición en los estudios sobre grupos sociales en la historiografía social cordobesa (Argentina)", Revista Dialogos, $\mathrm{n}^{\mathrm{o}} 7$.

----- (2005), "La historiografía de las últimas décadas: permanencias, virajes y retornos críticos", IV Jornadas Municipales de Historia de Córdoba, Córdoba.

---- (2011), "La historia social en los albores del siglo XXI: innovaciones e identidad", en Noemí Girbal y Beatriz Moreyra (comps.), Producción de conocimiento y transferencia en las ciencias sociales, Imago Mundi, Buenos Aires.

- MOREYRA, Beatriz y SOLVEIRA, Beatriz (1997), Estado, economía y sociedad: 18801950. Los procesos, los hombres, las vivencias, Centro de Estudios Históricos "Prof. Carlos S. A. Segreti", Córdoba.

- MOREYRA, Beatriz, REMEDI, Fernando y ROGGIO, Patricia (1998), El Hombre y sus circunstancias. Discursos, representaciones y prácticas sociales en Córdoba, 1900-1935, Centro de Estudios Históricos "Prof. Carlos S. A. Segreti", Córdoba. 
- MORGADO GARCÍA, Arturo (2000), Ser clérigo en la España del Antiguo Régimen, Universidad de Cádiz, Cádiz.

----- (2006), "El estamento eclesiástico en la Europa Moderna", en Antonio Luis Cortés Peña (coord.), Historia del Cristianismo, Editorial Trotta, Universidad de Granada, Granada.

----- (2007), "El clero en España en los siglos XVI y XVII. Estado de la cuestión y últimas tendencias", Manuscrits, 25.

- MORSEL, Joseph (2007a), Construire l'espace sans la notion d'espace. Le cas du Salzforst (Franconie) au XIVe siècle, Publications de la Sorbonne, Paris.

---- (2007b), L"histoire (du Moyen Âge) est un sport de combat. Réflexions sur les finalités de l'histoire du Moyen Âge destinées a une société dans laquelle même les étudiants d'histoire s"interrogent, LAMOP-I, Paris.

---- (2009), "Les logiques communautaires entre logiques spatiales et logiques catégorielles (XIIe-XVe siècles)", Bulletin du Centre d'Etudes Médiévales d'Auxerre, Hors série 2.

- MOUTOUKIAS, Zacarías (1995), "Narración y análisis en la observación de vínculos y dinámicas sociales: el concepto de red personal en la historia social y económica", en María Bjerg y Hernán Otero (comps.), Inmigración y redes sociales en la Argentina moderna, Tandil, IEHS-CEMLA.

- MOYANO, Javier (1997), "Articulaciones entre política municipal y provincial en el proceso de formación de grupos sociales dominantes en Córdoba entre 1908-1918", Cuadernos de Historia, Año 1, ${ }^{\circ} 1$, Córdoba.

----- (2007), “Clericales y liberales en la política cordobesa entre 1890 y 1930 ¿Polarización permanente o fracturas coyunturales?, Estudios Sociales, $\mathrm{n}^{\circ} 32$.

- MOYANO, Rafael (1864), "Necrología biográfica del Ilmo. Señor Obispo de la Diócesis de Córdoba Dr. D Fr. Reginaldo Toro", Archivo Dominicano de Córdoba. Defunciones, I, 91 inédito.

- NICOLETTI, María Andrea (2004), "Ciudadanía incompleta y mediación: indígenas e inmigrantes italianos en el proyecto de evangelización salesiana en la Patagonia (1904)", I Jornadas de Estudio sobre Religiosidad, Cultura y Poder, GERE-PROHAL-Instituto Ravignani, Buenos Aires.

- NOVILLO SARAVIA, Lisandro (1923), "La enseñanza laica". Discursos pronunciados en la Honorable Convención Reformadora en las Sesiones del 9 y 12 de mayo de 1922, Los Principios, Córdoba.

- OLIVER BOUDON, Jacques (2004), "De la biographie à la prosopographie dans l'historiographie religieuse contemporaine", en L'Histoire religieuse en France et en Espagne, Casa de Velázquez, Madrid.

- ORTIZ, A. (1883), El Padre Esquiú Obispo de Córdoba. Sus Sermones, Discursos, Cartas Pastorales, Oraciones Fúnebres, Imprenta El Comercio, Córdoba.

- ORTIZ, Esteban (1992), Los conservadores de Córdoba y el poder, Edición del Autor, Córdoba.

- O’DOGHERTY, Laura (2000), "Los laicos como instrumentos de influencia eclesial. La Arquidiócesis de Guadalajara durante el porfiriato", Historia y Grafía, n 14, México.

- PAGANO, Nora (1999), "Biografía e historiografia", en Actas del II Congreso Internacional Historia a Debate. T. II. 
- PANETTIERI, José (1998), "El informe Buchanan: primer estudio sobre salarios y precios en la Argentina, 1886-1896", Cuadernos del CISH, vol. 3, n 4, La Plata.

- PAVONI, Norma (1993), "Una etapa en el proceso fundacional del Estado Argentino. 1852-1862", Córdoba y el gobierno nacional, Banco de la Provincia de Córdoba, Córdoba.

- PAZ SOLDÁN, Mariano Felipe (1887), Atlas geográfico de la República Argentina, Lajouane, Buenos Aires.

- PAZOS, Antón (1990), El clero navarro, 1900-1936. Origen social, procedencia geográfica y formación sacerdotal, Ediciones de la Universidad de Navarra, Pamplona.

---- (1995), "Una aproximación a la historia religiosa de Europa. El Coloquio de Roncesvalles (noviembre 1993)", Anuario de Historia de la Iglesia, vol. 4, Universidad de Navarra. Dossier: "Historia Religiosa en Europa, 1980-1993".

----- (1997), “América Latina y el Caribe hacia 1898 según la diplomacia Vaticana”, Hispana Sacra, $\mathrm{n}^{\circ} 49$.

----- (2004), "Parroquias y clero parroquial", en L'histoire religieuse en France et en Espagne, Casa de Velásquez, Madrid.

---- (2005), "El párroco eficaz. Técnica parroquial y mentalidad eclesiástica en la bibliografía recomendada por el Boletín de Pamplona (1900-1930)", Hispania Sacra, vol. LVII, $\mathrm{n}^{\mathrm{o}} 116$.

- PEIRE, Jaime (2000), El taller de los espejos. Iglesia e imaginario 1767-1615, Claridad, Buenos Aires.

- PELLISTRANDI, Benoît (2007), “Clericalismo y anticlericalismo en Francia. ¿Una denominación de origen?”, en Julio de la Cueva Merino y Feliciano Montero (eds.), La secularización conflictiva. España (1898-1931), Biblioteca Nueva, Madrid.

- PELliZA, Mariano (1888), Manuel de l'Inmigrant dans L'Republique Argentine, Publication Oficielle, Imprimerie du Courrier de la Plata, Buenos Aires.

- PEÑA Gabriela A. (2005), "Perfil misionero de un Obispo dominico, Fray Reginaldo Toro", Actas de las Segundas Jornadas de Historia de la Orden Dominicana en la Argentina, UNSTA, Tucumán.

- PEÑA, R. (1911), El Deán Funes, Coni, Buenos Aires.

- PEPPOLONI, Marcela F. (2001), El pensamiento social cristiano en Córdoba, cambios y permanencias 1910-1940, UNC, Tesis de Licenciatura.

- PEREYRA, Liliana (1999), La muerte en Córdoba a fines del siglo XIX, Alción, Córdoba.

- PERRIN, Luc (2002), "Des curés tridentins aux nouveaux curés", en Michel Lagrée, Nicole Lemaître y Catherine Vincent, Histoire des Curés, Fayard, Paris.

- PETIT, Vincent (2003), Le curé et l'ivrogne. Une histoire sociale et religieuse du Haut Doubs au XIXe siècle, L'Harmattan, Paris.

- PEYRET, Alejo (1973), "Una visita a las Colonias de la República Argentina (Buenos Aires, 1889, TII)", en Carlos S. A. Segreti, Córdoba, Ciudad y Provincia, siglos XVI al XX, según relatos de viajeros y otros testimonios, Junta Provincial del Estudios Históricos, Córdoba.

- PIANETTO, Ofelia y GALIARI, Mabel (1989), "La inserción social de los inmigrantes españoles en la ciudad de Córdoba, 1870-1914”, Estudios Migratorios Latinoamericanos, $\mathrm{n}^{\circ} 13$, Año 4.

- PICARDO, Diego y PAZOS, Antón (2002), Concilio Plenario de América Latina, Roma 1899, Iberoamericana Vervuert, Madrid. 
- PIERRARD, Pierre (1986), La vie quotidienne du prêtre français au XIX siècle 18011905, Hachette, Paris.

----- (1998), Histoire des curés de campagne, de 1789 à nos jours, Terres Bartillat, Paris.

- POUPARD, Paul (coord.) (1987), Diccionario de las Religiones, Herder, Barcelona.

----- (1987), Voz "Laicismo", en Diccionario de las religiones, Herder, Barcelona.

- PRO RUIZ, Juan (1995), "Las elites de la España liberal, clases y redes en la definición del espacio social (1808-1931)", Historia Social, n 31, Valencia.

- PROVOST, Georges (2013), "Territoire en communauté: les parisses urbaines en question dan Bretagne du XVIII siecle", B. Merdrignac, D. Pichot, L. Plouchard y G. Provost (eds.), Paroisse, Communauté et Territoire. Constitucion et recompossition du maillage paroissial, PUR, Rennes.

- PONTAL, Odette (1975), "Les Statuts Synodaux", Leopold Genicot (dir.), Typologie des Sources du Moyen Age Occidental, Brepols-Turnhout, Belgium. Fasc. 70.

- RAMOS MEDINA, Manuel (comp.) (1998), Historia de la Iglesia en el siglo XIX, CONDEMEX, México.

- RAPALO, María Ester (2005), "La relación entre los círculos de obreros y los sectores patronales en las dos primeras décadas del siglo XX", Prismas, $\mathrm{n}^{\circ} 9$.

- RECALDE, Héctor (1985), La Iglesia y la cuestión social (1874-1910), CEAL, N 110 , Buenos Aires.

- REGUERA, Andrea (2007), "Enfoques dominantes en el análisis social de la historia latinoamericana. ¿Una historia de la burguesía, de las elites o de los grupos dominantes?, Interpretaciones Revista de Historiografía Argentina, $\mathrm{n}^{\circ} 2$.

- REMEDI, Fernando (1996), Condiciones de vida material de la población rural cordobesa (1900-1914), Centro de Estudios Históricos "Prof. Carlos S. A. Segreti", Córdoba.

----- (2009), "Los grupos sociales en la historiografía social Argentina. Décadas 1980-1990. Un recorrido por las revistas de historia", en Beatriz Moreyra y Silvia Mallo (coords.), Pensar y construir los grupos sociales, Centro de Estudios Históricos "Prof. Carlos S. A. Segreti", Córdoba.

- REMOND, Rene (2001), Religion et société en Europe: la sécularisation aux XIXème et XXème siècles (1789-2000), Seuil, Paris.

- RESTIF, Bruno (2006), La révolution des paroisses. Culture paroissiale et réforme catholique en Haute-Bretagne aux XVI ${ }^{e}$ et XVII siècles, Presses Universitaires de Rennes, Rennes.

- REVEL, Jacques (2005), Un momento historiográfico. Trece ensayos de historia social, Manantial, Buenos Aires.

- REVUELTA GONZÁLEZ, Manuel (1979), "Clero viejo y clero nuevo en el siglo XIX", en Estudios Históricos sobre la Iglesia española contemporánea, El Escorial.

---- (2002), "El anticlericalismo español en el siglo XIX", en Paul Aubert y Jean Michel Desvois (eds), Religión y sociedad en España (siglos XIX y XX), Casa de Velázquez, Madrid.

- RIBA, Jordi (2006), "Filosofía política, república y educación del ciudadano", Revista Res Publica, $\mathrm{n}^{\circ} 16$. 
- RIQUELME, Norma (1999), “Ideas y partidos políticos en Córdoba. Una aproximación al marco del pensamiento político al promediar el siglo XIX", en Carlos S. A. Segreti In Memoriam. Historia e historias, Córdoba, T. I.

- RICCOEUR, Paul (1988), Tiempo y Narración, Cristiandad, Madrid.

- RIO Manuel y ACHAVAL, Luis (1904), Geografia de la Provincia de Córdoba, Publicación Oficial del Gobierno de la Provincia de Córdoba, Compañía Sud-Americana de Billetes de Banco, Córdoba. Vol. I y II.

- ROCCA, D’Andrea (1899), Il Comitato Parrochiale, Luigi Bufete, Parma.

- ROCCHIETTI, Ana María y TAMAGNINI, Marcela (2007), Arqueología de la Frontera. Estudios sobre los campos del sur cordobés, UNRC, Córdoba.

- RODRÍGUEZ, Julio (1907), Sinopsis Histórica de Córdoba, Imprenta y Casa Editora Adolfo Grau, Buenos Aires.

- RODRIGUEZ de la TORRE, Miguel (1948), Ensayo Histórico sobre la fundación de Marcos Juárez, Córdoba, Imprenta de la Universidad.

ROITENBURD, Silvia (1989), "El papel de las mayorías en el proyecto global del nacionalismo católico (1910-1919)", en Jornadas Rioplatenses de Historia Comparada. El Reformismo en contrapunto. Los procesos de modernización en el Río de la Plata, 18901930, CLAEH/CLACSO, Ediciones de la Banda Oriental, Montevideo.

----- (1993), Educación y control social. El Nacionalismo Católico Cordobés, (1862-1944), en Adriana Puiggrós (dir.), La educación en las Provincias y Territorios Nacionales (18851945), Galerna, Buenos Aires.

----- (1998), Nacionalismo católico cordobés. Educación en los dogmas para un proyecto global restrictivo, 1862-1943, Tesis de Doctorado, UNC, Córdoba.

---- (2000), Nacionalismo Católico Cordobés (1862-1943). Educación en los dogmas para un proyecto global restrictivo, Ferreira Editor, Córdoba.

----- (2002), "Católicos: entre la política y la fe (1862-1890)", en Gardenia Vidal y Pablo Vagliente (comps.), Por la Señal de la Cruz. Estudios sobre Iglesia Católica y sociedad en Córdoba, ss. XVII-XX, Ferreira Editor, Córdoba.

- ROJAS de VILLAFAÑE, Emilio (1976) La economía de Córdoba en el siglo XIX: su relación con el tiempo presente: la misión histórica de Córdoba, Revista de Economía del Banco de la Provincia de Córdoba, Córdoba.

- ROMANO, Silvia (1992), "Finanzas públicas de la provincia de Córdoba, 1830-1855", Boletín del Instituto de Historia Argentina y Americana "Dr. Emilio Ravignani", $\mathrm{n}^{\circ} 6$.

---- (1993), "Economía y Sociedad en Córdoba, 1830-1855, Grupos dominantes y poder político", Tesis de Doctorado, Universidad Nacional de Córdoba, Córdoba, 1993.

- ROMANO, Silvia y AYROLO, Valentina (2001), "Poder y representación política en Córdoba (Argentina) a mediados del siglo XIX", História Unisinos, vol. 5.

- ROMERO, José Luis (1945), Sobre la Biografía y la Historia, Sudamericana, Buenos Aires.

- ROMERO, Luis Alberto (1997), "Católicos en movimiento, activismo en una parroquia de Buenos Aires, 1935-1946", Estudios Sociales, n 12, Santa Fe.

----- (1999a), "Una nación católica 1880-1946", en Carlos Altamirano (ed.), La Argentina en el siglo XX, Ariel, Buenos Aires.

----- (1999b), "Nueva Pompeya, libros y catecismo", en Leandro H. Gutiérrez y Luis A. Romero (coords.), Sectores populares, cultura y política. Buenos Aires en la entreguerra, Sudamericana, Buenos Aires. 
- ROMERO CABRERA, Lilian (1973), "Córdoba en el decenio anterior a la Revolución del '90", en Homenaje al Dr. Ceferino Garzón Maceda, Instituto de Estudios Americanistas, UNC y Dirección General de Publicaciones, Córdoba.

- ROMERO CARRANZA, Ambrosio (1976) [1951], Ambrosio Ozanam y sus contemporáneos, Difusión, Buenos Aires.

- RONZANI, Mauro (2014), "L'organizzazione spaziale della cura d'anime e la rete delle chiese (secoli V-IX)", en Chiese local e chiese regionalli nell'alto Medioevo, Spoleto.

- ROSA, Mario (2006), Clero cattólico e società europea nell'età moderna, Laterza, Italia.

- ROSANVALlON, Pierre (1996), "Por uma historia conceitual do político", Revista História, vol. 15, São Paulo.

- ROSOLI, Gianfausto (1992), "L'asociacionismo católico degli emigrati italiani in America tra '800 e '900" en Fernando Devoto y Eduardo Míguez (comps.), Asociacionismo, trabajo e identidad étnica. Los italianos en América en un perspectiva comparada, CEMLA-CSR-IEHS, Buenos Aires.

- RUBIO, Alicia (1997), "Crítica y desacralización de la herencia colonial: Córdoba vista por Sarmiento", Cuadernos de Historia, Año 1, n 1, Córdoba.

SABATO, Hilda (2007), "La política argentina en el siglo XIX: notas sobre una historia renovada", en Guillermo Palacios (coord.), Ensayos sobre la Nueva Historia Política en América Latina, siglo XIX, El Colegio de México, México.

- SANCHEZ DE LORIA PARODI, H. (2002), Ideas político-jurídicas de fray Mamerto Esquiú, Editorial Quorum - EDUCA, Buenos Aires.

- SANTAMARÍA, Daniel (1990), "Iglesia e inmigración en la Argentina moderna", Estudios Migratorios Latinoamericanos, $\mathrm{n}^{\circ} 14$.

- SANTOS LEPERA, Lucía (2015a), "Modelos en tensión: las disputas entre el obispo y los curas párrocos en torno a la centralización de la Iglesia católica en la década de 1930 (Tucumán, Argentina)", Secuencia, México.

---- (2015b), "Entre la autoridad eclesiástica y el liderazgo local: los curas párrocos de la diócesis de Tucumán durante el primer peronismo", Quinto Sol, vol. 19, n 3.

- SARMIENTO, Domingo F. (2006) (1845), Civilización y barbarie. Vida de Juan Facundo Quiroga, y aspecto físico, costumbres y hábitos de la República Argentina, Puerto de Palos, Buenos Aires.

- SCHMITT, Jean-Claude e IOGNA-PRAT, Dominique (2002), Una historiografía en medio del vado (Une historiographie au milieu du gué), Publicación de La Sorbonne, Paris. - SCHMITT, Jean-Claude y LE GOFF, Jacques (1996), "L'Histoire médiévale", Cahiers de Civilisation Médiévale, ${ }^{\circ} 39$.

- SCHMITT Jean-Claude y OEXLE, Otto-Gerhard (dirs.) (2002), Les tendances actuelles de l'Histoire du Moyen Âge en France et en Allemagne, Publications de la Sorbonne, Paris.

- SCOBIE, James (1968), La Revolución de las Pampas. Historia social del trigo argentino 1860-1910, Solar Hachette, Buenos Aires.

- SEGOVIA, Juan Fernando (1999), "El liberalismo católico de Manuel Pizarro: la relación Iglesia-Estado en el marco de la Constitución Nacional", en Carlos S. A. Segreti, In Memoriam. Historia e historias, Centro de Estudios Históricos "Prof. Carlos S. A. Segreti", Córdoba. T. I.

----- (2000), El liberalismo argentino de la generación del 80. Historia y Evolución de las ideas políticas y filosóficas argentinas, Ediciones de la Academia Nacional del Derecho y Ciencias Sociales de Córdoba, Córdoba, vol. XVII. 
- SEGRETI, Carlos S. A. (1998), Córdoba. Ciudad y provincia (siglos XVI-XX) según relatos de viajeros y otros testimonios, Centro de Estudios Históricos, Córdoba.

- SEMAN, Pablo (2007), "Secularización ente los cientistas de la religión del Mercosur", en Julio Carozzi y César Cerani Cernadas (coords.), Ciencias Sociales y Religión en América latina. Perspectivas en debate, Biblos, Buenos Aires.

- SERRANO Carlos (1996), "Historia cultural: un género en perspectiva", Historia Social, $\mathrm{n}^{\circ} 26$.

- SERRANO, Sol (1998), "La conflictiva definición de lo público en un Estado católico. El caso de Chile, 1810-1885", Anos 90, 6: 10.

----- (2003), "Espacio público y espacio religioso en el Chile republicano", Teología y Vida, vol. XLIV.

----- (2008a), ¿Qué hacer con Dios en la república? Política y secularización (1845-1885), FCE, México.

----- (2008b), Entrevista con motivo de la presentación del libro ¿Qué hacer con Dios en la república? Política y secularización (1845-1885).

- SINODO DIOCESANO CELEBRADO EN CÓRDOBA (1907), Por el Ilmo. y Rmo. Señor Obispo Don Fray Bustos y Ferreira, En el año del Señor MCMVI. Resoluciones y Apéndices, La Industrial, Córdoba.

- SIRINELLI, Jean-François (1993), "El retorno de lo político", Historia Contemporánea, $\mathrm{n}^{\circ} 9$.

- SOCIÉTÉ DES HISTORIENS MÉDIÉVISTES DE L’ENSEIGNEMENT SUPÉRIEUR PUBLIC (ed.) (2007), Construction de l'espace au Moyen Âge: pratiques et représentations, Publications de la Sorbonne, Paris.

- SONEIRA, Abelardo J. (1978), Las estrategias institucionales de la Iglesia Católica, CEAL, Buenos Aires.

- SORREL, Christian (2004), "La historia religiosa en Francia", en René Remond, Javier Tusell, Benoît Pellistrandi y Susana Sueiro (coords.), Hacer la historia del siglo XX, Casa de Velázquez, Madrid.

- SPINELli, María E., SERVETTO, Alicia y CLOSA, Gabriela (comps.) (2000), La conformación de las identidades políticas en la Argentina del siglo XX, UNC/UNCPBA/UNMdP, Córdoba.

- STOFFEL, Edgardo (1991), "La evangelización de la pampa gringa santafesina. Pautas para un trabajo de investigación", en Néstor T. Auza y Luiggi Favero (coords.), Iglesia e inmigración en la Argentina, CEMLA, Buenos Aires.

----- (1994), "El clero secular nacional. Ámbitos de reclutamiento y nacionalización. Estudio de las vocaciones sacerdotales ingresadas en Santa Fe hasta 1930", en Néstor T. Auza y Luiggi Favero (coords.), Iglesia e inmigración en la Argentina, CEMLA, Buenos Aires.

----- (1997), "El clero secular español y su actuación en Santa Fe, 1856-1930", Néstor T. Auza y Luiggi Favero (coords.), Iglesia e inmigración en la Argentina, CEMLA, Buenos Aires.

- STONE, Lawrence (1986) [1979], "Prosopografía", en El pasado y el presente, FCE, México.

- STROZZI, Susana (1993), "Sujeto y persona en la biografía histórica", en Historia a Debate, Santiago de Compostela. Tomo "América Latina". 
- STURM de CARNERO, Graciela (1981), Aportes para el estudio de una cuestión nacional: liberales y católicos en 1884, Tesis de Licenciatura, UNC, Córdoba.

- SURIANO, Juan (2000), La Cuestión Social Argentina, 1870-1943, La Colmena, Buenos Aires.

- TACKETT, Timothy (1979), "L'histoire sociale du clergé diocésain dans la france du XVIII siècle", Revue d'histoire moderne et contemporaine, tome XXVII.

- TAMAGNINI, Marcela (1995), Cartas de la Frontera. Los documentos del conflicto interétnico, Editorial de la UNRC, Río Cuarto.

- TAMAGNINI, Marcela y PEREZ ZABALA, Graciana (2003), "La confrontación por el espacio. El avance de la frontera hacia el río Quinto (1869), Claroscuro, $\mathrm{n}^{\circ} 3$, Rosario.

---- (2010), El fondo de la tierra. Destinos errantes en la Frontera Sur, Editorial de la UNRC, Río Cuarto.

- TAYLOR, William (1995), "El camino de los curas y de los borbones hacia la modernidad" en Álvaro Matute, Evelia Trejo y Brian Connaughton (coords.), Estado, Iglesia y sociedad en México. Siglo XIX, UNAM y Grupo Editorial Porrúa, México.

---- (1999), Ministros de lo Sagrado. Sacerdotes y feligreses en México en el siglo XVIII, Colegio de Michoacán, México. vol. I.

- TELL, Sonia (2008), Córdoba rural, una sociedad campesina (1750-1850), Prometeo, Buenos Aires.

- TERUEL GREGORIO DE TEJADA, Manuel (1993), Vocabulario básico de la Historia de la Iglesia, Crítica, Barcelona.

- TERZAGA, Alfredo (1963), Geografía de Córdoba, Assandri, Córdoba.

- THOMPSOM, E. P. (2002), Edward Palmer Thompsom, Edición de Dorothy Thompsom, Crítica, Barcelona.

- TONDA, Américo (1949a), "Castro Barros, su ideario político religioso", en Revista de la Universidad Nacional de Córdoba, $\mathrm{n}^{\mathrm{0}} 1$.

----- (1949b), Castro Barros, Librería Imprenta de la Universidad Nacional de Córdoba, Córdoba.

----- (1961), Castro Barros. Sus Ideas, Academia del Plata, Buenos Aires, T. III.

---- (1981), El Obispo Orellana y la Revolución, Junta Provincial de Estudios Históricos de Córdoba, Córdoba.

- TOURIS, Claudia (2011), "La historiografía de la religión sobre la Argentina contemporánea. Núcleos consolidados, aportes recientes y debates en curso", en Patricia Fogelman (comp.), Religiosidad, cultura y poder. Tareas y problemas de la historiografía reciente, Lumiere, Buenos Aires.

- TSCHANNEN, Olivier (2004), "La revaloración de la teoría de la secularización mediante la perspectiva comparada Europa Latina-América Latina", en Jean-Pierre Bastian (coord). La modernidad religiosa: Europa Latina y América Latina en perspectiva comparada, FCE, México.

- TURCHINI, Angelo (2013), "Les visites pastorales en Italie après le Concile de Trente", en La paroisse communauté et territoire. Constitution et recomposition du maillage paroisal, PUR, Rennes. 
- VAGLIENTE, Pablo (1995), "La construcción de un proyecto moderno por la élite de Córdoba. Una mirada socio-cultural desde el campo periodístico entre 1857 y 1877”, Tesis de Licenciatura, Córdoba.

----- (1997), "Distintos, distantes y filántropos. Una mirada sociocultural a la clase dominante cordobesa (1857-1877)”, Cuadernos de Historia, Año 1, n 1, Córdoba.

---- (2002), "El asociativismo religioso en Córdoba: del modelo cofradial al de acción social (1850-1880)", en Gardenia Vidal y Pablo Vagliente (comps.), Por la señal de la Cruz. Estudios sobre Iglesia Católica y Sociedad en Córdoba, ss. XVII-XX, Ferreira Editor, Córdoba.

- VALENZUELA GARCÍA, Catalina (2006), "Una aproximación al conocimiento del bajo clero rural en la Andalucía del siglo XVIII", Anuario Jurídico y Económico Escurialense, XXXIX.

- VÁSQUEZ POSADA, Carlos (1999), "La Ratio: sus inicios, desarrollo y proyección”, La Ratio Studiorum en América Latina. Su vigencia en la actualidad, UCC, Córdoba.

- VENARD, Marc (1968), "Pour une sociologie du clergé du XVI siècle. Recherche sur le recrutement sacerdotal dans la province d'Avignon", Annales E.S.C., t. XIII.

----- (1999), "L'istituto delle visite pastorali tra storia sociale e storia religiosa. Reflessioni sull'esempio francese", en Cecilia Nubola y Angelo Turchini (eds.), Fonti ecclessiastiche per la storia sociale e religiosa d'Europa: XVI-VIII séculos, Il Mulino, Bologna.

- VERA DE FLACHS, Cristina (1977), El estado de la ganadería en la provincia de Córdoba. 1870-1880, Academia Nacional de la Historia, Buenos Aires.

----- (1978), El desarrollo socio-económico del sur de la provincia de Córdoba, 1870-1880, Junta Provincial de Historia de Córdoba, Córdoba.

---- (1982), El ferrocarril andino y el desarrollo socio-económico del sur de Córdoba. 1870-1880, Fecic, Buenos Aires.

---- (1994), “Revolución y crisis política. El ocaso del roquismo, 1905-1909”, Cuadernos de Historia, $\mathrm{n}^{\circ} 45$, Junta Provincial de Historia, Córdoba.

- VERA VAlLEJOS, J. C. (1940), Tres figuras del clero de Córdoba: Pbro. José Gabriel Brochero, Mons. Juan Martín Yaniz y Paz, Mons. Jerónimo Emiliano Clara, Córdoba.

- VERDE, Amelia (1978), El Partido Demócrata de Córdoba (1913-1925), Tesis de Licenciatura, UNC, Córdoba.

- VIDAL, Gardenia (1994), "Los partidos políticos y el fenómeno clientelístico luego de la aplicación de la ley Sáenz Peña: la UCR de la provincia de Córdoba, 1912-1930”, en Fernando Devoto y Marcela Ferrari (comps.), La construcción de las democracias rioplatenses. Proyectos institucionales y prácticas políticas. 1900-1930, Biblos/UNMdP, Buenos Aires.

----- (1995), Radicalismo de Córdoba, 1912-1930. Los grupos internos: alianzas, conflictos, ideas, actores, Dirección General de Publicaciones, Universidad Nacional de Córdoba, Córdoba.

---- (1996), "Fragmentación de la élite y ampliación del espacio político: la UCR de Córdoba, 1912-1930", en Julio C. Melón Pirro y Elisa Pastoriza (eds.), Los caminos de la democracia. Alternativas y prácticas políticas. 1900-1943, Universidad Nacional de Mar del Plata/Editorial Biblos, Buenos Aires.

---- (2000), "El avance del poder clerical y el conservadurismo político en Córdoba durante la década del 20”, en: http://lasa.international.pitt.edu/Papers.PDF. 
----- (2006), “Ciudadanía y asociacionismo. Los Círculos de Obreros en la ciudad de Córdoba, 1897-1912”, Revista de la Escuela de Historia, vol. 1, n 5.

----- (2010), "Círculos Obreros en la ciudad de Córdoba, 1912-1930. Organización, propuestas, actividades, repertorios de acción colectiva", en María Inés Tato y Martín O. Castro (comps.), Del Centenario al peronismo. Dimensiones de la vida política argentina, Imago Mundi, Buenos Aires.

----- (2011), "La organización interna del Círculo Obrero de Córdoba y la participación de los socios, 1897-1930”, Jornadas Interescuelas/Departamentos de Historia, Catamarca, 10-13 de agosto de 2011.

- VIEL MOREIRA, Luiz Felipe (2003), “Los caminos del 'progreso' en la provincia de Córdoba," Diálogos, vol. 5, Maringá.

- VONES LIEBENSTEIN, Ursula (2005), "El método prosopográfico como punto de partida de la historiografía eclesiástica", Anuario de Historia de la Iglesia, Navarra.

- VOVELLE, Michel (1978) [1973] Piété baroque et déchristianisation en Provence au XVIIIe siècle. Les attitudes devant la mort d'après les clauses de testaments, Seuil, Paris.

---- (1985), Ideologías y mentalidades, Ariel, Barcelona.

----- (2007), Entrevista publicada el periódico El Comercio de Lima, 09/07/2007.

- WALDMANN, Peter (2007), "Algunas consideraciones y reflexiones críticas sobre el concepto de elite(s), en Peter Birle, Wilhelm Hofmeistes, Günther Maihold y Barbara Potthast (eds), Elites en América Latina, Iberoamericana Vervuert, Madrid-Frankfurt.

- ZANATTA, Loris (1996), Del Estado liberal a la Nación católica. Iglesia y Ejército en los orígenes del peronismo, 1930-1945, Universidad Nacional de Quilmes, Buenos Aires.

- ZANCA, José (2006), Los intelectuales católicos y el fin de la cristiandad: 1955-1966, Fondo de Cultura Económica / Universidad de San Andrés, Buenos Aires.

- ZIEGLER, Walter (1996), "Storia religiosa e storia sociale in Germania in età moderna. Un bilancio storiografico", en Cecilia Nubola y Angelo Turchini, "Fonti ecclesiastiche per la storia sociale e religiosa d' Europa: XV-XVIII secolo", Il Mulino, Bologna.

- ZORRAQUÍN BECÚ, Ricardo (1964), "Las instituciones políticas y sociales", Historia de la Argentina Contemporánea, 1862-1930, Academia Nacional de la Historia, Buenos Aires, vol. II.

- ZULETA RUIZ, Fabián A. B. (2013), Territorio y catolicismo en Colombia: Antioquia (siglos XVII-XX), Universidad Nacional de Colombia, Bogotá. 


\section{ANEXOS}

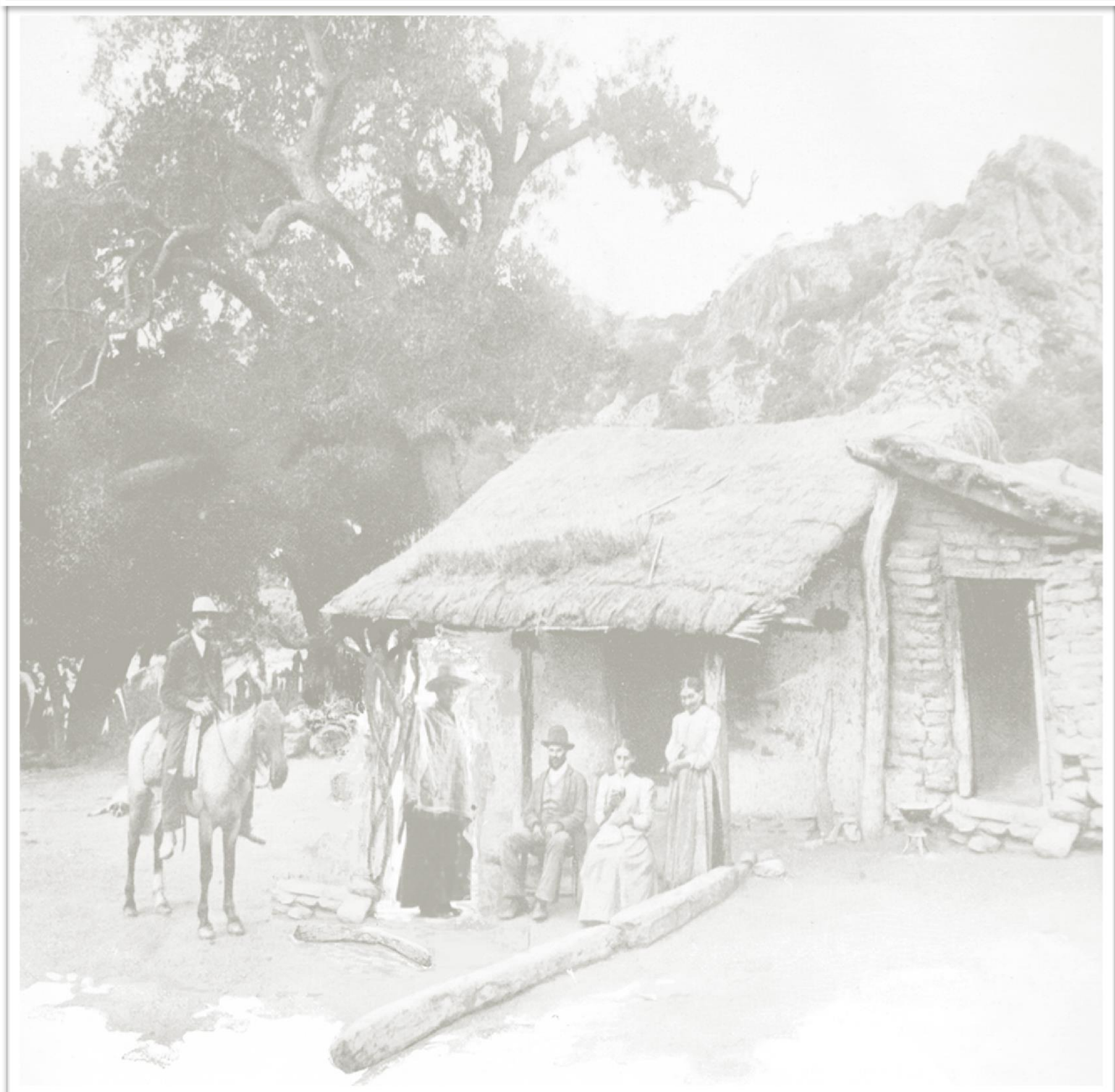


Anexo I 


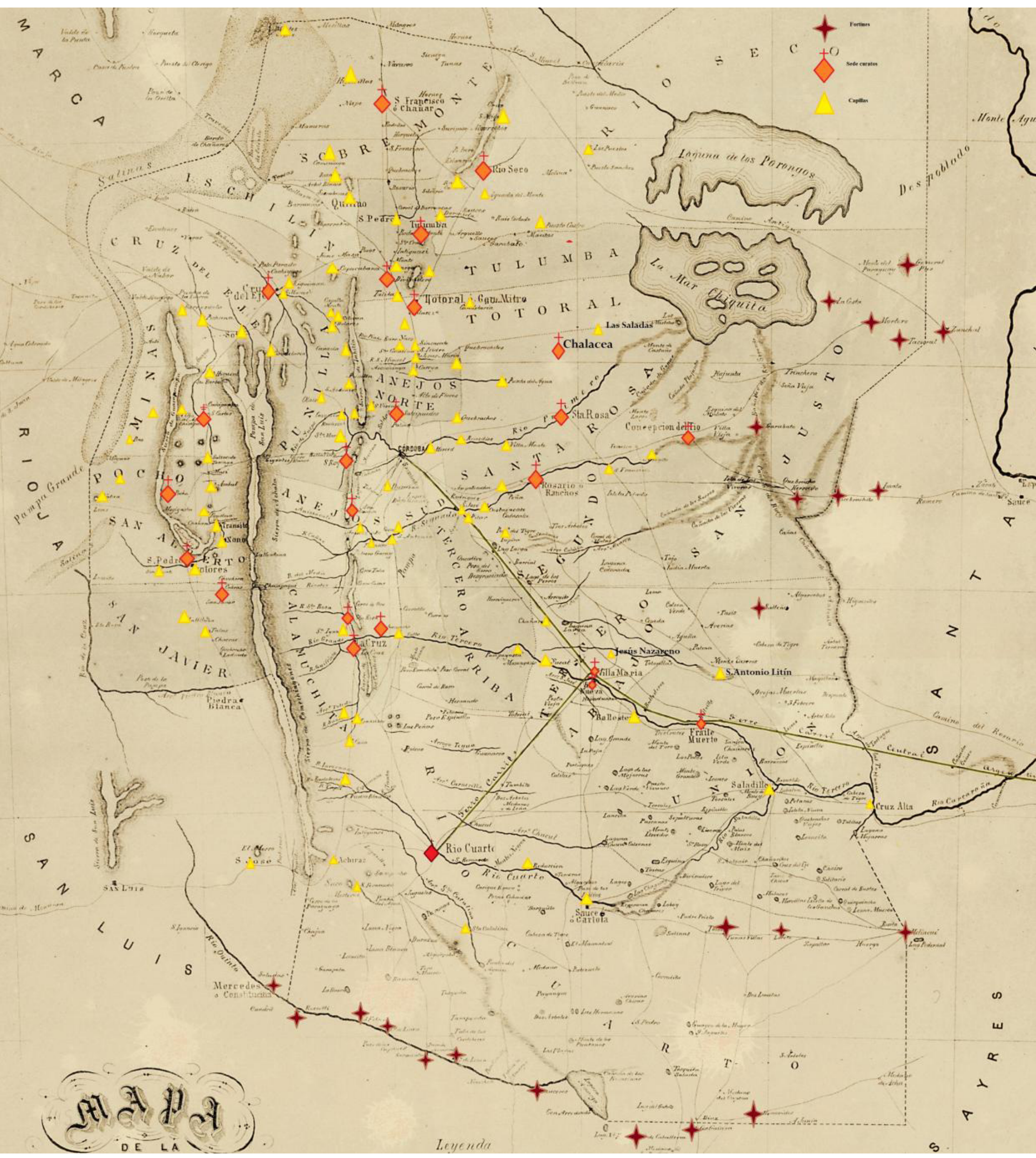




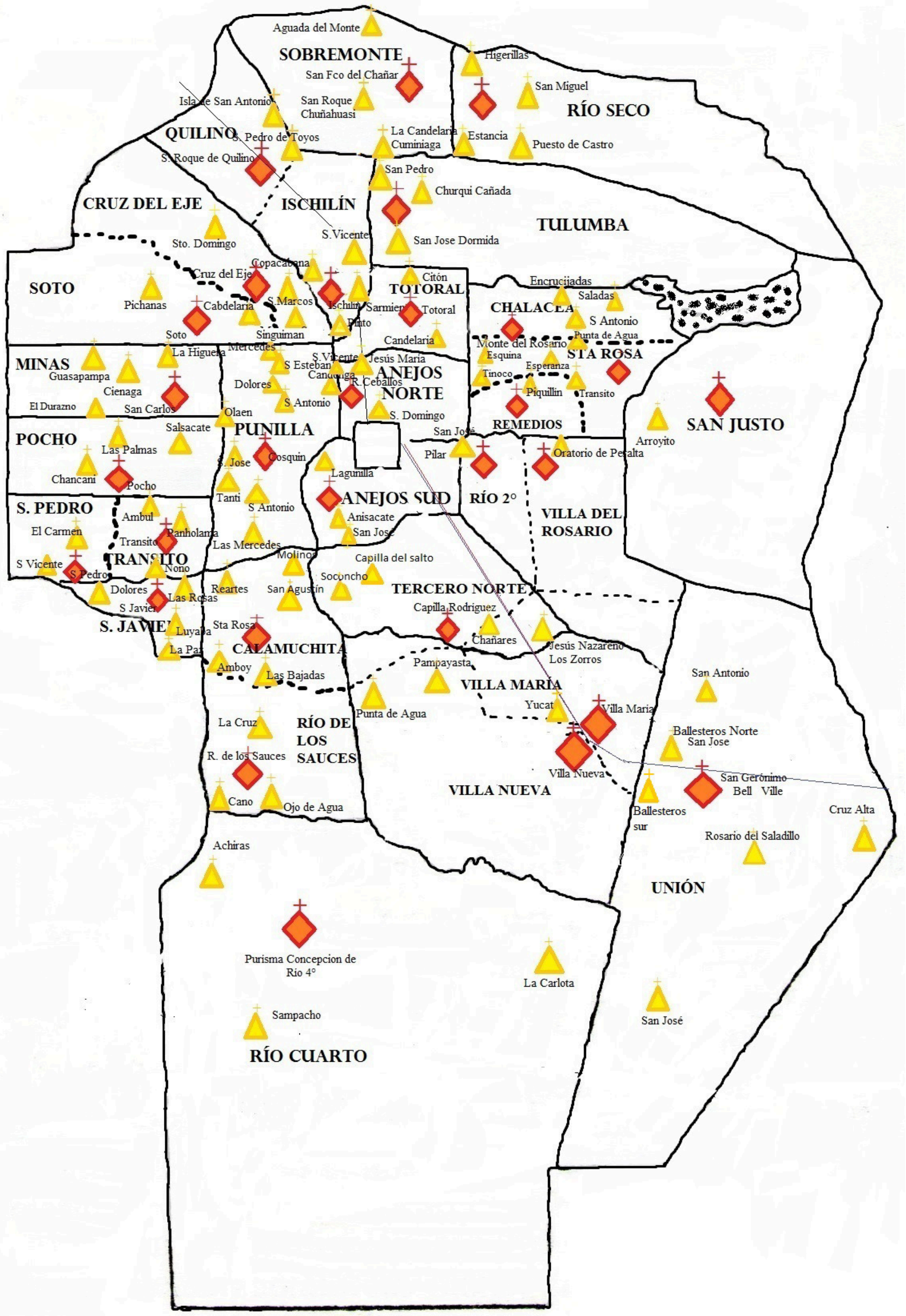




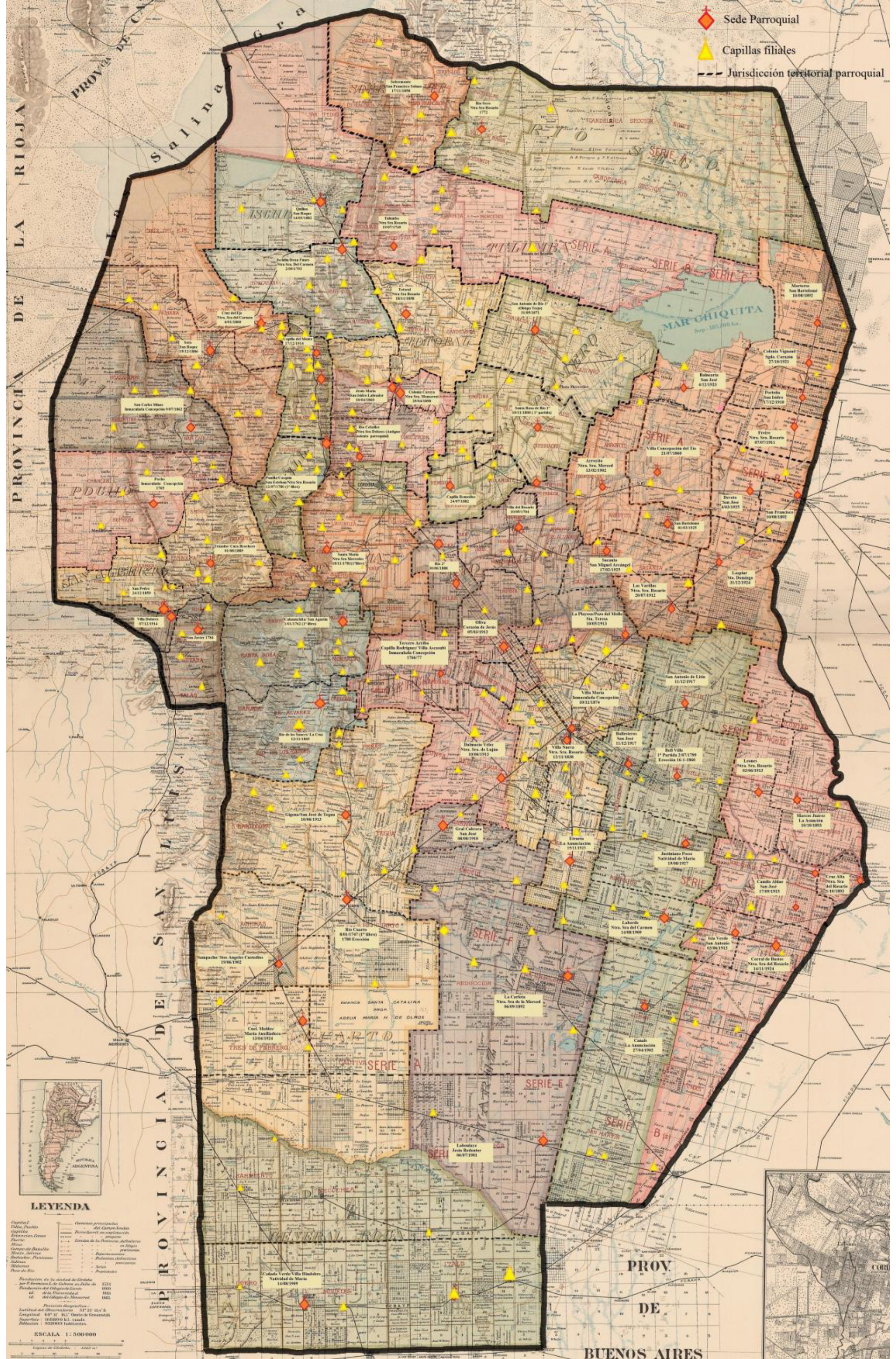


Anexo II 


\begin{tabular}{|c|c|c|c|c|c|c|c|}
\hline \multicolumn{8}{|c|}{$\begin{array}{c}\text { TABLA 1 } \\
\text { Ordenaciones Presbiterales, 1859-1874 }\end{array}$} \\
\hline $\mathbf{N}^{\mathbf{0}}$ & Apellido & Nombre & $\begin{array}{l}\text { Condición del } \\
\text { ordenado }\end{array}$ & Orden & Fecha & Prelado & $1^{\circ}$ Destino \\
\hline 1 & González & $\begin{array}{l}\text { Narciso de } \\
\text { Jesús }\end{array}$ & $\begin{array}{l}\text { Diocesano de } \\
\text { Córdoba }\end{array}$ & Presb. & $29 / 01 / 1860$ & $\begin{array}{l}\text { Ramírez de } \\
\text { Arellano }\end{array}$ & $\begin{array}{l}\text { Córdoba. Ciudad. } \\
\text { Seminario }\end{array}$ \\
\hline 2 & $\begin{array}{l}\text { Galcerán y } \\
\text { La Torre }\end{array}$ & José Leandro & $\begin{array}{l}\text { Diocesano de } \\
\text { Córdoba }\end{array}$ & Presb. & $29 / 01 / 1860$ & $\begin{array}{l}\text { Ramírez de } \\
\text { Arellano }\end{array}$ & $\begin{array}{l}\text { Córdoba. Campaña. } \\
\text { Anejos/ Santa María. }\end{array}$ \\
\hline 3 & Luque & Adolfo & $\begin{array}{l}\text { Diocesano de } \\
\text { Córdoba }\end{array}$ & Presb. & $00 / 11 / 1863$ & $\begin{array}{l}\text { Ramírez de } \\
\text { Arellano }\end{array}$ & No consta \\
\hline 4 & Gallioz & León M. & $\begin{array}{l}\text { Diocesano de } \\
\text { Córdoba }\end{array}$ & Presb. & $21 / 06 / 1864$ & $\begin{array}{l}\text { Ramírez de } \\
\text { Arellano }\end{array}$ & La Rioja. Campaña \\
\hline 5 & $\begin{array}{l}\text { Barros } \\
\text { Casamayor }\end{array}$ & Pedro & $\begin{array}{l}\text { Extra diocesano } \\
\text { Paraná }\end{array}$ & Presb. & $21 / 06 / 1864$ & $\begin{array}{l}\text { Ramírez de } \\
\text { Arellano }\end{array}$ & ------------- \\
\hline 6 & Otesonin & Ramón & $\begin{array}{l}\text { Extra diocesano } \\
\text { Paraná }\end{array}$ & Presb. & $21 / 06 / 1864$ & $\begin{array}{l}\text { Ramírez de } \\
\text { Arellano }\end{array}$ & ------------- \\
\hline 7 & Brochero & Gabriel & $\begin{array}{l}\text { Diocesano de } \\
\text { Córdoba }\end{array}$ & Presb. & 04/11/1866 & $\begin{array}{l}\text { Ramírez de } \\
\text { Arellano }\end{array}$ & $\begin{array}{l}\text { Córdoba. Campaña } \\
\text { San Alberto }\end{array}$ \\
\hline 8 & Yániz & Juan Martín & $\begin{array}{l}\text { Diocesano de } \\
\text { Córdoba }\end{array}$ & Presb. & 04/11/1866 & $\begin{array}{l}\text { Ramírez de } \\
\text { Arellano } \\
\end{array}$ & Córdoba ciudad \\
\hline 9 & Castellano & Domingo & $\begin{array}{l}\text { Diocesano de } \\
\text { Córdoba }\end{array}$ & \begin{tabular}{|l} 
Dimiso- \\
rias para \\
ordenar- \\
se en \\
España \\
\end{tabular} & $20 / 05 / 1867$ & $\begin{array}{l}\text { Ramírez de } \\
\text { Arellano }\end{array}$ & Córdoba. Ciudad \\
\hline 10 & Cabanillas & Filemón & $\begin{array}{l}\text { Diocesano de } \\
\text { Córdoba }\end{array}$ & Presb. & $24 / 06 / 1869$ & $\begin{array}{l}\text { Ramírez de } \\
\text { Arellano }\end{array}$ & Córdoba. Ciudad \\
\hline 11 & Mercado & Eleuterio & $\begin{array}{l}\text { Extra diocesano } \\
\text { Cuyo }\end{array}$ & Presb. & $02 / 11 / 1869$ & $\begin{array}{l}\text { Ramírez de } \\
\text { Arellano }\end{array}$ & $\begin{array}{l}\text { Regresa a Córdoba } \\
\text { en } 1882 \text { y es } \\
\text { destinado a Totoral }\end{array}$ \\
\hline 12 & Félix & Castellano & $\begin{array}{l}\text { Extra diocesano } \\
\text { Salta }\end{array}$ & Presb. & $24 / 06 / 1869$ & $\begin{array}{l}\text { Ramírez de } \\
\text { Arellano }\end{array}$ & ------------ \\
\hline 13 & $\begin{array}{l}\text { Mariño de } \\
\text { Romero }\end{array}$ & José María & $\begin{array}{l}\text { Español, con } \\
\text { dimisorias de su } \\
\text { Prelado el Arzobispo } \\
\text { de Santiago de } \\
\text { Compostela } \\
\end{array}$ & Presb. & $12 / 03 / 1870$ & $\begin{array}{l}\text { Ramírez de } \\
\text { Arellano }\end{array}$ & $\begin{array}{l}\text { Córdoba. Campaña. } \\
\text { Tercero Arriba / } \\
\text { Pampayasta }\end{array}$ \\
\hline 14 & Aguerri & Esteban & $\begin{array}{l}\text { Extra diocesano } \\
\text { Arq. de Bs. As. }\end{array}$ & Presb. & $12 / 03 / 1870$ & $\begin{array}{l}\text { Ramírez de } \\
\text { Arellano }\end{array}$ & ------------- \\
\hline 15 & $\begin{array}{l}\text { Luz de } \\
\text { Cabrera }\end{array}$ & Vicente & $\begin{array}{l}\text { Diocesano de } \\
\text { Córdoba }\end{array}$ & Presb. & $05 / 01 / 1871$ & $\begin{array}{l}\text { Ramírez de } \\
\text { Arellano }\end{array}$ & $\begin{array}{l}\text { La Rioja. Campaña } \\
\text { Chilecito }\end{array}$ \\
\hline 16 & $\begin{array}{l}\text { Luz de } \\
\text { Cabrera }\end{array}$ & Lorenzo & $\begin{array}{l}\text { Diocesano de } \\
\text { Córdoba }\end{array}$ & Presb. & 05/01/1871 & $\begin{array}{l}\text { Ramírez de } \\
\text { Arellano }\end{array}$ & $\begin{array}{l}\text { La Rioja. Campaña } \\
\text { Chilecito }\end{array}$ \\
\hline 17 & Díaz & José María & $\begin{array}{l}\text { Diocesano de } \\
\text { Córdoba } \\
\end{array}$ & Presb. & $06 / 11 / 1871$ & $\begin{array}{l}\text { Ramírez de } \\
\text { Arellano }\end{array}$ & $\begin{array}{l}\text { Córdoba. Ciudad. } \\
\text { Capellanía }\end{array}$ \\
\hline 18 & Gordillo & Basilio & $\begin{array}{l}\text { Diocesano de } \\
\text { Córdoba }\end{array}$ & Presb. & $06 / 11 / 1871$ & $\begin{array}{l}\text { Ramírez de } \\
\text { Arellano }\end{array}$ & Cuidad. Catedral \\
\hline 19 & $\begin{array}{l}\text { Arconte } \\
\text { (Lopez } \\
\text { Archante) }\end{array}$ & José & $\begin{array}{l}\text { Diocesano de } \\
\text { Córdoba }\end{array}$ & Presb. & $06 / 11 / 1871$ & $\begin{array}{l}\text { Ramírez de } \\
\text { Arellano }\end{array}$ & No consta \\
\hline 20 & Padilla & Pablo & $\begin{array}{l}\text { Extra diocesano } \\
\text { Tucumán }\end{array}$ & Presb. & $10 / 12 / 1871$ & $\begin{array}{l}\text { Ramírez de } \\
\text { Arellano }\end{array}$ & |----------- \\
\hline 21 & Moyano & Belarmino & $\begin{array}{l}\text { Diocesano de } \\
\text { Córdoba }\end{array}$ & Presb. & $27 / 04 / 1873$ & $\begin{array}{l}\text { Ramírez de } \\
\text { Arellano }\end{array}$ & No consta \\
\hline
\end{tabular}




\begin{tabular}{|c|c|c|c|c|c|c|c|}
\hline 22 & Ramos & Ambrosio & $\begin{array}{l}\text { Diocesano de } \\
\text { Córdoba }\end{array}$ & Presb. & $27 / 04 / 1873$ & $\begin{array}{l}\text { Ramírez de } \\
\text { Arellano }\end{array}$ & $\begin{array}{l}\text { Anejos Norte. } \\
\text { Campaña }\end{array}$ \\
\hline 23 & Compañy & Miguel & $\begin{array}{l}\text { Diocesano de } \\
\text { Córdoba }\end{array}$ & $\begin{array}{l}\text { Dimiso- } \\
\text { rias para } \\
\text { ordenes } \\
\text { mayores }\end{array}$ & $17 / 02 / 1874$ & $\begin{array}{l}\text { Ramírez de } \\
\text { Arellano }\end{array}$ & San Javier. Campaña \\
\hline 24 & Prieto & $\begin{array}{l}\text { Camilo } \\
\text { Domingo }\end{array}$ & $\begin{array}{l}\text { Diocesano de } \\
\text { Córdoba }\end{array}$ & $\begin{array}{l}\text { Dimiso- } \\
\text { rias para } \\
\text { ordenes } \\
\text { mayores }\end{array}$ & $24 / 03 / 1874$ & $\begin{array}{l}\text { Gaspar } \\
\text { Martiarena. } \\
\text { Vicario } \\
\text { Capitular en } \\
\text { Sede Vacante }\end{array}$ & $\begin{array}{l}\text { Capellán del obispo. } \\
\text { Ciudad }\end{array}$ \\
\hline 25 & $\begin{array}{l}\text { Gerica } \\
\text { (Gherica) }\end{array}$ & Bonifacio & $\begin{array}{l}\text { Natural de Vitoria } \\
\text { España. Diocesano } \\
\text { de Córdoba }\end{array}$ & $\begin{array}{l}\text { Dimiso- } \\
\text { rias para } \\
\text { ordenes } \\
\text { mayores }\end{array}$ & $24 / 03 / 1874$ & $\begin{array}{l}\text { Gaspar } \\
\text { Martiarena. } \\
\text { Vicario } \\
\text { Capitular en } \\
\text { Sede Vacante }\end{array}$ & $\begin{array}{l}\text { Anejos /Santa María } \\
\text { campaña }\end{array}$ \\
\hline 26 & $\begin{array}{l}\text { Martínez } \\
\text { del Val }\end{array}$ & Francisco & $\begin{array}{l}\text { Natural de Sgo. de } \\
\text { Compostela } \\
\text { (España). Diocesano } \\
\text { de Córdoba }\end{array}$ & $\begin{array}{l}\text { Dimiso- } \\
\text { rias para } \\
\text { ordenes } \\
\text { mayores }\end{array}$ & $24 / 03 / 1874$ & $\begin{array}{l}\text { Gaspar } \\
\text { Martiarena. } \\
\text { Vicario } \\
\text { Capitular en } \\
\text { Sede Vacante }\end{array}$ & La Rioja. Campaña \\
\hline
\end{tabular}




\begin{tabular}{|c|c|c|c|c|c|}
\hline \multicolumn{6}{|c|}{$\begin{array}{c}\text { TABLA } 2 \\
\text { Clérigos seculares diocesanos que no alcanzaron el presbiterado } \\
1875-1925\end{array}$} \\
\hline $\begin{array}{l}\text { Apellido y } \\
\text { Nombre }\end{array}$ & Condición & $\begin{array}{c}\text { Orden } \\
\text { Alcanzada } \\
\text { Fecha }\end{array}$ & $\begin{array}{c}\text { Tipo de } \\
\text { orden }\end{array}$ & Ministro y Lugar & Fuentes \\
\hline $\begin{array}{l}\text { Miranda, } \\
\text { Pedro }\end{array}$ & $\begin{array}{l}\text { Alumno interno de } 2^{\circ} \\
\text { año de Filosofía y } \\
\text { Matemáticas del } \\
\text { Seminario Conciliar. } \\
\text { Natural y domiciliario } \\
\text { Diócesis de Córdoba }\end{array}$ & $08 / 09 / 1881$ & $\begin{array}{l}\text { Tonsura y } \\
\text { Ordenes } \\
\text { Menores }\end{array}$ & $\begin{array}{l}\text { Fr. Mamerto } \\
\text { Esquiú. Catedral }\end{array}$ & $\begin{array}{l}\text { AAC. Leg.24 } \\
\text { TIX 1873-1880. } \\
\text { Libro 23. } \\
\text { Ordenes } 1876- \\
1925, \text { f.10 }\end{array}$ \\
\hline $\begin{array}{l}\text { Rodríguez } \\
\text { Jacinto, Cirilo }\end{array}$ & $\begin{array}{l}\text { Alumno de } 3^{\circ} \text { año de } \\
\text { Filosofía y Cs. Exactas }\end{array}$ & $19 / 12 / 1881$ & $\begin{array}{l}\text { Tonsura y } \\
\text { Ordenes } \\
\text { Menores }\end{array}$ & $\begin{array}{l}\text { Fr. Mamerto } \\
\text { Esquiú. Catedral }\end{array}$ & $\begin{array}{l}\text { AAC. Leg.24 } \\
\text { TIX 1873-1880. } \\
\text { Libro 23, } \\
\text { Ordenes } 1876- \\
1925, \text { f.16 }\end{array}$ \\
\hline $\begin{array}{l}\text { López, } \\
\text { Antonio }\end{array}$ & $\begin{array}{l}\text { Natural y domiciliario } \\
\text { Diócesis de Córdoba }\end{array}$ & $08 / 09 / 1883$ & $\begin{array}{l}\text { Tonsura y } \\
\text { Ordenes } \\
\text { Menores }\end{array}$ & Iglesia Catedral & $\begin{array}{l}\text { Libro 23, } \\
\text { Ordenes } 1876- \\
1925, \text { f.11 }\end{array}$ \\
\hline $\begin{array}{l}\text { Alonzo, } \\
\text { Raymundo }\end{array}$ & $\begin{array}{l}\text { Alumno interno de } 4^{\circ} \\
\text { año de Filosofia del } \\
\text { Seminario. Natural y } \\
\text { domiciliario Diócesis } \\
\text { de Córdoba }\end{array}$ & $24 / 05 / 1887$ & $\begin{array}{l}\text { Tonsura y } \\
\text { Ordenes } \\
\text { Menores }\end{array}$ & $\begin{array}{l}\text { Obispo de Cuyo, } \\
\text { de paso por la } \\
\text { ciudad }\end{array}$ & $\begin{array}{l}\text { Libro 23, } \\
\text { Ordenes 1876- } \\
1925\end{array}$ \\
\hline $\begin{array}{l}\text { Barrionuevo, } \\
\text { Juan Manuel }\end{array}$ & $\begin{array}{l}\text { Alumno interno de } 4^{\circ} \\
\text { año de Filosofía del } \\
\text { Seminario }\end{array}$ & $24 / 05 / 1887$ & $\begin{array}{l}\text { Tonsura y } \\
\text { Ordenes } \\
\text { Menores }\end{array}$ & $\begin{array}{l}\text { Obispo de Cuyo, } \\
\text { de paso por la } \\
\text { ciudad }\end{array}$ & $\begin{array}{l}\text { Libro } 23, \\
\text { Ordenes } 1876- \\
1925\end{array}$ \\
\hline $\begin{array}{l}\text { Dávila Porcel, } \\
\text { Ángel }\end{array}$ & $\begin{array}{l}\text { Natural y domiciliario } \\
\text { Diócesis de Córdoba }\end{array}$ & $22 / 08 / 1893$ & $\begin{array}{l}\text { Tonsura y } \\
\text { Ordenes } \\
\text { Menores }\end{array}$ & $\begin{array}{l}\text { Fr. Reginaldo } \\
\text { Toro Catedral }\end{array}$ & $\begin{array}{l}\text { AAC. Libro 23, } \\
\text { Ordenes } 1876- \\
\text { 1925. f.34 }\end{array}$ \\
\hline $\begin{array}{l}\text { Ferreira, } \\
\text { Ignacio }\end{array}$ & $\begin{array}{l}\text { Alumno interno del } \\
\text { Seminario. Natural y } \\
\text { domiciliado en la } \\
\text { Diócesis de Córdoba }\end{array}$ & $24 / 07 / 1898$ & $\begin{array}{l}\text { Tonsura y } \\
\text { Ordenes } \\
\text { Menores }\end{array}$ & $\begin{array}{l}\text { Fr. Reginaldo } \\
\text { Toro. Capilla del } \\
\text { seminario }\end{array}$ & $\begin{array}{l}\text { Leg.24 TXIII } \\
1895-1900 . \\
\text { AAC. Libro 23, } \\
\text { Ordenes 1876- } \\
1925, \text { f.50 }\end{array}$ \\
\hline $\begin{array}{l}\text { Argüello, } \\
\text { Heraclio } \\
\text { Segundo }\end{array}$ & $\begin{array}{l}\text { Alumno de } 3^{\circ} \text { año de } \\
\text { Filosofía del Seminario }\end{array}$ & $10 / 08 / 1902$ & $\begin{array}{l}\text { Tonsura y } \\
\text { Ordenes } \\
\text { Menores }\end{array}$ & $\begin{array}{l}\text { Aquilino Ferreyra } \\
\text { Obispo auxiliar. } \\
\text { Capilla del } \\
\text { Seminario }\end{array}$ & $\begin{array}{l}\text { Leg.24 TXIII, } \\
\text { 1901-1909 }\end{array}$ \\
\hline $\begin{array}{l}\text { Ferreira } \\
\text { Rasposando }\end{array}$ & & $10 / 08 / 1902$ & $\begin{array}{l}\text { Tonsura y } \\
\text { Ordenes } \\
\text { Menores }\end{array}$ & $\begin{array}{l}\text { Aquilino Ferreyra } \\
\text { Obispo auxiliar. } \\
\text { Capilla del } \\
\text { Seminario }\end{array}$ & $\begin{array}{l}\text { AAC. Libro 23, } \\
\text { Libro de } \\
\text { Órdenes, 1876- } \\
1925, \text { f.63 }\end{array}$ \\
\hline $\begin{array}{l}\text { Quiroga, } \\
\text { Antonio } \\
\text { Doroteo }\end{array}$ & $\begin{array}{l}\text { Alumno de } 1^{\circ} \text { año de } \\
\text { Filosofia del Seminario } \\
\text { Conciliar }\end{array}$ & $12 / 08 / 1906$ & $\begin{array}{l}\text { Tonsura y } \\
\text { Ordenes } \\
\text { Menores }\end{array}$ & $\begin{array}{l}\text { Filemón } \\
\text { Cabanillas } \\
\text { Catedral }\end{array}$ & $\begin{array}{l}\text { Leg.24 TXIII, } \\
\text { 1901-1909. } \\
\text { AAC. Libro 23, } \\
\text { Libro de } \\
\text { Órdenes, 1876- } \\
\text { 1925, f.73 }\end{array}$ \\
\hline $\begin{array}{l}\text { Farías Leal, } \\
\text { Ángel }\end{array}$ & $\begin{array}{l}\text { Alumno interno del } \\
\text { Seminario. Natural y } \\
\text { domiciliado en la } \\
\text { Diócesis de Córdoba }\end{array}$ & $06 / 08 / 1911$ & $\begin{array}{l}\text { Tonsura y } \\
\text { Ordenes } \\
\text { Menores }\end{array}$ & $\begin{array}{l}\text { Filemón } \\
\text { Cabanillas Capilla } \\
\text { del Seminario }\end{array}$ & $\begin{array}{l}\text { AAC. Libro 23, } \\
\text { Libro de } \\
\text { Ordenes, 1876- } \\
1925, \text { f.80 }\end{array}$ \\
\hline Pagani, Luis & $\mathrm{Nc}$ & $06 / 08 / 1911$ & Tonsura y & Filemón & AAC. Libro 23, \\
\hline
\end{tabular}




\begin{tabular}{|c|c|c|c|c|c|}
\hline & & & $\begin{array}{l}\text { Ordenes } \\
\text { Menores }\end{array}$ & $\begin{array}{l}\text { Cabanillas Capilla } \\
\text { del Seminario }\end{array}$ & $\begin{array}{l}\text { Libro de } \\
\text { Ordenes, 1876- } \\
1925, \text { f.80 }\end{array}$ \\
\hline Cuello, Gil & $\begin{array}{l}\text { Natural y domiciliado } \\
\text { en la Diócesis de } \\
\text { Córdoba }\end{array}$ & 19/03/1914 & & $\begin{array}{l}\text { Zenón Bustos } \\
\text { Obispo, Capilla } \\
\text { del Seminario }\end{array}$ & $\begin{array}{l}\text { AAC. Libro 23, } \\
\text { Libro de } \\
\text { Ordenes, 1876- } \\
1925, \text { f.82 }\end{array}$ \\
\hline $\begin{array}{l}\text { Maldonado, } \\
\text { Fabián }\end{array}$ & $\begin{array}{l}\text { Natural y domiciliado } \\
\text { en la Diócesis de } \\
\text { Córdoba }\end{array}$ & $19 / 03 / 1914$ & $\begin{array}{l}\text { Tonsura y } \\
\text { Ordenes } \\
\text { Menores }\end{array}$ & $\begin{array}{l}\text { Zenón Bustos } \\
\text { Obispo, Capilla } \\
\text { del Seminario }\end{array}$ & $\begin{array}{l}\text { AAC. Libro 23, } \\
\text { Libro de } \\
\text { Ordenes, 1876- } \\
1925, \text { f.82 }\end{array}$ \\
\hline $\begin{array}{l}\text { Robles, Julio } \\
\text { César }\end{array}$ & $\begin{array}{l}\text { Natural y domiciliado } \\
\text { en la Diócesis de } \\
\text { Córdoba }\end{array}$ & $19 / 03 / 1914$ & $\begin{array}{l}\text { Tonsura y } \\
\text { Ordenes } \\
\text { Menores }\end{array}$ & $\begin{array}{l}\text { Zenón Bustos } \\
\text { Obispo, Capilla } \\
\text { del Seminario }\end{array}$ & $\begin{array}{l}\text { AAC. Libro 23, } \\
\text { Libro de } \\
\text { Ordenes, 1876- } \\
1925, \text { f.82 }\end{array}$ \\
\hline Cuello, Gil & $\begin{array}{l}\text { Natural y domiciliario } \\
\text { de la Diócesis }\end{array}$ & $19 / 03 / 1914$ & $\begin{array}{l}\text { Tonsura y } \\
\text { Ordenes } \\
\text { Menores }\end{array}$ & $\begin{array}{l}\text { Zenón Bustos } \\
\text { Obispo, Capilla } \\
\text { del Seminario }\end{array}$ & $\begin{array}{l}\text { AAC. Libro 23, } \\
\text { Libro de } \\
\text { Ordenes, 1876- } \\
1925, \text { f.82 }\end{array}$ \\
\hline $\begin{array}{l}\text { Brandan, } \\
\text { Tristán }\end{array}$ & $\begin{array}{l}\text { Natural y domiciliado } \\
\text { en la Diócesis de } \\
\text { Córdoba }\end{array}$ & $14 / 03 / 1915$ & $\begin{array}{l}\text { Tonsura y } \\
\text { Ordenes } \\
\text { Menores }\end{array}$ & $\begin{array}{l}\text { Zenón Bustos } \\
\text { Obispo, Capilla } \\
\text { del Seminario }\end{array}$ & $\begin{array}{l}\text { AAC. Libro 23, } \\
\text { Libro de } \\
\text { Ordenes, 1876- } \\
1925, \text { f.83 }\end{array}$ \\
\hline $\begin{array}{l}\text { López, } \\
\text { Ambrosio }\end{array}$ & $\begin{array}{l}\text { Natural y domiciliado } \\
\text { en la Diócesis de } \\
\text { Córdoba }\end{array}$ & $18 / 03 / 1917$ & $\begin{array}{l}\text { Tonsura y } \\
\text { Ordenes } \\
\text { Menores }\end{array}$ & $\begin{array}{l}\text { Inocencio Dávila } \\
\text { Capilla del } \\
\text { Seminario }\end{array}$ & $\begin{array}{l}\text { AAC. Libro 23, } \\
\text { Libro de } \\
\text { Ordenes, 1876- } \\
1925 \text {, f.90 }\end{array}$ \\
\hline $\begin{array}{l}\text { Pelliza, } \\
\text { Alberto }\end{array}$ & $\begin{array}{l}\text { Natural y domiciliado } \\
\text { en la Diócesis de } \\
\text { Córdoba }\end{array}$ & $18 / 03 / 1917$ & $\begin{array}{l}\text { Tonsura y } \\
\text { Ordenes } \\
\text { Menores }\end{array}$ & $\begin{array}{l}\text { Inocencio Dávila } \\
\text { Capilla del } \\
\text { Seminario }\end{array}$ & $\begin{array}{l}\text { AAC. Libro 23, } \\
\text { Libro de } \\
\text { Ordenes, 1876- } \\
1925 \text {, f.90 }\end{array}$ \\
\hline $\begin{array}{l}\text { Villarubia } \\
\text { González, } \\
\text { Ricardo }\end{array}$ & $\begin{array}{l}\text { Domiciliado en la } \\
\text { Diócesis de Córdoba }\end{array}$ & $13 / 04 / 1918$ & $\begin{array}{l}\text { Tonsura y } \\
\text { Ordenes } \\
\text { Menores }\end{array}$ & $\begin{array}{l}\text { Luque, José A } \\
\text { Catedral }\end{array}$ & $\begin{array}{l}\text { AAC. Libro 23, } \\
\text { Libro de } \\
\text { Ordenes, 1876- } \\
1925, \text { f.85 }\end{array}$ \\
\hline Hera, José A. & $\begin{array}{l}\text { Domiciliado en la } \\
\text { Diócesis de Córdoba }\end{array}$ & $07 / 12 / 1919$ & $\begin{array}{l}\text { Tonsura y } \\
\text { Ordenes } \\
\text { Menores }\end{array}$ & $\begin{array}{l}\text { Luque, José A } \\
\text { Seminario }\end{array}$ & $\begin{array}{l}\text { AAC. Libro 23, } \\
\text { Libro de } \\
\text { Órdenes, 1876- } \\
1925, \text { f.88 }\end{array}$ \\
\hline $\begin{array}{l}\text { López, } \\
\text { Ambrosio }\end{array}$ & $\begin{array}{l}\text { Domiciliado en la } \\
\text { Diócesis de Córdoba }\end{array}$ & $14 / 03 / 1920$ & $\begin{array}{l}\text { Tonsura y } \\
\text { Ordenes } \\
\text { Menores }\end{array}$ & $\begin{array}{l}\text { Luque, José A } \\
\text { Seminario }\end{array}$ & $\begin{array}{l}\text { Libro de } \\
\text { Órdenes, 1876- } \\
1925, \text { f.88 }\end{array}$ \\
\hline Díaz, Amado & $\begin{array}{l}\text { Domiciliado en la } \\
\text { Diócesis de Córdoba }\end{array}$ & $17 / 03 / 1923$ & Diaconado & $\begin{array}{l}\text { Luque, José A } \\
\text { Seminario }\end{array}$ & $\begin{array}{l}\text { Libro de } \\
\text { Órdenes, 1876- } \\
1925, \text { f.92 }\end{array}$ \\
\hline $\begin{array}{l}\text { Deco, } \\
\text { Ricardo }\end{array}$ & & $02 / 12 / 1923$ & $\begin{array}{l}\text { Acolitado y } \\
\text { exorcistado }\end{array}$ & $\begin{array}{l}\text { Inocencio Dávila. } \\
\text { Obispo Auxiliar. } \\
\text { Catedral. }\end{array}$ & $\begin{array}{l}\text { Libro de } \\
\text { Órdenes, 1876- } \\
1925, \text { f.96 }\end{array}$ \\
\hline
\end{tabular}




\begin{tabular}{|c|l|l|l|c|}
\hline \multicolumn{7}{|c|}{\begin{tabular}{l} 
TABLA 3 \\
\multicolumn{7}{|c|}{ VISITAS PASTORALES EN LA PROVINCIA DE CÓRDOBA } \\
OBISPO ÁLVAREZ
\end{tabular}} \\
\hline $\mathbf{N}^{\circ}$ & \multicolumn{1}{|c|}{ Cugar } & \multicolumn{1}{c|}{ Curato } & Departamento & Fecha \\
\hline 1 & Cruz del Eje & Cruz del Eje & Cruz de Eje & $30 / 04 / 1877$ \\
\hline 2 & Bell Ville & Bell Ville & Unión & $17 / 05 / 1877$ \\
\hline 3 & Totoral & Totoral & Totoral & $14 / 09 / 1877$ \\
\hline 4 & Ischilín & Ischilín & Ischilín & $06-15 / 10 / 1877$ \\
\hline
\end{tabular}

\begin{tabular}{|c|c|c|c|c|}
\hline \multicolumn{5}{|c|}{$\begin{array}{l}\text { VISITAS PASTORALES EN LA PROVINCIA DE CÓRDOBA } \\
\text { OBISPO ESQUIÚ }\end{array}$} \\
\hline $\mathbf{N}^{\circ}$ & Lugar & Curato & Departamento & Fecha \\
\hline 1 & Tulumba & Tulumba & Tulumba & 14 al 22/02/1882 \\
\hline 2 & Quilino & Quilino & Ischilín & $23 / 02 / 1882$ \\
\hline 3 & $\begin{array}{l}\text { Villa María del Río } \\
\text { Seco }\end{array}$ & Río Seco & Río Seco & $00 / 02 / 1882$ \\
\hline 4 & Avellaneda & Ischilín & Ischilín & $00 / 02 / 1882$ \\
\hline $4 *$ & Jesús María & Totoral & Anejos Norte & 6-9/03/1882 \\
\hline & Quilino & Quilino & Ischilín & 09 al $12 / 03 / 1882$ \\
\hline 5 & $\begin{array}{l}\text { San José de la } \\
\text { Dormida }\end{array}$ & Tulumba & Tulumba & 16 al 19/03/1882 \\
\hline 6 & $\begin{array}{l}\text { San Gerónimo de } \\
\text { Fraile Muerto }\end{array}$ & Bell Ville & Unión & $\begin{array}{l}9 / 05 / 1882 \text { al } \\
30 / 06 / 1882\end{array}$ \\
\hline 7 & Cruz Alta & Bell Ville & Unión & $14 / 05 / 1882$ \\
\hline 8 & San José & Bell Ville & Unión & $21 / 05 / 1882$ \\
\hline 10 & Las Cañas & Bell Ville & Unión & $23 / 05 / 1882$ \\
\hline 9 & El Saladillo & Bell Ville & Unión & $24 / 05 / 1882$ \\
\hline 11 & $\begin{array}{l}\text { San Gerónimo Bell } \\
\text { Ville }\end{array}$ & Bell Ville & Unión & 30 al 5/06/1882 \\
\hline 12 & Piquillín & Remedios & Río Primero & $14 / 06 / 1882$ \\
\hline 13 & Mercedes & Remedios & Río Primero & -------- \\
\hline 14 & Carlota & Río Cuarto & Juárez Celman & $16 / 06 / 1882$ \\
\hline 15 & Villa Nueva & Villa Nueva & Tercero Abajo & $28 / 06 / 1822$ \\
\hline 16 & Ballesteros & Bell Ville & Unión & $21 / 07 / 1882$ \\
\hline 17 & San Antonio de Litín & Bell Ville & Unión & $10 / 08 / 1882$ \\
\hline 18 & Sacanta & San Justo & San Justo & $01 / 09 / 1882$ \\
\hline 19 & $\begin{array}{l}\text { Villa Concepción del } \\
\text { Tío }\end{array}$ & San Justo & San justo & $06 / 09 / 1882$ \\
\hline 20 & Arroyito & San Justo & San Justo & $24 / 09 / 1882$ \\
\hline 21 & $\begin{array}{l}\text { Capilla Ntra. Sra. de } \\
\text { Lujan de las Cañas }\end{array}$ & & Río Segundo & $27 / 09 / 1882$ \\
\hline 22 & Villa del Rosario & Villa del Rosario & Villa del Rosario & $\begin{array}{l}29 / 09 / 1882 \text { y } \\
25 / 10 / 1882\end{array}$ \\
\hline 23 & Oratorio de Peralta & Río Segundo & Villa del Rosario & $16 / 11 / 1882$ \\
\hline 24 & El Tránsito & San Justo & San Justo & $6 / 11 / 1882$ \\
\hline 25 & $\begin{array}{l}\text { Casa de Eusebio } \\
\text { Sarmiento Corral de } \\
\text { Mulas }\end{array}$ & Villa del Rosario & Río Segundo & 22 al 30/11/1882 \\
\hline 26 & Capilla Jesús & Villa María & Tercero Abajo & $01 / 12 / 1882$ \\
\hline
\end{tabular}




\begin{tabular}{|l|l|l|l|c|}
\hline & Nazareno & & & \\
\hline 27 & Chañares & Villa María & Río Segundo & $13 / 12 / 1882$ \\
\hline 28 & Jesús María & Jesús María & Anejos Norte & 15 al 19/03/1883 \\
\hline
\end{tabular}

\begin{tabular}{|c|c|c|c|c|}
\hline \multicolumn{5}{|c|}{$\begin{array}{l}\text { VISITAS PASTORALES EN LA PROVINCIA DE CÓRDOBA } \\
\text { OBISPO TISSERA }\end{array}$} \\
\hline $\mathbf{N}^{\circ}$ & Lugar & Curato & Departamento & Fecha \\
\hline 1 & Alta Gracia & Punilla & & $30 / 01$ al $25 / 02 / 1886$ \\
\hline 2 & Capilla de Cosme & Punilla & & $07 / 02 / 1886$ \\
\hline 3 & Capilla San Antonio & Alta Gracia & Anejos sud & $09 / 02 / 1886$ \\
\hline 4 & Capilla del Tránsito & Alta Gracia & Anejos sud & $14 / 02 / 1886$ \\
\hline 5 & $\begin{array}{l}\text { Vice Parroquia de la } \\
\text { Candelaria }\end{array}$ & Alta Gracia & Anejos sud & $20 / 02 / 1886$ \\
\hline \multirow[t]{3}{*}{6} & Capilla del Carmen & Alta Gracia & Anejos sud & $21 / 02 / 1886$ \\
\hline & Ischilín & Ischilín & Ischilín & $25 / 03 / 1886$ \\
\hline & Iglesia Parroquial & Cruz del Eje & Cruz del Eje & $26-27 / 03 / 1886$ \\
\hline 7 & $\begin{array}{l}\text { Higuera (capilla } \\
\text { inhabilitada) }\end{array}$ & San Carlos Minas & Minas & $28 / 03$ al $15 / 05 / 1886$ \\
\hline 8 & $\begin{array}{l}\text { Capilla Ciénaga del } \\
\text { Coro }\end{array}$ & San Carlos Minas & San Carlos Minas & 28 al $31 / 03 / 1886$ \\
\hline 9 & $\begin{array}{l}\text { Capilla de } \\
\text { Guasapampa }\end{array}$ & San Carlos Minas & San Carlos Minas & 04 al 07/04/1886 \\
\hline 10 & Capilla de Ninalquín & San Carlos Minas & San Carlos Minas & 08 al 12/04/1886 \\
\hline 11 & $\begin{array}{l}\text { Capilla Parroquia de } \\
\text { San Carlos }\end{array}$ & San Carlos Minas & San Carlos Minas & $15 / 04 / 1886$ \\
\hline 12 & Parroquia Salsacate & Pocho & Pocho & 16 al 23/04/1886 \\
\hline 13 & $\begin{array}{l}\text { Capilla de las } \\
\text { Palmas }\end{array}$ & Pocho & Pocho & $26 / 04 / 1886$ \\
\hline 13 & Capilla de Pocho & Pocho & Pocho & $27 / 04 / 1886$ \\
\hline 14 & $\begin{array}{l}\text { Capilla de Chancani } \\
\text { Ntra. Sra. del } \\
\text { Carmen }\end{array}$ & Pocho & Pocho & 03 al 06/05/1886 \\
\hline 15 & Parroquia de Pocho & Pocho & Pocho & $15 / 05 / 1886$ \\
\hline 16 & $\begin{array}{l}\text { Iglesia de Villa } \\
\text { Dolores }\end{array}$ & San Javier & San Javier & $05 / 05 / 1886$ \\
\hline 17 & $\begin{array}{l}\text { Parroquia de San } \\
\text { Pedro }\end{array}$ & San Alberto & San Javier & $11-12 / 05 / 1886$ \\
\hline 18 & Capilla San Antonio & San Alberto & San Javier & $13 / 05 / 1886$ \\
\hline 19 & $\begin{array}{l}\text { Parroquia de San } \\
\text { Javier }\end{array}$ & San Javier & San Javier & $17 / 06 / 1886$ \\
\hline 20 & Capilla Las Rosas & San Javier & San Javier & 21 al $23 / 06 / 1886$ \\
\hline 21 & $\begin{array}{l}\text { Vice-Parroquia de } \\
\text { Nono }\end{array}$ & Tránsito & San Alberto & $25 / 06 / 1886$ \\
\hline 22 & Capilla Panaholma & Tránsito & San Alberto & $04 / 07 / 1886$ \\
\hline 23 & Capilla Ambul & Tránsito & San Alberto & $04 / 07 / 1886$ \\
\hline 24 & Parroquia Tránsito & Tránsito & San Alberto & $24 / 07 / 1886$ \\
\hline
\end{tabular}




\begin{tabular}{|c|c|c|c|c|}
\hline \multicolumn{5}{|c|}{$\begin{array}{l}\text { TABLA } 4 \\
\text { VISTAS PASTORALES EN LA PROVINCIA DE CÓRDOBA } \\
\text { OBISPO TORO }\end{array}$} \\
\hline $\mathbf{N}^{\circ}$ & Lugar & Curato & Departamento & Fecha \\
\hline 1 & Iglesia Parroquial de Concepción & San Justo & San Justo & $12 / 12 / 1888$ \\
\hline & $\begin{array}{l}\text { Parroquia San Gerónimo de Bell } \\
\text { Ville }\end{array}$ & Unión & Unión & $08-10$ y $12 / 12 / 1888$ \\
\hline & Capilla San Agustín & Calamuchita & Calamuchita & $21 / 03$ al $07 / 04 / 1889$ \\
\hline & Capilla Los Reartes & Calamuchita & Calamuchita & $21 / 03$ al $07 / 04 / 1889$ \\
\hline & Parroquia Santa Rosa & Calamuchita & Calamuchita & $21 / 03$ al $07 / 04 / 1889$ \\
\hline & Deán Funes & Deán Funes & Totoral & $25-30 / 05 / 1889$ \\
\hline & Cruz del Eje & Cruz del Eje & Cruz del Eje & 05/06/1889 \\
\hline & Soto & Soto & Cruz del Eje & $00 / 06 / 1889$ \\
\hline & La Higuera & Soto & Cruz del Eje & $00 / 06 / 1889$ \\
\hline & Salsacate & Pocho & Pocho & $00 / 06 / 1889$ \\
\hline & Tránsito & Tránsito & San Alberto & $00 / 06 / 1889$ \\
\hline & Alta Gracia & Santa María & Santa María & $00 / 08 / 1889$ \\
\hline & Río Segundo & Río Segundo & Río Segundo & 1890 \\
\hline & Carlota & La Carlota & Juárez Celman & 1890 \\
\hline & Reducción & La Carlota & Juárez Celman & 1890 \\
\hline & Parroquia La Merced & Río de los Sauces & Calamuchita & $30 / 04 / 1890$ \\
\hline & Capilla de la Cruz & Río de los Sauces & Calamuchita & $13 / 04 / 1890$ \\
\hline & Igl. Parroquial Villa Mitre & Totoral & Totoral & $10 / 07 / 1890$ \\
\hline & Capilla Avellaneda & Ischilín & Ischilín & 09-10/07/1892 \\
\hline & Capilla Copacabana & Ischilín & Ischilín & $17-19 / 07 / 1892$ \\
\hline & Oratorio Privado de La Paz & Ischilín & Ischilín & $18 / 02 / 1894$ \\
\hline & Capilla Santa Catalina & Ischilín & Ischilín & $20 / 04 / 1894$ \\
\hline & Capilla Santa Catalina & Ischilín & Ischilín & $21 / 04 / 1894$ \\
\hline & Capilla Santa Catalina & Ischilín & Ischilín & 22/04/1894 \\
\hline & Leones & La Asunción & Marcos Juárez & $15-18 / 08 / 1893$ \\
\hline & Capilla Cruz Alta Ntra. Sra. Rosario & La Asunción & Marcos Juárez & $\begin{array}{c}08-10 / 09 / 1893 \\
20 / 10 / 1893\end{array}$ \\
\hline & La Asunción & Marcos Juárez & Marcos Juárez & $11 / 09 / 1893$ \\
\hline & $\begin{array}{l}\text { Parroquia San Gerónimo de Bell } \\
\text { Ville }\end{array}$ & Unión & Unión & $20 / 10 /$ y $09 / 12 / 1893$ \\
\hline & Oratorio de la Cañada del Rosario & Ischilín & Ischilín & $06 / 02 / 1895$ \\
\hline & Parroquia Ntra. Sra. del Carmen & Deán Funes & Ischilín & $04 / 05 / 1898$ \\
\hline & Iglesia de Montserrat & Caroya & Anejos Norte & $05 / 05 / 1898$ \\
\hline & Igl. San Bartolomé Morteros & Morteros & & $23-25 / 08 / 1899$ \\
\hline
\end{tabular}




\begin{tabular}{|c|c|c|c|c|}
\hline \multicolumn{5}{|c|}{$\begin{array}{c}\text { VISTAS PASTORALES EN LA PROVINCIA DE CÓRDOBA } \\
\text { ULADILAO CASTELLANO ( OBISPO TORO) }\end{array}$} \\
\hline $\mathbf{N}^{\circ}$ & Lugar & Curato & Fecha & Visitador \\
\hline \multirow[t]{16}{*}{1} & Santa Rosa de Río $1^{\circ}$ & Santa Rosa & $02 / 04 / 1889$ & Uladislao Castellano \\
\hline & Parroquia Ntra. Sra. del Rosario & Tulumba & $25-29 / 05 / 1889$ & Uladislao Castellano \\
\hline & Iglesia San José de la Dormida & Tulumba & $25-29 / 05 / 1889$ & Uladislao Castellano \\
\hline & Parroquia de Villa Mitre & Totoral & $30 / 05 / 1889$ & Uladislao Castellano \\
\hline & Parroquia San Francisco del Chañar & Chañar & $01-15 / 07 / 1890$ & Uladislao Castellano \\
\hline & Capilla Chuñahuasi & Chañar & $01-15 / 07 / 1890$ & Uladilao Castellano \\
\hline & Capilla Caminiaga & Chañar & $01-15 / 07 / 1890$ & Uladislao castellano \\
\hline & Villa Cruz del Eje, Parroquia & cruz del Eje & $02-03 / 09 / 1893$ & Uladislao Castellano \\
\hline & $\begin{array}{l}\text { Oratorio Público Cañada del Río } \\
\text { Pinto }\end{array}$ & Ischilín & $27 / 01 / 1895$ & Uladislao Castellano \\
\hline & Villa Cruz del Eje Parroquia & Cruz del Eje & $04-05 / 02 / 1895$ & Uladislao Castellano \\
\hline & Oratorio de la Cañada del Rosario & Cruz del Eje & $06 / 02 / 1895$ & Uladislao Castellano \\
\hline & Villa Sarmiento & Río Cuarto & $\begin{array}{l}17,26-31 / 07 / y \\
01 / 08 / 1895\end{array}$ & Uladislao Castellano \\
\hline & El Nacional & Río Cuarto & $3-4 / 08 / 1895$ & Uladislao Castellano \\
\hline & El Cristiano & Río Cuarto & $5-10 / 08 / 1895$ & Uladislao Castellano \\
\hline & El Retiro & Río Cuarto & $11 / 08 / 1895$ & Uladislao Castellano \\
\hline & Washington & Rio Cuarto & $12 / 08 / 1895$ & Uladislao Castellano \\
\hline
\end{tabular}

\begin{tabular}{|l|l|l|c|l|}
\hline \multicolumn{5}{|c|}{$\begin{array}{c}\text { VISTAS PASTORALES EN LA PROVINCIA DE CÓRDOBA } \\
\text { AQUILINO FERREYRA (OBISPO TORO) }\end{array}$} \\
\hline \multicolumn{1}{|c|}{ Lugar } & \multicolumn{1}{|c|}{ Curato } & \multicolumn{1}{c|}{ Fecha } & \multicolumn{1}{c|}{ Visitador } \\
\hline & \multicolumn{1}{|c|}{ Capilla de San Marcos } & Cruz del Eje & $03-06 / 10 / 1890$ & Aquilino Ferreyra \\
\hline & Capilla de Salsipuedes & Jesús María & $13 / 11 / 1890$ & Aquilino F. \\
\hline & Capilla de San Marcos & Cruz del Eje & $07 / 10 / 1903$ & Aquilino Ferreyra \\
\hline & $\begin{array}{l}\text { Iglesia Parroquial Monte del } \\
\text { Rosario }\end{array}$ & Chalacea & $18 / 05$ al 03/06/1891 & Aquilino F. \\
\hline & $\begin{array}{l}\text { Oratorio Público Ntra. Señora del } \\
\text { Rosario de Avellaneda }\end{array}$ & Ischilín & $29 / 01 / 1898$ & Ferreyra Aquilino \\
\hline & Parroquia La Merced & La Carlota & & Aquilino Ferreyra \\
\hline & $\begin{array}{l}\text { Parroquia San Gerónimo de Bell } \\
\text { Ville }\end{array}$ & Unión & $28 / 04$ al 5/05/1892 & Aquilino Ferreyra \\
\hline & $\begin{array}{l}\text { Parroquia San Gerónimo de Bell } \\
\text { Ville }\end{array}$ & Unión & $25 / 08 / 1896$ & Ferreyra Aquilino \\
\hline & $\begin{array}{l}\text { Parroquia San Gerónimo de Bell } \\
\text { Ville }\end{array}$ & Unión & $19 / 05 / 1897$ & De La Lastra Rosendo \\
\hline & $\begin{array}{l}\text { Parroquia San Gerónimo de Bell } \\
\text { Ville }\end{array}$ & Unión & $26-28 / 10 / 1898$ & Ferreyra Aquilino \\
\hline & $\begin{array}{l}\text { Parroquia San Gerónimo de Bell } \\
\text { Ville }\end{array}$ & Unión & $05-06 / 11 / 1898$ & Ferreyra Aquilino \\
\hline & Parroquia San Bartolomé & Morteros & $23-25 / 08 / 1899$ & Ferreyra Aquilino \\
\hline & Parroquia de La Merced & La Carlota & $20 / 09 / 1900$ & Ferreyra Aquilino \\
\hline
\end{tabular}




\begin{tabular}{|c|c|c|c|c|}
\hline \multicolumn{5}{|c|}{$\begin{array}{c}\text { TABLA 5 } \\
\text { VISITAS PASTORALES EN LA PROVINCIA DE CÓRDOBA } \\
\text { ZENÓN BUSTOS, 1905-1912 }\end{array}$} \\
\hline $\mathbf{N}^{\circ}$ & Lugar & Curato & Departamento & Fecha \\
\hline 1 & Parroquia Inmaculada Concepción & Villa María & Tercero Abajo & $26 / 10 / 1905$ \\
\hline 2 & Parr. Ntra. Sra. del Rosario & Villa Nueva & Tercero Abajo & $24 / 10 / 1905$ \\
\hline 3 & Parr. Inmaculada Concepción & Río Cuarto & Río Cuarto & $09 / 11 / 1905$ \\
\hline 4 & Parr. Ángeles Custodios & Sampacho & Río Cuarto & $12 / 11 / 1905$ \\
\hline 5 & Parr. San Javier & San Javier & San Javier & $18 / 11 / 1905$ \\
\hline 6 & Parr. San Pedro Apóstol & San Alberto & San Alberto & 24/11/1905 \\
\hline 7 & Parr. Ntra. Sra. de las Mercedes & Alta Gracia & Santa María & $01 / 03 / 1906$ \\
\hline 8 & Parr. Ntra. Sra. del Rosario & Villa del Rosario & Río Segundo & $03 / 08 / 1906$ \\
\hline 9 & Parr. Inmaculada Concepción & $\begin{array}{l}\text { San Gerónimo de } \\
\text { Bell Ville }\end{array}$ & Tercero Abajo & $10 / 08 / 1906$ \\
\hline 10 & Parr. Ntra. Sra. del Rosario & Cruz Alta & Marcos Juárez & $23 / 08 / 1906$ \\
\hline 11 & Parr. Inmaculada Concepción & Villa María & Tercero Abajo & $26 / 09 / 1906$ \\
\hline 12 & Parr. Ntra. Sra. del Rosario & Río Seco & Río Seco & $11 / 10 / 1906$ \\
\hline 13 & Parr. San Isidro Labrador & Jesús María & Colón & $28 / 02 / 1907$ \\
\hline 14 & $\begin{array}{l}\text { Santuario El Señor de la Buena Muerte } \\
\text { de Reducción }\end{array}$ & La Carlota & Juárez Celman & $04 / 05 / 1907$ \\
\hline 16 & Parr. Ntra. Sra. del Rosario Cruz Alta & Cruz Alta & Marcos Juárez & $23 / 08 / 1907$ \\
\hline 17 & Parr. Anunciación Arias & Canals/Arias & Marcos Juárez & $02 / 09 / 1907$ \\
\hline 18 & Parr. V. Concepción del Tío & San Justo & San Justo & $01 / 10 / 1907$ \\
\hline 19 & San Francisco & San Francisco & San Justo & $5 / 10 / 1907$ \\
\hline 20 & Parr. San Bartolomé & Morteros & San Justo & $21 / 10 / 1907$ \\
\hline 21 & Parr. Villa Concepción del Tío & San Justo & San Justo & 26/10/1907 \\
\hline 22 & Parr. Remedios & Remedios & Río Primero & $00 / 11 / 1907$ \\
\hline \multirow[t]{2}{*}{23} & Santa Rosa de Río Primero & Santa Rosa & Río Primero & $00 / 11 / 1907$ \\
\hline & Hermanas Dominicas & Santa Rosa & Río Primero & $00 / 11 / 1907$ \\
\hline 24 & Parr. San Antonio & Chalacea & Río Primero & $05 / 11 / 1907$ \\
\hline 25 & Parr. Ntra. Sra. Mercedes & Altagracia & Santa María & $00 / 10 / 1907$ \\
\hline 26 & Parr. Virgen de Monserrat & Caroya & Colón & $11 / 03 / 1908$ \\
\hline 27 & $\begin{array}{l}\text { Igl. Ntra. Sra. de los Dolores de Río } \\
\text { Ceballos }\end{array}$ & Colón & Colón & $12 / 03 / 1908$ \\
\hline 28 & Igl. Ntra. Sra. del Rosario & Ischilín & Ischilín & $16 / 03 / 1908$ \\
\hline 29 & $\begin{array}{l}\text { Parr. Ntra. Sra. del Carmen de Deán } \\
\text { Funes }\end{array}$ & Ischilín & Ischilín & 18/03/1908 \\
\hline 30 & Parr. San Francisco Solano & $\begin{array}{l}\text { San Francisco del } \\
\text { Chañar }\end{array}$ & Sobremonte & 20/03/1908 \\
\hline 31 & Parr. Ntra. Sra. del Carmen & Cruz del Eje & Cruz del Eje & $22 / 03 / 1908$ \\
\hline 32 & Parr. San Roque & Soto & Soto & 26/03/1908 \\
\hline 33 & Parr. Inmaculada Concepción & San Carlos Minas & Minas & $05 / 04 / 1908$ \\
\hline 34 & Parr. Ntra. Sra. del Rosario & Pocho & Pocho & $00 / 04 / 1808$ \\
\hline \multirow[t]{2}{*}{35} & Parr. Ntra. Sra. del Tránsito & Tránsito & San Alberto & $07 / 04 / 1908$ \\
\hline & Hermanas Esclavas & Tránsito & San Alberto & $08 / 04 / 1908$ \\
\hline
\end{tabular}




\begin{tabular}{|c|c|c|c|c|}
\hline 36 & Parr. San Agustín & Calamuchita & Calamuchita & $13 / 04 / 1908$ \\
\hline 37 & Parr. Ntra. Sra. de la Merced. & La Cruz & Calamuchita & $15 / 04 / 1908$ \\
\hline 39 & Parr. San Francisco Solano & $\begin{array}{l}\text { San Francisco del } \\
\text { Chañar }\end{array}$ & Sobremonte & $24 / 07 / 1908$ \\
\hline 39 & Parr. San Roque de Quilino & Quilino & Ischilín & $29 / 07 / 1908$ \\
\hline 40 & Parr. Ntra. Sra. del Rosario & Cruz Alta & Marcos Juárez & $24 / 10 / 1908$ \\
\hline 41 & Capilla Matacos/ Colonia Bargés & Cruz Alta & Marcos Juárez & $24 / 10 / 1908$ \\
\hline 42 & Capilla La Italiana & Cruz Alta & Marcos Juárez & $25 / 10 / 1908$ \\
\hline 43 & Parr. La Anunciación & Arias & Marcos Juárez & $02 / 08 / 1908$ \\
\hline 44 & Parr. Inmaculada Concepción & Río Cuarto & Río Cuarto & $00 / 00 / 1909$ \\
\hline 45 & Parr. Ntra. Sra. de Lourdes & Río Segundo & Río Segundo & $24 / 02 / 1910$ \\
\hline 46 & Parr. Ntra. Señora del Rosario & Tulumba & Tulumba & $05 / 10 / 1910$ \\
\hline 47 & Parr. Nuestra Señora del Rosario & Totoral & Totoral & $17 / 10 / 1910$ \\
\hline 48 & Parr. San Antonio & Chalacea & Río Primero & $00 / 00 / 1910$ \\
\hline 49 & Iglesia de Candelaria & Minas & Minas & $09 / 01 / 1911$ \\
\hline 50 & Iglesia de Concepción & Minas & Minas & $23 / 01 / 1911$ \\
\hline 51 & $\begin{array}{l}\text { Iglesias del Valle de Calamuchita } \\
\text { Igl. Villa Dolores }\end{array}$ & San Javier & San Javier & \multirow[t]{7}{*}{$\begin{array}{c}12 \text { al } \\
17 / 04 / 1912\end{array}$} \\
\hline 52 & Parr. San Javier & San Javier & San Javier & \\
\hline 53 & $\begin{array}{l}\text { Iglesias del Valle de Calamuchita } \\
\text { Parr. San Pedro }\end{array}$ & San Alberto & San Alberto & \\
\hline 54 & $\begin{array}{l}\text { Iglesias del Valle de Calamuchita } \\
\text { Parr. Tránsito }\end{array}$ & Tránsito & San Alberto & \\
\hline 55 & $\begin{array}{l}\text { Iglesias del Valle de Calamuchita } \\
\text { Parr. Ntra. Sra del Rosario }\end{array}$ & Pocho & Pocho & \\
\hline 56 & $\begin{array}{l}\text { Iglesias del Valle de Calamuchita } \\
\text { Parr. Inmaculada Concepción }\end{array}$ & Minas & Minas & \\
\hline 57 & $\begin{array}{l}\text { Iglesias del Valle de Calamuchita } \\
\text { Parr. San Roque }\end{array}$ & Soto & Soto & \\
\hline 58 & Santuario de Reducción & La Carlota & Juárez Celman & $02 / 05 / 1912$ \\
\hline 59 & Parr. Inmaculada Concepción & Tercero Arriba & Tercero Arriba & $09 / 05 / 1912$ \\
\hline 60 & Parr. Ntra. Sra. del Rosario a & Cruz Alta & Marcos Juárez & $09 / 09 / 1912$ \\
\hline
\end{tabular}

\begin{tabular}{|c|c|c|c|c|}
\hline \multicolumn{5}{|c|}{$\begin{array}{l}\text { VISITAS PASTORALES EN LA PROVINCIA DE CÓRDOBA } \\
\text { OBISPO ZENÓN BUSTOS Y FERREYRA, 1913-1919 }\end{array}$} \\
\hline$n^{\circ}$ & Lugar & Curato & Departamento & Fecha \\
\hline 1 & $\begin{array}{l}\text { Parroquia de Inmaculada } \\
\text { Concepción }\end{array}$ & Río Cuarto & Río Cuarto & $25 / 01 / 1913$ \\
\hline 2 & Parroquia Los Ángeles Custodios & Sampacho & Rio Cuarto & $19 / 06 / 1913$ \\
\hline 3 & Santuario de Reducción & La Carlota & Juárez Celman & $26 / 06 / 1913$ \\
\hline 4 & Parroquia Las Mercedes & La Carlota & Juárez Celman & $27 / 06 / 1913$ \\
\hline 5 & Parroquia Ntra. Sra. Del Rosario & Villa Nueva & Tercero Abajo & $30 / 06 / 1913$ \\
\hline 6 & Capilla San Francisco & $\begin{array}{l}\text { Cañada Verde } \\
\text { Villa Sarmiento }\end{array}$ & Gral Roca & $21 / 07 / 1913$ \\
\hline 7 & Parr. Natividad de María & Cañada Verde & Gral. Roca & $31 / 07 / 1913$ \\
\hline 8 & Vice Parroquia Buchardo & Laboulaye & Gral. Roca & $31 / 07 / 1913$ \\
\hline 9 & Parroquia Cristo Redentor & Laboulaye & Gral. Roca & $01 / 08 / 1913$ \\
\hline
\end{tabular}




\begin{tabular}{|c|c|c|c|c|}
\hline 10 & Cruz del Eje & Cruz del Eje & Cruz del Eje & $13 / 08 / 1913$ \\
\hline 11 & Soto & Soto & Cruz del Eje & $17 / 08 / 1913$ \\
\hline 12 & Río Cuarto & Rio Cuarto & Rio Cuarto & $14 / 09 / 1913$ \\
\hline 13 & San Justo & San Justo & San Justo & $18 / 09 / 1913$ \\
\hline 14 & $\begin{array}{l}\text { Parroquia de las Mercedes. } \\
\text { Arroyito }\end{array}$ & Arroyito & San Justo & $18 / 09 / 1913$ \\
\hline 15 & Santuario de Reducción & La Carlota & Juárez Celman & $\begin{array}{l}04 \text { al } \\
11 / 05 / 1914\end{array}$ \\
\hline 16 & $\begin{array}{l}\text { Parroquia San José. Estación } \\
\text { Cabrera }\end{array}$ & Gral. Cabrera & Juárez Celman & $05 / 05 / 1914$ \\
\hline 17 & $\begin{array}{l}\text { Parroquia Ntra. Señora de Luján } \\
\text { (Dalmasio Vélez) }\end{array}$ & Dalmasio Vélez & Tercero Abajo & $06 / 05 / 1914$ \\
\hline 18 & $\begin{array}{l}\text { Ntra. Sra. del Carmen. Médanos- } \\
\text { Las cañas) }\end{array}$ & Laborde & Unión & \multirow[t]{3}{*}{$30 / 06 / 1914$} \\
\hline 19 & Pascanas & Laborde & Unión & \\
\hline 20 & Las Liebres. & Laborde & Unión & \\
\hline 21 & Parroquia San Gerónimo & Bell Ville & Bell Ville & $06 / 07 / 1914$ \\
\hline 22 & Parroquia de San Francisco & San Francisco & San Justo & $11 / 07 / 1914$ \\
\hline 23 & Parroquia de Cruz Alta & Cruz Alta & Cruz Alta & $21 / 07 / 1914$ \\
\hline 24 & Parroquia de Villa María & Villa María & Tercero Abajo & $10 / 08 / 1914$ \\
\hline 25 & Parroquia de Oliva & Oliva & Tercero Arriba & $14 / 08 / 1914$ \\
\hline 26 & Parroquia de la Asunción & Marcos Juárez & Marcos Juárez & $16 / 08 / 1914$ \\
\hline 27 & $\begin{array}{l}\text { Parroquia Ntra. Señora del Rosario } \\
\text { Leones }\end{array}$ & Leones & Marcos Juárez & $19 / 08 / 1914$ \\
\hline 28 & Parroquia de la Anunciación & Canals & Unión & $01 / 09 / 1914$ \\
\hline 29 & Reducción & La Carlota & Juárez Celman & $03 / 05 / 1915$ \\
\hline 30 & $\begin{array}{l}\text { Médano de las Cañas Ntra. Sra. del } \\
\text { Carmen }\end{array}$ & Laborde & Unión & $20 / 06 / 1915$ \\
\hline 31 & San Francisco & San Francisco & San Justo & $11 / 07 / 1915$ \\
\hline 32 & Parroquia Ntra. Señora del Rosario & Freyre & San Justo & $14 / 07 / 1915$ \\
\hline 33 & Parroquia de San Isidro & Porteña & San Justo & $14 / 07 / 1915$ \\
\hline 34 & Santa Rosa de Río Primero & Santa Rosa de Río I & Rio Primero & $17 / 07 / 1915$ \\
\hline 35 & San Antonio de Rio Primero & Chalacea & Río Primero & $22 / 07 / 1915$ \\
\hline 36 & Parroquia de Montserrat & Caroya & Colón & $04 / 08 / 1915$ \\
\hline 37 & Parroquia de Jesús María & Jesús María & Colón & $06 / 08 / 1915$ \\
\hline 38 & Parroquia de Santiago Temple & Santiago Temple & Río Segundo & $10 / 08 / 1815$ \\
\hline 39 & Parroquia Inmaculada Concepción & San Justo & San Justo & $15 / 08 / 1915$ \\
\hline 40 & Parroquia Ntra. Sra. del Rosario & Leones & San Justo & $17 / 08 / 1915$ \\
\hline 41 & Parroquia Las Mercedes & Arroyito & San Justo & $20 / 08 / 1915$ \\
\hline 42 & Parroquia de Morteros & Morteros & San Justo & $26 / 08 / 1915$ \\
\hline 43 & Nuestra Señora del Rosario & Varillas & San Justo & $01 / 09 / 1915$ \\
\hline 44 & Adoratrices Villa del Rosario & Villa del Rosario & Río Segundo & $15 / 09 / 1915$ \\
\hline 45 & Villa del Rosario & Villa del Rosario & Río Segundo & $18 / 09 / 1915$ \\
\hline 46 & Bell Ville & Bell Ville & Unión & $\begin{array}{l}19 \mathrm{al} \\
23 / 11 / 1915\end{array}$ \\
\hline
\end{tabular}




\begin{tabular}{|c|c|c|c|c|}
\hline \multirow[t]{2}{*}{47} & Villa María & Villa María & Tercero Abajo & $20 / 06 / 1916$ \\
\hline & Colegio San Francisco & Villa María & Villa María & $20 / 06 / 1916$ \\
\hline 48 & $\begin{array}{l}\text { Colegio San Francisco de Villa } \\
\text { Nueva }\end{array}$ & Villa Nueva & Villa Nueva & $24 / 06 / 1916$ \\
\hline 49 & $\begin{array}{l}\text { Parroquia de Inmaculada } \\
\text { Concepción }\end{array}$ & San Justo & San Justo & $15 / 08 / 1916$ \\
\hline \multirow[t]{2}{*}{50} & $\begin{array}{l}\text { Colegio de Adoratrices de Villa del } \\
\text { Rosario }\end{array}$ & Villa del Rosario & Río Segundo & $\begin{array}{l}11 \text { al } \\
15 / 09 / 1916\end{array}$ \\
\hline & Parroquia de Villa del Rosario & Villa del Rosario & Río Segundo & $21 / 09 / 1916$ \\
\hline 51 & Santuario de la Reducción & La Carlota & Juárez Celman & \\
\hline 52 & San Francisco & San Francisco Colonias & San Francisco Colonias & $24 / 03 / 1917$ \\
\hline 53 & $\begin{array}{l}\text { Parroquia Iglesia de Ntra. Sra. Del } \\
\text { Rosario }\end{array}$ & Soto & Soto & $11 / 04 / 1917$ \\
\hline 54 & San Carlos Minas & Minas & Minas & $15 / 04 / 1917$ \\
\hline 55 & Ntra. Sra. del Rosario & Pocho & Pocho & 19/04/1917 \\
\hline 56 & Parroquia del Tránsito & Tránsito & San Alberto & $23 / 04 / 1917$ \\
\hline 57 & Parroquia Villa Dolores & Villa Dolores & San Javier & $29 / 04 / 1917$ \\
\hline 58 & $\mathrm{La} \mathrm{Paz}$ & Villa Dolores & San Javier & $02 / 05 / 1917$ \\
\hline 59 & Parroquia de San Pedro & San Alberto & San Alberto & $04 / 05 / 1917$ \\
\hline 60 & Iglesia de Ambul & Tránsito & San Alberto & $19 / 05 / 1917$ \\
\hline 61 & Parroquia San Bartolomé & Morteros & Morteros & $23 / 08 / 1917$ \\
\hline 62 & Parroquia Ntra. Sra. del Rosario & Freyre & Freyre & $28 / 05 / 1917$ \\
\hline 63 & Iglesia Santa Rosa de Lima Arias & La Anunciación & Marcos Juárez & $24 / 09 / 1917$ \\
\hline 64 & Parr. La Anunciación Canals & La Anunciación & Unión & $27 / 09 / 1917$ \\
\hline 65 & Rio Seco & Rio Seco & Rio Seco & $\begin{array}{l}11 \mathrm{al} \\
15 / 10 / 1917\end{array}$ \\
\hline 66 & Parroquia Deán Funes & Ischilín & Ischilín & $17 / 10 / 1917$ \\
\hline 67 & Parroquia San Isidro & Porteña & San Justo & $28 / 10 / 1917$ \\
\hline 68 & Parroquia de Quilino & Quilino & Ischilin & \\
\hline 69 & Nuestra Señora de las Mercedes & Arroyito & San Justo & $29 / 10 / 1917$ \\
\hline 70 & Santuario de Reducción & La Carlota & Juárez Celman & $03 / 05 / 1918$ \\
\hline
\end{tabular}




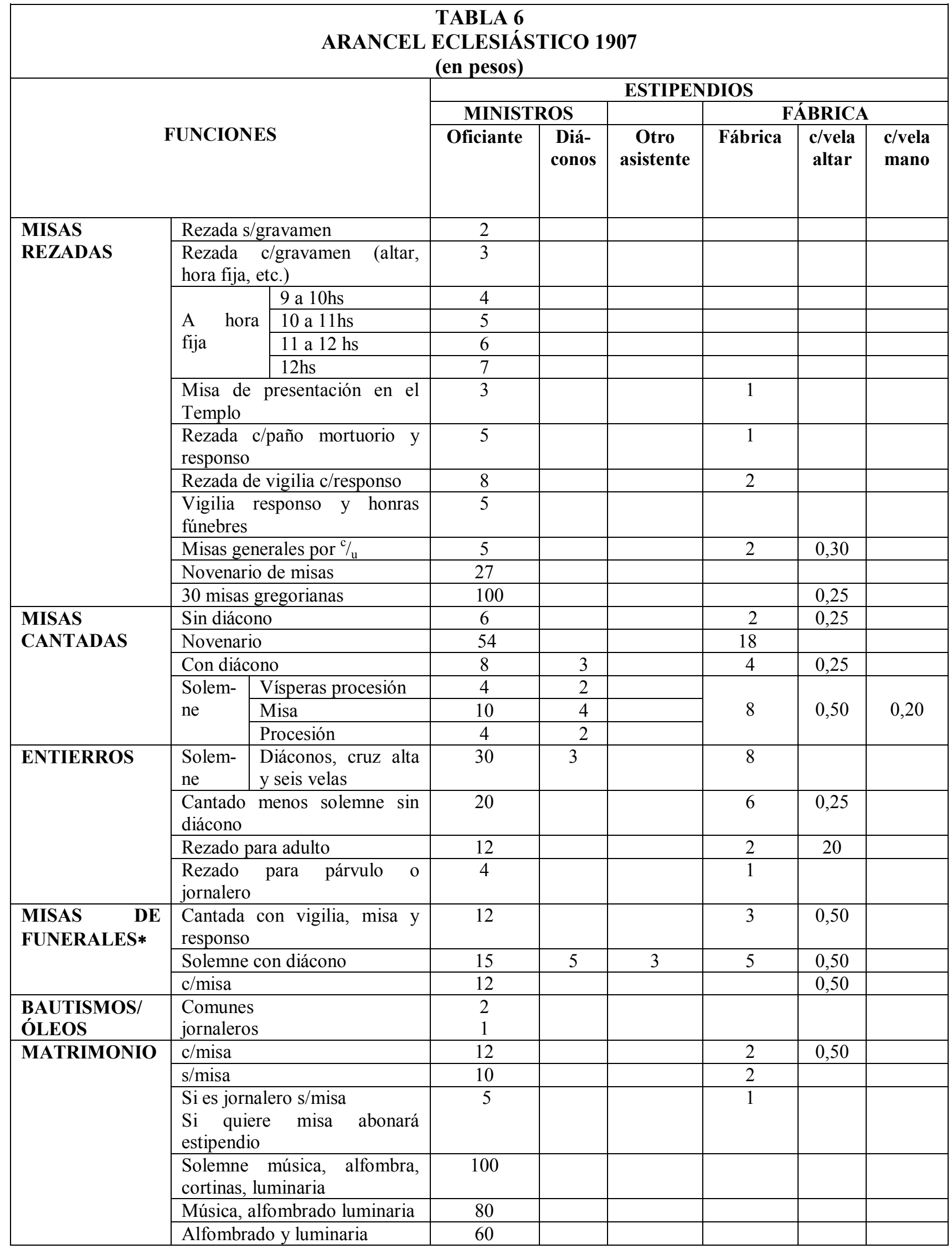




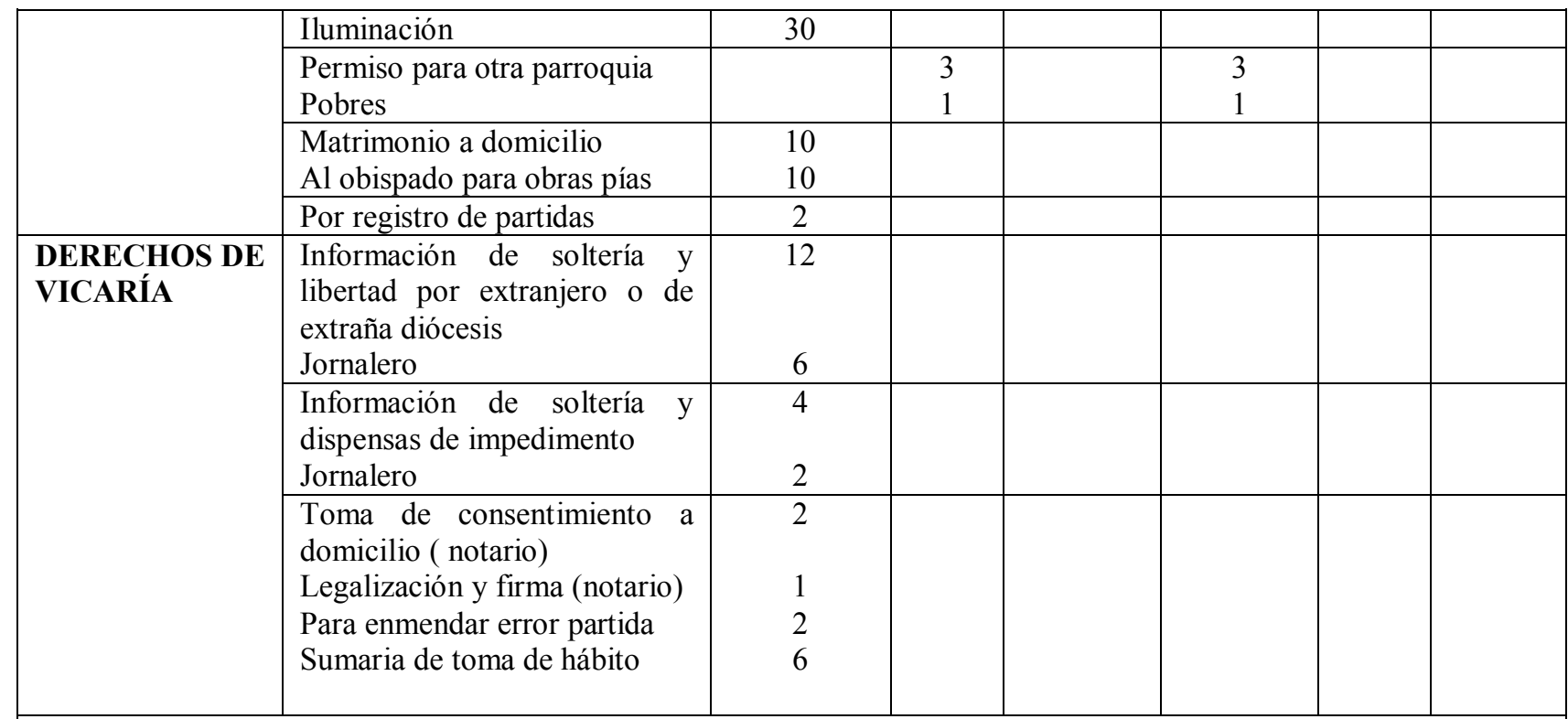

Disposiciones generales: Declárense derechos meramente parroquiales los siguientes:

a) El oficio de entierro de los propios feligreses o extraños que fallecieren o fueran sepultados en la parroquia, así mismo la misa de cuerpo presente rezada o cantada que quisieran hacer celebrar sus deudos.

b) La bendición del matrimonio y las velaciones de los esposos.

c) La administración del bautismo u óleo a los niños.

Art. 30: Cuando por alguna razón se rebajen los derechos parroquiales determinados en este arancel se rebajarán los de fábrica proporcionalmente.

Art.31: Por un Te Deum en la Iglesia catedral o matriz se aplicará lo que se acostumbra hasta el presente dar, de lo cual deducidos los gastos y la décima parte para el cura, se aplicará a la fábrica el sobrante.

Art. 32: En las parroquias de campaña por la distribución que marca el artículo anterior se pagarán 50 pesos, partibles entre el cura y la fábrica $[\ldots]$

Art. 33: En las funciones de ánimas que celebren los curas con limosnas de los fieles, deducidos los gastos, el remanente corresponde al párroco.

Art. 34: Por el rezo de una novena se dará 1 peso por distribución.

Art. 35: Nadie podrá obtener dispensas de proclamas, satisfaciendo el derecho acostumbrado que es de 4 pesos por cada una, sin haber satisfecho íntegros los derechos parroquiales esto es $\$ 12$.

Art. 36: Es lícito aceptar limosnas que voluntariamente se ofrezcan al sacerdote a más de lo que fija el arancel.

Art. 37: Fuera de las obligaciones que impone a los fieles este arancel, es entendido que están obligados a pagar a los párrocos, las primicias de los frutos que se cosechen, en la forma que lo establece el Sínodo del Dr. Alvarez.

Art. 38: Las cuotas fijadas en este arancel serán pagadas en moneda nacional de curso legal.

Art. 39: El pago de los músicos y cantores se hará siempre por los interesados que pidieran su asistencia: en las funciones religiosas que hiciere el párroco para fomentar la piedad de los fieles, los pagará la fábrica.

Art. 40: Los párrocos deberán entenderse directamente con los músicos y cantores en la retribución de sus servicios de conformidad a lo mutuamente convenido.

Fuente: AAC. Leg. 16. Sínodos y Aranceles. Arancel Eclesiástico de la Diócesis de Córdoba, 1907. 
TABLA 7

Rentas del beneficio y la fábrica de los curatos la Provincia de Córdoba, 1906-1910 (en pesos)

\begin{tabular}{|c|c|c|c|c|c|c|c|c|c|c|c|c|c|c|}
\hline TULUMBA & \multicolumn{7}{|c|}{ Renta del Beneficio } & \multicolumn{6}{|c|}{ Renta de la Fabrica } & \\
\hline Trimestres & $1^{\circ}$ & $2^{\circ}$ & $3^{\circ}$ & $4^{\circ}$ & $\begin{array}{c}\text { Total } \\
\text { Anual } \\
\end{array}$ & $\begin{array}{l}\text { Total \% } \\
\text { mensual }\end{array}$ & media & $1^{\circ}$ & $2^{\circ}$ & $3^{\circ}$ & $4^{\circ}$ & $\begin{array}{c}\text { Total } \\
\text { Anual } \\
\end{array}$ & $\begin{array}{l}\text { Total \% } \\
\text { mensual }\end{array}$ & media \\
\hline 1906 & 434 & 685 & 1066 & 604 & 2789 & 232,41 & \multirow{5}{*}{195,23} & 148 & 195 & 383 & 208 & 934 & 77,83 & \multirow{5}{*}{64,86} \\
\hline 1907 & 650 & 903 & 565 & 0 & & 235,33 & & 202 & 267 & 272 & 0 & & 82,33 & \\
\hline 1908 & 490 & 951 & 636 & 397 & 2474 & 274,88 & & 231 & 375 & 234 & 163 & 1003 & 83,58 & \\
\hline 1909 & 310 & 0 & 683 & 280 & & 141,44 & & 148 & 0 & 169 & 123 & & 48,80 & \\
\hline 1910 & 145 & 495 & 0 & 189 & & 92,11 & & 69 & 168 & 0 & 49 & & 31,77 & \\
\hline
\end{tabular}

\begin{tabular}{|c|c|c|c|c|c|c|c|c|c|c|c|c|c|c|}
\hline CHAÑAR & \multicolumn{7}{|c|}{ Renta del Beneficio } & \multicolumn{6}{|c|}{ Renta de la Fábrica } & \\
\hline Trimestres & $1^{\circ}$ & $2^{\circ}$ & $3^{\circ}$ & $4^{\circ}$ & $\begin{array}{c}\text { Total } \\
\text { Anual }\end{array}$ & $\begin{array}{l}\text { Total \% } \\
\text { mensual }\end{array}$ & media & $1^{\circ}$ & $2^{\circ}$ & $3^{\circ}$ & $4^{\circ}$ & $\begin{array}{c}\text { Total } \\
\text { Anual }\end{array}$ & $\begin{array}{l}\text { Total \% } \\
\text { mensual }\end{array}$ & Media \\
\hline 1906 & 600 & 0 & 587 & 372 & & 173,22 & \multirow{5}{*}{152} & 108 & 0 & 190 & 51 & & 38,77 & \multirow{5}{*}{30,55} \\
\hline 1907 & 541 & 396 & 700 & 267 & 1904 & 158,66 & & 76 & 71 & 113 & 88 & 348 & 29 & \\
\hline 1908 & 398 & 193 & 0 & 0 & & 89,5 & & 92 & 73 & 0 & 0 & & 27,5 & \\
\hline 1909 & 644 & 171 & 889 & 472 & 2176 & 181,33 & & 82 & 25 & 103 & 110 & 320 & 26,6 & \\
\hline 1910 & 339 & 540 & 747 & 263 & 1889 & 157,41 & & 118 & 50 & 102 & 101 & 371 & 30,9 & \\
\hline
\end{tabular}

\begin{tabular}{|c|c|c|c|c|c|c|c|c|c|c|c|c|c|c|}
\hline RIO SECO & \multicolumn{7}{|c|}{ Renta del Beneficio } & \multicolumn{6}{|c|}{ Renta de la Fábrica } & \\
\hline Trimestres & $1^{\circ}$ & $2^{\circ}$ & $3^{\circ}$ & $4^{\circ}$ & $\begin{array}{r}\text { Total } \\
\text { Anual }\end{array}$ & $\begin{array}{l}\text { Total \% } \\
\text { mensual }\end{array}$ & media & $1^{\circ}$ & $2^{\circ}$ & $3^{\circ}$ & $4^{\circ}$ & $\begin{array}{l}\text { Total } \\
\text { Anual }\end{array}$ & $\begin{array}{l}\text { Total \% } \\
\text { mensual }\end{array}$ & media \\
\hline 1906 & 140 & 612 & 449 & 393 & 1594 & 132,83 & \multirow{5}{*}{137,29} & 37 & 151 & 129 & 109 & 426 & 35,5 & \multirow[t]{5}{*}{36,45} \\
\hline 1907 & 0 & 0 & 378 & 378 & 756 & 126 & & 0 & 0 & 0 & 0 & & & \\
\hline 1908 & 0 & 0 & 0 & 455 & & & & 0 & 0 & 0 & 103 & & 43,33 & \\
\hline 1909 & 205 & 554 & 491 & 373 & 1623 & 135,25 & & 47 & 150 & 128 & 68 & 393 & 32,75 & \\
\hline 1910 & 153 & 505 & 693 & 510 & 1861 & 155,08 & & 28 & 127 & 137 & 119 & 411 & 34,25 & \\
\hline
\end{tabular}

\begin{tabular}{|c|c|c|c|c|c|c|c|c|c|c|c|c|c|}
\hline ISCHILIN & \multicolumn{7}{|c|}{ Renta del Beneficio } & \multicolumn{6}{|c|}{ Renta de la Fabrica } \\
\hline Trimestres & $1^{\circ}$ & $2^{\circ}$ & $3^{\circ}$ & $4^{\circ}$ & $\begin{array}{c}\text { Total } \\
\text { Anual }\end{array}$ & $\begin{array}{l}\text { Total \% } \\
\text { mensual }\end{array}$ & media & $1^{\circ}$ & $2^{\circ}$ & $3^{\circ}$ & $4^{\circ}$ & $\begin{array}{c}\text { Total } \\
\text { Anual }\end{array}$ & $\begin{array}{l}\text { Total \% } \\
\text { mensual }\end{array}$ \\
\hline 1906 & 394 & 751 & 573 & 1044 & 2762 & 230,16 & \multirow{6}{*}{140,94} & 300 & 232 & 62 & 359 & 953 & 79,41 \\
\hline 1907 & 266 & 0 & 0 & 0 & & & & 54 & 0 & 0 & 0 & & \\
\hline 1908 & 0 & 0 & 0 & 1261 & 1261 & 105,08 & & 0 & 0 & 0 & 105 & & \\
\hline 1909 & 0 & 0 & 0 & 0 & & & & 0 & 0 & 0 & 0 & & \\
\hline 1910 & 0 & 0 & 0 & 0 & & & & 0 & 0 & 0 & 0 & & \\
\hline 1926 & & & & & 1051 & 87,58 & & & & & & & \\
\hline
\end{tabular}

\begin{tabular}{|c|c|c|c|c|c|c|c|c|c|c|c|c|c|c|}
\hline QUILINO & \multicolumn{7}{|c|}{ Renta del Beneficio } & \multicolumn{6}{|c|}{ Renta de la Fabrica } & \\
\hline Trimestres & $1^{\circ}$ & $2^{\circ}$ & $3^{\circ}$ & $4^{\circ}$ & $\begin{array}{c}\text { Total } \\
\text { Anual } \\
\end{array}$ & $\begin{array}{l}\text { Total \% } \\
\text { mensual }\end{array}$ & media & $1^{\circ}$ & $2^{\circ}$ & $3^{\circ}$ & $4^{\circ}$ & $\begin{array}{l}\text { Total } \\
\text { Anual } \\
\end{array}$ & $\begin{array}{l}\text { Total \% } \\
\text { mensual }\end{array}$ & media \\
\hline 1906 & 101 & 101 & 501 & 236 & 936 & 78 & \multirow{5}{*}{88,33} & 15 & 15 & 50 & 57 & 137 & 11,40 & \multirow[t]{5}{*}{14,61} \\
\hline 1907 & 156 & 436 & 0 & 0 & - & 98,66 & & 35 & 72 & 0 & 0 & - & 17,83 & \\
\hline 1908 & 0 & 0 & 0 & 0 & & & & 0 & 0 & 0 & 0 & & & \\
\hline 1909 & 0 & 0 & & 0 & & & & 0 & 0 & 0 & 0 & & & \\
\hline 1910 & & & & & & & & 0 & 0 & 0 & 0 & & & \\
\hline
\end{tabular}




\begin{tabular}{|c|c|c|c|c|c|c|c|c|c|c|c|c|c|c|}
\hline PUNILLA & \multicolumn{7}{|c|}{ Renta del Beneficio } & \multicolumn{6}{|c|}{ Renta de la Fabrica } & \\
\hline Trimestres & $1^{\circ}$ & $2^{\circ}$ & $3^{\circ}$ & $4^{\circ}$ & $\begin{array}{c}\text { Total } \\
\text { Anual }\end{array}$ & $\begin{array}{l}\text { Total \% } \\
\text { mensual }\end{array}$ & media & $1^{\circ}$ & $2^{\circ}$ & $3^{\circ}$ & $4^{\circ}$ & $\begin{array}{c}\text { Total } \\
\text { Anual }\end{array}$ & $\begin{array}{l}\text { Total \% } \\
\text { mensual }\end{array}$ & media \\
\hline 1907 & 300 & 253 & 188,7 & $\mathrm{~s} / \mathrm{d}$ & & 82,41 & \multirow{4}{*}{90,79} & 120 & 55 & 78,5 & $\mathrm{~s} / \mathrm{d}$ & & 84,5 & \multirow{4}{*}{56,67} \\
\hline 1908 & 349 & 216 & 352 & $\mathrm{~s} / \mathrm{d}$ & & 101 & & 21 & 74 & 98 & $\mathrm{~s} / \mathrm{d}$ & & 21,44 & \\
\hline 1909 & 83 & 243 & 360 & $\mathrm{~s} / \mathrm{d}$ & & 76,2 & & 31 & 165 & 90 & 399 & 685 & 57.08 & \\
\hline 1910 & 169 & 418 & 345 & $\mathrm{~s} / \mathrm{d}$ & & 103,55 & & 32 & 60 & 99 & $\mathrm{~s} / \mathrm{d}$ & & 63,66 & \\
\hline
\end{tabular}

\begin{tabular}{|c|c|c|c|c|c|c|c|c|c|c|c|c|c|c|}
\hline CRUZ & \multicolumn{7}{|c|}{ Renta del Beneficio } & \multicolumn{6}{|c|}{ Renta de la Fabrica } & \\
\hline Trimestr & $1^{\circ}$ & $2^{\circ}$ & $3^{\circ}$ & $4^{\circ}$ & $\begin{array}{c}\text { Total } \\
\text { Anual }\end{array}$ & $\begin{array}{l}\text { Total \% } \\
\text { mensual }\end{array}$ & media & $1^{\circ}$ & $2^{\circ}$ & $3^{\circ}$ & $4^{\circ}$ & $\begin{array}{c}\text { Total } \\
\text { Anual }\end{array}$ & $\begin{array}{l}\text { Total \% } \\
\text { mensual }\end{array}$ & media \\
\hline 1906 & $\mathrm{~s} / \mathrm{d}$ & 400 & 511 & 531 & & 160,2 & \multirow{5}{*}{106,92} & $\mathrm{~s} / \mathrm{d}$ & 123 & 79 & 147 & & 38,77 & \multirow{5}{*}{36,90} \\
\hline 1907 & 270 & 260,7 & 352 & 455 & 1337,7 & 111,4 & & 230 & 76,2 & 142,5 & 151,5 & 600,2 & 50,01 & \\
\hline 1908 & 209 & 250 & 357 & 130 & 946 & 78,33 & & 21 & 91,4 & 115 & 83 & 310,4 & 25,86 & \\
\hline 1909 & 188 & 378 & 322 & 359 & 1247 & 103,01 & & 31 & 75 & 132 & 141 & 379 & 31,58 & \\
\hline 1910 & 146 & 326 & 283 & 225 & 980 & 81,66 & & 81 & 77 & 155 & 150 & 463 & 38,50 & \\
\hline
\end{tabular}

\begin{tabular}{|c|c|c|c|c|c|c|c|c|c|c|c|c|c|c|}
\hline SOTO & & & Renta & lel Ber & ficio & & & & & & abric & & & \\
\hline Trimestres & $1^{\circ}$ & $2^{\circ}$ & $3^{\circ}$ & $4^{\circ}$ & $\begin{array}{c}\text { Total } \\
\text { Anual }\end{array}$ & $\begin{array}{l}\text { Total \% } \\
\text { mensual }\end{array}$ & media & $1^{\circ}$ & $2^{\circ}$ & $3^{\circ}$ & $4^{\circ}$ & $\begin{array}{c}\text { Total } \\
\text { Anual }\end{array}$ & $\begin{array}{l}\text { Total \% } \\
\text { mensual }\end{array}$ & media \\
\hline 1906 & 1036 & 778 & 1355 & 1384 & 4553 & 379,41 & \multirow{5}{*}{292,81} & 181 & 318 & 397 & 203 & 1099 & 91,58 & \multirow{5}{*}{69.72} \\
\hline 1907 & 582 & 896 & 893 & 895 & 3266 & 272,16 & & 185 & 193 & 193 & 183 & 754 & 62,83 & \\
\hline 1908 & $\mathrm{~s} / \mathrm{d}$ & 828 & 570 & $\mathrm{~s} / \mathrm{d}$ & & 233 & & $\mathrm{~s} / \mathrm{d}$ & 191 & 107 & $\mathrm{~s} / \mathrm{d}$ & & 17,96 & \\
\hline 1909 & 1002 & 730 & 683 & 911 & 3326 & 277,11 & & 254 & 142 & 149 & 230 & 775 & 64,58 & \\
\hline 1910 & 632 & 553 & 1372 & 1072 & 3629 & 302,41 & & 184 & 550 & 341 & 265 & 1340 & 111,66 & \\
\hline
\end{tabular}

\begin{tabular}{|c|c|c|c|c|c|c|c|c|c|c|c|c|c|}
\hline POCHO & \multicolumn{6}{|c|}{ Renta del Beneficio } & \multicolumn{6}{|c|}{ Fabrica } & \\
\hline Trimestres & $1^{\circ}$ & $2^{\circ}$ & $3^{\circ}$ & $4^{\circ}$ & $\begin{array}{c}\text { Total } \\
\text { Anual }\end{array}$ & $\begin{array}{l}\text { Total \% } \\
\text { mensual }\end{array}$ & $1^{\circ}$ & $2^{\circ}$ & $3^{\circ}$ & $4^{\circ}$ & $\begin{array}{c}\text { Total } \\
\text { Anual }\end{array}$ & $\begin{array}{l}\text { Total \% } \\
\text { mensual }\end{array}$ & media \\
\hline 1906 & $\mathrm{~s} / \mathrm{d}$ & $\mathrm{s} / \mathrm{d}$ & $\mathrm{s} / \mathrm{d}$ & 237 & & & $\mathrm{~s} / \mathrm{d}$ & $\mathrm{s} / \mathrm{d}$ & $\mathrm{s} / \mathrm{d}$ & 77 & & & \multirow{4}{*}{129} \\
\hline 1907 & 634 & 451 & $\mathrm{~s} / \mathrm{d}$ & 324 & & 156 & 252 & 90 & $\mathrm{~s} / \mathrm{d}$ & 821 & 1163 & 129 & \\
\hline 1909 & & & & & & & & & & & & & \\
\hline 1910 & & & & & & & & & & & & & \\
\hline
\end{tabular}

\begin{tabular}{|c|c|c|c|c|c|c|c|c|c|c|c|c|c|c|}
\hline MINAS & \multicolumn{6}{|c|}{ Renta del Beneficio } & & \multicolumn{6}{|c|}{ Fabrica } & \multirow[b]{2}{*}{ media } \\
\hline Trimestres & $1^{\circ}$ & $2^{\circ}$ & $3^{\circ}$ & $4^{\circ}$ & $\begin{array}{l}\text { Total } \\
\text { Anual }\end{array}$ & $\begin{array}{l}\text { Total \% } \\
\text { mensual }\end{array}$ & media & $1^{\circ}$ & $2^{\circ}$ & $3^{\circ}$ & $4^{\circ}$ & $\begin{array}{l}\text { Total } \\
\text { Anual }\end{array}$ & $\begin{array}{l}\text { Total \% } \\
\text { mensual }\end{array}$ & \\
\hline 1906 & 145 & 88 & 303 & 37 & & 47,75 & \multirow[t]{2}{*}{107,37} & 23 & 14 & 40 & 37 & 114 & 9,5 & \multirow[t]{2}{*}{42,08} \\
\hline 1910 & 504 & 570 & 429 & $\mathrm{~s} / \mathrm{d}$ & & 167 & & 172 & 286 & 214 & $\mathrm{~s} / \mathrm{d}$ & 672 & 74,66 & \\
\hline
\end{tabular}

\begin{tabular}{|c|c|c|c|c|c|c|c|c|c|c|c|c|c|c|}
\hline SAN & \multicolumn{7}{|c|}{ Renta del Beneficio } & \multicolumn{6}{|c|}{ Fabrica } & \multirow[b]{2}{*}{ media } \\
\hline Trimestres & $1^{\circ}$ & $2^{\circ}$ & $3^{\circ}$ & $4^{\circ}$ & $\begin{array}{c}\text { Total } \\
\text { Anual }\end{array}$ & $\begin{array}{l}\text { Total \% } \\
\text { mensual }\end{array}$ & media & $1^{\circ}$ & $2^{\circ}$ & $3^{\circ}$ & $4^{\circ}$ & $\begin{array}{l}\text { Total } \\
\text { Anual }\end{array}$ & $\begin{array}{l}\text { Total \% } \\
\text { mensual }\end{array}$ & \\
\hline 1906 & 444 & 495 & 392 & 349,34 & 1680 & 140,02 & \multirow[t]{3}{*}{144} & 44 & $\mathrm{~s} / \mathrm{d}$ & $\mathrm{s} / \mathrm{d}$ & 28,45 & & 12,07 & \multirow[t]{3}{*}{9,33} \\
\hline 1908 & $\mathrm{~s} / \mathrm{d}$ & 515 & 515 & $\mathrm{~s} / \mathrm{d}$ & & 171 & & $\mathrm{~s} / \mathrm{d}$ & 20 & 20 & $\mathrm{~s} / \mathrm{d}$ & & 6,6 & \\
\hline 1909 & 345 & 343 & 407 & $\mathrm{~s} / \mathrm{d}$ & & 121 & & $\mathrm{~s} / \mathrm{d}$ & $\mathrm{s} / \mathrm{d}$ & $\mathrm{s} / \mathrm{d}$ & $\mathrm{s} / \mathrm{d}$ & & - & \\
\hline
\end{tabular}

\begin{tabular}{|c|c|c|c|c|c|c|c|c|c|c|c|c|c|c|}
\hline SAN & \multicolumn{7}{|c|}{ Renta del Beneficio } & \multicolumn{6}{|c|}{ Renta Fabrica } & \multirow[b]{2}{*}{ media } \\
\hline Trimestr & $1^{\circ}$ & $2^{\circ}$ & $3^{\circ}$ & $4^{\circ}$ & $\begin{array}{c}\text { Total } \\
\text { Anual }\end{array}$ & $\begin{array}{l}\text { Total \% } \\
\text { mensual }\end{array}$ & media & $1^{\circ}$ & $2^{\circ}$ & $3^{\circ}$ & $4^{\circ}$ & $\begin{array}{c}\text { Total } \\
\text { Anual }\end{array}$ & $\begin{array}{l}\text { Total \% } \\
\text { mensual }\end{array}$ & \\
\hline 1906 & 218 & 215 & $\mathrm{~s} / \mathrm{d}$ & 640 & & 119,22 & \multirow{4}{*}{145,64} & 68 & 68 & $\mathrm{~s} / \mathrm{d}$ & $\mathrm{s} / \mathrm{d}$ & & 22,66 & \multirow[t]{4}{*}{51,62} \\
\hline 1907 & 784 & 1033 & 900 & 519,5 & 3236,65 & 269,70 & & $\mathrm{~s} / \mathrm{d}$ & $\mathrm{s} / \mathrm{d}$ & $\mathrm{s} / \mathrm{d}$ & 136,9 & & - & \\
\hline 1908 & 226 & $\mathrm{~s} / \mathrm{d}$ & 616 & $\mathrm{~s} / \mathrm{d}$ & & 93 & & 144 & $\mathrm{~s} / \mathrm{d}$ & 303 & $\mathrm{~s} / \mathrm{d}$ & & 49,66 & \\
\hline 1909 & 302 & 302 & $\mathrm{~s} / \mathrm{d}$ & 305 & & 100,66 & & 205 & 205 & $\mathrm{~s} / \mathrm{d}$ & 333 & & 82,55 & \\
\hline
\end{tabular}




\begin{tabular}{|c|c|c|c|c|c|c|c|c|c|c|c|c|c|c|}
\hline SAN & \multicolumn{7}{|c|}{ Renta del Beneficio } & \multicolumn{6}{|c|}{ Renta Fabrica } & \multirow[b]{2}{*}{ Media } \\
\hline Trimestres & $1^{\circ}$ & $2^{\circ}$ & $3^{\circ}$ & $4^{\circ}$ & $\begin{array}{c}\text { Total } \\
\text { Anual }\end{array}$ & $\begin{array}{l}\text { Total \% } \\
\text { mensual }\end{array}$ & media & $1^{\circ}$ & $2^{\circ}$ & $3^{\circ}$ & $4^{\circ}$ & $\begin{array}{l}\text { Total } \\
\text { Anual }\end{array}$ & $\begin{array}{l}\text { Total \% } \\
\text { mensual }\end{array}$ & \\
\hline 1906 & 460 & 506 & 441 & 494 & & 158,4 & \multirow{4}{*}{135,4} & 96 & $\mathrm{~s} / \mathrm{d}$ & 131 & 77 & & 33,77 & \multirow{4}{*}{22,40} \\
\hline 1907 & 642 & $\mathrm{~s} / \mathrm{d}$ & 384,85 & 387,66 & & 157 & & $\mathrm{~s} / \mathrm{d}$ & $\mathrm{s} / \mathrm{d}$ & 30,5 & $\mathrm{~s} / \mathrm{d}$ & & - & \\
\hline 1908 & 488 & 504 & $\mathrm{~s} / \mathrm{d}$ & 275 & & 140 & & $\mathrm{~s} / \mathrm{d}$ & $\mathrm{s} / \mathrm{d}$ & $\mathrm{s} / \mathrm{d}$ & $\mathrm{s} / \mathrm{d}$ & & - & \\
\hline 1909 & 259 & 331 & 306 & 139 & 1035 & 86,25 & & $\mathrm{~s} / \mathrm{d}$ & 53 & 47 & $\mathrm{~s} / \mathrm{d}$ & & 11,11 & \\
\hline
\end{tabular}

\begin{tabular}{|c|c|c|c|c|c|c|c|c|c|c|c|c|c|c|}
\hline SAN & \multicolumn{7}{|c|}{ Renta del Beneficio } & \multicolumn{6}{|c|}{ Fabrica } & \multirow[b]{2}{*}{ media } \\
\hline Trimestres & $1^{\circ}$ & $2^{\circ}$ & $3^{\circ}$ & $4^{\circ}$ & $\begin{array}{c}\text { Total } \\
\text { Anual }\end{array}$ & $\begin{array}{l}\text { Total \% } \\
\text { mensual }\end{array}$ & media & $1^{\circ}$ & $2^{\circ}$ & $3^{\circ}$ & $4^{\circ}$ & $\begin{array}{r}\text { Total } \\
\text { Anual }\end{array}$ & $\begin{array}{l}\text { Total \% } \\
\text { mensual }\end{array}$ & \\
\hline 1906 & 844 & 454 & - & 409 & 1707 & 189,66 & \multirow{5}{*}{279,20} & 95 & 56 & - & 65 & 216 & 24 & \multirow{5}{*}{54,90} \\
\hline 1907 & 601 & 666 & - & 647,65 & 1914,65 & 212,73 & & 111 & 110 & - & 132 & 353 & 39 & \\
\hline 1908 & 885 & 677 & - & 1207 & 2769 & 307,66 & & 217 & 150 & - & 196 & 563 & 62,55 & \\
\hline 1909 & 996 & 990 & - & 1865 & 3851 & 427,88 & & 453 & 80 & - & 314 & 847 & 94,11 & \\
\hline 1910 & 865 & 1013 & 108 & 1111 & 3097 & 258,08 & & 224 & 133 & 143 & 163 & 663 & 55,25 & \\
\hline
\end{tabular}

\begin{tabular}{|c|c|c|c|c|c|c|c|c|c|c|c|c|c|c|}
\hline MORTEROS & & & & enta del & Benefic & & & & & & & brica & & \\
\hline Trimestres & $1^{\circ}$ & $2^{\circ}$ & $3^{\circ}$ & $4^{\circ}$ & $\begin{array}{c}\text { Total } \\
\text { Anual }\end{array}$ & $\begin{array}{l}\text { Total \% } \\
\text { mensual }\end{array}$ & media & $1^{\circ}$ & $2^{\circ}$ & $3^{\circ}$ & $4^{\circ}$ & $\begin{array}{c}\text { Total } \\
\text { Anual }\end{array}$ & $\begin{array}{l}\text { Total \% } \\
\text { mensual }\end{array}$ & \\
\hline 1906 & 562 & 443 & - & - & 905 & 150,83 & \multirow{5}{*}{146} & 128 & 93 & - & - & 221 & 24,55 & \multirow{5}{*}{55,84} \\
\hline 1907 & 394 & 423,5 & 446 & 235,5 & 1399 & 116,58 & & 68,5 & 68 & 60 & 38 & 234 & 19,5 & \\
\hline 1908 & 759 & 668 & 403 & 99 & 1929 & 160,75 & & 224 & 224 & 44 & 44 & 536 & 44,66 & \\
\hline 1909 & 761 & 690 & - & $1128 *$ & 1279 & 106,58 & & 136 & 413 & - & 800 & 1448 & 160,88 & \\
\hline 1910 & 754 & 418 & - & - & 1172 & 195,33 & & 10 & 145 & - & - & 155 & 25,83 & \\
\hline
\end{tabular}

\begin{tabular}{|c|c|c|c|c|c|c|c|c|c|c|c|c|c|c|}
\hline ARROYITO & \multicolumn{7}{|c|}{ Renta del Beneficio } & \multicolumn{7}{|c|}{ Fabrica } \\
\hline Trimestres & $1^{\circ}$ & $2^{\circ}$ & $3^{\circ}$ & $4^{\circ}$ & $\begin{array}{c}\text { Total } \\
\text { Anual }\end{array}$ & $\begin{array}{l}\text { Total \% } \\
\text { mensual }\end{array}$ & media & $1^{\circ}$ & $2^{\circ}$ & $3^{\circ}$ & $4^{\circ}$ & $\begin{array}{c}\text { Total } \\
\text { Anual }\end{array}$ & $\begin{array}{l}\text { Total \% } \\
\text { mensual }\end{array}$ & Media \\
\hline 1906 & 208 & 378 & 596 & 380 & 1562 & 130 & \multirow{4}{*}{164,25} & 41 & 90 & 137 & 105 & 373 & 31,10 & \multirow[t]{4}{*}{52,36} \\
\hline 1907 & 222 & 213 & 598 & 287 & 1320 & 110 & & 49 & 59 & 105 & 84 & 297 & 24,75 & \\
\hline 1908 & 519 & 378 & 809 & 350 & 2056 & 171 & & 93 & 98 & 139 & 83 & 413 & 34,4 & \\
\hline 1909 & - & 978 & 938 & $1026 *$ & 2956 & 246 & & - & 369 & 355 & 349 & 1073 & 119,22 & \\
\hline
\end{tabular}

\begin{tabular}{|c|c|c|c|c|c|c|c|c|c|c|c|c|}
\hline $\begin{array}{c}\text { VILLA } \\
\text { CONCEPCION }\end{array}$ & \multicolumn{9}{|c|}{ Renta del Beneficio } & \multicolumn{7}{c|}{ Fabrica } \\
\hline Trimestres & $\mathbf{1}^{\circ}$ & $\mathbf{2}^{\circ}$ & $\mathbf{3}^{\circ}$ & $\mathbf{4}^{\circ}$ & $\begin{array}{c}\text { Total } \\
\text { Anual }\end{array}$ & $\begin{array}{c}\text { Total \% } \\
\text { mensual }\end{array}$ & $\mathbf{1}^{\circ}$ & $\mathbf{2}^{\circ}$ & $\mathbf{3}^{\circ}$ & $\mathbf{4}^{\circ}$ & $\begin{array}{c}\text { Total } \\
\text { Anual }\end{array}$ & $\begin{array}{c}\text { Total \% } \\
\text { mensual }\end{array}$ \\
\hline $\mathbf{1 9 0 6}$ & - & - & - & - & & & - & - & - & - & & \\
\hline 1907 & - & - & - & 1000 & & & - & - & - & 130 & & \\
\hline 1908 & - & - & - & - & & & - & - & - & - & & \\
\hline 1909 & - & - & - & - & & & - & - & - & - & & \\
\hline
\end{tabular}

\begin{tabular}{|c|c|c|c|c|c|c|c|c|c|c|c|c|c|c|}
\hline VILLA & \multicolumn{7}{|c|}{ Renta del Beneficio } & \multicolumn{7}{|c|}{ Fabrica } \\
\hline Trimestres & $1^{\circ}$ & $2^{\circ}$ & $3^{\circ}$ & $4^{\circ}$ & $\begin{array}{c}\text { Total } \\
\text { Anual }\end{array}$ & $\begin{array}{l}\text { Total \% } \\
\text { mensual }\end{array}$ & media & $1^{\circ}$ & $2^{\circ}$ & $3^{\circ}$ & $4^{\circ}$ & $\begin{array}{c}\text { Total } \\
\text { Anual }\end{array}$ & $\begin{array}{l}\text { Total \% } \\
\text { mensual }\end{array}$ & Media \\
\hline 1906 & 528 & 551 & 475 & - & 1554 & 172,66 & \multirow[t]{4}{*}{182,82} & 270 & 192 & 64 & - & 526 & 58,44 & \multirow{4}{*}{39,06} \\
\hline 1907 & 365 & 258 & 509,5 & 315 & 943,95 & 78,66 & & 95 & 56 & 61 & 114 & 326 & 27,16 & \\
\hline 1908 & 749 & 888 & 920 & 709 & 3266 & 272,16 & & 43 & 154 & 181 & 131 & 509 & 42,16 & \\
\hline 1909 & 733 & 514 & - & - & 1247 & 207,83 & & 105 & 66 & - & - & 171 & 28,5 & \\
\hline
\end{tabular}

\begin{tabular}{|c|c|c|c|c|c|c|c|c|c|c|c|c|c|c|}
\hline VILLA & \multicolumn{7}{|c|}{ Renta del Beneficio } & \multicolumn{7}{|c|}{ Fabrica } \\
\hline Trimestres & $1^{\circ}$ & $2^{\circ}$ & $3^{\circ}$ & $4^{\circ}$ & $\begin{array}{l}\text { Total } \\
\text { Anual }\end{array}$ & $\begin{array}{l}\text { Total \% } \\
\text { mensual }\end{array}$ & media & $1^{\circ}$ & $2^{\circ}$ & $3^{\circ}$ & $4^{\circ}$ & $\begin{array}{l}\text { Total } \\
\text { Anual }\end{array}$ & $\begin{array}{l}\text { Total \% } \\
\text { mensual }\end{array}$ & media \\
\hline 1906 & 1200 & 950 & 1025 & - & 3175 & 352,77 & \multirow{4}{*}{268,15} & 390 & 300 & 300 & - & 990 & 110 & \multirow{4}{*}{105,75} \\
\hline 1907 & 663 & 1100 & 1133 & 1101,66 & 2997,66 & 249,80 & & 100 & 800 & 332 & 366 & 1598 & 133,16 & \\
\hline 1908 & 667 & 850 & 300 & - & 1817 & 201,88 & & 100 & 300 & 267 & - & 667 & 74,11 & \\
\hline 1909 & & & & & & & & & & & & & & \\
\hline
\end{tabular}




\begin{tabular}{|c|c|c|c|c|c|c|c|c|c|c|c|c|}
\hline MARCOS & \multicolumn{6}{|c|}{ Renta del Beneficio } & \multicolumn{6}{|c|}{ Fabrica } \\
\hline Trimestres & $1^{\circ}$ & $2^{\circ}$ & $3^{\circ}$ & $4^{\circ}$ & $\begin{array}{c}\text { Total } \\
\text { Anual }\end{array}$ & $\begin{array}{l}\text { Total \% } \\
\text { mensual }\end{array}$ & $1^{\circ}$ & $2^{\circ}$ & $3^{\circ}$ & $4^{\circ}$ & $\begin{array}{c}\text { Total } \\
\text { Anual }\end{array}$ & $\begin{array}{l}\text { Total \% } \\
\text { mensual }\end{array}$ \\
\hline 1910 & 675 & 699 & 828 & & & 244 & 312 & 467 & 406 & & 1185 & 131,66 \\
\hline
\end{tabular}

\begin{tabular}{|c|c|c|c|c|c|c|c|c|c|c|c|c|c|c|}
\hline CRUZ & \multicolumn{7}{|c|}{ Renta del Beneficio } & \multicolumn{7}{|c|}{ Fabrica } \\
\hline Trimestres & $1^{\circ}$ & $2^{\circ}$ & $3^{\circ}$ & $4^{\circ}$ & $\begin{array}{c}\text { Total } \\
\text { Anual }\end{array}$ & $\begin{array}{l}\text { Total } \% \\
\text { mensual }\end{array}$ & Media & $1^{\circ}$ & $2^{\circ}$ & $3^{\circ}$ & $4^{\circ}$ & $\begin{array}{r}\text { Total } \\
\text { Anual } \\
\end{array}$ & $\begin{array}{l}\text { Total \% } \\
\text { mensual }\end{array}$ & Media \\
\hline 1907 & 252 & 320 & 223,5 & 447 & 1342,50 & 111 & \multirow{3}{*}{115,83} & 33 & 88 & 17,7 & 89 & 227,7 & 18,97 & \multirow[t]{3}{*}{21,56} \\
\hline 1908 & 383 & 380 & 427 & 416 & 1605,99 & 133 & & 95 & 80 & 32 & 83 & 290 & 24,16 & \\
\hline 1909 & 343 & 336 & 253 & - & & 103,55 & & 65 & - & 28 & - & & & \\
\hline
\end{tabular}

\begin{tabular}{|c|c|c|c|c|c|c|c|c|c|c|c|c|}
\hline CANALS & \multicolumn{6}{|c|}{ Renta del Beneficio } & \multicolumn{6}{|c|}{ Fabrica } \\
\hline Trimestres & $1^{\circ}$ & $2^{\circ}$ & $3^{\circ}$ & $4^{\circ}$ & $\begin{array}{c}\text { Total } \\
\text { Anual }\end{array}$ & $\begin{array}{l}\text { Total \% } \\
\text { mensual }\end{array}$ & $1^{\circ}$ & $2^{\circ}$ & $3^{\circ}$ & $4^{\circ}$ & $\begin{array}{c}\text { Total } \\
\text { Anual }\end{array}$ & $\begin{array}{l}\text { Total \% } \\
\text { mensual }\end{array}$ \\
\hline 1906 & - & - & - & 382 & & & - & - & - & 90 & & \\
\hline 1907 & - & 433 & - & 280 & & & - & 80 & - & 76 & & \\
\hline 1908 & 588 & 498 & 560 & 373 & 2019 & 168,25 & 124 & 78 & 70 & 40 & 312 & 26 \\
\hline 1909 & 923 & 358 & 360 & - & & & 183 & 54 & 32 & - & & \\
\hline
\end{tabular}

\begin{tabular}{|c|c|c|c|c|c|c|c|c|c|c|c|c|c|c|}
\hline & \multicolumn{7}{|c|}{ Renta del Beneficio } & \multicolumn{7}{|c|}{ Fabrica } \\
\hline Trimestres & $1^{\circ}$ & $2^{\circ}$ & $3^{\circ}$ & $4^{\circ}$ & $\begin{array}{c}\text { Total } \\
\text { Anual } \\
\end{array}$ & $\begin{array}{l}\text { Total \% } \\
\text { mensual }\end{array}$ & media & $1^{\circ}$ & $2^{\circ}$ & $3^{\circ}$ & $4^{\circ}$ & $\begin{array}{r}\text { Total } \\
\text { Anual } \\
\end{array}$ & $\begin{array}{l}\text { Total \% } \\
\text { mensual }\end{array}$ & Media \\
\hline 1906 & 270 & 478 & - & 758 & & 167,33 & \multirow{4}{*}{155,54} & 151 & 221 & - & 307 & 679 & 75,44 & \multirow[t]{3}{*}{55,33} \\
\hline 1907 & 298 & 477 & - & 506 & & 142,30 & & 109 & 154 & - & 188 & 451 & 50,11 & \\
\hline 1908 & 238 & 562 & - & 619 & & 157 & & 17 & 67 & - & 280 & 364 & 40,44 & \\
\hline 1909 & & & & & & & & & & & & & & \\
\hline
\end{tabular}

\begin{tabular}{|c|c|c|c|c|c|c|c|c|c|c|c|c|c|}
\hline LABOULAYE & \multicolumn{7}{|c|}{ Renta del Beneficio } & \multicolumn{6}{|c|}{ Fabrica } \\
\hline Trimestres & $1^{\circ}$ & $2^{\circ}$ & $3^{\circ}$ & $4^{\circ}$ & $\begin{array}{c}\text { Total } \\
\text { Anual }\end{array}$ & $\begin{array}{l}\text { Total \% } \\
\text { mensual }\end{array}$ & media & $1^{\circ}$ & $2^{\circ}$ & $3^{\circ}$ & $4^{\circ}$ & $\begin{array}{c}\text { Total } \\
\text { Anual }\end{array}$ & $\begin{array}{l}\text { Total \% } \\
\text { mensual }\end{array}$ \\
\hline 1906 & 1271 & 1271 & 624 & - & & 351,77 & \multirow{4}{*}{374,38} & 224 & 224 & 94 & - & & \\
\hline 1907 & - & - & - & - & - & - & & - & - & - & - & - & \\
\hline 1908 & 982 & 1261 & 1261 & 1261 & & 397 & & 231 & 105 & 105 & 104 & 545 & 45,41 \\
\hline 1909 & & & & & & & & & & & & & \\
\hline
\end{tabular}

\begin{tabular}{|l|l|l|l|l|l|l|l|l|l|l|l|l|l|}
\hline $\begin{array}{c}\text { RIO } \\
\text { CUARTO }\end{array}$ & \multicolumn{9}{|c|}{ Renta del Beneficio } & \multicolumn{6}{c|}{ Fabrica } \\
\hline Trimestres & $\mathbf{1}^{\circ}$ & $\mathbf{2}^{\circ}$ & $\mathbf{3}^{\circ}$ & $\mathbf{4}^{\circ}$ & $\begin{array}{c}\text { Total } \\
\text { Anual }\end{array}$ & $\begin{array}{l}\text { Total \% } \\
\text { mensual }\end{array}$ & $\mathbf{1}^{\circ}$ & $\mathbf{2}^{\circ}$ & $\mathbf{3}^{\circ}$ & $\mathbf{4}^{\circ}$ & $\begin{array}{c}\text { Total } \\
\text { Anual }\end{array}$ & $\begin{array}{c}\text { Total \% } \\
\text { mensual }\end{array}$ \\
\hline $\mathbf{1 9 0 6}$ & - & - & - & - & - & - & - & - & - & - & - & - \\
\hline $\mathbf{1 9 0 7}$ & - & - & - & - & - & - & - & - & - & - & - & - \\
\hline $\mathbf{1 9 0 8}$ & - & - & - & - & - & - & - & - & - & - & - & - \\
\hline 1909 & - & - & - & - & - & - & - & - & - & - & - & - \\
\hline
\end{tabular}

\begin{tabular}{|c|c|c|c|c|c|c|c|c|c|c|c|c|c|c|}
\hline SAMPACHO & \multicolumn{7}{|c|}{ Renta del Beneficio } & \multicolumn{6}{|c|}{ Fabrica } & \\
\hline Trimestres & $1^{\circ}$ & $2^{\circ}$ & $3^{\circ}$ & $4^{\circ}$ & $\begin{array}{c}\text { Total } \\
\text { Anual }\end{array}$ & $\begin{array}{l}\text { Total \% } \\
\text { mensual }\end{array}$ & media & $1^{\circ}$ & $2^{\circ}$ & $3^{\circ}$ & $4^{\circ}$ & $\begin{array}{c}\text { Total } \\
\text { Anual }\end{array}$ & $\begin{array}{l}\text { Total \% } \\
\text { mensual }\end{array}$ & Media \\
\hline 1906 & 228 & 202 & 780 & - & & 134 & \multirow{4}{*}{129,70} & 72 & 65 & 104 & & & & \multirow{4}{*}{26,7} \\
\hline 1907 & 329 & 327 & 318 & 279 & & 104,41 & & 80 & 86 & 104 & 55 & 325 & 27,0 & \\
\hline 1908 & 573 & 609 & 545 & 558 & 2285 & 190,41 & & 95 & 69 & 67 & 86 & 317 & 26,41 & \\
\hline 1909 & 464 & 490 & 545 & - & & 90 & & 61 & 60 & 82 & - & & & \\
\hline
\end{tabular}




\begin{tabular}{|l|l|l|l|l|l|l|l|l|l|l|l|l|}
\hline Bell Ville & \multicolumn{9}{|c|}{ Renta del Beneficio } & \multicolumn{6}{c|}{ Fabrica } \\
\hline Trimestres & $\mathbf{1}^{\circ}$ & $\mathbf{2}^{\circ}$ & $\mathbf{3}^{\circ}$ & $\mathbf{4}^{\circ}$ & $\begin{array}{c}\text { Total } \\
\text { Anual }\end{array}$ & $\begin{array}{l}\text { Total \% } \\
\text { mensual }\end{array}$ & $\mathbf{1}^{\circ}$ & $\mathbf{2}^{\circ}$ & $\mathbf{3}^{\circ}$ & $\mathbf{4}^{\circ}$ & $\begin{array}{c}\text { Total } \\
\text { Anual }\end{array}$ & $\begin{array}{c}\text { Total \% } \\
\text { mensual }\end{array}$ \\
\hline 1906 & - & - & - & - & - & - & - & - & - & - & - & - \\
\hline 1907 & - & - & - & - & - & - & - & - & - & - & - & - \\
\hline 1908 & - & - & - & - & - & - & - & - & - & - & - & - \\
\hline 1909 & - & - & - & - & - & - & - & - & - & - & - & - \\
\hline
\end{tabular}

\begin{tabular}{|c|c|c|c|c|c|c|c|c|c|c|c|c|}
\hline BALLESTEROS & \multicolumn{9}{|c|}{ Renta del Beneficio } & \multicolumn{1}{|c|}{ Fabrica } \\
\hline Trimestres & $\mathbf{1}^{\circ}$ & $\mathbf{2}^{\circ}$ & $\mathbf{3}^{\circ}$ & $\mathbf{4}^{\circ}$ & $\begin{array}{c}\text { Total } \\
\text { Anual }\end{array}$ & $\begin{array}{c}\text { Total \% } \\
\text { mensual }\end{array}$ & $\mathbf{1}^{\circ}$ & $\mathbf{2}^{\circ}$ & $\mathbf{3}^{\circ}$ & $\mathbf{4}^{\circ}$ & $\begin{array}{c}\text { Total } \\
\text { Anual }\end{array}$ & $\begin{array}{c}\text { Total \% } \\
\text { mensual }\end{array}$ \\
\hline 1906 & - & - & - & - & - & - & - & - & - & - & - & - \\
\hline 1907 & - & - & -- & & - & - & - & - & - & - & - & \\
\hline 1908 & - & - & - & - & - & - & - & - & - & - & - & - \\
\hline 1909 & - & - & - & - & - & - & - & - & - & - & - & - \\
\hline
\end{tabular}

\begin{tabular}{|l|l|l|l|l|l|l|l|l|l|l|l|l|}
\hline \multicolumn{1}{|c|}{ LITIN } & \multicolumn{9}{|c|}{ Renta del Beneficio } & \multicolumn{6}{c|}{ Fabrica } \\
\hline Trimestres & $\mathbf{1}^{\circ}$ & $\mathbf{2}^{\circ}$ & $\mathbf{3}^{\circ}$ & $\mathbf{4}^{\circ}$ & $\begin{array}{c}\text { Total } \\
\text { Anual }\end{array}$ & $\begin{array}{l}\text { Total \% } \\
\text { mensual }\end{array}$ & $\mathbf{1}^{\circ}$ & $\mathbf{2}^{\circ}$ & $\mathbf{3}^{\circ}$ & $\mathbf{4}^{\circ}$ & $\begin{array}{c}\text { Total } \\
\text { Anual }\end{array}$ & $\begin{array}{c}\text { Total \% } \\
\text { mensual }\end{array}$ \\
\hline 1906 & - & - & - & - & - & - & - & - & - & - & - & - \\
\hline 1907 & - & - & - & - & - & - & - & - & - & - & - & - \\
\hline 1908 & - & - & - & - & - & - & - & - & - & - & - & - \\
\hline 1909 & - & - & - & - & - & - & - & - & - & - & - & - \\
\hline
\end{tabular}

\begin{tabular}{|c|c|c|c|c|c|c|c|c|c|c|c|c|c|c|}
\hline TOTORAL & \multicolumn{7}{|c|}{ Renta del Beneficio } & \multicolumn{7}{|c|}{ Fabrica } \\
\hline Trimestres & $1^{\circ}$ & $2^{\circ}$ & $3^{\circ}$ & $4^{\circ}$ & $\begin{array}{c}\text { Total } \\
\text { Anual }\end{array}$ & $\begin{array}{l}\text { Total \% } \\
\text { mensual }\end{array}$ & Media & $1^{\circ}$ & $2^{\circ}$ & $3^{\circ}$ & $4^{\circ}$ & $\begin{array}{c}\text { Total } \\
\text { Anual } \\
\end{array}$ & $\begin{array}{l}\text { Total \% } \\
\text { mensual }\end{array}$ & Media \\
\hline 1906 & 410 & 287 & 294 & 272 & 1263 & 105,25 & \multirow{5}{*}{138,65} & 145 & 79 & 48 & 57 & 329 & 27,16 & \multirow{5}{*}{46,64} \\
\hline 1907 & 282 & 269 & 307 & 390 & 1248 & 104 & & 67 & 99 & 289 & 121 & 576 & 48 & \\
\hline 1908 & 359 & 380 & 942 & 403 & 2084 & 173 & & 122 & 135 & 275 & 87 & 612 & 51,58 & \\
\hline 1909 & 297 & 340 & 917 & 436 & 1990 & 165 & & 101 & 85 & 394 & 149 & 729 & 60,75 & \\
\hline 1910 & 275 & 400 & 658 & 426 & 1759 & 146 & & 201 & 61 & 194 & 93 & 549 & 45,75 & \\
\hline
\end{tabular}

\begin{tabular}{|l|c|c|c|c|c|c|c|c|c|c|c|c|}
\hline $\begin{array}{l}\text { VILLA del } \\
\text { ROSARIO }\end{array}$ & \multicolumn{9}{|c|}{ Renta del Beneficio } & \multicolumn{7}{c|}{ Fabrica } \\
\hline Trimestres & $\mathbf{1}^{\circ}$ & $\mathbf{2}^{\circ}$ & $\mathbf{3}^{\circ}$ & $\mathbf{4}^{\circ}$ & $\begin{array}{c}\text { Total } \\
\text { Anual }\end{array}$ & $\begin{array}{c}\text { Total \% } \\
\text { mensual }\end{array}$ & $\mathbf{1}^{\circ}$ & $\mathbf{2}^{\circ}$ & $\mathbf{3}^{\circ}$ & $\mathbf{4}^{\circ}$ & $\begin{array}{c}\text { Total } \\
\text { Anual }\end{array}$ & $\begin{array}{c}\text { Total \% } \\
\text { mensual }\end{array}$ \\
\hline $\mathbf{1 9 0 6}$ & 2125 & 0 & 0 & 0 & & & 504 & 0 & 0 & 0 & & \\
\hline 1907 & 0 & 0 & 0 & 0 & & & 0 & 0 & 0 & 0 & & \\
\hline $\mathbf{1 9 0 8}$ & 0 & 0 & 0 & 0 & & & 0 & 0 & 0 & 0 & & \\
\hline 1909 & 0 & 0 & 0 & 0 & & & 0 & 0 & 0 & 0 & & \\
\hline
\end{tabular}

\begin{tabular}{|c|c|c|c|c|c|c|c|c|c|c|c|c|c|c|}
\hline RIO & \multicolumn{7}{|c|}{ Renta del Beneficio } & \multicolumn{7}{|c|}{ Fabrica } \\
\hline Trimestres & $1^{\circ}$ & $2^{\circ}$ & $3^{\circ}$ & $4^{\circ}$ & $\begin{array}{c}\text { Total } \\
\text { Anual }\end{array}$ & $\begin{array}{l}\text { Total \% } \\
\text { mensual }\end{array}$ & media & $1^{\circ}$ & $2^{\circ}$ & $3^{\circ}$ & $4^{\circ}$ & $\begin{array}{c}\text { Total } \\
\text { Anual }\end{array}$ & $\begin{array}{l}\text { Total \% } \\
\text { mensual }\end{array}$ & Media \\
\hline 1906 & 148 & 435 & 345 & 0 & & 103,1 & \multirow{4}{*}{155,85} & 195 & 288 & 291 & 0 & & 86 & \multirow{4}{*}{63,5} \\
\hline 1907 & 472 & 0 & 0 & 780 & & 208,6 & & 147 & 0 & 0 & 104 & & 41 & \\
\hline 1908 & 0 & 0 & 0 & 0 & & & & 0 & 0 & 0 & 0 & & & \\
\hline 1909 & 0 & 0 & 0 & 0 & & & & 0 & 0 & 0 & 0 & & & \\
\hline
\end{tabular}

\begin{tabular}{|c|c|c|c|c|c|c|c|c|c|c|c|c|c|c|}
\hline SANTA & \multicolumn{7}{|c|}{ Renta del Beneficio } & \multicolumn{7}{|c|}{ Fabrica } \\
\hline Trimestres & $1^{\circ}$ & $2^{\circ}$ & $3^{\circ}$ & $4^{\circ}$ & $\begin{array}{c}\text { Total } \\
\text { Anual }\end{array}$ & $\begin{array}{l}\text { Total \% } \\
\text { mensual }\end{array}$ & media & $1^{\circ}$ & $2^{\circ}$ & $3^{\circ}$ & $4^{\circ}$ & $\begin{array}{c}\text { Total } \\
\text { Anual }\end{array}$ & $\begin{array}{l}\text { Total \% } \\
\text { mensual }\end{array}$ & Media \\
\hline 1906 & 351 & 416 & 222 & 295 & 1284 & 107 & \multirow{5}{*}{96,85} & 42 & 32 & 18 & 41 & 133 & 11,08 & \multirow{5}{*}{14,02} \\
\hline 1907 & 38 & 346 & 462 & 258 & 1104 & 92 & & 0 & 43 & 81 & 24 & & 16,44 & \\
\hline 1908 & 389 & 332 & 408 & 103 & 1232 & 102,66 & & 26 & 21 & 39 & 6 & 92 & 7,6 & \\
\hline 1909 & 200 & 250 & 232 & 216 & 890 & 74,33 & & 27 & 18 & 15 & 17 & 77 & 6,4 & \\
\hline 1910 & 312 & 368 & 418 & 200 & 1298 & 108,16 & & 225 & 44 & 56 & 18 & 343 & 28,58 & \\
\hline
\end{tabular}




\begin{tabular}{|c|c|c|c|c|c|c|c|c|c|c|c|c|c|c|}
\hline TERCERO & \multicolumn{7}{|c|}{ Renta del Beneficio } & \multicolumn{7}{|c|}{ Fabrica } \\
\hline Trimestres & $1^{\circ}$ & $2^{\circ}$ & $3^{\circ}$ & $4^{\circ}$ & $\begin{array}{c}\text { Total } \\
\text { Anual } \\
\end{array}$ & $\begin{array}{l}\text { Total \% } \\
\text { mensual }\end{array}$ & media & $1^{\circ}$ & $2^{\circ}$ & $3^{\circ}$ & $4^{\circ}$ & $\begin{array}{c}\text { Total } \\
\text { Anual } \\
\end{array}$ & $\begin{array}{l}\text { Total \% } \\
\text { mensual }\end{array}$ & Media \\
\hline 1906 & 335 & 0 & 0 & 510 & & 140,83 & \multirow{4}{*}{134,70} & 72 & 0 & 0 & 73 & & 24 & \multirow{4}{*}{33,41} \\
\hline 1907 & 678 & 381 & 293 & 437 & 1789 & 179.83 & & 208 & 36 & 77 & 112 & 433 & 36 & \\
\hline 1908 & 367 & 487 & 418 & 476 & 1748 & 145,66 & & 126 & 99 & 121 & 118 & 464 & 38,66 & \\
\hline 1909 & 0 & 259 & 276 & 0 & & 72,5 & & 0 & 10 & 93 & 212 & 315 & 35 & \\
\hline
\end{tabular}

\begin{tabular}{|c|c|c|c|c|c|c|c|c|c|c|c|c|}
\hline \multirow{2}{*}{$\begin{array}{c}\text { SANTA ROSA } \\
\text { RIO } 1^{\circ} \\
\text { Trimestres }\end{array}$} & \multicolumn{6}{|c|}{ Renta del Beneficio } & \multicolumn{6}{|c|}{ Fabrica } \\
\hline & $1^{\circ}$ & $2^{\circ}$ & $3^{\circ}$ & $4^{\circ}$ & $\begin{array}{c}\text { Total } \\
\text { Anual }\end{array}$ & $\begin{array}{l}\text { Total \% } \\
\text { mensual }\end{array}$ & $1^{\circ}$ & $2^{\circ}$ & $3^{\circ}$ & $4^{\circ}$ & $\begin{array}{c}\text { Total } \\
\text { Anual }\end{array}$ & $\begin{array}{l}\text { Total } \% \\
\text { mensual }\end{array}$ \\
\hline 1906 & 0 & 0 & 0 & 0 & & & 0 & 0 & 0 & 0 & & \\
\hline 1907 & 0 & 0 & 0 & 1000 & & & 0 & 0 & 0 & 130 & & \\
\hline 1908 & 0 & 0 & 0 & 633 & & & 0 & 0 & 0 & 133 & & \\
\hline 1909 & 567 & 567 & 567 & 567 & 2268 & 189 & 400 & 400 & 400 & 400 & 1600 & 133 \\
\hline
\end{tabular}

\begin{tabular}{|c|c|c|c|c|c|c|c|c|c|c|c|c|c|c|}
\hline CHALA- & \multicolumn{7}{|c|}{ Renta del Beneficio } & \multicolumn{7}{|c|}{ Fabrica } \\
\hline Trimestr & $1^{\circ}$ & $2^{\circ}$ & $3^{\circ}$ & $4^{\circ}$ & $\begin{array}{c}\text { Total } \\
\text { Anual }\end{array}$ & $\begin{array}{c}\text { Total } \\
\% \\
\text { mensu } \\
\text { al }\end{array}$ & media & $1^{\circ}$ & $2^{\circ}$ & $3^{\circ}$ & $4^{\circ}$ & $\begin{array}{c}\text { Tota } \\
\text { Anual }\end{array}$ & $\begin{array}{l}\text { Total \% } \\
\text { mensual }\end{array}$ & Media \\
\hline 1906 & 280 & 200 & 250 & 0 & & 81,11 & \multirow{5}{*}{196,61} & 0 & 75 & 0 & 0 & & & \multirow{5}{*}{69,77} \\
\hline 1907 & 1000 & 1000 & 1000 & 1000 & 4000 & 333,33 & & 200 & 200 & 200 & 200 & 800 & 66,6 & \\
\hline 1908 & 1200 & 0 & 1200 & 800 & & 355,5 & & 200 & 0 & 470 & 400 & 1070 & 89,16 & \\
\hline 1909 & 0 & 375 & 383 & 363 & & 124,45 & & 0 & 322 & 302 & 342 & & & \\
\hline 1910 & 304 & 233 & 267 & 260 & & 88,66 & & 133 & 0 & 217 & 132 & & 53,55 & \\
\hline
\end{tabular}

\begin{tabular}{|c|c|c|c|c|c|c|c|c|c|c|c|c|c|c|}
\hline \multirow{2}{*}{$\begin{array}{l}\text { REMEDIOS } \\
\text { Trimestres }\end{array}$} & \multicolumn{7}{|c|}{ Renta del Beneficio } & \multicolumn{7}{|c|}{ Fabrica } \\
\hline & $1^{\circ}$ & $2^{\circ}$ & $3^{\circ}$ & $4^{\circ}$ & $\begin{array}{l}\text { Total } \\
\text { Anual }\end{array}$ & $\begin{array}{l}\text { Total \% } \\
\text { mensual }\end{array}$ & media & $1^{\circ}$ & $2^{\circ}$ & $3^{\circ}$ & $4^{\circ}$ & $\begin{array}{l}\text { Total } \\
\text { Anual }\end{array}$ & $\begin{array}{l}\text { Total \% } \\
\text { mensual }\end{array}$ & media \\
\hline 1906 & 403 & 686 & 147 & 523 & 1759 & 146 & \multirow{5}{*}{174,47} & 202 & 213 & 206 & 201 & & 68,5 & \multirow{5}{*}{74,18} \\
\hline 1907 & 485 & 477 & 713,25 & 0 & & 186,13 & & 170 & 185 & 279,55 & 0 & & 59,39 & \\
\hline 1908 & 591 & 757 & 709 & 611 & 2668 & 222,33 & & 375 & 397 & 255 & 318 & 1345 & 112,08 & \\
\hline 1909 & 190 & 664 & 648 & 453 & 1955 & 162,91 & & 95 & 349 & 253 & 178 & 875 & 72,16 & \\
\hline 1910 & 468 & 0 & 0 & 462 & & 155 & & 221 & 0 & 214 & 94 & & 58,77 & \\
\hline
\end{tabular}

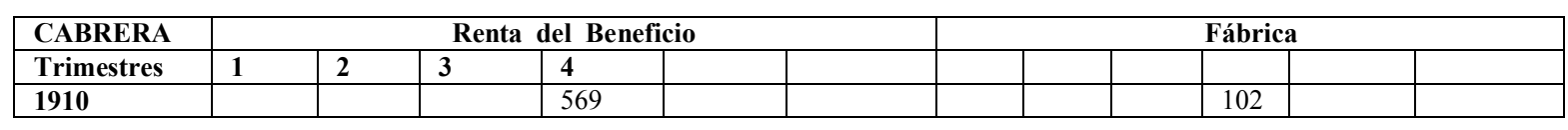

Fuentes: AAC. Leg. 28 Planillas Movimiento económico de las parroquias/ Libro Movimiento religioso y económico de la Diócesis 


\begin{tabular}{|c|c|c|c|c|c|c|}
\hline \multicolumn{7}{|c|}{$\begin{array}{c}\text { Tabla } 8 \\
\text { Expansión parroquial en la campaña cordobesa, } 1875-1904 \\
\end{array}$} \\
\hline $\mathbf{N}^{\circ}$ & Curatos 1875 & $\mathbf{N}^{\circ}$ & Curatos 1885 & $\mathbf{N}^{\circ}$ & Curatos 1905 & Departamento \\
\hline \multirow[t]{2}{*}{1} & \multirow{2}{*}{$\begin{array}{l}\text { Río } 2^{\circ} \text { Abajo (Villa del } \\
\text { Rosario) }\end{array}$} & \multirow[t]{2}{*}{1} & \multirow{2}{*}{ Villa del Rosario } & 1 & Villa del Rosario & \multirow[t]{2}{*}{ RIO SEGUNDO } \\
\hline & & & & 2 & Central Río $2^{\circ 5}$ & \\
\hline \multirow[t]{4}{*}{2} & \multirow[t]{4}{*}{ Justo y Pastor } & \multirow[t]{4}{*}{2} & \multirow{4}{*}{ Justo y Pastor } & 3 & San Justo & \multirow{4}{*}{ SAN JUSTO } \\
\hline & & & & 4 & $\begin{array}{l}\text { Morteros }^{6} \\
\text { Colonia San Pedro }\end{array}$ & \\
\hline & & & & 5 & San Francisco $^{8}$ & \\
\hline & & & & 6 & Arroyito $^{9}$ & \\
\hline 3 & Tulumba & 3 & Tulumba & 7 & Tulumba & TULUMBA \\
\hline 4 & Totoral & 4 & Totoral & 8 & $\begin{array}{l}\text { Totoral (Villa Gral. } \\
\text { Mitre) }\end{array}$ & TOTORAL \\
\hline \multirow[t]{2}{*}{5} & \multirow[t]{2}{*}{ Ischilín } & 5 & Ischilín & 9 & Deán Funes $^{10}$ & \multirow[t]{2}{*}{ ISCHILÍN } \\
\hline & & 6 & Quilino $^{2}$ & 10 & Quilino & \\
\hline \multirow[t]{2}{*}{6} & \multirow[t]{2}{*}{ Calamuchita } & 7 & Santa Rosa & \multirow[t]{2}{*}{11} & \multirow[t]{2}{*}{ Calamuchita } & \multirow[t]{3}{*}{ CALAMUCHITA } \\
\hline & & 8 & San Agustín ${ }^{2 \mathrm{a}}$ & & & \\
\hline 7 & Río de los Sauces & 9 & $\begin{array}{l}\text { Río de los Sauces/La } \\
\text { Cruz }\end{array}$ & 12 & Río de los Sauces & \\
\hline 8 & Pocho (Salsacate) & 10 & Pocho & 13 & Pocho & POCHO \\
\hline 9 & Minas & 11 & Minas & 14 & Minas & MINAS \\
\hline 10 & Rio Seco & 12 & Río Seco & 15 & Río Seco & RIO SECO \\
\hline 11 & Sobremonte & 13 & Sobremonte & 16 & Sobremonte & SOBREMONTE \\
\hline 12 & Punilla & 14 & Punilla & 17 & Cosquín & PUNILLA \\
\hline \multirow[t]{2}{*}{13} & \multirow[t]{2}{*}{ Cruz del Eje } & \multirow[t]{2}{*}{15} & \multirow[t]{2}{*}{ Cruz del Eje } & 18 & Cruz del Eje & \multirow[t]{2}{*}{ CRUZ DEL EJE } \\
\hline & & & & 19 & Soto $^{12}$ & \\
\hline \multirow[t]{4}{*}{14} & \multirow[t]{4}{*}{ Río Cuarto } & 16 & Río Cuarto & 20 & Río Cuarto & RIO CUARTO \\
\hline & & & & 21 & Sampacho $^{13}$ & \\
\hline & & & & 22 & La Carlota $^{14}$ & JUAREZ CELMAN \\
\hline & & & & 23 & Laboulaye $^{15}$ & \\
\hline 15 & $\begin{array}{l}\text { Río Tercero Arriba (Capilla } \\
\text { Rodríguez) }\end{array}$ & 17 & Tercero Arriba & 24 & Tercero Arriba & TERCERO ARRIBA \\
\hline & Jesús Nazareno $^{1}$ & & & & & \\
\hline 16 & Anejos Norte & 18 & Anejos Norte & 25 & Colón $^{16}$ & COLÓN \\
\hline & & & & 26 & Colonia Caroya $^{17}$ & \\
\hline 17 & Anejos Sur & 19 & Anejos Sur & 27 & Santa María & SANTA MARÍA $^{21}$ \\
\hline 18 & San Javier & 20 & San Javier & 28 & San Javier & SAN JAVIER \\
\hline 19 & San Pedro (San Alberto) & 21 & Tránsito $^{3}$ & 29 & Tránsito & SAN ALBERTO \\
\hline & & 22 & $\begin{array}{l}\text { (San Pedro) San } \\
\text { Alberto }\end{array}$ & 30 & $\begin{array}{l}\text { (San Pedro) San } \\
\text { Alberto }\end{array}$ & \\
\hline 20 & Santa Rosa & 23 & Santa Rosa Río $1^{\circ}$ & 31 & Santa Rosa Río $1^{\circ}$ & RÍO PRIMERO \\
\hline & & 24 & Remedios $^{4}$ & 32 & Remedios & \\
\hline 21 & Chalacea & 25 & Chalacea & 33 & $\begin{array}{l}\text { Chalacea } \\
\text { (Obispo Trejo) }\end{array}$ & \\
\hline 22 & Tercero Abajo & 26 & $\begin{array}{l}\text { Tercero Abajo } \\
\text { (Villanueva) }\end{array}$ & 34 & $\begin{array}{l}\text { Tercero Abajo } \\
\text { (Villanueva) }\end{array}$ & TERCERO ABAJO \\
\hline 23 & Villa María & 27 & Villa María & 35 & Villa María & \\
\hline
\end{tabular}




\begin{tabular}{|c|c|c|c|c|c|c|}
\hline \multirow[t]{5}{*}{24} & \multirow[t]{5}{*}{$\begin{array}{l}\text { San Gerónimo } \\
\text { Unión (Fraile Muerto) }\end{array}$} & \multirow[t]{5}{*}{28} & \multirow[t]{5}{*}{$\begin{array}{l}\text { San Gerónimo } \\
\text { Unión }\end{array}$} & 36 & $\begin{array}{l}\text { San Gerónimo } \\
\text { (Bell Ville) }\end{array}$ & \multirow[t]{2}{*}{ UNIÓN } \\
\hline & & & & \multirow[t]{2}{*}{37} & \multirow[t]{2}{*}{ Marcos Juárez $^{18}$} & \\
\hline & & & & & & \multirow[t]{3}{*}{ MARCOS JUÁREZ } \\
\hline & & & & 38 & Cruz Alta $^{19}$ & \\
\hline & & & & 39 & Canals/Arias ${ }^{20}$ & \\
\hline
\end{tabular}

1. Se crea por el Auto del 28/12/1874. Se suprime mediante el auto del 09/08/1876 y se agrega al curato de Villa María. AAC. Libro de Autos, 1876-1905, f.1.

2. Se crea por el Auto del 29/10/1881. Se desmembró del Curato de Ischilín con el Nombre de San Roque. AAC. Leg. 50 Ischilin $\mathrm{s} / \mathrm{f}$.

$2^{a}$. Se crea por el Auto del 10/04/1883. Libro de Autos... fs.52-53. Se suprime por incongruo por auto del 21/07/1885 y se une a Santa Rosa de Calamuchita. Libro de Autos... f. 67.

3. Había sido suprimido por Incongruo. Al crearse el Dpto. del Tránsito, se vuelve a crear el curato por el auto del 04/08/1885. AAC. Libro de Autos... f.62.

4. Se crea por el Auto del 24/07/1882. Datos parroquias. Capilla Remedios, respuesta circular 1924 s/f.

5. Se crea por el Auto del 30/03/1888. AAC. Datos parroquias. Río Segundo, respuesta circular 1924 s/f.

6. Se crea por el Auto del 30/06/1888. Por el Auto del 24/08/1899 se traslada la parroquia de la Asunción a la Iglesia de San Bartolomé. Libro de Autos...fs.179-180.

7 y 8. Se crean por el Auto del 10/08/1892. AAC. Libro de Autos... f.160.

9. Se crea por el Auto del 13/02/1892. AAC. Libro de Autos...f.195 .

10. Creación por Auto del 29/04/1898. Titular la Virgen del Carmen. Se suprime por incongruo por Auto del 01/05/1902 (pasa a ser parte del curato de Quilino en calidad de vice parroquia).

12. Se crea por el Auto del 10/12/1886. AAC. Compilación de datos relacionados con las parroquias de la arquidiócesis. Curato de Soto s/f.

13. Se crea por el Auto del 19/06/1902. Con el nombre de Angeles Custodios. AAC. Libro de Autos...f.220.

14. Se crea por el Auto del 03/09/1892. AAC. Libro de autos...f.162.

15. Se crea el curato de Laboulaye, con el nombre de Jesús Redentor desmembrándolo de Río Cuarto por Auto del 06/07/1901. AAC. Libro de Autos...f.191.

16. Se Nombra a Jesús María Parroquia de Colón Auto del 07/04/1902. AAC. Libro de Autos...f.197.

17. Se crea por el Auto del 29/04/1898. Con el nombre de Ntra. Sra. De Monserrat. AAC. Libro de Autos... f.171.

18. Se crea por el Auto del 10/10/1893. Con el nombre de La Asunción. AAC. Libro de Autos, 1876-1905...f.164.

19. Se crea por el Auto del 08/09/1895. Titular Ntra. Sra. del Rosario. AAC. Libro de Autos, 1876-1905, f.167.

20. Se crea por Auto del 27/06/1902. Con el nombre de la Anunciación. AAC. Libro de Autos..., f.201.

21. Por Decreto del 07/10/1892 se cambia el nombre de Anejos Sur por Santa María.

Fuentes: AAC. Cosquín, julio 1879. Nómina de Curatos. AHPC, Gobierno: 1891, T.9, s/f. Liendo, Ramón, Nomina de las Parroquias de la Provincia de Córdoba. AAC. Leg. $1^{\circ}$ Catedral, 1723-1900, Exp. № 85, fs.439-443. AAC. Zenón Bustos Obispo, Caja No 3: Informe Visitador de Parroquias 1903. AAC. Libro de Autos, 1876-1905. AAC. Compilación de datos relacionados con las parroquias de la arquidiócesis. 


\begin{tabular}{|c|c|c|c|c|}
\hline \multicolumn{5}{|c|}{ Tabla $\mathbf{N}^{\circ} 9$} \\
\hline $\mathbf{N}^{\circ}$ & Curatos 1905 & $\mathbf{N}^{\circ}$ & Curatos 1927 & Departamento \\
\hline \multirow[t]{2}{*}{1} & \multirow{2}{*}{ Villa del Rosario } & 1 & Villa del Rosario & \multirow{4}{*}{ RIO SEGUNDO } \\
\hline & & 2 & Santiago Temple ${ }^{I}$ & \\
\hline \multirow[t]{3}{*}{2} & \multirow[t]{3}{*}{ Río Segundo } & 3 & Río Segundo & \\
\hline & & 4 & Laguna Larga $^{2}$ & \\
\hline & & 5 & Oliva $^{3}$ & TERCERO ARRIBA \\
\hline \multirow[t]{8}{*}{3} & \multirow[t]{8}{*}{ San Justo } & 6 & San Justo & \multirow[t]{13}{*}{ SAN JUSTO } \\
\hline & & 7 & Porteña $^{4}$ & \\
\hline & & 8 & Las Varillas ${ }^{5}$ & \\
\hline & & 9 & Balnearia $^{6}$ & \\
\hline & & 10 & Laspiur $^{7}$ & \\
\hline & & 11 & Colonia San Bartolomé ${ }^{8}$ & \\
\hline & & 12 & Sacanta $^{9}$ & \\
\hline & & 13 & Devoto $^{10}$ & \\
\hline \multirow[t]{2}{*}{4} & \multirow[t]{2}{*}{ Morteros } & 14 & Morteros & \\
\hline & & 15 & Colonia Vignaud & \\
\hline \multirow[t]{2}{*}{5} & \multirow[t]{2}{*}{ San Francisco } & 16 & San Francisco & \\
\hline & & 17 & Freyre $^{11}$ & \\
\hline 6 & Arroyito & 18 & Arroyito & \\
\hline 7 & Tulumba & 19 & Tulumba & TULUMBA \\
\hline 8 & Totoral (Villa Gral. Mitre) & 20 & Totoral & TOTORAL \\
\hline 9 & Deán Funes & 21 & Deán Funes & \multirow[t]{2}{*}{ ISCHILÍN } \\
\hline 10 & Quilino & 22 & Quilino & \\
\hline 11 & $\begin{array}{l}\text { Calamuchita } \\
\text { San Agustín }\end{array}$ & 23 & Calamuchita & \multirow[t]{2}{*}{ CALAMUCHITA } \\
\hline 12 & Río de los Sauces & 24 & Río de los Sauces/la Cruz & \\
\hline 13 & Pocho & 25 & Pocho & POCHO \\
\hline 14 & Minas & 26 & Minas & MINAS \\
\hline 15 & Río Seco & 27 & Río Seco & RIO SECO \\
\hline 16 & Sobremonte & 28 & Sobremonte & SOBREMONTE \\
\hline \multirow[t]{3}{*}{17} & \multirow[t]{3}{*}{ Cosquín } & 29 & Cosquín & \multirow[t]{3}{*}{ PUNILLA } \\
\hline & & 30 & Capilla del Monte $^{12}$ & \\
\hline & & 31 & La Cumbre ${ }^{13}$ & \\
\hline 18 & Cruz del Eje & 32 & Cruz del Eje & CRUZ DEL EJE \\
\hline 19 & Soto & 33 & Soto & \\
\hline \multirow[t]{3}{*}{20} & \multirow[t]{3}{*}{ Río Cuarto } & 34 & Río Cuarto & \multirow[t]{4}{*}{ RIO CUARTO } \\
\hline & & 35 & Gigena $^{14}$ & \\
\hline & & & Coronel Moldes $^{15}$ & \\
\hline 21 & Sampacho & 36 & Sampacho & \\
\hline \multirow[t]{2}{*}{22} & \multirow[t]{2}{*}{ La Carlota } & 37 & La Carlota & \multirow[t]{2}{*}{ JUAREZ CELMAN } \\
\hline & & 38 & Gral. Cabrera $^{16}$ & \\
\hline 23 & Tercero Arriba & 39 & Río Tercero & TERCERO ARRIBA \\
\hline 24 & Colón & 40 & Colón & COLÓN \\
\hline
\end{tabular}




\begin{tabular}{|c|c|c|c|c|}
\hline & & 41 & Villa Allende/Calera ${ }^{17}$ & \\
\hline 25 & Colonia Caroya & 42 & Colonia Caroya & \\
\hline 26 & Alta Gracia & 43 & Alta Gracia & SANTA MARÍA \\
\hline \multirow[t]{2}{*}{27} & \multirow[t]{2}{*}{ San Javier } & 44 & Villa Dolores ${ }^{18}$ & \multirow[t]{2}{*}{ SAN JAVIER } \\
\hline & & 45 & San Javier ${ }^{19}$ & \\
\hline 28 & Tránsito & 46 & Tránsito / Villa Cura Brochero & TRÁNSITO \\
\hline 29 & (San Pedro) San Alberto & 47 & San Pedro & SAN ALBERTO \\
\hline 39 & Santa Rosa Río $1^{\circ}$ & 48 & Santa Rosa & \multirow[t]{3}{*}{ RÍO PRIMERO } \\
\hline 31 & Remedios & 49 & Remedios & \\
\hline 32 & Chalacea (Obispo Trejo) & 50 & Obispo Trejo & \\
\hline \multirow[t]{3}{*}{33} & \multirow{3}{*}{$\begin{array}{l}\text { Tercero Abajo } \\
\text { (Villanueva) }\end{array}$} & 51 & Tercero Abajo & \multirow{4}{*}{ TERCERO ABAJO } \\
\hline & & 52 & La Playosa/Pozo del Molle ${ }^{20}$ & \\
\hline & & 53 & Etruria $^{21}$ & \\
\hline \multirow{2}{*}{34} & \multirow[t]{2}{*}{ Villa María } & 54 & Villa María & \\
\hline & & 55 & Hernando/ Dalmacio Vélez ${ }^{22}$ & \multirow{6}{*}{$\begin{array}{l}\text { TERCERO ARRIBA } \\
\text { UNIÓN }\end{array}$} \\
\hline \multirow[t]{5}{*}{35} & \multirow{5}{*}{$\begin{array}{l}\text { Bell Ville } \\
\text { San Gerónimo }\end{array}$} & 56 & San Gerónimo & \\
\hline & & 57 & Laborde $^{23}$ & \\
\hline & & 58 & San Antonio de Litin ${ }^{24}$ & \\
\hline & & 59 & Ballesteros ${ }^{25}$ & \\
\hline & & 60 & Justiniano Posse $^{26}$ & \\
\hline 36 & Canals & 61 & Canals & \multirow{8}{*}{ MARCOS JUÁREZ } \\
\hline \multirow[t]{2}{*}{37} & \multirow[t]{2}{*}{ Cruz Alta } & 62 & Cruz Alta & \\
\hline & & 63 & Camilo Aldao $^{27}$ & \\
\hline \multirow[t]{5}{*}{38} & \multirow{5}{*}{$\begin{array}{l}\text { Marcos Juárez } \\
\text { La Asunción }\end{array}$} & 64 & Marcos Juárez & \\
\hline & & 65 & Leones $^{28}$ & \\
\hline & & 66 & Isla Verde ${ }^{29}$ & \\
\hline & & 67 & Corral de Bustos ${ }^{30}$ & \\
\hline & & 68 & Los Surgentes $^{31}$ & \\
\hline \multirow[t]{2}{*}{39} & \multirow[t]{2}{*}{ Laboulaye } & 69 & Laboulaye & JUAREZ CELMAN \\
\hline & & 70 & Cañada Verde ${ }^{32}$ & GRAL. ROCA \\
\hline \multicolumn{5}{|c|}{$\begin{array}{l}\text { * No se considera el departamento Capital. } \\
\text { 1. Fecha de erección: } 26 / 02 / 1914 \text {, titular San Antonio de Padua. } \\
\text { 2. Erección: } 10 / 09 / 1929 \text {, titular Ntra. Sra. del Rosario. } \\
\text { 3. Erección: } 05 / 03 / 1912 \text {, titular Sagrado Corazón de Jesús. AAC. Compilación... } \\
\text { 4. Erección: } 17 / 12 / 1910 \text {, titular San Isidro. } \\
\text { 5. Erección: } 30 / 07 / 1912 \text {, titular Ntra. Sra. del Rosario (REOBA, 1911). } \\
\text { 6. Erección: } 04 / 12 / 192 \text {, titular San José. } \\
\text { 7. Erección: } 31 / 12 / 1924 \text {, titular María Auxiliadora. } \\
\text { 8. Erección: } 16 / 02 / 1925 \text {, titular San Bartolomé. } \\
\text { 9. Erección: } 17 / 02 / 1925 \text {, titular San Miguel Arcángel. } \\
\text { 10. Erección: } 04 / 03 / 1925 \text {, titular San José. } \\
\text { 11. Erección } 07 / 07 / 1911 \text {, titular Ntra. Sra. del Rosario. } \\
\text { 12. Erección: } 17 / 12 / 1915 \text {, titular San Antonio de Padua. } \\
\text { 13. Erección: } 03 / 05 / 1924 \text {, titular San Antonio. } \\
\text { 14. Erección } 07 / 06 / 1913 \text {, titular San José de Tegua (REOBA, 1913: } 595 \text { ). } \\
\text { 15. Erección como parroquia el 03/05/1924, como capellanía independiente el } 02 / 04 / 1916 \text {, titular María } \\
\text { Auxiliadora. } \\
\text { 16. Erección: } 01 / 08 / 1910 \text {, titular San José. } \\
\text { 17. Erección: } 04 / 07 / 1914 \text {, titular Ntra. Sra. del Carmen. } \\
\text { 18. Erección: } 07 / 12 / 1914 \text {, titular Ntra. Sra. de los Dolores (pasa a ser la cabecera del antiguo curato de San } \\
\text { Javier). } \\
\text { 19. Erección como curato independiente de Villa Dolores el 01/10/1921. } \\
\text { 20. Erección: } 10 / 05 / 1913 \text {, titular Santa Teresa (REOBA, 1913: } 595 \text { ). }\end{array}$} \\
\hline
\end{tabular}


21. Erección: $15 / 11 / 1923$.

22. Erección: 10/06/1913, titular Ntra. Sra. de Luján (REOBA, 1913: 595).

23. Erección: 14/08/1909, titular Ntra. Sra. de la Asunción.

24. Erección: 11/12/1917, titular San Antonio.

25. Erección: 11/12/1917, titular San José.

26. Erección: 30/12/1926, titular San José.

27. Erección: 17/12/1917, titular San José.

28. Erección: 03/06/1913, titular Ntra. Sra. del Rosario (REOBA, 1911: 641).

29. Erección: 03/06/1913, titular San Antonio (REOBA, 1911: 641).

30. Erección: 14/11/1924, titular Ntra. Sra. del Rosario.

31. Erección: 08/06/1926, titular San Carlos Borromeo.

32. Erección: 14/08/1909, titular Natividad de María.

Fuentes: AAC. Compilación de datos relacionados con las parroquias de la arquidiócesis. Inicio del libro 1914. AAC. Respuestas a la circular de 1924 donde se solicitan los siguientes datos: fecha de erección; fecha de comienzo de los primeros libros de bautismos, matrimonios, confirmaciones y defunciones. Pueblos que componen el curato, fecha de fundación según el archivo parroquial, desmembramientos y anexiones. 


\begin{tabular}{|c|c|c|c|c|c|c|}
\hline \multicolumn{7}{|c|}{$\begin{array}{c}\text { TABLA 10a } \\
\text { Iglesias, Capillas y Oratorios en la campaña de Córdoba, } 1875\end{array}$} \\
\hline \multirow[t]{2}{*}{ Fuente } & \multirow{2}{*}{$\begin{array}{l}\text { Curatos } \\
\text { Nombre }\end{array}$} & \multirow[t]{2}{*}{$\mathbf{P}$} & \multirow[t]{2}{*}{$\mathbf{C}$} & \multicolumn{3}{|c|}{ Templos } \\
\hline & & & & $\begin{array}{l}\text { Construcción / } \\
\text { reconstrucción }\end{array}$ & Titular & Ubicación \\
\hline $\begin{array}{l}\text { Cajas Parroquias: Río } \\
\text { Seco. } \\
\text { Datos Parroquias, } \\
\text { respuesta circular } 1924\end{array}$ & Río Seco & 1 & 4 & $\begin{array}{l}\text { Muy antigua } \\
\text { Antigua (ruinas) } \\
\text { Muy antigua } \\
\text { Muy antigua } \\
\text { Muy antigua }\end{array}$ & $\begin{array}{l}\text { Ntra. Sra. del Rosario (Sede) } \\
\text { San Roque } \\
\text { San Miguel Arcángel } \\
\text { El Carmen } \\
\text { Ntra. Sra. Rosario. }\end{array}$ & $\begin{array}{l}\text { Villa de María } \\
\text { Rayo Cortado } \\
\text { Higuerillas } \\
\text { Estancia } \\
\text { Puesto de Castro }\end{array}$ \\
\hline $\begin{array}{l}\text { Cajas Parroquias: } \\
\text { Sobremonte, f.172 y } \\
22\end{array}$ & Chañar & 1 & 2 & $\begin{array}{l}\text { Muy antigua } \\
\text { Muy antigua } \\
\text { Muy antigua }\end{array}$ & $\begin{array}{l}\text { San Francisco Solano (Sede) } \\
\text { Ntra. Sra. de la Candelaria } \\
\text { San Roque }\end{array}$ & $\begin{array}{l}\text { Villa S. Francisco } \\
\text { Caminiaga } \\
\text { Chuñahuasi }\end{array}$ \\
\hline $\begin{array}{l}\text { AAC. Compilación de } \\
\text { datos relacionados con } \\
\text { las parroquias de la } \\
\text { arquidiócesis. } \\
\text { Río y Achával (1904: } \\
\text { 480) }\end{array}$ & Tulumba & 1 & 6 & $\begin{array}{l}\text { Muy antigua } \\
\text { Muy antigua } \\
\text { Muy antigua } \\
\text { Muy antigua } \\
\text { Muy antigua } \\
\text { Muy antigua } \\
\text { Muy antigua }\end{array}$ & $\begin{array}{l}\text { Ntra. Sra. del Rosario (Sede) } \\
\text { Ntra. Sra. Rosario } \\
\text { San Pedro } \\
\text { San José } \\
\text { Ntra. Sra. Pilar } \\
\text { Ntra. Sra. del Rosario } \\
\text { S. Antonio de Padua }\end{array}$ & $\begin{array}{l}\text { Villa Tulumba } \\
\text { Rosario del Saladillo } \\
\text { San Pedro Norte } \\
\text { S. José de la Dormida } \\
\text { Churqui Cañada } \\
\text { Puesto de Castro } \\
\text { Simbolar }\end{array}$ \\
\hline $\begin{array}{l}\text { AAC. Compilación de } \\
\text { datos..., fs. } 50 \text { y } 262\end{array}$ & Ischilín & 1 & 5 & 1706 & $\begin{array}{l}\text { Ntra. Sra. del Rosario (Sede) } \\
\text { San Vicente } \\
\text { Ntra. Sra. de Copacabana } \\
\text { San Pedro Apóstol } \\
\text { San Roque } \\
\text { Inmaculada Concepción }\end{array}$ & $\begin{array}{l}\text { Ischilín } \\
\text { Parroquia } \\
\text { Copacabana } \\
\text { Toyos } \\
\text { Quilino } \\
\text { Ciénaga }\end{array}$ \\
\hline $\begin{array}{l}\text { AAC. Parroquias: } \\
\text { Cruz del Eje, fs. } 195 \text { y } \\
\text { ss. }\end{array}$ & Cruz del Eje & 1 & 6 & & $\begin{array}{l}\text { Ntra. Sra. del Carmen (Sede) } \\
\text { San Marcos } \\
\text { Inm.Concepción/San Roque } \\
\text { Santo Domingo } \\
\text { Virgen del Rosario } \\
\text { Virgen del Rosario } \\
\text { Virgen de la Candelaria }\end{array}$ & $\begin{array}{l}\text { Villa Cruz Eje } \\
\text { San Marcos Sierra } \\
\text { Villa de Soto } \\
\text { Santo Domingo } \\
\text { Higuera } \\
\text { Pichana } \\
\text { Candelaria }\end{array}$ \\
\hline $\begin{array}{l}\text { Parroquias: San Carlos } \\
\text { Minas, fs.302-304. } \\
\text { Compilación de } \\
\text { datos..., f.196 }\end{array}$ & Minas & 1 & 4 & & $\begin{array}{l}\text { San Carlos (Sede) } \\
\text { Virgen del Rosario } \\
\text { Virgen de la Candelaria } \\
\mathrm{Nc} \\
\mathrm{Nc}\end{array}$ & $\begin{array}{l}\text { Villa } \\
\text { Guasapampa } \\
\text { Ciénaga del Coro } \\
\text { Orat. Ninalquin } \\
\text { Orat. de Pinas }\end{array}$ \\
\hline $\begin{array}{l}\text { AAC. Compilación de } \\
\text { datos..., f. } 248\end{array}$ & $\begin{array}{l}\text { Pocho } \\
\text { (Salsacate) }\end{array}$ & 1 & 3 & $\begin{array}{l}\text { Muy antigua } \\
\text { Muy antigua } \\
\text { Muy antigua } \\
\text { Muy antigua } \\
\end{array}$ & $\begin{array}{l}\text { Inmaculada Concepción(Sede) } \\
\text { Ntra. Sra. del Rosario } \\
\text { Ntra. Sra. del Carmen } \\
\text { Ntra. Sra. del Rosario }\end{array}$ & $\begin{array}{l}\text { Pocho } \\
\text { Salsacate } \\
\text { Chancani } \\
\text { Las Palmas } \\
\end{array}$ \\
\hline $\begin{array}{l}\text { Compilación de } \\
\text { datos..., f.295 }\end{array}$ & San Alberto & 1 & 4 & (en ruinas) & $\begin{array}{l}\text { San Pedro (Sede) } \\
\text { San Vicente } \\
\text { El Tránsito (Residencia del } \\
\text { párroco a partir de 1872) } \\
\text { Nono } \\
\text { Panaholma }\end{array}$ & $\begin{array}{l}\text { San Pedro } \\
\text { San Vicente } \\
\text { El Tránsito } \\
\text { Nono } \\
\text { Panaholma }\end{array}$ \\
\hline $\begin{array}{l}\text { AAC. Compilación de } \\
\text { datos..., f.293 }\end{array}$ & San Javier & 1 & 2 & $\begin{array}{l}1875 \\
1762 \text { (en ruinas) } \\
\text { en ruinas }\end{array}$ & $\begin{array}{l}\text { San Javier (Sede) } \\
\text { La Paz } \\
\text { Ntra. Sra. de las Mercedes }\end{array}$ & $\begin{array}{l}\text { San Javier } \\
\text { La Paz } \\
\text { Luyaba }\end{array}$ \\
\hline $\begin{array}{l}\text { Compilación de } \\
\text { datos... fs. } 106 \text { y } 291\end{array}$ & Calamuchita & 1 & 2 & $\begin{array}{l}\text { Muy antigua } \\
1803 \\
1783\end{array}$ & $\begin{array}{l}\text { San Agustín (Sede) } \\
\text { Santa Rosa } \\
\text { Inmaculada Concepción }\end{array}$ & $\begin{array}{l}\text { San Agustín } \\
\text { Santa Rosa } \\
\text { Los Reartes }\end{array}$ \\
\hline
\end{tabular}




\begin{tabular}{|c|c|c|c|c|c|c|}
\hline $\begin{array}{l}\text { Compilación de } \\
\text { datos..., f.106 }\end{array}$ & $\begin{array}{l}\text { Río de los } \\
\text { Sauces }\end{array}$ & 1 & 3 & $\begin{array}{l}1860 \\
1775 \text { (Flia. } \\
\text { Ramos) }\end{array}$ & $\begin{array}{l}\text { El Señor de la Agonía (Sede) } \\
\text { Ntra. Sra. del Rosario } \\
\text { Ntra. Sra. de las Mercedes. } \\
\text { San Antonio }\end{array}$ & $\begin{array}{l}\text { Río de los Sauces } \\
\text { El Quebracho } \\
\text { La Cruz } \\
\text { El Cano }\end{array}$ \\
\hline $\begin{array}{l}\text { AAC. Parroquias: } \\
\text { Punilla. Compilación } \\
\text { de datos..., f.250. } \\
\text { Caja Parroquias: } \\
\text { Cosquín, f.10 }\end{array}$ & Punilla & 1 & 11 & $\begin{array}{l}\text { Muy antigua } \\
\text { Muy antigua } \\
\text { Muy antigua } \\
\text { Muy antigua } \\
\text { Muy antigua } \\
\text { Muy antigua } \\
\text { Muy antigua } \\
\text { Muy antigua } \\
\text { (deteriorada) } \\
\text { Muy Antigua } \\
\text { Muy antigua } \\
\text { Antigua }\end{array}$ & $\begin{array}{l}\text { San Antonio (sede) } \\
\text { San Esteban } \\
\text { Ntra. Sra. del Rosario } \\
\text { Ntra. Sra. Rosario } \\
\text { San Roque } \\
\text { San José } \\
\text { Ntra. Sra. de las Mercedes } \\
\text { Ntra. Sra. de los Dolores. } \\
\text { Ntra. Sra. Dolores } \\
\text { San Antonio del Monte } \\
\text { San Antonio ( sur) } \\
\text { Santa Bárbara }\end{array}$ & $\begin{array}{l}\text { San Antonio } \\
\text { San Esteban } \\
\text { Tanti } \\
\text { Rosario } \\
\text { Cosquín } \\
\text { Rosario } \\
\text { Cañada } \\
\text { Río Pinto } \\
\text { Dolores } \\
\text { Dolores } \\
\text { Rosario } \\
\text { Olaen }\end{array}$ \\
\hline $\begin{array}{l}\text { AAC. Compilación de } \\
\text { datos..., f.302 }\end{array}$ & Totoral & 1 & 3 & $\begin{array}{l}(1872) \\
1837 / 1885 \\
1875\end{array}$ & $\begin{array}{l}\text { Ntra. Sra. del Rosario (Sede) } \\
\text { La Purísima } \\
\text { San José } \\
\text { Ntra. Sra. Candelaria }\end{array}$ & $\begin{array}{l}\text { Villa Totoral } \\
\text { Citon } \\
\text { Sarmiento } \\
\text { Candelaria }\end{array}$ \\
\hline $\begin{array}{l}\text { AAC. Compilación de } \\
\text { datos..., fs. } 40,47 \text { y } \\
136\end{array}$ & Anejos Norte & 1 & 3 & $\begin{array}{l}\text { Muy antigua } \\
1647 \\
1659\end{array}$ & $\begin{array}{l}\text { Ntra. Sra. de los Dolores (Sede) } \\
\text { San Isidro Labrador } \\
\text { Ntra. Sra. de la Candelaria } \\
\text { Ntra. Sra. del Rosario }\end{array}$ & $\begin{array}{l}\text { Río Ceballos } \\
\text { Jesús María } \\
\text { Lagunilla } \\
\text { Salsipuedes }\end{array}$ \\
\hline $\begin{array}{l}\text { Compilación de } \\
\text { datos..., f.44 }\end{array}$ & Chalacea & 1 & 2 & 1871 & $\begin{array}{l}\text { Ntra. Sra. del Rosario,(Sede) } \\
\text { San Antonio } \\
\text { Purísima Concepción }\end{array}$ & $\begin{array}{l}\text { Monte del Rosario } \\
\text { Timón Cruz } \\
\text { La Salada }\end{array}$ \\
\hline $\begin{array}{l}\text { Santa Rosa Río } 1^{\circ} \text {. } \\
\text { Leg. } 30 \text {. Nota del } \\
\text { 19/01/1877, s/f }\end{array}$ & $\begin{array}{l}\text { Santa Rosa } \\
\text { Río Primero }\end{array}$ & 1 & 4 & $\begin{array}{l}1800 \\
\text { Muy antigua/ } \\
1910 \\
1830 \\
\text { Colonial }\end{array}$ & $\begin{array}{l}\text { Santa Rosa de Lima (Sede) } \\
\text { Ntra. Sra. del Carmen } \\
\text { Ntra. Sra. del Tránsito } \\
\text { San José } \\
\text { Ntra. Sra. de Copacabana }\end{array}$ & $\begin{array}{l}\text { Villa Santa Rosa } \\
\text { Tinoco } \\
\text { Punta de Agua } \\
\text { Esquina } \\
\text { Villamonte }\end{array}$ \\
\hline $\begin{array}{l}\text { AAC. Compilación de } \\
\text { datos..., f. } 4\end{array}$ & Anejos Sur & 1 & 3 & $\begin{array}{l}1672 \\
1808 \\
1810 \\
1659\end{array}$ & $\begin{array}{l}\text { Ntra. Sra. Mercedes (Sede) } \\
\text { Ntra. Sra. de las Mercedes } \\
\text { San Antonio } \\
\text { Ntra. Sra. de la Candelaria }\end{array}$ & $\begin{array}{l}\text { Alta Gracia } \\
\text { Cosme } \\
\text { Lagunilla }\end{array}$ \\
\hline $\begin{array}{l}\text { Compilación de } \\
\text { datos..., fs. } 234,284 \text {, } \\
312\end{array}$ & $\begin{array}{l}\text { Villa del } \\
\text { Rosario }\end{array}$ & 1 & 4 & $\begin{array}{l}1792 / 1894 \\
\text { Muy antigua } \\
1849\end{array}$ & $\begin{array}{l}\text { Ntra. Sra. del Rosario (Sede) } \\
\text { Ntra. Sra. del Pilar } \\
\text { San José } \\
\text { Ntra. Sra. Mercedes } \\
\text { Río II } \\
\text { San Roque } \\
\end{array}$ & $\begin{array}{l}\text { Villa del Rosario } \\
\text { Pilar } \\
\text { Costa Sacate } \\
\text { Impiria } \\
\text { Río II } \\
\text { Chañares } \\
\end{array}$ \\
\hline $\begin{array}{l}\text { Compilación de } \\
\text { datos..., fs.174, 178, } \\
306\end{array}$ & $\begin{array}{l}\text { Capilla } \\
\text { Rodríguez }\end{array}$ & 1 & 3 & $\begin{array}{l}1728 \\
\text { Antigua }\end{array}$ & $\begin{array}{l}\text { La Purísima Concepción (Sede) } \\
\text { San José } \\
\text { Inmaculada Concepción } \\
\text { Oratorio Las Mercedes (Flia } \\
\text { Molina) } \\
\text { Orat. Ntra. Sra. del Carmen } \\
\text { (Flia. Acuña) } \\
\text { Orat. Ntra.Sra Mercedes. (Flia. } \\
\text { Farias de la Torre) }\end{array}$ & $\begin{array}{l}\text { Salto } \\
\text { Salto } \\
\text { Pampayasta } \\
\text { Salto Sud } \\
\text { Río Tercero } \\
\text { Tancacha }\end{array}$ \\
\hline $\begin{array}{l}\text { AAC. Compilación de } \\
\text { datos... }\end{array}$ & San Justo & 1 & 5 & Muy antigua & $\begin{array}{l}\text { Inmaculada Concepción (Sede) } \\
\text { San Francisco } \\
\text { Ntra. Sra. de las Mercedes }\end{array}$ & $\begin{array}{l}\text { Villa Concepción Tío } \\
\text { San Francisco } \\
\text { Arroyito }\end{array}$ \\
\hline
\end{tabular}




\begin{tabular}{|l|l|l|l|l|l|l|}
\hline & & & & 1870 & $\begin{array}{l}\text { La Asunción } \\
\text { San Agustín } \\
\text { Ntra Sra. Mercedes }\end{array}$ & $\begin{array}{l}\text { Transito } \\
\text { Sacanta } \\
\text { Punta de Agua }\end{array}$ \\
\hline $\begin{array}{l}\text { AAC. Parroquias: } \\
\text { Villa María, f.174 }\end{array}$ & Villa María & 1 & 2 & 1874 & $\begin{array}{l}\text { Inmaculada Concepción ( Sede) } \\
\text { Jesús Nazareno } \\
\text { San Antonio de Padua }\end{array}$ & $\begin{array}{l}\text { Villa María } \\
\text { Los Zorros } \\
\text { Yucat }\end{array}$ \\
\hline $\begin{array}{l}\text { AAC. Compilación de } \\
\text { datos..., f.316 }\end{array}$ & Villa Nueva & 1 & 1 & & $\begin{array}{l}\text { Ntra. Sra. del Rosario (Sede) } \\
\text { Ntra. Sra. del Rosario }\end{array}$ & $\begin{array}{l}\text { Villanueva } \\
\text { Punta de Agua }\end{array}$ \\
\hline $\begin{array}{l}\text { AAC. Compilación de } \\
\text { datos..., fs.20, 48, 336, } \\
357\end{array}$ & Unión & 1 & 4 & 1781 & $\begin{array}{l}\text { Inmaculada Concepción (Sede) } \\
\text { San Antonio } \\
\text { Ntra. Sra. de la Merced } \\
\text { San José } \\
\text { Inmaculada Concepción }\end{array}$ & $\begin{array}{l}\text { Bell Ville } \\
\text { Litín } \\
\text { Saladillo } \\
\text { Ballesteros } \\
\text { Cruz Alta }\end{array}$ \\
\hline $\begin{array}{l}\text { AAC. Compilación de } \\
\text { datos... }\end{array}$ & Río Cuarto & 1 & 4 & $\begin{array}{l}1850 \\
\text { Antiguo Fuerte } \\
\text { Muy antigua } \\
\text { destruida }\end{array}$ & $\begin{array}{l}\text { Inmaculada (Sede) } \\
\text { El Señor de la Buena Muerte. } \\
\text { Virgen de la Merced. } \\
\text { San Bartolomé } \\
\text { Ntra. Sra. de las Mercedes } \\
\text { San José }\end{array}$ & $\begin{array}{l}\text { Villa de Río Cuarto } \\
\text { Reducción } \\
\text { Achiras. } \\
\text { San Bartolomé } \\
\text { La Carlota } \\
\text { Tegua }\end{array}$ \\
\hline
\end{tabular}




\section{TABLA 10b}

Iglesias parroquiales y capillas filiales de la campaña cordobesa en 1905

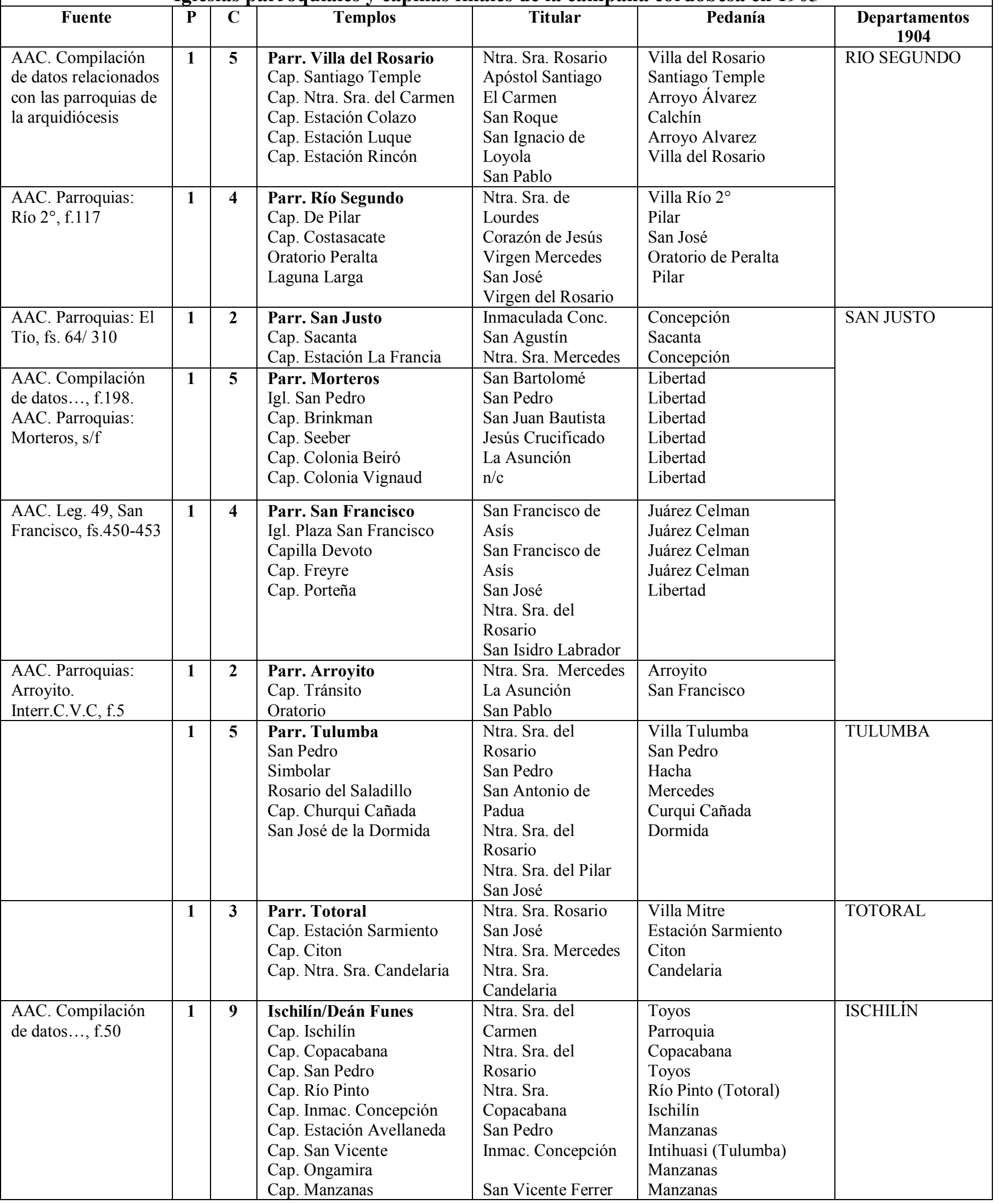




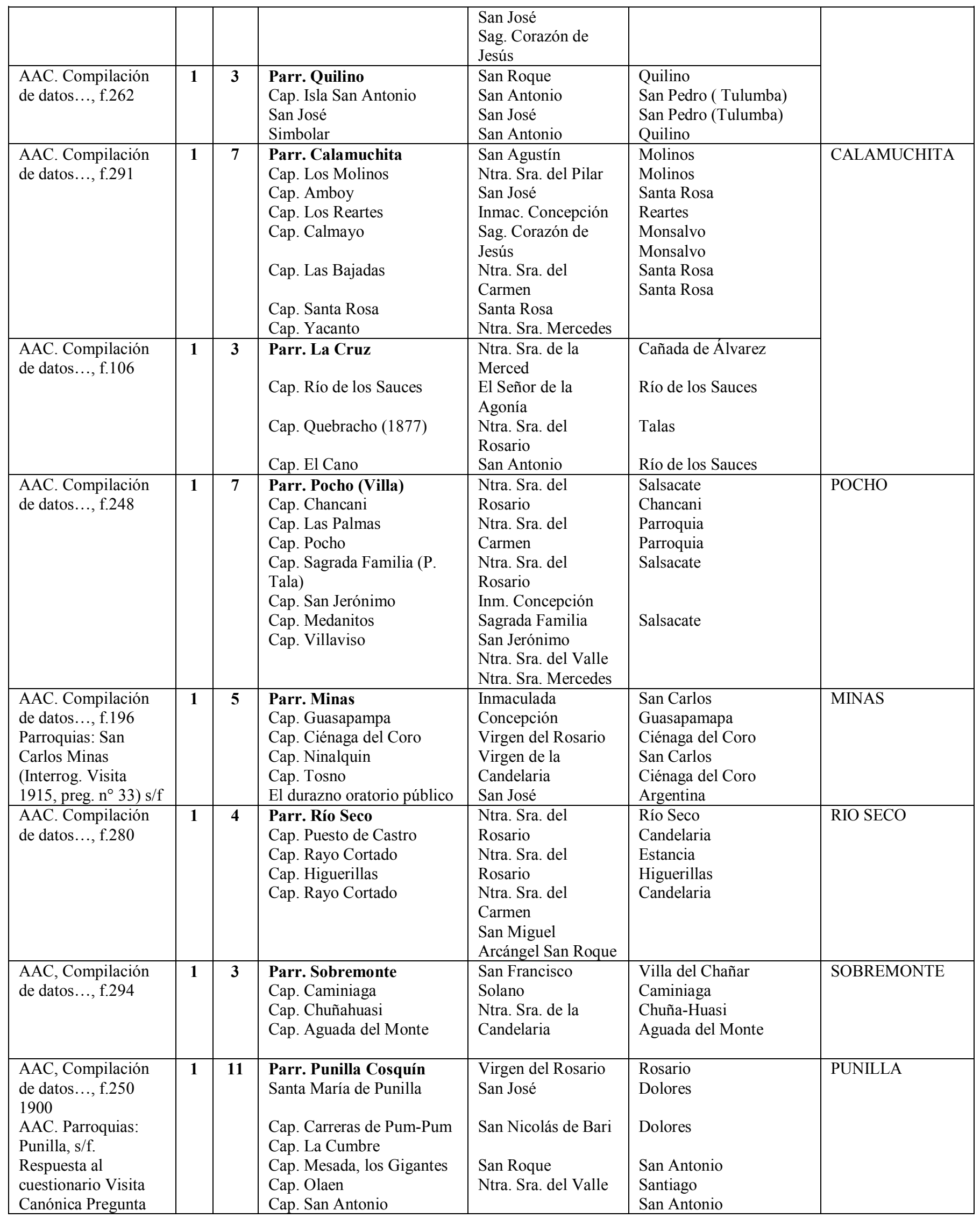




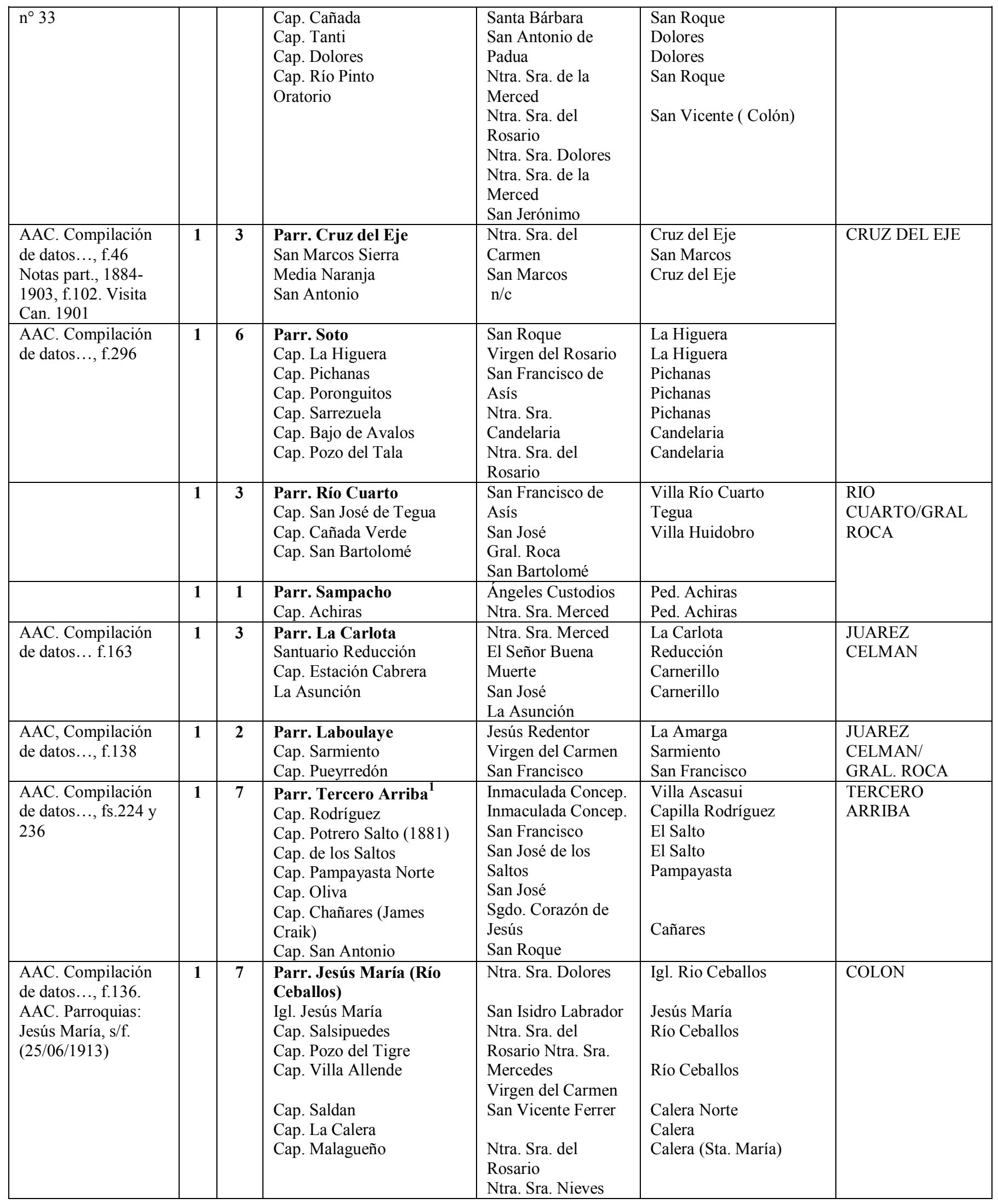




\begin{tabular}{|c|c|c|c|c|c|c|}
\hline & 1 & 2 & $\begin{array}{l}\text { Parr. Colonia Caroya } \\
\text { Col. Tirolesa } \\
\text { La Cuesta }\end{array}$ & $\begin{array}{l}\text { Ntra. Sra.Montserrat } \\
\text { nc } \\
\text { Ntra. Sra. Mercedes }\end{array}$ & $\begin{array}{l}\text { Ped. Cañas } \\
\text { Ped. Constitución }\end{array}$ & \\
\hline & 1 & 6 & $\begin{array}{l}\text { Parr. Alta Gracia } \\
\text { Cap. Cosme } \\
\text { Cap. Lagunilla } \\
\text { Cap. San Antonio } \\
\text { Cap. Bajo Grande } \\
\text { Cap. Potrero de Garay } \\
\text { Cap. Falda del Carmen }\end{array}$ & $\begin{array}{l}\text { Ntra. Sra.Mercedes } \\
\text { Ntra. Sra.Mercedes } \\
\text { Ntra. Sra. Rosario } \\
\text { San Antonio } \\
\text { Santo Domingo } \\
\text { Ntra. Sra. } \\
\text { Candelaria }\end{array}$ & $\begin{array}{l}\text { Pueblo Alta Gracia } \\
\text { Ped. Cosme } \\
\text { Lagunilla } \\
\text { Alta Gracia } \\
\text { Molinos (Calamuchita) } \\
\text { Lagunilla }\end{array}$ & SANTA MARÍA \\
\hline & 1 & 5 & $\begin{array}{l}\text { Parr.San Javier } \\
\text { Cap. Villa Dolores } \\
\text { Cap. Las Rosas } \\
\text { Cap. Luyaba } \\
\text { Cap. La Paz }\end{array}$ & $\begin{array}{l}\text { San Francisco Javier } \\
\text { Ntra. Sra. del } \\
\text { Carmen } \\
\text { Ntra. Sra. Mercedes }\end{array}$ & $\begin{array}{l}\text { San Javier } \\
\text { Dolores } \\
\text { Las Rosas } \\
\text { Luyaba } \\
\text { Talas }\end{array}$ & SAN JAVIER \\
\hline & 1 & 4 & $\begin{array}{l}\text { Parr. San Alberto } \\
\text { Cap. Mercedes } \\
\text { Cap. Toscas } \\
\text { Cap. San Vicente } \\
\text { Cap. del Carmen }\end{array}$ & $\begin{array}{l}\text { San Pedro } \\
\text { Ntra. Sra. Mercedes } \\
\text { Purísima } \\
\text { Concepción } \\
\text { San Vicente } \\
\text { Ntra. Sra. del } \\
\text { Carmen } \\
\end{array}$ & $\begin{array}{l}\text { San Pedro } \\
\text { San Pedro } \\
\text { Las Toscas } \\
\text { Las Toscas } \\
\text { Carmen }\end{array}$ & SAN ALBERTO \\
\hline & 1 & 4 & $\begin{array}{l}\text { Villa del Tránsito } \\
\text { Nono } \\
\text { Panaholma } \\
\text { Ambul } \\
\text { Ciénaga }\end{array}$ & $\begin{array}{l}\text { Ntra. Sra. del } \\
\text { Tránsito } \\
\text { San Juan Bautista } \\
\text { Ntra Sra. Rosario } \\
\text { Inmac. Concepción } \\
\text { Sagrado Corazón }\end{array}$ & $\begin{array}{l}\text { Tránsito } \\
\text { Nono } \\
\text { Panaholma } \\
\text { Ambul } \\
\text { Panaholma }\end{array}$ & TRANSITO \\
\hline & 1 & 6 & $\begin{array}{l}\text { Parr. Santa Rosa } \\
\text { Cap. Esquina } \\
\text { Cap. Tinoco } \\
\text { Capilla Esperanza } \\
\text { Cap. Punta de Agua } \\
\text { Cap Sagrada familia } \\
\text { Cap. Higuerillas }\end{array}$ & $\begin{array}{l}\text { Santa Rosa de } \\
\text { Lima } \\
\text { Del Rosario } \\
\text { Del Carmen } \\
\text { Ntra. Sra. de la } \\
\text { Esperanza } \\
\text { Ntra. Sra. Tránsito } \\
\text { Sagrada Familia } \\
\end{array}$ & $\begin{array}{l}\text { Ped. Santa Rosa } \\
\text { Pedania Esquina } \\
\text { Pedania Esquina } \\
\text { Pedania Esquina } \\
\text { Pedania Esquina } \\
\text { Ped. Cañada del } \\
\text { Quebracho }\end{array}$ & RIO PRIMERO \\
\hline & 1 & 4 & $\begin{array}{l}\text { Parr. Monte del Rosario } \\
\text { Chalecea } \\
\text { Cap. San Antonio } \\
\text { Cap. Las Saladas } \\
\text { Cap. Las Mercedes } \\
\text { Cap. Santa Rita }\end{array}$ & $\begin{array}{l}\text { De Rosario } \\
\text { San Antonio } \\
\text { Purísima } \\
\text { Concepción } \\
\text { Ntra. Sra. Merced } \\
\text { Santa Rita }\end{array}$ & $\begin{array}{l}\text { Ped. Timón Cruz } \\
\text { Ped Timón Cruz } \\
\text { Ped. De Castaños } \\
\text { Ped. De Castaños } \\
\text { Ped. Castaños } \\
\text { Ped. Castaños }\end{array}$ & \\
\hline $\begin{array}{l}\text { AAC. Leg. 48. Fraile } \\
\text { Muerto (Bell Ville) } \\
\text { Villa Nueva, f.681 }\end{array}$ & 1 & 8 & $\begin{array}{l}\text { Parr. Villanueva } \\
\text { Estación Cabrera } \\
\text { Dalmasio Vélez } \\
\text { Punta de Agua } \\
\text { Perdices } \\
\text { Pampayasta Sud } \\
\text { Arroyo Cabral } \\
\text { Palestina } \\
\text { Etruria }\end{array}$ & $\begin{array}{l}\text { Ntra. Sra. del } \\
\text { Rosario } \\
\text { San José } \\
\text { Virgen de Lujan } \\
\text { Virgen del Rosario } \\
\text { Purísima Concep. } \\
\text { La Anunciación }\end{array}$ & $\begin{array}{l}\text { Villa Nueva } \\
\text { Carnerillo (J. Celman) } \\
\text { Punta de Agua ( T. } \\
\text { Arriba) } \\
\text { Punta de Agua ( } \\
\text { T.Arriba) } \\
\text { Punta de Agua } \\
\text { (T.Arriba) } \\
\text { Pampayasta ( T. Arriba) } \\
\text { Yucat } \\
\text { Chazon }\end{array}$ & $\begin{array}{l}\text { TERCERO } \\
\text { ARRIBA/ } \\
\text { TERCERO } \\
\text { ABAJO }\end{array}$ \\
\hline
\end{tabular}




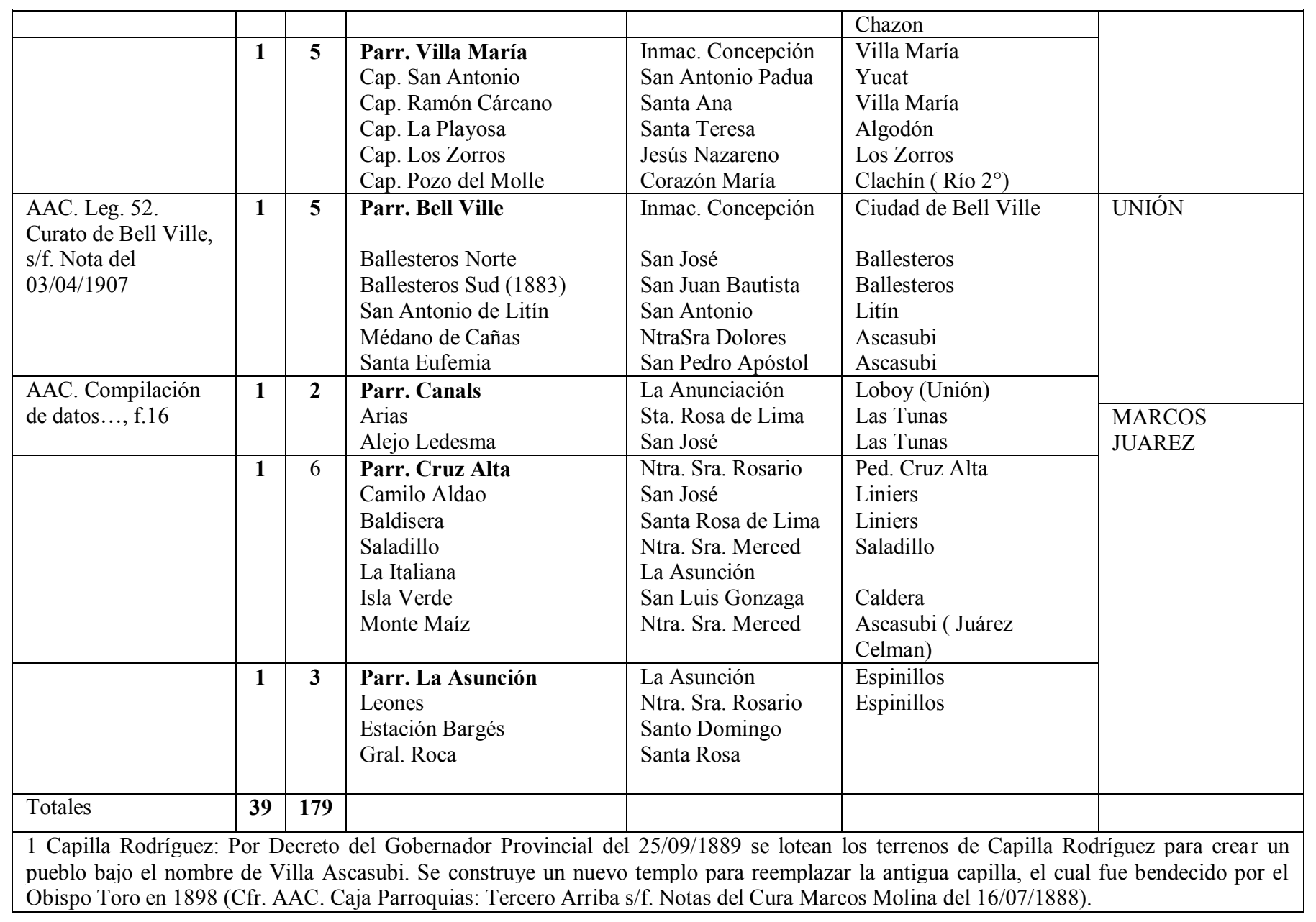




\begin{tabular}{|c|c|c|c|c|c|}
\hline \multicolumn{6}{|c|}{$\begin{array}{c}\text { Tabla 10c } \\
\text { Iglesias parroquiales y capillas filiales de la campaña cordobesa en } 1925\end{array}$} \\
\hline $\mathbf{P}$ & C & Curato & Titular & Lugar & Departamento \\
\hline \multirow[t]{6}{*}{1} & \multirow[t]{6}{*}{5} & \multirow{6}{*}{$\begin{array}{l}\text { Villa del } \\
\text { Rosario }\end{array}$} & Ntra. Sra. del Rosario (S) & Villa del Rosario & \multirow[t]{27}{*}{ RIO SEGUNDO } \\
\hline & & & Ntra. Sra. del Carmen & El Carmen & \\
\hline & & & San Roque & Estación Colazo & \\
\hline & & & San Ignacio de Loyola & Estación Luque & \\
\hline & & & San Pablo & Estación Rincón & \\
\hline & & & & Estación Junturas & \\
\hline \multirow[t]{3}{*}{1} & \multirow[t]{3}{*}{2} & \multirow{3}{*}{$\begin{array}{l}\text { Santiago } \\
\text { Temple }\end{array}$} & Santiago Apóstol (S) & Estacón Santiago Temple & \\
\hline & & & Capilla los Chañaritos & Pedanía Oratorio de Peralta & \\
\hline & & & Ntra. Sra. del Transito & Pedanía San Francisco & \\
\hline \multirow[t]{6}{*}{1} & \multirow[t]{6}{*}{5} & \multirow[t]{6}{*}{ Río Segundo } & Virgen de Lourdes (S) & Villa Rio segundo & \\
\hline & & & Corazón de Jesús & Pilar & \\
\hline & & & Virgen del Rosario & Estación Laguna & \\
\hline & & & San José & Costasacate & \\
\hline & & & Virgen de las Mercedes & & \\
\hline & & & Virgen del Perpetuo Socorro & Estación Toledo & \\
\hline \multirow[t]{2}{*}{1} & \multirow[t]{2}{*}{2} & \multirow[t]{2}{*}{ Laguna Larga } & Ntra. Sra. el Rosario (S) & Laguna Larga & \\
\hline & & & Corazón Jesús & Costasacate & \\
\hline \multirow[t]{5}{*}{1} & 4 & \multirow{5}{*}{$\begin{array}{l}\text { Oliva } \\
17 / 02 / 1912\end{array}$} & Sagrado Corazón (S) & Oliva & \\
\hline & & & San Isidro Labrador & Oncativo & \\
\hline & & & San Roque (16/08/1913) & Colazo & \\
\hline & & & Ntra. Sra. de las Mercedes & Impiria & \\
\hline & & & San Roque & James Craik (Chañares) & \\
\hline \multirow[t]{6}{*}{1} & 6 & \multirow[t]{6}{*}{ Tercero Arriba } & Villa Ascasubi (S) & Pedanía Capilla Rodríguez & \\
\hline & & & $\begin{array}{l}\text { Cap. Sta Teresa de Jesús } \\
\text { Tancacha }(1915)\end{array}$ & Pedanía Capilla Rodríguez & \\
\hline & & & $\begin{array}{l}\text { Ntra. Sra Lourdes Rio } \\
\text { Tercero (1923 bendecida). }\end{array}$ & Pedanía El Salto & \\
\hline & & & Almafuerte & Pedanía El Salto & \\
\hline & & & Corralito & El Salto & \\
\hline & & & $\begin{array}{l}\text { Colonia Almada Sta. Rosa } \\
\text { de Lima (1912-1929) }\end{array}$ & Capilla Rodríguez & \\
\hline \multirow[t]{6}{*}{1} & 5 & \multirow{6}{*}{$\begin{array}{l}\text { San Justo } \\
(21 / 07 / 1860)\end{array}$} & Inmaculada Concepción (S) & Pedanía Concepción & \multirow[t]{17}{*}{ SAN JUSTO } \\
\hline & & & La Francia & Pedanía Concepción & \\
\hline & & & El Tío & PedaníaConcepción & \\
\hline & & & San Rafael & PedaníaConcepción & \\
\hline & & & Calchín & PedaníaCalchín & \\
\hline & & & San Antonio & Pedanía Concepción & \\
\hline 1 & & Porteña & San Isidro (S) & Pedanía Libertad & \\
\hline \multirow[t]{2}{*}{1} & 1 & \multirow[t]{2}{*}{ Las Varillas } & Ntra. Sra. del Rosario (S) & Las varillas & \\
\hline & & & Las Varas & Estación Las Varas & \\
\hline 1 & 2 & Balnearia & San José (S) & Pedanía Concepción & \\
\hline & & & Marull & Pedanía Concepción & \\
\hline & & & Miramar & Concepción & \\
\hline 1 & 2 & Laspiur & Santo Domingo (S) & Juárez Celman & \\
\hline & & & Prosperidad & Juárez Celman & \\
\hline & & & Alicia & Juárez Celman & \\
\hline 1 & & $\begin{array}{l}\text { Colonia San } \\
\text { Bartolomé }\end{array}$ & San Bartolomé (S) & Sacanta & \\
\hline 1 & 2 & Sacanta & San Miguel Arcángel (S) & Sacanta & \\
\hline
\end{tabular}




\begin{tabular}{|c|c|c|c|c|c|}
\hline & & & San Agustín & Sacanta & \\
\hline & & & Calchín & Calchín & \\
\hline \multirow[t]{3}{*}{1} & \multirow[t]{3}{*}{2} & \multirow{3}{*}{ Devoto } & San José (S) & Libertad & \\
\hline & & & Colonia Marina & Libertad & \\
\hline & & & Luxardo & Libertad & \\
\hline \multirow[t]{2}{*}{1} & 1 & \multirow[t]{2}{*}{ Morteros } & San Bartolomé (S) & Libertad & \\
\hline & & & San Pedro & Libertad & \\
\hline \multirow[t]{3}{*}{1} & 2 & \multirow{3}{*}{$\begin{array}{l}\text { Colonia } \\
\text { Vignaud }\end{array}$} & Viganud (S) & Libertad & \\
\hline & & & Brinkmann & Libertad & \\
\hline & & & Seeber & Libertad & \\
\hline \multirow[t]{3}{*}{1} & 2 & \multirow[t]{3}{*}{ San Francisco } & San Francisco & Juárez Celman & \\
\hline & & & Plaza San Francisco & Juárez Celman & \\
\hline & & & Quebracho Herrado & Juárez Celman & \\
\hline 1 & 0 & Freyre & Ntra. Sra. del Rosario & Libertad & \\
\hline \multirow[t]{2}{*}{1} & 1 & \multirow[t]{2}{*}{ Arroyito } & Ntra. Sra. de la Merced & Arroyito & \\
\hline & & & Audagna & Arroyito & \\
\hline \multirow[t]{6}{*}{1} & 5 & \multirow[t]{6}{*}{ Tulumba } & Ntra. Sra. del Rosario (S) & Villa Tulumba & \multirow[t]{6}{*}{ TULUMBA } \\
\hline & & & San José & San José de la Dormida & \\
\hline & & & San Pedro & San Pedro & \\
\hline & & & San José & Churqui Cañada & \\
\hline & & & Mercedes & Rosario del Saladillo & \\
\hline & & & Simbolar & Hacha & \\
\hline \multirow[t]{3}{*}{1} & 2 & \multirow[t]{3}{*}{ Totoral } & Ntra. Sra. del Rosario & Gral. Mitre & \multirow[t]{3}{*}{ TOTORAL } \\
\hline & & & Sarmiento & Gral. Mitre & \\
\hline & & & Cañada de Luque & Candelaria & \\
\hline \multirow[t]{7}{*}{1} & 6 & \multirow[t]{7}{*}{ Deán Funes } & Ntra. Sra. del Carmen (S) & Estación Deán Funes & \multirow[t]{11}{*}{ ISCHILÍN } \\
\hline & & & Ntra. Sra. del Rosario & Ischilín & \\
\hline & & & Ntra. Sra. de Copacabana & Copacabana & \\
\hline & & & Sagrado Corazón de Jesús & Río Pinto & \\
\hline & & & Inmaculada Concepción & Estación Avellaneda & \\
\hline & & & San Vicente Ferrer & Manzanas & \\
\hline & & & San José & Ongamira & \\
\hline 1 & 4 & Quilino & San Roque & Villa de Quilino & \\
\hline & & & San Antonio & Copacabana & \\
\hline & & & San Pedro Apóstol & San Pedro de Toyos & \\
\hline & & & & Estación San José & \\
\hline 1 & 6 & San Agustín & San Agustín (S) & San Agustín & CALAMUCHITA \\
\hline & & & Ntra. Sra. del Pilar & Los Molinos & \\
\hline & & & San José & Amboy & \\
\hline & & & Inmaculada Concepción & Los Reartes & \\
\hline & & & Sagrado Corazón de Jesús & Calmayo & \\
\hline & & & Ntra. Sra. del Carmen & Las Bajadas & \\
\hline & & & Santa Rosa & Santa Rosa & \\
\hline 1 & 3 & Río de los & Ntra. Sra. de la Merced (S) & La Cruz & \\
\hline & & Sauces/la Cruz & El Señor de la Agonía & Rio de los Sauces & \\
\hline & & & Ntra. Sra. del Rosario & El Quebracho & \\
\hline & & & San Antonio & El Cano & \\
\hline 1 & 7 & Pocho & Ntra. Sra. del Rosario (S) & Salsacate & POCHO \\
\hline & & & Ntra. Sra. del Carmen & Chancani & \\
\hline & & & Ntra. Sra. del Rosario & Palmas & \\
\hline & & & Inmaculada Concepción & Pocho & \\
\hline & & & Sagrada Familia & Salsacate & \\
\hline & & & San Jerónimo & Salsacate & \\
\hline
\end{tabular}




\begin{tabular}{|c|c|c|c|c|c|}
\hline & & & Ntra. Sra. del Valle & Medanitos & \\
\hline & & & Ntra. Sra. de las Mercedes & Villaviso & \\
\hline 1 & \multirow[t]{3}{*}{3} & \multirow[t]{3}{*}{ Minas } & Inmaculada Concepción & San Carlos Minas & \multirow[t]{3}{*}{ MINAS } \\
\hline & & & Virgen del Rosario & Guasapampa & \\
\hline & & & Virgen de la Candelaria & Cienaga del Coro & \\
\hline \multirow[t]{5}{*}{1} & 4 & \multirow[t]{5}{*}{ Río Seco } & Ntra. Sra. del Rosario (S) & Villa de Rio Seco & \multirow[t]{5}{*}{ RIO SECO } \\
\hline & & & Ntra. Sra. del Rosario & Puesto de Castro & \\
\hline & & & Ntra. Sra. del Carmen & Estancia & \\
\hline & & & San Roque & Rayo Cortado & \\
\hline & & & San Miguel Arcángel & Higuerillas & \\
\hline \multirow[t]{3}{*}{1} & 2 & \multirow{3}{*}{$\begin{array}{l}\text { San Francisco } \\
\text { del Chañar }\end{array}$} & San Francisco Solano & Villa del Chañar & \multirow[t]{3}{*}{ SOBREMONTE } \\
\hline & & & Ntra. Sra. de la Candelaria & Caminiaga & \\
\hline & & & San Roque & Chuñahuasi & \\
\hline \multirow[t]{5}{*}{1} & 4 & \multirow[t]{5}{*}{ Cosquín } & Ntra. Sra. del Rosario(S) & Cosquín & \multirow[t]{12}{*}{ PUNILLA } \\
\hline & & & Carlos Paz & Carlos Paz & \\
\hline & & & Ntra. Sra. Rosario & Tanti & \\
\hline & & & Vialet Massé & Vialet Massé & \\
\hline & & & San Antonio & Ped. Santiago & \\
\hline \multirow[t]{4}{*}{1} & 4 & \multirow{4}{*}{$\begin{array}{l}\text { Capilla del } \\
\text { Monte }\end{array}$} & Dolores (S) & Ped. Dolores & \\
\hline & & & Los Cocos & Ped. Dolores & \\
\hline & & & San Esteban & Ped Dolores & \\
\hline & & & Olaen & Ped. Dolores & \\
\hline \multirow[t]{3}{*}{1} & 2 & \multirow[t]{3}{*}{ La Cumbre } & Ntra. Sra. del Carmen & La Cumbre & \\
\hline & & & Ped. San Antonio & Huerta Grande & \\
\hline & & & Ped. San Antonio & Cruz Grande & \\
\hline \multirow[t]{6}{*}{1} & 5 & \multirow[t]{6}{*}{ Cruz del Eje } & Ntra. Sra. del Carmen & Villa Cruz del Eje & \multirow[t]{13}{*}{ CRUZ DEL EJE } \\
\hline & & & San Marcos & San Marcos Sierra & \\
\hline & & & Singuimán & Cruz del Eje & \\
\hline & & & Media Naranja & Cruz del Eje & \\
\hline & & & Santo Domingo & Cruz del Eje & \\
\hline & & & Los Sauces & Cruz del Eje & \\
\hline 1 & 6 & \multirow[t]{7}{*}{ Soto } & San Roque & Villa de Soto & \\
\hline & & & La Higuera & Higuera & \\
\hline & & & Pichanas & Pichana & \\
\hline & & & Serrezuela & Pichana & \\
\hline & & & Candelaria & Candelaria & \\
\hline & & & Concepción Poronguitos & Pichana & \\
\hline & & & Parada Avalos & Candelaria & \\
\hline 2 & & $\begin{array}{l}\text { Inmaculada } \\
\text { Concepción de } \\
\text { Río Cuarto }\end{array}$ & Inmaculada Concepción & Rio Cuarto Ciudad & RIO CUARTO \\
\hline & & La Merced & La Merced & Río Cuarto ciudad & \\
\hline 1 & 1 & Alcira Gigena & San José (S) & Tegua & \\
\hline & & & Ntra. Sra. del Rosario & Rodeo Viejo & \\
\hline 1 & 0 & $\begin{array}{l}\text { Coronel Moldes } \\
(13 / 05 / 1924)\end{array}$ & María Auxiliadora & Tres de Febrero & \\
\hline 1 & 2 & $\begin{array}{l}\text { Sampacho } \\
(19 / 06 / 1902)\end{array}$ & $\begin{array}{l}\text { Stos. Ángeles Custodios/ } \\
\text { Ntra. Sra. de la Consolata }\end{array}$ & Sampacho & \\
\hline & & & NtraSra de la Merced & Achiras & \\
\hline & & & Santa Inés & Jagueles & \\
\hline & & & Ntra. Sra. del Carmen & Chaján & \\
\hline 1 & 6 & La Carlota & La Merced & La Carlota & \\
\hline & & $(03 / 09 / 1892)$ & Ntra. Sra. de la Asunción & Alejandro Roca & \\
\hline
\end{tabular}




\begin{tabular}{|c|c|c|c|c|c|}
\hline & & & El Sr. De la Buena Muerte & Reducción & \multirow[t]{8}{*}{ JUAREZ CELMAN } \\
\hline & & & Ntra. Sra del Rosario & Ucacha & \\
\hline & & & Santa Rosa de Lima & Olaeta & \\
\hline & & & Los Cisnes & La Carlota & \\
\hline & & & Asunta & La Carlota & \\
\hline 1 & 2 & \multirow{3}{*}{$\begin{array}{l}\text { Gral. Cabrera } \\
(08 / 08 / 1910)\end{array}$} & San José & Gral. Cabrera & \\
\hline & & & Ntra. Sra. de la Asunción & Gral. Deheza & \\
\hline & & & Santa Paula & Estación Carnerillo & \\
\hline \multirow[t]{3}{*}{1} & \multirow[t]{3}{*}{2} & \multirow[t]{3}{*}{ Colón } & San Isidro labrador $(\mathrm{S})$ & Jesús María & \multirow[t]{12}{*}{ COLÓN } \\
\hline & & & Ascochinga & Ped. San Vicente & \\
\hline & & & Santa Catalina & Ped. Río Pinto & \\
\hline \multirow[t]{7}{*}{1} & 6 & \multirow{7}{*}{$\begin{array}{l}\text { Villa } \\
\text { Allende/Calera }\end{array}$} & Ntra. Sra. del Rosario & Villa Allende & \\
\hline & & & Malagueño & Calera & \\
\hline & & & Lagunilla & Lagunilla & \\
\hline & & & Unquillo & Río Ceballos & \\
\hline & & & Río Ceballos & Rio Ceballos & \\
\hline & & & Salsipuedes & Río Ceballos & \\
\hline & & & Calera & Calera & \\
\hline \multirow[t]{2}{*}{1} & 1 & \multirow[t]{2}{*}{ Colonia Caroya } & Ntra. Sra. de Montserrat & Colonia Caroya & \\
\hline & & & & Colonia Tirolesa & \\
\hline \multirow[t]{6}{*}{1} & 5 & \multirow[t]{6}{*}{ Alta Gracia } & Ntra. Sra. de las Mercedes & Alta Gracia & \multirow[t]{6}{*}{ SANTA MARÍA } \\
\hline & & & Ntra. Sra. Mercedes & Cosme & \\
\hline & & & San Antonio & San Antonio & \\
\hline & & & San Isidro & Potrero de Garay & \\
\hline & & & Lagunilla & Falda del Carmen & \\
\hline & & & & Lozada & \\
\hline \multirow[t]{6}{*}{1} & 5 & \multirow{6}{*}{$\begin{array}{l}\text { Villa } \\
\text { Dolores/San } \\
\text { Javier }\end{array}$} & & Villa Dolores & \multirow[t]{6}{*}{ SAN JAVIER } \\
\hline & & & San Javier & San Javier & \\
\hline & & & El Carmen & Las Rosas & \\
\hline & & & Mercedes & Yacanto & \\
\hline & & & & Luyaba & \\
\hline & & & Mercedes & $\mathrm{La} \mathrm{Paz}$ & \\
\hline \multirow[t]{5}{*}{1} & 5 & \multirow[t]{5}{*}{ Tránsito } & Ntra. Sra. Tránsito & V. del Tránsito & \multirow[t]{10}{*}{ SAN ALBERTO } \\
\hline & & & & Nono & \\
\hline & & & & Ambul & \\
\hline & & & & Panaholma & \\
\hline & & & & Ciénaga de Allende & \\
\hline \multirow[t]{5}{*}{1} & 4 & \multirow[t]{5}{*}{ San Pedro } & San Pedro (S) & San Pedro & \\
\hline & & & Ntra. Sra. Mercedes & Toscas & \\
\hline & & & Purísima Concepción & San Pedro & \\
\hline & & & San Vicente & San Pedro & \\
\hline & & & Ntra. Sra. del Carmen & Carmen & \\
\hline 1 & 4 & Santa Rosa & Santa Rosa de Lima (S) & Villa Santa Rosa de Río $1^{\circ}$ & RÍO PRIMERO \\
\hline & & & Esquina & Esquina & \\
\hline & & & Punta de Agua & Punta de Agua & \\
\hline & & & La Esperanza & Esquina & \\
\hline & & & Sagrada Familia & Tinoco & \\
\hline 1 & 5 & Remedios & Virgen de los Remedios (S) & Villa de Remedios & \\
\hline & & & Ntra. Sra. de los Dolores & Yegua Muerta & \\
\hline & & & Virgen del Rosario & Rio Primero & \\
\hline & & & Virgen del Valle & $\begin{array}{l}\text { Ambrosio Funes (antes } \\
\text { Piquillín) }\end{array}$ & \\
\hline
\end{tabular}




\begin{tabular}{|c|c|c|c|c|c|}
\hline & & & Inmaculada Concepción & $\begin{array}{l}\text { Estación } 27 \text { de abril (antes } \\
\text { Monte Cristo) }\end{array}$ & \\
\hline \multirow[t]{9}{*}{1} & 7 & \multirow[t]{9}{*}{ Obispo Trejo } & San Antonio de Padua & Villa de san Antonio Rio $1^{\circ}$ & \\
\hline & & & & Cañada Honda & \\
\hline & & & Ntra. Sra. del Rosario & Monte Rosario & \\
\hline & & & & La Para & \\
\hline & & & Inmaculada Concepción & Saladas & \\
\hline & & & Ntra. Sra. de la Merced & Plaza Mercedes. & \\
\hline & & & & Atahona & \\
\hline & & & & La Puerta & \\
\hline & & & & Fontana & \\
\hline \multirow[t]{4}{*}{1} & 3 & \multirow[t]{4}{*}{ Villa Nueva } & Ntra. Sra. del Rosario & Villa Nueva & \multirow[t]{30}{*}{ TERCERO ABAJO } \\
\hline & & & & Arroyo Cabral & \\
\hline & & & & Palestina & \\
\hline & & & & Sanabria & \\
\hline 1 & 4 & \multirow{5}{*}{$\begin{array}{l}\text { La Playosa/Pozo } \\
\text { del Molle }\end{array}$} & Santa Teresa & La Playosa & \\
\hline & & & $\begin{array}{l}\text { Santa Teresa Inmaculado } \\
\text { Corazón de María }\end{array}$ & Pozo del Molle (S) & \\
\hline & & & Jesús Nazareno & Los Zorros & \\
\hline & & & La Asunción (1923) & Carrilobo & \\
\hline & & & & Chazón & \\
\hline \multirow[t]{7}{*}{1} & 6 & \multirow[t]{7}{*}{ Villa María } & Inmaculada Concepción & Villa María & \\
\hline & & & & Tío Pugio & \\
\hline & & & San Antonio & Yucat & \\
\hline & & & & Estación Cárcano & \\
\hline & & & San Antonio de Padua & Punta de Agua & \\
\hline & & & & Silvio Pellico & \\
\hline & & & & Arroyo Algodón & \\
\hline \multirow[t]{3}{*}{1} & 2 & \multirow[t]{3}{*}{ Etruria } & La Anunciación & Etruria & \\
\hline & & & & Santa Victoria & \\
\hline & & & & La Laguna & \\
\hline \multirow[t]{9}{*}{1} & 7 & \multirow{11}{*}{$\begin{array}{l}\text { Dalmacio } \\
\text { Vélez (confiada } \\
\text { a los Trinitarios) }\end{array}$} & Ntra. Sra. del Luján (S) & Hernando & \\
\hline & & & & Dalmacio Vélez & \\
\hline & & & & Las Perdices & \\
\hline & & & NtraSra del Rosario & Punta de Agua & \\
\hline & & & $\begin{array}{l}\text { San José (1922-1924 } \\
\text { bendecida) }\end{array}$ & Hernando & \\
\hline & & & $\begin{array}{l}\text { Cap. Ntra. Sra. del Carmen } \\
\text { (1918) }\end{array}$ & Hernando & \\
\hline & & & $\begin{array}{l}\text { Capilla San José (1875) } \\
1881 \text { construcción de un } \\
\text { nuevo templo }\end{array}$ & Pampayasta norte & \\
\hline & & & $\begin{array}{l}\text { La Merced } 1880 \text { (Flia. } \\
\text { Mayorga) pasa al obispado } \\
1913\end{array}$ & Pampayasta norte & \\
\hline & & & $\begin{array}{l}\text { La Purísima }(1757) \\
\text { (reconstruida 1908) }\end{array}$ & Pampayasta Sur & \\
\hline & & & & Luca & \\
\hline & & & & Ticino & \\
\hline \multirow[t]{4}{*}{1} & 5 & \multirow{4}{*}{$\begin{array}{l}\text { Laborde } \\
(14 / 08 / 1909)\end{array}$} & Ntra. Sra. de la Asunción & Laborde & \multirow[t]{4}{*}{ UNIÓN } \\
\hline & & & & Alto Alegre & \\
\hline & & & & Médano de las Cañas & \\
\hline & & & & Pascanas & \\
\hline
\end{tabular}




\begin{tabular}{|c|c|c|c|c|c|}
\hline & & & & Santa Eufemia & \\
\hline & & & & Médanos de Cañas & \\
\hline 1 & 1 & $\begin{array}{l}\text { San Antonio de } \\
\text { Litín }\end{array}$ & $\begin{array}{l}\text { Exaltación de la Cruz (1926) } \\
\text { San Antonio }\end{array}$ & $\begin{array}{l}\text { Noetinger } \\
\text { San Antonio de Litín }\end{array}$ & \\
\hline \multirow[t]{2}{*}{1} & 1 & \multirow[t]{2}{*}{ Ballesteros } & Natividad de María & & \\
\hline & & & Ballesteros Sur & Ballesteros sud & \\
\hline \multirow[t]{4}{*}{1} & 3 & \multirow[t]{4}{*}{$\begin{array}{l}\text { Canals } \\
(27 / 06 / 1902)\end{array}$} & $\begin{array}{l}\text { Ntra. Sra. de la Anunciación } \\
\text { (S) }\end{array}$ & Canals & \\
\hline & & & & Benjamín Gould & \\
\hline & & & Santa Rosa de Lima & Arias & \\
\hline & & & & Alejo Ledesma & \\
\hline \multirow[t]{3}{*}{1} & 2 & \multirow[t]{3}{*}{ Justiniano Posse } & Natividad de María & Justiniano Posse & \\
\hline & & & & Idiazábal & \\
\hline & & & & Ordoñez & \\
\hline \multirow[t]{2}{*}{1} & 1 & \multirow[t]{2}{*}{ Cruz Alta } & Ntra. Sra. del Rosario & Cruz Alta & \multirow[t]{24}{*}{ MARCOS JUÁREZ } \\
\hline & & & & Inriville & \\
\hline \multirow[t]{2}{*}{1} & 1 & \multirow[t]{2}{*}{ Camilo Aldao } & San José & Camilo Aldao & \\
\hline & & & & Baldisera & \\
\hline \multirow[t]{4}{*}{1} & 3 & \multirow[t]{4}{*}{ Los Surgentes } & San Carlos Borromeo(S) & Los Surgentes & \\
\hline & & & & Inriville & \\
\hline & & & & Saladillo & \\
\hline & & & & Monte Buey & \\
\hline \multirow[t]{3}{*}{1} & 2 & \multirow[t]{3}{*}{ Marcos Juárez } & La Asunción (S) & Marcos Juárez & \\
\hline & & & Santa Rosa & Gral. Roca & \\
\hline & & & Sagrada Familia (1917) & $\begin{array}{l}\text { Establecimiento La Capilla } \\
\text { (Sres. Dellarosa) }\end{array}$ & \\
\hline \multirow[t]{2}{*}{1} & 1 & \multirow[t]{2}{*}{ Leones } & Ntra. Sra. del Rosario & Leones & \\
\hline & & & San Marcos & Bell Ville & \\
\hline \multirow[t]{4}{*}{1} & 2 & \multirow{4}{*}{$\begin{array}{l}\text { Isla Verde } \\
(03 / 06 / 1913)\end{array}$} & San Antonio de Padua & Isla Verde & \\
\hline & & & Santo Domingo de Guzmán & Colonia Bargés & \\
\hline & & & Ntra. Sra. de la Merced & Monte Maíz & \\
\hline & & & & Matacos & \\
\hline \multirow[t]{2}{*}{1} & \multirow[t]{2}{*}{0} & \multirow{2}{*}{$\begin{array}{l}\text { Corral de } \\
\text { Bustos } \\
(14 / 11 / 1924)\end{array}$} & Ntra. Sra. del Rosario (S) & Corral del Bustos & \\
\hline & & & Ntra. Sra. de la Asunción & Colonia Italiana & \\
\hline \multirow[t]{5}{*}{1} & 4 & \multirow{5}{*}{$\begin{array}{l}\text { Laboulaye } \\
(26 / 07 / 1910)\end{array}$} & Jesús Redentor & Laboulaye & \\
\hline & & & & Mackenna & \\
\hline & & & Sta. Rosa de Lima & Gral. Levalle & \\
\hline & & & & Serrano & \\
\hline & & & & Rosales & \\
\hline 1 & 4 & Cañada Verde & & Villa Huidobro & GRAL. ROCA \\
\hline & & & Ntra. Sra del Carmen & Huinca-Renancó & \\
\hline & & & Corazón de Jesús & Villa Valeria & \\
\hline & & & San José & Buchard & \\
\hline & & & San Francisco & Villa Sarmiento & \\
\hline 70 & 208 & & & & \\
\hline
\end{tabular}


Tabla 11

Distribución del clero. Córdoba, 1875

\begin{tabular}{|c|c|c|c|c|c|c|}
\hline $\begin{array}{l}\text { Apellido y } \\
\text { Nombre }\end{array}$ & $\begin{array}{l}\text { Argentino/ } \\
\text { Extranjero }\end{array}$ & $\begin{array}{c}\text { Diocesano/ } \\
\text { Extradioces. }\end{array}$ & Ocupación & Lugar & Institución & $\begin{array}{c}\text { Ciudad/ } \\
\text { Campaña }\end{array}$ \\
\hline $\begin{array}{l}\text { Ramírez de } \\
\text { Arellano, Vicente }\end{array}$ & Argentino & Diocesano & $\begin{array}{l}\text { Obispo } \\
\text { Diocesano }\end{array}$ & Córdoba & Obispado & ciudad \\
\hline $\begin{array}{l}\text { Alvarez, Manuel } \\
\text { Eduardo }\end{array}$ & Argentino & Diocesano & $\begin{array}{l}\text { Obispo } \\
\text { Diocesano }\end{array}$ & Córdoba & Obispado & ciudad \\
\hline $\begin{array}{l}\text { Chiannea, Fr. } \\
\text { Antonio }\end{array}$ & Extranjero & Franciscano & $\begin{array}{l}\text { Cura y Vicario } \\
\text { Interino }\end{array}$ & Villa María & Curato & campaña \\
\hline Yanicelli & Extranjero & Franciscano & Ayudante & Villa María & Curato & campaña \\
\hline Guerra, Domingo & Extranjero & $\begin{array}{l}\text { Extradiocesa. } \\
\text { ex religioso }\end{array}$ & $\begin{array}{l}\text { Cura y Vicario } \\
\text { Interino }\end{array}$ & $\begin{array}{l}\text { Santa Rosa } \\
\text { Calamuchita }\end{array}$ & Curato & campaña \\
\hline Anselmi, Isidoro & Extranjero & $\begin{array}{l}\text { Extradiocesa. } \\
\text { exfranciscano }\end{array}$ & $\begin{array}{l}\text { Cura y Vicario } \\
\text { Interino }\end{array}$ & $\begin{array}{l}3^{\circ} \text { Arriba } \\
\text { (Capilla } \\
\text { Rodríguez) }\end{array}$ & Curato & campaña \\
\hline Gallo, Tomás & Extranjero & $\begin{array}{l}\text { Extradiocesa. } \\
\text { exfranciscano }\end{array}$ & $\begin{array}{l}\text { Cura y Vicario } \\
\text { Interino } \\
(22 / 08 / 1876 \text { a } \\
21 / 07 / 877)\end{array}$ & Río Seco & Curato & campaña \\
\hline Abriola, Luis & Extranjero & Extradiocesa. & $\begin{array}{l}\text { Cura y Vicario } \\
\text { Interino }\end{array}$ & Chalacea & Curato & campaña \\
\hline Abregu, Pantalén & Criollo & Diocesano & Cura Propio & $\begin{array}{l}\text { Pocho/ } \\
\text { Salsacate }\end{array}$ & Curato & campaña \\
\hline Ametha y Planell & Extranjero & Extradiocesa. & Excusador & $\begin{array}{l}\text { Pocho } \\
\text { /Salsacate }\end{array}$ & Curato & campaña \\
\hline $\begin{array}{l}\text { García Pedrosa, } \\
\text { Francisco }\end{array}$ & Extranjero & Extradiocesa. & Sin datos & $\mathrm{nc}$ & nc & nc \\
\hline Latella, Donato & Extranjero & Extradiocesa. & Capellán & $\begin{array}{l}\text { Cementerio } \\
\text { San Jerónimo }\end{array}$ & Cementerio & ciudad \\
\hline $\begin{array}{l}\text { Martínez del Val, } \\
\text { Francisco }\end{array}$ & Extranjero & Extradiocesa. & $\begin{array}{l}\text { Cura y Vicario } \\
\text { (en 1875) }\end{array}$ & $\begin{array}{l}\text { La Rioja } \\
\text { Aguyón }\end{array}$ & Curato & campaña \\
\hline Preseo, Rafael & Extranjero & Extradiocesa. & $\begin{array}{l}\text { Cura y Vicario } \\
\text { Interino }\end{array}$ & $\begin{array}{l}\text { La Rioja San } \\
\text { Blas- }\end{array}$ & curato & campaña \\
\hline Lonzino, Vicente & Extranjero & Extradiocesa. & Capellán & Sampacho & Colonia & campaña \\
\hline Lima, Antonio & Extranjero & Extradiocesa. & $\begin{array}{l}\text { Cura y vicario } \\
\text { Interino }\end{array}$ & Villanueva & Curato & campaña \\
\hline $\begin{array}{l}\text { Armesto, } \\
\text { Arcángel }\end{array}$ & Extranjero & Extradiocesa. & $\begin{array}{l}\text { Cura y Vicario } \\
\text { Interino } \\
(02 / 07 / 1877 \text { a } \\
22 / 11 / 1878)\end{array}$ & Río Seco & Curato & campaña \\
\hline $\begin{array}{l}\text { Falorni, Luis } \\
\text { Fernando }\end{array}$ & Extranjero & Extradiocesa. & $\begin{array}{l}\text { Cura y Vicario } \\
\text { Interino }\end{array}$ & Ischilín & Curato & campaña \\
\hline $\begin{array}{l}\text { García de la } \\
\text { Serna, Doroteo }\end{array}$ & Extranjero & Extradiocesa. & $\begin{array}{l}\text { Cura y Vicario } \\
\text { Interino }\end{array}$ & Bell Ville & Curato & campaña \\
\hline Guarino, José & Extranjero & Extradiocesa. & $\begin{array}{l}\text { Cura y Vicario } \\
\text { Interino }\end{array}$ & Río Ceballos & Curato & campaña \\
\hline $\begin{array}{l}\text { Raynoldi, } \\
\text { Ambrosio }\end{array}$ & Extranjero & Extradiocesa. & $\begin{array}{l}\text { Cura y Vicario } \\
\text { Interino }\end{array}$ & Punilla & Curato & campaña \\
\hline Peciña, Nicolás & Extranjero & Extradiocesa. & Ayudante & $\begin{array}{l}\text { San Javier } \\
\text { Calamuchita }\end{array}$ & Curato & Campaña \\
\hline $\begin{array}{l}\text { Villar y Pastor, } \\
\text { Olegario }\end{array}$ & Extranjero & Extradiocesa. & $\begin{array}{l}\text { Cura y Vicario } \\
\text { Interino }\end{array}$ & $\begin{array}{l}\text { San Carlos } \\
\text { Minas }\end{array}$ & Curato & campaña \\
\hline Aguilar Francisco & Extranjero & Extradiocesa. & Cura & \multicolumn{2}{|c|}{ La Rioja San Blas } & campaña \\
\hline
\end{tabular}




\begin{tabular}{|c|c|c|c|c|c|c|}
\hline $\begin{array}{l}\text { Sotomayor, } \\
\text { Tristán }\end{array}$ & Argentino & Extradiocesa. & Cura y Vicario & $\begin{array}{l}\text { La Rioja } \\
\text { Vinchina }\end{array}$ & Curato & campaña \\
\hline Lynch, Pablo & Extranjero & Extradiocesa. & La Rioja & La Rioja & $\begin{array}{l}\text { Ministerio } \\
\text { libre }\end{array}$ & ciudad \\
\hline Leiba, Francisco & Extranjero & Extradiocesa. & Cura y Vicario & $\begin{array}{l}\text { Vinchina y } \\
\text { Guandacol- La } \\
\text { Rioja }\end{array}$ & Curato & campaña \\
\hline Tagle, Luis & Argentino & $\begin{array}{l}\text { Diocesano ex- } \\
\text { mercedario }\end{array}$ & $\begin{array}{l}\text { Cura y Vicario } \\
\text { Interino }\end{array}$ & Quilino & Curato & campaña \\
\hline Pérez, Francisco & Argentino & $\begin{array}{l}\text { Diocesano ex- } \\
\text { mercedario }\end{array}$ & Cura y Vicario & $\begin{array}{l}\text { Río de los } \\
\text { Sauces }\end{array}$ & Curato & campaña \\
\hline Fierro, Eleodoro & Argentino & $\begin{array}{l}\text { Diocesano ex- } \\
\text { mercedario }\end{array}$ & $\begin{array}{l}\text { Cura y Vicario } \\
\text { Interino (hasta } \\
\text { el 03/02/1878) }\end{array}$ & Sobremonte & Curato & campaña \\
\hline $\begin{array}{l}\text { Alvarez, Manuel } \\
\text { Eduardo }\end{array}$ & Argentino & Diocesano & $\begin{array}{l}\text { Obispo } \\
\text { Diocesano }\end{array}$ & $\begin{array}{l}\text { Córdoba, } \\
\text { ciudad }\end{array}$ & Obispado & ciudad \\
\hline $\begin{array}{l}\text { Martiarena, } \\
\text { Gaspar }\end{array}$ & Argentino & Diocesano & Deán & $\begin{array}{l}\text { Córdoba, } \\
\text { ciudad }\end{array}$ & $\begin{array}{l}\text { Cabildo } \\
\text { Catedral }\end{array}$ & ciudad \\
\hline $\begin{array}{l}\text { Núñez Bravo, } \\
\text { José R. }\end{array}$ & Argentino & Diocesano & Arcedeano & $\begin{array}{l}\text { Córdoba, } \\
\text { ciudad }\end{array}$ & $\begin{array}{l}\text { Cabildo } \\
\text { Catedral }\end{array}$ & ciudad \\
\hline $\begin{array}{l}\text { Fernández, Juan } \\
\text { Isidro }\end{array}$ & Argentino & Diocesano & $\begin{array}{l}\text { Canónigo } \\
\text { Honorario }\end{array}$ & $\begin{array}{l}\text { Córdoba, } \\
\text { ciudad }\end{array}$ & $\begin{array}{l}\text { Cabildo } \\
\text { Catedral }\end{array}$ & ciudad \\
\hline $\begin{array}{l}\text { Vázquez de } \\
\text { Novoa, Andrés }\end{array}$ & Argentino & Diocesano & Chantre & $\begin{array}{l}\text { Córdoba, } \\
\text { ciudad }\end{array}$ & $\begin{array}{l}\text { Cabildo } \\
\text { Catedral }\end{array}$ & ciudad \\
\hline $\begin{array}{l}\text { Ferreyra, } \\
\text { Aquilino }\end{array}$ & Argentino & Diocesano & $\begin{array}{l}\text { Cura Propio / } \\
\text { Canónigo } \\
\text { Honorario }\end{array}$ & $\begin{array}{l}\text { Villa del } \\
\text { Rosario Depto } \\
\text { Río } 2^{\circ}\end{array}$ & Curato & campaña \\
\hline $\begin{array}{l}\text { Honesterosa, } \\
\text { Roque }\end{array}$ & Extranjero & Diocesano & Sin ocupación & & Curato & campaña \\
\hline $\begin{array}{l}\text { Martínez, José } \\
\text { Florentino }\end{array}$ & Argentino & Diocesano & \multicolumn{2}{|c|}{ Cura Propietario Calamuchita } & Curato & campaña \\
\hline $\begin{array}{l}\text { Brizuela, Juan } \\
\text { Vicente }\end{array}$ & Argentino & Diocesano & \multicolumn{2}{|c|}{$\begin{array}{l}\text { La Rioja, Independencia } \\
\text { (Chamical) }\end{array}$} & Curato & campaña \\
\hline Clara, Jerónimo & Argentino & Diocesano & Tesorero & $\begin{array}{l}\text { Córdoba, } \\
\text { ciudad }\end{array}$ & $\begin{array}{l}\text { Cabildo } \\
\text { Catedral }\end{array}$ & ciudad \\
\hline Vélez, José María & Argentino & Diocesano & $1^{\circ}$ Ración & $\begin{array}{l}\text { Córdoba, } \\
\text { ciudad }\end{array}$ & $\begin{array}{l}\text { Cabildo } \\
\text { Catedral }\end{array}$ & ciudad \\
\hline $\begin{array}{l}\text { Abregú, Juan } \\
\text { Pantaleón }\end{array}$ & Argentino & Diocesano & $\begin{array}{l}\text { Cura y Vicario } \\
\text { Interino }\end{array}$ & Pocho & Curato & campaña \\
\hline $\begin{array}{l}\text { Rodríguez, } \\
\text { Wilfrido Felipe }\end{array}$ & $\mathrm{nc}$ & Diocesano & nc & & $\mathrm{nc}$ & $\mathrm{nc}$ \\
\hline Juárez, Justino & Argentino & Diocesano & Cgo. Magistral & $\begin{array}{l}\text { Córdoba, } \\
\text { ciudad }\end{array}$ & $\begin{array}{l}\text { Cabildo } \\
\text { Catedral }\end{array}$ & ciudad \\
\hline $\begin{array}{l}\text { Cabanillas, } \\
\text { Emiliano }\end{array}$ & Argentino & Diocesano & $\mathrm{nc}$ & $\begin{array}{l}\text { Córdoba, } \\
\text { ciudad }\end{array}$ & $\begin{array}{l}\text { Ministerio } \\
\text { libre }\end{array}$ & ciudad \\
\hline Bula, Juan & Argentino & Diocesano & $\begin{array}{l}\text { Cura y Vicario } \\
\text { Interino }\end{array}$ & $\begin{array}{l}\text { Sta. Rosa de } \\
\text { Río } 1^{\circ}\end{array}$ & Curato & campaña \\
\hline Márquez, Rubén & Argentino & Diocesano & $\begin{array}{l}\text { Cura y Vicario } \\
\text { Interino }\end{array}$ & Cruz del Eje & Curato & campaña \\
\hline $\begin{array}{l}\text { Castellano, } \\
\text { Uladislao }\end{array}$ & Argentino & Diocesano & Cgo. $2^{\circ}$ ración & $\begin{array}{l}\text { Córdoba, } \\
\text { ciudad }\end{array}$ & $\begin{array}{l}\text { Cabildo } \\
\text { Catedral }\end{array}$ & ciudad \\
\hline Luque, David & Argentino & Diocesano & $\begin{array}{l}\text { Cgo. } \\
\text { Honorario/ } \\
\text { Capellán/ }\end{array}$ & $\begin{array}{l}\text { Córdoba, } \\
\text { ciudad }\end{array}$ & $\begin{array}{l}\text { Seminario/ } \\
\text { Esclavas del } \\
\text { Corazón de }\end{array}$ & ciudad \\
\hline
\end{tabular}




\begin{tabular}{|c|c|c|c|c|c|c|}
\hline & & & $\begin{array}{l}\text { Profesor } \\
\text { Seminario }\end{array}$ & & Jesús & \\
\hline $\begin{array}{l}\text { Bustamante, } \\
\text { Claudio }\end{array}$ & Argentino & Diocesano & nc & nc & nc & $\mathrm{Nc}$ \\
\hline Torres, Delfín & Argentino & Diocesano & $\begin{array}{l}\text { Capellán de } \\
\text { Coro }\end{array}$ & $\begin{array}{l}\text { Córdoba, } \\
\text { ciudad }\end{array}$ & $\begin{array}{l}\text { Cabildo } \\
\text { Catedral }\end{array}$ & ciudad \\
\hline $\begin{array}{l}\text { De la Fuente, } \\
\text { Samuel }\end{array}$ & Argentino & Diocesano & Cura y Vicario & $\begin{array}{l}\text { La Rioja, } \\
\text { Costa de } \\
\text { Arauco }\end{array}$ & Curato & campaña \\
\hline Cesar, Francisco & Argentino & Diocesano & $\begin{array}{l}\text { Secretario } \\
\text { Capitular, } \\
\text { Inspector y } \\
\text { Profesor }\end{array}$ & $\begin{array}{l}\text { Córdoba, } \\
\text { ciudad }\end{array}$ & \multicolumn{2}{|c|}{ Curia/ Cabildo/ Seminario } \\
\hline $\begin{array}{l}\text { Villafañe, Adolfo } \\
\text { Agustín }\end{array}$ & Argentino & Diocesano & $\begin{array}{l}\text { Cura y Vicario } \\
\text { Interino }\end{array}$ & $\begin{array}{l}\text { Río de los } \\
\text { Sauces }\end{array}$ & Curato & $\begin{array}{l}\text { Córdoba, } \\
\text { campaña }\end{array}$ \\
\hline $\begin{array}{l}\text { Ramallo, José } \\
\text { Mateo (conocido } \\
\text { por Lindor) }\end{array}$ & Argentino & Diocesano & Cura Interino & $\begin{array}{l}\text { San Francisco } \\
\text { del Chañar } \\
\text { Nombrado } \\
(05 / 01 / 1877)\end{array}$ & Curato & campaña \\
\hline $\begin{array}{l}\text { González, } \\
\text { Narciso de Jesús }\end{array}$ & Argentino & Diocesano & $\mathrm{nc}$ & nc & $\mathrm{nc}$ & $\mathrm{nc}$ \\
\hline Gallioz, León M. & Extranjero & Diocesano & $\begin{array}{l}\text { Maestro de } \\
\text { Ceremonias }\end{array}$ & Catedral & Catedral & ciudad \\
\hline $\begin{array}{l}\text { Brochero, José } \\
\text { Gabriel }\end{array}$ & Argentino & Diocesano & $\begin{array}{l}\text { Cura y Vicario } \\
\text { Interino }\end{array}$ & San Alberto & Curato & campaña \\
\hline $\begin{array}{l}\text { Yániz, Juan } \\
\text { Martín }\end{array}$ & Argentino & Diocesano & $\begin{array}{l}\text { Prebendado } 1^{\circ} \\
\text { media ración }\end{array}$ & $\begin{array}{l}\text { Córdoba, } \\
\text { ciudad }\end{array}$ & $\begin{array}{l}\text { Cabildo } \\
\text { Catedral }\end{array}$ & ciudad \\
\hline $\begin{array}{l}\text { Castellano, } \\
\text { Domingo }\end{array}$ & Argentino & Diocesano & Cgo. $2^{\circ}$ ración & $\begin{array}{l}\text { Córdoba, } \\
\text { ciudad }\end{array}$ & $\begin{array}{l}\text { Cabildo } \\
\text { Catedral } \\
\end{array}$ & ciudad \\
\hline Luque, Domingo & Argentino & Diocesano & $\begin{array}{l}\text { Cura y Vicario } \\
\text { Interino (1868 } \\
\text { a 20/12/1877) }\end{array}$ & Totoral & Curato & campaña \\
\hline $\begin{array}{l}\text { Cabanillas, } \\
\text { Filemón }\end{array}$ & Argentino & Diocesano & $\begin{array}{l}\text { Cura y Vicario } \\
\text { Interino } \\
(20 / 12 / 1877 \text { a } \\
1882)\end{array}$ & Totoral & Curato & campaña \\
\hline $\begin{array}{l}\text { Galcerán y La } \\
\text { Torre, José } \\
\text { Laureano }\end{array}$ & Argentino & Diocesano & $\begin{array}{l}\text { Prebendado } 2^{\circ} \\
\text { media ración }\end{array}$ & $\begin{array}{l}\text { Córdoba, } \\
\text { ciudad }\end{array}$ & $\begin{array}{l}\text { Cabildo } \\
\text { Catedral }\end{array}$ & ciudad \\
\hline $\begin{array}{l}\text { Luz de Cabrera, } \\
\text { Vicente }\end{array}$ & Argentino & Diocesano & Cura & $\begin{array}{l}\text { Chilecito- La } \\
\text { Rioja }\end{array}$ & Curato & campaña \\
\hline $\begin{array}{l}\text { Luz de Cabrera, } \\
\text { Lorenzo }\end{array}$ & Argentino & Diocesano & Cura y Vicario & $\begin{array}{l}\text { Chilecito- La } \\
\text { Rioja }\end{array}$ & Curato & campaña \\
\hline Díaz, José María & Argentino & Diocesano & $\begin{array}{l}\text { Cgo. Capellán } \\
\text { Carmelitas }\end{array}$ & $\begin{array}{l}\text { Córdoba, } \\
\text { ciudad }\end{array}$ & $\begin{array}{l}\text { Cabildo } \\
\text { Catedral }\end{array}$ & ciudad \\
\hline Gordillo, Basilio & Argentino & Diocesano & $\begin{array}{l}\text { Sacristán } \\
\text { Mayor }\end{array}$ & $\begin{array}{l}\text { Córdoba, } \\
\text { ciudad }\end{array}$ & Catedral & ciudad \\
\hline $\begin{array}{l}\text { López Arcante, } \\
\text { José Evaristo }\end{array}$ & Extranjero & Diocesano & $\begin{array}{l}\text { Cura y Vicario } \\
\text { Interino }\end{array}$ & Tulumba & Curato & campaña \\
\hline $\begin{array}{l}\text { Moyano, } \\
\text { Belarmino }\end{array}$ & Argentino & Diocesano & nc & nc & $\mathrm{nc}$ & $\mathrm{nc}$ \\
\hline $\begin{array}{l}\text { Ramos, } \\
\text { Ambrosio }\end{array}$ & Argentino & Diocesano & $\begin{array}{l}\text { Cura y Vicario } \\
\text { Interino }\end{array}$ & Jesús María & Curato & campaña \\
\hline $\begin{array}{l}\text { Compañy, } \\
\text { Miguel }\end{array}$ & Extranjero & Diocesano & $\begin{array}{l}\text { Cura y Vicario } \\
\text { Interino }\end{array}$ & $\begin{array}{l}\text { San Javier } \\
\text { Calamuchita }\end{array}$ & Curato & campaña \\
\hline
\end{tabular}




\begin{tabular}{|c|c|c|c|c|c|c|}
\hline $\begin{array}{l}\text { Gerica (Gherica), } \\
\text { Bonifacio }\end{array}$ & Extranjero & Diocesano & $\begin{array}{l}\text { Cura y Vicario } \\
\text { Interino }\end{array}$ & Alta Gracia & Curato & campaña \\
\hline $\begin{array}{l}\text { Cuestas, } \\
\text { Francisco }\end{array}$ & $\begin{array}{l}\text { Argentino/ } \\
\text { Cordobés }\end{array}$ & Diocesano & $\begin{array}{l}\text { Vicario } \\
\text { Foráneo }\end{array}$ & La Rioja & Curato & ciudad \\
\hline Luque, Adolfo & Argentino & Diocesano & $\begin{array}{l}\text { Fiscal } \\
\text { eclesiástico }\end{array}$ & $\begin{array}{l}\text { Córdoba, } \\
\text { ciudad }\end{array}$ & Curia & ciudad \\
\hline $\begin{array}{l}\text { Argañarás, } \\
\text { Apolinario }\end{array}$ & Argentino & Diocesano & $\begin{array}{l}\text { Cura Rector } \\
\text { más antiguo }\end{array}$ & $\begin{array}{l}\text { Córdoba, } \\
\text { ciudad }\end{array}$ & Curato & ciudad \\
\hline Torres, Ajenor & Argentino & Diocesano & $\begin{array}{l}\text { Cura y Viario } \\
\text { Interino }\end{array}$ & Justo y Pastor & Curato & campaña \\
\hline Ríos, Jacinto & Argentino & Diocesano & Profesor & $\begin{array}{l}\text { Córdoba, } \\
\text { ciudad }\end{array}$ & Seminario & ciudad \\
\hline Bustos, Samuel & Argentino & Diocesano & Profesor & $\begin{array}{l}\text { Córdoba, } \\
\text { ciudad }\end{array}$ & Seminario & ciudad \\
\hline Pérez, Tomas & Argentino & Diocesano & Profesor & $\begin{array}{l}\text { Córdoba, } \\
\text { ciudad }\end{array}$ & Seminario & ciudad \\
\hline $\begin{array}{l}\text { Mariño de } \\
\text { Romero, José } \\
\text { María }\end{array}$ & Extranjero & Diocesano & $\begin{array}{l}\text { Cura y Vicario } \\
\text { Interino }\end{array}$ & Chalacea & Curato & campaña \\
\hline $\begin{array}{l}\text { Fraile del } \\
\text { Convento de Río } \\
\text { Cuarto }\end{array}$ & Extranjero & Franciscano & Cura y Vicario & Río Cuarto & Curato & campaña \\
\hline Prisco, Rafael & Extranjero & $\begin{array}{l}\text { Franciscano- } \\
\text { enclaustrado }\end{array}$ & Administrador & Sobremonte & Curato & campaña \\
\hline $\begin{array}{l}\text { Pristo, Camilo } \\
\text { Domingo }\end{array}$ & $\mathrm{nc}$ & Diocesano & $\begin{array}{l}\text { Capellán del } \\
\text { Obispo }\end{array}$ & $\begin{array}{l}\text { Córdoba, } \\
\text { ciudad }\end{array}$ & Curia & ciudad \\
\hline $\begin{array}{l}\text { Ardiles, José } \\
\text { Gregorio }\end{array}$ & Argentino & Diocesano & & & nc & nc \\
\hline $\begin{array}{l}\text { Gil López, Don } \\
\text { Andrés }\end{array}$ & Extranjero & Extradiocesa. & $\begin{array}{l}\text { Cura y Vicario } \\
\text { Interino }\end{array}$ & $\begin{array}{l}\text { La Rioja } \\
\text { Costa de } \\
\text { Arauco }\end{array}$ & Curato & campaña \\
\hline $\begin{array}{l}\text { Ramírez, Pedro } \\
\text { Pascual }\end{array}$ & $\mathrm{nc}$ & Extradiocesa. & $\begin{array}{l}\text { Cura y Vicario } \\
\text { Interino }\end{array}$ & $\begin{array}{l}\text { La Rioja, } \\
\text { Famatina }\end{array}$ & Curato & campaña \\
\hline Bonoris, Santiago & Extranjero & Extradiocesa. & $\begin{array}{l}\text { Capellán } \\
\text { permanente }\end{array}$ & Caroya & Curato & campaña \\
\hline $\begin{array}{l}\text { Bataglia, Juan } \\
\text { José }\end{array}$ & Extranjero & Extradiocesa. & $\begin{array}{l}\text { Cura y Vicario } \\
\text { Interino }\end{array}$ & Minas & Curato & campaña \\
\hline $\begin{array}{l}\text { Barreda, José } \\
\text { Mercedes }\end{array}$ & Argentino & $\begin{array}{l}\text { Diocesano } \\
\text { incardinado ex } \\
\text { religioso }\end{array}$ & Ayudante & Pocho & Curato & campaña \\
\hline $\begin{array}{l}\text { RP Forneli, } \\
\text { Ramiro }\end{array}$ & Extranjero & Religioso & Cura & $\begin{array}{l}\text { Capilla } \\
\text { Esquina } \\
\text { Curato Santa } \\
\text { Rosa Río } 1^{\circ}\end{array}$ & Curato & campaña \\
\hline Lucero, Samuel & $\begin{array}{l}\text { Argentino/ } \\
\text { Mendoza }\end{array}$ & $\begin{array}{l}\text { Extradiocesa. } \\
\text { ex mercedario }\end{array}$ & $\begin{array}{l}\text { Ministerio } \\
\text { libre }\end{array}$ & Ciudad & & ciudad \\
\hline Ibáñez, Nemesio & Argentino & $\begin{array}{l}\text { Diocesano ex } \\
\text { mercedario }\end{array}$ & Cura y Vicario & Anejos Norte & Curato & campaña \\
\hline $\begin{array}{l}\text { Ludueña, } \\
\text { Benjamín }\end{array}$ & Argentino & Diocesano & Cura y Vicario & \multicolumn{2}{|c|}{ Santa Rosa Río Primero } & campaña \\
\hline Luque, David & Criollo & Diocesano & $\begin{array}{l}\text { Cgo. } \\
\text { Honorario } \\
\text { Fundador de } \\
\text { las Esclavas }\end{array}$ & $\begin{array}{l}\text { Córdoba } \\
\text { ciudad }\end{array}$ & Cabildo & ciudad \\
\hline
\end{tabular}




\begin{tabular}{|c|c|c|c|c|c|c|c|c|c|}
\hline \multicolumn{10}{|c|}{$\begin{array}{c}\text { TABLA } 12 \\
\text { Ordenaciones presbiterales del clero diocesano secular o "clero propio" } \\
1875-1925\end{array}$} \\
\hline $\begin{array}{c}\mathrm{N} / \\
\text { Quinqueño }\end{array}$ & \multicolumn{2}{|c|}{$\begin{array}{c}\mathrm{N} \% \\
\text { Condición }\end{array}$} & $\begin{array}{l}\text { Apellido y } \\
\text { Nombre }\end{array}$ & Condición & Oriundo & Edad & $\begin{array}{c}\text { Fecha } \\
\text { presbiterado }\end{array}$ & $\begin{array}{c}\text { Lugar / } \\
\text { Ministro }\end{array}$ & Fuentes \\
\hline \multirow[t]{5}{*}{$\begin{array}{c}1875-1889 \\
4\end{array}$} & \multirow[t]{5}{*}{$\begin{array}{c}\text { Arg } \\
3\end{array}$} & \multirow[t]{5}{*}{$\begin{array}{c}\text { Extr } \\
2\end{array}$} & $\begin{array}{l}\text { Compañy, } \\
\text { Miguel }\end{array}$ & Diocesano & $\begin{array}{l}\text { España, } \\
\text { Diócesis de } \\
\text { Barcelona }\end{array}$ & $\mathrm{n} / \mathrm{c}$ & $17 / 02 / 1874$ & Buenos Aires & $\begin{array}{l}\text { Títulos del clero, } \\
\text { 1854-1904, f.55 }\end{array}$ \\
\hline & & & Pérez, Tomás & Diocesano & Córdoba & $\mathrm{n} / \mathrm{c}$ & 1875 & $\begin{array}{l}\text { Buenos Aires } \\
\text { Federico } \\
\text { Aneiros }\end{array}$ & $\begin{array}{l}\text { "E1 Progreso" } \\
27 / 05 / 1880\end{array}$ \\
\hline & & & $\begin{array}{l}\text { Ríos, Jacinto } \\
\text { Roque }\end{array}$ & Diocesano & $\begin{array}{l}\text { Río } \\
\text { Segundo }\end{array}$ & $\mathrm{n} / \mathrm{c}$ & $21 / 11 / 1876$ & $\begin{array}{l}\text { Álvarez, } \\
\text { Obispo. } \\
\text { Monasterio } \\
\text { Santa Catalina }\end{array}$ & $\begin{array}{l}\text { Libro de Órdenes, } \\
1876-1925, \text { f.2 }\end{array}$ \\
\hline & & & $\begin{array}{l}\text { García } \\
\text { Colmena, } \\
\text { Andrés }\end{array}$ & $\begin{array}{l}\text { Alumno de este } \\
\text { Seminario desde marzo } \\
\text { de } 1873 \text {. Cursó filosofía } \\
\text { y matemáticas en el } \\
\text { Seminario de San Julián } \\
\text { de Cuenca (España) }\end{array}$ & $\begin{array}{l}\text { España, } \\
\text { Diócesis de } \\
\text { Cuenca }\end{array}$ & & $1878^{1}$ & $\mathrm{n} / \mathrm{c}$ & $\begin{array}{l}\text { Leg.24, TIX, 1873- } \\
\text { 1880/AAC. Libro } \\
\text { de Títulos, 1859- } \\
\text { 1904, f.70/ Libro } \\
\text { de Ordenes, 1876- } \\
\text { 1925, f.4 }\end{array}$ \\
\hline & & & $\begin{array}{l}\text { Purcell, Juan } \\
\text { José }\end{array}$ & $\begin{array}{l}\text { Se trasladó de niño a la } \\
\text { América Británica y de } \\
\text { allí a Buenos Aires en } \\
\text { 1859. Domiciliario } \\
\text { obispado Córdoba } \\
\text { Ordenado en Córdoba. } \\
\text { Muere en Buenos Aires }\end{array}$ & Irlanda & 36 & $\begin{array}{l}1879 \\
\text { Dimisorias p/ } \\
\text { órdenes } \\
\text { mayores p/ } \\
\text { arquidiócesis } \\
\text { de Bs As }\end{array}$ & Buenos Aires & $\begin{array}{l}\text { Libro 23, Ordenes, } \\
\text { 1876-1925, f.2 / } \\
\text { AAC. Libro } \\
\text { Licencias } \\
\text { Ministeriales, } \\
\text { 1859-1932, f.116 } \\
\text { /Leg. 42. Notas al } \\
\text { Obispo, s/f }\end{array}$ \\
\hline $\begin{array}{c}1880-1884 \\
16\end{array}$ & 14 & 2 & Chanetón, José & $\begin{array}{l}\text { Domiciliario obispado } \\
\text { Córdoba }\end{array}$ & Córdoba & 27 & $20 / 04 / 1880$ & $\begin{array}{l}\text { Sede vacante. } \\
\text { Dimisorias p/ } \\
\text { ordenes } \\
\text { mayores hasta } \\
\text { el presbiterado }\end{array}$ & $\begin{array}{l}\text { Libro Licencias } \\
\text { Ministeriales, f.130 }\end{array}$ \\
\hline
\end{tabular}

\footnotetext{
${ }^{1}$ García Colmena, Andrés, el 15/12/1877 recibió en Córdoba el subdiaconado. No consta en los libros la fecha del diaconado y presbiterado. Pero en el Libro de Títulos figura que fue nombrado cura y vicario interino de Tulumba el 24/09/1881. Por este motivo, deducimos que fue ordenado en otra diócesis con dimisorias por sede-vacancia de la silla episcopal cordobesa.
} 


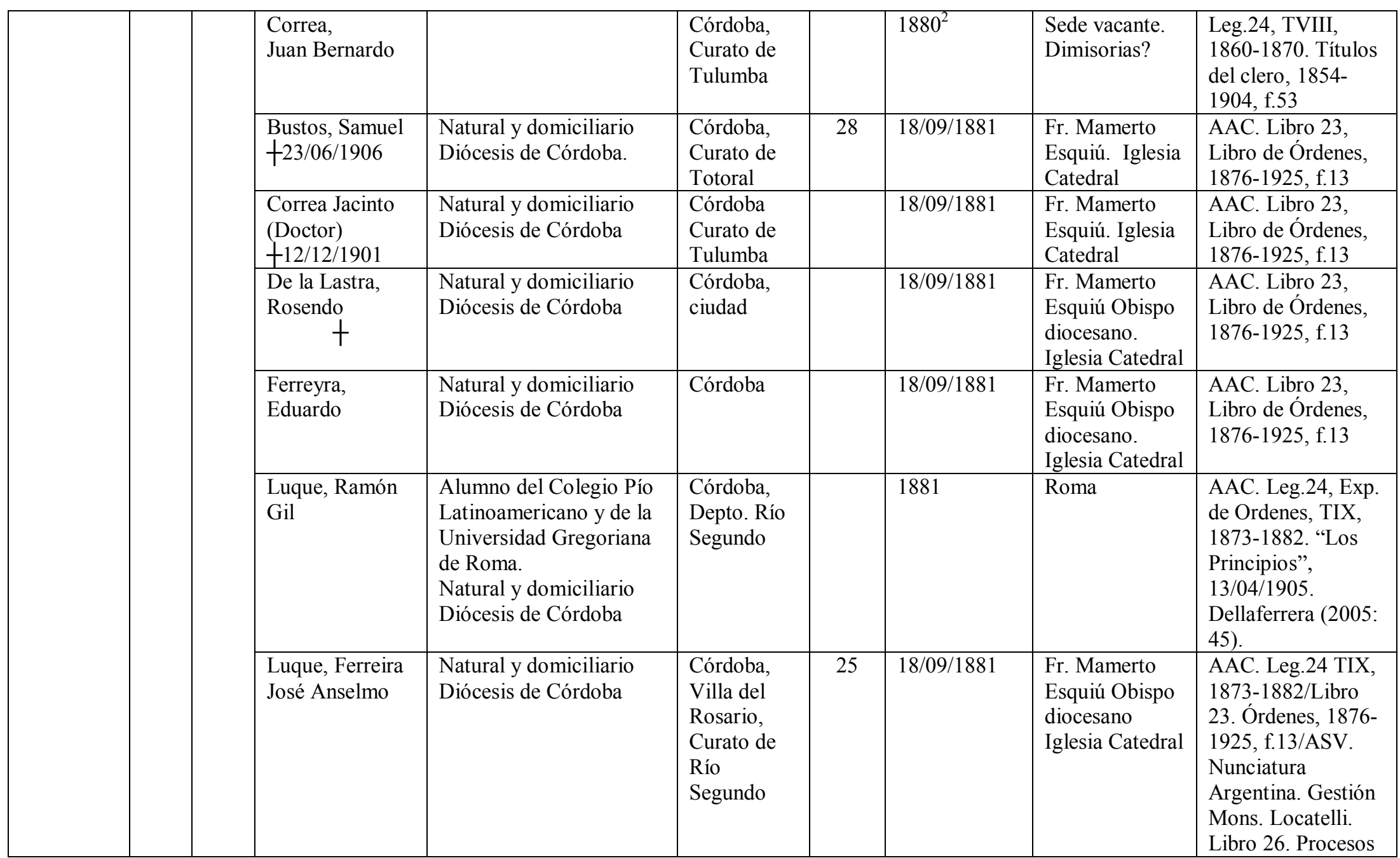

\footnotetext{
${ }^{2}$ Correa Juan Bernardo. Se abre el expediente a órdenes menores y mayores. Sólo figura el de menores, recibiendo la Tonsura y las cuatro órdenes a la edad de 21 años el 24/06/1877 junto a su hermano Jacinto (Ordenes, 1876-1925, f.2). No consta su ordenación presbiteral. En el Libro de Títulos figura en 1912 como capellán de la capilla de Citón, perteneciente al curato de Totoral y ubicada en el límite con Tulumba.
} 


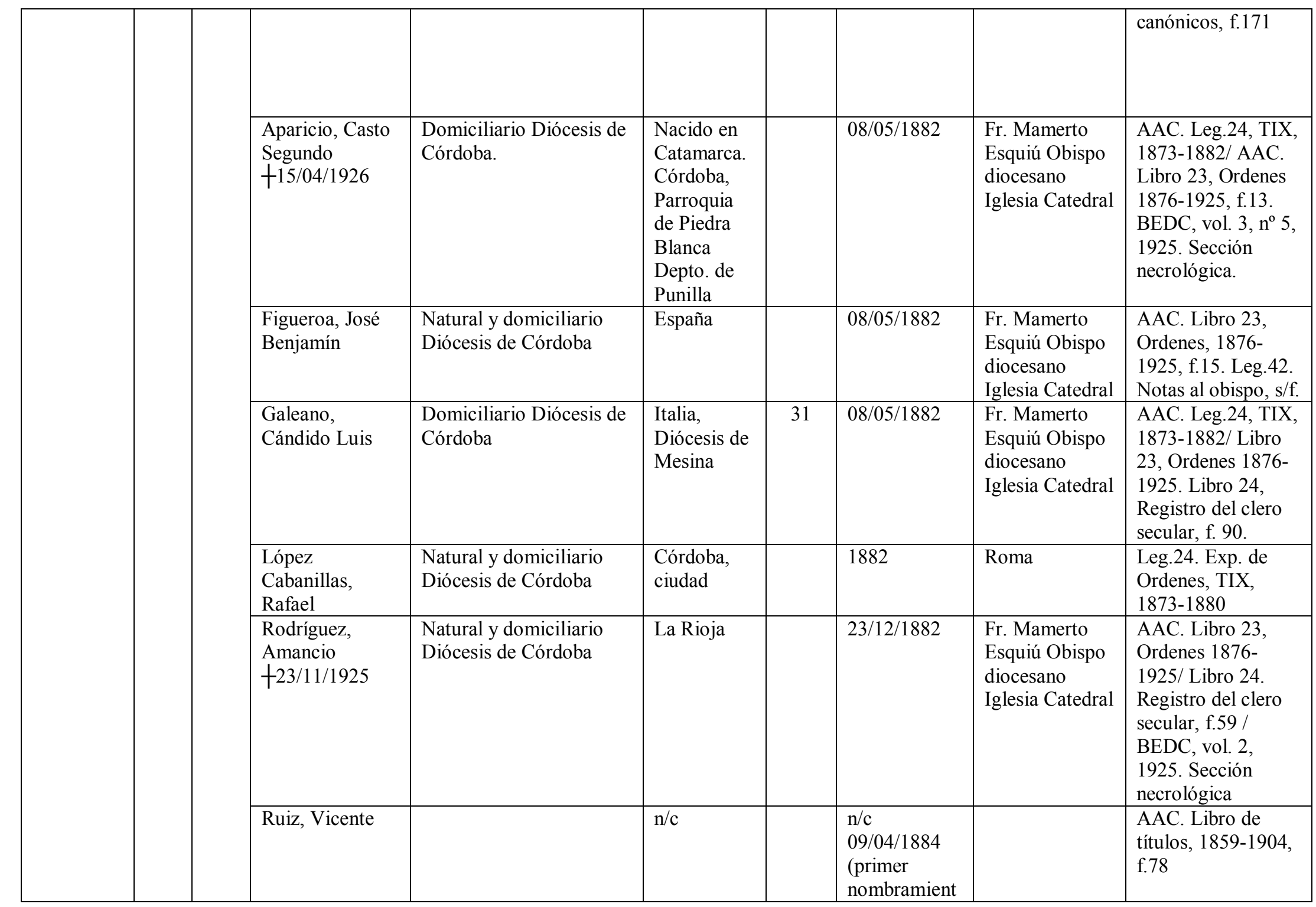




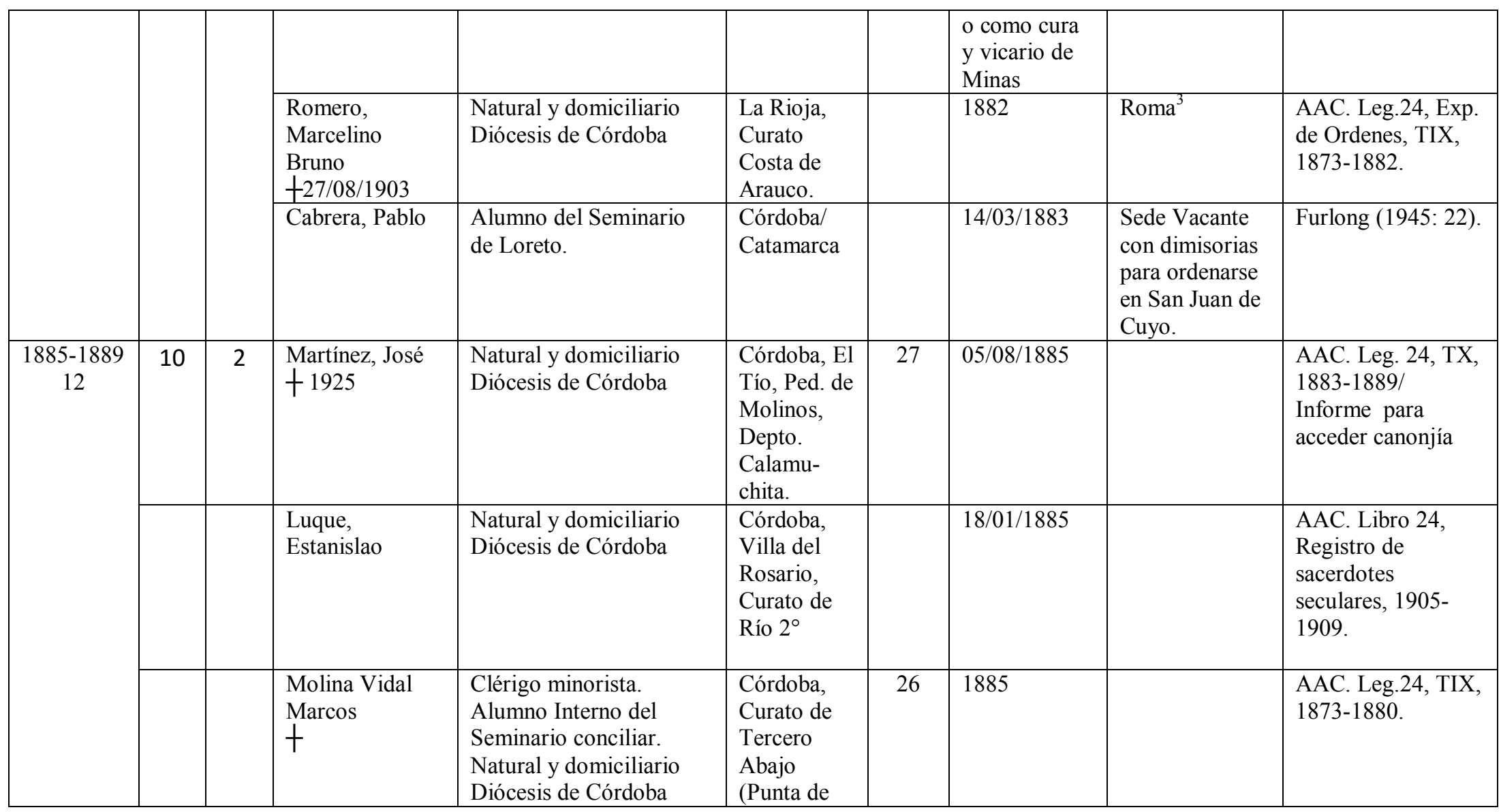

\footnotetext{
${ }^{3}$ Nelson Dellaferrera lo ubica como alumno del Pío Latinoamericano y de la Universidad Gregoriana (1876-1881). Pongo en duda este dato teniendo en cuenta que en el expediente a órdenes menores, iniciado en 1875, el postulante señala que ocupa una de las becas dotadas por el gobierno nacional y le "es difícilmente dificultosa la continuación de mi carreara por estado de pobreza de mis padres y la larga distancia que me separa de ellos. Para poder subvenir a los gastos que demanda el colegio he sido protegido con pequeñas asignaciones por el gobierno de La Rioja" (AAC. Leg.24, TIX, 1873-1880), por tanto, creo poco probable la posibilidad del pago de sus estudios en el extranjero. Sin embargo, no he podido constatar el lugar y fecha de su ordenación presbiteral. El 04/03/1882 recibe el título de cura y vicario de Chilecito (Cfr. Dellaferrera, Nelson, "La actividad del provisor en córdoba un ejemplo de las postrimerías del siglo XIX (1881-1883)", Cuadernos de Historia, n 15. Instituto de Historia del Derecho y de las Ideas Políticas, Roberto Peña, Córdoba, 2005, p. 45).
} 


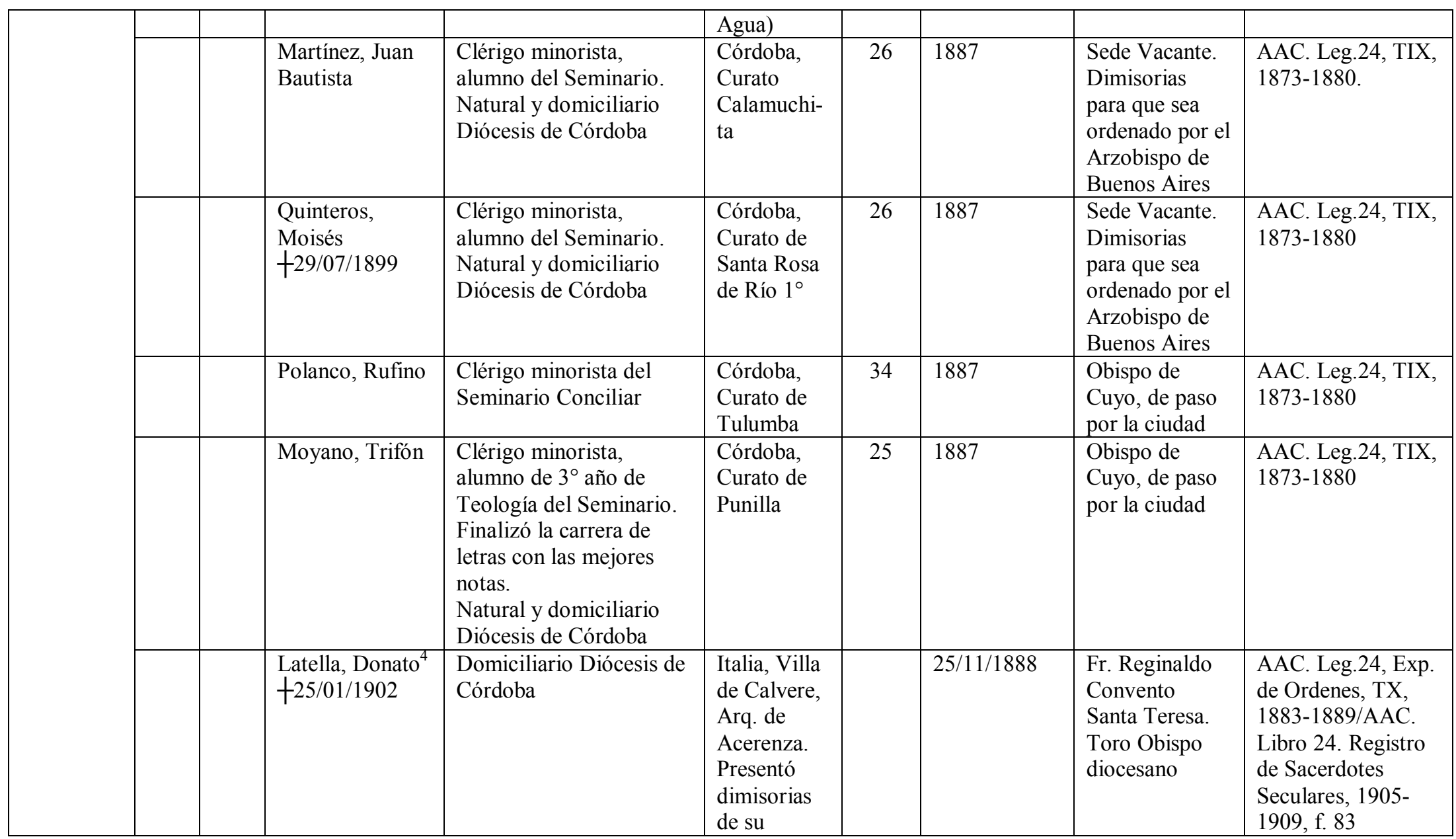

\footnotetext{
${ }^{4}$ Donato Latella fue alumno del Seminario de Loreto entre 1881 y 1883. Luego se trasladó a Europa con su familia. En 1888 regresó e ingresó al Seminario. El Rector, Juan Martín Yaniz, informa que le es completamente desconocida la preparación científica del joven Latella, pues en el establecimiento no ha cursado ninguna materia en los pocos meses que ha permanecido. Antes bien, por referencias de personas fidedignas, este joven no está preparado para recibir las sagradas órdenes. Firma Juan Yaniz, 12/11/1888 (Cfr. Leg.24). Existe otro Donato Latella que fue cura y vicario interino de Río Seco en 1877 (Cfr. Libro de Títulos, 1859-1904, f.66
} 


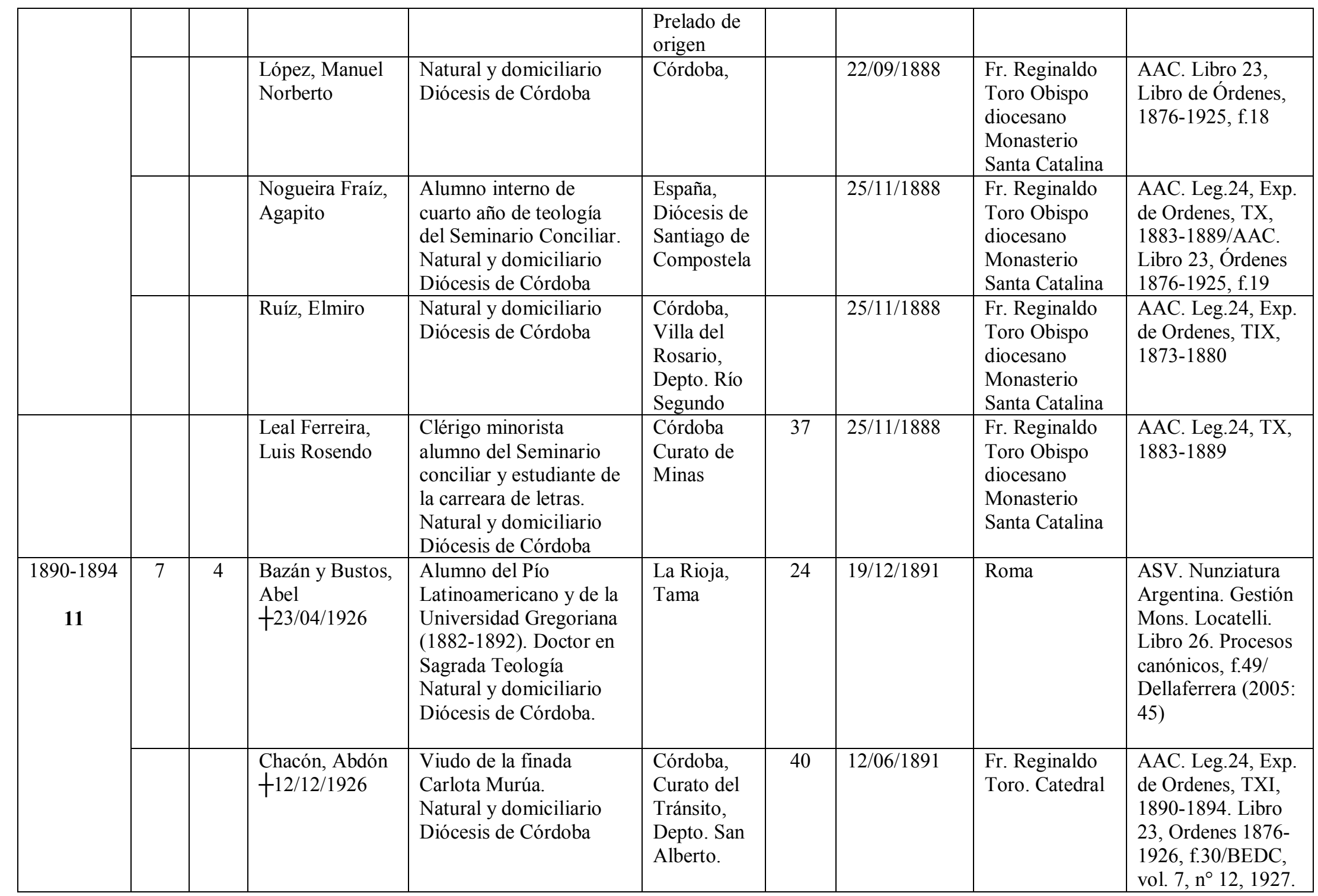




\begin{tabular}{|c|c|c|c|c|c|c|c|c|c|}
\hline & & & $\begin{array}{l}\text { Echenique, } \\
\text { Carlos }\end{array}$ & $\begin{array}{l}\text { Alumno del Pio } \\
\text { Latinoamericano de } 1889 \\
\text { a } 1891 \text {. Doctor en } \\
\text { Sagrada Teología por la } \\
\text { Universidad Gregoriana. }\end{array}$ & $\begin{array}{l}\text { Córdoba, } \\
\text { ciudad }\end{array}$ & 24 & $19 / 11 / 1891$ & Roma & $\begin{array}{l}\text { AAC. Leg.24, TX, } \\
\text { 1883-1889/ASV. } \\
\text { Nunziatura } \\
\text { Argentina. Gestión } \\
\text { Mons. Locatelli. } \\
\text { Libro 26. Procesos } \\
\text { canónicos, f.243 }\end{array}$ \\
\hline & & & $\begin{array}{l}\text { Luque, Ferreira } \\
\text { David }\end{array}$ & $\begin{array}{l}\text { Alumno del Pio } \\
\text { Latinoamericano y de la } \\
\text { Universidad Gregoriana. } \\
\text { Natural y domiciliario } \\
\text { Diócesis de Córdoba }\end{array}$ & $\begin{array}{l}\text { Córdoba, } \\
\text { Curato } \\
\text { Villa del } \\
\text { Rosario, } \\
\text { Depto. Río } \\
\text { Segundo } \\
\end{array}$ & & $12 / 12 / 1891$ & $\begin{array}{l}\text { Dimisorias } \\
\text { hasta el } \\
\text { Presbiterado } \\
\text { inclusive } \\
\text { Roma }\end{array}$ & $\begin{array}{l}\text { AAC. Leg.24, Exp. } \\
\text { de Ordenes, TIX, } \\
\text { 1873-1880. }\end{array}$ \\
\hline & & & $\begin{array}{l}\text { García Insúa. } \\
\text { Luis }\end{array}$ & $\begin{array}{l}\text { Domiciliario de la } \\
\text { Diócesis de Córdoba }\end{array}$ & España & & $15 / 06 / 1892$ & $\begin{array}{l}\text { Fr. Reginaldo } \\
\text { Toro. Catedral }\end{array}$ & $\begin{array}{l}\text { AAC. Leg.24, Exp. } \\
\text { de Ordenes, TXI, } \\
\text { 1890-1894/AAC. } \\
\text { Libro 23, Ordenes } \\
\text { 1876-1925, f. 32/ } \\
\text { AAC. Libro 24, } \\
\text { Registro de } \\
\text { sacerdotes } \\
\text { seculares... f.148 }\end{array}$ \\
\hline & & & $\begin{array}{l}\text { Portella, Jacinto } \\
\text { Cirilo }\end{array}$ & $\begin{array}{l}\text { Alumno Interno del } \\
\text { Seminario conciliar, de } \\
2^{\circ} \text { año de filosofía. } \\
\text { Domiciliario Diócesis de } \\
\text { Córdoba }\end{array}$ & $\begin{array}{l}\text { Uruguay, } \\
\text { Diócesis de } \\
\text { Montevideo }\end{array}$ & & $30 / 11 / 1893$ & $\begin{array}{l}\text { Fr. Reginaldo } \\
\text { Toro. Catedral }\end{array}$ & $\begin{array}{l}\text { AAC. Leg.24, Exp. } \\
\text { de Ordenes, TX, } \\
\text { 1883-1889/AAC. } \\
\text { Libro 23, Ordenes } \\
\text { 1876-1925, Libro } \\
\text { 24, f.71 }\end{array}$ \\
\hline & & & Álvarez, Luis & $\begin{array}{l}\text { Clérigo minorista. } \\
\text { Alumno del Seminario } \\
\text { Conciliar. } \\
\text { Natural y domiciliario } \\
\text { Diócesis de Córdoba }\end{array}$ & $\begin{array}{l}\text { Córdoba, } \\
\text { ciudad }\end{array}$ & 25 & $13 / 08 / 1894$ & $\begin{array}{l}\text { Fr. Reginaldo } \\
\text { Toro. Capilla } \\
\text { del Seminario }\end{array}$ & $\begin{array}{l}\text { AAC. Leg.24, } \\
\text { Exp. de Ordenes, } \\
\text { TX, 1883-1889/ } \\
\text { AAC. Libro 23, } \\
\text { Ordenes, } 1876- \\
\text { 1925, f. } 39\end{array}$ \\
\hline & & & $\begin{array}{l}\text { Angulo, Pío } \\
\text { Benito }\end{array}$ & $\begin{array}{l}\text { Alumno del Seminario } \\
\text { dos años externo y los } \\
\text { últimos dos interno. } \\
\text { Natural y domiciliario }\end{array}$ & $\begin{array}{l}\text { Córdoba, } \\
\text { Curato de } \\
\text { Chalacea, } \\
\text { Monte del }\end{array}$ & 25 & $25 / 12 / 1894$ & $\begin{array}{l}\text { Fr. Reginaldo } \\
\text { Toro. } \\
\text { Iglesia Colegio } \\
\text { de Educandas }\end{array}$ & $\begin{array}{l}\text { AAC. Leg.24, Exp. } \\
\text { de Ordenes, TX, } \\
\text { 1883-1889/AAC. } \\
\text { Libro 23, Ordenes }\end{array}$ \\
\hline
\end{tabular}




\begin{tabular}{|c|c|c|c|c|c|c|c|}
\hline & & Diócesis de Córdoba & $\begin{array}{l}\text { Rosario. } \\
\text { Depto. Río } \\
\text { Primero }\end{array}$ & & & & 1876-1925, f.41 \\
\hline & Ferreira, Bruno & $\begin{array}{l}\text { Clérigo minorista, } \\
\text { Alumno interno del } \\
\text { seminario. } \\
\text { Natural y domiciliario } \\
\text { Diócesis de Córdoba }\end{array}$ & $\begin{array}{l}\text { Córdoba, } \\
\text { Villa del } \\
\text { Rosario, } \\
\text { Curato de } \\
\text { Río } 2^{\circ}\end{array}$ & 25 & $16 / 06 / 1894$ & $\begin{array}{l}\text { Fr. Reginaldo } \\
\text { Toro Obispo } \\
\text { Diocesano. } \\
\text { Iglesia de las } \\
\text { Teresas }\end{array}$ & $\begin{array}{l}\text { AAC. Leg.24, TX, } \\
\text { 1883-1889/AAC. } \\
\text { Libro 23, Ordenes } \\
1876-1925, \text { f.39 }\end{array}$ \\
\hline & $\begin{array}{l}\text { Gallioz, } \\
\text { Feliciano }\end{array}$ & $\begin{array}{l}\text { Alumno interno del } \\
\text { último año de teología } \\
\text { del Seminario. } \\
\text { Domiciliario Diócesis de } \\
\text { Córdoba }\end{array}$ & $\begin{array}{l}\text { Natural de } \\
\text { Thyl, } \\
\text { Francia. } \\
\text { Parroquia } \\
\text { de la } \\
\text { diócesis de } \\
\text { Maurrienn }\end{array}$ & 23 & $16 / 06 / 1894$ & $\begin{array}{l}\text { Fr Reginaldo } \\
\text { Toro Obispo } \\
\text { Diocesano. }\end{array}$ & $\begin{array}{l}\text { AAC. Leg.24, Exp. } \\
\text { de Ordenes, TXI, } \\
\text { 1890-1894/AAC. } \\
\text { Libro 23, Ordenes, } \\
\text { 1876-1925/AAC. } \\
\text { Libro 24. Registro } \\
\text { de Sacerdotes } \\
\text { seculares, 1905- } \\
\text { 1909, f. } 76\end{array}$ \\
\hline & Gallioz, Joel & $\begin{array}{l}\text { Domiciliario Diócesis de } \\
\text { Córdoba }\end{array}$ & $\begin{array}{l}\text { Natural, } \\
\text { Francia }\end{array}$ & $\mathrm{n} / \mathrm{c}$ & $16 / 06 / 1894$ & $\begin{array}{l}\text { Fr. Reginaldo } \\
\text { Toro Obispo } \\
\text { diocesano. } \\
\text { Iglesia de } \\
\text { Santa Teresa }\end{array}$ & $\begin{array}{l}\text { AAC. Libro } 23, \\
\text { Ordenes, } 1876- \\
1925, \text { f. } 39\end{array}$ \\
\hline 1895-1899 & $\begin{array}{l}\text { Correa Cruz, } \\
\text { Benjamín } \\
\text { Florencio }\end{array}$ & $\begin{array}{l}\text { Alumno interno del } \\
\text { último año de teología } \\
\text { del Seminario. } \\
\text { Domiciliario Diócesis de } \\
\text { Córdoba }\end{array}$ & $\begin{array}{l}\text { Córdoba, } \\
\text { Curato de } \\
\text { Totoral, } \\
\text { parroquia } \\
\text { de Jesús } \\
\text { María, } \\
\text { Depto. de } \\
\text { Anejos } \\
\text { Norte }\end{array}$ & 24 & $20 / 12 / 1895$ & $\begin{array}{l}\text { Fr Reginaldo } \\
\text { Toro Obispo. } \\
\text { Iglesia Colegio } \\
\text { de Educandas }\end{array}$ & $\begin{array}{l}\text { AAC. Leg.24 Exp. } \\
\text { de Ordenes, TX, } \\
\text { 1883-1889/AAC. } \\
\text { Libro 23. Ordenes } \\
1876-1925, \text { f.42 }\end{array}$ \\
\hline & $\begin{array}{l}\text { Ríos, Félix } \\
\text { Alejo }\end{array}$ & $\begin{array}{l}\text { Alumno del Pio } \\
\text { Latinoamericano. } \\
\text { Natural y domiciliario de } \\
\text { la Diócesis de Córdoba }\end{array}$ & $\begin{array}{l}\text { Córdoba, } \\
\text { ciudad }\end{array}$ & 24 & $00 / 12 / 1895$ & Roma & $\begin{array}{l}\text { AAC. Leg.24, Exp. } \\
\text { de Ordenes, TX, } \\
\text { 1883-1889/ "Los } \\
\text { Principios", 30/11/ } \\
1895 \text { y "E1 Pueblo } \\
\text { de Río Cuarto", } \\
\text { 19/12/1895 }\end{array}$ \\
\hline
\end{tabular}




\begin{tabular}{|c|c|c|c|c|c|c|c|c|c|}
\hline & & & $\begin{array}{l}\text { Infante Doncel, } \\
\text { José }\end{array}$ & $\begin{array}{l}\text { Clérigo minorista. } \\
\text { Alumno del Seminario. } \\
\text { Domiciliario Diócesis de } \\
\text { Córdoba }\end{array}$ & $\begin{array}{l}\text { España, } \\
\text { provincia y } \\
\text { obispado de } \\
\text { Málaga }\end{array}$ & 35 & $31 / 12 / 1896$ & $\begin{array}{l}\text { Fr Reginaldo } \\
\text { Toro Obispo. } \\
\text { Iglesia Colegio } \\
\text { de Educandas }\end{array}$ & $\begin{array}{l}\text { AAC. Leg.24, Exp. } \\
\text { de Ordenes, TXIII, } \\
\text { 1895-1900/AAC. } \\
\text { Libro 23, Ordenes } \\
\text { 1876-1925, f.44 / } \\
\text { AAC. Libro 24, } \\
\text { Registro...f.149 }\end{array}$ \\
\hline & & & $\begin{array}{l}\text { Ferreira Liendo, } \\
\text { Francisco }\end{array}$ & $\begin{array}{l}\text { Clérigo minorista. } \\
\text { Alumno del Seminario. } \\
\text { Natural y Domiciliario } \\
\text { de Córdoba. }\end{array}$ & Córdoba, & 21 & $00 / 00 / 1896$ & $\begin{array}{l}\text { Fr Reginaldo } \\
\text { Toro }\end{array}$ & $\begin{array}{l}\text { AAC. Leg.24, } \\
\text { TXIII, 1900-1905/ } \\
\text { AAC. Libro 23, } \\
\text { Ordenes 1876- } \\
\text { 1925, f.34 }\end{array}$ \\
\hline & & & $\begin{array}{l}\text { Alonzo Prado, } \\
\text { Antonio }\end{array}$ & $\begin{array}{l}\text { Clérigo minorista. } \\
\text { Alumno durante tres } \\
\text { años del Seminario de } \\
\text { Loreto. } \\
\text { Domiciliario Diócesis de } \\
\text { Córdoba. } \\
\text { En } 1911 \text { ingresó a los } \\
\text { Jesuitas }\end{array}$ & $\begin{array}{l}\text { España, } \\
\text { Diócesis de } \\
\text { Granada, } \\
\text { Molvizán }\end{array}$ & 24 & $21 / 11 / 1897$ & & $\begin{array}{l}\text { AAC. Leg.24, Exp. } \\
\text { de Ordenes, TXIII, } \\
\text { 1895-1900/AAC. } \\
\text { Libro 23, Ordenes } \\
\text { 1876-1925, f.48 }\end{array}$ \\
\hline & & & $\begin{array}{l}\text { Dávila, } \\
\text { Inocencio } \\
+30 / 04 / 1930\end{array}$ & $\begin{array}{l}\text { Natural y Domiciliario } \\
\text { de Córdoba }\end{array}$ & $\begin{array}{l}\text { Córdoba, } \\
\text { Villa de } \\
\text { Santa Rosa } \\
\text { Río Primero }\end{array}$ & 23 & $21 / 11 / 1897$ & $\begin{array}{l}\text { Fray Reginaldo } \\
\text { Toro, obispo. } \\
\text { Catedral }\end{array}$ & $\begin{array}{l}\text { AAC. Libro 23, } \\
\text { Ordenes, 1876- } \\
\text { 1925, f.48/ ASV. } \\
\text { Nunziatura } \\
\text { Argentina. Gestión } \\
\text { Mons. Locatelli. } \\
\text { Libro 26. Procesos } \\
\text { canónicos, f. 191/ } \\
\text { BEDC, vol.7, n } 6 \\
(1930: 209)\end{array}$ \\
\hline & & & $\begin{array}{l}\text { Ferreira Liendo, } \\
\text { Francisco }\end{array}$ & $\begin{array}{l}\text { Clérigo minorista. } \\
\text { Alumno del Seminario } \\
\text { de Loreto. } \\
\text { Natural y Domiciliario } \\
\text { Diócesis de Córdoba }\end{array}$ & Córdoba & 23 & $18 / 12 / 1897$ & $\begin{array}{l}\text { Fr Reginaldo } \\
\text { Toro Obispo. } \\
\text { Catedral }\end{array}$ & $\begin{array}{l}\text { AAC. Leg.24, Exp. } \\
\text { de Ordenes, TXIII, } \\
\text { 1900-1905/AAC. } \\
\text { Libro 23, Ordenes } \\
\text { 1876-1925, f.48 }\end{array}$ \\
\hline & & & $\begin{array}{l}\text { González } \\
\text { Fermoselle, } \\
\text { Raymundo }\end{array}$ & $\begin{array}{l}\text { Clérigo minorista. } \\
\text { Alumno interno del } \\
\text { Seminario conciliar de }\end{array}$ & $\begin{array}{l}\text { España, } \\
\text { Villa de } \\
\text { Valdeávila }\end{array}$ & 23 & $21 / 11 / 1897$ & $\begin{array}{l}\text { Fr Reginaldo } \\
\text { Toro Obispo. } \\
\text { Catedral }\end{array}$ & $\begin{array}{l}\text { AAC. Leg.24, Exp. } \\
\text { de Ordenes, TXIII, } \\
\text { 1895-1900/AAC. }\end{array}$ \\
\hline
\end{tabular}




\begin{tabular}{|c|c|c|c|c|c|c|c|c|c|}
\hline & & & $+13 / 01 / 1931$ & $\begin{array}{l}\text { Loreto. Hizo sus } \\
\text { primeros estudios en el } \\
\text { Seminario de Ciudad } \\
\text { Rodrigo y continuó en el } \\
\text { Seminario de Salamanca. } \\
\text { Domiciliario Diócesis de } \\
\text { Córdoba }\end{array}$ & $\begin{array}{l}\text { de la } \\
\text { Ribera, } \\
\text { Diócesis de } \\
\text { Salamanca }\end{array}$ & & & & $\begin{array}{l}\text { Libro 23, Ordenes } \\
\text { 1876-1925, f..48/ } \\
\text { Libro 24, Registro } \\
\text { f.84/ BEDC, vol.8, } \\
\mathrm{n}^{\circ} 2(1931: 54)\end{array}$ \\
\hline & & & $\begin{array}{l}\text { Herrera, Cortés } \\
\text { Juan }\end{array}$ & $\begin{array}{l}\text { Clérigo, minorista. } \\
\text { Alumno interno del } \\
\text { Seminario conciliar de } \\
\text { Loreto } \\
\text { Natural y Domiciliario } \\
\text { Diócesis de Córdoba }\end{array}$ & $\begin{array}{l}\text { Córdoba, } \\
\text { ciudad }\end{array}$ & 24 & $21 / 11 / 1897$ & $\begin{array}{l}\text { Fr Reginaldo } \\
\text { Toro Obispo. } \\
\text { Catedral }\end{array}$ & $\begin{array}{l}\text { AAC. Leg.24, Exp. } \\
\text { de Ordenes, TXI, } \\
\text { 1890-1894/AAC. } \\
\text { Libro 23, Ordenes, } \\
\text { 1876-1925, f.48 }\end{array}$ \\
\hline & & & $\begin{array}{l}\text { Ludueña, } \\
\text { Miguel }\end{array}$ & $\begin{array}{l}\text { Clérigo minorista, } \\
\text { alumno interno del } \\
\text { Seminario conciliar. } \\
\text { Ingresó en } 1877 \text {. Cursó } \\
\text { hasta } 3^{\circ} \text { año de teología, } \\
\text { salió en } 1884 \text { para } \\
\text { ingresar en la Compañía } \\
\text { de Jesús, ingresó } \\
\text { nuevamente en el } \\
\text { Seminario diocesano en } \\
\text { 1895, completando el } \\
\text { plan de estudios. } \\
\text { Natural y Domiciliario } \\
\text { Diócesis de Córdoba }\end{array}$ & $\begin{array}{l}\text { Córdoba, } \\
\text { Curato de } \\
\text { Río } 2^{\circ} \\
\text { Abajo }\end{array}$ & 33 & $21 / 11 / 1897$ & $\begin{array}{l}\text { Fr Reginaldo } \\
\text { Toro Obispo. } \\
\text { Catedral }\end{array}$ & $\begin{array}{l}\text { AAC. Leg.24, Exp. } \\
\text { de Ordenes, TIX, } \\
1871-1882\end{array}$ \\
\hline & & & $\begin{array}{l}\text { Mabrés, } \\
\text { Valentín } \\
+18 / 10 / 1904\end{array}$ & $\begin{array}{l}\text { Clérigo tonsurado en } \\
\text { Barcelona en } 1861 . \\
\text { Viudo de Dolores Luque. } \\
\text { Profesor de enseñanza } \\
\text { primaria y secundaria, } \\
\text { residente más de } 30 \text { años. } \\
\text { Domiciliario Diócesis de } \\
\text { Córdoba }\end{array}$ & $\begin{array}{l}\text { España, } \\
\text { Diócesis de } \\
\text { Vich, Prov. } \\
\text { Barcelona. } \\
\text { Domicilia. } \\
\text { en la ciudad }\end{array}$ & 55 & $24 / 04 / 1897$ & $\begin{array}{l}\text { Fr Reginaldo } \\
\text { Toro Obispo. } \\
\text { Iglesia de } \\
\text { Santo Domingo }\end{array}$ & $\begin{array}{l}\text { AAC. Leg.24, Exp. } \\
\text { de Ordenes, TXII, } \\
\text { 1895-1900/AAC. } \\
\text { Libro 23, Ordenes } \\
\text { 1876-1925, f.46/ } \\
\text { Libro 24, } \\
\text { Registro... f.150 }\end{array}$ \\
\hline & & & $\begin{array}{l}\text { Moyano } \\
\text { Centeno, José }\end{array}$ & $\begin{array}{l}\text { Clérigo minorista, } \\
\text { alumno interno del } \\
\text { Seminario conciliar. }\end{array}$ & Córdoba & 22 & $21 / 11 / 1897$ & $\begin{array}{l}\text { Fr Reginaldo } \\
\text { Toro Obispo. } \\
\text { Catedral } \\
\end{array}$ & $\begin{array}{l}\text { AAC. Leg.24, Exp. } \\
\text { de Ordenes, TXI, } \\
\text { 1890-1894/ AAC. }\end{array}$ \\
\hline
\end{tabular}




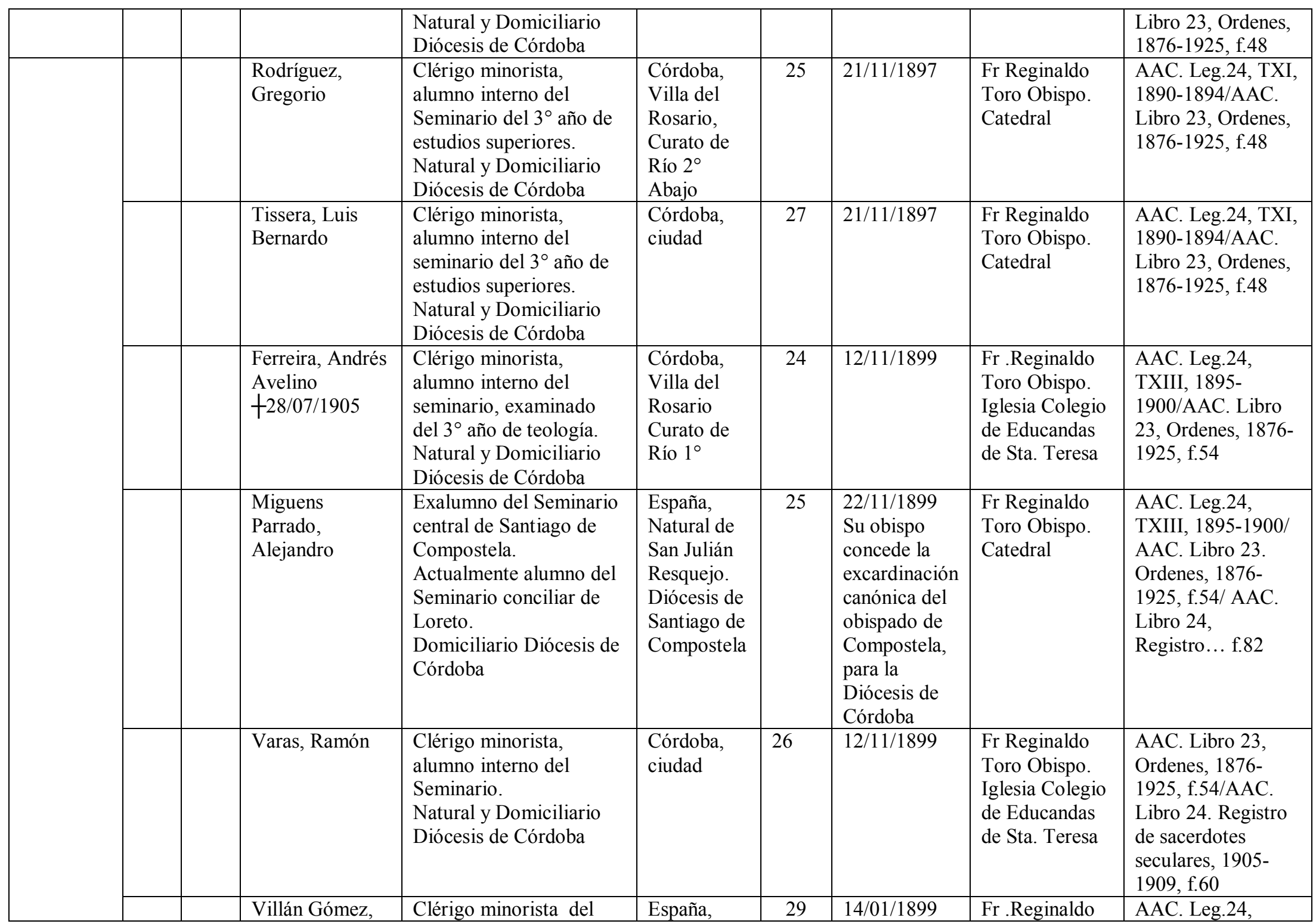




\begin{tabular}{|c|c|c|c|c|c|c|c|c|c|}
\hline & & & Ramón & $\begin{array}{l}\text { Seminario diocesano, } \\
\text { Ingresó al Seminario de } \\
\text { Loreto en mayo de } \\
\text { 1898, habiendo hecho en } \\
\text { España casi todos los } \\
\text { estudios exigidos en los } \\
\text { seminarios para abrazar } \\
\text { el estado eclesiástico. } \\
\text { Domiciliario Diócesis de } \\
\text { Córdoba }\end{array}$ & $\begin{array}{l}\text { Santiago de } \\
\text { Compostela }\end{array}$ & & & $\begin{array}{l}\text { Toro Obispo. } \\
\text { Iglesia Colegio } \\
\text { de Educandas } \\
\text { de Sta. Teresa }\end{array}$ & $\begin{array}{l}\text { TXIII, 1895- } \\
\text { 1900/AAC. Libro } \\
\text { 23, 1876-1925, } \\
\text { f.42/ AAC. Libro } \\
\text { 24. Registro...f.47 }\end{array}$ \\
\hline \multirow[t]{2}{*}{ 1900-1904 } & 8 & 3 & $\begin{array}{l}\text { Ferroni, } \\
\text { Bernardo }\end{array}$ & $\begin{array}{l}\text { Ingresó a mediados de } \\
1897 \text { al Seminario de } \\
\text { Loreto. Realizó los } \\
\text { cursos preparatorios y } \\
\text { algunos tratados de los } \\
\text { que aquí se estudian en } \\
2^{\circ} \text { año. En virtud de esto, } \\
\text { y en atención a su edad, } \\
\text { se le permitió ingresar } \\
\text { en el curso de } 3^{\circ} \text { año de } \\
\text { filosofía y preparar al } \\
\text { mismo tiempo } \\
\text { privadamente las } \\
\text { materias restantes } \\
\text { correspondientes al } 2^{\circ} \\
\text { año. Terminó sus } \\
\text { estudios en } 1901, \text { los que } \\
\text { cursó como alumno } \\
\text { interno con toda } \\
\text { regularidad. }\end{array}$ & $\begin{array}{l}\text { Italia, } \\
\text { Parroquia } \\
\text { de Arossio, } \\
\text { Prov. del } \\
\text { Tesino } \\
\text { (Suiza) }\end{array}$ & 29 & $30 / 11 / 1901$ & $\begin{array}{l}\text { Filemón } \\
\text { Cabanillas. } \\
\text { Obispo } \\
\text { auxiliar. } \\
\text { Catedral }\end{array}$ & $\begin{array}{l}\text { AAC. Leg.24, } \\
\text { TXIII, 1895- } \\
\text { 1900/AAC. Libro } \\
\text { 23, Ordenes, 1876- } \\
\text { 1925, f.61 }\end{array}$ \\
\hline & & & $\begin{array}{l}\text { Figueroa } \\
\text { Ghesteira, José }\end{array}$ & $\begin{array}{l}\text { Alumno del Seminario } \\
\text { central de Santiago: } \\
\text { interno, en los cursos de } \\
1891 \text { a } 1896 \text { y externo de } \\
1896 \text { a } 1899 \text {. } \\
\text { Domiciliario Diócesis de } \\
\text { Córdoba }\end{array}$ & $\begin{array}{l}\text { España, } \\
\text { Prov. de } \\
\text { Pontevedra, } \\
\text { Diócesis de } \\
\text { Santiago de } \\
\text { Compostela } \\
\text { Galicia, } \\
\text { Parroquia }\end{array}$ & 28 & $\begin{array}{l}\text { 16/07/1901 } \\
\text { Dimisorias } \\
\text { para recibir } \\
\text { las ordenes } \\
\text { menores y } \\
\text { mayores } \\
\text { hasta el } \\
\text { presbiterado }\end{array}$ & $\begin{array}{l}\text { Filemón } \\
\text { Cabanillas. } \\
\text { Obispo auxiliar } \\
\text { Con execuat de } \\
\text { su obispo }\end{array}$ & $\begin{array}{l}\text { AAC. Leg.24, } \\
\text { TXIII, 1901- } \\
\text { 1909/AAC. Libro } \\
\text { 24. Registro de } \\
\text { Sacerdotes } \\
\text { seculares, 1905- } \\
\text { 1909, f.126 }\end{array}$ \\
\hline
\end{tabular}




\begin{tabular}{|c|c|c|c|c|c|c|c|c|c|}
\hline & & & & & $\begin{array}{l}\text { de San } \\
\text { Pedro } \\
\text { Tenorio }\end{array}$ & & $\begin{array}{l}\text { inclusive, de } \\
\text { manos del } \\
\text { Obispo de } \\
\text { Córdoba o } \\
\text { de otro } \\
\text { cualquiera } \\
\end{array}$ & & \\
\hline & & & Frías, Belidoro & $\begin{array}{l}\text { Clérigo minorista del } \\
\text { Seminario de Loreto. } \\
\text { Alumno del último año } \\
\text { de estudios superiores. } \\
\text { Domiciliario Diócesis de } \\
\text { Córdoba (el obispo de } \\
\text { Cuyo desliga jurisdicción } \\
\text { en razón del domicilio de } \\
\text { origen), debido a } \\
\text { motivos familiares }\end{array}$ & San Juan & 25 & $30 / 11 / 1901$ & $\begin{array}{l}\text { Filemón } \\
\text { Cabanillas. } \\
\text { Obispo } \\
\text { auxiliar. } \\
\text { Catedral }\end{array}$ & $\begin{array}{l}\text { AAC. Leg.24, } \\
\text { TXIII, 1900- } \\
\text { 1905/AAC. Libro } \\
\text { 23, Ordenes, 1876- } \\
\text { 1925, f.61 }\end{array}$ \\
\hline & & & $\begin{array}{l}\text { Moreno Muñoz, } \\
\text { Carlos }\end{array}$ & $\begin{array}{l}\text { Llegó al seminario } \\
\text { enviado por el Obispo de } \\
\text { la Lastra el 15/03/1894 y } \\
\text { se le asignó una beca. } \\
\text { Clérigo minorista. } \\
\text { Alumno externo del } \\
\text { Seminario desde octubre } \\
\text { de } 1900 \text {. Cursando } 4^{\circ} \\
\text { año de Teología. Natural } \\
\text { y Domiciliario Diócesis } \\
\text { de Córdoba }\end{array}$ & $\begin{array}{l}\text { La Rioja, } \\
\text { Obispado } \\
\text { de Córdoba }\end{array}$ & 24 & $30 / 11 / 1901$ & $\begin{array}{l}\text { Filemón } \\
\text { Cabanillas. } \\
\text { Obispo } \\
\text { auxiliar. } \\
\text { Catedral }\end{array}$ & $\begin{array}{l}\text { AAC. Leg.24, } \\
\text { TXIII, 1901-1909/ } \\
\text { AAC. Libro 23, } \\
\text { Ordenes, 1876- } \\
\text { 1925, f. 61/AAC. } \\
\text { Libro 24, } \\
\text { Registro... f.48 }\end{array}$ \\
\hline & & & $\begin{array}{l}\text { Rodríguez, Juan } \\
\text { Antonio }\end{array}$ & $\begin{array}{l}\text { Clérigo minorista. } \\
\text { Alumno interno del } 3^{\circ} \\
\text { año de estudios } \\
\text { superiores del Seminario } \\
\text { de Loreto. } \\
\text { Natural y Domiciliario } \\
\text { Diócesis de Córdoba }\end{array}$ & $\begin{array}{l}\text { Córdoba, } \\
\text { ciudad }\end{array}$ & 23 & $30 / 11 / 1901$ & $\begin{array}{l}\text { Filemón } \\
\text { Cabanillas. } \\
\text { Obispo } \\
\text { auxiliar. } \\
\text { Catedral }\end{array}$ & $\begin{array}{l}\text { AAC. Leg.24, } \\
\text { TXIII, 1895-1900 }\end{array}$ \\
\hline & & & Ardiles, Rafael & $\begin{array}{l}\text { Clérigo minorista. } \\
\text { Estudiante del } 4^{\circ} \mathrm{y} \\
\text { último año de estudios } \\
\text { del Seminario de Loreto. }\end{array}$ & $\begin{array}{l}\text { Córdoba, } \\
\text { ciudad }\end{array}$ & 23 & $14 / 06 / 1903$ & $\begin{array}{l}\text { Filemón } \\
\text { Cabanillas. } \\
\text { Obispo } \\
\text { auxiliar. }\end{array}$ & $\begin{array}{l}\text { AAC. Leg.24, } \\
\text { TXIII, 1895-1900 }\end{array}$ \\
\hline
\end{tabular}




\begin{tabular}{|c|c|c|c|c|c|c|c|c|c|}
\hline & & & & $\begin{array}{l}\text { Natural y Domiciliario } \\
\text { Diócesis de Córdoba }\end{array}$ & & & & Catedral & \\
\hline & & & Isla, Pastor & $\begin{array}{l}\text { Clérigo minorista. } \\
\text { Estudiante del } 4^{\circ} \text { y } \\
\text { último año de estudios } \\
\text { superiores del Seminario } \\
\text { de Loreto. } \\
\text { Natural y Domiciliario } \\
\text { Diócesis de Córdoba }\end{array}$ & $\begin{array}{l}\text { Córdoba, } \\
\text { ciudad }\end{array}$ & 23 & $19 / 04 / 1903$ & $\begin{array}{l}\text { Filemón } \\
\text { Cabanillas. } \\
\text { Obispo } \\
\text { auxiliar. } \\
\text { Catedral }\end{array}$ & $\begin{array}{l}\text { AAC. Leg.24, } \\
\text { TXIII, 1895-1900/ } \\
\text { Libro 23, Ordenes } \\
\text { 1876-1925, f.65/ } \\
\text { Libro 24, f.97 }\end{array}$ \\
\hline & & & $\begin{array}{l}\text { Montenegro, } \\
\text { Pedro }\end{array}$ & $\begin{array}{l}\text { Clérigo minorista. } \\
\text { Estudiante del } 4^{\circ} \text { y } \\
\text { último año de estudios } \\
\text { superiores del Seminario } \\
\text { de Loreto. Desempeña el } \\
\text { cargo de Prefecto de la } \\
\text { división de los mayores. } \\
\text { Natural y Domiciliario } \\
\text { Diócesis de Córdoba }\end{array}$ & $\begin{array}{l}\text { Córdoba, } \\
\text { San } \\
\text { Francisco } \\
\text { del Chañar }\end{array}$ & 25 & $19 / 04 / 1903$ & $\begin{array}{l}\text { Filemón } \\
\text { Cabanillas. } \\
\text { Obispo } \\
\text { auxiliar. } \\
\text { Catedral }\end{array}$ & $\begin{array}{l}\text { AAC. Leg.24, } \\
\text { TXIII, 1895-1900 }\end{array}$ \\
\hline & & & Ríos, Laureano & $\begin{array}{l}\text { Natural y Domiciliario } \\
\text { Diócesis de Córdoba }\end{array}$ & $\begin{array}{l}\text { Córdoba, } \\
\text { Ped. de } \\
\text { Calchín, } \\
\text { Curato de } \\
\text { Río } 2^{\circ}\end{array}$ & 23 & $14 / 06 / 1903$ & $\begin{array}{l}\text { Filemón } \\
\text { Cabanillas. } \\
\text { Obispo } \\
\text { auxiliar. } \\
\text { Catedral }\end{array}$ & $\begin{array}{l}\text { AAC. Leg.24, } \\
\text { TXIII, 1895- } \\
\text { 1900/AAC. Libro } \\
\text { 23, f.66/ Ordenes } \\
\text { 1876-1925, Libro } \\
\text { 24, f.102 }\end{array}$ \\
\hline & & & Della Casa, Luis & $\begin{array}{l}\text { Clérigo minorista. } \\
\text { Estudiante del } 3^{\circ} \text { año de } \\
\text { estudios superiores del } \\
\text { Seminario de Loreto. } \\
\text { Domiciliario Diócesis de } \\
\text { Córdoba }\end{array}$ & $\begin{array}{l}\text { Italia, } \\
\text { Diócesis de } \\
\text { Utinensis, } \\
\text { Veneto }\end{array}$ & 29 & $08 / 05 / 1904$ & $\begin{array}{l}\text { Filemón } \\
\text { Cabanillas. } \\
\text { Obispo } \\
\text { auxiliar. } \\
\text { Catedral }\end{array}$ & $\begin{array}{l}\text { ACC. Leg.24, } \\
\text { TXIII, 1901- } \\
\text { 1909/AAC. Libro } \\
\text { 23, Ordenes 1876- } \\
\text { 1925, f. 69/Libro } \\
\text { 24, f.107 }\end{array}$ \\
\hline & & & $\begin{array}{l}\text { Fernández, } \\
\text { Celestino }\end{array}$ & $\begin{array}{l}\text { Clérigo minorista. } \\
\text { Estudiante del } 3^{\circ} \text { año de } \\
\text { estudios superiores del } \\
\text { Seminario de Loreto. } \\
\text { Natural y domiciliario } \\
\text { Diócesis de Córdoba }\end{array}$ & $\begin{array}{l}\text { Córdoba, } \\
\text { Curato de } \\
\text { Villa del } \\
\text { Rosario, } \\
\text { Depto. de } \\
\text { Río } 1^{\circ}\end{array}$ & 32 & $08 / 05 / 1904$ & $\begin{array}{l}\text { Filemón } \\
\text { Cabanillas. } \\
\text { Obispo } \\
\text { auxiliar. } \\
\text { Catedral }\end{array}$ & $\begin{array}{l}\text { AAC. Leg.24, } \\
\text { TXIII, 1901-1909/ } \\
\text { Libro 23, Ordenes, } \\
\text { 1876-1925, } \\
\text { f.69/Libro 24, f.111 }\end{array}$ \\
\hline 1905-1909 & 17 & 6 & $\begin{array}{l}\text { Acevedo, } \\
\text { Domingo }\end{array}$ & $\begin{array}{l}\text { Clérigo minorista. } \\
\text { Estudiante del } 3^{\circ} \text { año de }\end{array}$ & $\begin{array}{l}\text { Córdoba, } \\
\text { Curato de }\end{array}$ & 23 & $19 / 11 / 1905$ & $\begin{array}{l}\text { Zenón Bustos. } \\
\text { Obispo }\end{array}$ & $\begin{array}{l}\text { AAC. Leg.24, } \\
\text { TXIII, 1901- }\end{array}$ \\
\hline
\end{tabular}




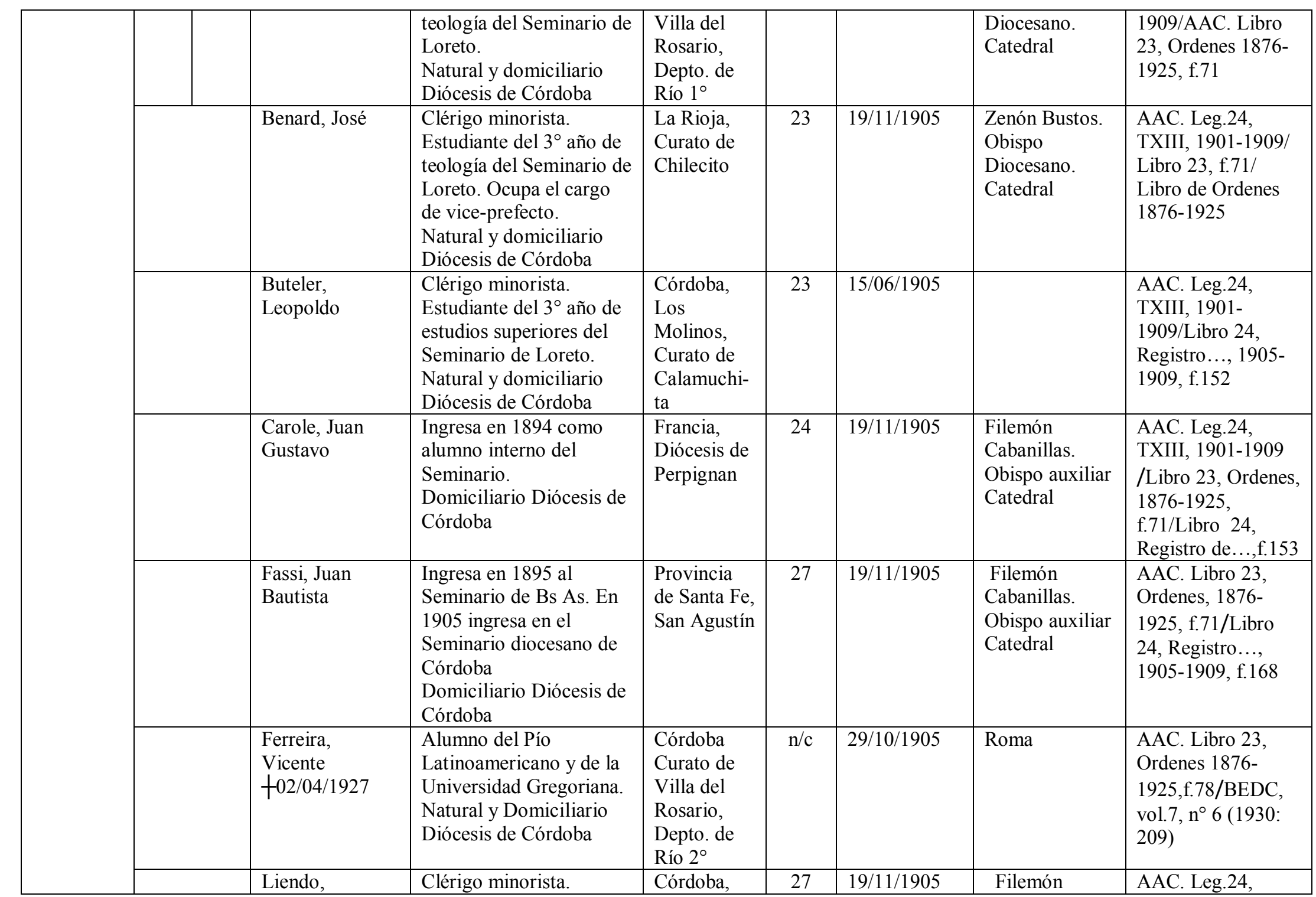




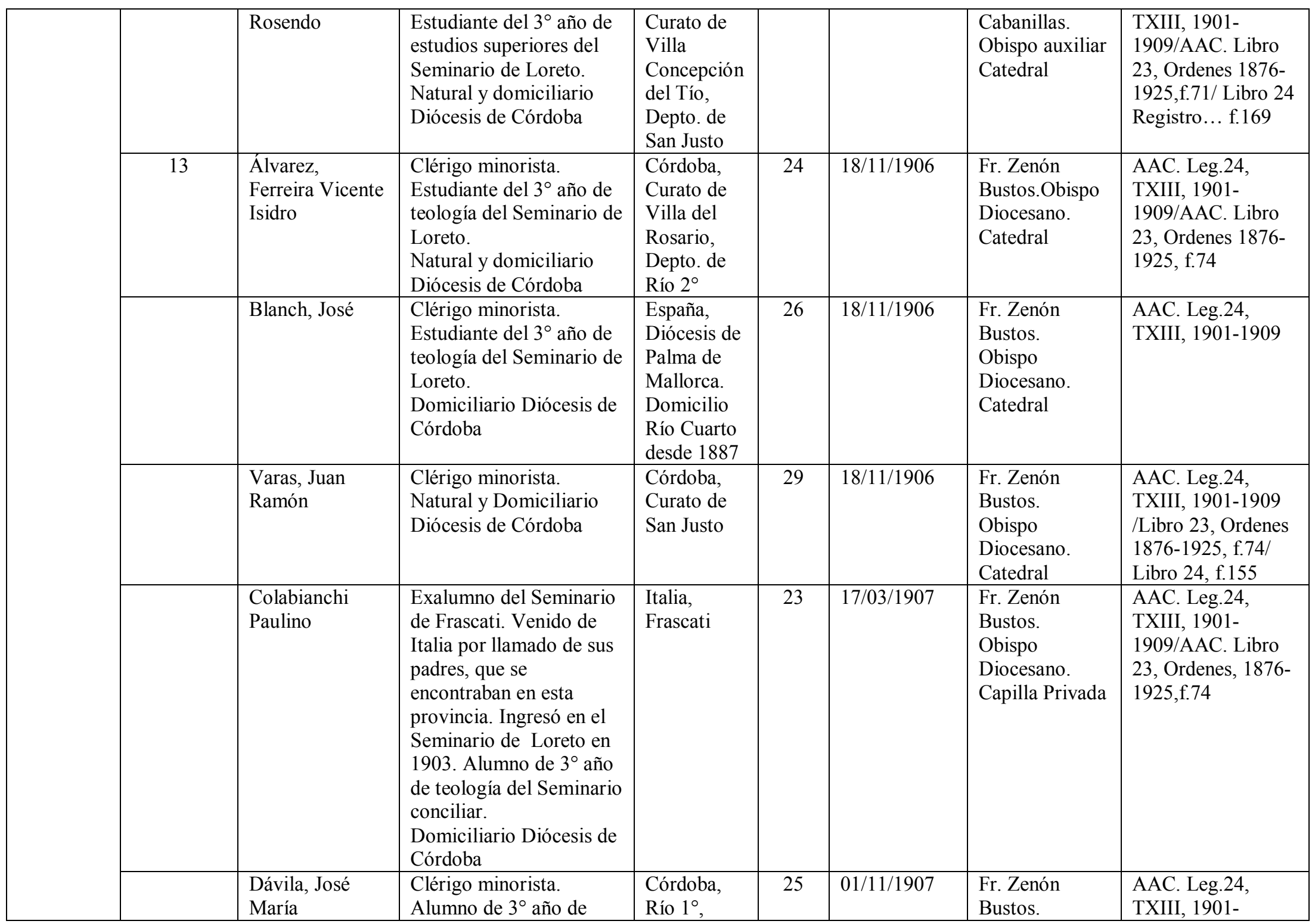




\begin{tabular}{|c|c|c|c|c|c|c|c|c|}
\hline & & & $\begin{array}{l}\text { teología del Seminario } \\
\text { conciliar. } \\
\text { Domiciliario Diócesis de } \\
\text { Córdoba }\end{array}$ & $\begin{array}{l}\text { Curato de } \\
\text { Santa Rosa }\end{array}$ & & & $\begin{array}{l}\text { Obispo } \\
\text { Diocesano }\end{array}$ & $\begin{array}{l}\text { 1909/Libro 23, } \\
\text { Ordenes, 1876- } \\
\text { 1925,f 79/Libro 24, } \\
\text { Registro... 1905- } \\
\text { 1909, f. } 159\end{array}$ \\
\hline & & Ferreira, Froilán & $\begin{array}{l}\text { Alumno del Pío } \\
\text { Latinoamericano. } \\
\text { Natural y Domiciliario } \\
\text { Diócesis de Córdoba }\end{array}$ & $\begin{array}{l}\text { Córdoba, } \\
\text { Curato de } \\
\text { Villa del } \\
\text { Rosario, } \\
\text { Depto. de } \\
\text { Río } 2^{\circ} \\
\end{array}$ & & $26 / 09 / 1907$ & Roma & $\begin{array}{l}\text { AAC. Libro 23, } \\
\text { Ordenes, 1876- } \\
\text { 1925,f.75 }\end{array}$ \\
\hline & & $\begin{array}{l}\text { Figueroa, } \\
\text { Genaro }\end{array}$ & $\begin{array}{l}\text { Clérigo minorista. } \\
\text { Estudiante del } 3^{\circ} \text { año de } \\
\text { teología del Seminario de } \\
\text { Loreto. } \\
\text { Natural y Domiciliario } \\
\text { Diócesis de Córdoba }\end{array}$ & $\begin{array}{l}\text { Córdoba, } \\
\text { San } \\
\text { Agustín, } \\
\text { Curato de } \\
\text { Calamuchi- } \\
\text { ta }\end{array}$ & 27 & $17 / 03 / 1907$ & $\begin{array}{l}\text { Fr. Zenón } \\
\text { Bustos. } \\
\text { Obispo } \\
\text { Diocesano }\end{array}$ & $\begin{array}{l}\text { AAC. Leg.24, } \\
\text { TXIII, 1901- } \\
\text { 1909/Libro 23, } \\
\text { Ordenes 1876- } \\
\text { 1925, f.79/ Libro } \\
24, \text { f.173 }\end{array}$ \\
\hline & & García, Moisés & $\begin{array}{l}\text { Clérigo minorista. } \\
\text { Natural y Domiciliario } \\
\text { Diócesis de Córdoba }\end{array}$ & $\begin{array}{l}\text { Córdoba, } \\
\text { ciudad }\end{array}$ & $\mathrm{n} / \mathrm{c}$ & $01 / 11 / 1907$ & $\begin{array}{l}\text { Fr. Zenón } \\
\text { Bustos. } \\
\text { Obispo } \\
\text { Diocesano }\end{array}$ & $\begin{array}{l}\text { AAC. Leg.24, } \\
\text { TXIII, 1901- } \\
\text { 1909/AAC. Libro } \\
\text { 23, Ordenes 1876- } \\
\text { 1925, f.79/ Libro } \\
\text { 24, f.161 }\end{array}$ \\
\hline & & $\begin{array}{l}\text { Magnoni, } \\
\text { Francisco }\end{array}$ & $\begin{array}{l}\text { Clérigo minorista. } \\
\text { Estudiante del } 3^{\circ} \text { año de } \\
\text { teología del Seminario de } \\
\text { Loreto. Ocupa una de las } \\
\text { becas destinadas a la } \\
\text { Prov. de La Rioja y es } \\
\text { ayudado en sus gastos } \\
\text { particulares por Abel } \\
\text { Bazán, Ministro de la } \\
\text { Suprema Corte Nacional. } \\
\text { Natural y Domiciliario } \\
\text { Diócesis de Córdoba }\end{array}$ & $\begin{array}{l}\text { La Rioja, } \\
\text { Diócesis de } \\
\text { Córdoba }\end{array}$ & 28 & $01 / 11 / 1907$ & $\begin{array}{l}\text { Fr. Zenón } \\
\text { Bustos. } \\
\text { Obispo } \\
\text { Diocesano }\end{array}$ & $\begin{array}{l}\text { AAC. Leg.24, } \\
\text { TXIII, 1901- } \\
\text { 1909/AAC. Libro } \\
\text { 23, Ordenes 1876- } \\
\text { 1925, f.79/Libro } \\
\text { 24, f.160 }\end{array}$ \\
\hline & & $\begin{array}{l}\text { Amuchástegui, } \\
\text { Ramón }\end{array}$ & $\begin{array}{l}\text { Clérigo minorista. } \\
\text { Estudiante del } 3^{\circ} \text { año de } \\
\text { teología del Seminario de }\end{array}$ & $\begin{array}{l}\text { Córdoba, } \\
\text { Curato de } \\
\text { Santa Rosa }\end{array}$ & 26 & $22 / 11 / 1908$ & & $\begin{array}{l}\text { AAC. Leg.24, } \\
\text { TXIII, 1901-1909/ } \\
\text { Libro 23, Libro }\end{array}$ \\
\hline
\end{tabular}




\begin{tabular}{|c|c|c|c|c|c|c|c|c|c|}
\hline & & & & $\begin{array}{l}\text { Loreto } \\
\text { Natural y Domiciliario } \\
\text { Diócesis de Córdoba }\end{array}$ & de Río $1^{\circ}$ & & & & $\begin{array}{l}\text { Ordenes } 1876- \\
1925, \text { f.76 }\end{array}$ \\
\hline & & & Borello, Carlos & $\begin{array}{l}\text { Clérigo minorista. } \\
\text { Estudiante del } 3^{\circ} \text { año de } \\
\text { teología del Seminario de } \\
\text { Loreto. } \\
\text { Domiciliario Diócesis de } \\
\text { Córdoba }\end{array}$ & $\begin{array}{l}\text { Italia, } \\
\text { Diócesis de } \\
\text { Cúneo }\end{array}$ & 22 & $22 / 11 / 1908$ & & $\begin{array}{l}\text { AAC. Leg.24, } \\
\text { TXIII, 1901-1909/ } \\
\text { Libro 23, Ordenes } \\
\text { 1876-1925, f.76 }\end{array}$ \\
\hline & & & $\begin{array}{l}\text { Ferreira, } \\
\text { Aquilino }\end{array}$ & $\begin{array}{l}\text { Clérigo minorista. } \\
\text { Estudiante de } 2^{\circ} \text { año de } \\
\text { teología del Seminario de } \\
\text { Loreto }\end{array}$ & $\begin{array}{l}\text { Córdoba, } \\
\text { Villa del } \\
\text { Rosario. } \\
\text { Curato de } \\
\text { Río 2}\end{array}$ & 23 & 14/11/1909 & $\begin{array}{l}\text { Fr. Zenón } \\
\text { Bustos. } \\
\text { Obispo } \\
\text { Diocesano. } \\
\text { Catedral }\end{array}$ & $\begin{array}{l}\text { AAC. Leg.24, } \\
\text { TXIII, 1901-1909/ } \\
\text { Libro 23, Ordenes } \\
\text { 1876-1926, f.77 }\end{array}$ \\
\hline & & & $\begin{array}{l}\text { Salgueiro, } \\
\text { Guillermo }\end{array}$ & $\begin{array}{l}\text { Domiciliario Diócesis de } \\
\text { Córdoba }\end{array}$ & Portugal & $\mathrm{n} / \mathrm{c}$ & $08 / 08 / 1909$ & $\begin{array}{l}\text { Cabanillas } \\
\text { Filemón }\end{array}$ & $\begin{array}{l}\text { AAC. Leg.24, } \\
\text { TXIII, 1901- } \\
\text { 1909/AAC. Libro } \\
\text { 23, Ordenes 1876- } \\
\text { 1925, f.77 }\end{array}$ \\
\hline & & & $\begin{array}{l}\text { Saravia, } \\
\text { Juan Benito } \\
\text { Damasceno del } \\
\text { Rosario }\end{array}$ & $\begin{array}{l}\text { Clérigo minorista } \\
\text { Natural y Domiciliario } \\
\text { Diócesis de Córdoba }\end{array}$ & $\begin{array}{l}\text { Córdoba, } \\
\text { Curato de } \\
\text { Chalacea. } \\
\text { Depto. de } \\
\text { Río } 1^{\circ}\end{array}$ & 26 & $14 / 11 / 1909$ & $\begin{array}{l}\text { Fr. Zenón } \\
\text { Bustos. } \\
\text { Obispo } \\
\text { Diocesano. } \\
\text { Catedral }\end{array}$ & $\begin{array}{l}\text { AAC. Leg.24, } \\
\text { TXIII 1901- } \\
\text { 1909/Libro 23, } \\
\text { Ordenes 1876- } \\
\text { 1925, f.77 }\end{array}$ \\
\hline & & & $\begin{array}{l}\text { Visca Caviglia, } \\
\text { Enrique }\end{array}$ & $\begin{array}{l}\text { Clérigo minorista de } \\
\text { edad, incardinado in } \\
\text { perpetumm en la } \\
\text { Diócesis de Córdoba }\end{array}$ & $\begin{array}{l}\text { Buenos } \\
\text { Aires/Italia }\end{array}$ & 25 & $14 / 11 / 1909$ & $\begin{array}{l}\text { Fr. Zenón } \\
\text { Bustos. } \\
\text { Obispo } \\
\text { Diocesano. } \\
\text { Catedral } \\
\end{array}$ & $\begin{array}{l}\text { AAC. Leg.24, } \\
\text { TXIII, 1901-1909/ } \\
\text { Libro 23, Ordenes } \\
\text { 1876-1925, f.77/ } \\
\text { Libro 24, f.161 }\end{array}$ \\
\hline & & & García, Moisés & & Córdoba & & $14 / 11 / 1909$ & $\begin{array}{l}\text { Fr. Zenón } \\
\text { Bustos. } \\
\text { Obispo } \\
\text { Diocesano. } \\
\text { Catedral }\end{array}$ & $\begin{array}{l}\text { AAC. Leg.24, } \\
\text { TXIII, 1901-1909/ } \\
\text { Libro de Órdenes } \\
\text { 1876-1925. Libro } \\
24, \text { f.161 }\end{array}$ \\
\hline 1910-1914 & 12 & 3 & $\begin{array}{l}\text { Moyano, } \\
\text { Benjamín }\end{array}$ & $\begin{array}{l}\text { Alumno del Pío } \\
\text { Latinoamericano. } \\
\text { Natural y Domiciliario } \\
\text { Diócesis de Córdoba }\end{array}$ & $\begin{array}{l}\text { Córdoba, } \\
\text { Curato de } \\
\text { Tulumba }\end{array}$ & 20 & $29 / 08 / 1910$ & $\begin{array}{l}\text { Roma } \\
\text { Dimisoriales } \\
\text { Ordenes } \\
\text { Mayores Pío }\end{array}$ & $\begin{array}{l}\text { AAC. Leg.24, } \\
\text { TXIII, 1901-1909/ } \\
\text { Libro 23, Ordenes } \\
\text { 1876-1925, f.73-79 }\end{array}$ \\
\hline
\end{tabular}




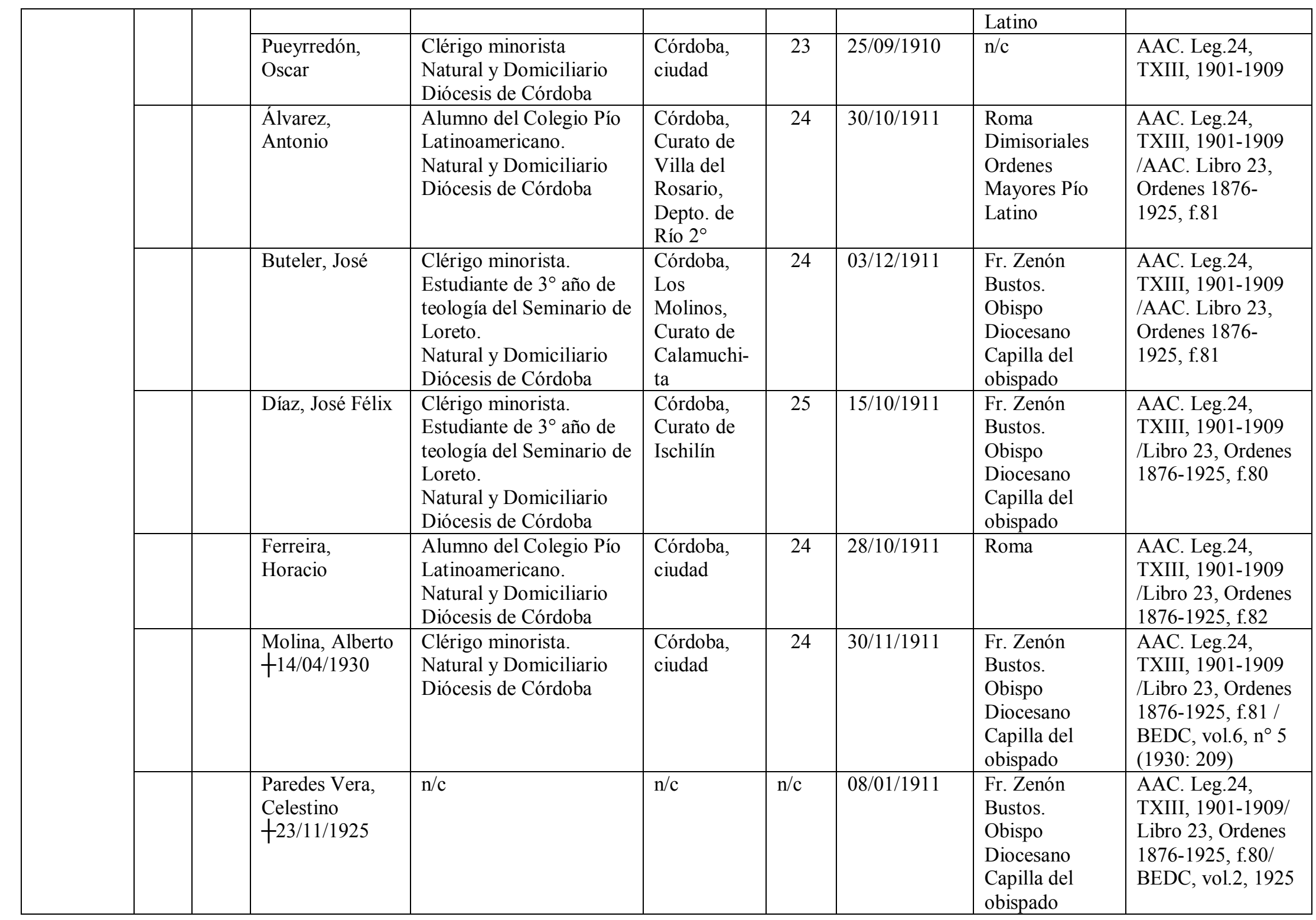




\begin{tabular}{|c|c|c|c|c|c|c|c|c|c|}
\hline & & & $\begin{array}{l}\text { Bertolotti, } \\
\text { Augusto }\end{array}$ & $\begin{array}{l}\text { Natural de Italia y } \\
\text { Domiciliado en Córdoba } \\
\text { desde los } 11 \text { años }\end{array}$ & $\begin{array}{l}\text { Italia, } \\
\text { Diócesis de } \\
\text { Castelleto, } \\
\text { Prov. de } \\
\text { Alejandría }\end{array}$ & 29 & $20 / 12 / 1912$ & $\begin{array}{l}\text { Fr. Zenón } \\
\text { Bustos. } \\
\text { Obispo } \\
\text { Diocesano } \\
\text { Capilla del } \\
\text { seminario }\end{array}$ & $\begin{array}{l}\text { AAC. Leg. } 24, \\
\text { TXIII, 1901-1909 } \\
\text { /Libro 23, Ordenes } \\
\text { 1876-1925, f.81 }\end{array}$ \\
\hline & & & $\begin{array}{l}\text { Centurión, } \\
\text { Gerardo } \\
+06 / 05 / 1924\end{array}$ & $\begin{array}{l}\text { Clérigo minorista. } \\
\text { Estudiante de } 3^{\circ} \text { año de } \\
\text { teología del Seminario de } \\
\text { Loreto. } \\
\text { Natural y Domiciliario } \\
\text { Diócesis de Córdoba }\end{array}$ & $\begin{array}{l}\text { Córdoba, } \\
\text { Curato de } \\
\text { Tulumba }\end{array}$ & 26 & $20 / 12 / 1912$ & $\begin{array}{l}\text { Fr. Zenón } \\
\text { Bustos. } \\
\text { Obispo } \\
\text { Diocesano } \\
\text { Capilla del } \\
\text { seminario } \\
\end{array}$ & $\begin{array}{l}\text { AAC. Leg.24, } \\
\text { TXIII, 1901-1909/ } \\
\text { Libro 23, Ordenes } \\
\text { 1876-1925, f.81/ } \\
\text { BEDC, vol.1, n }{ }^{\circ} \\
11,15 / 09 / 1924 \\
\end{array}$ \\
\hline & & & $\begin{array}{l}\text { Gómez Jaén, } \\
\text { Francisco }\end{array}$ & $\begin{array}{l}\text { Clérigo minorista. } \\
\text { Estudiante de } 3^{\circ} \text { año de } \\
\text { teología del Seminario de } \\
\text { Loreto. } \\
\text { Domiciliario Diócesis de } \\
\text { Córdoba }\end{array}$ & $\begin{array}{l}\text { España, } \\
\text { Prov. de } \\
\text { Salamanca } \\
\text { Diócesis de } \\
\text { Ávila }\end{array}$ & 24 & $\begin{array}{l}\text { 20/12/1912 } \\
\text { Se acepta la } \\
\text { excardinacion } \\
\text { y se lo } \\
\text { incardina en } \\
\text { la diócesis de } \\
\text { Córdoba }\end{array}$ & $\begin{array}{l}\text { Fr. Zenón } \\
\text { Bustos. } \\
\text { Obispo } \\
\text { Diocesano } \\
\text { Capilla del } \\
\text { seminario }\end{array}$ & $\begin{array}{l}\text { AAC. Leg.24, } \\
\text { TXIII, 1901-1909 } \\
\text { /Libro 23, Ordenes } \\
\text { 1876-1925, f.82 }\end{array}$ \\
\hline & & & $\begin{array}{l}\text { Martínez, } \\
\text { Victorino }\end{array}$ & $\begin{array}{l}\text { Clérigo minorista. } \\
\text { Estudiante de } 3^{\circ} \text { año de } \\
\text { teología del Seminario de } \\
\text { Loreto. } \\
\text { Natural y Domiciliario } \\
\text { Diócesis de Córdoba }\end{array}$ & $\begin{array}{l}\text { Córdoba, } \\
\text { Curato de } \\
\text { Tulumba }\end{array}$ & 24 & $20 / 12 / 1912$ & $\begin{array}{l}\text { Fr. Zenón } \\
\text { Bustos. } \\
\text { Obispo } \\
\text { Diocesano } \\
\text { Capilla del } \\
\text { seminario } \\
\end{array}$ & $\begin{array}{l}\text { AAC. Leg.24, } \\
\text { TXIII, 1901-1909 } \\
\text { /Libro 23, Ordenes } \\
\text { 1876-1925,f.82 }\end{array}$ \\
\hline & & & $\begin{array}{l}\text { Quiroga, } \\
\text { Antonio } \\
\text { Doroteo }\end{array}$ & $\begin{array}{l}\text { Clérigo minorista. } \\
\text { Natural y Domiciliario } \\
\text { Diócesis de Córdoba }\end{array}$ & $\begin{array}{l}\text { Córdoba, } \\
\text { Curato de } \\
\text { Totoral }\end{array}$ & 27 & $20 / 12 / 1912$ & $\begin{array}{l}\text { Fr. Zenón } \\
\text { Bustos. } \\
\text { Obispo } \\
\text { Diocesano } \\
\text { Capilla del } \\
\text { seminario } \\
\end{array}$ & $\begin{array}{l}\text { AAC. Leg.24, } \\
\text { TXIII, 1901-1909/ } \\
\text { Libro 23, Ordenes } \\
1876-1925, f .82\end{array}$ \\
\hline & & & $\begin{array}{l}\text { Rodríguez, } \\
\text { Audino }\end{array}$ & $\begin{array}{l}\text { Alumno del Colegio Pío } \\
\text { Latinoamericano. } \\
\text { Natural y Domiciliario } \\
\text { Diócesis de Córdoba }\end{array}$ & Córdoba & $\mathrm{n} / \mathrm{c}$ & $30 / 10 / 1912$ & Roma & $\begin{array}{l}\text { AAC. Libro 23, } \\
\text { Ordenes, 1876- } \\
1925, f .82\end{array}$ \\
\hline & & & $\begin{array}{l}\text { Bustamante, } \\
\text { Arturo }\end{array}$ & $\begin{array}{l}\text { Clérigo minorista. } \\
\text { Estudiante de } 4^{\circ} \text { año de } \\
\text { teología }\end{array}$ & $\begin{array}{l}\text { Córdoba, } \\
\text { Curato de } \\
\text { Tulumba }\end{array}$ & 26 & $20 / 12 / 1912$ & $\begin{array}{l}\text { Fr. Zenón } \\
\text { Bustos. } \\
\text { Obispo }\end{array}$ & $\begin{array}{l}\text { AAC. Leg.24, } \\
\text { TXIII, 1901-1909 }\end{array}$ \\
\hline
\end{tabular}




\begin{tabular}{|c|c|c|c|c|c|c|c|c|c|}
\hline & & & & & & & & $\begin{array}{l}\text { Diocesano } \\
\text { Capilla del } \\
\text { seminario }\end{array}$ & \\
\hline & & & $\begin{array}{l}\text { Oliverio de } \\
\text { Vito, José María }\end{array}$ & $\begin{array}{l}\text { Clérigo minorista. } \\
\text { Estudiante de } 3^{\circ} \text { año de } \\
\text { teología del Seminario de } \\
\text { Loreto. } \\
\text { Domiciliario Diócesis de } \\
\text { Córdoba (incardinado en } \\
\text { la Diócesis de Córdoba. } \\
\text { Decreto del 02/10/1912) }\end{array}$ & $\begin{array}{l}\text { Italia, } \\
\text { Diócesis de } \\
\text { Calabria }\end{array}$ & 28 & $28 / 03 / 1914$ & $\begin{array}{l}\text { Fr. Zenón } \\
\text { Bustos. } \\
\text { Obispo } \\
\text { Diocesano }\end{array}$ & $\begin{array}{l}\text { AAC. Leg.24, } \\
\text { TXIII bis / Libro } \\
\text { 23, Ordenes, 1876- } \\
\text { 1925, f.82 }\end{array}$ \\
\hline \multirow[t]{6}{*}{$\begin{array}{c}\text { 1915-1919 } \\
14\end{array}$} & 10 & 2 & Cabral, José Pío & $\begin{array}{l}\text { Diácono. Natural y } \\
\text { Domiciliario Diócesis de } \\
\text { Córdoba }\end{array}$ & $\begin{array}{l}\text { Córdoba, } \\
\text { Curato de } \\
\text { Río Cuarto }\end{array}$ & 25 & $5 / 12 / 19015$ & & $\begin{array}{l}\text { AAC. Leg.24, } \\
\text { TXIII, 1901-1909 }\end{array}$ \\
\hline & & & $\begin{array}{l}\text { Vera Vallejo, } \\
\text { Juan Carlos }\end{array}$ & $\begin{array}{l}\text { Alumno del Colegio Pío } \\
\text { Latinoamericano. } \\
\text { Natural y Domiciliario } \\
\text { Diócesis de Córdoba }\end{array}$ & $\begin{array}{l}\text { La Rioja, } \\
\text { diócesis de } \\
\text { Córdoba }\end{array}$ & 25 & 1915 & Roma & $\begin{array}{l}\text { AAC. Leg.24, } \\
\text { TXIII, 1901-1909 }\end{array}$ \\
\hline & & & Taborda, Juan & $\begin{array}{l}\text { Alumno del Colegio Pío } \\
\text { Latinoamericano. } \\
\text { Natural y Domiciliario } \\
\text { Diócesis de Córdoba }\end{array}$ & $\begin{array}{l}\text { Córdoba, } \\
\text { Curato de } \\
\text { Villa del } \\
\text { Rosario, } \\
\text { Depto. de } \\
\text { Río 2 } \\
\end{array}$ & 24 & $28 / 10 / 1916$ & $\begin{array}{l}\text { Roma } \\
\text { Dimisoriales } \\
\text { Ordenes } \\
\text { Mayores Pio } \\
\text { Latino }\end{array}$ & $\begin{array}{l}\text { AAC. Leg.24, } \\
\text { TXIII, 1901-1909 } \\
\text { /Libro 23, Ordenes } \\
\text { 1876-1925, f.79 }\end{array}$ \\
\hline & & & Campos, Carlos & $\begin{array}{l}\text { Clérigo minorista. } \\
\text { Estudiante de } 3^{\circ} \text { año de } \\
\text { teología del Seminario de } \\
\text { Loreto. } \\
\text { Natural y Domiciliario } \\
\text { Diócesis de Córdoba }\end{array}$ & $\begin{array}{l}\text { Córdoba, } \\
\text { Depto. de } \\
\text { Punilla }\end{array}$ & 23 & $03 / 12 / 1916$ & $\begin{array}{l}\text { Dávila } \\
\text { Inocencio. } \\
\text { Obispo } \\
\text { Auxiliar. } \\
\text { Seminario } \\
\text { diocesano }\end{array}$ & $\begin{array}{l}\text { AAC. Leg.24, } \\
\text { TXIII bis / Libro } \\
\text { 23, Ordenes, 1876- } \\
\text { 1925, f.84 }\end{array}$ \\
\hline & & & Paulí, Luis & $\begin{array}{l}\text { Clérigo minorista. } \\
\text { Estudiante de } 3^{\circ} \text { año de } \\
\text { teología del Seminario de } \\
\text { Loreto. } \\
\text { Natural y Domiciliario } \\
\text { Diócesis de Córdoba }\end{array}$ & $\begin{array}{l}\text { Córdoba, } \\
\text { Curato de } \\
\text { Tulumba }\end{array}$ & 24 & $03 / 12 / 1916$ & $\begin{array}{l}\text { Dávila } \\
\text { Inocencio. } \\
\text { Obispo } \\
\text { Auxiliar. } \\
\text { Seminario } \\
\text { diocesano }\end{array}$ & $\begin{array}{l}\text { AAC. Leg.24, } \\
\text { TXIII bis / Libro } \\
\text { 23, Ordenes, 1876- } \\
\text { 1925, f.84 }\end{array}$ \\
\hline & & & Porcel de & Natural y Domiciliario & Córdoba, & 23 & $24 / 09 / 1916$ & $\mathrm{n} / \mathrm{c}$ & AAC. Leg.24, \\
\hline
\end{tabular}




\begin{tabular}{|c|c|c|c|c|c|c|c|c|c|}
\hline & & & Peralta, Teótimo & Diócesis de Córdoba & $\begin{array}{l}\text { Curato de } \\
\text { Villa del } \\
\text { Rosario, } \\
\text { Depto. de } \\
\text { Río 2 }\end{array}$ & & & & TXIII, 1901-1910 \\
\hline & & & $\begin{array}{l}\text { Bridarolli, } \\
\text { Silvio }\end{array}$ & $\begin{array}{l}\text { Clérigo minorista. } \\
\text { Domiciliario Diócesis de } \\
\text { Córdoba }\end{array}$ & Italia & & $30 / 09 / 1917$ & $\begin{array}{l}\text { Dávila } \\
\text { Inocencio. } \\
\text { Obispo } \\
\text { Auxiliar. } \\
\text { Seminario } \\
\text { diocesano }\end{array}$ & $\begin{array}{l}\text { AAC. Libro 23, } \\
\text { Ordenes, 1876- } \\
1925, \text { f.84 }\end{array}$ \\
\hline & & & $\begin{array}{l}\text { Farías Leal, } \\
\text { Ángel }\end{array}$ & $\begin{array}{l}\text { Clérigo minorista. } \\
\text { Domiciliario Diócesis de } \\
\text { Córdoba }\end{array}$ & $\begin{array}{l}\text { Córdoba, } \\
\text { Curato de } \\
\text { Cruz del } \\
\text { Eje }\end{array}$ & 24 & $02 / 12 / 1917$ & $\mathrm{n} / \mathrm{c}$ & $\begin{array}{l}\text { AAC. Leg. } 24 \text {, } \\
\text { TXIIIbis }\end{array}$ \\
\hline & & & Brizuela, Arturo & Clérigo minorista. & La Rioja & & $07 / 12 / 1919$ & $\begin{array}{l}\text { José A. Luque, } \\
\text { Obispo } \\
\text { Auxiliar. } \\
\text { Capilla } \\
\text { seminario }\end{array}$ & $\begin{array}{l}\text { AAC. Libro 23, } \\
\text { Ordenes, 1876- } \\
1925, \text { f.88 }\end{array}$ \\
\hline & & & Fuentes, Juan & & $\mathrm{n} / \mathrm{c}$ & & $07 / 12 / 1919$ & $\begin{array}{l}\text { José A. Luque, } \\
\text { Obispo } \\
\text { Auxiliar. } \\
\text { Capilla } \\
\text { seminario }\end{array}$ & $\begin{array}{l}\text { AAC. Libro 23, } \\
\text { Ordenes, 1876- } \\
1925, \text { f.88 }\end{array}$ \\
\hline & & & Verde, Lino & $\begin{array}{l}\text { Clérigo minorista. } \\
\text { Natural y Domiciliario } \\
\text { Diócesis de Córdoba }\end{array}$ & Córdoba & & $07 / 12 / 1919$ & $\begin{array}{l}\text { José A. Luque, } \\
\text { Obispo } \\
\text { Auxiliar. } \\
\text { Capilla } \\
\text { seminario }\end{array}$ & $\begin{array}{l}\text { AAC. Libro 23, } \\
\text { Ordenes, 1876- } \\
1925, \text { f.88 }\end{array}$ \\
\hline & & & $\begin{array}{l}\text { Vergongeanne, } \\
\text { Gastón }\end{array}$ & $\begin{array}{l}\text { Clérigo minorista. } \\
\text { Domiciliario Diócesis de } \\
\text { Córdoba }\end{array}$ & Francés & & $26 / 10 / 1919$ & $\begin{array}{l}\text { José A. Luque, } \\
\text { Obispo } \\
\text { Auxiliar. Bajo } \\
\text { Galán }\end{array}$ & $\begin{array}{l}\text { AAC. Libro 23, } \\
\text { Ordenes, 1876- } \\
1925, \text { f.88 }\end{array}$ \\
\hline $1920-1925$ & 20 & 2 & $\begin{array}{l}\text { Campos, } \\
\text { Ignacio }\end{array}$ & Clérigo minorista. & $\begin{array}{l}\text { Córdoba, } \\
\text { Depto. de } \\
\text { Punilla }\end{array}$ & & $05 / 12 / 1920$ & $\begin{array}{l}\text { Dávila } \\
\text { Inocencio. } \\
\text { Obispo } \\
\text { Auxiliar }\end{array}$ & $\begin{array}{l}\text { AAC. Libro 23, } \\
\text { Ordenes, 1876- } \\
1925, \text { f.89 }\end{array}$ \\
\hline
\end{tabular}




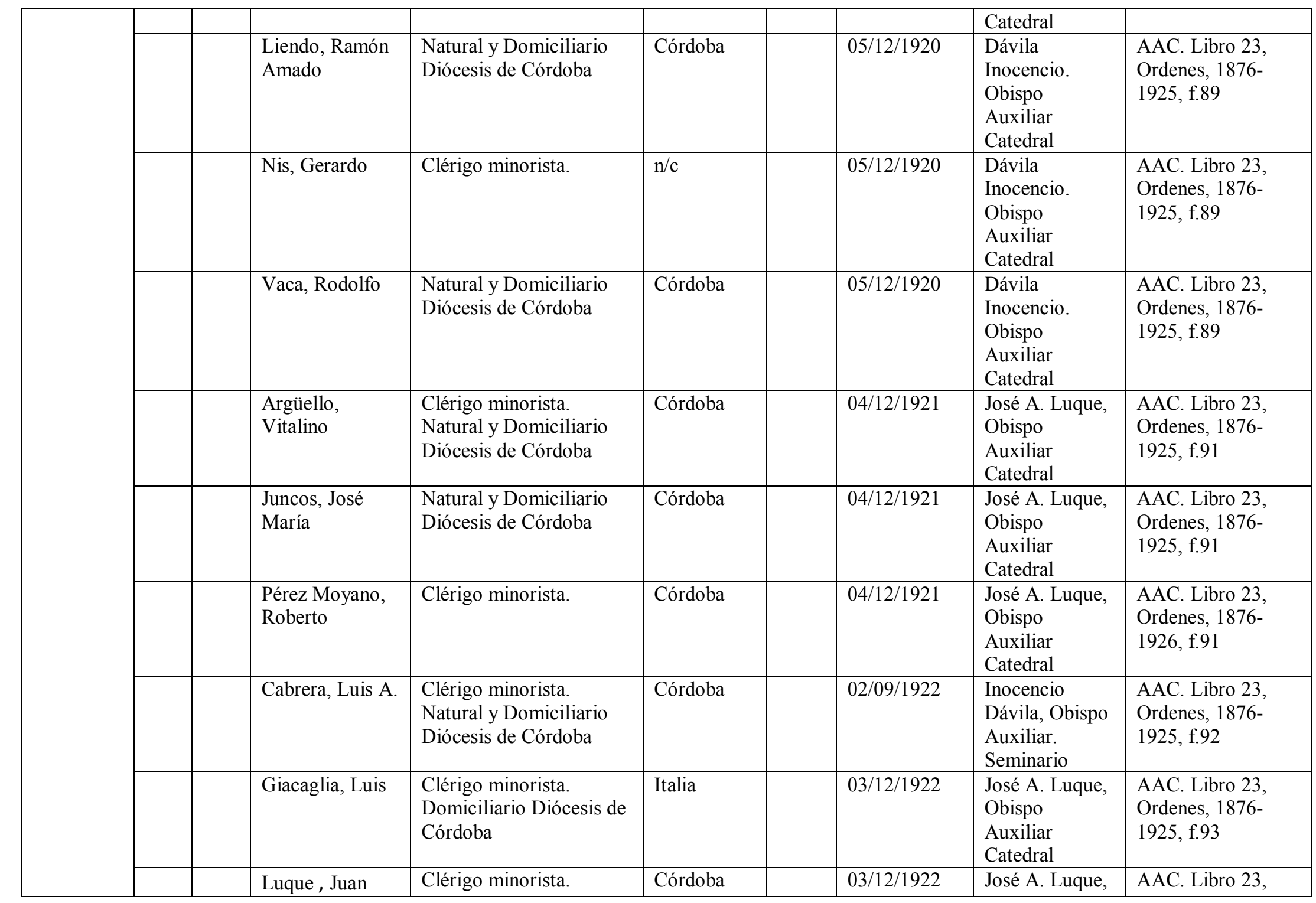




\begin{tabular}{|c|c|c|c|c|c|c|c|c|}
\hline & & & Segundo & $\begin{array}{l}\text { Natural y Domiciliario } \\
\text { Diócesis de Córdoba }\end{array}$ & & & $\begin{array}{l}\text { Obispo } \\
\text { Auxiliar } \\
\text { Catedral }\end{array}$ & $\begin{array}{l}\text { Ordenes, 1876- } \\
1925, \text { f.93 }\end{array}$ \\
\hline & & & Uthera, José & $\begin{array}{l}\text { Clérigo minorista. } \\
\text { Natural y Domiciliario } \\
\text { Diócesis de Córdoba }\end{array}$ & $\begin{array}{l}\text { Córdoba, } \\
\text { Río } 1^{\circ}\end{array}$ & $03 / 12 / 1922$ & $\begin{array}{l}\text { José A. Luque, } \\
\text { Obispo } \\
\text { Auxiliar } \\
\text { Catedral }\end{array}$ & $\begin{array}{l}\text { AAC. Libro 23, } \\
\text { Ordenes, 1876- } \\
1925, \text { f.93 }\end{array}$ \\
\hline & & & $\begin{array}{l}\text { Argañarás, José } \\
\text { Remigio }\end{array}$ & $\begin{array}{l}\text { Clérigo minorista. } \\
\text { Domiciliario Diócesis de } \\
\text { Córdoba }\end{array}$ & $\begin{array}{l}\text { Obispado } \\
\text { de Córdoba }\end{array}$ & $02 / 12 / 1923$ & $\begin{array}{l}\text { Inocencio } \\
\text { Dávila, Obispo } \\
\text { Auxiliar } \\
\text { Catedral }\end{array}$ & $\begin{array}{l}\text { AAC. Libro 23, } \\
\text { Ordenes, 1876- } \\
1925, \text { f.96 }\end{array}$ \\
\hline & & & Pappa, Calógero & $\begin{array}{l}\text { Clérigo minorista. } \\
\text { Domiciliario Diócesis de } \\
\text { Córdoba }\end{array}$ & Italia & $02 / 12 / 1923$ & $\begin{array}{l}\text { José A. Luque, } \\
\text { Obispo } \\
\text { Auxiliar } \\
\text { Catedral }\end{array}$ & $\begin{array}{l}\text { AAC. Libro 23, } \\
\text { Ordenes, 1876- } \\
1925, \text { f.96 }\end{array}$ \\
\hline & & & Ferrari, Alfredo & $\begin{array}{l}\text { Clérigo minorista. } \\
\text { Domiciliario Diócesis de } \\
\text { Córdoba }\end{array}$ & Córdoba & $07 / 12 / 1924$ & $\begin{array}{l}\text { Inocencio } \\
\text { Dávila y } \\
\text { Matos. Obispo } \\
\text { Auxiliar. } \\
\text { Catedral } \\
\end{array}$ & $\begin{array}{l}\text { AAC. Libro 23, } \\
\text { Ordenes, 1876- } \\
1925, \text { f.98 }\end{array}$ \\
\hline & & & $\begin{array}{l}\text { Ferreira, } \\
\text { Virgilio C. }\end{array}$ & $\begin{array}{l}\text { Clérigo minorista. } \\
\text { Natural y Domiciliario } \\
\text { Diócesis de Córdoba }\end{array}$ & Córdoba & $09 / 12 / 1924$ & $\begin{array}{l}\text { Inocencio } \\
\text { Dávila y } \\
\text { Matos. Obispo } \\
\text { Auxiliar. } \\
\text { Catedral } \\
\end{array}$ & $\begin{array}{l}\text { AAC. Libro 23, } \\
\text { Ordenes, 1876- } \\
1925, \text { f.98 }\end{array}$ \\
\hline & & & $\begin{array}{l}\text { Tejerina, } \\
\text { Manuel A. }\end{array}$ & Clérigo minorista. & Córdoba & $08 / 12 / 1924$ & $\begin{array}{l}\text { Inocencio } \\
\text { Dávila y } \\
\text { Matos. Obispo } \\
\text { Auxiliar. } \\
\text { Catedral }\end{array}$ & $\begin{array}{l}\text { AAC. Libro 23, } \\
\text { Ordenes, 1876- } \\
1925, \text { f.98 }\end{array}$ \\
\hline & & & $\begin{array}{l}\text { Bergero, } \\
\text { Sebastián }\end{array}$ & & $\mathrm{n} / \mathrm{c}$ & $29 / 11 / 1925$ & $\begin{array}{l}\text { José A. Luque, } \\
\text { Obispo } \\
\text { Auxiliar. } \\
\text { Capilla } \\
\text { seminario } \\
\end{array}$ & $\begin{array}{l}\text { AAC. Libro 23, } \\
\text { Ordenes, 1876- } \\
\text { 1925, f.102/BEOC, } \\
\text { vol. } 3, \mathrm{n}^{\circ} 1 \text { (1926: } \\
27)\end{array}$ \\
\hline & & & $\begin{array}{l}\text { Fernández, } \\
\text { Serafín }\end{array}$ & & Córdoba, & $29 / 11 / 1925$ & $\begin{array}{l}\text { José A. Luque, } \\
\text { Obispo }\end{array}$ & $\begin{array}{l}\text { AAC. Libro 23, } \\
\text { Ordenes, 1876- }\end{array}$ \\
\hline
\end{tabular}




\begin{tabular}{|c|c|c|c|c|c|c|c|c|}
\hline & & & & & & & $\begin{array}{l}\text { Auxiliar. } \\
\text { Capilla } \\
\text { seminario }\end{array}$ & $\begin{array}{l}\text { 1925, f. 02/BEOC, } \\
\text { vol. } 3, \mathrm{n}^{\circ} 1 \text { (1926: } \\
27)\end{array}$ \\
\hline & & & $\begin{array}{l}\text { Martínez } \\
\text { Echenique, Luis }\end{array}$ & $\begin{array}{l}\text { Clérigo minorista. } \\
\text { Natural y Domiciliario } \\
\text { Diócesis de Córdoba }\end{array}$ & Córdoba & $29 / 11 / 1925$ & $\begin{array}{l}\text { José A. Luque, } \\
\text { Obispo } \\
\text { Auxiliar. } \\
\text { Vicario } \\
\text { Capitular } \\
\text { Capilla } \\
\text { seminario }\end{array}$ & $\begin{array}{l}\text { AAC. Libro 23, } \\
\text { Ordenes, 1876- } \\
\text { 1925, f.103/BEOC, } \\
\text { vol. } 3, n^{\circ} 1 \text { (1926: } \\
27)\end{array}$ \\
\hline & & & Moreno, Rafael & $\begin{array}{l}\text { Clérigo minorista. } \\
\text { Natural y Domiciliario } \\
\text { Diócesis de Córdoba }\end{array}$ & $\mathrm{n} / \mathrm{c}$ & $29 / 11 / 1925$ & $\begin{array}{l}\text { José A. Luque, } \\
\text { Obispo } \\
\text { Auxiliar. } \\
\text { Vicario } \\
\text { Capitular } \\
\text { Capilla } \\
\text { seminario }\end{array}$ & $\begin{array}{l}\text { AAC. Libro 23, } \\
\text { Ordenes, 1876- } \\
\text { 1925, f.103/BEOC, } \\
\text { vol. } 3, n^{\circ} 1 \text { (1926: } \\
27)\end{array}$ \\
\hline & & & Gatica, Julio A. & $\begin{array}{l}\text { Clérigo minorista. } \\
\text { Domiciliario Diócesis de } \\
\text { Córdoba }\end{array}$ & La Plata & $29 / 11 / 1925$ & $\begin{array}{l}\text { Obispo de la } \\
\text { Plata }\end{array}$ & $\begin{array}{l}\text { BEOC, vol. } 3, n^{\circ} 1 \\
(1926: 27)\end{array}$ \\
\hline & 115 & 30 & & & & & & \\
\hline TOTAL & & & & & & & & \\
\hline
\end{tabular}




\begin{tabular}{|c|c|c|c|c|c|}
\hline \multicolumn{6}{|c|}{$\begin{array}{c}\text { Tabla } 13 \\
\text { Clero regular secularizado en la diócesis de Córdoba, 1875-1925 }\end{array}$} \\
\hline $\begin{array}{c}\text { Apellido, } \\
\text { Nombre } \\
\end{array}$ & $\begin{array}{c}\text { Congregación } \\
\text { origen }\end{array}$ & Observaciones & Ocupación & Fecha & Fuentes \\
\hline Abregu, Gregorio & $\begin{array}{l}\text { Franciscana de } \\
\text { Asunción del } \\
\text { Paraguay y } \\
\text { conventual de } \\
\text { Santa Fe }\end{array}$ & $\begin{array}{l}\text { Secularización concedida en } 1857 \text { por } \\
\text { Mons. Marini. } \\
\text { Incardinado en Córdoba 29/04/1857 }\end{array}$ & & & $\begin{array}{l}\text { AAC. Nombramientos de curas, 1777- } \\
\text { 1904, s/f. Exp. de secularización }\end{array}$ \\
\hline $\begin{array}{l}\text { Pérez } \\
\text { Honesterosa, } \\
\text { Roque Gregorio }\end{array}$ & $\begin{array}{l}\text { Orden de los } \\
\text { Predicadores }\end{array}$ & $\begin{array}{l}\text { Prescripto de secularización perpetua } \\
\text { concedido por el internuncio en Brasil } \\
\text { delegado apostólico de su santidad en la } \\
\text { Repíblica del Plata, Marino Marini } \\
31 / 07 / 1857 \text {. } \\
\text { Eduardo Ramírez de Arellano le } \\
\text { concede la incardinación como } \\
\text { domiciliario, } 05 / 08 / 1858\end{array}$ & & & AAC. Leg.24, TVII, 1845-1865 \\
\hline Frías, Hipólito & $\begin{array}{l}\text { Mercedaria } \\
\text { secularizado }\end{array}$ & $\begin{array}{l}\text { Se retiró suspenso de la diócesis de } \\
\text { Córdoba en septiembre de } 1876\end{array}$ & & & AAC. Notas, 1876-1879, f.21 \\
\hline $\begin{array}{l}\text { Barreda, José } \\
\text { Mercedes }\end{array}$ & $\begin{array}{l}\text { Mercedaria. } \\
\text { Profesó en } \\
\text { Mendoza cuando } \\
\text { no estaba } \\
\text { entablada la vida } \\
\text { en común }\end{array}$ & $\begin{array}{l}\text { Secularización concedida en } 1873 \\
\text { Solicita incardinación pero no se le } \\
\text { concede. } \\
\text { Extra diocesano }\end{array}$ & $\begin{array}{l}\text { Sacerdote de } \\
\text { ministerio libre }\end{array}$ & $16 / 4 / 1896$ & $\begin{array}{l}\text { AAC. Nombramientos de curas, 1777- } \\
\text { 1904, s/f. Exp. de secularización }\end{array}$ \\
\hline López, Andrés A. & $\begin{array}{l}\text { Religioso } \\
\text { franciscano } \\
\text { exclaustrado }\end{array}$ & $\begin{array}{l}\text { Solicita licencias para permanecer fuera } \\
\text { del claustro. El Obispo Álvarez avala el } \\
\text { pedido y envía carta al delegado } \\
\text { apostólico } 28 / 08 / 1876\end{array}$ & & & AAC. Copiador de Notas, 1876, f.18 \\
\hline Baigorri, Juan & $\begin{array}{l}\text { Franciscana } \\
\text { de la diócesis de } \\
\text { Córdoba }\end{array}$ & $\begin{array}{l}\text { Secularización concedida en } 1884 \text { por la } \\
\text { Sagrada Congregación para la disciplina } \\
\text { de los regulares. } \\
\text { Incardinado el } 29 / 10 / 1884\end{array}$ & & & $\begin{array}{l}\text { AAC. Nombramiento de curas, 177- } \\
\text { 1904, s/f. Exp. de secularización }\end{array}$ \\
\hline Portilla, Eleuterio & $\mathrm{n} / \mathrm{c}$ & $\begin{array}{l}\text { Pbro. secularizado residente en la } \\
\text { Provincia de La Rioja }\end{array}$ & $\begin{array}{l}\text { Se lo suspende para } \\
\text { ejercer el ministerio }\end{array}$ & $14 / 02 / 1859$ & AAC. Libro de Notas, $1859-1873$, f.32 \\
\hline Luque, José & Ex Dominico & Incardinado a la diócesis & Se lo nombra & $04 / 08 / 1860$ & AAC. Libro de Notas, 1859-1873, f.61 \\
\hline
\end{tabular}




\begin{tabular}{|c|c|c|c|c|c|}
\hline Tomás & & & $\begin{array}{l}\text { prebendado de } \\
\text { Primera ración }\end{array}$ & & \\
\hline Anselmi Isidro & Ex franciscano & Extra-diocesano italiano & & & \\
\hline Gallo, Tomás & Ex franciscano & Extra-diocesano & & & \\
\hline Lucero, Samuel & $\begin{array}{l}\text { Mercedaria } \\
\text { Sacerdote } \\
\text { conventual de } \\
\text { Córdoba. } \\
\text { Ex Mercedario }\end{array}$ & $\begin{array}{l}\text { Secularización concedida en } 1873 \text {. } \\
\text { Extra-diocesano } \\
\text { Pide ser incorporado al clero secular de } \\
\text { la diócesis de Córdoba. } \\
\text { No ha lugar el pedido. Se recomienda } \\
\text { que siendo natural de Mendoza, teniendo } \\
\text { allí a sus padres por cuyas necesidades } \\
\text { ha obtenido el indulto de secularización } \\
\text { más propio es que se incorpore al escaso } \\
\text { clero de su país natal que en Córdoba }\end{array}$ & $\begin{array}{l}\text { Sacerdote } \\
\text { ministerio libre }\end{array}$ & & $\begin{array}{l}\text { AAC. Nombramientos de curas 1777- } \\
\text { 1904, s/f. Leg.24, TIX, 1873-1880, } \\
\text { Bodas, p.12 }\end{array}$ \\
\hline Álvarez, Ramón & Jesuita & & $\begin{array}{l}\text { Sacerdote de } \\
\text { ministerio libre }\end{array}$ & & \\
\hline Arroyo, Luis & Ex-dominico & & $\begin{array}{l}\text { Sacerdote de } \\
\text { ministerio libre }\end{array}$ & $\begin{array}{l}01 / 10 / 1890 \\
\text { Ordenac. } \\
\text { Presb. } \\
\text { Colegio } \\
\text { Educandas }\end{array}$ & \\
\hline Borras, N. & Ex-Dominico & & Cura de Chilecito & $14 / 08 / 1885$ & \\
\hline Fierro, Eleodoro & Ex-Mercedario & & Cura y Vicario & $30 / 11 / 1866$ & AAC. Leg.24, TVII, 1845-1865 \\
\hline Gherra, Domingo & Ex-Jesuita & & $\begin{array}{l}\text { Cura y Vicario Sta. } \\
\text { Rosa }\end{array}$ & 1901 & \\
\hline $\begin{array}{l}\text { Isaguirre, } \\
\text { Manuel }\end{array}$ & Ex-Dominico & $\begin{array}{l}\text { Secularización Perpetua concedida en } \\
1856 \text { por Mons. Marini }\end{array}$ & $\begin{array}{l}\text { Sacerdote de } \\
\text { ministerio libre }\end{array}$ & 1894 & $\begin{array}{l}\text { AAC. Nombramiento de curas, 1777- } \\
1904, \mathrm{~s} / \mathrm{f}\end{array}$ \\
\hline Vaggio, Luis & $\begin{array}{l}\text { Sacerdote } \\
\text { exclaustrado de la } \\
\text { Orden de Santo } \\
\text { Domingo } \\
\text { Extranjero natural } \\
\text { de Aderno }\end{array}$ & $\begin{array}{l}\text { Prescripto de secularización perpetua } \\
\text { Incardinado en Córdoba posee suficiente } \\
\text { patrimonio }\end{array}$ & & & $\begin{array}{l}\text { AAC. Nombramiento de curas, 1777- } \\
1904\end{array}$ \\
\hline
\end{tabular}




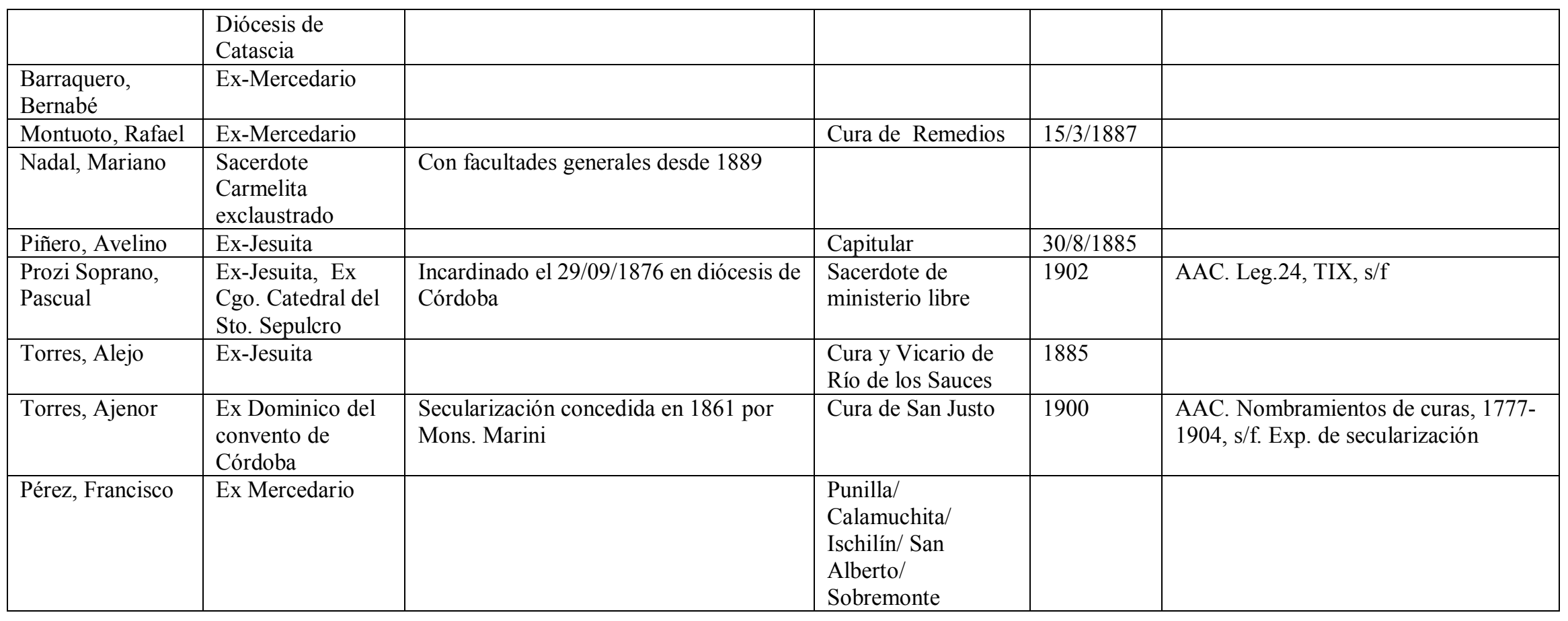




\begin{tabular}{|c|c|c|c|c|c|c|c|c|}
\hline \multicolumn{9}{|c|}{$\begin{array}{c}\text { Tabla14 } \\
\text { Ordenaciones presbiterales del clero regular en Córdoba 1875-1925 }\end{array}$} \\
\hline $\begin{array}{c}\text { Por } \\
\text { Quinquenio }\end{array}$ & Apellido & Nombre & $\begin{array}{c}\text { Orden/ } \\
\text { congregación }\end{array}$ & Observaciones & $\begin{array}{c}\text { Fecha } \\
\text { presbiterado }\end{array}$ & Ministro y lugar & Fuentes & Folio \\
\hline \multirow[t]{10}{*}{$\begin{array}{l}\text { 1876-1880: } \\
\text { cantidad: } 10\end{array}$} & Caú, & Fr. Demetrio & Mercedario & & $21 / 11 / 1876$ & $\begin{array}{l}\text { Alvarez, Manuel E. } \\
\text { Obispo Monasterio } \\
\text { Sta. Catalina }\end{array}$ & $\begin{array}{l}\text { AAC. Libro } \\
23, \text { Ordenes, } \\
1876-1925\end{array}$ & 2 \\
\hline & Gómez & Fr. Clemente & Franciscano & & $22 / 12 / 1877$ & $\begin{array}{l}\text { Álvarez Manuel E. } \\
\text { Obispo Convento } \\
\text { San Francisco }\end{array}$ & $\begin{array}{l}\text { AAC. Libro } \\
23, \text { Órdenes } \\
1876-1925\end{array}$ & 5 \\
\hline & Grimao & Fr. Benito & Franciscano & & $22 / 12 / 1877$ & $\begin{array}{l}\text { Álvarez Manuel E. } \\
\text { Obispo Convento } \\
\text { San Francisco }\end{array}$ & $\begin{array}{l}\text { AAC. Libro } \\
23, \text { Ordenes } \\
1876-1925 \\
\end{array}$ & 5 \\
\hline & Ludueña & Fr. Ramón & Franciscano & & $22 / 12 / 1877$ & $\begin{array}{l}\text { Álvarez Manuel E. } \\
\text { Obispo Convento } \\
\text { San Francisco }\end{array}$ & $\begin{array}{l}\text { AAC. Libro } \\
23, \text { Órdenes } \\
1876-1925\end{array}$ & 5 \\
\hline & Osán & Fr. Vicente & Mercedario & & $22 / 12 / 1877$ & $\begin{array}{l}\text { Álvarez Manuel E. } \\
\text { Obispo Convento } \\
\text { San Francisco }\end{array}$ & $\begin{array}{l}\text { AAC. Libro } \\
23, \text { Órdenes } \\
1876-1925 \\
\end{array}$ & 60 \\
\hline & Pereyra & Fr. Sisto & Franciscano & & $22 / 12 / 1877$ & $\begin{array}{l}\text { Álvarez Manuel E. } \\
\text { Obispo Convento } \\
\text { San Francisco }\end{array}$ & $\begin{array}{l}\text { AAC. Libro } \\
23, \text { Órdenes } \\
1876-1925\end{array}$ & 2 \\
\hline & Recabarren & Fr. Francisco & Franciscano & & $22 / 12 / 1877$ & $\begin{array}{l}\text { Álvarez Manuel E. } \\
\text { Obispo Convento } \\
\text { San Francisco }\end{array}$ & $\begin{array}{l}\text { AAC. Libro } \\
23, \text { Ordenes } \\
1876-1925 \\
\end{array}$ & 5 \\
\hline & Riba & Santiago & Jesuita & & $29 / 07 / 1877$ & $\begin{array}{l}\text { Álvarez Manuel E. } \\
\text { Obispo Convento } \\
\text { San Francisco }\end{array}$ & $\begin{array}{l}\text { AAC, Libro } \\
23, \text { Ordenes } \\
1876-1925\end{array}$ & 5 \\
\hline & Rodríguez & Fr. Raimundo & Dominico & & $22 / 12 / 1877$ & $\begin{array}{l}\text { Álvarez Manuel E. } \\
\text { Obispo Convento } \\
\text { San Francisco } \\
\end{array}$ & $\begin{array}{l}\text { AAC. Libro } \\
23, \text { Órdenes } \\
1876-1925 \\
\end{array}$ & 2 \\
\hline & Vázquez & Fr. Salvador & Dominico & & $22 / 12 / 1877$ & $\begin{array}{l}\text { Álvarez Manuel E. } \\
\text { Obispo Convento } \\
\text { San Francisco }\end{array}$ & $\begin{array}{l}\text { AAC. Libro } \\
23, \text { Ordenes } \\
1876-1925 \\
\end{array}$ & 2 \\
\hline \multirow[t]{2}{*}{$\begin{array}{l}\text { 1881-1885 } \\
\text { Cantidad: } 8\end{array}$} & Díaz & Fr. Agustín & Dominico & & $21 / 05 / 1881$ & $\begin{array}{l}\text { Fr. Mamerto Esquiú } \\
\text { Obispo Convento } \\
\text { San Francisco }\end{array}$ & $\begin{array}{l}\text { AAC. Libro } \\
23, \text { Órdenes } \\
1876-1925 \\
\end{array}$ & 9 \\
\hline & Domínguez. & Fr. Moisés & Franciscano & & $23 / 12 / 1882$ & $\begin{array}{l}\text { Fr. Mamerto Esquiú } \\
\text { Obispo Iglesia } \\
\text { Catedral }\end{array}$ & $\begin{array}{l}\text { AAC. Libro } \\
23, \text { Ordenes } \\
1876-1925 \\
\end{array}$ & 17 \\
\hline
\end{tabular}




\begin{tabular}{|c|c|c|c|c|c|c|c|c|}
\hline & Egrin & Fr. Manuel & $\begin{array}{l}\text { Franciscano, } \\
\text { Convento de San } \\
\text { Lorenzo, Santa Fe }\end{array}$ & & $21 / 05 / 1881$ & $\begin{array}{l}\text { Fr. Mamerto Esquiú } \\
\text { Obispo Convento } \\
\text { San Francisco }\end{array}$ & $\begin{array}{l}\text { AAC. Libro } \\
23, \text { Órdenes } \\
1876-1925\end{array}$ & 9 \\
\hline & Ludueña & Fr. Manuel & Franciscano & & $23 / 12 / 1882$ & $\begin{array}{l}\text { Fr. Mamerto Esquiú } \\
\text { Obispo Iglesia } \\
\text { Catedral }\end{array}$ & $\begin{array}{l}\text { AAC. Libro } \\
\text { 23, Órdenes } \\
1876-1925\end{array}$ & 17 \\
\hline & Ríos & Fr.Félix & Franciscano & & $23 / 12 / 1882$ & $\begin{array}{l}\text { Fr. Mamerto Esquiú } \\
\text { Obispo Iglesia } \\
\text { Catedral }\end{array}$ & $\begin{array}{l}\text { AAC. Libro } \\
23, \text { Órdenes } \\
1876-1925\end{array}$ & 17 \\
\hline & Solís & Fr. José & $\begin{array}{l}\text { Franciscano, } \\
\text { Convento de San } \\
\text { Lorenzo, Santa Fe }\end{array}$ & & $21 / 05 / 1881$ & $\begin{array}{l}\text { Fr. Mamerto Esquiú } \\
\text { Obispo Convento } \\
\text { San Francisco }\end{array}$ & $\begin{array}{l}\text { AAC. Libro } \\
\text { 23, Órdenes } \\
1876-1925\end{array}$ & 9 \\
\hline & Taborda & Fr. Venancio & Mercedario & & $21 / 05 / 1881$ & $\begin{array}{l}\text { Fr. Mamerto Esquiú } \\
\text { Obispo Convento } \\
\text { San Francisco }\end{array}$ & $\begin{array}{l}\text { AAC. Libro } \\
\text { 23, Órdenes } \\
1876-1925\end{array}$ & 9 \\
\hline & Tissera & Fr. Juan & Franciscano & & $23 / 12 / 1882$ & $\begin{array}{l}\text { Fr. Mamerto Esquiú } \\
\text { Obispo Iglesia } \\
\text { Catedral }\end{array}$ & $\begin{array}{l}\text { AAC. Libro } \\
\text { 23, Órdenes } \\
1876-1925\end{array}$ & 17 \\
\hline \multirow[t]{5}{*}{$\begin{array}{l}\text { 1886-1890 } \\
\text { Cantidad } 6\end{array}$} & Arroyo & Fr. Luis & Dominico & $\begin{array}{l}\text { Secularizado } \\
\text { Sacerdote de } \\
\text { ministerio libre }\end{array}$ & $01 / 10 / 1890$ & $\begin{array}{l}\text { Fr. Reginaldo Toro } \\
\text { Obispo. Iglesia } \\
\text { Colegio de } \\
\text { Educandas }\end{array}$ & $\begin{array}{l}\text { AAC. Libro } \\
23, \text { Órdenes } \\
1876-1925\end{array}$ & 24 \\
\hline & Gramajo & José Gabriel & $\begin{array}{l}\text { Dominicos de } \\
\text { Tucumán }\end{array}$ & & $16 / 10 / 1890$ & $\begin{array}{l}\text { Fr. Reginaldo Toro } \\
\text { Obispo Santo } \\
\text { Domingo }\end{array}$ & $\begin{array}{l}\text { AAC. Libro } \\
23, \text { Órdenes } \\
1876-1925\end{array}$ & 25 \\
\hline & Jaciano & Fr. Pedro M. & $\begin{array}{l}\text { Dominicos de } \\
\text { Tucumán }\end{array}$ & & $16 / 10 / 1890$ & $\begin{array}{l}\text { Fr. Reginaldo Toro } \\
\text { Obispo. Santo } \\
\text { Domingo }\end{array}$ & $\begin{array}{l}\text { AAC. Libro } \\
23, \text { Órdenes } \\
1876-1925\end{array}$ & 25 \\
\hline & Martínez & Fr. Antonio & $\begin{array}{l}\text { Dominico Diócesis } \\
\text { de Salta }\end{array}$ & & $13 / 07 / 1890$ & $\begin{array}{l}\text { Fr. Reginaldo Toro } \\
\text { Obispo. Iglesia Sta } \\
\text { Teresa }\end{array}$ & $\begin{array}{l}\text { AAC. Libro } \\
23, \text { Órdenes } \\
1876-1925 \\
\end{array}$ & 22 \\
\hline & Palavecino & Fr. Alberto & $\begin{array}{l}\text { Dominico de } \\
\text { Tucumán }\end{array}$ & & $16 / 10 / 1890$ & $\begin{array}{l}\text { Fr. Reginaldo Toro } \\
\text { Obispo. Santo } \\
\text { Domingo }\end{array}$ & $\begin{array}{l}\text { AAC. Libro } \\
\text { 23, Órdenes } \\
1876-1925\end{array}$ & 25 \\
\hline
\end{tabular}




\begin{tabular}{|c|c|c|c|c|c|c|c|}
\hline & Robles & Fr. Miguel & $\begin{array}{l}\text { Dominicos de } \\
\text { Tucumán }\end{array}$ & $16 / 10 / 1890$ & $\begin{array}{l}\text { Fr. Reginaldo Toro } \\
\text { Obispo. Santo } \\
\text { Domingo }\end{array}$ & $\begin{array}{l}\text { AAC. Libro } \\
\text { 23, Órdenes } \\
1876-1925 \\
\end{array}$ & 25 \\
\hline \multirow[t]{12}{*}{$\begin{array}{l}1891-1895 \\
\text { Cantidad } 18\end{array}$} & Aris & Jerónimo & Dominico ciudad & $19 / 12 / 1891$ & $\begin{array}{l}\text { Fr. Reginaldo Toro } \\
\text { NtraSra de la Merced }\end{array}$ & $\begin{array}{l}\text { AAC. Libro } \\
\text { 23, Órdenes } \\
1876-1925\end{array}$ & 31 \\
\hline & Biagino & Fr. Enrique & $\begin{array}{l}\text { Franciscano } \\
\text { misionero de Rio } \\
\text { Cuarto }\end{array}$ & $12 / 06 / 1891$ & $\begin{array}{l}\text { Fr. Reginaldo Toro } \\
\text { Santa Catalina de } \\
\text { Siena }\end{array}$ & $\begin{array}{l}\text { AAC. Libro } \\
23, \text { Órdenes } \\
1876-1925\end{array}$ & 29 \\
\hline & Chaves & Fr. Alberto & Dominicos ciudad & $19 / 12 / 1891$ & $\begin{array}{l}\text { Fr. Reginaldo Toro } \\
\text { Ntra. Sra. de la } \\
\text { Merced }\end{array}$ & $\begin{array}{l}\text { AAC. Libro } \\
23, \text { Órdenes } \\
1876-1925\end{array}$ & 31 \\
\hline & Farías & Fr. Juan & Dominicos ciudad & $19 / 12 / 1891$ & $\begin{array}{l}\text { Fr. Reginaldo Toro } \\
\text { Ntra. Sra. de la } \\
\text { Merced }\end{array}$ & $\begin{array}{l}\text { AAC. Libro } \\
23, \text { Órdenes } \\
1876-1925 \\
\end{array}$ & 31 \\
\hline & Gigena & $\begin{array}{l}\text { Fr. José de la } \\
\text { Cruz }\end{array}$ & $\begin{array}{l}\text { Franciscano } \\
\text { convento de Río } \\
\text { Cuarto }\end{array}$ & $24 / 09 / 1891$ & $\begin{array}{l}\text { Fr. Reginaldo Toro } \\
\text { Santa Catalina de } \\
\text { Sena }\end{array}$ & $\begin{array}{l}\text { AAC. Libro } \\
23, \text { Ordenes } \\
1876-1925 \\
\end{array}$ & 31 \\
\hline & González & Fr. Nicolás & Dominicos ciudad & $19 / 12 / 1891$ & $\begin{array}{l}\text { Fr. Reginaldo Toro } \\
\text { Iglesia de la Merced }\end{array}$ & $\begin{array}{l}\text { AAC. Libro } \\
\text { 23, Órdenes } \\
1876-1925\end{array}$ & 31 \\
\hline & Tula & Pacífico & Franciscano ciudad & $01 / 08 / 1891$ & $\begin{array}{l}\text { Fr. Reginaldo Toro } \\
\text { Iglesia San Francisco }\end{array}$ & $\begin{array}{l}\text { AAC. Libro } \\
23, \text { Órdenes } \\
1876-1925\end{array}$ & 35 \\
\hline & Chacón & Fr. Agustín & $\begin{array}{l}\text { Franciscanos } \\
\text { ciudad }\end{array}$ & $06 / 09 / 1893$ & $\begin{array}{l}\text { Fr. Reginaldo Toro } \\
\text { Colegio de } \\
\text { Educandas }\end{array}$ & $\begin{array}{l}\text { AAC. Libro } \\
23, \text { Órdenes } \\
1876-1925\end{array}$ & 35 \\
\hline & Chacón & Fr. Antonio & $\begin{array}{l}\text { Franciscanos } \\
\text { ciudad }\end{array}$ & $06 / 09 / 1893$ & $\begin{array}{l}\text { Fr. Reginaldo Toro } \\
\text { Colegio de } \\
\text { Educandas }\end{array}$ & $\begin{array}{l}\text { AAC. Libro } \\
\text { 23, Órdenes } \\
1876-1925\end{array}$ & 36 \\
\hline & Díaz Ceballos & Fr. Juan de Dios & Dominico & $05 / 11 / 1893$ & $\begin{array}{l}\text { Fr. Reginaldo Toro } \\
\text { Iglesia Sto. Domingo }\end{array}$ & $\begin{array}{l}\text { AAC. Libro } \\
23, \text { Órdenes } \\
1876-1925\end{array}$ & 35 \\
\hline & Gutiérrez & Fr. Buenaventura & $\begin{array}{l}\text { Franciscanos } \\
\text { ciudad }\end{array}$ & $06 / 09 / 1893$ & $\begin{array}{l}\text { Fr. Reginaldo Toro } \\
\text { Colegio de } \\
\text { Educandas }\end{array}$ & $\begin{array}{l}\text { AAC. Libro } \\
\text { 23, Órdenes } \\
1876-1925\end{array}$ & 35 \\
\hline & Maldonado & Fr. Leonardo & Franciscanos & $06 / 09 / 1893$ & Fr. Reginaldo Toro & AAC. Libro & 37 \\
\hline
\end{tabular}




\begin{tabular}{|c|c|c|c|c|c|c|c|}
\hline & & & ciudad & & $\begin{array}{l}\text { Colegio de } \\
\text { Educandas }\end{array}$ & $\begin{array}{l}23, \text { Órdenes } \\
1876-1925\end{array}$ & \\
\hline & Maldonado & Fr. Leonardo & Franciscano & $23 / 12 / 1893$ & $\begin{array}{l}\text { Fr. Reginaldo Toro } \\
\text { Colegio de } \\
\text { Educandas }\end{array}$ & $\begin{array}{l}\text { AAC. Libro } \\
23 \text {, Órdenes } \\
1876-1925\end{array}$ & 35 \\
\hline & Martínez & Fr. José & $\begin{array}{l}\text { Franciscanos } \\
\text { ciudad }\end{array}$ & $06 / 09 / 1893$ & $\begin{array}{l}\text { Fr. Reginaldo Toro } \\
\text { Colegio de } \\
\text { Educandas }\end{array}$ & $\begin{array}{l}\text { AAC. Libro } \\
23, \text { Órdenes } \\
1876-1925\end{array}$ & 33 \\
\hline & Medina & $\begin{array}{l}\text { Fr. Antonio de } \\
\text { Sto. Tomás }\end{array}$ & Dominico & $22 / 01 / 1893$ & $\begin{array}{l}\text { Fr. Reginaldo Toro } \\
\text { Santo Domingo }\end{array}$ & $\begin{array}{l}\text { AAC. Libro } \\
23, \text { Órdenes } \\
1876-1925\end{array}$ & 35 \\
\hline & Aborg & Fr. Gil & Dominico & $06 / 10 / 1894$ & $\begin{array}{l}\text { Uladislao Castellano. } \\
\text { Obispo Auxiliar }\end{array}$ & $\begin{array}{l}\text { AAC. Libro } \\
\text { 23, Órdenes } \\
1876-1925\end{array}$ & 39 \\
\hline & Romero & Juan & Dominico & $06 / 10 / 1894$ & $\begin{array}{l}\text { Uladislao Castellano. } \\
\text { Obispo Auxiliar }\end{array}$ & $\begin{array}{l}\text { AAC. Libro } \\
23, \text { Órdenes } \\
1876-1925\end{array}$ & 40 \\
\hline & Viacava & Juan & $\begin{array}{l}\text { Domiciliario del } \\
\text { Obispado de } \\
\text { Buenos Aires }\end{array}$ & $06 / 10 / 1894$ & $\begin{array}{l}\text { Uladislao Castellano. } \\
\text { Obispo Auxiliar }\end{array}$ & $\begin{array}{l}\text { AAC. Libro } \\
23 \text {, Órdenes } \\
1876-1925\end{array}$ & 40 \\
\hline 1896-1900: 30 & Amuchástegui & Fr. Nicolás & Franciscano & $28 / 12 / 1897$ & $\begin{array}{l}\text { Fr. Reginaldo Toro } \\
\text { Iglesia de Santa } \\
\text { Teresa }\end{array}$ & $\begin{array}{l}\text { AAC. Libro } \\
23, \text { Órdenes } \\
1876-1925\end{array}$ & 48 \\
\hline & Coria & Fr. Ceferino & Mercedario & $24 / 04 / 1897$ & $\begin{array}{l}\text { Fr. Reginaldo Toro } \\
\text { Convento de la } \\
\text { Merced }\end{array}$ & $\begin{array}{l}\text { AAC. Libro } \\
23, \text { Órdenes } \\
1876-1925\end{array}$ & 46 \\
\hline & Durán & Fr. Manuel & Mercedario & $24 / 04 / 1897$ & $\begin{array}{l}\text { Fr. Reginaldo Toro } \\
\text { Convento de la } \\
\text { Merced }\end{array}$ & $\begin{array}{l}\text { AAC. Libro } \\
23 \text {, Órdenes } \\
1876-1925\end{array}$ & 46 \\
\hline & Ferreira & Fr. Arnado & Mercedario & $24 / 04 / 1897$ & $\begin{array}{l}\text { Fr. Reginaldo Toro } \\
\text { Convento de la } \\
\text { Merced }\end{array}$ & $\begin{array}{l}\text { AAC. Libro } \\
23 \text {, Órdenes } \\
1876-1925 \\
\end{array}$ & 46 \\
\hline & Garzón & $\begin{array}{l}\text { Fr. Juan } \\
\text { Capistrano }\end{array}$ & Franciscano ciudad & $28 / 12 / 1897$ & $\begin{array}{l}\text { Fr. Reginaldo Toro } \\
\text { Iglesia de Santa } \\
\text { Teresa }\end{array}$ & $\begin{array}{l}\text { AAC. Libro } \\
23 \text {, Órdenes } \\
1876-1925\end{array}$ & 49 \\
\hline & González & Fr. Mamerto & Franciscano ciudad & $28 / 12 / 1897$ & $\begin{array}{l}\text { Fr. Reginaldo Toro } \\
\text { Iglesia de Santa }\end{array}$ & $\begin{array}{l}\text { AAC. Libro } \\
\text { 23, Órdenes }\end{array}$ & 48 \\
\hline
\end{tabular}




\begin{tabular}{|c|c|c|c|c|c|c|}
\hline & & & & Teresa & $1876-1925$ & \\
\hline Juncos & Fr. José María & Dominico & $24 / 04 / 1897$ & $\begin{array}{l}\text { Fr. Reginaldo Toro } \\
\text { Iglesia de Santo } \\
\text { Domingo }\end{array}$ & $\begin{array}{l}\text { AAC. Libro } \\
23 \text {, Órdenes } \\
1876-1925\end{array}$ & 46 \\
\hline Linares & Fr. Olegario & Dominico & $24 / 04 / 1897$ & $\begin{array}{l}\text { Fr. Reginaldo Toro } \\
\text { Iglesia de Santo } \\
\text { Domingo }\end{array}$ & $\begin{array}{l}\text { AAC. Libro } \\
23 \text {, Órdenes } \\
1876-1925\end{array}$ & 46 \\
\hline Lobo & Fr. Antonio & Franciscano ciudad & $13 / 01 / 1897$ & $\begin{array}{l}\text { Fr. Reginaldo Toro } \\
\text { Iglesia de Santa } \\
\text { Teresa }\end{array}$ & $\begin{array}{l}\text { AAC. Libro } \\
23 \text {, Órdenes } \\
1876-1925\end{array}$ & 45 \\
\hline Mansilla & Fr. Antonio & Franciscano ciudad & $28 / 12 / 1897$ & $\begin{array}{l}\text { Fr. Reginaldo Toro } \\
\text { Iglesia de Santa } \\
\text { Teresa }\end{array}$ & $\begin{array}{l}\text { AAC. Libro } \\
23, \text { Órdenes } \\
1876-1925 \\
\end{array}$ & 49 \\
\hline Montoya & Fr. Guillermo & Mercedario & $21 / 11 / 1897$ & $\begin{array}{l}\text { Fr. Reginaldo Toro } \\
\text { Catedral }\end{array}$ & $\begin{array}{l}\text { AAC. Libro } \\
23 \text {, Órdenes } \\
1876-1925\end{array}$ & 48 \\
\hline Moyano & Fr. Constantino & Dominico & $24 / 04 / 1897$ & $\begin{array}{l}\text { Fr. Reginaldo Toro } \\
\text { Iglesia de Santo } \\
\text { Domingo }\end{array}$ & $\begin{array}{l}\text { AAC. Libro } \\
23 \text {, Órdenes } \\
1876-1925\end{array}$ & 46 \\
\hline Vaca & Fr. Ramón & Dominico & $24 / 04 / 1897$ & $\begin{array}{l}\text { Fr. Reginaldo Toro } \\
\text { Iglesia de Santo } \\
\text { Domingo }\end{array}$ & $\begin{array}{l}\text { AAC. Libro } \\
23 \text {, Órdenes } \\
1876-1925\end{array}$ & 46 \\
\hline Vallejo & Fr. Paulino & Mercedario & $24 / 04 / 1897$ & $\begin{array}{l}\text { Fr. Reginaldo Toro } \\
\text { Convento de la } \\
\text { Merced }\end{array}$ & $\begin{array}{l}\text { AAC. Libro } \\
23 \text {, Órdenes } \\
1876-1925 \\
\end{array}$ & 46 \\
\hline Obregón & Fr. Adelmo & Mercedario & $21 / 11 / 1897$ & $\begin{array}{l}\text { Fr. Reginaldo Toro } \\
\text { Catedral }\end{array}$ & $\begin{array}{l}\text { AAC. Libro } \\
23 \text {, Órdenes } \\
1876-1925\end{array}$ & 48 \\
\hline Pujol & Fr. José Antonio & Franciscano ciudad & $28 / 12 / 1897$ & $\begin{array}{l}\text { Iglesia de Santa } \\
\text { Teresa }\end{array}$ & $\begin{array}{l}\text { AAC. Libro } \\
23 \text {, Órdenes } \\
1876-1925\end{array}$ & 49 \\
\hline Capelli & Fr. Buenaventura & Franciscano, ciudad & $04 / 10 / 1898$ & $\begin{array}{l}\text { Fr. Reginaldo Toro } \\
\text { Capilla colegio de } \\
\text { Educandas }\end{array}$ & $\begin{array}{l}\text { AAC. Libro } \\
23 \text {, Órdenes } \\
1876-1925\end{array}$ & 51 \\
\hline Armendaris & José María & Escolapio & $12 / 11 / 1899$ & $\begin{array}{l}\text { Fr. Reginaldo Toro } \\
\text { Educandas Sta. } \\
\text { Teresa }\end{array}$ & $\begin{array}{l}\text { AAC. Libro } \\
23, \text { Órdenes } \\
1876-1925 \\
\end{array}$ & 54 \\
\hline
\end{tabular}




\begin{tabular}{|c|c|c|c|c|c|c|c|}
\hline & Bava & Juan & Escolapio & $12 / 11 / 1899$ & $\begin{array}{l}\text { Fr. Reginaldo Toro } \\
\text { Educandas Sta. } \\
\text { Teresa }\end{array}$ & $\begin{array}{l}\text { AAC. Libro } \\
23, \text { Ordenes } \\
1876-1925\end{array}$ & 54 \\
\hline & Brualla & José María & Escolapio & $12 / 11 / 1899$ & $\begin{array}{l}\text { Fr. Reginaldo Toro } \\
\text { Educandas Sta. } \\
\text { Teresa }\end{array}$ & $\begin{array}{l}\text { AAC. Libro } \\
23, \text { Órdenes } \\
1876-1925\end{array}$ & 54 \\
\hline & Ortigos & Félix & Escolapio & $12 / 11 / 1899$ & $\begin{array}{l}\text { Fr. Reginaldo Toro } \\
\text { Educandas Sta. } \\
\text { Teresa }\end{array}$ & $\begin{array}{l}\text { AAC. Libro } \\
23, \text { Órdenes } \\
1876-1925\end{array}$ & 54 \\
\hline & Sadoco & Battista & Dominico & 21/09/1899 & $\begin{array}{l}\text { Fr. Reginaldo Toro } \\
\text { Iglesia Santo } \\
\text { Domingo }\end{array}$ & $\begin{array}{l}\text { AAC. Libro } \\
23, \text { Ordenes } \\
1876-1925\end{array}$ & 53 \\
\hline & Cabrera & Fr .Luis María & Dominico & $18 / 03 / 1900$ & $\begin{array}{l}\text { Fr. Reginaldo Toro } \\
\text { Iglesia Santo } \\
\text { Domingo }\end{array}$ & $\begin{array}{l}\text { AAC. Libro } \\
23, \text { Ordenes } \\
1876-1925\end{array}$ & 55 \\
\hline & Costa & Fr. Gundisalvo & Dominico & $18 / 03 / 1900$ & $\begin{array}{l}\text { Fr. Reginaldo Toro } \\
\text { Iglesia Santo } \\
\text { Domingo }\end{array}$ & $\begin{array}{l}\text { AAC. Libro } \\
23, \text { Órdenes } \\
1876-1925\end{array}$ & 55 \\
\hline & Godoy & Fr. Antonio & $\begin{array}{l}\text { Franciscanos } \\
\text { ciudad }\end{array}$ & $06 / 12 / 1900$ & $\begin{array}{l}\text { Ferreira Aquilino } \\
\text { Iglesia Sta. Catalina }\end{array}$ & $\begin{array}{l}\text { AAC. Libro } \\
23, \text { Órdenes } \\
1876-1925\end{array}$ & 57 \\
\hline & Mansilla & Fr. José & $\begin{array}{l}\text { Franciscanos } \\
\text { ciudad }\end{array}$ & $06 / 12 / 1900$ & $\begin{array}{l}\text { Ferreira Aquilino } \\
\text { Iglesia Sta. Catalina }\end{array}$ & $\begin{array}{l}\text { AAC. Libro } \\
23, \text { Órdenes } \\
1876-1925\end{array}$ & 57 \\
\hline & Oro & $\begin{array}{l}\text { Fr. Buenaventura } \\
\text { Oro }\end{array}$ & $\begin{array}{l}\text { Franciscanos } \\
\text { ciudad }\end{array}$ & $22 / 12 / 1900$ & $\begin{array}{l}\text { Dr. Filemón } \\
\text { Cabanillas Iglesia } \\
\text { San Francisco }\end{array}$ & $\begin{array}{l}\text { AAC. Libro } \\
23, \text { Órdenes } \\
1876-1925\end{array}$ & 57 \\
\hline & Bravo & Eugenio & Escolapio & $15 / 07 / 1900$ & $\begin{array}{l}\text { Capilla Colegio de } \\
\text { Educandas }\end{array}$ & $\begin{array}{l}\text { AAC. Libro } \\
23, \text { Órdenes } \\
1876-1925\end{array}$ & 56 \\
\hline & Perpetuo & Fr. Alberto & Dominico & $19 / 12 / 1900$ & $\begin{array}{l}\text { Dr. Filemón } \\
\text { Cabanillas Iglesia } \\
\text { Santo Domingo }\end{array}$ & $\begin{array}{l}\text { AAC. Libro } \\
23, \text { Ordenes } \\
1876-1925\end{array}$ & 57 \\
\hline & Roldan & Fr. Gregorio & Dominico & $19 / 12 / 1900$ & $\begin{array}{l}\text { Dr. Filemón } \\
\text { Cabanillas Iglesia } \\
\text { Santo Domingo }\end{array}$ & $\begin{array}{l}\text { AAC. Libro } \\
23, \text { Órdenes } \\
1876-1925\end{array}$ & 57 \\
\hline 1901-1905 & Ferreira & Fr. Vicente & Dominico & $25 / 03 / 1902$ & Dr. Filemón & AAC. Libro & 61 \\
\hline
\end{tabular}




\begin{tabular}{|c|c|c|c|c|c|c|c|}
\hline \multirow[t]{10}{*}{ Cantidad . 11} & & & & & $\begin{array}{l}\text { Cabanillas Iglesia de } \\
\text { Santo Domingo }\end{array}$ & $\begin{array}{l}23, \text { Órdenes } \\
1876-1925 \\
\end{array}$ & \\
\hline & Lascano & Enrique & Dominico & $25 / 03 / 1902$ & $\begin{array}{l}\text { Dr. Filemón } \\
\text { Cabanillas Iglesia de } \\
\text { Santo Domingo }\end{array}$ & $\begin{array}{l}\text { AAC. Libro } \\
23, \text { Órdenes } \\
1876-1925 \\
\end{array}$ & 61 \\
\hline & Battista & Fr. Antonio & Dominico & $25 / 03 / 1902$ & $\begin{array}{l}\text { Aquilino Ferreyra } \\
\text { Iglesia de Santo } \\
\text { Domingo }\end{array}$ & $\begin{array}{l}\text { AAC. Libro } \\
23, \text { Órdenes } \\
1876-1925\end{array}$ & 63 \\
\hline & Ferrari & Fr. Inocencio & Dominico & $19 / 12 / 1902$ & $\begin{array}{l}\text { Aquilino Ferreyra } \\
\text { Iglesia Santo } \\
\text { Domingo }\end{array}$ & $\begin{array}{l}\text { AAC. Libro } \\
23, \text { Órdenes } \\
1876-1925\end{array}$ & 67 \\
\hline & Castillo & Fr. José & Dominico & 19/12/1902 & $\begin{array}{l}\text { Aquilino Ferreyra } \\
\text { Iglesia Santo } \\
\text { Domingo }\end{array}$ & $\begin{array}{l}\text { AAC. Libro } \\
23, \text { Órdenes } \\
1876-1925\end{array}$ & 67 \\
\hline & Capas & Fr. Cristóforo & Dominico & $08 / 12 / 1903$ & $\begin{array}{l}\text { Obispo de Cuyo Fr. } \\
\text { Marcelino } \\
\text { Bustamante Iglesia } \\
\text { Santo Domingo }\end{array}$ & $\begin{array}{l}\text { AAC. Libro } \\
\text { 23, Órdenes } \\
1876-1925\end{array}$ & 67 \\
\hline & Lira & Jordan & Dominico & $08 / 12 / 1903$ & $\begin{array}{l}\text { Obispo de Cuyo Fr. } \\
\text { Marcelino } \\
\text { Bustamante Iglesia } \\
\text { Santo Domingo }\end{array}$ & $\begin{array}{l}\text { AAC. Libro } \\
\text { 23, Órdenes } \\
1876-1925\end{array}$ & 67 \\
\hline & Palomba & Fr. Guillermo & Dominico & $08 / 12 / 1903$ & $\begin{array}{l}\text { Obispo de Cuyo Fr. } \\
\text { Marcelino } \\
\text { Bustamante Iglesia } \\
\text { Santo Domingo }\end{array}$ & $\begin{array}{l}\text { AAC. Libro } \\
23, \text { Órdenes } \\
1876-1925\end{array}$ & 67 \\
\hline & Ramos & Fr. Domiciano & Dominico & $01 / 01 / 1903$ & $\begin{array}{l}\text { Aquilino Ferreyra. } \\
\text { Catedral }\end{array}$ & $\begin{array}{l}\text { AAC. Libro } \\
\text { 23, Órdenes } \\
1876-1925 \\
\end{array}$ & 67 \\
\hline & Romero & Fr. Tomás & Dominico & $08 / 12 / 1903$ & $\begin{array}{l}\text { Obispo de Cuyo Fr. } \\
\text { Marcelino } \\
\text { Bustamante. Iglesia } \\
\text { Santo Domingo }\end{array}$ & $\begin{array}{l}\text { AAC. Libro } \\
\text { 23, Órdenes } \\
1876-1925\end{array}$ & 67 \\
\hline & Leite & Fr. Enrique & Dominico & $23 / 09 / 1905$ & $\begin{array}{l}\text { Filemón Cabanillas. } \\
\text { Santo Domingo }\end{array}$ & $\begin{array}{l}\text { AAC. Libro } \\
23 \text {, Ordenes } \\
1876-1925\end{array}$ & 71 \\
\hline 1906-1910 & Báez & Fr. Reginaldo & Dominico & $24 / 03 / 1906$ & Filemón Cabanillas & AAC. Libro & 73 \\
\hline
\end{tabular}




\begin{tabular}{|c|c|c|c|c|c|c|c|}
\hline \multirow[t]{4}{*}{ Cantidad: 4} & & & & & Iglesia Catedral & $\begin{array}{l}23, \text { Órdenes } \\
1876-1925\end{array}$ & \\
\hline & Caminos & Fr. Miguel & Dominico & $31 / 12 / 1906$ & $\begin{array}{l}\text { Filemón Cabanillas } \\
\text { Catedral }\end{array}$ & $\begin{array}{l}\text { AAC. Libro } \\
23 \text {, Órdenes } \\
1876-1925\end{array}$ & 74 \\
\hline & Catán & Fr. Juan & Dominico & $31 / 12 / 1906$ & $\begin{array}{l}\text { Filemón Cabanillas. } \\
\text { Catedral }\end{array}$ & $\begin{array}{l}\text { AAC. Libro } \\
23 \text {, Órdenes } \\
1876-1925\end{array}$ & 74 \\
\hline & Rearte & Fr. Lorenzo & Dominico & $18 / 12 / 1909$ & Oratorio Privado & $\begin{array}{l}\text { AAC. Libro } \\
23 \text {, Órdenes } \\
1876-1925\end{array}$ & 77 \\
\hline \multirow[t]{9}{*}{$\begin{array}{l}1911-1915 \\
\text { Cantidad } 12\end{array}$} & Herfort & Eugenio & & $24 / 12 / 1911$ & Iglesia Catedral & $\begin{array}{l}\text { AAC. Libro } \\
\text { 23, Órdenes } \\
1876-1925\end{array}$ & 81 \\
\hline & Molina & Fr. Miguel Angel & Dominico & $23 / 09 / 1911$ & Capilla del Obispado & $\begin{array}{l}\text { AAC. Libro } \\
\text { 23, Órdenes } \\
1876-1925\end{array}$ & 80 \\
\hline & Ochoa & Fr. Jordán & Dominico & $30 / 07 / 1911$ & Santo Domingo & $\begin{array}{l}\text { AAC. Libro } \\
23 \text {, Órdenes } \\
1876-1925\end{array}$ & 80 \\
\hline & Ardiles & Fr. Jeremías & Mercedario & 29/12/1912 & & $\begin{array}{l}\text { AAC. Libro } \\
23 \text {, Órdenes } \\
1876-1925\end{array}$ & 82 \\
\hline & Herrera & Fr. Pedro & Mercedario & $29 / 12 / 1912$ & & $\begin{array}{l}\text { AAC. Libro } \\
23 \text {, Órdenes } \\
1876-1925\end{array}$ & 82 \\
\hline & López & Pío & Dominico & $29 / 12 / 1912$ & & $\begin{array}{l}\text { AAC. Libro } \\
23 \text {, Órdenes } \\
1876-1925\end{array}$ & 82 \\
\hline & Palacios & $\begin{array}{l}\text { Fr. Eudocio de } \\
\text { Jesús }\end{array}$ & Mercedario & $29 / 12 / 1912$ & & $\begin{array}{l}\text { AAC. Libro } \\
23 \text {, Órdenes } \\
1876-1925\end{array}$ & 82 \\
\hline & Pereyra & $\begin{array}{l}\text { Fr. Antonio del } \\
\text { Smo. Rosario }\end{array}$ & Mercedario & $29 / 12 / 1912$ & & $\begin{array}{l}\text { AAC. Libro } \\
23, \text { Órdenes } \\
1876-1925\end{array}$ & 82 \\
\hline & Bermúdez & Fr. Bernardino & Franciscano & $02 / 02 / 1915$ & $\begin{array}{l}\text { José A. Luque e } \\
\text { Inocencio Dávila }\end{array}$ & $\begin{array}{l}\text { AAC. Libro } \\
\text { 23, Órdenes }\end{array}$ & 83 \\
\hline
\end{tabular}




\begin{tabular}{|c|c|c|c|c|c|c|c|}
\hline & & & & & $\begin{array}{l}\text { Obispos Auxiliares } \\
\text { San Francisco }\end{array}$ & $1876-1925$ & \\
\hline & Liendo & Esteban & Mercedario & $25 / 12 / 1915$ & $\begin{array}{l}\text { Inocencio Dávila } \\
\text { Iglesia de la Merced }\end{array}$ & $\begin{array}{l}\text { AAC. Libro } \\
23, \text { Órdenes } \\
1876-1925\end{array}$ & 83 \\
\hline & Ludueña & Fr. Valentino & Franciscano & $25 / 07 / 1915$ & n/c. José A. Luque & $\begin{array}{l}\text { AAC. Libro } \\
23, \text { Órdenes } \\
1876-1925 \\
\end{array}$ & 84 \\
\hline & Oyola & Fr. Pedro & Franciscano & $02 / 02 / 1915$ & $\begin{array}{l}\text { José A. Luque e } \\
\text { Inocencio Dávila } \\
\text { Obispos Auxiliares } \\
\text { San Francisco }\end{array}$ & $\begin{array}{l}\text { AAC. Libro } \\
23, \text { Órdenes } \\
1876-1925\end{array}$ & 83 \\
\hline \multirow[t]{9}{*}{$\begin{array}{l}\text { 1916-1920 } \\
\text { Cantidad } 10\end{array}$} & Barraza & Fr. Moisés & Franciscano & $03 / 12 / 1916$ & $\begin{array}{l}\text { Capilla del } \\
\text { Seminario Inocencio } \\
\text { Dávila }\end{array}$ & $\begin{array}{l}\text { AAC. Libro } \\
23, \text { Ordenes } \\
1876-1925 \\
\end{array}$ & 85 \\
\hline & Heredia & Fr. Leopoldo & Franciscano & $03 / 12 / 1916$ & $\begin{array}{l}\text { Capilla del } \\
\text { Seminario Inocencio } \\
\text { Dávila }\end{array}$ & $\begin{array}{l}\text { AAC. Libro } \\
23, \text { Órdenes } \\
1876-1925\end{array}$ & 84 \\
\hline & Machado & Fr. Buenaventura & Franciscano & $03 / 12 / 1916$ & $\begin{array}{l}\text { Capilla del } \\
\text { Seminario Inocencio } \\
\text { Dávila }\end{array}$ & $\begin{array}{l}\text { AAC. Libro } \\
23, \text { Órdenes } \\
1876-1925 \\
\end{array}$ & 85 \\
\hline & Marechal & Fr. Ivón & Franciscano & $03 / 12 / 1916$ & $\begin{array}{l}\text { Capilla del } \\
\text { Seminario Inocencio } \\
\text { Dávila }\end{array}$ & $\begin{array}{l}\text { AAC. Libro } \\
23, \text { Órdenes } \\
1876-1925\end{array}$ & 84 \\
\hline & Vallejos & Fr. Abelardo & Mercedario & 20/12/1919 & $\begin{array}{l}\text { n/c. Luque José A. } \\
\text { Obispo Auxiliar }\end{array}$ & $\begin{array}{l}\text { AAC. Libro } \\
23 \text {, Órdenes }\end{array}$ & 88 \\
\hline & & $\begin{array}{l}\text { Fr. Joaquín de } \\
\text { San José }\end{array}$ & Carmelitas & $25 / 07 / 1919$ & $\begin{array}{l}\text { Zenón Bustos } \\
\text { Convento de Santa } \\
\text { Teresa }\end{array}$ & $\begin{array}{l}\text { AAC. Libro } \\
23, \text { Órdenes }\end{array}$ & 87 \\
\hline & & $\begin{array}{l}\text { Fr. Valentín de la } \\
\text { Cruz }\end{array}$ & Carmelitas & $25 / 07 / 1919$ & $\begin{array}{l}\text { Zenón Bustos } \\
\text { Convento de Santa } \\
\text { Teresa }\end{array}$ & $\begin{array}{l}\text { AAC. Libro } \\
23 \text {, Órdenes }\end{array}$ & 87 \\
\hline & & $\begin{array}{l}\text { Fr. Antonio de } \\
\text { Jesús María }\end{array}$ & Carmelitas & $25 / 07 / 1919$ & $\begin{array}{l}\text { Zenón Bustos } \\
\text { Convento de Santa } \\
\text { Teresa }\end{array}$ & $\begin{array}{l}\text { AAC. Libro } \\
23 \text {, Órdenes }\end{array}$ & 87 \\
\hline & & $\begin{array}{l}\text { Fr. Ignacio de la } \\
\text { Virgen del }\end{array}$ & Carmelitas & $25 / 07 / 1919$ & $\begin{array}{l}\text { Zenón Bustos } \\
\text { Convento de Santa }\end{array}$ & $\begin{array}{l}\text { AAC. Libro } \\
23, \text { Órdenes }\end{array}$ & 87 \\
\hline
\end{tabular}




\begin{tabular}{|c|c|c|c|c|c|c|c|}
\hline & & Carmen & & & Teresa & & \\
\hline & & $\begin{array}{l}\text { Fr. Vicente de } \\
\text { San José }\end{array}$ & Carmelitas & $25 / 07 / 1919$ & $\begin{array}{l}\text { Zenón Bustos } \\
\text { Convento de Santa } \\
\text { Teresa }\end{array}$ & $\begin{array}{l}\text { AAC. Libro } \\
23 \text {, Órdenes }\end{array}$ & 87 \\
\hline \multirow[t]{11}{*}{$\begin{array}{l}1921-1925 \\
\text { Cantidad } 10\end{array}$} & Castellano & Antonio & & $04 / 01 / 1925$ & & $\begin{array}{l}\text { AAC. Libro } \\
23 \text {, Ordenes }\end{array}$ & 100 \\
\hline & Ferreira & Avelino & & $04 / 01 / 1925$ & & $\begin{array}{l}\text { AAC. Libro } \\
23, \text { Ordenes }\end{array}$ & 100 \\
\hline & & $\begin{array}{l}\text { Serafín de la } \\
\text { Sagrada Familia }\end{array}$ & Carmelitas & $29 / 11 / 1925$ & $\begin{array}{l}\text { Luque José A. Iglesia } \\
\text { Ntra. Sra. del } \\
\text { Carmen }\end{array}$ & $\begin{array}{l}\text { AAC. Libro } \\
23 \text {, Órdenes }\end{array}$ & 103 \\
\hline & & $\begin{array}{l}\text { Bautista de la } \\
\text { Virgen del } \\
\text { Carmen }\end{array}$ & Carmelitas & $29 / 11 / 1925$ & $\begin{array}{l}\text { Luque José A. Iglesia } \\
\text { Ntra. Sra. del } \\
\text { Carmen }\end{array}$ & $\begin{array}{l}\text { AAC. Libro } \\
23 \text {, Órdenes }\end{array}$ & 103 \\
\hline & & $\begin{array}{l}\text { Estanislao de } \\
\text { Jesús María }\end{array}$ & Carmelitas & $29 / 11 / 1925$ & $\begin{array}{l}\text { Luque José A. Iglesia } \\
\text { Ntra. Sra. del } \\
\text { Carmen }\end{array}$ & $\begin{array}{l}\text { AAC. Libro } \\
23 \text {, Órdenes }\end{array}$ & 103 \\
\hline & & $\begin{array}{l}\text { Enrique de la } \\
\text { Virgen del } \\
\text { Carmen }\end{array}$ & Carmelitas & $29 / 11 / 1925$ & $\begin{array}{l}\text { Luque José A. Iglesia } \\
\text { Ntra. Sra. del } \\
\text { Carmen }\end{array}$ & $\begin{array}{l}\text { AAC. Libro } \\
23 \text {, Órdenes }\end{array}$ & 103 \\
\hline & & $\begin{array}{l}\text { Eugenio de la } \\
\text { Inmaculada }\end{array}$ & Carmelitas & $29 / 11 / 1925$ & $\begin{array}{l}\text { Luque José A. Iglesia } \\
\text { Ntra. Sra. del } \\
\text { Carmen }\end{array}$ & $\begin{array}{l}\text { AAC. Libro } \\
23 \text {, Órdenes }\end{array}$ & 103 \\
\hline & & $\begin{array}{l}\text { Ricardo del } \\
\text { Purísimo Corazón } \\
\text { de María }\end{array}$ & Carmelitas & $29 / 11 / 1925$ & $\begin{array}{l}\text { Luque José A. Iglesia } \\
\text { Ntra. Sra. del } \\
\text { Carmen }\end{array}$ & $\begin{array}{l}\text { AAC. Libro } \\
23 \text {, Órdenes }\end{array}$ & 103 \\
\hline & & $\begin{array}{l}\text { Eliseo de la } \\
\text { Sagrada Familia }\end{array}$ & Carmelitas & $29 / 11 / 1925$ & $\begin{array}{l}\text { Luque José A. Iglesia } \\
\text { Ntra. Sra. del } \\
\text { Carmen }\end{array}$ & $\begin{array}{l}\text { AAC. Libro } \\
23 \text {, Órdenes }\end{array}$ & 103 \\
\hline & & $\begin{array}{l}\text { Claudio de Santa } \\
\text { Teresa }\end{array}$ & Carmelitas & $29 / 11 / 1925$ & $\begin{array}{l}\text { Luque José A. Iglesia } \\
\text { Ntra. Sra. del } \\
\text { Carmen }\end{array}$ & $\begin{array}{l}\text { AAC. Libro } \\
23 \text {, Órdenes }\end{array}$ & 103 \\
\hline & & $\begin{array}{l}\text { Victorino del } \\
\text { Purísimo Corazón } \\
\text { de María }\end{array}$ & Carmelitas & $29 / 11 / 1925$ & $\begin{array}{l}\text { Luque José A. Iglesia } \\
\text { Ntra. Sra. del } \\
\text { Carmen }\end{array}$ & $\begin{array}{l}\text { AAC. Libro } \\
23 \text {, Órdenes }\end{array}$ & 103 \\
\hline Total: 119 & & & & & & & \\
\hline
\end{tabular}




\begin{tabular}{|c|c|c|c|c|c|c|c|c|c|c|c|c|}
\hline \multicolumn{13}{|c|}{$\begin{array}{l}\text { TABLA } 15 \\
\text { Carreras personales de los capitulares, 1875-1925 }\end{array}$} \\
\hline $\begin{array}{l}\text { Apellido y } \\
\text { Nombre }\end{array}$ & $\begin{array}{c}\text { Capellanes } \\
\text { de Coro/ } \\
\text { Oficios } \\
\text { menores }\end{array}$ & $\begin{array}{l}\text { Cgos. } \\
\text { Medio- } \\
\text { racioneros }\end{array}$ & $\begin{array}{c}\text { Cgos. } \\
\text { Racioneros }\end{array}$ & $\begin{array}{c}\text { Cgo. } \\
\text { Peniten. }\end{array}$ & $\begin{array}{c}\text { Cgo. } \\
\text { Merced }^{2} \\
\text { Canonjía } \\
\text { Teologal }\end{array}$ & $\begin{array}{c}\text { Cgo. } \\
\text { Magistral }\end{array}$ & $\begin{array}{c}\text { Cgo. } \\
\text { Lectoral }\end{array}$ & Tesorero & Chantre & Arcedeán & Deán & fallecimiento \\
\hline $\begin{array}{l}\text { MARTIARENA, } \\
\text { Gaspar }\end{array}$ & & & & & & & & & & & $\begin{array}{c}3 / 03 / 185 \\
9\end{array}$ & $+8 / 10 / 1880$ \\
\hline $\begin{array}{l}\text { ALVAREZ, } \\
\text { Manuel Eduardo }\end{array}$ & & & & & & & & & & $1871-7 / 07 / 1876$ & & $+24 / 08 / 1878$ \\
\hline CLARA, Pedro N. & & & & & & & & & 1859 & $31 / 08 / 1876$ & & \\
\hline $\begin{array}{l}\text { NUÑEZ BRAVO, } \\
\text { José Rufino }\end{array}$ & & & & & & & & $28 / 09 / 1871$ & $31 / 08 / 1876$ & $\begin{array}{c}\text { 24/11/1876: } \\
\text { (nombramiento) } \\
15 / 03 / 1877\end{array}$ & & $+5 / 10 / 1880$ \\
\hline $\begin{array}{l}\text { VAZQUEZ DE } \\
\text { NOVOA, Andrés }\end{array}$ & & & & & $\begin{array}{c}\text { 28/09/1871 } \\
\text { (Queda } \\
\text { vacante } \\
1876)\end{array}$ & & & $\begin{array}{l}31 / 08 / 1876 \\
6 / 10 / 1876\end{array}$ & $1877-1881$ & & $\begin{array}{c}6 / 03 / 188 \\
1\end{array}$ & $+12 / 02 / 1887$ \\
\hline $\begin{array}{l}\text { CLARA, Gerónimo } \\
\text { Emiliano }\end{array}$ & & & & & & $2 / 02 / 1874$ & & $\begin{array}{c}\begin{array}{c}24 / 11 / 1876: \\
\text { (nombra- }\end{array} \\
\text { miento) } \\
1877-1881\end{array}$ & & $6 / 03 / 1881$ & & $+29 / 12 / 1892$ \\
\hline $\begin{array}{l}\text { CASTELLANO, } \\
\text { Uladislao }\end{array}$ & & $\mathrm{X}$ & $\begin{array}{c}31 / 08 / 1876 \\
6 / 10 / 1876 \\
\end{array}$ & & $11 / 05 / 1877$ & & & & $6 / 03 / 1881$ & & $\begin{array}{c}15 / 10 / 18 \\
88 \\
\end{array}$ & $+6 / 02 / 1900$ \\
\hline $\begin{array}{l}\text { ALDERETE, } \\
\text { Salvador }\end{array}$ & & $\mathrm{X}$ & $\begin{array}{c}31 / 08 / 1876 \\
\text { No asume } \\
\text { porque } \\
\text { fallece }\end{array}$ & & & & & & & & & \\
\hline $\begin{array}{l}\text { CESAR, Francisco } \\
\text { Solano }\end{array}$ & & 1877 & & & & & & & & & & \\
\hline $\begin{array}{l}\text { DE LA LASTRA, } \\
\text { Rosendo }\end{array}$ & & $15 / 10 / 1888$ & & & & & & & & $1892 / 1898$ & & $+3 / 07 / 1909$ \\
\hline $\begin{array}{l}\text { FERREIRA, } \\
\text { Aquilino }\end{array}$ & & & & & & & & $1 / 04 / 1885$ & $15 / 10 / 1888$ & & $\begin{array}{c}6 / 04 / 189 \\
8 \\
\end{array}$ & $+23 / 08 / 1910$ \\
\hline $\begin{array}{l}\text { YANIZ, Juan } \\
\text { Martín }\end{array}$ & & $31 / 08 / 1876$ & $\begin{array}{c}19 / 09 / 1876 \\
6 / 10 / 1876\end{array}$ & & & & $20 / 08 / 1881$ & $18 / 10 / 1888$ & & $6 / 04 / 1898$ & & $+16 / 04 / 1926$ \\
\hline $\begin{array}{l}\text { LUQUE, José } \\
\text { Anselmo }\end{array}$ & & $15 / 10 / 1888$ & $6 / 04 / 1898$ & & & & 1906 & & $12 / 05 / 1906$ & $21 / 04 / 1910$ & $\begin{array}{c}02 / 09 / 19 \\
10\end{array}$ & $+5 / 04 / 1930$ \\
\hline $\begin{array}{l}\text { DAVILA, } \\
\text { Inocencio }\end{array}$ & $17 / 11 / 1906$ & & & & & & & & & $14 / 03 / 1923$ & & $\uparrow 30 / 04 / 1930$ \\
\hline JUAREZ, Justino & & & & & & $12 / 09 / 1877$ & & $6 / 03 / 1881$ & & & & \\
\hline VELEZ, José María & & & 1877 & & & & & & & & & \\
\hline
\end{tabular}




\begin{tabular}{|c|c|c|c|c|c|c|c|c|c|c|c|}
\hline $\begin{array}{l}\text { CASTELLANO, } \\
\text { Domingo }\end{array}$ & & & $\begin{array}{c}19 / 09 / / 1876 \\
\text { Decreto } \\
6 / 10 / 1876\end{array}$ & $1 / 08 / 1885$ & & & & & & & \\
\hline GALCERÁN, José & & $6 / 10 / 1876$ & $20 / 06 / 1881$ & & & & & & 1887 & & + \\
\hline TORRES, Delfín & 1877 & & & & & & & & & & \\
\hline $\begin{array}{l}\text { GORDILLO, } \\
\text { Basilio }\end{array}$ & $5 / 01 / 1879$ & & & & & & & & & & \\
\hline $\begin{array}{l}\text { CLARA, Pedro } \\
\text { Nolasco }\end{array}$ & & & & & & & & & 1871- 1876 & 1876 & $+13 / 11 / 1876$ \\
\hline $\begin{array}{l}\text { ARGAÑARÁS, } \\
\text { Apolinario }\end{array}$ & & & & & & $20 / 08 / 1881$ & & & 1898- & & †1904 \\
\hline TAGLE, Luis & & $1 / 08 / 1885$ & $16 / 03 / 1887$ & & & $6 / 04 / 1898$ & & & $08 / 06 / 1904$ & & \\
\hline $\begin{array}{l}\text { LEAL, Luis } \\
\text { Rosendo }\end{array}$ & & & & & & 27/11/1906 & & & $14 / 03 / 1923$ & & \\
\hline ALVAREZ, Luis & & & & & & & $19 / 11 / 1906$ & $\begin{array}{c}13 / 04 / 1912 \\
?\end{array}$ & $\begin{array}{c}00 / 00 / 1927 \\
?\end{array}$ & & \\
\hline $\begin{array}{l}\text { CABANILLAS, } \\
\text { Filemón }\end{array}$ & & $8 / 10 / 1880$ & $1 / 09 / 1885$ & & & & $10 / 10 / 1888$ & $6 / 04 / 1898$ & & & †1913 \\
\hline $\begin{array}{l}\text { GONZÁLEZ, } \\
\text { Narciso }\end{array}$ & & $19 / 10 / 1886$ & $15 / 10 / 1888$ & $6 / 04 / 1898$ & & & & $08 / 06 / 1904$ & & & $+00 / 11 / 1906$ \\
\hline $\begin{array}{l}\text { MERCADO, } \\
\text { Eleuterio }\end{array}$ & & & $6 / 04 / 1898$ & $14 / 06 / 1904$ & & & & $31 / 05 / 1910$ & & & \\
\hline BUSTOS, Samuel & $00 / 07 / 1882$ & & & & & & $15 / 07 / 1898$ & & & & $+23 / 06 / 1906$ \\
\hline $\begin{array}{l}\text { MONTENEGRO, } \\
\text { Pedro }\end{array}$ & & & & & & $17 / 03 / 1923$ & & & & & \\
\hline FIERRO, Eleodoro & & & & & $14 / 03 / 1881$ & & & & & & \\
\hline $\begin{array}{l}\text { ECHENIQUE, } \\
\text { Carlos }\end{array}$ & & & & $31 / 06 / 1910$ & & & & & & & \\
\hline MARTINEZ, José & & & $\begin{array}{c}26 / 08 / 1902 \\
1 / 07 / 1906\end{array}$ & $29 / 07 / 1912$ & & & & & & & \\
\hline $\begin{array}{l}\text { RODRIGUEZ, } \\
\text { Juan Antonio }\end{array}$ & & & $12 / 03 / 1925$ & $12 / 03 / 1925$ & & & & & & & \\
\hline LÓPEZ, Norberto & & & & $30 / 11 / 1925$ & & & & & & & \\
\hline $\begin{array}{l}\text { GARCÍA } \\
\text { COLMENA, } \\
\text { Andrés }\end{array}$ & & & $14 / 06 / 1904$ & & & & & & & & \\
\hline $\begin{array}{l}\text { FERREYRA, } \\
\text { Eduardo }\end{array}$ & & $01 / 07 / 1906$ & Hasta 1922 & & & & & & & & \\
\hline $\begin{array}{l}\text { MOYANO, Juan } \\
\text { Trifón }\end{array}$ & $17 / 11 / 1906$ & $06 / 09 / 1915$ & $18 / 03 / 1923$ & & & $00 / 00 / 1927$ & & & & & \\
\hline $\begin{array}{l}\text { LÓPEZ } \\
\text { CABANILLAS, } \\
\text { Rafael }\end{array}$ & & $\begin{array}{c}14 / 06 / 1904 \\
1 / 07 / 1906\end{array}$ & $01 / 08 / 1909$ & & & & & & & & \\
\hline
\end{tabular}




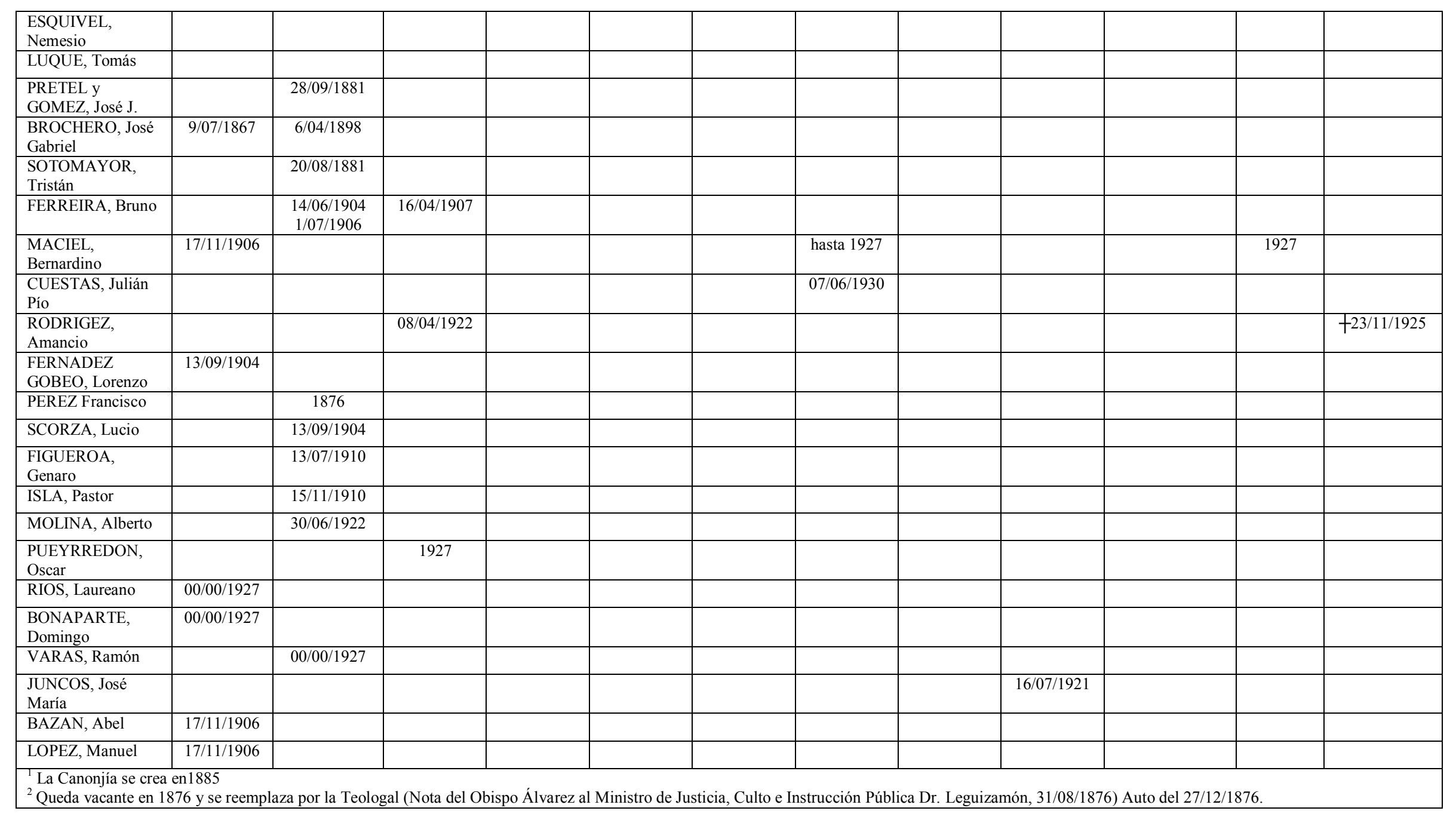




\begin{tabular}{|c|c|c|c|c|c|c|c|c|c|c|c|}
\hline \multicolumn{12}{|c|}{$\begin{array}{l}\text { TABLA } 16 \\
\text { Familias proveedoras de vocaciones. Los Ferreira }\end{array}$} \\
\hline FUENTES & \multicolumn{3}{|c|}{ DATOS PERSONALES } & \multicolumn{6}{|c|}{ FILIACIONES FAMILIARES } & \multicolumn{2}{|c|}{ CARGOS MAS IMPORTANTES } \\
\hline & Procedencia & Nombre & Orden & Padre & Madre & Bautismo & Padrino & Madrina & Ministro & Parroquias & Otros \\
\hline $\begin{array}{l}\text { Leg.24, T7 / } \\
\text { Cútolo }\end{array}$ & $\begin{array}{l}\text { Río II. Curato } \\
\text { Villa del } \\
\text { Rosario }\end{array}$ & $\begin{array}{l}\text { Aquilino } \\
\text { Ferreira }\end{array}$ & 1855 Presb. & $\begin{array}{l}\text { Francisco Froilán } \\
\text { Ferreira }\end{array}$ & $\begin{array}{l}\text { Eulalia } \\
\text { Álvarez } \\
\text { Argüello }\end{array}$ & 1824 & & & & Cura Propio Río $2^{\circ}$ & $\begin{array}{l}\text { Provisor y Vicario } \\
\text { General. Rector } \\
\text { del Seminario. } \\
\text { Tesorero Cabildo } \\
\text { Eclesiástico. } \\
\text { Chantre. Deán. } \\
\text { Obispo Auxiliar }\end{array}$ \\
\hline Leg.24, T7 & $\begin{array}{l}\text { Córdoba, } \\
\text { Ciudad }\end{array}$ & $\begin{array}{l}\text { Gregorio } \\
\text { Ardiles } \\
\text { Ferreira }\end{array}$ & $\begin{array}{l}1843 \\
\text { Minorista } \\
1846 \text { Presb. }\end{array}$ & $\begin{array}{l}\text { José Francisco } \\
\text { Ardiles }\end{array}$ & $\begin{array}{l}\text { Francisca } \\
\text { Paula } \\
\text { Ferreira }\end{array}$ & 1823 & $\begin{array}{l}\text { Juan } \\
\text { Frontera }\end{array}$ & $\begin{array}{l}\text { Andrea } \\
\text { Peralta }\end{array}$ & & $\begin{array}{l}\text { Teniente San Javier } \\
\text { Cura y Vicario Sta. } \\
\text { Rosa Río } 1^{\circ} \\
\text { Cura y Vicario de } \\
\text { Villa del Rosario }\end{array}$ & \\
\hline Leg.24, T9 & $\begin{array}{l}\text { Río } 2^{\circ} \text { Curato } \\
\text { Villa del } \\
\text { Rosario }\end{array}$ & $\begin{array}{l}\text { Lindor } \\
\text { Ferreira }\end{array}$ & $\begin{array}{l}1877 \\
\text { minorista }\end{array}$ & Vidal Ferreira & $\begin{array}{l}\text { Rosario } \\
\text { Gómez }\end{array}$ & 1855 & $\begin{array}{l}\text { Pbro. José } \\
\text { Gregorio } \\
\text { Ardiles } \\
\end{array}$ & $\begin{array}{l}\text { Juana } \\
\text { Fernández }\end{array}$ & $\begin{array}{l}\text { A.Ferreira } \\
\text { Cura y } \\
\text { Vicario } \\
\end{array}$ & $\begin{array}{l}\text { Cura y Vicario } \\
\text { Tercero Abajo }\end{array}$ & $\begin{array}{l}\text { Cgo. de la } \\
\text { Catedral }\end{array}$ \\
\hline Leg.24, T9 & Ciudad & $\begin{array}{l}\text { Eduardo } \\
\text { Ferreyra }\end{array}$ & $\begin{array}{l}1881 \\
\text { minorista } \\
1881 \text { Presb. }\end{array}$ & Eleuterio Ferreyra & $\begin{array}{l}\text { Dolores } \\
\text { Pérez }\end{array}$ & 1851 & & & & & $\begin{array}{l}\text { Secretario } \\
\text { Obispado }\end{array}$ \\
\hline Leg.24, T10 & $\begin{array}{l}\text { Río } 2^{\circ} \text { Curato } \\
\text { Villa del } \\
\text { Rosario }\end{array}$ & $\begin{array}{l}\text { Nicandro } \\
\text { Ferreira }\end{array}$ & $\begin{array}{l}1888 \\
\text { minorista }\end{array}$ & Nicandro F. & $\begin{array}{l}\text { Josefa } \\
\text { Álvarez }\end{array}$ & 1871 & $\begin{array}{l}\text { José T. } \\
\text { Ferreira }\end{array}$ & $\begin{array}{l}\text { Fortunata } \\
\text { Luque }\end{array}$ & $\begin{array}{l}\text { Pbro. } \\
\text { Narciso } \\
\text { González }\end{array}$ & & \\
\hline Leg.24, T11 & $\begin{array}{l}\text { Río } 2^{\circ} \text { Curato } \\
\text { Villa del } \\
\text { Rosario }\end{array}$ & $\begin{array}{l}\text { Bruno } \\
\text { Ferreira }\end{array}$ & 1894 Presb. & $\begin{array}{l}\text { José Ángel } \\
\text { Ferreira }\end{array}$ & $\begin{array}{l}\text { Teresa } \\
\text { González }\end{array}$ & 1869 & & & $\begin{array}{l}\text { Pbro. } \\
\text { Narciso } \\
\text { González }\end{array}$ & $\begin{array}{l}\text { Cura y Vicario del } \\
\text { Tránsito }\end{array}$ & $\begin{array}{l}\text { Canónigo Primer } \\
\text { Diácono }\end{array}$ \\
\hline Leg.24, T12 & $\begin{array}{l}\text { Río } 2^{\circ} \text { Curato } \\
\text { Villa del } \\
\text { Rosario }\end{array}$ & $\begin{array}{l}\text { Francisco } \\
\text { Ferreira }\end{array}$ & 1897 Presb. & Genivero F. & $\begin{array}{l}\text { Aurora } \\
\text { Liendo }\end{array}$ & & & & & $\begin{array}{l}\text { Cura y Vicario } \\
\text { Santa R Río I }\end{array}$ & $\begin{array}{l}\text { Cura y Vicario } \\
\text { Río Cuarto }\end{array}$ \\
\hline $\begin{array}{l}\text { Leg.24, T13 } \\
\text { /Libro } 20 \text {, } \\
\text { f.112 y } 114 / \\
\text { Libro } 21 \\
\text { f.12,23, } 37\end{array}$ & $\begin{array}{l}\text { Río } 2^{\circ} \text { Curato } \\
\text { Villa del } \\
\text { Rosario }\end{array}$ & Gil Ferreira & $\begin{array}{l}1898 \\
\text { minorista }\end{array}$ & Nicandro F. & $\begin{array}{l}\text { Josefa } \\
\text { Alvarez }\end{array}$ & 1882 & & & & $\begin{array}{l}\text { Cura y Vicario } \\
\text { Castro Barros }\end{array}$ & $\begin{array}{l}\text { Vicerrector } \\
\text { Seminario } \\
\text { Juez Pro Sinodal } \\
\text { Capellán } \\
\text { Convento Sta. } \\
\text { Catalina } \\
\end{array}$ \\
\hline Leg.24, T12 & $\begin{array}{l}\text { Río } 2^{\circ} \text { Curato } \\
\text { Villa del } \\
\text { Rosario }\end{array}$ & $\begin{array}{l}\text { Ignacio } \\
\text { Ferreira }\end{array}$ & $\begin{array}{l}1898 \\
\text { minorista }\end{array}$ & Vidal Ferreira & $\begin{array}{l}\text { Laureana } \\
\text { Gómez }\end{array}$ & 1879 & $\begin{array}{l}\text { Macario } \\
\text { Luque }\end{array}$ & $\begin{array}{l}\text { Jacinta } \\
\text { Luque }\end{array}$ & $\mathrm{n} / \mathrm{c}$ & & \\
\hline
\end{tabular}




\begin{tabular}{|c|c|c|c|c|c|c|c|c|c|c|}
\hline Leg.24, T12 & $\begin{array}{l}\text { Río } 2^{\circ} \text { Curato } \\
\text { Villa del } \\
\text { Rosario }\end{array}$ & $\begin{array}{l}\text { Avelino } \\
\text { Ferreira }\end{array}$ & $\begin{array}{l}1897 \\
\text { minorista } \\
1899 \text { Presb. }\end{array}$ & Nicandro F. & $\begin{array}{l}\text { Josefa } \\
\text { Álvarez }\end{array}$ & 1882 & $\begin{array}{l}\text { Lucas } \\
\text { Álvarez }\end{array}$ & & $\begin{array}{l}\text { Curra y Vicario de } \\
\text { Bell Ville }\end{array}$ & \\
\hline $\begin{array}{l}\text { Libro } 23, \\
\text { f. } 78\end{array}$ & $\begin{array}{l}\text { Río } 2^{\circ} \text { Curato } \\
\text { Villa del } \\
\text { Rosario }\end{array}$ & $\begin{array}{l}\text { Vicente } \\
\text { Ferreira }\end{array}$ & $\begin{array}{l}1905 \text { Presb. } \\
\text { (Roma) }\end{array}$ & & & & & & & $\begin{array}{l}\text { Prefecto Estudios } \\
\text { Seminario. } \\
\text { Juez eclesiástico } \\
\text { Secretario de } \\
\text { Cámara y Gob. } \\
\text { Canónigo } \\
\text { teologal. Vicario } \\
\text { Foráneo La Rioja }\end{array}$ \\
\hline Leg.24, T13 & $\begin{array}{l}\text { Río } 2^{\circ} \text { Curato } \\
\text { Villa del } \\
\text { Rosario }\end{array}$ & $\begin{array}{l}\text { Ramón } \\
\text { Ferreira }\end{array}$ & $\begin{array}{l}1902 \\
\text { minorista }\end{array}$ & Ramón F. & $\begin{array}{l}\text { Eloísa } \\
\text { Pérez }\end{array}$ & & & & & \\
\hline Leg.24, T13 & $\begin{array}{l}\text { Río } 2^{\circ} \text { Curato } \\
\text { Villa del } \\
\text { Rosario }\end{array}$ & $\begin{array}{l}\text { Aquilino } \\
\text { Ferreira }\end{array}$ & $\begin{array}{l}1904 \\
\text { minorista } \\
1909 \text { Presb. }\end{array}$ & $\begin{array}{l}\text { José Tiburcio } \\
\text { Ferreira }\end{array}$ & $\begin{array}{l}\text { Minervina } \\
\text { Ferreira }\end{array}$ & 1885 & $\begin{array}{l}\text { Pbro. } \\
\text { Aquilino } \\
\text { Ferreira }\end{array}$ & $\begin{array}{l}\text { Cenovia } \\
\text { Ferreira }\end{array}$ & $\begin{array}{l}\text { Cura y Vicario } \\
\text { Sobremonte }\end{array}$ & \\
\hline & $\begin{array}{l}\text { Río } 2^{\circ} \text { Curato } \\
\text { Villa del } \\
\text { Rosario }\end{array}$ & $\begin{array}{l}\text { Horacio } \\
\text { Ferreira }\end{array}$ & $\begin{array}{l}1907 \\
\text { minorista } \\
\text { (Roma) }\end{array}$ & Bonifacio Ferreira & $\begin{array}{l}\text { Rosa } \\
\text { Quinteros }\end{array}$ & 1887 & & & $\begin{array}{l}\text { Cura Vicario Sta. } \\
\text { Rosa Río } 1^{\circ}\end{array}$ & \\
\hline $\begin{array}{l}\text { Libro 23, f. } \\
83\end{array}$ & $\begin{array}{l}\text { Río } 2^{\circ} \text { Curato } \\
\text { Villa del } \\
\text { Rosario } \\
\end{array}$ & $\begin{array}{l}\text { Luis Lindor } \\
\text { Ferreira }\end{array}$ & $\begin{array}{l}1915 \\
\text { Minorista }\end{array}$ & & & & & & & \\
\hline $\begin{array}{l}\text { Libro 23, } \\
\text { f.90,91 }\end{array}$ & $\begin{array}{l}\text { Río } 2^{\circ} \text { Curato } \\
\text { Villa del } \\
\text { Rosario }\end{array}$ & $\begin{array}{l}\text { Virgilio } \\
\text { Ferreira }\end{array}$ & $\begin{array}{l}1921 \\
\text { minorista } \\
1924 \text { Pbro. }\end{array}$ & & & & & & & \\
\hline $\begin{array}{l}\text { Libro 23, } \\
\text { f.97 }\end{array}$ & $\begin{array}{l}\text { Río } 2^{\circ} \text { Curato } \\
\text { Villa del } \\
\text { Rosario }\end{array}$ & $\begin{array}{l}\text { Ángel Julio } \\
\text { Ferreira }\end{array}$ & $\begin{array}{l}1924 \\
\text { minorista }\end{array}$ & & & & & & & \\
\hline $\begin{array}{l}\text { Libro 21, } \\
\text { f. } 27\end{array}$ & $\begin{array}{l}\text { Río } 2^{\circ} \text { Curato } \\
\text { Villa del } \\
\text { Rosario }\end{array}$ & $\begin{array}{l}\text { Florencio } \\
\text { Ferreira }\end{array}$ & 1912 Pbro. & & & & & & $\begin{array}{l}\text { Cura y Vicario de } \\
\text { Bell Ville }\end{array}$ & \\
\hline $\begin{array}{l}\text { Libro 21, } \\
\text { f.36 }\end{array}$ & $\begin{array}{l}\text { Río } 2^{\circ} \text { Curato } \\
\text { Villa del } \\
\text { Rosario }\end{array}$ & $\begin{array}{l}\text { Froilán } \\
\text { Ferreira }\end{array}$ & $\begin{array}{l}1916 \text { Pbro. } \\
\text { (Roma) }\end{array}$ & & & & & & $\begin{array}{l}\text { Ayudante Cura Río } \\
\text { IV }\end{array}$ & Obispo La Rioja \\
\hline $\begin{array}{l}\text { Libro 23, } \\
\text { f.10 }\end{array}$ & & $\begin{array}{l}\text { Luis R. Leal } \\
\text { Ferreira }\end{array}$ & $\begin{array}{l}1881 \\
\text { Minorista }\end{array}$ & & & & & & & Cgo. subdiácono \\
\hline Leg.24, T13 & Río $1^{\circ}$ & $\begin{array}{l}\text { Ramón } \\
\text { Amuchástegui } \\
\text { Ferreira }\end{array}$ & $\begin{array}{l}1904 \\
\text { minorista } \\
1908 \text { Pbro. }\end{array}$ & $\begin{array}{l}\text { Ramón } \\
\text { Amuchástegui }\end{array}$ & $\begin{array}{l}\text { Estaurofia } \\
\text { Ferreira }\end{array}$ & 1883 & $\begin{array}{l}\text { Ramón } \\
\text { Ferreira }\end{array}$ & $\begin{array}{l}\text { Asunción } \\
\text { Brochero }\end{array}$ & $\begin{array}{l}\text { Cura y Vicario de } \\
\text { Chalacea }\end{array}$ & \\
\hline
\end{tabular}




\begin{tabular}{|c|c|c|c|c|c|c|c|c|c|c|c|}
\hline \multicolumn{12}{|c|}{ PRESBITEROS DE LA FAMILIA LUQUE } \\
\hline $\begin{array}{l}\text { Leg.24, T7/ } \\
\text { Abel Bazán }\end{array}$ & $\begin{array}{l}\text { Río } 2^{\circ} \text { Curato } \\
\text { de Villa del } \\
\text { Rosario }\end{array}$ & David Luque & $\begin{array}{l}\text { Alumno de la } \\
\text { Universidad. No } \\
\text { ingresa al } \\
\text { Seminario } 1858 \\
\text { Presb. }\end{array}$ & Hilario Luque & $\begin{array}{l}\text { Fortunata } \\
\text { Cordero }\end{array}$ & 1828 & & & $\begin{array}{l}\text { Cgo. } \\
\text { Manuel } \\
\text { Cordero } \\
\text { (Tío) }\end{array}$ & & $\begin{array}{l}\text { Capellán del } \\
\text { Monasterio } \\
\text { Sta. Catalina } \\
\text { Prof. del } \\
\text { Seminario } \\
\text { Director } \\
\text { Conferencias } \\
\text { Vicentinas } \\
\text { Cofundador } \\
\text { de las } \\
\text { Esclavas }\end{array}$ \\
\hline Leg.24, T7 & $\begin{array}{l}\text { Córdoba, } \\
\text { ciudad }\end{array}$ & $\begin{array}{l}\text { De los reyes } \\
\text { Sarmiento } \\
\text { Luque, Manuel }\end{array}$ & $\begin{array}{l}1848 \text { Minorista } \\
1852 \text { Presb. }\end{array}$ & $\begin{array}{l}\text { Manuel } \\
\text { Sarmiento }\end{array}$ & $\begin{array}{l}\text { Concepción } \\
\text { Luque }\end{array}$ & 1824 & $\begin{array}{l}\text { José } \\
\text { Domingo } \\
\text { Allende }\end{array}$ & $\begin{array}{l}\text { Centeno, } \\
\text { Petrona }\end{array}$ & & & $\begin{array}{l}\text { Se traslada a } \\
\text { Bs As }\end{array}$ \\
\hline $\begin{array}{l}\text { Libro } 20, f \text {. } \\
36\end{array}$ & & Adolfo Luque & $\begin{array}{l}1863 \text { Minorista } \\
1863 \text { Presb }\end{array}$ & & & & & & & & \\
\hline Leg.24, T9 & $\begin{array}{l}\text { Río } 2^{\circ} \text { Curato } \\
\text { Villa del } \\
\text { Rosario }\end{array}$ & $\begin{array}{l}\text { José A. Luque } \\
\text { Ferreira }\end{array}$ & $\begin{array}{l}1876 \text { Minorista. } \\
1882 \text { Presb. }\end{array}$ & Pedro Luque & $\begin{array}{l}\text { María Jesús } \\
\text { Ferreira }\end{array}$ & 1856 & $\begin{array}{l}\text { Proceso } \\
\text { Cordero }\end{array}$ & $\begin{array}{l}\text { Magdalena } \\
\text { Ferreira }\end{array}$ & $\begin{array}{l}\text { Pbro. } \\
\text { Aquilino } \\
\text { Ferreira. }\end{array}$ & $\begin{array}{l}\text { Cura y Vicario } \\
\text { Villa del } \\
\text { Rosario }\end{array}$ & $\begin{array}{l}\text { Rector } \\
\text { Seminario. } \\
\text { Deán Cabildo. } \\
\text { Obispo Aux. } \\
\text { Córdoba }\end{array}$ \\
\hline Leg.24, T9 & $\begin{array}{l}\text { Río } 2^{\circ} \text { Curato } \\
\text { Villa del } \\
\text { Rosario }\end{array}$ & $\begin{array}{l}\text { David Luque } \\
\text { Ferreira }\end{array}$ & $\begin{array}{l}1893 \text { Minorista } \\
1893 \text { Presb. } \\
\text { (Roma) }\end{array}$ & $\begin{array}{l}\text { Samuel } \\
\text { Luque }\end{array}$ & $\begin{array}{l}\text { Cenovia } \\
\text { Ferreira }\end{array}$ & 1862 & $\begin{array}{l}\text { Ferreira, } \\
\text { Senibero }\end{array}$ & $\begin{array}{l}\text { Ferreira } \\
\text { María Jesús }\end{array}$ & $\begin{array}{l}\text { Pbro. } \\
\text { Narciso } \\
\text { González }\end{array}$ & $\begin{array}{l}\text { Cura y Vicario } \\
\text { de Ullapes }\end{array}$ & $\begin{array}{l}\text { Subsecretario } \\
\text { del Obispado }\end{array}$ \\
\hline Leg.24 & $\begin{array}{l}\text { Río } 2^{\circ} \text { Curato } \\
\text { Villa del } \\
\text { Rosario }\end{array}$ & $\begin{array}{l}\text { Ramón Gil } \\
\text { Luque }\end{array}$ & $\begin{array}{l}1876 \text { Minorista } \\
1881 \text { Presb. } \\
\text { (Roma) }\end{array}$ & Justo Luque & $\begin{array}{l}\text { Vicenta } \\
\text { Álvarez }\end{array}$ & 1856 & $\begin{array}{l}\text { Dn. Pilar } \\
\text { Luque }\end{array}$ & $\begin{array}{l}\text { Dña. Zoila } \\
\text { Álvarez }\end{array}$ & $\begin{array}{l}\text { Pbro } \\
\text { Aquilino } \\
\text { Ferreira }\end{array}$ & & $\begin{array}{l}\text { Prof. } \\
\text { Seminario } \\
\text { Fiscal Ecles. }\end{array}$ \\
\hline $\begin{array}{l}\text { Leg.24, } \\
\text { Libro } 24\end{array}$ & $\begin{array}{l}\text { Río } 2^{\circ} \text { Curato } \\
\text { Villa del } \\
\text { Rosario }\end{array}$ & $\begin{array}{l}\text { Estanislao } \\
\text { Luque }\end{array}$ & $\begin{array}{l}1878 \text { Minorita } \\
1885 \text { Presb. }\end{array}$ & Justo Luque & $\begin{array}{l}\text { Vicenta } \\
\text { Álvarez }\end{array}$ & 1858 & $\begin{array}{l}\text { Agustín } \\
\text { Álvarez }\end{array}$ & $\begin{array}{l}\text { Leocadia } \\
\text { Luque }\end{array}$ & $\begin{array}{l}\text { Pbro } \\
\text { Aquilino } \\
\text { Ferreira }\end{array}$ & $\begin{array}{l}\text { Cura y Vicario } \\
\text { Santa Rosa de } \\
\text { Río } 1^{\circ} \\
\text { Cura y Vicario } \\
\text { de Santa María }\end{array}$ & \\
\hline Leg.24, T9 & $\begin{array}{l}\text { Río } 2^{\circ} \text { Curato } \\
\text { Villa del } \\
\text { Rosario }\end{array}$ & $\begin{array}{l}\text { Nicanor } \\
\text { Sarmiento } \\
\text { Luque }\end{array}$ & & $\begin{array}{l}\text { Samuel } \\
\text { Sarmiento }\end{array}$ & $\begin{array}{l}\text { Teresa } \\
\text { Luque }\end{array}$ & 1871 & $\begin{array}{l}\text { Wenceslao } \\
\text { Ferreira }\end{array}$ & $\begin{array}{l}\text { Fortunata } \\
\text { Luque }\end{array}$ & $\begin{array}{l}\text { Pbro. } \\
\text { Aquilino } \\
\text { Ferreira }\end{array}$ & & \\
\hline Leg.24, T13 & & Domingo Luque & 1911 Presb. & & & & & & & $\begin{array}{l}\text { Cura y Vicario } \\
\text { de Totoral }\end{array}$ & \\
\hline $\begin{array}{l}\text { Libro 24, f. } \\
27\end{array}$ & & Tomas Luque & 1924 Minorista & & & & & & & $\begin{array}{l}\text { Cura y Vicario } \\
\text { Famatina }\end{array}$ & \\
\hline Libro 23, & & Juan Segundo & 1922 Presb. & & & & & & & Vic. Coop. & \\
\hline
\end{tabular}




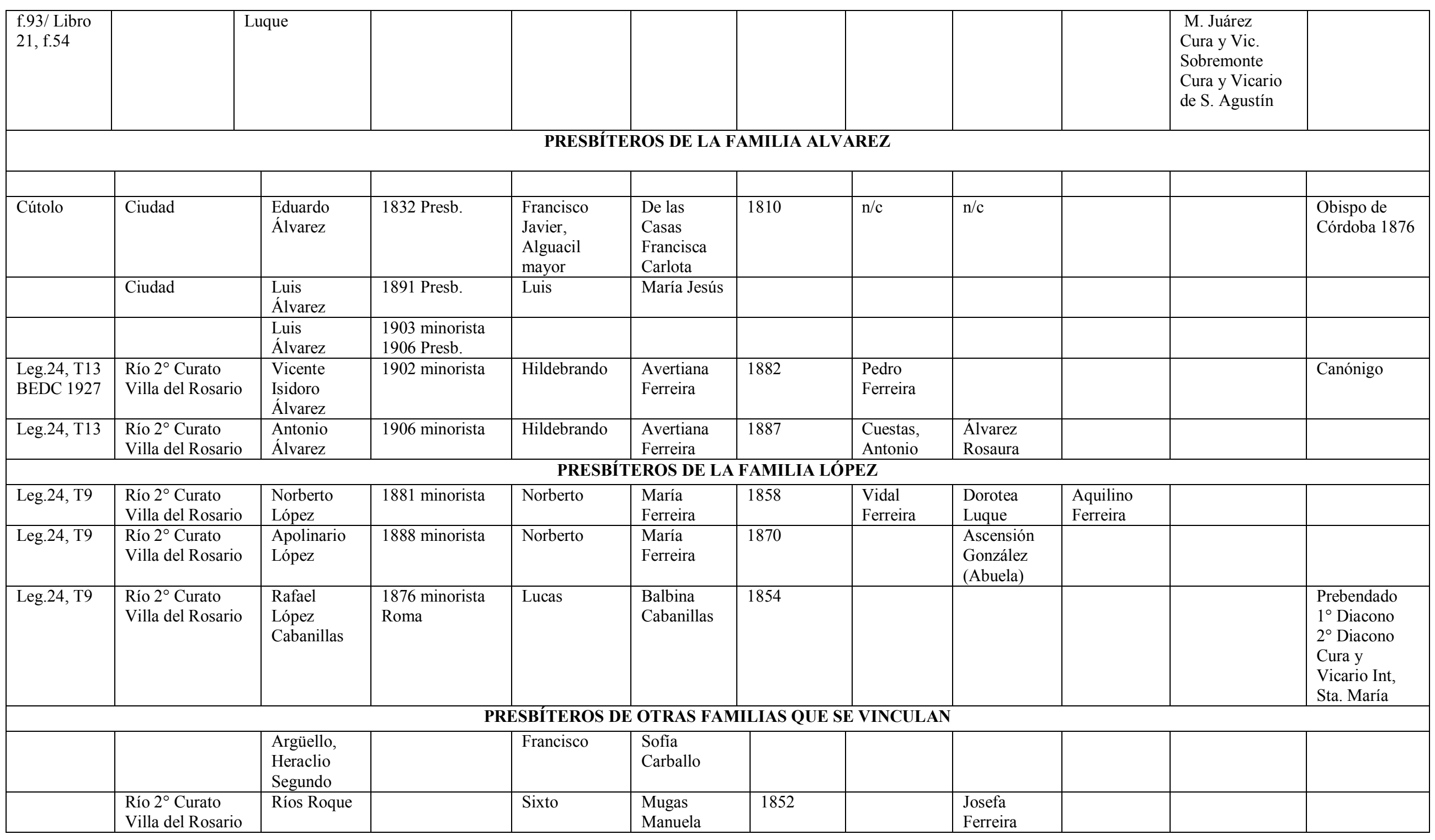




\begin{tabular}{|c|c|c|c|c|c|c|c|c|c|c|}
\hline & Córdoba, Ciudad & Ríos Alejo & & Eloy & $\begin{array}{l}\text { Encarnación } \\
\text { López }\end{array}$ & 1873 & $\begin{array}{l}\text { Hermógene } \\
\text { Ferreira }\end{array}$ & $\begin{array}{l}\text { Matilde } \\
\text { Páez }\end{array}$ & & \\
\hline & $\begin{array}{l}\text { Río } 2^{\circ} \text { Curato } \\
\text { Villa del Rosario }\end{array}$ & $\begin{array}{l}\text { Ríos } \\
\text { Laureano }\end{array}$ & & Modesto & $\begin{array}{l}\text { Presentación } \\
\text { Quiroga }\end{array}$ & & $\begin{array}{l}\text { Felipe } \\
\text { Castro }\end{array}$ & & & \\
\hline & $\begin{array}{l}\text { Río } 2^{\circ} \text { Curato } \\
\text { Villa del Rosario }\end{array}$ & $\begin{array}{l}\text { Acevedo } \\
\text { Domingo }\end{array}$ & & Agustín & $\begin{array}{l}\text { Ángela } \\
\text { Liendo }\end{array}$ & & & & $\begin{array}{l}\text { Cura y Vicario } \\
\text { del Tránsito }\end{array}$ & \\
\hline & $\begin{array}{l}\text { Santa Rosa de } \\
\text { Río } 1^{\circ}\end{array}$ & $\begin{array}{l}\text { Brochero, } \\
\text { José Gabriel }\end{array}$ & & $\begin{array}{l}\text { Ignacio } \\
\text { Brochero }\end{array}$ & Josefa Dávila & $17 / 03 / 847$ & $\begin{array}{l}\text { Manuel } \\
\text { Antonio } \\
\text { Ceballos }\end{array}$ & $\begin{array}{l}\text { Josefa } \\
\text { Dávila }\end{array}$ & & \\
\hline BEC 1931 & $\begin{array}{l}\text { Santa Rosa de } \\
\text { Río } 1^{\circ}\end{array}$ & $\begin{array}{l}\text { Dávila y } \\
\text { Matos } \\
\text { Inocencio }\end{array}$ & 1897 Presb. & & & & & & $\begin{array}{l}\text { Cura y Vicario } \\
\text { Tulumba }\end{array}$ & $\begin{array}{l}\text { Rector } \\
\text { Seminario } \\
\text { Canónigo } \\
\text { teologal. } \\
\text { Obispo de } \\
\text { Catamarca }\end{array}$ \\
\hline
\end{tabular}

Fuentes: Expedientes de Ordenes, Leg.24, tomos 7,8,9,10,11,12; Libro 23, Ordenes, 1876-1926; Libro 20, Títulos del Clero, 1854-1904; Libro 21, Títulos del Clero, 1905-1927; Libro 24, Registro de Sacerdotes Seculares, 1905-1909; Libro 30, Licencias Ministeriales, 1859-1932; Parroquias de Córdoba del padre Liendo. 


\begin{tabular}{|c|c|c|c|c|c|c|c|c|c|c|}
\hline \multicolumn{11}{|c|}{$\begin{array}{c}\text { TABLA } 18 \\
\text { Clero extra diocesano inmigrante, } 1875-1925\end{array}$} \\
\hline $\mathbf{N}^{\circ}$ & Apellido & Nombre & Nacionalidad & $\begin{array}{l}\text { Diócesis } \\
\text { propia }\end{array}$ & $\begin{array}{l}\text { Arribo } \\
\text { año }\end{array}$ & $\begin{array}{c}\text { Primer } \\
\text { nombra- } \\
\text { miento }\end{array}$ & $\begin{array}{l}\text { Primera } \\
\text { licencia }\end{array}$ & $\begin{array}{c}\text { Ultimo } \\
\text { registro }\end{array}$ & $\begin{array}{c}\text { Salida/ } \\
\text { fallecimiento }\end{array}$ & Fuente/ folio \\
\hline 1 & Abriola & Luis & Italiano & & 1874 & 1876 & & 1899 & $+26 / 10 / 1903$ & $\begin{array}{l}\text { AAC. Títulos (1859-1904), } \\
\text { f.62/ Licencias Ministeriales, } \\
\text { 1859-1932, f.86 }\end{array}$ \\
\hline 2 & Alberti & Juan Pedro & Italiano & Napolitano & 1897 & 1899 & & 1899 & 1899 & $\begin{array}{l}\text { AAC. Lic. Min., 1859-1932 } \\
\text { f. } 273 / \text { Leg. } 51 \mathrm{~s} / \mathrm{f}\end{array}$ \\
\hline 3 & Aleña & Narciso & Español & $\mathrm{n} / \mathrm{c}$ & 1914 & no & 1914 & 1916 & & $\begin{array}{l}\text { AAC. Lic. Min., 1859-1932, } \\
\text { f.363/Parroquias, San } \\
\text { Francisco, s/f. Nota del } \\
11 / 06 / 1916\end{array}$ \\
\hline 4 & Alladío & José & Italiano & $\mathrm{n} / \mathrm{c}$ & 1913 & 1913 & & 1922 & & AAC. Parroquias Oliva \\
\hline 5 & Allegro & Alberto & Italiano & $\begin{array}{l}\text { Colta, } \\
\text { Canónigo } \\
\text { Honorario } \\
\text { de aquella } \\
\text { catedral }\end{array}$ & 1889 & 1889 & & 1892 & $\begin{array}{l}1892 . \\
\text { Expulsado de } \\
\text { la diócesis }\end{array}$ & $\begin{array}{l}\text { AAC. Títulos (1859-1904), } \\
\text { f.93/Lic. Min., 1859-1932, f. } \\
\text { 249 /Copiador de cartas, } \\
\text { 1889-1893, f.33 }\end{array}$ \\
\hline 6 & Alonzo Prado & Juan & Español & Granada & 1892 & 1892 & & 1905 & & $\begin{array}{l}\text { AAC. Lic. Min., 1859-1932, } \\
\text { f.254/AAC. Títulos (1859- } \\
\text { 1904), f.97 }\end{array}$ \\
\hline 7 & Ametha Planell & José & Español & Barcelona & 1874 & 1874 & & 1902 & +1902 & $\begin{array}{l}\text { AAC. Lic. Min. 1859-1932, } \\
\text { fs. 86,116,131,244; AAC. } \\
\text { Títulos (1859-1904), f.56,76 }\end{array}$ \\
\hline 8 & Anglada & Pedro & Español & $\begin{array}{l}\text { Calahorra } \\
\text { y Calzada }\end{array}$ & 1878 & sí & & 1885 & & $\begin{array}{l}\text { AAC. Títulos, 1859-1904, } \\
\text { f.67/ Lic. Min., 1859-1932, } \\
\text { f.113 y } 400\end{array}$ \\
\hline 9 & Añan & José & $\mathrm{n} / \mathrm{c}$ & & 1889 & 1889 & & 1891 & & $\begin{array}{l}\text { AAC. Lic. Min., 1859-1932, } \\
\text { f. } 224\end{array}$ \\
\hline 10 & Aramiz y Mata & Aniceto & Español & Burgos & 1906 & 1907 & & 1908 & & $\begin{array}{l}\text { AAC. Lic. Min., 1859-1932, } \\
\text { f.295/Títulos (1905-1927), } \\
\text { f.7 }\end{array}$ \\
\hline 11 & Armesto & Arcángel & Español & & 1872 & 1877 & & 1878 & & \\
\hline 12 & Arnedo & Domingo & Español & Granada & 1899 & 1899 & & 1911 & 1911 & AAC. Registro Sacerdotes \\
\hline
\end{tabular}




\begin{tabular}{|c|c|c|c|c|c|c|c|c|c|c|}
\hline & & & & & & & & & APOSTATÓ & $\begin{array}{l}\text { seculares, 1905-1909, f. 55/ } \\
\text { Títulos, 1859-1904, f.107, } \\
\text { 112/ Lic. Min., 1859-1932, } \\
\text { f.342 }\end{array}$ \\
\hline 13 & Asenzza & Rafael & Italiano & $\begin{array}{l}\text { Noto } \\
\text { (Sicilia) }\end{array}$ & 1923 & 1923 & & 1927 & & $\begin{array}{l}\text { AAC. Registro de sacerdotes } \\
\text { extra-diocesanos, f.75/ } \\
\text { Títulos 1905-1927, f.62/ } \\
\text { Registro de Firmas de } \\
\text { sacerdotes y religiosos }\end{array}$ \\
\hline 14 & Baca & José & Italiano & Torino & 1921 & 1922 & & 1927 & & $\begin{array}{l}\text { AAC. Registro de sacerdotes } \\
\text { extra-diocesanos/Títulos } \\
\text { 1905-1927, f.50 }\end{array}$ \\
\hline 15 & Balbín & $\begin{array}{l}\text { Victorico } \\
\text { Ramón }\end{array}$ & Español & Oviedo & 1922 & 1924 & & 1925 & & $\begin{array}{l}\text { AAC. Registro de sacerdotes } \\
\text { extra-diocesanos, f. 97/ } \\
\text { Títulos 1905-1927, f.66 }\end{array}$ \\
\hline 16 & Basso & Guillermo & Italiano & $\begin{array}{l}\text { Cesena, } \\
\text { Emilia } \\
\text { Romagna }\end{array}$ & 1905 & 1917 & & 1926 & & $\begin{array}{l}\text { AAC. Registro de sacerdotes } \\
\text { extra-diocesanos, f.5/Títulos } \\
\text { 1905-1927, f.34/ Registro de } \\
\text { firmas }\end{array}$ \\
\hline 17 & Beresaluge & Caetano & Español & Orihuela & 1911 & no & 1911 & 1911 & & $\begin{array}{l}\text { AAC. Lic. Minis., 1859- } \\
\text { 1932, f.341 }\end{array}$ \\
\hline 18 & Berga & Máximo & Italiano & Turín & 1900 & no & 1905 & 1905 & $25 / 10 / 1905$ & $\begin{array}{l}\text { AAC. Parroquias, Freyre } \\
\text { f. } 120\end{array}$ \\
\hline 19 & Berthardth & Cipriano & otro & & 1888 & no & & 1888 & suspenso & AAC. Títulos, 1859-1904 \\
\hline 20 & Berthons & Pedro & $\mathrm{n} / \mathrm{c}$ & & 1907 & no & 1907 & 1910 & & $\begin{array}{l}\text { AAC. Notas de secretaría, } \\
1885-1913, \text { f.129 }\end{array}$ \\
\hline 21 & Bidone & Luis & Italiano & & 1908 & no & 1908 & 1909 & & $\begin{array}{l}\text { AAC. Registro de firmas... } \\
\text { Lic. Minis., 1859-1932, } \\
\text { f.313, } 317,324\end{array}$ \\
\hline 22 & Bolfa & Angel $\mathrm{P}$. & Argentino & Cuyo & 1871 & no & 1871 & 1876 & & $\begin{array}{l}\text { AAC. Lic. Minis., 1859- } \\
\text { 1932, f.67 }\end{array}$ \\
\hline 23 & Bonoris & José & Italiano & Ultinensis & 1880 & sí & & 1891 & $+26 / 07 / 1891$ & $\begin{array}{l}\text { AAC. Lic. Minis., 1859- } \\
\text { 1932, f 193/Títulos, 1859- } \\
\text { 1904, f.105 }\end{array}$ \\
\hline 24 & Bonoris & Santiago & Italiano & Ultinensis & 1880 & no & sí & 1904 & +1904 & \\
\hline 25 & Borrás & José & Español & $\begin{array}{l}\text { viste por } \\
\text { devoción }\end{array}$ & 1873 & 1873 & & 1885 & $+14 / 08 / 1885$ & $\begin{array}{l}\text { AAC. Lic. Minis.,1859- } \\
\text { 1936, f 135/Títulos 1859- }\end{array}$ \\
\hline
\end{tabular}




\begin{tabular}{|c|c|c|c|c|c|c|c|c|c|c|}
\hline & & & & $\begin{array}{l}\text { el hábito } \\
\text { de la } \\
\text { Merced }\end{array}$ & & & & & & 1904, f.55 \\
\hline 26 & Botta & Angel & Italiano & Aquinaga & 1898 & 1898 & & 1920 & $+31 / 08 / 1948$ & $\begin{array}{l}\text { AAC. Títulos, 1859-1904, } \\
\text { f.106 }\end{array}$ \\
\hline 27 & Botta & $\begin{array}{l}\text { Miguel } \\
\text { Angel }\end{array}$ & Italiano & $\begin{array}{l}\text { Saluzzo } \\
\text { (Piamonte) }\end{array}$ & 1920 & 1920 & & 1927 & & $\begin{array}{l}\text { AAC. Registro de sacerdotes } \\
\text { extra-diocesanos f.59 } \\
\text { /Parroquias. Villa María s/f }\end{array}$ \\
\hline 28 & Boy & Pablo & $\mathrm{n} / \mathrm{c}$ & & 1878 & 1879 & & 1889 & & \\
\hline 29 & Bravo & Antonio & $\begin{array}{l}\text { Argentino, } \\
\text { Santiago del } \\
\text { Estero }\end{array}$ & $\begin{array}{l}\text { Santiago } \\
\text { del Estero }\end{array}$ & 1914 & 1921 & & & $\begin{array}{l}\text { 1908: Se fue a } \\
\text { Santiago del } \\
\text { Estero sin } \\
\text { avisar a nadie } \\
\text { porque veía } \\
\text { inminente su } \\
\text { relevo }\end{array}$ & $\begin{array}{l}\text { AAC. Títulos, 1905-1927, } \\
\text { f.44/Lic. Minis., 1859-1932, } \\
\text { f.362,364,368,374,377,380/ } \\
\text { REOBA (1908: 227) }\end{array}$ \\
\hline 30 & Cagnina & Cayetano & Italiano & $\begin{array}{l}\text { Caltamisea } \\
\text { Sicilia }\end{array}$ & 1898 & 1903 & 1898 & 1925 & +1953 & $\begin{array}{l}\text { AAC. Registro de sacerdotes } \\
\text { extra-diocesanos, f.11/ } \\
\text { Títulos, 1859-1904, f.113 }\end{array}$ \\
\hline 31 & Cala & Pedro & Italiano & & 1900 & 1901 & no & 1902 & 1902 & $\begin{array}{l}\text { AAC. Títulos, 1859-1904, } \\
\text { f.110 }\end{array}$ \\
\hline 32 & Calabreses & Juan & Italiano & & 1900 & 1900 & & 1904 & $\begin{array}{l}21 / 05 / 1904 \\
\text { La pro-templo } \\
\text { informa que el } \\
\text { cura notificó } \\
\text { que se retiraba } \\
\text { de los oficios } \\
\text { eclesiásticos }\end{array}$ & $\begin{array}{l}\text { AAC. Títulos, 1859-1904, } \\
\text { f.108/ Leg.49, San } \\
\text { Francisco, s/f }\end{array}$ \\
\hline 33 & Carabasa & $\begin{array}{l}\text { Hilario } \\
\text { Benito }\end{array}$ & Italiano & & 1893 & 1893 & & 1893 & & $\begin{array}{l}\text { AAC. Títulos, 1859-1904, f. } \\
100\end{array}$ \\
\hline 34 & Carcavale & Amado & Italiano & $\begin{array}{l}\text { Gaeta } \\
\text { (Lacio) }\end{array}$ & 1910 & 1921 & 1925 & 1925 & & $\begin{array}{l}\text { AAC. Registro de sacerdotes } \\
\text { extra diocesanos/ Libro de } \\
\text { Títulos, 1905-1927, f.46 }\end{array}$ \\
\hline 35 & Cardinali & José & Italia & & $\begin{array}{l}1860 \text { se } \\
\text { retira a } \\
\text { Salta } \\
1865\end{array}$ & 1864 & & & $\begin{array}{l}29 / 09 / 1865 \mathrm{se} \\
\text { le admitió la } \\
\text { renuncia } \\
\text { permitiéndole }\end{array}$ & $\begin{array}{l}\text { AAC. Títulos, 1859-1904, } \\
\text { f.39 }\end{array}$ \\
\hline
\end{tabular}




\begin{tabular}{|c|c|c|c|c|c|c|c|c|c|c|}
\hline & & & & & & & & & $\begin{array}{l}\text { pasar al } \\
\text { obispado de } \\
\text { Salta }\end{array}$ & \\
\hline 36 & Carles & José & Español & Español? & 1906 & 1907 & 1906 & 1907 & & $\begin{array}{l}\text { AAC. Títulos, 1905-1927, } \\
\text { f.7 /Lic. Minis., 1859-1932, } \\
\text { f. } 297\end{array}$ \\
\hline 37 & Cassaso & $\begin{array}{l}\text { José } \\
\text { Arnaudo }\end{array}$ & Italiano & Como & 1914 & 1916 & 1814 & 1927 & & $\begin{array}{l}\text { AAC. Registro de sacerdotes } \\
\text { extra-diocesanos/ Títulos, } \\
\text { 1905-1927, f. } 33 \text { y } 46\end{array}$ \\
\hline 38 & Castellini & José & Italiano & & 1900 & sí & 1900 & 1904 & +1904 & $\begin{array}{l}\text { AAC. Leg.47 / Títulos, } \\
\text { 1859-1904, f.108 }\end{array}$ \\
\hline 39 & Caubejans & Modesto & Español & Barcelona & 1909 & 1909 & 1909 & 1918 & $\begin{array}{l}\text { Cura de La } \\
\text { Rioja; } 1909 \\
\text { Cura de } \\
\text { Salsacate }\end{array}$ & $\begin{array}{l}\text { AAC. Cajas Parroquias, } \\
\text { Salsacate, f.171. ASV, Libro } \\
\text { 67. Nunciatura, 1916-1922, } \\
\text { f.514 }\end{array}$ \\
\hline 40 & Caviglia & Pedro & Italiano & Savonna & 1918 & 1918 & 1918 & 1927 & & \\
\hline 41 & Cimino & & Italiano & & 1901 & 1901 & & 1901 & & $\begin{array}{l}\text { AAC. Lic. Minis., 1859- } \\
\text { 1932, f.378 }\end{array}$ \\
\hline 42 & Cinotto & Juan & Italiano & Torino & 1903 & 1905 & & 1925 & +1954 & \\
\hline 43 & Colabianchi & Valeriano & Italiano & & 1902 & 1912 & 1902 & 1912 & & $\begin{array}{l}\text { AAC. Registro de sacerdotes } \\
\text { extra-diocesanos, f.13/ } \\
\text { Títulos, 1905-1927, f.2 }\end{array}$ \\
\hline 44 & Coll & Rafael & Español & & 1903 & 1903 & & 1909 & & $\begin{array}{l}\text { AAC. Títulos, 1859-1904, } \\
\text { f.111 }\end{array}$ \\
\hline 45 & Cornet & Lorenzo & Español & & 1912 & 1913 & 1912 & 1913 & & $\begin{array}{l}\text { AAC. Títulos, 1859-1904, } \\
\text { f.113 }\end{array}$ \\
\hline 46 & Coronado & Juan & Español & & 1911 & 1918 & 1911 & 1920 & & $\begin{array}{l}\text { AAC. Títulos, 1905-1927, } \\
\text { f. } 23\end{array}$ \\
\hline 47 & Coronado & Severiano & Español & & 1911 & 1913 & 1911 & 1920 & $1920 ?$ & \\
\hline 48 & Coto & Manuel & Español & Cuyo & 1892 & 1895 & 1892 & 1912 & 1912 & $\begin{array}{l}\text { AAC. Títulos, 1905-1927, } \\
\text { f.25 /Registro de firmas... }\end{array}$ \\
\hline 49 & Coutino & Feliciano & Portugués & & 1862 & 1862 & & 1863 & & $\begin{array}{l}\text { AAC. Títulos, 1859-1904, } \\
\text { f.102/ Lic. Minis., 1859- } \\
\text { 1932, f.252, } 256\end{array}$ \\
\hline 50 & Cravero & Francisco & Español & & 1901 & 1901 & & 1908 & & AAC. Parroquias \\
\hline
\end{tabular}




\begin{tabular}{|c|c|c|c|c|c|c|c|c|c|c|}
\hline 51 & Cuadrado & $\begin{array}{l}\text { Julián } \\
\text { Arturo }\end{array}$ & Español & Salamanca & 1925 & no & 1925 & 1927 & & $\begin{array}{l}\text { AAC. Títulos, 1859-1904, } \\
\text { f.110 }\end{array}$ \\
\hline 52 & Cuadrelli & Pablo & Italiano & & 1923 & 1923 & & 1927 & & $\begin{array}{l}\text { AAC. Lic. Minis., 1859- } \\
\text { 1932, f. } 398\end{array}$ \\
\hline 53 & Cúneo & Celestino & Italiano & Montevide & 1925 & no & 1925 & 1927 & & $\begin{array}{l}\text { AAC. Títulos, 1905-1927, } \\
\text { f.56 }\end{array}$ \\
\hline 54 & D'agnilli & Francisco & Italiano & Trienti & 1877 & no & 1877 & 1888 & & $\begin{array}{l}\text { AAC. Lic.Minis., 1859- } \\
\text { 1932, f. } 396\end{array}$ \\
\hline 55 & De Diego & José & Italiano & $\begin{array}{l}\text { Cassano } \\
\text { (Calabria) }\end{array}$ & 1887 & no & 1918 & 1918 & & $\begin{array}{l}\text { AAC. Lic. Minis., 1859- } \\
\text { 1932, f.99 }\end{array}$ \\
\hline 56 & Deogracias & Monisgnor & Italiano & & & no & no & 1908 & $\begin{array}{l}1908 \\
\text { suspenso }\end{array}$ & $\begin{array}{l}\text { AAC. Registro de sacerdotes } \\
\text { extra-diocesanos. f. } 21\end{array}$ \\
\hline 57 & Desmonto & Julio & Italiano & & 1894 & no & 1894 & 1894 & & $\begin{array}{l}\text { AAC. Lic. Minis., 1859- } \\
\text { 1932, f.290, } 307\end{array}$ \\
\hline 58 & Di Bella & Javier & Italiano & Trofea & 1908 & 1911 & & 1928 & & $\begin{array}{l}\text { AAC. Lic. Minis. 1859- } \\
\text { 1932, f.266 }\end{array}$ \\
\hline 59 & Di Galileo & Monsignor & Italiano & & 1909 & 1909 & no & & Laboulaye & $\begin{array}{l}\text { AAC. Registro de sacerdotes } \\
\text { extra-diocesanos, f. } 15\end{array}$ \\
\hline 60 & Di Lorenzo & $\begin{array}{l}\text { Pablo } \\
\text { Emilio }\end{array}$ & Italiano & & 1897 & no & 1897 & 1897 & & $\begin{array}{l}\text { AAC. Títulos,1905-1927, f. } \\
11\end{array}$ \\
\hline 61 & Di Paola & Gregorio & Italiano & Trivente & 1878 & no & no & 1879 & & $\begin{array}{l}\text { AAC. Lic. Minis., 1859- } \\
\text { 1932, f.273 }\end{array}$ \\
\hline 62 & Di Stasio & Roque & Italiano & & 1913 & no & no & 1913 & & $\begin{array}{l}\text { AAC. Lic. Minis., 1859- } \\
\text { 1932, f.116 }\end{array}$ \\
\hline 63 & Díaz & $\begin{array}{l}\text { Issac } \\
\text { Miguel }\end{array}$ & Español & Burgos & 1881 & no & 1881 & 1881 & & AAC. Parroquias Oliva \\
\hline 64 & Díaz & Reyes & Español & & 1887 & no & 1887 & 1888 & & $\begin{array}{l}\text { AAC. Lic. Minis., 1859- } \\
\text { 1932, f.151 }\end{array}$ \\
\hline 65 & Dilianoff & Cipriano & Búlgaro & Bulgaria & 1923 & 1924 & & 1925 & & \\
\hline 66 & Fabiani & Miguel & $\mathrm{n} / \mathrm{c}$ & & 1894 & no & 1894 & 1894 & & $\begin{array}{l}\text { AAC. Títulos, 1859-1904, f. } \\
35\end{array}$ \\
\hline 67 & Falcone & Francisco & Italiano & $\begin{array}{l}\text { Conversan } \\
\text { Puglia (sur } \\
\text { de Italia) }\end{array}$ & 1910 & 1911 & 1911 & 1925 & & \\
\hline 68 & Falorni & Fernando & Italiano & & 1863 & & & $1892 ?$ & & $\begin{array}{l}\text { AAC. Registro de sacerdotes } \\
\text { extra diocesanos, f. } 23\end{array}$ \\
\hline
\end{tabular}




\begin{tabular}{|c|c|c|c|c|c|c|c|c|c|c|}
\hline 69 & $\begin{array}{l}\text { Fernández } \\
\text { Monje }\end{array}$ & Rafael & Español & Calahorra & 1914 & no & 1914 & 1927 & $\begin{array}{l}1922 \text { regresó } \\
\text { a España }\end{array}$ & \\
\hline 70 & Fernández & Manuel & Español & & 1921 & sí & 1921 & 1927 & & $\begin{array}{l}\text { AAC. Registro de sacerdotes } \\
\text { extra diocesanos, f. } 83\end{array}$ \\
\hline 71 & $\begin{array}{l}\text { Fernández } \\
\text { Gobeo }\end{array}$ & & $\begin{array}{l}\text { Español ex } \\
\text { mercedario }\end{array}$ & 1873 & 1876 & 1873 & 1889 & & & $\begin{array}{l}\text { AAC. Registro de sacerdotes } \\
\text { extra diocesanos, f. } 95\end{array}$ \\
\hline 72 & $\begin{array}{l}\text { Fernández } \\
\text { Manzanera }\end{array}$ & Juan & Español & $\begin{array}{l}\text { Carlojera? } \\
\text { España }\end{array}$ & 1908 & no & 1908 & 1908 & & \\
\hline 73 & Ferrer y Arce & Eduardo & Español & $\begin{array}{l}\text { Calahorra } \\
\text { y Calzada }\end{array}$ & 1910 & 1911 & 1910 & 1910 & & $\begin{array}{l}\text { AAC. Lic. Minis., 1859- } \\
\text { 1932, f.309 }\end{array}$ \\
\hline 74 & Ferrero & Francisco & Italiano & $\begin{array}{l}\text { Pinerolo } \\
\text { (Piamonte) }\end{array}$ & 1894 & 1897 & & 1923 & $+06 / 12 / 1923$ & $\begin{array}{l}\text { AAC. Títulos, 1905-1927, f. } \\
\text { 20/ Lic. Minist., 1859-1932, } \\
\text { f.333 }\end{array}$ \\
\hline 75 & Ferreyra & $\begin{array}{l}\text { Andrés } \\
\text { Avelino }\end{array}$ & Español & Barcelona & 1900 & sí & & 1900 & & $\begin{array}{l}\text { AAC. Registro de sacerdotes } \\
\text { extra-diocesanos, f.25/ } \\
\text { Títulos, 1905-1927, f.63 }\end{array}$ \\
\hline 76 & Ferreyra & Florencio & Español & Mallorca & 1914 & 1914 & & 1914 & & $\begin{array}{l}\text { AAC. Títulos, 1859-1904, } \\
\text { f.108 }\end{array}$ \\
\hline 77 & Fiuza Varas & Tomás & Español & $\begin{array}{l}\text { Incardinao } \\
\text { Santiago } \\
\text { de Chile }\end{array}$ & 1924 & 1924 & & 1927 & & $\begin{array}{l}\text { AAC. Lic. Minis., 1859- } \\
\text { 1932, f.69 }\end{array}$ \\
\hline 78 & Fraiz Troitiño & Serafino & Portugués & & 1900 & 1900 & & 1900 & & $\begin{array}{l}\text { AAC. Registro de sacerdotes } \\
\text { extra-diocesanos, f. } 107\end{array}$ \\
\hline 79 & Frizzotti & Luis & Italiano & & 1902 & no & 1908 & 1908 & & $\begin{array}{l}\text { AAC. Parroquias, V. } \\
\text { Concepción del Tío }\end{array}$ \\
\hline 80 & Gagliardi & José & Italiano & & 1902 & 1902 & & 1902 & & $\begin{array}{l}\text { AAC. Lic. Minis., 1859- } \\
\text { 1932, f.316 }\end{array}$ \\
\hline 81 & Gaino & Atilio & Italiano & $\begin{array}{l}\text { Acqui } \\
\text { (Piamonte) }\end{array}$ & 1914 & 1915 & & 1926 & $00 / 10 / 1926$ & $\begin{array}{l}\text { AAC. Títulos, 1859-1904, } \\
\text { f.111 }\end{array}$ \\
\hline 82 & Gambini & Fortunato & Italiano & $\begin{array}{l}\text { Pescia } \\
\text { (Toscana) }\end{array}$ & 1901 & 1909 & & 1924 & $+22 / 11 / 1924$ & $\begin{array}{l}\text { AAC. Registro de sacerdotes } \\
\text { extra diocesanos, f. 27/ } \\
\text { Parroquias Porteña }\end{array}$ \\
\hline 83 & García & José & $\mathrm{n} / \mathrm{c}$ & & 1906 & 1906 & & 1907 & & $\begin{array}{l}\text { AAC. Registro de sacerdotes } \\
\text { extra-diocesanos, f. } 19 \text { / } \\
\text { REDC n }{ }^{\circ}\end{array}$ \\
\hline 84 & García & Ulpiano & Español & & 1915 & 1915 & & 1915 & & \\
\hline 85 & García Lerma & Dolores & Español & & 1872 & no & 1872 & 1872 & & AAC. Títulos, 1905-1927, \\
\hline
\end{tabular}




\begin{tabular}{|c|c|c|c|c|c|c|c|c|c|c|}
\hline & & & & & & & & & & f.32 \\
\hline 86 & $\begin{array}{l}\text { García de la } \\
\text { Serna }\end{array}$ & Doroteo & Español & Cuenca & 1873 & 1873 & & 1881 & +1881 & \\
\hline 87 & García Morón & Emilio & Español & & 1904 & 1904 & & 1906 & & $\begin{array}{l}\text { AAC. Títulos, 1859-1904, } \\
\text { f.62 y } 69\end{array}$ \\
\hline 88 & García Pedrosa & Antonio & Español & & 1872 & 1872 & 1872 & 1876 & & $\begin{array}{l}\text { AAC. Títulos, 1859-1904, } \\
\text { f.115 }\end{array}$ \\
\hline 89 & García Soriano & Carmelo & Español & Orihuela & 1921 & no & 1921 & 1921 & & \\
\hline 90 & Gattin & Delfino & Español & & 1877 & no & 1877 & 1877 & & $\begin{array}{l}\text { AAC. Registro de sacerdotes } \\
\text { extra diocesanos, f. } 103\end{array}$ \\
\hline 91 & Gherica & Bonifacio & Italiano & & 1874 & & & 1885 & $28 / 11 / 885$ & \\
\hline 92 & Ghersi & José & Italiano & & 1905 & 1905 & & 1916 & & \\
\hline 93 & Gianchetti & Enrique & Italiano & $\begin{array}{l}\text { Camerino } \\
\text { (Marcas) }\end{array}$ & 1911 & no & no & 1911 & & $\begin{array}{l}\text { AAC. Títulos, 1905-1927, } \\
\text { f.3 y } 33\end{array}$ \\
\hline 94 & Gil & Máximo & Español & Segovia & 1883 & no & & 1883 & & $\begin{array}{l}\text { AAC. Registro de sacerdotes } \\
\text { extra diocesanos, f. } 83\end{array}$ \\
\hline 95 & Gil López & $\begin{array}{l}\text { Antonio/ } \\
\text { Andrés }\end{array}$ & Español & & 1879 & 1879 & & 1881 & & $\begin{array}{l}\text { AAC. Lic. Minis., 1859- } \\
\text { 1932, f.192 }\end{array}$ \\
\hline 96 & Giorgini & José & Italiano & $\begin{array}{l}\text { Fermo } \\
\text { (Marcas) }\end{array}$ & 1908 & 1909 & & 1923 & $\begin{array}{l}1923 \text { regresa a } \\
\text { Italia }\end{array}$ & \\
\hline 97 & $\begin{array}{l}\text { Gómez Laín } \\
\text { (Yacin?) Juan }\end{array}$ & Juan & Español & & 1912 & no & 1921 & 1921 & & $\begin{array}{l}\text { AAC. Registro de sacerdotes } \\
\text { extra diocesanos, f.29/ Lic. } \\
\text { Minis., 1859-1932, f.318 }\end{array}$ \\
\hline 98 & Gomila Benegas & Juan & Español & Menorca & 1921 & no & no & 1927 & & \\
\hline 99 & Grosso & $\begin{array}{l}\text { Miguel } \\
\text { Ángel }\end{array}$ & Italiano & $\begin{array}{l}\text { Torino } \\
\text { (Piamonte) }\end{array}$ & 1921 & no & 1925 & 1925 & & $\begin{array}{l}\text { AAC. Registro de sacerdotes } \\
\text { extra diocesanos, f.93 }\end{array}$ \\
\hline 100 & Guarino & José & $\mathrm{n} / \mathrm{c}$ & secularizad & 1872 & 1873 & 1872 & 1878 & & $\begin{array}{l}\text { AAC. Registro de sacerdotes } \\
\text { extra diocesanos, f.81/ Parr. } \\
\text { Las Varillas, f. } 73\end{array}$ \\
\hline 101 & Guerra & Domingo & Italiano & ex jesuita & 1867 & sí & & 1901 & & \\
\hline
\end{tabular}




\begin{tabular}{|c|c|c|c|c|c|c|c|c|c|c|}
\hline 102 & Guida Francisco & Italiano & & 1893 & no & no & 1893 & & & $\begin{array}{l}\text { AAC. Títulos,1859-1904, } \\
\text { f.40 }\end{array}$ \\
\hline 103 & Ibladi & José & Italiano & Aquilia & 1881 & no & 1881 & 1881 & & \\
\hline 104 & Kurtchen & Teodoro & Otro & & 1879 & no & 1879 & 1888 & & $\begin{array}{l}\text { AAC. Lic. Minis., 1859- } \\
\text { 1932, f.146 }\end{array}$ \\
\hline 105 & Lamónaca & Antonio & Italiano & $\begin{array}{l}\text { Sansevero } \\
\text { Puglia }\end{array}$ & 1909 & 1910 & & 1922 & $+26 / 07 / 1922$ & \\
\hline 106 & Larrea & Alberto & Uruguay & Montevide & 1908 & 1918 & 1908 & 1927 & & $\begin{array}{l}\text { AAC. Registro de sacerdotes } \\
\text { extra diocesanos, f.31/ } \\
\text { Registro de firmas... }\end{array}$ \\
\hline 107 & Latella & Donato & Italiano & Ascenza & 1876 & no & 1878 & & & Lic.Minis. 1859-1932, f 309 \\
\hline 108 & Lavant Ros & $\begin{array}{l}\text { Juan } \\
\text { Bautista }\end{array}$ & Italiano & Torino & 1901 & 1901 & & 1915 & & \\
\hline 109 & Leoncini & $\begin{array}{l}\text { Juan } \\
\text { Francisco }\end{array}$ & Italiano & $\begin{array}{l}\text { Acqui } \\
\text { (Piamonte) }\end{array}$ & 1907 & 1908 & & 1928 & & $\begin{array}{l}\text { AAC. Fondo Zenón Bustos } \\
\text { Caja 3, f. } 947 \text { y ss/Títulos } \\
\text { 1905-1927, f.12/ Lic. } \\
\text { Minist., 1859-1932, f.323 }\end{array}$ \\
\hline 110 & Lima & Antonio & Portugués & Portugal & 1867 & 1867 & & 1882 & 1882 & $\begin{array}{l}\text { AAC. Lic. Minis., 1859- } \\
\text { 1932, f.277 }\end{array}$ \\
\hline 111 & Llabres & $\begin{array}{l}\text { Angel } \\
\text { Antonio }\end{array}$ & Español & Mallorca & 1911 & 1915 & 1911 & 1929 & & $\begin{array}{l}\text { AAC. Títulos, 1859-1904, } \\
\text { f.43/E1 Progreso, 28/08/1878 }\end{array}$ \\
\hline 112 & $\begin{array}{l}\text { López } \\
\text { Fernández }\end{array}$ & Deogracias & Español & $\begin{array}{l}\text { Calahorra- } \\
\text { La Calzada }\end{array}$ & 1925 & no & 1925 & 1927 & & $\begin{array}{l}\text { AAC. Registro de sacerdotes } \\
\text { extra diocesanos, f.17/Lic. } \\
\text { Minist., 1859-1932, f.332 y } \\
333\end{array}$ \\
\hline 113 & $\begin{array}{l}\text { López } \\
\text { Fernández }\end{array}$ & José & Español & Uruguay & 1881 & no & 1881 & 1885 & & $\begin{array}{l}\text { AAC. Registro de sacerdotes } \\
\text { extra diocesanos, f.105/ Lic. } \\
\text { Minist., 1859-1932, f.397 }\end{array}$ \\
\hline 114 & Lorenzo & Emilio & $\mathrm{n} / \mathrm{c}$ & & 1900 & no & no & 1900 & & $\begin{array}{l}\text { AAC. Lic. Minist., 1859- } \\
\text { 1932, f.154 y 199/Títulos }\end{array}$ \\
\hline
\end{tabular}




\begin{tabular}{|c|c|c|c|c|c|c|c|c|c|c|}
\hline & & & & & & & & & & 1859-1904, f.88 y 94 \\
\hline 115 & Losmo & Domingo & Italiano & Génova & 1899 & no & no & 1902 & Mayo de 1902 & \\
\hline 116 & Lovera & Esteban & Italiano & & 1905 & 1910 & & 1918 & & $\begin{array}{l}\text { AAC. Parroquias, Leones, f. } \\
100\end{array}$ \\
\hline 117 & Lozino & Vicente & Italiano & Piamonte & 1875 & no & no & 1897 & 1897 & $\begin{array}{l}\text { AAC. Registro de sacerdotes } \\
\text { extra-diocesanos, f. } 63\end{array}$ \\
\hline 118 & Luciani & Luis M. & Italiano & $\begin{array}{l}\text { Geéova. } \\
\text { Ex } \\
\text { saleciano }\end{array}$ & 1901 & 1903 & & 1927 & & \\
\hline 119 & Luissiotti & Cesar & Italiano & Lucca & 1909 & 1909 & 1909 & 1909 & & $\begin{array}{l}\text { AAC. Registro de sacerdotes } \\
\text { extra diocesanos, f.5/Fondo } \\
\text { Zenón Bustos, Caja 3, f. } 947 \\
\text { y ss/Títulos, 1859-1904, } \\
\text { f. } 113\end{array}$ \\
\hline 120 & Lupo & Domingo & Italiano & $\begin{array}{l}\text { Torino } \\
\text { (Piamonte) }\end{array}$ & $\begin{array}{l}00 / 101 \\
907\end{array}$ & 1911 & 1905 & 1920 & $05 / 11 / 1920$ & $\begin{array}{l}\text { AAC. Lic. Minis., 1859- } \\
\text { 1932, f.323, } 326\end{array}$ \\
\hline 121 & Magnini & Carlos & Italiano & & 1882 & 1882 & & 1882 & & $\begin{array}{l}\text { AAC. Títulos, 1905-1927, } \\
\text { f,19/Lic. Minis., 1859-1932, } \\
\text { f.305 /Fondo Franciscano } \\
\text { Zenon Bustos, Cartas } \\
\text { s/catalogar/Registro de } \\
\text { sacerdotes extra diocesanos, } \\
\text { f.47/ Parroquias Freyre, f.34 }\end{array}$ \\
\hline 122 & Magno & Alfonso & Italiano & & 1897 & no & no & 1897 & & $\begin{array}{l}\text { AAC. Títulos, 1859-1904, } \\
\text { f.75 }\end{array}$ \\
\hline 123 & Malachina & Santiago & Italiano & & 1864 & si & & 1967 & & AAC. Leg.49 \\
\hline 124 & Marchini & Amadeo & Italiano & & 1897 & no & 1897 & 1897 & & $\begin{array}{l}\text { AAC. Títulos, 1859-1904, f. } \\
37\end{array}$ \\
\hline 125 & $\begin{array}{l}\text { Mariño de } \\
\text { Romero }\end{array}$ & & Español & 1873 & 1873 & & 1893 & $\begin{array}{l}\text { Mariño } \\
\text { de } \\
\text { Romero }\end{array}$ & Español & $\begin{array}{l}\text { AAC. Lic. Minist., 1859- } \\
\text { 1932, f.273/ Leg.47 }\end{array}$ \\
\hline 126 & Marravicini & Rafael & Italiano & & 1908 & 1908 & & 1908 & & \\
\hline 127 & Martí & $\begin{array}{l}\text { Ramón } \\
\text { Antonio }\end{array}$ & $\mathrm{n} / \mathrm{c}$ & & 1900 & 1900 & no & 1904 & & AAC. Leg.47 \\
\hline
\end{tabular}




\begin{tabular}{|c|c|c|c|c|c|c|c|c|c|c|}
\hline 128 & $\begin{array}{l}\text { Martínez, } \\
\text { Modenes }\end{array}$ & Raimundo & Español & $\begin{array}{l}\text { Incardinad } \\
\text { en Chile }\end{array}$ & 1923 & 1923 & & 1927 & & \\
\hline 129 & Marzolla & Angelo & Italiano & $\begin{array}{l}\text { Adria } \\
\text { Triveneto }\end{array}$ & 1911 & 1913 & & 1924 & & $\begin{array}{l}\text { AAC. Registro de sacerdotes } \\
\text { extra diocesanos, f.99 }\end{array}$ \\
\hline 130 & Mattio & Félix & Italiano & & 1892 & 1892 & 1892 & 1922 & $+09 / 03 / 1922$ & $\begin{array}{l}\text { AAC. Registro de sacerdotes } \\
\text { extra diocesanos, f.49/ } \\
\text { Títulos, 1905-1927, f.23/ } \\
\text { Registro de firmas... }\end{array}$ \\
\hline 131 & Mayorana & Lorenzo & Italiano & & 1889 & 1889 & & 1890 & 1890 & \\
\hline 132 & Mier & Juan & Italiano & campiña & 1880 & no & 1880 & 1880 & & \\
\hline 133 & Mollo & Antonio & Italiano & Trofea & 1921 & 1921 & & 1925 & & $\begin{array}{l}\text { AAC. Lic. Minis., 1859- } \\
\text { 1933, f.129 }\end{array}$ \\
\hline 134 & Montes & Celestino & Español & $\mathrm{n} / \mathrm{c}$ & 1905 & no & sí & 1907 & & $\begin{array}{l}\text { AAC. Registro de sacerdotes } \\
\text { extra diocesanos, f. } 57 / \\
\text { Títulos, 1905-1927, f.46 }\end{array}$ \\
\hline 135 & Morandini & Juan & Italiano & & 1883 & 1883 & & 1913 & & $\begin{array}{l}\text { AAC. Parroquias San } \\
\text { Francisco } 11 / 06 / 1915\end{array}$ \\
\hline 136 & Moscone & José V. & Italiano & Venne & 1911 & 1913 & & 1927 & & $\begin{array}{l}\text { AAC. Títulos, 1859-1904, } \\
\text { f.77 }\end{array}$ \\
\hline 137 & Mosso & Antonio & Italiano & $\begin{array}{l}\text { Torino } \\
\text { (Piamonte) }\end{array}$ & 1910 & 1912 & & 1924 & & $\begin{array}{l}\text { AAC. Registro de sacerdotes } \\
\text { extra diocesanos, f.53/ } \\
\text { Títulos, 1905-1927, f.59 }\end{array}$ \\
\hline 138 & $\begin{array}{l}\text { Muiños de } \\
\text { Revoreda }\end{array}$ & Prudencio & Español & Tuy & 1878 & no & & 1878 & & $\begin{array}{l}\text { AAC. Registro de sacerdotes } \\
\text { extra diocesanos, f.55/Lic. } \\
\text { Minist., 1859-1932 }\end{array}$ \\
\hline 139 & Mujerza & Arturo & Español & $\mathrm{n} / \mathrm{c}$ & 1924 & no & no & 1925 & 1925 & $\begin{array}{l}\text { AAC. Lic. Minis., 1859- } \\
\text { 1932, f.108 }\end{array}$ \\
\hline 140 & Mussi & Miguel & Italiano & Adria & 1913 & 1914 & & 1927 & & $\begin{array}{l}\text { AAC. Registro de sacerdotes } \\
\text { extra diocesanos, f.101 }\end{array}$ \\
\hline 141 & Nistal & Francisco & Español & Astorga & 1903 & no & 1911 & 1911 & & $\begin{array}{l}\text { AAC. Registro de sacerdotes } \\
\text { extra diocesanos, f.39/ } \\
\text { Títulos, 1905-1927, f.28 }\end{array}$ \\
\hline 142 & Nolasangeli & Luis & Italiano & Aquila? & 1907 & no & 1907 & & & $\begin{array}{l}\text { AAC. Fondo Zenón Bustos, } \\
\text { Caja 3, f. } 947 \text { y ss. }\end{array}$ \\
\hline 143 & Nosi & Luis & Italiano & Mondovi & 1905 & no & 1905 & 1913 & & $\begin{array}{l}\text { AAC. Lic. Minist., 1859- } \\
\text { 1932, f. } 299\end{array}$ \\
\hline
\end{tabular}




\begin{tabular}{|c|c|c|c|c|c|c|c|c|c|c|}
\hline 144 & Occhinzzini. & Pascual & Italiano & Carranza & 1881 & no & no & & & $\begin{array}{l}\text { AAC. Fondo Zenón Bustos, } \\
\text { Caja 3, f. } 947 \text { y ss. }\end{array}$ \\
\hline 145 & $\begin{array}{l}\text { Oliva y } \\
\text { Almenzor }\end{array}$ & Cosme & Español & & 1900 & no & 1900 & 1900 & & $\begin{array}{l}\text { AAC. Lic. Minist., 1859- } \\
\text { 1904, f.141/Fondo Zenón } \\
\text { Bustos, Caja 3, f. } 947 \text { y ss. }\end{array}$ \\
\hline 146 & Orlando & Félix & Italiano & & 1906 & 1909 & & 1909 & & $\begin{array}{l}\text { AAC. Lic.Minist., 1859- } \\
\text { 1932, f. } 276\end{array}$ \\
\hline 147 & Paybar & Félix & Italiano & Rivoli & 1873 & no & & 1893 & & $\begin{array}{l}\text { AAC. Títulos, 1905-1927, } \\
\text { f.10 }\end{array}$ \\
\hline 148 & Payo & $\begin{array}{l}\text { Miguel } \\
\text { Fausto }\end{array}$ & $\mathrm{n} / \mathrm{c}$ & & 1883 & 1883 & & 1883 & & $\begin{array}{l}\text { AAC. Lic. Minis., 1859- } \\
\text { 1935, f.131 }\end{array}$ \\
\hline 149 & Peciña & Nicolás & Español & & 1882 & 1882 & & 1895 & & $\begin{array}{l}\text { AAC. Registro de sacerdotes } \\
\text { extra diocesanos, f.51/Lic. } \\
\text { Minis., 1859-1932, f.253 }\end{array}$ \\
\hline 150 & Pérez Bueno & Diego & Español & Málaga & 1910 & 1919 & 1910 & 1919 & & \\
\hline 151 & Pérez Montoro & Julián & $\mathrm{n} / \mathrm{c}$ & & 1923 & 1923 & & 1925 & & \\
\hline 152 & Perrucci & Gerardo & Italiano & Tricaris & 1903 & 1904 & & 1909 & & $\begin{array}{l}\text { AAC. Fondo Zenón Bustos, } \\
\text { Caja 3, f. } 947 \text { y ss./Libro de } \\
\text { Títulos, 1905-1927, f.38 }\end{array}$ \\
\hline 153 & Petrone & Leonardo & Italiano & Cassano & 1904 & 1912 & & 1913 & & \\
\hline 154 & Pichotino & Emilio & Italiano & $\begin{array}{l}\text { Torino } \\
\text { (Piamonte) }\end{array}$ & 1905 & 1902 & & 1930 & & $\begin{array}{l}\text { AAC. Fondo Zenón Bustos, } \\
\text { Caja 3, f. } 947 \text { y ss. }\end{array}$ \\
\hline 155 & Pignolo & Juan & Italiano & Torino & 1874 & 1883 & 1881 & 1925 & $+09 / 06 / 1926$ & $\begin{array}{l}\text { AAC. Fondo Zenón Bustos, } \\
\text { Caja 3, f. } 947 \text { y ss./Títulos, } \\
\text { 1905-1927, f.21 }\end{array}$ \\
\hline 156 & Porfirio & Constantin & $\mathrm{n} / \mathrm{c}$ & & 1894 & 1894 & & 1894 & & $\begin{array}{l}\text { AAC. Registro de sacerdotes } \\
\text { extra diocesanos, f.37/ } \\
\text { Títulos, 1859-1904, f.111 }\end{array}$ \\
\hline 157 & Porta & Juan & Italiano & & 1923 & 1824 & & 1926 & & $\begin{array}{l}\text { AAC. Fondo Zenón Bustos, } \\
\text { Caja 3, f. } 947 \text { y ss./Lic. } \\
\text { Minist., 1859-1932, f.301/ } \\
\text { REOBA, vol. 3, no } 7,1926\end{array}$ \\
\hline 158 & Pozzo & $\begin{array}{l}\text { Angel } \\
\text { Rigosto }\end{array}$ & Italiano & & 1901 & 1901 & 1901 & 1901 & & \\
\hline 159 & Pretel y Gómez & Joaquín & Español & & 1870 & & & 1884 & $+20 / 02 / 1884$ & AAC. Registro de sacerdotes \\
\hline
\end{tabular}




\begin{tabular}{|c|c|c|c|c|c|c|c|c|c|c|}
\hline & & & & & & & & & & extra diocesanos, f. 69 \\
\hline 160 & $\begin{array}{l}\text { Puentedura } \\
\text { Alonzo }\end{array}$ & Plácido & Español & Granada & 1899 & 1899 & & 1908 & & $\begin{array}{l}\text { AAC. Títulos, 1859-1904, } \\
\text { f.110/ Lic. Minis., 1859- } \\
\text { 1932, f.277 }\end{array}$ \\
\hline 161 & Pulccinelli & Ricardo & Italiano & Camerino & 1911 & 1911 & & 1927 & & $\begin{array}{l}\text { IEA, Bodas de un sacerdote } \\
\text { cordobés }\end{array}$ \\
\hline 162 & Quadrelli & Pablo & Italiano & La Plata & 1923 & no & 1923 & 1928 & & $\begin{array}{l}\text { AAC. Fondo Zenón Bustos, } \\
\text { Caja 3, f. } 947 \text { y ss. }\end{array}$ \\
\hline 163 & Ramírez & $\begin{array}{l}\text { Pedro, } \\
\text { Pascual }\end{array}$ & Español & Calhorra & 1875 & 1878 & & 1889 & & $\begin{array}{l}\text { AAC. Registro de sacerdotes } \\
\text { extra diocesanos, f. } 41\end{array}$ \\
\hline 163 & $\begin{array}{l}\text { Ramírez y } \\
\text { Aparicio }\end{array}$ & Luis & Español & Calahorra & 1889 & 1890 & & 1892 & 1892 & $\begin{array}{l}\text { AAC. Registro de sacerdotes } \\
\text { extra diocesanos, f. } 71\end{array}$ \\
\hline 165 & Raynoldi & Ambrosio & Italiano & $\mathrm{n} / \mathrm{c}$ & 1872 & 1872 & & 1900 & & $\begin{array}{l}\text { AAC. Lic. Minist., 1859- } \\
\text { 1933, f. } 114\end{array}$ \\
\hline 166 & Requejo & Antonio & Español & Salamanca & 1899 & no & no & 1907 & & $\begin{array}{l}\text { AAC. Lic. Minist., 1859- } \\
\text { 1932, f. } 223\end{array}$ \\
\hline 167 & Rinaldi & Luis & Italiano & $\begin{array}{l}\text { Manfredo- } \\
\text { nia }\end{array}$ & 1913 & 1920 & & 1924 & & \\
\hline 168 & Rispandelli & Andrés & Italiano & $\begin{array}{l}\text { Ex } \\
\text { mercedario }\end{array}$ & 1863 & 1863 & & 1863 & & $\begin{array}{l}\text { AAC. Fondo Zenón Bustos, } \\
\text { Caja 3, f. } 947 \text { y ss./Leg.51, } \\
\text { Cruz Alta }\end{array}$ \\
\hline 169 & Rizzo & Manuel & Italiano & $\begin{array}{l}\text { Paleruso } \\
\text { Sicilia }\end{array}$ & 1889 & 1892 & & 1892 & & $\begin{array}{l}\text { AAC. Registro de sacerdotes } \\
\text { extra diocesanos, f. } 43\end{array}$ \\
\hline 170 & Romero Yañez & $\begin{array}{l}\text { José } \\
\text { Eusebio }\end{array}$ & Español & $\begin{array}{l}\text { Domicilia. } \\
\text { de Chile }\end{array}$ & 1903 & 1918 & 1903 & 1918 & & \\
\hline 171 & $\begin{array}{l}\text { Rosello y } \\
\text { Santandrea }\end{array}$ & Martín & Español & Mallorca & 1901 & & & & & $\begin{array}{l}\text { AAC. Lic. Minist., f.220 y } \\
236\end{array}$ \\
\hline 172 & Roucco & $\begin{array}{l}\text { Francisco } \\
\text { Javier }\end{array}$ & Español & & 1894 & 1894 & & 1894 & & $\begin{array}{l}\text { AAC. Lic. Minist., 1859- } \\
1932, \text { f.282, 325,330 }\end{array}$ \\
\hline 173 & Rufo & Arístides & Italiano & Veroli & 1925 & no & 1925 & 1926 & & $\begin{array}{l}\text { AAC. Leg.52, Bel Ville, } \\
\text { letras comendaticias del } \\
\text { Obispo de Mallorca }\end{array}$ \\
\hline 174 & Ruiz & Leandro & Español & $\begin{array}{l}\text { Calahorra } \\
\text { y Calzada }\end{array}$ & 1875 & no & 1875 & 1877 & & $\begin{array}{l}\text { AAC. Títulos, 1859-1904, f. } \\
10\end{array}$ \\
\hline 175 & Ruiz Martínez & Emilio & Español & Granada & 1903 & 1909 & 1906 & 1928 & & $\begin{array}{l}\text { AAC. Lic. Minist., 1859- } \\
\text { 1932, f. } 397\end{array}$ \\
\hline
\end{tabular}




\begin{tabular}{|c|c|c|c|c|c|c|c|c|c|c|}
\hline 176 & Russo & José & Italiano & & 1890 & 1890 & & 1903 & & $\begin{array}{l}\text { AAC. Lic. Minist., 1859- } \\
\text { 1932, f.1000 }\end{array}$ \\
\hline 177 & Salguero & Miguel & & & 1903 & 1903 & & 1912 & & $\begin{array}{l}\text { AAC. Registro de sacerdotes } \\
\text { extra diocesanos, f. } 85\end{array}$ \\
\hline 178 & Salomone & Luis & Italiano & & 1899 & no & no & 1900 & & $\begin{array}{l}\text { AAC. Títulos, 1859-1904, } \\
\text { f.94, 96, } 112\end{array}$ \\
\hline 179 & $\begin{array}{l}\text { Sánchez } \\
\text { Manzanera }\end{array}$ & Juan & Español & $\begin{array}{l}\text { Barbastro } \\
\text { (Huesca) }\end{array}$ & 1907 & 1910 & 1907 & 1927 & & \\
\hline 180 & $\begin{array}{l}\text { Sánchez } \\
\text { Martínez }\end{array}$ & Miguel & Español & Almería & 1914 & 1918 & & 1915 & & AAC. Leg.47, Morteros \\
\hline 181 & Sangorrin & Francisco & Español & $\begin{array}{l}\text { La Calzada } \\
\text { (Badajoz) }\end{array}$ & 1910 & no & no & 1912 & & $\begin{array}{l}\text { AAC. Registro de sacerdotes } \\
\text { extra diocesanos, f.89 }\end{array}$ \\
\hline 182 & Sarti & Blas & Italiano & Mossa & 1910 & no & 1911 & 1919 & & $\begin{array}{l}\text { AAC. Registro de sacerdotes } \\
\text { extra diocesanos }\end{array}$ \\
\hline 183 & Scorza & Lucio & Italiano & Cassano & 1905 & no & 1912 & 1912 & & $\begin{array}{l}\text { AAC. Fondo Zenón Bustos, } \\
\text { Caja 3, f. } 947 \text { y ss. }\end{array}$ \\
\hline 184 & Seligrat & Donato & Español & Cuenca & 1916 & no & no & 1927 & & $\begin{array}{l}\text { AAC. Fondo Zenón Bustos, } \\
\text { Caja 3, f. } 947 \text { y ss./Lic. } \\
\text { Minist., 1859-1932, f.345 }\end{array}$ \\
\hline 185 & Shulte & Enrique & Otro & & 1920 & 1920 & 1920 & 1920 & & $\begin{array}{l}\text { AAC. Fondo Zenón Bustos, } \\
\text { Caja 3, f. } 947 \text { y ss. }\end{array}$ \\
\hline 186 & Sierra Alvarez & Teodoro & Español & León & 1900 & 1902 & 1902 & 1902 & & $\begin{array}{l}\text { AAC. Fondo Zenón Bustos, } \\
\text { Caja 3, f. } 947 \text { y ss. }\end{array}$ \\
\hline 187 & Silva & Mateo & $\mathrm{n} / \mathrm{c}$ & & 1924 & 1924 & & 1924 & & $\begin{array}{l}\text { AAC. Títulos, 1905-1927, } \\
\text { f.42 }\end{array}$ \\
\hline 188 & Simoni & Pedro & Italiano & $\begin{array}{l}\text { Fermo } \\
\text { (Las } \\
\text { Marcas) }\end{array}$ & 1914 & no & no & 1917 & $\begin{array}{l}\text { Suspenso por } \\
\text { enterrar a un } \\
\text { suicida. Retiro } \\
\text { de la diócesis }\end{array}$ & $\begin{array}{l}\text { AAC. Registro de sacerdotes } \\
\text { extra diocesanos, } \\
\text { f.91/Títulos, 1859-1904, } \\
\text { f.33 y } 111\end{array}$ \\
\hline 189 & Soete & $\begin{array}{l}\text { Julio } \\
\text { Eduardo } \\
\text { Augusto }\end{array}$ & Belga & Foirman & 1889 & no & 1889 & 1892 & & \\
\hline 190 & Soldi & Pío & Italiano & Pistoia & 1915 & 1916 & & 1927 & & $\begin{array}{l}\text { AAC. Fondo Zenón Bustos, } \\
\text { Caja 3, f. } 947 \text { y ss./Registro } \\
\text { de sacerdotes extra } \\
\text { diocesanos, f. } 33\end{array}$ \\
\hline 191 & Spina & Miguel & Italiano & & 1878 & 1879 & 1878 & 1895 & & AAC. Lic. Minist., 1859- \\
\hline
\end{tabular}




\begin{tabular}{|c|c|c|c|c|c|c|c|c|c|c|}
\hline & & & & & & & & & & 1932, f. 233,245 \\
\hline 192 & Spolidoro & Vicente & Italiano & $\begin{array}{l}\text { Mascien- } \\
\text { zena }\end{array}$ & 1869 & no & no & 1871 & 1871 & $\begin{array}{l}\text { AAC. Registro de sacerdotes } \\
\text { extra diocesanos, f.35/ } \\
\text { Títulos, 1905-1927, f.33 }\end{array}$ \\
\hline 193 & Tartaglia & Genaro & Italiano & $\mathrm{n} / \mathrm{c}$ & 1886 & no & & 1902 & & $\begin{array}{l}\text { AAC. Títulos, 1859-1904, } \\
\text { f.67 }\end{array}$ \\
\hline 194 & Taulaigo & Pedro & Francés & Francia & 1886 & 1886 & & 1900 & & AAC. Leg.34, T4, s/f \\
\hline 195 & Tello & Javier & Italiano & & & & & 1905 & 1905 & $\begin{array}{l}\text { AAC. Fondo Zenón Bustos, } \\
\text { Caja 3, f. } 947 \text { y ss. }\end{array}$ \\
\hline 196 & Terraza & Antonio & Italiano & & 1898 & no & no & 1900 & & $\begin{array}{l}\text { AAC. Fondo Zenón Bustos, } \\
\text { Caja 3, f. } 947 \text { y ss./Leg.48, } \\
\text { f. } 227 / \text { Títulos, 1859-1904, } \\
\text { f. } 88\end{array}$ \\
\hline 197 & Terzuolo & Jacinto & Italiano & $\begin{array}{l}\text { Incardinad } \\
\text { en Cuyo }\end{array}$ & 1897 & 1897 & & 1918 & & $\begin{array}{l}\text { AAC. Leg.33. Juicios } \\
\text { eclesiásticos, 1871-1905, } \\
\text { TVIII }\end{array}$ \\
\hline 198 & Trevé & Jaime & Español & Barcelona & 1909 & no & 1908 & 1909 & & $\begin{array}{l}\text { AAC. Fondo Zenón Bustos, } \\
\text { Caja 3, f. } 947 \text { y ss. }\end{array}$ \\
\hline 199 & Trias & Antonio & Español & Mallorca & 1905 & 1909 & & 1918 & $\begin{array}{l}1918 \text { regresa a } \\
\text { España }\end{array}$ & $\begin{array}{l}\text { AAC. Títulos, 1859-1905, } \\
\text { f.13 }\end{array}$ \\
\hline 200 & Triboli & Pablo & Italiano & Piamonte & 1895 & 1895 & 1895 & 1896 & & $\begin{array}{l}\text { AAC. Fondo Zenón Bustos, } \\
\text { Caja 3, f. } 947 \text { y ss./Lic. } \\
\text { Minist., 1859-1932 }\end{array}$ \\
\hline 201 & Triboli & Luis & Italiano & Piamonte & 1896 & 1896 & 1896 & 1897 & & $\begin{array}{l}\text { AAC. Fondo Zenón Bustos, } \\
\text { Caja 3, f. } 947 \text { y ss./Lic. } \\
\text { Minist., 1859-1932, f.305 }\end{array}$ \\
\hline 202 & Ugolini & Domingo & Italiano & Rimini & 1907 & no & 1924 & 1927 & & $\begin{array}{l}\text { AAC. Lic. Minist., 1859- } \\
\text { 1932, fs. } 305,307,317,320 \text {, } \\
323,393\end{array}$ \\
\hline 203 & Utrera & José & Otro & & 1923 & 1923 & & 1927 & & $\begin{array}{l}\text { AAC. Títulos, 1905-1927, f. } \\
63\end{array}$ \\
\hline 204 & Valli & Raimundo & Italiano & & 1922 & 1922 & & 1922 & & $\begin{array}{l}\text { AAC. Fondo Zenón Bustos, } \\
\text { Caja } 3 \text {, f. } 947 \text { y ss./ Registro } \\
\text { de sacerdotes extra } \\
\text { diocesanos, f. } 79\end{array}$ \\
\hline
\end{tabular}




\begin{tabular}{|c|c|c|c|c|c|c|c|c|c|c|}
\hline 205 & Valut & Juan & Español & $\begin{array}{l}\text { Mallorca. } \\
\text { con } \\
\text { permiso } \\
\text { del Obispo } \\
\text { de La Plata } \\
\text { por un año }\end{array}$ & 1925 & no & 1925 & 1927 & & $\begin{array}{l}\text { AAC. Títulos, 1905-1927, } \\
\text { f.63 }\end{array}$ \\
\hline 206 & Viaggio & Luis & Italiano & $\begin{array}{l}\text { Aderno } \\
\text { Catascia }\end{array}$ & 1882 & 1884 & & 1911 & 1911 & $\begin{array}{l}\text { AAC. Registro de sacerdotes } \\
\text { extra diocesanos, f. } 67\end{array}$ \\
\hline 207 & Vignolo & Matías & Italiano & & 1899 & 1899 & & 1899 & & $\begin{array}{l}\text { AAC. Fondo Zenón Bustos, } \\
\text { Caja 3, f. } 947 \text { y ss./Registro } \\
\text { de sacerdotes extra } \\
\text { diocesanos, f. } 109\end{array}$ \\
\hline 208 & Villaescusa & Lorenzo & Español & Granada & 1899 & 1899 & & 1913 & & $\begin{array}{l}\text { AAC. Fondo Zenón Bustos, } \\
\text { Caja 3, f. } 947 \text { y ss./Títulos, } \\
\text { 1859-1904, f.92 }\end{array}$ \\
\hline 209 & Villanueva & Domingo & Español & Lugo & 1903 & no & 1907 & 1911 & & $\begin{array}{l}\text { AAC. Fondo Zenón Bustos, } \\
\text { Caja 3, f. } 947 \text { y ss./Títulos, } \\
\text { 1859-1904, f.108 }\end{array}$ \\
\hline 210 & Villar García & José & Español & Tuy & 1887 & 1889 & 1887 & 1892 & $\begin{array}{l}\text { 1892: Regresa } \\
\text { a su diócesis }\end{array}$ & $\begin{array}{l}\text { AAC. Lic. Minist., 1859- } \\
\text { 1932, f.296 }\end{array}$ \\
\hline 211 & Villar y Pastor & Olegario & Español & & 1874 & 1877 & 1874 & 1882 & & $\begin{array}{l}\text { AAC. Fondo Zenón Bustos, } \\
\text { Caja 3, f. } 947 \text { y ss. }\end{array}$ \\
\hline 212 & Virgilio & Julio & Italiano & $\mathrm{n} / \mathrm{c}$ & 1894 & no & 1894 & 1894 & & $\begin{array}{l}\text { AAC. Títulos, 1859-1904, } \\
\text { f.91/Lic. Minist., 1859-1932, } \\
\text { f. } 256\end{array}$ \\
\hline 213 & Vozzi & Juan José & Italiano & $\mathrm{n} / \mathrm{c}$ & 1904 & 1903 & & 1905 & & $\begin{array}{l}\text { AAC. Lic. Minist., 1859- } \\
\text { 1932, f.266 }\end{array}$ \\
\hline
\end{tabular}


Anexo III 


\section{ANEXO III}

\section{Interrogatorios para las Visitas Pastorales}

\section{Año 1906}

$1 \quad$ ¿Cuándo fue erigida la parroquia? ¿Por quién?

$2 \quad$ ¿Cuáles son los confines de la parroquia?

3 ¿Cuántas almas cuenta?

$4 \quad$ ¿Hay en la parroquia no católicos? ¿Qué población no católica se calcula? ¿Tiene templos? ¿Cuántos? ¿Cuántas escuelas tiene? ¿Por qué medios se procura su conversión?

$5 \quad$ ¿Hay casa parroquial? Si no hay ¿cómo se provee el alojamiento?

6 ¿Quién vive con el cura? (Indicar el número de personas, nombre, apellido, conducta, edad, sexo, condición, profesión, grado de parentela con el Cura)

$7 \quad$ ¿Hay uno o más tenientes? ¿Quiénes son? ¿Quién los nombró? Si no viven con el Cura, decir dónde, indicar las personas que viven con ellos como en el $n^{\mathrm{o}} 6$.

8 ¿Hay otros eclesiásticos en la parroquia? Presentar una lista de ellos. Nombre, apellido, patria, edad, oficio que tienen, conducta que llevan, donde viven, con quién, etc., como en el $n^{\circ} 6$.

9 ¿Cuáles son las rentas fijas del cura? ¿Cuáles las inciertas? ¿Cuánto se cobra por los bautismos? ¿Cuánto por los matrimonios? ¿Cuánto por los funerales? ¿Cuánto por otras funciones?

10 ¿Cuál es el titular de la iglesia parroquial? ¿Dónde está situada? ¿Cuántas misas de hora tiene y a qué hora cada una?

11 ¿Cuándo y por quién fue edificada? ¿Fue consagrada? ¿Cuándo y por quién?

12 Además de la casa parroquial, ¿tiene la parroquia otras casas? ¿Están alquiladas? ¿A quién? ¿Por cuánto?

13 ¿La Iglesia está bien defendida de la humedad? ¿Necesita reparaciones? ¿Cuáles? ¿Son urgentes? ¿Quién cuida de ejecutarlas?

14 ¿La Iglesia tiene puertas seguras? ¿Quién guarda las llaves? ¿Cómo se hace la vigilancia? ¿A qué hora se abre? ¿Está abierta durante el día? ¿A qué hora se cierra?

15 ¿Cómo se provee la limpieza de la Iglesia? ¿Cada cuanto tiempo se barre y se sacude? ¿Cada cuánto tiempo se cambia el agua bendita?

16 ¿Cuántos altares tiene la iglesia? De cada altar se indicará: a) El titular, b) Si está consagrado, cuándo y por quién, c) De qué materia es construido y de qué estilo, d) Quién lo cuida, e) Si la persona que lo cuida provee a las reparaciones necesarias, manteles y 
demás adornos del altar, f) ¿El ara está en buen estado? ¿El altar tiene frontal? ¿Hay otras imágenes en el altar? ¿Cuáles son?

17 Para reservar al Smo. ¿Tiene sagrario fijo? ¿De qué materia? ¿Está forrado por dentro con seda blanca o dorada? ¿La puerta está bien asegurada? ¿La llave es de plata o metal dorado? ¿Quién la guarda? ¿El sagrario tiene su cortina por fuera según rúbricas? ¿Sobre el Sagrario hay imágenes o reliquias? ¿Hay a lo menos una lámpara encendida día y noche? ¿Con qué frecuencia se renuevan las santas hostias? ¿Cuál es el altar del Smo.? ¿Hay comulgatorio?

18 ¿De qué materia es el piso de la iglesia? ¿Está bien conservado?

19 ¿Hay confesonarios? ¿Cuántos? ¿Están todos a la vista? ¿Tienen rejillas? ¿Se limpian con frecuencia? ¿Tienen cortina interior?

20 ¿Hay alcancías en la Iglesia? ¿Quién tiene la llave? ¿Quién cuenta el dinero? ¿A quién lo entrega?

21 ¿Dónde se guardan los santos Olios?

22 ¿Hay reliquias en la Iglesia? ¿Dónde se guardan? ¿Quién tiene la llave? ¿Conservan los auténticos?

23 ¿Hay campanario? ¿Cuántas campanas?

24 ¿Hay una o más sacristías? ¿Cómo se aseguran las puertas?

25 ¿Hay armarios para ornamentos y vasos sagrados? ¿Hay misales completos? ¿Cuántos?

26 ¿De qué cautela se usa para el vino de la misa?

27 ¿Hay lavamentos con sus toallas con la limpieza debida?

28 ¿La parroquia tiene capellanías? En caso afirmativo hacer una lista de ellas y de las cargas y ponerlas en la sacristía.

29 ¿Hay registro para escribir las misas encargadas? ¿Las de las capellanías? ¿Se lleva un libro en el que cada día firman los sacerdotes que dicen la misa? ¿Quién recibe las limosnas de las aplicaciones de las misas? ¿Cuántas suelen ser al mes, al año?

$30 \quad$ ¿Se tiene cuidado de pedir el celebrat a los sacerdotes desconocidos?

31 ¿La Iglesia está provista de ornamentos y vasos sagrados? Hágase un prolijo inventario de todos ellos. Otro tanto se hará del archivo y demás bienes de la parroquia.

$32 \quad ¿$ ¿El archivo se tiene en sitio seco? ¿Seguro? ¿Quién tiene la llave? ¿Los libros tienen índice?

33 ¿Hay otras iglesias en la parroquia? ¿Cómo se llaman? ¿Son del clero secular o regular? ¿Dónde están situadas? 
$34 \quad$ ¿Hay órdenes religiosas o congregaciones en la parroquia? ¿Dónde están situadas? ¿Tienen iglesia u oratorio público o semi-público?

35 ¿Hay bautisterio? ¿Dónde se ha colocado? ¿Tiene llave? ¿Está cubierta la pila?

$36 \quad$ ¿Se cumplen las disposiciones de SS PIO X acerca de la enseñanza del catecismo? ¿Está establecida la Cofradía de la Doctrina Cristiana? ¿Se usa el catecismo aprobado por los Obispos en Salta?

37 ¿El Cura y el teniente están prontos siempre para asistir a los enfermos? ¿Qué medidas toma el Cura para promover la frecuencia de los Santos sacramentos? ¿Se procura que los enfermos cumplan con la Iglesia en el tiempo pascual?

38 ¿Se predica en los días festivos? ¿Quién? ¿Hay además otros sermones en cuaresma? ¿Cuántos? ¿Hay mes de María?

39 ¿Cuántas y cuáles horas está abierto el despacho parroquial?

40 Para la celebración del matrimonio, ¿se usa la fórmula aprobada por los Obispos reunidos en Salta? ¿Se procura que los novios se acerquen a los Santos sacramentos? ¿Hay en la parroquia personas unidas por el solo vínculo civil? ¿Qué se hace para que regularicen dicha situación?

$41 \quad$ ¿El cura aplica personalmente en los días festivos la misa pro populo?

42 ¿El cura y los tenientes observan la residencia prescripta por los cánones? ¿Salen de la parroquia al mismo tiempo?

43 ¿Hay cofradías en la Iglesia Parroquial o fuera de ella? ¿Cuantas y cómo se llaman? ¿Hay círculo de obreros? ¿Quién es su director? ¿Hay Conferencias de San Vicente de Paul?

$44 \quad$ ¿Se tiene en el archivo encuadernado el Concilio Plenario de la América Latina y las Pastorales, autos, edictos, decretos y disposiciones diocesanas? ¿Se tiene un ejemplar del manual Litúrgico de D. Joaquín Solans y la Revista Eclesiástica?

$45 \quad$ ¿Hay escuela parroquial y colegios católicos?

46 ¿Cuántos oratorios privados hay en la parroquia? ¿Cuántas familias lo tienen? Hacer dos listas con identificación de la calle y número de la casa, una para el visitador y otra para el archivo parroquial.

$47 \quad$ ¿Se observa lo referente a la asignación para el Seminario? Deben presentarse los últimos recibos durante la visita.

$48 \quad$ ¿Se observa el motu Proprio de SS Pío X sobre la música sacra?

49 ¿Se bina en la parroquia? ¿Qué motivos hay para ello? ¿Quién lo concedió? ¿Por cuánto tiempo?

Fuente: AAC. Pastorales, Edictos y Circulares, 1905-1920. 


\section{Año 1917}

$1 \quad$ ¿Cuando fue erigida la Parroquia? ¿Por quién?

$2 \quad$ ¿Cuáles son los confines de la parroquia?

$3 \quad$ ¿Cuántas almas cuenta? ¿Hay en la parroquia no católicos?

4 ¿Qué población no católica se calcula? ¿Tiene templos? ¿Cuántos? ¿Cuántas escuelas tiene? ¿Por qué medios se procura su conversión?

$5 \quad$ ¿Hay casa parroquial? Si no hay ¿cómo se provee el alojamiento?

6 ¿Quién vive con el cura? (Indicar el número de personas, nombre, apellido, conducta, edad, sexo, condición, profesión, grado de parentela con el Cura)

$7 \quad$ ¿Hay uno o más tenientes? ¿Quiénes son? ¿Quién los nombró? Si no viven con el Cura, decir dónde, indicar las personas que viven con ellos como en el $n^{\circ} 6$.

8 ¿Hay otros eclesiásticos en la parroquia? Presentar una lista de ellos. Nombre, apellido, patria, edad, oficio que tienen, conducta que llevan, donde viven, con quién, etc., como en el $n^{\circ} 6$.

9 ¿Cuáles son las rentas fijas del cura? ¿Cuáles las inciertas? ¿Cuánto se cobra por los bautismos? ¿Cuánto por los matrimonios? ¿Cuánto por los funerales? ¿Cuánto por otras funciones?

10 ¿Cuál es el titular de la iglesia parroquial? ¿Dónde está situada? ¿Cuántas misas de hora tiene y a qué hora cada una?

11 ¿Cuándo y por quién fue edificada? ¿Fue consagrada? ¿Cuándo y por quién?

12 Además de la casa parroquial, ¿tiene la parroquia otras casas? ¿Están alquiladas? ¿A quién? ¿Por cuánto?

13 ¿La Iglesia está bien defendida de la humedad? ¿Necesita reparaciones? ¿Cuáles? ¿Son urgentes? ¿Quién cuida de ejecutarlas?

14 ¿La Iglesia tiene puertas seguras? ¿Quién guarda las llaves? ¿Cómo se hace la vigilancia? ¿A qué hora se abre? ¿Está abierta durante el día? ¿A qué hora se cierra?

15 ¿Cómo se provee la limpieza de la Iglesia? ¿Cada cuanto tiempo se barre y se sacude? ¿Cada cuánto tiempo se cambia el agua bendita?

16 ¿Cuántos altares tiene la iglesia? De cada altar se indicará: a) El titular, b) Si está consagrado, cuándo y por quién, c) De que materia es construido y de qué estilo, d) Quién lo cuida, e) Si la persona que lo cuida provee a las reparaciones necesarias, manteles y demás adornos del altar, f) ¿El ara está en buen estado? ¿El altar tiene frontal? ¿Hay otras imágenes en el altar? ¿Cuáles son? 
17 Para reservar al Smo., ¿tiene sagrario fijo? ¿De qué materia? ¿Está forrado por dentro con seda blanca o dorada? ¿La puerta está bien asegurada? ¿La llave es de plata o metal dorado? ¿Quién la guarda? ¿El sagrario tiene su cortina por fuera según rúbricas? ¿Sobre el Sagrario hay imágenes o reliquias? ¿Hay a lo menos una lámpara encendida día y noche? ¿Con que frecuencia se renuevan las santas hostias? ¿Cuál es el altar del Smo.? ¿Hay comulgatorio?

18 ¿De qué materia es el piso de la iglesia? ¿Está bien conservado?

19 ¿Hay confesonarios? ¿Cuántos? ¿Están todos a la vista? ¿Tienen rejillas? ¿Se limpian con frecuencia? ¿Tienen cortina interior?

20 ¿Hay alcancías en la Iglesia? ¿Quién tiene la llave? ¿Quién cuenta el dinero? ¿A quién lo entrega?

$21 \quad$ ¿Dónde se guardan los santos Olios?

22 ¿Hay reliquias en la Iglesia? ¿Donde se guardan? ¿Quién tiene la llave? ¿Conservan los auténticos?

23 ¿Hay campanario? ¿Cuántas campanas?

$24 \quad$ ¿Hay una o más sacristías? ¿Cómo se aseguran las puertas?

25 ¿Hay armarios para ornamentos y vasos sagrados? ¿Hay misales completos? ¿Cuántos?

$26 \quad$ ¿De qué cautela se usa para el vino de la misa?

$27 \quad$ ¿Hay lavamentos con sus toallas con la limpieza debida?

$28 \quad$ ¿La parroquia tiene capellanías? En caso afirmativo hacer una lista de ellas y de las cargas y ponerlas en la sacristía.

29 ¿Hay registro para escribir las misas encargadas? ¿Las de las capellanías? ¿Se lleva un libro en el que cada día firman los sacerdotes que dicen la misa? ¿Quién recibe las limosnas de las aplicaciones de las misas? ¿Cuántas suelen ser al mes, al año?

$30 \quad$ ¿Se tiene cuidado de pedir el celebrat a los sacerdotes desconocidos?

31 ¿La Iglesia está provista de ornamentos y vasos sagrados? Hágase un prolijo inventario de todos ellos. Otro tanto se hará del archivo y demás bienes de la parroquia.

32 ¿El archivo se tiene en sitio seco? ¿Seguro? ¿Quién tiene la llave? ¿Los libros tienen índice?

33 ¿Hay otras iglesias en la parroquia? ¿Cómo se llaman? ¿Son del clero secular o regular? ¿Donde están situadas?

$34 \quad ¿$ ¿Hay órdenes religiosas o congregaciones en la parroquia? ¿Dónde están situadas? ¿Tienen iglesia u oratorio público o semi-público? 
35 ¿Hay bautisterio? ¿Dónde se ha colocado? ¿Tiene llave? ¿Está cubierta la pila?

$36 \quad$ ¿Se cumplen las disposiciones de SS PIO X acerca de la enseñanza del catecismo? ¿Está establecida la Cofradía de la Doctrina Cristiana? ¿Se usa le catecismo aprobado por los Obispos en Salta?

$37 \quad$ ¿El Cura y el teniente están prontos siempre para asistir a los enfermos? ¿Qué medidas toma el Cura para promover la frecuencia de los Santos sacramentos? ¿Se procura que los enfermos cumplan con la Iglesia en el tiempo pascual?

38 ¿Se predica en los días festivos? ¿Quién? ¿Hay además otros sermones en cuaresma? ¿Cuántos? ¿Hay mes de María?

39 ¿Cuántas y cuáles horas está abierto el despacho parroquial?

40 Para la celebración del matrimonio, ¿se usa la fórmula aprobada por los Obispos reunidos en Salta? ¿Se procura que los novios se acerquen a los Santos sacramentos? ¿Hay en la parroquia personas unidas por el solo vínculo civil? ¿Qué se hace para que regularicen dicha situación?

$41 \quad$ ¿Se inscriben en el libro de bautismo los nombres de las personas que se casan?

42 ¿Cuántas personas quedan sin casarse por no querer o no poder pagar los derechos matrimoniales?

43 ¿Cada cuánto tiempo se dan Misiones en el Curato?

$44 \quad ¿$ Se han hecho bautismos o autorizado matrimonios en casas particulares? ¿Por qué causa? ¿Con qué permiso?

45 ¿Que número de fieles cumplen los preceptos de la confesión y comunión anual?

$46 \quad$ ¿Se hacen primeras comuniones de los niños colectivamente, una o más veces al año?

$47 \quad ¿$ ¿Se hace en oportunidad la novena del Espíritu Santo? ¿Se reza el rosario en la misa durante el mes de octubre?

$48 \quad$ ¿Se fomentan las devociones aprobadas por la Iglesia Exposición al Smo. Sacramento, Vía Crucis, Rosario, mes de María, y otras semejantes celebrándolas en la Iglesia?

49 ¿Se hace colecta anual para el óbolo de San Pedro, con preferencia a otras, Propaganda Fidei y Tierra Santa?

50 ¿Hay difusión de libros y periódicos malos? ¿Qué se hace para contrarrestar ese mal? ¿Se fomenta la buena prensa? ¿Qué cooperación se presta a la prensa católica de la Diócesis?

$51 \quad$ ¿El cura aplica personalmente en los días festivos la misa pro popolo? 
52 ¿El cura y los tenientes observan la residencia prescrita en los cánones? ¿Salen de la Parroquia al mismo tiempo? ¿Solicitan el permiso necesario?

53 ¿Hay cofradías en la iglesia parroquial o fuera de ella? ¿Cuántas y cómo se llaman? Hay círculo de obreros? ¿Quién es su director? ¿Hay Conferencia de San Vicente de Paul y otras asociaciones católicas?

$54 \quad ¿$ Se tiene en el archivo encuadernado el Concilio Plenario de la América Latina y las Pastorales, autos, edictos, decretos y disposiciones diocesanas? ¿Se tiene un ejemplar del manual Litúrgico de D. Joaquín Solans y la Revista Eclesiástica?

$55 \quad$ ¿Hay escuela parroquial y colegios católicos?

56 ¿Cuántos oratorios privados hay en la parroquia? ¿Cuántas familias lo tienen? Hacer dos listas con identificación de la calle y número de la casa, una para el visitador y otra para el archivo parroquial.

$57 \quad$ ¿Se observa lo referente a la asignación para el Seminario? Deben presentarse los últimos recibos durante la visita.

$58 \quad$ ¿Se observa el motu Proprio de SS Pío X sobre la música sacra?

59 ¿Se bina en la parroquia? ¿Qué motivos hay para ello? ¿Quién lo concedió? ¿Por cuánto tiempo?

Fuente: AAC. Parroquias, 12/01/1917. 


\section{Año 1925}

1. Erecion de la Parroquia. ¿Por quién fue erigida y en qué fecha? ¿Se conserva en el archivo parroquial copia del decreto de erección? Si después del decreto de erección ha sufrido alguna modificación en cuanto a su extensión territorial, ¿se conserva en el archivo copia del decreto o decretos respectivos? Límites actuales de la parroquia. Extensión que ocupa su perímetro. Ciudades, villas, pueblos, estaciones de ferrocarril comprendidas dentro de sus límites. Importancia de estos pueblos especialmente en cuanto al número de habitantes. ¿Tienen iglesias? Si no las tiene, ¿dónde cumplen estos feligreses sus deberes de católicos? Número total de almas que comprende la feligresía. ¿Existe plano o croquis de la parroquia, donde conste con claridad y precisión cuál sea el territorio de la parroquia? Está hecho conforme al decreto de erección y demás modificaciones que ha sufrido la parroquia en su extensión territorial? ¿Se conserva el plano o croquis en cuadro colocado en el despacho parroquial con el fin de consultarlo fácilmente?

2. Iglesia parroquial. ¿Cuál es su titular? Situación. ¿Está consagrada o bendecida conservándose en el archivo el acta correspondiente? Si consagrada, ¿se conservan las cruces en los muros? ¿Cuándo fue edificada, qué dimensiones tiene y se conserva en buen estado? ¿De qué material es el pavimento? ¿Tiene puertas seguras, buenas cerraduras y está bien defendida de la humedad? ¿Tiene campanario, cuántas campanas, bendecidas o consagradas?

3. ¿Cuántos altares tiene la iglesia? ¿Cada uno tiene titular? ¿Las aras están en buen estado? Si hay algún altar consagrado, ¿cuándo fue consagrado y por quién? Si hay algún altar privilegiado, ¿por cuánto tiempo y por qué prescripto, y tiene la inscripción distintiva conforme al canon 918? ¿El presbiterio está separado de alguna manera de lo demás de la iglesia? ¿Permanecen en él los seglares durante los sagrados ritos? ¿Tiene banco para tomar asiento el oficiante y los ministros?

4. ¿El altar del Sagrario es el mejor y más adornado de la Iglesia? (canon 1268). ¿De qué materia es el sagrario y está forrado por dentro con seda blanca o dorado? ¿Tiene en su remate una cruz pequeña? ¿La puerta está bien asegurada? ¿La llave es de palta o metal dorado, y quién la guarda? ¿El sagrario está adornado con el conopeo o al menos con una cortinilla en la parte exterior? ¿Alguna vez se colocan sobre el sagrario imágenes o reliquias? ¿El copón cubierto con velo de seda blanco o cuando sea posible dorado descansa sobre un corporal bendito, bien limpio y destinado ad hoc? ¿Delante y cerca del altar arde día y noche una lámpara alimentada con aceite de oliva o con cera de abejas, o con el debido permiso del Ordinario del lugar se usan otros aceites vegetales? (canon 1271) ¿Con qué frecuencia se renuevan las sagradas hostias? ¿Hay tabernáculo para la exposición solemne del Santísimo, cómo está decorado? ¿Hay comulgatorio decentemente vestido y bandeja para la comunión conservada con especial esmero y limpieza? 
5. ¿Hay otras iglesias en la parroquia? Si las hay, y están bajo la atención del párroco, responder sobre cada una de ellas a las preguntas de los números precedentes. ¿Hay oratorios privados en la parroquia? ¿Reúnen todas las condiciones debidas? (canon 11951196)

6. Custodia y limpieza de cada una de las iglesias. ¿Quién guarda la llave? ¿Durante qué horas del día está abierta, especialmente si es la iglesia parroquial para que los fieles puedan visitar el Santísimo? (canon 1266) ¿Cómo se provee la limpieza? ¿Con qué frecuencia se barre y desempolvan las bóvedas, cielorrasos, retablos, imágenes, cuadros y muebles? (canon 1178)

7. Pilas de agua bendita. Número, materia y lugar que ocupan. ¿Están siempre limpias? ¿Con qué frecuencia se cambia el agua?

8. Baptisterio. Si la iglesia tiene baptisterio, ¿por qué título? (canon 774) ¿Qué lugar ocupa y de qué materia está construida la pila bautismal? ¿Está dividida en dos partes, una para contener el agua consagrada y otra menor para recibir la que cae de la cabeza del bautizado y conducirla bajo tierra? ¿La pila tiene tapa o cubierta que cierre con llave? ¿Se consagra agua el sábado de Santo y Vigilia de Pentecostés? ¿El baptisterio tiene verja que también cierre con llave? ¿Qué imágenes o pinturas hay en el baptisterio? ¿Hay armarios para custodiar utensilios? ¿Tanto en el baptisterio como los utensilios para administración del bautismo guardan la debida limpieza?

9. Santo Oleos. ¿Cómo o cuándo se provee de ellos la iglesia? (canon 734) ¿De qué metal son las ampolletas o crismeras, y para evitar la corrupción de los óleos tienen dentro un vaso de vidrio? ¿Para distinguirlas sin dificultad cada una tiene su inscripción? ¿Se custodian en la iglesia, en lugar dedicado solo a ellos, seguro, decente, y bajo llave? (canon 735)

10. Reliquias ¿Cuántas posee la Iglesia y de que Santos? ¿Cada relicario está bien cerrado y sellado? (canon 1287\&2) ¿La reliquia de la Santísima Cruz se conserva en relicario propio y separado? ¿Todas las reliquias tienen su correspondiente auténtica? (canon 1283) ¿Dónde se custodian?

11. Púlpito, coro y órgano. Colocación, materia y decorado del púlpito. Situación del coro para los cantores. ¿Tiene rejas que impida que los cantores sean vistos por el público? ¿Tiene puerta de entrada buena y segura? ¿El órgano o armónium se conserva en buen estado? ¿Tiene cubierta de tela para defenderlo del aire y la tierra? ¿Hay armario seguro y con llave para guardar la música sacra?

12. Confesonarios. Su número, materia y colocación en un sitio visible (canon 999\&1) Limpieza interior y exterior particularmente de las rejillas. ¿Estas son fijas y de agujeros pequeños? (canon 999\&2). ¿Tienen por dentro alguna cubierta de tela de color oscuro? 
¿Por dentro tiene una percha con estola morada? ¿A los hombres se los oye en confusión en confesionarios? (Res. de la Com. Pont. 24 de Nbre. 1920)

13. Bancos. Número, estado, limpieza y colocación ordenada de los bancos. ¿Pertenecen a la iglesia?

14. Alcancías: ¿las que hay en la iglesia tienen la inscripción de su destino? ¿Cuántas son y a qué se destinan? ¿Son bien seguras? ¿Quién conserva las llaves, con qué frecuencia se abren, en quién se deposita el dinero y se lleva la cuenta del mismo y de su inversión?

15. Objetos de arte... Si la iglesia poseyera pinturas, esculturas, mosaicos, u otros objetos de arte, descríbanse indicándose su materia, destino, estilo, y valor en que se hayan apreciado y si se hallan bien guardados y defendidos.

16. Sacristía. ¿Hay una o más sacristías? ¿Cada una está bien guardada y defendida? ¿Quién corre con la llave? ¿Tienen las cómodas o armarios correspondientes según las necesidades? ¿Se conserva limpia y exenta de todo lo que desdiga de su objeto? ¿El aguamanil está en buen estado, y la toalla se renueva con frecuencia? ¿La piscina está tras el altar, en la Sacristía o cerca de ella? ¿Está bien hecha, cuyo fondo deja que se pierda el agua en la tierra, y cuya tapa esté armada de una argolla para poderla levantar? ¿Se tiene siempre con la debida limpieza?

17. Objetos de culto. Aquí se hace inventario de los objetos de culto, no sólo de la iglesia parroquial, sino también de cada una de las iglesias que están bajo su jurisdicción. Este inventario figurará en pliego aparte, a fin de que al llegar a la curia pase a la sección correspondiente.

18. Cementerios. ¿Cuántos cementerios hay en la parroquia? ¿Qué distancia los separa de la iglesia? ¿Son parroquiales, municipales o mixtos? ¿Qué altura miden sus muros? ¿Las entradas se cierran con puertas o verja fuerte, con buena cerradura y llave? ¿Tienen capilla, o al menos una cruz de metal, piedra o madera en lo alto del muro, o en medio del cementerio, que esté a la vista de todos? ¿Quién guarda la llave del cementerio? ¿Además del cementerio bendecido se tiene otro lugar cerrado y custodiado, donde sean enterrados aquellos a quienes no se haya de dar sepultura eclesiástica) (Ca. 1212) i En los cementerios que están bajo la inmediata jurisdicción y administración del párroco se observa perfecto orden, respecto a la ubicación de la sepultura, y cómo se provee a la limpieza, conservación y ornato de estos lugares sagrados? ¿No existe en la parroquia algún cementerio antiguo ya clausurado y quién tiene la llave?

19. Casa parroquial. ¿Hay casa parroquial de propiedad de la parroquia? ¿Es suficientemente cómoda? Hágase una breve descripción. ¿Se conserva en buen estado? ¿Qué distancia está de la iglesia parroquial? ¿Existe alguna otra casa propiedad de la 
parroquia, donde se halla situada, cuál sea su estado, quién la ocupa y en qué condiciones? Hágase una breve descripción de cada una de ellas.

20. Rentas. ¿La parroquia tiene alguna subvención nacional, provincial o municipal para el culto o la fábrica? ¿A qué cantidad aproximada asciende anualmente lo ingresado en fábrica por derechos de arancel? Ídem procedente de limosnas de los fieles. ¿Tiene propiedades la parroquia en tierras, valores públicos, etc. pertenecientes a la fábrica? ¿Cuáles son las rentas que producen? ¿Está gravada la fábrica con alguna deuda? Fecha de la última aprobación de cuentas y liquidación o resumen de ellas. ¿Tiene el párroco alguna subvención? ¿Cuáles son más o menos los emolumentos anuales que percibe por derechos parroquiales? ¿Existen propiedades o valores cuyas rentas correspondan al párroco suman las rentas más o menos? ¿Se aplican estrictamente los aranceles de la Diócesis? ¿Se cumple fidelísimamente el canon 1523, que trata de los administradores de bienes eclesiásticos?

21. Párrocos. Se nombre, apellido, edad, fecha de su ordenación de presbítero y de la toma de posesión de la parroquia. Casa donde habita y personas que viven con él (indicar el número de personas, nombre, apellido, conducta, edad, sexo, profesión y grado de parentesco con el párroco) ¿Se pone especial cuidado en observar el canon 133 del Código Canónico?

22. Vicarios cooperadores y otros eclesiásticos. ¿Hay uno o más vicarios? Para cada uno las mismas notas antes indicadas para el párroco. Si no viven con el párroco, decir donde habitan e indicar las personas que viven con ellos como el número anterior, y qué dificultades existen para que vivan juntamente con el párroco (can. 476 \&5). ¿Se cumple el párrafo séptimo del canon 476? ¿Cómo se remunera a los vicarios? Si hay otros eclesiásticos en la parroquia, presentar una lista de ellos con sus respectivas notas siguientes: nombre, apellido, patria, edad, oficio que tienen, conducta que llevan, donde viven, con quien, etc. Como en el número anterior.

23. Residencia. Ausencias anuales que hace el párroco. Forma como cumple el canon 465 en todas sus partes. Ausencia de los vicarios cooperadores.

24. Misa. ¿Cómo se provee de la harina para las hostias y del vino legítimo para el Santo Sacrificio de la Misa? ¿No se tiene en cuenta para este fin el artículo 14 de las Resoluciones del Episcopado Argentino del 18 de Agosto de 1922? ¿Cómo se cumple el canon 466 ? Número de misas que se dicen diariamente en la parroquia. Estipendios que se reciben. Libro de misas según el canon 843. Entrega de los estipendios sobrantes a fin de año según el canon 841. Cumplimiento del canon 810 en forma que sirva de edificación a los fieles. Número de los que oyen misa diariamente y en los días festivos.

25. Bautismo. ¿Qué número de niños, más o menos no están bautizados y por qué causa? ¿A los cuántos días de nacidos se los suele bautizar? ¿Se instruye a las parteras para administrar el bautismo en caso de necesidad? ¿Los bautizadores de la parroquia son 
personas dignas de desempeñar tan alto oficio, se les ha extendido el nombramiento según norma establecida en el artículo 131 del Sínodo Diocesano, y se les ha instruido bien sobre el modo de administrar el bautismo? (canon 743) ¿Tienen registro de certificados con talón impreso para anotar los bautismos que se hicieren conforme a lo ordenado en el artículo 138 del Sínodo Diocesano?

26. Penitencia y Eucaristía. ¿Qué número de fieles más o menos cumplen anualmente con el precepto pascual, hombres y mujeres? Número de comuniones diarias, semanales y en fiestas principales. ¿El párroco y sus vicarios están siempre prontos y dispuestos para administrar la penitencia y la Eucaristía a quienes lo pidan? ¿De qué medios se usan para fomentar la frecuencia de sacramentos? ¿Se cumple con rigurosa estrictez el inciso e) del artículo 73 de las Resoluciones del Episcopado Argentino del 18 de agosto de 1922 "que no se admitan a la santa comunión personal que se presenten con el pecho y brazos descubiertos"?.

27. Primera Comunión. ¿En qué edad se admiten a los niños a la primera comunión (canon 854)? ¿Qué número de niños más o menos comulgan cada año por primera vez? ¿Con este motivo no se celebra una fiesta especial para ellos y en qué consiste?

28. Visitas de enfermos, Viático y Extremaunción. Cuando hay algún enfermo en alguna casa, ¿existe la práctica de dar aviso al párroco? ¿Con qué solicitud el párroco y los vicarios visitan y ayudan a los enfermos? (Canon 468) ¿Cómo se cumplen los cánones 865 y 944 ? Mueren muchos fieles sin recibir el Viático o la Extremaunción y por qué causa? Forma y acompañamiento con que se administra el Viático. ¿Se exige de las personas que vienen en busca del párroco para auxiliar los enfermos, costear los medios de locomoción cuando ellos mismos no los ofrecen?

29. Sepultura eclesiástica y funerales. ¿Se observa el ritual romano en las exequias y funerales? Deficiencias o abusos que haya, sus causas y remedios. ¿Cómo se hace el entierro de los pobres? Número y causa de negación de sepultura eclesiástica.

30. Matrimonio. ¿Para la celebración del matrimonio se usa la formula aprobada por los Obispos reunidos en Salta? ¿Antes de proceder a autorizar los matrimonios se observan los cánones 1019-1034? Cuando el matrimonio se ha de celebrar en distinta parroquia de donde se hace la información, ¿se envía al párroco que ha de asistir al matrimonio los datos pertinentes para poder asentar la partida de matrimonio, a saber nombre, apellido, profesión etc. de los contrayentes, nombre apellido, etc. de los padres y demás datos necesarios? ¿Hay muchos amancebados o casados civilmente, y qué diligencias se hacen para casar canónicamente? ¿Se quedan algunas personas sin casarse por no querer o poder pagar derechos? ¿Se cumplen los cánones 1065 y $1066 ?$

31. Moralidad y malas lecturas. Escándalos graves que ocurran en la parroquia. Vicios dominantes, y los medios que se emplean para extirparlos o disminuirlos. ¿Qué periódicos 
se reciben o leen habitualmente por los feligreses? ¿Qué libros circulan entre ellos contrarios a la fe o la moral? ¿Se fomenta la buena prensa? ¿Qué cooperación se presta a la prensa católica de la Diócesis?

32. Predicación y catecismo. ¿Todos los días de precepto se predica de acuerdo al canon 1344? ¿En qué otros días u ocasiones se predica y por quiénes? ¿Se cumplen fielmente el canon 3144 en cuanto a los predicadores, y el canon 1347 en cuanto a la materia y forma de la predicación (canon 1349)? ¿Se hace el catecismo de adultos en estilo acomodado a su capacidad los domingos y días festivos de precepto de conformidad en todo a lo prescripto por el canon 1332? ¿Cómo se cumplen con el deber gravísimo de procurar la enseñanza de catecismo? (canon 1329) ¿Se practican los cánones 1330, 1331, y en qué forma?

33. Cofradias, hermandades y asociaciones piadosas. ¿Cuáles son las establecidas en la parroquia? Su denominación y sus fines. Su aprobación o erección con su correspondiente documento (canon 708). Si hay algunas agregadas a las archicofradías o a las primarias, si se conserva el diloma de agregación. Si tiene reglamentos aprobados por el Ordinario (canon 689). Si tienen directores o capellanes nombrados por el Ordinario (can. 6989). Si viven regularmente o hay defectos que corregir. Si existen la del Santísimo Sacramento y la de la Doctrina Cristiana (can. 711). Si se procura fomentarlas, y que los jóvenes de ambos sexos se inscriban desde luego en las más apropiadas a su estado y condición (can. 684).

34. Culto. ¿Se observan cuidadosamente las rúbricas en los actos del culto? ¿Se procura edificar a los fieles, guardando la modestia y la compostura debida en el templo, especialmente en el ejercicio de los actos religiosos? ¿Se observa el Motu Propio de SS Pío X sobre la Música Sagrada? ¿Se hace la novena del Espíritu Santo, y en ella como también el día de Pentecostés se rezan las preces por el fomento de las vocaciones eclesiásticas? ¿Se reza el rosario en la misa durante el mes de octubre, o por la tarde delante del Santísimo Sacramento expuesto? ¿Se fomentan las devociones piadosas como la exposición y visita del Santísimo Sacramento, Vía Crucis, Santo Rosario, Med. del Corazón de Jesús, de María y de San José y de otros semejantes, celebrándose en la iglesia correspondiente los actos?

35. Obras Sociales. ¿Hay obras sociales informadas del espíritu de la Iglesia Católica? Su denominación y aprobación de sus estatutos. ¿Se promueve prudentemente la institución de dichas obras y se favorecen? ¿Qué centros o instituciones de carácter social hay en la parroquia contrarios a la iglesia, número de socios y daños que causan?

36. Casas religiosas. Número y nombre de las casas religiosas que haya en la feligresía. ¿El párroco o alguno de sus vicarios desempeñan el oficio de capellán? ¿Cuáles son las obligaciones y qué remuneración reciben? ¿Si fueren casas de religiones clericales, ayudan los religiosos al párroco en el ministerio?

37. Escuelas. Escuelas públicas y privadas existentes en la parroquia. Si las hay dirigidas por religiosos o religiosas, ¿cuáles son el número de las existentes? ¿En ellas se enseña el 
catecismo? (canon 1373) ¿Hay escuelas neutras o mixtas en el sentido en que habla el canon 1374? ¿Se procura evitar la asistencia de los niños católicos a tales escuelas; y al permitirla se tiene bien en cuenta el mismo canon 1374? ¿Se recuerda a los padres y a todos los que hacen sus veces lo prescripto por el canon 1372?

38. Archivo parroquial y libros parroquiales. Lugar en que está situado el archivo. Si se cierra bajo llave que guarde el párroco. ¿Los armarios están bien asegurados? ¿Los documentos del archivo están bien arreglados formando legajos separados y encuadernados o cosidos, o por lo menos ligados con broches? ¿Cada legajo lleva la carátula correspondiente al asunto de que se trata con indicación de fecha? ¿Existe en él además el índice o catálogo del mismo archivo, el inventario de los objetos de culto, y el de los bienes eclesiásticos? ¿Se tienen en el archivo todos los títulos o documentos o en su defecto copias, que acrediten la propiedad de todos los bienes eclesiásticos pertenecientes a la parroquia? ¿Se conserva en él el libro de cuentas de fábrica, el de misas mensuales, un ejemplar del Código, del Concilio Plenario, Sínodo Diocesano, Colección completa de la Revista Eclesiástica de Buenos Aires, la del Boletín Eclesiástico de la Diócesis, ambas colecciones encuadernadas, el Catecismo de San Pío V, el Manual Litúrgico de Solans y demás documentos que interesan a la parroquia, como serían las Resoluciones del Episcopado Argentino, las Pastorales y los Autos Episcopales? ¿Se cumplen con suma diligencia y gran fidelidad las prescripciones referentes a los libros parroquiales contenidas en los cánones 470, 777, 778, 1133, 1238? ¿Hay defectos que corregir en las partidas ya inscriptas?

39. Fundaciones Pías. ¿Cuáles son las que están de algún modo localizadas en la parroquia? ¿Sobre qué clase de bienes están hechas? Sus rentas y aplicación. ¿Se conserva en el archivo un ejemplar de la escritura de fundación? (canon 1548) ¿Para el fiel cumplimiento de las cargas de la fundación, se observa el parágrafo primero del canon 1549? ¿Existe el libro de fundaciones y cómo se lleva? (canon 1549\&2)

40. Tasas y colectas. ¿Se satisface puntualmente el tributo para el Seminario de conformidad con todo lo establecido en la Diócesis? (cánones 1355 y 1356) ¿Se realizan las colectas mandadas, a saber el 29 de junio para el Obolo de San pedro, el 6 de enero a favor de la redención y educación cristiana de los esclavos africanos, el domingo siguiente para los Santos Lugares, y el segundo domingo después de la Epifanía a favor de la santa infancia y las escuelas orientales (Sínodo Diocesano Art. 250 y 251), las colectas extraordinarias recomendadas por el indulto del ayuno de los días de la Circuncisión del Señor, destinadas en el orden respectivo para los gastos del culto Divino, de las instrucción cristiana de la juventud, de las obras caritativas y de misiones y finalmente el día de Pentecostés la colecta para el sostenimiento del Seminario? (Resoluciones del Episcopado Argentino, 1922). Para que las colectas sean eficaces se avisa con anterioridad a los fieles los días en que deban hacerse, explicándoles al mismo tiempo los fines de cada una. ¿Se 
remite lo recolectado al Ecónomo de la Diócesis, dentro de los quince días subsiguientes a cada una de las fechas fijadas?

Fuente: AAC. Caja Parroquias: Sobremonte, 1926. Boletín Eclesiástico (1925: 16-24). 
Anexo IV 


\section{Río de los Sauces 1905}

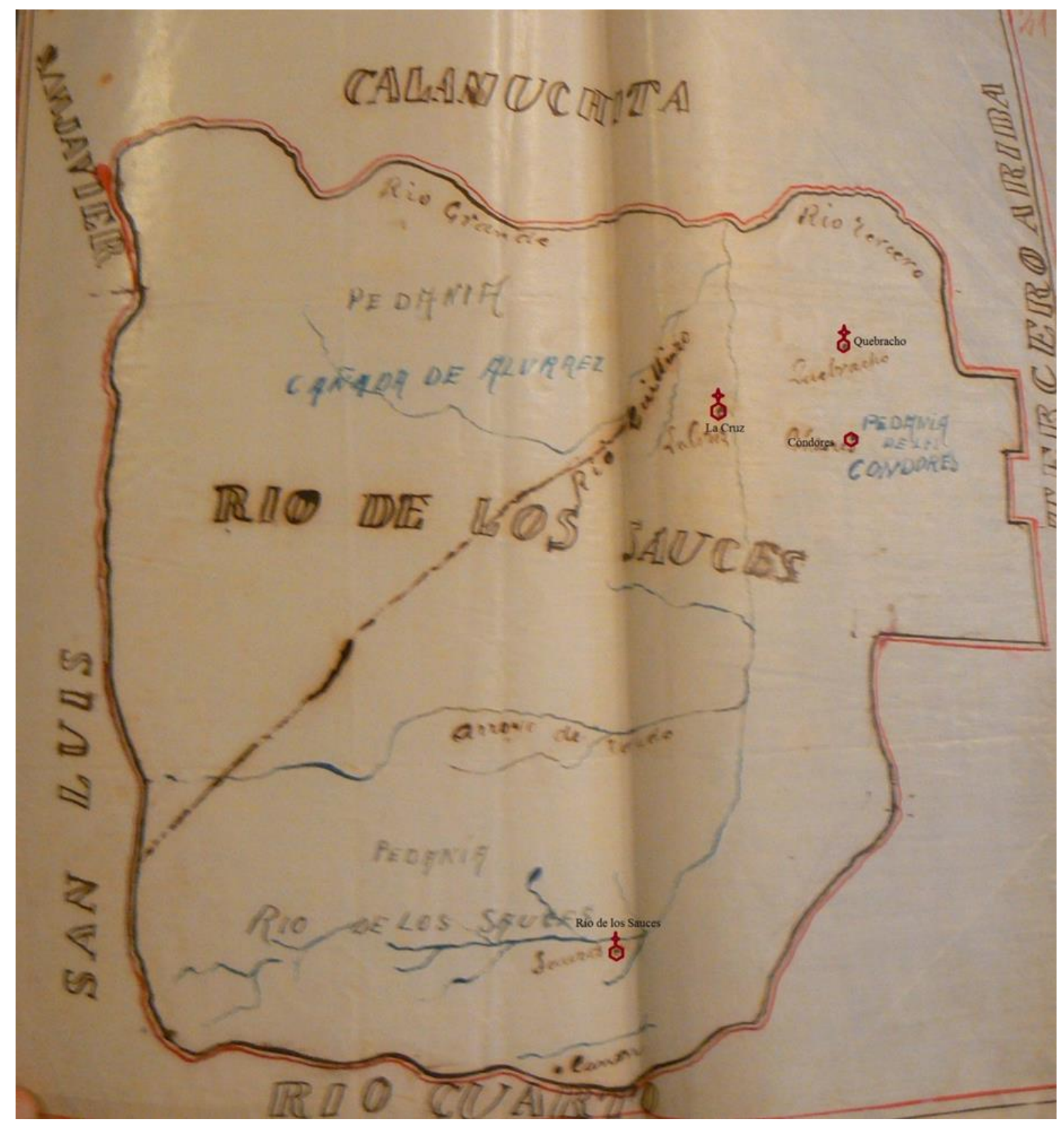




\section{Río de los Sauces 1925}

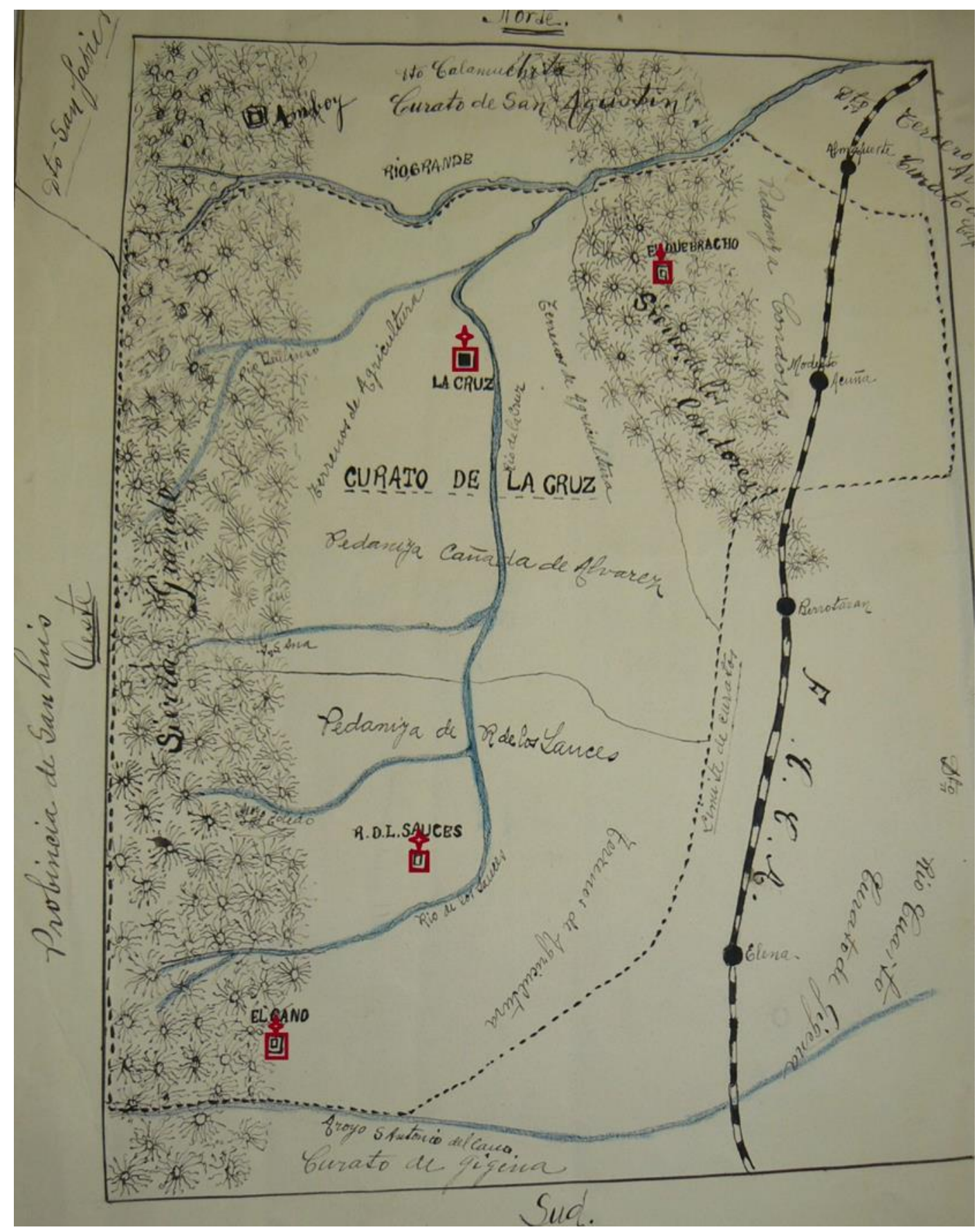




\section{CARICATURAS}

\section{Participación de curas en las elecciones}

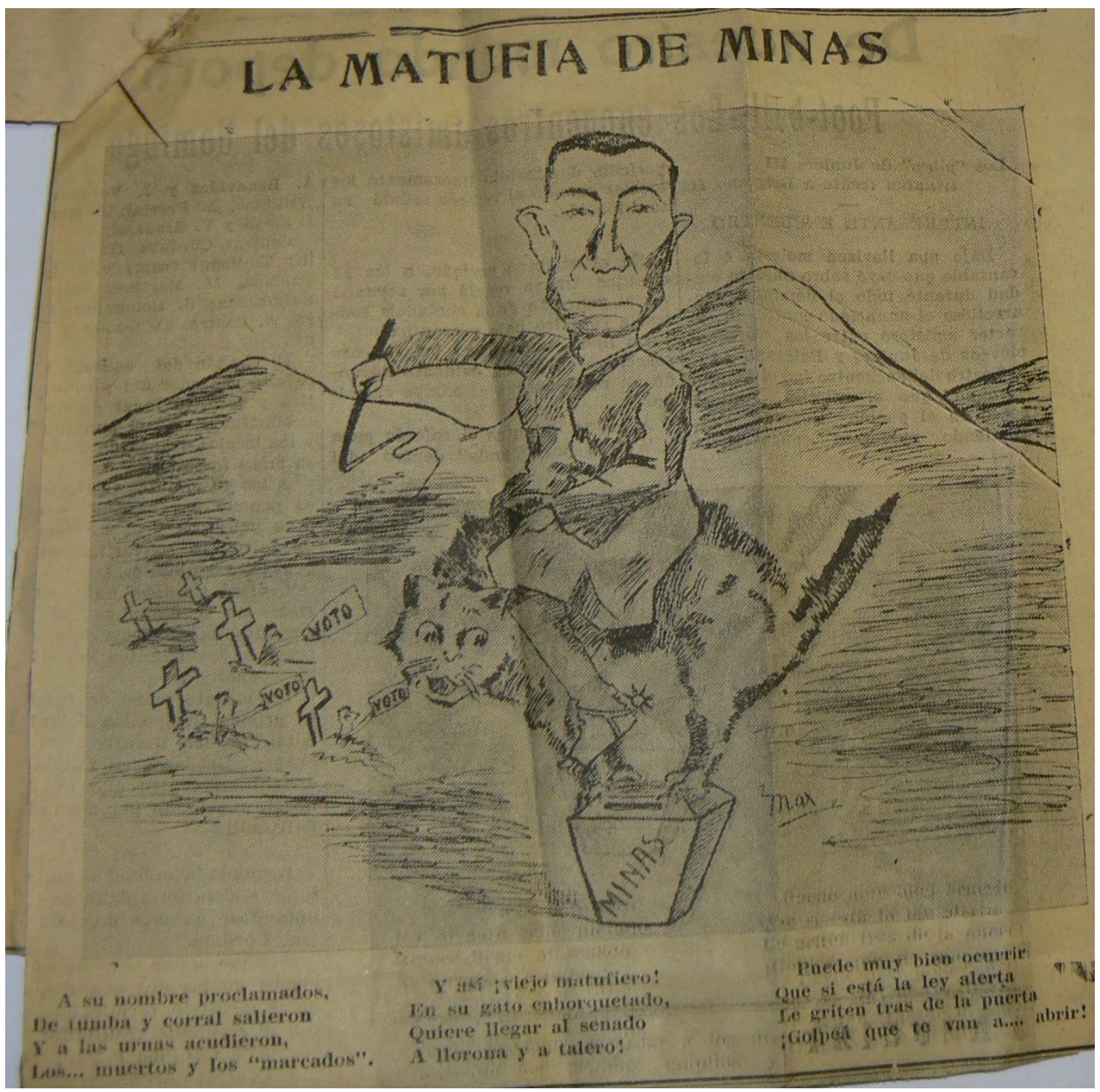



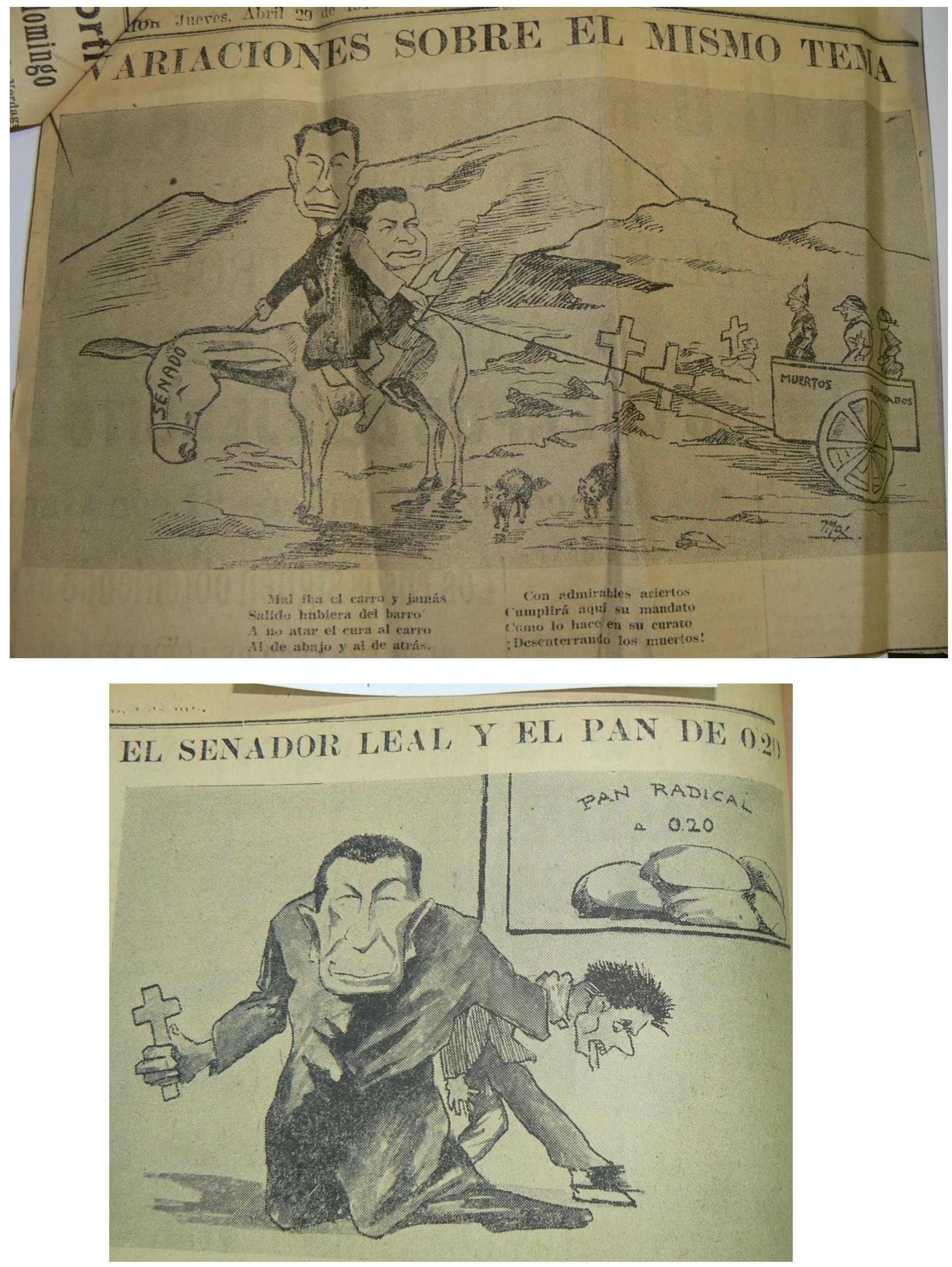


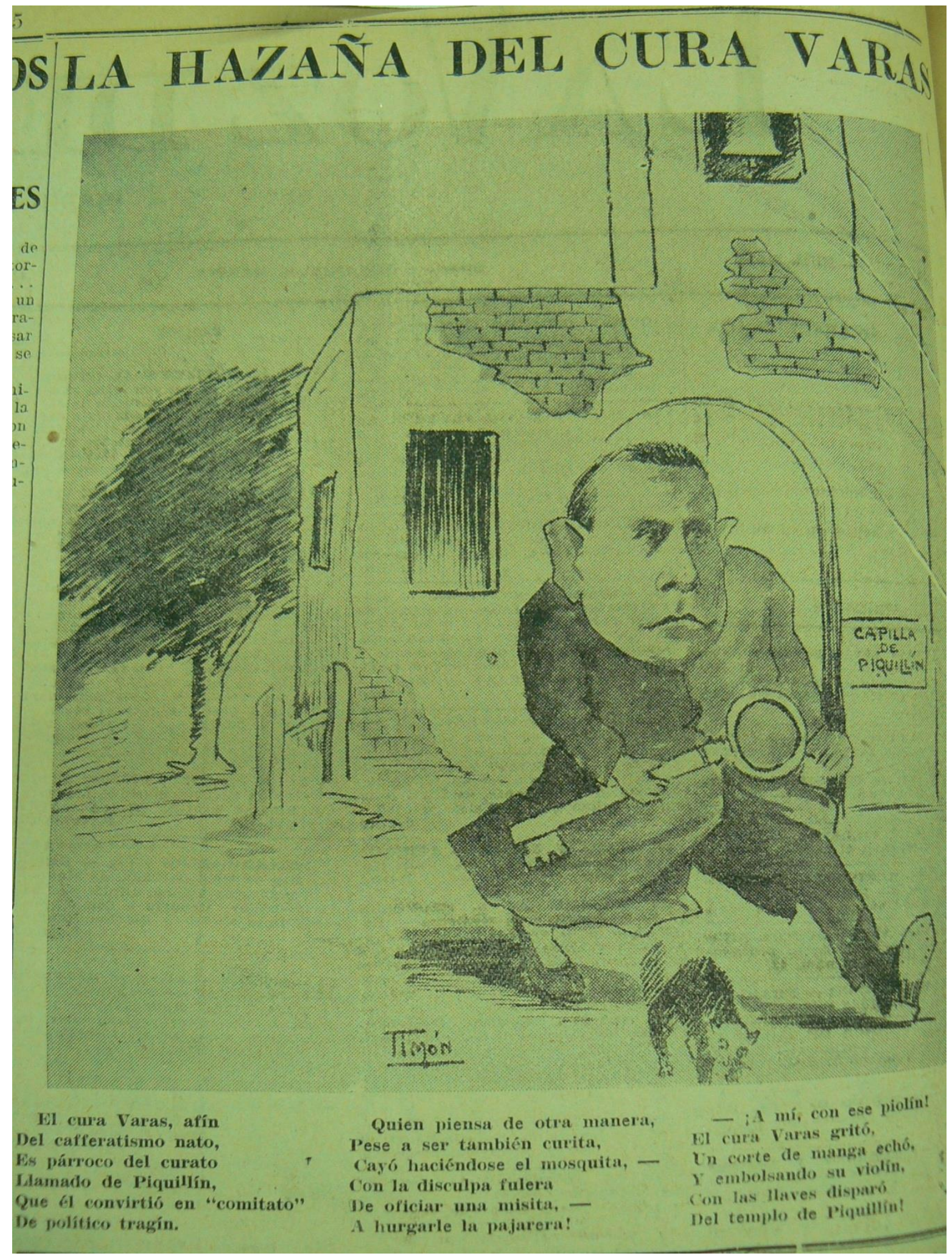




\section{Trilladora (1910)}

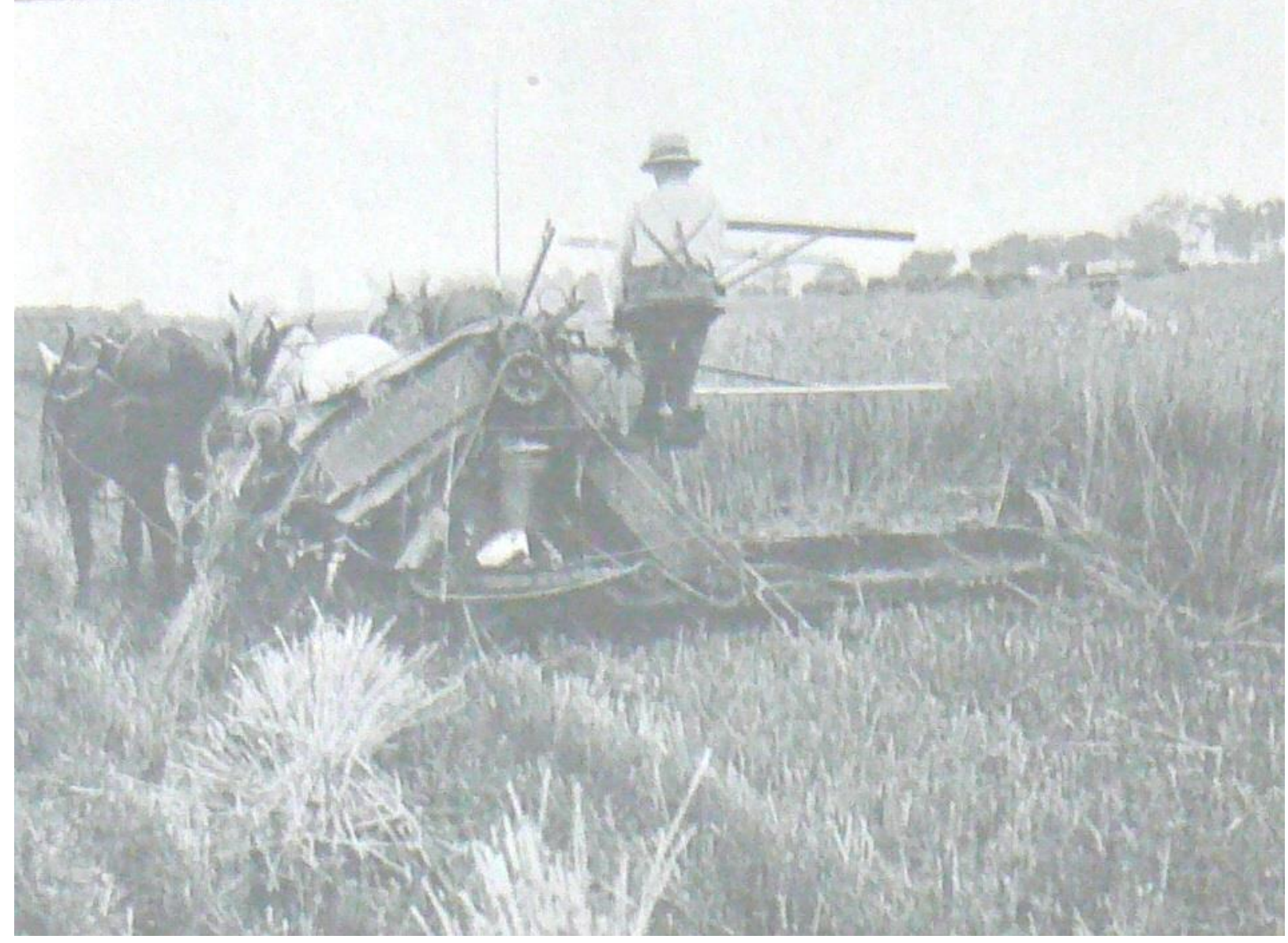


Fiesta del XX Septiembre

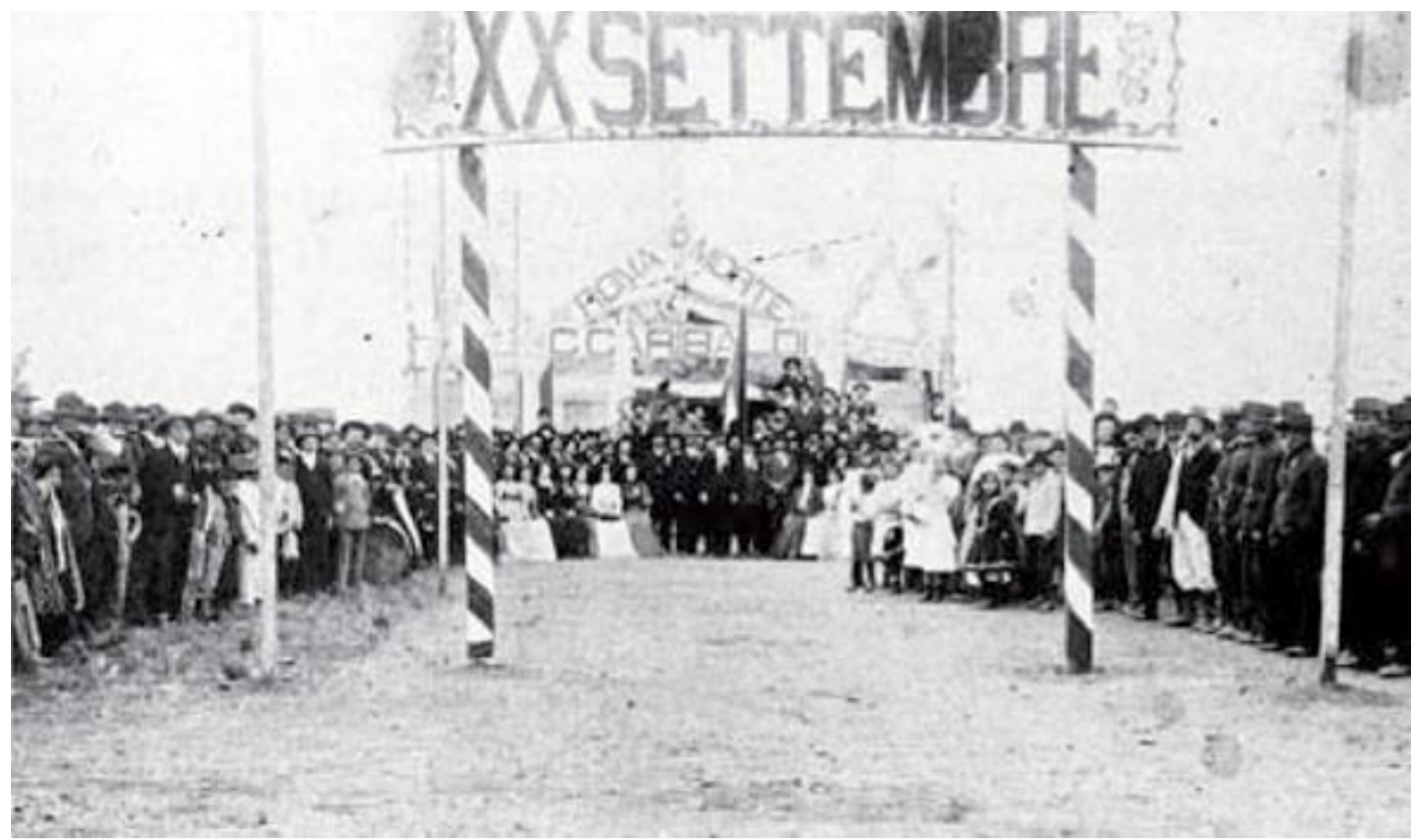

Entierro en Pozo del Molle (1923)

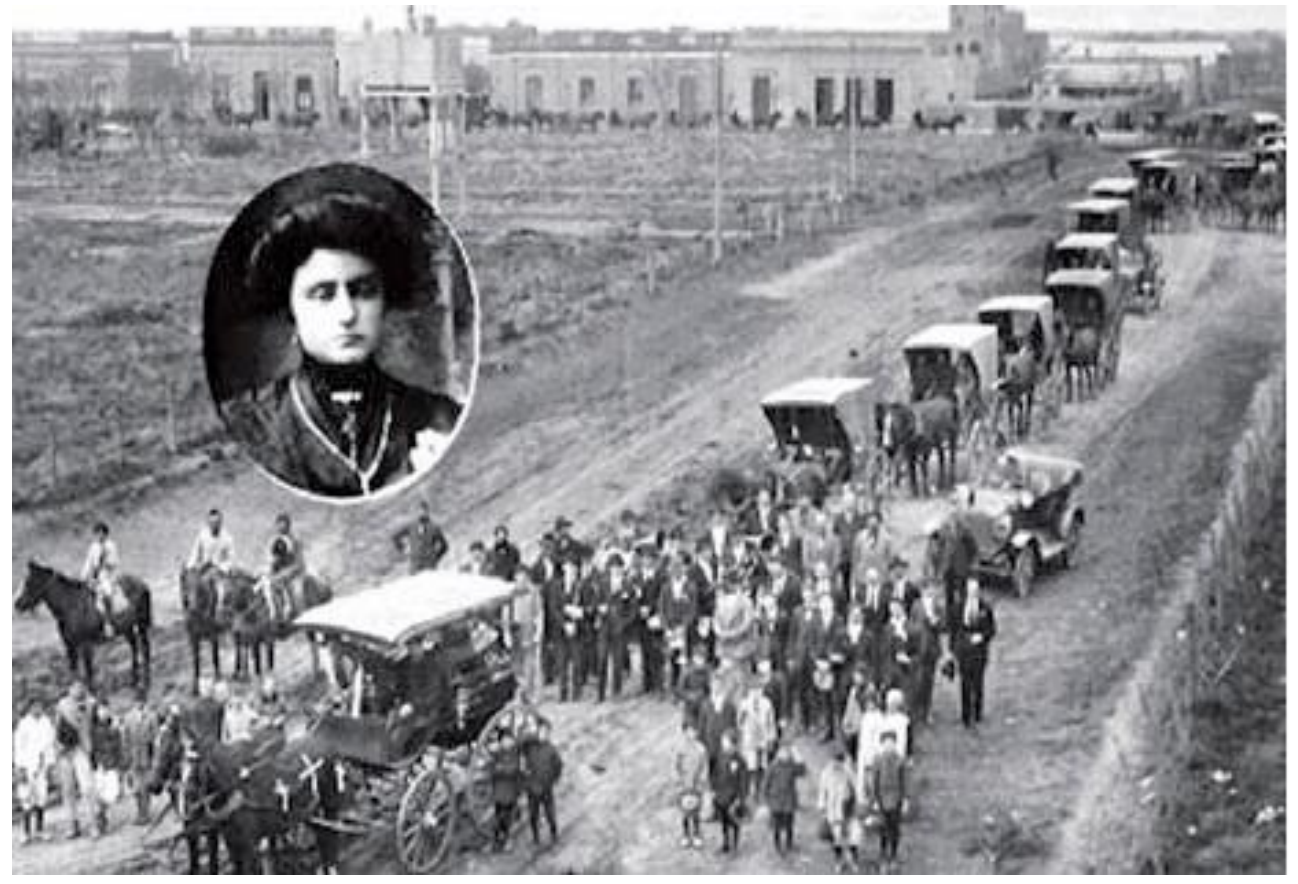




\section{Misiones rurales, 1890}

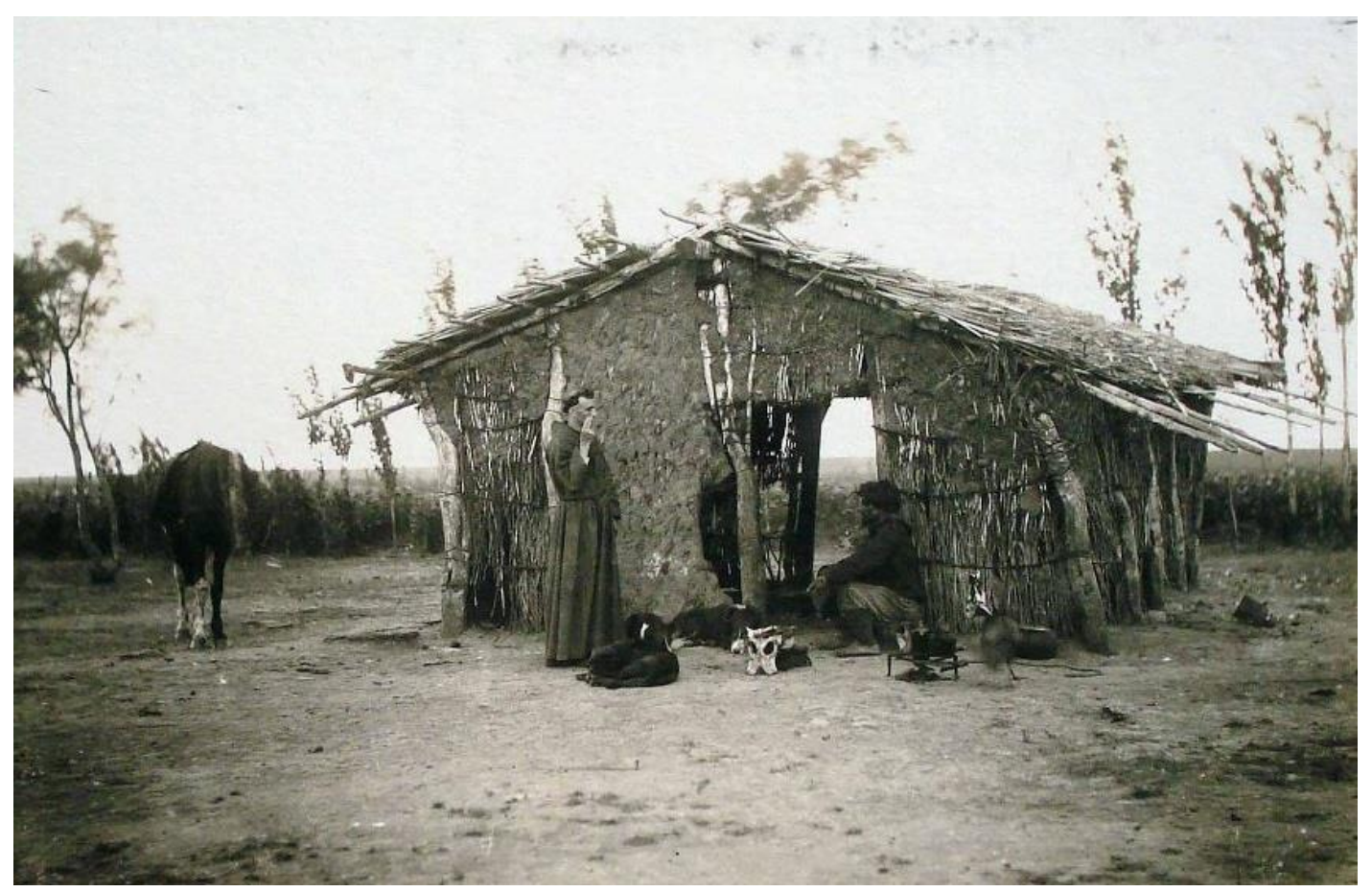

Misiones rurales, 1918

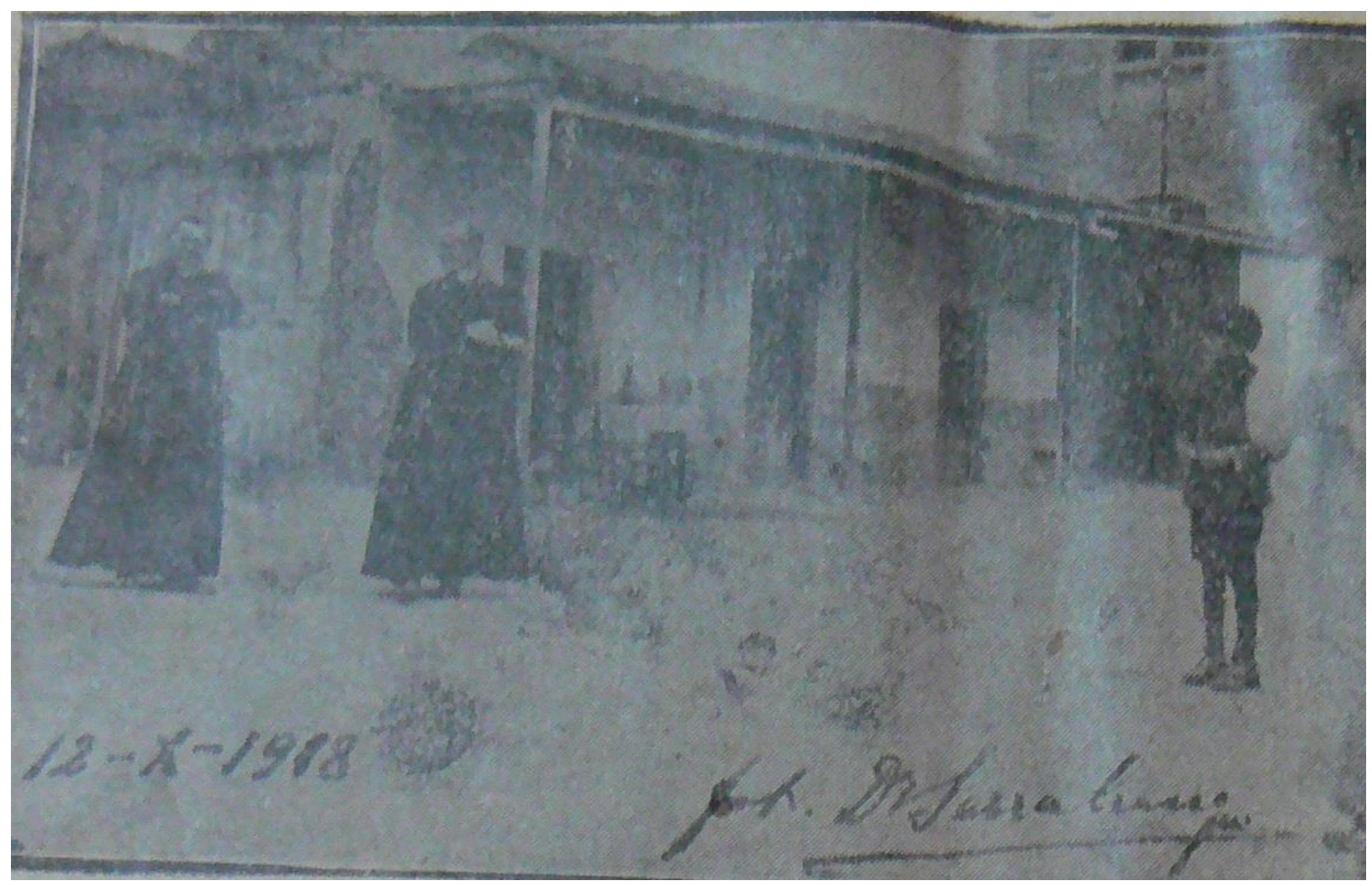




\section{Procesión en Sacanta}

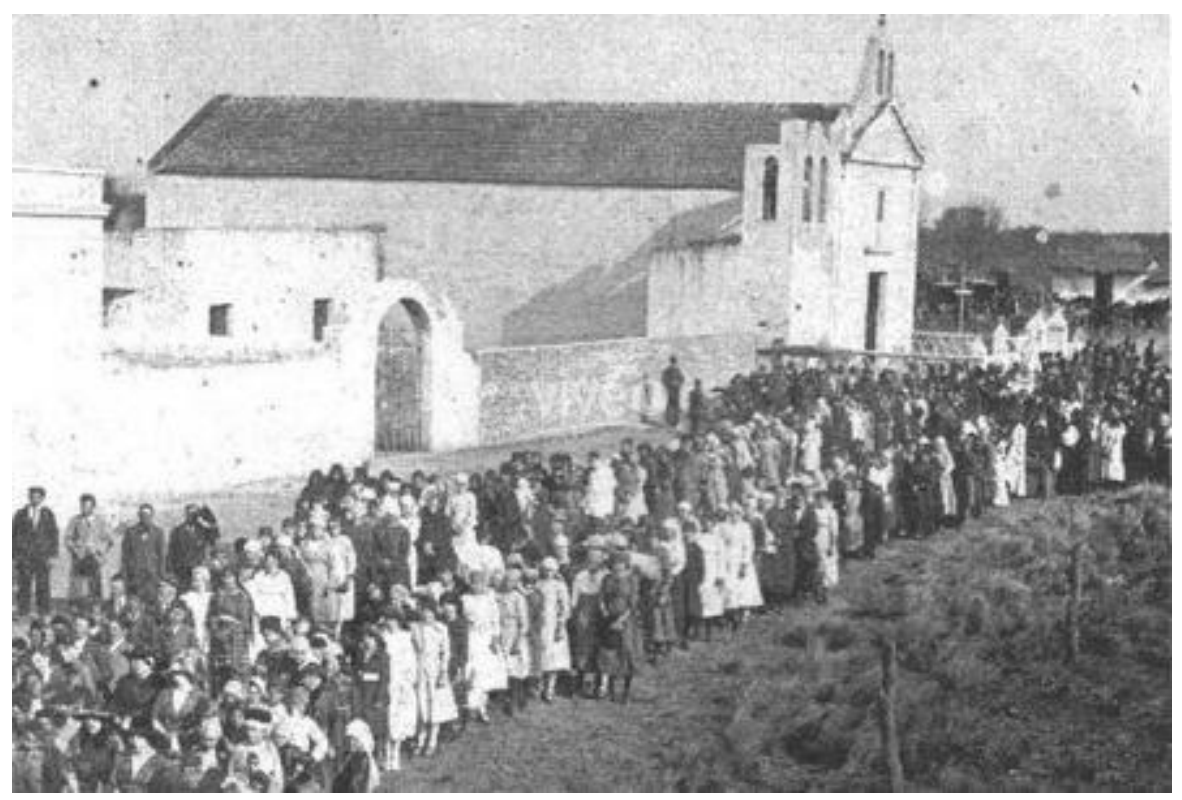

\section{Procesión en Reducción 1899}

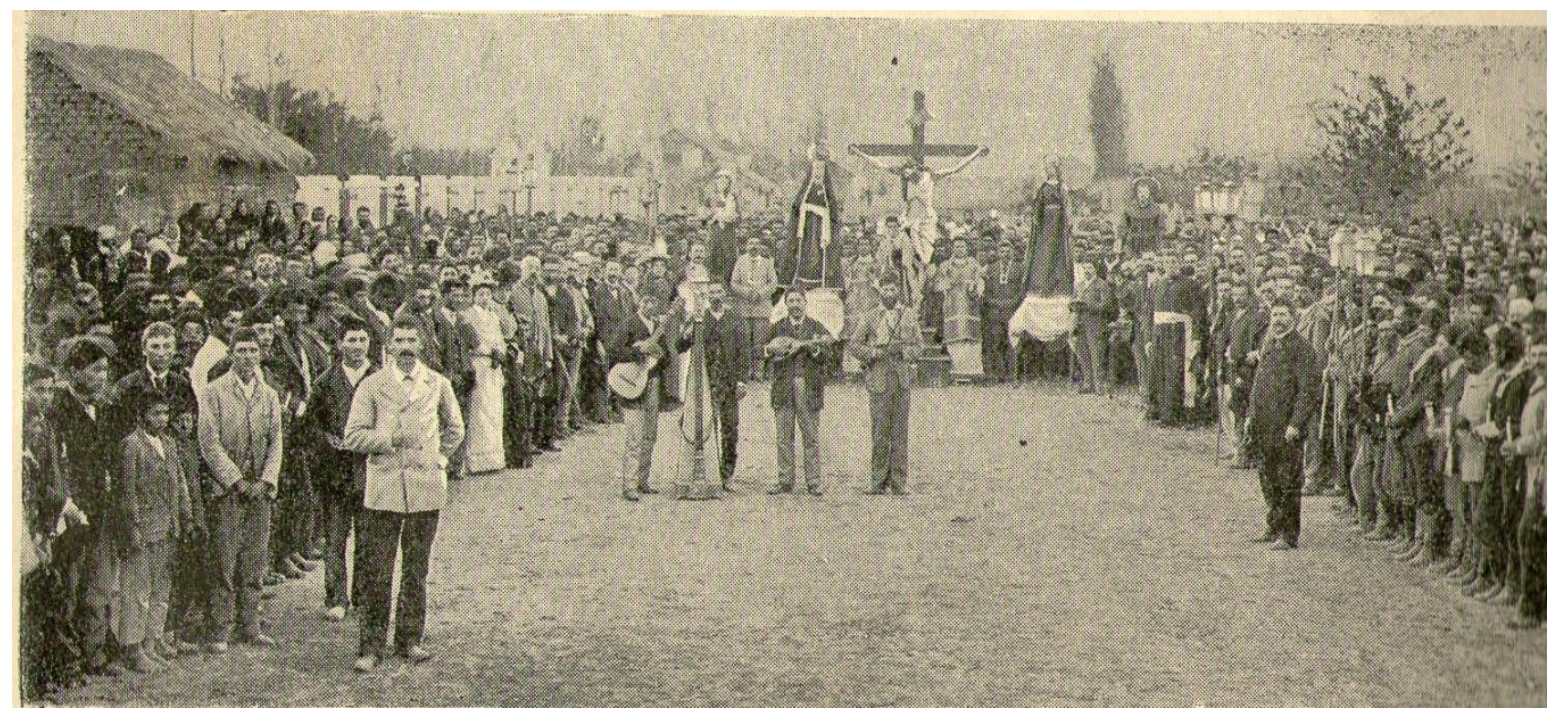




\section{Procesión Inriville 1929}

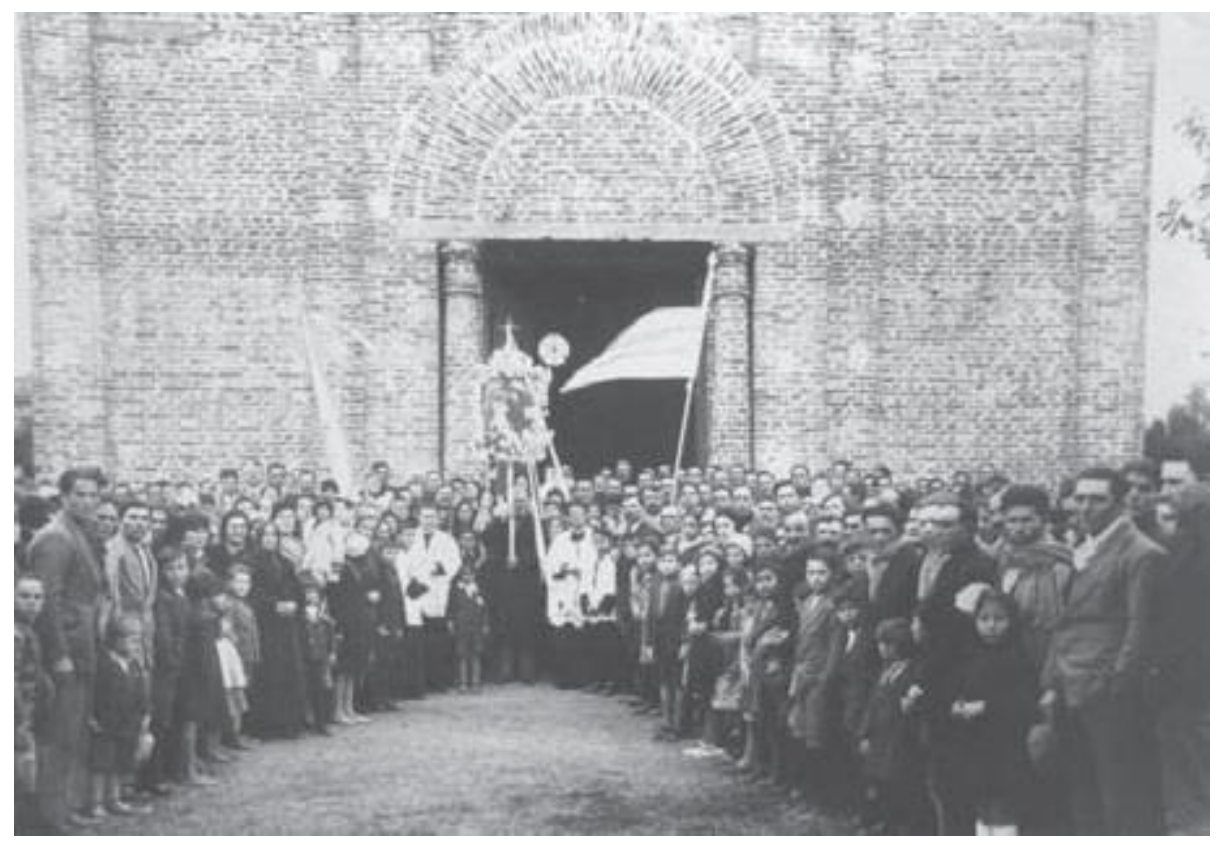

\section{Procesión Colonia Vignaud}

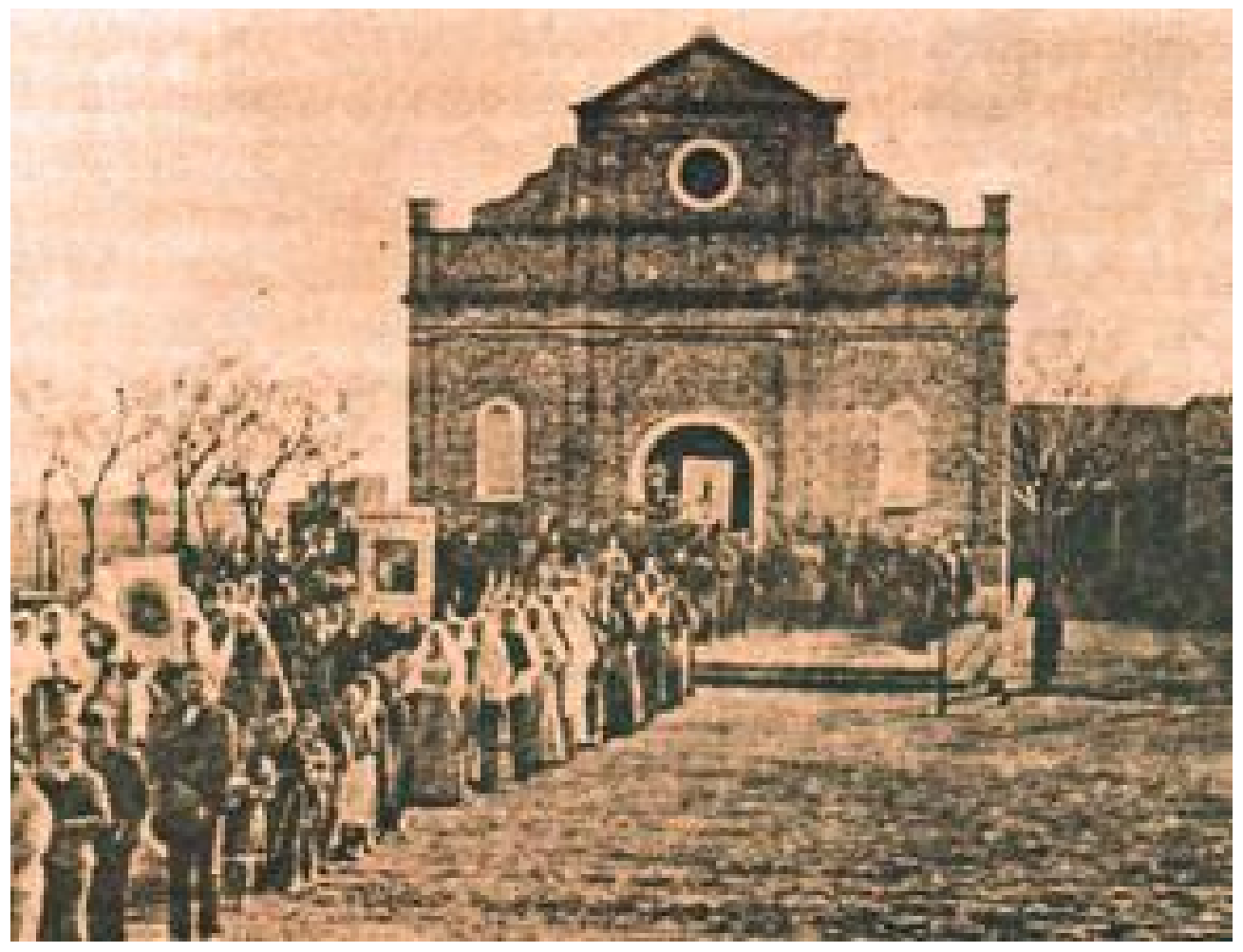




\section{Procesión La Playosa}

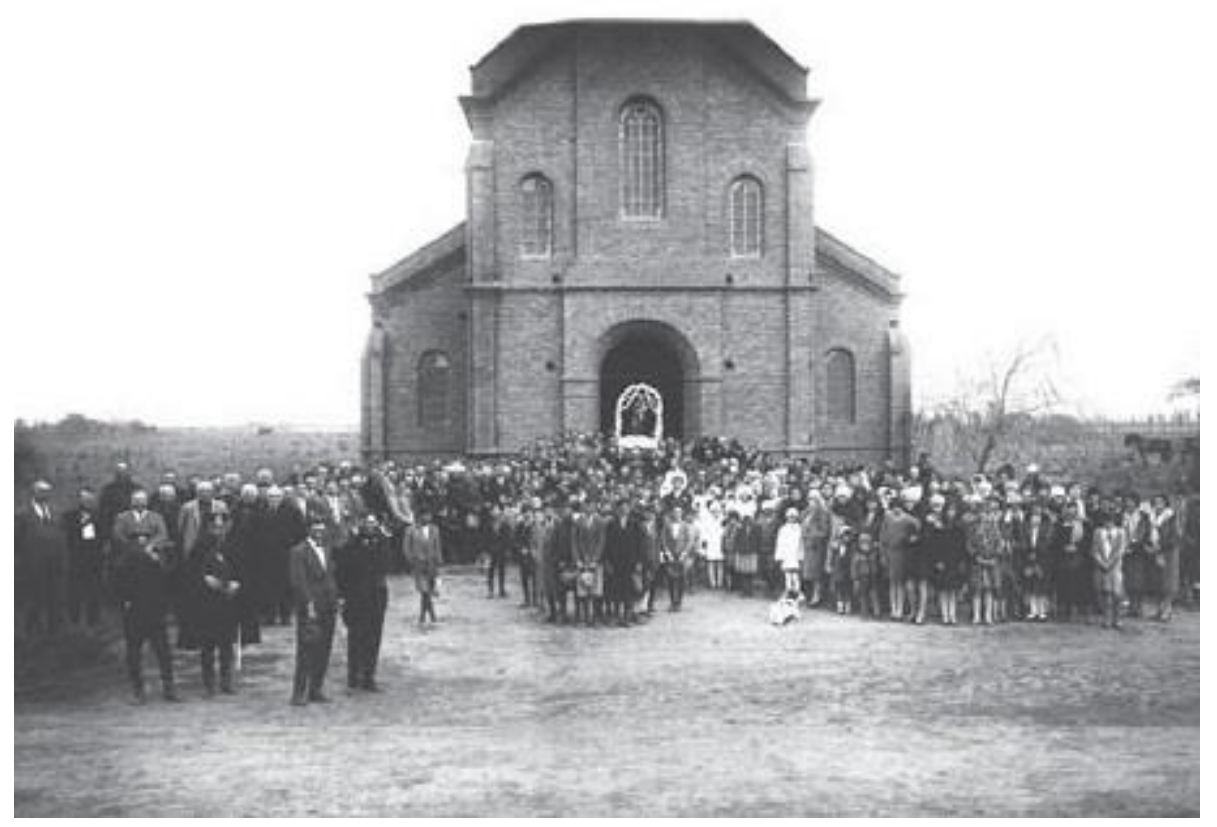

Templo La Playosa (actual)

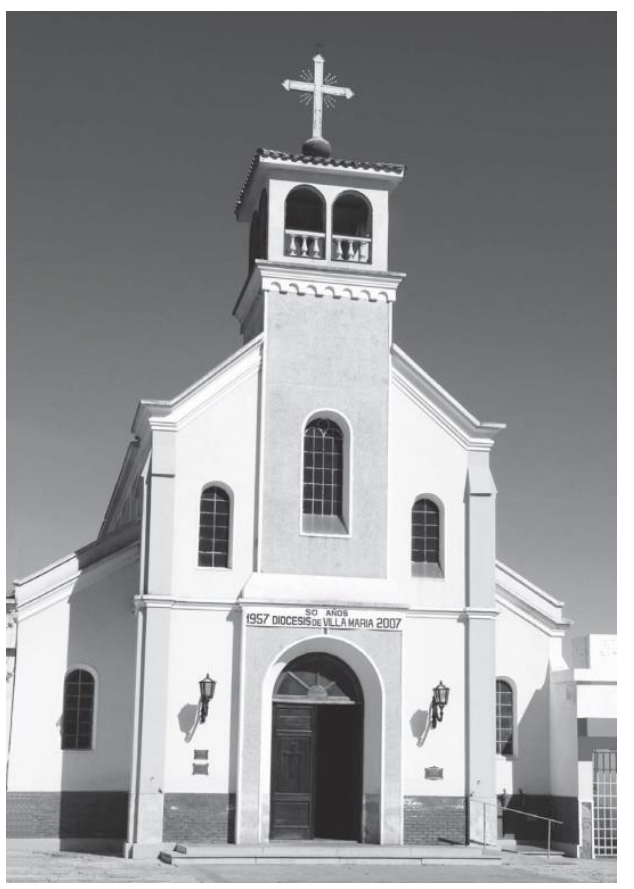

